

\section{Studies on Arabic Dialectology and Sociolinguistics}

Proceedings of the 12th International Conference of AIDA held in Marseille from May 30th to June 2nd 2017

Actes des $12^{e}$ rencontres internationales de Aida

Catherine Miller, Alexandrine Barontini, Marie-Aimée Germanos, Jairo Guerrero and Christophe Pereira (dir.)

DOI: $10.4000 /$ books.iremam.3878

Publisher: Institut de recherches et d'études sur les mondes arabes et musulmans

Place of publication: Aix-en-Provence

Year of publication: 2019

Published on OpenEdition Books: 24 January 2019

Series: Livres de l'IREMAM

Electronic EAN: 9791036533891

\section{Q OpenEdition}

Books

https://books.openedition.org

\section{Electronic reference}

MILLER, Catherine (ed.) ; et al. Studies on Arabic Dialectology and Sociolinguistics: Proceedings of the 12th International Conference of AIDA held in Marseille from May 30th to June 2nd 2017. New edition [online]. Aix-en-Provence: Institut de recherches et d'études sur les mondes arabes et musulmans, 2019 (generated 22 avril 2022). Available on the Internet: <http://books.openedition.org/iremam/ 3878>. ISBN: 9791036533891 . DOI: https://doi.org/10.4000/books.iremam.3878.

(c) Institut de recherches et d'études sur les mondes arabes et musulmans, 2019 Terms of use:

http://www.openedition.org/6540 


\section{ABSTRACTS}

This volume contains over fifty articles related to various fields of modern Arabic dialectology. All the articles are revised and enhanced versions of papers read on the $12^{\text {th }}$ Conference of the Association Internationale de Dialectologie Arabe (AIDA) held in Marseille in June 2017. Since its first conference in Paris in 1993, AIDA members gather every two years in different country. The collection of the AIDA proceedings offer an updated insight of the development of the field. During the past few decadesthe the study of Arabic dialects has become an important branch of research covering a wide range of subjects from phonological analyses, morphosyntax, semantics to pragmatics, sociolinguistics, folk linguistics, studies on literacy and writings, cultural and artistic practices, etc. As many articles of this volume illustrate, the study of Arabic dialects explores different aspects of the languages and cultures of the contemporary Arab world. A remarkable feature is the growing and constant participation of young scholars from all around the globe.

\section{EDITOR'S NOTE}

AIDA (fr. Association Internationale de Dialectologie Arabe) - International Association of Arabic Dialectology / الرابطة الدولية لدراسة اللهجات العربية - is an association of researchers in Arabic dialects, from all over the world.

AIDA was founded in 1993, in Paris, at the initiative of a group of prestigious Arabists, with the aim to encourage and promote the study of Arabic dialects.

AIDA is nowadays the leading international association in this field of research and it has become a center that joins scholars from all over the world who are interested in any aspect of Arabic dialectology, including dialects which have not been described yet, dialectal geography, specific aspects of phonology, morphology and syntax, codeswitching, koiné language, pidgin, creole, the lexicon of Arabic dialects, dialectal atlases, comparative and diachronic studies, sociolinguistics, teaching of Arabic dialects, and so on.

AIDA organizes conferences every two years, hosted by well-known universities from all around the world.

AIDA 11 was organized in Bucharest in 2015 . Its web site provides many valuable information about Aida members and Aida publication (http:// aidabucharest2015.lls.unibuc.ro/).

AIDA 12 was organized in Marseilles in 2017 (https://aida12.sciencesconf.org/). Download the Program of the 12th International Conference of AIDA https:// aida12.sciencesconf.org/data/pages/Programme_1_A3_plie_A_9.pdf Aida's activities can also be followed on its facebook group at : https://www.facebook.com/groups/792649064183347/ 
This volume contains over fifty articles related to various fields of modern Arabic dialectology. All the articles are revised and enhanced versions of papers read on the $12^{\text {th }}$ Conference of the Association Internationale de Dialectologie Arabe (AIDA) held in Marseille in June 2017. Since its first conference in Paris in 1993, AIDA members gather every two years in different country. The collection of the AIDA proceedings offer an updated insight of the development of the field. During the past few decadesthe the study of Arabic dialects has become an important branch of research covering a wide range of subjects from phonological analyses, morphosyntax, semantics to pragmatics, sociolinguistics, folk linguistics, studies on literacy and writings, cultural and artistic practices, etc. As many articles of this volume illustrate, the study of Arabic dialects explores different aspects of the languages and cultures of the contemporary Arab world. A remarkable feature is the growing and constant participation of young scholars from all around the globe. 


\section{TABLE OF CONTENTS}

Preface

\section{Arabic Dialectology - Linguistic Descriptions}

Africanisms in Turku

Andrei A. Avram

Introduction

1. Lexical items

2. Calques

Conclusions

Les futurs en arabe de Tripoli (Libye) : temporalité, aspectualité et modalités Najah Benmoftah and Christophe Pereira

Introduction

1. Le participe actif

2. La conjugaison préfixale nue

3. Les préverbes $b-$, hă- et taw-

Conclusion

Variation in Prosodic and segmental marking of yes-no questions in Tunisian Arabic Nadia Bouchhioua, Sam Hellmuth and Rana Almbark

Introduction

1. Background

2. Methods

3. Results

Conclusion

The Tense in Central Asian Arabic Dialects: (Complex (Immediate)) Future and Present Definite (Continuous tense)

Guram Chikovani

1. The complex (immediate) future

2. Present definite

Conclusion

La reduplication totale dans l'arabe levantin septentrional. Le cas de la faune Emma De Murtas

La réduplication

La réduplication et l'arabe

Le corpus

La faune

La réduplication et l'iconicité

Zara'nā Law Tala'et Yā Rēt! On Wish, Hope, and other Bouletic Modalities in Spoken Arabic from Syria

Daniela Rodica Firanescu

Introduction

1. Definition of terms and theoretical approach

2. Corpus

3. The core of bouletic in spoken Arabic from Syria (according to criteria of meaning, conventionalization, and frequency)

4. Some other expressions of wish and hope at various distances from the core

5. Illustrations of the "hard core" of bouletic

Final remark 
Preliminary Notes on the Arabic Dialect of the Chiadma (North of Essaouira)

Felipe Benjamin Francisco

Introduction

1. The Chiadma tribe

2. Fieldwork and data collection

3. Description

Final considerations

Acoustic Correlates of Rhotic Emphasis in Fessi Spoken Arabic

Aaron Freeman

1. Background

2. Methodology

3. Results

5. Conclusions and Further Directions

Référents des marques de personne et deixis sociale et émotionnelle en arabe dialectal libanais

Marie-Aimée Germanos

Introduction

Emplois de 1PL en décalage avec le référent

Emplois de la deuxième personne en décalage avec le référent

Emplois de la troisième personne en décalage avec le référent

Quelques perspectives, en guise de conclusion

Deontic Modality in Baghdadi Arabic

George Grigore

Introduction

1. The obligation

2. The permission

Final remark

Les marqueurs des constructions analytiques du réfléchi et du réciproque en arabe du Caire Julie Haslé

Introduction

1. Usages de nafs

2. Usages de ba'd

Conclusion

Persian Loanwords in Baghdadi Arabic

Stefan lonete

1. Phonetic considerations

2. Morphological integration

Verbal Negation in the Lebanese Dialect of Zeitoun, Keserwan

Natalie Khairallah and David Wilmsen

Introduction

Negation in northern Lebanese Arabic dialects

Negation in The Vernacular Arabic of the Lebanon

Negation in the Arabic dialect of Zeitoun

Negation with -š: penultimate stress

Observations and conclusions

Gulf Arabic: Recent Data about the Variety Spoken in the Emirate of Dubai Najla Kalach

1. The Emirate of Dubai: Geographical and Historical Hints

2. Previous Studies on Gulf Eastern Arabic Varieties and Aim of the Study

3. Methodology and Informants

4. Morphosyntactic Features

5. Final Comments

6. Sample Text 
Khuzestan Arabic and the Discourse Particle ča

Bettina Leitner

1. Introduction and data

2. Main features \& typology

3. Comparison with Ingham's data: An update

4. Discourse particle $\check{c} a$

5. Conclusions and outlook

B(i)- / fi comme marqueur de l'objet dans les dialectes arabes. Premières considérations Jérôme Lentin
1. Présentation
2. Le problème $b i-/ f i$
3. Dialectes orientaux
4. Dialectes occidentaux
5. Autres marqueurs
6. Conclusions

\section{Syllabification in Moroccan Arabic}

Nabila Louriz

Introduction

1. Background

2. The study

2. Discussion

Conclusion

An Omani Evolving Lexicon: From Carl Reinhardt (1894) to the Present Day

Ph.d. Roberta Morano

1. Carl Reinhardt and his work

2. Classification of Omani Arabic

3. Location, methodology and participants

4. Omani lexicon

5. Remarks

6. Conclusion

The Diminutive in the Arabic Dialect of Tunis

Stephan Procházka

Introduction

1. Forms and patterns

2. Functions of the diminutive

Conclusion

Les pseudo-verbes dans le dialecte de Benghazi : valeurs possessives et non possessives Aisha Saad

Introduction

1. Valeurs possessives

2. Valeurs non possessives

Conclusion

On Pragmatics of Circumstantial Clauses in Egyptian Proverbs

Tatyana Savvateeva

1. Problem Formulation as an Introduction

2. Circumstantial Clause in a Proverb: Terminology

3. Circumstantial Clause in a Proverb: Pragmatics 
The Dialect of Sfax (Tunisia)

Zeineb Sellami

1. Introduction

2. Phonology

3. Morphology

4. Morphosyntax

5. Lexical items

6. Comparison with Narbeshuber's data

7. Outlook: Pre-Hilali revisited?

Éléments lexicaux hébreux ou pseudo-hébreux dans le parler judéo-arabe de Fès des années 40. Emplois contextuels, dérivations sémantiques, adaptations phonologiques Jonas Sibony

1. Emprunts lexicaux simples

2. Emprunts identifiés comme hébreux, comportant évolutions phonétiques et morphologiques

3. Mots fonctionnels

4. Evolutions sémantiques pour mots identifiés comme hébreux

5. Créations de verbes

6. Hypercorrection

Conclusion

Étude des particules apparentées aux vocatifs/exclamatifs yāet iyyā $(k)$

Catherine Taine-Cheikh

1. Introduction : le vocatif

2. De la particule vocative à la conjonction de but

3. Interrogatifs et interrogations

4. Insistance, topicalisation et focalisation

5. Conclusion

Vowel Harmony in Old and Central Asian Arabic Dialects

Zviadi Tskhvediani

Introduction

Vowel harmony in $\mathrm{C}_{1} \mathrm{aC}_{2} \mathrm{iC}_{3}$ and $\mathrm{C}_{1} \mathrm{aC}_{2} \mathrm{iC}$ type word-forms

Vowel harmony in $\mathrm{C}_{1} \mathrm{VC}_{2} \mathrm{C}_{3}$ and $\mathrm{C}_{1} \mathrm{VC}_{2} \mathrm{C}_{3}$-at type word-forms

Vowel harmony in verbal domain

Conclusion

Origin of the Plural Adjectives of the Fu'äl Pattern in the Modern Arabic Dialects Marijn van Putten

Introduction

Conditioning of $i$ and $u$ in Eastern Libyan Arabic

$F u^{\prime} \bar{a} l$ nouns and adjectives in Cairene Arabic

Labialisation in Skūra Arabic

i-umlaut in Jewish and Christian Baghdadi

A Neo-Arabic innovation?

Conclusion

On Morpho-Syntactic Levantisms in Maltese

David Wilmsen and Amany Al-Sayyed

1. Introduction

2. Data sources

3. Polar interrogative $\breve{s}$

4. Prohibitive $t$... $\check{s}$

5. Dehortative $m \bar{u} \check{s}$

6. Double object marking with 1 -/lil

7. Pronominal circumstantial clauses

8. Are these Levantine traits alone?

9. Discussion 
Issues in Sociolinguistics: Contact and Change, Discourse Analysis, Cultural Practises, Mixed Styles and Written Sources

The Impact of Topic on Hybrid Forms: The Case of Arabic in Morocco Mina Afkir

1. Introduction

2. Method

3. Results and discussion

4. Conclusion

A Lexicological Study of Arabic and Judaeo-Arabic in Iraqi Hebrew Novels Mohamed A. H. Ahmed

1. Introduction

2. The Data

3. Arabic use in the corpus

4. Conclusion

De la mise en mots de la masculinité et de la féminité en arabe marocain Karima Ziamari and Alexandrine Barontini

1. Cadrage

2. Le corpus et les informateurs

3. Ce qui constitue la masculinité (rožōliyya)

4. Ce qui ne constitue pas la rožōiyya: le concept de ${ }^{\text {S }}$ niba

5. Ce qui constitue la féminité, représentations associées aux femmes

6. La masculinité ou la féminité ne sont pas biologiques

7. Synthèse

Une approche sociolinguistique du parler arabe de Ouezzane depuis la perspective du genre Montserrat Benítez Fernández
1. Introduction
2. Informateurs
3. Phonétique
4. Morphologie
5. Conclusions

Le soi jeune dedans et dehors

Laila Ben Salah

1. Introduction

2. Ancrage théorique

3. Socialisation et image de soi dans les parlers jeunes

4. Conclusion

Vers une littératie numérique pour la darija au Maroc, une démarche collective Dominique Caubet

1. Un historique des différents supports et lieux

2. Graphie latine

3. Arrivée de la graphie arabe

4. Analyse des habitudes orthographiques en graphie arabe

5. Le monde du livre : deux expériences de publications récentes en darija

6. Conclusion et perspectives 
Cross-generational Differences in Spatial Language in aṣ-Șāni Arabic Letizia Cerqueglini

1. Linguistic Change and Spatial Representations in aș-Șāni A Arabic

2. Background Research and Study Scope

3. Methodology

4. Data

5. Discussion and Conclusion

Linguistic Analysis of Puns and Common Sayings in Texts of Bilād aš-Šām Emanuela De Blasio

1. Introduction

2. Material and methodology

3. General remarks about the texts

4. Texts

5. Conclusion

Communication écrite sur Internet et par sms en arabizi : analyse de corpus relevant des glosses dialectales libanaise et marocaine

Joseph Dichy, Fatima-Zahra Driss, Hassiba Lagraf and Djamel Mostefa

1. Introduction

2. Le travail sur corpus marocains, syro-libanais et égyptiens

3. Analyse de corpus

4. Conclusion : vers une définition élargie de l'arabizi en interaction dans un contexte de communication multiforme

Better Sound Rural or Criminal? Data from a Case Study: The City Of Temara, Morocco Jacopo Falchetta

1. The field study and the media corpus

2. The media corpus

3. The features chosen for analysis

Conclusion

On the Way to Understand the Pan-Arab Voice Mona Farrag Attwa

1. Introduction: framework

2. Definitions

3. Arabic Cross Country Communication

4. Study and Research Questions

5. Analysis and Results

6. Discussion and conclusion

Standard Arabic and Moroccan Arabic in the Royal Academy of Morocco Latest Publications (2010-2013)

Laura Gago Gómez

1. Introduction: the sociolinguistic situation in Morocco and the role of the Royal Academy

2. Multilingualism: an overview

3. Standard Arabic before and after the 2011 Constitution

4. MA before and after the 2011 Constitution

5. Conclusions

Amin SO9RAT: a Moroccan Rapper from the North-Eastern Region

Jairo Guerrero

Introduction

1. The rap singer Amin So9rat

2. Linguistic study

3. Morphosyntactic features

4. Lexical features

5. Conclusions 
Exploring the Conventionalized Directional Greetings with 'Where?' in the Southeastern Gilit Dialects Area

Qasim Hassan

1. Introduction

2. Data Corpus

3. 'Where?' greetings: Features and uses

4. Responses to 'Where?' greetings

5. Possible Leave-takings for 'Where?' greetings

6. Conclusion

Ways of Expressing Verbal Aggression in Egyptian Arabic Valeriia Lakusta

1. Sexually related invectives

2. Invectives of mental and behavioral characteristics

3. Interjectional Invective

4. Conclusion

Le Journal de la Médina. Un récent projet éditorial en arabe tunisien Angela Daiana Langone and Giuliano Mion

Introduction

1. L'Association Derja

2. Le journal sous analyse

3. Structure du journal

4. Conclusions

The Spoken Omani Arabic of "Ibrī : A "Crossing Point" in Gulf Dialects Letizia Lombezzi

1. Oman: Territory and Geography

2. Oman: Tribes and Ties

3. The Key Concept of "Transitional Dialect"

4. Main General Characteristics of the Omani Arabic

5. The city and the variety of 'Ibri

6. A Text from 'Ibrī : "Fi mahall"

Le discours politique en Tunisie entre fușhā et 'āmmiyya

Cristina La Rosa

Le discours politique en Tunisie

Stratégies de persuasion : emploi et fonctions de l'arabe tunisien

Code-switching : le rôle de la fușhā

Les marqueurs discursifs

Observations conclusives

Le texte inédit de la première constitution mauritanienne écrite en hassāniyya en 1959.

Historique et analyse des traits linguistiques du manuscrit

Ahmed Salem Ould Mohamed Baba

1. Introduction

2. Historique

3. Traits linguistiques du texte

4. Quelques échantillons du texte

5. Conclusions 
Euphémisme et/ou violence verbale féminine. Sur le comportement langagier de jeunes filles cairotes

Sherin Rizk

Introduction

1. «Gender studies » et différences sexolectales

2. Collecte des données $(2014-2015)$

3. Catégories de violence verbale

4. Néologisme : bīp, tīt, no'aț ...euphémismes passe-partout

5. Résultats

6. Construction de l'idéologie linguistique

6.3. Médias : légitimation et homogénéisation

Negotiating Authenticity in Casual Speech: Moroccan Rappers and the /t/Variable Sarah Ruth Schwartz
1. Introduction
2. Background
3. Data and Methodology
4. Results
5. Discussion

Perceptual Dialectology of Egypt. A View from the Berber-Speaking Periphery Valentina Serrel
1. Introduction
2. Perceptual dialectology
3. Presentation of the study
4. Results and discussion
5. Closing remarks

Mixed Varieties in Political Language in Egypt: the Presidential Debate between 'Amr Mūsa and 'Abd al-Min'im Abu l-Futūh.

Nina van Kampen

1. Introduction

2. Methods

3. Results 


\section{EDITOR'S NOTE}

AIDA (fr. Association Internationale de Dialectologie Arabe) - International Association of Arabic Dialectology / الرابطة الدولية لدراسة اللهجات العربية - is an association of researchers in Arabic dialects, from all over the world.

AIDA was founded in 1993, in Paris, at the initiative of a group of prestigious Arabists, with the aim to encourage and promote the study of Arabic dialects.

AIDA is nowadays the leading international association in this field of research and it has become a center that joins scholars from all over the world who are interested in any aspect of Arabic dialectology, including dialects which have not been described yet, dialectal geography, specific aspects of phonology, morphology and syntax, codeswitching, koiné language, pidgin, creole, the lexicon of Arabic dialects, dialectal atlases, comparative and diachronic studies, sociolinguistics, teaching of Arabic dialects, and so on.

AIDA organizes conferences every two years, hosted by well-known universities from all around the world.

AIDA 11 was organized in Bucharest in 2015 . Its web site provides many valuable information about Aida members and Aida publication (http:// aidabucharest2015.lls.unibuc.ro/).

AIDA 12 was organized in Marseilles in 2017 (https://aida12.sciencesconf.org/).

Download the Program of the 12th International Conference of AIDA https:// aida12.sciencesconf.org/data/pages/Programme_1_A3_plie_A_9.pdf

Aida's activities can also be followed on its facebook group at :

https://www.facebook.com/groups/792649064183347/ 


\section{Preface}

1 The development of Arabic dialectology in the last two decades certainly owes much to the Association Internationale de Dialectologie Arabe (AIDA) which was founded in 1993 in Paris under the headship of Dominique Caubet with the collaboration of several leading international scholars. Its main goal was to encourage and promote the study of Arabic dialects by enhancing contact and exchange between linguists working on this field. Since then, Aida has organized regular meetings every two years in different countries with a growing success in terms of number and origin of participants.

2 Studies on Arabic dialects have become a very dynamic field of research and the Proceedings of each conference illustrate the evolution of the research. There is no doubt that AIDA is nowadays the leading international association that joins scholars from all over the world interested in various aspects of Arabic dialectology. The field includes several trends such as dialectal geography and dialectal atlases, comparative and diachronic studies, descriptive linguistics (phonology, morpho-syntax, semantics, lexicon), pragmatics, code-switching, contact, Arabic-based pidgin-creoles, sociolinguistics, studies of variation and change, folk linguistics, attitudes and ideology, dialectal writings, cultural productions and so on. All the proceedings have been digitalized and can be found online at http://independent.academia.edu/ AIDAAssociationInternationaledeDialectologieArabe , thanks to our colleague and AIDA's president George Grigore.

After Paris (France) in 1993, Cambridge (UK) in 1995, Valetta (Malta) in 1998, Marrakech (Morocco) in 2000, Cadiz (Spain) in 2002, Hammamet (Tunisia) in 2004, Vienna (Austria) in 2006, Colchester (UK) in 2008, Pescara (Italy) in 2011, Doha (Qatar) in 2013, Bucharest (Romania) in 2015, Aix-Marseille hosted the $12^{\text {th }}$ Aida International Conference from May $30^{\text {th }}$ to June $2^{\text {nd }} 2017$ in the Campus Saint Charles.

4 The $12^{\text {th }}$ conference was organized jointly by Catherine Miller and Jairo Guerrero from IREMAM (Aix-Marseille University), Marie-Aimée Germanos from CERMOM (INALCOParis), and Alexandrine Barontini and Christophe Pereira from LACNAD (INALCO-Paris), with the financial support of IREMAM, Aix-Marseille University, CERMOM, LACNAD, INALCO, the city of Marseille and AIDA. The conference call met great success with more than 180 abstracts submitted. After evaluation by the members of the organizing and 
scientific committees, 126 papers were selected and about 150 participants from more than 30 countries attended the conference.

5 The presentations were organized in three parallel thematic sessions. One dealt mainly with descriptive linguistics (phonology, morpho-syntax, semantics), the other with presentations of little known dialects and contact phenomena, and the third one with pragmatics, language attitudes, dialect writings and cultural productions. The Conference hosted also a thematic sociolinguistic workshop coordinated by the Essex Arabic Sociolinguistics Research Group headed by Enam Al-Wer, Areej Al-Hawamdeh and Uri Horesh presenting variationist researches undertaken in a number of cities of Jordan, Palestine-Israel, Saudi Arabia.

6 The presence of many young researchers from Europe, USA and several Arab countries testifies the vitality of the field. Over the years, more and more participants from Arab countries have expressed their willingness to attend the AIDA conferences. Their increasing interest toward the (socio)-linguistic description of Arabic vernaculars is a very encouraging sign that reflects the development of the studies of Arabic vernaculars within Arab countries and suggests opportunities for stronger collaborations.

7 The volume of the proceedings contains fifty articles, which are revised and enhanced versions of the papers read on the $12^{\text {th }}$ conference. Following the AIDA tradition, all the papers discuss on-going researches based on original field-work data. The volume includes contributions by senior scholars, as well as young Master and PhD students. Among the growing trends of research within the AIDA network, one notices the development of studies dealing with syntax, processes of grammaticalization and pragmatics, which for long were rather marginal domains within Arabic dialectology. Another trend concerns studies dealings with new genres and new practices of written and oral cultural productions such as rap songs, internet writings, TV shows, and so on. These trends testify, once again, that studies on the practices of Arabic dialects are important venues to understand the current social changes.

8 The organizers of the conference and editors of the volume would like to thank the many people who helped at various stages.

9 Aziza Boucherit, Peter Benhstedt, Kristen Brustad, Dominique Caubet, George Grigore, Angela Langone, Jérôme Lentin, Stefano Manfredi, Gunvor Mejdell, Stephane Procházka, Veronika Ritt-Benmimoun, Catherine Taine-Cheikh, Martine Vanhove, Ángeles Vicente, Manfred Woidich, Liesbeth Zack, Karima Ziamari kindly accepted to help in the evaluation and the selection of the 180 submitted abstracts.

10 Absa D'Agaro- N'diaye from Aix-Marseille University coordinated the financial and logistic aspects of the Conference with the help of Christine Miretti and Christelle Vayssière from IREMAM, and the members of the logistic department of the Campus Saint Charles at Marseille (Mirjana Mrajevic, Eric Chevalier, Christophe Poggi, Jean-Pierre Lopez). Marie-Pierre Oulié from IREMAM created and managed the web site. Btissam Abkari, a young Master student greatly helped in all aspects of the organization.

11 Sabine Partouche, Chief editor at IREMAM, took in charge all the digital editing process. She managed to finish the editing in a few months in spite of her intensive editorial duties within IREMAM.

12 Finally, we would like to thank all the participants, some of whom come from far away, for their enthusiastic involvement in the success of this conference. It was an intense emotional moment to witness the presence and encounter of the AIDA old timers and 
AIDA newcomers! The spirit of academic friendship, scientific opening and mutual respect is an important component of the AIDA branding.

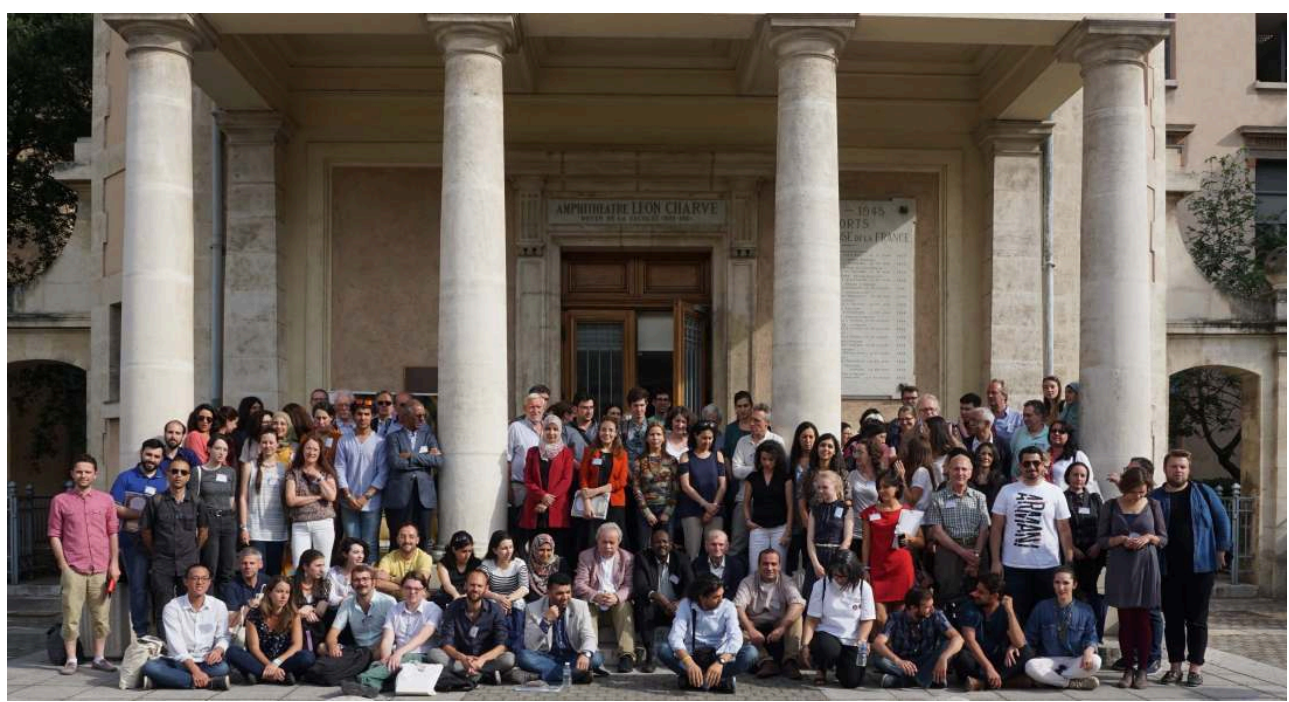

AIDA 2017 MARSEILLES 
Arabic Dialectology - Linguistic Descriptions 


\title{
Africanisms in Turku
}

\author{
Andrei A. Avram
}

\section{Introduction}

1 Turku is an extinct Arabic-lexifier pidgin, formerly spoken in Chad. It was documented in Muraz (1926), which includes a short grammatical sketch (Muraz 1926: 11-17), a vocabulary of approximately 1,300 entries (Muraz 1926: 113-187), and six dialogues amounting to 175 sentences, 1,160 words (Muraz 1926: 265-294).

2 The phonology, morphology and syntax of Turku are analyzed in detail by Tosco \& Owens (1993). The vocabulary is discussed in two short sections (Owens \& Tosco 1993: 231 and 235); in addition, appendix I "Non-Arabic words in Turku" (Tosco \& Owens 1993: 261-264) lists the non-Arabic words in Turku, with etyma suggested only for borrowings from European languages.

3 This paper is the first investigation of the African component of the vocabulary of Turku, which consists of lexical items, including ideophones, as well as semantic calques.

\section{Lexical items}

4 Two classes of African-derived lexical items have been identified: those which appear to be recorded in Turku exclusively, and those which also occur in varieties of Western Sudanic Arabic (WSA) such as Chadian Arabic (CA) and Nigerian Arabic (NA). In several cases the donor language cannot be determined.

5 Consider first lexical items attested only in Turku.

6 BELING ' 'CHAUVE' (Muraz 1926: 123): < Bagirmi mbilàn 'calvitie, chauve' (Keegan \& Djibrine 2016: 104).

7 BONG 'ÉTRIER' (Muraz 1926: 124): < Bagirmi mbòy 'étrier' (Keegan \& Djibrine 2016: 105).

8 BOUROUMBA2 'CHAPEAU' (Muraz 1926: 125): < Kanuri gurumbá 'hat (usu. made of straw)' (Cyffer 1994: 86); Hausa gurumba 'a large straw-hat' (Robinson 1914: 110). 
GAO 'CHASSEUR' (Muraz 1926: 139): < Sar gáw 'chasseur (de grands animaux)' (Constant \& Keegan 2016: 26).

missil' Yомво 'GLUANT' (Muraz 1926: 158): < Sar gòmbo 'esp. de plante qu'on utilise dans la sauce gluante' (Constant \& Keegan 2016: 49).

HADINNBANG 'EUNUQUE' (Muraz 1926: 143): < Bagirmi ádim mbày 'serviteur du sultan ou d'un chef' (Keegan \& Djibrine 2016: 2).

KAYE 'PAGAIE' (Muraz 1926: 151): < Kaba káì (Fedry 1980: 126); Sango kay 'pagaie' (Gérard 1930: 69), kái 'a paddle for a canoe' (Taber 1965: 76), kai 'pagaie' (Bouquiaux \& al. 1984: 140), kâ̂i 'pagaie' and 'rame' respectively (Ngalasso-Mwatha 2013: 686 and 805 respectively); Sara Madjinngaye and Sara M'Baye kaye 'pagaie' (Muraz 1926: 151). The word is ultimately of Bangala/Lingala origin: nkai (de Boeck 1904: 122), kai / nkai 'paddle' (Stapleton 1914: 89), nkáí 'pagaie' and 'rame' (Ngalasso-Mwatha 2013: 686 and 805 respectively).

KELKELBANDJI 'PERLES DORÉES' (Muraz 1926: 151): < Fulfulde kelkel-banja 'a very brittle, cheap 'golden' bead' (Mukoshi 2014: 302).

KOPORO 'PIÈCE DE 0 FR. 10' (Muraz 1926: 152): < Fulfulde koporo 'sou' (Bah 2014: 135); Sango koporo 'pièce(s) de monnaie' (Bouquiaux \& al. 1984: 638); Sara Madjinngaye and Sara M’Baye koporo (Muraz 1926: 152).

M'BARR ‘CUL' (Muraz 1926: 158): < Sar mbù Rุ ${ }^{5 ‘}$ fesse' (Constant \& Keegan 2016: 158).

M'BIKI ‘MUET' (Muraz 1926: 158): < Sara-Bagirmi languages: Bagirmi mbiki ‘sourd' (Keegan \& Djibrine 2016: 104), Mango mbiki, Nar mbiki, both 'sourd muet' (Keegan 2014a: 67), Sar mbiki 'sourd' (Constant \& Keegan 2016: 76). On phonetic grounds, Sara-Bagirmi languages are a much more likely source than the Arabic etymon abkam 'dumb' suggested by Tosco \& Owens (1993: 264).

NGARI 'MANIOC' (Muraz 1926: 162): < Mbay ngàrì (Keegan 2014b: 46). This is a variant of ngali 'manioc' (see below).

OUÉLIK 'ÉCLAIR' (Muraz 1926: 165): < Kanuri wulak 'flash of light (e.g. of lightning)' (Cyffer 1994: 107).

POTO-POTO ‘SOL MARÉCAGEUX, ARGILE, BOUE' (Muraz 1926: 168): < Hausa potopoto 'mud, slush' (Robinson 1913: 281), Sango potopoto 'boue' (Gérard 1930: 106), pJtJpòto 'anything of a soft mushy consistency: mud, soft clay' (Taber 1965: 158), potopoto 'boue, vase' (Bouquiaux \& al. 1984: 290), potopôto 'boue' (Ngalasso-Mwatha 2013: 131). According to Tosco \& Owens (1993: 255), "its most likely path into Turku would have been from a coastal language via the Ubangui/Zaire river basins". On this view, Bangala poto poto 'mud' (Stapleton 1914: 87) or Lingala potopòto ‘boue' (Ngalasso-Mwatha 2013: 131) was first borrowed by Sango and then reached Turku.

TIPOYE ‘SORTE DE HAMAC PORTÉ PAR DEUX ÉQUIPAGES DE 4 HOMMES, SE RELAYANT’ (Muraz 1926: 270, fn. 1): < Sango tipói 'a sort of carrying hammock [...] in which important people used to be carried on the shoulders of four men' (Taber 1965: 183). The word is ultimately of Bangala/Lingala origin: tipoye (de Boeck 1904: 104), tipoi 'hammock' (Stapleton 1914: 160), tipói 'hamac' (Ngalasso-Mwatha 2013: 494).

21 The following are African-derived lexical items which Turku shares with varieties of WSA. Most of these occur in CA, but some are also found in NA. 
ANZAYE 'CAPITAINE (POISSON)' (Muraz 1926: 118): < Sango nzai '(poisson) "capitaine "' (Bouquiaux \& al. 1984: 266), nzaï 'poisson d'eau douce [...] à la chair très appréciée' (Ngalasso-Mwatha 2013: 170). CA amzâye 'nom d'un poisson' (Jullien de Pommerol 1999: 147) must have been borrowed from Sango and subsequently modeled on the many names of animal, insect and plant species with am-. BADJIO 'COUVERTURE' (Muraz 1926: 121): < Sar bájò 'couverture' (Constant \& Keegan 2016: 4). The word is found in CA: bâjo 'couverture' (Jullien de Pommerol 1999: 235). BANGAO 'PATATE' (Muraz 1926: 122): < Sara-Bagirmi languages: Bebote bāngàw, Bediondo bāngàw, Daba bāngàw, Gor bāngàw, Gulay bāngàw, Kaba bāngàw, Kaba Na bāngàw, Laka bāngàw, Mbay bāngàw, Ngam bángàw, Ngambay bāngàw, Sar bāngàw, all 'patate douce' (Keegan 2014b: 54). The word occurs in CA: bangâw 'patate douce' (Jullien de Pommerol 1999: 244).

BOUBOU 'SINGE' (Muraz 1926: 124): < Sango bubu 'petit singe, singe apprivoisé' (Bouquiaux \& al. 1984: 78). The word is found in CA: bûbu 'singe rouge' (Jullien de Pommerol 1999: 280), buubu 'singe' (Heath 2013: 29).

IONGOUR, NIOUGOUR 'CHIFFON' (Muraz 1926: 148): < Zaghawa (Beria) ñûngûr 'Chiffon, du papier que l'on utilise pour cirer les chaussures ou enlever la poussière de quelque chose' (Faris 2007: 41). Similar forms are recorded in CA: niongo 'chiffon, haillon' (Deredinger 1923: 158), nyangûr 'empr (Ouaddaï, Mimi) chiffon' (Jullien de de Pommerol 1999: 1018).

27 KALKaL 'SEMBlable' (Muraz 1926: 150): < Kanuri kálkál 'correct' (Cyffer 1990: 39). An identical form is attested in NA: kalkal 'exactly' (Lethem 1920: 426).

28 KIRDI 'IDOLÂTRE' (Muraz 1926: 149): < Kanuri kórdi 'pagan' (Cyffer 1994: 130). An identical

form occurs in CA: kirdi 'païen, sauvage' (Deredinger 1923: 146), kirdi 'païen (-nne), animiste' (Jullien de Pommerol 1999: 149). A similar form is recorded in NA: kardi 'pagan' (Lethem 1920: 378). Note that Jullien de Pommerol (1999: 149) specifies that CA kirdi is an "empr (usité au Bornou)", but does not indicate the source language. Seignobos \& Tourneux (2002: 154) write that "nous pensons plutôt que « kirdi » vient de l'arabe [qird], qui signifie « singe »". However, this would presuppose a drastic semantic change.

LAALÉ 'BONJOUR' (Muraz 1926: 154): < Kanuri lalê 'greeting' (Cyffer 1994: 83). The greeting is also used in CA, lälé 'bonjour' (Deredinger 1923: 151), lâlê 'expression, formule de salutation' (Jullien de Pommerol 1999: 762), and NA, lâlê (Lethem 1920: 267).

NGALI 'MANIOC' (Muraz 1926: 162): < Sara-Bagirmi languages: Bebote ngàlì, Bediondo ngàlì, Gor ngàlì, Gu ngàlì, Kaba ngàlì, Mango ngàlì, Ngambay ngàlì, Sar ngàlì (Keegan 2014b: 46). A similar form is recorded in CA: angâli 'empr (sud du Tchad) manioc' (Jullien de Pommerol 1999: 162).

31 N'GoUl 'IGNAME' (Muraz 1926: 162): > Sara-Bagirmi languages: Bagirmi ngúlù 'manioc' (Keegan \& Djibrine 2016: 117), Bebote ngúl, Daba ngúl, Gor ngúl, Gulay ngúl, Mbay ngúl, Mango ngúl, Nar ngúl, Ngam ngúl, Ngambay ngúl, Sar ngúl (Keegan 2014b: 42), all 'manioc'. Similar forms are recorded in CA: angulu / ngulu 'manioc' (Deredinger 1923: 77). NYARKOU 'ENFANT, BÉBÉ, NOURISSON' (Muraz 1926: 162): < Dinka nyer-kug/nyárkuk 'child' (Behnstedt \& Woidich 2011: 37, Avram 2017) or Bari nyerkuk/nyereku / nyerku 'child' (Avram 2017), neither of which is spoken in Chad. Tosco \& Owens (1993: 249) list nyarkou among the vocabulary items linking Turku, Juba Arabic and $\mathrm{Nubi}^{6}$ and serving as evidence for what the authors call "Common Sudanic pidgin/creole Arabic". However, similar forms are also recorded in CA - nyirku 'small child' (Lethem 1920: 279), nierku/nirgu 'bébé' 
(Deredinger 1923: 158) - as well as Sudanese Arabic (SA) - nyirikuk 'Kind' (Behnstedt \& Woidich 2011: 34). This fact points to a possible alternative route: the lexical item at issue might be a mot voyageur, first borrowed from Bari and/or Dinka by SA, then transmitted to $\mathrm{CA}$, and finally entering Turku. SILÉ 'PIÈCE DE 1 FRANC' (Muraz 1926: 175): < Sara-Bagirmi languages: Sara Madjinngaye silé, Sara M'baye silé (Muraz 1925: 175), Bagirmi silēe 'pièce en argent' (Keegan \& Djidrine 2016: 138); Zaghawa sîle 'pièces de monnaie' (Faris 2007: 46). The word occurs in CA: silé 'pièce de 1 franc' (Deredinger 1923: 167), sile 'pièce de monnaie, sou' (Jullien de Pommerol 1999: 1133). Jullien de Pommerol (1999: 1133) writes that CA silé is "empr haoussa". However, the Hausa form is with [u]: sule 'shilling' (Newman 2007: 189). While Hausa may be the ultimate source, the Turku and CA forms suggest that other African languages - most likely Sara - served as intermediaries. TOMBO 'PERCHE DE PIROGUE' (Muraz 1926: 182): < Sango tombo 'perche' (Gérard 1930: 109), tômbô 'perche employée pour faire avancer la pirogue' (Bouquiaux \& al. 1984: 343). The word occurs in CA: tombo 'perche' (McKone 2013: 48). Finally, four ideophones have been identified. MALANN TAP 'TOUT À FAIT PLEIN' (Muraz 1926: 157): < Hausa cika taf 7 'filled completely, filled to the brim' (Newman 2007: 193).

ABIETT KARR 'TRÈS BLANC' (Muraz 1926: 16): etymology unknown. The ideophone is also attested in WSA: CA abiod karr 'très blanc' (Deredinger 1912: 358), abyad karr 'blanc immaculé' Jullien de Pommerol (1999: 707); NA abiad kar 'very white' (Lethem 1920: 174), ábyad kár 'very white' (Owens 1993: 215).

AZREG KROUM 'TRÈS BLEU' (Muraz 1926: 16): Fulfulde baleejum kurum 'very black' (Mukoshi 2014: 320). It also occurs in WSA: CA asraq krrum 'très noir' (Deredinger 1912: 358), azrag kurum 'très noir, noir cirage' (Jullien de Pommerol 1999: 746); NA ázrag kúrum 'very black' (Owens 1993:203).

HAMEUR TIOU 'TRÈS ROUGE' (Muraz 1926: 16): etymology unknown. It is also attested in WSA: CA ahmar tiū 'très rouge' (Deredinger 1912: 358), ahmar tcu 'rouge vif, écarlate' (Jullien de Pommerol 1999: 1206); NA: áhamar čú 'very red' (Owens 1993: 203).

\section{Calques}

In addition to lexical items, a number of expressions (set phrases) and compounds appear to be modeled on various African languages. Some of these may be traced to models offered by several source languages.

41 The following (potential) calques are found, on currently available evidence, only in Turku.

42 BAGAR MARA 'VACHE' (Muraz 1926: 121), lit. 'bovine woman': cf. Sango wali ti bagra 'vache' (Gérard 1930: 87), wale (tí) bágara 'cow' (Taber 1965: 244), wâli-bâgara 'vache' (NgalassoMwatha 2013: 976), lit. 'woman (of) cow, woman cow'; Sara mang diha 'vache' (Muraz 1926: 121), lit. 'bovine woman'. BAHR GOUM 'CRUE' (Muraz 1926: 122), lit. 'river rises': cf. Ngambaye màn-kàw 'crue (du fleuve)' (Chata \& al. 2015: 78), lit. 'river goes'. 
BETT OURAR 'WATER-CLOSET' (Muraz 1926: 123), lit. 'house excrements': cf. Sango da (ti) puru (Bouquiaux \& al. 1984: 84), dapurû 'toilettes, WC' (Ngalasso-Mwatha 2013: 33), lit. 'house (of) excrements'; Sara Madjinngaye koudiou yédé Muraz (1926: 123), lit. 'house of excrements'.

45 NOUGRA ANA HASSAL 'RUCHE' (Muraz 1926: 163), lit. 'hole of honey': cf. Ngambaye bòlè tánji

'trou à miel' (Chata \& al. 2015: 135), lit. 'hole honey'.

NOUGRA HADJER 'GROTTE' (Muraz 1926: 162), lit. 'hole mountain/stone': cf. Kanuri kûl kaube 'cave' (Cyffer 1994: 28), lit. 'cavity mountain-of'; Ngambaye: bذ̀l̀̀-mbàl 'grotte' (Chata \& al. 2015: 84), lit. 'hole mountain'; Sango dûtênë 'grotte' (NgalassoMwatha 2013: 487), lit. 'hole stone'.

OULED BAGAR 'VEAU' (Muraz 1926: 165), lit. 'child cow': cf. Sango mérengé tí bágara 'calf' (Taber 1965: 235), môlenge tî bâgara 'veau' (Ngalasso-Mwatha 2013: 981); Sara Madjingaye / Sara M’Baye gonn mang (Muraz 1926: 165), lit. 'child bovine'.

Listed below are calques found not only in Turku, but also in varieties of WSA.

BETT TER 'NID' (Muraz 1926: 123), lit. 'house bird': cf. Fulfulde suudu foondu 'nest' (Bautista \& al. 1991: 30), lit. 'house bird'; Kanuri njîm ngudobe 'nest' (Cyffer 1994: 124), lit. 'room birdof'; Sango da ti hu/da ti ndeke 'nid' (Gérard 1930: 66), da tî ndeke 'nid' (Ngalasso-Mwatha 2013: 654), lit. 'house of bird'; Sar kúj̄̄ yèl' 'nid' (Constant \& Keegan 2016: 152), lit. 'house bird'. There is a similar form in CA: bēt et êr 'nid' (Deredinger 1923: 83).

BOURMA TOUMBAK 'PIPE' (Muraz 1926: 125), lit. 'pot tobacco': cf. Kanuri kólo tawâbe 'pipe' (Cyffer 1994: 193); lit. 'pot tobacco-of'; Laga: bày-sà 'pipe' (Keegan 2014b: 124), lit. 'pot tobacco'; Ngambay bày-sà 'pipe' (Chata \& al. 2015: 7), lit. 'pot tobacco'. A similar form is recorded in NA: burma dukhân9 'pipe' (Lethem 1920: 260).

CACHIM BETT 'PORTE' (Muraz 1926: 126), lit. 'mouth house': cf. Sango nio da/yanga da/yanga ti da 'porte' (Gérard 1930: 75), lit. 'mouth house/mouth of house', yángá tí da 'door' (Taber 1965: 250), yanga-da 'porte' (Bouquiaux \& al. 1984: 80), lit yângâda 'porte' (NgalassoMwatha 2013: 755), lit. 'mouth of house/mouth house'; Sara languages - Bebote tà-káy, Daba tà-kúj, Gor tà-káy, Gulay tà-káy, Kaba tà-káy, Mango tà-káy, Nar tò-kújz̄, Ngam tàkújź, Ngambay tà-kóy, Sar tà-kújī (Keegan 2016: 57-58), all lit. 'mouth house'; Zaghawa bîye a 'littéralement la porte (ou la bouche) de la maison)' (Faris 2007: 13). Similar forms are attested in WSA: CA khachim bit 'porte' (Decorse \& GaudefroyDemombynes 1905: 51), qacham el-bèt 'porte' (Deredinger 1923: 91), xacum bêt 'porte' (Jullien de Pommerol 1999: 1275); NA khasham beit 'door' (Lethem 1920: 59).

FAROUA HENN 'PAUPIÈRE' (Muraz 1926: 135), lit. 'skin eye': cf. Fulfulde laral gite 'eyelid' (Mukoshi 2014: 333), lit. 'skin eyes'; Ngambaye form ndār-kùm 'paupière' (Constant \& Keegan 2016: 133), lit. 'skin eye'. Similar forms are found in CA: farwa 'aïn 'paupières' (Decorse \& Gaudefroy-Demombynes 1905: 51), djild el-héin 'paupière' (Deredinger 1923: 88), farwit al ên 'paupière' (Jullien de Pommerol 1999: 442).

HIDE GOHOUI 'AVARE' (Muraz 1926: 145), lit. 'hand hard': cf. Kanuri músko cíbbua 'stingy' (Cyffer 1994: 178), lit. 'hand strong'; Sar ji-ngàng 'être avare' (Constant \& Keegan 2016: 62), lit. 'hand hard'; Zaghawa ba kônûy 'avare' (Faris 2007: 33), lit. 'arm strong'. The same expression is attested in CA: idi göwi 'avare' (Deredinger 1923: 134).

KoUtoUlou NAR 'ÉTEINDRE LE FEU' (Muraz 1926: 153), lit. 'kill fire': cf. Bidiya daa-ta wa-?ako 'extinguish the fire' (Owens 1996: 314), lit. 'kill fire'; Hausa káshée wútáa 'extinguish the fire' (Owens 1996: 314), 'kill fire'. Similar forms are recorded in WSA: CA qtel nar 'éteindre 
le feu' (Decorse \& Gaudefroy-Demombynes 1905: 45), qatala nar 'éteindre' (Deredinger 1923: 57), katilîn al-nar '[fait d'] éteindre le feu' (Jullien de Pommerol 1999: 162); NA aktul an-naar 'extinguish the fire' (Owens 1996: 314).

oussoUTT FILLLELL 'MINUIT' (Muraz 1926: 167), lit. 'middle night': cf. Fulfulde caka jemma 'midnight' (Mukoshi 2014: 80), lit. middle night'; Hausa tsăkan dăre 'midnight' (Robinson 1914: 149), lit. 'middle night'; Sar, dàn ndj̀ว̄ 'milieu de la nuit' (Constant \& Keegan 2016: 25). There is a similar form in CA: usut el lell 'minuit' (Deredinger 1923: 79).

RASS BETT 'TOÎT’ (Muraz 1926: 169), lit. 'head house': cf. Bidiya káay beena 'roof' (Owens 1996: 291), lit. 'head-his house'; Hausa kâ-n gidá 'roof' (Owens 1996: 291), lit. 'head-of house'; Kanuri kəlá fáto-be 'roof' (Owens 1996: 291), lit. 'head house-of'; Sango li tí da 'roof' (Taber 1965: 108), lì tí dà 'toit' (Bouquiaux \& al. 1984: 199), lida 'toit' (Ngalasso-Mwatha 2013: 945), lit. 'head of house/head house'; Sara languages: Ngambaye d’̀-kə́y 'toit' (Chata \& al. 2015: 96), Sar dò-kúji 'toit' (Constant \& Keegan 2016: 160), both lit. 'head house'. Similar forms occur in WSA: CA ras el bèt 'toit' (Deredinger 1923: 163), râs al bêt/râs bêt 'toit' (Jullien de Pommerol 1999: 1049); NA raas al-beet 'roof' (Owens 1996: 291).

57 RASS GOHOUI 'ENTÊTÉ' (Muraz 1926: 169), lit. 'hard head': cf. Fulfulde sattugol hoore (Bah 2014: 196), lit. 'be strong head'; Hausa táurín kâi 'stubborn' (Owens 1996: 312), lit. 'hardness-of head'; Kanuri kalâ cíbbua 'stubborn' (Cyffer 1994: 181), lit. 'head strong-having'; Sango (tî) ngangü-li (Ngalasso-Mwatha 2013: 393), lit. '(of) hard head'; Sara languages - Ngambaye dj̀ng̀àng 'entêtement, obstination' (Chata \& al. 2015: 26), Sar dò-ngàng 'entêtement, caractère récalcitrant' (Constant \& Keegan 2016: 32), both lit 'hard head'. Similar forms are attested in WSA: CA ras göwi 'entété' (Deredinger 1923: 134); NA raasa gawi 'stubborn' (Owens 2014: 150), lit. 'his head is hard'.

\section{Conclusions}

Turku, initially a military pidgin, emerged in the latter half of the $19^{\text {th }}$ century and was still in use in the early decades of the $20^{\text {th }}$ century, as one of the trade languages in French Equatorial Africa (Tosco \& Owens 1993: 181-183). At the time, Arabic had not made as yet significant inroads into Southern Chad. Chabrelie (1935: 130), for instance, writes that "l'Arabe du Tchad [a] pénétré très peu en pays Sara", while "au Sud c'est le Sango qui domine", which "s'infiltre de plus en plus dans les villages des pays Sara". In Chad, Turku was one of the langues véhiculaires used, together with Bagirmi, Fulfulde, Sara, and Sango (Jullien de Pommerol 1997: 54-55). Adding to the complexity of the language situation in Chad are two other important languages, Hausa and Kanuri.

The lexical data examined in this paper accord well with the sociolinguistic context in which Turku emerged and was used. The findings illustrate the important lexical influence on Turku of Sara-Bagirmi languages as well as of Sango. The latter also served as an intermediary for words of ultimately Bangala and/or Lingala origin. As shown, the lexical contribution of Fulfulde, Hausa and Kanuri is less significant.

60 Turku shares with WSA a number of African-derived lexical items; (some of) these may have reached Turku indirectly, via varieties of WSA.

61 As noted by Owens (1993: 298), the only varieties of Arabic which have a lexical class of ideophones are those spoken in the Sudanic area. The occurrence of ideophones is thus another commonality of Turku and WSA. 
The semantic calques recorded in Turku provide further evidence for an "idiomatic structure", which is the result of areal convergence, cutting across genetic affiliations (see also Owens 1996, 2014). However, forms structurally similar or identical to some of these calques are widely recorded in pidgins/creoles, with various lexifier languages (Avram 2003: 37-35, Parkvall \& Baker 2012). Therefore, it may be the case that for some speakers "struggling to communicate" such forms were actually "lexical innovations" (Parkvall \& Baker 2012: 231-232), rather than calques.

\section{BIBLIOGRAPHY}

Avram, Andrei A. 2003. "Arabic Pidgins and Creoles from a Comparative Perspective”, RomanoArabica III. 25-40.

Avram, Andrei A. 2017. Evidence of variation in early records of Nubi. Paper presented at Eleventh Creolistics Workshop "Assessing Old Assumptions. New Insights on the Dynamics of Languages”, 22-24 March 2017, “Justus-Liebig” Universität, Giessen.

Bah, Oumar. 2014. Dictionnaire pular - français. http://pular.webonary.org.

Bautista, Andreliz, Boukary, Hamadou, \& Goubb, Moussa. 1991. Dictionnaire de fulfulde. Niamey: Peace Corps.

Behnstedt, Peter, \& Woidich, Manfred. 2011. Wortatlas der arabischen Dialekte, vol. I, Mensch, Natur, Fauna und Flora. Leiden • Boston: Brill.

de Boeck, Egide. 1904. Grammaire et vocabulaire du lingala ou langue du Haut Congo. Bruxelles: Polleunis \& Ceuterick.

Bouquiaux, Luc, Kobozo, Jean-Marie, \& Diki-Kidiri, Marcel. 1984. Dictionnaire sango-français. Bàkàrí sāng̀̀-fàránzí. Lexique français-sango. Kćté fàránzí-sāngò. Paris: Société d'Études Linguistiques et Anthropologiques de France SELAF.

Chabrelie, L. 1935. "Notes sur la langue des Sara, avec un vocabulaire comparatif des différents dialectes", Journal de la Société des Africanistes 5 (2). 125-151.

Chata, Nangone Jacob, Djimadoum, Simeon Mbayrem, \& Keegan, John. M. 2015. Petit dictionnaire de la langue Ngambaye. Cuenca: Morkeg Books.

Constant, Gotengaye, \& Keegan, John. M. 2016. Dictionnaire Sar. Cuenca: Morkeg Books.

Cyffer, Norbert. 1994. English - Kanuri Dictionary Cologne: Rüdiger Köppe.

Decorse, Gaston Jules, \& Gaudefroy-Demombynes, Maurice. 1905. Rabah et les arabes du Chari. Documents arabes et vocabulaire. Paris: Librairie Orientale \& Américaine.

Deredinger, Robert. 1912. Notes sur le dialecte arabe du Tchad. Revue Africaine 56. 341-358.

Deredinger, Robert. 1923. Vocabulaire pratique du dialecte arabe centre-africain. Paris: André Tournon.

Faris, David. 2007. Dictionnaire beria - français français - beria. Iriba: ADESK. 
Fedry, Jacques. 1980. Un précieux instrument de référence: le dictionnaire sango. Journal des africanistes 50 (1): 120-127.

Gérard, Marcel. 1930. Sango. Langue commerciale de l'Oubangui-Chari. Rome: Sodalité de S. Pierre Claver.

Heath, Judith. 2013. Lexique arabe tchadien - français. N'Djamena: Association SIL.

Jullien de Pommerol, Patrice. 1997. L'arabe tchadien. Émergence d'une langue véhiculaire. Parus: Karthala.

Jullien de Pommerol, Patrice. 1999. Dictionnaire arabe tchadien français suivi d'un index françaisarabe et d'un index des racines arabes. Paris: Karthala.

Keegan, John. M. 2014a. The Western Sara Languages. Cuenca: Morkeg Books.

Keegan, John. M. 2014b. Sara Languages Lexicon. Français - Langues Sara. English - Sara Languages. Cuenca: Morkeg Books.

Keegan, John. M., \& Djibrine, Mahamat Idriss. 2016. Bagirmi Lexicon. Bagirmi-French, French-Bagirmi, with Grammatical Introduction in English, second edition. Cuenca: Morkeg Books

Lethem, Gordon J. 1920. Colloquial Arabic. Shuwa Dialect of Bornu, Nigeria and of the Region of Lake Chad. London: Crown Agent for the Colonies.

McKone, Louise. 2013. Dictionnaire visual français - arabe tchadien, $4^{\text {th }}$ edition. N’Djaména: Association SIL.

Mukoshi, Ibrahim. A. 2014. A Fulfulde-English Dictionary. Ibadan: Hern.

Muraz, Gaston. 1926. Vocabulaire du patois arabe tchadien ou "Tourkou" et des dialectes saramadjinngaye et sara-m'baye (S.-O. du Tchad). Paris: Charles Lavauzelle.

Newman, Paul. 2007. A Hausa-English Dictionary. New Haven: Yale University Press.

Ngalasso-Mwatha, Musanji. (ed.). 2013. Dictionnaire Français - Lingala - Sango. Bagó lifalansé lingála - sángó. Bakarî farânzi - lingäla - sängö. http://www.francophonie.org/ dico_pdf.

Owens, Jonathan. 1993. A Grammar of Nigerian Arabic. Wiesbaden: Harrassowitz Verlag.

Owens, Jonathan. 1996. "Idiomatic Structure and the Theory of Genetic Relationship", Diachronica XIII. 283-318.

Owens, Jonathan. 2014. "Many Heads are Better than One: The Spread of Motivated Opacity via Contact", Lingustics 52. 125-165.

Parkvall, Mikael, \& Baker, Philip. 2012. "Idiomatic (potential) calques and semantic borrowing", Bartens, Angela, \& Baker, Philip (eds.), Black against White. African Words and Calques which Survived Slavery in Creoles and Transplanted European Languages. London: Battlebridge Publications. 231-248.

Robinson, Charles. H. 1914. Dictionary of the Hausa Language, vol. II, English-Hausa, $3^{\text {rd }}$ edition.

Cambridge: Cambridge University Press.

Seignobos, Christian, \& Tourneux, Henri. 2002. Le Nord-Cameroun à travers ses mots. Dictionnaire de termes anciens et modernes. Paris: Karthala.

Stapleton, Walter. H. 1914. Suggestions for a Grammar of "Bangala" the "Lingua Franca" of the Upper Congo with Dictionary, $2^{\text {nd }}$ edition, revised and enlarged by Frank Longland. Bolobo: Congo Belge.

Taber, Charles. R. 1965. A Dictionary of Sango. Hartford: Hartford Seminary Foundation. 
Tosco, Mauro, \& Owens, Jonathan. 1993. “Turku: A Descriptive Comparative Study”, Sprache und Geschichte in Afrika 14. 177-267.

\section{NOTES}

1. The $<$ ng $>$ is a transcription error and should read $<\mathrm{gn}>$

2. The $<b>$ is a misprint and should read $<\mathrm{g}>$.

3. The $<y>$ is a misprint, and should read <g>; cf. GLUANT 'missil-gombo' (Muraz 1926: 55).

4. The $<n n>$ is a misprint and should read $<$ mm>; cf. EUNUQUE 'haddimmbang' (Muraz 1926: 49)

5. The $<\mathrm{a}>$ is a transcription error, and should read $<\mathrm{u}>$.

6. Cf. Juba Arabic: nyerekú / nyerekúk (Tosco \& Owens 1993: 249), nyirikuk (Behnstedt \& Woidich 2011: 37); early Nubi: nyaruku / nerakūk (Avram 2017), modern Nubi: nyeréku (Behnstedt \& Woidich 2011: 37).

7. In some Hausa dialects /f/ is realized as [p] (Newman 2007: $\mathrm{x}$ ).

8. The $<\mathrm{h}>$ is a misprint and should read $<\mathrm{y}>$, cf. diyá 'femme'.

9. In NA duHān also means 'tobacco' (Lethem 1920: 460)

\section{ABSTRACTS}

Turku is an extinct Arabic-lexifier pidgin, formerly spoken in Chad. The only available description is found in Muraz (1926) and it consists of a brief grammatical sketch, a vocabulary, and six dialogues. Tosco \& Owens (1993) have analyzed in great detail the phonology and morphosyntax of Turku; their study also includes two short sections on the vocabulary and an appendix containing the non-Arabic words in Turku, in which etyma are suggested only for borrowings from European languages. The present paper is the first investigation of the African component of the vocabulary of Turku, which consists of lexical items, including ideophones, as well as semantic calques. For each of these categories, wherever possible, their source languages are identified. It is shown that the source languages include mostly Sara-Bagirmi languages and Sango, but also Fulfulde, Hausa or Kanuri. A distinction is made between lexical items taken directly from various African languages and those which may have entered Turku via Western Sudanic Arabic, given their occurrence in Chadian varieties (Decorse \& Gaudefroy-Demombynes 1905, Deredinger 1912, Lethem 1920, Jullien de Pommerol 1999, Behnstedt \& Woidich 2011, Heath 2013, McKone 2013). The analysis of semantic calques makes reference to potential areal features, beyond genetic affiliations. The findings are briefly discussed in relation to the external history of Turku, with a focus on the sociohistorical context of its formation and use.

\section{INDEX}

Keywords: Turku, Africanisms, lexical items, ideophones, semantic calques 


\section{AUTHOR}

\section{ANDREI A. AVRAM}

University of Bucharest, Department of English, 7-13 Pitar Moş Str., 010451 Bucharest, Romania; andrei.avram@lls.unibuc.ro 


\title{
Les futurs en arabe de Tripoli (Libye) : temporalité, aspectualité et modalités
}

\author{
Najah Benmoftah and Christophe Pereira
}

\section{Introduction}

1 L'arabe de Tripoli contemporain possède divers marqueurs qui permettent d'exprimer différents futurs : le participe actif, la conjugaison préfixale nue et trois préverbes $(b-, h \bar{a}-$ et taw-). Dans les travaux anciens, seuls la conjugaison préfixale nue et le préverbe $b$ - sont mentionnés (Cesàro 1939: 248 ; Stumme $1898: 240$ ). Le préverbe hā- n'a été signalé que dans les travaux plus récents portant sur le système aspectuel (Pereira 2008:345) et il existe un troisième préverbe, taw-, qui n’a jamais été examiné ${ }^{1}$. Dans tous les travaux précédents, le futur n'a été abordé que succinctement et les analyses qui y sont proposées sont peu approfondies, parfois approximatives, voire erronées ${ }^{2}$.

2 Si l'arabe de Tripoli s'est doté de cinq marqueurs de futur - ce qui n'est pas surprenant pour une langue de se doter de plusieurs marqueurs de futur (Bybee, Perkins \& Pagliuca 1994 : 243) - chacun d'entre eux ne s'est-il pas spécialisé dans l'expression d'un futur bien particulier? La viabilité de ces derniers n'est-elle pas assurée parce qu'ils occupent des fonctions différentes? Sinon, pourquoi l'arabe de Tripoli tolèrerait-il différents morphèmes pour exprimer le même contenu?

Le but fixé par cette étude est donc de déterminer précisément la ou les fonction(s) de chacun de ces marqueurs, afin d'en préciser le sémantisme, par le biais d'une approche transcatégorielle (Caubet 1993: 149 ; Novakova 1999), c'est-à-dire en considérant la façon dont vont s'entrecroiser les catégories du temps, de l'aspect et des modalités : à savoir si le procès est toujours situé postérieurement au moment de l'énonciation; le regard que porte l'énonciateur sur le procès, exprimé en termes de continuité ou de rupture par rapport au moment de l'énonciation; et la prise en charge plus ou moins forte de l'énoncé par l'énonciateur, ainsi que les degrés de certitude et de réalité. 
4 Pour ce faire, nous avons examiné une centaine d'énoncés extraits de nos données spontanées (Benmoftah 2015 ; Pereira 2010). La mise en commun de nos corpora donne ainsi accès à une liste d'énoncés conséquente, avec des données recueillies auprès de jeunes hommes et de jeunes femmes nés dans les années 1970, 1980 et 1990 permettant de mettre en évidence des évolutions (et notamment l'intégration récente de ḥā-).

Dans cet ordre, nous examinerons le participe actif, la conjugaison préfixale nue, le préverbe $b$-, puis le préverbe hăa- et, enfin, le préverbe taw-.

\section{Le participe actif}

6 Outre la conjugaison suffixale et préfixale, le participe actif est pris en compte dans l'étude du système aspecto-temporel de l'arabe de Tripoli (Pereira $2008: 334,338$ ), où il peut prendre une valeur de parfait, exprimant l'état résultant de l'accomplissement d'un procès (01), ainsi qu'une valeur d'actuel, exprimant la concomitance avec l'acte d'énonciation, le progressif (02).

(01) wākal!

"J'ai déjà mangé ! "

(02) matrayyas f-al-lacb.

« Il est en train de mener le jeu. »

7 C'est la combinaison du contexte temporel et de l'aspect sémantique du verbe sousjacent, l'aktionsart, qui permet au participe actif de prendre ces valeurs aspectotemporelles (Caubet 1993 : 231-246 ; Eades \& Persson 2013 : 348).

8 En arabe de Tripoli, le participe actif peut également prendre une valeur temporelle de futur. C'est en tant qu'expression de la concomitance qu'il est utilisé pour nommer un procès donné pour imminent, orienté vers l'avenir ou qui anticipe sur l'avenir proche: l'aspect prospectif (Cohen $1984: 272$ ).

(03) wallāhi mā̄̌ya ka“ābi !

« Vraiment, j'y vais à pied!»

(04) rāākab fōg?

«Tu montes?»

(05) šənu žāy nīzār ?

« Est-ce que Nizar vient?»

Le procès y est situé en contigüité avec le moment d'énonciation. Dans ce cas, la référence temporelle s'étend du moment où l'intention est formulée, jusqu'au moment dans le futur où l'action est réalisée. Le procès énoncé s'actualise dans le présent de l'énonciateur, qui pose comme actuel et comme certain un procès qui n'a pas encore commencé, comme étant sur le point de se dérouler.

Les verbes dits "translocatifs », c'est-à-dire indiquant le changement de lieu ou de position (Eades \& Persson 2013 : 357-360), se prêtent le mieux à exprimer cette valeur, surtout si l'état futur peut être planifié ou prédit avec un haut degré de certitude, au moyen de déictiques temporels.

(06) 'āne māši li bārīs yōm sob'a dis̄āmbor 'in šă'a lḷăh u mrawwah tāni yōm f-ol-'ǎšìya.

«Je vais à Paris le 7 décembre, si Dieu veut, et je repars deux jours après en fin de journée. »

11 Le participe actif peut être précédé de l'adverbe tawwa qui dénote l'immédiateté, ce qui permet de renforcer l'idée d'imminence véhiculée par la forme participiale. 
(07) f-əș-șêf mHatțăța āne nomši l-bəng்āzi lākon taHțtițti hāda kull-a mutawaqqəf ‘ăle 'awdat-'umm-i man as-safar li'anna māmạa tawwa mā̄̌ya l-ālmānya fa 'awwol-ma tarža hìa ḥa-nomši āne.

«L'été, j'ai prévu d'aller à Benghazi mais tout ce que j'ai prévu dépendra du retour de voyage de ma mère parce que maman va très prochainement aller en Allemagne donc dès qu'elle reviendra, moi je partirai. »

De par son ancrage dans le présent de l'énonciation, il s'agit d'exprimer une proximité modale où le futur appartient au domaine du certain, du réel.

\section{La conjugaison préfixale nue}

13 La conjugaison préfixale nue permet quant à elle d'exprimer le futur dès que le contexte situe la réalisation du procès postérieurement au moment de l'énonciation. Il s'agit d'un futur aspectuel, c'est-à-dire un futur qui résulte de l'utilisation d'une forme dont la principale fonction est de marquer le (temps) présent ou l'aspect inaccompli (Bybee, Pagliuca \& Perkins 1994 : 245, 275), qui est, en fonction du contexte, interprétée comme un futur.

14 A la différence du participe actif - et l'aspect prospectif qu'il véhicule, qui est vu dans son prolongement du moment de l'énonciation - la conjugaison préfixale nue permet d'exprimer un futur dont le procès est coupé de l'acte de parole. Il y a donc une rupture, une mise à distance : le localisateur n'est plus l'acte de parole, mais le contexte énonciatif par rapport auquel se situe le procès, qui devient le repère des événements. Par son ancrage dans l'avenir, le futur aspectuel est coupé du moment de l'énonciation et appartient au domaine du non certain.

(08) hādi toșbīra u ba'dēn not'aššu f-al-lèl.

«Ceci est une collation et puis nous dînerons ce soir. »

(09) tžī-ni ba'tāli l-ol-hōǒs?

«Tu viendras me voir plus tard à la maison?»

Précédant un verbe à la conjugaison préfixale nue, l'adverbe tawwa indiquant l'immédiateté permet de mettre en rapport deux événements succédant l'un immédiatement à l'autre. Le premier événement étant situé après le moment de l'énonciation, le verbe à la conjugaison préfixale nue située après tawwa s'actualise dans le futur, concomitamment avec le premier élément.

(10) gudwa b-nomši u tawwa nas'al.

« J'ai l'intention d'y aller demain et à ce moment-là je demanderai. »

(11) lamma nkūn mrawwoh, tawwa nākal.

«Lorsque je serai sur le chemin du retour, à ce moment-là je mangerai. »

De plus, le premier événement peut être nommé au moyen de l'impératif employé pour exprimer une recommandation à réaliser dans le futur. Le deuxième événement exprimé au moyen de la conjugaison préfixale après l'adverbe tawwa s'actualisera dans le futur.

(12) tă āli l-žayya ž-žāya, tawwa talgī-ha.

"Viens la prochaine fois, à ce moment-là tu la trouveras. "

(13) kūl mlïh, tawwa tosmon!

« Mange bien, à ce moment-là tu grossiras !"

17 Comme tawwa, la conjonction de coordination $w$ permet de situer deux événements dans un rapport de concomitance, l'un se succédant immédiatement à l'autre, après le moment de l'énonciation, donc dans un contexte futur. Dans l'exemple (14), c'est l'élément placé après $w$ qui est situé après le moment de l'énonciation et qui sert de déictique 
temporel, et c'est le verbe à la conjugaison préfixale situé dans la première proposition qui s'actualise dans le futur concomitamment avec le second élément.

(14) nŏtașșal bì-kw āne f-ol-žāmita.

«Je t'appellerai une fois que je serai à l'université »

18 La conjugaison préfixale nue permet aussi d'exprimer le futur dans une subordonnée temporelle qui situe tout l'énoncé dans un contexte futur. Dans les propositions principales, l'énonciateur annonce un procès futur situé par rapport à des événements décrits dans les subordonnées circonstancielles de temps, introduites par ba‘d-ma « après que » (14) ou lamma « lorsque» (16). L'action de la proposition principale, exprimée au moyen d'un verbe à la conjugaison préfixale, ne se réalisera que lorsque l'action de la subordonnée sera réalisée.

(15) ba‘d-ma tabda l-blād hādya u nabdu kull-na zayy ba'ḍ-na, kull-na natkātfu u ndīrū-

hum l-'ìmārāat u ndīru l-'istitmār u yabda fi 'iqtișād u kull-na mắa ba'ḍ-na.

"Après que le pays sera devenu calme et que nous serons tous égaux, nous nous

épaulerons, et nous les construirons les immeubles et nous ferons des

investissements et l'économie reprendra et nous serons tous ensemble. »

(16) nătașșol bī-k lamma nūṣal li maydān ol-žazāyar.

« Je t'appellerai lorsque j'arriverai à la Place d'Algérie. »

19 Étant donné qu'il existe une incertitude, un doute, dans les subordonnées temporelles de temps exprimant un fait postérieur, c'est la conjugaison préfixale nue qui convient le mieux puisqu'elle permet l'expression d'un futur non certain.

Ainsi, la nuance entre la conjugaison préfixale nue et le participe actif réside dans le lien entre l'action future et le moment de l'énonciation. Contrairement au participe actif, la conjugaison préfixale présente une action future dissociée de l'acte de parole. En raison de cette rupture, les faits évoqués avec la conjugaison préfixale ont une charge d'hypothèse plus importante et les événements sont considérés comme non certains.

\section{Les préverbes $b$-, hāa- et taw-}

21 Les préverbes de l'arabe de Tripoli contemporain seraient issus de la grammaticalisation de verbes ou d'un adverbe, à la suite d'érosions phonétiques et après avoir subi une décatégorisation (notamment lors du passage $d u$ verbe fléchi vers un marqueur invariable), suivie d'une recatégorisation en tant que préverbes. Développer un marqueur temporel de futur à partir d'un verbe de mouvement (Bybee, Perkins \& Pagliuca 1994 : 266-270), d'un adverbe de temps (Bybee, Perkins \& Pagliuca 1994 : 270-271), ou d'un verbe modal signifiant « vouloir, souhaiter, avoir l'intention » est un processus courant dans les langues du monde (Bybee, Perkins \& Pagliuca 1994 : 254).

Le préverbe $b$ - se serait développé à travers un processus de grammaticalisation, à partir d'un verbe signifiant «vouloir » $b(\dot{g}) a-i b(\dot{g}) i$, qu'on retrouve à Tripoli sous la forme $b a-$ $y a b b i^{3}$. Les données sur l'arabe de Benghazi contemporain s'avèrent particulièrement éclairantes pour montrer les évolutions de ce préverbe et notamment les degrés de grammaticalisation qui ont permis le passage du verbe au préverbe: contrairement à l'arabe de Tripoli, l'arabe de Benghazi connait encore des stades intermédiaires avec des formes raccourcies yib- et $i b i$ - où on reconnaît la première syllabe du verbe à la troisième personne du masculin singulier de la conjugaison préfixale (Benkato $2014: 75)^{4}$.

Le préverbe ha- (hă-en arabe de Tripoli) proviendrait du participe actif du verbe signifiant «aller» rāh : par troncation, on serait passé de rāyoh à une forme mono- 
syllabique reăh, puis à 'aḥ, après la disparition du /ṛ/ et, par métathèse, à ha- ; à moins qu'il ne provienne directement, par troncation, de la forme féminine rạhha (Taine-Cheikh 2009 : 95) ${ }^{5}$. Ce préverbe aurait intégré l'arabe de Tripoli récemment, à la suite de contacts linguistiques, entraînant l'évolution de la catégorie du futur (Heine \& Kuteva 2005 : 103-107) ${ }^{6}$.

Quant au préverbe taw-, il est un cas de grammaticalisation à partir du déictique temporel tawwa qui dénote l'immédiateté, la concomitance.

\subsection{Le préverbe $b$ -}

Plusieurs études ont montré que les valeurs que véhicule le préverbe $b$ - dépassent celle du futur, notamment dans des variétés d'arabe parlées en Syrie et au Koweït (Brustad 2000), ainsi que dans d'autres États du Golfe Persique (Persson 2008). Ce préverbe y est décrit comme un marqueur modal d'intention, de volition, de conditionnel et d'irréel ${ }^{7}$.

\subsubsection{Marqueur d'intention}

26 A Tripoli, le préverbe b- peut exprimer l'intention : il s'agit en effet de se proposer ou d'essayer d'atteindre un but déterminé, mais indépendamment de sa réalisation, qui est incertaine.

\subsubsection{Intention au moment de l'énonciation}

27 Le préverbe $b$ - peut s'employer pour exprimer l'intention au moment de l'énonciation. D'un point de vue aspectuel, l'action se présente comme un processus qui s'amorce au moment de l'énonciation dont on vise la réalisation dans le futur. On y présente à l'avance, un événement orienté vers le futur, mais il ne s'agit pas d'exprimer principalement le futur.

(17) b-yug'ud fi bəng்āzi 'osbū' taqriban.

«Il a l'intention de rester à peu près une semaine à Benghazi. »

(18) b̆̌-nšadd-ha xadma lēn yāHad-ni n-nōm.

«J'ai l'intention de passer mon temps à travailler, jusqu'à ce que le sommeil

m'emporte. »

(19) hādūmāas-ššs̄āšìr, mā-'ond-i šon bà-ndīr bi-hum.

«Ces chaussettes, je n'ai pas l'intention d'en faire quoi que ce soit ».

Son utilisation n'est pas limitée aux intentions des humains ; il permet aussi d'exprimer le but assigné à une action, ce que l'on cherche à atteindre, donc l'intention au moment de l'énonciation.

(20) hādi bă-tkūn kāda u hādi bă-tkūn kāda.

«Celle-ci va être ainsi et celle-ci va être ainsi (c'est l'intention). »

Ce préverbe peut également s'employer dans des phrases interrogatives. On le trouve dans des questions ouvertes (21) et fermées (22).

(21) škūn b-yžāwab ?

"Qui a l'intention de répondre?»

(22) b-tomši 'ăle ražlè- $k$ walla b-as-sayyāra?

«Tu as l'intention d'y aller à pied ou en voiture?»

Il peut également s'employer dans des phrases négatives, où l'intention est niée. En arabe de Tripoli, seul le morphème continu de négation məš peut précéder les verbes à la conjugaison préfixale préverbés ${ }^{8}$. 
(23) məš b-y̌̌u ?

« N'ont-ils pas l'intention de venir?"

(24) məš bă-tbīî̀-h li bant mabrūka?

« N'as-tu pas l'intention de le vendre à la fille de Mabrouka?»

31 On le trouve aussi avec l'adverbe temporel de négation $m \bar{a}$-'ād-š comme dans l'énoncé suivant, où le sujet est un inanimé.

(25) šakl-a musalsal al-ḥurūb māa-'âd-š b-yokmol.

«Il semble que la série des guerres ne va plus s'arrêter (l'intention n'est plus que cela s'arrête). »

(26) $m \bar{a}-' \bar{a} d-s ̌ b$-yagra.

«Il n'a plus l'intention d'étudier.»

\subsubsection{Intention dans le passé}

Le préverbe $b$ - peut en outre exprimer l'intention dans le passé. Il s'agit de situer l'intention de faire quelque chose qui aurait dû se réaliser avant l'acte de parole. Pour imaginer l'intention dans le passé, on peut faire précéder le préverbe de kān (qui s'accorde avec le sujet grammatical).

(27) kānu b-yəšru šagga fi ț̣āblos.

« Ils avaient l'intention d'acheter un appartement à Tripoli. »

(28) kunt b-nəmši l-mālța, mšèt ăl-tūnəs.

«J'avais l'intention d'aller à Malte, je suis allé en Tunisie. »

Un autre verbe à la conjugaison suffixale peut également situer le procès dans le passé.

(29) žêt b-nākal, žā-ni tīlījōn.

«J'étais sur le point de me mettre à table, j'ai reçu un coup de téléphone. »

(30) Haššèt b-nəšri karăt, grēt-ha, ḍhakăt u țla't.

"Je suis entré avec l'intention d'acheter une carte (recharge pour le téléphone

portable), je l'ai lue, j'ai rigolé et je suis sorti. »

\subsubsection{Intention dans le futur imminent}

De plus, le préverbe $b$ - peut indiquer une intention dans un futur imminent, lorsque l'imminence est précisée grâce à des adverbes de temps qui dénotent l'immédiateté tels que kif (31) et tawwa (32 et 33), qui situent le procès en contigüité avec le moment d'énonciation.

(31) kif b̆̀-nhuțț la-še.

"J'ai l'intention de servir le dîner sous peu. »

(32) tawwa b-nhadărzu 'ăle ḥāža stāḥašnā-ha hālba l-ḥagg.

«Maintenant, nous avons l'intention de parler d'une chose qui nous manque beaucoup.»

(33) šan bă-ndìr tawwa tawwa?

«Ce que j'ai l'intention de faire là tout de suite?»

\subsubsection{Intention dans l'avenir}

Autrement, on peut employer le préverbe $b$ - pour situer une intention dans l'avenir. Le contexte futur peut être exprimé au moyen d'un participe actif de verbe de mouvement (à valeur de prospectif) qui précède le préverbe.

(34) məš žāy li’onna b-yḥașșal ḥāža, lā, lākon li’onna b-ymattal libya.

«Il ne vient pas parce qu'il a l'intention d'obtenir quelque chose, non, mais parce

qu'il a l'intention de représenter la Libye. »

(35) mā̌šìn l-əl-ḥwāza, māšyin b-yotzarrdu. 
« Ils vont à la maison de campagne, ils y vont (avec l'intention de) pique-niquer. » situé dans l'avenir, on voit bien que le préverbe $b$ - ne véhicule pas la temporalité, mais la valeur modale d'intention.

\subsubsection{Marqueur d'antériorité}

37

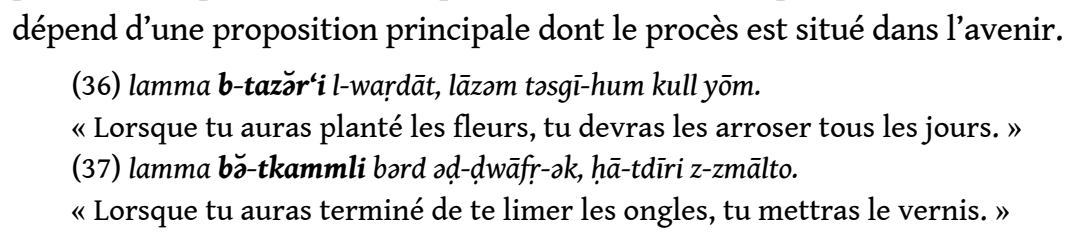

Employée dans une subordonnée temporelle introduite par la conjonction lamma, le préverbe $b$ - permet de marquer l'antériorité, lorsque cette subordonnée temporelle

Par rapport au moment de l'énonciation, les procès décrits dans les deux propositions sont situés dans l'avenir, mais c'est une fois l'action de la subordonnée nommée, que l'événement de la principale se réalisera. Ici, les deux événements ont lieu successivement, l'un après l'autre.

\subsubsection{Marqueur d'irréel}

39

Outre l'intention et l'antériorité, le préverbe $b$ - permet d'exprimer l'irréel. Le procès indiqué par le verbe préverbé n'est pas repéré par rapport au moment de l'énonciation, mais par rapport à un repère temporel imaginaire. Il s'agit d'exprimer des suppositions, des éventualités, de décrire des situations connues uniquement à travers l'imagination, de se projeter fictivement dans l'avenir.

(38) lākan ŏnḥsss fi-ha b-tațla '́gabìya, hmmāra!

«Mais j'ai l'impression qu'elle pourrait se révéler bizarre, stupide!»

(39) al-Hadma hiya lli anta b-totțawwur fi-ha nafs-ək. b-totbat fi-ha wužūd-ək. b-tabni bi-

ha l-mužtama' w hāda 'ahəmm hāža f-əl-mawḍ̄'c.

« Le travail, c'est là où tu évoluerais. Tu y prouverais ton existence. Tu construirais

grâce à lui la société et ça c'est la chose la plus importante du sujet. »

On trouve aussi l'expression de l'irréel dans des propositions subordonnées temporelles.

Il s'agit d'imaginer des situations, de projeter fictivement des événements, que l'avenir pourra éventuellement confirmer.

41 Dans l'exemple (40), la subordonnée temporelle est introduite par la conjonction lamma «lorsque, quand », qui dépend d'une principale dont le procès est situé dans l'avenir non certain, au moyen d'un futur exprimé par la conjugaison préfixale nue.

(40) as-slāḥ olli bēn 'ìdēn on-nās, hūwa lli msabbəb al-fawḍa tawwa, li'onna olli 'ond-a slāḥ, lamma b-yḩıll 'ayyi muškila, yətkalləm bi manțaq əs-slāh, məš b-əl-qānūn.

"L'arme qui est entre les mains des gens, c'est elle qui cause le chaos actuellement, parce que celui qui a une arme, lorsqu'il aura (éventuellement) l'intention de résoudre un problème, il parlera selon la logique de l'arme, pas de la loi. »

Dans l'exemple (41), la subordonnée temporelle est introduite par la locution conjonctive al-wagăt alli « au moment où », qui dépend d'une principale dont le procès est également situé dans l'avenir.

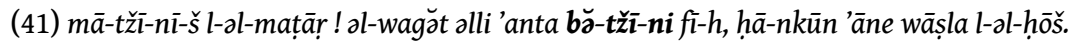

« Ne viens pas à moi (à ma rencontre) à l'aéroport! Au moment où toi tu viendras (éventuellement) à moi (ma rencontre), je serai moi déjà arrivée à la maison. » 
Contrairement aux exemples (36) et (37) - où le préverbe b- de la proposition subordonnée temporelle marquait l'antériorité par rapport au verbe de la proposition principale et où l'action de la proposition principale avait lieu après celle évoquée dans la proposition temporelle, successivement, l'une après l'autre - le préverbe $b$-véhicule dans les énoncés (40) et (41) une valeur d'irréel : il permet l'expression d'une éventualite, d'une supposition, et les événements décrits dans ces derniers exemples sont considérés dans leur simultanéité.

\subsection{Le préverbe $h \bar{a} \overline{-}$}

Avec hă-, on est d'emblée dans un contexte futur : ce préverbe n'apparaît que lorsque le procès est situé postérieurement au moment de l'énonciation et un repère temporel futur n'est pas nécessaire. D’un point de vue modal, ḩā- véhicule un degré de certitude fort visà-vis de la réalisation du procès localisé dans l'avenir. On est dans le domaine du factuel, du réel. La valeur de hăa- est donc celle de la certitude de l'énonciateur corrélée à la projection dans l'avenir, à laquelle vient s'ajouter une valeur de conviction liée à la certitude.

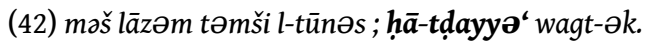

"Il est inutile que tu ailles à Tunis ; tu perdras ton temps. »

(43) 'วnd-a kābāb ya šābāb hāa-ya'žbb-kum!

«Il a un kebab, eh les gars, qui vous plaira!»

(44) at-trāyning ămtā'-i yabda l-yōm. fa hāa-nkūn məšğūl l-as-satta.

"Mon entrainement commence aujourd'hui. Je serai donc occupé jusqu'à six

heures. »

Le préverbe hāa- peut également s'employer dans des phrases négatives, où l'énonciateur nie avec certitude et conviction l'action mentionnée par la forme verbale préverbée en $h \bar{a}-$. Seul le morphème continu de négation məš peut précéder les verbes à la conjugaison préfixale préverbée.

(45) məš ḥā-namši l-bārīs ‘ăle ḥagg-ət-tadkว̆ra.

" Je n'irai pas à Paris à cause du prix du billet. »

(46) məš ḥā-nəgdər ngìm oț-țāwla hādi b-rūḥ-i.

"Je ne pourrai pas soulever cette table tout seul. "

(47) məš hāa-ykəmməl Hədə̆mt-əh.

« Il ne terminera pas son travail. »

Etant donné que le préverbe ḥ̄a- véhicule un degré de certitude fort vis-à-vis de la réalisation $d u$ procès, son utilisation ne semble pas être compatible avec les subordonnées temporelles où il s'agit d'exprimer un fait envisagé, incertain, irréel. On ne trouve donc pas de participe actif et de préverbes ḩ⿳亠幺- qui expriment tous deux des futurs certains dans les subordonnées temporelles, mais plutôt la conjugaison préfixale nue qui véhicule la valeur de futur non certain (Bybee, Pagliuca \& Perkins 1991 : 19).

Dans l'énoncé (48), la conjonction 'awwal-ma « dès que », qui introduit la subordonnée temporelle, permet de marquer la postériorité immédiate de l'action de la principale par rapport à celle de la subordonnée. L'énonciateur, étant convaincu de la certitude de la réalisation de l'action de la proposition principale, aussitôt celle de la subordonnée réalisée, va employer ḥ̄a-.

(48) 'awwol-ma tarža' hìya, ḥā-nomši āne.

« Dès qu'elle reviendra, moi je partirai. » 
dans l'exemple (49), la conjonction $b a^{\prime} d-m a$ " après que » situe le procès exprimé dans la subordonnée temporelle en postériorité par rapport à l'action de la proposition principale. L'action de la principale se déroulera très certainement après que celle décrite dans la subordonnée aura eu lieu : on emploie donc hăa-.

(49) ba'd-ma nkammol ad-dəktōrāh, 'akīd hāa-nrawwoh li lïbya li'onna lïbya moḥtāžot-na. «Après que j'aurai terminé mon doctorat, c'est sûr que je retournerai en Libye parce la Libye a besoin de nous. »

Aussi, d'un point de vue de la structuration de l'espace de l'avenir, lorsque différents futurs sont utilisés en série, la suite (chrono)logique hăa-suivi de la conjugaison préfixale nue reflète l'opposition modale et temporelle du procès en liaison avec le moment de l'énonciation (avec $h \bar{a} \overline{-}$ ) ou en rupture avec ce dernier (au moyen de la conjugaison préfixale).

Dans les exemples (50) et (51), une proposition contenant hă- situe le procès dans l'avenir avec un degré de certitude fort. De ce fait, elle peut servir à établir un repérage futur pour d'autres éléments de l'énoncé, notamment ceux exprimés au moyen des verbes à la conjugaison préfixale nue qui suivent.

(50) 'akìd hạa-ythassan ol-wad̆ă u tarža' tamām.

"C'est sûr que la situation s'améliorera et tu reviendras parfaitement. »

(51) hāa-ndawwŭr-a u nā $m \breve{a} \cdot \bar{a}-h$.

«Je le chercherai et je le prendrai. Mon beau-frère fait des allers-retours à Paris. Je

prendrai le livre et je te l'enverrai par son intermédiaire. »

Enfin, les exemples (52) et (53) permettent d'opposer les emplois du préverbe ḥā- et ceux du préverbe $b$ -

(52) anti 'in šă'a lḷāh ḥāa-tg்ayyri s-sakăn. šan muwāṣāfāt al-hōǒs alli b-tuskŭni fi-h ?

«Toi, si Dieu veut, tu changeras de logement. Quelles sont les caractéristiques de la

maison dans laquelle tu habiterais (bien) ?»

(53) olli b-yarfa' os-slāh ma'nā-ha məš hāa-yṣallah li'onna wad̆ă ol-blād fawḍa 'amnīya.

«Celui qui a l'intention de porter une arme, eh bien, il ne réformera pas parce que

la situation du pays est chaotique du point de vue sécuritaire. »

L'opposition entre les deux se situe entre réel et irréel: alors que le préverbe hăa- y apparait clairement comme un marqueur de futur situé dans le domaine du certain, exprimant le réel, le préverbe $b$ - y marque une intention ou une éventualité sans que la réalisation en soit assurée, donc l'irréel.

\subsection{Le préverbe taw-}

Enfin, le préverbe taw- s'emploie également pour situer un procès dans l'avenir par rapport au moment de l'énonciation, mais avec taw-, il s'agit de signifier un «futur d'engagement » : au moment de l'énonciation, l'énonciateur s'engage verbalement en vue d'une action à venir et, pour ce faire, le préverbe taw- ne s'emploie qu'aux premières personnes et le sujet ne peut être qu'un humain. Annonçant un procès qui se situe ultérieurement au moment de l'énonciation, ce préverbe va situer le procès dans le domaine du non certain.

Comme on peut le voir dans les exemples (54) et (55), l'engagement fort du locuteur peut avoir des valeurs qui se traduisent par une menace ou une promesse.

(54) taw-ănworrī-k!

"Je vais te montrer ! (attends que je t'attrape)» 
(55) al-ktāb, taw-ănduwwor-l-ək ă ${ }^{\prime} \bar{e}-h$.

«Le livre, (promis) je vais te le chercher.» permis de préciser le sémantisme du participe actif, de la conjugaison préfixale nue et des trois préverbes $b-, h \bar{a}$ - et taw-. Ces catégories linguistiques coexistent, s'entrecroisent et se manifestent à des degrés différents, permettant ainsi à quatre « futurs » de se distinguer : - le participe actif permet l'expression de l'aspect prospectif et nomme un procès orienté vers l'avenir, mais situé en contigüité avec le moment d'énonciation, avec valeur de certitude et d'engagement de l'énonciateur ;

- la conjugaison préfixale nue permet d'exprimer un futur en rupture avec le moment de l'énonciation, donc non certain ;

-le préverbe ḩā-exprime, quant à lui, un futur de certitude, de conviction, et, bien que le procès soit en rutpure avec le moment d'énonciation, il situe le futur dans le domaine du certain ;

- enfin, le préverbe taw- permet l'expression du futur d'engagement: l'énonciateur s'engage au moment de l'énonciation à réaliser une action dans un futur situé en rupture avec le moment d'énonciation, donc dans le domaine du non certain.

Les futurs et les modalités ont, en effet, un lien évident : en renvoyant à un univers d'incertitudes, les futurs appellent intrinsèquement à des jugements du locuteur sur le procès, donc à des modalisations (Barceló 2006 ; Novakova 1999).

En revanche, l'examen du préverbe $b$ - a permis de mettre en évidence qu'il ne s'agit pas d'un préverbe de futur, mais plutôt d'un marqueur d'intention que ce soit dans le passé, au moment de l'énonciation ou dans l'avenir. Outre la valeur d'intention, le préverbe bpermet de marquer l'antériorité dans les subordonnées temporelles en corrélation avec 
une principale où est nommée une action à venir. Enfin, le préverbe b- est un marqueur d'irréel permettant l'expression de l'imaginaire, de l'éventuel.

\section{BIBLIOGRAPHY}

Barceló, Gerard Joan. 2006. « Le futur des langues romanes et la modalité : monosémie et dialogisme ». Cahiers de praxématique 47. 177-190.

Benkato, Adam. 2014. "The Arabic Dialect of Benghazi (Libya): Historical and Comparative Notes". Zeitschrift für Arabische Linguistik 59. 57-102.

Benmoftah, Najah. 2016. Des ligateurs de cause : étude contrastive entre le français parlé à Paris et l'arabe parlé à Tripoli (Libye). Propriétés syntaxiques et fonctionnements pragmatico-discursifs. Thèse de Doctorat. Paris : Université Sorbonne Nouvelle - Paris 3.

Benmoftah, Najah \& Pereira, Christophe. 2017. "Preliminary Remarks on the Arabic Spoken in AlKhums (Libya)", Ritt-Benmimoun, Veronika (ed.), Tunisian and Libyan Arabic Dialects. Common trends - Recent developments - Diachronic aspects. Zaragoza: PUZ. 301-325.

Brustad, Kristen. 2000. The Syntax of Spoken Arabic. A Comparative Sudy of Moroccan, Egyptian, Syrian, and Kuwaity Dialects. Washington: Georgetown University Press.

Bybee, Joan, Perkins, Revere \& Pagliuca, William. 1991. "Back to the Future", Closs Traugott, Elizabeth \& Heine, Bernd (eds.), Approaches to Grammaticalization: Volume II. Types of Grammatical Markers. Amsterdam / Philadelphia: John Benjamins Publishing Company.

Bybee, Joan, Perkins, Revere \& Pagliuca, William. 1994. The Evolution of Grammar. Tense, Aspect, and Modality in the Languages of the World. Chicago / London: The University of Chicago Press.

Caubet, Dominique. 1993. L'arabe marocain. Tome II. Syntaxe et catégories grammaticales, textes. Paris / Louvain : Editions Peeters.

Caubet, Dominique. 2017. "A Tentative Description of Aspect and Modality in the Fezzan: W. and Ph. Marçais' Texts Revisited”, Ritt-Benmimoun, Veronika (ed.), Tunisian and Libyan Arabic Dialects. Common trends - Recent developments - Diachronic aspects. Zaragoza: PUZ. 327-350.

Cohen, David. 1984. La phrase nominale et l'évolution du système verbal en sémitique. Etudes de syntaxe historique. Leuven / Paris: Peeters.

Eades, Domenyk \& Persson, Maria. 2013. “Aktionsart, Word Form and Context: On the Use of the Active Participle in Gulf Arabic Dialects”. Journal of Arabic and Islamic Studies 58. 343-367.

Heine, Bernd \& Kuteva, Tania. 2005. Language Contact and Grammatical Change. Cambridge: Cambridge University Press.

Marçais, Philippe. 2001. Parlers arabes du Fezzân. Textes, traductions et éléments de morphologie rassemblés et présentés par Dominique Caubet, Aubert Martin et Laurence Denooz. Genève : Librairie DROZ.

Marçais, William \& Guîga, Abderrahmân. 1958. Textes arabes de Takroûna, II. Glossaire. Paris: Paul Geuthner. 
Miller, Catherine. 2004. « Saillance, marquage et prestige dans les processus d'accomodation dialectale en arabe égyptien ", Mejri, Salah (ed.), L'arabe dialectal : enquêtes, descriptions, interprétations. Actes d'AIDA 6. Tunis : CERES. 305-318.

Mion, Giuliano. 2017. « A propos du futur à Tunis », Ritt-Benmimoun, Veronika (ed.), Tunisian and Libyan Arabic Dialects. Common trends - Recent developments - Diachronic aspects. Zaragoza: PUZ. 205-217.

Novakova, Iva. 1999. « Une approche transcatégorielle pour l'analyse du futur simple et du futur périphrastique français ", Mantcheva, A. et al. (eds.), Mélanges de linguistique, sémiotique et narratologie, dédiés à la mémoire du Professeur Krassimir Mantchev, à l'occasion de son 60e anniversaire. Sofia: Editions Colibri. 301-323.

Pereira, Christophe. 2008. «Aperçu du système aspecto-temporel du parler arabe de Tripoli (Libye) », Procházka, Stephan \& Ritt-Benmimoun, Veronika (eds.), Between the Atlantic and Indian Oceans. Studies on Contemporary Arabic Dialects. Proceedings of the 7th AIDA Conference, Held in Viena from 5-9 September 2006. Wien: Institut für Orientalistik der Universität Wien. 329-348.

Pereira, Christophe. 2010. Le parler arabe de Tripoli (Libye). Zaragoza: IEIOP.

Pereira, Christophe. 2018. Dialectologie, linguistique et sociolinguistique de l'arabe maghrébin. Approches comparatives. Mémoire d'Habilitation à Diriger des Recherches. Paris : INALCO.

Persson, Maria. 2008. "The Role of the b- Prefix in Gulf Arabic Dialects as a Marker of Future, Intent and/or Irrealis". Journal of Arabic and Islamic Studies 8. 26-52.

Retsö, Jan. 2014. “The b- imperfect once again: typological and diachronic perspectives”, Edzard, Lutz \& Huehnergard, John. (eds.), Proceedings of the Oslo-Austin Workshop in Semitic Linguistics. Oslo, May 23 and 24, 2013. Wiesbaden: Harrassowitz Verlag. 64-72.

Taine-Cheikh, Catherine. 2009. « Les morphèmes de futur en arabe et en berbère. Réflexions pour une typologie ». Faits de langues 33. 91-102.

Yoda, Sumikazu. 2005. The Arabic Dialect of the Jews in Tripoli (Libya). Wiesbaden: Harrassowitz Verlag.

\section{NOTES}

1. On le retrouve en arabe tunisien, mais avec une valeur de «futur intentionnel » (Mion 2017 : 210-211).

2. Cette étude corrige et remplace notamment toutes les analyses précédentes (dans Pereira 2008, Pereira 2010 et dans Benmoftah \& Pereira 2017 : 317-318).

3. Une autre étymologie est proposée et rapprocherait $b$ - d'un verbe de racine '- $b-y$ (Cohen 1984, note 43 ; Stumme $1898: 239-240)$. Cette idée a été reprise dans Pereira $2010: 140-141$, où il est mentionné que ba-yabbi est de racine ' $-b-y$. On trouve également cette racine en arabe de Takroûna, avec le sens de « consentir, accepter, admettre » (Marçais \& Guîga 1958 : 14).

4. Quant à l'arabe des Juifs de Tripoli, pour exprimer le futur, il a recours à d'autres marqueurs plus ou moins grammaticalisés, formés sur le verbe habb-yḥobb « vouloir » : il possède (y)habb et (y)hobbu, ainsi que les formes courtes (n)həom-, hən- et hət- (Yoda $2005: 194$ ).

5. Ce préverbe est en usage dans tout le Moyen-Orient, ainsi qu'en Egypte et en Erythrée (TaineCheikh 2009 : 95). On trouve également ha- en maltais, où il pourrait provenir de l'impératif hálli « laisse », du verbe 'aHada « prendre » ou du verbe habba « aimer » (Vanhove 1993 : 184-185).

6. Il serait principalement employé par les jeunes générations scolarisées ; les personnes âgées ne l'emploiraient pas. Bien qu'il s'agisse d'une intégration récente, il ne semble pas y avoir de 
recoupements de valeurs entre le préverbe hha- et les autres marqueurs, qui relèveraient d'un processus d'accommodation dialectale (Miller 2004), qui pourrait résulter de l'influence de parlers arabes du Moyen Orient, considérés comme prestigieux par les Libyens (Pereira 2018 : 38-40).

7. Pour un état de l'art, voir Persson 2008, ainsi que Retsö 2014. D'un point de vue comparatif, les données sur le préverbe $b$ - fournies par Dominique Caubet pour l'arabe du Fezzân des années 1940 et 1950 permettent de distinguer plus de valeurs qu'en arabe de Tripoli : celle de volition, d'intention, de futur, d'imminence (Caubet 2017 : 345-348).

8. Alors que dans les parlers du Fezzân, le morphème de négation ma peut précéder les formes préverbées, comme dans $w$-ŭl-gáda mạ-b-ijîkum «Le déjeuner ne vous arrivera pas " (Marçais $2001: 100-101)$.

\section{ABSTRACTS}

L'arabe de Tripoli contemporain possède divers marqueurs qui permettent d'exprimer différents futurs : le participe actif, la conjugaison préfixale nue et trois préverbes ( $b-$-, hă- et taw-). Le but de cette étude est de déterminer précisément la ou les fonction(s) de chacun de ces marqueurs, afin d'en préciser le sémantisme, par le biais d'une approche transcatégorielle, qui considère la façon dont vont s'entrecroiser les catégories du temps, de l'aspect et des modalités. Ces catégories linguistiques coexistent et se manifestent à des degrés différents, permettant à quatre "futurs » de se distinguer: le participe actif exprime l'aspect prospectif et nomme un procès situé en contigüité avec le moment d'énonciation, avec valeur de certitude ; la conjugaison préfixale nue exprime un futur aspectuel en rupture avec le moment de l'énonciation, donc non certain; le préverbe hă- exprime un futur de certitude, mais en rutpure avec le moment d'énonciation; le préverbe taw-exprime un futur d'engagement: l'énonciateur s'engage au moment de l'acte de parole à réaliser une action dans un futur situé en rupture avec le moment d'énonciation, donc dans le domaine du non certain. Quant au préverbe $b$-, il dit l'intention; il marque en outre l'antériorité dans les subordonnées temporelles ; il exprime enfin l'éventuel et l'irréel.

\section{INDEX}

Mots-clés: arabe, Tripoli, Libye, futurs, temps, aspect, modalités

\section{AUTHORS}

\section{NAJAH BENMOFTAH}

INALCO - LACNAD (Paris); njouhben@gmail.com; Département Études Arabes, 65 Rue des Grands Moulins 75013 Paris.

\section{CHRISTOPHE PEREIRA}

INALCO - LACNAD (Paris); christophe.pereira@inalco.fr; Département Études Arabes, 65 Rue des Grands Moulins 75013 Paris. 


\title{
Variation in Prosodic and segmental marking of yes-no questions in Tunisian Arabic
}

\author{
Nadia Bouchhioua, Sam Hellmuth and Rana Almbark
}

\section{AUTHOR'S NOTE}

Acknowledgments: Thanks are due to the participants for their patience and help, and to Anna Bruggemann and Francesco Cangemi for sharing Praat scripts used in visualisation of prosodic contours. Thanks also to the audience at AIDA 2017 for their helpful comments and suggestions.

\section{Introduction}

1 Tunisian Arabic (TA) displays a segmental marker of yes-no questions, in the form of a vowel epenthesised to the end of polar interrogatives. Although the marker appears to be well known - being described as "the pan-Tunisian question marker clitic" (Herin and Zammit 2017: 141) - there seems to be little work on its realisation and distribution. Recent work on TA intonational phonology has shown variable use of the segmental marker by gender, and that it always co-occurs with a rise-fall prosodic contour, rather than a plain rise (Hellmuth in press). This suggests that the prosodic (i.e. tonal) component of the question marker is at least as important as its vocalic content in marking yes-no questions in TA.

This paper reports the results of a small production study designed to further explore the relationship between segmental and prosodic marking of yes-no questions in TA. We focus on regional variation between the north (Tunis) and the south-east of Tunisia, and transfer of the pattern into speakers' spoken second language English, due to anecdotal observations of variable use of the segmental marker in these contexts. The study also 
serves to replicate the results of Hellmuth (in press) with a new set of speakers in the same age range.

\section{Background}

\subsection{Prior descriptions of the Tunisian Arabic question marker}

3 The existence of a vocalic question polar interrogative clitic in TA is not a wholly new discovery, since it is described as a pan-Tunisian feature as noted above. However, no detailed descriptions exist, to the best of our knowledge, and the marker fails to be mentioned in some descriptions (e.g. Gibson 2008). In an investigation of data from the TUNICO corpus (Procházka and Mörth 2017), Dallaji, Gabsi \& Procházka (n.d.) argue against Gibson's (2008) suggestion that the suffix -ši functions as an interrogative marker in TA, noting instead that "the overwhelming majority of yes/no questions in the Arabic dialect of Tunis are not marked as questions except by a rising intonation" (Dallaji et al. n.d.: 1), and without any mention of an accompanying segmental (vocalic) marker.

Recent work on the intonational phonology of TA as spoken in Tunis (Hellmuth in press) revealed frequent co-occurrence of the segmental marker (an epenthesised vowel) with a prosodic marker (a complex prosodic contour) in yes-no questions extracted from the TA portion of the Intonational Variation in Arabic database (Hellmuth and Almbark 2017). The data were recorded with 12 TA speakers (6 females/6 males) from Tunis, aged 20-24, and were taken from read (a scripted dialogue) and semi-spontaneous speech (a map task). Incidence of the segmental marker was variable, but always contingent on use of a complex prosodic contour, as no tokens of epenthesis were observed in yes-no questions produced with a plain rising or falling contour. The reverse was not true, however, as some speakers produced complex rise-fall contours in yes-no questions without accompanying epenthesis. A marginal effect of gender was found, with female speakers using the segmental marker more frequently than male speakers. A range of potentially explanatory properties of the last lexical item in the analysed utterances was investigated, including number of syllables, position of stress and final consonant type, but none showed any association with the occurrence of the epenthetic vowel. This last finding supports analysis of the epenthesised vowel in TA yes-no questions as a question clitic particle, rather than as a by-product of the choice to deploy a complex prosodic contour as has been argued for other languages (see Hellmuth in press for details). Nevertheless, the segmental and prosodic marking strategies are clearly very closely tied together, and further work is needed to understand the role of each in marking yes-no questions, to which we hope to contribute here.

\subsection{Dialectal variation in the Tunisian Arabic regions under study}

5 Our data were collected with speakers from two regions of Tunisia (North and South East) which are approximately $500 \mathrm{~km}$ apart, and whose dialects are known to differ. Examples of lexical variation (south north, respectively) include: /'tzala/ /iza/ 'come here' and / masnid/ /'mxada/ 'pillow'. Phonological variation at segmental and prosodic levels is sufficiently prominent to function as an indicator of speaker identity. The phoneme /q/ has two variants $/ \mathrm{g} / \sim / \mathrm{q} /$ in the south, but is realized as /q/ in the north, as in (1) below; 
the $[\mathrm{g}]$ realization is found in other regions also and is generally an indicator of a rural accent.

(1) /qal/ (North) /gal/ (South) 'to say'

Vowel quality differences between the north and south are illustrated in (2).

(2) a. /dwe/ (North) /dwa/ (South) 'medicine'

b. /hwe/ (North) /hwa/ (South) 'air'

Finally, Ghazali (1973) notes differences in stress assignment, which we find also, as in (3).

(3) /'stilu:/ (North) /sti'lo:/ (South) <stylo> (French) 'pen'

6 Recent work suggests that the two regions also exhibit variation in use of intonation in different contexts. Saadi (2014) is the first study of regional variation in TA intonation, treating dialects from the cities in the north (Nabeul, in north east Tunisia, $60 \mathrm{~km}$ from Tunis), the centre (Mahdia, $250 \mathrm{~km}$ from Tunis) and the south (Gabes, in south east Tunisia), and investigating intonation in a range of sentence types. The main locus of variation between dialects was in the realization of declaratives, imperatives, exclamations and yes/no questions. The author did not investigate co-occurrence of epenthetic vowels with specific contours in yes/no questions in any of the regions under study, though we note that figures illustrating the productions of southern speakers are consistent with the presence of epenthetic vowels (e.g. Saadi 2014: 94-6).

\subsection{L1 transfer effects in L2 English}

It is common in research on second language (L2) speech production to assume that the learner's first language (L1) sound system affects pronunciation in the target L2, in an effect known as 'transfer', and to differing extents through the acquisition process (Odlin 1989). Early theories, such as the Contrastive Analysis Hypothesis (Lado 1957), suggested that differences between languages would cause the most difficulties for learners, but recent studies have shown that the presence of similar (but not identical) sounds, or patterns of sounds, in the L1 and L2 makes an equal if not greater contribution to perception of an L2 learner's speech as displaying a non-native or foreign accent (Flege 1995).

Ghazali and Bouchhioua (2003) show that the stress rules of TA influence Tunisian learners' production of L2 English lexical stress. In TA stress is assigned to a final superheavy syllable (with a VVC or VCC rhyme), otherwise to the penult syllable. The Tunisian students often incorrectly put stress on the initial syllable in English 'until' *

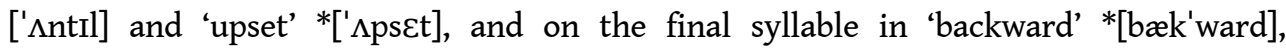
following precisely the rule which assigns stress to TA words. At the phonetic level, Bouchhioua (2008) compared the acoustic correlates of word-level and phrase-level stress in TA and English to look for evidence of use of L1 phonetic correlates of stress and accent in L2 productions. Results showed frequent use of TA L1 stress correlates, in particular F0 (pitch) and unreduced vowel quality; the learners produced L2 English stressed syllables with higher pitch, greater intensity and less vowel reduction than native English speakers do. Finally, Aloulou (2003: 115) found that intermediate Tunisian learners used different intonation patterns from those used by native English speakers in almost all sentence types, except in yes/no questions and exclamations. The author attributed this behavior to various factors, including interference from the native language's intonation patterns or lack of exposure to native English speech. The same tendency was also observed in Saadi (2014), who found differences in the boundary tones used by Tunisian learners 
compared to native English speakers (especially in declaratives). In all these studies, L1 transfer was hypothesized to be the major cause of the pronunciation errors observed, informing our decision to investigate the L2 English of Tunisian learners in the present study.

\section{Methods}

\subsection{Materials}

9 The material used to elicit yes-no questions in Tunisian Arabic consisted of the same scripted dialogue used in Hellmuth (in press) which yields 6 yes-no questions, and a new role play conversation script designed to yield a further 8 yes-no questions, controlling for the final consonants in the last lexical item in the utterance ( 4 obstruents +4 sonorants). To elicit L2 English, an English role play conversation script was devised which yields 9 yes-no questions, again controlling for the final sound in the utterance (4 obstruents, 4 sonorants, 1 vowel). The speakers read each dialogue twice, exchanging roles so that each speaker plays both roles. They were asked to speak as naturally as possible. Arabic tasks were performed first, then tasks in English. Recordings were made via the internal microphone of a laptop computer in a quiet language laboratory, directly to .wav format, using Praat software (Boersma and Weenink 2015).

\subsection{Participants and procedures}

The participants in this study are 10 speakers (4 females and 6 males), aged between 22 and 24 years. They are all native speakers of Tunisian Arabic and none of them had a parent who is not Tunisian. They come from two different regions in Tunisia. Two male and two female speakers represent the North since they were born and have lived their whole lives in Tunis. The other six speakers represent the South East region of Tunisia since they have lived most of their lives in south eastern towns (Zarzis, Djerba, Tatawin). All the speakers were students of English at the University of La Manouba, Tunis at the time of recording. The level of study differed: 8 speakers $(2$ males +2 females from the North, and 2 males +2 females from the South East) were first year students; the two other South-Eastern speakers were third year students. All the speakers had the same educational background; they all studied in public Tunisian schools where they learn Standard Arabic (the official language of the country) from the age of six, French (a first foreign language which almost has the status of a second language) from the age of eight, and English as a foreign language from the age of 12-14. The rationale for recruiting first year English major students as participants was twofold. First, the goal was to record Southern participants who still retain their local accent and are less likely to be influenced by other accents since moving to study and live in the capital city of Tunis. Second, these students have not yet studied the phonetics or prosody of English, unlike third year students who have studied English phonetics for two years.

\subsection{Analysis}

11 Individual utterances were extracted from the recorded conversations for analysis. Each of the 10 speakers produced 14 yes-no questions in Arabic (6 from the scripted dialogue 
coded 'ynq' + 8 from the Arabic conversation, coded 'arc') and 9 in English (from the English conversation, coded 'enc'), yielding a potential dataset of 230 questions for analysis (140 in Arabic + 90 in English). The 230 extracted questions were annotated by all authors independently for presence of a question marker vowel and prosodic contour shape (to identify non-rising contours). If the authors disagreed regarding the presence of epenthesis, the majority ('2 out of 3') view was recorded; there was however full agreement in $77 \%$ of cases $(\mathrm{N}=176)$. A total of 10 tokens in Arabic and 8 tokens in English were identified by the first author as disfluent or not interpretable as a question, and excluded from further analysis. The remaining 212 tokens were subjected to quantitative acoustic analysis: the target word and (if present) question marker vowel were manually labelled in a Praat Textgrid by the second author, and a Praat script used to extract F1 and F2 values at the midpoint of the epenthetic vowel and the trajectory of F0 through the target word (20 measuring points). Statistical analysis was performed in R (R Core Team 2014).

\section{Results}

\subsection{L1 Tunisian Arabic regional variation}

The results in Arabic show the same basic generalisation as found in Hellmuth (in press), regarding the relationship between segmental and prosodic marking of TA yes-no questions. No epenthesis was observed on any of the small number of tokens $(\mathrm{N}=6)$ produced with a falling contour. Among fluent tokens produced with a rise-fall contour $(\mathrm{N}=130), 80$ tokens $(62 \%)$ were produced with an epenthetic vowel (cf. $54 \%$ in Hellmuth in press); two examples are provided in Figure 1.

Figure 1: Pitch trace of yes-no questions from a north (left) and a south-east (right) speaker.
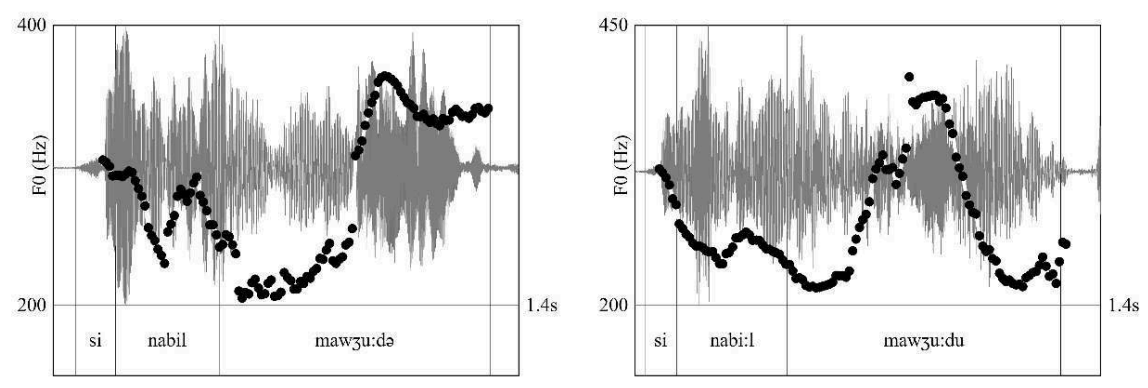

SI NA'BIL /MAW'ZUD/ [MAW'ZUDə/U]

MR NABIL PRESENT

'IS MR NABIL THERE?" (TUNO-ARC1-F\&/TUSE-ARC1-F1)

13 Although female speakers use epenthetic vowels more frequently than males ( $70 \%$ vs. $55 \%$ ), a Classification by Regression Tree (CART) analysis, exploring gender, final consonant type and region as predictors of the occurrence of epenthesis in tokens with a rise-fall contour, shows that the only significant predictor of presence of an epenthetic vowel in this dataset is region ${ }^{1}$, with a much higher incidence of epenthesis among speakers from the south-east, as illustrated in Figure 2. 


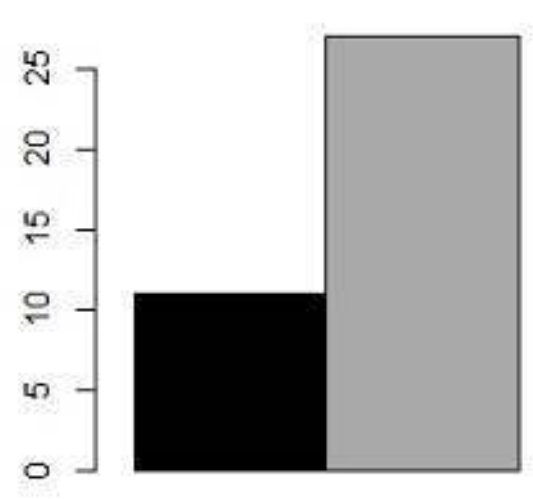

female

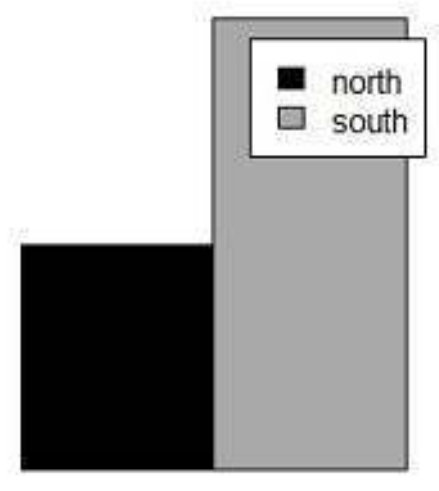

male

14 A breakdown of the results by speaker (see top panel of Figure 6 below for details) reveals that all south-east speakers produce epenthesis to some degree, but that both female speakers from the south-east produce epenthesis near categorically (that is, in $90-100 \%$ of tokens); a similar near-categorical pattern is observed for one northern female speaker.

Auditorily, the quality of the epenthesised vowel tends towards a high back vowel [u] for south-east speakers, though a plot of F1/F2 of vowels split by region (Figure 3) indicates considerable variability in the quality of the epenthesised vowel. This suggests probable vowel harmony, influenced by the vowel in the preceding syllable, but further investigation of this possibility is beyond the scope of this initial study.

Figure 3: F1/F2 values in epenthesised vowels in TA yes-no questions, by region.

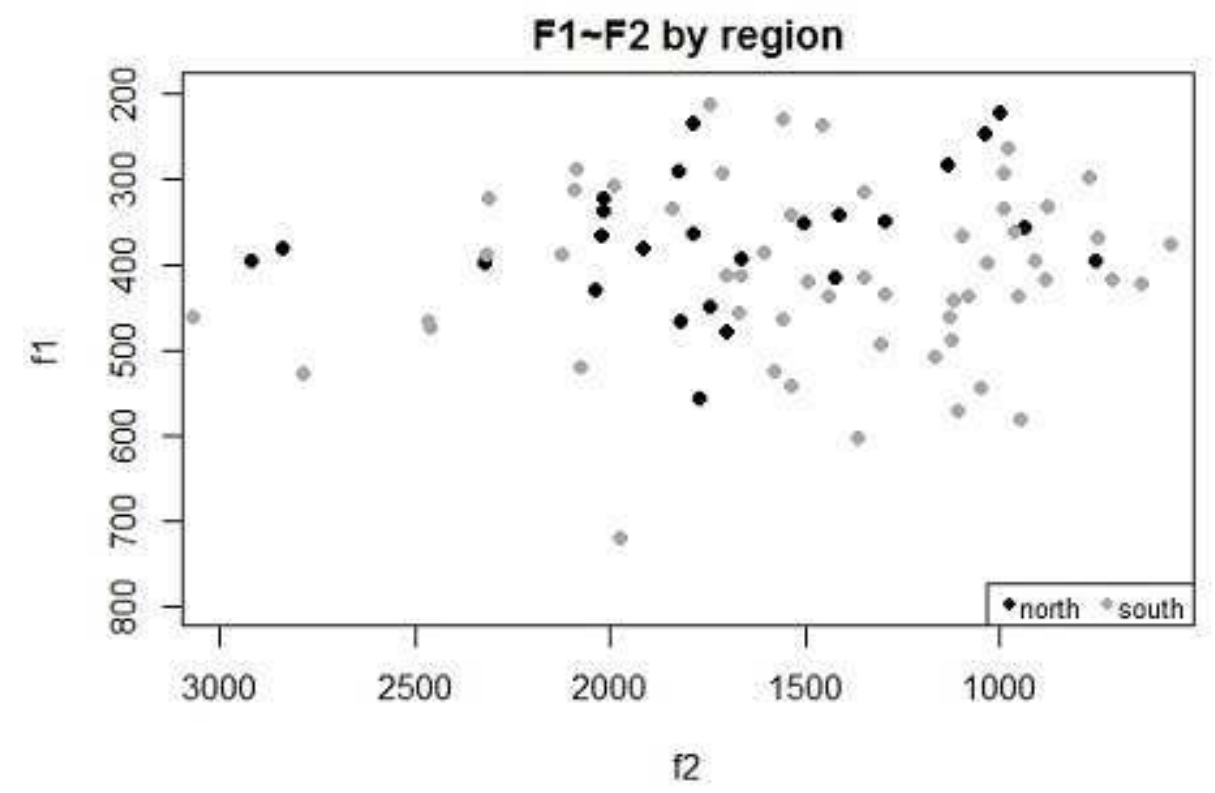

16 Inspection of the shape of the prosodic contour in the last lexical item in each utterance (Figure 4) shows a clear regional difference in the shape of the contour, with a rise-pluspartial-fall (a 'rise-plateau') in the north, but a full rise-fall contour in the south-east. 
Figure 4: F0 contours in semitones for female (black) and male (grey) speakers, by presence of epenthesis (yes/no) and by language (Arabic/English).
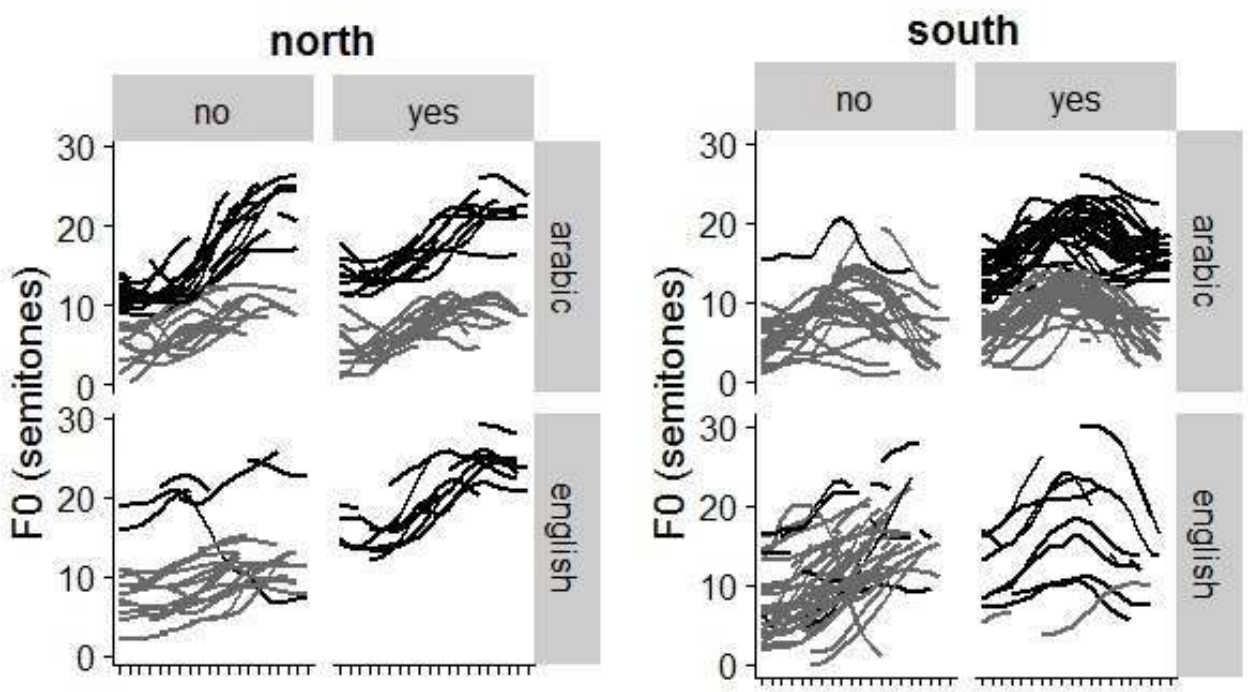

In summary, we find that yes-no questions are consistently marked in TA with a rising prosodic contour, confirming the observations of Dallaji et al (n.d.) for data from Tunis. Our study allows us to provide further detail about the shape of the contour, which is a rise-plateau in Tunis, but a rise-fall in the South-East. This prosodic marking is accompanied by segmental marking (an epenthetic vowel), to a variable extent across speakers, with more epenthesis produced by speakers from the south-east, and near categorical use of prosodic and segmental marking in parallel by female speakers from the south-east (and one northern female speaker).

\subsection{L2 English}

A total of 8 English tokens were produced with a falling contour, though were interpretable as a question in context; none of these tokens were produced with an epenthetic vowel, and they are excluded from further analysis. Of the remaining tokens produced with a non-falling contour, just 18 tokens (22\%) were produced with an epenthetic vowel; an example is provided in Figure 5. 
Figure 5: Pitch trace of an L2 English yes-no question produced with epenthesis.

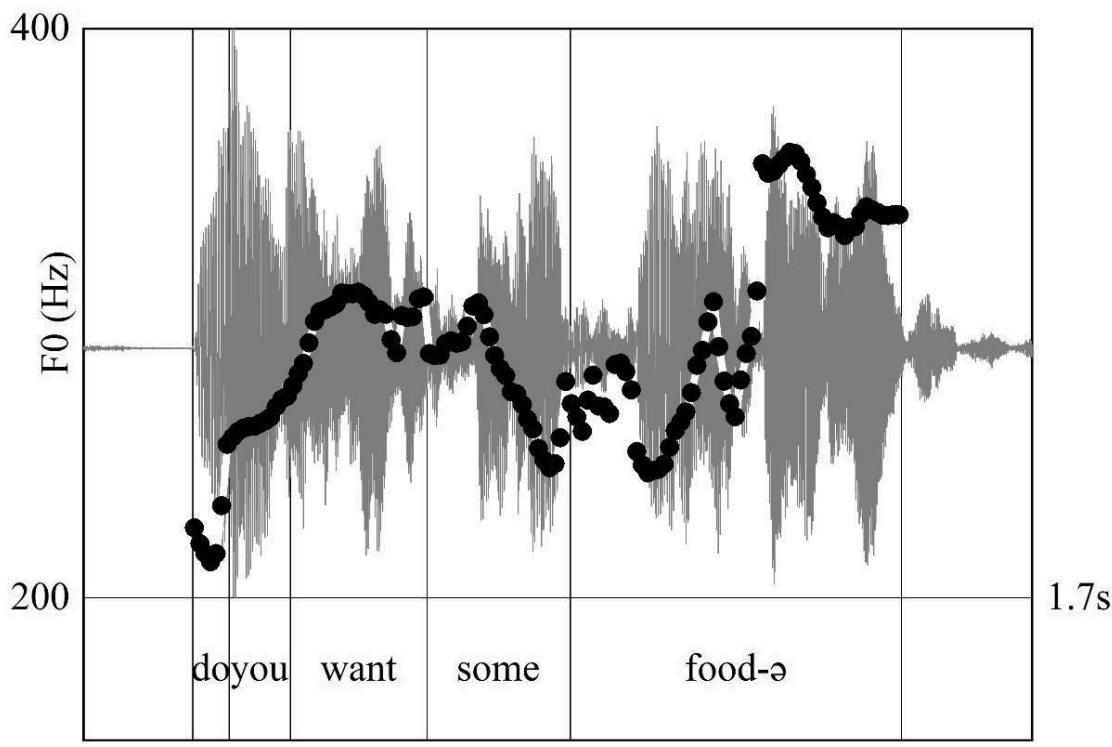

'DO YOU WANT SOME FOOD?' [FUDə] (TUNO-ENC2-F1)

Inspection of the prosodic contours (in Figure 4 above) shows that all of the L2 English tokens which were produced with epenthesis have a prosodic contour which is similar in shape to that used by speakers in their L1 dialect (a rise-plateau for females from the north, a rise-fall for speakers from the south-east).

Figure 6 below shows the proportion of tokens produced with/without epenthesis by speaker in both Arabic and English. The three (female) speakers who regularly produce epenthesis in their L2 English are those who produce epenthesis in their L1 Arabic to a near-categorical degree.

Figure 6: Count of epenthesis tokens by individual speaker in L1 Arabic and in L2 English.

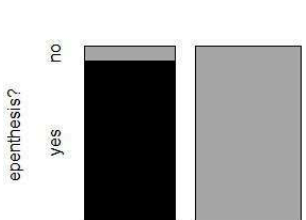

tuno-f1

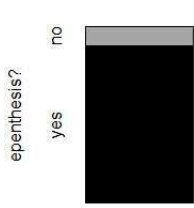

tuno-f1

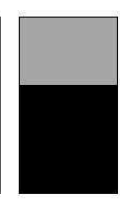

tuno-m1

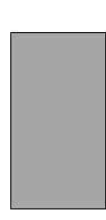

tuno-m1

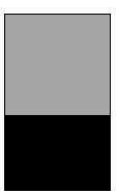

tuno-m2

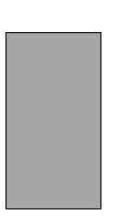

tuno-m2

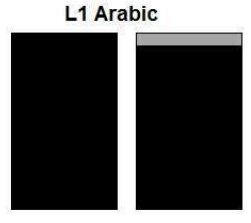

tuse-f1

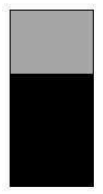

tuse-m1

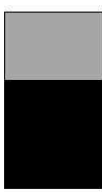

tuse-m2

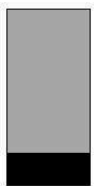

tuso-m1

\section{L2 English}

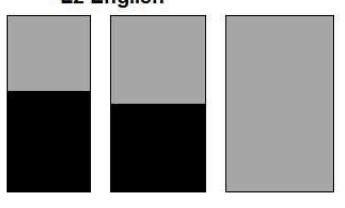

tuse-f1

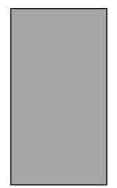

tuse-m2

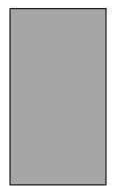

tuso-m1

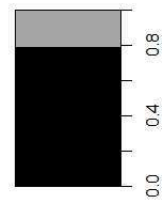

tuso-m2

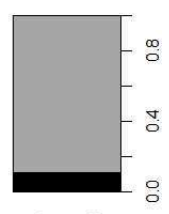



earlier claims (e.g. Dallaji n.d.), co-occurring to a varying extent with a segmental vowel marker. There is a difference in the shape of the prosodic contour produced on yes-no questions in TA; the south-east region uses a more pronounced rise-fall prosodic contour, which is accompanied by increased use of the segmental marker. Three out of our four female participants produced the segmental + prosodic markers in parallel and to a nearcategorical extent, as markers of yes-no questions; these speakers were also those who showed the greatest tendency to produce a complex contour and epenthetic vowel on yes-no questions in their L2 English. None of the male speakers in the study produced complex rise-fall contours in their L2 English, and no epenthetic vowels either. It seems that the distribution of segmental and prosodic markers in TA yes-no questions is quite closely related, and further research is needed to determine the relative contribution of each marker to the perception of an utterance as a question, or not. The quality of the epenthesised vowel appears to be variable and future research could usefully investigate vowel harmony as an explanation of this variation, and whether the degree of harmony also varies across regions.

presence of a clear transfer effect of the L1 Arabic question marking strategy into the L2 English of some speakers confirms that question marking would be a suitable variable for inclusion in larger studies of Tunisian learners' L2 English phonological acquisition.

\section{BIBLIOGRAPHY}

Aloulou, M. 2003. The intonation patterns of Tunisian Arabic and English: a comparative study. MA dissertation, Institut Supérieur des Langues de Tunis, University of Carthage, Tunis.

Baayen, R.H. 2008. Analyzing linguistic data: A practical introduction to statistics using R. Cambridge: Cambridge University Press.

Boersma, P. \& Weenink, D. 2015. Praat: doing phonetics by computer (Version 5.4.09) [http:// www.praat.org]. 
Bouchhioua, N. 2008. The acoustic correlates of stress and accent in Tunisian Arabic: A comparative study with English. Unpublished PhD Dissertation. University of Carthage.

Dallaji, I., Gabsi, I., \& Procházka, S. n.d. Yes/no questions in Tunis Arabic. Ms., University of Vienna https://tunico.acdh.oeaw.ac.at/yes-no-questions.html.

Flege, J. E. 1995. "Second language speech learning: Theory, findings, and problems", Strange W. (ed.), Speech perception and linguistic experience: Issues in cross-language research, Timonium M D: York Press, 233-277.

Ghazali, S. 1973. Tunisian Arabic and French interference with English: word stress and the phoneme. MA dissertation, University of Texas at Austin.

Ghazali, S. \& Bouchhioua, N. 2003. "The learning of English prosodic structures by speakers of Tunisian Arabic: word stress and weak forms", Solé M. J., Recasens D. \& Romero J. (eds.), Proceedings of the 15th International Congress of Phonetic Sciences. Rundle Mall: Casual Productions Pty Ltd. 961-964.

Gibson, M. 2008. "Tunis Arabic", K. Versteegh (ed.), Encyclopedia of Arabic Language and Linguistics. 4. Leiden: Brill. 563-571.

Hellmuth, S. in press. "Text-tune alignment in Tunisian Arabic yes-no questions", Cruz M., Frota S. \& Oliveira P. (eds.), Prosodic variation (with)in languages: Intonation, phrasing and segments. London: Equinox.

Hellmuth, S. \& Almbark, R. 2017. Intonational Variation in Arabic Corpus. UK Data Archive, Colchester, Essex.

Herin, B. \& Zammit, M. R. 2017. "Three for the price of one: the dialects of Kerkennah (Tunisia)", Ritt-Benmimoun V. (ed.), Tunisian and Libyan Arabic Dialects: Common Trends-Recent DevelopmentsDiachronic Aspects. Zaragoza: Prensas de la Universidad de Zaragoza. 135-146.

Lado, R. 1957. Linguistics Across Cultures. Ann Arbor: University of Michigan Press.

Odlin, T. 1989. Language transfer: Cross-linguistic influence in language learning. Cambridge: Cambridge University Press.

Procházka, S. \& Mörth, K. 2017. Linguistic dynamics in the Greater Tunis Area: a corpus-based approach (TUNICO). University of Vienna. https://tunico.acdh.oeaw.ac.at/about_corpus.html

R Core Team. 2014. R: A language and environment for statistical computing, R Foundation for Statistical Computing, Vienna, Austria.

Saadi, S. 2014. Regional Effects on the Intonation Patterns of Three Different Groups of Tunisian EFL Learners. MA dissertation, University de la Manouba, Tunis.

\section{NOTES}

1. A cost complexity pruned CART model showed only marginal improvement (32\% vs. $35 \%$ misclassification) over a baseline model in which only region is included as a predictor (Baayen 2008). 


\section{ABSTRACTS}

Recent work has highlighted the consistent co-occurrence of a partial rise-fall prosodic contour with a segmental vowel epenthesis marker to mark yes-no questions in the Tunisian Arabic of Tunis; the incidence of the segmental marker (epenthesis) varied according to the external factor gender, but did not vary according to language internal factors, such as phonological environment. In this paper we explore the relationship between the prosodic and segmental question-marking strategies further in a production study which investigates: i) regional variation between the north (Tunis) and the south-east of Tunisia; and ii) potential transfer of one or both strategies into speakers' spoken second language English. Greater incidence of epenthesis is observed in yes-no questions produced by speakers from the south-east, accompanied by a different prosodic contour (with a lower boundary tone), and a difference in the quality of the inserted vowel (tending towards [u]). In L2 English yes-no questions, a small subset of speakers displayed TA epenthesis in their English productions, but only when accompanied by a TA rise-fall contour. Taken together the results confirm the close relationship between the presence of epenthesis and the complexity of the accompanying prosodic contour (a rise-fall rather than a plain rise).

\section{INDEX}

Keywords: Tunisian Arabic, prosody, intonation, epenthesis, regional variation, L2 transfer

\section{AUTHORS}

\section{NADIA BOUCHHIOUA}

Faculty of Arts and Humanities, Université de la Manouba, Tunisia

\section{SAM HELLMUTH}

Department of Language and Linguistic Science, University of York, UK

\section{RANA ALMBARK}

Department of Language and Linguistic Science, University of York, UK 


\title{
The Tense in Central Asian Arabic Dialects: (Complex (Immediate)) Future and Present Definite (Continuous tense)
}

\author{
Guram Chikovani
}

1 Verb formation in Central Asian Arabic dialects is characterized by several peculiarities. It is noteworthy that in Qashqa-darya Arabic dialect exist two main forms (with fatha and with kasra) of regular triliteral verbs (Chikovani 2002a: 102), conjugation types specified by the position of emphatic consonants (Chikovani 2002a: 107; Chikovani 2002b: 182), mi prefixed forms of the imperfective in Bukhara Arabic (Tsereteli 1947: 461-470; Akhvlediani 1985: 66; Chikovani 2009: 17-18), imperative of facali type in Qashqa-darya Arabic (Chikovani 2002a: 112), etc.

2 Particularly should be emphasized the forms conveying tenses different from the Literary Arabic. The majority of them are the result of long-lasting relations of Arabic dialects with structurally different Indo-European (Tajik) and Turkic (Uzbek) languages. The category of tenses in Qashqa-darya Arabic dialect is represented with the following forms: Present Definite (Continuous Tense), Present Indefinite, Past Perfect, Past Continuous, Past Indefinite, Simple Future, Complex (Immediate) Future.

3 I would like to draw attention to forming of Future and Present Definite in Central Asian Arabic dialects. This last one conveys a continuous prolonged action in the present.

\section{The complex (immediate) future}

One of the main elements forming Complex (Immediate) Future in Central Asian Arabic is the prefix ta-: ta-nogdi 'let's go (immediately)!', 'we will go right now'; ta-nōkul 'let's eat (immediately)!'; ta-noǵsa 'let us take it immediately!'; ta-iktub 'let him write immediately!;

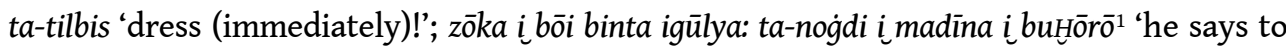
the Bey's daughter, '[Let's] go to the town Bukhara. ${ }^{2} ;$; zōca pōšo mūya šăfata Hairōn sōrat, 
zikka ịpōsō i izōča-ta-tušrub-gālat '[when] the Pasha's wife saw the [magical] water, she was [very] surprised. She said to the Pasha [to her husband], '[Come on,] drink it [right now]!'

5 Prefix ta-conveying future is added to the imperfective of the verb. George Tsereteli connects it with Arabic matā (متى): "Like Syro-Palestinian and Mesopotamian, in the studied dialect have emerged the forms of future, produced with the particle $t a$ > متى : $t a-$ tiktila 'will kill her'; ta-nogdi 'let's go'; ta-iəkūn 'will be', etc.” (Tsereteli 1941: 143).

Arabic matā (متى) is also independently fixed in Central Asian Arabic and its meaning is 'when', 'whenever'. Here are some examples from Bukhara Arabic: mata bint-ki kabiret mantia al-zōğ (Chikovani 2009: 125) 'When a girl grows up, we (give her) in a marriage.' inti di' $i$, middi, hal šiyātik i_andi tuōguf, toimitin toHsiña (Chikovani 2008: 77). 'Bring me these (your) belongings and put them here with me, whenever [you wish], take them.'

7 Earlier, George Tsereteli connected the prefix ta- with Arabic hattā: "Like Syro-Palestinian and Mesopotamian the forms of future tense are produced with the help of the particle $t a$ > حتى" - says the scientist (Tsereteli 1937: 20).

Mentioned particle was dealt by Vladimer Akhvlediani in his monograph 'Bukhara Arabic Dialect', who, like George Tsereteli, connected the element $t a$ - conveying future with hatt $\bar{a}$ (حتى):

...As a subjunctive mood with the meaning of future is used the particle ta $(<$ hattā $)+$ imperfect: da'u täjnām 'leave him, let him sleep', mäje 'rif fisāb tājoǵdi 'he does not know where to go'. The same construction can be used as an imperative mood of plural of the $1^{\text {st }}$ person and both singular and plural of the $3^{\text {rd }}$ person: imši, waro tāningalab 'go, let's go back!', iıbejt täjiği 'let him go into the house!' (Akhvlediani 1985: 62), etc.

In Isaak Vinnikov's dictionary of Bukhara Arabic dialect verbal particle ta- is explained as an element conveying purpose and wish: " $t a$ - is a particle; used with the verb it conveys purpose and wish" (Vinnikov 1962: 42). As examples the dictionary gives the sentences with verbal forms using particle ta-. Its origination is not discussed.

In Bukhara and Qashqa-darya dialects is fixed the particle tō of Persian origin, which conveys time and is also found in Turkish: ta baştan 'from the very beginning' (Baskakov 1994: 814). In Persian its meaning is 'to', 'till then', 'before that', 'from there on': tā-tehrān 'to Tehran'. With the same meaning it is used in Bukhara and Qashqa-darya dialects: ilay to- si rūza, ilay salās yumāt qabrī qaraulya sū! 'Watch over my grave for three days' (Chikovani 2009: 82). The mentioned particle is conveying time but I consider unlikely to connect it with Central Asian Arabic prefix ta-.

11 As a result of observations made over the materials obtained during my dialectological expeditions to Central Asia I came to the conclusion that the particle ta-, could be originated from Arabic dialectal form ta'âl, the meaning of which is 'come', 'come on!'. I would like to mention here that in my earlier publications I shared the opinion of abovementioned scientists about the connection of the prefix ta- with hattā (حتى) (Chikovani 2012; 127).

ta'āl is widespread in Arabic dialects. In Qashqa-darya it is characterized by the ability to have variations in gender and number:

\begin{tabular}{|l|l|l|l|}
\hline & & Sing. & Pl. \\
\hline II & Masc. & $t a^{\prime} \bar{a} l / / t a^{\prime} \bar{a} l a$ & $t a^{\prime} \bar{a} l \bar{u}$ \\
\hline
\end{tabular}




\begin{tabular}{|l|l|l|l|}
\hline & Fem. & ta'ā $l i ̄$ & ta'ālínna \\
\hline
\end{tabular}

13

In one of the districts (mahalla) of kishlak Jeinau, particularly in Avona, the variability of the verb ta'a $a$ la was fixed not only in gender and number, but also in person. This case indicates the tendency to produce forms in the dialect (Chikovani 2002a: 151).

14 In parallel with independent form of existence we can assume the reduction and transformation of the form $t a^{\prime} \bar{a} l$ into verbal prefix, which has obtained the function of future marker.

5 Thus, ta-nog்di 'let's go now!' should originate from the expression ta'āl nog்di 'let's go!' Similarly: ta'āl nušrub 'let's drink!' > ta-nušrub; ta'āl tuktub 'come on, write!' > ta-tuktub, etc.

Besides Georgian and Arabic the verbal form 'come on!' expresses future tense in other languages as well. At the same time it also expresses a call. There is an expression 'come on!' in English as well.

7 It is possible that eventually the prefix ta- had acquired a range of different nuances to express future, such as purpose, intention, aspiration, ability, etc.

Here are some examples from the texts recorded by me in Central Asia:

hama matala ta-nismaha. (Chikovani 2007: 29, 4³).

'[Let's] listen to this fairy-tale.'

'ahlu l-madina ademiyāta 'orba 'ašar yōm leyl e nahār i ifrahūn. (Chikovani 2007: 36, 4).

'The inhabitants of the town were looking at the lion's [severed] head for forty days and nights and were happy.'

ies ta-asi ana? (Chikovani 2007: 39, 3).

'What can I do [now]?'

nahnāt hamzōk ademin aswad ta-nelgi (Chikovani 2007: 31, 7).

'[We'll go] to find that black man [immediately].'

hama ademin aswad ilga, ta'âl! ${ }^{4}$

'Go, find that black man [right away, immediately, quickly]!'

ugūb hama sabī morta gālat: -sandūq ta-naftiša ta-inšūfa (Chikovani 2007: 33, 3).

'Then the son's wife said, 'Let's now open the coffer [and] take a look [what is inside].'

hama 'andiāni tangayāti to min madīna angilib ağì i _andkum tayōguf-gultinni (Chikovani 2007: 42, 2).

'I said [to him], 'I'll [leave] my money to you till I return from the town.'

ilai kōn hamrayāt kōn šìit hast, il hamzōk šiyāt, ỉ bētkum, ta-ağỉba, ta-di'ī (Chikovani 2007: $42,5)$.

'I have a lot of money [and] belongings. [I'll go] and bring this belongings to your house, I'll [store] them [in your house].'

waldak il hamāza ieš guftan bakana ta-idri, ta-iği! (Chikovani 2007: 45, 7).

'Let your son find out why he is crying, let him come [right away and tell me].'

inta i_bēt uǵda i_morti gūl: -laham, ǧizār, diḥin, bașal ta-tištari, ta-toHuz, zat tasī (Chikovani 2007: 60, 4).

'Go home, tell my wife, 'Immediately buy meat, carrot, fat, onion. Take [all of these] and cook pilaf! ${ }^{5}$

sawdogar sawdogaria ġadān, bāt hat Hațīb hat walad kēn kober ki-magder wihay taišraH, qul: - haț zagiir baham ta-nența ia šamiš ța-nsu, ta-nišraH (Chikovani 2009: 57, 4).

'Sowdagar went off to trade. [Here is, what happened] then: this khatib [the lover of Sowdagar's wife] could not spend time [have fun] with his [mistress because] the 
boy was [home]. [He] told [the woman], 'Let's drive out this boy, get rid [of him], and we'll spend time together [enjoy ourselves].'

maratak wahad dunya ta-tog்dī, muh ta-tisšrab, ta-tiğì, iHlāf 'ašara miṣōr (Chikovani 2009: $63,3)$.

'Your wife must [immediately] go to one country; she must drink the water [there]. [When] she comes back, (then) she'll get pregnant.'

i_kulla madināni ademiyāt i.ham waHt amr asi ta-ilbisunāt mustin ğadīdāt! (Chikovani 2007: 47, 4).

'From this moment (from now on) I order every resident (all the residents) of the town to put new boots (shoes) on!'

wai sahriya pōšō in nās 'amir sawa-ki il-mūzatūmat ỉ usțoyāt ta-iwuddūnat, ta-iHaytunāt, taitrawanū (Chikovani 2007: 49, 13).

'In the morning the Pasha ordered the people to take the shoes to tradesmen and mend (repair), walk [easily].'

Examples given above illustrate how widespread is the particle ta- in Qashqa-darya and Bukhara dialects. Presented opinion on the origins of the particle ta- can be extended on the Arabic dialects of Syria and Iraq, where the mentioned prefix also conveys future.

It is important that dialectal verbal form $t a^{\prime} \bar{a} l$ can also be found in Arabic dialects in a reduced form - $t \bar{a}^{c} / / t \bar{a}^{\prime} \bar{l}: t \bar{a}^{c}$, $t a^{\prime} \bar{i} l a$ 'andi 'come to me [come here]'. Such pronouncement is characteristic for quick speech and expresses language economy. This is also another argument to connect the particle $t \bar{a}-$ with the form $t a^{\prime} \bar{a} l$.

In some cases, to express Immediate Future in Central Asian Arabic dialects are fixed elements different from the prefix tāa. These are rāh and Halli. Both forms express quick, unconditional, immediate future. They are found in the dialects of Syria and Iraq. rāh is also fixed in Egyptian dialect in the form of ha (Sharbatov 1968: 127).

Let me discuss mentioned forming elements separately. B. Sharbatov relying on S. Willmore considers that rāh comes from the verb rāha (Sharbatov 1968: 127). Its meaning is 'was going, started, was ready to do (something)' (Wehr 1994).

As I have already mentioned, rāh is widely spread in Arabic dialects producing Immediate Future, especially in Syria and Iraq. In the materials recorded by me in Central Asia, in particular in kishlak Kamashi of Qashqa-darya region I have fixed formation of Immediate Future by means of the prefix rāh: rāh iktub 'he will write quickly', 'let him write quickly': سوف يكتب او سيكتب فوراً:

zōk arabča, lafzi arap ma idriya, rāh tuktub!

'He does not know Arabic, [thus] you write!'

As for Halli, this is also a common form for producing of Immediate Future in Eastern Arabic dialects. The meaning of Hallās.th.); to leave, leave هـ is "to vacate, evacuate (خلّّ) alone (o s.o.); to release, let go (o s.o., ه s.th.); to desist, abstain, refrain (ع ع from), give خلى بين فلان sabilahū) to let s.o. off, let s.o. go, release s.o.; خلى سبيله | (s.th.)

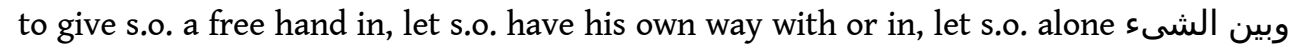
with; to open the way for s.o. to; خل علك هذه الميول kalli 'anka h. l-muyūla desist from such desires! خل عنك هذا الهراء (hurā’a) stop this nonsense!" (Wehr 1994: 301). Based on my long life experience in Syria, namely in Homs and Damascus, I can say, that in Syrian Arabic dialect $H a l l i$ is one of the most widespread forms to produce future. In this case, it is important that unlike Classical Arabic Imperfective, which simultaneously conveys Present and Future according to the context, in the dialects through different elements eventually had developed the formation of future tense. Sometimes in Syrian dialect Halli adds the pronominal suffix: 
Hallina nu'ūl 'innu ğuwa.

'Let's say that he is inside [in the house].'

In Qashqa-darya dialect are also fixed some cases of producing future by means of Halli:

xalli nušrub šāy, awalāni nōkul ugūb gappāt nuzrub nugā'id. hek imši: awal ța'ōm, ugub kalōm!

'Let's [at first] drink tea, first of all let's eat, and then talk (throw words). So [well] it will work: 'Eat first [and] then talk!'

The existence in Central Asian Arabic of the elements of Eastern Arabic dialects ( $t a, r a \bar{h}$, Halli) indicates the following: the ancestors of Qashqa-darya and Bukhara Arabs were from different geographic regions and preserved their speech peculiarities. It should be assumed that in VII-VIII centuries the Arab warrior soldiers spreading Islam as well as the Arabs captured by Timur Lang in XIV century were of different tribes. They gathered and localized in those regions of Qashqa-darya and Bukhara where their descendants live at present.

\section{Present definite}

The Present Definite Tense (present of the given moment) in Bukhara and Qashqa-darya Arabic dialects conveys a continuous prolonged action. It is formed by adding of nāyim to a verb in the imperfect, e.g.: ițbuH nāyim '(smb.) is now baking (smth.)', nōkul nāyimínni 'we're now eating'. The auxiliary verbal form nāyim is frequently provided with a pronominal suffix: ieš ithamlūnāt nayiminkumāt? 'What are you carrying?'

By the opinion of Prof. G. Tsereteli (1937) and V. Akhvlediani (1985) nāyim has originated from Arabic nām 'to sleep'. Previously, I also shared this opinion (Chikovani 2002a: 252). In iği nāyim 'he is coming' nāyim is a particle form. It has the function of an auxiliary verb. In his article 'Dialect Differences in Uzbekistan Arabic' Prof. O. Jastrow also connected nāyim with the verbal form nām the meaning of which is referred to 'sleeping' (Jastrow 2014: 210).

The origination of nāyim from Arabic نام ('to sleep') has become doubtful for me. As a result of my recent observations, I came to the conclusion that it is more expectable this auxiliary verb to be related with $n \bar{a}$ 'im ناعم

iği nayim means - yatafaddal يَتَفَدَّلُ - 'he is coming with God's mercy, by the will of God ( (بإذن أللّه

In Arabic na'ima (ian'am) means "to live in comfort and luxury, lead a life of ease, lead a comfortable and carefree life; to be delighted (بby), be happy, be glad (ب about, at), be pleased (ب with), delight, take pleasure ( s.th.) | نعم بالا ب (na'ima bālan) to feel serene and confident about...; - na'ima a (na'am) to be green and tender (twig); to be or become fine, powdery; - na'uma u (نعومة'u'üma) to be soft, tender, smooth" (Wehr 1994). So, the meaning of $n \bar{a}$ ' $i m$ is 'to be happy', 'to be glad', 'be pleased', 'take pleasure', 'to enjoy', which is very important. See also (Ul-Bustani 1977: 904).

2 In the speech of Qashqa-darya and Bukhara Arabs n $n \bar{a}^{\top} i m$ sometimes expresses satisfaction and respect: hā iǧi nāyim 'look at him (he is so kind to be coming)'.

In Lane's Arabic-English dictionary we find varieties of meanings of ni'ma, mostly expressing favor: 


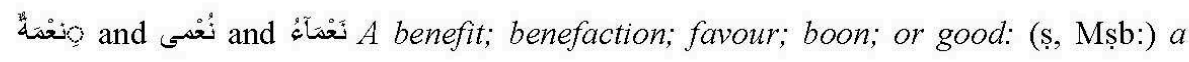
blessing; [bounty; gratuity;] or what God bestows upon one: and so (s) [grace of

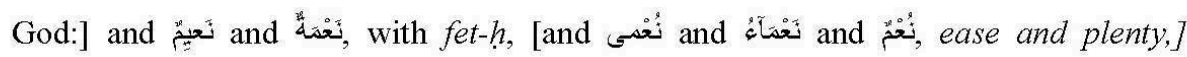

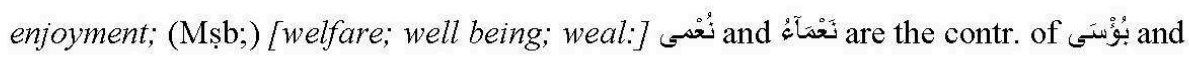

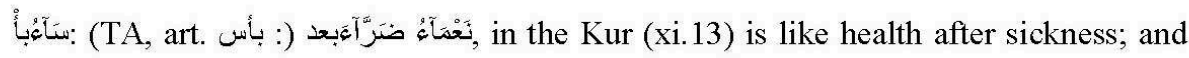
richness, or competence, after want. (Bḍ.)

- 2 io A blessing; (s;) a cause of happiness. (K.) A favour; a benefit; and the like. (s.)

- Oن Wealth, or property.

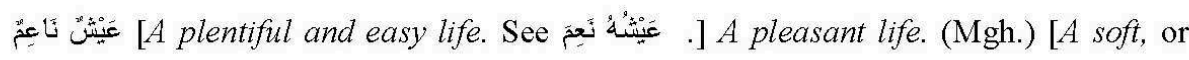

delicate, life] (Lane 1968). of an action we have in Central Asian Arabic dialects. Examples:

nahnāt hamïk zēn yōm inšū i i nayminna (Chikovani, 2007: 66, 2).

'Today we live [so] well [today our life goes so well].'

ugūb kokōyata iğadū nayminkin ịpōšo (Chikovani, 2007: 25, 4).

'Then (meanwhile) the brothers go to the Pasha.'

fad yōm pōšō harōn rašỉd fad šiāten ğaganda labas, i_madina mad, kōne ademiyāt ieš isūn naymin (Chikovani, 2007: 29, 4).

'One day the Pasha Harun al-Rashid put on old clothes and went to the town. [He was eager to know how the people lived] (what the people were doing now).'

min darb fad ademin aswad kēyn iği nāym (Chikovani, 2007: 31, 6).

'[Suddenly, I saw] a black man walking on the road.'

min họyițak min foga walt sawdagar 'abar-ğā'. zōka i_'and bintak ğāy, i_ 'and bintak iǧi nāyim (Chikovani, 2007: 32, 2).

'Sowdagar's son jumped down from [the fence of] your palace (from above). He is visiting your daughter. [He came to your daughter even now].'

rusțōm min 'askarāt sayal: -ies ithamlūnāt naiminkumāt intuwāt? (Chikovani, 2007: 37, $6)$.

'Rustom asked the soldiers, 'What are you carrying in this chest?'

min bèt äfändi kōn ademiyat itla' ū naimīn (Chikovani, 2007: 52, 1).

'[The Pasha sees]: People gathered at Effendi's house.'

In Qashqa-darya Arabic the continuity of an action in the present tense is also conveyed by $g \bar{a}^{c} i d$, which is used with the imperfective of the verb: ibki gā'id 'is crying'. The same 
production is found in Iraqi dialect. Let me recall one occasion in Iraq. During my visit to Baghdad, at the end of one of the meetings, someone called my Iraqi colleague on a mobile phone. From the conversation it seemed that he was asked where he was. He replied thus: anā emši gāa'id 'I'm coming now [I'm coming out; I'm coming back; I'm moving]'. In Baghdad they say anā akūl gā'id 'I'm eating now', and in Qashqa-darya's Jeinau anā okul ga $\bar{a}^{c} i d$. In both cases is conveyed the continuity of an action in the present. In most cases the element $g \bar{a}^{\prime} i d$ is placed in the postposition and follows the imperfective of a verb (لاحقة فعلية):išrub gā'id 'he drinks [tea] now'. Rarely gā'id is found in the preposition (سابقة فعلية): gā́lid inšūf 'looks'.

Sometimes, mentioned construction can also convey Immediate Future as well. It mainly happens when $g \bar{a}^{\prime} i d$ is found in the preposition: $g \bar{a}^{c} i d i k t u b$ 'Let him write immediately!' In the Literary Arabic one of the meanings of qa'ada is 'to start', 'to begin': قعد يتكلّم 'started talking' (Baranov 2007: 650). In my opinion among the variety of meanings of qa'ada 'starting of an action' is a noteworthy one in our case. This meaning should have played an important role in establishing of qa'ada as an auxiliary element of the verb's active participle.

Rarely, in the discussed construction, gā'id can be replaced by verbal form ga' $a d$ and the following verb instead of imperfective can stand in the perfective. In this case, the action takes place in the past in a certain, definite time specified by context. For example: zōka $i$ hama gufur ğa' ga'ad '[Meanwhile] he came to the well.'

There are cases when Continuous tense is presented in the past. In this case, the construction is preceded by kān:

fad yōm mullō mim füg mačit ozōn kēyin yenti igā' ịd (Chikovani, 2007: 73, 1).

'Once a Mullah was [standing] on the top of the mosque [minaret] and performing a prayer (Azan).'

Below are examples of the Present Continuous from Central Asian Arabic:

adrūn Hुōỵt fad nāb ademi ibki gā' id (Chikovani, 2007: 45, 7).

'In the house (inside the house) one old man is crying constantly.'

pōšō ị rūha gāl-ki, -ỉ bēt Haldōr aġaddi, ieš kōr isī gā‘id ašūfa (Chikovani, 2007: 48, 10).

'The Pasha thought, [let me] go to Khaldor (Khaldor's house) and see what he is doing.'

pōšo igūl-ki: -min i füq hoyiț ițla', libōsāta agar ienza'a, ğo'ōn fad leyla ikæen gā'id la imūt agar, pōšō ị hama ādemi alf-hazōr țanga ienți (Chikovani, 2007: 52, 1).

'The Pasha says, 'The one, who will climb up (ascend) the roof of the palace, take off his clothes [undress and] spend [the whole] night hungry [in the coldness], if he does not die, the Pasha will give him (that person) one thousand tanga.'

zōka fad yōm ỉ hawlìta Hizma kēn isi igā'ịd (Chikovani, 2007: 77, 1).

'One day he was working in his yard [homestead].'

diqōn Hizma kān isi igā'ịd ỉ bōga (Chikovani, 2007: 77, 2).

'The peasant [at this time] was working in his garden.'

fad yōm îüg ġarabta fad laglag fār ğay gā'ịd (Chikovani, 2007: 77, 3).

'One day a stork flew up [he saw how it flew up] on the top of his garden [agricultural site].'

čūpōn ugūb Hūum Haza, ịpōšō mad. pōšō ỉ bèta kēn gā'id (Chikovani, 2007: 84, 3).

'Then the shepherd took the pot [and] went to the Pasha. [At this time] the Pasha was [sitting] in (his) house [palace].' 


\section{Conclusion}

According to the material presented, we can conclude that the usage of Present Continuous in Central Asian Arabic is productive. To convey the mentioned time Qashqadarya dialect currently uses two ways of morphological production clearly reflected in the texts of Qashqa-darya Arabic recorded by me in the kishlak Jeinau.

\section{BIBLIOGRAPHY}

Akhvlediani, V. 1985. Buxarskiy arabskiy dialekt (Bukhara Arabic Dialect). Tbilisi: Mecniereba (in Russian).

Baranov, X.K. 2007. Arabsko-russkiy slovar' (Arabic-Russian Dictionary). Moskva: Izdatel' Valeriy Kostin (in Russian).

Baskakov, A.N., Golubeva N.P., Kamileva, A.A., Lyubimov, K.M., Salimzyanova, F.A., \& Yusipova R. R. 1994. Büyük Türkçe-Rusça Sözlük. Istanbul: Multilingual.

Chikovani, G. 2002a. Shua aziis arabuli dialeqtebi. kashkadariuli dialeqti (fonologia, gramatika, leqsika) (Central Asian Arabic Dialects. Qashqa-darya Dialect (Phonology, Grammar, Vocabulary). Tbilisi: Ena da cultura (in Georgian).

Chikovani, G. 2002b. "The Verb in the Central Asian Arabic Dialects, Aspects of the Dialects of Arabic Today", Proceedings of the $4^{\text {th }}$ Conference of the International Arabic Dialectology Association (AIDA), Marrakesh, Apr. 1-4. 2000, in Honor of Professor David Cohen. 179-188.

Chikovani, G. 2007. Centraluri aziis arabuli dialeqtebi. kashkadariuli dialeqti (teqsti, targmani, ganmartebebi) (Central Asian Arabic Dialects. Qashqa-darya Dialect (Text, Translation, Comment). Tbilisi: Xironi (in Georgian).

Chikovani, G. 2008. Kashkadar'iskiy arabskiy dialect Central'noy Azii (Qashqa-darya Arabic Dialect of Central Asia). Tbilisi: Mtsignobari (in Russian).

Chikovani, G. 2009. Arabuli enis buxaruli dialeqti (Bukhara Dialect of Arabic Language). Tbilisi: Mtsignobari (in Georgian).

Chikovani, G. 2012. “Arabic Dialects of Central Asia: Internal Development Tendencies of Arabic Language Material”, Folia Orientalia, Studia Andreae Zaborski Dedicata, Vol. XLIX. 121-128.

Jasrow, Otto. 2014. "Dialect Differences in Uzbekistan Arabic", Durand, Olivier, Lanqone, Angela Daiana \& Mion, Guiliano (eds.), Alf Lahğa wa Lahğa: Proceedings of the $9^{\text {th }}$ AIDA Conference. Vienna: Lit Verlag. 205-212.

Lambdin, Thomas O. 2006. Introduction to Classical Ethiopic (Ge'ez). Harvard Semitic Studies 24, printed in the United States of America (first printed in 1978, originally published: Missoula, Mont: Scholars Press, 1978) (Library of Congress Cataloging in Publication Data): Amer Oriental Society.

Lane, E.W. 1968. Arabic-English Lexicon, Beirut: Librairie Du Liban. 
Leslau, Wolf. 1987. Comparative Dictionary of Ge'ez (Classical Ethiopic). Ge'ez-English/English-Ge'ez with an Index of the Semitic Roots, Part 2. Wiesbaden: Otto Harrassowitz Verlag.

Sharbatov, G. 1968. "Virajenie vremeni v sovremennom egipetskom dialekte”, Arabskaya filologija. Sbornik statey ("Expression of time in Modern Egyptian Dialect", Arabic Philology. Collection of articles). Moskva: izdatel'stvo Moskovskogo Universiteta. 121-132 (in Russian).

Testen, D. 1997. “The Suppletive Imperative of Arabic "Come”, Eid, Mushira \& Radcliffe, Robert, R. (eds.), Perspectives on Arabic linguistics X: Papers from the Tenth Annual Symposium on Arabic Linguistics. Amsterdam/Philadelphia: John Benjamin's Publishing Company. 173-187.

Tsereteli, G. 1937. "Shua aziis arabuli dialeqtebi (winaswari angarishi)”, enimkis moambe, I, ("Arabic Dialects of Central Asia (Preliminary Report)", The Herald of the Institute of History, Language and Material Culture, I). 295-307 (in Georgian).

Tsereteli, G. 1941. “K xarakteristike jazika sredneaziatskix arabov (predvaritel'noe soobshchenie)". Trudi vtoroy sessii assotsiatsii arabistov ("To the Characteristics of the Language of Central Asian Arabs (Preliminary Report)", Proceedings of the Second Session of the Association of Arabists), Moskva-Leningrad: izdatel'stvo Akademii Nauk SSR, 133-148 (in Russian).

Tsereteli, G. 1947. “Zmnis zogierti ziritadi formis warmoebisatvis buxaris arabul dialeqtshi”, tbilisis saxelmwifo universitetis shromebi, XXX/I b ("To the Formation of Some Verbal Forms in Bukhara Arabic Dialect", The Papers of Tbilisi State University, XXX/I b). 461-470 (in Georgian).

Ul-Bustani, Butrus. 1977. Muhit-Ul-Muhit, An Arabic-Arabic Dictionary, Beirut: Librairie DuLiban ( (بطرس البستاني , محيط المحيط , مكتبة لبنان , بيروت , 1977

Vinnikov, I. 1962. Slovar' dialekta buxarskix arabov, Palestinskij sbornik, 10 (73) (A Dictionary of Bukhara Arabic Language, Palestinian Collection, 10(73). Moskva-Leningrad: izdatel'stvo Akademii Nauk SSR (in Russian).

Wehr, Hans. 1994.A Dictionary of Modern Written Arabic(Arabic-English), Cowan,J. Milton (ed.), Urbana, IL:Spoken Language Services, Inc.

\section{NOTES}

1. Some examples are given from unpublished dialectological material recorded by me in Central Asia.

2. In round brackets are given verbatim translations and in square brackets - explanations.

3. The texts in the indicated book are divided into pieces. With the number of the page I indicate the number of the piece.

4. Here ta'a $a$ expresses a call to an immediate action. It is a good example to illustrate that the prefix $t a$ - should be a shortened form of $t a^{\prime} a \bar{l}$.

5. The meaning of zat is 'fat', but in this particular case it means 'pilaf'. 


\section{ABSTRACTS}

The peculiarities of Bukhara (BAD) and Qashqa-darya (QAD) Arabic dialects are mostly resulted by linguistic contacts with non-kindred to the Semitic languages Turkic (Uzbek, Turkmen) and Indo-European (Tajik, Dari and partly Russian) languages. In the mentioned dialects we see the old Arabic/Semitic forms and morphological formation as well as the cases of internal development. The changes caused by extra linguistic features must be taken into account as well. Central Asian Arabs' century long isolation from Arab world makes linguistic features of verb formation in Bukhara and Qashqa-darya dialects extremely interesting and important from the point of view of independent development of Semitic linguistic material.

In the paper is given analyse of the Complex (Immediate) Future and Present Definite Tenses as well as the origins of the morphological elements used for the formation of the mentioned tenses.

\section{INDEX}

Keywords: Central Asia, verb formation, Complex Future, Present Definite, Continuous Tense.

\section{AUTHOR}

\section{GURAM CHIKOVANI}

Free University of Tbilisi, Kakha Bendukidze University Campus, \#240 David Aghmashenebeli Alley, 0159, Tbilisi, Georgia, g.chikovani@freeuni.edu.ge 


\title{
La reduplication totale dans l'arabe levantin septentrional. Le cas de la faune
}

\author{
Emma De Murtas
}

\section{La réduplication}

1 Bien que le terme réduplication soit très utilisé en linguistique, une définition satisfaisante n'a pas encore été formulée selon Procházka (1995: 39) : beaucoup de phénomènes différents sont attribués à la réduplication, $\mathrm{y}$ compris celui où le seul signe de distinction est représenté par la simple répétition. Carl Rubino (2005: 11) définit la réduplication comme une répétition systématique de matériel phonologique à l'intérieur d'un mot avec des buts sémantiques ou grammaticaux et il estime qu'il s'agit d'un outil morphologique très utilisé dans de nombreuses langues du monde. Toutefois, la définition commune de ce concept n'applique la réduplication qu'au simple aspect morphologique.

Haspelmath (2002: 274) par exemple, définit la réduplication comme " un processus morphologique basé sur la répétition, totale ou partielle, de la base morphologique ». La définition de Maas (2005: 395), selon laquelle «il s'agit d'un expédient linguistique formel qui pourrait être utilisé à tous niveaux de la structure linguistique " semble être plus efficace. La réduplication a une incidence considérable sur la phonétique et sur la morphologie et, dans certaines langues, elle a également des fonctions grammaticales comme dans le grec où le temps parfait se forme par le redoublement de la première syllabe (grapho/gegrapha «j'écris/j’ai écrit»). Toutefois, la fonction de la réduplication que nous voulons rechercher réside dans la sémantique.

3 C'est en effet un moyen employé fréquemment pour décrire des actions ou des conditions non verbales ; il s'agit d'une forme d'expression imitative et analogique, c'est à dire que dans la plupart des cas elle est utilisée de façon spontanée (il suffit de penser au langage des enfants très riche de mots redoublés). D'un point de vue sémantique il existe une 
relation évidente entre les formes simples et celles redoublées ; le cadre sémantique concerné par toutes ces formes est celui de la pluralisation, de l'intensité et, peut-être, de la causativité selon le principe de l'iconicité. Ce dernier indique qu'une augmentation de la forme implique une augmentation de signification.

4 La réduplication implique souvent une extension de la signification d'un mot par rapport à la base non redoublée. Toutefois, il existe des exemples pour lesquels les dictionnaires n'enregistrent aucune acception différente entre la forme base et celle redoublée. Dans les cas où la réduplication comporte une augmentation de significations les noms redoublés sont normalement classés dans des groupes sémantiques bien définis tels que les diminutifs, les intensifs, les mots décrivant des sons ou des caractéristiques physiques ou personnelles. Beaucoup de ces groupes sémantiques sont de nature iconique (par exemple il y a une relation évidente entre la répétition des consonnes et les catégories sémantiques exprimées).

5 Pour ce qui est de l'onomatopée, phénomène qui est utilisé souvent dans les lemmes décrivant des effets acoustiques, optiques et de mouvements aussi bien rythmiques que continus, les structures et les sons diffèrent considérablement d'une langue à une autre. Cela nous empêche d'affirmer qu'il y a un rapport constant entre les sons de la nature, et leurs reproductions dans les différents langages. Le coq en allemand chante kikeriki, en français cocorico et en arabe kūkūkūk.

6 Selon la notion générale des changements sémantiques d'éléments lexicaux redoublés, l'aspect sémantique d'un lexique redoublé est soumis à l'augmentation puisque la réduplication est fortement liée, dans plusieurs langues, à des concepts grammaticaux tels que la distribution, la pluralité, la répétition et l'augmentation de dimension. Toutefois, la réduplication en tant que mesure d'iconicité, s'applique également à la dérivation, par exemple au changement entre catégories grammaticales (Butts $2011: 88$ ).

\section{La réduplication et l'arabe}

7 Dans les langues sémitiques, ce phénomène a été longtemps négligé. Les travaux de Pott (1862) et Fraenkel (1878) ont été les premiers à avoir consacré à la réduplication une valeur sémantique. Successivement Nöldeke (1904) a comparé un grand nombre de noms d'animaux qui, dans plusieurs langues sémitiques, avaient tendance à la réduplication. Brockelmann (1908) était convaincu que les verbes aussi étaient concernés par ce phénomène et Boekels (1990) a analysé en entier un dictionnaire d'arabe classique, il en a énuméré toutes les racines redoublées même s'il a limité son analyse à l'examen d'un seul lexème par racine : le verbe.

8 La situation de l'arabe est différente par rapport à celle enregistrée dans les langues indoeuropéennes : en effet, la structure de la racine (tri)consonantique, typique des langues sémitiques, a une influence considérable sur ce phénomène.

9 La forme de réduplication en arabe que l'on examinera ici est la répétition d'une base radicale à deux consonnes $(\mathrm{C} 1 \mathrm{C} 2)$ qui porte à une racine quadrilitère $(\mathrm{C} 1 \mathrm{C} 2 \mathrm{C} 1 \mathrm{C} 2)$. A titre d'exemple, DQDQ : daqdaq/ydaqdiq - «battre plusieurs fois : frapper plusieurs fois ».

On appelle cette forme "réduplication totale d'une base bilitère ». Cela n'implique pas que la base bilitère existe, au contraire, elle est presque inexistante. D'autres formes de réduplication existent, mais elles ne font pas l'objet d'analyse dans le cadre de cet article (notamment le redoublement d'une seule lettre radicale). 
11 Plusieurs tentatives de mieux spécifier les fonctions sémantiques de la réduplication ont été effectuées par le passé : Pott a été l'un des premiers, en 1862 à anticiper ce qui un siècle plus tard sera repris par Harold Key en 1965 dans un article intitulé «Some Semantic Functions of Reduplication in Various Languages ». Key a réussi à attribuer quelques fonctions à la réduplication en retenant plusieurs catégories: il a classé les verbes en 13 catégories différentes selon leur fonction:

1. Repétitivité, 2. Pluralisation, 3. Intensification, 4. Distributivité, 5. Continuité, 6. Action habituelle, 7. Verbe d'état, 8. Un changement sémantique générique, 9. Verbe qui indique impatience, 10. Future proche, 11. Verbe d'état au passé, 12. Possessivité, 13. Verbe possessif.

12 Les substantifs en 9 catégories :

1. Quelqu'un qui a l'habitude de faire quelque chose, 2. Diminutif, 3. Pluriel, 4. Substantif possessif, 5. Volume augmenté, 6 . Un changement sémantique générique, 7. Abondance, 8. Substantif distributif, 9. Dans les langues codifiées.

Les adjectifs en 3 :

1. Augmentation ou comparaison, 2. Augmentation ou pluralité, 3. Pluralité.

14 Par la suite Procházka (1995), sur la base du travail de Key, a relevé que les verbes représentent $53 \%$ des mots redoublés, les substantifs $35 \%$ et les adjectifs $12 \%$ et il a identifié 10 classes sémantiques : phénomènes acoustiques, mouvements, effets optiques, façons d'être, noms d'animaux, noms de plantes et de fruits, rondeur, parties du corps, géomorphologie et divers.

15 Quelle que soit la langue, l'onomatopée joue un rôle spécifique dans le cadre de la réduplication, mais en arabe la situation est compliquée en raison de la rigidité de la structure verbale :

$16 \mathrm{C} 1 \mathrm{aC} 2 \mathrm{aC} 3 \mathrm{a}$ au temps parfait et $\mathrm{Ya} \mathrm{C} 1 \mathrm{C} 2 \mathrm{a} / \mathrm{i} / \mathrm{uC} 3 \mathrm{u}$ au présent. Cette rigidité du schéma verbal arabe explique la difficulté à introduire des sons atypiques qui, au contraire, sont fréquents dans les langues indoeuropéennes : en allemand les sons tsch- ou qui- au début d'un mot ne se vérifient que dans des lemmes onomatopéiques ou dans les mots empruntés d'autres langues. Chaque langue a une sorte de rigidité, et souvent l'onomatopée ou les phénomènes phonosymboliques obligent à des exceptions aux règles grammaticales.

\section{Le corpus}

Le sujet traité dans cet article est analysé dans le cadre d'une recherche plus vaste, qui porte sur l'ensemble des valeurs sémantiques de la réduplication dans le dialecte arabe levantin septentrional. Les instruments de cette recherche sont les ressources lexicographiques de l'arabe palestinien. Plus particulièrement on a utilisé les dictionnaires de Barthélemy (1939 - 1955) et Denizeau (1960) pour les variétés levantines des dialectes sédentaires urbains et ruraux, ainsi que le répertoire le plus récent de Seeger (2009) qui a recueilli ses données dans les villages autour Ramallah. Bien que le lexique de l'arabe levantin septentrional soit bien décrit dans de nombreux dictionnaires, nous n'avions pas la possibilité matérielle d'utiliser toutes les ressources lexicographiques existantes et, en conséquence, nous avons choisi ceux qui, pour différentes raisons, semblaient plus appropriés à cette recherche. 
18 Au départ nous avions envisagé de n'utiliser que le dictionnaire de Seeger qui, étant le plus récent, est également le plus représentatif de la situation linguistique actuelle. Nous avons ensuite décidé de recourir à d'autres ressources lexicographiques afin d'avoir une base de données plus large et rendre ainsi nos résultats plus fiables.

19 Nous avons collecté tous les lemmes intéressés par la réduplication et plus proprement par la réduplication totale. Donc on a dépouillé les dictionnaires en sélectionnant les racines du type $\mathrm{C} 1 \mathrm{C} 2 \mathrm{C} 1 \mathrm{C} 2$ et on a collecté tous les lemmes dérivés de ces racines. Pour ce qui concerne l'ordre, nous avons retenu les critères des dictionnaires utilisés, les verbes d'abord et ensuite les noms. Tous les lemmes sont organisés sous les racines qui sont disposées par ordre alphabétique arabe. Nous avons construit le glossaire (qui est consultable en annexe) de cette façon: dans la première colonne se trouve la racine, ensuit le lemme arabe et puis sa traduction.

$20 \mathrm{Au}$ total le corpus (duquel la classe de la faune est une partie intégrante) compte 289 racines, 1.129 lemmes : 645 verbes et 484 nominaux (noms et adjectifs) répartis dans 9 classes sémantiques: /mouvement/, /bruit/, /faune/, /flore/, /effet optique/, / changement d'état/, /état/, /état d'esprit/, /rondeur : parties du corps/, /autres/.

Cet article traitera uniquement de la classe de la faune.

\section{La faune}

Les 52/1.129 lemmes que contient cette classe sémantique sont divisés selon les espèces d'animaux : oiseaux, insectes, quadrupèdes et animaux de la mer.

a) On commence par les lemmes que désignent les oiseaux qui sont les plus nombreux dans cette classe (26/52). Chaque langue souvent nomme les oiseaux sur la base de leurs attitudes ou de leurs caractéristiques physiques ou éthologiques, sans qu'il y ait nécessairement une conformité entre les différents idiomes. Le siqsāq en français prends son nom, "pluvier ", des pluies vers lesquelles il émigre. Le warwar " guêpier ${ }^{1}$ " selon Barthélemy est nommé par son cris. De même Barthélemy enregistre le lemme fsēfse en expliquant qu'il s'agit d'un : " petit oiseau dont le chant rappelle celui du rossignol et qui doit son nom à son plumage bigarré ${ }^{2}$ ». La plupart des oiseaux de cette catégorie sont petits. En effet, on a hudhud " upupa epops, huppe » et différents sont les passériformes comme basbūs « carduelis spinus, tarin des aulnes", zaqzūq « carduelis cannabina, linotte mélodieuse", fisfis "tout oiseau très petit», phylloscopus trochilus, pouillot fitis, phylloscopus collybita, pouillot véloce, prinia gracilis, prinia gracile ». Bien évidemment en Palestine on trouve aussi le bulbul « bulbul d'Arabie ou rossignol ».

b) Le deuxième groupe d'animaux (11/52) est celui des insectes: encore une fois on trouve une notion de petitesse. On a les insectes qui sautent comme șēsîr "petite sauterelle », ceux qui volent comme hishis «moustique, moucheron », ceux qui rampent comme daqdūq « vers à soie qui restent toujours petits et ne peuvent pas faire de cocon ».

c) Parmi les 10/52 lemmes qui désignent les quadrupèdes, trois réfèrent à l'agneau: barbūr «mouton, agneau », qarqū ${ }^{3}$ " agneau » et gargūr «agneau d'un an ». Le féminin gargūra désigne une "agnelle entrée dans sa deuxième année ». Les autres quadrupèdes sont duldul " hérisson », kabkāb " porc-épic », nasnās " espèce de singe plus petit que le sa'dān » (Barthélemy) et nisnās (Seeger) « mangouste d'Égypte ». 
26 d) Les derniers animaux de cette classe sont les animaux aquatiques (5/52). Encore une fois se présente le sémantisme de petitesse dans le cas de taftäfe «menus poissons, fretin » et farfüra «sorte de petit poisson sarcelle». Les autres créatures marines sont zifzif « coquillage » et nūnu « anguille ».

Comme on peut le voir dans cette classe il y a un sémantisme qui recoure : celui de la petitesse. On l'examinera dans le paragraphe suivent.

\section{La réduplication et l'iconicité} mouvements) mais aussi parce que, selon le principe de l'iconicité, l'augmentation de la forme entraine une augmentation dans le sens même dans le cas de la petitesse : șrēṣir "petite sauterelle », les traits sémantiques exprimés sont /sauterelle/ et /petite/. Donc l'augmentation du sens est donné par la spécification de la taille (dans cet exemple une petit taille). Pour ce qui concerne la classe sémantique de la faune, on peut noter que la plupart des lemmes qui la composent sont des oiseaux de petite taille ou des insectes: hishis, « moustique, moucheron »; șarșūr/șarāṣir, « coléoptère, cigale, coccinelle »; katkūt, «poussin, poulet». Et aussi pour ce qui concerne les autres animaux on revient sur le sens de petitesse : farfüra, « sorte de petit poisson »; nasnās, « espèce de singe plus petit que le sa'dān ». Donc la réduplication est utilisée, dans certains cas, pour la formation des diminutifs.

31 En même temps, on peut dire qu'il s'agit d'un système morphologique que d'un point de vue sémantique exprime la fonction augmentative comme en italien on a le suffixe -one. Par exemple le mot gatto " chat » avec le suffixe -one devient gattone " gros chat ».

ien qu'il existe une littérature sur les phénomènes du symbolisme phonétique, on a rencontré deux ordres des problèmes : premièrement les études sur ce phénomène en 
arabe (littéraire et dialectal) sont peu nombreuses. Donc on n'a pas des références sur lesquelles appuyer les théories formulées sur ce sujet. En même temps, les études qui ont été menées sur les phénomènes du symbolisme phonétique dans d'autres familles linguistiques ne sont pas toujours compatibles avec les langues sémitiques. Par exemple, la valeur des voyelles est déterminante pour les phénomènes du symbolisme phonétique : ainsi, selon les études menées par Ultan (1978), la voyelle [i] est-elle associée de façon naturelle, voire universelle, à l'idée de petitesse, alors que le [a] et le [o] renvoient à l'idée de grandeur. Les effets symboliques phonétiques peuvent concerner aussi la morphologie : d'une analyse typologique menée sur un vaste échantillon des langues, il résulte que $90 \%$ des langues considérées utilisent la voyelle [i] dans la formation du diminutif.

Mais aussi la valeur des consonnes est pertinente pour ce qui concerne le symbolisme phonétique. Il suffit penser à la célèbre expérience de Köhler « maluma - takete » (1929) au cours de laquelle, en montrant deux dessins, l'un curvilinéaire et l'autre pointu, les participants devaient associer les mots imaginaires maluma et takete aux deux figures. Le résultat a été que le $98 \%$ associait le mot maluma à la figure curvilinéaire et le mot takete à la figure pointue. Cette expérience montrerait qu'il y a, parfois, une correspondance non arbitraire entre la forme visuelle d'un objet et les phonèmes qu'on lui associe. Pour ce qui concerne cette recherche, par contre, on considère que la réduplication est porteuse d'iconicité. Si on pense à des verbes comme baqbaq/ybaqbiq, tartar/ytarter, lablab/ylableb, warwar/ywarwer «jaser» ou barbar/ybarber, tamtam/ytamtim, 'ad'ad/y'ad'ed, qarqar/ yqarqer, qa'qa'/yqa'qe' "murmurer" on ne trouve pas des phonèmes homogènes entre eux afin que l'on puisse établir que la valeur iconique concerne les consonnes.

Dans notre cas spécifique, le fait que des racines différentes aient la même signification montrerait que la forme, notamment $\mathrm{C} 1 \mathrm{C} 2 \mathrm{C} 1 \mathrm{C} 2$, est porteuse de sens et non les consonnes avec la valeur phono symbolique. Plus précisément le redoublement en soit peut-être porteur de sens et dans les cas dans lesquelles la réduplication a une valeur iconique on peut parler d'idéophones. Le mot anglais idéophone, forgé à l'origine par Doke (1935) pour les langues bantoues a été largement utilisé pour les descriptions des langues de l'Asie du Sud ou de l'Océanie et est aussi maintenant utilisé pour les langues occidentales.

L'idéophone, instrument de l'iconicité, est une catégorie linguistique ayant une fonction référentielle. Hagège affirme que «dans plusieurs langues, pas dans toutes, il existe des idéophones, des mots qui, comme le mot même l'indique, offrent une image sonore d'une idée pour exprimer un état, une impression sensorielle, une façon d'être ou de bouger, une action qui ne reproduit pas forcément un son ou un bruit " (Hagège 2009: 307). Il définit ces idéophones comme une sorte d'onomatopée qui utilise des articulations ou des combinaisons phoniques plutôt rares pour exprimer des impressions mentales particulières, associées à certains objets, mouvements ou situations (Hagège 1985 : 122)

Raphael Kaboré nous ramène à notre cas spécifique. En effet selon lui « les idéophones ne sont pas toujours redoublés, mais parmi ceux qui le sont, une grande partie est utilisée pour décrire des petits objets, des petits animaux, des insectes ou pour dénommer des façons d'être ou des processus de manière très précise et spécifique » (Kaboré, 1998 pp. 359-376).

37 Comme pour les onomatopées et, en général pour les phénomènes phono-symboliques, même dans la formation des idéophones il y a des mécanismes phonologiques et morphologiques tels que la répétition de syllabes ou des mots plus longs ainsi que l'alternance de voyelles entre des mêmes consonnes. Il s'agit d'un phénomène typique de 
la langue parlée, surtout dans des contextes familiers ou dans des contextes pragmatiques liés à l'affection. Il suffit de penser au langage enfantin.

On peut donc imaginer que la réduplication est un procédé expressif utilisé dans certaines classes sémantiques pour exprimer le diminutif, l'augmentatif, l'intensité, la pluralité ou, dans d'autres cas, pour imiter des sons, pour former des onomatopées, ou encore pour reproduire des phénomènes non acoustiques.

\section{BIBLIOGRAPHIE}

Barthélemy, Adrien, 1935-1969. Dictionnaire arabe-français, dialectes de Syrie : Alep, Damas, Liban, Jérusalem, Paris : Geuthner.

Boekels, Klaus, 1990. Quadriradikalia in den semitischen Sprachen unter besonderer Berücksichtigung des Arabischen. Thèse de doctorat, Berlin.

Brockelmann, Carl, 1908-13. Grundriss der vergleichenden Grammatik der semitischen Sprachen. Bde. III, Berlin.

Butts, Aaron M., 2011. Reduplicated nominal patterns in Semitic: Journal of the American Oriental Society 131, 83-108.

Denizeau, Claude, 1960. Dictionnaire des parlers arabes de Syrie, Liban et Palestine (Etudes Arabes et Islamiques : Etudes et Documents, 3), Paris : Éditions G.-P. Maisonneuve.

Fraenkel, Sigmund, 1878. Beiträge zur Erklärung der mehrlautigen Bildungen im Arabischen. Leyde : E. J. Brill.

Doke, Clement M., 1935. Bantu linguistic terminology. Londres : Longmans, Green.

Hagège, Claude, 1985. L'homme de paroles. Paris : Fayard.

----, 2009. Dictionnaire amoureux des langues. Paris : Plon-Odile Jacob.

Haspelmath, Martin, 2002. Understanding Morphology, New York : Oxford University Press.

Holes, Clive, 2004. "Quadriliteral verbs in the Arabic dialects of Eastern Arabia”, Haak, Martine et alii (éds) Approaches to Arabic dialects. A collection of articles presented to Manfred Woidich on the occasion of his sixtieth birthday. Leyde : Brill, 97-116.

Kabore, Raphaël, 1998. « La réduplication », Suzy Platiel \& Raphaël Kabore (dirs), Les langues d'Afrique subsaharienne (Faits de Langues 11-12). Paris: Ophrys, 359-376.

Key, Harold 1965. "Some semantic functions of reduplication in various languages", Anthropological Linguistics 7.3. 88-102.

Köhler, Wolfgang, 1929. Gestalt Psychology. New York: Liveright.

Lentin, Jérôme, 2012. « Le lexique du langage bébé (baby-talk) dans les dialectes arabes » Barontini, Alexandrine, Pereira, Christophe, Vicente, Ángeles et al. (éds) Dynamiques langagières en Arabophonies : Variations, contacts, migrations et créations artistiques. Hommage offert à Dominique Caubet par ses élèves et collègues. Saragosse : Universidad de Zaragoza / INALCO. 
Maas, Utz, 2005. "Syntactic reduplication in Arabic”, dans Bernhard Hurch (ed.), Studies on reduplication. Berlin. New York : Mouton De Gruyter : 395-429.

Nöldeke, Theodor, 1904. "Tiernamen mit Reduplikation”, dans Theodor Nöldeke, Beiträge zur semitischen Sprachwissenschaft. Strasbourg : Trübner, 107-123.

Pott, August F. 1862. Doppelung (Reduplikation, Gemination) als eines der wichtigsten Bildungsmittel der Sprache, beleuchtet aus Sprachen aller Welttheile. Lemgo u. Detmold: Meyer.

Procházka, Stephan, 1995. "Semantische Funktionen der reduplizierten Wurzeln im Arabischen”, Archiv Orientální 63, 39-70.

Rubino, Carl, 2005. "Reduplication: form, function and distribution", dans Bernhard Hurch (ed.), Studies on reduplication. Berlin. New York : Mouton De Gruyter : 11-29.

Seeger, Ulrich, 2009. Der arabische Dialekt der Dörfer um Ramallah. Bd. I : Texte. Bd. II : Glossar. Wiesbaden: Harrassowitz.

Ultan, Russell. 1978. “The Nature of Future Tenses”, Greenberg, Joseph H. (ed.), Universals of Human Language. Stanford : Stanford University Press : 83-123.

\section{ANNEXES}

\section{Glossaire}

Tous les lemmes sont organisés sous les racines qui sont classées par ordre alphabétique arabe. À l'intérieur de la classe sémantique nous avons indiqué les dictionnaires et ordonné les sous-classes.

\section{Abréviations}

Dictionnaires : $\mathrm{B}$ = Barthélémy, $\mathrm{D}=$ Denizeau, $\mathrm{S}=$ Seeger

Tableaux $:$ RAC $=$ Racine, DIC $=$ Dictionnaire .

Nous avons retenu les traductions de Barthélemy et Denizeau et nous avons traduit de l'allemand les traductions apportées par Seeger.

Faune

\begin{tabular}{|l|l|l|l|l|}
\hline RAC & LEMME & NOMS & DIC & Sous-classe \\
\hline ZRZR & zarzūr & cigale, grillon & D & INSECTE \\
\hline ȘRṢR & șarșūr/șarāṣir & coléoptère; cigale; coccinelle & S & INSECTE \\
\hline ȘRṢR & șrēṣir & petite sauterelle & D & INSECTE \\
\hline ȘRȘR & șarșor pl. șarāṣer & blatte, cafard, cri-cri, grillon & B & INSECTE \\
\hline ȘLȘL & șelāṣāl & cricri, grillon & D & INSECTE \\
\hline FRFR & farfūr & papillon & B & INSECTE \\
\hline FSFS & fesfos n. coll. & punaises & B & INSECTE \\
\hline
\end{tabular}




\begin{tabular}{|c|c|c|c|c|}
\hline FSFS & fesfse pl. -at & une punaise & B & INSECTE \\
\hline$L^{c} L^{c}$ & la'la'/yla'lec & $\begin{array}{l}\text { vers à soie qui restent toujours petits et ne } \\
\text { pas faire de cocon peuvent }\end{array}$ & $\mathrm{D}$ & INSECTE \\
\hline HSHS & hishis & moustiques & $\mathrm{D}$ & INSECTE \\
\hline HSHS & hishis-e/-āt & moustique ; moucheron & $\mathrm{S}$ & INSECTE \\
\hline BSBS & basbūs/basābìs & carduelis spinus (oiseau) & S & OISEAU \\
\hline BG்B $\dot{G}$ & bag்bag்ān & perroquet & $\mathrm{D}$ & OISEAU \\
\hline BLBL & bulbul/bulābil & pycnonotus xanthopygos; rossignol & S & OISEAU \\
\hline BLBL & blēbil/blēblāt & petit rossignol & $\mathrm{S}$ & OISEAU \\
\hline BLBL & belbol pl. balabel & rossignol & B & OISEAU \\
\hline TKTK & teketkiyye & petit oiseau & $\mathrm{D}$ & OISEAU \\
\hline ZQZQ & $z u q z u q$ & rouge-gorge & $\mathrm{S}$ & OISEAU \\
\hline ZQZQ & $z a q z \bar{u} q$ & carduelis cannabina & S & OISEAU \\
\hline SQSQ & siqsāq/sqāsīq & pluvier (oiseau) & $\mathrm{D}$ & OISEAU \\
\hline 'Q'Q & 'eq'oq pl 'aqā'i $q$ & pie (oiseau) & B & OISEAU \\
\hline FSFS & fisfis/fasāfis & $\begin{array}{l}\text { tout oiseau très petit } \\
\text { phylloscopus trochilus, phylloscopus collybita, } \\
\text { prinia gracilis; petite bille }\end{array}$ & $\mathrm{S}$ & OISEAU \\
\hline FSFS & fsēefse pl. $-\bar{a} t$ & $\begin{array}{l}\text { mosaïque; marqueterie faite de diverses } \\
\text { sortes de bois; petit oiseau dont le chant } \\
\text { rappelle celui du rossignol et qui doit son } \\
\text { nom à son plumage bigarré }\end{array}$ & B & OISEAU \\
\hline QRQR & qarqūra pl. -āt & vieille poule, vieille femme & B & OISEAU \\
\hline KTKT & katkūt f. -e /katākìt & poussin, poulet; enfant douce & S & OISEAU \\
\hline KWKW & $k \bar{u} k \bar{u}$ & coucou & $\mathrm{S}$ & OISEAU \\
\hline KWKW & $k u k u$ & coucou (oiseau) & $\mathrm{D}$ & OISEAU \\
\hline KWKW & $k \bar{u} k u$ & oiseau de basse-cour, volaille, pigeon & B & OISEAU \\
\hline KWKW & kūkìye & une cocotte, un pigeon, une tourterelle & B & OISEAU \\
\hline LQLQ & laqlaq & cigogne & $\mathrm{D}$ & OISEAU \\
\hline LGLG & laglag pl. lagāleg & cigogne & B & OISEAU \\
\hline
\end{tabular}




\begin{tabular}{|c|c|c|c|c|}
\hline MŠMŠ & mešmeši f. -ìye & $\begin{array}{l}\text { qui est couleur d'abricot; nom d'une espèce } \\
\text { de pigeons }\end{array}$ & B & OISEAU \\
\hline NMNM & namnūme pl. - $\bar{a} t$ & un petit pou (de poule) & B & OISEAU \\
\hline HDHD & $\begin{array}{l}\text { huhud, hidhid, abu l- } \\
\text { hudhud/hadāhid }\end{array}$ & upupa epops & $\mathrm{s}$ & OISEAU \\
\hline WRWR & warwār $/-\bar{a} t$ & merops & S & OISEAU \\
\hline WRWR & warwar & $\begin{array}{l}\text { merops apiaster, nom d'oiseau des champs } \\
\text { semblable à un gros moineau, il a le bec } \\
\text { long et la tête grosse, le plumage du } \\
\text { moineau femelle, la taille du merle ou du } \\
\text { loriot; revolver }\end{array}$ & B & OISEAU \\
\hline WṬWṬ & wațwaț/wațāwiț & chauve-souris & SBD & OISEAU \\
\hline$B Q B Q$ & baqbaq/ybaqbeq & animal aquatique qui plonge & B & POISSON \\
\hline TFTF & taftāfe & menus poissons, fretin & B & POISSON \\
\hline ZFZF & zifzif & coquillage & S & POISSON \\
\hline FRFR & farfüra pl. farāfir & $\begin{array}{l}\text { sorte de petit poisson; sarcelle; verge de } \\
\text { petit enfant }\end{array}$ & B & POISSON \\
\hline NWNW & $n \bar{u} n u$ & anguille & B & POISSON \\
\hline BRBR & barbūr & mouton, agneau & D & QUADRUPÈDE \\
\hline TFTF & taftaf & nom de chien & $S$ & QUADRUPÈDE \\
\hline DLDL & duldul & hérisson & D & QUADRUPÈDE \\
\hline DLDL & duldul pl. dalādel & hérisson & B & QUADRUPÈDE \\
\hline QRQR & qarqūr pl. qarāqīr & vieux coq ; agneu & B & QUADRUPÈDE \\
\hline KBKB & $k a b k a \bar{b} b$ & porc-épic & D & QUADRUPÈDE \\
\hline GRGR & gargūr & agneau d'un an & B & QUADRUPÈDE \\
\hline GRGR & gargūra & agnelle entrée dans sa deuxième année & B & QUADRUPÈDE \\
\hline NSNS & nisnās/nasānīs & herpestes ichneumon (mangouste d'Égypte) & S & QUADRUPÈDE \\
\hline NSNS & nasnās & espèce de singe plus petite que le $s a^{\prime} d a \bar{n}$ & B & QUADRUPÈDE \\
\hline
\end{tabular}

\section{NOTES}

1. En français son nom provient du fait qu'il se nourrit de guêpes. 
2. Du grec psefosis « mosaïque ».

3. Le dictionnaire de Barthélemy enregistre aussi « vieux coq ».

\section{RÉSUMÉS}

Cet article se propose d'examiner l'incidence de la réduplication sur le sémantisme des unités linguistiques et, de façon spécifique, sur les aspects iconiques qu'elle comporte. Bien que le terme réduplication soit très utilisé en linguistique, une définition satisfaisante n'a pas été encore formulée. Beaucoup de phénomènes différents sont attribués à la réduplication, y compris celui où le seul signe de distinction est représenté par la simple répétition. De nombreuses études ont été menées sur la réduplication et ses fonctions dans l'ensemble des langues. Ces études ont montré que, jusqu'à nos jours, la réduplication a été étudiée en tant que phénomène principalement morphologique ou phonologique. Il parait donc utile d'effectuer une étude sur l'incidence de la réduplication sur la sémantique, en analysant les aspects iconiques de ce phénomène. Pour cela il est nécessaire de se confronter aux variétés dialectales, moins soumises aux règles formelles que l'arabe standard moderne et que l'arabe classique, afin d'approfondir les thèses proposées par Clive Holes sur la valeur expressive et idiomatique des quadrilitères dans les dialectes néo-arabes. Pour cette raison, cet article portera sur le dialecte arabe levantin septentrional. La forme principale de réduplication en arabe est la répétition d'une base radicale à deux lettres $(\mathrm{C} 1 \mathrm{C} 2)$ : on appelle cette forme "réduplication totale d'une racine bilitère ". D'autres formes de réduplication existent, mais elles ne font pas l'objet d'analyse dans cet article (notamment le redoublement d'une seule lettre radicale).

\section{INDEX}

Mots-clés : réduplication, quadrilitères, sémantique, iconicité, arabe levantin septentrional

\section{AUTEUR}

\section{EMMA DE MURTAS}

Université Sorbonne Paris Cité - Paris Descartes, emmademurtas@hotmail.it 


\title{
Zara'nā Law Tala' et Yā Rēt! On Wish, Hope, and other Bouletic Modalities in Spoken Arabic from Syria
}

\author{
Daniela Rodica Firanescu
}

\section{Introduction}

1 With this paper, we pursue our journey with modalities in spoken Arabic from Syria, illustrated through articles presented, for their great majority, in AIDA conferences ${ }^{1}$. It focuses on the bouletic (also 'boulomaic') category, intimately related to the area of irrealia, possibilia or 'possible worlds'. While the alethic and deontic modalities (that we have examined elsewhere ${ }^{2}$ ) are rather the domain of truth and reality (although the literature on modalities acknowledges that certain varieties of deontic are necessarily imbued with a volitive, speaker-oriented illocutionary force), bouletic modalities are, par excellence, the realm of subjectivity that pertains to volition and possible worlds.

We analyze conventionalized expressions used in spoken Arabic from Syria to convey the meanings of wish and hope that form the core of the bouletic modality: mainly desiderative operators (law, 'izā, 'alaww, wēn, barki), the semantically complex expression $y \bar{a}$ rêt (would God...!; if only...!), as marker of 'desirable' and some specific combined expressions. Other various bouletic expressions, situated at the negative pole - unsuitable (makrūh/bəkarrih), frightening (muHīf/bəHawwəf), rejectable, repulsive (marfūḍ/karih, bəšə) will, hopefully, be the object of further observation.

The interpretative approach highlights the hybrid character of the illocutionary acts performed through the use of bouletic operators, proving that in Syrian - as, in general, in natural languages - the bouletic modality is deeply connected with (and, sometimes, dependant on) other modalities, especially evaluative and deontic. Ultimately, our approach sheds light on the linguistic creativity manifested by Syrian Arabic speakers when modalizing their discourse, an aspect that emphasizes the virtues of the colloquial mode that sets no limits to expressivity. 
4 Abbreviations: we use 'n.d.' for non-dated references (mainly electronic); 'el.' for electronic resources.

\section{Definition of terms and theoretical approach}

\subsection{Bouletic: definition}

5 A simple definition of bouletic modality is: "A type of modality that expresses what is possible or necessary given someone's desires" (ODLT, el.). In general linguistics, bouletic is most of the times considered a root modality (perhaps since Hoffman's - 1966 classification), "root" modalities being all modalities other than epistemic: deontic, circumstantial, dynamic (ability and disposition generally included), bouletic, teleological, etc. (the number and categories of modalities depending on the various existent typologies at various authors). For Kilpatrick \& Barker (n.d., 3, el.), "bouletic modality is a type of non-root modality, somewhat similar to deontic modality, but specifically concerning the desires and wishes of some relevant agent"; it is, for these authors, a 'volitional modality' - i.e., supposing a volitional agent - "that is not reliant on the lexical features of a verb".

6 According to Hacquard's (2011: 3, el.) definition (based on Kratzer's - 1981, 1991, etc, seminal work on modalities), who takes into account deontic and alethic aspects, but still emphasizes the desiderative as a core of bouletic, the "bouletic modality expresses possibilities and necessities given particular desires (from Greek boule 'wish')".

Other definitions of bouletic are schematic, non-detailed. The bouletic modality may be completely omitted as a modal category, "core" bouletic expressions being treated as "optative examples of contra-factivity" (Mitchell \& Hassan (1994:12) - referring to ya retni ruht I wish I had gone). Bouletic seems to be a sort of "waste-basket of modalities" (paraphrasing Bar-Hillel's 1971 metaphorical expression "waste-basket of linguistics" that depicts pragmatics as being considered, sometimes, the waste-basket of linguistics, especially of syntax and semantics).

\subsection{Bouletic among other modalities; symbouletic modality}

8 Portner (2009: 36) notes: "Not all modality in natural language can be classified as epistemic or deontic. We need other categories. Some of the other general varieties of modality include, besides epistemic and deontic, the modalities of ability, desire (called 'bouletic modality'), goals (also called teleological modality) and perhaps history". 'Symbouletic', a term proposed by Igor Yanovich $(2013,2014)$, defines the modality of suggestion and advice, that we will take into account herein, as it is very close to the core (hope and wish) of bouletic.

\subsection{Bouletic accessibility relation}

Portner's (2009: 36-37) vision of bouletic highlights the role of the "accessibility relation":

$\mathrm{R}$ is a bouletic accessibility relation iff for some individual $i, R=$ the relation which holds between two worlds $w$ and $w^{\prime}$ iff all of $i$ 's desires in $w$ are satisfied in $w^{\prime}$. (...) A bouletic frame is one which has the set of possible worlds conceivable by humans as $W$ and a bouletic accessibility relation as $R$. 


\subsection{Modal flavor and bouletic ordering source} related to the interpretation of a sentence as conveying a bouletic modal meaning. It has been noted that "natural language modals seem to vary along (at least) two dimensions: 'force' (whether they express possibility or necessity), and type of interpretation, or modal 'flavor"' (Hacquard 2011: 3, el.) that needs to be detected then interpreted. As a generally applicable view, "modal interpretations differ in their selection of a modal base, of an ordering source, and in the requirements they place on the optimal worlds picked out by the ordering source" (Kilpatrick \& Barker, n.d., 11, el.). The bouletic ordering source "reflects the desires and intentions of some agent involved in the described event".

\subsection{The role of the context in interpreting the modal flavor}

Discussing the example below, Portner (2009: 49) insists on the role of the context in the determination of sentence meaning:

For example, if we are talking about the fact that Mary loves broccoli, (70) naturally receives a bouletic interpretation, while if we are trying to enforce the idea that children should eat everything on their plates, it naturally receives a deontic interpretation:

(70) Mary should eat her broccoli.

For our further interpretation, we retain the implied idea that bouletic and deontic values may be very closely related, the final interpretation we give to a sentence depending - to a great extent - on detecting the speaker's intended meaning and volition. Indexical information may play a vital role in assigning a final meaning to a modal.

\section{Corpus}

13 The corpus is almost entirely formed from samples of expressions used in spoken Arabic of Damascus and Aleppo (the provenience of the examples is indicated by the abbreviations $D$ and $A$ ) that we collected (sometimes tape-recorded, some other times conserved as written notes) during our stays in Syria, on several occasions, and during conversations with Syrian informants, in latest years. For space reasons, the examples included here are limited to the strictly necessary; they are selected from a much larger corpus on which we base some considerations regarding the core expressions that convey the modal meanings examined.

\section{The core of bouletic in spoken Arabic from Syria (according to criteria of meaning, conventionalization, and frequency)}

Positive pole - Wish, Hope:

A. Constructions with desiderative law (sometimes 'izā);

B. Conventionalized expressions: $y \bar{a} r \bar{e} t, r \bar{e} t, r \bar{e} t+$ suffix pronouns 

these (non-recommendable, undesirable, unwanted, negative wish, etc.), from the speaker's subjective perspective:

- 'ahsanla(i)k - you'd better, you should [rather /better] do... (symbouletic)

- Constructions containing the word 'Allāh: 'Allāh yəhfaz-ak May God preserve you/keep you, 'Allāh yeblik May God afflict you, in šăa'a 'Allāh God willing, I hope that...; also: I believe/trust that. Variant: $n$ šalla (at the end of the statement, possibly grammaticalized for expressing vindictive or resentful reproach); 'iza 'Allah rād, 'in rād 'Allah, 'in 'Allah sahhal, etc. (with short vowel $a$ in the word Allah).

- la'alla wa-'asā+Subjunctive: hopefully - intense hope/aspiration, mixed with uncertainty, but may express, as well, a certain degree of conviction/trust that the desired event will happen; implies that there is little hope for the desired thing to happen, but the agent keeps hoping that it will occur, eventually.

2. la'alla w-'asā nšūf-ik ši masa (maybe/hopefully I'll see you one evening! = I so much wish I can see you; lyrics of the song La'alla $w$-'asā performed by Syrian singer Noor Mhanna).

- barki/balki (that we have approached elsewhere; also, thoroughly analyzed by Salamé \& Lentin (2010:107), as always including, to various extents "une implication du locuteur sur la conjecture qu'il introduit (...), et souvent (...) ses craintes ou ses espoirs à l'égard de cette conjecture") - perhaps, maybe, possibly, could/may/might be that, it may/might happen that, hopefully (will/will not) occur/happen with complex modal flavor, predominant deontic-bouletic (would include symbouletic)

- wa-law! - so, what?! I wish/hope you do (implied: no worries, I won't be upset if you do, on the contrary!)

- various imperative formulas (also with kirmāl for someone's sake, as a bouletic marker)

- 'alaww ('alawwāh), wēn (in rhetoric interrogation) - It would be so nice/great! - both conveying the sense of longing for something, wishing it to happen, etc. 
- evaluative expressions: niyālak! Lucky you! (admiration, positive evaluation; or ironic,

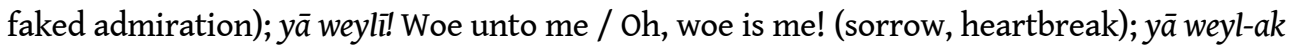
Woe unto you!

- some constructions with $l \bar{a}+$ Subjunctive (in interrogation)

3. kêf / šū baddi sāwī la-tsāmihịnī?! D (How / what should I do so that you forgive me?!)

- various expressions of unsuitable - (makrūh/bəkarrih), 'frightening' (muHīf/bəHawwəə), rejectable, repulsive (marfüd/karih, bəšð') - which define a specific type of subjectively defined necessity that expresses in fact the speaker's perception and/or emotional attitude towards what is or is not suitable/desirable

- cursing and swearing

- using allusive talk and proverbs, with evaluative purpose

- etc.

\section{Illustrations of the "hard core" of bouletic}

We can only deal here with expressions that mainly convey (directly or in mitigated ways) wish and hope, focusing on the "hard core", namely the categories A and B (see above, 3.). The following are illustrations of such conventionalized expressions with high frequency in the corpus:

Law and 'izā: conditional versus desiderative

Both particles are part of conditional constructions (not approached here), but both are used as well in desiderative expressions (sometimes not easy to be delimitated from the "purely" conditional ones), desiderative law being much more frequent than desiderative 'izā.

A construction that seems to stand for a hypothesis or expectation that has a chance to be achieved in the future, often carrying a bouletic modal flavor, when it refers to a positive possible development, interpretable as such depending on context (otherwise, it remains a marker of supposition - 'in the case that...') is 'izā kān (Past, uninflected)+verb at Past (although the expectancy is directed towards the future):

4. 'iza kān țla'nā mən ha-n-nār, bəddi rabbì wlādī wēnma kān! D (If we get out of this hell, I will raise my kids anywhere!)

Desiderative law

Does law always refer to a failed hope in the past? Does it refer to an unrealized / unrealizable hypothesis or unachieved /unachievable hope?

Cowell (1964: 335) states that "most conditions expressed with law are hypothetical and most, therefore, are contrary to the fact or expectation. The verb of a law-clause is generally in the perfect tense", but adds that "in desiderative (if only, would that) conditions, however, law is commonly followed by verbs in the imperfect (indicative or subjunctive) or by non-verbal clauses. The apodosis is often suppressed". The following example from Cowell illustrates the desiderative value of law followed by imperfect: 5. law yəhki kalme wahde btənhall əl-məškle D (If he would just speak up once, the problem would be solved!) Intonation and contextual factors may make conditional statements with law interpretable as carrying a desiderative complex meaning (bouletic modality). The use of 
law implies the regret that the desired event has not happened so far, but it does not necessarily indicate that it cannot occur in the future. The nuance of regret/ disappointment is almost always present, but possibly mixed with the flavor of resilient hope.

Structures containing law

- Followed by Past; kān at past tense + verb at past tense, in the main clause:

kənt rəhət ma'kon əmbērha law žitu la-'anna bakkir! D (I would have gone with you yesterday if you had come to us/our place early/earlier!)

37 - Present in the conditional clause - Present tense of kān (uninflected) followed by the present, in the main clause because the condition/situation affects the current decision making:

7. law bābā məš mašğūl, kān nəțla' 'a bēt nēnt-ak ya habibī, yā karbūğ! A (Should Daddy not be busy, we would go to your Grandma's, my sweetie, my pumpkin!).

However, usually, kān is followed by the past tense:

8. law rahti la-'ando bə-l-'eiyyāde! kənti ta'arrafti 'a-d-daktōr yalli mart-o rōmāniyye. Bas yallah, l-marra ž-žāye. Mhammad birūh l-o kəll žəm'a. A If you had gone to him to the clinic! (=You should have gone to him to the clinic!) You would have made the acquaintance of the doctor whose wife is Romanian. But no problem, next time. Muhammad goes to him every week.

41 - In the context, and with the main clause omitted, the bouletic value is prominent: hope is open for the future; $k \bar{a} n$ is absent from both clauses:

9. $\bar{a} \mathrm{H}$, law šaft-o tānì! D, A Oh, if I'd see him again! (Intonation conveying the meaning of regret, longing, and hope)

10. law rakab aț-țeyyāra 'ab’l ma yisakkarū l-mațār! Bas ma mna'ref! Yā rēt-o laha'! D If he only could get on the plane before they closed the airport! But we don't know! I wish he made it! (Intonation of fear+hope).

- Followed by kān (perfect) with apodosis suppressed; the hope seems to be directed mostly towards the future, but the context may clarify if it is just a failed hope in the past:

12. law kənt ${ }^{2}$ bmahall-ak bas! D If I only were in your position/shoes [in the past, now, or in the future]! Bas reinforces the sense of regret, but also of hope (like 'only' in English).

47 13. law kān วl-žaw 'arham b-šuwayy! D If only the weather were/was/will be a bit milder! (Out of the larger context, it is not possible to determine the temporal orientation).

48 - Followed by the indicative present:

49 14. law bətšŭfi šad kānet zarīfe w-habbābe ma'nā! A I wish you had seen / You should have seen how kind and affectionate she was with us! The law clause expresses the regret for the past (that the interlocutor has not seen or witnessed the signs of kindness, but the Indicative Present induces the hope that the desired thing may happen in the future.

50 - Present conditional: lawlā mā

51 15. kənnā bənrūḥ ma'kon lawlā mā kān 'annā maw'ed ed-daktōr el-lēle. Yā Hsăara! D We would go with you if we hadn't the doctor's appointment today. What a pity! 

[could] do, etc. It is a conventionalized expression of failed hope, as illustrated by the saying: builds a house, i.e. With "if only" / "I wish it were" [with a defeatist attitude], one can never build a house. to what he is being told! Analyzed in context (omitted here), it expresses failed hope (based on past experience of failure) with the indicative present after kān indicating that the illocutionary force is oriented towards the present.

72 25. yā rēt-o kān səme kalām! - I wish he had listened to what he was told! Past after kān indicates failed hope in the past.

73 - Construction with $y \bar{a}$ elided: rēt +pronoun suffix: would sooner/rather do... than...; the desiderative flavor persists: 
"would that"; we threw the seeds of "if", they germinated "if only"; we have sown "if", it came up "it would have been so nice!", etc. Sometimes considered a saying (maqūla), some other times a proverb (matal), this expression figures on many lists of Syrian proverbs, but it is also on Palestinian Arabic lists and seems to be spread over the whole Levantine area (possibly a pan-Arabic proverb?). It expresses affliction caused by an unfulfilled wish, the deep regret caused by a failed (or failing) hope to see a good outcome of some action or development.

81 A cultural aspect, perhaps relevant, is that in the Islamic tradition, law marks a statement negatively, if used to express the regret related to one's deeds in the past or past events. A prophetical tradition recounted by Muslim (cf. Al-Nawawī, el., Šarh...: Kitāb al-qadar, Bāb al-'amr bi-l-quwwa...) warns about the fact that "law opens the [way to the] work of the devil" (law taftahu 'amal aš-šayțān); al-Nawawī's explanation is that law "sows in the heart the opposition to the divine decree and [through this] Satan awakes in the heart his temptation/doubts" (yulqi fí-l-qalb mu'āradat al-qadar wa-yuwaswisu bi-hi š-šayțān).

Versions of the same expression (29) are wordplay, pun-like expressions, not as widely spread sayings or frequent formulas; sometimes, they seem to be individual creations; checked with Syrian informants, they proved to be functional and meaningful:

30. law zara'nā law kān țala'et yā rēt! If we had sown/planted "if", it would have come up "if only" / "would that it were..."

31. zara'nā al-law țala' et / tala' bi-l-'äHer yō rēt We sowed the seeds of "the if", at the end it came up "if only" / "would that it were...". Note that law is articulated or substantivized, meaning "the" if, a specific type of if, well defined, interpretable as the one carrying by excellence the meaning of doubt (defeatist, pessimistic view).

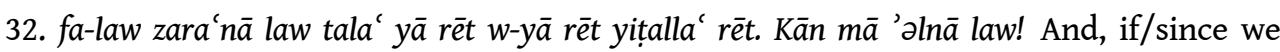
sowed "if", it came up "if only"; and "if only" sprouts/germinates "would that it were". Were it not that we said "if"! 


\section{versatile modal, but whose main flavors are deontic-bouletic. "Should" is often a part of a} double modal construction. It has been noted that (Kilpatrick \& Barker, el.: 4):

(...) the meaning of a double-modal construction cannot be equated with any interpretation of the lower modal alone, nor can it be paraphrased by the meaning of any single modal. Rather, each modal makes its own characteristic and irreducible contribution to the meaning of the construction as a whole.

The same authors emphasize (p.13) that "there are two crucial restrictions evident: the lower modal [the first] always has a circumstantial base, and the upper modal [the second] always has a bouletic ordering source". The following example would reveal the virtues of the construction 'ahsan l(a)+pronoun suffix (all words pronounced together, in one sequence) that seems to play in Syrian the role of deontic-bouletic "should". In both 37 and 38, this construction represents the upper modal; in 38, both modals carry a bouletic modal meaning, together conveying a symbouletic modal flavor (strong recommendation). core of the positive pole of the bouletic modality in spoken Arabic from Syria. Beyond conventionalization (or, sometimes, right because of it), there is wide room for the speaker's creativity, as far as the main syntactic constructions and key-words are preserved. Further investigation should probably focus on the core of the negative pole, followed by the expressions situated at variable distances from the two poles, but liable to convey bouletic meaning. The material available for analysis suggests that the less conventionalized are some expressions, the more we need to incorporate pragmatic analysis tools (indirect speech acts, conversational implicatures, pragmatic politeness theories, mitigation, etc.), as the bouletic flavor may be evasive or blended with other modal flavors, depending on the complex pragmatic context. 


\section{BIBLIOGRAPHY}

\section{Printed}

Abderraḥīm, Y. 2003. Mawsū'atu l- 'àmmiyyati s-sūriyya. Dirāsa luġawiyya naqdiyya fìl-tafșịh wa t-ta' șīl wa-l-muwallad wa-d-daHīl. 4 vols., Damascus: Manšūrāt wizārati ț-țaqāfa.

Bar-Hillel, Y. 1971. "Out of the Pragmatic Wastebasket”, Linguistic Inquiry 2. 401-407.

Cowell, M.W. 1964. A Reference Grammar of Syrian Arabic. Washington, D.C.: Georgetown University Press.

Firanescu, D.R. 2000. « De vouloir à devoir en arabe syrien », Bucuresti : Analele Universitatii Bucuresti XLIX. 109-120.

Firanescu, D.R. 2016. "Hāšă-ki yā bintī! On Alethic and Deontic Modalities in spoken Arabic from Syria", George Grigore and Gabriel BiȚună (eds), Arabic Varieties: Far and Wide. Proceedings of the 11 th International Conference of AIDA - Bucharest, 2015. Bucharest: Editura UniversităȚii din București. 251-258.

Firanescu, D.R. 2017. “Ḍalli Žāye La-'annā! Keep Coming to Us! On Modalitites of Continuity and Persistence in Spoken Arabic from Syria", Al-Hamad, Muntasir F.F., Ahmad, R. \& Alaoui, H. (eds), Lisan Al-Arab. Studies in Arabic Dialects. Proceedings of the $10^{\text {th }}$ International Conference of AIDA Qatar University, 2013. Vienna: LIT Verlag. 163-186.

Hoffmann, T.R. 1966. "Past tense replacement and the modal system". A. Oettinger (ed.). Mathematical Linguistics and Automatic Translation. Cambridge, MA: Harvard University, Harvard Computational Laboratory. Report NSF -17.

Kratzer, A. 1981. “The Notional Category of Modality” In Eikmeyer, H. J. \& Rieser, H. (eds), Words, Worlds, and Contexts: New Approaches in Word Semantics, Berlin: de Gruyter. 38-74.

Kratzer, A. 1991. "Modality" in von Stechow, A. and Wunderlich, D. (eds). Semantik/Semantics: An International Handbook of Contemporary Research. Berlin: de Gruyter. 639-50.

Mitchell, T.F. \& (al-)Hassan, S.A. 1994. Modality, Mood and Aspect in Spoken Arabic (With special reference to Egypt and the Levant), London, New York: Kegan Paul International.

Portner, P. 2009. Modality. Oxford University Press.

Salamé, C. \& Lentin, J. 2010. Dictionnaire d'arabe dialectal syrien (parler de Damas), <halshs-00504180v2>.

\section{Electronic}

Hacquard, V. 2011. "Modality”, C. Maienborn, K. von Heusinger, and P. Portner (eds.) Semantics: An International Handbook of Natural Language Meaning. HSK 33.2 Berlin: Mouton de Gruyter. 1484-1515.

http://ling.umd.edu/ hacquard/papers/HoS_Modality_Hacquard.pdf

Kilpatrick, C. \& Barker, C. n.d "Volitional Modality in the double-modal construction in Southern US English"

http://citeseerx.ist.psu.edu/viewdoc/download?doi=10.1.1.184.443\&rep=rep1\&type=pdf 
(Al-) Nawawī, Yaḥyā Bin Šaraf Abū Zakariyā. Šarḥ al-Nawawī 'alā Muslim. Dār al-Huayr. 1996. http:// library.islamweb.net/newlibrary/display_book.php?idfrom=7802\&idto=7803\&bk_no=53\&ID=1245

ODLT (Online Dictionary of Linguistic Terminology) : http://www.odlt.org/ballast/

bouletic_modality.html

Yanovich, I. 2013. "On Advice Modality”

http://www.sfs.uni-tuebingen.de/ yanovich/papers/on-advice-modality.pdf

Yanovich, I. 2014. "Symbouletic Modality”, Christopher Piñón (ed.) Empirical Issues in Syntax and Semantics 10. 161-178

http://www.cssp.cnrs.fr/eiss10/

\section{NOTES}

1. Published articles cover the period 2002-2017.

2. Firanescu 2016 and 2017.

\section{ABSTRACTS}

In this paper we deal with bouletic (or boulomaic) modalities in spoken Arabic from Syria, a modal variety intimately related to the area of irrealia, possibilia or possible worlds. While the categories of alethic and deontic are rather the domain of truth and reality, bouletic modalities are, par excellence, the realm of interlocutors' subjectivity. Our paper analyzes conventionalized expressions used in spoken Arabic from Syria to convey the meanings of wish and hope (that form the hard core of the larger bouletic modality); we focus on the 'hard core' of bouletic: the semantically complex expression yā rēt (would God...!; if only...!), with its possible combinations, as marker of desirable, and on desiderative operators law, 'izä, 'alaww, wēn, barki, etc.

The interpretative approach highlights the hybrid character of the illocutionary acts performed through the use of bouletic operators, proving that in Syrian - as in natural languages, in general - the bouletic modality is deeply connected with (and even dependant on) other modalities, especially evaluative and deontic. Ultimately, our approach sheds light on the linguistic creativity manifested by Syrian Arabic speakers when modalizing their discourse: an aspect that emphasizes the virtues of the colloquial mode that sets no limits to expressivity.

\section{INDEX}

Keywords: modalities, bouletic flavor, volitive, desiderative, speakers' creativity 
AUTHOR

DANIELA RODICA FIRANESCU

Dalhousie University, Halifax, Canada 


\title{
Preliminary Notes on the Arabic Dialect of the Chiadma (North of Essaouira)
}

\author{
Felipe Benjamin Francisco
}

\section{Introduction}

1 The Chiadma's territory is situated at the Province of Essaouira - in the Region of Marrakesh-Safi. Their lands are limited on the north by the Tensift river, on the south by the Haha (Ihahen) territory; west by the Atlantic Ocean and east by the Al-Haouz Plains (Faụlillāh 1994:241).

2 From the standpoint of the Historical Dialectology of the Maghreb, we suppose that the Arabic of the Chiadma probably contains Bedouin type traits, which are well known to characterize the varieties along the Atlantic plains from Asilah as far as Essaouira (Colin 1938:230). Similarly, Heath (2002) classifies what he calls the "Atlantic strip" varieties as belonging to his Central-type category, just as Boukous (1995) who labels the varieties of this same area as $\{r \bar{u} b i$. In fact, the latter is the same term, used by the inhabitants of Essaouira, when referring to the variety spoken in the outskirts of the city, inside the Chiadma territory. Despite of that, we still do not have access to the varieties spoken in many parts heading south Casablanca, especially inside the Chiadma territory, except for nearby areas such as Safi and Azemmour (Heath 2002) and the Doukkala region (Premare 1993).

3 To this end, this study provides new information about the variety spoken in the Chiadma territory. Firstly, we try to shed the light on the origin and lineage of the Chiadma as a tribe. Then, we explain the method of data collection during our fieldwork in a village ( dŭwwār) at Bhaybəh beach, in Akermoud. Lastly, we propose a brief description of the variety, presenting its linguistic systems: Phonetics, Morphosyntax and Lexicon. 


\section{The Chiadma tribe}

4 The origins of the Chiadma are not very clear, even though they are usually considered Arabs since they are an Arabic speaking tribe. Moreover, they identify themselves Arabs in opposition to the Haha, whom they call slüh, and with whom they have been in contact for centuries. And even though, in modern times, the borders between the Chiadma Arabic speaking territory and the Haha (Ihahen) tachelhit speaking territory are very well marked, yet some authors argue the Chiadma are of Berber origin.

Boukous 1995 - Carte linguistique du Maroc. Arabic speaking (orange). Berber speaking (yellow).

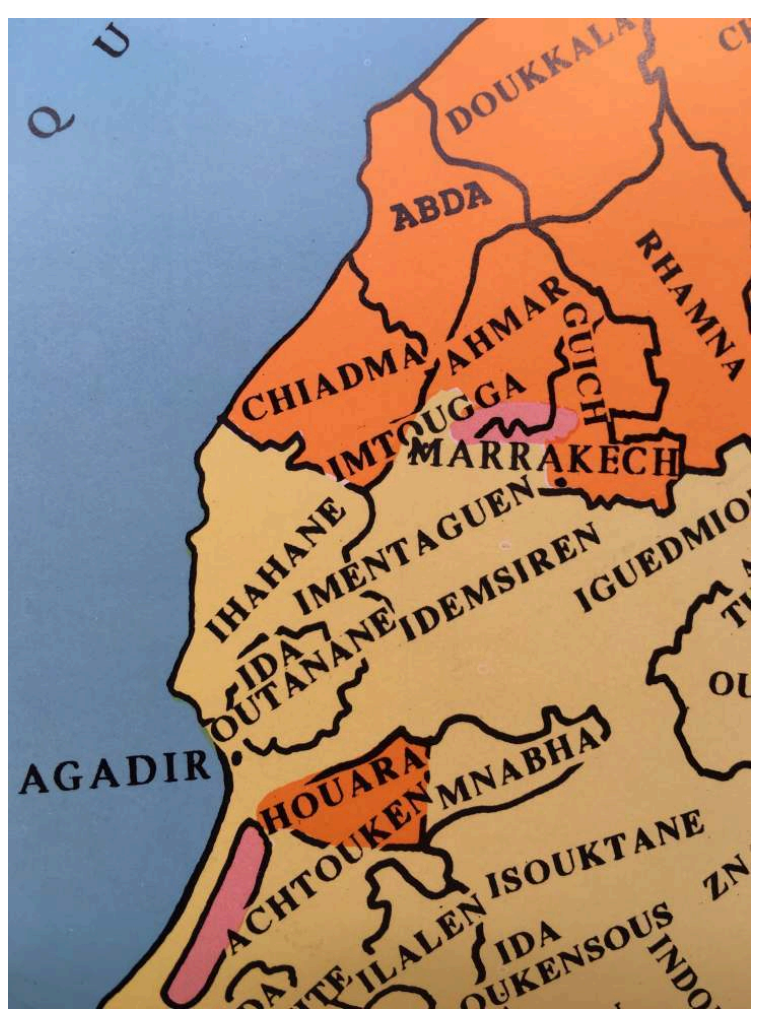

5 First of all, the etymology of their name is clearly Arabic as in Ibn Mandūr: šaydam and (شيظم) šaydami with the plural form (شيظميّ) šayādima meaning tawil 'tall', ğasim 'big, corpulent, great', and it can be applied to people, but to animals as well, such as horses, camels or lions; for instance: riḡăl šayādima 'big men'. In the current pronunciation at this region, in the vernacular Arabic, the word lost the diphthong /ay/ and the phoneme /d / [ظ] became /ḍ/ [ض], resulting in šyādmawhat explains , شياضمة] the current romanized version of the name in use "Chiadma".

Works written by historians from the $16^{\text {th }}$ century seem to confirm the Arab origins of the Chiadma. As we can notice in the following lines, they used to distinguish between the Haha and the Arab tribes who used to live in their territory, and the Chiadma were among them.

7 The Chiadma are often mentioned as living side by side the Al-Hāanit of the Banī Hilāl tribe. Leo Africanus mentions the Chiadma in his Descrittione dell'Africa (1528) when talks about the Banī Hilāl: "Elcherit [Al-Ḥārit] dwell upon the Heli plains in the company of the Saidima [Chiadma] and collect tribute from the people of Hea [Haha].They are vile and poor 
people". In the same way, Luis del Mármol in his Descripción general de África (1573), strongly based on the latter, also mentions the Chiadma when describes the Pueblo de Hilela - the Banī Hilāl:

The ninth is called Vled el Querid [Al-Hārit] and they dwell upon the Helin plains in the province of the Heha [Haha], which is located in the Kingdom of Morocco, in the company of Vled Saydima [Chiadma]. Although they were used to collect tribute from the Berber of that province, they were a vile and poorly armed people ${ }^{2}$.

On the other hand, in the Kitāb al-\{ibar, Ibn Khaldoun states that the Kilābiyya tribes were in the Haha territory with the Al-Hārit and not the Chiadma as we saw above, what could make us think of the possibility of the Chiadma, being related to the Kiläbiyya at some point, as we see below:

La tribu de Sofyan était établie à demeure fixe: elle occupait les bords de la province de Temsna, du côtè d'Anfa; les Kholt leur ayant enlevé la possession des vastes plaines de cette contrée. De toutes leurs familles il n'y a que les Hareth et les Kelabïa qui ont continué à parcourir, avec leurs troupeaux, le territoire du Sous et le désert qui en dépend; ils fréquentent les plaines du pays des Hèha, branche des Masmouda [...] . (Histoire des Berbères, pp 63-64).

9 The most evident anyway is that the Chiadma were not considered Haha. Damião de Góis in his Chronica do felicissimo rei Dom Manuel (1566-67) on the Portuguese Empire in Morocco, distinguishes clearly between the two groups, denominating the Chiadma " Arabes" (Arabs), as opposed to the "barbaros" (Berber) (Fol.88-89). He also mentions the " Xiatima" - the Chiadma - several times when referring to the charging of tributes by the Portuguese on the tribes established in the area between the Oumm ar- $\mathrm{Rbi}^{\text {' }}$ river and Mogador (Essaouira) (Fol. 30), which corresponds clearly to the current Chiadma territory. Moreover, Góis delimits the specific location of an Arab territory under the control of the Chiadma inside the Province of the Doukkala: "From the river Daguz [Tensift] heading south, midday direction, it is located the land of the xiatima [Chiadma], where there are many Arabs[... $]^{3}$.

This Chiadma territory mentioned by Góis in the Doukkala region lead authors like Michaux-Bellaire to claim that the Chiadma were arabized Berbers who turned to speak Arabic: «Les Chtouka et les Chiadma, Berbères arabisés, ont perdu l'usage de la langue tamazight et parlent l'arabe.» (1937:187). He argues that they are ethnically Berber because of their use of "mots berbères", such as: sārūt < tāsārūt 'key'; mūka <tāmūkt 'owl'; mūšs < āmš̌šš 'cat' ( ibid.). However, these words are very common borrowings to most of the Moroccan Arabic varieties, what might invalidate his statement, except for original Berber words he cites such as: tāgüūālt 'little snail'; tārānīmt 'reed'; and tāfōtna 'Turkish bath'. In this case, we could also doubt of his statement since these words could have resulted from the contact of the Chiadma with the neighboring Berber tribes, like the Chtouka themselves, in the Doukkala Region specifically, not being very representative of the whole Chiadma territory.

11 More recently, Moroccan contemporary authors reaffirm the Arab origins of the Chiadma. Besides the linguistic differentiation between the two groups, Al-Kānūni (1932:34) and Ar-Regrāgi (1935:88) claim that the Chiadma are Arabs and have among them Mafqil Arabs and even a few Berber origin tribes, like the Regraga and the Meskala.

Finally, we consider that although the Chiadma have been in contact with the Haha for a long period until the current times, the historical sources above highlight the distinction between the two groups and do not mention a Berber origin for the Chiadma. 


\section{Fieldwork and data collection} located approximately $48 \mathrm{Km}$ north from the city of Essaouira. The Bhəybəh beach is under the jurisdiction of the city of Akermoud inside the Province of Essaouira, in Chiadma territory. Its dwellers live mainly on fishing and agriculture. fieldwork at the city of Essaouira in 2016. Most of the data was obtained by oral text collection and free speech recording (Payne, 1997; Vaux \& Cooper, 2003), as well as elicitation in a lesser extent.

The informants are represented mostly by women (5) whose ages varied between 30 and 60 years old. We also recorded three men, one of them around sixty years old and two around thirty years old. the same day, to the family of our female main informant, from Essaouira. The context of the recordings are gatherings which have taken place with men, women and children together, sitting on the floor of a room and talking, while drinking tea or eating lunch. The informants are literate even though they seem not to have completed the secondary school and they do not speak other foreign languages. Women are housewives and men work in agriculture and fishing.

Concerning the dialectologist's role in the interaction with the informants, while recording their speech and collecting oral texts, we played the roles of auditor-ratified as a participant in the conversation- and overhearer - present but an unratified participant in it- as conceived by Bell (1984:172). We consider these types of audience role played by us to have influenced positively in obtaining spontaneous speech data while facing the observer's paradox (Labov, 1972).

The interaction with the informants was exclusively in Moroccan Arabic, even though we are aware that we resorted to standard Arabic forms and let them notice Levantine Arabic traits in our speech and thus we received a feedback from the elder male informant on our speech itself as sounding "Lebanese". Despite of that, we did not notice a clear linguistic accommodation to our speech, as we see in Arabic cross-dialectal interactions between Arabic speakers from the Maghreb and the Levant, such as introducing standard forms or resorting to Levantine or Egyptian Arabic words. And we evaluate that positively concerning the quality of the data collected.

\section{Description}

\subsection{Phonetics}

\subsubsection{Consonants}

${ }^{*} q \bar{a}$ : realized as [q] and [g]. Differently from what we have been told by Essaouira informants previously about the $\{$ rūbi variety spoken around the city, the [q] realization predominates abundantly in the speech of all informants: qāsha "fresh, hard (pea)", qbol "before", qșị̂ "short", qrīb "next", maqț̄e "cutted", nfiqu "we wake up", Gqal "to 
remember", sūq "market". For [g] we have: Yăgrab "scorpion"; la-hrìga "the burnt", bagra "cow"; gabda "knife handle". We also find the usual $[g]$ realization, in this part of the country, in words such as ygūl "he says" and $g \bar{a} Y$ "all". $n \uparrow \bar{a} w d u$ "we repeat", t $\{$ rrfu? "do you know it?". Differently from Essaouira and Marrakesh, the ka- prefix predominates like in the Doukkala region. The absence of the prefix could be verified in the elderly speech and can be explained as a Bedouin variant of the Saharan type. la-qyās dyāl ātāy "the quantity (measurement) of tea"; hdikk ka-ngūlu liha l-madra, dyālt olhdid "that one, we call it pitchfork, the iron one". For referring to relatives, they use the construct state: žəddi "my grandfather", โəmmi "my paternal uncle", โəmmha "her partenal uncle"; mrātu "his wife"; but also in kāssk "your glass". habits/tradition"; but in the speech of the elder male informant the plural word flus "money" agreed with the adjective in the feminine singular: Səndu flüs ktìra "he has a lot of money".

tribe", usually pronounced also as r-rəgrāga; hāža "thing"; โ̌̌ūza or $\{z \bar{u} z a$ - resulted from sibilant-harmony- "old woman" and the realization [g] in Sgüza "mother-in-law".

*/ḍ/: is realized as [d]]: mard "illness", drab "hit, punch".

[t] or [T]]: ktīra "much, a lot" (fem.); Kăwtor < *Kawtar (fem. name). */d/: [d] in madra "pitchfork" (<*midran/ mid̆āh), dəbbān "flies" (< * dibbān). */d/: [d] in dfäạ "animal nails"(<*'adfār).

*/ay/ are mostly reduced to /ū/ and /î/ (Aguadé 2008:292): *al-yawm > l-yūma "today"; * zayt > zit "oil"; *laymūn> limūn "orange", but in emphatic contexts: ḅăyd "eggs", dəw "light, electricity"; bu brrəyș "gecko", xw dăyra "green (dim.)".

\subsubsection{Vowels}

elision or inversion of the short vowel /ə/ in the word: rāăli < rāăz̆l + -i "my husband"; $k \bar{a}$ $y n a<$ <āyən + -a "existencial (f.)"; ka-yfolhu < ka-yəfloh + u "they cultivate (the land)".

\subsection{Morphology and Syntax}

2. The future particle is $\dot{g} \bar{a} d i: \dot{g} \bar{a} d i$ nsolHa "I'm going to punish her (remove her skin)".

3. The possessive is marked by the particle dyāl- : at-tollis dyāl əž-žmal "camel saddle bag",

5. Some of the interrogative particles are: āšnu "What?": hāda āšnu hŭwwa? "This, what is it?"; fin "Where?"; ki dāyra? "How are you doing? (f.)”; škūn? "Who?"; šhāl Səndha? "How old is she?"; wāš for yes/no questions. 

"now" both frequent in the Atlantic Coast (Aguadé 2008:297). For "little", we find šwāy šwi šwiryya: ka-thățt šwāy dyāl ən-nəSnə९ "you put a bit of mint".

The indefinite article is wāhad l-: ka-ngūlūha b-wāhad at-triqa ŭHra "we say it in another way". There is also the indetermination quantifier ši: bqāw mYāna ši sīmāna "stay (2.p.pl) with us over a week"; ši smŭyyāt "some names".

8. The negation is formed with $m a-\ldots-$ š for verb, noun and prepositional phrase respectively: ma-tansāy-šs "Do not forget" (2.p.f.); ma nโəmmrūu-š bəzzāf "we do not make a lot of it (tea)"; l-qəhwa ma Hुāybā-š "The coffee is not bad"; ma Sondū-š Həmsin "He is not even fifty years old";

9. The imperative form of the verb "to come" is $t$ âala (s.m.), t $t$ āli (s.f.) or āži.

10. The verb "to want" occurs in the form $b a / y b i$ in the speech of an elderly woman along

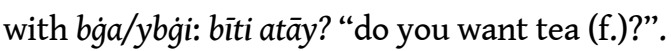

\subsection{Lexicon}

The lexicon of this variety does not differ significantly from the other southern Atlantic Strip varieties (Premare 1993; Heath 2002; Behnstedt \& Woidich 2014). We present bellow some curious examples recorded in Bhəyybəh.

For animals, we highlight: qəždor "gecko", also said bu ḅ̣ịș bu brəyș, confirmed until now exclusively in Essaouira; bu ržila bu ržilāa "centipede", composed of bu "the one with" +

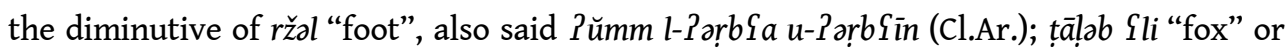
"Ali's student", probably a pun for taYlab> *taYlab, which is also attested in the area; bu Cya (pl. -āt) a general name for insects used in child talk by adults to scare them; lbūya "chameleon", very common in other parts of the country, being the word tāta completely unknown by our informants. Many other names are the same as in other parts of the country, such as: sarrāq z-zìt "cockroach", bəgra "cow", ḥmār "donkey", džăža "a hen", ?̌rnəb "hare", gənfūd "hedgehog", fəkrūn "turtle".

For the vegetables and fruits we have: d̦lăf "the Indian fig cactus" (Opuntia ficus-indica);

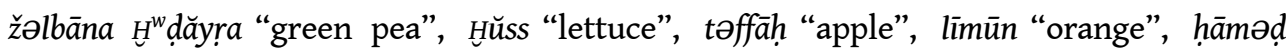

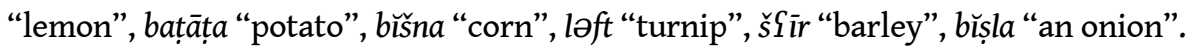

Some borrowings from European languages appear among the lexicon, such as: girra "war" (<esp.guerra), nīgro "tea bag sachet", mōtōor dyāl l-flüka "boat engine", though we could not attest any borrowings from tachelhit.

We also came across the word kōma used in the expression Səndu kōma "he has a big amount of money", but whose origin is not clear.

\section{Final considerations}

To conclude, the features described here seem to confirm the Arab identity of the Chiadma, since their speech does not show a relevant contact with the tachelhit, despite their historical relation with the Haha for many centuries. As we see above the data presented here indicate that the Arabic dialect spoken by the Chiadma in Bhəybəh share many features with the hilalian Moroccan dialects of the Central-type, or $\{r \bar{u} b i$, in the Atlantic strip. 


\section{BIBLIOGRAPHY}

Aguadé, J. 2008. “Árabe marroquí (Casablanca)”. Corriente, Federico, \& Vicente, Ángeles. (ed.). Manual de dialectología neoárabe. Zaragoza: Instituto de Estudios Islámicos y del Oriente Próximo. $281-310$.

Al-Kānūnī, Muḥammad bin PAḥmad al-SAbdī. 1932. Āsfi wa-ma ilayhi qadīman wa-ḥadịtan. Cairo: Mațba Ia Mușțafa Muhammad.

Ar-Regrāgi ar-Ribāți, ?Aḥmad bin al-Ḥāžž. 1935. aš-Šumūs al-munīra fi-PaHbār madīnat aṣ-Ṣuwayra. Rabat: Al-mațbafa al-wațaniyya.

Behnstedt, P, \& Woidich, M. 2010. Wortatlas der arabischen Dialekte. Band I: Mensch, Natur, Fauna und Flora. Leiden: Brill.

Bell, Allan. 1984. "Language style as audience design", Language in Society. n13.145-204.

Boukous, Ahmed. 1995. Société, langues et cultures au Maroc. Casablanca: Faculté des Lettres et des Sciences Humaines Rabat.

Colin, George. 1945 [1938]. «Les parlers : l'arabe ». Initiation au Maroc. Paris: Institut des Hautes Etudes Marocaines. 219 - 47.

Faḍlillāh, SAbdullāh Al-Lațīf. 1994. "Tațawwur sukkān aṣ-Ṣuwayra". Essaouira: mémoire et empreintes du présent. Casablanca : Matba Ia an-Nažāḥ al-žadīda. 241-42.

Góis, Damião. 1567. Chronica do Feliçissimo Rei Dom Emanuel. Terceira parte. Lisboa: Casa de Francisco Correa. Retrieved August $2^{\text {nd }} 2017$ from https://books.google.es/books? id=RB1UAAAACAAJ\&printsec=frontcover\&hl=pt-

BR\&source=gbs_ge_summary_r\&cad=0\#v=onepage \&q\&f=false .

Heath, Jeffrey. 2002. Jewish and Muslim dialects of Moroccan Arabic. New York: Routledge.

Ibn Khaldoun. 1852. Histoire des Berbères et des dynasties musulmanes de l'Afrique septentrionale. Trad. Slane. Alger: Impr. du Gouvernement.

Ibn Mandūr. Lisān al-SArab. Retrieved August $15^{\text {th }} 2017$ from www.lisaan.net.

Labov, W. 1972. Sociolinguistic patterns. University of Pennsylvania Press.

Mármol Carvajal, Luis del. 1573. De la Descripcion General de Affrica. Granada. Retrieved August 2nd 2017 from https://books.google.es/books?hl=pt-BR\&id=1WVevz1cDnwC\&dq=descripcion+general + de + africa\&q=saydima\#v=snippet $\& q=$ saydima\&f=false.

Michaux-Bellaire, M. 2012 [1932]. Villes et tribus du Maroc (Volume XI). Region des Doukkala: Tome II, Azemmour et sa banlieu. Rabat: Publications de la Faculté des Lettres et des Sciences Humaines.

Payne, Thomas E. 1997. Describing morphosyntax. A guide for field linguists. Cambridge, UK: Cambridge University Press.

Premare, Alfred-L (org.). 1993. Dictionnaire arabe-français (Langue et Culture Marocaines). Paris : l'Harmattan.

Ramusio, G. 1613. Della Descrittione dell'Africa per Giovan Africano. In:Delle nauigationi et viaggi raccolte da m. Gio. Battista Ramusio. Vol.I. Venezia. Retrieved August $2^{\text {nd }} 2017$ from https:// 
books.google.es/books?id=xA_fOoebGzkC\&dq=saidima+ramusio\%27\&hl=pt-

BR\&source=gbs_navlinks_s .

Vaux, Bert; Justin Cooper. 2003. Introduction to linguistic field methods. München: Lincom Europa.

\section{NOTES}

1. Our translation of "Elcherit habitano nelle pianure hi Heli in compagnia di Saidima, \& hanno tributo dal popolo di Hea. fono huomini vili, \& male agiati." (Ramusio, Fol. I. 4f).

2. Our translation of "El noueuo es llaman Uled el Querid [Al-Hārit], y viuen en los llanos de Helin [Haha], en la prouincia de Heha [Haha], que es enel reyno de Marruecos, en compañía de Uled Saydima [Chiadma], y aunque folian coger tributo de los bereberes de aquella prouincia, fon gente vil y mal armada..." (Fol.38).

3. Our translation of "Do rio Daguz contra ho Sul, \& meo dia eftá ha terra de xiatima, em q ha muitos Arabes [...]” (Fol.89)

\section{ABSTRACTS}

This paper aims at presenting a general description of the linguistic features of the Arabic variety spoken in the Chiadma tribe territory, in the rural area north of Essaouira. Since there are scarce publications on the linguistic reality of this part of the Atlantic strip, not to mention on the Chiadma tribe themselves, we share here some data collected in a brief one day stay in a fishermen village by the Bhəybəh beach (Akermoud), which took place during our fieldwork in the city of Essaouira, in 2016. The linguistic traits described here seem indeed to belong to a $Y r \bar{u} b i$ or Central-type variety (Heath 2002), as we can attest in other localities nearby, such as Essaouira and Casablanca.

INDEX

Keywords: Arabic dialectology, Chiadma, Essaouira, Moroccan Arabic.

\section{AUTHOR}

\section{FELIPE BENJAMIN FRANCISCO}

Universidade de São Paulo, felipe.francisco@usp.br 


\title{
Acoustic Correlates of Rhotic Emphasis in Fessi Spoken Arabic
}

\author{
Aaron Freeman
}

\section{Background}

\subsection{Emphasis in Arabic Phonology}

1 The consonantal feature known as 'emphasis' is among the most distinctive features of Arabic and other Semitic languages. It involves a secondary phonetic articulation, generally identified as pharyngealization, ${ }^{1}$ which characterizes emphatic consonant phonemes in opposition to their 'plain' counterparts and can also appear as a subphonemic property of other consonants and vowels. In Modern Standard Arabic (MSA), phonemically contrastive emphasis is restricted to coronal obstruents, with the exception of historical palatals $/ S /$ and $/ 3 /$. Thus, there is a phonemic contrast in MSA

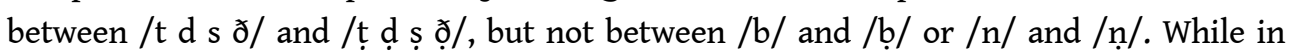
MSA, there are two plain coronal obstruents $(/ \theta /$ and $/ z /)$ which do not have emphatic counterparts, this asymmetry has been levelled out of most colloquials, including the Moroccan dialect. There, interdentals have merged with alveolar stops and a phonemic / $\mathrm{z} / \mathrm{has}$ become established, yielding a one-to-one correspondence between the set of coronal obstruents and the articulatory range of unambiguously phonemic emphasis. In what follows, these contrastively emphatic coronal obstruents /ț d s z $\mathrm{z} /$ will be referred to as the 'primary emphatics' of Moroccan Arabic.

In contrast to primary emphasis, secondary emphasis is a subphonemic property of segments which are not underlyingly pharyngealized. When the pharyngealization associated with emphasis spreads to nearby segments, it causes secondarily pharyngealized variants of both vowels and consonants. The emphatic allophones of vowels are also characterized by changes in tongue body position, which vary by dialect; in Morocco, these may be described roughly as as [a] for /a/, [i] for /i/, and [o] for $/ \mathrm{u} /$ (Heath 1987). While emphasis spread has different properties in different dialects, it is ubiquitous in Arabic; in most of Morocco, spreading extends to all segments within a 
word and is only clearly blocked by inflectional morpheme boundaries. (Heath 1987; Dell \& Elmedlaoui 2002).

The focus of this paper is a third category of emphatic-like consonants, neither clearly primary nor clearly secondary, which I call 'marginal emphatics'. Marginal emphatics do not acquire pharyngealization from feature spreading, yet are not unambiguously in categorical contrast with their plain counterparts; their characteristic secondary articulation may also have different phonetic properties to the articulation of primary emphatics. In Moroccan Arabic, [r], [l], [b], [f], and [m] may all be considered marginal emphatics, and the uvular stop /q/ also exhibits some emphatic-like qualities. Since the marginal emphatic labials are mostly restricted to loanwords and intersect with the structurally complex and unrelated issue of labialization, and the marginal emphatic / $/$ / has an extremely limited distribution, I am restricting my attention here to the behavior of $[\mathrm{r}]$ and its interaction with /q/.

4 The existence of $[r]$ outside of secondary emphatic contexts is historically due to a separate phonological process by which $/ \mathrm{r} /$ is pronounced with pharyngealization except when adjacent to a front vowel (Younes 1994). While this rule has been preserved in some dialects of Arabic, in Morocco reduction of the vowel system and a tendency towards paradigm regularization has resulted in a shift towards a lexical distribution of rhotic emphasis. The structure of the resulting system is poorly understood, with the 'quasiphoneme' / $\mathrm{r} /$ being favored in certain phonetic environments over others and reportedly triggering a 'weaker' variant of emphasis spread. This paper offers preliminary quantitative data on rhotic pharyngealization among Moroccan speakers in the city of Fès, which suggest that $[r]$ may indeed be a distinct phoneme, causing uvularization, if not pharyngealization, of adjacent vowels.

\subsection{Quantifying Marginal Emphasis}

5 The clearest acoustic correlates of pharyngealization and uvularization in sonorants are lowering of the second formant (F2) and raising of the first formant (F1) (Al-Masri \& Jongmann 2004, Bin-Muqbil 2006). This makes it quite easy to measure emphasis spread quantitatively, and to use the pronunciation of adjacent vowels to determining whether a consonant is emphatic. Differences in frequency shift patterns can also be used to contrast different classes of conditioned pharyngealization - in this case, to distinguish intermediate effects associated with marginal emphatics from canonical emphasis spread.

6 The questions answerable with this acoustic toolkit relate to phonemicization and feature mapping, which are central to structural models of the organization of speech sounds. If conflicting evidence exists for the phonological status of [r] , how do individual speakers learn to organize the segment in their grammar? What feature serves to distinguish it from $[r]$ - the existing emphatic feature, or a new category with different phonological effects? Is there in fact a difference between marginal and primary emphatics, and, if so, what is it?

7 In this paper I seek to address these questions quantitatively, by investigating the distribution of $[r]$ through the phonetics of adjacent vowels to determine its phonemic status, and by comparing its phonetic effects to those of uvular stops and primary emphatics to assess their phonological similarity. Even though the initial results presented here may only scratch the surface of the problem, they demonstrate what quantitative data analysis can contribute to the resolution of phonological problems that 
have traditionally been addressed through qualitative descriptive work in Arabic dialectology.

\section{Methodology}

8 I collected a dataset for analysis by recording a corpus of native Moroccan Arabic speech, targeting emphasis spread and rhotic emphasis. During fieldwork, I administered a standardized interview targeting free speech and wordlists to 24 participants, with the help of native-speaker assistants. Post-collection, data were first manually transcribed and segmented, and raw formant measures were extracted from segments using Praat (Boersma \& Weenink 2017). The resulting values were checked and iteratively recalculated to remove false measurements, and then normalized using the Lobanov techniqe (Adank et al. 2004). More details concerning data collection follow below.

\subsection{Subject Recruitment and Demographics}

9 I conducted my interviews over the course of a five-month stay in Morocco, with logistical assistance from the American Language Center-Fès. Both my interview assistants and the majority of my participants were recruited through existing networks between students, teachers, and staff at the center, a method which is reflected in the demographics of my speaker sample. Of my 24 participants, 8 were Moroccan university students studying English at the ALC and another 8 worked as language teachers at the school. 5 more were employed by the center as administrative or maintenance staff, and the remaining 3 were referred to me by contacts within the center. As a result, my speaker sample reflects individuals associated with a more affluent, Western-educated sector of Fessi society, even while including some individuals of a more traditional social background.

Though this sample of Fessi society skews young, male, and well-educated, it still provides sufficient diversity to control for gender, age, and class. Class was evaluated indirectly through neighborhood of residence, educational level, and occupation. Individuals who had received some higher education were classed as upper class, while individuals who had received less than a fifth-grade education and held jobs involving manual labor were judged to be lower class. Table 1 charts the makeup of my participant sample by age group, sex, and social class.

Table 1. Distribution of Participants by Age, Sex, and Social Class

\begin{tabular}{|l|cc|cc|c|}
\hline & Age 18-25 [8] & \multicolumn{2}{|c|}{ Age 26-40 [11] } & \multicolumn{2}{|c|}{ Age 40+ [7] } \\
\hline Male [17] & Upper: $4 \quad---$ & Upper: 3 & Lower: 3 & Upper: 4 Lower: 3 \\
\hline Female [9] & Upper: 4 & --- & Upper: 3 & Lower: 2 & \multicolumn{2}{|c|}{} \\
\hline
\end{tabular}

I also considered whether each participant had been born in Fès, and if not, how long they had resided there. In general, I admitted anyone who had moved to Fès as a child or adolescent into the study, but not individuals who had relocated to the city from another 
part of Morocco as an adult. 16 of my 24 speakers were lifelong Fessi native speakers of Arabic, and the rest had long-standing membership in the speech community.

\subsection{Interview and Wordlist Structure} segment lasted between fifteen and thirty minutes, and involved responses to two written wordlist prompts presented in Arabic script. The first list consisted of 86 words designed to ensure elicitation of a comprehensive vowel tokens in as many phonetic contexts as possible. ${ }^{2}$ The second list of 60 words targeted specific vocabulary items reported to exhibit marginal emphatics, as well as control words differing minimally from the targets. For certain words, plural or diminutive forms were elicited.

The wordlists were followed by a short reading passage and, finally, a list of five homophone pairs contextualized in sentence frames, reported to exhibit a minimal contrast between [r] and [r] by Hilili (1979). I found that most of these words were considered archaic or marginal by my participants.

\section{Results}

The results presented here are preliminary, and explore the behavior of my Fessi speaker sample in aggregate. They confirm the structural ambiguities reported in earlier work through quantitative phonetic measurements, and also suggest an explanation that will require further analysis to confirm. I focus on F1 and F2 differences across selected paradigms and phonological contexts. The data generally support the view that $[r]$ is a separate phoneme with an 'emphatic' feature that is distinguishable from primary emphasis, and has some phonetic similarity to the uvularization associated with /q/. They also, however, indicate that restricted phonetic conditioning perseveres in lexically specific contexts.

Two intentional restrictions on the analysis should be kept in mind. First, I only use measurements from the vowels /a/ and /i/, since these vowels exhibit the most robust emphasis-related differences in both the first and second formants, and tend to be long enough to allow for reliable steady-state measures at the midpoint. Second, I make no $a$ priori determinations of rhotic emphasis prior to analysis, but instead begin by evaluating all rhotics together and consider patterns of emphasis contrast as acoustic evidence emerges for them.

\subsection{General Distribution of Vowel Variants}

16 I established general patterns of emphasis spread by calculating formant means and ranges for normalized midpoints of /a/ and /i/ in monosyllables with emphatic coronal obstruents (EMPH), rhotics (R), uvular stops (Q), and plain coronal obstruents (COR), respectively (Figure 1). The contexts are ordered from lowest to highest mean frequency in each plot. It is evident that vowels near primary emphatics have uniformly lower F2 and higher $\mathrm{F} 1$ than vowels near primary coronals, and that in general, vowel frequencies associated with / $/ \mathrm{r}$ and /q/ lie somewhere in between those two extremes. The only exception to this last statement is the exceptionally high mean F1 of /a/ adjacent to /r/, which was not, however, found to be statistically significant from /a/ adjacent to either / 
$\mathrm{q} /$ or the emphatic coronals according to a t-test analysis. Almost all other two-way intergroup comparisons, however, were found to be significantly different from each other. $^{3}$

Figure 1. Formant Ranges of /a/ and /i/ by phonetic context.
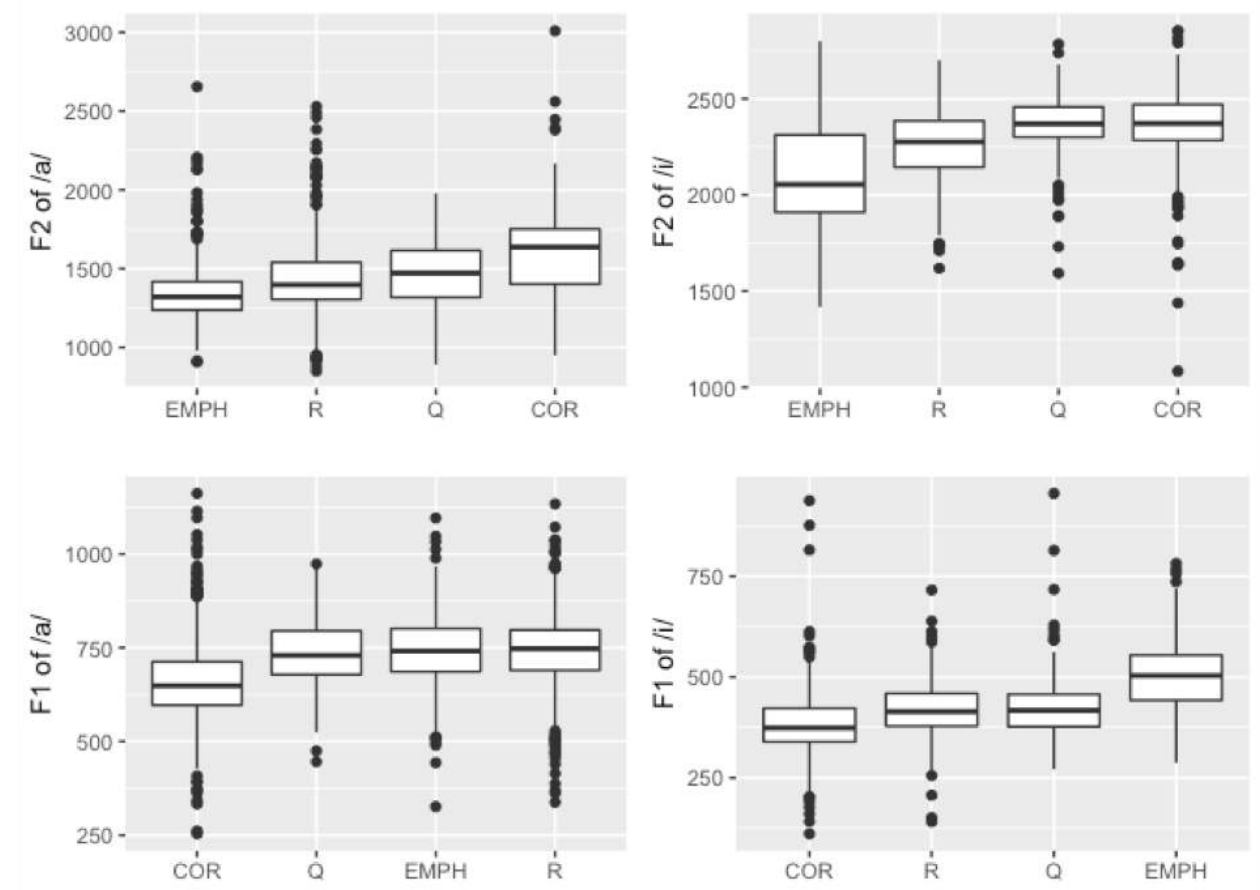

One notable result from this aggregated comparison is that the respective effects of primary emphatics, /r/, and /q/ on the midpoint of the following vowel are all phonetically distinct. It cannot be said that / $\mathrm{r}$ / conditions the same allophone of /a/ as / $\mathrm{q} /$ or $/ \mathrm{t} / \mathrm{does}$, or even that a coarticulatory effect from uvularization applies uniformly to vowels after $/ \mathrm{r} /$ and /q/. Another important consequence of this data is that the simple allophonic hypothesis must be discarded: /i/ after / $r$ / does not belong to the same distribution as /i/ after a plain coronal, and /a/ after / $/$ / does not belong to the same distribution as /a/ after a primary emphatic. The phonological situation, then, cannot be described by phonetic conditioning alone.

\subsection{Emphasis spread to following /a/}

For more detailed data on consonant effects, I considered sets of words differing minimally from each other in which a vowel was immediately preceded by a conditioning consonant from each class. For /a/, I used the minimal quadruplet tas, qas, ras, and kas, with F2 frequency distributions as shown in Figure 2. In this set we see that /a/ in ras is close to, if not identical with, the emphatic /a/ in țas, while qas is intermediate and / $/$, the plain consonant, is next to the frontest vowel. 
Figure 2. F2 values of /a/ in tas, ras, qas, and kas.

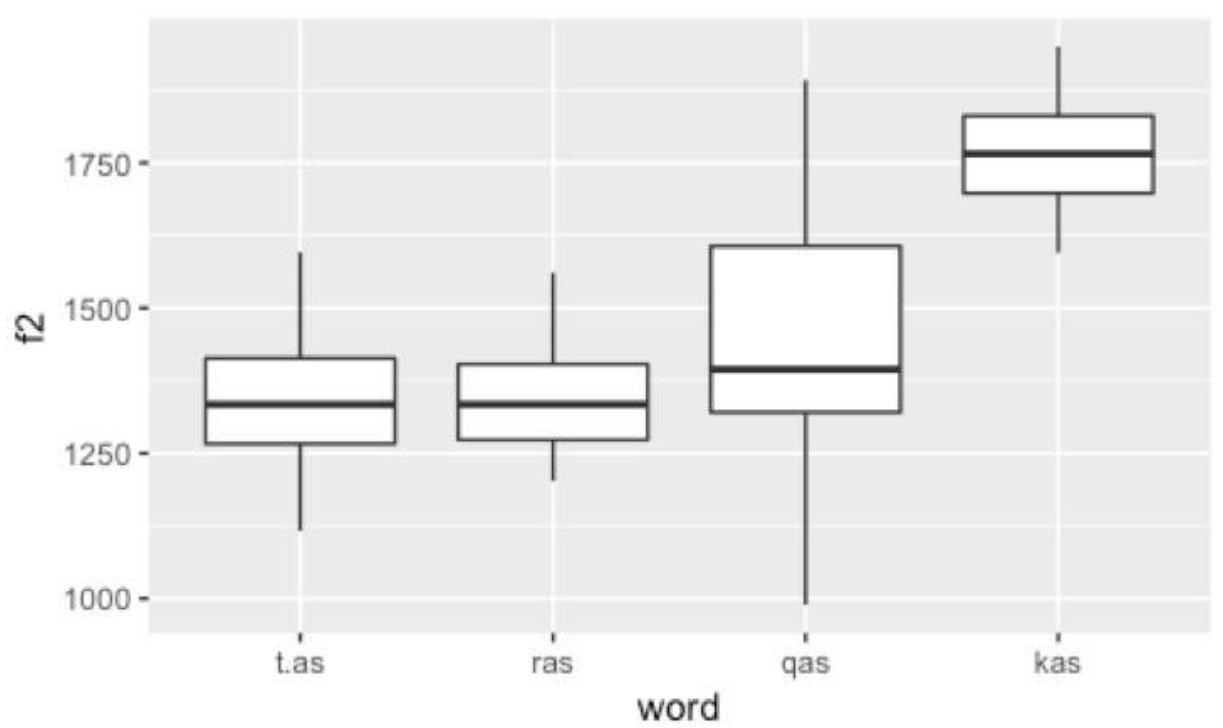

19 A closer look, however, reveals that speakers are split on the pronunciation of qas, with some opting for a front [a] and others producing the emphatic allophone [a]. No such bimodal split operates on ras - all speakers produce this word as [ras], with the emphatic allophone of the vowel. Figure 3 is a scatterplot of individual datapoints highlighting this split. 7 speakers produced [a] after /q/, 13 speakers had [a] after /q/, and 3 speakers produced both variants.

These data suggest that the intermediate formant values of /q/ which we saw in the aggregated data may be due at least in part to a bimodal distribution. While the same may turn out to be true for $/ r /$, in this particular word all speakers agree that $[r]$ is the appropriate variant, and its F2 effect on the following vowel is quite similar to the effect of $/ \mathrm{t} /$ in tas $(|t|(143)=0.385, p=0.70)$. This comparison, then, is instructive with regards to / $\mathrm{q} /$, and also shows that $[\mathrm{r}]$ is closely allied to primary emphatics as pronounced in some words. 
Figure 3. Formant values of /a/ in tas, qas, ras, and kas.

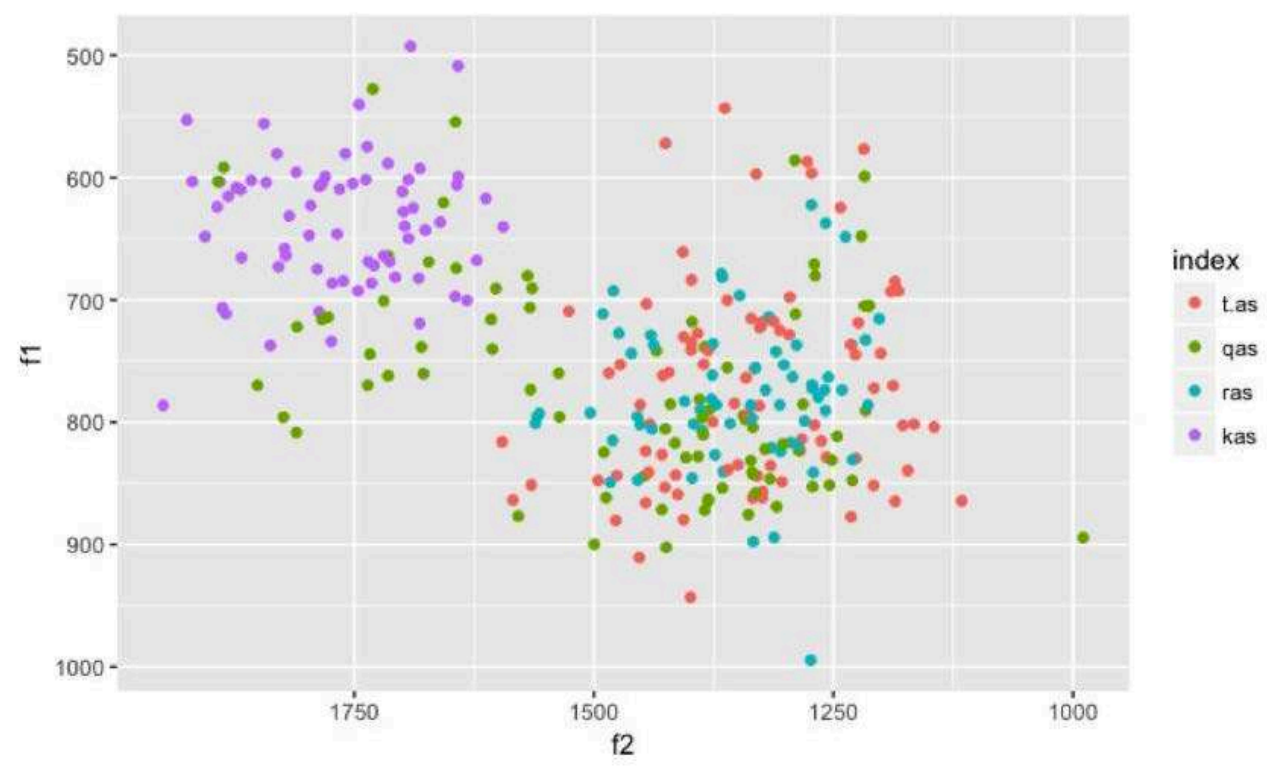

\subsection{Emphasis Spread to following /i/}

Repeating this exercise with /i/ directly following consonants of different classes, we next compare the midpoint of the /i/ vowel in tisan, rib, baqi, and tis. These words do not form a minimal quadruplet, but are the best sample for comparison in this context that could be extracted from the wordlist.

Figure 4 compares the F2 means and ranges among these four words. The clearest indication is that /q/ patterns with non-emphatics with respect to $\mathrm{F} 2$ of /i/, with no significant difference between baqi and tis $(|t|(127)=0.98, p=0.33)$. There is, however, a significant difference in F1 $(|\mathrm{t}|(107)=10.1, p<0.001)$, with means of $449 \mathrm{~Hz}$ and $339 \mathrm{~Hz}$ respectively. /i/ in tisan has a markedly lower F2 than either of these, and a correspondingly higher F1 centered around $508 \mathrm{~Hz}$. /i/ in rib, on the other hand, has a widely scattered range of F2 values, possibly suggesting a bimodal distribution such as we saw for /a/ in qas above. 
Figure 4. F2 values of /i/ in tisan, rib, baqi, and tis.

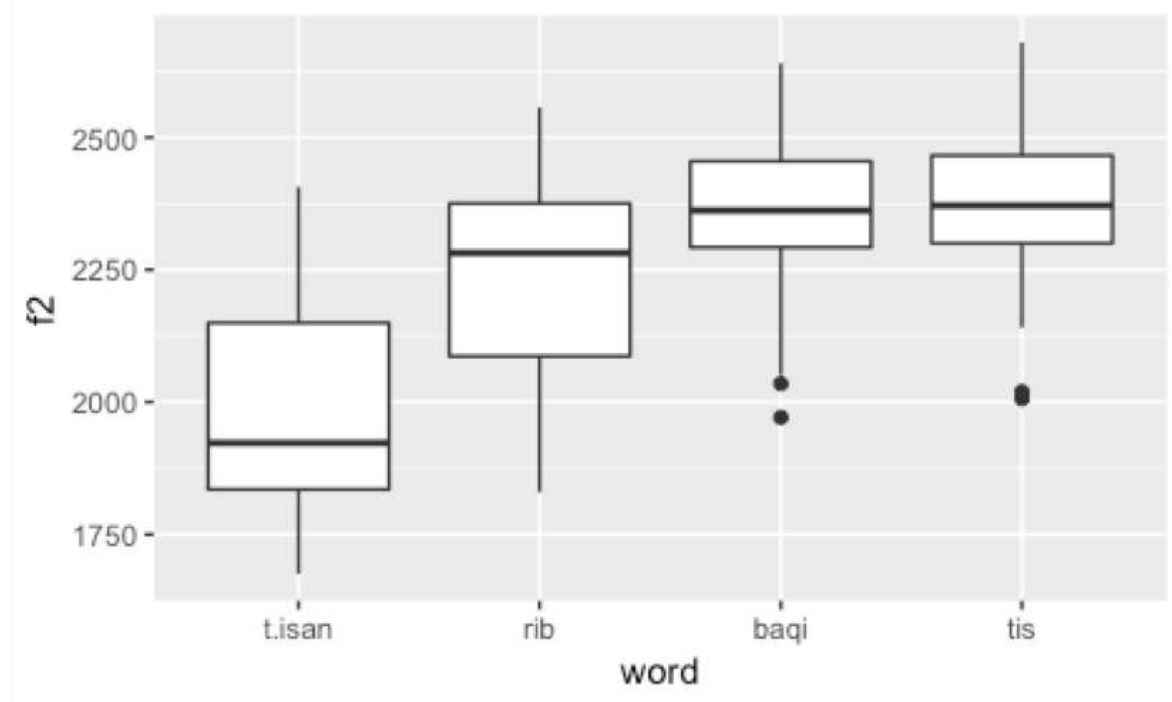

In Figure 5, we see a scatterplot of these tokens in the F1-F2 vowelspace. Two distinct clusters for tis and tisan are clearly visible, as well as the lowered $\mathrm{F} 1$ of /i/ in baqi in a cluster which overlaps with tis on the F2 dimension. The /i/ in rib, however, is quite diffuse, and does not clearly overlap with any of the other three distributions.

Figure 5. Formant values of /a/ in tisan, baqi, rib, and tis.

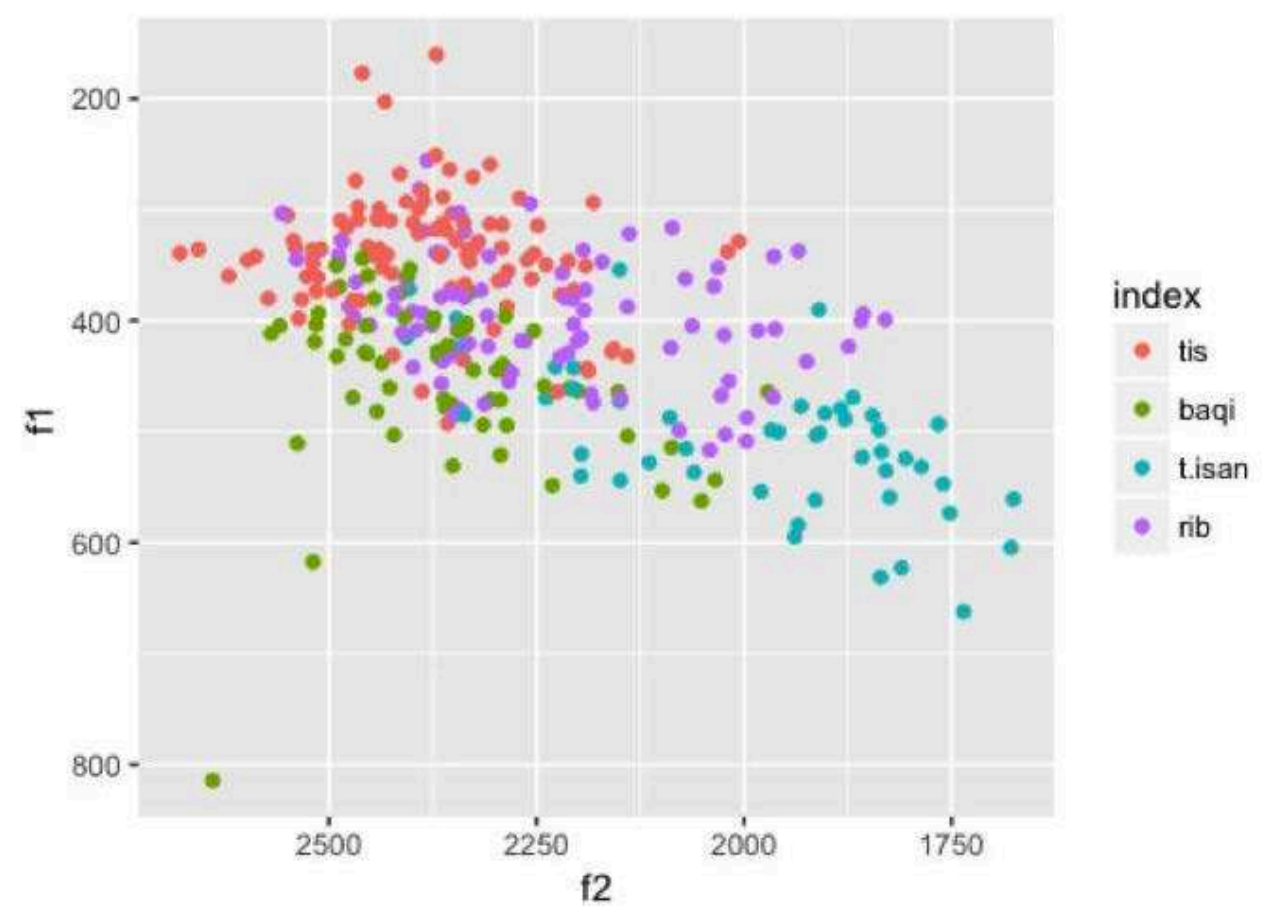

Unfortunately, the parameters of a possible rib/rib distinction are difficult to discern from this data. This item was one of Hilili's archaic minimal pairs, and the reported emphatic lexeme, meaning 'fall apart, deteriorate', was rejected by many speakers. The lexical item with the plain variant, 'curdle', was more accessible, but often altered to past tense rayeb by participants (those tokens are not presented here). A t-test comparison of rib 
'deteriorate' and rib 'curdle' reveals a significant difference in F2 but not in F1, but even so the distributions overlap extensively, are quite diffuse, and do not pattern closely with the other distributions.

\subsection{The minimal pair biran/biran}

The strongest evidence found so far in the data for a phonemic split between $[r]$ and $[r]$ is the existence of a minimal pair biran 'bars'/ biran 'wells' in the speech of many participants. This pair was not previously attested, as biran appears to be a novel plural form of bir 'well', placing it in minimal opposition to the plural biran of the French loanword bar. Since in both paradigms, the plain or emphatic rhotic is preserved as part of the root, this is a strong indication that an underlying contrast exists between $/ \mathrm{r} /$ and $/ \mathrm{r} /$.

Comparisons of formant values between biran and biran confirm that the difference between the two asserted by speakers has a phonetic basis. Table 2 gives mean formant values and interword $\mathrm{t}$-test comparisons across all speakers who had the minimal pair. For comparison, the mean formant values of /i/ were $494 \mathrm{~Hz}$ (F1) and $2107 \mathrm{~Hz}$ (F2) adjacent to primary emphatics and $382 \mathrm{~Hz}$ (F1) and $2381 \mathrm{~Hz}$ (F2) adjacent to plain coronals, and those of /a/ were $742 \mathrm{~Hz}$ (F1) and $1340 \mathrm{~Hz}$ (F2) adjacent to primary emphatics and $660 \mathrm{~Hz}$ (F1) and $1582 \mathrm{~Hz}$ (F2) adjacent to plain coronals. ${ }^{4}$

Table 2. Formant comparisons for the biran/biran minimal pair.

\begin{tabular}{|c|c|c|c|c|}
\hline Vowel & Formant & mean for biran & mean for biran & t-test result \\
\hline \multirow{2}{*}{$/$ i/ } & F1 & $528 \mathrm{~Hz}$ & $463 \mathrm{~Hz}$ & $|\mathrm{t}|(97)=4.75, p<0.001^{* *}$ \\
\cline { 2 - 5 } & $\mathrm{F} 2$ & $1994 \mathrm{~Hz}$ & $2116 \mathrm{~Hz}$ & $|\mathrm{t}|(82)=3.46, p<0.001^{* *}$ \\
\hline \multirow{2}{*}{$/ \mathrm{a} /$} & $\mathrm{F} 1$ & $781 \mathrm{~Hz}$ & $706 \mathrm{~Hz}$ & $|\mathrm{t}|(90)=3.75, p<0.001^{* *}$ \\
\cline { 2 - 5 } & $\mathrm{F} 2$ & $1411 \mathrm{~Hz}$ & $1599 \mathrm{~Hz}$ & $|\mathrm{t}|(100)=5.02, p<0.001^{* *}$ \\
\hline
\end{tabular}

A further aspect of this alternation which is of structural interest is the lack of a significant difference in the pronunciation of the vowels in biran 'bars' between speakers who used the biran plural for 'wells' and speakers who used a different form such as byur or byar. ${ }^{5}$ This result reinforces the conclusion that phonetic differences between biran and biran are not merely due to functional dissimilation.

\subsection{The alternating paradigm ḥmậh ḥmir}

While the biran/biran contrast provides data in favor of categorical rhotic emphasis, there is also some evidence for allophonic alternation. Perhaps the clearest example of this is the paradigm hmar/hmir 'donkey (sg./pl.)'. With respect to F2 effects, shown in Table 3, speakers consistently produced this pair with an emphatic-like variant of $a$ in the singular and a plain variant of $i$ in the plural, conforming to the distributional generalization that $/ \mathrm{r} /$ should be de-emphaticized when adjacent to a front vowel, but should be emphatic elsewhere. ${ }^{6}$ 
Table 3. F2 comparisons for hmar/hmir

\begin{tabular}{|c|c|c|c|}
\hline Vowel & Condition & Mean frequency & t-test comparison with 'donkey' \\
\hline \multirow{3}{*}{$/ a /$} & hmmar & $1294 \mathrm{~Hz}$ & \\
\hline & plain /a/ & $1584 \mathrm{~Hz}$ & $|\mathrm{t}|(55)=11.6, p<0.001^{* *}$ \\
\hline & emphatic /a/ & $1341 \mathrm{~Hz}$ & $|\mathrm{t}|(55)=1.86, p=0.06$ \\
\hline \multirow{3}{*}{ /i/ } & hmmir & $2305 \mathrm{~Hz}$ & \\
\hline & plain /i/ & $2362 \mathrm{~Hz}$ & $|t|(55)=1.92, p=0.06$ \\
\hline & emphatic /i/ & $2106 \mathrm{~Hz}$ & $|t|(83)=6.04, p<0.001^{* *}$ \\
\hline
\end{tabular}

\section{Conclusions and Further Directions}

Considering the vowel comparisons and morphological paradigms presented above, we see the analytical difficulties presented by marginal emphasis well represented in the acoustic data. Rhotics pattern with emphatics in some words and trigger intermediate pharyngealization spread in others; only in the isolated plural form hmir do we see $/ \mathrm{r} /$ conditioning the plain allophone of a vowel. /q/, on the other hand, varies between plain and emphatic pronunciations, as some speakers associate it with weak pharyngealization of neighboring vowels and others do not. Previously attested minimal pairs differentiating $/ r /$ and $/ r /$ have gone out of use, while new ones have emerged to take their place.

Even so, the use of quantitative acoustic data allows a precision of description that will allow for resolution of these difficulties in time, and offers testable, reproducible data that do not rely on the judgments of individual researchers. Native speakers, influenced by orthography or traditional grammatical analyses, often have contradictory intuitions with respect to marginal emphatics, and the true complexity of the situation is best captured by direct analysis of the speech signal itself.

31 In the next stages of research, individual speakers' patterns of emphasis spread will be compared, and a wider variety of individual vocabulary items will be tested for the behavior of /r/ and /q/. Free speech recordings will be drawn upon to help fill gaps in the data, and evidence from non-adjacent vowels will be used to test the coarticulatory nature of intermediate levels of emphasis spread. The end result will, I hope, provide conclusive answers to outstanding questions on 'quasi-phonemes' in Arabic, and further demonstrate the value of acoustic data to phonological research. 


\section{BIBLIOGRAPHY}

Adank, P., Smits, R. and Van Hout, R., 2004. A comparison of vowel normalization procedures for language variation research. The Journal of the Acoustical Society of America, 116(5). 3099-3107.

Al-Masri, M., and Jongman, A. 2004. 'Acoustic correlates of emphasis in Jordanian Arabic: Preliminary results.' In Proceedings of the 2003 Texas Linguistics Society Conference. Somerville, MA: Cascadilla Proceedings Project. 96-106.

Bermúdez-Otero, Ricardo. 2007. 'Diachronic Phonology'. In The Cambridge Handbook of Phonology, ed. Paul de Lacy, chapter 21. Cambridge: Cambridge University Press. 497-517.

Bessell, N. J. 1992. Towards a Phonetic and Phonological Typology of Post-Velar Articulation. Doctoral Dissertation, University of British Columbia.

Bin-Muqbil, Musaed. 2006. Phonetic and Phonological Aspects of Arabic Emphatics and Gutturals. Doctoral Dissertation, University of Wisconsin-Madison.

Boersma, Paul \& Weenink, David. 2017. Praat: doing phonetics by computer [Computer program]. Version 6.0.25, Retrieved 12 February 2017 from http://www.praat.org.

Dell, François, and Mohamed Elmedlaoui. 2002. Syllables in Tashlhiyt Berber and in Moroccan Arabic. Dordrecht, NL: Kluwer Academic Publishers.

Ghazeli, S. 1977. Back consonants and backing coarticulation in Arabic. Doctoral dissertation, University of Texas at Austin.

Heath, Jeffrey. 1987. Ablaut and Ambiguity: Phonology of a Moroccan Arabic Dialect. Albany: SUNY Press.

Heath, Jeffrey. 2002. Jewish and Muslim Dialects of Moroccan Arabic. London: Routledge.

Hilili, Abdelaziz. 1979. Phonologie et morphologie de l'ancien fassi (parler arabe marocain). Paris: Université Paris III MA thesis.

Maamouri, Mohamed. 2015 [in press]. Georgetown Dictionary of Modern Moroccan Arabic: Arabic to English. Washington: Georgetown University Press.

Sylak-Glassman, J. 2014. Deriving Natural Classes: The Phonology and Typology of Post-Velar Consonants. Doctoral Dissertation, University of California, Berkeley.

Watson, J. C. 2007. The phonology and morphology of Arabic. Oxford: Oxford University Press.

Younes, Munther. 1994. 'On Emphasis and $\mathrm{r}$ in Arabic.' In Perspectives on Arabic Linguistics VI, ed. M Eid, V. Cantarino and K. Walters. Amsterdam: John Benjamins.

Zawaydeh, B. A., and K. de Jong. 2011. 'The phonetics of localizing uvularisation in AmmaniJordanian Arabic: An acoustic study.' In Instrumental Studies in Arabic Phonetics, ed. Z. Hassan and B. Heselwood. Amsterdam: John Benjamins.

Zeroual, C., J. Esling, and P. Hoole. 2011. 'EMA, endoscopic, ultrasound and acoustic study of two secondary articulations in Moroccan Arabic: Labial-velarisation vs. emphasis'. In Instrumental Studies in Arabic Phonetics, ed. Z. Hassan and B. Heselwood. Amsterdam: John Benjamins. 


\section{NOTES}

1. Consonantal emphasis is distinct from the pharyngeal articulation of [C] and [H], which exhibit constriction in the lower pharynx. Emphatics are instead characterized by upper pharyngeal and/or uvular constriction (Sylak-Glassman 2014; Ghazeli 1977; Zawaydeh \& de Jong 2011).

2. This list was largely drawn from a pre-publication copy of the Georgetown University Dictionary of Moroccan Arabic (Maamouri 2016).

3. The only exception in this respect was the $\mathrm{Q} /$ COR contrast for $\mathrm{F} 2$ of /i/.

4. No significant formant effect of adjacency to a labial consonant was found in these contexts.

5. $\mathrm{t}$-test results for these comparisons were as follows: $\mathrm{F} 1$ of $/ \mathrm{a} /:|\mathrm{t}|(66)=0.41, p=0.68 ; \mathrm{F} 2 \mathrm{of} / \mathrm{a} / \mathrm{t}|\mathrm{t}|$ $(84)=0.23, p=0.82 ; \mathrm{F} 1$ of $/ \mathrm{i} /:|\mathrm{t}|(67)=1.00, p=0.32 ; \mathrm{F} 2$ of $/ \mathrm{i} /: \mathrm{t} \mid(54)=1.58, p=0.12$.

6. F1 comparisons, however, found the vowel distributions in hmar/hmir to be distinct from both plain and emphatic distributions. This situation is reminiscent of the raised F1 in vowels adjacent to /q/ discussed above, but may simply be a relic of the data structure. Given the large number of datapoints and the unequal sample sizes in many of these t-test comparisons, I judge a lack of significant difference between two distributions - as found in the F2 tests here - to be a much more noteworthy finding.

\section{ABSTRACTS}

This paper considers the phonological patterning of pharyngealised / $\mathrm{r} /$ in a dialect of Moroccan Arabic. Through acoustic analysis of recorded interviews targeting specific vocabulary and morphological paradigms, I describe a marginally contrastive distribution of emphatic and plain rhotic variants among Arabic speakers in Fès, indicating that pharyngealised variants trigger a process similar to, but distinct from, the emphasis spread associated with the canonical emphatic consonants /ț/, /d/, and /ș/. While in some varieties of Arabic, rhotic pharyngealisation is an allophonic alternation conditioned by adjacent back vowels, in others [r] has spread through morphological and lexical diffusion to attain quasi-phonemic status. In the changing urban dialect of Fès, the presence of conflicting dialect norms allows us to study how individuals resolve ambiguous phonological input with respect to $/ \mathrm{r} /$, and how this is manifested in their phonetic output.

For this study, I conducted 24 mixed sociolinguistic/phonetic interviews, with the help of native Fessi interview assistants. The interviews provide a comprehensive sample of rhotics for each speaker, which were analyzed for their phonetic effects on adjacent vowels. The acoustic data indicate a wide range of individual variability in the patterning of emphatic $/ \mathrm{r} /$, tempered by predictable patterns in certain paradigms such as hmar. 'donkey' with non-emphatic plural hmmir, or the minimal contrast between biran 'bars' and biran 'wells'. Speakers also exhibited variability in the scope of pharyngealisation spread from $/ \mathrm{r} /$, even though all speakers exhibited predictable long-range spread from /ț/, /ș/, and /ḍ/. These results point to a phonological change in progress, moving in the direction of phonemic pharyngealized $/ \mathrm{r} /$. 
INDEX

Keywords: emphasis, rhotics, pharyngealization, phonology, Morocco, phonemicization, levelling

AUTHOR

AARON FREEMAN

University of Pennsylvania 


\title{
Référents des marques de personne et deixis sociale et émotionnelle en arabe dialectal libanais
}

\author{
Marie-Aimée Germanos
}

\section{NOTE DE L'AUTEUR}

\author{
Abréviations \\ 1PL : première personne du pluriel \\ 2SG : deuxième personne du singulier \\ 2PL : deuxième personne du pluriel \\ 3SG : troisième personne du singulier \\ 3PL : troisième personne du pluriel
}

\section{Introduction}

1 Les études de pragmatique et de sociolinguistique menées sur différents domaines linguistiques mettent au jour le réinvestissement de marques de personnes dans une forme de deixis secondaire (sociale ou attitudinale). Ainsi, pronoms personnels ou affixes verbaux peuvent-ils rendre compte du rang, du statut ou de la génération du (ou des) individu(s) au(x)quel(s) ils réfèrent, de son/leur degré d'intimité ou de distance d'avec le locuteur, ou encore du caractère formel, privé ou public du discours (Siewierska 2004 : 214 s.). En anglais, par exemple, les démonstratifs sont eux aussi réinvestis dans une forme secondaire de deixis, qualifiée d'émotionnelle et d'empathique par Lakoff (1974: 347) et Lyons (1977 : 677) respectivement.

2 Ces valeurs déictiques secondaires demeurent peu étudiées pour l'arabe dialectal ${ }^{1}$. Elles sont repérables, pour ce qui concerne les pronoms personnels et affixes verbaux, à un décalage entre marque de personne employée et référent réel, phénomène sur lequel se concentre cette contribution. On se propose d'y répertorier et d'illustrer, pour l'arabe 
dialectal libanais, les décalages entre marques de personne et référents repérables dans un corpus, réuni pour l'occasion, composé de productions médiatiques, culturelles et artistiques (séries et émissions télévisées, one-man show, films, pièces de théâtre) ${ }^{2}$.

3 Ce panorama, qui s'accompagne d'une réflexion sur les valeurs pragmatiques des décalages relevés, est ordonné selon les marques de personnes réinvesties pour la deixis secondaire en arabe dialectal libanais. Il s'agit en l'occurrence des première personne du pluriel (dorénavant $1 \mathrm{PL})$, deuxième personne du singulier (2SG) et du pluriel (2PL) et troisième personne du singulier (3SG) et du pluriel (3PL).

\section{Emplois de 1PL en décalage avec le référent}

$4 \quad$ 1PL se prête plus volontiers que les quatre autres personnes dont il sera question ici à des usages relevant de la deixis secondaire. Les décalages observables peuvent concerner la personne - auquel cas 1PL est employée par référence à l'interlocuteur (1.1) ou à un tiers (1.2) - ou uniquement sur le nombre - 1PL renvoie alors au seul locuteur (1.3).

\section{PL employée par référence à l'interlocuteur}

\section{Demande faite à l'interlocuteur}

5 1PL est employée par référence à l'interlocuteur le plus souvent dans le cadre d'une demande (12 occurrences), en particulier - mais pas exclusivement, voir l'exemple (ii) lorsque cette dernière est adressée par un soignant à un patient ou par un parent ou un éducateur à un enfant.

6 Ainsi, dans l'exemple (i), Sarah invite-elle ses enfants, dans la chambre desquels elle se trouve, à se coucher en leur disant que 'nous devons dormir' :

(i) Sāra : yalḷa ḥabībe kəll wāḥad 'ala taHtto bänna nnēm yalḷa

Lama : mən dūn ' oșșa?

Sāra : la' 'äkīd fi 'əșșa

7 Dans l'exemple (ii), c'est plutôt à sa mère que Sarah demande de confirmer qu'elle a bien compris sa demande. Dans cet échange, la mère, venue raccompagner Sarah au domicile conjugal hors duquel elle avait été (littéralement) jetée par un mari violent, se félicite du retour à la «normale " sociale. Elle se voit demander en retour par Sarah de ne plus évoquer le sujet en ces termes :

(ii) La mère de Sāra: tə'əbre 'älbe! 'e, hēk, hə! mīn 'əlha l-wəḥde gēer bäyta w žawza?

Sāra : ṃāṃa ma bədde 'əsma' wala kəlme mən hōn la-nūṣal 'a-l-bēt wa 'əlla bbatțil rūḥ ! šu fhomna ?4

\section{Réprobation affectueuse de l'attitude, des propos ou des agissements de} l'interlocuteur

L'autre contexte dans lequel 1PL est employée par référence à l'interlocuteur est celui dans lequel la personne qui prend la parole évoque une attitude, des propos ou des agissements qu'elle réprouve, de la part de la personne à laquelle elle s'adresse, lorsque toutes deux entretiennent un lien affectif fort ( 2 occurrences).

Dans l'exemple (iii), Tarek, amoureux de Sarah, relève ainsi qu'elle s'inquiète - en plus de ses nombreux soucis personnels - de la santé financière de son employeuse : 
(iii) Sāra : ya'ne fi kämm ºbūn 'am bifūto 'a-hä-l-maḥall məš 'äktär! ma ba'rif kīf bädda tədfa'le ma'āše

Ṭāre' : tfaḍdalo ba'a șorna bänna nə'ṭal hämm Fadwa mnäyn bädda tədfa'əlna! Sāra, 'ənte htämme bi-šəğlik w ma tə'țale hämm ši ${ }^{5}$

\section{PL employée par référence à un tiers}

C'est avec une valeur similaire à la précédente que 1PL peut être employée par référence à un tiers (1 occurrence). On retrouve là aussi une attitude réprobatrice du locuteur vis-àvis du comportement d'une personne avec laquelle il entretient un lien affectif fort.

11 Ainsi, dans l'exemple (iv) entendu dans un contexte privé (hors corpus), une amie se plaignait-elle d'une crise de pleurs de son enfant en bas âge :

(iv) hōn, ma ši ! bkīna w z'alna w- ya'ne it was hell'

\section{PL employée par référence au seul locuteur}

12 L'emploi de 1PL par référence au seul locuteur est le tour le plus souvent relevé (22 occurrences) parmi ceux qui sont présentés ici. Ailleurs au Proche-Orient, Henkin (2010 : 257, n. $4 ; 217$, n. 27) le note comme "très fréquent » dans les variétés du Néguev, et Traverso (2006: 120-121; 237-240) l'observe dans des émissions radiophoniques syriennes, où il est employé par les auditeurs, avec une valeur de modestie, et par des experts, avec une valeur de majesté ou en guise de reflet de leur position de « représentant ».

\section{PL employée par un locuteur en position de représentant}

Le corpus contient deux exemples d'un nous " de représentant », qui réunit le locuteur et une communauté élargie dans laquelle il s'insère.

14 Ainsi, dans son discours aux habitants du village, le maire du film $W$ halla' la-wèn? s'adresse-t-il à Abou Ali (dont la chèvre, Brigitte, s'est tuée sur une mine) en usant du pluriel pour lui-même, qui prend effectivement la parole, mais dans une volonté de s'exprimer au nom des habitants du village en sa qualité de représentant municipal :

(v) mnəškur 'Abu 'Ali w mən' əllo Brigitte ma rāḥit ḍi 'ēn yā 'Abu 'Ali’

\section{PL employée dans une attitude d'humilité du locuteur}

Les vingt autres exemples pourraient être regroupés sous la deuxième valeur notée par Traverso (2006) en ce qu'ils relèvent globalement d'une posture d'humilité.

Cette dernière s'exprime par exemple lorsque le locuteur exprime une demande, comme le coiffeur à domicile du film Beirut after Shave (vi), ou encore lorsqu'il fait une concession ou tire une conséquence, sur ses propres actions, des agissements de l'interlocuteur. Ainsi, dans le même film, la femme de ménage explique-t-elle à Raymond Baddar que, n'ayant pu nettoyer sa chambre à coucher du fait qu'il soit resté endormi, elle remet cette partie du ménage à la semaine prochaine (vii) :

(vi) baddna kēn šwayyit mayy ${ }^{8}$

(vii) 'a-kəll ḥāl monnaḍ̣̣fa l-'erb'a lle žēye ${ }^{9}$ 
17 1PL est également employée par un locuteur décrivant une action qu'il a accomplie à l'encontre de son bon gré, comme Sarah qui, dans l'exemple (viii), finit par s'installer dans le quad dans lequel elle ne voulait pas poser le pied :

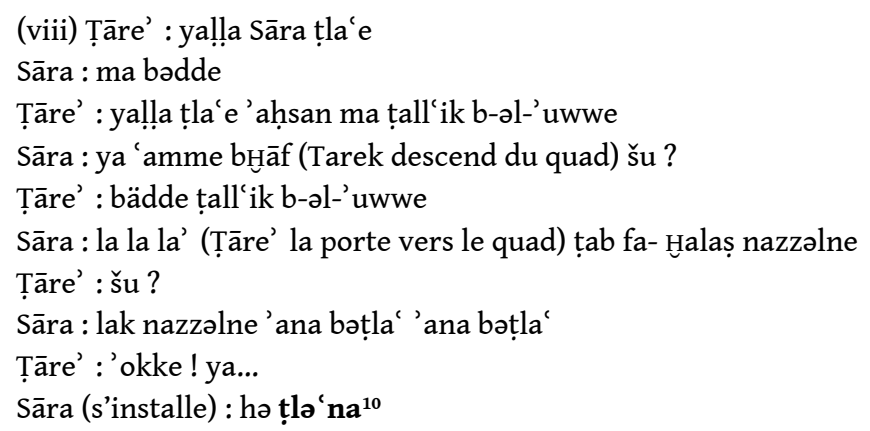

Du fait qu'elle soit employée pour évoquer une action contrainte, 1PL est également un moyen, pour le locuteur, d'atténuer ce qui pourrait être perçu comme un exploit de sa part, alors qu'il ne le considère pas lui-même comme tel. Ainsi, pour le professeur de musique de Leba, le fait de supporter la vie à Beyrouth n'est-il pas source de fierté, mais simple conséquence d'une habitude :

(ix) Lēba : kîf 'ēyiš b-hä-ḍ-ḍažže b-Bäyrūt hawn 'əstēz?

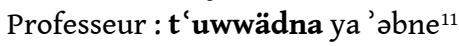

\section{PL employée par un locuteur qui réagit à la dévalorisation de ses propos ou} actions

Enfin, 1PL, dont l'emploi participe souvent d'une stratégie d'humilité, peut également être investie par un locuteur prenant acte de la dévalorisation de ses propos ou de ses actions mais cherchant à y remédier. On trouve ainsi le pluriel au lieu du singulier dans des exemples où une personne rappelle des propos ou des actions de sa part qui n'ont pas été suivis de l'effet escompté.

C'est le cas ci-dessous, lorsque le père de Lama et Amine relève que ses enfants n'ont pas répondu à son 'bonjour' $(\mathrm{x})$ :

(x) 'Ișām : hāy

'Ișām (s'approche de Lama) : ' ’lna hāy

Lama : hāy ${ }^{12}$

\section{Emplois de la deuxième personne en décalage avec le référent}

Comme pour 1PL, les décalages observés avec la deuxième personne concernent la personne, lorsque 2SG est employée par référence au locuteur (2.1), et le nombre, lorsque 2PL est employée par référence au seul interlocuteur (2.3). Mais on trouve également un exemple de décalage qui a trait au genre, avec un énoncé au masculin de la 2SG adressé à une interlocutrice (2.2).

\section{SG employée par référence au locuteur}

L'emploi de 2SG par référence au locuteur (6 occurrences) est un procédé visant à impliquer affectivement l'interlocuteur dans le propos. Il y est fait recours dans des 
récits, lorsqu'un aspect de l'évènement rapporté, qui affecte émotionnellement le locuteur, est présenté de façon généralisatrice, par le biais notamment du recours à l'inaccompli. Les émotions concernées sont variées, aussi bien «négatives » que «neutres » ou « positives ».

L'énoncé ci-dessous est adressé par Tarek à sa mère. Il y évoque la joie suscitée par l'avancement de la construction de sa future maison:

(xi) bta'ərfe ya 'əmme 'addē șa'ib al-'amār ma fi 'aḥsan mən 'ənnik hēk 'tš̌ūe

bäytik 'am byərkäb ḥažar wara ḥažar ${ }^{13}$

On notera que le féminin employé pour 2SG correspond ici au genre de l'interlocutrice, en l'occurrence la mère, et non du référent effectif, Tarek, dont la maison est en cours de construction.

\section{Masculin de la deuxième personne, employé par référence à une interlocutrice}

Le décalage en genre pour la deuxième personne n'est pas fréquent dans le corpus. Un seul exemple a été noté, dans un contexte familial (hors corpus). Il s'agit d'un acte de parole expressif, adressé par une mère à son bébé (une fille) qu'elle cajolait :

(xii) wale šu helo 'onta !14

\section{PL employée par référence au seul interlocuteur}

Contrairement aux emplois de $2 \mathrm{SG}$ avec des décalages portant sur la personne ou le genre, qui relèvent de la deixis émotionnelle, l'emploi de 2PL avec un décalage sur le nombre concerne en premier lieu la deixis sociale. 2PL est en effet occasionnellement employée au Liban à l'adresse du seul interlocuteur, mais principalement en arabe standard ou mélangé, dans des contextes extrêmement codifiés (lecture de documents légaux) ou formels (interview avec un responsable de premier plan). Il s'agit alors d'une marque de respect et de distance.

Les deux exemples d'emploi de 2PL à l'intention de l'interlocuteur seul qui ont été repérés dans le corpus révèlent, contrairement à ceux formels et codifiés évoqués ci-dessus, un usage non systématique. Ils sont en effet employés dans une partie de l'échange - voire dans un énoncé unique -, et non dans son intégralité. Dans les deux cas où 2PL est noté par référence à un seul interlocuteur - exemples (xiii) et (xiv) -, il est le signe d'une déférence exagérée, risible ou ironique, comme dans l'échange suivant, extrait d'une émission satirique.

Ce passage illustre les difficultés rencontrées par les usagers dans l'accomplissement de leurs démarches administratives en raison d'exigences multiples - et pas toujours justifiées - de la part de l'administration :

(xiii) Fonctionnaire : bäddak ’tžəble 'awwälän wärä' bōl 'läyun șūrit 'äl'it ’b'albäk bətle'iya mən wēn ma kēn mən hōn 'a-ț-țarì' taḥ ${ }^{`} t, w$ zyēde bətžəbəlna ma'ak Harịta mən 'ahd əl-'əntidēb w kamēn bädde mənnak məkwēye 'a-l-faḥm hō l'adäma 'roftun ? bətžib kamēn nəșs raț’l läbän 'așfūr wä bətžəble 'əšbit 'ayzä’ān w 'orš mä' dūḥ, w ta'a bukra

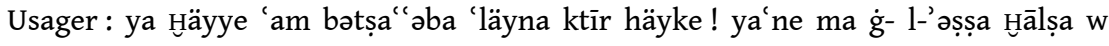
mənthiyye ma bədda gäyr Hätmukum al-kärīm ${ }^{15}$ 


\section{Emplois de la troisième personne en décalage avec le référent}

La troisième personne, au singulier $(3.1,3.2)$ comme au pluriel $(3.3)$, peut quant à elle être employée avec un décalage de personne.

\section{SG employée par référence au locuteur}

3SG peut renvoyer au locuteur lui-même, notamment lorsque ce dernier intercepte une conversation où il est question de lui puis qu'il rebondit sur ce qu'il vient d'entendre, qui le concerne, et dont il a à se plaindre.

31 L'exemple relevé dans le corpus concerne Zaven qui rejoint la conversation de Kasem et Miss Zahra, lesquels venaient d'évoquer ses deux magasins visés par des attentats :

(xiv) 'Āsem : tfaḍḍale häyda Zavēn marrtēn fa' a'ūlo mahallo hawn w hawnīk məš ḥarām?

Miss Zähra : ma 'lūm ḥarām Hูabbrtne halla' 1-miss Säyde

'Asem : ya'ne law 'ana məntəbih 'ädd ma fiyye w mēri' ' əddēm mahallo šu kēn șār fiyye?

Miss Zähra: halla' hēk 'ā'id ’tfäkkir 'ənta? fäkkir ’’-ṣāḥbak Zavēn kîf ’tụarrar mahallo!

Zavēn : wēn maḥallo ? țār maḥallo ! ya ḍi ān əšššūm ! wāḥad žəm'a tnēn maḥall ! ${ }^{16}$

\section{SG employée par référence à l'interlocuteur}

3SG est également employée par référence à l'interlocuteur. Cet usage participe d'une stratégie de prise à témoin d'un public imaginaire par un locuteur qui a des félicitations (1 occurrence) ou des reproches (3 occurrences) à adresser.

Cette stratégie est tournée en dérision dans un one-man-show de l'humoriste Fady Raidy, dans le passage suivant, qui met en scène les sujets de dissension possibles au sein du couple :

(xv) 'aṣ 'ab ši bäss ykūn š- fi šwäyyit 'až a nəḥna dēymän 'abaḍayêt 'ənno bäddna nnzawrib w n'awdim w 'ənno 'abțāl bat' əllak hiyye : balēha l''ēdumiyye bət'əlla la' mənfūt b-əl-'ēdumiyye w btațla' msäkkra 'až' a bta 'la' bi-lsēna la-tūṣalo la-l-bēt ma bət' ūd təH̆laṣ 'altallak ma tf- kəll əț-țarī' ' altallak ma tfūt mən hōn 'altəllak ma tfūt mən hōn ma bətrədd 'altallak ma tfūt mən hōn lašu fatt mən hōn bətșī təḥke ma' nēs 'ənta ma batšūfun bäss hī btəḥke ma'un 'altəllo ma biradd bəddo yfüt mən hōn mīn hō n-nēs ma ba' rif btēkul bähdäle 'eddēmun ${ }^{17}$

\section{PL employée par référence à l'interlocuteur}

3PL peut, tout comme 3SG, être employée lorsque les propos du locuteur sous-tendent un jugement sur les agissements de l'interlocuteur (1 occurrence). Miss Najat choisit ainsi 3SG dans l'exemple ci-dessous pour reprocher indirectement à Hani de ne pas l'avoir saluée :

(xvi) Miss Nažāt : ma bi' ūlo bōnžūr 'abukra ya Häni ?

Häni : bōnžūr ya 'əĤte bi-'amərkun ${ }^{18}$ 
Contrairement aux exemples du corpus avec 3SG, l'observation de Miss Najat, formulée comme une interrogation négative, a été suivie d'un effet sur le comportement de Hani. Il s'agit moins ici de prendre à témoin un tiers imaginaire que d'adresser un reproche à l'interlocuteur, mais d'une façon plus indirecte que ne le supposerait l'emploi de 2SG.

\section{Quelques perspectives, en guise de conclusion}

On notera, en guise de conclusion, que les décalages entre marques de personne et référents présentés ci-dessus relèvent de deux types de deixis secondaire. La deixis sociale, qui concerne «le statut social et le rôle des participants " (Levinson 2004 : 119), semble davantage en jeu dans les cas où le décalage porte, à la première et à la deuxième personne, sur le nombre $(1.3,2.3)$. La deixis émotionnelle, liée à «l'implication émotionnelle du locuteur» $(2.1,2.2,3.2,3.2)$ - voire une double deixis sociale et émotionnelle $(1.1,1.2,3.1)$ - entre pour sa part en compte dans les autres cas.

Enfin, on notera que, comme dans les autres domaines linguistiques où l'emploi de formes impersonnelles peut se faire pour marquer respect ou déférence (Siewierska $2004: 236$ ), en arabe dialectal libanais, les marques de personnes réinvesties dans la deixis secondaire sont également - à l'exclusion de 2PL - celles qui servent à former des énoncés impersonnels.

\section{BIBLIOGRAPHIE}

\section{Sources primaires}

Dora, Amin. 2013. Ghadi. The talkies : Beyrouth.

Ḥabši, Samīr. 2009-2010. Sāra, 26 épisodes. Zalka (Liban) : Marwa Group, retransmis par la MTV.

Épisodes des exemples cités mis en ligne sur la chaîne Youtube de la MTV :

Épisode $1:$ https://www.youtube.com/watch?v=05YAzfK-MS0

Épisode $8:$ https://www.youtube.com/watch?v=OvwSvPj9-kg

Épisode $11:$ https://www.youtube.com/watch?v=WV64yQ3JsSM

Épisode 12 : https://www.youtube.com/watch?v=IQ2hR0zS5ZI

Ḥanna, Šādi. 1995. S.L.Chi. Sketch mis en ligne sur Youtube par un usager :

https://www.youtube.com/watch?v=psXDek0upCA\&feature=youtu.be

Labaki, Nadine. 2011. Whalla' la-wēn ? Paris \& Beyrouth : Les Films des Tournelles, Pathé, Les

Films de Beyrouth, United Artistic Group, Prima TV, France 2 Cinéma, ChaoCorp.

Raḥbāni, Ziad. 1993. Film 'amerike țawill, 3 volumes. Beyrouth : Ṣawt Bayrūt li al-'intāğ al-fannī [1 re représentation 1980]. 
Raidy, Fady. 2016. The Fady Raidy Show. Représentation au Regency Palace Hotel (Adma, Liban) et retransmission sur la LBCI le 17 décembre 2016. Mis en ligne sur Youtube par un usager : https:// www.youtube.com/watch?v=aU8eBnYQ32w

Tamba, Hany. 2005. Beirut After Shave. Paris \& Beyrouth : Bizibi productions \& VIP films.

\section{Sources secondaires}

Henkin, Roni. 2010. Negev Arabic. Dialectal, sociolinguistic and stylistic variation. Wiesbaden : Harrassowitz.

Lakoff, Robin. 1974. "Remarks on This and That", LaGaly, Michael, Fox, Robert \& Bruck, Anthony (éds), Papers from the Tenth Regional Meeting of the Chicago Linguistic Society. Chicago: Chicago Linguistic Society. 345-356.

Lentin, Jérôme. 2015. «L'emploi déictique du féminin singulier dans les dialectes arabes et une voie possible de sa formation ", Al-Wer, Enam, Hadjidemetriou, Chryso, Herin, Bruno \& Horesh, Uri (eds), Proceedings of the 8th Conference of Association Internationale de Dialectologie Arabe (AIDA). Colchester (Royaume-Uni). 15-46.

Levinson, Stephen. C. 2004. "Deixis”, Horn, Laurence \& Ward, Gregory (éds), The Handbook of Pragmatics. Malden, MA: Blackwell. 97-121.

Lyons, John. 1977. Semantics. Volume 2. Cambridge : Cambridge University Press.

Maloom, Hanan, Dufour, Julien \& François, Dumas. 2009. « Expression de la politesse et de la civilité dans la société sanaanie ». EDNA 13. 121-152.

Siewierska, Anna. 2014. Person. Cambridge : Cambridge University Press.

Taine-Cheikh, Catherine. 1993. « Du sexe au genre : le féminin dans le dialecte arabe de Mauritanie », MAS-GELLAS n.s. 5. 67-121.

Traverso, Véronique. 2006. Des échanges ordinaires à Damas : aspects de l'interaction en arabe. Lyon \& Damas : Presses Universitaires de Lyon \& IFPO.

\section{NOTES}

1. On trouve des observations sur la deixis sociale dans des travaux traitant de politesse, par exemple dans celui de Maloom, Dufour et Dumas (2009) pour Sanaa. On reviendra plus loin sur les remarques de Traverso (2006) et Henkin (2010) relatives aux emplois de la première personne du pluriel à Damas et dans le Néguev. On notera aussi que Taine-Cheikh (1993) relève des emplois du masculin pour un référent féminin dans la poésie mauritanienne et que Lentin (2015) se penche sur la valeur «neutre » de la troisième personne du féminin singulier dans différentes dialectes.

2. Traiter des décalages repérables dans les formules de politesses (äs-sälämu 'aläykum, etc.) et dans les expressions figées ('amərna la-'alla, etc.) aurait démesurément rallongé cette contribution : ils n'y ont donc pas été inclus.

3. Ḥabši (2009-2010, épisode 1 - 35'55) : 'S : allez, les enfants, que chacun de vous se couche, il faut [nous devons] dormir, allez / L : sans histoire ? / S : non, bien sûr, il y aura une histoire'.

4. Habši (2009-2010, épisode 12 - 39'42) : 'La mère de $S$ : ma chérie, ah, voilà ! Qu'y a t-il de plus important pour une femme que son foyer et son mari? / $\mathrm{s}$ : maman, je ne veux plus rien entendre jusqu'à ce que nous arrivions à la maison, sinon, je n'y vais plus ! Compris [qu'avonsnous compris] ?'.

5. Ḥabši (2009-2010, épisode 8 - 15'57) : 'S : il y a juste quelques clients qui entrent dans ce magasin! Je ne sais pas comment elle va me payer mon salaire / T : et voilà ! On s'inquiète [nous 
nous sommes mis à nous inquiéter] à présent de la façon dont Fadwa payera un [notre] salaire ! Sarah, toi, concentre-toi sur ton travail, et ne te préoccupe de rien d'autre'.

6. 'Elle, je ne te dis pas! Elle a pleuré, s'est fâchée [nous avons pleuré, nous nous sommes fâché (e)] et- c'était l'enfer quoi'.

7. Labaki (2011, 11'15) : 'nous remercions Abou Ali et nous lui disons : 'le sacrifice de Brigitte n'a pas été vain, Abou Ali".

8. Tamba $(2005,07$ '58) : 'j'aurais besoin d'un peu [nous aurions voulu un peu] d'eau'.

9. Tamba (2005, 04'48) : 'enfin, j’y ferai le ménage [nous la nettoierons] mercredi prochain'.

10. Ḥabši (2009-2010, épisode 11 - 20’30) : ‘ $\mathrm{T}$ : allez Sarah, monte / S : je ne veux pas / $\mathrm{T}$ : allez, monte, sinon, je te fais monter par la force ! / S : mais enfin, j’ai peur ! (Tarek descend du quad) quoi ? / $\mathrm{T}:$ je vais te faire monter par la force ! / S : non non non (Tarek la porte vers le quad) bon, c'est bon, lâche-moi / T : quoi ? / S : mais laisse-moi descendre, j'y vais moi-même, j'y vais moi-même / T : d'accord ! Bon... / S (s'installe) : voilà, je suis montée [nous sommes monté(e)]'.

11. Dora $(2013,22$ '00) : 'L : comment vivez-vous à Beyrouth, avec ce bruit, professeur ? E : je m'y suis habitué [nous nous y sommes habitué(s)], Leba [mon fils]'.

12. Ḥabši (2009-2010, épisode 1 - 11'50) : ‘I : bonjour / I : j’ai dit [nous avons dit] 'bonjour' / L : bonjour'.

13. Habši (2009-2010, épisode 1 - 33’05) : 'Tu sais, maman, ça a beau être difficile, le bâtiment, il n'y a rien de mieux que de voir [que tu voies] ta maison prendre forme, pierre par pierre !'.

14. 'Oh là là, tu es trop belle [beau], toi [m.] !'.

15. Hanna (1995, 01'40) : ‘Fonctionnaire : tu dois m'apporter, d'abord, des timbres fiscaux, avec la photo des colonnes de Baalbeck, tu pourras les trouver n'importe où dans la rue, en bas. En plus, tu apportes une carte établie à l'époque du mandat. Il me faut aussi un fer à repasser au charbon, comme les anciens, tu vois? Tu apportes aussi un litre de lait de jabot, un bouquet de sauge, une pièce d'une piastre trouée [retirée de la circulation plusieurs années plus tôt], et tu reviens demain / Usager : ah monsieur [mon frère], avec tout ça, vous me [nous] compliquez bien les choses ! La démarche est terminée, il n'y manque plus que votre honorable apostille'.

16. Rahbāni (1993, vol. 1 - 12’50) : ‘K: prenons Zaven! Deux fois son magasin a sauté, ici [à Beyrouth-Ouest] et là-bas [à Beyrouth-Est], ce n'est pas terrible? / Miss Z: bien sûr, c'est terrible! Miss Sayde vient juste de me le raconter / $\mathrm{K}$ : eh bien, j'aurais pu faire attention autant que je voulais, si j'étais passé près de son magasin, qu'est-ce que je serais devenu ? / Miss Z : mais c'est à ça que tu penses, toi ? Pense plutôt à ton ami Zaven, qui a perdu son magasin ! / Z : il est où mon [son] magasin ? Il a disparu, mon [son] magasin! Quelle misère! Semaine, un, magasin, deux !'. (Dans la pièce, les répliques de Zaven, d'origine arménienne, comportent des maladresses linguistiques qui représentent l'arabe dialectal libanais tel qu'on pourrait l'imaginer parlé par des locuteurs pour qui il s'agirait d'une langue seconde. Dans la réplique citée ici, ces maladresses sont concentrées dans la phrase « wāḥad žəm'a tnēn mahall ». Elles y portent sur l'inversion de l'ordre des mots et l'absence d'accord en genre et de marquage du duel. La formulation «maladroite» de Zaven est plus percutante que les énoncés acceptables auxquels on pourrait penser. Elle juxtapose deux groupes nominaux aux composants identiques et, de ce fait, sa construction ressemble à celle d'un slogan publicitaire. L'emploi de la troisième personne du singulier par référence au locuteur dans cet exemple n'est quant à lui pas à mettre sur le compte de ces maladresses linguistiques : il s'agit bien d'un emploi acceptable, dans ce contexte, en arabe dialectal libanais).

17. Raidy $(2016,58$ '30) : 'Le pire, c'est quand ça roule un peu mal. Nous [les hommes], on est malins, on a envie d'échapper à la circulation en prenant des petites ruelles, on est des champions de la route quoi. Elle, elle te dit: 'laisse tomber cette ruelle!' Tu lui dis : 'non' ; tu y vas, et hop : c'est bouché ! Là, tu es cuit : elle râle jusqu'à ce que vous arriviez à la maison. Ça ne s'arrête plus : 'je t'avais bien dit de ne pas p-'... ça dure pendant tout le trajet : 'je t'avais bien dit de ne pas passer par là... tu ne réponds pas... je t'avais bien dit de ne pas passer par là... je t'avais 
bien dit de ne pas passer par là, pourquoi es-tu passé par là ?'. Puis elle se met à parler à des gens. Toi, tu ne les vois pas, mais elle, elle leur parle. 'Je le lui avais dit, mais il ne répond pas! Il voulait passer par là'. Qui sont ces gens? Je n'en sais rien, mais en tout cas, tu reçois un savon devant eux'.

18. Raḥbāni (1993, vol. 1 - 42'04) : 'Miss N : on ne dit pas [ils ne disent pas] bonjour le matin, Hani ? / H : bonjour, bonjour [ma sœur], à vos ordres'.

\section{RÉSUMÉS}

La forme des pronoms personnels et plus généralement des marques de personne est bien documentée pour de nombreuses aires dialectales de l'arabe. C'est moins le cas de leurs emplois hors deixis personnelle stricto sensu, autrement dit, pour des référents différents de ceux qui seraient normalement attendus en termes de personne (le locuteur, l'interlocuteur ou un tiers), de genre ou de nombre.

Cet article s'intéresse à de tels emplois en arabe dialectal libanais, variété ainsi qualifiée car le corpus qui a servi de base à l'étude est composé de productions médiatiques, culturelles et artistiques. On s'y penche sur les décalages entre marque de personne et référent lorsqu'ils relèvent de la deixis sociale et de la deixis empathique ou émotionnelle.

Ces décalages sont regroupés selon les marques pour lesquelles ils ont été observés, en l'occurrence celles des première (pluriel), deuxième (singulier) et troisièmes (singulier et pluriel) personnes. Cet inventaire s'accompagne d'une réflexion sur leurs valeurs pragmatiques.

\section{INDEX}

Mots-clés : pragmatique, personne, genre, nombre, deixis sociale, deixis émotionnelle, deixis empathique

\section{AUTEUR}

\section{MARIE-AIMÉE GERMANOS}

INALCO, CERMOM 


\title{
Deontic Modality in Baghdadi Arabic
}

\author{
George Grigore
}

\section{Introduction}

1 In this paper, I tried to present and analyze the possibilities of expressing the deontic with its multiple facets - in the Spoken Arabic of Baghdad, using, as basis, a corpus of data that I have gathered throughout the years during my visits in Baghdad, corroborated with al-Ḥanafī (1978), BiȚună (2013), Grigore (2010), McCarthy and Raffouli (1964, 1965).

The deontic modality indicates the permission or the obligation, imposed externally, to complete an action according to a set of preexisting principles whose basic meanings refer to what is obligative ("You must go now") or permitive ("You may/can go now") (Palmer 2001: 71). The most known manifestation of deontic modality consists in the directives which Searle defines as "where we try to get others to do things" (Searle 1983: 166). Another subdivision of the deontic modality, the commissive, is defined by the same author as "where we commit ourselves to do things" (Searle 1983: 166) known also as the volitive/desiderative deontic which indicates the decisions that are taken based on the wishes of the individual instead of being based on previously established rules or principles. This type of deontic has a high degree of subjectivism with respect to the obligation and permission of completing a specific action (e.g. I want you to eat; you may eat ). From Zafiu's point of view, the real deontic is based on extra linguistic support, an independent set of rules, and, when it doesn't exist, the speaker may operate upon false rules which correspond to its own subjective willingness, in this case, the deontic draws near the volition (Zafiu 2005: 687).

Other authors, such as Bybee, Perkins, and Pagliuca reject the denomination of deontic and replace it by two concepts which are the speaker-oriented modality, where the speaker imposes conditions on an addressee, and the agent-oriented modality that reports the existence of an obligation imposed by external conditions to an agent forced to complete an action (1994: 176-181). 
I will analyze below the directives (obligation and permission) in Baghdadi Arabic.

\section{The obligation}

\subsection{Imperative}

5 The verb's imperative mood, in its affirmative form, always suggests the necessity or compulsiveness of performing the required act:

rūḥ 'uHud min Hāțir aHūu-k 'almūd mā yibqā za'lān 'alē-k!

Go make up with your brother so he doesn't stay upset with you.

lahhib id-dīč zeyn gabul mā tuțabH-a!

Singe the rooster well before you cook it!

6 The negative form of the imperative verb - realized by using the negation particle $l \bar{a}-$ indicates the prohibition of an action:

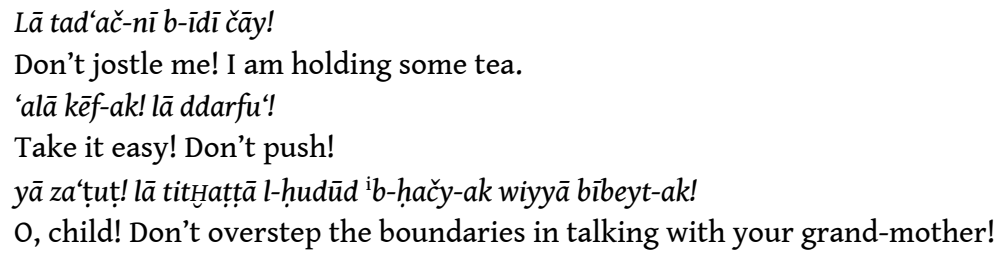

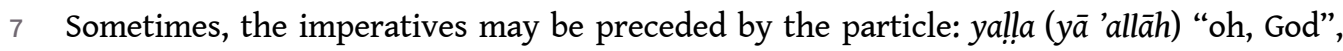
"come on", "go on", "hurry up", which signifies an encouragement, an incentive to perform the required task:

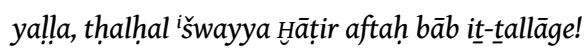

Come on, move a little so I can open the door of the refrigerator!

8 For reinforcement yalla can be combined with Halli "let's" in many cases:

yalla, Hasan, Hallī ninzil min il-buruğ, tarā ānī dāyH!

Come on, Hasan, let's go down from the tower because I am dizzy!

Also, yalla can sometimes precede the particle de which strengthens the imperative, thus indicating that the speaker lost patience and the recipient should proceed with performing the required task:

de-yalla, Halli nirğa' li-ț-țarma!

oh, come on, let's come back to the porch!

10 Besides the aforementioned one, there is another reinforced form of the imperative which is formed by adding the particle de before the simple imperative verb: de-rūh "go immediately!", de-ktib "write immediately!", etc.

11 The particle de seems to have its origin in Ottoman Turkish where it is used as an abbreviation for hayde/haydi, hadi "come on":

Haydi qoš čabuq!

Allons, cours vite!

Come on, run quickly!

Hayde qîz-îm biz-e bir-er qahve söyle!

Allons, ma fille, commande-nous un café à chacun!

Come on, my girl, order a coffee for each of us! (Deny 1928: 714).

This preverbal particle is also found in contemporary varieties of Anatolian Turkish:

de-git!

Go immediately! 
The similarity, on all levels, of the Mesopotamian preverbal particle de with the Turkish particle de is more than obvious. Haim Blanc considers that: "Such imperatives with /de/ are perhaps a shade more energetic than the plain imperative and a shade less energetic than the imperfect plus /ma/" (1964:117):

'alī gāl hīči? d-Hallīinā min hādāà! msawdan!

Ali said that? Spare us from him! He's crazy!

\subsection{The VII stem}

Out of all the derived Arab verbal stems, the VII stem (which represents the passive voice in the Mesopotamian dialects), at the imperfective aspect shows the necessity of performing an action in a certain fashion and comes as a recommendation, as an advice to be cautious so that the usual practice is respected in the given conditions:

li-hdūm tinHisil ihnā bi-ț-țašit!

The clothes can be washed here in the wash basin!

15 The most prevalent use of this derived stem is the negation which adds a meaning different from the affirmative form, thus indicating the stringent need to not perform a certain action, insisting on this fact which, hence, becomes totally prohibited:

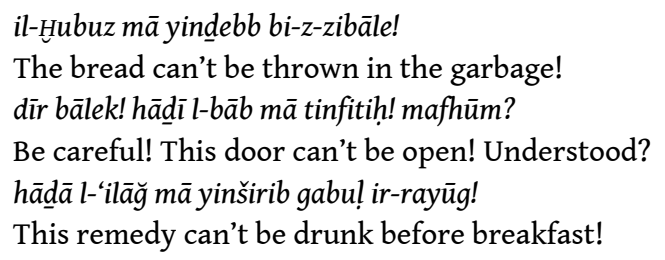

In all the above mentioned examples, the verb can be preceded, for strengthening, by lāzim "must". The insertion of lāzim decreases the degree of prohibition, drawing it nearer to a recommendation:

li-hdūm lāzim tinHisil i hnā bi-ț-țašit!

The clothes must be washed here in the wash basin!

\subsection{Derivatives from the root I.z.m.}

17 Most of times, in Baghdadi Arabic, for expressing the deontic, derivatives from the root l.z.m. - yilzam, lāzim, malzūm, luzūm - that indicate the necessity of performing an action, action which cannot be delayed - are used:

-āku luzūm ă̆ī-k bāčir?

- lā, māku luzūm tiği ent, tigdar tdizz fadd wāhid aHar.

- Is there need that I come to you tomorrow?

- No, there is not need that you come, you can send another one.

- bāčir kull šōfer lāzim 'alē yințīnī fad[d] pāket ğigāyir.

- Tomorrow every driver must give me a packet of cigarettes.

mū lāzim tdallil iț-țifil, li'an yikbur mițil wilid ni'ma $w$ dalāl.

You must not spoil the child, because he will grow up as the pampered rich.

āni malzūm arūh wiyyā-k.

I am obliged to go with you. 


\subsection{Prepositional structures}

18 The preposition "ind or "idd "at" has the meaning of property when it indicates a material thing at the disposal of its owner "ind-i H Hāšñge "I have a spoon" or it has metaphoric meaning with respect to abstract notions such as time, science etc. When used with verbal nouns it has the meaning of performing an action:

'ind-a kitāba.

He has to write.

'ind-ī hačì wiyy $\bar{a}-k$.

I have to talk to you.

19 The use of the preposition warā "behind" is more common than the use of "ind "at" as if the action pursues the performer, forcing him to solve it or to act upon it in order to get rid of it:

warā-y rūha li-bēt 'amm-i.

I have to go to my uncle's house.

il-yōm warā-y Hasil iz-zūliyye w țabuH.

Today I have to wash the carpet and to cook.

mā agdar addān-ak il-yōm..., walla, warā-y daf'at il-kahrabā'.

I cannot lend you today, by God, I have to pay the electricity.

20 At times, the spatial orientation can be opposite with regards to what I just presented, more exactly warā is replaced by giddām "in front of"; in this situation the action that must be performed becomes a hurdle for the performer, thus, forcing him to remove it in order to continue his way.

21 The expressions used in the Standard Arabic al-fush $\bar{a}$ for introducing the deontic modality, such as lā budda, lā maHrağa, lā mafarra, etc. (the common denominator - "there is no escape" - being the lack of any possibility of escaping from accomplishing the required action) can also be found in Baghdadi Arabic: māku mafarr "there is no escape", $m \bar{a} k u$ țfra "there is no jumping", māku šarda "there is no fleeing", māku mukān "there is no place", etc. Generally, they appear together with lāzim:

māku šarda min id-dōlma, yōmiyye lāzim tinwakil.

There is no escape from the dolma, you have to eat it daily.

māku šarda min iğ-ğihāl, lāzim trabbì-hum, tlabbis-hum, tnawwim-hum, t'akkil-hum.

There is no escape from children, you must raise them, dress them, put them to

sleep, and feed them.

māku țafra min hādā l-msawdan, lāzim tințī-h fad(d) rašde.

There is no escape (jumping) from this crazy, you must hit him.

māku mukān trūḥ l-a, lāzim tibqā hnā.

There is no place to go, you must stay here.

māku ayy hall, lāzim tnām mustašfā.

There is no solution, you must enter hospital.

Sometimes, the reinforcement of the deontic is attained by the repetition of the verb, underlining the indomitable destiny:

Māku țafra min[n] iz-zawā̄̆, titzawwağ-titzawwă̆.

There is no escape (jumping) from marriage, you get married-you get married. 


\subsection{Be careful!}

The phrase dì bāl-ak "be careful", "pay attention" is used for warning the recipient upon a punishment that follows the execution of a certain action. Hence, it indicates the forbidding of an action, or, better said, the abstinence from performing it:

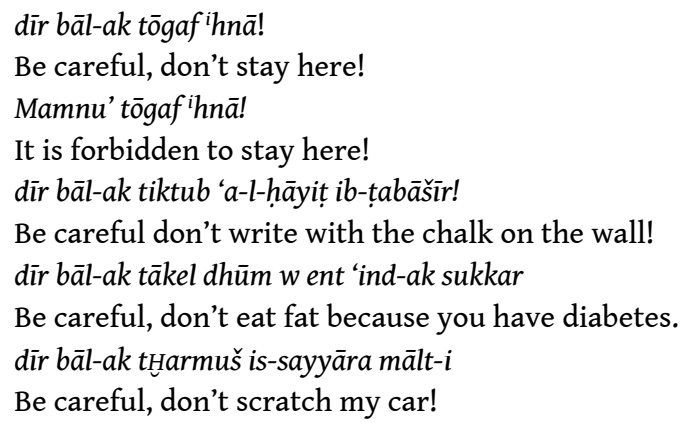

\section{6. rād-yrīd "to want"}

The verb rād-yrid "to want" at the imperfective aspect $3^{\text {rd }}$ person, plural, signifies an imposition of an act from the authorities (dōl, hā power"):

yirdūn minn-ak viyez, id̄ā tidHul Turkiyā.

They want visa from you, if you enter Turkey.

Yrād, an abbreviation from yinrād, the VII stem has a role of passive voice of the verb rādyrid "to want" with the assimilation of the consonant $/ \mathrm{n} /$ by the consonant $/ \mathrm{r} /$ followed by the latter's reduction - due to usage - to a simple $/ \mathrm{r} /$ :

yrādl-ak šugul hwāye, hattā tkawwin nafs-ak.

There is much work needed from you, until you fulfil yourself.

\subsection{The necessity meaning}

All the names that have the meaning of necessity, need - such as hāăga, darūra, darūri - are used for expressing a deontic meaning:

'aku hāăğa tițla' min il-bēt ib-hāda l-wakit?

Is there any need to get out of the house in this time?

māku hāăga tsawwī kull hāy il-hōse.

There is no need to make all this uproar.

darūri thūäbir-nī l-yōm.

You must call me today.

\section{8. ġașban 'alā}

The expressiongaşban 'alä "in spite of" is used to express the coercion of somebody, hence, in spite of his will, to perform an action, the coerced not being convinced of its utility:

rah tsudd il-bāb ǵaṣban 'ale-k $k$

You are going to close the door in spite of your wish.

gașban 'alè-k, tidrus il-handase, $m \bar{u} l-a d a b$.

In spite of you(r) (wish), you are going to study engineering, not literature. 


\subsection{Past participles}

to show an action imposed by a situation that has no other way out:

mudțarr iddāyan flūs min 'amm-a.

He is obliged to borrow money from his uncle.

mağbūr il-yōm arūh li-l-hiwāza.

I am obliged today to go to the farm (i.e. private estate).

\subsection{The oath}

The oath is defined as the binding of self to refrain from something or to set out to perform something, bearing the meaning of absolute truth for the one who takes an oath, of pure faith. Its insertion in a sentence gives the acceptation of compulsiveness of fulfilling the mentioned act in such a way that the speaker will not lose his credibility in front of peers:

w dā't abūya rāḥ adrub-ak bi-s-siččīn.

By my father's honor, I'll bit you with the knife.

\subsection{The verb halla “let's"}

The imperative of the verb Halla, even though it has deontic acceptations, still holds the predominant meanings of advice, incentive:

Hallì nfūt minnā Hāạtir mā yšūfnā.

Let's go this way so he won't see us.

là tHallì l-'itwī ybūl bi-t-țarma!

Don't let the tomcat piss on the porch!

\section{The permission}

\subsection{The verb yğūz}

31 The manifestation of permissiveness is accomplished with the help of the verb y y̆guz:

yğ $\bar{u} z$ tākel hassa.

It is fit to eat now.

\section{2. masmūḥ "permitted"}

The past participle of the verb sumah "to permit":

masmūḥ l-ak tākel hassa.

It is permitted for you to eat now.

\subsection{The verb hallā}

And, also, with the imperfective and imperative of the verb Halla

aHalli-k tig'ud wiyyā-nā ba'ad ma tiğlib el-nā raggiyye ellī tahat ič-čerpāye.

I allow/ I permit you to sit with us after you bring us the watermelon which is under the bed. 
lā tHallìl-'itwī ybūl bi- t-țarma!

Don't let the tomcat piss on the porch!

\section{Final remark}

34 A remark emerges from all the given examples that, across this research, the verb is either imperative or imperfective (present), the perfective form eliminating the deontic meaning, hence the sentence becomes purely descriptive:

mā čān lāzim tgūmīn min il-firāš w tușubgīn ša'r-eč bi-l-ḥanna.

You should not have got out of the mattress and to dye your hair with henna.

\section{BIBLIOGRAPHY}

al-Ḥanafī, Ğalāl. 1978. Mu'ğamu l-luġati l-'āmmiyyati l-baġdādiyyati. Baghdad: Dāru l-ḥurriyya li-lțibā'ati.

BiȚună, Gabriel. 2013. “Š-aku māku? A Lexical-Semantic Approach to the Specific Vocabulary of the spoken Arabic of Iraq", Romano-Arabica 13. 61-78.

Blanc, Haim. 1964. Communal Dialects in Baghdad. Cambridge: Harvard University Press.

Bybee, Joan L. \& Perkins, Revere \& Pagliuca, William. 1994. The evolution of grammar: Tense, aspect and modality in the languages of the world. Chicago: The University of Chicago Press.

Deny, J. 1920. Grammaire de la langue turque (Dialecte osmanli). Paris : Éditions Ernest Leroux.

Dury, Richard. s.a. A Brief Glossary of Modality [online]. Available at: http://dinamico2.unibg.it/

anglistica/slin/modgloss.htm [Accesed July 11, 2015)..

Grigore, George. 2007. L'arabe parlé à Mardin: monografie d'un parler arabe périphérique. București: Editura UniversităȚii din București.

Grigore, George. 2010. "Les verbes à racines quadriconsonantiques dans l'arabe parlé à Bagdad", Analele UniversităŢii din Bucureşti - Limbi şi Literaturi Străine. Year LIX. Bucharest: Editura UniversităŢii din Bucureşti. 55-64.

Jacobsson, Bengl. 1994. "Recessive and emergent uses of modal auxiliaries in English", English Studies 72(2): 166-182.

Kärkkäinen, Elise. 1992. "Modality as a Strategy in Interaction: Epistemic Modality in the Language of Native and Non-Native Speakers of English", Pragmatics and Language Learning, Vol. 3. 197-216.

Lyons, John. 1977. Semantics. Volume 2. Cambridge: Cambridge University Press.

McCarthy, Joseph; Raffouli, Faraj. 1964. Spoken Arabic of Baghdad. Beirut: Librairie Orientale.

McCarthy, Joseph; Raffouli, Faraj. 1965. Spoken Arabic of Baghdad. Part two (A) - Anthology of Texts. Beirut: Librairie Orientale.

Palmer, F. R. 2001. Mood and Modality. Cambridge: Cambridge University Press. 
Searle, J, R. 1983. Intentionality. Cambridge: Cambridge University Press.

Woodhead, D. R.; Beene, Wayne (eds.). 1967. A Dictionary of Iraqi Arabic. Arabic-English. Washington D. C.: Georgetown University Press.

Zafiu, Rodica. 2005. "Modalizarea”, Valeria GuȚu Romalo (coord.), Gramatica academică a limbii române (GALR),vol. II. Bucharest: Editura Academiei Române. 673-697.

\section{ABSTRACTS}

The deontic modality - also known in the literature on the topic as speaker-oriented modality indicates an obligation or permission imposed externally, compelling an agent to complete an action, in accordance with a corpus of pre-existent rules. In this paper, I will present an analysis of the possibilities to express the deontic modality - with its multiple facets - in Baghdadi Arabic, analysis based on a corpus of data gathered by me in the last ten years, during my visits to Iraq. The present analysis will point out the main modal verbs (i.e.: yimkin "to be possible", yrid "to want", etc.), modal expressions (i.e.: lā budd min "it is inevitable", akū luzūm "there is an obligation", etc.), pre-verbal particles (i.e.: $d-, d$-rūh "go immediately", etc.) and so on used to introduce the subjective degree of the compulsoriness or the permissibility, the necessity or the acceptability of an action.

INDEX

Keywords: Baghdadi Arabic, deontic modality, permission, obligation.

\section{AUTHOR}

\section{GEORGE GRIGORE}

Department of Arabic, University of Bucharest, Romania 


\section{Les marqueurs des constructions analytiques du réfléchi et du réciproque en arabe du Caire}

Julie Haslé

\section{Introduction}

1 Les marqueurs qui vont nous occuper en cairote sont pour le réfléchi nafs et pour le réciproque $b a^{\prime} d$. Ils encodent le réfléchi et le réciproque dans le cadre de constructions analytiques qui impliquent une réorientation des actants faisant usage de marqueurs syntaxiques, et n'impliquant pas de modification morphologique de la forme verbale utilisée.

2 Il ne s'agit pourtant pas de leur seul emploi, puisqu'ils peuvent remplir d'autres fonctions. Ils ont donc subi un processus de recaractérisation en marqueurs de diathèse. Il s'agit ici d'exposer les critères qui permettent à un même mot de remplir ces différentes fonctions, et quelle notion les unit.

3 Nous distinguons deux types d'usages de ces mots en dehors de leur fonction diathétique : des fonctions parallèles, aussi issues d'un premier niveau de recaractérisation, et des usages étendus des marqueurs de diathèse, permis par leur rôle dans la réorganisation des actants. L'étude conjointe des différents usages de ces mots nous renseigne sur les valeurs associées au réfléchi et au réciproque en cairote.

4 Les sources des exemples sont indiquées en bibliographie, à l'exception de ceux issus de nos données, recueillies lors d'entretiens avec trois locuteurs cairotes, Amāni (Am), Ayā (Ay) et Karīm (Ka). 


\section{Usages de nafs}

\subsection{Premier emploi : substantif}

\begin{tabular}{|l|l|l|l|l|l|}
\hline kallem & nafs-ek & $u$ & 'ale-ha & tșāleḥ \\
\hline parler.IMP.SG.M & âme-2SG.M & CONJ & PREP-3SG.F & se_réconcilier.IMP.SG.M \\
\hline \multicolumn{4}{l}{ Parle à ton âme et sois réconcilié avec elle. (Cairokee 2015: Kull hạaga bet'addi) } \\
\hline
\end{tabular}

7 Il est productif dans cet usage, que nous considérons comme premier sens du mot.

\subsection{Premier niveau de recaractérisation}

8 L'ordre dans lequel les usages de nafs seront présentés dans cette section n'indique pas un rapport chronologique de leur développement.

\subsection{1. nafs préposé à un groupe nominal défini : Indicateur d'état (IE)}

9 Une première recaractérisation est l'usage de nafs préposé à un groupe nominal. Celui-ci est toujours déterminé par l'article défini.

ii.

\begin{tabular}{|l|l|l|l|l|l|}
\hline te-dris & nafs & Ed-drāsa & lli & ana & 'amal-ta-ha \\
\hline 2/3.F.INACC-étudier & IE & ART-étude & REL & 1SG & faire-1SG/2SG.M.INACC-3SG \\
\hline
\end{tabular}

11 À première vue, cette construction semble indiquer l'identité. Pourtant, à y regarder de plus près, elle indique rarement l'identité factuelle d'une chose avec elle-même. Au contraire, il s'agit la plupart du temps de marquer la similitude de deux référents distincts. Dans cet emploi, nafs indique qu'il existe entre deux référents des traits communs qui permettent de les ramener à la même notion. Ainsi, la présence d'un seul groupe nominal masque la mise en rapport d'au moins deux éléments distincts.

\subsection{2. nafs-PRO : pronom emphatique}

nafs peut également être postposé à un groupe nominal (ex. iii.) ou un pronom personnel indépendant (ex. iv.). Dans ce cas, il est suffixé d'un pronom personnel, qui est accordé en genre et en nombre avec l'élément qui le précède.

13 iii. 


\begin{tabular}{|c|c|c|c|c|c|c|c|c|c|}
\hline \multicolumn{3}{|c|}{ al-gām'a } & \multicolumn{2}{|l|}{ nafsa-ha } & ya'ni & El-mabna & $n a f s-u$ & mabna & tārīH \\
\hline \multicolumn{3}{|c|}{ ART-université } & \multicolumn{2}{|c|}{ EMP-3SG.F } & MD & ART- & EMP-3SG.M & bâtiment & historique \\
\hline ya'ni & 'aẓìm & ya'n & & gamil & & geddan & & & \\
\hline MD & magnifique & MD & & beau & & ADV & & & \\
\hline $\begin{array}{l}\text { L'uni } \\
\text { très } k\end{array}$ & $\begin{array}{l}\text { versité elle-n } \\
\text { eau. (Am) }\end{array}$ & lême & enfin le b & nent 1 & me & t un bâtiment $h$ & historique, en & ffin magnif & fique, enfin \\
\hline
\end{tabular}

14 iv.

\begin{tabular}{|c|c|c|c|c|c|c|c|c|c|}
\hline ana & \multicolumn{2}{|l|}{$n a f s-i$} & $m a$ & \multicolumn{2}{|c|}{$b-a-h \varepsilon b b a-h a$} & \multicolumn{2}{|l|}{ 'awi } & \multicolumn{2}{|l|}{ lāken } \\
\hline $1 \mathrm{SG}$ & \multicolumn{2}{|c|}{ EMP-1SG } & NEG & \multicolumn{2}{|c|}{$\begin{array}{l}\text { PVB-1SG.INACC- } \\
\text { aimer-3SG.F }\end{array}$} & \multicolumn{2}{|l|}{ ADV } & \multicolumn{2}{|l|}{ CONJ } \\
\hline \multicolumn{2}{|c|}{$b e-n-n e s b a$} & \multicolumn{2}{|l|}{ la-l-'arab } & $\begin{array}{l}\text { kullu- } \\
\text { hum }\end{array}$ & \multicolumn{2}{|l|}{ Ummu Kalsūm } & \multicolumn{2}{|l|}{$d i$} & ilāh \\
\hline \multicolumn{2}{|c|}{ pour } & \multicolumn{2}{|l|}{$\begin{array}{l}\text { PREP-ART- } \\
\text { Arabes }\end{array}$} & tout-3PL & \multicolumn{2}{|l|}{ Oum_Kalsoum } & \multicolumn{2}{|l|}{ DEM.F.SG } & divinité \\
\hline \multicolumn{10}{|c|}{$\begin{array}{l}\text { Personnellement, moi je ne l'aime pas trop, mais pour tous les Arabes, Oum Kalsoum c'est une } \\
\text { divinité. (Am) }\end{array}$} \\
\hline
\end{tabular}

15 Par ce procédé, nafs-PRO singularise l'élément avec lequel il s'accorde, ayant en cela une fonction isolante. L'élément n'est plus compris dans une liste de référents aux caractéristiques similaires, et avec lesquels il est en concurrence dans le réel ou le lexique, mais bien par ce qui le caractérise en propre, en tant qu'individu. Cette fonction isolante crée un effet d'emphase, qui conduit à parler de pronom emphatique pour cet emploi de nafs. L'emphase est l'effet de l'attention portée à la nature de l'objet.

\section{3. nafs-PRO : marqueur de réfléchi}

\subsubsection{Description de la construction analytique du réfléchi}

La troisième recaractérisation de nafs est celle qui forme la construction analytique du réfléchi. Elle est formellement identique à la précédente, puisqu'elle se construit avec un pronom personnel suffixé. Cependant, les similitudes s'arrêtent là. Le marqueur du réfléchi est en effet postposé à un groupe verbal, et le pronom personnel suffixé s'accorde en genre et en nombre avec le sujet du verbe. nafs est, dans cette construction, syntaxiquement ancré, en ce qu'il suit toujours le verbe, et que rien ne peut être inséré entre les deux éléments. 


\begin{tabular}{|l|l|l|l|l|l|}
\hline ana & law & meš & fãḍi & ha-faḍ̂ī-l-ek & nafs-i \\
\hline ISG & CONJ & NEG & libre & PVB.FUT-1SG.INACC-libérer-PREP-2SG.F & REF-1SG \\
\hline
\end{tabular}

\begin{tabular}{|l|l|l|l|}
\hline lāzem & bi-idē-na & $n$-ġayyar & nafse-na \\
\hline il_faut & PREP-main-1PL & 1PL.INACC-changer & REF-1PL \\
\hline \multicolumn{2}{|l}{ Il faut que nous nous changions nous-mêmes (litt. : par nos mains) (Cairokee 2011: Yã l-mīdān) } \\
\hline
\end{tabular}

vii.

\begin{tabular}{|l|l|l|l|l|}
\hline lāzem & kull & el-banāt & ye-hebb-u & nafsu-hum \\
\hline il_faut & ADV.IND & ART-fille.PL & 3.INACC-aimer-3.PL & REF-3PL \\
\hline \multicolumn{4}{|l}{ Toutes les filles doivent s'aimer (elles-mêmes) ('Abd al-'Āl 2008: 20) } \\
\hline
\end{tabular}

La construction nafs-PRO est appelée par la réflexivisation du procès. Comme nous pouvons le voir avec les exemples (v) et (vi), qui présentent des cas dans lesquels le sujet est une première personne, elle ne sert pas à lever l'ambiguïté liée à la coréférence, puisque l'ambiguïté n'existe pas dans ces cas. Il est donc nécessaire à la construction du réfléchi.

Le marqueur de réfléchi a donc la même place syntaxique qu'un complément qui ne serait pas coréférencé sur le sujet. C'est en cela que le procès est réorienté a posteriori : l'objet sur lequel l'action est exercée est donné par la construction, et n'est pas un trait inhérent du verbe.

La construction analytique du réfléchi permet la conservation du schéma syntaxique du verbe, en prenant la place de son complément. Si le verbe a une transitivité indirecte, la préposition régie par ce verbe est conservée, ainsi qu'illustré en (viii). viii.

\begin{tabular}{|l|l|l|l|l|l|}
\hline${ }^{2} u l-t$ & la-nafs- $i$ & $m a$ & xadam-ak & ella & men \\
\hline dire-1/2.SG.M.ACC & $\begin{array}{l}\text { PREP- } \\
\text { REF-1SG }\end{array}$ & NEG & servir.ACC.3SG.M-2SG.M & PREP & PREP \\
\hline sagan-ak
\end{tabular}


Je me suis dit il n'y a personne d'autre pour te servir que celui qui t'emprisonne. (Cairokee : EHna ěs-ša $a^{\mathrm{s}} b$ )

\subsubsection{Traits du réfléchi}

\begin{tabular}{|c|c|c|c|c|c|c|}
\hline \multicolumn{2}{|l|}{ si:b } & $n a f s-\varepsilon k$ & law hatta & $y \bar{o} m$ & law & kull \\
\hline \multicolumn{2}{|c|}{ quitter.IMP.SG.M } & REF-2SG.M & CONJ & jour & CONJ & QT \\
\hline en-nās & \multicolumn{3}{|c|}{$h a-y i-' \bar{u} l-u$} & 'ale-k $k$ & \multicolumn{2}{|c|}{ magnūn } \\
\hline ART-gens & \multicolumn{3}{|c|}{ PVB.FUT-3.INACC-dire-3PL } & PREP-2SG.M & \multicolumn{2}{|l|}{ fou } \\
\hline
\end{tabular}

Dans certains cas, le marqueur du réfléchi semble optionnel. Nous prenons l'exemple du verbe $s i b$ « laisser, quitter », pour lequel deux constructions sont attestées.

ix.

\begin{tabular}{|c|c|c|c|c|}
\hline$s i ̄ b-\varepsilon k$ & men & $n-n \bar{a} s$ & rabbe-na & b-yi-sāmeḥ \\
\hline quitter-IMP.SG.M & PREP & ART-gens & seigneur-1PL & PVB-3.INACC-pardonner \\
\hline \multicolumn{5}{|c|}{$\begin{array}{l}\text { Ne t'inquiète pas de ce que les gens disent (litt. : quitte les gens) le Seigneur pardonne } \\
\text { (Cairokee } 2014: \text { Kull ḥāga bet'addī) }\end{array}$} \\
\hline
\end{tabular}

$\mathrm{X}$.

En (ix), l'objet direct est marqué sur le verbe par le pronom personnel suffixé -عk. En (x), on voit à la même place, l'apparition du marqueur de réfléchi nafs. Dans les deux phrases, le sens de quitter, se débarrasser de quelque chose est conservé. Il s'agit donc de comprendre son absence en (ix). Pour cela, il faut prendre en compte la présence du groupe prépositionnel men en-nās. Dans l'exemple (ix), le sujet n'est pas perçu comme le patient du procès. Il est agent et lieu de causation, mais le rôle de patient est porté par le complément d'objet indirect men en-nās. Le procès sort du sujet et n'y revient pas. Il s'agit donc de « se débarrasser des autres ». Au contraire en (x), le procès est directement dirigé sur le sujet, qui se prend lui-même comme objet de l'action. Ainsi, le marqueur du réfléchi n'apparaît que lorsque le référent du sujet et de l'objet présente tous les attributs du réfléchi, qu'il est à la fois agent, patient et lieu de causation.

\subsubsection{Coexistence des constructions synthétique et analytique du réfléchi}

Le marquage de la réorientation permet d'introduire une remarque sur la relation entre construction analytique et construction synthétique du réfléchi. La construction 
synthétique marque la réorganisation de l'orientation actancielle par une modification morphologique de la forme verbale, en cairote par l'ajout d'un préfixe, qui la rend intransitive. Les deux constructions sont souvent possibles pour un même verbe.

xi.

\begin{tabular}{|l|l|l|}
\hline$m a$ & ta-ḥšr-i-i-s & $n a f s-e k$ \\
\hline NEG & 2/3.F.INACC-se_mêler-2SG.F.INACC-NEG & REF-2SG.F \\
\hline Ne t'en mêle pas. (El-asad el-malik 1994) \\
\hline
\end{tabular}

30 xii.

\begin{tabular}{|l|l|l|}
\hline${ }^{2} \bar{a} l a-l-h a$ & $m a$ & te-t-ḥešr-i- $-\check{s}$ \\
\hline dire-3SG.M.ACC-PREP-3SG.F & NEG & F.INACC-PREF-se_mêler-2SG.F.INACC-NEG \\
\hline Il lui a dit « Ne t'en mêle pas ». (Ka) \\
\hline
\end{tabular}

31 Lorsque c'est le cas, la construction analytique semble traduire une volonté plus forte du sujet. En effet, l'exemple (xi) est interprété par les locuteurs comme un conseil, alors que l'exemple (xii) est entendu comme un ordre. La différence réside dans la place accordée à la volonté du sujet dans la prise de décision. En fait, la conservation des deux positions syntaxiques sujet et complément permet de conserver les rôles sémantiques associés agent et patient, là où la construction synthétique les refond dans la fonction de l'actant unique sujet. Cette conservation a pour effet de donner l'impression d'une volonté plus forte du sujet, en ce que son rôle d'agent n'est dès lors pas entamé.

Nous retrouvons dans l'utilisation de nafs-PRO en marqueur de réfléchi des valeurs similaires aux autres usages de ce premier niveau de recaractérisation, malgré quelques différences dans le traitement de l'objet mis en rapport. En effet, comme dans le cas de nafs préposé à un groupe nominal, nafs met en rapport deux éléments qui sont syntaxiquement présentés comme deux éléments distincts. Cependant, dans le cas du réfléchi, la distinction est seulement formelle, et il s'agit d'établir un rapport d'identité réelle entre les deux éléments mis en relation. Ainsi, le sujet du verbe est singularisé, en étant reconnu comme seul objet du verbe dans un contexte énonciatif donné.

\subsection{Emplois issus de l'usage diathétique du marqueur du réfléchi}

Nous avons présenté jusqu'ici l'usage de nafs dans la construction réfléchie, et ses usages parallèles. Il s'est en effet agi d'expliciter les liens qu'ils entretiennent, pour comprendre en quoi le rôle de chacun nourrit l'emploi des autres.

Il sera à présent question des usages étendus du marqueur de réfléchi, c'est-à-dire des emplois dans lesquels nafs-PRO marqueur du réfléchi est utilisé hors diathèse, mais qui sont rendus possible par son rôle diathétique et les valeurs associées à ce rôle, 
notamment l'intensification et l'expression de l'agentivité du sujet. Il s'agit de cas dans lesquels la coréférence est introduite par une préposition qui n'est pas régie par le verbe.

\subsubsection{Prépositions de lieu}

Les premiers cas que nous allons observer sont ceux dans lesquels il y a une coréférence entre le sujet du verbe et un complément, celle-ci n'impliquant pourtant pas l'usage de nafs. La coréférence avec le sujet peut être établie avec un pronom introduit par une préposition de lieu.

xiii.

\begin{tabular}{|l|l|l|l|l|}
\hline bāṣeș & wara-k & meš & 'oddām-ak \\
\hline regarder.PTCP.SG.M & PREP-2SG.M & NEG & PREP-2SG.M \\
\hline \multicolumn{2}{|l|}{ Tu regardes derrière toi, pas devant toi. (Cairokee 2015: Ǵammed 'aynak) } \\
\hline
\end{tabular}

37 xiv.

\begin{tabular}{|l|l|l|l|l|}
\hline kull & ḥad & \multicolumn{1}{l|}{ b-i-dHul } & El-fașl \\
\hline QT & PRO.IND & PVB-3.INACC-entrer & ART-classe \\
\hline$m a$ & b-i-bușs- $\varepsilon \check{s}$ & ḥawal- $\bar{e}$ & \\
\hline NEG & $\begin{array}{l}\text { PVB.INACC-3.M.INACC-regarder- } \\
\text { NEG }\end{array}$ & PREP-3SG.M & \\
\hline
\end{tabular}

Dans ce cas, le sujet est pris comme repère spatial, mais ni comme patient du procès décrit, ni comme lieu de causation de celui-ci, ce qui n'implique pas l'usage du marqueur du réfléchi. Il y a pourtant une exception avec la préposition gowwa « dedans », comme le présente l'exemple (xv).

xv.

\begin{tabular}{|l|l|l|l|}
\hline gowwa & nafs-i & l-waḥd-i & $b-a-\dot{g} r a '$ \\
\hline PREP & EMP-1SG & seul-1SG & PVB.-1SG.INACC-noyer \\
\hline \multirow{2}{|c|}{ À l'intérieur de moi seul je me noie. (Cairokee 2012: Lāken ehsāsi meš kefāya) } \\
\hline
\end{tabular}

40 Dans ce cas au contraire, le sujet n'est toujours pas le patient du procès, mais il est explicitement signalé comme son lieu de causation. Le sujet comme lieu de causation du procès est un trait du réfléchi, ce qui explique l'apparition du marqueur. La préposition 
gowwa peut également être utilisée sans le marqueur de réfléchi, lorsque le référent ne remplit pas les critères du réfléchi exposés plus tôt.

\subsubsection{Autobénéfactif}

La volonté de renforcer le rôle causateur du sujet se retrouve également dans la construction de l'autobénéfactif. Le bénéfactif désigne un procédé syntaxique permettant d'ajouter un bénéficiaire au procès (Kulikov 2011:390). Le bénéfactif dans le dialecte cairote se construit avec la préposition li-, et peut exprimer une co-référence entre le sujet et le bénéficiaire sans appeler le marqueur du réfléchi. On parle dans ce cas d'autobénéfactif (Kulikov 2013: 270). Le marqueur nafs-PRO n'est pas nécessaire à la construction autobénéfactive, comme l'atteste l'exemple (xvi).

xvi.

\begin{tabular}{|l|l|l|l|l|l|}
\hline kulli & wāhid & fi-ku & yi-na'"ī-l-u & turba \\
\hline QT & quelqu'un & PREP-2PL & $\begin{array}{l}\text { 3.INACC-choisir- } \\
\text { PREP-3SG.M }\end{array}$ & tombe \\
\hline
\end{tabular}

Lorsqu'il apparait, à l'instar de l'exemple (xvii), il marque la volonté de signaler l'agentivité du sujet.

xvii.

\begin{tabular}{|l|l|l|l|l|}
\hline$b-a-t \underline{b u H}$ & li-nafs-i & ṃamma & $m e \check{s}$ & mawgūd- $a$ \\
\hline PVB-1SG.INACC-cuisiner & PREP-REF-1SG & maman & NEG & présent-F.SG \\
\hline
\end{tabular}

L'utilisation de nafs-PRO dans ce cas sert à intensifier le rôle causateur et le caractère volontaire du sujet, plus qu'à le désigner comme bénéficiaire, ce qui est possible avec un pronom suffixé seul.

Dans un premier temps, nous avons explicité le lien entre les différents emplois de nafs, afin de comprendre les motifs de sa recaractérisation en marqueur du réfléchi. Nafs porte les notions de mise en relation et de singularisation du référent, qui lui permettent de remplir la fonction de marqueur du réfléchi, et de renforcer le rôle agentif du sujet. Dans un second temps, nous avons exposé les emplois étendus du marqueur de réfléchi, qui rendent apparents les traits fonctionnels du réfléchi strict qu'ils partagent, et qui leur permettent d'en emprunter la forme.

$b a^{\prime} d$ est, comme nafs, le marqueur de réorganisations actancielles qui ont en commun de rendre le sujet du verbe patient du procès qu'il est lui-même en train d'exercer. Si le 
réfléchi en cairote est en effet marqué par l'agentivité du sujet, est-ce également un critère pertinent dans l'analyse des valeurs associées à l'expression de la réciprocité ?

\section{Usages de ba'ḍ}

\subsection{Premier usage : quantifieur (QT)}

$b a^{\prime} d$ est d'abord un quantifieur, avec le sens de «quelques, certains ». Il est préposé à un groupe nominal au pluriel.

xviii.

\begin{tabular}{|l|l|l|l|l|l|l|}
\hline bass & fi & kalime:t & fih & ba'd & ik-kalime:t & bi-t-eHtalif \\
\hline CONJ & il_y_a & mot.PL & il_y_a & QT & ART-mot.PL & PVB-2/3.F.INACC-changer \\
\hline
\end{tabular}

Il a un rôle d'actualisateur, c'est-à-dire qu'en contexte, il indique qu'un groupe d'objets ou de personnes peuvent être renvoyés à la notion désignée par le substantif. Il procède donc au découpage d'un champ autour des participants, afin d'indiquer ce qui permet de les associer. En partageant la même notion, ils participent en contexte d'un même état.

\subsection{Recaractérisation en marqueur du réciproque}

\subsubsection{Description de la construction analytique du réciproque}

51 C'est cette notion de participation à un état que l'on retrouve dans son utilisation en marqueur du réciproque. $b a^{\prime} d$ apparaît alors après le verbe qui est toujours au pluriel, et qui conserve sa préposition en cas de transitivité indirecte.

xix.

\begin{tabular}{|l|l|l|l|l|}
\hline hāyel & ta'ala & kulle-na & na-'raf & ba'd \\
\hline super & MD & PRO.IND-1PL & 1PL.INACC-connaître & REC \\
\hline \multicolumn{4}{|l}{ Super, maintenant nous nous connaissons tous. (El-asad el-malik 1994) } \\
\hline
\end{tabular}

$\mathrm{xx}$.

\begin{tabular}{|l|l|l|}
\hline kullu-hum & $b i-y-s \bar{a}^{\prime} d-u$ & $b a^{\prime} d \underline{~}$ \\
\hline ADJ.IND-3PL & PVB-3.INACC-aider-PL & REC \\
\hline Alle helfen einander. (Woidich 2006: 355) \\
\hline \multicolumn{2}{|l|}{ Tous s'entraident. } \\
\hline
\end{tabular}




\begin{tabular}{|l|l|l|l|}
\hline$u$ & $b a^{\prime} d \bar{e} n$ & seb-tu & $b a^{\prime} d ? ?$ \\
\hline CONJ & ensuite & quitter.ACC-2PL.ACC & REC \\
\hline \multicolumn{2}{|l}{ Et ensuite vous vous êtes séparés? (Am) } \\
\hline
\end{tabular}

La chose la plus notable, c'est l'alternance entre la présence en (xix), (xx) et (xxi), et l'absence de pronom personnel suffixé ainsi que présentée dans les exemples (xxii) et (xxiii) à suivre. La forme non marquée est celle sans pronom. L'idée de conservation du schéma syntaxique du verbe, dans lequel ba'd viendrait prendre la place du complément est dès lors difficilement envisageable. Il renvoie au sujet multiple du verbe. On retrouve alors l'idée de découpage d'un champ autour des participants à l'action, qui sont mis en lien par et à travers le procès. La valeur principale du réciproque n'est donc pas le double rôle sémantique agent-patient du sujet, mais la participation de plusieurs référents à une action unique.

\subsubsection{Présence du pronom personnel suffixé}

Dans un second temps, il s'agit de comprendre les critères d'apparition du pronom. Lorsqu'il apparaît, il est accordé en genre et en nombre avec le sujet du verbe.

57 xxii.

\begin{tabular}{|c|c|c|c|c|c|}
\hline esnān-u & \multicolumn{2}{|l|}{ bi-ye-hebb-u } & ba'ḍu-hum & geddan & la-darga \\
\hline dent.PL-3SG.M & \multicolumn{2}{|c|}{ PVB-3.INACC-aimer-3PL } & REC-3PL & ADV & $\begin{array}{l}\text { PREP- } \\
\text { degré }\end{array}$ \\
\hline enno-hum & rākbin & $f \bar{o}^{p}$ & \multicolumn{3}{|l|}{$b a^{c} d u-h u m$} \\
\hline REL-3PL & monter.PTCP.PL & PREP & \multicolumn{3}{|l|}{ REC-3PL } \\
\hline
\end{tabular}

Ses dents s'aiment beaucoup, au point qu'elles se montaient les unes sur les autres. ('Abd al'āl 2008:15)

xxiii.

\begin{tabular}{|l|l|l|l|}
\hline ehnna & be-n-kammel & $b a^{\prime}$ de-na \\
\hline 1 1PL & PVB-1PL.INACC-compléter & REC-1PL \\
\hline \multicolumn{2}{|l}{ Nous nous complétons. (El-asad el-malik 1994) } \\
\hline
\end{tabular}

Le pronom a une fonction aspectuelle, il induit une homogénéité au processus, qui est dès lors conçu comme indivisible. Le procès est perçu dans son entièreté, ce qui crée un effet 
d'achèvement. Il a un rôle conclusif, mais qui n'est pas en lien avec la fonction de marqueur de réciproque de $b a^{\prime} d$.

\subsection{Emplois de ba'd issu de son usage réciproque}

Tout comme nafs, la recaractérisation de ba'd en marqueur du réciproque fait émerger des emplois permis par les valeurs associées à sa fonction diathétique.

\subsubsection{Pseudo-réciproque}

Il permet de former un pseudo-sociatif. $b a^{\prime} d$ est un élément de la locution $m a^{\prime} a b a^{\prime} d$ d « ensemble ».

xxiv.

\begin{tabular}{|l|l|l|}
\hline yalla & $n$-rawwah & ma'a ba'd \\
\hline allez & 1PL.INACC-rentrer & ensemble \\
\hline Allez, rentrons, ensemble. (El-asad el-malik 1994) \\
\hline
\end{tabular}

XXv.

\begin{tabular}{|c|c|c|c|c|}
\hline$u$ & eḥna & $n a-f d a l$ & dayman & $m a^{\prime} a b a^{\prime} d ?$ ? \\
\hline CONJ & $1 \mathrm{PL}$ & 1PL.INACC-rester & toujours & ensemble \\
\hline
\end{tabular}

La locution $m a^{\Upsilon} a b a^{\Upsilon} d$ prend une valeur sociative lorsqu'elle est employée avec des verbes ne permettant pas sémantiquement l'association de plusieurs sujets à une action unique. Le sociatif est un procédé syntaxique qui associe à l'exercice du procès un participant qui n'est pas le sujet. Cependant, contrairement au sociatif, les exemples (xxiv) et (xxv) présentent des verbes dont le sujet est pluriel, et contient déjà les différents participants. Ils sont donc mentionnés a priori. Parce que ces verbes sont intransitifs, ils ne peuvent désigner un objet sur lequel s'exerce le procès qu'ils décrivent.

Il en va de même pour les phrases nominales, comme illustré par l'exemple (xxvi).

\begin{tabular}{|l|l|l|l|l|l|l|l|}
\hline$d a$ & bardu & kwayyes & la-enno & \multicolumn{1}{|l|}{$n e-n z \varepsilon l$} & mașr & fih \\
\hline DEM.SG.M & aussi & bien & CONJ & \multicolumn{1}{l|}{$\begin{array}{l}\text { 1PL.INACC- } \\
\text { descendre }\end{array}$} & Égypte & il_y_a \\
\hline walad & HE:l-i & ma'a-ya & $\bar{u}$ & ehnna & 'ala țūl & ma'a ba'd \\
\hline fils & oncle-1SG & PREP-1SG & CONJ & 1PL & ADV & ensemble \\
\hline
\end{tabular}


Ça aussi c'est chouette, parce que quand on va en Égypte mon cousin (litt. : fils de mon oncle) est avec moi et on est tout le temps ensemble. (Am)

L'association de la valeur de concomitance de $m a^{\prime} a$ et de celle de marqueur du réciproque de $b a^{\prime} d \underline{d}$ permet d'exprimer la simultanéité lorsque la réciprocité en propre est impossible, du fait de la notion du verbe.

\subsubsection{Prépositions de lieu}

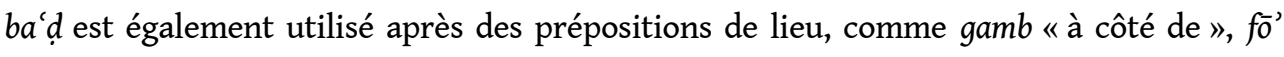
« sur » (cf. (xxii)), ou 'ala « sur».

xxvii.

\begin{tabular}{|l|l|l|l|}
\hline talat & 'uwad & gambi & ba'du-hum \\
\hline trois & pièce.PL & PREP & REC-3PL \\
\hline \multicolumn{2}{|l}{ Drei Zimmer nebeneinander (Woidich 2006: 355) } \\
\hline \multicolumn{2}{|l}{ Trois pièces à coté les unes des autres. } \\
\hline
\end{tabular}

\begin{tabular}{|l|l|l|l|}
\hline hoțt & ek-kotob-dōl & 'ala & $b a^{\prime} d$ \\
\hline mettre.IMP.SG.M & ART-livre.PL-DEM.PL & PREP & REC \\
\hline \multicolumn{2}{|l|}{ Mets ces livres les uns sur les autres, les uns près des autres. (Jomier \& Khouzam $1965: 48$ ). } \\
\hline
\end{tabular}

71 Le point commun entre toutes les prépositions de lieu est que, paradoxalement, la position physique d'un objet à un endroit donné empêche toute réciprocité. En fonction de sa position, chaque participant ne peut pas être effectivement en rapport avec tous les autres. Mais $b a^{\prime} d$ construit pourtant la participation à cet état comme une coordonnée unique. Ainsi, les prépositions de situation physique puisent dans la valeur de construction d'un champ, d'un « entre » de ba'd pour assigner à tous les participants un rapport unique, alors que chacun d'eux y participe en fait de manière différente. Ils participent à la construction d'un état, dont ils sont chacun des points dont les rôles ne sont pas interchangeables, contrairement au réciproque.

72 La réduction de participants multiples dans un type de rapport se retrouve également lorsque $b a^{\prime} d$ construit le comparatif d'égalité.

73 xxix

\begin{tabular}{|l|l|l|l|}
\hline kull & ir-rāgala & zayyi & ba'd \\
\hline
\end{tabular}




\begin{tabular}{|l|l|l|l|}
\hline QT & ART-homme.PL & COMP & REC \\
\hline Alle Männer sind einander gleich. (Woidich $2006: 355)$ \\
\hline Tous les hommes sont pareils. \\
\hline
\end{tabular}

Le comparatif d'égalité zayyi ba'ḍ, comme présenté dans l'exemple (xxix) peut être mis en relation avec la comparaison entre deux éléments illustrée en (xxx).

$\mathrm{xxx}$.

\begin{tabular}{|l|l|l|l|l|l|}
\hline el-fann & damm-o & t'ìl & zayy-o & zayy & el-i'lām \\
\hline ART-art & sang-3SG.M & lourd & COMP-3SG.M & COMP & ART-information \\
\hline
\end{tabular}

L'art est aussi pénible que les informations (litt.: l'art, son sang est lourd comme les informations). (Cairokee 2015 : Et-telefiziōn)

Contrairement aux constructions qui établissent un lien d'égalité entre deux parties distinctes, l'usage de ba'd permet de ne plus répéter zayy, puisque les éléments comparés ne sont plus différenciés. Ils sont dès lors tous considérés sous le même rapport, à savoir la notion exprimée par ce qui est comparé.

\section{Conclusion}

L'étude de ces marqueurs de diathèses a mis en avant deux constructions très différentes. Si les deux procèdent à une réorganisation a posteriori des actants, ils ne le font pas sous le même régime.

Les deux marqueurs sont recaractérisés pour leur fonction diathétique. Cependant, le marqueur du réciproque n'est pas issu du marqueur du réfléchi. On parle dans ce cas de non-reflexive oriented marker (Geniušiené 2001 : 53).

Les deux marqueurs ne remplissent pas les mêmes fonctions syntaxiques. Dans sa fonction de marqueur de réfléchi, nafs-PRO occupe la place du complément d'objet. Dans sa fonction de marqueur du réciproque, $b a^{\prime} d$ ne remplace pas le complément, il referme la portée du procès.

80 Leur indépendance s'exprime également dans le rapport notionnel qu'ils construisent entre les actants. Nafs et $b a^{\prime} d$ construisent pour des référents distincts un rapport à une notion commune. Avec nafs, cette notion commune est celle des actants eux-mêmes. Le rapport est établi grâce à des traits que possèdent les référents. Ce sont les traits inhérents qu'ils portent qui sont rapprochés. Avec ba'ḍ, les actants sont mis en rapport à travers leur participation à un procès ou à un état de choses, sans que leurs référents ne doivent partager aucune notion ni aucun trait sémantique inhérent communs.

Ainsi, ils ont des traits sémantiques très différents. Les deux constructions n'associent pas les mêmes valeurs à la réorganisation actancielle, dû aux traits notionnels de leurs marqueurs. Le réfléchi prend la valeur de mise en avant de la volonté du sujet, marquée par la valeur intensive associée à nafs, alors que le réciproque accentue la coopération et 
la simultanéité, permise par la construction d'un champ par ba'ḍ. Le double rôle sémantique, agent et patient, rempli par le sujet semble peu pertinent dans le second cas. Les constructions analytiques du réfléchi et du réciproque sont donc bien distinctes et indépendantes. En cairote, le réciproque n'est pas compris comme une sous-catégorie du réfléchi, et ne permet aucune ambiguïté quant à l'interprétation de l'orientation du procès.

\section{BIBLIOGRAPHIE}

Geniušiené, Emma. 2001. "Towards a typology of the polysemy of reciprocal markers”, Barentsen, A. A, Poupynin, Youri A, \& Bondarko A. V (eds), Functional Grammar: Aspect and Aspectuality, Tense and Temporality. Essays in Honour of Alexander Bondarko. Munich: Lincom Europa. 51-65.

Jomier, Jacques, \& Joseph Khouzam. 1965. Manuel d'arabe égyptien : parler du Caire. Paris : Klincksieck.

Kulikov, Leonid. 2011. "Voice typology”, Song, Jae Jung (ed). The Oxford Handbook of Linguistic Typology. Oxford, Royaume-Uni: Oxford University Press. 368-398.

Kulikov, Leonid. 2013. “Middles and Reflexives”, Luraghi, Silvia, \& Parodi, Claudia (eds), The Bloomsbury Companion to Syntax. Londres, New York: Bloomsbury Academic. 216-280.

Woidich, Manfred. 2002. Ahlan wa sahlan: eine Einführung in die Kairoer Umgangssprache. Wiesbaden: L. Reichert.

Woidich, Manfred. 2006. Das Kairenisch-Arabisch: eine Grammatik. Wiesbaden: Harrassowitz.

\section{SOURCES ÉCRITES}

'Abd al- 'Âl, Ġāda. 2008. 'Āyeza etgawwaz [Je veux me marier]. Le Caire: Dār al-šurūk.

\section{SOURCES AUDIO-VISUELLES}

Cairokee. 2011. Mațlūb za'ìm [Recherche leader].

2012. W ana ma'a nafsi 'à'ed [Perdu dans mes pensées].

2014. Es-sekka šmāl [Le mauvais chemin].

2015. Nās $w$ nās [Les uns et les autres].

Walt Disney Pictures. 1994. El-asad el-malik [Le Roi Lion].

\section{RÉSUMÉS}

Cet article aborde les marqueurs des constructions analytiques de réorientation des actants en arabe cairote, à savoir nafs pour le réfléchi, et $b a^{\uparrow} d$ pour le réciproque. Dans les deux cas, il s'agit de marqueurs recaractérisés pour leur fonction diathétique, et non de marqueurs propres à cet emploi. Nous comparons les caractéristiques fonctionnelles et notionnelles de ces mots lorsqu'ils occupent d'autres fonctions syntaxiques, afin de mettre en avant les critères de leur sélection en 
marqueurs de voix.

D'un premier usage de nafs, nous retenons qu'il met en relation différents éléments, et établit un rapport entre eux sur la base d'une notion auxquels les référents peuvent tous être rapportés. Un second usage expose son rôle de singularisation du référent, qui le retire alors de toute mise en contraste, et créer ainsi un effet d'emphase, ne prenant en compte que la nature du référent luimême. Ces fonctions parallèles de nafs contribuent à éclairer son choix en marqueur de réfléchi, ainsi que l'intensification de la valeur agentive du sujet qui lui est associée.

Les différents usages de $b a^{\Upsilon} d$ révèlent que s'il a aussi pour rôle de mettre différents éléments en rapport, la relation ne s'établit pas dans une notion à laquelle peuvent se rapporter les éléments,

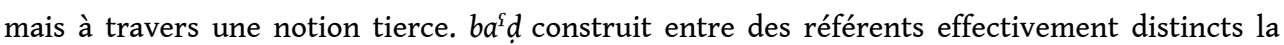
participation à un même état, statif ou processif.

Dans les deux cas, leur recaractérisation en marqueurs diathétiques permet leur utilisation dans des structures qui empruntent à ces modèles, tout en y apportant des nuances diathétiques, comme l'autobénéfactif ou le sociatif.

Ainsi, l'identification d'un ensemble de traits notionnels associés à ces mots permet de montrer les valeurs associées aux constructions analytiques du réfléchi et réciproque, et de mettre en avant deux constructions bien distinctes.

\section{INDEX}

Mots-clés : réfléchi, réciproque, constructions analytiques, marqueurs de voix, rôles syntaxiques, valeur notionnelle

\section{AUTEUR}

\section{JULIE HASLÉ}

INALCO - CERMOM 


\title{
Persian Loanwords in Baghdadi Arabic
}

\author{
Ștefan lonete
}

\section{Phonetic considerations}

1 Haim Blanc states that among the characteristics of the Mesopotamian qəltu-gələt dialects (1964:6-7), there is, also, the presence of the phonemes /p/ and / $\check{c} /$, due the large number of Persian and Turkish loanwords.

\section{1. /p/ - voiceless bilabial stop}

2 While the voiceless bilabial stop $/ \mathrm{p} /$ is recorded in loans from other languages, such as English (e.g. plakk, "plug" from Eng.: plug, panyūn, from Eng.: pinion) (BiȚună 2014: 67-68), its presence in Baghdadi Arabic (from now on, BA) is attributed to both Persian and Turkish loans (e.g. pāša "pasha", "general", from Turk.: pașa "general", p̣āra "the smallest unit of Turkish money", from Turk.: para "money"):

\begin{tabular}{|l|l|l|}
\hline $\begin{array}{l}\text { pā̌ca "stew made of the head, feet, stomach } \\
\text { and neck of an animal" }\end{array}$ & $\begin{array}{l}\text { from } \\
\text { Pers.: }\end{array}$ & $\begin{array}{l}\text { kale pāče "dish made of the head and } \\
\text { trotters of an animal" }\end{array}$ \\
\hline pāya "leg" & $\begin{array}{l}\text { from } \\
\text { Pers.: }\end{array}$ & pā/pāy "leg" \\
\hline puHta "mush" & $\begin{array}{l}\text { from } \\
\text { Pers.: }\end{array}$ & poHte "cooked" \\
\hline pahlawān "circus performer", "acrobat" & $\begin{array}{l}\text { from } \\
\text { Pers.: }\end{array}$ & pahlavān "champion", "hero" \\
\hline
\end{tabular}


\begin{tabular}{|l|l|l|}
\hline$p \bar{l} \bar{a} d$ "high quality steel" & from & pūlād "steel"1 \\
\hline
\end{tabular}

3 It is possible that in some words, the voiceless bilabial stop /p/ shifts into the voiced /b/, despite the fact that $/ \mathrm{p} /$ exists as a phoneme in BA:

\begin{tabular}{|l|l|l|}
\hline$b \bar{a} b u \bar{u} \breve{g}$ “slipper” & from Pers.: & pāpū̌̌ “slipper” \\
\hline
\end{tabular}

\section{2. /č/ - voiceless palatal affricate}

4 The voiceless palatal affricate / $\check{c} /$ is, in many cases, an internal evolution of the voiceless velar stop /k/ into /č/ from Arabic roots (čaleb "dog" from OA kalb "dog"; čān "he was" from OA kāna) (Blanc, 1964: 25). However, its presence in $\mathrm{BA}^{2}$ is reinforced by Persian loans, where it is rendered as such:

\begin{tabular}{|l|l|l|}
\hline čāra "cure", "remedy" & from Pers.: & čāre "remedy" \\
\hline čārpāya "bed", "bedstead" & from Pers.: & čārpāye "stool" \\
\hline čādir "tent" & from Pers.: & čādor "tent" \\
\hline čārak "quarter" & from Pers.: & čārek "quarter" \\
\hline
\end{tabular}

\section{3. /g/ - voiced velar stop}

5 While the voiceless post-velar stop /q/ often shifts into the voiced velar stop /g/ in Arabic roots ( $g \bar{a} l$ "he said", from OA qāla "he said"; galeb "heart", from OA qalb "heart"), it also appears in Persian loans:

\begin{tabular}{|l|l|l|}
\hline gīpa "stuffed lamb stomach dish" & from Pers.: & gīpe "stuffed sheep's stomach dish" \\
\hline guldān "vaze" & from Pers.: & goldān "vaze" \\
\hline gēwa "cotton slippers" & from Pers.: & geyve "slippers" \\
\hline ligan "large metal wash basin" & from Pers.: & lagan "basin", "pan" \\
\hline langa "bale" & from Pers.: & lenge "bale" \\
\hline
\end{tabular}

\section{4. /v/ shifts into /w/}

6 The voiced labio-dental spirant / $/$ is not a phoneme in BA, thus, in Persian loans it shifts from /v/ into the voiced, bilabial, velar, constrictive /w/: 


\begin{tabular}{|l|l|l|}
\hline pahlawān "circus performer", "acrobat" & from Pers.: & pahlavān "champion", "hero" \\
\hline taHttaruwān "sedan chair", & from Pers.: & taHterevān "palanquin", "sedan chair" \\
\hline gēwa "cotton slippers" & from Pers.: & geyve "slippers" \\
\hline mēwa "fruit"* & from Pers.: & mive "fruit" \\
\hline
\end{tabular}

7 *The word mēwa also exists as mēwān, loaned together with the plural suffix -ān (e.g. salata mālt mēwān "fruit salad"). The word mewān also exists in Kurdish.

\subsection{The diphthong /ay/}

8 Sometimes the diphthong /ay/, rendered as /ey/ in the original Persian, is contracted and shifts into the long middle unrounded vowel $/ \overline{\mathrm{e}} /$ in BA. The same situation also occurs with the OA diphthong /ay/ (e.g. OA: bayt "house" => BA: bēt "house"):

\begin{tabular}{|l|l|l|}
\hline$g \bar{e} w a$ "cotton slippers" & $\begin{array}{l}\text { from } \\
\text { Pers.: }\end{array}$ & geyve "slippers" \\
\hline $\begin{array}{l}\text { šerraz - yišeriz "to sew a border around the edge (of a garment)", } \\
\text { "to stitch together the pages in a book" }\end{array}$ & $\begin{array}{l}\text { from } \\
\text { Pers.: }\end{array}$ & $\begin{array}{l}\text { širaze "head band (of } \\
\text { a book)" }\end{array}$ \\
\hline
\end{tabular}

9 I mention that the word šerraz is also recorded as šayraz, where the diphthong /ay/ is rendered as such (see also Grigore 2010: 60). The same rule applies to other loanwords from Persian:

\begin{tabular}{|l|l|l|}
\hline mayH̄̄na "bar" & from Pers.: & meyHāne "tavern" \\
\hline čayHāna "tea house" & from Pers.: & čayHāne "tea house" \\
\hline
\end{tabular}

\subsection{The diphthong /aw/}

The situation is similar with the diphthong /aw/ which is contracted and shifts into the long middle rounded vowel /ō/ (as in l-firdōs "Paradise", from Pers.: ferdows "paradise"; it also happens with the OA diphthong, for instance mawz => BA: mōz "banana"):

\begin{tabular}{|c|c|c|c|c|}
\hline $\begin{array}{l}\text { čōdar - yičōdir "to pitch a tent", } \\
\text { "to make tent" }\end{array}$ & $<=$ & $\begin{array}{l}\text { čādir-čwādir } \\
\text { "tent" }\end{array}$ & $\begin{array}{l}\text { from } \\
\text { Pers.: }\end{array}$ & čādor "tent" \\
\hline tHōrad - yitHōrad "to treat" & $<=$ & $\begin{array}{l}\text { Hwarda } \\
\text { "generous" }\end{array}$ & cf. Pers.: & $\begin{array}{l}\text { Hār dādan "to give food } \\
\text { and drinks" }\end{array}$ \\
\hline
\end{tabular}


11 Here, the loanwords suffered modifications of morphological structures to achieve harmony with the established Arabic quadriconsonantal root system. Thus, the root for čodar is č.w.d.r. (see čādir-čwādir). When inserted in the 1st stem quadriconsonantal verb pattern ( $\left.f a^{\imath} l a l\right)$, the result is čawdar*, hence čōdar.

12 The same situation can be pointed out in the case of thörad - yitHōrad, where the root is H.w.r.d. (see Hwarda "generous"). When inserted in the $2^{\text {nd }}$ stem quadriconconantal verb pattern ( $t f a$ 'lal), the result is tHawrad*, hence tHōrad.

13 Sometimes, as it also happens with the diphthong /ay/, the diphthong /aw/, rendered as /ow/ in the original Persian words, remains unchanged, the same case being recorded with some OA words, such as faw

\begin{tabular}{|l|l|l|}
\hline gawğa "a kind of large, light-colored, plum-like fruit" & from Pers.: & gowğe "greengage”, “plum” \\
\hline
\end{tabular}

\subsection{Emphasizing of some consonants}

When the Persian words contains an open vowel, /a:/, or a middle vowel /o:/, the neighboring consonant have the possibility of becoming emphatic:

\begin{tabular}{|c|c|c|}
\hline ḅādkēšs “cupping” & from Pers.: & $b \bar{a} d k \bar{e} s ̌$ “dry cupping” \\
\hline beāzband "talisman worn on the upper arm" & from Pers.: & bāzūband "armlet", "amulet" \\
\hline pāța "even" & from Pers.: & pāt "stalemate" \\
\hline șurmāya "capital", "financial assets" & from Pers.: & sarmāye "capital" \\
\hline țurši “pickles” & from Pers.: & torši “pickles" \\
\hline
\end{tabular}

15 However, unlike English or Turkish loans, where / $\mathrm{k} /$ posteriorizes and becomes /q/ when it is in proximity of a middle or a back vowel, in Persian loans the voiceless velar stop $/ \mathrm{k} /$ is rendered as such:

\begin{tabular}{|l|l|l|}
\hline$k \bar{u}$ s "sparse beard" & from Pers.: & $k \bar{u} s$ “thin (of a beard)" \\
\hline dumbuk - danābik "brass drum with skin head" & from Pers.: & tombak "one headed long drum" \\
\hline balqūn - balqūnāt "balcony" & from Eng.: & balcony (BiȚună 2014: 70) \\
\hline qăt "floor", "level" & from Turk.: & kat "floor" (BiȚună 2014: 70) \\
\hline
\end{tabular}

Here, due to the existence of a middle vowel following the voiceless dental stop $/ t /$ in the Persian tombak, in BA it shifts into the voiced dental stop /d/.

17 I mention that the words balqūn, qāt also occur in other dialects. 


\section{Morphological integration}

Persian and Arabic are typologically different from the point of view of their morphology. There are two possible types of integration of the loanwords in BA: either by receiving suffixes or by suffering modifications in order to achieve harmony with the established root system of BA.

\subsection{Sound plurals}

19 Some of the Persian loans have the plural formed in - $\bar{a} t$ (the sound feminine plural morpheme):

\begin{tabular}{|c|c|c|}
\hline parda-pardāt "curtain" & from Pers.: & parde "curtain" \\
\hline dāya-dāyāt "wet nurse" & from Pers.: & dāye "wet nurse" \\
\hline rūznāma - rūznāmāat "calendar" & from Pers.: & rūznāme "newspaper", literally, "daily letter" \\
\hline$k \bar{a} r-k \bar{a} r \bar{a} t$ "occupation", "vocation" & from Pers.: & kār "work", “job” \\
\hline bibi - bibiyyāt "grandmother" & from Pers.: & bìbi "grandmother" \\
\hline patu - patuwāt "blanket" & from Pers.: & patu "blanket" \\
\hline dìzi - dìziyyāt "small cooking pot" & from Pers.: & dìzi "small earthen pot" \\
\hline
\end{tabular}

In other cases, the sound masculine plural -in is also used (e.g. čarraH - čarraHin "lathe operator"). Besides these well-known and established plurals, in BA another sound plural is recorded formed with the morphemes -a/-iya (e.g. zabbāl - zabbāla "garbage man") (McCarthy \& Raffouli 1964: 126). The aforementioned suffix appears in loans from other languages, such as English (e.g. sapūrtar-sapūrtarīya „supporter”) (BiȚună 2014: 73):

\begin{tabular}{|c|c|c|}
\hline $\begin{array}{l}\text { pahlawān - pahlawāniya "circus performer", } \\
\text { "acrobat" }\end{array}$ & $\begin{array}{l}\text { from } \\
\text { Pers.: }\end{array}$ & pahlavān "champion", "hero" \\
\hline tanbal - tanbaliya "lazy person", & $\begin{array}{l}\text { from } \\
\text { Pers.: }\end{array}$ & tanbal "lazy" \\
\hline čarraH - čarraHa "lathe operator" & $\begin{array}{l}\text { from } \\
\text { Pers.: }\end{array}$ & čarH "wheel" \\
\hline $\begin{array}{l}\text { Hurdafarūš - Hurdafarūšīya "dealer in notions or } \\
\text { miscellaneous small articles" }\end{array}$ & $\begin{array}{l}\text { from } \\
\text { Pers.: }\end{array}$ & $\begin{array}{l}\text { harīd o forūš "transaction", } \\
\text { "buying and selling" }\end{array}$ \\
\hline satami - satamiyya "bill of ladding" & $\begin{array}{l}\text { from } \\
\text { Pers.: }\end{array}$ & setami "bill of ladding" \\
\hline
\end{tabular}


The word qușsaHūn is a loan from a loan, the starting point being the OA noun qișsa "story", which, after entering Persian, formed an entire word family: qesse "story", qesse Hūāndan "to tell a story", qesseHāan "story teller".

Also, nouns that denote jobs and vocations formed, in BA, from a Persian loanword with the Turkish suffix for occupations -či, have their plural marked with the same suffix $-a /$ iya. I mention that these words exist in Turkish, as well, and it is possible that they are not derived internally in BA, but loaned as such:

\begin{tabular}{|c|c|c|c|c|}
\hline țurušči - țuruščìya "pickles vendor" & cf. Turk.: & turșucu "pickles vendor" & cf. Pers.: & torši “pickles" \\
\hline $\bar{a} s ̌ c ̌ i-\bar{a} \check{s ̌ c} \bar{y} y a$ "cook" & cf. Turk.: & aşçı "cook" & cf. Pers.: & $\bar{a} \check{s}$ “soup" \\
\hline
\end{tabular}

\subsection{Broken plurals}

23 The presence of broken plurals in the structure of Persian loanwords in BA indicates both the total assimilation of these words in the target language and their integration on triconsonantal and quadriconsonantal roots. In my research, I identified the following broken plural stems:

$\mathrm{C}_{1} \mathrm{C}_{2} \overline{\mathrm{a}} \mathrm{C}_{3} \mathrm{a}$

\begin{tabular}{|l|l|l|l}
\hline $\begin{array}{l}\text { pùl - pwāla "piece (in backgammon, domino etc.)", "small } \\
\text { Persian coin" }\end{array}$ & $\begin{array}{l}\text { from } \\
\text { Pers.: }\end{array}$ & pūl “money" & $\begin{array}{l}\text { root: } \\
\text { p.w.l. }\end{array}$
\end{tabular}

\begin{tabular}{|c|c|c|c|}
\hline 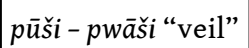 & from Pers.: & $p \bar{u} s ̌$ “covering" & root: p.w.š \\
\hline
\end{tabular}

\begin{tabular}{|l|l|l|l|}
\hline taHat - $t H \bar{u} t$ "upholstered chair" & from Pers.: & taHt "throne" & root: t.H.t. \\
\hline čariH - črūH "wheel" & from Pers.: & čarH “wheel" & root: č.r.H. \\
\hline
\end{tabular}

$27 \quad \mathrm{C}_{1} \mathrm{uC}_{2} \mathrm{aC}_{3}$

$\breve{g} u f t a$ - $\breve{g} u f a t$ "in dominoes, a piece with the same number on both ends"

\begin{tabular}{|c|c|}
\hline $\begin{array}{l}\text { from } \\
\text { Pers.: }\end{array}$ & $\begin{array}{l}\text { ğoft "pair", “even } \\
\text { number" }\end{array}$ \\
\hline
\end{tabular}




\begin{tabular}{|l|l|l|l|}
\hline lūla-luwal "pipe", "tube" & $\begin{array}{l}\text { from } \\
\text { Pers.: }\end{array}$ & lūle "pipe", "tube" & $\begin{array}{l}\text { root: } \\
\text { l.w.l. }\end{array}$ \\
\hline
\end{tabular}

$\mathrm{C}_{1} \mathrm{iC}_{2} \mathrm{aC}_{3}$

\begin{tabular}{|l|l|l|l|}
\hline čihra - čihar "ugly face", "mug" & from Pers.: & čehre "face" & root: č.h.r. \\
\hline
\end{tabular}

$\mathrm{C}_{1} \mathrm{aC}_{2} \overline{\mathrm{a}} \mathrm{C}_{3} \mathrm{iC}_{4}$

\begin{tabular}{|c|c|c|c|}
\hline tanbal - tanābil "lazy person" & $\begin{array}{l}\text { from } \\
\text { Pers.: }\end{array}$ & tanbal "lazy" & root: t.n.b.l. \\
\hline $\begin{array}{l}\text { Hānim - Hawānim "a term of respectful } \\
\text { address to a lady" }\end{array}$ & $\begin{array}{l}\text { from } \\
\text { Pers.: }\end{array}$ & Hānom "lady" & $\begin{array}{l}\text { root: } \\
\text { H.w.n.m. }\end{array}$ \\
\hline namūna-namāyin "sample", "specimen" & $\begin{array}{l}\text { from } \\
\text { Pers.: }\end{array}$ & $\begin{array}{l}\text { nemūne "specimen", } \\
\text { "sample" }\end{array}$ & $\begin{array}{l}\text { root: } \\
\text { n.m.y.n. }\end{array}$ \\
\hline
\end{tabular}

$30 \quad \mathrm{C}_{1} \mathrm{C}_{2} \overline{\mathrm{a}} \mathrm{C}_{3} \mathrm{i} \mathrm{C}_{4}$

\begin{tabular}{|c|c|c|c|}
\hline $\begin{array}{l}\text { ğōrāb - ğwārīb "pair of socks", } \\
\text { "stockings" }\end{array}$ & $\begin{array}{l}\text { from } \\
\text { Pers.: }\end{array}$ & ğūuāb "socks" & $\begin{array}{l}\text { root: } \\
\text { ğ.w.r.b. }\end{array}$ \\
\hline čārak - čwārīk "a quarter" & $\begin{array}{l}\text { from } \\
\text { Pers.: }\end{array}$ & $\begin{array}{l}\text { čārek (continuous of čahar yek) } \\
\text { "quarter" }\end{array}$ & $\begin{array}{l}\text { root: } \\
\text { č.w.r.k. }\end{array}$ \\
\hline sirdāb - srādīb "cellar", "basement" & $\begin{array}{l}\text { from } \\
\text { Pers.: }\end{array}$ & serdāb "cellar", "crypt" & $\begin{array}{l}\text { root: } \\
\text { s.r.d.b. }\end{array}$ \\
\hline$b \bar{a} b \bar{u} \breve{g}$ - bwābĭg “slipper" & $\begin{array}{l}\text { from } \\
\text { Pers.: }\end{array}$ & pāpūš “slipper" & $\begin{array}{l}\text { root: } \\
\text { b.w.b.ğg. }\end{array}$ \\
\hline
\end{tabular}

$31 \quad \mathrm{C}_{1} \mathrm{C}_{2} \overline{\mathrm{a}} \mathrm{C}_{3} \mathrm{iC}$

\begin{tabular}{|l|l|l|l|}
\hline$\check{c} a \bar{d}$ dir - čwādir "tent" & from Pers.: & čādor "tent" & root: č.w.d.r. \\
\hline
\end{tabular}

32

In the collected data, I also identified a root formed with five consonants. I mention that, in the original Persian, the word kārHāne "factory", "studio" is obtained through the nominal composition of the nouns kār "work" and Hु̄ane "house":

$33 \mathrm{C}_{1} \mathrm{aC}_{2} \mathrm{C}_{3} \overline{\mathrm{a}} \mathrm{C}_{4} \mathrm{iC}$ 


\begin{tabular}{|l|l|l|l|}
\hline $\begin{array}{l}\text { karHāna - karHāyin "factory", "workshop", } \\
\text { "brothel" }\end{array}$ & $\begin{array}{l}\text { from } \\
\text { Pers.: }\end{array}$ & $\begin{array}{l}\text { kārHāne "factory", } \\
\text { "studio" }\end{array}$ & $\begin{array}{l}\text { root: } \\
\text { k.r.H.y.n. }\end{array}$ \\
\hline
\end{tabular}

\subsection{Invariable loanwords}

The Persian language doesn't possess the grammatical category of gender. Thus, a series of loanwords, either adjectives or adverbs, were borrowed as such, remaining invariable in BA:

\begin{tabular}{|c|c|c|}
\hline puHta "mush" & from Pers.: & poHte "cooked" \\
\hline pyāda "on foot", "walking" & from Pers.: & piyāde "on foot" \\
\hline tāza "fresh", "new" & from Pers.: & tāze "fresh", "new" \\
\hline Hwarda "generous" & cf. Pers.: & Hār dādan "to give food and drinks" \\
\hline Hōšs "good", “excellent" & from Pers.: & Hōǒs “good”, “pleasant” \\
\hline sāda "plain", "uniform", "straight" & from Pers.: & sāde "simple", "plain", “pure" \\
\hline
\end{tabular}

\subsection{Collective nouns}

Throughout my research, I identified a number of collective nouns, specifically names of fruit, which exist in BA, loaned from Persian, along with their nomina unitatis:

\begin{tabular}{|c|c|c|}
\hline $\begin{array}{l}\text { ālubālu "variety of large cherries } \\
\text { resembling plums" }\end{array}$ & from Pers.: & $\bar{a} l \bar{u} b \bar{a} l u$ "black cherry" \\
\hline $\bar{a}$ lubāluwwa - ālubāluwwāt & $\begin{array}{l}\text { nomens unitatis } \\
\text { of: }\end{array}$ & $\begin{array}{l}\text { àlubālu "variety of large cherries } \\
\text { resembling plums" }\end{array}$ \\
\hline $\bar{a} \operatorname{lu} c ̌ a$ "a variety of dried plums" & from Pers.: & ālūče "damson" \\
\hline $\bar{a} \operatorname{lu} \check{c} a y a-' \bar{a} l \bar{u} c ̌ a y \bar{a} t$ & $\begin{array}{l}\text { nomens unitatis } \\
\text { of: }\end{array}$ & $\bar{a} l \bar{u} c ̌ a$ "a variety of dried plums" \\
\hline $\begin{array}{l}\text { gawğa "a kind of large, light-colored, } \\
\text { plum-like fruit" }\end{array}$ & from Pers.: & gowğe "greengage", "plum" \\
\hline gawğ $\bar{a} y a-g a w \breve{g} \bar{a} y \bar{a} t$ & $\begin{array}{l}\text { nomens unitatis } \\
\text { of: }\end{array}$ & $\begin{array}{l}\text { gawğa "a kind of large, light-colored, } \\
\text { plum-like fruit" }\end{array}$ \\
\hline kišmiš "raisins" & from Pers.: & kešmeš "raisins" \\
\hline
\end{tabular}




\begin{tabular}{|l|l|l|}
\hline kišmiša - kišmišāt & $\begin{array}{l}\text { nomens unitatis } \\
\text { of: }\end{array}$ & kišmiš “raisins” \\
\hline
\end{tabular}

\subsection{Verbs of BA with Persian origin} integrated to the $5^{\text {th }}$ stem.

\begin{tabular}{|l|l|l|l|l|l|}
\hline tpawwaš - yitpawwaš “to veil oneself", "to wear a veil” & <= & pūši “veil” & from Pers.: & pūši “veil” \\
\hline
\end{tabular}

Arabic didn't loan verbs from Persian directly because the verbal morphology is very different, rather it developed words from other loans, such as nouns or adjectives, obtaining denominative verbs. They are integrated in either triconsonantal or quadriconsonantal verb stems.
The triconsonantal verbs identified are the following:
Derived on the $1^{\text {st }}$ stem:

\begin{tabular}{|l|l|l|l|l|}
\hline čiraH - yičraH "to turn on a lathe" & $<=$ & čariH "wheel” & from Pers.: & čarH "wheel" \\
\hline kiraH - yikraH "to dredge" & $c f$. & Pers.: KarHe "river in Hūzestān, Iran" \\
\hline
\end{tabular}

Derived on the $2^{\text {nd }}$ stem:

\begin{tabular}{|l|l|l|l|l|}
\hline $\begin{array}{l}\text { pawwaš - yipawwiš “to cause to } \\
\text { wear the veil", "to veil" }\end{array}$ & $<=$ & pūši "veil” & $\begin{array}{l}\text { from } \\
\text { Pers.: }\end{array}$ & $p \bar{u}$ ši “veil” \\
\hline $\begin{array}{l}\text { ğaffat - yiğaffit "to rebuild a } \\
\text { motor" }\end{array}$ & $<=\begin{array}{l}\breve{g} \text { ufta "in dominoes, a piece with the } \\
\text { same number on both ends" }\end{array}$ & $\begin{array}{l}\text { from } \\
\text { Pers.: }\end{array}$ & ğoft "pair" \\
\hline
\end{tabular}

In Persian, the noun ğoft "pair" forms the verb ğoft kardan with the primary meaning of "to pair", "to match". The same verb has other secondary bearings, such as "to invent", "to fit or join together". It is possible that the acceptation of the verb ğaffat - yiğaffit "to rebuild a motor" in BA to be derived from one of the secondary meanings of the Persian verb ğoft kardan.

Derived on the $3^{\text {rd }}$ stem:

\begin{tabular}{|l|l|l|l|l|}
\hline $\begin{array}{l}\text { pāwak - yipāwik "to settle a debt", "to pay } \\
\text { back" }\end{array}$ & $<\bar{a}$ "even" & $\begin{array}{l}\text { from } \\
\text { Pers.: }\end{array}$ & $\begin{array}{l}\text { pāk } \\
\text { "pure" }\end{array}$ \\
\hline
\end{tabular}

Derived on the $5^{\text {th }}$ stem: The 2nd stem verbs can also serve as a basis for the production of reflexive verbs,

\begin{tabular}{|l|l|l|l|l|}
\hline tpawwaš - yitpawwaš “to veil oneself”, "to wear a veil” & $<=$ & ūši “veil” & from Pers.: & pūši "veil" \\
\hline
\end{tabular}

Derived on the $6^{\text {th }}$ stem: 

kermes ilicis, from the family with the same name, kermesidae.

51 A series of 1st stem quadriconsonantal verbs present in BA are derived from onomatopoeia that are common with Persian. While their origin is unclear due the nature of onomatopoeia, I consider some worthy of mention:

baqbaq-ybaqbuq "to bubble", "to gurgle", "to cluck"

cf. Pers.: baj̇bagu "cooing" 


\begin{tabular}{|c|c|c|}
\hline ğažğaz - yiğaz̆ğuz "to squeak" & $c f$. & $\begin{array}{l}\text { Pers.: ğezğez "frizzing or } \\
\text { crackling noise" }\end{array}$ \\
\hline $\begin{array}{l}\text { HamHam - yiHamHुum "to become spoiled, tainted", "to loaf, } \\
\text { lounge", "to rummage, fumble about" }\end{array}$ & $c f$. & $\begin{array}{l}\text { Pers.: HamHam "in a stooping } \\
\text { posture" }\end{array}$ \\
\hline
\end{tabular}

\section{BIBLIOGRAPHY}

al-Ḥanāfī, Ğalāl. 1963. Mu ğamu l-luġati l-'āmmiyyati l-baġdādiyya. Baghdad: Dāru al-ḥurriyya li-ṭțibā'a.

Alkım, Bahadır et. al. 1999. Redhouse Türkçe/Osmanlıca-İnglizce Sözlük. Istanbul: Redhouse Yayınevi.

Anvari, Hassan. 2009. Farhange Fešorde-ye SoHan. Teheran: Farhang-e Moaser.

Beene, Wayne; Stowasser, Karl; Woodhead, Daniel (eds). 2003. A Dictionary of Iraqi Arabic. Washington D.C.: Georgetown University Press.

BiȚună, Gabriel. 2014. "The Assimilation of English Loan Words in the Spoken Arabic of Baghdad”. Alf lahğa wa lahğa - Proceedings of the 9th Aida Conference. Vienna: LIT Verlag. 67-77.

Blanc, Haim. 1964. Communal Dialects in Baghdad. Cambridge: Harvard University Press.

Dehkhoda, Ali Akbar.1993. Dehkhoda Dictionary. Tehran: Tehran University.

Erwin, Wallace. 1963. A Short Reference Grammar of Iraqi Arabic. Washington D.C.: Georgetown University Press.

Grigore, George. 2010. "Les verbes à racines quadriconsonantiques dans l'arabe parlé à Bagdad". Analele UniversităȚii din București LIX. 55-64.

Grigore, George. 2007. L'arabe parlé à Mardin: monografie d'un parler arabe périphérique. București: Editura UniversităȚii din București.

Haim, Soliman. 1986. Persian - English Dictionary. Teheran: Farhang-e Moaser.

Jastrow, Otto. 1981. Die mesopotamisch-arabischen qəltu-Dialecte. Vol. 2. Stuttgart: Franz Steiner.

McCarthy, Richard \& Faraj Raffouli. 1964. Spoken Arabic of Bagdad. Part One. Beirut: Librairie Orientale.

Reinkowski, Maurus. 1998. “Türkische Lehnwörter im Bagdadisch-Arabischen: Morphologische Adaptation an die arabische Schemabildung und Bedeutungsveränderung". Turkologie heute Tradition und Perspektive: Materialien der dritten Deutschen Turkologen-Konferenz, Leipzig, 4. - 7. Oktober 1994, 239-253. Wiesbaden: Harrassowitz in Komm.

Wehr, Hans \& Cowan, Milton. 1979. A Dictionary of Modern Written Arabic: (Arabic - English). Wiesbaden: Harrassowitz. 


\section{NOTES}

1. In Old Arabic (OA), this word was adopted as fülāe.

2. BA stands for Baghdadi Arabic.

\section{ABSTRACTS}

Arabs and Persians never ceased to influence each other due to their proximity. This statement is also valid on a linguistic level, with the exchange particularly observable on the vocabulary. Mesopotamian Arabic was the most exposed to influence, being the closest neighbor of territories inhabited by Persian populations. For this study, I chose to analyze the Baghdadi Arabic as exponent of this dialectal group. Throughout the past centuries up until today, loanwords were transferred from one language into the other.

In my paper, I will analyze the phonetic and semantic transformations of Persian loans and their evolution in Baghdadi Arabic (i.e. the Persian čangāl, "fork", formed a lexical family in Baghdadi Arabic with the verb čangāl, meaning "to fasten together", "to hook together" and with the noun čingāl pl. čnāgīl meaning "hook", "safety pin”, "fork”). Also, I will examine whether the loanwords are borrowed directly from Persian or through Ottoman Turkish, such as pušt, "someone with an ugly character", from pușt, "scoundrel" <Turk. (Reinkowski, 1998: 242), which, in its turn entered Ottoman Turkish form Persian (pošt, "back", "rear"). Thus, although the original word is Persian, its meaning in Baghdadi Arabic was altered by Ottoman Turkish.

My study is based on published dictionaries, phrasebooks and textbooks (such as: al-Hanāfĩ 1963, Alkım 1999, Anvari 2009 \& Beene 2003) as well as on a corpus of data that I gathered in the past two years directly from Baghdadi Arabic speakers.

\section{INDEX}

Keywords: Persian, Baghdadi Arabic, Iraq, loanwords, phonology, morphology

\section{AUTHOR}

\section{ȘTEFAN IONETE}

University of Bucharest, Department of Arabic, Romania 


\section{Verbal Negation in the Lebanese Dialect of Zeitoun, Keserwan}

Natalie Khairallah and David Wilmsen

\section{Introduction}

1 The data presented here are part of a larger study of the negation patterns of the Maronite Christian community in the village of Zeitoun, Keserwan, Mount Lebanon (Figure 1), specifically involving variation in negation with the post-positive negative marker -š.

\section{Village of Zeitoun}

2 Christians have been settling in Mount Lebanon since at the latest the middle of the 7th century A.D (Harris 2012). By the 11th century, other religious minority communities had settled in the mountains of Lebanon, including Shiites. Starting about 1545, Ottoman administrations encouraged Maronites from the northern regions of Mount Lebanon to settle in the villages of Keserwan as a counterbalance to the turbulent Shiite element in the region (Salibi 1988: 14). Present day Zeitoun continues to host Shiite and Maronite populations. 
Figure 1 : Location of Zeitoun on the map of Lebanon.

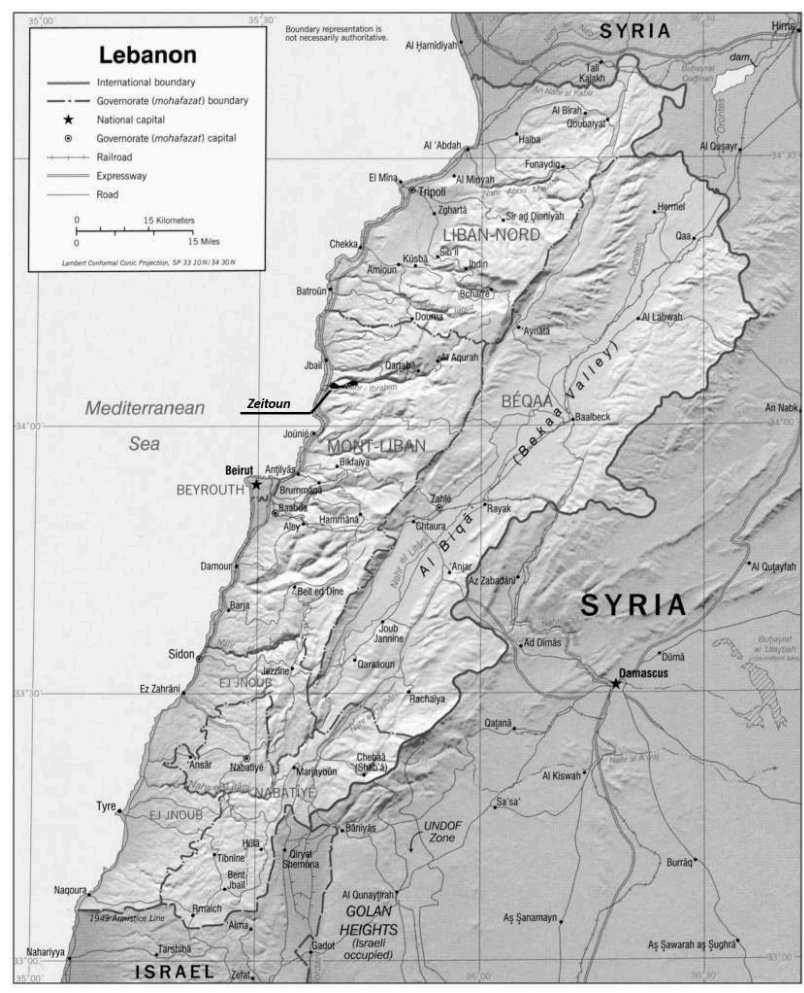

\section{Field technique}

3 The participants of the study were selected as part of a judgment sample, based on age and amount of time spent in Zeitoun. They included both males and females between the ages of 20-30, 50-65, and 66-85. Fifteen participants were chosen to be representative of the Zeitouni dialect. Of these 15 participants, three were of the age bracket 20-30; five were of the age bracket 50-65; and seven were of the age bracket of 66-85 (Table 1).

Table 1. Distribution of participants

\begin{tabular}{|c|c|c|c|}
\hline$\underline{\text { Age }}$ & $\underline{\text { Female }}$ & $\underline{\text { Male }}$ & $\underline{\text { Total }}$ \\
\hline $\begin{array}{c}20- \\
30\end{array}$ & 2 & 1 & 3 \\
\hline $\begin{array}{c}50- \\
65\end{array}$ & 4 & 1 & 5 \\
\hline $\begin{array}{c}66- \\
85\end{array}$ & 5 & 2 & 7 \\
\hline Total & 11 & 4 & $\underline{15}$ \\
\hline
\end{tabular}

The fieldwork was conducted from December 2013 to February 2014. Recordings were mainly conducted in the residences of the participants' homes in Zeitoun, but they also took place in their alternative residences in Beirut. Participants gave their permission for 
the recording and linguistic analysis of their conversations. The participants were informed that they would be recorded in order to study their use of negation. Conversations usually lasted anywhere from 30 minutes to two hours, totaling to about 10-12 hours of usable recordings. Recordings were made with the Apple Macintosh garageband program. When needed, due to limited electricity in the mountains, conversations were also recorded using a handheld recording device, which was then inputted into the computer for analysis. The programs Audacity and Pratt were used for isolating sequences and occasionally for the production and examination of spectrographic analysis.

5 Participants were familiar with the field researcher from her regular family trips to Lebanon, as well as from her past four years as a resident in Lebanon. This imparted to her a significant level of trust. She was, thus, both an insider and outsider as the primary data collector: an outsider since she was not actively part of the conversations; and an insider, because she had become a familiar face in the community. This situation was ideal, as it enabled relatively easy observation of the Zeitouni dialect in its natural settings. Those were group conversations, oftentimes conversations during the preparation of and participation in meals, during television commercial breaks, during games of cards, or while neighbours and friends visited to have coffee throughout the day. They usually included at least two and often more people conversing with each other. The opportunity also arose to record an occasional phone conversation, in which only one party of the conversation was available for recording. The recording technique was simply to leave the computer open and on during these interactions.

\section{Participants}

6 All participants were born and raised in Zeitoun, and all have spent parts of their lives elsewhere: Beirut, Jbeil (Byblos), Ballouneh, and outside Lebanon. All participants continue to live all or part-time in Zeitoun, returning daily as commuters or as summer and weekend visitors. Some aged 60 and over have returned to live as permanent residents. These are characteristic Lebanese living arrangements.

\section{Negation in northern Lebanese Arabic dialects}

7 Descriptions of negation in Levantine dialects as a whole tend to observe an isogloss between the northern and southern varieties, with the boundary line in Lebanon falling around Beirut. Common these and to all Arabic dialects is the negative particle $m \bar{a}$ 'not' that precedes or is perhaps enclitic to the verb. Southern Levantine varieties participate in the well-known split-morpheme negation construction, comprising the preverbal negation element $m \bar{a}$ as well as the post-verbal enclitic particle -š (Obler 1975: 35-41). Figure 2 is a graphic illustration of its distribution in the Levantine varieties of Arabic. It shows the conventionally understood dialect area of the southern Levant in which negation proceeds with the discontinuous negator $m \bar{a}$... $\check{s}$ with an isogloss boundary roughly south of Beirut, inclining slightly northward and eastward toward the Lebanese border with Syria. The northern Levantine dialects and those of Damascus and eastwards negate with $m \bar{a}$ alone. 


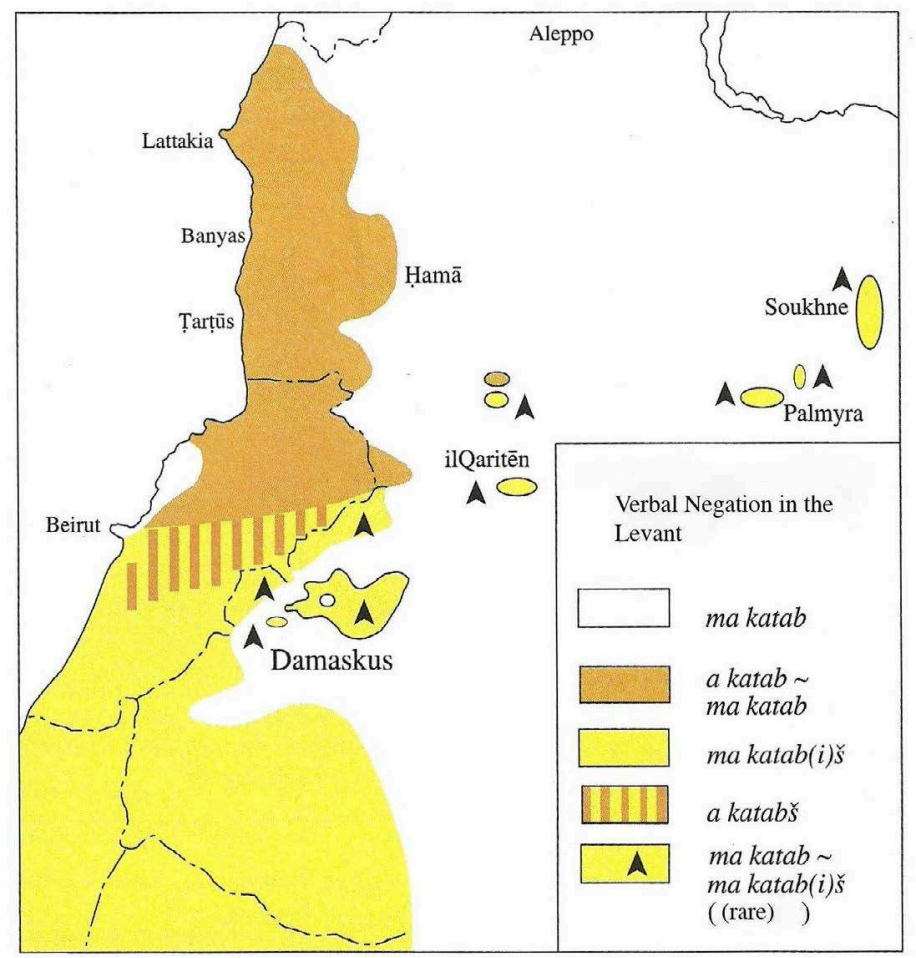

Source: Behnstedt \& Woidich (2005: 101)

The isogloss does not fall along clear boundary lines, however, with some mountain dialects eastward of Beirut participating in the split-morpheme technique, and some from the central to southern and mid-mountainous regions of Lebanon, also exhibiting an alternate split morpheme $a$....̌, which has been documented as far south as Palestine and central Jordan (Driver 1925: 197; Palva 2004).

What is more, both types have been documented north and east of Beirut. In her study of the dialects of Baskinta, a village in the Metn Governorate about 45 kilometers northeast of Beirut, at 1200 meters above sea level, Abu-Haidar (1979: 109-110) states, "mā cannot occur in a negative context in B without the suffix $-s^{\prime \prime}$ :

(1) Baskinta

ma' allam-it-nī-š

NEG teach.PFV-3FS-PRO.1S-NEG

'She did not teach me'

10 As for $a$....̌, she says: "The particle ' $a+\check{s}$ negates the imperfective with the prefix $b i$ - and also the particle fi" (Abu-Haidar 1979: 110), the implication being that it must co-occur with bilabial consonants. Feghali (1919; cf. also Feghali 1928: 221) states that plainly about its use in his native dialect of Kfār 'Abìda, about 50 kilometres up the coast from Beirut: “ $\mathrm{m}$ tombe par dissimulation dans le voisinage d'une labiale sonore" (Feghali 1919: 81): 
(2) a. Baskinta

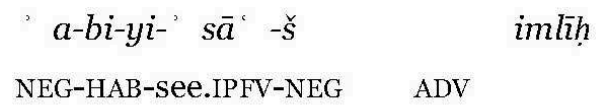

'He doesn't see well' (Abu-Haidar 1979: 110)

b. Kfār ' Abīda

$a-b-\bar{z} \bar{\imath}-\check{s}$

NEG-HAB-[1S]come.IPFV-NEG

'Je ne viens pas' (Feghali 1919: 81)

11 Writing about southern Levantine dialects of Arabic (Palestinian and Jordanian dialects), others (Blau 1960: 193-8; Hoyt 2007: passim; Lucas 2010: passim; Alqassas 2012: passim) have made similar claims regarding the reduction or deletion of the negator $m \bar{a}$, most recently Alqassas 2012:

" $m a$ cannot be reduced to 'a or to zero when negating (non)-labial-initial perfect verbs, non-labial-initial imperfect verbs, and non-labial-initial pseudo verbs" (Alqassas 2012: 157)

12 Against such assertions are those making the opposite claim, Bauer (1926: 121), Driver (1925: 197) and Obler (1975: passim) about Palestinian dialects and Palva (2004: passim) about the dialect of Salt in Jordan.

\section{Negation in The Vernacular Arabic of the Lebanon}

13 Writing about Lebanese dialects, without specifying which region, Thackston (1996) falls into the latter group of observers.

An optional ... negative suffix $-\check{s}$... may be added to all verbs and quasi-verbs [here pseudo verbs (Psv)] ...that are negated with $m a$. With the $-\check{s}$ suffix, the negative $m a$ is optional. (Thackston 1996: 145)

14 He presents a paradigm by which pseudo-verbs and imperfective and perfective verbs may all be negated with sole post-positive -š: 
(3)

\begin{tabular}{|c|c|c|c|c|}
\hline \multirow[t]{3}{*}{ a. } & ma-bi-ftikir $(-s)$ & $>$ & b. & bi-ftikir-š \\
\hline & NEG-HAB-think.IPFV-NEG & & & HAB-think.IPFV-NEG \\
\hline & 'I [do] not think so' & & & 'I [do] not think so' \\
\hline \multirow[t]{3}{*}{ c. } & ma-bidd $-\bar{I}(-\breve{s})$ & $>$ & d. & bidddī-š \\
\hline & NEG-PSV-PRO.1S-NEG & & & PSV-PRO.1S-NEG \\
\hline & 'Not in my desire $(=I \mathrm{dc}$ & (ant)' & & 'I don't want' \\
\hline \multirow[t]{3}{*}{ e. } & $m a-f i-(-s)$ & $>$ & f. & $f i-\check{s}$ \\
\hline & NEG-PSV-NEG & & & PSV-NEG \\
\hline & 'There is not' & & & 'There is not' \\
\hline \multirow[t]{3}{*}{ g. } & $m a-i n d-n \bar{a}(-\bar{s})$ & $>$ & h. & ind-nā-š \\
\hline & NEG-PSV-PRO.1PL-NEG & & & PSV-PRO.1PL-NEG \\
\hline & 'Not at us' (= 'We [do] n & ve') & & 'We [do] not have' \\
\hline \multirow[t]{3}{*}{ i. } & $m a-k u n-t i-s ̌[k i n-i t]$ & $>$ & $\mathrm{j}$. & $k u n-t i-s$ \\
\hline & NEG-be.PFV-PRo.1S-NEG & & & PRO.1S-NEG \\
\hline & 'I was not' & & & 'I was not' \\
\hline \multirow[t]{3}{*}{$\mathrm{k}}$. & $m a-t i-h s a b-n i(-\bar{I} \bar{s})$ & $>$ & 1. & $t i-h \ln s a b-n \bar{l}-\check{s}$ \\
\hline & NEG-2MS-reckon.PFV-PRO & & & 2MS-reckon.PFV-PRo.1S-NEG \\
\hline & 'Count me not $(=$ Count & $u t)^{\prime}$ & & 'Count me out' \\
\hline
\end{tabular}

Remarking upon prohibitives such as that in (3l) specifically, Palva (2004: 227) observes that a bilabial consonant constraint cannot be absolute, inasmuch prohibitives by definition are in the $2^{\text {nd }}$ person, which are marked with $t$-, a coronal consonant.

\section{Negation in the Arabic dialect of Zeitoun}

Our observations of the dialects of Zeitoun confirm those of observers of other Levantine dialects that negation with $a . . . s ̌$ and sole post-positive -š can proceed without constraint. Specifically, we have found negations with $m \bar{a}$, with and without $-\check{s}$; with ' $a$, with and without post-positive $-\check{s}$; and with post-positive -š alone with any initial consonant.
Negation with $m \bar{a} . . . \check{s}^{\prime}$
Negation with $m \bar{a} . . .$.
Negation with $a . . . \check{s}$
Negation with $a \ldots . .0$
Negation with $ø . . . \check{s}$

Examples (4) through (8) demonstrate these various combinations: 
(4)

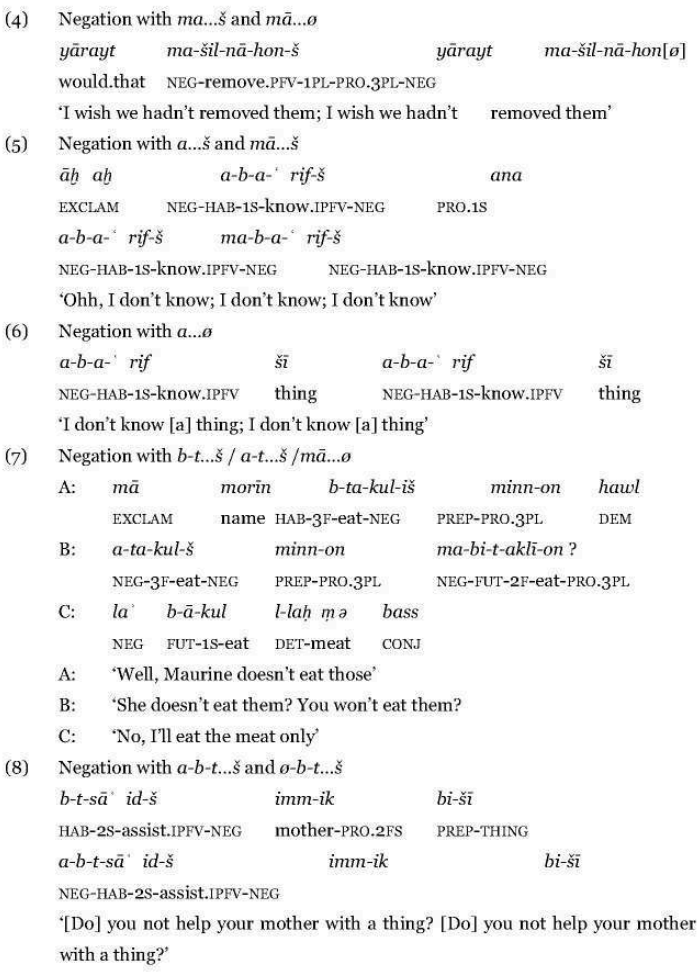

18 We have observed negation with sole post-positive $-\check{s}$ with imperfective verbs, which are generally preceded by $/ y /, / t /$ or $/ \mathrm{n} /$, that is, not bilabial consonants. Example (9), however, exhibits a peculiarity of some Levantine dialects, wherewith the initial person marker on verbs may optionally go unexpressed:

(9) Negation of non-labials with $\varnothing \ldots . . \check{s}$
hibbi-š
it-huțt-i[household item]
fi-l-gasl
$b i-s ̌ s ?$
like.IPFV-NEG 2S-put.IPFV-F
PREP-DET-wash
PREP-thing'
'[Do] you like not [that] you put [item] in the wash with [any] thing?'

This particular example is fortuitous in that it begins with two verbs with the initial radical [h], a backmost consonant, providing the opportunity to compare the verb with and without the 2nd-person marker $t$-. A spectrographic image of the utterance (Figure 3) demonstrates this clearly, wherein the initial word spoken hibbi-š 'you like not' begins without the characteristic vertical spike indicating the release burst of the /t/, whereas that may be seen in the articulation of the / $t /$ of $t$-hutt $-i$ 'you put', corresponding to the first blank space on Channel 1. 


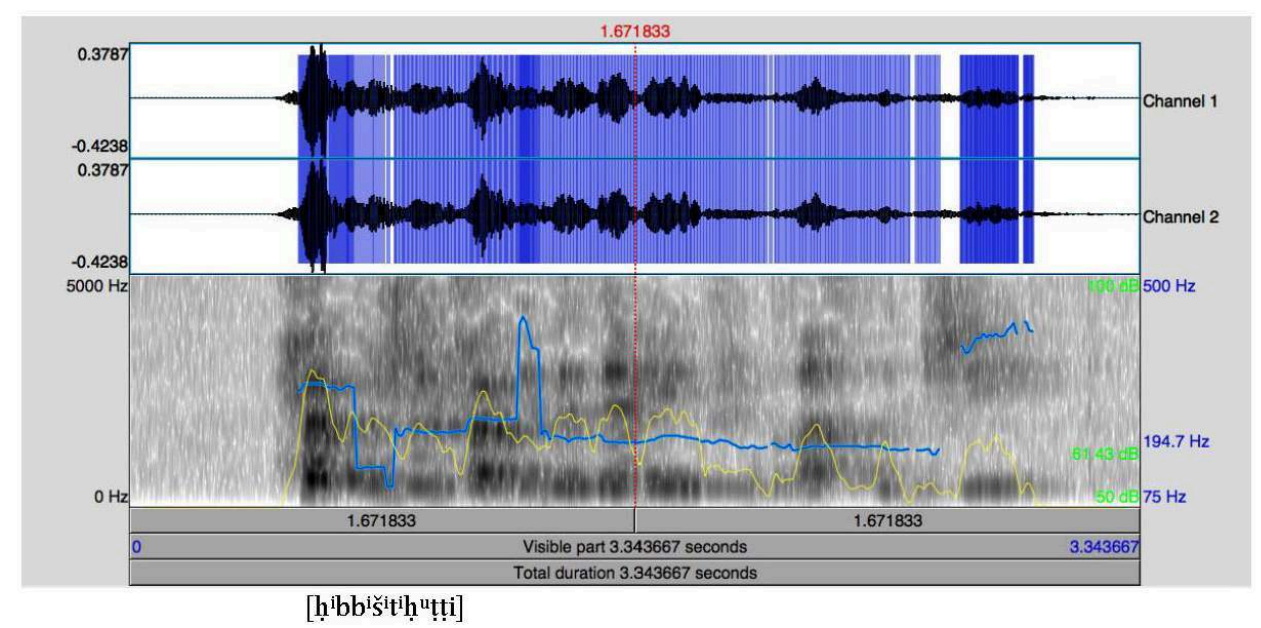

The elision of the 2nd-person marker / $t /$ in Levantine dialects has been documented in prohibitives, specifically in the dialects of the Jordanian (Cleveland 1963: 61) and Syrian (Wilmsen 2014: 108) Hawrān. Both of those studies adduce the verb Hī $\bar{f}$ 'to fear' in the prohibitive: $H \bar{a} \bar{a}-\bar{s}$ 'fear not'. We have found the same in Zeitouni (10a); but it occurs with other prohibitives as well (e.g., [10b]):

(10) Negation of non-labials with ø...š: Prohibitives
a. $\quad h a f-\bar{\imath}-\check{s}$
a morīn
fear.PROH-2FS-NEG PREP name
'[Do] not you worry about Maurine!' (cf. Clevland 1963: 61h âfi-š;:
b. šs̆l-l-ì-š $\quad y \bar{a}$-hon
carry.PROH-DAT-PRO.1S-NEG ACC-PRO.PL
'[Do] not carry them for me'

21 Clearly, such negations will proceed from the initial consonant of the root, regardless of its point of articulation. The same may be said for verbs in the perfective, whose initial consonants could be articulated anywhere. We have found those, too, negated with sole post-positive -š: 
(11) Negation of non-labials with ø...š: Perfective verbs
a. awwal ma ḥ akē-na kan-š nāṣ eh
first REL talk.PFV-PRO.1PL be.PFV-NEG overweight
'When we first we talked, he wasn't overweight'
b. barke waș ul-t-š 'a žbayl
ADV arrive.PFV-PRO.1S-NEG PREP place.name
'Perhaps I [will have] arrived not in Jbeil [Byblos]'
c. māya redd-it-š aley-yi ?
name answer.PFV-PRO.3FS-NEG PREP-PRO.1S
'[Has] Maya answered not me?'
b. 'aț $\bar{a}-t i-n \bar{\imath}-\check{s}$
give.PFV-2FS-PRO.1S-NEG
'You gave me not [a card]'

\section{Negation with -š: penultimate stress}

It bears mentioning, also, that we have noticed that the penultimate stress that Grotzfeld (1980: 186) had noted for some Palestinian dialects often but not always operates in Zeitouni. As a general principle, the consonant cluster or long vowel resulting from the affixation of -š usually obliges the attraction of stress to the ultimate syllable. This is not always so in Zeitouni. In example (5), shown again as (12), with the affixation of $-\check{s}$, the stress remains on the penult, where would occur in the verb in the affirmative. This is shown graphically in Figure 4:

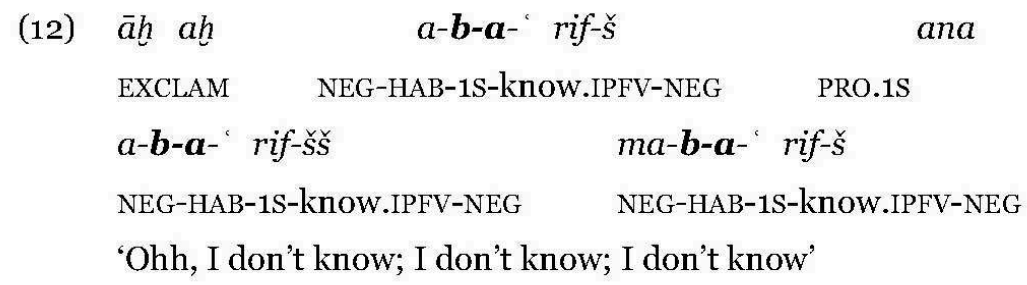




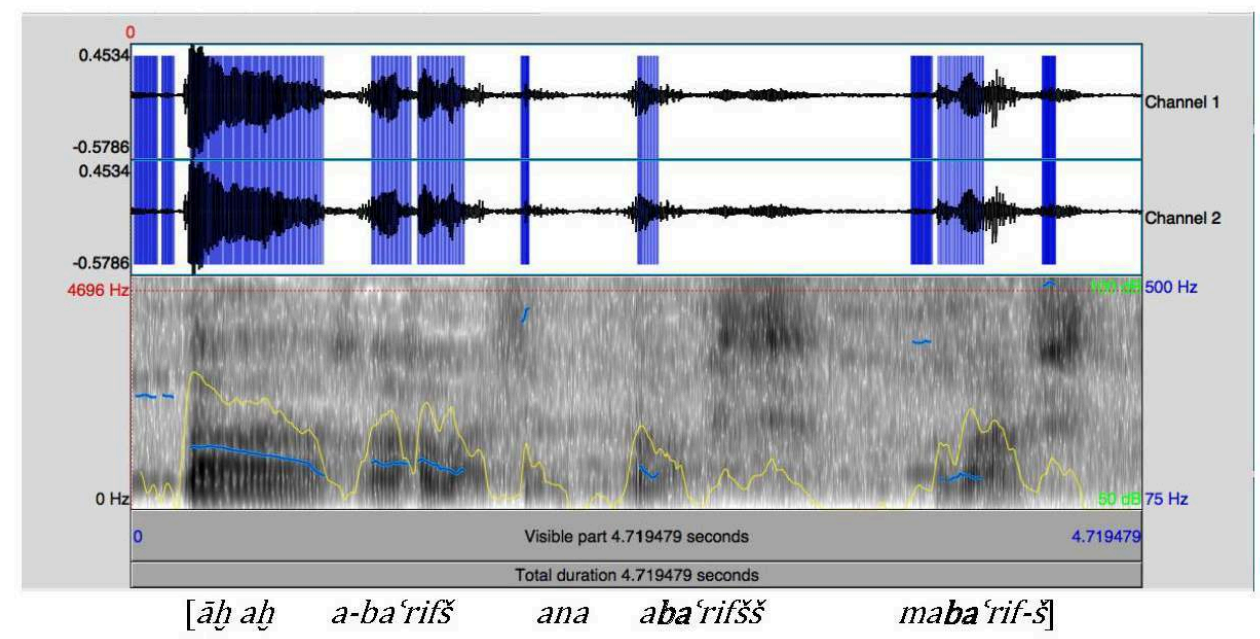

\section{Observations and conclusions}

With its negation with sole post-positive $-\check{s}$ and with $a . . . \check{s}$ the Zeitouni dialect shares features with other highland Levantine dialects of Arabic, extending into the Hawrān of southern Syria and northern Jordan, and as far south as Salt, near Amman (Cantineau 1938; Palva 2004; Wilmsen 2014: 105-110). Researchers into the dialect of Salt remark that it is "essentially Ḥōrāni" (Herin 2013: 99). This means that regardless of some regional variations, a more-or-less contiguous dialect area extends from an area to the north of Amman; through the Hawrān Plateau, encompassing northern Jordan, the Golan Heights, and south-western Syria; to the highlands of Lebanon north and east of Beirut. Herin concurs: "The strong homogeneity of Hōōanni dialects ... makes it possible to consider them a single variety and thus suitable for comparison for other more localized dialects" (Herin 2013: 100). A closer examination and re-examination is thus warranted of more localized dialects within and adjacent to that single dialect area. Negation with sole postpositive $-s ̌$ and with $a$...s seems to be a widespread highland Levantine feature, with the designation 'highland' including the Hawrān. Generalizations covering southern dialects inside and outside that area should be reconsidered.

A more pressing question is how the Hawrān dialect area came to be in the first place. Worth considering is that these areas include Christian populations that are descendants of communities that were in place before the advent of Islam (Harris 2012). McCarus (personal communication 2013) observes that in the Lebanese highlands, the Christian and Druze dialects are essentially the same. One of the main branches of the Druze, the Banī TanūH, originally from southern Arabia, were in the Syrian hinterlands at least four centuries before the Muslim era, and were staunch Christians before converting to Islam and eventually responding to the "unification call" to become what they themselves call muwahhidūn 'witnesses to God's oneness' (Hitti 1928: 51-52; Shahîd 1986: 419 \& 422 and passim; Harris 2012: 46-47). The largest populations of speakers of Druze dialects are in the Hawrān and the Lebanese highlands (Hitti 1928). The highland dialect areas may encompass remnants of a Christian Arabic dialect or dialects that had or have been in 
place in the Levantine hinterlands before the arrival there of Arabic-speaking Muslims in the seventh century (Wilmsen 2014: 133-137).

\section{BIBLIOGRAPHY}

Abu-Haidar, Farida. 1979. A Study of the Spoken Arabic of Baskinta. Leiden: Brill.

Alqassas, Ahmad. 2012. The Morpho-Syntax and Pragmatics of Levantine Arabic Negation: A synchronic and diachronic analysis. Unpublished PhD dissertation, Indiana University.

Bauer, Leonhard. 1926. Das palästinische Arabisch: Die Dialekte des Städters und des Fellachen: Grammatik, Übungen und Chrestomathie dargestellt. Leipzig: J.C. Hinrichssche Buchhandlung. Behnstedt, Peter \& Manfred Woidich. 2005. Arabische Dialektgeographie Eine Einführung. Leiden: Brill.

Blau, Joshua. 1960. Syntax des palästinensischen Bauerndialektes Bir Zeits. Hessen: Verlag für Orientkunde Walldorf.

Cantineau, J. 1938, Le parler des Drûz de la montagne Ḥōrânaise. Paris: Librairie Larose.

Cleveland, Ray L. 1963. A Classification for the Arabic Dialects in Jordan. Bulletin of the American Schools of Oriental Research, 171: 55-63

Driver, G.R. 1925. A Grammar of the Colloquial Arabic of Syria and Palestine. London: Probsthain \& Co.

Feghali, Michel T. 1919. Le Pparler de Kfar'abida (Liban-Syrie): Essai linguistique sur la phonétique et la morphologie d'un parler arabe moderne. Paris: Imprimerie Nationale.

Feghali, Michel T. 1928. Syntaxe des parlers arabes actuels du Liban. Paris: Imprimerie Nationale.

Fleisch, Henri. 1974. Etudes d'arabe dialectal. Beirut: Dar al-Machreq.

Grotzfeld, Heinz. 1980. "Das syrische-palästinensische Arabisch”, Fischer, Wolfdietrich, \& Jastrow, Otto (eds) Handbuch der arabischen Dialekte. Wiesbaden: Harrassowitz, 174-190.

Harris, William. 2012. Lebanon: A History 600-2011. Oxford: Oxford University Press.

Herin, Bruno. 2013. “Do Jordanians really speak like Palestinians?”, Journal of Arabic and Islamic Studies 13, 99-114.

Hitti, Philip. 1928. Origins of the Druze People and Religion. New York: Columbia University Press.

Hoyt, Frederick M., 2007. “An Arabic Wackernagel Clitic? The morphosyntax of negation in Palestinian Arabic”, Mughazy, Mustafa (ed.), Perspectives on Arabic Linguistics XX: Papers from the Twentieth Annual Symposium on Arabic Linguistics. Amsterdam, Philadelphia John Benjamins: 105131.

Hoyt, Frederick M. 2010. Negative Concord in Levantine Arabic. Unpublished PhD dissertation. Austin: University of Texas.

Lucas, Christopher. 2010. "Negative -š in Palestinian (and Cairene) Arabic: President and possible past”, Brill's Annual of Afroasiatic Languages and Linguistics 2. 165-201. 


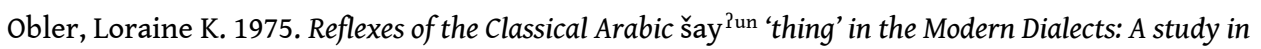
patterns of language change. Ann Arbor: UMI Dissertations Publishing.

Palva, Heikki. 2004. "Negations in the Dialect of Es-Salt, Jordan”. Muraoka, Takamitsu and Versteegh, Cornelis H.M. (eds) Approaches to Arabic Dialects: A Collection of Articles presented to Manfred Woidich on the Occasion of his Sixtieth Birthday. Leiden: Brill, 222-236.

Salibi, Kamal. 1988. A House of Many Mansions: The History of Lebanon Reconsidered. London: I.B. Tauris.

Shahid, Irfan. 1984. Byzantium and the Arabs in the Fourth Century. Washington, D.C: Dumbarton Oaks.

Thackston, Wheeler M. Jr. 1996. The Vernacular Arabic of the Lebanon. Cambridge: Dept. of Near Eastern Languages and Civilizations, Harvard University.

Wilmsen, David. 2014. Arabic Indefinites, Interrogatives and Negators: A linguistic history of western dialects. Oxford: Oxford University Press.

\section{APPENDIXES}

\section{Abbreviations}

ADV adverbial

CONJ conjunction

DET determiner

EXCLAM exclamative

F feminine

FUT future

HAB habitual

IPFV imperfective

M masculine

NEG negative

PFV perfective

PL plural

PREP preposition

PRO pronoun

PROH prohibitive

PSV pseudo-verb

REL relative

s singular

$11^{\text {st }}$ person 


\author{
$22^{\text {nd }}$ person \\ $33^{\text {rd }}$ person
}

\title{
ABSTRACTS
}

The dialect of Zeitoun village in the northern Keserwan district of Lebanon exhibits both the

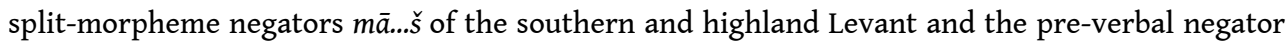
$m \bar{a}$ without the post-positive $-\check{s}$ of the northern Levant, with the $-\check{s}$ of negation optionally appearing in identical contexts. It also exhibits the form $a$...s of southern and highland Levantine Arabic dialects. Some researchers propose that the negator $a$ - can only appear before labial consonants, such as the $b$ - prefix marking habitual action or imminent futurity. Others note that it may also occur with the prohibitive, usually marked by the 2nd-person prefix $t$-. Neither of these observations holds for the Zeitouni dialect, in which prohibitives negated with sole -š may be formed without the prefix, the initial consonant being whatever the radical might be. Sole post-positive -š also occurs in negation of an unmarked imperfective verb, there, too, sometimes without an overt proclitic person marker. Another feature that is occasionally noted in the literature is the negation of perfective verbs with sole post-positive -š. This, too, occurs in the Zeitouni dialect. This type of verbal negation is characteristic of dialects from the Lebanese highlands and through the Hawrān. Finally, it is noticed that a word-final consonant cluster generated by the enclitic -š does not necessarily attract stress.

\section{INDEX}

Keywords: arabic dialects (Levant), Druze, Keserwan, Ḥawrān, Maronite, negation

\section{AUTHORS}

\section{NATALIE KHAIRALLAH}

Urban Land Institute, Washington, DC 20036, natalie.khairallah@gmail.com

\section{DAVID WILMSEN}

American University of Sharjah, Department of Arabic and Translation Studies, dwilmsen@aus.edu 


\title{
Gulf Arabic: Recent Data about the Variety Spoken in the Emirate of Dubai
}

\author{
Najla Kalach
}

\section{The Emirate of Dubai: Geographical and Historical Hints}

1 The eastern coastal region, including the port of Dubai, became a fundamental route to the Indies especially for Britons: since the very beginning of the $19^{\text {th }}$ century a series of treaties have been signed between Britain and local sheikhs ${ }^{2}$ (Sato 2016: 9).

2 The city of Dubai was founded in 1833 by less than half of the members of the Bani Yas tribe, led by the Al-Maktoum Family, who settled near the creek and established the Maktoum rule in this Emirate. This placement provided the opportunity to increase sea trading, fishing and pearling.

3 After more than a century from the foundation of Dubai, oil was discovered in UAE in 1966: Sheikh Rashid bin Saeed Al-Maktoum used the incomes to develop the area of Dubai by building roads, schools, Universities, hospitals. The Emirate quickly became an important business center for many expatriates to work and live.

In 1971, Sheikh Zayed bin Sultan Al-Nahyan - ruler of Abu Dhabi - and Sheikh Rashid bin Saeed Al-Maktoum founded a federation made of Abu Dhabi, Dubai, Sharjah, Ajman, Umm al-Quwain, Fujairah and, in 1972, Ras al-Khaimah, gaining the independence from Britain and becoming the United Arab Emirates (Séllier 2004: 76-82). 


\section{Previous Studies on Gulf Eastern Arabic Varieties and Aim of the Study}

5 The development of the Gulf region sparked the interest of the scholars who started studying the languages of Gulf countries, in fact local varieties have been the subject of important piece of research in the field of Arabic Dialectology.

6 This paper is based on a corpus of recent transcriptions and on literature mostly published on Eastern Gulf Arabic. To name but a few, the work of Thomas M. Johnstone Eastern Arabian Dialects Studies (1967) is noteworthy, as it describes the main characteristics of Eastern Gulf Arabic. Another fundamental study is A Short Reference Grammar of Gulf Arabic by Hamdi A. Qafisheh (1977) mostly based on the variety of Abu Dhabi, besides Bahraini and Qatari varieties, as well as North East Arabian Dialects by Bruce Ingham published in 1982 regarding the varieties of Kuwait, the northern areas of Saudi Arabia, southern Iraq and Khuzistan. The essential studies conducted by Clive Holes are also worth mentioning, among them Gulf Arabic (1990) a descriptive grammar mainly based on the spoken varieties of southern Iraq, Kuwait, Bahrain, Qatar and the United Arab Emirates, besides Dialect, Culture, and Society in Eastern Arabia (2000, 2005, 2016), a three-volume study based on the transcribed conversations of the varieties spoken in Bahrain in the mid-1970s.

7 All of these mentioned studies have already shown the main linguistic features of Gulf Arabic rather well, including Emirati variety.

8 The purposes that come with this paper are firstly to provide updated examples of the current spoken variety in the Emirate of Dubai, since there has been very little research about Emirati varieties over the recent decades by Western scholars. Secondly it also attempts to verify if the collected modern data match morphologically and syntactically with those of the previous studies conducted on Gulf varieties ${ }^{3}$.

\section{Methodology and Informants}

9 The data collected between 2015 and 2016 by the author during various fieldworks in the United Arab Emirates, consist of about a 6-hour recording. The sample of informants includes young women aged between 20 and 30 who were born and grew up in Dubai. Some of them are University students who are attending for Master Degree at American University of Sharjah and some others are teachers at Al Ramsa Institute ${ }^{4}$, the first language center dedicated to Emirati Arabic and culture in Dubai. They accepted to be recorded mentioning their name, age, city of origin, profession and level of instruction. The speakers personally chose to discuss some general topics, such as customs and traditions in UAE, travelling, food, daily life.

Furthermore a number of expressions, sentences, single words, grammatical notes are also taken into consideration in order to provide additional examples through the support of a questionnaire submitted to Ms Hanan Al-Fardan, Co-founder and Managing Director of Al Ramsa Institute. Then, recordings have been transcribed and translated into English for the linguistic analysis. 


\section{Morphosyntactic Features}

\subsection{Independent Pronouns}

Basic forms of independent subject pronouns are the following:

\begin{tabular}{|l|l|l|l|l|l|}
\hline & Singular & & & Plural & \\
\hline 1 p. & 'ana & 'I' & 1 p. & 'ihnna, nihnna & 'we' \\
\hline 2 p.m. & 'inta & 'you' ${ }^{\mathrm{m} '}$ & 2 p. m/f. & 'intū & 'you p.m./f.' \\
\hline 2 p.f. & 'inti & 'you' ff' $^{\prime}$ & & & \\
\hline 3 p.m. & $h \bar{u}$ & 'he' & 3 p.m./f. hum & 'they p.m./f.' \\
\hline 3 p.f. & $h \bar{\imath}$ & 'she' & & & \\
\hline
\end{tabular}

12 According to the data, the majority of speakers, in Dubai variety, do not use gender differentiation, in fact only one form for the $2^{\text {nd }}$ plural person masculine and feminine is used, which is 'intū, as well as in the $3^{\text {rd }}$ plural person masculine and feminine hum, unlike, for example, the Abu Dhabi variety that distinguishes for the $2^{\text {nd }}$ plural person a masculine form 'intum and a feminine one 'intin, as well as for the $3^{\text {rd }}$ person masculine hum and hin for feminine (Qafisheh 1977: 159). According to Holes (1990: 159) separate feminine forms occur in educated speech, but no example has been found in the gathered data for this study.

\section{Examples}

(1) taḥt iš-šēla nhutțt nihnna šabbāṣa

'we wear a clothes peg under the veil'

(2) il-lōn il-'abyad hū iš-šă'ic Eind iš-šabāb

'the white colour is the most popular among boys'

(3) il-mara ma lābsa hī Eabāya

'the woman does not wear abaya'

(4) hum yabūn tagiyir baed

'they also want a change'

(5) il-yōm ḥatta tšūfin 'inti mumkin iš-šề Muhammad bin Rāšid yilbis 'alwān 'today youf can see even Sheikh Mohammed bin Rashid wearing colours'

(6) 'ana lèn il-hīn ma ruht 'umm il-gēwìn

'I have never been in Umm al-Quwain until now'

\subsection{Suffixed Pronouns}

\begin{tabular}{|l|l|l|}
\hline & After Consonant & after Vowel \\
\hline 1 p.sg. & $-i$ & - niandyi /ya \\
\hline 2p.sg. m. & $-i k$ & $-k$ \\
\hline
\end{tabular}




\begin{tabular}{|l|l|l|}
\hline 2 p.sg. f. & $-i \check{c}$ & $-\check{c}$ \\
\hline 3 p.sg. m. & $-a h$ & $-h$ \\
\hline 3 p.sg. f. & $-h a$ & $-h a$ \\
\hline 1 p.pl. & $-n a$ & $-n a$ \\
\hline 2p.pl. m./f. & $-k u m$ & $-k u m$ \\
\hline 3 p.pl. m./f. & $-h u m$ & $-h u m$ \\
\hline
\end{tabular}

13 The data confirm the suffixed pronouns found by Qafisheh (1977: 164-170) and Holes

(1990: 234-235).

\section{Examples}

(11)zamill-i min abu dabi

'my colleague from Abu Dhabi'

(12)bi-'imkān-i ma 'ilbis Eabāya

'I have the possibility (I can) to do not wear abaya'

(13)yacni ma kint min 'ahal-hum bass hì șadiqt-i

'I mean I was not part of her family, but I was her friend'

(14)naErif iš-šaHș min țarīqat libs-ah

'We recognise where the person is from, depending on his clothing'

(16)bi-'imkān-ah hū yzūr-ha fi-l-bēt bass bi-wuǧūd 'ahal-ha

'he can visit her but in the presence of her family'

(17) in-nās tis'al: zōğt-ah ḥāmil?

'people ask: is his wife pregnant?'

(19)kil dawla Halī̌riyya la-ha stāyl-ha il- Huāṣ̦

'each Gulf country has its own style'

(20)hū ğarīb min bēt-na taqrīban masāfat Eašra dagāyig

'it is close, about 10 minutes away from our house'

(21)kān 'ihtikāk-hum 'aktar bēn-hum w bēn bac d

'they mostly had contact with each other'

(22) lēš tḥuțțūn burğ Halīfa fōg rās-kum?

'Why do you put Burj Khalifa over your head?'

\subsection{Demonstratives}

\begin{tabular}{|c|c|c|c|}
\hline & Sing.m. & Sing.f. & Pl.m./f. \\
\hline Proximal demonstrative & $h \bar{a} \underline{d} a$ & $h \bar{a} \underline{d} i, h \bar{a} y$ & hadēl, hadēela \\
\hline Distal demonstrative & hadāāk & hadīič & hadiliāk, hadōōā $k^{6}$ \\
\hline
\end{tabular}

Examples of demonstratives in a pronominal function:

(23) hadilāk šabāb min il-Eēn

'those are boys from Al-Ain'

(24) kān yis'al: mnu hādi?

'he was asking: who is this?'

(25) fi-ha wāyid 'imārātiyyīn w hadèela yacni maerūfin

'there are a lot of Emiratis and those are well-known'

(26) hāy matalan saeūdiyya 'aw hāy matalan gațiyya 
'for example this one is Saudi or that one is Qatari'

Examples of demonstratives in adjectival function according to Holes (1990: 175): "the demonstrative may be placed either directly before or after the complete noun phrase", as follows:

(27) fi-hāda il-matal

'in this way of saying'

(28) hāda šššay 'ashal

'this thing is easier'

(29) il-fatra hādi

'at this time (of the year)'

(30) l-qabila hāy la-ha țariqa mu\&ayyana fi ramsa-ha

'this tribe has its own way of speaking'

(31) Habbart-ič Ean hadī̌ is-sālfa?

'Have I told youf about that story?'

According to the majority of Arabic varieties, the invariable stem ha- prefixed to a definite noun occurs in adjectival function:

Examples:

(32)w ha-l'ašyā' mațalan

'and these things for example'

(33) min ha-l-qabila

'from this tribe'

(34) Eigb ha-l-fatra

'after this period'

(35)fa-dāyman kān ir-rayyāl yilbis bi-ha-ț-țarīqa

'man always used to dress this way'

(36)ha-n-nās ykūn Eādatan 'ahal il-Earūs

'these people are usually the bride's relatives'

16 It is worth noting that in the recordings more hāy than hādi occurs. It is likely that other demonstratives exist in Dubai and other regions of UAE depending on the origin of tribes and families, but they did not occur in the data collected for this study.

\subsection{Interrogatives}

\begin{tabular}{|c|c|c|}
\hline šù & 'what?' & (37) niḥna šū ngūul? \\
\hline \multirow[t]{3}{*}{$-\check{s}$} & & 'how do we say?' \\
\hline & & $(38) \check{s}-f i-\check{c}$ ? \\
\hline & & 'what's wrongf?' \\
\hline \multirow[t]{4}{*}{ lēš } & 'why?' & (39) lēš ir-rayyāl yilbis kandōra bēẹda? \\
\hline & & 'why do men wear a white kandoora?' \\
\hline & & (40) lēš il-abyad w lēš il-'aswad bi-ha-ț-țarīqa? \\
\hline & & 'why white and why black this way?' \\
\hline mita & 'when?' & (41) mita Eind-ič klās-ič? \\
\hline
\end{tabular}




\begin{tabular}{|c|c|c|}
\hline & & 'when do you ${ }^{\mathrm{f}}$ have class?' \\
\hline $\operatorname{kam}($ čam), & 'how much?' & (42) kam marra sirti عağmān? \\
\hline \multirow[t]{5}{*}{ bi-kam } & 'how many?' & 'how many times have you been in Ajman?' \\
\hline & & (43) kam wāhid tabīn? \\
\hline & & 'how many do you ${ }^{\mathrm{f}}$ want?' \\
\hline & & (44) bi-kam hādidi š-šanța? \\
\hline & & 'how much does this bag cost?' \\
\hline \multirow[t]{4}{*}{ wēn } & 'where?' & (45) 'agūl yā rabbī ma Earef il-muškila wēn? \\
\hline & & 'I say oh Lord! Where is the problem?' \\
\hline & & (46) wèn nhutț-ha il-hīin? wēn nwuddì-ha? \\
\hline & & 'where do we put them now? Where do we bring them?' \\
\hline kēf (čēf), & 'how?' & (47) 'intū s-sūriyyìn kēftgū $\operatorname{lu} n$ ? \\
\hline šlōn & & 'how do you say in Syria?' \\
\hline \multirow[t]{2}{*}{ 'ay } & 'which?' & (48) 'ay ktāb garēti? \\
\hline & & 'which book did you read?' \\
\hline \multirow[t]{2}{*}{$\mathrm{mnu}$} & 'who?' & (49) mnu hādi? \\
\hline & & 'who is she?' \\
\hline
\end{tabular}

\subsection{The Annexation}

17 Possessive and genitive relationships are expressed by a synthetic construct composed of two noun phrases. The first noun is indefinite while the second noun could be definite or indefinite according to the meaning of the phrase (Qafishesh 1977: 116-118).

18 However, the analytic construct is also very common: it is expressed by the genitive exponent māl or hagg 'belonging to, of'. According to Holes (1990: 170-171) the particles $m \bar{a}$ l or hagg "may only be predicated of or attributed to a definite noun".

Examples of synthetic constructs:

(50) duwal il-Halïg

'the Gulf States'

(51) wayh il-mar'a

'the woman's face'

(52) 'istiHdām il-Eabāya

'the use of the abaya'

(53) rās il-Hēma

'Rās Al-Khaimah' 
(54) 'umm il-gēwìn

'Umm al-Quwain'

(55) mașārifil-Eurs

'the wedding's expenses'

(56) ḥafalāt il-ḥarim

'the women's parties'

(57) masāḥat 'arād

'the area of the United Arab Emirates'

(lit. the head of the tent')

Examples of analytic constructs with hagg ${ }^{7}$ and $m \bar{a} \mathbf{l}$ :

(58) il-manțiqa hagg il-'istiğmām

'the region of rest'

(59) il-markaz hagg is-suwwāh

'the tourists'center'

(60) haflat 'istiqbāl hagg il-'ahal

'the family's welcome party'

(61) il-kandōra māl ir-rayyāl

'the kandoora of the man'

(62) hü 'illi daqqaq Ea-l-manhağ māl-na

'it is him who examined our programme'

\subsection{Negation}

19 Like most Gulf varieties, the basic particles that occur for negation are ma, mub, (variant miš) and la 'not'. These stems are used to negate nouns, adverbs, perfect and imperfect tense, active and passive participles, prepositions, adjectives, pseudo-verbs and independent pronouns (Holes 1990: 71-76), such as the following examples:

Examples with ma:

(63) ma had yadri

'nobody knows'

(64) ma lābsa hī Eābaya

'she is not wearing an Abaya'

(65) ma kān yilbis lōn il-'abyad

'he did not use to wear white'

(66) 'ana lēn l-hīn ma ruht 'umm il-gēwīn

'I have never been in Umm al-Quwain until now'

(67) 'ana ma (a)bā sīr mōl dbayy

'I do not want to go to Dubai Mall'

(68) w bi-t-tāli ma Eindo-na wagt nilahhịig

'besides we do not even have time'

(69) ma Eind-ha šuğ

'she does not have a job'

Examples with mub:

(70) lahğat dōlat il-'imārāt mub waḥda fi-kil il-'imārāt is-sabic

'the dialect of UAE is not only one among the whole seven Emirates'

(71) yacni mub mawșūla Ean hafalāt li-ḥrīm

'I mean it is not connected to the women's parties'

Examples with miš:

(72) hū miš 'aqall عan in-nās

'he is not less than others'

(73) il-ḥin miš mhimm wāyid

'now it is not very important'

(74) miš kil 'imārāāti yirmis bi-nafs iț-țarīqa

'not all Emiratis speak the same way'

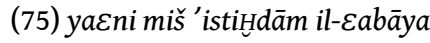


'I mean not the use of the abaya'

It has been found only one example with the particle gèer 'different from':

(76) iš-šay 'illi ġer mawğùd fi-makān tāāni

'the thing that there is not available somewhere else'

Imperative is negated by the particle la: it either used for a negative command or for absolute negation (Qafisheh 1977: 240-241).

Examples with la:

(77) la tāklìn il-hịn!

'do not eat now!'

\subsection{Agreement with inanimate plurals}

Inanimate plural nouns usually have feminine singular agreement in adjectives, verbs, and pronouns, according to the Bedouin typology features.

\section{Examples:}

(79) la-ha kalimāt wāyid șąba

'it has many difficult words'

(80) li'anna qabā'il dōlat il-'imārāàt ma kānat ticišs fi makān wāhid

'because Emirati tribes did not use to live only in one place'

(81) fĩ qabā'il badawiyya kānat ticīš fi-l-barr

'there are Bedouin tribes that used to live in the desert'

(82) l-hīn ysāwūn musalsalāt tāriHiyya 'aw l-'ašyā l-qadìma

'now they make historical soap operas or this kind of old stuff'

(83) yilbisūn mōdèlāt cimāniyya

'they wear Omani models'

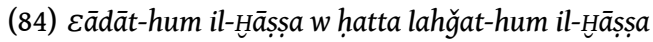

'their own customs and even their own dialect'

\section{Final Comments}

Far from giving an exhaustive description of the variety spoken in Dubai, this study aims to provide examples of recent data. According to Versteegh (2014: 192): "The Arabian peninsula, the homeland of the Arab tribes, remains the least-known dialect area of the Arabophone world". In fact, further investigation concerning Gulf Arabic is still needed. Linguistically, the data show a mixed typology including Bedouin and sedentary features due to the strategic geographic position of Dubai on the Arabian Gulf, as well as the mixed distribution of Arab nationalities besides the huge presence of expats that have influenced the local language. In addition there are also many linguistic differences among tribes. These factors make the recognition of authentic specific features quite hard.

On one hand, it is possible to find Bedouin's typology features such as: the preservation of interdentals phonemes /ț/, /d /, /d / and realization of /q/ as /g/ or / $/ \check{g} / ;$ the use of feminine singular agreement for inanimate plurals; the pronominal suffix of the thirdperson singular masculine is -ah, example: bēt-ah 'his house' (Versteegh 2014: 193).

On the other hand, according to the data, sedentary features are the following: loss of gender distinction in the second and third person plural of pronouns and verbs; loss of in as a marker of indefinite words; the prefix vowel of the verb is $-i$, for example: yilbis 'he wears'; use of genitive exponent for possessive construction through the particles $m \bar{a} l$ and hagg (Durand 2009: 165-166). These features, included in the recent data presented in this 
paper, match with the data collected many years ago, for example by Qafisheh (1977) and Holes (1990).

The important geopolitical role of UAE on the world stage gives rise to a reflection concerning its linguistic situation: is it possible for Emirati variety to be bound to become one of the most well-known ${ }^{8}$ Gulf varieties in the upcoming years, despite the limited extension of the territory?

It may be probable for many different reasons. Firstly, in very recent years, local people have matured a tendency of preserving their customs and language because globalisation caused contamination including, for example, a partial loss of their everyday use of local language, which is frequently substituted by English. The foundation of a language center dedicated to Emirati Arabic and culture like Al Ramsa Institute represents a first evidence of local Emiratis' interest to enhance and promote their local language and traditions.

Secondly, the soap opera business has changed: due to difficult circumstances in the Arab world, such as in Syria, the broadcasting market is now developing in the Gulf Region, especially in UAE. Therefore the presence of Gulf Arabic, especially the Emirati variety, is now frequently heard in soap operas because Emirati-speaker actors are involved, together with Syrian ones, in the production. To give an example about this point it occurs in Syrian soap operas such as Sabaya +971 Season 4 (2012) shot in Dubai and Fitnet zamanha (2015) shot in Abu Dhabi.

Furthermore the broadcast of social media among the Gulf countries, is allowing anyone to express their opinions and forms of art $^{9}$ (i.e. tutorials, reviews) in a home-based environment.

That does not mean that Arab speakers will start speaking fluently Emirati, but rather that this it may contribute to make Emirati variety more accessible to other Arab speakers or foreigners such as scholars, students or employees: in fact, Gulf varieties are less studied and known if compared to other Arabic varieties such as Syrian, Egyptian, Tunisian, Moroccan etc. However UAE have good chances to promote the dissemination of Gulf Arabic in and outside the Gulf territory.

\section{Sample Text}

Speaker: Hassa, 24 years old, graduated student at Sharjah University, born and raised in Dubai.

lahğat-na muqāranatan bi-bāgi duwal il-Halīğ hiyya 'araqa lahğa, la-ha kalimāt wāyid șąba, lahğat dōlat il-'imārāt mub waḥda fi kil il-'imārāt is-sabic: abū dِabi la-

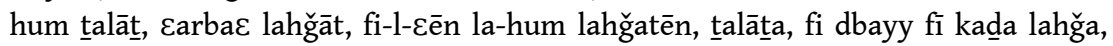
tiHtilif min 'iHtiliāf il-qabā'il, miš kil 'imārāti yirmis bi-nafs iț-țarīqa la'anna kil

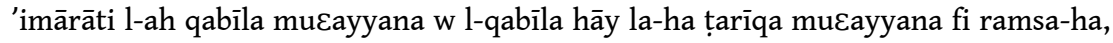
ha-ššsay rāğie la'anna qabā'il dōlat il-'imārāt ma kānat ticišs fi makān wāḥid, fī qabā'il kānat Eind il-baḥr fa-lahğat-ha 'absat li-'ihtikāk-ha bi-t-tiǧāra w l-'ağānib w fĩ qabā'il badawiyya kānat tiغī̌s fi-l-barr w kān 'iḥtikāk-hum 'akțar bēn-hum w bēn baed, fa-muștalaḥāt-hum 'aṣeab, w fĩ qabā'il min kitrat it-tirḥāl Hुadat lahğāât

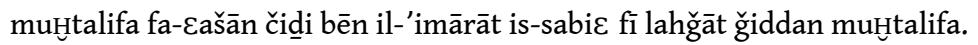

\subsection{Translation}

'Our dialect, if compared to the other Gulf dialects, is the more elegant one. It has very difficult words and it is not only one dialect in the whole UAE: Abu Dhabi has 
three or four dialects; Al-Ain has two or three dialects, in Dubai there are many more dialects. It differs according to the tribe, not every Emirati person speaks in the same way because each Emirati belongs to a specific tribe and every specific tribe has its own dialect. This difference exists because the tribes of UAE did not use to live in the same place: some tribes used to live at the sea so their dialect is easier thanks to their commercial links and to the foreign members. On the other hand there were other tribes who used to live in the desert: so they used to be more in contact with each other, this is why their words are more difficult. Some other tribes used to move around a lot so they took over many different dialects. That's why there are various dialects throughout the UAE'.

\section{BIBLIOGRAPHY}

Ingham, Bruce. 1982. North East Arabian Dialects. London: Kegan Paul International.

Durand, Olivier. 2009. Dialettologia araba. Roma: Carocci.

Holes, Clive. 1990. Gulf Arabic. London: Routledge.

Holes, Clive. 2000. Dialect, Culture and Society in Eastern Arabia, Volume 1 Glossary. Leiden, Boston, Köln: Brill.

Holes, Clive. 2005. Dialect, Culture and Society in Eastern Arabia, Volume 2 Ethnographic Texts. Leiden, Boston, Köln: Brill.

Holes, Clive. 2016. Dialect, Culture and Society in Eastern Arabia, Volume III: Phonology, Morphology, Syntax, Style. Leiden, Boston, Köln: Brill.

Johnstone, Thomas M. 1967. Eastern Arabian Dialect Studies. London: Oxford University Press.

Qafisheh, Hamdi A. 1977. A Short Reference Grammar of Gulf Arabic. Tucson: Librairie du Liban \& University of Arizona Press.

Qafisheh, Hamdi A. 1997. NTC's Gulf Arabic-English Dictionary. Chicago: NTC Publishing Group.

Sato, Shohei. 2016. Britain and the formation of the Gulf States: Embers of Empire. Manchester: Manchester University Press.

Séllier, Jean \& Séllier, André. 2004. Atlas des peuples d'Orient. Moyen-Orient, Caucase, Asie Centrale. Paris: Éditions La Découverte.

Versteegh, Kees. 2014. The Arabic Language, Second edition. Edinburgh: Edinburgh University Press.

\section{NOTES}

1. i.e.United Arab Emirates.

2. The lines refer to the treaty in 1820 for the cessation of piracy in the area; lately known as the Perpetual Treaty of Maritime Peace in 1853 which prohibited local parties to take military actions and obligated the British to maintain the order in the region. 
3. For this paper two selected works have been taken into consideration for a data comparison: A Short Reference Grammar of Gulf Arabic by Hamdi A. Qafisheh (1977) and Gulf Arabic by Clive Holes (1990), as these studies thoroughly analysed Emirati varieties.

4. A special thank goes to the Al Ramsa Institute in Dubai, represented by Mr Abdulla Al-Kaabi and Ms Hanan Al-Fardan. The Al Ramsa Institute for Emirati Dialect and Culture is the first institute in UAE with the aim of teaching spoken Emirati dialect, besides doing other Emirati cultural activities.

5. nihin is more common in Bedouin varieties.

6. Thanks to Dr. Yousuf B. AlBader from University of Kuwait for his suggestions on demonstratives.

7. It is worth noting that the particle hagg occurs also to express purpose 'for', as in the following example (found in the recordings): 'ana 'asī hagg il-Earūs 'aw hagg il-maEris 'I go for the bride or for the broom'. The examples containing hagg in paragraph 4.5. express possession, according to their context in the recordings.

8. Here 'Well-known' means that Arab native speakers or Arabic speakers can recognise and are familiar with Emirati variety more than in the past, when the contacts with the Emirates were less frequent. This does not mean that people will speak Emirati fluently or that they will substitute their native variety with Emirati.

9. Lastly also the current trend of talent shows has included Emiratis as part of the judge panel: for example the very popular singer Ahlam Al-Shamsi on Arab Idol.

\section{ABSTRACTS}

The aim of this paper is to present some recent examples of the variety spoken in the well-known Emirate of Dubai, the second largest of the seven Emirates that constitute the federation, located in the South Eastern shore of the Arabian Peninsula.

The study is based on data gathered by the author between 2015 and 2016 during her recent fieldwork in the $\mathrm{UAE}^{1}$ : the informants were young Emirati women aged between 20 and 30 years old. The purpose of the study is to contribute to the previous ones about Gulf Arabic, by presenting more recent examples and some morphological and syntactic features of the local variety in Dubai.

\section{INDEX}

Keywords: Arabic Dialectology, Spoken Arabic, Gulf Arabic, Emirati Variety, United Arab Emirates, Dubai

\section{AUTHOR}

\section{NAJLA KALACH}

Tuscia University 


\title{
Khuzestan Arabic and the Discourse Particle $\check{c} a$
}

\author{
Bettina Leitner
}

\section{Introduction and data}

1 This paper presents first results of my doctoral thesis, which aims at a complete description of the grammar of Khuzestan Arabic, though its principal point of reference will be the dialect spoken in the province's capital Ahwaz.

2 Khuzestan is a southwestern Iranian province on the border with Iraq, with approximately four to five million inhabitants (Shabibi 2006: 12). The province's capital Ahwaz alone is home to more than a million people ${ }^{1}$. Khuzestan Arabic is spoken by over 3 million people (Matras 2007: 134). The percentage of Arabs is very high throughout the region, in some villages and towns it reaches almost 100 per cent. $^{2}$

The main contributions to the study of Khuzestan Arabic have been made by the British arabist Bruce Ingham in the 1970s. Since 2007 there is also an entry in EALL written by him.

4 I have carried out preliminary field work in September 2016 and stayed in Ahwaz for a month with the family of an informant who is now living in Vienna. Recordings of around 25 people have been made (amounting approximately 5 hours), mainly in Ahwaz, but also in other towns or villages, like Ḥamidiyye, Tustar (pers. Šūštar), Xafağiyye (pers. Sūsangerd) and Muhammara (pers. Hुorramšahr). The recordings are mainly of elderly, less-educated people, many of them women. Furthermore, not all people who have been recorded in Ahwaz were originally from that town.

Of course, as an Arabic speaking enclave in a Persian dominated society, there is a rather strong influence from the Persian language, particularly on young and educated speakers, who have had more contact with Persian speakers at school, university, work or with Persian-speaking friends. However, since the data analysed for the present paper consists mainly of recordings of elderly, female - which unfortunately often means less educated persons, Persian features or phenomena of language contact will not be discussed in the 
present paper. But, of course, phenomena of contact-induced change present an important part of the study of the dialects of Khuzestan and will be discussed in another paper.

6 All the examples given throughout this paper are taken from my own data if not indicated otherwise.

\section{Main features \& typology}

7 As a gələt dialect of the South-Mesopotamian group, Khuzestan Arabic has many Bedouin and conservative features, such as the preservation of fem. pl. forms in the $2^{\text {nd }}$ and $3^{\text {rd }} \mathrm{ps}$. in the verb domain as well as in pronouns (independent and suffixed ones), or the existence of the gahawa-syndrome, which is however limited to some items, such as colours, e.g. (a)xadar. ${ }^{3}$

8 Khuzestan Arabic is grouped and shares features with the gələt dialects of Iraq (e.g. Muslim Arabic of Baghdad) and the Bedouin dialects of Syria. Furthermore, it has strong dialectal links to the Gulf dialects, especially Bedouin Bahraini Arabic, i.e. the Arabic spoken by the Sunni Arab population, descendant from Najd.

9 A typically Mesopotamian characteristic, apart from lexical features, ${ }^{4}$ is the usage of the so-called indefinite article farəd, e.g. farəd Pəbnayye 'a girl'. ${ }^{5}$

10 Khuzestan Arabic shows some features that are only rarely documented in other Arabic varieties, e.g. the usage of the $1^{\text {st }} \mathrm{ps}$. sg. imperfect suffix -an. This is an optional suffix for hollow and geminated verbs, e.g. Padullan 'I stay', Parūhan 'I go' (Ingham 2000: 127). Ingham considers it a South-Mesopotamian feature and explains it as a contraction of the postponed $1^{\text {st }}$ ps. sg. pronoun ane (Ingham 2000: 127). Ingham compares this feature to the suffixation of the $2^{\text {nd }}$ ps. msc. sg. pronoun ant after perfect verb forms in the dialect of the Âl Murrah of Southern and Eastern Arabia, as in šifhant 'did you see' < šift ant (Ingham 2000: 127 , fn. 4$){ }^{6}$

11 A further characteristic feature of this dialect is the formation of the perfect tense

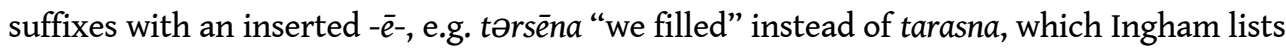
as an urban feature (Ingham 1973: 544) and Bruno Meißner considers a mark of Mif dān or Marsh Arab speech (Ingham 1973: 544). This second claim was confirmed by my main informant and additionally by its appearance in the recording of a woman born and raised in Ḥuwayza, now living in Ahwaz.

Another interesting feature are the different forms of diminutives in Khuzestan Arabic. The usual (internal) diminutive shows the patterns CCìeC(e)/CCèC and CwayyaC, e.g. lbiene < laban 'buttermilk', šwayyəb < šāyəb 'old man', or żayyar < șagiir 'small'. A further construction of the diminutive is formed with the combination: (internal) diminutive + $\bar{u} n^{7}$, e.g. šwayyūn 'a little bit'. Further, we find a construction, which to my knowledge has not been described so far, i.e. the combination of the suffix - $\bar{n}$ n and a diminutive form CēCiC/CayCiC before the suffix, e.g. hêlisūn 'plucked'. The development of this diminutive morpheme remains unexplained. hēlis might derive from the participle hälis, which turned into a diminutive hēlis via huwaylis, and deletion of /uw/, but this remains only a speculative theory for the moment. Its usage in the given example is clearly for minimization or expressing affection, since the example text is a fairy tale and it is animals who are speaking.

Examples: 


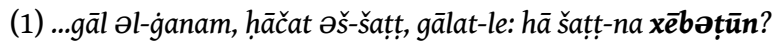

'...so, the sheep, they talked to the river and asked it: Our river, why are you polluted?'

(2) - gāl-ha: šațt-na xēbəțūn $w$ sidrat-na haytitūn $w$ țwēr-na hēlisūn $w$ gmayla bieč̌ičūn, Sala brēgiš țāḥ b-ət-tannūr...

'- It answered: Our river is polluted and the Jujube tree has no leaves and our bird is plucked and Gmayla is crying because the brēgiš ${ }^{8}$ fell into the oven.'

(Informant: Umm Sa Sad, 40 years, Ahwaz)

\section{Comparison with Ingham's data: An update} descriptions, certain parts do require updating. One point that strongly diverged in my data concerns Ingham's dialectal subdivision into Yarab vs. hadar, and urban vs. rural dialects, especially in the case of the dialect spoken in the city Ahwaz. Ingham made this division into two groups mainly according to morphological, morpho-phonological, and lexical distinctions (Ingham 1973: 534).

Regarding the first analysis of my data, we have to question whether Ingham's listing of the dialect of Ahwaz - among other newer towns - as Sarab (Ingham 2007: 572) is still justifiable. The comparison of my recently gathered data with Ingham's description indicates that the dialectal features of Ahwaz correspond to what Ingham describes as hadar in some respects, but in others again with Garab, and we can state just the same with his urban-rural distinction, which again demonstrates the dual characteristics of Ahwaz Arabic. In the following section, I will discuss some features that Ingham uses as distinguishing characteristics between the postulated dialectal groups and contrast his descriptions and the findings from my own data.

\subsection{Morphological distinctions}

\section{a) $3^{\text {rd }}$ ps. fem. sg. perfect form}

One feature that Ingham classifies as typically Garab or rural - and with that as the form used in Ahwaz - is the syllabic structure CCvCat for the $3^{\text {rd }}$ ps. fem. sg. perfect, e.g. ktəbat 'she wrote' (Ingham 2007: 573). However, in my data this form never appeared for Ahwaz. Instead we find the form that Ingham lists for hadar or urban dialects (CvCCat), which, according to Ingham, include the towns along the Shatt al-Arab and Lower Karun, like Muhammara (Ingham 2007: 571-572). Examples of this (hadar/urban) form found in Ahwaz are gəlbat 'she turned (around)', kətbat 'she wrote', šubgat 'she hugged'. ${ }^{9}$ The rural/Sarab form, according to informants, is nowadays rather typical of north-western towns and villages, like Xafağiyye (Sūsangerd) or Ḥuwayza. ${ }^{10}$

\section{b) Msc. sg. imperative of weak verbs ( $3^{\text {rd }}$ radical w/y)}

Ingham describes the imperative form of final weak verbs which lacks the final vowel, e.g. ?əməš 'go!', ?əhəと̌ 'speak!', as rural and, conversely, the form which shows the final vowel, e.g. Pəmši, ?əhčí, as urban (Ingham 1973: 544 and Ingham 2007: 577). The dialect of Ahwaz uses both variants nowadays. ${ }^{11}$ 


\subsection{Lexical distinctions}

17 The information on the lexical differences, which served as a basis for the following comparison with my Khuzestani/Ahwazi data, is taken from Ingham's list on variant vocabulary items of urban and rural Khuzestan Arabic (Ingham 1973: 538).

a) Certain lexical features typically used in Ahwaz today are of the rural type, as classified by Ingham, e.g. le-ḡäd for 'there'. Its urban variant $h n \bar{a} k$ is not in use in Ahwaz.

b) On the other hand, certain lexical items, for instance taiadda 'to pass on', belong to what Ingham classifies as urban. The rural form would be mərag, which has, so far, appeared only once in my data, in a recording from the outskirts of Ahwaz.

c) Sometimes items from both types are used, which in some cases leads to the coexistence of several forms. For example 'to see' can nowadays in Ahwaz be expressed by the verbs șţba (urban) as well as bāwa or $\{\bar{a} y a n$ (both rural).

d) Finally, in some cases none of the lexemes Ingham mentions are still in use or known anymore, e.g. the word for 'meal' nowadays is neither marag (urban) nor ydām (rural), but Pakəl.

According to these observations, we can assume a recent change of the dialectal mapping or subgrouping in Khuzestan, especially regarding the dialect of Ahwaz, for which we can postulate a levelling of (urban and rural) features. Thus, the dialect of Ahwaz cannot be classified along these dialectal categories anymore. Consequently, it appears necessary to test the usefulness of these categories in other towns or villages outside Ahwaz by analysing further recordings and data from these regions. The reasons for the observed mixture of dialectal features probably lie in the demographic changes that have occurred during recent years due to the Iran-Iraq war and socio-economic reasons such as job opportunities and better access to educational institutions in bigger towns, especially in Ahwaz.

\section{Discourse particle ča}

19 Finally, I will give a brief preliminary outline of the main features and usage of the discourse particle $\check{c} a$, illustrated by some examples taken from my data. A more detailed study on discourse particles in Khuzestan Arabic is planned.

In using the term discourse particle, I follow the definition of Kerstin Fischer, who, with the employment of this term, suggests a focus on "...small, uninflected words that are only loosely integrated into the sentence structure, if at all. The term particle is used in contrast to clitics, full words, and bound morphemes. Using the term discourse particle furthermore distinguishes discourse particles/markers from larger entities, such as phrasal idioms, that fulfil similar functions." (Fischer 2006: 4).

21 Regarding the frequently used Khuzestan Arabic discourse particle $\check{c} a,{ }^{12}$ there are so far no in-depth studies of it or any other comparable particles in Khuzestan Arabic and its discussion has mainly been limited to footnotes. Ingham, for instance, states that " $\check{c} a$, wilak, wilič, wilkum, wilčan... are Mesopotamian and have no equivalent in Arabian dialects" and defines these particles as "expletives" (Ingham 1982: 87). In a later article however, $\check{c} a$ or $\check{c} \bar{e}^{13}$ are referred to as characteristic for Marshland dialects (Ingham 2000: 128), a description which is too reductive, as I will demonstrate below. In a recent paper 
Qasim Hassan mentions the particle ča in his list on South Iraqi modal particles (Hassan 2016: 47, 53).

22 As to the question of the origin of $\check{c} a$, there is still no clear answer. However, there are several indicators that point to a possible origin rooted in the deictic particle or element $/ \mathrm{k} /$. The following indicators appear to support this hypothesis:

1) The discourse particle $\check{c} a$ could be related to the presentatives used in the Gulf region, e.g. ka in Bahrain, as in "ka-hiyya yāya "here she comes now"' (Holes 2001: 447), which is also known for Kuwait (Johnstone 1967: 92).

2) In many other dialects of Syria and Anatolia, we find presentatives containing the deictic element $/ \mathrm{k} /$ or the deictic particle $/ \mathrm{ka} /$, e.g. $k w a / k o ̄ / k e \overline{~ i n ~ N-M e s o p o t a m i a / ~}$ Anatolia (Procházka forthcoming: chapter 4).

3) We might even connect $\check{c} a$ and its origins to the (origins of the) Mesopotamian existential particle ?aku 'there is', with its negative form māku 'there is not', which might be related to the Aramaic deictic indicator k' (Müller-Kessler 2003: 643, 645). ${ }^{14}$

\subsection{Functions}

The primary functions that the discourse particle $\check{c} a$ can fulfil in sentences or utterances are the following: focus, attention, emphasis, astonishment (often in questions), urgency (cf. Ingham 1973: 550, fn. 38), affection, discontent (negative response to a question), objection, and deixis (with $\check{c} a$ in this case being translated to 'look, lo and behold'). It can express attitudes, feelings and evaluations (see e.g. example (4) below). It can also be used for explanation, justification or support for a position (Aijmer 2002: 36).

\subsection{Linguistic features of ča}

24 a) As with all discourse particles, it is often difficult to find an accurate translation, since every language has its very own discourse particles and clear equivalences across languages rarely exist (Aijmer 2002: 1).

b) ča is not always optional or propositionally empty, since without it sentences can bear a different meaning, as in the example (4) given below. ${ }^{15}$

c) Its usage is limited to oral speech and dialogues ${ }^{16}$ and is characteristic of informal conversation (Aijmer 2002: 33).

d) It is often - but as example (9) shows not exclusively ${ }^{17}$ - used in sentence or utterance initial position, which is why we should rather describe it as sentence or utterance peripheral (Aijmer 2002: 18). ${ }^{18}$

e) Like many discourse particles, $\check{c} a$ itself holds no meaning, but can rather fulfil several functions (Aijmer 2002: 22), which can change according to the desired communication purpose (consider the functions listed above and in the examples below). Thus, it is polyfunctional ${ }^{19}$ and can obtain many different nuances of meaning according to its context.

\section{Examples:}

(3) gāl-la xōš, gāl-le ča āne anse!

'He said alright, (and) he told him, but see, I (always) forget!'

(Informant: Umm SaSad, 40 years, Ahwaz)

The function of ča in example (3) is to put a stress on the explanation (as to why the speaker always forgets to convey the bird's message to his mother), as in 'I really 
always forget it'. Without ča, the sentence would simply mean 'I forget' and thus cause it to express an attenuated meaning.

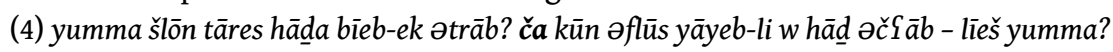
'My beloved, how come you have filled up your pocket with earth? You should rather bring me money, and these bones - why, my dear?'

(Informant: Umm Sa Iad, 40 years, Ahwaz)

In example (4), $\check{c} a$ is apparently used to express the mother's astonishment but also her affection ${ }^{20}$ towards her son, since without $\check{c} a$ the sentence would be a stronger imperative.

(5) xayye taSāli, ča mšēna yā mōze! - xayye žāye ča āne hā hăa ${ }^{21}$ arīd ažỉi ${ }^{22}$ əl-manžal.

'Sister, come here, we are already leaving, Mōze! - Sister, I'm coming, I just want to quickly get the sickle.'

(Informant: Hağǧiyyet Mōze, 60 years, Huwayza)

In example (5), $\check{c} a$ is used to stress the urgency of the situation.

(6) yumma ča dīč əd-digge w hāy d-digge, hāy dāgge w hāy dāgg(e) - āne ham sawwal-li!

'My dear, look at this tattoo and that tattoo, this tattooed woman and that one (please) also make me one!'

(Informant: elderly woman, Hamidiyye)

Example (6) is a clear example for a deictic usage of $\check{c}$.

Examples (7), (8) and (9) are created by an informant in Vienna, Majed Naseri, who is originally from Ahwaz:

(7) ča lēš mā tgəlī-li? arğū-č!

'Why don't you tell me? I urge you!'

Function: Stress on plea, astonishment.

(8) ...ča lā tənsīn!

'But don't forget (I urge you)!'

Function: Focus, emphasis, raising the importance of the utterance/imperative.

(9) əš Yandi, ġēr ? əmyēmt-i ča!?

'What do I have but my mother!?'

Function: Affection, attention. This example shows that the particle is not exclusively sentence-initial.

\section{Conclusions and outlook}

As for the grammar of Khuzestan Arabic, many aspects have not undergone significant changes since Ingham's description, which is probably due to its position as a linguistic enclave in a Persian-speaking society with almost no access to Modern Standard Arabic. Changes that have been noticed so far mainly concern Ingham's division into urban and rural (or hadar and Sarab) dialects, which has lost some of its accuracy, especially for the dialect of Ahwaz. In Ahwaz, there has apparently occurred an interregional mixing of dialects, most probably as a consequence of migration movements.

As to the discourse particle ča, we can state that today it is not only characteristic for the Marshland dialects, but of more or less the whole region (though less common in southern towns, such as Fellahiyye), and it is certainly used frequently in Ahwaz and its surroundings, e.g. Xafağiyye and Ḥuwayza.

My dissertation finally shall help to develop a dialect map of the region and to provide a detailed picture of the current distribution of - especially syntactic and morphological features within the dialects of Khuzestan. 


\section{BIBLIOGRAPHY}

Aijmer, Karin. 2002. English Discourse Particles: Evidence from a Corpus. Amsterdam: Benjamins.

Alshamari, Murdhy R. 2015. "A Relevance-Theoretical Account of Three Discourse Markers in North Hail Arabic", Studies in Literature and Language 11, No. 1. 6-15.

Fischer, Kerstin. 2006. "Towards an Understanding of the Spectrum of Approaches to Discourse Particles: Introduction to the Volume”, Fischer, Kerstin (ed.), Approaches to Discourse Particles. Amsterdam: Elsevier. 1-20.

Fleisch, Henri. 1961. Traité de philologie arabe: Préliminaires, Phonétique, Morphologie Nominale, Vol I. Beyrouth: Imprimerie Catholique.

Fraser, Bruce. 2006. “Towards a Theory of Discourse Markers”, Fischer, Kerstin (ed.), Approaches to Discourse Particles. Amsterdam: Elsevier. 189-217.

Hassan, Qasim. 2016. "The Grammaticalization of the Modal Particles in South Iraqi Arabic", Romano-Arabica XVI. 45-55.

Holes, Clive. 2001. Dialect, Culture, and Society in Eastern Arabia. I: Glossary. Leiden: Brill.

Holes, Clive. 2016. Dialect, Culture, and Society in Eastern Arabia. III: Phonology, Morphology, Syntax, Style. Leiden: Brill.

Ingham, Bruce. 1973. "Urban and Rural Arabic in Khūzistān", Bulletin of the School of Oriental and African Studies 36 (3). 533-55.

Ingham, Bruce. 1982. North East Arabian Dialects. London: Kegan Paul.

Ingham, Bruce. 2000. “The Dialect of the Micdān or 'Marsh Arabs”, Mifsud, Manwel (ed.), Proceedings of the Third International Conference of AIDA: Association Internationale de Dialectologie Arabe. Malta. 125- 130.

Ingham, Bruce. 2007. "Khuzestan Arabic”, Versteegh, Kees (ed.), Encyclopedia of Arabic Language and Linguistics, Vol. 2. Brill: Leiden. 571-578.

Johnstone, T. M. 1967. Eastern Arabian Dialect Studies. London: Oxford University Press.

Masliya, Sadok. 1997. “The Diminutive in Spoken Iraqi Arabic”, Zeitschrift für Arabische Linguistik 33. 68-88.

Matras, Yaron, \& Shabibi, Maryam. 2007. "Grammatical borrowing in Khuzistani Arabic", Matras, Yaron, \& Sakel, Jeanette (eds.), Grammatical Borrowing in Cross-linguistic Perspective. Berlin, New York: Mouton de Gruyter. 134-149.

Müller-Kessler, Christa. 2003. “Aramaic ' $k$ ', lyk' and Iraqi Arabic 'aku, māku: The Mesopotamian particles of existence", Journal of the American Oriental Society 123. 641-646.

Procházka, Stephan. Forthcoming. "Presentatives in Syrian and Lebanese Arabic".

Retsö, Jan. 2005. "The Number-Gender-Mood Markers of the Prefix Conjugation in Arabic Dialects. A Preliminary Consideration”, Edzard, Lutz, \& Retsö, Jan (eds.), Current Issues in the Analysis of Semitic Grammar and Lexicon: Oslo-Göteborg Cooperation 3rd - 5th June 2004. Wiesbaden: Harrassowitz. 31-40. 
Shabibi, Maryam. 2006. Contact-induced Grammatical Changes in Khuzestani Arabic. Unpublished PhD dissertation, University of Manchester.

Shachmon, Ori. 2015. "Agglutinated Verb Forms in the Northern Province of Yemen”, Edzard, Lutz (ed.), Arabic and Semitic Linguistics Contextualized: A Festschrift for Jan Retsö. 260-273.

\section{NOTES}

1. http://www.citypopulation.de/php/iran-khuzestan.php [access 23.08.17]. To my knowledge there are no reliable sources for the exact number of Arab people living in Iran.

2. For the distribution of the Arab population in the province Khuzestan see the map provided by CNRS: http://www.irancarto.cnrs.fr/record.php?q=AR-040537\&f=local\&l=en [access 23.08.17].

3. Contrast e.g. gahwa in Ahwaz and not ghawa, which would be the common form in, for example, Huwayza, according to my informant.

4. E.g. bazzūna 'cat', xōš 'good' or the existential particle Paku 'there is' (Ingham 1973: 546). SouthMesopotamian lexical features are e.g. farax 'child', dahruyye 'egg', rōba 'yoghurt', kad d 'to grasp', harfi 'early', hadər 'under', tāna 'to await' (Ingham 1973: 547).

5. The form $\mathrm{fad}$, as Ingham transcribes the indefinite article in the EALL (Ingham 2007: 575), never appeared in my data.

6. Similarly, Ori Shachmon also notes for the Jewish dialects of northern Yemen that $2^{\text {nd }}$ ps. pronouns are suffixed to verbs, e.g. katabtant, probably for the disambiguation of $1^{\text {st }}$ and $2^{\text {nd }} p s$. sg. perfect forms (Shachmon 2015: 261).

7. The diminutive suffix - ūn may be of Aramaic origin and is for example also found in Bahrain, in all Baghdadi dialects, in Kuwait, Oman and Lebanon (Holes 2016: 127, fn. 54; Masliyah 1997: 72 and Fleisch 1961: 454, fn.2).

8. Diminutive of bargaš 'small insect, midge'.

9. A rural feature in verbal forms that is still found in Ahwaz is the form $\mathrm{CaCaC}$ in the contiguity of gutturals, e.g. $x a \underline{d} a$, not $x \partial \underline{d} a$, la $\{a b$, not lə $\{a b$, etc. (Ingham 1973: 539-540).

10. More transcribed material on these towns will follow in future articles.

11. See also Jan Retsö, who states that the forms of the imperatives of IIIw/y without a final vowel in the msc. forms are further found in the North Yemen Highlands, the southern SAsir, Central Arabia, the Syrian desert, the Negev, and Eastern Arabia (Retsö 2005: 33).

12. Its usage is even considered one of the hallmarks of the more northern Khuzestan Arabic dialects by speakers themselves, who contrasted it to other towns' dialects, e.g. that of Fellahiyye

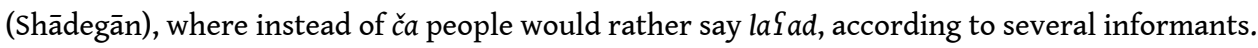

13. There is no evidence for this form in my data.

14. There is still no common opinion about the origin of this Mesopotamian existential particle, but Müller-Kessler traces it back to the (central and southeastern Babylonian) Aramaic particle of existence ' $y t$ 'there is' (and lyt 'there is not'), which was, according to her, augmented by the Aramaic deictic element $k$ ', with assimilation of $k$ ' to the final consonant $t$ of the particle of existence 'yt (Müller-Kessler 2003: 643, 645). Diem however, suggests that a possible origin for ? aku may be the combination of the deictic element $/ \mathrm{k} /$ with the $3^{\text {rd }}$ ps. sg. msc. pronoun (Müller-Kessler 2003: 644). Holes suggests that its origin lies in the Akkadian common verb and noun makū, meaning 'want, lack, need; to be absent, missing', with aku being a later reanalysis of $m \bar{a} k u$ as $m \bar{a}+a k u$ (Holes 2016: 17).

15. Cf. Fraser and Alshamari, who also do not support the theory that discourse particles are necessarily optional but state that they can also be obligatory in some cases (Fraser 2006: 195; Alshamari 2015: 13).

16. Cf. Aijmer (2002: 34), who also mentions discourse particles appearing in monologues. 
17. Ingham describes it as a particle appearing in sentence initial position (Ingham 1973: 550, fn. 38; Ingham 2000: 128).

18. Aijmer describes elements in sentence initial position as: "cognitively salient, i.e. hearers listen for them in conversation and use them as help to interpretation" (Aijmer 2002: 15).

19. Cf. Fischer (2006: 12) on the polyfunctionality of discourse particles.

20. Cf. Aijmer, who states that "discourse particles...have high scores on the dimensions of involvement and affect" (Aijmer 2002: 33).

21. The interjection $h \bar{a} h \bar{a}$ means in this utterance 'quickly'.

22. Note the usage of /ž/ as a reflex of /ğ/, typical for the Marshland dialects, instead of /y/ which is the common pronunciation for the rest of the area.

\section{ABSTRACTS}

The dialect of the southwestern Iranian province Khuzestan belongs to the gələt-subgroup of Mesopotamian Arabic. It also shows great affinity to other northeast-Arabian dialects such as the Arabic dialects of Bahrain - of the SAnaza type - or Najdi Arabic. The province's vernacular language has been given little attention in the field of Arabic dialectology so far. Khuzestan Arabic is an Arabic enclave in a predominantly Persian-speaking environment. As such, it shows signs of stronger influence by Persian, the language of education and work, than by Modern Standard Arabic. For the same reason, this peripheral Arabic dialect also shows some interesting conservative features. The first part of this paper will present data collected in September 2016 during fieldwork in Khuzestan and compare it with the results of Bruce Ingham's seminal studies on Khuzestan Arabic published in the 1970s. Furthermore, this paper will present a short discussion of the discourse particle $\check{c} a$, a topic, which has hitherto attracted the attention of Arabic dialectologists only marginally. The analysis of the particle will concentrate mainly on its syntactic and semantic characteristics.

INDEX

Keywords: gələt dialects; Khuzestan-Arabic; discourse particles; language contact; Arabic as a minority language.

\section{AUTHOR}

\section{BETTINA LEITNER}

Institute of Oriental Studies - Vienna 


\section{B(i)- / fi comme marqueur de l'objet dans les dialectes arabes. Premières considérations}

Jérôme Lentin

\section{NOTE DE L'AUTEUR}

J'adresse mes chaleureux remerciements à Nadia Comolli et Marie-Aimée Germanos pour leur précieuse relecture, et pour m'avoir généreusement fourni, comme Dominique Caubet et Catherine Taine-Cheikh, exemples et références, à Manel Boubaya qui a bien voulu me laisser consulter son corpus tunisien de Ghomrassen (région de Tatouine), ainsi qu'à Margherita Pallottino et Veronika Ritt-Benmimoun, qui m'ont aimablement envoyé leurs articles sous presse.

\section{Présentation}

1 On sait qu'il existe, dans la plupart des dialectes arabes, parallèlement à la construction directe, une construction où la relation entre un verbe transitif et son objet direct est rendue manifeste par une préposition (la plus fréquente étant fi). ${ }^{1} \mathrm{Ce}$ 'marquage différentiel de l'objet'2 est souvent signalé dans les descriptions, mais les caractérisations de sa valeur distinctive y sont en général assez rapides, et diverses, sinon contradictoires. Il est vrai que les situations sont contrastées suivant les dialectes. À la $6^{\mathrm{e}}$ conférence de l'AIDA, M. Woidich ${ }^{3}$ avait présenté une première étude pour l'égyptien, qu'il qualifiait luimême de 'preliminary and preparatory stage' d'une longue recherche encore à mener. Depuis, plusieurs études, portant principalement sur des dialectes tunisiens ${ }^{4}$ et libyens ${ }^{5}$ ont confirmé la complexité du problème, et la nécessité d'étendre l'enquête à l'ensemble des dialectes. Si la présente contribution ne peut avoir cette ambition, elle se propose de dresser un premier état des lieux ( $\$ \S 3$ et 4$)^{6}$ et tente, tout en faisant ressortir la grande diversité des paramètres d'emploi de la construction avec fi, d'en présenter une 
caractérisation relativement générale ( $\$ 6$ ). Auparavant est posée la question de savoir s’il est justifié de voir l'origine de la construction dialectale avec fi dans celle avec bi- de l'arabe ancien et du moyen arabe, d'autant que dans plusieurs dialectes contemporains, certes moins nombreux, c'est cette construction avec b(i)- qui est attestée ${ }^{7}(\$ 2$.$) .$

\section{Le problème bi- / fi}

\subsection{Arabe ancien}

Des exemples sont attestés dès les stades anciens de l'arabe. ${ }^{8}$ Les auteurs classiques reprennent souvent les mêmes (ainsi ceux d'Ibn Qutayba (m. 889) dans son 'Adab al-kätib ou dans son Ta'wïl muškil al-Qur'ān, repris, parmi beaucoup d'autres, par Ibn Sīdah (m. 1066) dans al-MuHașsas fì al-luga). ${ }^{9}$ Citons, pour les exemples coraniques: (Coran) 96,1 'iqra' bi-smi rabbika 'Proclame le nom de ton Seigneur' ${ }^{10}$; 23,20 tunbitu bi-duhnin '(qui) produit de l'huile'; 60,25 wa huzzi 'ilayki bi-ğuz'i l-naHlati 'Secoue vers toi le stipe du palmier'; et, pour des exemples poétiques anciens: Imru'u l-Qays (m. 565) hașartu bigușnin 'j’ai incliné vers moi une branche'; Al-Rā̄ī (m. 714/715) lā yaqra’na bi-l-suwari 'elles ne récitent pas les sourates' ; 'Umayya b. 'Abī al-Ṣalț (m. 630) 'id yusaffüna bi-l-daqiqqi 'on les nourrissait de farine'; Al-Nābigiga al-Ǧa 'dī (m. 670) nadribu bi-l-sayfi wa-narğū bi-l-farağ 'nous frappons de nos sabres en espérant la délivrance'.

Les grammairiens parlent de $b \vec{a}^{\prime}$ al-ta' diya, $b \bar{a}^{\prime}$ 'de transitivité', auquel ils ne semblent pas accorder de valeur (sémantique ou stylistique) très particulière. Ainsi Ibn Ğinnī, dans le Sirr șinā'at al-'I'rāab: 'innamā ğìa bihā tawkīdan li-l-kalām wa lam tuhdit ma'nan ('on l'emploie pour renforcer l'énoncé sans qu'elle apporte de modification sémantique'). Parfois des remarques vont dans le même sens, e.g. Ibn Sayyid al-Bațliyūsī (m. 1127) dans le Kitāb al-iqtidāb fi šarh 'adab al-kuttāb, ${ }^{11}$ à propos de l'exemple cité wa-narğū bi-l-farağ, explique que le $b \bar{a}$ ' est ajouté car rağa $\bar{a}^{\prime}$ 'désir' signifie ici țam 'désir ardent' (et que țami' $a$ se construit avec bi-).

Reckendorf 1895-1898 : 244 donne quelques autres exemples : kasar bi-qalbī 'il m’a brisé le cœur' ; 'in kāna l-maliku yurīdu bi-hād 'awfā llāhu bika (al-BuHāāī, m. 870) 'tu as rempli tous tes engagements envers moi, puisse Dieu faire de même envers toi' ; šawwahtum bì (Hamāsa de 'Abū Tammām m. 845.) 'vous m'avez défiguré', et décrit ainsi l'effet induit par l'emploi de bi-: “l'objet affecté par l'action est perçu comme ce dans, ou par quoi, cette action devient manifeste". ${ }^{12}$

\subsection{Moyen arabe}

5 C'est également la construction avec bi- qui est attestée dans les textes anciens étudiés par J. Blau, chrétiens (Blau $1967: 411$, § 301.2. et n. 8) : wada'a bi-yadihi 'il posa sa main' (trad. de l'Évangile de Matthieu, ms du 9e s); li-rağākum bi-wahy rabb-nā 'parce que vous espérez la révélation de notre Seigneur' (vers 900); wa bi-l-rubūbiyya ${ }^{13}$ yazdarūn 'et ils méprisent le gouvernement' ( $9^{\mathrm{e}} \mathrm{s}$.), ou juifs (Blau 1965 : 81) yut bitū bi-l-'ațab 'ils prouveront le naufrage' (Maïmonide, m. 1204, Responsa).

On ne saurait déduire du nombre relativement réduit de ces exemples le déclin de cette construction. Il faut bien plutôt considérer que nous manquons encore dramatiquement 
d'études et de dépouillements de textes en moyen arabe, pour cette époque comme pour les suivantes.

7 Pour des périodes plus récentes, on trouve par exemple dans des manuscrits chrétiens ya'nī bi-mawlidihi min al-'ab qabla kull al-duhūr (ms du $14^{\mathrm{e}} \mathrm{s}$.) 'il voulait signifier: sa naissance, du Père, de toute éternité', ou hattā yašă l-'ilāh bi-naqlihi 'ilā l-firdaws (ms de 1606) 'jusqu'à ce que Dieu veuille le transporter au Paradis' (González Casado $2000: 128$, avec d'autres exemples). V. aussi les exemples des 1001 nuits (by', ksr) cités par MarçaisGuîga 1958-1961: 3081.

Dans un corpus de textes datant de 1600 à 1860 (Syrie, Liban et Palestine) les exemples des deux constructions sont nombreux (Lentin 1997 : 292-294, § 6.13.2.). On remarque que celle avec fi y est plus fréquente que celle avec bi-, même s'il faut tenir compte du fait que lorsque fi est suivi d'un pronom personnel suffixe, il peut s'agir d'une influence dialectale, puisque les dialectes des scripteurs appartiennent en majorité à ceux où, dans ce cas, bi$\rightarrow$ fi. $^{14}$ Quelques exemples ${ }^{15}$ :

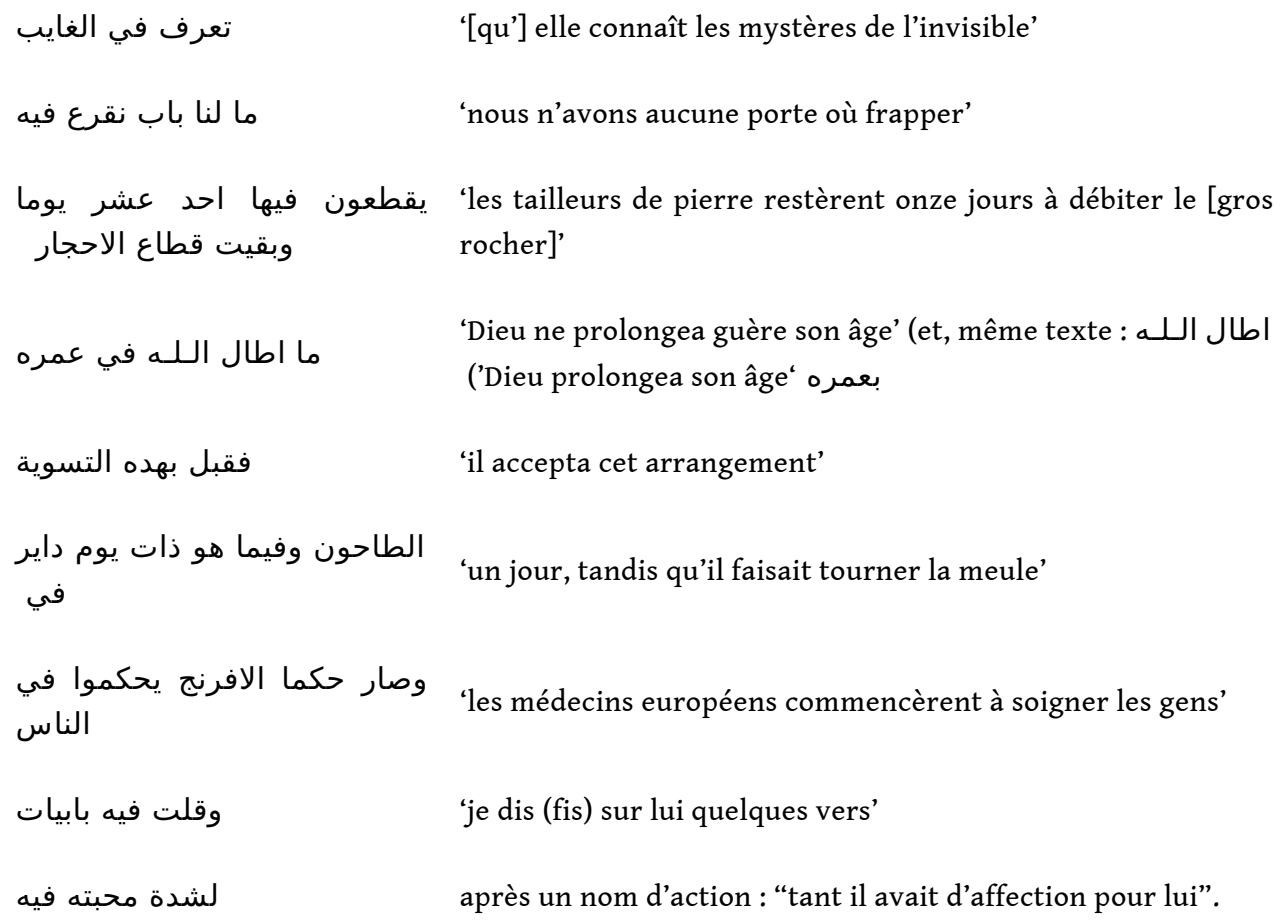

Plusieurs de ces exemples semblent liés à l'aspect verbal (dans une ğumla hăliyya ou avec des verbes précédés d'auxiliaires du type 'rester à', 'continuer à') ou au mode d'action ( Aktionsart), e.g. șirt 'aqtul fih 'je me mis à le rouer de coups'. Le plus souvent cependant, la construction met en relief (plus que l'autre MDO لى/J) l'engagement du sujet dans le procès et son adhésion à celui-ci, ou sur le fait que l'objet en est affecté (noter la diversité des verbes concernés : de cognition ('rf), de 'sentiment' ( $q b l$, ḥbb), d'action affectant l'objet, péniblement (drrb, qtl), ou non (tb', msk)).

10 On notera aussi par ailleurs que la construction n'est pas rare avec des verbes à l'accompli ( $4^{\mathrm{e}}, 6^{\mathrm{e}}$ et $9^{\mathrm{e}}$ exemples ci-dessus).

11 N.B. Les textes en moyen arabe maghrébin sont encore complètement inexploités. On notera simplement que, pour la même époque tardive, on observe également l'emploi de 
fi. Exemples marocains (vers 1737) : وله مدة طويلة يعمر فيه 'on travaille à sa construction

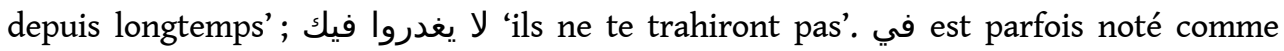
enclitique :

انه يبعث فجوبت [= في جوابات] مع واحد :

'qu'il enverrait des réponses avec quelqu'un' (exemple libyen, 1844). ${ }^{16}$

\subsection{De bi- à $f i$}

12 Si on admet l'hypothèse vraisemblable que, dans la construction avec bi-, c'est la valeur locative de cette préposition qui est en jeu, ${ }^{17}$ on ne peut s'étonner qu'en moyen arabe, et dans de nombreux dialectes, fi ait largement supplanté bi- (d'autant que, dans la langue classique, cette tendance était déjà à l'œuvre ${ }^{18} \mathrm{ni}$, inversement, que dans les dialectes ou fi est absent, la construction avec bi- se soit maintenue.

On ajoutera que la tendance, bien représentée en moyen arabe, oriental au moins, de construire avec $f i$ des verbes qui ont en classique et/ou en dialectal un régime avec $b(i)$ (e.g. استعان في 'se réjouir de', فرح في 'demander le secours de qqn'), pour souligner le rôle actif du sujet dans le procès, ou le fait que l'objet en est affecté, ${ }^{19} \mathrm{a}$ probablement joué un rôle d'adjuvant, sinon de modèle, au passage de bi- à fi pour les verbes originellement directement transitifs.

\section{Dialectes orientaux}

\subsection{Golfe}

14 fi est employé avec une large variété de verbes et 'apporte généralement un sens extensif [e.g. akal fi 'manger ou grignoter constamment ; éroder', aHad fi 'prélever constamment'] ou intensif [e.g. țăh $f i$ et darab $f i$ 'rouer de coups', Hallas $f i$ 'achever, terminer complètement']' (Holes 2015 : 321-323). Tous les exemples donnés sont à l'inaccompli, sauf un au participe actif : 'ād inta tạyih fini halayūs 'tu vas me donner une sacrée raclée'.

\subsection{Irak (où bi- a complètement évincé fi) ${ }^{20}$}

15 'āni ma-aṣaddig bihum il-han-nās 'Moi, je ne les crois pas, ces gens-là' (Erwin 1963 : 333). Exemple trouvé sur youtube : تتعرى و ترقص داخل السيارة و حبيبها يسوق و يصور فيها 'elle ' enlève son voile et danse dans la voiture tandis que son petit ami la filme en conduisant'.

\subsection{Syrie : dialecte de Damas}

Les constructions avec $b$ - des verbes par ailleurs transitifs directs semblent parfois équivalentes (et jugées stylistiquement supérieures par certains locuteurs) : 'Allla yțawwel $b$-'omrak 'que Dieu te prête longue vie'; byəmdah fik 'il chante tes louanges' (mais seulement byəmdah bi-'aHlä'ak 'il loue tes qualités morales'). Mais les deux types d'énoncés sont en réalité rarement strictement équivalents. L'emploi de $b$-indique en général que l'action du verbe est considérée de façon plus circonstanciée, en référence à une situation particulière, et à l'implication de l'agent; il peut de ce fait indiquer aussi itérativité ou intensivité. $m a$ 'ab lto (accompli) 'elle n'a pas voulu de lui (comme mari)', ${ }^{21}$ simple rapport sur ou constatation de ce qui s'est passé vs. $m a$ 'ablet $f i$ ' $d{ }^{\circ}$ (car il y a des 
choses précises qui ne lui ont pas plu)' ; u n-nihāye mu hēk, mġayyrīn fiha (participe actif) 'la fin n'est pas comme ça [dans le roman] ; [dans le film] ils y ont apporté des modifications' vs. mġayyrīna 'ils l'ont complètement changée'. Le fait que la présence de $b$ - soit souvent associée à celle de 'am ou de l'auxiliaire șār montre qu'elle est passible d'une analyse en termes d'aspect et de mode : 'am yo'tel b-hāalo (à côté de 'am yo'tel hạ̄lo) 'il se tue (au travail etc.)' avec la connotation que c'est continu et permanent ; șāru y'ālžu fi 'ils se mirent à le soigner' (Salamé/Lentin 2010 : 8-9). žz-žǎže 'am tabhat ol-'arḍ 'la poule gratte le sol' vs. 'am yabhat bo l-kis 'il farfouille dans le sac' (id. : 49). Dans d'autres cas, l'emploi de b-permet d'indiquer un rapport plus concret avec l'objet du verbe, ainsi désigné plus précisément : ballaš ə̌̌s-šog ’l 'il a commencé son travail, il a (re)pris le travail, il a commencé à travailler' vs. ballaš bəš-šag’l 'il a commencé le travail (concret) qu'il a à faire' (id. : 199-200).

\subsection{Liban}

nezel 'an dahr el-faras u-'eHुed išedd fi hamlt el-hatab ta yeqleba 'il descendit de cheval et entreprit de tirer la charge de bois pour la retourner' (Feghali 1976:67,17-18). Dans cet exemple, on note l'emploi de fi alors que, dans le suivant, ${ }^{22}$ on a be- devant un nom d'action : qwä̈m dabbert f'äle w-ballešt be-'mār es-sekr u-dellayt 'ammer fih men yawm el-Hmis lyawm el-'arb'a be-ž-žem'a $t$-tänye [...] 'āwedna stekrayna f'äle täni marra u-'ammernähh men rada wē-ždìd [...] ta yhâsseb el-f'äle we-l-m'allemûn elli 'ammeru l-hâra l-raffâl [...] u-qelt-ellu le-lHûre ta y'ammer es-sekr mațrah ma 'aHettu ț-tawfe 'je fis aussitôt venir des ouvriers et commençai à rebâtir ce bief, y travaillant [sans relâche] du jeudi au mercredi suivant [...] nous engageâmes à nouveau des ouvriers et nous le rebâtîmes à neuf [...] en le chargeant de payer les ouvriers et les maîtres maçons qui avaient construit la maison de Raffoul [...] Je chargeai le curé de faire restaurer le bief là où il avait été pris par l'inondation' (Feghali 1977 : 58,12-14, 19-20, 24-26). On remarquera l'auxiliaire dans dellayt 'ammer fih, l'ensemble étant suivi de la mention explicite de la durée de l'opération. Pour ce type d'exemple, on peut donc ajouter aux valeurs données ci-dessus pour Damas celle de durativité.

(Dialogue) ${ }^{23}$ : - A : fatah hä-l-yawmèn 'abbū '[le supermarché] a ouvert ces deux jours, ils l'ont rempli [de produits]); - B : mən žəm'a bälläšo y'abbo fi ‘[en fait] ça fait une semaine qu'ils ont commencé à le remplir'.

lik yoHrib bäytik la ba'a tlazz'e fiya 'Mais enfin! Arrête de lui [la statue cassée] recoller [des morceaux] !' (dialogue du film U halla' la-wēn / Et maintenant, on va où ? de Nadine Labaki, 2011).

Exemple d'un dialogue de roman contemporain : رؤوف بيحبّك بيحمد فيكِ 'Ra'ūf t'aime et ne tarit pas d'éloges sur toi' (Ṣubḥ $2006: 192)$.

\subsection{Palestine}

Dans les contes de Bīr Zēt recueillis par Schmidt \& Kahle (1918 = I, 1930 = II), et dont la syntaxe a été faite par J. Blau, on trouve majoritairement, à côté de quelques exemples de b- (Allāh yičsir b-Hātrak 'que Dieu ne te vienne pas en aide' II, 154,14), des exemples de fi : I 224,-4/-3 ka'dat tiğli fiha 'elle se mit à la frotter'; 230,1 u ka'ad yišwi fih u yốcil 'il se mit à le rôtir puis à [le] manger'; 232, 9-10 kā' 'id yišrab fi han-nafas 'en train de fumer un narguilé' ; II, 4,12 u dār yikța' fi hal-hatatab 'il se mit à couper du bois' et II, 4,15 bakațti fi hațab 'je 
coupe du bois'(vs. II, 4,10 biddi arûh akța' hațab 'je vais aller couper du bois' et 6,11 uhū bikațti' hatabab fil-hiš 'tout en coupant du bois dans la forêt').

$B l a u^{24}$ écrit que "Après des inaccomplis itératifs-duratifs, on peut avoir fi avant l'objet direct ; autrement dit, si on compare à l'arabe standard, fi sert d'exposant de l'accusatif", ce qui rend en effet compte de beaucoup d'exemples, mais pas de tous. Il faut en outre noter que la construction avec fi peut se trouver aussi après des accomplis. Ainsi pour le verbe dakk: si on trouve bien sûr des inaccomplis, comme I, 34 (\$ 4, 5-6) kabil-ma hada $y$ dukk fi t-tabïH 'avant que quiconque ait touché au plat', la construction avec des accomplis n'est pas rare : I 122, $-5 /-4(\S 24,4 / 5) u$ hâda hâda illi dakku fiye 'et ceux-là sont ceux qui m’ont poursuivie de leurs assiduités'; I, 148, 10 (§ 7,5) u dakk fi čabč X 'et il attrapa le bouc de X'.

Linder/Ringgren 1952 : p. $28 \mathrm{n}^{\circ} 43$ vers 1 : eḥlimt inni bahammus fi binn 'Je rêvai que j'étais en train de griller du café'.

\subsection{Jordanie}

C'est, sauf erreur, T.-F. Mitchell qui fut le premier à consacrer plus de quelques lignes à la question du MDO, d'abord en jordanien (Mitchell 1978: 237-241) puis au Levant et en Égypte (Mitchell \& El-Ḥassan 1994 : 92-95, 98-99).

Entre autres observations intéressantes, il remarque qu'en jordanien, des énoncés comme qara't il-kitāb 'j'ai lu le livre' ou katabt ir-risāle 'j'ai écrit la lettre' ne peuvent se combiner avec un circonstant du type 'iddit sā' āt 'pendant des heures', que si on ajoute fi (qara't fi-lkitāb 'iddit să $\bar{a} t)$, contrairement à ce qui se passe avec des énoncés comportant des verbes de mouvement (suqt is-sayyāra 'j'ai conduit la voiture') ou de perception (smi't iṣ-șōt 'j'ai entendu le bruit').

Il montre par ailleurs qu'en Jordanie le 'marqueur de l'aspect progressif' bi/fi (bi'ra bi-lžarìde 'je suis en train de lire le journal', Égypte huwwa 'ā'id yiktib fi g-gawāb 'il est en terrain d'écrire la lettre', Syrie ' 'á'id byi'ra bi-l-žarìde 'il est en train de lire le journal') a des emplois et des valeurs parfois différentes de ceux de dialectes voisins: si, par opposition à byilbas il-badle (futur ou habituel : 'il va mettre / porte habituellement un costume'), 'ammāl byilbas bi-l-badle 'il est en train de mettre le/son costume' est un progressif (= Égypte 'ammāl byilbis (fi) l-badla), on aura par exemple en égyptien byilbis (fi) l-badla (habituel), et même byilbis fi l-badla kulli yōm 'il a continué à porter le costume jour après jour' (impossible et tout à fait incompréhensible pour un Jordanien).

\subsection{Negev}

Plusieurs exemples dans les textes recueillis par R. Henkin : lak hawl, waná bastanna fik. 'Hé ! Ça fait un an que je t'attends !' (Henkin 2010 : 197), wbitgūm ițhabbib fih 'et elle se mit à l'embrasser' (242), șāraw 'ysūguw fih. lamman sāgaw (accompli) fih 'Ils [les alliés] se mirent à les pousser. Tandis qu'ils les guidaient...' (comparer scēygih lahadd al-maġārah 'et il le ramena jusqu'à la grotte'); wiyjīk 'ysūg fiha mrawwih 'et il la [la jument] ramena à la maison' (248), uhī 'ddugg fih, al-kalbih 'et elle le frappa, la chienne' (328). ${ }^{25}$ 


\section{8. Égypte}

Dans la contribution évoquée plus haut $(\S 1)$, M. Woidich présentait ses premières hypothèses, caractérisant fi comme un 'marker for intensification and prolongation', dont l'usage est "déterminé principalement par l'aspect lexical de l'événement et son interaction avec l'une des fonctions principales de la préposition, le 'focussing'. [...] L'événement doit être télique et en cours ('progressive'). Ces conditions sont remplies par les verbes qui décrivent un accomplissement, fi mettant le focus sur le stage inhérent de la préparation, avant que l'événement soit accompli, ce qui induit l'effet de prolongation et d'intensification [...]. Par ailleurs [...] d'autres types de situations, comme des 'activités' [il renvoie ici à l'exemple kull ma tu' 'udi f-hitta lāzim tištimi fi hadd 'chaque fois que tu te trouves quelque part, il faut que tu insultes quelqu'un' et à un autre avec darab 'frapper']" permettent cet emploi de fi qui 'prolonge' et 'intensifie' le procès (Woidich $2006: 485$ ). ${ }^{26}$

\subsection{Soudan}

Dans leur étude de l'aspect dans l'arabe parlé au centre-nord du Soudan, M. Ahmed Ali \& C. Miller avaient eux aussi traité, en liaison avec la 'concomitance', et particulièrement avec l'auxiliaire $g \bar{a}^{c} i d$, de l'emploi de $f i(1985-86: 180-187)$ et montré que la préposition s'emploie avec deux (des quatre) catégories de verbes qu'ils distinguent: les 'transitifs externes qui expriment une action concrète se produisant sur un objet extérieur' ( $g \bar{a}^{\top} i d$ išrab fi šăy 'il est en train de boire du thé') et ceux comme libis 'mettre' $\rightarrow$ 'porter', masak 'prendre' $\rightarrow$ 'tenir', šăf 'voir' $\rightarrow$ 'connaître', simi ' 'entendre' $\rightarrow$ 'écouter', šamma 'sentir' $\rightarrow$ 'humer' (gā'id ašūf fi t-tilifizyōn 'il est en train de regarder la télévision') - et pas avec les deux autres (verbes d'état, de perception, de jugement, de sensation; de déplacement ou de mouvement). Fì est employé (obligatoirement) pour exprimer la durativité (ou l'itérativité) du procès, et l'implication simultanée de l'agent, et donc la 'concomitance durative' (mais jamais l'habituel).

\section{Dialectes occidentaux}

\subsection{Libye}

Stumme 1898 : 19,16-17 : emši ar'a el-ġnam 'va paître les moutons'; mše ir'a fil-ġnam 'il partit paître les moutons'. 19,19 ar'a l-mä'iz 'ala Huățar elginam tahleb fiha 'va paître [aussi] les chèvres, parce que les brebis tu n'as qu'à les traire'27; $g^{\prime} a d$ yar' $a$ fi-l-m $\bar{a}^{\prime} i z$ 'il se mit à paître les chèvres'.

Panetta 1943 : I, 113,-3 u-lgô-hom mega'mezāt fōg el-kerâsī imaššețō fi-hom 'ils les trouvèrent assises sur les chaises en train de les peigner'. Pour elle, $f_{i}$ “sert à indiquer que l'action exprimée par le verbe est habituelle, intense ou qu'elle se déroule au moment du discours" (II : 253-254). ${ }^{28}$

Owens (1984: 133-135) montre que si, parfois, fi s'emploie sans condition particulière dans les complétives, et "sans effet de sens" : šurēt-l-a sayyāra isūg-ha / fiha 'je lui ai acheté une voiture pour qu'il puisse la conduire', son utilisation est le plus souvent soumise à des restrictions grammaticales et sémantiques. $F i$ 'véhiculant une notion d'immédiateté et d'habitualité (? 'currency') de l'action : Hallih yiğsil f-il-milābis 'qu'il continue à laver les 
vêtements' (vs. Hallih yig̈sil il-miläbis 'qu'il lave les vêtements'), i'allim fiyya f-il-luga l'arabiyya 'il m'apprend l'arabe', il est employé après les verbes qu'il appelle 'd'action concomitante' ('concurrent action'), souvent des verbes de perception, qui ont une complétive, et après gā'id et kān: šăyf-a isakkir f-il-bāb 'je l'ai vu fermer la porte', gā'id yiktib $f$-iž-žuwāb 'il est en train d'écrire la lettre', mais ne peut l'être, par exemple, associé à des adverbes renvoyant au futur

Pour Börjars e.a. (2016), la préposition $f i$ s'est par ailleurs constituée en marqueur d'aspect duratif ('continuous') ou habituel. Elle ne peut s'employer après des formes d'accompli, mais est obligatoire après des verbes 'dynamiques', quand ils renvoient à une action progressive ou habituelle (et non générique ou de 'futur programmé').

\subsection{Tunisie}

C'est probablement en arabe tunisien, au moins dans certains dialectes, que l'emploi de $f_{i}$ est le plus développé. Il a fait depuis peu l'objet d'études fouillées, ${ }^{29}$ mais avait attiré l'attention depuis longtemps (Marçais-Guîga 1958-1961 : 3079-3082). Son importance peut être symbolisée par l'interrogatif fäšs ‘quoi ?', pourtant peu remarqué jusque récemment.

On trouve des exemples dans Stumme 1893 I $^{30}: 51,37$ ( cf. en particulier le passage I 16, 14-17, où contrastent constructions avec et sans fi : $q^{\prime}$ ad fôq ežžëbél idûr, yâkul fi l-ḥ̌šš w-iHámmem fi 'áqlū, qâl āš înrū äna qấad hûnî? w-ihámmem fi 'áqlū iqálla' fi l-hálfa u-yá'mel fä-ḥbél, bā̄s yá'mel sellûm 'Il commença à errer dans la montagne, mangeant de l'herbe et se disant : jusqu'à quand vais-je rester ici? Et il se dit qu'il allait arracher de l'alfa et faire une corde pour fabriquer une échelle'.

Marçais-Guîga 1958-1961 : 3079 évoquent d'abord fi qui introduit le second complément d'objet des verbes causatifs : el-maddab i'arrod loeulad f-al-lwahhum 'le maître d'école fait réciter aux enfants ce qu'ils ont écrit sur leurs planchettes', puis (3080-3082) fi qui introduit le complément d'objet "quand, la durée de l'action étant envisagée, ce qu'il désigne est conçu comme la sphère où se poursuit le procès" : yuṭulbu for-ṛahmoe 'ils imploraient la miséricorde'; maz-zelt thokk fi 'ênêk 'tu en es encore à te frotter les yeux'; imayyil fi rẩṣu 'il dodelinait de la tête en la penchant'. "L'aspect duratif peut résulter de la notion d'une finalité qui commande ou accompagne le développement du procès" : nada bəš-šriâb iqușș fi 'agfoe 'il prit le chemin des terres arrosées pour s'y couper une crosse'. La construction apparaît aussi après des adjectifs verbaux en $\mathrm{C}_{1} \mathrm{C}_{2} \mathrm{C}_{2} \overline{\mathrm{a}} \mathrm{C}_{3}$ : dallêna hașsẩda fa-ššị̂ 'nous avons été occupés à moissonner l'orge' et après des participes actifs : $u$ ma tra $n$ nâs kân məthākmîn f-oHdəmhum 'et vous auriez vu les gens empoisonner à l'envi leur besogne'.

À Tunis juif, fi "peut introduire le complément de certains verbes normalement transitifs. Dans ce cas, il apporte une nuance d'action habituelle, durable ou répétée : kənni nțåll' $u$ fol-flūš mə-l-wäd 'comme si nous puisions (habituellement) l'argent dans la rivière'; itəbb'u fa-l-lamudāa 'ils suivent les (différentes) modes' " (Cohen 1975 : 248-249). Pour Tunis musulman, la construction de l'objet avec fi indiquerait "l'action non achevée" (Singer 1984 : 624), mais les exemples donnés montrent que cette caractérisation est insuffisante :

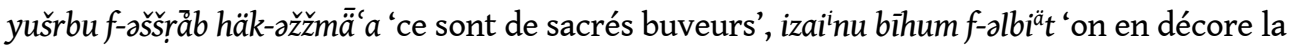
maison' ou, avec un accompli, hall f-əlfniq 'il ouvrit (avec précaution) le coffret à bijoux'.

À Tozeur (Saada $1984: 74): 3$ ex. avec 'allom ; yemsah fi temmo 'il s'essuie la bouche'.

Très nombreux exemples sur internet, e.g. : 


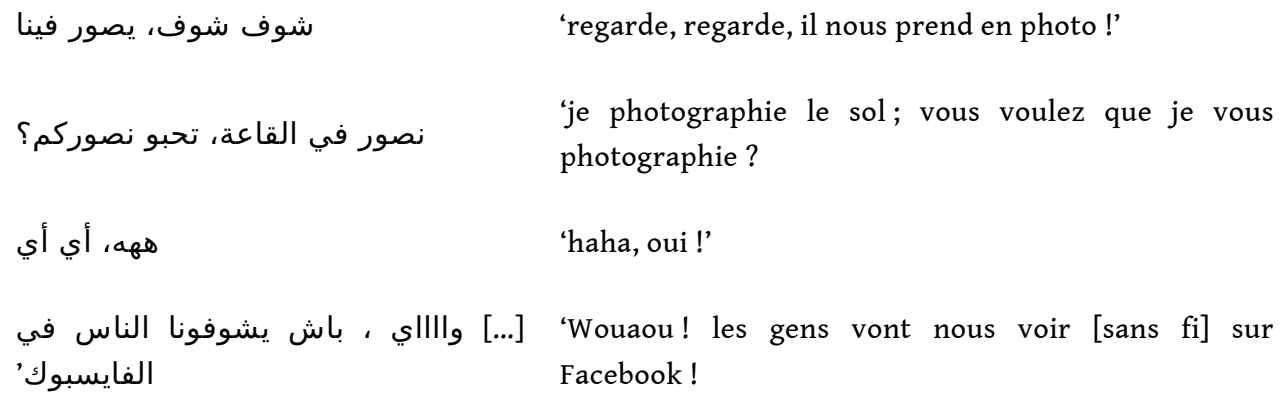

شوف شوف، يصور فينا

نصور في القاعة، تحبو نصوركم؟

'regarde, regarde, il nous prend en photo!'

'je photographie le sol; vous voulez que je vous photographie?

'haha, oui !'

'Wouaou! les gens vont nous voir [sans fi] sur Facebook!

الفايسبوك' connu), A. Brahim étudiait "le marquage locatif des objets" dans les dialectes arabes et berbères ${ }^{31} \mathrm{du}$ Maghreb (surtout au centre, "de l'Est algérien à l'Ouest libyen en passant par la Tunisie"), et constatait que "ce marquage prépositionnel locatif du second actant est de règle quand le verbe transitif est à l'inaccompli [...] de valeur progressive" (exemples : išúffi rūhu fi-l-mrǟyä 'il est en train de se regarder dans la glace', mä nestännä fì hadd 'Je n'attends personne'), et qu'il "n'est pas normalement utilisé lorsque la forme inaccomplie a une valeur générique", ni avec les verbes d'état du type 'aimer', 'posséder', ni avec ceux "d'achèvement (...) de sens instantané ponctuel (comme 'faire éclater')" sauf "en cas d'itération obtenue, par exemple, par simple pluralisation de l'objet" (yeflaq fi lbalūnät 'il est en train de faire éclater les ballons'). Il observait aussi que "des facteurs liés notamment à l'objet lui-même peuvent faire pencher la balance en faveur de l'interprétation habituelle même quand le second actant du verbe est précédé de fi" (ainsi peut-on avoir, à côté de ișallah fi-t-tälvzä 'il est en train de réparer la télévision', ișallah fi-ttlävəz 'c'est un réparateur de télévisions'). Enfin, il donnait (comme Marçais-Guîga) des exemples de constructions ditransitives et causatives (šayy ikarreh fi l-kusksi 'de quoi faire détester le couscous'), ainsi que de l'extension de la construction à des noms déverbaux ( tärbyet-hä fi awläd-ha 'l'éducation qu'elle donne à ses enfants').

Pour Saddour (2009: § 2.4.) le 'marqueur progressif postverbal' fi “semble pénétrer le Temps de la situation de telle façon qu'il est possible de focaliser sur l'une de ses phases internes pour en faire une situation 'in progress', ce qui est rendu possible par le fait que son sémantisme comporte l'idée d'être à l'intérieur d'un intervalle de temps ou d'espace. De la même façon, $f i$ peut faire percevoir comme 'in progress' une situation du monde réel [normalement] perçue comme ponctuelle (e.g. 'comprendre quelqu'un') et mettre l'accent sur une possible phase interne : nifhim fik 'je te comprends' ".

Pallottino (2016) montre qu'en 'arabe tunisien'32 les verbes à l'inaccompli ne peuvent avoir un objet direct défini que précédé de $f_{i}$ : $X$ yəkl kosksi ' $X$ mange du couscous' mais $X$ yəkl fi-l-kosksi ( ${ }^{*} \mathrm{X}$ yəkl $\left.ə \mathrm{l}-k o s k s i\right)$ 'X mange le couscous' (on peut avoir par contre $X$ yəkl fi kosksi 'X mange du couscous), sauf les verbes du type 'croire', 'savoir', 'aimer' : Х yнəbb əl$k l e b$ 'X aime les chiens'. Quand l'objet est indéfini (noms comptables) : X yqra fi kitab 'X est en train de lire un livre' (mais $X$ yqra ktob 'X lit des livres (est un lecteur)'). Les verbes à l'accompli ne sélectionnent pas cette valeur de fi: f-eš yəkl $X$ ? 'que mange $X$ ?', mais $f$-eš $k l \varepsilon X$ ? 'dans quoi (= dans quel récipient) X mange-t-il ?’. Un point important est que les énoncés avec fi ont la négation 'nominale' : $m a-h u-\check{s}$ yqra fi-l-kitab 'il n'est pas en train de lire le livre' (vs. ma-yqra-š ktob 'il ne lit pas de livres', ma-yHəbb-š əl-kleb 'il n'aime pas les chiens'). 
43 McNeil (2017) étudie ${ }^{33} f$, 'marqueur de l'aspect progressif', en relation avec l'autre marqueur $q \bar{a}^{\prime} i d$, et le participe actif, constatant elle aussi qu'il ne peut être utilisé qu'avec des inaccomplis de verbes transitifs, et que, s'il ne peut apparaittre après bāš (particule de futur ou conjonction de subordination), on peut le trouver par contre après la conjonction illì : škūn qāl-li-k illi ānā n-žỉb-l-ū fi al-nsā 'qui t'a dit que je lui amène des femmes?'. Au nombre des conclusions de cette étude fouillée, qui traite aussi, comme la précédente, de la distribution des types de négation, elle propose que, si $q \bar{a}^{\prime} i d$ est probablement antérieur à fi comme marqueur aspectuel, $f i$ 'est le marqueur fondamental et obligatoire de l'aspect progressif en arabe tunisien, $q \bar{a}^{\prime} i d$ étant secondaire par rapport à lui'.

Enfin, Ritt-Benmimoun (2017) propose une étude très détaillée de fi comme marqueur objectif et aspectuel dans le dialecte bédouin de Dūz (sud tunisien), avec de nombreux éléments comparatifs. Parmi ses conclusions nuancées, on en citera trois, particulièrement suggestives. D'abord (p. 348-349), il semble dans de nombreux cas possible d'interpréter la différence entre énoncés avec et sans fi comme une opposition entre énoncés apportant, dans la chaîne narrative, de nouveaux éléments d'information, et énoncés décrivant en détail ces nouveaux éléments ainsi introduits (qu'il s'agisse d'un habituel ou d'un duratif par exemple).

Ensuite (p. 349), les verbes de 'perception sensorielle' (yašbaḥ / yšūf 'voir', yțāli' 'regarder', et yasma' 'écouter') sont presque toujours employés avec $f i$, de même que des verbes comme ytabbi' 'suivre', yūži ' 'faire mal', yākil fi- 'dévorer', yistanna 'attendre', ysūg 'conduire' etc., 'peut-être parce leur sens implique la durativité'.

Enfin (p. 349-350), il semble que l'emploi de $f i$ soit plus fréquent dans les dialectes qui n'ont pas développé de marqueur de l'indicatif (comme ka-).

\subsection{Malte}

47 Aquilina 1987: 333 ( $f i, \mathrm{n}^{\circ}$ 13) note un emploi particulier de $f i$, "après certains verbes comportant l'idée de 'mettre la pagaille, bricoler, manipuler' ("the idea of messing about or tampering with s.th.")". Toq ${ }^{\circ}$ odš tba ${ }^{\circ} b a s^{34}$ fi-l-frott ! 'arrête de tripoter ce fruit !'. Mais on trouve aussi en maltais un emploi de fi comparable à ceux inventoriés ici : "Le maltais autorise des constructions alternatives ('conative alternations') employant... fi... seulement dans des contextes où le verbe imperfectif... peut être interprété comme un progressif (par contraste avec l'habituel)". Les exemples donnés semblent indiquer une différence subtile : $d$-dum $t$ - $a$-qra dal-ktieb 'on met longtemps à lire le livre' vs. $d$-dum $t$ - $a$ qra fdal-ktieb 'on met longtemps à lire ce livre’ (Camilleri 2016 : 57-59).

\subsection{Mauritanie}

48 En hassāniyya " $v$ - introduit souvent le second régime d'un verbe factitif : isarrḥu vloḤlof 'il lui fera paître les chamelles"; "devant le complément d'un verbe à régime normalement direct, $v$ - exprime l'habitude, la répétition, la prolongation de l'action: itabba' vih 'il le suit (continuellement, pendant un long moment)' "(Cohen 1963 : 215-216).

Exemples dans des contes: kiv el-'eyyel elli yuHarrras vïhum 'tel un de ces jeunes gens que l'on regarde' (Tauzin 1993 : 174, 1-2) ; Hुālgä kälbä 'andhä terkä w-'ātt (= 'ādet) ällā džì lhum / v-el-lham w-džib lhum v-l-ukil 'Il était une fois une chienne qui avait des chiots; elle leur 
apportait toujours de la viande et de la nourriture' (Ould Mohamed Baba \& Aguadé 1991 : $330,-7 /-6$; exemple comparable 331,3$){ }^{35}$

\subsection{Algérie}

Pour Saïda v. W. Marçais 1906: [63] /167. Des verbes généralement transitifs "se construisent avec $f i$ lorsqu'on veut indiquer que l'action [...] a été durable ou répétée", lorsqu'ils ont "une valeur de حال".

51 Djidjelli : fi est employé “pour exprimer la continuité de l'action, sa répétition, ou encore l'intensité de l'action qui s'exerce sur plusieurs objets: le verbe est alors souvent un thème II et toujours à l'imparfait" : iselHu $f$-əl-bqar 'ils écorchent les bovins (abattus)'; $d$ âna dde n'ollem faddrâri 'c'est moi qui instruis les enfants' ; ku-nnow do fih kell șbāh 'je le fais lever chaque matin' (Ph. Marçais 1956 : 511-512 ; autres exemples avec la II ${ }^{e}$ forme p. 180). Nombreux exemples sur internet, e.g. : تقول كان يصور فيهم سبع : 'on dirait qu'un lion les a pris en photo'.

\subsection{Maroc}

Pour Colin (1993-1997: 1418) fi "insiste sur la concentration de l'action, son intensification sur l'objet. šăf fiya (accompli) 'il m'a regardé avec insistance', différent de šăfni 'il m'a vu' ; bda kā-ibūs fiha 'il se mit à la couvrir de baisers'; cf. p. 19 bqāt ən-nār kāatākul fihom mä:kla 'le feu continuait à les dévorer’ ; p. 1765 hād əž-žolläba, lbast fiha Həoms snin 'cette djellaba, je l'ai portée durant cinq (longues) années'.

Dans son étude sur Taza, il écrivait (Colin 1921 : 81) : “Cette préposition apparaît souvent devant un régime direct et semble alors marquer que l'action s'exerce fragmentairement, sur une partie seulement du régime et non sur l'ensemble". Si cette caractérisation peut à la rigueur s'appliquer aux deux derniers exemples qu'il donne (hannaw fih (accompli) 'ils lui ont teint les mains et les pieds de henné' ; klaw (accompli) fo-s-sfonj 'ils mangèrent une partie des «sfendjs »'), elle semble peu adéquate pour les trois premiers (brok ibūs fiha 'il se mit à la couvrir de baisers', mālak adšŭf fiya 'qu'as-tu à me dévisager ?', qbot fih 'agrippele!'). ${ }^{36}$

Il semble pourtant suivi par Harrell qui, commentant l'exemple (1962:228, texte $8^{37} 1$. 5-6: u-modda u huwwa ka-iqtel fi-hom hetta ma-bqaw gir žûžz mHebyin 'and waḥd el-beqqal ('au bout d'un moment passé à les tuer il n'en resta que deux cachés chez un épicier'), écrit (229 n. 9) : 'L'emploi de $f$ - devant l'objet direct d'un verbe transitif indique la continuité ou l'incomplétion de l'action, e.g. qtelhom 'il les tua', qtel fihom 'il en tua certains', kan kaiqtel fihom 'il s'affairait à les tuer' ".

À partir d'exemples comme t'yay ma tHebb'i fi-ha 'Tu (fém.) auras beau la [la vérité] dissimuler', (itératif) ṃm-i kull șbah kant t'ti fi-na f-l-'sel 'Ma mère, chaque matin elle nous donnait du miel', (habituel) ntuma l-'yal-at dima ka-t-žibu f-șda' 'Vous les femmes, apportez toujours des ennuis', Chatar-Moumni (2013: 246-247) ${ }^{38}$ constate (248) que "La préposition $f i$ - de l'arabe marocain localise un objet $X$ à l'intérieur d'un intervalle $D$. La localisation opérée par fi- peut être statique ou dynamique ; $X$ peut n'occuper qu'un point de $D$ ou le parcourir entièrement". 
Bensimon-Choukroun (1993: 62) donne, pour divers dialectes judéo-arabes marocains, des exemples avec dirb (accompli) mais aussi avec ḥbb : (29 B) ka-yihəbba vs. s ka-yihəbb feha 'il l'aime' / 'comme il l'aime !'.

Internet:

kan crééyiw [= ka-nkrééyiw, cf. français 'créer'] f collectif hed liam 'on s'est lancés dans la création d'un collectif ces jours-ci'. 39

had l-bHar lli tanšufu fih 'cette mer que vous voyez [devant vous]' (0'4" de la vidéo), à côté d'exemples sans fi : nšufu l-žamal dyal had l-mandar 'nous voyons la beauté de ce paysage' (0'21"), etc. ${ }^{40}$

N.B. On aura remarqué (également en tunisien, cf. § 4.2.) la double valeur de šăf fi : 'voir/regarder' / 'dévisager'; v. plusieurs exemples dans un épisode de la série animée Lascars ${ }^{41}$, e.g. (0'15") : gàadi ibqa išūf fìya 'il va continuer à me fixer [du regard longtemps comme ça] ?!'.

(Dessin humoristique de l'artiste ED oner, ${ }^{42}$ 19/08/2017): - Bnadem a sahbi mamezyanch, hta katbda tersem feh 3ad keynod men blasto!! - Ch baghi bnadem a sat... Rsemni ana wlah maghantherek men blasty!! - 'Les gens, mon vieux, ils sont pas sympa ; à peine t'as commencé à les dessiner, ils bougent de leur place !' - 'Laisseles tomber, t'as qu'à me dessiner moi, je risque pas de bouger !'.

\subsection{Le parallèle avec le berbère}

Si Brahim (2007), qui étudie en parallèle les constructions semblables de l'arabe (avec fi) et berbère (avec $g$ ), ne suggère aucune parenté entre les deux, plusieurs auteurs ont voulu voir une influence de la construction berbère sur celle de l'arabe. Déjà Panetta (1943 : II 253) écrivait: "Dans cet emploi de la particule locative stative on sent l'influence du berbère". Vycichl (1973 : 132) compare des exemples en judéo-arabe de Sousse (yä̈kül fi șwāb'u 'il se ronge les ongles (lit. 'se mange les doigts')', qá da tá'mel fi wežžä "elle est en train de s'épiler (lit. 'elle fait') le visage”, etc.) à des exemples berbères de Djerba. Reesink (1984: 340-344) est plus prudent lorsqu'il présente la construction parmi les 'similitudes syntaxiques' entre arabe et berbère maghrébins. Galand (1985: 90-93) approuve sa prudence, et ajoute (p. 93) que "si l'on considère que la tournure n'est attestée que dans la frange nord-est du domaine berbère, on sera enclin à expliquer sa présence, souvent discrète et hésitante, par une influence de l'arabe, déjà suggérée par P. Reesink". On ajoutera qu'évidemment la présence de la tournure en arabe ancien et en moyen arabe (également évoquée par L. Galand) et, surtout, le fait qu'elle soit attestée dans l'ensemble du domaine dialectal arabe permettent d'écarter la 'piste' berbère.

\section{Autres marqueurs}

On ne peut signaler ici qu'en passant, malgré son importance pour une étude globale de $b i$ -/fi, le fait que l'arabe possède d'autres MDO.

On pense d'abord bien sûr à li $(l(i), l(a)$, etc. dans les dialectes), bien que son rôle soit très différent de celui de $b i-/ f i$, en ce qu'il est, du moins au départ, un outil 'purement' syntaxique. Mais déjà en arabe andalou par exemple, on est frappé de ce que les verbes après lesquels il apparaît rappellent ceux que nous avons vus dans les exemples de différents dialectes : (Ibn Quzmān, m. 1160) lā niwaḨHar li-qișsatī 'je ne vais pas retarder mon récit', aštum li-wildì "insulte mon père", taqtul li-man yihibbak "tu tues ceux qui t'aiment", ra'á hārūt li-'aynayk "Hārūt a vu tes yeux"; (Doctrina Christiana,1566) tihueddéb lalledí yahtá "tu corrigeras ceux qui fautent" (Corriente 2013 : 108). Et il faut songer aussi 
aux multiples développements de li, par exemple dans les dialectes du Levant, avec emploi concomitant d'un pronom cataphorique, du type : šft-ha la-'ommi 'tu as vu ma mère' (lit. 'tu l'as vue à ma mère' (en arabe de Cilicie on a, à côté de la, 'a(la), Procházka 2002 : 158, § 3.3.3.); ou encore au développement, en maltais, du composé lil, dont l'emploi est très lié à des phénomènes aspectuels..$^{43}$ On note donc que dans plusieurs dialectes peuvent coexister, dans des fonctions certes différentes, deux MDO (li/la et bi-/fi au Levant, lil et fi à Malte).

61 Dans le dialecte de Siirt, c'est la préposition ša/šān ('à', 'pour', etc.) qui est le MDO: Haș̣satan šān-i yəh̆pp ‘il m’aime beaucoup’ (Biţună 2016 : 179, § 3.3.19.15. vi).

\section{Conclusions}

On aura compris qu'il ne peut encore être question de faire un tableau historique, ou une synthèse des emplois de la construction avec $f i$ dans les dialectes arabes, d'autant qu'ils sont loin d'être tous documentés et analysés. On peut cependant tirer de ce qui précède un certain nombre de constatations.

On peut poser d'abord avec quelque raison qu'historiquement, c'est bi- qui a précédé $f i$; mais le fait que celle-ci l'ait presque entièrement absorbée a entraîné des évolutions profondes du fait de son sémantisme de base.

L'emploi de fi est très inégalement grammaticalisé. Dans certains dialectes, son emploi est optionnel et les modifications qu'il apporte à l'énoncé sont relativement minimes. Dans d'autres, il est obligatoire dans certains cas. Dans certains dialectes, son emploi est impossible après une forme perfective (accompli ou participe actif), mais il est parfaitement possible dans d'autres (en Syrie, en Palestine, au Negev, en Tunisie, au Maroc - et déjà en Moyen Arabe). Si les modifications qu'il apporte à l'énoncé sont incontestablement de nature aspectuelle (mais souvent en lien avec d'autres phénomènes, et bien sûr avec l'aspect lexical des verbes concernés), celles-ci sont diverses. La progressivité, sur laquelle insistent beaucoup d'auteurs, est peut-être davantage un effet induit qu'une valeur fondamentale; la durativité et, surtout, l'itérativité et l'habitualité semblent attestées surtout au Maghreb (dialectes libyens, de Tunis, de Dūz, de Mauritanie); l'Égypte pourrait, de ce point de vue, être une aire intermédiaire (la valeur d'habituel est par exemple exclue de certains dialectes soudanais au moins).

S'il fallait faire un premier pas dans la tentative d'abstraire une éventuelle valeur fondamentale de fi, on pourrait dire que son emploi est un des procédés linguistiques, de natures diverses, et souvent associés (comme par exemple le recours à la $\mathrm{II}^{\mathrm{e}}$ forme dérivée) qui, s'ils permettent certes d'insister sur l'implication de l'agent, ou sur l'orientation vers l'objet, concourent fondamentalement à décrire les procès de façon circonstanciée, concrète, spécifiée, 'incarnée'. Il semble que cette perspective permette de mieux rendre compte de divers effets induits, aboutissant à des emplois très étendus ou, parfois, très particuliers (cf. certains exemples maltais) qui pourraient apparaître contradictoires. Il va sans dire que la typologie raisonnée de ces emplois reste encore largement à établir. 
tenir', šāf (fi) 'voir/connaître', etc. Mais, dans un cas comme (Damas) ma bəfham ol-kimya 'je ne comprends pas (rien à) la chimie' vs. ma bəfham bo-l-kimya 'je ne m'y connais pas (je ne suis pas un expert) en chimie' (Salamé/Lentin 2010 : 9), same 'entendre' vs. same ' b'entendre parler de, apprendre (une nouvelle)', peut-on considérer que c'est la différence entre la construction transitive directe et celle avec $b$ - qui a amené à une différenciation sémantique et donc à la lexicalisation de deux verbes devenus autonomes? Ou doit-on plutôt penser qu'il s'agissait au départ de deux verbes à régime différent? La réponse n'est pas simple, et probablement particulière pour chaque verbe. Pour ne prendre qu'un exemple, on trouve déjà, dans des recueils de hadịt-s, des énoncés comme mā sami ${ }^{\prime} t u$ fihi bi-šay' in 'je n'ai rien entendu dire à son sujet (personne) / là-dessus (chose)', tournure qui pourrait bien constituer une étape intermédiaire d'une évolution sémantico-syntaxique complexe.

\section{BIBLIOGRAPHIE}

Aquilina, Joseph. 1987 \& 1990. Maltese English Dictionary, 2 vol. La Valette (Malte) : Midsea Books Ltd.

Ahmed Ali, Mustapha \& Miller, Catherine. 1985-1986. “Aperçu sur le système verbal du dialecte du centre-nord Soudanais. L'expression de la concomitance”, Matériaux Arabes et SudarabiquesGELLAS 3. 167-187.

Bensimon-Choukroun, Georgette. 1993. “Objets en judéo-arabe maghrébin”, Actances 7. 35-64. http://lacito.vjf.cnrs.fr/documents/pdf_actances/Bensimon-Choukroun07.pdf

BiŢună, Gabriel. 2016. Morfo-sintaxa dialectului Arab Nord-Mesopotamian din Siirt, Turcia. Bucarest : Editura UniversităŢii din Bucureşti.

Blau, Josua. 1960. Syntax des palästinensischen Bauerndialekts von Bîr-Zêt, auf Grund der 'Volkserzählungen aus Palästina' von B. Schmidt und P. Kahle. Walldorf-Hessen : H. Vorndran.

Blau, Joshua. 1965 [2e éd. revue et augmentée, Jérusalem, Ben-Zvi Institute for the Study of Jewish Communities in the East, $1981 ; 3^{\mathrm{e}}$ éd. revue, Jérusalem, 1999]. The Emergence and Linguistic Background of Judaeo-Arabic. A Study of the Origins of Middle Arabic. Oxford : Oxford University Press.

Blau, Joshua. 1967. A Grammar of Christian Arabic based mainly on South Palestinian Texts from the First Millenium, vol. II. Louvain : Peeters.

Borg, Albert J. 1981. A Study of Aspect in Maltese. Ann Arbor : Karoma Publishers, Inc.

Börjars, Kersti, Ghadgoud, Khawla \& Payne, John. 2016. “Aspectual object marking in Libyan Arabic”, Arnold, Doug, Butt, Miriam, Crysmann, Berthold, King, Tracy Holloway, \& Müller, Stefan (éds), Proceedings of the Joint 2016 Conference on Head-driven Phrase Structure Grammar and Lexical Functional Grammar. Varsovie : Polish Academy of Sciences / Stanford, CA : CSLI Publications. 125-139.

http://web.stanford.edu/group/cslipublications/cslipublications/HPSG/2016/headlex2016bgp.pdf 
Brahim, Ahmed. 2007. "Marquage locatif de l'objet et aspect progressif en arabe et en berbère tunisiens”, François, Jacques \& Brahim, Ahmed (éds), Morphosyntaxe et sémantique du verbe. Relations actancielles, voix, aspect et statut grammatical en français et en arabe, Cahier du CRISCO (Université de Caen) n²3. 94-105.

http://documents.tips/documents/cahiers-crisco-23.html

Brockelmann, Carl. 1907 [1908] et 1911 [1913]. Grundriss der vergleichenden Grammatik der semitischen Sprachen, 2 vol. Berlin : Verlag von Reuther \& Reichard.

Camilleri, Maris. 2016. Temporal and Aspectual auxiliaries in Maltese. PhD Thesis, University of Essex. http://repository.essex.ac.uk/17171/1/2016.pdf

Chatar-Moumni, Nizha. 2013. "La préposition en du français comparée aux prépositions li- et bide l'arabe marocain", Mengozzi, Alessandro \& Tosco, Mauro (éds), Sounds and Words through the Ages : Afroasiatic Studies from Turin, Alessandria : Edizioni dell'Orso. 239-252.

Cohen, David. 1963. Le dialecte arabe hassānīya de Mauritanie (parler de la Gəbla). Avec la collaboration de Mohammed el Chennafi. Paris: Klincksieck.

Cohen, David. 1975. Le parler arabe des Juifs de Tunis. II. Étude linguistique. The Hague / Paris : Mouton.

Colin, Georges S. 1921. "Notes sur le parler arabe du Nord de la région de Taza", Bulletin de l'Institut français d'archéologie orientale XVIII. 33-119.

Colin, Georges-S. 1993-1997. Le Dictionnaire Colin d'Arabe dialectal marocain, sous la direction de Zakia Iraqui-Sinaceur, 8 vol. Rabat : Éditions Al-Manahil, Ministère des Affaires Culturelles.

[Corriente, Federico]. 2013. A descriptive and comparative grammar of Andalusi Arabic, edited by the Institute of Islamic Studies of the University of Zaragoza. Leiden/Boston : Brill.

Erwin, Wallace M. 1963. A short reference grammar of Iraqi Arabic. Washington, D.C. : Georgetown University Press.

Feghali, Michel \& Joseph. 1976, 1977. Contes, légendes et coutumes populaires du Liban, Texte arabe, transcription, traduction et notes, t. II et III. Louvain : Peeters.

Galand, Lionel. 1985. “Exemples berbères de la variation d'actance”, Actances 1. 79-96.

http://lacito.vjf.cnrs.fr/documents/pdf_actances/Galand01.pdf

González Casado, Pilar. 2000. Las relaciones lingüísticas entre el siríaco y el árabe en textos religiosos árabes cristianos. Tesis de la Universidad Complutense de Madrid, Facultad de Filología, Departamento de Estudios Hebreos y Arameos.

http://eprints.ucm.es/20438/1/T24828.pdf

Harrell, Richard S. 1962. A short reference grammar of Moroccan Arabic, with an Appendix of texts in urban Moroccan Arabic by Louis Brunot. Washington : Georgetown University Press.

Henkin, Roni. 2010. Negev Arabic. Dialectal, Sociolinguistic, and Stylistic Variation, Wiesbaden: Harrassowitz.

Holes, Clive. 2015. Dialect, Culture, and Society in Eastern Arabia, vol. III : Phonology, Morphology, Syntax. Leiden/Boston/Köln : Brill.

Ibn Sīdah, 'Alī b. 'Ismā' îl 'Abū al-Ḥasan. 1996. al-MuHașșaṣ fì al-lug̉a, éd. Hulīl 'Ibrāhīm Ğaffāl. Beyrouth : Dār 'ihyâ̄' al-turāt al-'arabì. 
Lentin, Jérôme. 1991. “À propos de la valeur 'intensive' de la II ${ }^{\text {ème }}$ forme verbale en arabe syrien : modalité et expressivité. Vers un renouvellement du système verbal ?”, Kaye, Alan S. (éd.), Semitic Studies in Honor of Wolf Leslau, vol. II. Wiesbaden : Harrassowitz. 891-916.

Lentin, Jérôme. 1997. Recherches sur l'histoire de la langue arabe au Proche-Orient à l'époque moderne. Thèse de Doctorat d'état ès-lettres, Paris III.

Lentin, Jérôme. 2008. “Unité et diversité du Moyen Arabe au Machreq et au Maghreb : quelques données d'après des textes d'époque tardive (16 $6^{\text {ème }}-19^{\text {ème }}$ siècles)", Lentin, Jérôme \& Grand'Henry, Jacques (éds), Moyen arabe et variétés mixtes de l'arabe à travers l'histoire - Actes du premier colloque international (Louvain-la-Neuve, 10-14 mai 2004). Louvain-la-Neuve : Université catholique de Louvain, Institut orientaliste de Louvain, Peeters. 305-319.

Linder, Sven Vilhelm \& Ringgren, Helmer. 1952. Palästinische Volksgesänge, aufgezeichnet und gesammelt von Sven Linder, aus dem Nachlass herausgegeben und mit Anmerkungen versehen von Helmer Ringgren. I. Mit einem Beitrag vom Herausgeber. Die Volksdichtung und das hohe Lied. Uppsala universitet : Lundequistska bokhandeln.

McNeil, Karen. 2017. “Fī ('in') as a Marker of the Progressive Aspect in Tunisian Arabic”, RittBenmimoun, Veronika e.a. (éds), Tunisian and Libyan Arabic Dialects: Common Trends, Recent Developments, Diachronic Aspects. Zaragoza : Prensas de la Universidad de Zaragoza. 161-190.

Marçais, Philippe. s. d. [1956]. Le parler arabe de Djidjelli (Nord-Constantinois, Algérie). Paris : Maisonneuve.

Marçais, William. 1906-1907. "Le dialecte arabe des Ūlâd Bṛāhîm de Saïda (Département d'Oran)", Mémoires de la Société de Linguistique de Paris XIV (1906), 97-164, 416-472, 481-499 ; XV (1907), 40-72, 104-129 (publié en volume, Paris, 1908).

Marçais, William \& Guîga, Abderrahmân. 1958-1961. Textes arabes de Takrouna II. Glossaire : contribution à l'étude du vocabulaire arabe, tomes I-VIII. Paris : Imprimerie nationale / CNRS / Librairie P. Geuthner.

Mitchell, Terence F. 1978. "Educated Spoken Arabic in Egypt and the Levant, with Special Reference to the Participle and Tense", Journal of Linguistics 14. 227-258.

Mitchell, Terence F. \& El-Ḥassan. Shahir. 1994. Modality, Mood and Aspect in Spoken Arabic. With Special Reference to Egypt and the Levant. Londres / New York : Kegan Paul International.

Nöldeke, Theodor. 1894. Compte rendu de Stumme 1893, Wiener Zeitschrift für die Kunde des Morgenlandes VIII. 250-271.

Ould Mohamed Baba, Ahmed Salem \& Aguadé, Jorge. 1991. "ānä smi bäynnä. Dos versiones de un cuento popular mauritano", Anaquel de Estudios Árabes 2. 327-337.

https://revistas.ucm.es/index.php/ANQE/article/view/ANQE9191110327A/4052

Owens, Jonathan. 1984. A short reference grammar of Eastern Libyan Arabic. Wiesbaden :

Harrassowitz.

Pallottino, Margherita. 2016. “" feš taqra? » What are You Reading? Prepositional Objects in Tunisian Arabic”, Brill's Journal of Afroasiatic Languages and Linguistics 8. 286-312.

Panetta, Ester. 1943. L'arabo parlato a Bengasi. I. Testi con traduzione e note. II. Grammatica. Rome : Libreria dello Stato.

Procházka, Stephan. 1993. Die Präpositionen in den neuarabischen Dialekten. Vienne : VWGÖ.

Procházka, Stephan. 2002. Die arabischen Dialekte der Çukurova (Südtürkei). Wiesbaden :

Harrassowitz. 
Reckendorf, Hermann. 1895-1898. Die syntaktischen Verhältnisse des Arabischen. Leiden : Brill.

Reckendorf, Hermann. 1921. Arabische Syntax. Heidelberg : Carl Winter's Universitätsbuchhandlung.

Reesink, Pieter. 1984. "Similitudes syntaxiques en arabe et en berbère maghrébins", Bynon, James (éd.), Current Progress in Afro-Asiatic Linguistics - Papers of the Third International HamitoSemitic Congress (London 1978). Amsterdam/Philadelphia : John Benjamins. 327-354.

Ritt-Benmimoun, Veronika. 2017. "The preposition fi- as an Object and Aspect Marker in a South Tunisian Bedouin Dialect”, Journal of Semitic Studies 62/2. 319-355.

Saada, Lucienne. 1984. Éléments de description du parler arabe de Tozeur (Tunisie). Phonologie, morphologie, syntaxe. Paris : diffusion Geuthner.

Saddour, Inès. 2009. "The expression of progressivity in Tunisian Arabic: A study of progressive markers in oral retellings of simultaneous situations", Revue de Sémantique et Pragmatique (Presses de l'Université d'Orléans) 25-26. 265-280.

https://hal.archives-ouvertes.fr/hal-00625548

Saïdi, Darine. 2014. Développement de la compétence narrative en arabe tunisien : rapport entre formes linguistiques et fonctions discursives. Thèse de doctorat, Université Lyon 2.

http://theses.univ-lyon2.fr/documents/lyon2/2014/saidi_d/pdfAmont/saidi_d_these.pdf

Salamé, Claude \& Lentin, Jérôme. 2010. Dictionnaire d'arabe dialectal syrien (parler de Damas), lettre B. http://halshs.archives-ouvertes.fr/IFPO/halshs-00504180/fr/.

Schmidt, Hans \& Kahle, Paul (éds). 1918, 1930. Volkserzählungen aus Palästina gesammelt bei den Bauern von Bir-Zeit und in Verbindung mit Dschirius Jusif, vol. 1-2. Göttingen : Vandenhoeck \& Ruprecht.

Singer, Hans-Rudolf. 1984. Grammatik der arabischen Mundart der Medina von Tunis. Berlin/New York : de Gruyter.

Stumme, Hans. 1893. Tunisische Märchen und Gedichte. Eine Sammlung prosaischer und poetischer Stücke im arabischen Dialecte der Stadt Tunis nebst Einleitung und Übersetzung, I-II. Leipzig : J.C. Hinrichs'sche Buchhandlung.

http://menadoc.bibliothek.uni-halle.de/ssg/content/titleinfo/1071301

Stumme, Hans. 1898. Märchen und Gedichte aus der Stadt Tripolis in Nordafrika. Sammlung transkribierter prosaischer und poetischer Stücke in arabischen Dialekt der Stadt Tripolis nebst Übersetzung, Skizze des Dialekts und Glossar, I-II. Leipzig : J.C. Hinrichs'sche Buchhandlung.

Șubh, 'Alawiyye. 2006. Dunyā. Beyrouth : Dār al-'ādāb.

Tauzin, Aline. 1993. Contes arabes de Mauritanie. Paris: Karthala.

Vycichl, Werner. 1973. "Les études chamito-sémitiques", Actes du premier congrès d'études des cultures méditerranéennes d'influence arabo-berbère. Alger : S.N.E.D. 128-135.

Woidich, Manfred. 2006. "fi Objects in Egyptian Arabic: the Case for Telic Verbs", Mejri, Salah (éd.), L'arabe dialectal : enquêtes, descriptions, interprétations. Actes d'Aida 6 [2004]. Travaux offerts au professeur Taïeb Baccouche. Tunis : Centre d'études et de recherches économiques et sociales (Série Linguistique 13). 473-486.

Wright, William. 1896, 1898. A Grammar of the Arabic Language, 3 ème éd. Cambridge : at the University Press. 


\section{NOTES}

1. Pour d'autres prépositions v. $\$ 5$.

2. 'Marquage/marqueur différentiel de l'objet' seront abrégés en MDO. Les hébraïsants et les aramaïsants parlent de nota accusativi, qu'on évitera ici vu qu'aucun dialecte arabe ne possède de désinences casuelles; nota objecti serait plus approprié.

3. Woidich 2006 ; v. ci-dessous $§ 3.8$.

4. V. $\S 4.2$.

5. V. $\S 4.1$.

6. V. Ritt-Benmimoun 2017 : 324-332 pour un riche état des lieux, qui recoupe largement le nôtre.

7. V. §§ 3.3., 3.5., 3.7.

8. Wright 1898 (II) : 159-160 ; Brockelmann 1911 [1913] : 366 et 368-369 ( $2237 \mathrm{f}$ et m), 313, 373 ; Reckendorf 1921 : 236-237 ; Reckendorf 1895-1898 : 244-246.

9. 1996 : vol. 4, 242-243.

10. Les traductions françaises sont celles de R. Blachère, sauf pour ce premier exemple, qu'il traduit 'Prêche au nom de ton Seigneur', conformément à une interprétation plus courante.

11. C'est à dire du 'Adab al-kātib d'Ibn Qutayba.

12. “(...) der von der Handlung getroffene Gegenstand als dasjenige aufgefasst ist, woran oder mittels dessen die Handlung zur Erscheinung kommt'.

13. Lire ainsi au lieu de rubūniyya.

14. Procházka 1993 : 104-105 (et carte 1, 259-261).

15. Pour les références précises v. Lentin 1997.

16. Lentin $2008: 314$.

17. Contrairement à ce qui se passe, dans tous les registres de l'arabe, avec les verbes de mouvement construits avec bi-, où c'est la valeur instrumentale de la préposition qui est en jeu.

18. Procházka $1993: 40$ et n. 64.

19. Lentin $1997: 286-288, \S 6.12 .2$.

20. Procházka $1993: 105$.

21. Courant dans plusieurs dialectes, e.g. ma gabalet fi (informatrice d'un village du Golan, juillet 2009). La construction ave fi est d'ailleurs attestée en arabe classique. Ainsi le grammairien Ibn 'Aqīl (m. 1367) هذا الاعراب قد قبل فيه أيضا: "Cette [autre] flexion désinentielle a été aussi acceptée".

22. Les traductions des auteurs (p. 70 et 60-61) ont été modifiées.

23. Noté par M.-A. Germanos (30/04/2017).

24. Qui donne plusieurs de ces exemples : Blau 1960 : 165 § 100d pour b-, 166-167 pour fi, avec exemples (ou références) pour les verbes suivants : garr, țabaH, lihik, madah, sabak, 'akal, dahhak, saḥab, ḥaka, fattaḥ, šawšah, ğamat, ḥammam, dabb, 'alla, ḳla, kamkaš, bārak.

25. Autres exemples p. 211, 228, 354, 372.

26. Un exemple de Louxor, dans un conte publié en 1885 par H. Dulac, est cité par Colin 1921 : 81, note 1 : وخيّتى تلقّط في عظمي 'tandis que ma petite sœur rassemble mes os'.

27. C'est ainsi que traduit Stumme (p. 107).

28. Exemples avec drb, sm`, wns III, žyb, šwf, by' (inaccomplis), et sm` et bht II (accomplis).

29. Brahim 2007, Saddour 2009, Saïdi 2014, et surtout Pallottino 2016, McNeil 2017 et RittBenmimoun 2017.

30. V. aussi le compte rendu de Nöldeke $1894: 264$.

31. Pour la question du rapport entre l'arabe et le berbère v. plus bas $\S 4.7$. 
32. Sans précision, ce qui est regrettable car les situations sont très diversifiées dans les dialectes tunisiens.

33. À partir de nombreux exemples majoritairement tunisois puisés dans le Tunisian Arabic Corpus (TAC, accessible sur http://tunisiya.org).

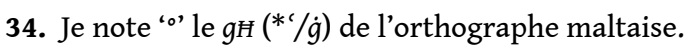

35. Lignes 1-2 \& 10-12 du texte ( http://www.semarch.uni-hd.de/pdf/arab/aguade/ chinguetti_aguade_baba.pdf) accompagnant l'enregistrement dans Das Semitische Tonarchiv (SemArch) de Heidelberg, où $v$ - est noté $f$ -

36. Il faut noter ici que Galand (1985 : 92) envisage lui aussi ce genre de valeur : "Il n'est donc pas impossible que l'arabe et le berbère aient développé séparément, en raison de cette relation entre inaccompli et partitif, la même construction prépositionnelle de l'inaccompli".

37. Recueilli par Louis Brunot et édité par Harrell.

38. Exemples respectivement issus du film Les filles de Rahma, du corpus de l'auteur et de la chaîne de télévision $2 M$.

39. Étudiant, né en 1990 à Casablanca où il vit toujours (famille originaire de la région de Settat), dans un échange sur Facebook avec Dominique Caubet (17/6/2017).

40.

https://www.facebook.com/100004353286370/videos/ pcb.865661613588940/865659760255792/?type=3\&theater, vidéo, 26/7/2017 (Oualidiya, sur l'atlantique).

41. https://www.youtube.com/watch?v=DUWeH51uNyI.

42. Originaire de Berrechid, dans la région de Casablanca-Settat, dans la Chaouia, il vit à Casablanca.

43. V. par exemple, parmi de nombreuses études, Borg 1981.

\section{RÉSUMÉS}

In the vast majority of Arabic dialects, $f i$ (rarely bi-) is the most used differential object marker. This contribution follows in the same vein as M. Woidich's presentation on Egyptian Arabic at the 6th AIDA conference and other recent papers on Maghrebine dialects (mainly Tunisian). In it, we first consider whether it is appropriate to see the origin of this dialectal construction with $f i$ in the bi- construction of Ancient and Middle Arabic. Then, within the limits of the presently available documentation on both Oriental and Maghrebine dialects, we try to provide a comprehensive overview of highly contrasting situations and, in an attempt to suggest future lines of research, we highlight the main differences existing between these situations. Finally, we propose to consider this use of $f i$ as one of the ways through which to describe a verbal process in a concrete and detailed manner, a characterization that allows for an explanation of the variety of context-induced values that we observe.

\section{INDEX}

Keywords : Differential Object Marking, Arabic dialects 


\section{AUTEUR}

\section{JÉRÔME LENTIN}

Institut National des Langues et Civilisations Orientales (Paris) 


\title{
Syllabification in Moroccan Arabic
}

\author{
Nabila Louriz
}

\section{AUTHOR'S NOTE}

This study was undertaken during my stays at the University of Graz in Austria. I am indebted to Erasmus Mobility Program for facilitating my first visits. I am, also, deeply grateful to Professor Utz Maas for making all resources necessary for undertaking this study available to me. I appreciate him for the fruitful discussions, valuable comments and instructive feedback. Without his considerable help, this work would not have been possible. This work was presented at $25^{\text {th }}$ Manchester Phonology Meeting and AIDA 2017. I would like to thank members of the audience for their insight.

\section{Introduction}

1 This paper discusses factors defining syllable structure in connected speech in Moroccan Arabic (MA henceforth). Although this topic seems to have been extensively studied, it continues to be a reminiscent issue. This is due to the uncertainty surrounding syllable boundaries, the status of schwa and its role in syllabification. This work - based on a corpus of a variety of MA spoken in the Middle Atlas - explores the interaction of different levels of grammar in influencing the speakers' preferences of syllabification.

The article is structured as follows. Section 2 will shed light on the main contributions to the study of syllable structure in MA. Section 3 presents and discusses data. Section 4 clarifies the interacting factors affecting syllabication in spontaneous speech. Since this is a work in progress, I will not attempt a final model of syllabification. Instead, I will conclude by summarizing the generalizations. 


\section{Background}

3 The unconventional nature of MA syllable structure was first noted decades ago in Harris (1942), Harrell (1962), Abdel Messih (1973), Heath (1987), to name but a few. Despite the excessive research that has taken place since then, there is no agreement on the possible syllables in MA. The first difficulty comes from whether the syllable margins are branching. There are scholars who adopt the 'Complex Onset Hypothesis', which defines consonantal string in such a word as [kla] 'eat' as a branching onset (Benhallam 1980; Heath 1987; Benkirane 1998; Maas 2011). On the other hand, others go for the 'Simplex Onset Hypothesis', and divide such strings into two syllables. Hence, [k.la] is composed of a minor syllable and a main one (Boudlal 2001). The second difficulty is related to the status of schwa and its role in syllabification. It is generally accepted that MA has three phonemic vowels $\{\mathrm{i}, \mathrm{a}, \mathrm{u}\}$. It has shortened the long vowels and lost the short vowels of Classical Arabic resulting in consonant clusters, which are eventually split by a short central vowel which the language has developed. This vowel is referred to in most literature as epenthetic schwa (Benhallam 1990; Boudlal 2001; Lahrouchi 2014). More importantly, the identity of schwa is fuzzy. What is referred to by some scholars as (i) schwa vowel (Harris 1942; Benhallam 1990; Heath 1987; Boudlal 2001), is considered as (ii) a schwa like element by others (Dell \& El Medlaoui 2002), or (iii) simply an audible release of the consonant by some phoneticians (Gafos et al. 2002). This disagreement is reflected in the transcription of MA which is not uniform across authors. The remainder of this section will elaborate on these points.

Benhallam (1990) distinguishes two types of syllabification in MA: full-vowel and schwa syllabification. He puts forward a Syllable Structure Assignment Algorithm (SSAA) which proceeds from right to left in four steps: first, the assignment of CV core syllables, e.g. / mat/ $\Rightarrow>$ [.ma.t] 'he died'. Second, the building of CaC from unsyllabified CC: e.g. /ktb $\Rightarrow$ [k.tab.] 'he wrote'. The coda assignment rule: e.g. .ma.t $=>$.mat. 'he died'. Finally, the syllabification of stray consonants: /k.təb.t/=> [.ktabt.] 'I wrote'. However, words with a second geminate consonant and $\mathrm{CaCC}$ nouns like [bərd] 'cold' remain problematic. These are regarded to have an underlying syllabic template. Besides, words like [ktab-t] 'I wrote' require syllabification to apply cyclically to yield the attested output. Also, Benhallam (1990) considers the examples above as monosyllabic, and the consonant sequences preceding and following the nucleus as branching onsets and codas, respectively.

Boudlal $(2001,2012)$ supports the claim made by Benhallam (1990) regarding the epenthetic status of schwa. Nonetheless, he disagrees on the complex nature of syllable edges. He argues that complex onsets are not permitted in MA, and, hence, supports the 'Simplex Onset Hypothesis'. When a word starts with two consonants, the first one forms a syllable on its own and acquires the status "minor syllable" (e.g. [k.la]). Adopting the Optimality framework, he posits a constraint ranking that generates simple onsets, and accounts for schwa epenthesis in verbs and nouns.

6 That onsets are simple in MA finds further support in Lahrouchi (2014), yet from a different perspective. He joins Kaye (1990) to argue that since MA does not impose sequential constraints on clustering and, hence, resorts to epenthetic schwa, it can be analyzed as having only open syllables at the phonological level. Lahrouchi (2014) adopts the strict $\mathrm{CV}$ approach to show that consonant clusters result from the computation of empty nuclei. 
7 Adopting Fischer's (1967) concept of "syllable of movement" (Arabic haraka), Maas (2011) develops an algorithm to generate syllables in MA. Basically, all consonantal lexical segments are potential openings of syllables: $\mathrm{C}<(\mathrm{k}<\mathrm{t}<\mathrm{t}, \mathrm{b}<$ ' to write'). In other words, each consonant is a potential onset. Subsequently, the last consonant loses the ability of opening a syllable $(k<. t<. b<\#=>k<. t<.>b \#)$. The third step is to get peripheral vowels integrated as sonorous articulations of the opening movement of consonants. The final closure is manifested in the length of the full vowel (e.g. k<.t<a>b\# 'book'). Prosody can require a sonorous substrate for intonation contours (e.g. $/ \mathrm{k}<. \mathrm{t}<.>\mathrm{b} \# / \Rightarrow[\mathrm{ktab}]$ 'he writes'). It is important to note that $\mathrm{C}<. \mathrm{C}<. \mathrm{C}<\ldots . . . . \#$ is avoided; instead, it is realized as $\mathrm{C}<>\mathrm{C}$. $C<. . . \#$ e.g. /xnfus/ 'beetle', in which case schwa is inserted between the first two consonants. Maas (2011) develops an Optimality constraint ranking which is different from that in Boudlal $(2001,2012)$. It accounts for schwa insertion and optimizes branching onsets.

Dell \& El Medlaoui (2002) embrace a different position regarding syllabification. Their study is different in a number of respects. First, their data comes from poetic verses. Second, they claim that syllables without onset can only occur at the start of a verse. Third, schwa is an unstable vowel, and its realization depends on the surrounding segments. More importantly, they argue that "transitional schwa" is inserted between words when the first one ends and the second one starts in a consonant, hence, creating a further syllable. Thus, their view of the role that schwa plays in syllabification differs from other studies to a great extent.

The different attempts made by phonologists have been examined in phonetic studies. A case in point is Shaw et al. $(2009,2011)$ who use temporal phonetic data to show the heterosyllabic parsing of initial clusters in words such as [ktab] 'book' and [sbati] 'belt'. Hence, their study provides evidence for simple onsets.

10 To recapitulate, there is little agreement regarding syllable structure in MA despite the various perspectives and frameworks used to study it. This is mainly because of (i) the doubt about the nature of the material between consonant clusters, and (ii) (not) accepting the complex syllable margins. Having this settled is crucial to the development of phonological research in MA. Hence, this study tackles the same phenomenon from yet a different perspective and based on new data.

\section{The study}

\subsection{Data}

11 Data used in the present study come from a large corpus of spontaneous interactive speech collected specially in the Middle Atlas. Part of it is available on this website: Zentrum.virtuos.uni-osnabruk.de\#/utz.maas/Main/Dateien. In order to come up with reliable generalizations, extracts used in this study come from different parts of the corpus denoting the variations possible. They represent productions made by male, female, young, old, literate, illiterate, Berber and non-Berber speaking individuals interacting in slow and fast pace.

Data are analyzed using PRAAT (Boersma \& Weenink 2005). The immediate remark concerns the difficulty in assembling segments into syllables. In specific, the way speakers arrange their production into syllables rarely satisfies the sonority based models 
of syllabification. The data consist of stretches of consonants superior to two, which presents a challenge not only to the Simplex Onset Hypothesis, but also to the predictions concerning schwa insertion. This results in such unexpected consonant clusters as [ndxlu] 'we get in'. Another observation is the presence of vocalic material where not predicted by the grammar. More importantly, there is a striking inconsistency in syllabifying some words with or without schwa; a case in point is [wahd] vs. [wahəd] 'one'. Such variation is found within and across speakers.

So, the hypothesis underlying this study is that speakers' organization of speech into syllables is based not solely on segmental sequencing; rather it is the result of the interaction of segmental, prosodic, morphological and syntactic information, as well as the pace of speech. The coming section will examine some examples in the light of this hypothesis.

\subsection{Analysis}

14 The following procedures are followed. Prosodic units are determined. Then, segments are delimited and measured in duration before they are assembled into syllables. The last step is not a straightforward task given the observations sketched above and the hypothesis underlying the study. In order to determine syllable boundaries, several levels of analysis are considered, namely, phonology, morphology, syntax, prosody, rate of speech. Since this is a work in progress, I will suffice by detangling the interaction between morphology and phonology and its influence by the rate of speech.

Syllabification of words is attempted; i.e. morphological words are taken out of their context and syllabified as if produced in isolation or in a carrier phrase as done in controlled data. However, the nature of the corpus used in this study makes examining morphological words an intricate job. First, words in controlled data are realized differently from those in spontaneous speech, and, hence, do not represent the actual speakers' production. This is because elements that control syllabification in normal speech are absent in controlled data. Second, the whole lexical word can be reduced, and in extreme cases, deleted altogether in connected speech, which makes determining syllable boundaries of a word challenging. Thus, in this study, syllabification is considered within the larger frame of prosody.

Let's start with the example in (1). The first line represents the actual production, the second line marks the morphemes and the location of schwa if words were in isolation. The third line provides transliteration and the fourth English translation.

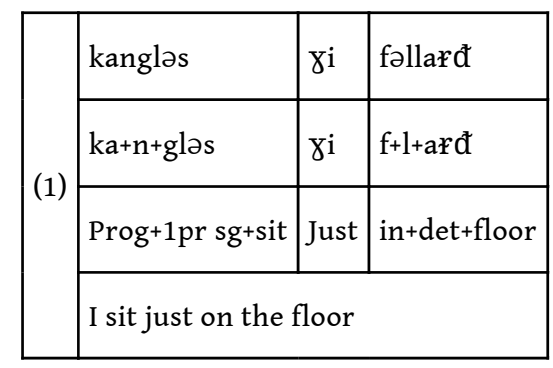

On the face of it, the actual production satisfies syllabification models proposed in the literature. Schwa is inserted to generate the expected syllable structure in [kan.gləs] or 
[kan.g.ləs] according to the Simplex Onset Hypothesis and Complex Onset Hypothesis, respectively. Notice that although the syllables in [fəl.larđ] are well-formed, schwa insertion is not predicted by the current approaches: they would generate [flard] or [f.larđ] instead. Also, Schwa insertion triggers gemination of the following consonant to guarantee a closed syllable.

So far, it seems that syllabification of words in connected speech is not different from that in controlled data. It is worthy to note that the utterance in (1) is produced by a female speaker in slow pace. However, as soon as the pace gets faster, different syllable structures appear. Consider the example below:

\begin{tabular}{|c|c|c|c|c|c|c|}
\hline \multirow{3}{*}{ (2) } & huma & kejgəlsu & G & ssnađq & Si & whdin \\
\hline & huma & $\mathrm{Ka}+\mathrm{i}+\mathrm{g} \partial \mathrm{ls}+\mathrm{u}$ & Sla & s-snađəq & Si & wəhd+in \\
\hline & They & prog + sit $+3^{\text {rd }} \mathrm{pl}$ & on & crates (broken pl) & some & one $+\mathrm{pl}$ \\
\hline
\end{tabular}

With the exception of the first two words ([hu.ma.kej.gəl.su]), syllabification diverges from the predicted output to a great extent. Gliding of [i] in / $k a+i+g l s+u /$ avoids hiatus, and results in a closed syllable with a raised nucleus as the outcome of coarticulation. Discussion about the latter is beyond the scope of this paper, and, thus, will be avoided.

As one proceeds in the analysis, syllable boundaries become unclear. Notice that the vowel and the preceding consonant are deleted in / $\mathrm{Gla} /$ resulting in [I] only. This becomes subject to re-syllabification: [issnađq] starts with a cluster of four consonants. PRAAT analysis confirms the lack of any vocalic element splitting these consonants, which makes it a challenging case to current models of syllabification. Also, given that the geminate /ss/ cannot be separated, schwa is expected to be inserted between /I/ and /ss/ and produced like [โəs.sna.đəq], but the speaker chooses not to do so. Such a case is neither predicted nor resolved by current approaches to syllabification in MA. The one that allows onsets to consist of maximally two consonants will be faced with an over-sized onset, whereas the other that resorts to minor syllable will have a series of three minor syllables preceding the main one. A flexible account that allows syllabic consonants is required. Thus, an alternative analysis would be one that considers / $\mathcal{I}$ / as the nucleus of the first syllable and the geminate /ss/ to be ambisyllablic.

21 Furthermore, note that schwa epenthesis does not occur between / $₫ /$ and /q/ as predicted. Phonetic analysis rules out the presence of a vowel separating the two consonants. Whether they form a cluster or a one complex consonant requires a meticulous phonetic investigation, which is not available at this stage of research. So, I will mark them as two separate consonants. The resulting syllable structure would, hence, be [Ss.s.nađq].

Since CCC cluster is not allowed in MA (Maas 2011), /whdin/ should be syllabified as [w วЋ.din]. However, Phonetic analysis shows no vocalic trace between the first three consonants. So, analogously to the previous example, it is produced as [wh.din] where / $\mathrm{h} /$ is the nucleus. 

Now that it is sure that there is no vowel involved, the question that remains is why / $\mathrm{I} /$ and $/ \mathrm{h} /$ are regarded to be syllabic. In the absence of a more detailed phonetic analysis at this stage, one can only speculate. To start with, / $/$ / is the nucleus for two reasons. First, it is more sonorous and longer than the next consonant. Second, /s/ is part of a geminate which is ambisyllabic and, hence, can only be a coda. Concerning the syllable [wh], the fricative acts as the nucleus because it is longer. Besides, there is certain degree of "vowelness" involved in both consonants, which makes them sometimes "unparsable" from the next vowel. Such claim requires an in-depth analysis to be conducted in a coming stage of this work.

Let's now discuss syllabification in the example below:

\begin{tabular}{|c|c|c|c|c|}
\hline (3) & mbyaws & ixliwna & ndxlu & liha \\
\hline & $m a+b \gamma a+u+\int$ & $i+x l l+i u+n a$ & $n+d x l-u$ & litha \\
\hline & neg+want $+3^{\text {rd }} \mathrm{pl}+$ neg & $3^{\text {rd }} \mathrm{pl}+\mathrm{let}+3^{\text {rd }} \mathrm{pl}+\mathrm{us}$ & we+enter+ $1^{\text {st }} \mathrm{pl}$ & To+ it (fem) \\
\hline & \multicolumn{4}{|c|}{ They did not let us get in } \\
\hline
\end{tabular}

There are two instances where schwa is not inserted as predicted. The first one is $/ \mathrm{i}+\mathrm{x} l 1+\mathrm{i}$ $+u+n a /$ 'they let $u s$ ', where schwa is expected between $/ x /$ and $/ 1 /$. The lack of schwa results in degeminating /11/ with a duration of $0.040 \mathrm{msc}$. This supports the view that MA onset is maximally two consonants (Maas 2011).

The second case is $/ \mathrm{n}+\mathrm{dxl}+\mathrm{u} /$ 'we enter'. Present approaches predict schwa insertion between $/ \mathrm{d} /$ and $/ \mathrm{x} /$ resulting in [ndəx.lu] or [n.dəx.lu]. However, phonetic analysis confirms the lack of any vowel element separating the consonants. This leads $/ \mathrm{x} /$ to acts the nucleus.

Finally, /ma+bya $+u+f /$ 'they did not want' is produced in spontaneous speech as [mbyawf] starting with a three consonant cluster. This presents a further challenge to most existing approaches to syllable structure in MA. There is no vocalic material separating $/ \mathrm{m} /$ and / $\mathrm{b} /$ according to phonetic analysis. $/ \mathrm{u} /$ acquires consonantal feature to avoid hiatus and, hence, becomes a coda. Finally, $/ S /$ is re-syllabified with the vowel starting the next word. Thus, the speaker organizes his utterance into syllables as follows: [mb.yaw.ji.xliw.nan.dx.lu.li.ha].

\begin{tabular}{|c|c|c|c|c|c|c|}
\hline (4) & gal $+\mathrm{li}+\mathrm{k}$ & $\mathrm{x} s \mathrm{~s}+\mathrm{k}$ & $t+3 i b$ & viza & $\mathrm{mn}$ & 1+məðrib \\
\hline & $\mathrm{k}^{\mathrm{x}}$ & xəsk & tzib & viza & $\mathrm{m}$ & mə yrib \\
\hline & $\begin{array}{l}\text { say } 3^{\text {rd }} \mathrm{pr} \text { sg+ to } \\
\text { +you (sg) }\end{array}$ & must+you (sg) & you(sg)+ bring & visa & from & Morocco \\
\hline
\end{tabular}


Like example (3), this is an extract from an interaction made in fast pace. The striking remark is the omission and reduction of several syllables. To start with, both syllables of the word /gal.lik/ disappear leaving behind just the affricate $\left[\mathrm{k}^{\mathrm{x}}\right]$ of $0.050 \mathrm{msc}$. This will evidently be re-syllabified with the subsequent word.

Current literature predicts schwa insertion in CCCC sequence between the first and the second pairs of consonants (CəC.CəC). Hence, /xssk/ 'you must' should be syllabified as [x əs.sək]. Nonetheless, this word is realized as one syllable: [xəsk]. Clearly /ss/ is degeminated with a duration of $0.046 \mathrm{msc}$; this is due to the choice of the speaker not to insert schwa.

The last part in this example (/mn\#1+myrib/ 'from Morocco') should be syllabified with three syllables ([mən.lməx.rib]) or more according to Dell and El Medlaoui (2002). However, it is syllabified differently in our data. Phonetic examination shows no vocalic element between /m/ of /mən/ 'from' and /m/ of /məyrib/ 'Morocco'. The speaker disposes of not only the rhyme of /mən/, but also of /l/ preceding /məyrib/. So, [m] is produced with a duration of $0.140 \mathrm{msc}$ and a falling F0. Hence, this utterance is produced with fewer syllables than predicted by the grammar.

One more important observation. Schwa is inserted between [xəsk] 'you must' and [tzib] 'you bring'. This is the first instance encountered so far where schwa occurs between two words as predicted in Dell and El Medlaoui (2002). Schwa is of a considerable length: 0.058 msc, and, so, is not mistaken for the release of the preceding stop. I assume that this is to avoid the succession of complex coda in [xəsk] and complex onset in [tzib]. So, the

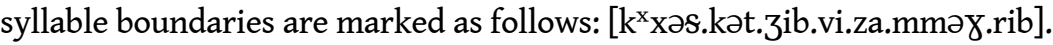

To recapitulate, the speakers' syllabification of the instances discussed in this study is summarized here:
a) [kan.gləs.Xi.fəl.larđ]
b) [hu.ma.kej.gəl.su.Ss.snađq.Si.wh.din]
c) [mb.Xaw.ji.xliw.nan.dx.lu.li.ha]
d) [ $k^{\mathrm{x}}$ xəs.kət.3ib.vi.za.mməy.rib]

These examples demonstrate that speakers can have different preferences of syllabification. I have shown that in spontaneous speech, full vowels can be deleted and schwa might not be inserted. The resulting consonant clusters, in turn, leads to syllables with no vowels. In the next section, I will elaborate on the interacting factors leading to such structures.

\section{Discussion}

Data investigated in this study provide ample evidence that there is more to syllabification than just segments. Syllable structure is the outcome of the interaction of various components of language and should, hence, be considered at different levels of analysis. In this section I will discuss how phonology and morphology interact in affecting the speakers' preferences in defining syllable boundaries. I will also briefly discuss how such interaction is affected by the pace of speech. For the sake of clarity, I will use a couple of examples to argue for this point.

Let's consider the underlying structure /ma+bya+u+f\#i+xll+iu+na/ 'they did not want to let us', which is realized as [mb.Xaw.Si.xliw.na]. The first part of the circumfix -ma... . 'not' is 
reduced to [m]. The second part of the cleft morpheme is maintained. It is regarded to be semantically transparent enough to denote negation on its own. Such reduction neither affects the meaning nor disturbs the flow of the conversation. This implies that the first half of the morpheme is taken to be semantically redundant by the speaker, and, hence, is disposed of in fast speech.

A slightly similar case is (4): /gal+li+k\#xss+k\#t+3ib\#viza\#mən\#l+məyrib/ is produced as [k ${ }^{x}$ xəs.kət.zib.vi.za.mməð.rib]. A supposedly ten syllable utterance (or more according to Dell \& El Medlaoui, 2002) is realized as seven syllables only. /gallik/ 'it is said' is semantically empty; it does not contribute to the meaning of the utterance, and, hence, lies outside the prosodic unit [xəsk t3ib viza mməyrib] 'you must get the visa in Morocco'. So, like the example above, reduction does not affect neither the meaning nor the abstract form of the morpheme. The two are cases of fast speech where phonology triggers a production with less syllables, and so erases redundant and semantically empty morphemes. What is striking is that despite reduction, research assistants who have participated at the transcription of the corpus have transcribed it as [gallək]. Why and how do hearers have access to deleted parts of speech is a question for a separate study.

On the other hand, morphemes are fully articulated when produced in slow pace. A case in point is [kan.gləs.yi.fəl.larđ]. The output maintains all segments in the input; a transitional schwa is added; and a greater number of syllables are produced.

To recapitulate, I have shown that morphemes which are redundant or do not contribute to meaning are reduced or deleted in spontaneous fast speech. As a result, the speaker produces a prosodic unit with fewer syllables than in fast pace. On the other hand, phonology and morphology interact differently in slow speech. All morphemes are realized, resulting in syllabification by schwa, and, hence, a production with more syllables.

\section{Conclusion}

40 This paper has argued that syllabification in spontaneous interactive speech in MA is different from that in words in isolation of controlled data. It has been shown that slow speech rate can cause transitional schwa insertions between consonant clusters which appear as vocalic traces in the acoustic signal. On the other hand, in faster speech, phonology removes redundant and semantically empty morphological material. So, the quantity of syllables is reduced and syllable structures vary allowing syllabic consonants and complex margins. Another important finding is that Faithfulness constraints are active only at the lexical level, the analysis of which is not always accessible in fast speech. The next step in the current research is to investigate how variation in syllabification is controlled within the wider window of prosody to include other levels of grammar. 


\section{BIBLIOGRAPHY}

Benhallam, A. 1980. Syllable Structure And Rule Types In Arabic. PhD Dissertation. Gainsville: University of Florida.

Benhallam, A. 1990. 'Moroccan Arabic Syllable structure'. Language et Literature VIII. 177-191.

Bensoukas, K. \& A. Boudlal. 2012. 'The Prosody of Moroccan Amazigh and Moroccan Arabic: Similarities in the Phonology of Schwa', Borowsky, T. et al. (eds.), Prosody Matters: Essays in Honor of Lisa Selkirk. London: Equinox. 3-42.

Boersma, P. \& D. Weenink. 2005. Praat: doing phonetics by computer (Version 4.3.01) [Computer program]. Retrieved from http://www.praat.org/

Dell, F. \& M. El Medlaoui. 2002. Syllables in Tashlhiyt Berber and in Moroccan Arabic. Dordrecht: Kluwer.

Heath, J. 1987. Ablaut and Ambiguity: Phonology of A Moroccan Arabic Dialect. Albany: SUNY Press.

Maas, Utz. 2011. Marokkanisches Arabisch. München: LINCOM Sprachlehrbucher

Shaw J, A. Gafos, P. Hoole, C. Zeroual. 2009. 'Syllabification in Moroccan Arabic: evidence from patterns of temporal stability in articulation'. Phonology 26. 187-215.

Zec, D. 2005. 'Prosodic Differences among Function Words'. Phonology 22 - 1. 77-112.

\section{APPENDIXES}

\section{List of Abbreviations}

$1^{\text {st }} \mathrm{pr}: 1^{\text {st }}$ person

$3^{\text {rd }}$ pr: $3^{\text {rd }}$ person

Det: determiner

Fem: feminine

Neg: negation

Prog: progressive

Sg: singular

Pl: plural

\section{ABSTRACTS}

The role of schwa in syllabification has been a challenging phenomenon in Moroccan Arabic (MA), and, consequently, defining syllable boundaries has been a thorny issue. This paper uses data of spontaneous speech to reveal that syllabification would be better understood when it is considered within the larger frame of prosody. It is argued that syllabification in MA is the 
outcome of the interaction of different components of grammar. This article particularly shows how morphology and phonology interact in slow and fast speech to guide the speaker's formation of syllables.

INDEX

Keywords: Syllabification, prosody, morphology, phonology, pace of speech

\section{AUTHOR}

\section{NABILA LOURIZ}

University Hassan II - Casablanca 


\title{
An Omani Evolving Lexicon: From Carl Reinhardt (1894) to the Present Day
}

\author{
Ph.d. Roberta Morano
}

\section{Carl Reinhardt and his work}

1 Carl Reinhardt's work - Ein arabischer Dialekt gesprochen in 'Oman und Zanzibar, dated 1894 still plays a very prominent role in the linguistic and neo-Arabic dialectological field. In fact, the Omani variety that he describes is different both from the one spoken in the Capital area (described by Jayakar 1889) and the one spoken on the coast.

introduction (Reinhardt 1894: VII-XVI), Reinhardt states that it took him five years of hard work to collect all the material presented in the book and that - due to illness he almost would have given up if his teacher Professor Theodor Noeldeke (1836-1930), the famous orientalist, had not encouraged him to continue. According to Noeldeke, only Reinhardt's data provide a clear overview of Omani Arabic, despite the high value of Jayakar's repertoire.

3 The dialect described by Reinhardt is the one spoken in Wādī Banī Harūṣ, today in the al'Awābī district (northern Oman). The people he employed as informants ('Abdallāh Harūṣī and 'Alī al-'Abrī from al-'Awābī) were natives from Oman who had only been in Zanzibar for a short while. Furthermore, Reinhardt states that this vernacular was spoken, at his time, by the Omani court and 2/3 of the Arabs living in Zanzibar. Thus, we can presume that it was so widespread as to require the writing of a practical and quick guide for German soldiers quartered on the East African colonies.

4 The Banū Harūṣ played an important role throughout Omani history, primarily in Ibādìyya ${ }^{1}$ : descendants of the Yahmad tribe - a branch of al-'Azd -, they moved to Oman during the pre-Islamic period, settling in a valley named after them Wādī Banī Harūṣ. The valley is situated among the western heights of the Hağar Mountains and is $26 \mathrm{~km}$ long, 
ending in the Ğabal AHḍār ${ }^{2}$. The Yahmad provided most of the Ibādi imams of Oman until the arrival of the Ya ${ }^{\text {rubi }}{ }^{3}$ dynasty in XI/XVII century.

Reinhardt's work is divided into four parts: 1. Phonology; 2. Morphology; 3. Remarks on the syntax and 4. Texts and stories (including some war songs). The feature that distinguishes this book from other teaching material is the fact that it is almost exclusively written in the Latin alphabet.

6 While, on the whole, appreciating the usefulness of Reinhardt's work, the reviews published by experienced Semitic scholars and Arabists such as Theodor Noeldeke $(1895 \mathrm{a} / \mathrm{b})$ and Karl Vollers (1895) pointed out a few obscure points in his description. Vollers, in particular, voiced some doubts as to the reliability of Reinhardt's book because of its educational rather than descriptive purpose.

7 Regarding morphology and syntax, Reinhardt's analysis is fairly accurate and detailed, though the lack of a lexical repertoire somewhat decreases its clarity.

\section{Classification of Omani Arabic}

8 Clive Holes, in his paper on Omani Arabic classification (Holes 1989), analyses features shared by all Omani dialects, both hadari and badu:

- The 2nd feminine singular possessive/object suffix is universally $-/ \check{s} /$, not -/č/, except some Bedouin dialects of North-East where it is realised as $-/ \check{c} /$ and the al-Wahiba dialect, where it is not affricated and is realised as $-/ \mathrm{k} /$;

- An -/in(n)/- infix is obligatorily inserted in all Omani dialects between an active participle having verbal force and a following object pronoun. Some Omani speakers also insert this infix between the imperfect verb and the suffix object, in particular on the Bātina coast (Holes 1989: 448);

- The absence of the "ghawa syndrome" ${ }^{4}$, peculiar of some central, northern and eastern Arabic dialects. Exceptions are some Bedouin vernaculars spoken in the areas at the UAE border (e.g. Buraymi, Oman);

- Feminine plural verb, adjective and pronoun forms occur regularly5;

- The internal passive of verbs Form I and II is of common occurrence. Holes (1989: 452) classification goes further subdividing these dialects in four main groups, two sedentary (S) and two Bedouin (B), which have some substantial differences, as shown in Table 1: 
Table 1. Holes' classification of Omani Arabic

\begin{tabular}{|c|c|c|c|}
\hline 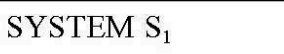 & ${\text { SYSTEM } \mathrm{S}_{2}}$ & SYSTEM B $_{1}$ & ${\text { SYSTEM } B_{2}}$ \\
\hline$/ \mathrm{q} /<\mathrm{CA} / \mathrm{q} /$ & $/ \mathrm{k} /<\mathrm{CA} / \mathrm{q} /$ & $/ \mathrm{g} /<\mathrm{CA} / \mathrm{q} /$ & $/ \mathrm{g} /<\mathrm{CA} / \mathrm{q} /$ \\
\hline$/ \mathrm{k} /<\mathrm{CA} / \mathrm{k} /$ & $/ \check{\mathbf{c}} /<\mathrm{CA} / \mathrm{k} /$ & $/ \mathrm{k} /<\mathrm{CA} / \mathrm{k} /$ & $/ \mathrm{k} /<\mathrm{CA} / \mathrm{k} /$ \\
\hline$/ \mathrm{g} /$ or $/ \check{\mathrm{g}} /<\mathrm{CA} / \check{\mathrm{g}} /$ & $/ \check{\mathrm{g}} /<\mathrm{CA} / \check{\mathrm{g}} /$ & $/ \mathrm{y} /<\mathrm{CA} / \mathrm{g} /$ & $/ \mathrm{y} /<\mathrm{CA} / \mathrm{g} /$ \\
\hline $\begin{array}{l}\text { Syllabic structure: } \\
\mathrm{CvC}(\mathrm{v}) \mathrm{Cv}(\mathrm{C})\end{array}$ & $\begin{array}{l}\text { Syllabic structure: } \\
\mathrm{CvC}(\mathrm{v}) \mathrm{Cv}(\mathrm{C})\end{array}$ & $\begin{array}{l}\text { Syllabic structure: } \\
\mathrm{CCvCv}(\mathrm{C}) \text { or } \\
\mathrm{CvC}(\mathrm{v}) \mathrm{Cv}(\mathrm{C})\end{array}$ & $\begin{array}{l}\text { Syllabic structure: } \\
\mathrm{CCvCv}(\mathrm{C}) \text { and } \\
\mathrm{CvC}(\mathrm{v}) \mathrm{Cv}(\mathrm{C})\end{array}$ \\
\hline only form qahwa & only form kahwa & $\begin{array}{l}\text { forms ghawa and } \\
\text { gahwa }\end{array}$ & only form gahwa \\
\hline$-/ \check{\mathrm{S}} / 2 \mathrm{FS}$ pronoun & - / /s/ 2FS pronoun & 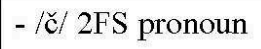 & - / $/ \check{\mathrm{S}} / 2 \mathrm{FS}$ pronoun \\
\hline $\begin{array}{l}\text { distinctive of Omani } \\
\text { interior }\end{array}$ & $\begin{array}{l}\text { central areas of } \\
\text { Ğabal Ahḍar }\end{array}$ & $\begin{array}{l}\text { Similar to Gulf } \\
\text { dialects }\end{array}$ & $\begin{array}{l}\text { Western and } \\
\text { Southern Oman }\end{array}$ \\
\hline
\end{tabular}

According to this classification, the al-'Awābi district vernacular belongs to the system $\mathrm{S}_{1}$.

\section{Location, methodology and participants}

The al-'Awābi district is located in the Bāțina region, north of Oman and consists of al'Awābi itself, a town with a population of about 15000, and twenty-four little villages spread between it and the Wādī Banī H̦arūṣ.

11 Wādī Banī Huarūṣ is about $26 \mathrm{~km}$ long deep in al-Hağar mountains and ends at Ğabal AHdar, the highest summit of Oman. The area is famous because of its heritage and history: in fact, in the Wādī there are many antique mosques and cave inscriptions, telling the story of great and famous imams of Ibādīiyya.

The collection and analysis of lexical items has been one of the richest areas of investigation of al-'Awābì vernacular. The fieldwork was conducted in the al-'Awābi district between the months of February and April 2017. Participants were mainly from the al-Hुarūṣi family, consisting of eleven women between twenty-eight and seventy-five years old, all of them school or university educated. They were born and still live in al'Awābī.

Other participants were from the Wādī Banī Harūṣ, which has a slightly older population (between fifty and sixty-five years old). Some of them were originally from the Wādī and then moved to al-'Awābī, some others remained in the mountains or in the valleys of the Wādī.

14 Participants were chosen according to three main criteria: age, gender and level of education. Based on the age of speakers, people has been divided in three main groups: 20-35 years old (young), 35-60 years old (middle-aged) and over 60 (elders). 
Informants were always ready to provide various items and discuss them with each other Some of the speakers recalled some items as very old and not in use anymore, or used by their parents' or grandparents' generation.

People living in the Wādī are usually not university educated and conduct a more traditional lifestyle, farming or breeding goats and sometimes camels.

Accessing men was more difficult for the researcher, except for elderly ones.

The research was conducted by submitting word lists divided by categories (food, body parts, plants, animals, tools and diseases) to participants, recording free speech and by direct questions. In some cases, vocal messages on WhatsApp were also used.

\section{Omani lexicon}

Lexical data presented by Reinhardt is extremely rich and characterized throughout by some specific traits which make this vernacular different from any other Southern Arabic dialect, mainly due to the geographic position of the country and to its linguistic contacts with different populations during its history.

Among Reinhardt's lexical items there are some archaic features in the semantics, such as rām "to be able to" from the Semitic root RYM, which means "to be high, raise" and also nouns known in other dialects but presented here with unusual meanings (e.g. the root ĞM' "to gather" stands in this variety for "to sweep" and mğumma ' for "broom").

An example is provided by fieldwork data:

(a) mā yrūm mițla‘ li-inna mā fì darağ

"He couldn't go up because there weren't any stairs"

In the vernacular the use of the Arabic verb SYR to mean "to go" alongside the

dialectal form RWH is also attested, as follows:

(b) sāyir martīn 'ilā l-mustašfi

"He went to the hospital twice"

(c) taww asìr ilā l-Rustāq

"I am now going to Rustaq"

22 The lexical items discussed in this paper are presented according to the format of Behnstedt and Woidich's Word Atlas of Arabic dialects / Wortatlas der arabischen Dialekte of 2011. The categories chosen are: food, house, weather, animals, body and disease.

\subsection{Food}

In this category names of spices, seafood, vegetables and fruit are presented.

Among the spices, we find: zangabil for "ginger", Hardāl for "mustard", granfel for "clove", na'na' for "mint", hil for "cardamom", zayt for "oil" and Hall for "vinegar".

Hobbār is the general term used for "squid", but in its plural form hobbārāt it also means "seafood". The names for "sardines" are interesting to note in this group: alongside the use of the most common sardin and 'üma, some elder speakers still use the word barriyya, which has been recognised among the youngsters as old and, in some cases, completely unknown.

Names of fruit and vegetables present many interesting peculiarities of al-'Awābi vernacular. Examples are the use of the Arabic noun zaytūn as "guava", whilst in other parts of the Arabic-speaking world it means "olive" and the presence of ancient and 
uncommon words, such as suhh for "dates". There are also nouns specifically used in the al-'Awābì district, such as gūh for "watermelon" and gurgūur for "peas" (outside al-'Awābì people tend to use the Arabic bāsilla to be clearer). Table 2 shows the most common names of fruit and vegetables in the al-'Awābi district:

Table 2. Names of fruit and vegetables in the al- 'Awābī district

\begin{tabular}{|c|c|c|c|}
\hline Fawākih & Fruit & Hoḍrawāt & Vegetables \\
\hline 'anba & mango & filfil rūmī & green pepper \\
\hline 'inab & grapes & țamāṭin & tomatoes \\
\hline fifāya & papaya & būbar & pumpkin \\
\hline kummitrah & pear & wāca & squash \\
\hline sanțāra & tangerine & kūsa & courgette \\
\hline šammām & white melon & laymūn & lemon \\
\hline gūḥ & watermelon & hyyār & cabbage \\
\hline suḥ̣ & dates & ‘ayš / rizz & rice \\
\hline zaytūn & guava & guurḡūr / bāsīlla & peas \\
\hline rummān & pomegranate & dang & chickpeas \\
\hline nargīl & coconut & findāl & sweet potatoes \\
\hline mūz & banana & qamḥa & wheat \\
\hline tīn & fig & 'adis & red lentils \\
\hline sta'fāl & large citrus fruit & zaytūn ahdộr & olive \\
\hline furșād & berries & lubyā & beans \\
\hline
\end{tabular}

\subsection{House and Utensils}

Nouns indicating house parts and kitchen stuff tend to differ between al-'Awābī and Wādī Banī Huarūs. Usually in the Wādì it is more likely to find older words or words recognised in the village as ancient. An example of this is the word used for "room": in al-'Awābi the noun gurfa is commonly used, whereas in the Wādi the noun higra is used instead. The "sitting room" is usually șala or dahriz, but elder people and people from the Wādī call it barza.

'arī̌ is used in the Wādī to name "open hut made of palm tree branches", a very common shelter in the mountains. Table 3 shows names of utensils: 
Table 3. Names of utensils in the al- 'Awābī district

\begin{tabular}{ll}
\hline Muwā̄in & Kitchen Stuff \\
\hline ḍalla / briq & coffee pot / Arabian coffee pot \\
\hline mqamša & spoon \\
\hline kūb & tea cup \\
\hline glas & glass (of any kind) \\
\hline furn & oven \\
\hline gahla & jug (used to keep water cold) \\
\hline mgumma' & broom \\
\hline țawla & table \\
\hline kašra / zibbala (middle-aged people) & rubbish \\
\hline mkabba & tin, plastic box \\
\hline
\end{tabular}

\subsection{Weather} wadis floods and big rivers comes down from the mountains, whilst matar is the noun used generally for "rain". "Cloud" is realised both as sahāb and gamma, with no difference in the use. Finally, the noun bill, which indicates specifically the blossom of a lemon tree, is also used to mean "spring".

\subsection{Animals}

31 There are a few studies on the flora and fauna of Oman, especially in recent decades ${ }^{6}$. Specific types of animals and plants are widespread across the entirety of Oman, but others are more peculiar to individual areas of the country. Table 4 presents a list of the most common names for animals and insects in the al-'Awābi district: 
Table 4. Names of animals and insects in the al- 'Awābī district

\begin{tabular}{|c|c|c|c|}
\hline bacūd & mosquito & luggga & gecko \\
\hline sannūr / qaț & cat & $\begin{array}{l}\text { šaḥlūb / } \\
\text { abū barīṣ }\end{array}$ & small lizard (not poisonous) \\
\hline nimr & tiger & šamaș / ḍabb & $\begin{array}{l}\text { big lizard (not poisonous and } \\
\text { edible) }\end{array}$ \\
\hline ga'd & ewe & šangūb / garād & grasshopper \\
\hline ganem & goat & fanzūz & black and white insect \\
\hline șaḩl & kid & șaqar / šāhīn & falcon / peregrine \\
\hline 'agl & calf & nisr & vulture \\
\hline anqabūt & spider & șarrīhn & date cricket \\
\hline qanfad & hedgehog & 'anfūf / ḩafāš & small bat \\
\hline šarnafa & crysalis & gadal & big bat \\
\hline yarqa & larva & $\begin{array}{l}\text { surțān al-baḥr } \\
\text { šangūb al-baḥr }\end{array}$ & crab \\
\hline sannūr al-ginn & hairy caterpillar & ḥalzūn al-ma' & snail \\
\hline dūdat al-'arḍ & warm & tōor al-ginn & slug \\
\hline
\end{tabular}

The most common name used for "cat" is certainly sannūr, but sometimes children and kids up to fifteen or sixteen years old name it qaț. In al-'Awābī there are some specific names used for "grasshopper" (šangūb) and for a "small and not poisonous lizard" ( $a b \bar{u}$ barīş), which is called šahlūb in other parts of Oman. Finally, the use in al-'Awābī of a specific word for "crab" (šangūb al-bahr) is peculiar, since the al-'Awābi district is in the mountainous region of Northern Oman.

\subsection{Body and diseases}

Most of the lexical items presented in this section have been collected in Wādī Banī Harūs, where the wasm, the traditional method of healing by cauterisation, is still in use. This practice is common among the people living in remote areas of Oman and it consists of cauterizing specific parts of the body in relation to the disease or the illness presented.

Table 5 shows a list of words used in this practice and in everyday life: 
Table 5. Names of parts of the body and disease in the al- 'Awābī district

\begin{tabular}{|c|c|}
\hline qafad & nape \\
\hline muhra & nose \\
\hline țūm & mouth \\
\hline šifa/šafāyif & lips \\
\hline \multicolumn{2}{|l|}{ mazbala/mzābil* } \\
\hline garrīn & throat \\
\hline ‘arq an-nisā & sciatic nerve \\
\hline šīṣa & throbbing in the leg \\
\hline ḥumma al-halālīyya & high and persistent fever \\
\hline šaqīqa & headache \\
\hline ġašya & gastritis \\
\hline ḥumūḍa & heartburn \\
\hline lu'an & nausea \\
\hline ar-rīh & hernia \\
\hline múālda & bones pressing on the lungs preventing \\
\hline
\end{tabular}

* This form has been recognised as old by some young speakers in the Wādī.

\section{Remarks}

During the collection of the data, many elderly speakers were able to recognise and detect old words not in use anymore or used much less nowadays. A clear example of this is the verb yšūm, only used in its imperfective form, which means "to go (inland)". The origin of the verb is not certain, a hypothesis might be the Classical Arabic root ŠYM "to go to Syria (Bilād aš-šām)" since "going inland" from Oman would necessarily mean "going north" (towards Syria).

The adverb hest is still in use to mean "very, many", although not much among young people any more. It comes from the Persian verb hast "to exist" and the correlation between the two might also be valid for the more widespread adverb, wāgid ("many, much") and the Arabic root WǦD ("to exist").

Gudri is a name of Hindi origin used in the past to indicate a "woollen blanket", nowadays it has been replaced by the noun bațāniyyah.

\section{Conclusion}

The main purpose of this paper was to analyse some interesting lexical data collected during the fieldwork and match them with Reinhardt's lexical core. Going further into the analysis of these data it has been clear that many of them were not valid anymore, since they were recognised only by elder speakers and almost completely unknown to people from middle-age or young groups. 
fashioned by people in al-'Awābī or young people in general. Moreover, not school or university educated speakers use nouns sometimes considered outdated or totally unknown.

more recent times, influences from other Omani vernaculars came into use as well as many more English loanwords and expressions.

41

\section{BIBLIOGRAPHY}

Agius, Dionisius. 2005. Seafaring in the Arabian Gulf and Oman: the People of the Dhow, London: Kegan Paul.

Agius, Dionisius. 2002. In the Wake of the Dhow: the Arabian Gulf and Oman. London: Ithaca Press.

Behnstedt, Peter, \& Woidich, Manfred. 2011a. Wortatlas der Arabischen Dialekte, Volume I. Mensch, Natur, Flora und Fauna. Leiden: Brill.

Behnstedt, Peter, \& Woidich, Manfred. 2011b. Wortatlas der Arabischen Dialekte, Volume II. Leiden: Brill.

Ghazanfar, Shahina. 1994. Handbook of Arabian Medicinal Plants. Boca Raton (FL): CRC Press.

Holes, Clive; 1988. "The typology of Omani Arabic Dialects", Proceedings of the BRISMES

International Conference on Middle Eastern Studies. 12-21.

Holes, Clive. 1989. “Towards a Dialect Geography of Oman”, BSOAS 52/3. 446-462.

Jayakar, A.S.G. 1889. “The O'manee Dialect of Arabic: Parts I-II”, JRAS 21. 649-687; 811-880.

Nöldeke, Theodor. 1895a. "Über einen arabischen Dialekt", WZKM 9. 1-25.

Nöldeke, Theodor. 1895b. "Nachträge zu dem Aufsatz "Über einen arabischen Dialekt”: WZKM 9. 177-179.

Reinhardt, Carl. 1894. Ein arabischer Dialekt gesprochen in 'Oman und Zanzibar. Lehrbücher des Seminars für Orientalische Sprachen zu Berlin 13. Stuttgart-Berlin: W. Spemann.

Vollers, Karl. 1895. "Rec. di Reinhardt 1894", ZDMG 49. 484-515.

\section{NOTES}

1. One of the major Hुariǧite branches, named after its founder 'Abd Allah b. Ibāḍl al-Murri alTamīmi. 
2. The highest peak in the chain that also includes the Ǧabal al-Šamm (3018m).

3. The Omani dynasty that reigned between $1024 / 1615$ and 1164/1749.

4. It is a syllabic readjustment: the tonic syllable $\mathrm{CaC}$, where $\mathrm{C} 2$ is a guttural / $\mathrm{H} \dot{\mathrm{g}} \mathrm{h}$ ' $\mathrm{h} /$, becomes CCa (e.g. qahwa "coffee" [CA] becomes ghawa in Bedouin dialects of Najd). In some other Bedouin varieties, it is possible to find the form gahawa, but essential is the insertion of the stressed vowel - $a$ - after the guttural consonant.

5. This feature is shared with some dialects of central and southern Arabia and make them distinctive from other Gulf dialects, where the gender distinction has been neutralized.

6. For further details, see works of Shahina Ghazanfar (1994) and Dionisius Agius (2002, 2005).

\section{ABSTRACTS}

Oman is a country in constant evolution linguistically, economically and socially. Most of the linguistic studies carried out so far in the Sultanate are located in specific areas of the country and date back to the end of the nineteenth and the beginning of the twentieth century.

Carl Reinhardt's work - Ein arabischer Dialekt gesprochen in 'Oman und Zanzibar, dated 1894 - is one of the most detailed and richest descriptions of Omani Arabic, specifically of the grammar, including the phonology and morphology, of the Banū Kharūs vernacular, spoken in the area of Nizwa and Rustāq (northern Oman), but also among the élite of Zanzibar island. The main purpose of his work was to provide a valuable linguistic guide to the German soldiers quartered on the island and in the Tanganyka region, which were an imperial German colony for a short time. The material supplied by Reinhardt still plays an absolutely essential role for neo-Arabic linguistics and dialectology, although it has some significant issues, such as the lack of Arabic original script and of a comprehensive glossary.

Reinhardt's lexical data, nevertheless, is extremely rich and characterized by some specific traits which make this vernacular different from any other Southern Arabic dialect.

In this paper, I will try to outline this richness of Omani lexicon, starting from some examples in Reinhardt's nineteenth-century core and exploring the variety and changes they underwent over time. These examples will be presented for specific semantic categories (e.g. body parts, food, animals), following the same format as that of the Behnstedt and Woidich's Word Atlas of Arabic dialects / Wortatlas der arabischen Dialekte (2011). Furthermore, a group of specific variations between the original meaning of a root and its different use in the Banū Kharūṣ vernacular, and a few borrowings from foreign languages will be presented and analysed.

\section{INDEX}

Keywords: Arabic dialectology, Omani Arabic, Oman, Carl Reinhardt, neo-Arabic linguistics, Arabic lexicon. 
AUTHOR

PH.D. ROBERTA MORANO

University of Leeds 


\title{
The Diminutive in the Arabic Dialect of Tunis
}

\author{
Stephan Procházka
}

\section{Introduction ${ }^{1}$}

1 Hitherto studies on Arabic dialects in general and on Tunisian Arabic in particular have mostly dealt with the formal aspects of diminutives. Thus reference works on the Arabic dialect of Tunis focus almost exclusively on the morphology of diminutives. Their functions beyond smallness and endearment are only marginally mentioned, if at all (Stumme 1896: 67-84, Cohen 1975: 204-208, Singer 1984: 480-496).

2 In his introduction to the paragraph on diminutives, Singer (1984: 480) states that diminution may be spatial and temporal and affect both quantity and quality. He adds that diminutives may also carry either a contemptuous or a sympathetic nuance. Trabelsi (1991: 89-90) dedicates a short paragraph to the different usage of diminutives in the speech of women and men. Maalej (2010) analyses some pragmatic functions of diminutives in addressing non-acquaintances.

3 The main source for the lexical data here was Singer (19842), which was thoroughly double-checked with informants from Tunis. ${ }^{3}$ The examples are either elicited from native speakers or taken from our Viennese TUNICO project and the Tunisiya corpus.

\section{Forms and patterns}

4 There are three main diminutive patterns in Tunis Arabic: (1) $C_{1} C_{2} i C_{3} a,(2) C_{1} C_{2}$ ayyi $C_{3}$ FEM $C_{1}$ $C_{2}$ ayy $C_{3} a$, and (3) $C_{1} C_{2} i C_{3} i C_{4}$ FEM $C_{1} C_{2} i C_{3} C_{4} a a^{4}$ Diminutives are predominantly derived from nouns, never from verbs. Besides nouns, diminutives can be formed from adjectives, one special adverb, and the numbers 'one' and 'two'.

5 A few words, all of them adjectives, exhibit the suffix -ūn, e.g. tahfün 'pretty'. Singer 1984:496 notes that -ūn is also attached to the two diminutives żayyir and qșayyir, but our informants used șağrūn and qașrūn instead. ${ }^{5}$ 
The pattern $C_{1} a C_{2} C_{2} \bar{u} C_{3}$ for which Singer 1984: 496 lists only proper names seems to have become more widespread in contemporary speech, e.g. nabbūla instead of nbayyla 'small bladder'.

\section{Functions of the diminutive}

7 Following the seminal works of Dressler \& Merlini Barbaresi 1994 and Jurafsky 1996, we will differentiate between the semantic and pragmatic functions of diminutives. ${ }^{6}$ As will be seen, the latter by far outweigh the purely denotative functions indicating diminution per se. It should be emphasized that almost all the semantic senses given in chapter 3.1 can appear with pragmatic connotations as well (cf. Jurafsky 1996: 535).

\subsection{Semantic (denotative) functions}

\subsubsection{Smallness}

8 The basic function of diminutives is the denotative diminution of typically tangible, perceptible, three-dimensional objects. Such diminutives may express nothing more than smallness, without any additional connotative nuance. Particularly when used with the names of domestic animals the diminutive seems to imply both youth and minuteness:

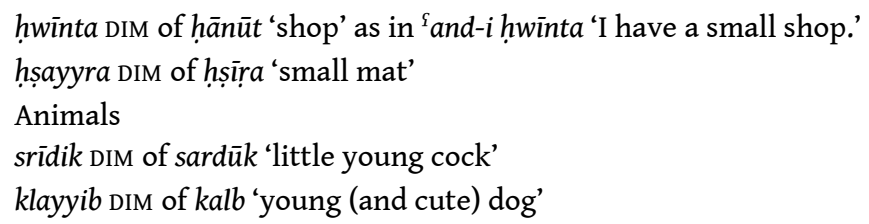

9 The diminution usually relates to visual impression (Dressler \& Merlini Barbaresi 1994: 121), although cases based on the other senses also exist:

șwayyiț DIM of șūt '(pleasant) voice' as in șūți māhūš țayyāra. - lā famma nās tbārkalla 'and-hum șwayyit fi- ...'My voice is not fantastic. - No, but there are people who really have a pleasant voice-DIM.' (Tunico: Two schoolgirls).

Diminution occurs not only with reference to size but also concerning other assayable features, particularly quality and importance. In such cases the boundaries between semantic and pragmatic functions are often blurred. Only the context, including intonation, determines the meaning of the diminutive, which may denote either poor quality and unpleasant physical appearance or prettiness and small size. The word hiwiža DIM of ḩāža may, for instance, denote a 'small thing' but also an unimportant matter. Singer's translation of xwitim as 'cheap and miserable ring' is only appropriate in a context like the following, in which a woman whose fiancé left her says:

šūf hāk il-xwìtim illi žāb-u! 'Look at that cheap little ring which he bought (for me!)'

11 But coming home from shopping she may say:

il-yūm šrit xwìtim mahlā- $h$ ! 'Today I bought a little ring: it's so nice!'

12 Singer's examples suggest that the diminutives of words denoting buildings usually are pejorative. In contemporary speech practically all of these words are no longer in use; but at least until the middle of the $20^{\text {th }}$ century a fridiq, DIM of funduq 'hostel' (Singer 1984: 492), was usually a 'miserable hostel' and not necessarily just small. 


\subsubsection{Intensity and exactness} meaning which can be termed minimizing. Adjectives that denote poor quality or stupidity also fall in this category.

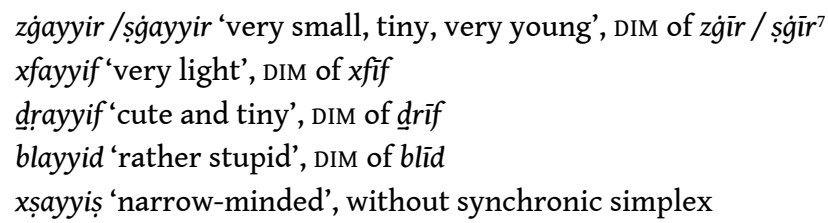

There is evidence of only one diminutive that is likely derived from a noun that already denotes something small. This is the adverb tšayša / tšiša / dšiša 'a little bit', which is apparently the DIM of tš̌š 'semolina'.

The diminutive of waqt 'time' may carry the notion of exactness, i.e. 'the right time' or even 'appointment'.

wqayyit il-hākəm ya žmāå $a$ 'Hey guys, curfew has come!' (Singer 1984: 485, fn. 32)

To this category belongs the only adverb with a diminutive, qbila and its extension qbilika 'recently; just' DIM of qbal 'before'.

\subsubsection{Approximation}

Diminutive formation is not restricted to countable and concrete nouns but also occurs with words whose denotative meaning does not logically admit diminution. ${ }^{8}$ Besides their pragmatic functions discussed below, such diminutives express approximation or fuzziness. Thus drayyiž, DIM of draž 'five minutes', may indicate an interval of more-or-less five minutes. The same holds true for ' wayyim, DIM of ' $\bar{a} m$ 'year', which does not necessarily mean less than 365 days.

Another class of adjectives have a semantic content virtually opposite to diminution but fit this category because their diminutives merely downgrade the actual meaning: kbir 'large, big' is a good example. The English equivalent of these diminutives can be roughly translated by adverbs like 'rather, quite, fairly'.

kbayyir 'rather big, not very big, kind of big', DIM of kbir'

rzayyin 'rather cumbersome', DIM of rzin

\subsubsection{Lexicalized diminutives}

Lexicalized diminutives are those which are usually not bound to specific speech situations. They are often semantically no longer linked to their simple forms, which may have become obsolete or even never existed, as in the first example below:

lwiza 'gold coin', labelled as DIM in Singer (1984: 489), but derived from the French coin called Louis d'or.

tahfün 'pretty, cute, charming, lovely' has no apparent simplex; etymologically it is likely related to tuhfa 'bijou, jewel, masterpiece'.

$d w i \bar{d} a$ 'Capellini, a very thin variety of pasta', actually DIM of dūda 'worm'. Noodles of the $d w i d a$ type are a very popular garnish in Tunisian cuisine.

One of the universal features of diminutives is that they often denote a small object that resembles a larger object in shape or use (Jurafsky 1996: 535-536). The few forms found in Tunis Arabic do not carry any connotative meaning, but constitute separate semantic 
items. This is indirectly proved by the fact that at least one can be combined with the adjective 'big', which completely contradicts the real diminutive meaning.

mgirrfa 'teaspoon', DIM of míarfa 'spoon'; the phrase mi்irfa kbira is often used in

recipes.

wriqqa 'slip (of paper)', DIM of warqa 'sheet (of paper)'

Most probably žnina 'garden', which is no longer perceived as the DIM of žnān 'orchard', also belongs to this category (cf. Singer 1984: 495).

Words that denote children's garments which are the small counterparts of similar adult garments are treated here as a subcategory of words expressing smallness.

sriwil 'children's trousers', DIM of sirwāl

ksiwa 'children's dress', DIM of kiswa.

Lexicalized diminutives may also denote objects that are in a metaphorical way similar to those expressed by their simplica:

'əffayyim (< fwayyim) 'nibble, snack', DIM of fumm 'mouth', e.g. kūl 'əffayyim! 'Take a nibble!'

rwayyiq 'gibberish', DIM of rīq 'spittle', e.g. malla rwayyiq! 'What gibberish!'

hwita, DIM of hūta 'fish', is used in the sense of 'pretty girl'; thus young men may say

to each other: šuft hāk il-hwita? 'Have you seen the pretty girl?'

glïbāt 'seeds for snacking', plural of the DIM of qalb 'seed; heart'

\subsection{Pragmatic (connotative) functions}

\subsubsection{Child-centred speech situations}

Most linguistic studies agree that the origin of diminutives is in speech for children (Dressler \& Merlini Barbaresi 1994, Jurafsky 1996). Child-directed speech is ideal for diminutives because they project a sense of endearment and emotional closeness. Typical of child-centred speech are diminutives of body parts, such as.

wdayyna 'ear-DIM'

trima 'bum, botty-DIM'

baššūla 'penis-DIM'10

Another domain of speech for children is the use of diminutives for food and beverages to encourage a child to eat and drink:

šrib il-hlayyba! 'Drink the milk-DIM!"11

kūl il-lhayyma! 'Eat the meat-DIM!'12

Insulting words like šițān 'devil' can be turned into their opposite by using the diminutive, e.g. for a very active, mischievous child:

ha-l-wlid šwîțin 'This boy is a devil-DIM.'

\subsubsection{Forms of address}

Situations where people are directly addressed require politeness or affection or both. Diminutives are of course less employed in very formal speech and thus occur most often in conversations among kin and peers. Interestingly, in Tunis, the diminutives of kinship terms such as $y \bar{a}$ bnayya and $y \bar{a}$ wlayyid are regarded as derogative or are used by parents when displeased with their children. 


\subsubsection{Affective evaluation}

Diminutives modify a proposition in the sense that they express emotions in the broadest sense (Ponsonnet 2018: 2.8). The emotion may be positive or negative, although the latter use is rare in the Arabic of Tunis. Thus, the speaker's choice of the diminutive is often related to his or her subjective joy or pleasure.

mahlā-ha is-smī̌sa! 'How nice the sun-DIM (is today)!'

nrawwah l-dwirt-i 'I go to my (much-loved) house-DIM.'

This usage seems to be especially frequent with beverages and tobacco:

šribt kwayyis tāy 'I drank a cup-DIM of tea.'

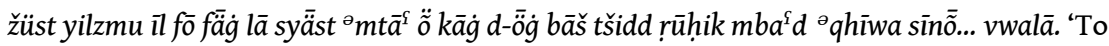
recharge yourself, you just have to take a siesta for a quarter of an hour. Then a coffee-DIM, and that's it!' (Tunico: Talking about Tunis)

Particularly with words belonging to this semantic field, the diminutive of the cardinal number 'one', whayyid FEM whayyda, is used as a kind of analytic diminutive:

nžỉu whayyda šiša! 'Let us bring a hookah-DIM!'

šrabt whayyda kūka. 'I drank a Coke-DIM.'

There is a wide array of domains where diminutives can be employed to elicit sympathy, affection, and harmony. In Tunis Arabic, familiarity or informality are not always a precondition for use of the diminutive, i.e. its pragmatic function cannot only be described as [non-serious]. Dressler \& Merlini Barbaresi (1994: 239) pointed out that here Arabic differs from European languages because diminutives are universally accepted in business transactions in bazars and many shops. ${ }^{13}$ According to our informants, the diminutive is frequently used when one starts negotiating price in a shop. Its use creates a light atmosphere of mutual sympathy that helps to smooth the subsequent bargaining. ${ }^{14}$ qaddāš ha-š-šlayyka 'How much are these slippers-DIM?'

Diminutives occasionally, but not frequently, may express negative feelings like distaste and contempt.

w-hāk il-xdìma lli lqit-ha 'This (damned) job-DIM I have!'

Singer (1984: 489) noted $x$ dima with only its negative meaning of 'miserable job'. However, it may also be used with a positive connotation, as in:

${ }^{3}$ ana nhibb ${ }^{\circ} x$ dimt-i. 'As for me, I love my job-DIM!'

\subsubsection{Hedging and mitigation}

In this section a variety of speech situations will be discussed in which the diminutive is used as a politeness strategy in its widest sense. This includes expressions of modesty and so-called pragmatic hedges for mitigation and attenuation (see Jurafsky 1996: 558).

\subsubsection{Attenuation of unpleasant or boastful statements}

Diminutives are used for mitigation in situations where the speaker tries to avoid harshness, seriousness, or precision, the latter particularly with measures. ${ }^{15}$

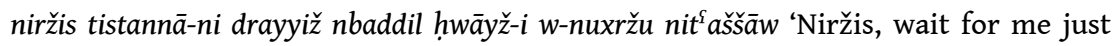

five minutes. I will change my clothes and then we'll go out for dinner.' (Tunisiya)

If one knows that the hearer is a person who does not like walking, the use of the diminutive in the following example suggests that the distance is less than it really is. 


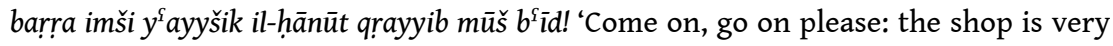

near, not far!'16 The diminutive may also serve to soften a proposition which contradicts ethical or religious norms. When a man tells his wife that last night šribt hwira bira 'I drank a fourpack-DIM of beer', the use of the diminutive makes the drinking of large quantities of alcohol sound less reprehensible.

Diminutives are also used to diminish the perceived seriousness of negative situations. In the next example qlayyib is intended as a kind of euphemism to lessen the anxiety of a person who suffers from a heart disease.

kïfinn-ik? 'āšniyya șahhht-ik? 'āšnūwa qlayyb-ik Brạhīm? 'How are you? How is your

health? How is your heart-DIM, Ibrahim? (Tunisiya)

A person who was unemployed for a long time might say:

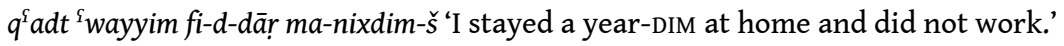

The last example again shows that the interpretation of the diminutive is often contextbased, because the same sentence can be uttered by a young mother who was happy to stay a year at home with her child.

\subsubsection{Softening of commands and requests}

Diminutives as hedging devices are widely used. When asking a favour of someone, the diminutive implies that it is a trifling, unimportant thing that the speaker needs. A diminutive emphasizes the modesty of the request and adds a polite touch that makes it more likely that the request will be successful. ${ }^{17}$ The use of diminutives to soften commands and requests is particularly important as Arabic in general lacks politeness strategies expressed by conditional terms like the English 'may, could, would' etc.

šidd-li blayyșa $y^{\mathrm{f} a y y s ̌-i k ! ~ ' P l e a s e ~ r e s e r v e ~ a ~ n i c e ~ p l a c e ~ f o r ~ m e ! ' ~}$

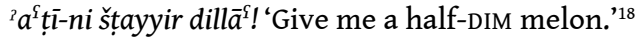

To a waiter in the restaurant one can say:

žỉb-li șhayyin bațāta! 'Bring me a plate-DIM of potatoes!'

The use of a diminutive can also be based on the speaker's assumption that the addressee might refuse the request because of lack of time, as in the following:

sāmaḥ-ni nnažžim naḥki $m^{\varsigma} \bar{a}-k$ drayyiž? 'Excuse me; can I talk five-minutes-DIM with you?' (Tunisiya)

$m a-t x \bar{a} f-s ̌ m \bar{a}-n \bar{i}-s ̌ b \bar{a} s ̌ n t ̦ a w w i l{ }^{~}$ and-i klimtīn ‘Don't be afraid; I will not detain you long.

I only have (to tell you) two words-DIM.' (Tunisiya)

Diminutives are also used to express modesty by downplaying the speaker's possessions or deeds. ${ }^{19}$ In Arab culture this is linked to the belief in the evil eye, which is mostly regarded as the consequence of a grudge. When somebody says šrit $d w i$ ira 'I have bought a house-DIM', the house can be, but is not necessarily, small in size: it is more likely that the person wants to belittle the value of the house, first, to seem modest, and second, for fear of arousing envy. The person who sees this large house for the first time may say:

walla kbayyra mašalla! 'By God, it's (rather) big-DIM, what God wills.'

The use of the phrase mašalla reinforced by the diminutive of the word 'big' reassures the owner of the house that the speaker does not begrudge it. 


\subsubsection{Compassion and empathy} listener or addressee, or for a third person (Dressler \& Merlini Barbaresi 1994: 206-212, Ponsonnet 2018: 2.4).

flisāt-u $\underline{d} \bar{a}^{\varsigma} u$ l-msikin! 'His money-DIM has been lost, the poor chap!'

sākna fi-bbitta șgayyra fi-dār ḥmāt-ha 'She lives in a very tiny room in the house of her mother-in-law.'

\section{Conclusion}

In Tunis Arabic, the use of diminutives serves primarily pragmatic functions and less often denotes smallness on a purely semantic level. Diminutives are more often associated with positive feelings and emotional attachment to a person or an object than with distain or contempt. In contrast to most European languages, there are fewer constraints for the use of the diminutive because it is not restricted to the domains of familiarity and intimacy but can also be used in conversations related to business, particularly in shops or restaurants.

Although the diminutive is certainly a productive morphological category in the Arabic of Tunis, the number of actually used diminutives is decreasing. Singer remarked in the 1980s that many of the forms collected by Stumme (1896: 67-84) more than half a century earlier were no longer known. A similar tendency is mentioned by Cohen (1975: 204), who wrote that "le diminutif n'est véritablement en usage que dans le langage des femmes (et de moins en moins parmi les générations les plus jeunes)." And "Il existe chez les hommes un emploi ironique du diminutif, mais il est beaucoup plus rare, à ce qu'il me parait, que chez les hommes musulmans." Data from recent fieldwork suggests that the number of diminutives has continued decreasing during the past few decades. About 30 per cent of the 251 diminutives listed by Singer (1984: 480-496) ${ }^{20}$ were not known to our informants. ${ }^{21}$ This tendency is corroborated by our corpus of Tunis Arabic, which contains almost 100,000 words but only five different diminutive forms.

47 A large percentage of the words for which the diminutives presented by Singer were not familiar to our informants denote objects such as tools and buildings, and words related to nature (like 'mountain' and 'tree'). Therefore we may assume that in the contemporary dialect the pragmatic functions of diminutives have gained even more importance compared to the pure diminution which had been previously applied mainly to such objects. Our corpus and the examples from informants suggest that in these cases there is a tendency towards analytic diminution by adding șgayyir $\sim$ żayyir to a noun. Such diminutives are particularly frequent with loanwords, e.g. minibüs ${ }^{\circ} z \dot{g} a y y r a$ 'a small minibus', but also found with nouns that still form an internal diminutive like karhba zǵayyra 'little car' besides krïhba. 


\section{BIBLIOGRAPHY}

Badarneh, Muhammad A. 2007. "The pragmatics of diminutives in colloquial Jordanian Arabic", Journal of Pragmatics 42 (2010). 153-167.

Brustad, Kristen. 2008. "Drink your milks! -āt as individuation marker in Levantine Arabic", Gruendler B. (ed.), Classical Arabic humanities in their own terms: Festschrift for Wolfhart Heinrichs on his $65^{\text {th }}$ birthday presented by his students and colleagues. Leiden-Boston: Brill. 1-19.

Cohen, David. 1975. Le parler arabe des juifs de Tunis. II: Étude linguistique. The Hague-Paris: Mouton. Dressler, Wolfgang U. \& Merlini Barbaresi, Lavinia. 1994. Morphopragmatics: Diminutives and intensifiers in Italian, German, and other languages. Berlin-New York: M. de Gruyter.

Lahrouchi, Mohamed \& Ridouane, Rachid. 2016. "On diminutives and plurals in Moroccan Arabic", Morphology 26 (3-4), 453-475.

Jurafsky, Daniel. 1996. "Universal tendencies in the semantics of the diminutive", Language 72. 533-578.

Leitner, Bettina. 2018. "Khuzestan Arabic and the discourse particle ča.", In this volume.

Maalej, Zouhair. 2010. “Addressing non-acquaintances in Tunisian Arabic: A cognitive-pragmatic account”, Intercultural Pragmatics 7. 147-173.

Marçais, William \& Guîga, Abderrahmân. 1958-1961. Textes arabes de Takroûna. II: Glossaire. 8 vols. Paris.

Masliyah, Sadok. 1997. “The diminutive in spoken Iraqi Arabic”, Zeitschrift für Arabische Linguistik 33. 68-88.

Ponsonnet, Maïa. 2018. “A preliminary typology of emotional connotations in morphological diminutives and augmentatives", Studies in Languages. Special issue on Morphology and emotions across languages (forthcoming).

Ritt-Benmimoun, Veronika. 2018. "Diminutives in South Tunisian Bedouin dialects: A formal and pragmatic analysis.” Wiener Zeitschrift für die Kunde des Morgenlandes 108, 181-228.

al-Rojaie, Yousef Ibrahim. 2012. "Diminutives in Najdi Arabic: An account of socio-pragmatic variation." Journal of Human and Administrative Sciences 1. 9-35.

Singer, Hans-Rudolf. 1984. Grammatik der arabischen Mundart der Medina von Tunis. Berlin-New York: de Gruyter.

Stumme, Hans. 1896. Grammatik des tunisischen Arabisch nebst Glossar. Leipzig: Hinrichs.

Taine-Cheikh, Catherine. 1988. "Les diminutifs dans le dialecte arabe de Mauritanie”, Al-Wasit 2. 89-118.

Taine-Cheikh, Catherine. 2018. "Expressiveness and evaluation in Arabic: the singular development of the diminutive in Hassāniyya Arabic", Studies in Languages. Special issue on Morphology and emotions across languages. (forthcoming)

Trabelsi, Chedia. 1991. "De quelques aspects du langage des femmes de Tunis", International Journal of the Sociology of Language 87. 87-98. 
Watson, Janet C. E. 2006. “Arabic morphology: diminutive verbs and diminutive nouns in San'ani Arabic”, Morphology 16. 189-204.

\section{Online sources}

Tunisiya - Tunisian Arabic Corpus: http://www.tunisiya.org/

TUNICO - https://tunico.acdh.oeaw.ac.at

\section{NOTES}

1. At the conference in Marseille the paper was presented in association with Veronika RittBenmimoun. Her findings, that also include remarks on the differences between bedouin and urban dialects, are published under the title "Diminutives in South Tunisian Bedouin Dialects: A Formal and Pragmatic Analysis" in Wiener Zeitschrift für die Kunde des Morgenlandes 108 (2018), 181-228.

2. Occasionally information from other sources was added, particularly from Stumme 1896, Marçais \& Guîga 1958-1961, and Cohen 1975.

3. Special thanks goes to our lecturer on Tunisian Arabic at the Department of Oriental Studies, Mag. Ines Mannoubi, who patiently answered my numerous questions on the diminutives.

4. A typical feature is the lack of any reflexes of the CA pattern fur ${ }^{\mathrm{a}}$ ayl. For more details cf. Singer 1984: 481-484.

5. This suffix is also attested for several Eastern dialects, e.g. in Iraq and Khuzestan (Masliyah 1997: 72; Leitner 2018 in this volume). It probably has an Aramaic origin.

6. These approaches have yet been rarely applied to Arabic dialects. Among the few exceptions are M.A. Badarneh 2010, Y.I. al-Rojaie 2012, and C. Taine-Cheikh 2018 who have made use of these methods in their articles on diminutives in Jordan, Najd, and Mauritania, respectively.

7. Cf. Latin parvus and parvulus, Italian piccolo and piccolino.

8. See also Dressler \& Merlini Barbaresi 1994: 122.

9. Cf. the Italian grandottino. Marçais \& Guîga (1958-1961: 3362) mention that kbayyir is used for children and animals in the sense of 'grandelet'.

10. The DIM zbayyib, however, is not used for addressing children, but euphemistically to avoid the word zibb 'penis', which is regarded as vulgar.

11. Cf. the use of hlïbāt '(literally) milks' in Syrian Arabic in Brustad 2008.

12. The equivalent of 'Eat your foodie!' is expressed by the verb mamma!

13. However, this is not the case in South Tunisian dialects, cf. Ritt-Benmimoun 2018: 202-205.

14. The informants did not confirm the statement in Dressler \& Merlini Barbaresi (1994: 239) that the use by the buyer of the diminutive of the object under price negotiation is meant to indicate the object's inferior value and that it therefore should have a lower price.

15. Cf. Dressler \& Merlini Barbaresi 1994: 238.

16. The same sentence may be used when the speaker only wants to emphasize that the shop is very close.

17. For a detailed discussion of the topic cf. Chapter 3.5.10 in Dressler \& Merlini Barbaresi 1994.

18. Singer (1984: 484) claims that the diminutive štayyir means something like 'the smaller half of'. This was not corroborated by our informants.

19. Cf. Badarneh (2010: 163): "The use of the diminutive as a minimizing hedge extends to its use to minimize one's good deeds or gestures toward others when talking about these acts in front of others, as a way of showing one's modesty and avoiding self-praise or bragging."

20. The complete list can be generated from our TUNICO dictionary by searching for "diminutive." in the "subc" category (https://vicav.acdh.oeaw.ac.at). 
21. The female informant (aged 41) did not recognize 81 forms, the male informant (aged 23) 69 forms.

\title{
ABSTRACTS
}

This paper presents a short overview of the formal aspects of diminutive forms used in the dialect of Tunis and discusses whether or not the diminutive can still be regarded a productive morphological category. Based on the approach of comprehensive studies on the topic, such as Dressler \& Merlini Barbaresi 1994, Jurafsky 1996, and Badarneh 2007, both the semantic and the pragmatic functions of diminutives are discussed in detail. It was found that the number of diminutives actually used has decreased during the past century. Moreover, it seems that diminutives serve primarily pragmatic functions and less often denote smallness on a purely semantic level. Our data further suggests that in Tunis diminutives are more often associated with positive feelings than with contempt and ridicule. The use of the diminutive is not restricted to the domains of familiarity and intimacy but is also appropriate in more formal settings, such as conversations in shops or restaurants.

\section{INDEX}

Keywords: diminutive, Tunisian Arabic, pragmatics, semantics

\author{
AUTHOR \\ STEPHAN PROCHÁZKA \\ Institute of Oriental Studies, University of Vienna, Spitalgasse 2/4, A-1090 Vienna, Austria; \\ stephan.prochazka@univie.ac.at
}




\title{
Les pseudo-verbes dans le dialecte de Benghazi : valeurs possessives et non possessives
}

\author{
Aisha Saad
}

\section{NOTE DE L'AUTEUR}

Les exemples étudiés dans cet article sont extraits d'un corpus oral enregistré à Benghazi en 2015.

Cette étude fait partie de mon travail de thèse (en préparation) dirigé par Samia Naïm que je remercie infiniment pour les échanges d'idées toujours enrichissants, pour ses conseils précieux et pour le temps qu'elle a consacré à la relecture de cet article. Je remercie également Adam Benkato et Christophe Pereira pour leurs remarques pertinentes et leur aide bienvenue.

\section{Introduction}

1 Dans son travail sur être et avoir, Benveniste (1966:195) souligne que "kāna l-, " être à", représente en arabe la seule équivalence possible de "avoir" ». Cohen (1982-1983) note que la relation de possession est définie dans les langues sémitiques par des prépositions dont le choix de l'une d'elles porte des nuances. Ces prépositions nommées " prédicatoïdes » ou " pseudo-verbes », tiennent le rôle d'un prédicat dans des énoncés non-verbaux (cf. Cohen 1975, Hagège 1982). Ces pseudo-verbes sélectionnent donc les arguments et permettent d'exprimer la possession, l'appartenance et l'accompagnement en tant que prédicat et marquent par ailleurs la valeur périphrastique. ${ }^{1}$ 


\section{Valeurs possessives}

2 Nous envisageons la construction possessive dans le dialecte de Benghazi par des schèmes cognitifs (Heine 1997). Suivant ces schèmes, le possesseur (désormais X), considéré comme le point de référence (Creissels 2006 : 143) est lié à l'élément possédé (désormais Y) par des relateurs. Selon le type de relateur, nous distinguons trois catégories de relation possessive à savoir locatives (1.1.), comitatives (1.2), et datives (1.3).

\subsection{Les relateurs locatifs}

\subsubsection{Le relateur 'ind}

3 'ind est le relateur possessif le plus utilisé dans le dialecte de Benghazi. Il revêt plusieurs valeurs. Dans un énoncé non verbal, il subit les contraintes de l'ordre des mots et de la définitude (Cohen 1975, Comrie1986). La construction possessive (1) avec 'ind se réalise par la focalisation du prédicat « 'ind- » et par l'indéfinitude du sujet (Ibid.).

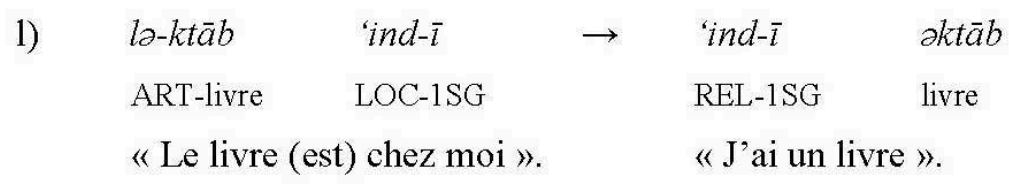

Dans le dialecte de Benghazi, comme dans d'autres dialectes arabes, la construction possessive avec 'ind est représentée selon ce schème : chez X (est) Y (cf. Naïm 2003). Ce prédicatoïde permet d'exprimer toutes les notions sémantiques de possession : aliénable, inaliénable et abstraite. Il est attesté dans les constructions métaphoriques où $Y$ est représenté par une partie du corps (2) qui est nécessairement indéfini.

2) ind-a $a k t u \bar{f}$

REL-3SGM épaules

« Il connaît des gens importants ».

\subsubsection{Le relateur $f i ̄$}

5 fi est un locatif qui se distingue de la préposition 'ind par le fait qu'il réfère à un objet localisé dans un contenant bien délimité (3). Le possesseur est nécessairement représenté par un pronom affixe suffixé au relateur fi (4) dans l'ordre : Dans $X$ est $Y$. 
3) $\quad f i-l-h \bar{o} \check{s}$

fì $\quad b \bar{a} b \bar{e} n$

PREP-ART-maison EXT deux portes

« Dans la maison, il y a deux portes ».

4) $\quad \partial l-h \bar{o} \check{s}$

$f_{i}-h \quad b \bar{a} b \bar{e} n^{*}$

ART-maison REL-3SGM deux portes

« La maison a deux portes ».

*bī peut remplacer $f \hat{l}$ dans cette structure possessive : $a l-h \bar{o} s ̌ s \bar{b} b \bar{a} b \bar{b} n$.

6 L'emploi possessif de fĩ implique que X soit inanimé. En revanche, lorsque le possesseur est animé, la relation attestée est de type attributif (5).
5) $\quad f_{i}-h a$
$\partial \check{S}-\check{s} \partial$ 'ar
$m \bar{a}-s ̌ \bar{a}-l l l a \bar{h}$
REL-3SGF ART-cheveux
ainsi-vouloir-ACC-3SGM-Allah

«Elle a des cheveux/mashaAllah : elle a de beaux cheveux ».

\subsection{Les relateurs comitatifs}

\subsubsection{Le relateur $m^{\prime} a$}

7 L'encodage avec le relateur possessif $m^{\prime} a$ implique le paramètre de la contiguité spatiale (Naïm 2003: 362) selon lequel l'élément possédé est présent physiquement avec le possesseur lors de l'énonciation suivant cet ordre: avec $X$ (est) $Y$. Notons que pour désigner la possession, le terme possédé introduit par le relateur $m^{\prime} a$ doit obligatoirement être inanimé (6), alors qu'avec un terme animé, on obtient un sens d'accompagnement (7) :
6) $\quad 2 m^{\prime} \bar{a}-k$
maftāh
as-sayyāra?
REL-2SGM clé
ART-voiture

«As-tu la clé de la voiture sur toi ?».

7) $a m^{\prime} \bar{a}-k \quad h a d d$ ?

avec-2SGM quelqu'un

«Il y a quelqu'un avec toi ? ».

$m^{\prime} a$ n'est donc pas compatible avec la possession inaliénable et son usage possessif dans le dialecte de Benghazi est occasionnel. En effet, il apparaît le plus souvent sur les marchés sous l'influence des commerçants égyptiens, comme dans (8): 


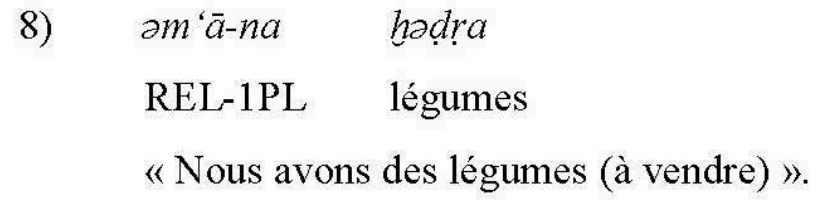

\subsubsection{Le relateur $b \bar{i}$}

9 La construction possessive avec le relateur bī prend une forme structurelle différente de celles attestées en arabe classique, ainsi que dans les travaux sur les dialectes arabes maghrébins et orientaux (cf. Marçais 1977 : 216, Feghali 1928 : 941). Toutefois, cet emploi est attesté dans certains dialectes arabes, comme ceux de Mauritanie en Hassāniyya (Taine-Cheikh 2006), du Tchad et de Sukriyya (Procházka 1993 : 109).

10 bì encode différentes notions de possession; aliénable, inaliénable et abstraite suivant l'ordre X (est) avec Y. Son emploi sert à encoder deux relations dont l'une est possessive : l'exemple (9) montre que bī combine la valeur possessive et la notion d'accompagnement, alors que (10) révèle que $b \bar{i}$, à part sa valeur possessive, sert à exprimer une valeur pragmatique, celle d'attribuer un bien à une personne avec une intention subjective ${ }^{2}$ :

9) $\begin{array}{llll}b \bar{a} t-\bar{l} & \text { məzawwวž } & w u & b \text {-' } \bar{a} \text { 'ilt-a } \\ \text { père-1SG marié } & \text { et } & \text { REL-famille-3SGM }\end{array}$
«Mon père est remarié et a (sa deuxième) famille (qu'il ramène dans le même logement que le nôtre) ».

$\begin{array}{lllll}\text { 10) hū -ya ayy } \bar{u} b & \text { hatta } & \text { huwwa } & b \text {-murattab-a } \\ \text { frère-1S Ayoub } & \text { même } & \text { lui } & \text { REL-salaire-3SGM } \\ w u \quad b \text {-sayyārt-a } & \text { wu } & b \text {-šaggt- } a & \\ \text { et } & \text { REL-voiture-3SGM } & \text { et } & \text { REL-appartement-3SGM }\end{array}$

«Mon frère Ayoub a lui aussi un salaire, une voiture et un appartement »

\subsection{Les relateurs datifs}

\subsubsection{Le relateur $\pi^{3}$}

11 lī est, dans le dialecte de Benghazi, le relateur datif par excellence. Il sert à exprimer la relation d'appartenance suivant l'ordre $Y(e s t) \grave{a} X$. Il peut encoder des relations variées, notamment les notions aliénables (11). Il a également un usage, même s'il est peu fréquent, de prédicatoïde désignant la possession (12): 
$\begin{array}{llll}\text { 11) } l-k t \bar{a} b & h \bar{a} d a & l \bar{l} & \text { man } \\ \text { ART-livre } & \text { DEM } & \text { DAT } & \text { qui }\end{array}$

« À qui (est) ce livre? ».

12) ma'aš $l \bar{l}-y a$

hadd fi

bang்āzi

NEG REL-1SG personne PREP Benghazi

« Je n'ai plus personne à Benghazi ».

\subsubsection{Le relateur šōr}

12 En tant que relateur possessif, šōr est, selon nos connaissances, une particularité libyenne au sein des dialectes arabes. Il n'a été considéré comme possessif qu'en 2014 par Benkato. En revanche, comme préposition locative, ce terme d'origine bédouine (Marçais 1977 : 223) a déjà été relevé par Panetta (1932 : 294) et Iannotta (1933 : 113).

Son usage dans la construction possessive est tardif et implique qu'il y ait un processus de grammaticalisation de sa valeur locative ${ }^{4}$. Nous proposons ci-dessous par des exemples un possible chemin de šōr à partir de sa valeur directionnelle (13) vers son emploi en tant que relateur de possession (16), en passant d'un emploi réflexif (14) à une valeur modale (15). La valeur possessive de šōr suit l'ordre suivant : Y (est) vers X.
13) $g \bar{a} l$
hayya
nəmรัu
$n^{\prime} a d d \bar{u} \quad \check{s} \bar{o} r$
Dire-ACC-3SGM allez
partir-INC-1PL
aller-INC-1PLvers
$i z ̌ d a ̄ b y a$
Ajdabia
« Il a dit : allez, partons vers Ajdabiya ».
14) git-lāa
'ali šōr-ī
šō $r-\bar{l} \quad n a s i \bar{l} b-\bar{l}$
Dire-ACC-1SG-DAT Ali REL-1SG
REL-1SG
beau-frère-1SG
halāṣ
fini
« Je lui ai dit : Ali, c'est mon affaire, je m'en occupe, c'est mon beau-frère, arrête ! ».
15) al-gahwa dima šorr-ī ind 'at sì $\bar{l}-\bar{l}$
ART-café toujours REL-1SG chez famille oncle-1SG
« Le café, c'est ma spécialité chez ma belle-famille ».

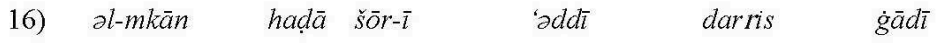
ART-place DEM DAT-1SG aller-IMP te garer là-bas
«Cette place est à moi, gare-toi là-bas ». 
En effet, l'usage le plus connu de šōr dans le dialecte de Benghazi se manifeste dans l'expression « mūš šōr-ī : ce n'est pas mon affaire ». C'est sa forme affirmative qui a donné lieu à la valeur modale: šōr met en relation une entité abstraite avec la sphère

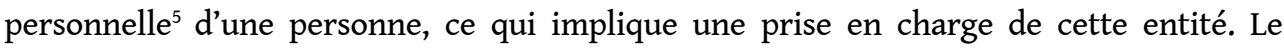
passage de l'emploi réflexif de šōr à l'emploi modal a donné naissance bien évidemment à une valeur d'appartenance.

\section{Valeurs non possessives}

15 Nous retraçons ci-dessous quelques valeurs non possessives que les relateurs réussissent à établir.

\subsection{Valeur existentielle}

16 L'énoncé existentiel dans le dialecte libyen de Benghazi est exprimé au moyen de fi qui assume cette fonction par excellence. Dans les constructions existentielles, le thème est nécessairement indéfini (Freez 1992 :941), comme dans cet exemple :

$$
\begin{aligned}
& \text { 17) fì abbahāt yihtamm- } \bar{u} \quad \text { bi-l-'yāl } \\
& \text { EXT pères s'occuper-INC-3PL PREP-ART-enfants } \\
& \text { « Il y a des pères qui s'occupent bien de (leurs) enfants ». }
\end{aligned}
$$

17 Dans le dialecte de Benghazi, les constructions existentielles peuvent être également exprimées par le relateur 'ind sans que l'indéfinitude soit une contrainte :

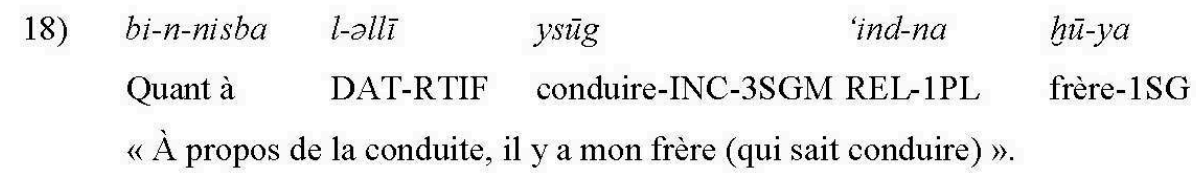

\subsection{Valeur expérientielle}

On entend par des énoncés expérientiels des énoncés qui renvoient à l'état de l'expérient. 'ind est le relateur le plus fréquent pour exprimer cette valeur, et il est compatible avec tous les types de maladies, c'est-à-dire passagères ou permanentes : 'ind-ī harāra « j'ai de la fièvre », 'ind-ī əd-daġ $t$ « j'ai de la tension ».

19 Lorsque 'ind se combine avec un terme défini désignant un organe intérieur du corps, contrairement à ce que nous avons vu dans (2), l'ensemble sert à marquer un sens expérientiel, tel que : 
$\begin{array}{lll}\text { 19) waliyya } \quad \text { ind-ha } & \text { l-gạlub } \\ \text { femme } & \text { REL-3SGF } & \text { ART-cour } \\ \text { «C'est une femme qui a une maladie cardiaque ! ». }\end{array}$

Quant au relateur fi, il est opérationnel dans des contextes de maladies chroniques, tel que le diabète :

20)
hatta
$\check{z}$ att $-\bar{l}$
$f_{i}-h \bar{a}$
as-sakkar
même
grand-mère-1SG
REL-3SGF
ART-diabète
« Ma grand-mère est aussi diabétique ».

21 Un troisième relateur est attesté dans le parler de Benghazi, il s'agit de bì qui sert à décrire l'état de santé d'une personne :
21) kwayys
$b-s \partial h t-a$
sallam
'alayya
bien
REL-santé-3SGM
saluer-ACC-3SGM
PREP-1SG
« Il est en bonne santé, il m'a salué ».

\subsection{Valeur modale}

Cette valeur modale est assurée par trois relateurs, à savoir šōr, 'ind et fi dont chacun exprime une notion modale : šor (15) donne le sens de la prise en charge alors que 'ind montre différentes valeurs modales avec deux structures syntaxiques différentes (2.3.1.). Quant au relateur fi (2.3.2.), il apporte une nuance modale située entre des notions différentes comme l'hésitation et l'interdiction.

\subsubsection{Le modal 'ind}

\subsubsection{1. 'ind + construction nominale}

Selon cette structure 'ind est suivi soit d'un substantif, soit d'une construction nominale pour exprimer la modalité déontique (22), la modalité subjective (23), la modalité aléthique (la non-permission) (24) et l'obligation avec un sujet inanimé (25) :
22) ind-a
tahlīl
'āhar
amtā'
$m a ' d a$
REL-3SGM
analyse autre
GEN
estomac
«Il doit faire une autre analyse de l'estomac ».
23) $m \bar{a}-$ 'ind-ī-š rag̉ba fi-t-ta'tīm
NEG-REL-1SG-NEG envie PREP-ART enseignement
« Je n'ai pas envie de travailler dans l'enseignement ». 
$\begin{array}{lllll}m \bar{a}-' i n d-n \bar{a}-\grave{s} & \text { banāt } & \text { yat l'an } & \text { 'agāb } & \text { al- } l \bar{e} l \\ \text { NEG-REL-1PL-NEG } & \text { filles } & \text { sortir-INC-3PL } & \text { fin } & \text { ART-nuit }\end{array}$

« Nous ne permettons pas à nos filles de sortir trop tard le soir ».

\begin{tabular}{|c|c|c|c|c|c|}
\hline 25) & $a z-z a k \bar{a}$ & 'ind-ha & wagt & yōmèn & $g a b l$ \\
\hline & ART-aumône & REL-3SG & temps & jour-2 & avant \\
\hline
\end{tabular}

( Il faut donner l'aumône deux jours avant l'Aïd ».

\subsubsection{2. 'ind + NEG + Interrogatif + Verbe}

24

'ind sert aussi à présenter la modalité lorsqu'il est précédé d'une particule de négation et suivi d'un interrogatif et d'un verbe. Dans les constructions modales exprimées ci-dessous les interrogatifs dont 'alīš, wēn, kē f véhiculent des sens différents et une valeur modale de l'empêchement. Cette structure composée d'un amalgame de deux propositions sert à exprimer l'absence de l'obligation (26), l'impossibilité (27), l'incapacité mentale (28) et l'impossibilité matérielle (29).

26) $m \bar{a}$-'ind-ak talī̌s təžr

NEG-REL-2SG pourquoi courir-INC-2SG

«Tu n'es pas obligé de courir ».

27) kān tog'ad waliyya mā-'ind-ha wēn athušš EXPT COP femme NEG-REL-3SGF où entrer-INC-3SGF

« Si c'était une femme (qui avait sonné), elle n'aurait pas pu entrer ».

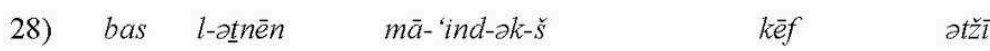

mais ART- deux NEG-REL-2SGF-NEG comment venir-INA

$m^{\prime} \bar{a}-h u m$

CONC-3PL M

" Mais, en tout cas, tu ne sais pas quoi faire avec les deux ». (Deux parties politiques)

29) $m \bar{a}-f-\bar{t} \breve{s}$

sayyāra

$m \bar{a}-$ 'ind $-\bar{l}$

NEG-EXT-NEG

voiture

NEG-REL-1SG

$k \bar{e} f$

namš̄i-l-hum

aller-INC-1SG-PREP-3PLM

«Il n'y a pas de voiture, je ne peux pas y aller».

\subsubsection{Le modal $f \bar{\imath}$}

En ce qui concerne le relateur fĭ, il sert à exprimer le conseil dans cet énoncé : 
30

\begin{tabular}{|c|c|c|c|}
\hline$m \bar{a}-f i-k \bar{\imath}$ & $m \bar{a}$ & $m s ̌ e ̄ t-i$ & halli $-k \bar{l}$ \\
\hline NEG-REL-2SGF & quoi & aller-ACC-2SGF & laisser-IMP-2SGF \\
\hline$g \bar{a} \cdot d \bar{a}$ & & & \\
\hline rester-INC-2SSF & & & \\
\hline
\end{tabular}

\subsection{Valeur attributive}

La valeur attributive est accordée par les relateurs lorsqu'ils se combinent avec des substantifs dénotant une qualité ou un défaut.

\subsubsection{L'expression d'une qualité}

La qualité morale est exprimée par les relateurs bī (31) et 'ind $(32)^{6}$ :
31)
rāžal
homme
muhtaram
$b$-'agl-a
homme
respectant
REL-esprit-3SGM

«C'est un brave homme, sage ».*

*Cette notion d'attribution ou d'association avec le relateur $b \bar{l}$ a été déjà signalée par Marçais (1977 :216) dans : «ṛāğal b- 'āql-u: un homme doué de bon sens ».
32)

$\begin{array}{lllll}\text { 'ind-a was'et } \quad \text { l-bāl } & \text { hanūn wu tayyib } \\ \text { REL-3SG ampleur } & \text { ART-esprit } & \text { tendre et } & \text { gentil } \\ \text { "Il est patient, tendre et gentil ». } & & \end{array}$

\subsubsection{L'expression d'un défaut}

Le défaut peut être exprimé par le relateur 'ind à condition que celui-ci soit suivi de la préposition 'ala « sur » comme dans (33):

$\begin{array}{lcccc}\text { lahbōt } & y \bar{a} & r \bar{a} z ̌ a l & \text { 'ind- } a & \text { 'a-l-lahboțta } \\ \text { Trompeur } & \text { oh } & \text { homme } & \text { REL-3SGM } & \text { PREP-ART-tromperie }\end{array}$

«Tiens, il est trompeur, il a l'habitude de tromper les autres! »

Le défaut est également exprimé par $m^{\prime} a$ (34) avec un degré d'intensité différent de celui exprimé par 'ind-'ala : avec le relateur $m^{\prime} a$, le défaut est moins marqué :
$m^{\prime} \bar{a}-h$
ad-duwwa
$w u-l-k a \underline{d} a b$
REL-3SGM ART-parole et-ART-mensonge
" Il peut être indiscret et menteur". 
Le défaut se considère par ailleurs quasi-constitutionnel de la personne et est beaucoup plus marqué avec l'usage du relateur šōr :

35) al-'èn

ART-œil šor $r-h a$

REL-3SGF al- 'èn

ART-œil

« Le mauvais œil est sa spécialité, c’est elle qui le porte en elle ».

Quant au relateur fi, il est compatible avec les qualités et les défauts :

$\begin{array}{llllc}h \bar{a} \underline{d} \bar{\imath} & \text { șarrāga } & f_{\bar{l}}-h a & \text { hașla } & \text { šena } \\ \text { DEM } & \text { voleuse } & \text { REL-3SGF } & \text { comportement } & \text { mauvaise }\end{array}$

«Elle est voleuse, c'est son défaut ».

\subsection{Valeur empathique}

On entend par valeur empathique, un emploi dans lequel le relateur prend une position thématique dans l'énoncé afin de véhiculer l'empathie et signaler l'implication et l'affectation (cf. Boisson 1987) du sujet dans la suite de l'énonciation $(\Omega)$, selon l'ordre syntaxique: REL $+\mathrm{SN}+\Omega$. Dans ce type d'énoncé, la tête du syntagme nominal est généralement rattachée à la sphère personnelle du sujet (37) de sorte qu'un terme étant communément hors de la sphère personnelle rend l'énoncé non acceptable (38) :

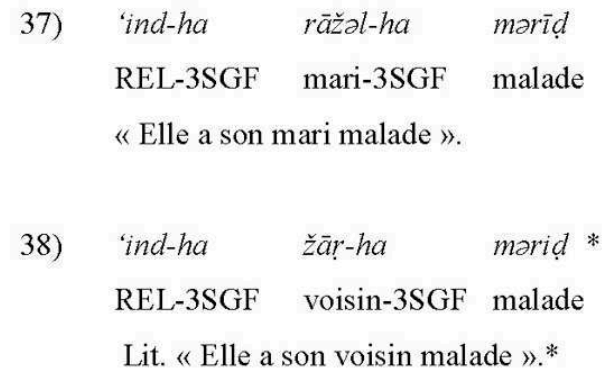

*Nous avons relevé un emploi probablement bédouin du relateur $l \bar{l}$ exprimant cette valeur, avec des termes de parenté sociale tel que nasīban $l-\bar{l}$ « un beau-frère à moi ».

Le relateur $m^{\prime} a$ sert aussi à exprimer cette valeur en étant suivi par l'indéfini wahad. L'ensemble m'a- wahad comme en (39) montre que la personne en question appartient au groupe d'amis ou de collègues et montre par ailleurs que le locuteur est témoin de la situation exprimée par la simple connaissance de la personne.

$\begin{array}{lllll}m \text { 'à-ya } & \text { wāhad } & \text { 'ind-a } & \text { mazra'a } & \text { ġādi } \\ \text { REL-1SG } & \text { un } & \text { REL-3SGM } & \text { ferme } & \text { là-bas }\end{array}$

" Je connais quelqu'un qui a une ferme là-bas ». 


\section{Conclusion}

34

La relation possessive est fonction de $\mathrm{X}$ et $\mathrm{Y}$ et de la nature de chaque relateur. 'ind présente un usage large et omniprésent, alors que fi exprime la relation de partie-tout avec un sujet inanimé. $b \bar{i}$ implique des usages possessifs précis. $b \bar{i}$ et $m^{\prime} a$ sont des comitatifs qui suivent des schèmes cognitifs différents. lī présente un emploi datif plus vaste que šōr qui est en évolution sémantique dans le dialecte, accompagnée d'un processus de grammaticalisation. Les six relateurs partagent des valeurs périphrastiques qui ne sont pas étrangères à leurs emplois originels. Les relateurs d'origine locative sont les plus modulables et les plus employés avec différentes valeurs notamment en tant que modaux.

\section{BIBLIOGRAPHIE}

Benkato, A. 2014. The Arabic Dialect of Benghazi (Libya): Historical and Comparative Notes. Zeitschrift für Arabische Linguistik 59, 57-102.

Benveniste, E. 1966. Problème de linguistique générale. Paris : Gallimard.

Boisson, C. 1987. « Anglais have, français avoir et l'empathie ». La transitivité, domaine anglais, Travaux du CIEREC LII, université de Saint-Etienne, 155-180.

Cohen, D. 1975. « Phrase nominale et verbalisation en sémitique ». Mélanges linguistiques offerts à Emile Benveniste, Paris. 87-98.

" Hébreu, araméen et sémitique comparé ». École pratique des hautes études. 4e section, sciences historiques et philologiques. Livret 2. Rapports sur les conférences des années 1981-1982 et 1982-1983. 1985. 58-59

Comrie, B.1986. «The Possessive Predicate in North Vernacular Arabic ». The Fergusonian Impact, Volume 1, From Phonology to Society, Mouton de Gruyter Berlin. New York. Amsterdam, 197-210

Creissels, D. 2006. Syntaxe générale, une introduction typologique 1, catégories et constructions. Lavoisier.

Feghali, M. 1928. Syntaxe des parlers arabes actuels du Liban (Bibl. de l'École des Langues orientales vivantes), Paris.

Freeze, R.1992. « Existentials and Other Locatives », Language 68, 553-95.

Hagège, C. 1982. La structure des langues. Paris : Presses universitaires de France.

Heine, B. 1997. Possession: Cognitive Sources, Forces, and Grammaticalization. Cambridge University Press.

Iannotta, E. 1933. L'arabo parlato in Cirenaica: nozioni di grammatica, vocaboli vari, saggio di composizioni beduine in prosa e in versi. Bengasi: Litografia del Governo, Governo della Cirenaica, Ufficio Studi, Tip. Pavone 
Marçais, P. 1977. Esquisse grammaticale de l'arabe Magrébin, Paris : Librairie d'Amérique et d'Orient.

Naïm, S. 2003. « La prédication possessive et l'émergence d'Avoir en arabe oriental ». Bulletin de la Société de linguistique de Paris, 98 (1), 359-383.

2009. «Possessive Genitive, Dative Construction and TAM Categories ». Journal of Semitic Studies, Oxford University Press (OUP), 181-194.

Panetta, E. 1943. L'arabo parlato a Bengasi. I Testi con traduzione e note. II Grammatica (Grammatiche e lessici delle lingue dell'Africa italiana). 2 vols. Rome, Libreria dello Stato.

Prochazka, S. 1993. Die Präpositionen in den neuarabischen Dialekten, Wien : VWGÖ.

Taine-Cheikh, C. 2008. « De l'expression de la cause et de la causalité dans l'arabe de Mauritanie ", Procházka, Stephan \& Ritt-Benmimoun, Veronika (eds.), Between the Atlantic and Indian Oceans. Studies on Contemporary Arabic Dialects. Proceedings of the 7th AIDA Conference, held in Vienna from 5-9 September 2006. Wien: Institut für Orientalistik der Universität Wien. 423-436.

\section{NOTES}

1. Par l'emploi périphrastique, nous faisons allusion à Benveniste (1966).

2. Son usage est fréquent lorsque nous faisons l'éloge d'un prétendant, par exemple.

3. Pour décrire la construction dative, nous nous sommes inspirée de Naïm (2009)

4. Cette question sera l'objet d'une publication ultérieure.

5. Cette notion a été créée par Bally (1926) et développée par Creissels (1979) pour déterminer la relation de l'association des entités à la sphère personnelle d'un individu.

6. Le relateur lī sert aussi à marquer une qualité valorisante telle que dans la-h gader «à lui une valeur ».

\section{RÉSUMÉS}

Cet article vise à étudier les valeurs possessives et non possessives des pseudo-verbes (désormais des relateurs) présentes dans le dialecte de Benghazi. L'ensemble des dialectes maghrébins, dont le dialecte de Benghazi fait partie, emploient le relateur 'ind dans la construction possessive. Néanmoins, les Benghaziens expriment aussi la possession par plusieurs autres relateurs qui ont à l'origine des valeurs différentes : comitative, dative, directionnelle et locative. Ces relateurs ont subi une évolution sémantique qui leur permet d'être employés comme expérientiels ('ind, $f i, b \bar{i}$ ), existentiels ( $f i$, 'ind), modaux ('ind, šōr, fì) et attributifs ('ind, šōr, bi, fī, $m^{\prime} a$ ). Le recours à tel ou tel relateur dépend de facteurs sémantiques et syntaxiques. Nous nous interrogeons dans cet article sur la différence entre les relateurs dans leurs emplois possessifs et dans les valeurs qu'ils visent à remplir sous une perspective cognitive. 
INDEX

Mots-clés : pseudo-verbes, localisation, possession, sphère personnelle, modalité, valeur périphrastique.

\section{AUTEUR}

AISHA SAAD

Paris III - LACITO 


\title{
On Pragmatics of Circumstantial Clauses in Egyptian Proverbs
}

\author{
Tatyana Savvateeva
}

\section{Problem Formulation as an Introduction}

1 The research of the structure of Egyptian proverbs reveals some questions about syntax and pragmatics of utterances which the first part may be represented by a clause (subject + predicate) (1) or a noun phrase (a word combination (2) or a single word (3)) and the second part - by a subordinate clause which is connected with the first part by $w(i)$ conjunction.

In the present article, we make an attempt to identify the type of syntactic structure that those clauses represent: whether it is a circumstantial clause or a clause of another syntactic type. By having analyzed a number of proverbs we managed to detect the following typical formal structure (or so-called typical syntactic scheme):

TOPIC (Syntax Structure A) + w(i)- + COMMENT (Syntax Structure B).

(1)

a. ibn-u 'ala kitf-u w-huwwa dāyir yidawwar 'alī-h (Badawi \& Hinds 1986: 736)

His son is on his shoulders, but he is looking around for him.

[He can't see what is under his nose.]

b. 'ummu 'ayyāša wi-'āmil bāša (Taymour 1986 - 5371)

His mother is a baker, and he acts like a lord (lit. "a pasha").

'uxt-u fi-l-ḥāra wi-‘āmil 'amāra (al-Baqli 1987 - 71)

His sister [lives] in a poor neighborhood, and he acts like an emir.

[He is of a poor origin, but puts on airs.]

c. bātit ga'āna w-gūz-ha Habbāz (al-Baqli 1987 - 361)

She went to sleep hungry although her husband is a baker.

bātit 'iryāna w-gūz-ha Ḩayyāṭ (al-Baqli 1987- 362)

She went to sleep naked although her husband is a tailor.

bātit 'ațšāna w-gūz-ha saqa (al-Baqli 1987 - 363)

She went to sleep thirsty although her husband is a water carrier.

[One does not have something that he should have by his occupation.]

d. yumūt iz-zammār wi-ṣba'-u b-yil'ab (Mahgoub 1968 - 894) 
A musician dies, and his finger plays.

[He is a master of his occupation.]

e. iš-šarr(i) bi-š-šarr(i) wi-l-bādi 'aẓlam (Mahgoub 1968 - 148)

An evil for an evil, but the one who starts is more of a tyrant.

[The one who starts the evil is responsible for its consequences.]

f. 'aftikir-l-ak 'îh bașala w-kull(i) 'aḍda b-dam'a (al-Baqli 1987 - 147)

What should I think of you, oh onion, if each bite is accompanied by tears?

[One judges someone/something based on the results of their interaction.]

(2)

kull(i) ta'Hīra w-fī-ha Hīr (Badawi \& Hinds 1986: 11)

In every delay there is something good.

[Every delay contains some benefit.]

kull(i) ‘uqda w-la-ha ḥallāl (Mahgoub 1968 - 650)

Each knot has someone who unties it.

[Every problem is solved by someone.]

kull(i) waqt(i) w-lu-u 'adān (Mahgoub 1968 - 660; Badawi \& Hinds 1986: 17)

Each time has its azan.

[Everything is in its own time.]

kull(i) fūla wi-l-ha kayyāl (Taymour 1986 - 2391)

Every bean has someone who weighs it.

[Everything has someone to take care of it.]

kull(i) kilma wi-l-ha mradd (Taymour 1986 - 2396)

Every question (lit. word) has an answer.

[Everything that is said is followed by an answer/a feedback.]

(3)

halla w-huwwa maġrafit-ha (Badawi \& Hinds 1986: 620)

A cooking pot and he's its ladle.

[He knows the matter through and through.]

hasana wa-ana sīda-k (Taymour 1986 - 1063)

Alms and I am your mister.

[The poor man should rely on the charity of the rich man who becomes his mister.]

humāâr wa-di(i) dīl-u (Taymour 1986 - 1102)

A donkey and this is his tail.

[One's sin is obvious.]

zabbāl wi-f-īd-u warda (Mahgoub 1968 - 441)

A garbage man but there is a rose in his hand.

[A contradiction between the expected and the reality.]

'arnab wi-b-yākul laḥm (al-Baqli 1987 - 102)

A hare and eats meat. [An unnatural contradiction.]

'aḥdab wi-yšaqlib (al-Baqli 1987 - 60)

A hunchback and somersaults. [An unnatural contradiction.]

šāyib wi-'āyib (Mahgoub 1968 - 498)

A grey-head and commits a sin. [An unnatural contradiction.]

4 Although the formal structure of these proverbs is the same, a throughout analysis shows that there is more than one type of semantic relations between two parts of the sentence as the semantic function of the conjunction $w(i)$ - can be different. The modern and medieval Arabic scholars state that there are at least three types of conjunction $\mathrm{w}(i)$ - (AsSuyūṭi 1978: 1211-1214):

- waw al-'atf (a coordinate conjunction as "and" or "but")

- waw al-hāl (a conjunction that introduces a circumstantial clause)

- waw al-qasam (a conjunction that marks an oath)

5 The last type of the mentioned above is not taken into account as it is easily distinguished from the others. It is the first and the second types that cause a problem of their syntactic 
and semantic interpretation. Furthermore, the first type of conjunction $w(i)$ - (coordinate) occurs in the sentence either linking its two parts or opposing them.

\section{Circumstantial Clause in a Proverb: Terminology}

The relations between TOPIC (A) and COMMENT (B) connected by the conjunction $w(i)$ - in the sentence that form a proverb are not necessary that of a main clause and a circumstantial clause. The Syntax Structure B may be represented by a coordinate clause or a subordinate clause (temporal or causal). It is to be underlined that in some cases it is quite hard to distinguish between a circumstantial clause and other options.

7 While looking for a definition of a circumstantial clause, we came to the conclusion that this term is usually used by scholars in Semitic studies while referring to a clause that is known in Arabic grammar tradition as jumla hăliyya. An English term circumstantial clause is mostly used in scientific and academic works on Arabic and Hebrew. According to various sources the definition of circumstantial clause must include the following features:

- it is a subordinate clause ("a clause providing 'background information' on an occurrence described by another clause" [Oren 2013]; it "describes the manner, circumstances, or conditions under which the main clause occurs" [Williams 2007: 176])

- it characterizes the state/qualities of the situation participants or conditions under which the situation occurs

- it has reference with the main clause subject or object (șăhib al-hāal)

- it is hard to distinguish from temporal, causal and concession clauses; "the difference is the matter of emphasis" [Williams 2007: 176] a conjunction $w(i)$ (waw al-hāl) that introduces the clause is optional

8 All in all, a circumstantial clause characterizes a state or condition (hâl - lit. "state, condition") of a main clause subject or object at the moment described in the main clause. Most scholars agree that in Arabic it is used "to express an action or event which took place simultaneously with the situation or event expressed in the main clause" [Woidich 2004: 191]. As for the circumstantial clauses in Egyptian Arabic in general, they can be classified as temporal and modal - based on their function - and according to Woidich's classification there are three types of structure of circumstantial clauses [Woidich 2006: $394-401]$ :

1) main clause + w(i) + Subject + Predicate ['allaha wi huwwa nāzil]

The main clause may or may not contain a verb (jumla ismiyya): ma-fiš hăga smaha g $\bar{u}^{c} w$ inta btur'us.

2) main clause (wi) + Predicate + Subject [rigi` wi ma'ā šanța plastik; țili min hināk ma‘āh iddibloom ikkibir]

3) main clause + Predicate [biyimši yzukk]

9 M. Woidich is interested in the internal structure of circumstantial clauses and gives a thorough analysis of various cases supplementing it with examples, their translation from EA to German and linguistic comments. The present research is mostly focused on the external relations between a main clause and a circumstantial clause in a sentence that forms a proverb.

10 It is common for the non-Arabic speakers for their practical needs to draw a line between two types of jumal hāliyya while using Arabic: temporal CC and modal CC. There is a 
referential coherence (context) between the main clause and the circumstantial clause if the clause is modal; and in case the clause functions as temporal, there is no such coherence. However, the referent does not have to be a subject or an object of the main clause, it could be the whole situation in general.

The English equivalent of what is known in traditional Arabic grammar theory as jumal hāliyya is not quite accurate. It is to be underlined that jumla hăliyya is a substitute of a syntax position called hāl in Arabic: an additional description (wasff fadla) that is mentioned to report about the state of a subject ('ism) that is initially described in the sentence [Al-galāyyīni n.d.: 78]; the meaning of it being additional is that it is not a subject (musnad) or a predicate (musnad ilay-h) of the clause, but it does not mean that the sentence can exist without $h \bar{a} l$ - in some cases it can not ${ }^{3}$.

This position is originally represented by a single word (which is by definition indefinite and accusative) ${ }^{4}$ [Al-galāyyini n.d.: 79, 82-85] as in the proverb rāhat min(i)-l-guzza härbah $q \bar{a} b l \bar{u}$-ha l-magāarbah (Taymour 1986 - 1283) She escaped running from the Turks and she was met by the Moroccans. Thus, any substitute that occurs in this position should be indefinite. However, even in the case when hăl is represented by a single word, this word has a potential of a clause, because it is usually a verb derivative. The subject or object which state of condition it describes (șāhib al-ḥall) are, on the contrary, definite.

Therefore, hăl is not a clause, it is a syntactic position that could be represented by a single word (a participle) or a clause - as any other syntactic position in Arabic sentence. In traditional Arabic grammar hăl is described as a "second predicate" (Habar), or comment, that forms the semantic and pragmatic focus of the sentence [Pak \& Soukhareva 2008: 255]. So, when it occurs in Egyptian paremia, hāl represents the essence of a proverb as in sentence-final position this syntactic structure is shifted to semantic focus.

\section{Circumstantial Clause in a Proverb: Pragmatics}

\subsection{The Internal Structure of a Proverb with a Conjunction w(i)-}

structure of a proverb which contains a conjunction $w(i)$ - is that of three types, COMMENT (B) may accede a clause, a genitive construction or a noun/adjective: CLAUSE + $(w(i)-+$ COMMENT), GC + (w(i)- + COMMENT), N/Adj + ( $w(i)-+$ COMMENT) (see examples (1-3) respectively in paragraph 1$)$.

There are two main problems that should be pointed out regarding these structures.

1) GC + (w(i)- + COMMENT); N/Adj + (w(i)- + COMMENT). Among the proverbs based on these two schemes, we regard only those that cause no doubts in their interpretation in terms of the presence of a circumstantial clause in their syntactic structure. However, even though COMMENT (B) looks like a circumstantial clause, its TOPIC (A) is not represented by a clause.

17 Problem \#1: the question arises on the reason of using the formal structure of jumla hāliyya in a proverb that does not have a main clause in its structure and, therefore, does not formally correspond to the features of hăl mentioned above (hāl is indefinite and accusative, șăhib al-hāal is definite).

In the group of examples (3) a noun normally does not have a definite article, and the circumstantial clause gives such a characteristic to the object that underlines its main 
feature or contradicts it. Coordinating conjunctions normally connect the items that are of the same grammatical type (e.g. words, phrases, clauses). The fact that a circumstantial clause may equally supplement in the sentence a noun or a clause demonstrates that pragmatically this noun is an equivalent of a whole clause. Nevertheless, the syntactic position that this single noun would have in a sentence remains unclear.

2) CLAUSE + (w(i) - + COMMENT)

Problem \#2: to distinguish between a circumstantial clause, a temporal clause and a causal clause; to tell them apart from a coordinate clause.

\subsection{Pragmatic role of a circumstantial clause in a proverb}

The formal structure of an utterance corresponds with its meaning. This approach appeared in the European linguistics in the $20^{\text {th }}$ century, but it did exist in the medieval Arabic linguistics and Arabic rhetoric ('ilm al-baläga).

In our attempt to resolve the problems stated above we propose a linguistic experiment of omitting the conjunction $w(i)$ - in the examples (1-3) in order to compare the meanings of the sentences that we obtain as a result of this experiment with the original utterances (see the pairs in the Tables $1-3$ ).

\section{Table 1}

\begin{tabular}{|c|c|c|}
\hline$i b n-u$ 'ala kitf-u & $w^{-}$ & huwwa dāyir yidawwar 'ali-h \\
\hline $\begin{array}{l}\text { 'aftikir-l-ak }{ }^{-} \text {inh } \\
\text { baș ala }\end{array}$ & $\overline{w^{-}}$ & kull (i) 'ad d a b-damea \\
\hline bātit ga 'āna & $\overline{w^{-}}$ & gūz-ha bu abbāz \\
\hline ' ummu' ayyāša & wi- & 'àmil bāša \\
\hline ibn-u 'ala kitf-u & & huwwa dāyir yidawwar 'alī-h \\
\hline $\begin{array}{l}\text { 'aftikir-l-ak ' in } \\
\text { baș ala }\end{array}$ & & kull (i) 'ad d a b-dam 'a \\
\hline bātit ga 'āna & & guz -ha h $\mathrm{h}$ abbāz \\
\hline ummu 'ayyāša & & 'āmil bāša \\
\hline
\end{tabular}




\begin{tabular}{|c|c|c|}
\hline kull (i) ta' h ira & $\mathrm{w}^{-}$ & fi-ha $h \overline{1} r$ \\
\hline kull (i) 'uqda & $\mathrm{w}^{-}$ & la-ha ḥ allāl \\
\hline kull (i) kilma & wi- & 1-ha mradd \\
\hline kull (i) ta' h îra & & fi-ha $h \bar{i} r$ \\
\hline kull (i) 'uqda & & la-ha ḥ allāl \\
\hline kull (i) kilma & & 1-ha mradd \\
\hline
\end{tabular}

Table 3

\begin{tabular}{|c|c|c|}
\hline zabbāl & $\mathrm{wi}^{-}$ & $\mathrm{f}^{-} \overline{\mathrm{l}} \mathrm{d}^{-} \mathrm{u}$ warda \\
\hline arnab & wi- & b-yākul lah m \\
\hline šāyib & wi- & 'āyib \\
\hline zabbāl & & $f^{-}-d^{-}-u$ warda \\
\hline arnab & & b-yākul lah m \\
\hline šāyib & & ‘āyib \\
\hline
\end{tabular}

We are to compare two cases - represented in examples (1), on the one hand, and in (2), (3) - on the other. By omitting the conjunction, we get two separate clauses that are no longer related to each other. In the second proverb, we even notice that without a referential pronoun the connection between two sentences becomes barely evident. As for the examples in (2) and (3), we notice that without a conjunction they are represented by a simple clause (2) or a noun phrase (3) the structure of which for pragmatic reasons has been changed in a proverb. 
In examples (2) when the conjunction $w(i)$ - is omitted, the general meaning of a proverb remains almost the same, but the expressiveness is reduced significantly. The proverb has a structure of a nominal sentence with a nominal clause as COMMENT. Although the subject does not have a definite article, its uncoordinated attribute specifies its meaning and makes the word combination act like TOPIC. So, by a strictly grammatical means (using hâl to split a nominal clause into what looks like a sentence with a main clause and a subordinate clause) in the proverbs (2) the stylistic diversity and expressiveness are achieved. This proves that when the function of the conjunction is to separate a subject (TOPIC) from a predicate (COMMENT) it is applied as means of strengthening the focus on TOPIC. In addition, the presence of the conjunction $w(i)$ - gives the utterance structural similarity with a subordinate clause. This reveals the pragmatic meanings of simultaneity and complementarity.

If a circumstantial clause is added to a main clause, it occurs in a COMMENT position and, therefore, gives the supplementary meaning to the whole utterance. Moreover, it represents the semantic essence of this utterance, its focus. If a clause is added to a single word or a word combination (in the cases when we assume that the "subordinate clause" is a circumstantial clause) in a proverb, the experiment of omitting this subordinate clause proves that the first part of the utterance can only assert a certain matter of fact. But in this case this single word or a word combination should have a figurative meaning. This is common for phraseological units and paremia (or proverbs): kalb wa-la yiswa (alBaqli 1987 - 1068) A dog, and is worth nothing; 'alìl wi-āmmil midāwi (Taymour 1986 - 1944) A diseased, and acts like a doctor. [One takes care of the others more than he does of himself.]

24 The expressiveness of the utterance in the proverbs such as in (2) and (3) is based on the semantic correlation between the first part of the proverb and a characteristic (a feature) mentioned in the second part:

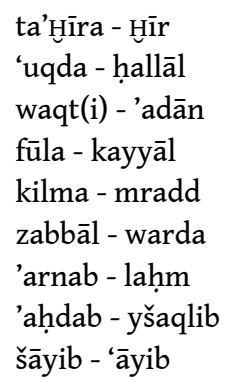

In these word pairs the elements are in a semantic opposition to each other. They are not necessarily complete opposites - in a linguistic meaning of this term - but they somehow contradict each other, the feature is not natural for the subject or opposes it in the given context.

The pragmatic function of a circumstantial clause in a proverb of a syntactic structure GC $+(w(i)-+$ COMMENT); N/Adj + (w(i)-+ COMMENT) is to draw a sentence predicate (Habar) or an attribute to a semantic focus and to emphasize the opposition between the TOPIC and its COMMENT. We may assume that the single indefinite noun at the beginning of a proverb can be a predicate of a noun clause (jumla 'ismiyya) where a subject is left out (the ellipsis occurs). This subject can be returned to its position in a form of a personal pronoun. However, even though this noun is indefinite by its grammar form, it is definite by its pragmatic function and is equal to a clause that reports about a certain situation. This explains the ability of this construction to be changed into a clause with jumla hāliyya for 
a pragmatic reason - the emphasis. If the first part of the proverb did not have such semantic and pragmatic weight, this change could not occur because the subject or object that hāl refers to in the main clause (sāhib al-hâll) has to be definite.

To conclude, the reason of using jumla hāliyya after a noun or a noun phrase is that this syntactic means helps to put an emphasis on a COMMENT in the TOPIC-COMMENT sentence structure.

As for the second problem stated above (to distinguish between circumstantial clauses and other types of syntactic structures in the position of a subordinate clause), we suggest to compare the proverbs in $(1 \mathrm{a}-\mathrm{h})$ : the second part of these proverbs may be interpreted as hāl for the existence of formal features (see the definition in paragraph 2). Nevertheless, this interpretation is not always clear and can be argued upon. There are examples that are even more unclear and need to be studied thoroughly, but this is a topic of additional research that goes beyond the borders of this article.

\section{BIBLIOGRAPHY}

al-Ġalāyyīni, aš-šayH Mustafa. n.d. Jāmi‘ ad-durūs al-'arabiyya. Saïda - Beyrut: Manšurāt almaktaba al-'arabiyya. as-Suyūṭi, Jalāl ad-Dīn ‘Abd ar-Raḥmān. 1978. al-'itqān fì ‘ulūm al-Qur'ān. al-Qāhira: al-Juz’ at-țāliț, 40.

Badawi, El-Said \& Hinds, Martin. 1986. A Dictionary of Egyptian Arabic. Arabic-English. Beirut: Typopress.

al-Baqli, Muhammad Qandol. 1987. Al-'amțāl aš-ša'biyya. Al-Qāhira.

Mahgoub, Fatma M. 1968. A Linguistic Study of Cairene Proverbs. Bloomington: Indiana University.

Oren, Mikhal. 2013. "Circumstantial Clause”, Khan, Geoffrey (ed.), Encyclopedia of Hebrew Language and Linguistics. Consulted online on 28 April $2017<\mathrm{http}: / /$

dx.doi.org/10.1163/2212-4241_ehll_EHLL_COM_00000927> First published online: 2013

Pak, V. M. \& Soukhareva, E. M. 2008. "Sintaksicheskiye modeli egipetskikh narodnikh poslovits i ikh tipoviye znacheniya”, Arabskaya filologiya Vypusk 3. Moscow. 240 - 270.

Taymour, Ahmad. 1986. Al-'amțāl al-'āmmiyya. al-Qāhira: Markaz al-'ahrām li-t-tarjama wa-n-našr.

Williams, Ronald J. 2007. Williams' Hebrew Syntax (Third Edition). Revised and expanded by John C. Beckman. Toronto : Toronto University Press.

Woidich, Manfred \& Heinen-Nasr, Rabha. 2004. Kullu Tamam! An Introduction to Egyptian Colloquial Arabic. Cairo: The American University in Cairo Press.

Woidich, Manfred. 2006. Das Kairenisch-Arabische. Eine Grammatik. Weisbaden: Harassowitz Verlag. 


\section{NOTES}

1. Numbers indicated after - refer to the proveb's number.

2. Compare with: The shoemaker's children are ill-shod. The shoemaker's child does barefoot. There is none worse shod than the shoemaker's wife. The tailor's wife worst clad. [http:// phraseology_ru_en.academic.ru]

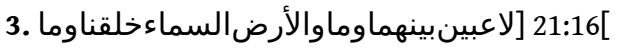

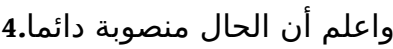

يشرط في الحال ... أن تكون نكرة لا معرلة مائما.

\section{ABSTRACTS}

This article concerns a problem of syntax and pragmatics of circumstantial clauses (jumal hāliyya) in Egyptian Arabic, and particularly, in Egyptian proverbs. According to the most common definition, a circumstantial clause characterizes a state or condition (hāl - lit. "state, condition") of a main clause subject or object at the moment described in the main clause. In Arabic, it is used "to express an action or event which took place simultaneously with the situation or event expressed in the main clause" (modal and temporal circumstantial clauses) [Woidich 2004: 191]. Firstly, we claim that hâl is not a clause, it is a syntactic position that could be represented by a single word (a participle) or a clause. In traditional Arabic grammar ḩăl is described as a "second predicate" (Habar), or comment, that forms the semantic and pragmatic focus of the sentence [Pak \& Soukhareva 2008: 255]. So, when it occurs in Egyptian paremia, hāl represents the essence of a proverb.

Secondly, the structure of a proverb which contains a circumstantial clause is one of three types: a circumstantial clause may accede a noun, a genitive construction or a clause; the conjunction $w$ (i)- (waw al-hāal) is optional.

The fact that a circumstantial clause may equally supplement a noun or a clause in the sentence demonstrates that pragmatically this noun is an equivalent of a whole clause. The question arises about the syntactic position that this single noun would have in a sentence.

INDEX

Keywords: syntax of Egyptian Arabic, Egyptian proverbs, circumstantial clauses, topic, comment

\section{AUTHOR}

\section{TATYANA SAVVATEEVA}

Institute of Asian and African Studies, Moscow State University

Apt.43, 29 Marshal Zhukov Avenue, Moscow, Russia, 123423

alakina.st@gmail.com 


\title{
The Dialect of Sfax (Tunisia)
}

\author{
Zeineb Sellami
}

\section{AUTHOR'S NOTE}

Abbreviations:

1: first person 2: second person 3: third person DEF: definite article

$\mathrm{F}$ : feminine FUT: future IPFV: imperfective PASS: passive

PFV: perfective PL: plural SG: singular

SUB: subordinate conjunction TOP: topicalizer

\section{Introduction}

Located 270km southeast of Tunis, Sfax (Șafāqis) is the second largest city in Tunisia, home to 211.301 people as of $2014^{1}$. Despite its weight in the country's economical and cultural life, it has not received as much attention from dialectologists as other areas may have $^{2}$. As a matter of fact, to the best of our knowledge, there are only two references available. The first one dates back to 1907 and is a body of texts collected by Karl Narbeshuber (Aus dem Leben der arabischen Bevölkerung in Sfax Regentschaft Tunis). The second one, more recent, is a short description written by Dhouha Lajmi in 2009. In her paper, the author regards Sfax and its countryside as a separate dialectal area, since it "presents very specific characteristics". Aside from this initial comment, a thorough analysis of the original data collected in September 2016 could help show in what ways the Sfaxi dialect stands out from the other Tunisian pre-Hilali dialects. The present paper is a preliminary study of the dialect spoken by the elderly inhabitants of the Old City. As it appears to be, it differs from the one spoken by their younger counterparts and from the one spoken outside of the walls. I intentionally chose to focus my efforts on these speakers in order to show the most outstanding features that can be regarded as retained archaisms. 
The fieldwork took place in September 2016, where I recorded eight people: two women and four men (born between 1930 and 1950) who have lived in the old City their whole life, and two young men and an old lady outside the old City. These last recordings will only be used as points of reference, as they are the most representative of today's Sfaxi dialect, which falls beyond the scope of this article.

As mentioned above, Sfax is a major city in Tunisia, and has been throughout history. The medina as seen today was founded in 849 between the ruins of ancient Roman Taparura and Thanae, by the Aghlabid SAli Ibn Aslam al-Bakrī. Taparura was first mentioned in Ptolemy's Geography around the year 140, and was one of Africa's bishoprics during the $5^{\text {th }}$ Century (Du Paty De Clam 1890: 6). After these mentions, the Roman toponym disappears and Sfax is the only name referring to the city, which remained under Roman rule until 655, when the Arabs started occupying it. The inhabitants of the city rebelled during the $11^{\text {th }} \mathrm{C}$ and Sfax was independent for a short period of time, before falling under Sicilian rule in 1148. Afterwards, its fate didn't differ much from the fate of the other Tunisian cities. Its dialect though, seems to have taken a very different direction from the other Tunisian pre-Hilali varieties.

\section{Phonology}

Sfaxi seems to be a differential dialect in the terms of J. Cantineau (1937: 49) who distinguishes between dialects which elide all short vowels in open syllables, calling them 'non-differential' and dialects which have a loss of the high vowels in such positions while keeping the low vowel. Though this distinction is mainly used for Eastern dialects of Arabic, it proves to be useful in this case, especially since Cantineau describes Maghrebi dialects as 'non-differential'. This feature is only found in nearby Kerkennah (Herin and Zammit 2017), as far as my knowledge of Pre-Hilali dialects goes.

\subsection{Short vowels}

There is a consistent maintenance of unstressed /a/ in open syllables, such as in the $\mathrm{CaCaC}$ and $\mathrm{CaCā} C$ patterns. As a matter of fact, the informants kept these vowels in words like: kalèm 'speech', zamēn 'time', hamē-tì 'my mother in-law', hatab 'wood', hanaš 'snake'. One would have expected these short vowels to be reduced or deleted as they are in the other sedentary Tunisian dialects.

With regard to the syllabic structure in this dialect, perhaps the most important pattern to look at is the CVCC one. As a matter of fact, the form qabal (*qabl) 'before' appears twice in our sample. The same pattern can be found in one dialect of Kerkennah (vestigial), on which B. Herin and M. Zammit (2017: 141) write that it "suggests that this dialect did not undergo the widespread North African shift $\mathrm{CvCC}$ [to] CCvC, unknown in Maltese (cf. Maltese qabel)." It is confirmed here that the old Sfaxi as well did not undergo that shift, and it can be witnessed more obviously than in the data from Kerkennah, since the reflexive adverb bå $\underline{d}$ followed by any suffix keeps its vowel in its original position: Sfaxi baS $\underset{d}{d a-n a}$ vs. Tunis ${ }^{3} b$ Gad-na.

7 Probably due to lack of evidence in the sedentary data, Zammit 2013 ("The Sfaxi Element in Maltese") considers this feature as a shared Bedouin-Maltese trait, but we can now assert that it is another feature that Sfaxi and Maltese share. 
In the same article referred to above, the authors note the form yrakkabu-hum (Herin \& Zammit 2017: 141-2) with the maintenance (or the addition) of the short /a/ in an "extremely unusual" position as far as pre-Hilali dialects are concerned. Interestingly enough, this unusual maintenance appears as the norm in the data I have collected. They argue that this short /a/ is more likely to be a retention than an epenthesis, explaining the shift from etymological /i/ to /a/ as a result of "some kind of euphony". The data seems to go in that direction: examples such as yHammar-ūh 'they let it raise', sakkarū 'they have closed', idaHHal-ok 'he lets you in', are prolific in the sample, and they are produced by different speakers. The /i/[to]/a/ shift can be explained as a result of an analogy with the perfective conjugation of the same verbs, the speakers keeping the same vowel /a/ for the two forms, as in sakkarū (PFV) / ysakkarū (IPFV).

\subsection{Treatment of $/ \bar{a} /$}

It has three different outcomes: raising (imāla), maintenance, and the shift to ō (tafHìm):

Imāla conditioning for medial /ā/ is the same as in Tunis (Mion 2008: 306), except for a few words. It is indeed raised to $\bar{e}$ in neutral environments, but when the vowel is preceded by a 'guttural' consonant (Mion's terminology), as it is the case for $/ \mathrm{q} /$, the rules found in Tunis don't necessarily apply ${ }^{4}$ as we can see in $q \bar{e} Y i d^{5}$ 'sitting'. Some cases of medial /ā/ raising involve diphthongization as in lonn $n^{i} \bar{e}$ 'to the people'.

11 Final /ā/ in monosyllabic words, as opposed to the other Tunisian dialects (Mion 2008: 307), is never raised as we can see in these words: $m \bar{a}$ 'water', ža 'he came', $s(a) n \bar{a}$ 'years', $h n \bar{a}$ 'here', lā 'no' ... These would all be raised to $\bar{e}$ in Tunis.

Finally, a very typical sound change in Sfax is the rounding and backing of $/ \bar{a} /$ to $x_{i}, \bar{\nu}$ and $\bar{o}$. As a general rule, back and emphatic consonants usually trigger the tafHim as in

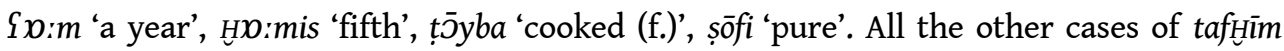
involve pharyngealized front consonants, as in nōr 'fire', dōr 'house', and $b z \bar{o} z^{6}$ 'provocation'.

\subsection{Diphthongs}

The majority of the pre-Hilali dialects have reduced etymological diphthongs /ay/ and / aw/ to $\bar{i}$ or $\bar{e}$ and $\bar{u}$ or $\bar{o}$ respectively. The high vowels are found in Tunis and Kairouan, while the mid-vowels are characteristic of the rural areas in the Sāhil region? . Almost all of the diphthongs in our sample are retained. Perhaps the most striking example for this feature was when one of the informants, a twenty-year-old man, asked an eighty-sevenyear-old woman whether she used to preserve food. He used the term $\mathcal{\text { unla }}$ (* Cawla), and the woman did not understand what he meant. After a few seconds of confusion, he said $G$ awla, to which she automatically answered, having finally understood the request.

This exchange shows not only how relevant diphthongs are in Old Sfaxi, but also how they are being reduced by the younger generations. ${ }^{8}$ Furthermore, the oldest speakers tend to reinterpret etymological long vowels as diphthongs, as it is the case in patronyms and toponyms, where this trait is particularly salient: For example, one of the informants said Țawzar for the city Tūzar. 


\section{Morphology}

\subsection{Morphological Dual in Nouns}

15 The morphological dual (-ayn suffix) has mostly been abandoned in pre-Hilali dialects, which, in most cases retain it for double body parts or time and measurement units. For all other cases involving two things, the speakers will naturally use the number two and the counted noun in its plural form. In Sfax, the dual seems much more productive than that, appearing in what can be considered as frozen duals such as weldayna 'our parents', but also suffixed to words that don't necessarily come in pairs. In the example below, an old man was saying that he still had to go back and forth (to the door) twice and used the French loanword voyage (trip), which seems to be completely integrated into the dialect:

(1) mēzēl fāyāž-ayn

There are still two trips remaining.

\subsection{Verbs}

The verbal system is overall very characteristic of the general pre-Hilali system: the III/y verbs are conjugated like yimši (3SG)/ yimšì (3PL) as opposed to Bedouin yimši /yimšu, but the few forms analysed below make Sfaxi stand out.

\subsubsection{The Passive}

17 The passive is, in the majority of cases, expectedly expressed with the prefixed $t$ - as in tabnēt 'it was built', except in one example where the informant used the N-Stem.

\begin{tabular}{|l|l|l|}
\hline (2) ammā & n-qața & l- - ad̃am \\
\hline but & PASS-cut.PFV.3SG & DEF-eggs \\
\hline \multicolumn{3}{|l}{ But there was a shortage of eggs. } \\
\hline
\end{tabular}

Unfortunately, one occurrence cannot give much evidence as to why this form was used in this particular context. It is unclear whether it conveys a different meaning than the prefixed $t$ - passive, or if this is a reflection of a much earlier stage of the dialect, where the Arabic N-Stem was somewhat productive.

\subsubsection{The Causative}

19 There is one residual occurrence of the C-Stem: no-Herž- $\bar{u}-h$ 'we get it out', this same form appearing twice in the corpus, with two different informants, but in the same context: the recipe of a typical Sfaxi dish. The form in itself can be confusing, since we clearly have a direct object $-\mathrm{h}$ affixed to a verb that would be intransitive (meaning to go out) for a speaker of Tunis Arabic for example. Taking into account the fact that in the data, the intransitive form of the same root has different prefix and thematic vowels, we can already establish an opposition between the G-Stem and the C-Stem ${ }^{9}$ of the root H.r.z.. From there, we can reconstruct the $3^{\text {rd }}$ person conjugation of this verb, imagining the 
whole paradigm could have been productive in earlier stages of the dialect. This is displayed in the table 1 below, where the C-Stem in Sfaxi corresponds morphologically to the G-Stem in Tunis $^{10}$.

Table 1: G-Stem vs C-Stem in Sfaxi

\begin{tabular}{|c|c|c|}
\hline & G-stem & C-stem \\
\hline 1PL & nihiržžü & noharžū \\
\hline $3 \mathrm{SG}$ & yihuriž & yohrəž \\
\hline
\end{tabular}

However, this is the only occurrence of the C-Stem, and all other causatives in the corpus are expressed via the D-Stem. One could wonder whether this is a very specific use within the context of the old recipe being transmitted unchanged from generation to generation, with that verb having that particular meaning, or if the C-Stem was a tangible morphological category at an earlier point in the history of the dialect that is now only residual.

\subsubsection{The verb rā}

21 M. Zammit states that in "Sfaxi Arabic, the verb for seeing is regularly expressed by 'šăf, and to a lesser extent by 'rā"' (Zammit 2013: 33), and that we find it mostly in frozen context, "very often in the perfective". However, a closer look at the data shows the contrary. Whereas šăf shows up numerous times, $r \bar{a}$ is still very productive. The whole paradigm, as shown in table 2 below, appears in the corpora, the most outstanding occurrences being the imperatives. It is worth noting that this paradigm is the same one as in Maltese (Borg \& Azzopardi-Alexander 1997: 366). To quote Zammit again, the verb rā is still seemingly common currency in one small part of the Maghreb. ${ }^{11}$ 


\section{Prefix Conj. Suffix Conj. Imperative}

\begin{tabular}{cccc}
\hline 1SG & rayt & nāra & \\
$2 \mathrm{SG}$ & rayt & tāra & lāra \\
$3 \mathrm{MSG}$ & ra & yāra & \\
$3 \mathrm{FSG}$ & rāt & tāra & \\
1PL & rayna & narāw & \\
$2 \mathrm{PL}$ & raytu & tarāw & Parāw \\
$3 \mathrm{PL}$ & rāw & yarāw & \\
\hline
\end{tabular}

\section{Morphosyntax}

In Old Sfaxi, the future is mainly expressed with the adverb məš, a reduced form of the active participle $m \bar{a} \bar{s} \check{i}$ of the root $m . \check{s} . y$ (to go), followed by the verb in the imperfective. In most Tunisian dialects, this reduced and grammaticalized form of the root has merged with the subordinate conjunction bəš (in order to), making bāš or its allomorph bəš the form expressing both the future and subordination (Mion 2014: 65). This merger is so engrained that, in his most recent paper on the future in Tunis Arabic, G. Mion talks about it as the prototypical form to express the future in Tunisian Arabic..$^{12}$

Old Sfaxi seems to have preserved the opposition between the two morphemes. One example in the data shows how clear the difference is for the speakers when both futurity and subordination are expressed:

\begin{tabular}{|c|c|c|c|c|}
\hline (3) məš nḥəbbu & naimlu & bēb & $\begin{array}{l}\text { hawniyya, barša } \\
\text { hwwēyiž }\end{array}$ & nqillik \\
\hline FUT want.IPFV.1PL & make.IPFV.1PL & door & here, many things & tell.IPFV.1SG \\
\hline a'lī-hom & bəš t Ŷ̄nū-na & fi-him & məš naßmlu & bēb mən ġōdi \\
\hline PREP-them & SUB help.IPFV.2PL-1PL & PREP-them & FUT make.IPFV.1PL & door over there \\
\hline bēšs mibqā-šs & yit Sadda & hatta hadd. & & \\
\hline SUB stay.IPFV-NEG & go.IPFV.2SG & any person & & \\
\hline
\end{tabular}


We're going to, we want to put a door here, I will tell you about a lot of things that you can help us with, we're going to put a door there so that no one goes there anymore.

Furthermore, some speakers have a less reduced form of the active participle, going as far as putting gender and number agreement on it, as in the example below:

\begin{tabular}{|l|l|l|}
\hline (4) rā-k & mēšy-a & tkassar-u \\
\hline TOP-2SG & go.PTCP-2FSG & break.IPFV.2SG-3SG \\
\hline \multicolumn{2}{|l}{ You're going to break it. } \\
\hline
\end{tabular}

Old Sfaxi thus displays an earlier stage of the grammaticalization of $m \bar{a} \check{s} i$ as the form expressing futurity in Tunisian Arabic.

\section{Lexical items}

Some lexical items seem to be very typical of this dialect, as shown by Zwari \& Sharfi's (1998) Arabic dictionary dedicated to Sfaxi vocabulary, where the authors write the words as pronounced. We can afford not to dwell on the roots analyzed by Zammit in his paper (2013: 35-41) and look into the items that do not appear there.

One particular root whose use is, as far as one can tell, limited to the Sfaxi area ${ }^{13}$, is g.d.s, which corresponds to the widespread q.S.d 'to sit' semantically and functionally, by also serving as the means of encoding the progressive. ${ }^{14}$ The dictionary (p. 500) gives this definition (translation mine) "he sat and thus became like a 'gids', and the 'gids' is the 'kuds' [pile]" ${ }^{15}$, thus referring to the Arabic root k.d.s. It is not particularly surprising that the voiceless velar stop is voiced, considering its environment, but it would be interesting to point out a few things. Sfaxi seems to be the only dialect where the root is completely reinterpreted as g.d.s, the voicing not being limited to forms where the velar stop is in direct contact with the second root consonant. Moreover, to the best of my knowledge, the G-Stem of k.d.s is not found in other Tunisian Sedentary dialects, though the D-Stem and the tD-Stem (meaning to pile up, to be numerous) are very common. The only G-Stem I could find is in the Arabic of the Marāzig, a Bedouin variety, where the verb $k^{e}$ das/yèkdes means living with someone, "vivre avec quelqu'un, se nourrir de frais communs" (Boris 1958: 524). It is conceivable to see in what ways the two meanings can be derived from each other, but it is unclear whether a possible contact situation or something else might have been the cause of the G-stem to be only found in these two dialects.

Finally, it is worth mentioning that the root appears with the voicing of the first consonant in Maltese, where the verb doesn't exist, but where 'heap' is gods with the root g.d.s given as a reference (Aquilina 1987: 440). This is yet another common feature between Maltese and Sfaxi, meaning that this voicing, and the subsequent reinterpretation, are likely to have occurred in much earlier times, as early as before Maltese developed into a language of its own, although at this stage, we still have to consider the parallel development possibility. 
Another item is the word šayn for 'thing', which is the same realization as in Maltese xejn, as opposed to šay $(y)$ for other dialects. It has been posited that this final [n], which shows up in many Arabic (Eastern and Western) interrogatives is a 'remnant nun', that is, a retention from the case system. J. Aquilina (1987: 1558) points to "a residue of the accusative case of Classical Arabic", but D. Wilmsen (2014: 177) argues that this kind of claim is "based purely in superficial similarity". While we can agree with Wilmsen, the final [n] is still interesting from a historical perspective, pointing out to a trait shared by both Sfaxi and Maltese, that is, a feature in older layers of Tunisian Arabic ${ }^{16}$ and perhaps more generally Maghrebi Arabic as a whole.

\section{Comparison with Narbeshuber's data}

More than a century ago, Karl Narbeshuber transcribed about three pages describing the traditional wedding celebrations in Sfax, followed by popular songs and poems. There is very little information on the conditions of the data collection of this scholar, and as useful these texts might be, they are to be read with caution, as some of their content contradicts the recent recordings as well as descriptions made by his contemporaries.

31 He recorded two examples of high short vowels in unstressed syllables: in erriz̄al 'the men' and yufturu 'they eat'. This might be an indication that, earlier than that, the vowel system of Sfaxi Arabic was more stable, just as Zammit \& Herin 2017 suggest for the differential dialect of Kerkennah. Words with unstressed /a/ in such position are much more numerous in his work, but surprisingly, their maintenance seems less regular. In fact, in the data I have collected, the retention of unstressed /a/ in open syllables seems to be non conditioned, wherein in these older texts, the vowel is regularly maintained when in the vicinity of a voiced pharyngeal fricative but dropped in other environments: arbaSin 'forty', arba\&a 'four', ițallaSūha 'they lift her' vs. idaHHlu in the same text, šeYir 'barley', Sarūsa 'bride', Saliha 'on her'. He also gives xlāxol 'bracelet' as an example, whereas in the more recent data, it is garēbal 'sieves' that appears, with the short vowel maintenance in a similar environment.

The raising pattern seems to be the same, although some tokens that appear in both my data and in his do not exhibit imāla, such as in $q \bar{a} Y d a$ where we have $q \bar{e} Y d a$ in all the cases, xlāxol cited above, where we would expect raising, especially in a neutral environment like this one. Final /â/ in monosyllabic words has the same outcome as in my recordings, with no to little raising in a few cases such as nsä̃.

As far as diphthongs are concerned, they are very rare in the texts, reported by Narbeshuber in three words: zawžtu 'his wife', heit 'wall', and fi Sawd 'instead of. This is rather unexpected, since they appear in my corpus, and W. Marçais mentions their retention in the first half of the $20^{\text {th }} \mathrm{C}^{17}$, that is, not so far after Narbeshuber had collected his data.

34 Finally, we also find the root g.d.s in its various forms, with $g$ as the first root consonant, except one occurrence displaying / $\mathrm{k} /$ in that position: $k \bar{d} d e s$ for the active participle. This single occurrence pushes us to nuance the hypothesis of an older reinterpretation of the root into g.d.s. 


\section{Outlook: Pre-Hilali revisited?}

Considering the features discussed in this paper, old Sfaxi seems to be a valuable example of early Pre-Hilali dialects, and its ties with Maltese deserve further investigation. An extensive work on this dialect as well as the differential dialect of Kerkennah (Herin \& Zammit 2017), and their comparison to other sedentary dialects is important to the better understanding of the development of North African Arabic, as far as the Pre-Hilali type is concerned. The data shows that this dialect differs from the ones it is related to, by lacking heavy syncopation, having a slightly different imāla conditioning, peculiar verbal forms, and shared vocabulary (Zammit 2013), to name a few features. It is important to point out the fact that these differences make it sound almost 'oriental' ${ }^{18}$ (especially its differentiality) and link it to Maltese in a tighter way than Zammit showed it in 2013. The latter already states that "excluding the possibility that Maltese could've been directly influenced by Bedouin varieties, these isoglosses [shared by Bedouin varieties of Arabic and Maltese] might be an indication that, a number of centuries ago, the features outlined below constituted some kind of homogenous 'common Tunisian' which were later innovated by the sedentary varieties". The Sfaxi data analyzed in this paper strengthens this hypothesis and compels us to look further into the development of North African Arabic, as this kind of data, in a similar manner to Maltese, bears older testimonies of this type of dialects. ${ }^{19}$

Zwari, Ali \& Sharfi, Youssef. 1998. Mu ğăam al-kalimāt wa-t-taqālīi aš-šsa'biyya bi-șafāqis. Sfax.

\section{BIBLIOGRAPHY}

Aquilina, Joseph. 1987-1990. Maltese-English Dictionary. Malta: Midsea Books.

Borg, Alexander. 1996. “On Some Levantine Linguistic Traits in Maltese”, Journal of Oriental Studies. Studies in Modern Semitic Languages 16. 133-152.

Borg, Albert \& Azzopardi-Alexander Marie. 1997. Maltese. Oxon: Routledge.

Boris, Gilbert. 1958. Lexique du parler Arabe des Marazig. Paris: Klincksieck.

Herin, Bruno \& Zammit, Martin. 2017. "Three for the price of one: the dialects the Kerkennah"

(Tunisia), Tunisian and Libyan Arabic Dialects, Common Trends, Recent Developments, Diachronic Aspects . Prensas de la Universidad de Zaragoza. 135-146.

Cantineau, Jean. 1937. Etude sur quelques parlers de nomades arabes d'Orient. Paris: Larose.

Gibson, Michael. 1998. Dialect Contact in Tunisian Arabic: Sociolinguistic and Structural Aspects. Ph.D Thesis. The University of Reading.

Gibson, Michael. 2009. “Tunis Arabic”, Versteegh, Kees et al. (eds.) Encyclopedia of Arabic Language and Linguistics IV. Leiden: Brill. 563-571.

Lajmi, Dhouha. 2009. “Spécificités du dialecte Sfaxien”, Synergies Tunisie 1. 135-142. 
Marçais, William. 1950. "Les parlers arabes", Basset, André et al. (eds.), Initiation à la Tunisie. Paris: Adrien-Maisonneuve, 195-226.

Mion, Giuliano. 2008. Le vocalisme et l'imaala en arabe tunisien, Stephan Procházka et Veronika Ritt-Benmimoun (eds), Between the Atlantic and Indian Oceans. Studies on Contemporary Arabic Dialects. Proceedings of the $7^{\text {th }}$ AIDA Conference, held in Vienna from 5-9 September 2006, 305-314.

Mion, Giuliano. 2014. "Eléments de description de l'arabe parlé à Mateur (Tunisie)", Al-Andalus Magreb 2. 57-77.

Mion, Giuliano. 2017. “A propos du futur à Tunis”. Veronika Ritt-Benmimoun (ed.),Tunisian and Libyan Arabic Dialects, Common Trends, Recent Developments, Diachronic Aspects. Prensas de la Universidad de Zaragoza.

Narbesuber, Karl. 1907. Aus dem Leben der arabischen Bevölkerung in Sfax Regentschaft Tunis, Leipzig: R. Voigländer.

Du Paty de Clam, Antoine. 1890. Fastes chronologiques de la ville de Sfax, Paris: Augustin Challamel.

Stumme, Hans. 1904. Maltesische Studien. Leipzig: J.C Hinrichs.

Vanhove, Martine. 1998. "De quelques traits préhilaliens en maltais". Aguade J., Cressier P. et Vicente, A. (eds.), Peuplement et Arabisation au Maghreb Occidental (Dialectologie et Histoire), Zaragoza: Casa Velazquez, Universidad de Zaragoza. 97-108.

Wilmsen D. 2014. Arabic Indefinites, Interrogatives, and Negators. A Linguistic History of Western Dialects. Oxford: Oxford University Press.

Zammit, Martin. 2013. The Sfaxi (Tunisian) Element in Maltese. Borg A. et al. (eds.) Perspectives on Maltese Linguistics. 23-44.

\section{NOTES}

1. In Sfax Ville and Sfax Ouest. Source: Institut National de Statistiques.

2. Tunisia can be counted as one of the most investigated areas in the field, its accessibility for fieldwork being one of the main reasons, and yet some of its dialects are still understudied.

3. All Tunis data in this paper is from the TuniCo Corpus, "a corpus of unmonitored speech that contains both conversations and narratives" with young speakers who grew up in Tunis. (url: http://www.oeaw.ac.at/acdh/de/tunico).

4. "L'imāla tunisienne est un phénomène spontané et bloqué seulement par une emphatique ou $q$ précédents et frappant tous les /ā/" (Mion 2008: 308)

5. Maltese cognate qiegHed.

6. In their dictionary, Zwāri and Sharfi (1998: 53) indicate the pharyngealization of /z/ in this word alongside with the definition "بزاز: بتفخيم الزاي"

7. "Les villageois réduisent à $\bar{e}$ l'ancienne diphtongue ay et à $\bar{o}$ l'ancienne diphtongue aw." (Marçais 1950: 211)

8. This is more likely due to sociolinguistic reasons, Tunis Arabic being established as a Koine, and people tending to level toward it (Gibson 1998, 2009).

9. In this paper I use the common Semitic linguistics terminology: The G-Stem is the ground stem, and corresponds to the form I ( $\mathrm{CaCaCa}$ ) in Arabic grammars, the C-Stem is the causative (form IV, $\mathrm{PaCCaCa}$ ) and the D-Stem, where the second consonant is geminated, is the form II (CaCCaCa).

10. Forms found in the TuniCo Corpus include 3sG yuxruž and 1PL nux rẹ̌u (author's transcription). 
11. "The archaic verb $r \bar{a}$ is still used in peripheral dialects of Arabic, including Maltese, and must hark back to a time when that verb was still common currency in the Maghreb." (Zammit 2013: 34).

12. "La littérature dialectologique concernant le Maghreb oriental, et notamment l'arabe tunisien, mentionne systématiquement bāš en tant que spécialisé dans la construction du futur." (Mion 2017: 207)

13. Including Kerkennah.

14. Tunis $q \bar{a}\{$ dìn yzìdū 'they are adding' vs. Sfax gēdsin naSmlū 'we are doing'

15."جلس فأصبح كالثدس والثدس هو الكدس

16. This lies in the largely accepted assumption that Maltese was historically part of Tunisian Arabic, as Vanohove (1998: 97) puts it: "il semble maintenant admis que la langue maltaise provient d'une variété d'arabe proche des parlers des vieilles cités maghrébines de la période préhilalienne, et plus précisément des vieilles cités tunisiennes (Cohen 1988: 106), tel Kairouan [...] L'histoire comme la langue [...] plaident en faveur d'une telle hypothèse".

17. "Toutefois, la ville de Sfax et les milieux féminins de Tunis ont maintenu la diphtongaison primitive" (Marçais 1950: 207).

18. This has been brought up for Maltese, for which H. Stumme (1904) argues a possible Levantine origin, that A. Borg (1996) describes with a more nuanced "Levantine linguistic traits". 19. "Le maltais intéresse la dialectologie historique comparée par les témoignages anciens qu'il peut encore apporter" (Vanhove 1998: 98).

\section{ABSTRACTS}

This paper aims to describe the most outstanding features of the Arabic spoken in Sfax, the second largest city in Tunisia, which is located $270 \mathrm{~km}$ southeast of Tunis. It is based on a fieldwork conducted in the old city of Sfax in September 2016. To the best of my knowledge, this dialect hasn't been thoroughly documented yet, except for one short description written by Dhouha Lajmi, which was based on her 'empirical experience of the linguistic situation in Sfax' (Lajmi 2009). This article is an attempt to fill this lacuna in the field of Tunisian dialectology, by providing a linguistic sketch of the most prominent features of the sfaxi dialect on the phonological, morphological, and morphosyntactic levels.

While falling into the pre-Hilali category, this dialect retains some archaisms that make it very different from other varieties in Tunisia, and more generally in North Africa, making it useful for the account of the history of Maghrebi Arabic.

\section{INDEX}

Keywords: dialectology, pre-Hilali, Sfax, Tunisia, Maghreb, phonology, morphology, morphosyntax. 
AUTHOR

ZEINEB SELLAMI

INALCO - LACNAD 


\title{
Éléments lexicaux hébreux ou
} pseudo-hébreux dans le parler judéo-arabe de Fès des années 40. Emplois contextuels, dérivations sémantiques, adaptations phonologiques

\author{
Jonas Sibony
}

Les parlers judéo-arabes sont les pendants communautaires juifs des parlers arabes. A Fès au Maroc, le judéo-arabe est une déclinaison de l'arabe fassi dont la culture spécifique et le mode de vie des locuteurs engage un renvoi vers la culture juive et se réfère constamment aux corpus de références de celle-ci (Bible hébraïque, Talmud etc.). C'est par là qu'un certain nombre de mots hébreux et araméens s'immiscent dans la langue de tous les jours. Ces apports apparaissent d'abord à l'écrit, puis dans le parler des lettrés ; la plupart d'entre eux ne sort jamais de ce cadre. Pourtant, une infime partie de ces mots, hébreux ou pseudo-hébreux ${ }^{1}$, s'intègre dans le parler courant des hommes comme des femmes du quartier juif. Coupés de leur étymologie, ces mots sont utilisés par les locuteurs juifs arabophones qui ne savent pas toujours qu'ils ne sont pas d'origine arabe ou berbère. Puisqu'ils évoluent indépendamment de leur corpus d'origine, à l'intérieur d'un système linguistique d'adoption, leur emploi se contextualise et leur sens se modifie. La réalisation de ces mots est remodelée par les conditions phonétiques et phonologiques du vieil arabe de Fès. Des néologismes arabes se forment alors sur des racines hébraïques. Ces termes n'ont le plus souvent jamais été utilisés dans ces sens ou sous ces formes en hébreu et puisqu'ils sont ici totalement intégrés à l'arabe dialectal, ils sont à considérer comme des mots arabes, quelle que soit leur étymologie.

La question de ces hébraïsmes et de leur place dans l'arabe dialectal des communautés juives a déjà fait l'objet d'une abondante littérature. Les principaux auteurs s'y étant attaqués sont: d'abord M. Cohen, puis le français L. Brunot, l'américain W. Leslau, les 
maghrébins E. Malka, D. Cohen, L. Saada et H. Zafrani et plus récemment M. Bar-Asher, J. Chétrit, Y. Henschke et J. Tedghi. Ce dernier rappelle dans son excellente synthèse publiée en 2003, les chiffres donnés par D. Cohen au sujet du judéo-tunisien des années $1950^{2}$ : la part du lexique arabe est de $79 \%$, celle des emprunts aux langues romanes de 15 $\%^{3}$, les hébraïsmes représentent $4,4 \%$ des mots et $1,6 \%$ sont d'origines diverses. La proportion de termes hébreux dans la langue est relativement faible et de surcroit, ces chiffres ne prennent pas en compte les fréquences d'emploi. En intégrant ce critère, les hébraïsmes ne concernent plus que 2,1\% des mots employés pour les textes à connotations religieuses et seulement $0,6 \%$ pour les conversations courantes (Tedghi $2003: 169)$.

Dans la même étude, J. Tedghi mentionne cette fois M. Cohen au sujet du parler arabe des Juifs d'Alger. Selon lui : « les emprunts sont purement lexicaux, ils concernent surtout la vie religieuse et culturelle et à ce titre, ils sont plus caractéristiques du langage des hommes que de celui des femmes ». Il dénombre néanmoins une trentaine de termes passés dans l'usage commun et deux termes seulement considérés comme «fonctionnels ».

La situation à Fès dans les années 40 est similaire à celles de Tunis et Alger. La proportion des hébraïsmes est faible et il est manifeste qu'ils sont plus nombreux à l'écrit, dans les productions des érudits. C'est à partir des textes religieux, parfois en passant par ces productions, que ces mots arrivent dans le langage courant. Il n'y a pas d'autre source d'hébraïsmes.

Si le locuteur juif a pu ressentir le besoin d'emprunter du lexique à l'hébreu, c'est d'abord pour nommer ce qui n'existe pas en langue arabe ; ce qui est relatif au culte, à la culture et à la vie juive. Toutefois, une inspection plus systématique de ces termes laisse apparaitre que certains d'entre eux ne répondent pas à ces critères. Il arrive qu'ils aient de très bons équivalents en arabe. Il peut alors s'agir d'adjectifs courants, de substantifs ou de formules de politesses etc. Ils sont cependant eux aussi issus du monde de l'écrit, qui peut toutefois s'élargir à d'autres formats de littérature : contes, poésies ...

L'objectif de cet article est de reprendre ces données déjà anciennes (Bruno \& Malka 1939 et 1940 ; M. Cohen 1912 ; D. Cohen 1964, 1975 \& 1981 ; Leslau 1945 ; Bar Asher 1992, Levy 1990 \& 1994 ; Tedghi 1995), de compiler les analyses linguistiques et surtout de tenter de les approfondir.

La liste qui suit est non exhaustive. Les termes mentionnés ci-dessous renvoient à des cas divers, qui ont cependant en commun le fait de s'inspirer du lexique hébreu. Les emprunts sont courants, mais ils connaissent le plus souvent des évolutions phonétiques, morphologiques et sémantiques les rendant méconnaissables.

\section{Emprunts lexicaux simples}

Le premier cas est celui des emprunts lexicaux simples, ne connaissant pas d'évolution contextuelle particulière :

- bəōōr, . « fils ainé »,

Il est réalisé béHōọ ${ }^{4}$, avec une légère teinte de la voyelle initiale et une emphase du /r/. Ces particularités phonétiques sont propres à l'arabe dialectal marocain ${ }^{5}$. Le mot a le même sens en judéo-arabe qu'en hébreu et est utilisé le plus souvent au singulier. Son emploi est courant mais son pluriel bĕHōọōt (< héb. bəkōrōt) n'est connu que des lettrés. Il n'existe pas 
d'innovation de pluriel spécifiquement dialectale comme c'est le cas pour d'autres exemples. Le terme prend l'article défini de l'arabe ${ }^{6}:$ l-bĕHōọ,, "l'ainé ». L'étymologie hébraïque du terme est largement ignorée par les locuteurs.

- șāra, ." peine, malheur », צָָ

Réalisé șăra, il fait partie du langage courant et apparaît le plus souvent précédé de la préposition $f_{i} / \mathrm{f}$ comme dans l'expression howa $f$-s-șăra $a^{7}$, « il est dans la misère, dans une mauvaise situation ». Le pluriel șarōt > șārōt est rare et réservé aux lettrés. M. Bar-Asher (1992), mentionne le fait que le substantif hébreu șarūt, issu de la même racine hébraïque est utilisé à Tlemcen et Ain-Tmouchent dans l'expression șarūt ddi iyyūb, « les malheurs de Job».

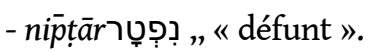

Réalisé nifțar. C'est probablement le participe actif nip̄țār ${ }^{8}$ qui est empruntée à l'hébreu plutôt que nipțar le verbe au passé, puisqu'il se retrouve en judéo-arabe avant tout sous une forme nominale (comme le participe hébreu) l-nifțār, «le défunt ». Il est parfois noté dans les textes en caractères hébreux, ce qui laisse supposer que son נפטאר / נפטטאר origine hébraïque n'est pas toujours ressentie, puisque la notation $N$ pour noter la voyelle /a/ est d'habitude réservée à la transcription des termes arabes. Les mots hébreux conservent habituellement leur orthographe hébraïque.

Le mot hébreu nipțār résulte du croisement de la racine VPṬR et du schème de la forme verbale nif'al, à préformante n-, qui équivaut à la forme VII de l'arabe infa'ala. L'emprunt nominal se re-verbalise en judéo-arabe et se comporte comme une racine quadrilitère VNFṬR, conjuguée à la première forme : $n f t ̦$ ror / infțar. Bien que les systèmes de l'hébreu et de l'arabe (classique comme dialectal) soient proches et connaissent tous deux une forme verbale avec préfixe n-, la préformante n- n'est ici pas ressentie comme telle et ne produit donc pas l'effet sémantique attendu en grammaire hébraïque. Les locuteurs empruntent des mots figés et non le système grammatical qui le précède. Cette construction n'est pas non plus amalgamée à la forme arabe dialectale à préformante n- puisqu'aucun verbe à racine VPṬR / VFṬR ne lui correspond à une autre forme verbale. Pour illustrer l'emploi de ce verbe, W. Leslau $(1945,75)$ cite l'énoncé : $m$-di l-bo ka-infțro, « si le père décède ».

\section{Emprunts identifiés comme hébreux, comportant évolutions phonétiques et morphologiques}

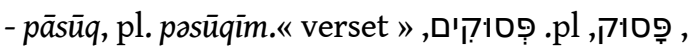

Réalisés pasō’, pl. psōīm. Deux transformations sont à noter; le passage de /u/ à /o/ et la réalisation /// de /q/. Ces mutations sont précisément celles que connaissent les mots arabes dans le parler fassi de l'époque. Elles correspondent donc à des articulations spécifiques, un accent local, sans que l'origine hébraïque ou arabe du terme ne vienne influencer la prononciation.

Puisque ce sont les règles phonétiques et phonologiques du vieux parler arabe fassi qui s'imposent ici, certaines formes hébraïques doivent trouver des solutions pour s'adapter. C'est le cas des mots à consonne initiale /q/. La réalisation /'/ de ce phonème engage la réaffirmation d'une voyelle entre /'/ (C1) et $\mathrm{C} 2$, l'arabe dialectal ne permettant pas la suite 'CVC. Cette dernière diffère d'ailleurs parfois de la voyelle sémitique d'origine, ce qui implique qu'il s'agit d'un réflexe articulatoire et que le choix du timbre est arbitraire : 
קברוּרָה - , qabūrâ, « tombe ».

Réalisé 'ibōra. Le sens se réduit à « tombe d'un saint », ce qui illustre bien le cas du recours au mot hébreu. En effet, le mot générique pour «tombe » est utilisé en arabe dialectal : qabr, 'abr (d'ailleurs de même racine historique). L'équivalent hébreu vient nommer l'objet spécifique. Au niveau de la forme, la fricative / $\underline{b} /$ passe à l'occlusive /b/ (comme pour la réalisation de n'importe quel mot hébreu dans la tradition marocaine), / $\mathrm{u} /$ passe à $/ \bar{o} /$ et $/ \mathrm{r} / \mathrm{à} / \mathrm{r} /$. La chute $\mathrm{du} / \mathrm{q} /$ quant à elle, entraine une compensation vocalique ; /a/ se précise en $/ \mathrm{i} /$.

- קִạ, qahillâ, « communauté ».

Réalisé 'ihilla. Les évolutions formelles sont les mêmes que pour qabuūrâ. Le sens est inchangé mais appartient au vocabulaire des lettrés.

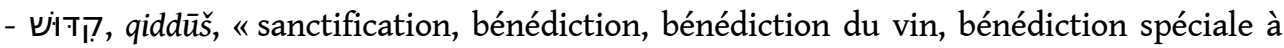
l'ouverture du shabbat».

Réalisé 'eddōs, même sens. La voyelle /i/ penche vers /e/ et la chuintante /š/ devient sifflante /s/, ce qui est une caractéristique généralisée du parler arabe des Juifs de Fès, comme dans d'autres vieux parlers citadins du Maroc.

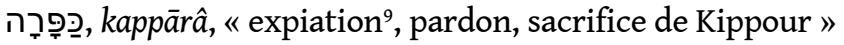

Réalisé kappāra / kappāra / kumpāra, « sacrifice de Kippour, bouc émissaire, sacrifice ». En plus de l'emphase sur le /r/, la troisième forme kumpāra présente une labialisation de la voyelle initiale, par assimilation, sous influence de la suite $/ \mathrm{pp} /$. Le premier $/ \mathrm{p} /$ quant à lui présente un cas de dissimilation et se nasalise en $/ \mathrm{m} /$. Le mot est présent dans un certain nombre d'expressions typiques qui renvoient d'abord à l'imaginaire de la fête de yōm kippūr: nəmsī kəppāra / kumpāra 'lik, "pour toi, je pourrais me sacrifier, être ton sacrifice expiatoire du Kippour ", énoncé typique d'une mère ou d'une grand-mère à l'attention de sa progéniture. C'est probablement à travers cet emploi, que le mot est réutilisé aujourd'hui en hébreu israélien ; d'abord par les enfants d'immigrés d'Afrique du Nord, puis par tous les locuteurs, dans le sens de "chérie» ou «bravo»: kapara, « chérie », kapara alexa, « bravo à toi ».

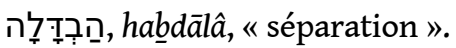

Réalisé bdala / bdāla. Le sens du mot est maintenu, il désigne le rite de sacralisation du samedi, une prière qui exprime la séparation du qōdeš et du hōl, c'est-à-dire du « sacré » et du "profane», du shabbat et des jours de la semaine. Bien que clairement identifié comme hébreu, c'est au niveau morphologique qu'il est mal interprété. Le préfixe ha-, élément des schèmes de noms haf'âlâ, dérivés de la forme verbale hifîl, est pris pour l'article défini $h a$-. Le locuteur lui substitut alors par reflexe l'article arabe quand le mot est défini : l-bdala, sans toutefois que confusion soit faite avec son cousin lexical de racine VBDL (bdāla, "période de mue des oiseaux»). L'hébreu hap̄tāâa, "séparation » (désignation de l'extrait hebdomadaire des livres des prophètes récité le samedi), construit sur le même schème, connaît le même emploi et devient dans le parler arabe 1 fțāra (Leslau $1945: 68$ et Brunot \& Malka $1940: 8,98$ ).

\section{Mots fonctionnels ${ }^{10}$}

Les mots qui suivent ont pour spécificité de sortir de la logique du simple emprunt lexical. Très probablement issus de la langue écrite, ils se sont installés dans la langue parlée, et peuvent jouer un rôle réel dans l'organisation des éléments de la phrase. Simon 
Levy attenue quelque peu l'aspect « fonctionnel » en les nommant « chevilles de langage » (Levy 2013 : 51); en tant qu'éléments utilisés pour assister la jonction entre propositions mais sans être complétement intégrés au système général.

,

Réalisé 'afillo / 'afollo, avec réduction courante de la voyelle /i/ vers /o/ et amalgame habituel /u/ - /o/. Il est très courant et s'emploie dans son sens hébreu : « même si », « au moins ». Marcel Cohen le mentionne également chez les Juifs d'Alger. D'après Brunot et Malka (1940 : 3), son étymologie est oubliée par les locuteurs, ce qui est un signe de son intégration dans la langue parlée.

,

Réalisé badday, le sens n'a pas bougé. L'origine $d u / b /$ initial est incertaine. Il peut être le fruit d'une assimilation $/ \mathrm{b} /+/ \mathrm{w} />/ \mathrm{bb} />/ \mathrm{b} /$, donc à partir de la forme hébraïque avec préposition bo-waddā’ i. Mais il est aussi potentiellement le résultat d'une mauvaise analyse $\mathrm{du} / \mathrm{w} /$ initial de la formule sans préposition waddāì̃. Il aurait ainsi été interprété comme la variante allophonique de $/ \mathrm{b} /$, non respectée dans les traditions marocaines de prononciation de l'hébreu et donc corrigé à tort : waddā'i >badday.

,

Réalisé had rabba, parfois draba (également mentionné par Marcel Cohen pour Alger). Il conserve son sens "au contraire", "d'autant plus». La réalisation had rabba laisse entendre que les locuteurs l'identifient comme arabe et constitué des éléments had, le démonstratif arabe dialectal et rabba, dont la forme fait peut-être écho à robbāma, «peutêtre bien que ».

Simon Levy (2013: 51) mentionne également les emplois de kbar, « déjà » (< héb. . kəb̄ār, « déjà ») et de l'araméen bine-bine, « entre temps ».

Comme contre modèle de ces cas « fonctionnels », apparait l'expression hébraïque utilisée

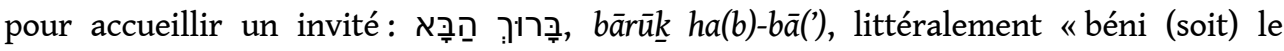
venant ». En hébreu, la formule se décline. Mais la construction de l'énoncé est ici soit mal comprise, soit le fait de l'accorder en hébreu serait insuffisamment évocateur et explicite dans un environnement arabophone; elle finit donc par s'accorder selon d'autres règles, internes, avec ajout d'une préposition arabe. Alors que l'hébreu propose une forme féminine borūka $h a(b)-b \bar{a}$ ’a (« bénie soit la venante »), ainsi que des formes au pluriel, l'expression dans son emploi au Maroc fige la forme initialement empruntée et n'accorde que la particule arabe : bāruH habbā bik, bāruH habbā biki, bāruH habbā bikum.

Cet exemple montre bien que c'est la préposition arabe et ses flexions qui font sens pour les locuteurs. Un concept est emprunté figé et ne s'intègre qu'en façade à la langue d'accueil, ayant nécessairement recours à un élément local pour s'imbriquer dans les rouages du parler.

\section{Evolutions sémantiques pour mots identifiés comme hébreux}

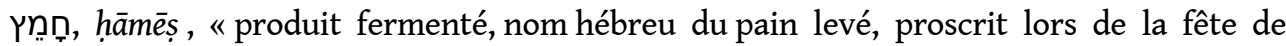
Pessah $»^{13}$.

Réalisé hāmēes, il conserve son sens hébreu, comme dans l'énoncé : f-pisāḥ, ḥrām naklō lHəobz u kall ma howa hāmeș ${ }^{14}$, " pendant la fête de Pessah, il nous interdit de manger du pain et tout ce qui est (ce qui contient du) hâameș ». Le mot connaît également un élargissement 
de sens; employé comme un adjectif, il devient symboliquement le prototype de l'interdit, de l'illicite d'après la loi mosaïque, ce qui en fait dans l'usage un synonyme de hārām / hrrām. A. de Prémare illustre cet emploi par l'énoncé ḥāmēṣ 'lēya nəšrəb əš-šrāb, « il m'est interdit (péché, «hāmēsṣ») de boire du vin ». L'élargissement sémantique fait passer " produit fermenté » à " pain interdit » (déjà en hébreu) puis en judéo-arabe "interdit, illicite, péché ", il va même se re-substantiver dans le sens de "lieu interdit » voire "quarantaine »: 'ămlọ 'lêh hâameș (de Prémare 2003, tome 3:226) : "ils l'ont mis en quarantaine (ils lui ont fait ḥāmeṣ) ».

רַּ̣, rabbī, « rabbin ».

Réalisé rabbi / rabbi / rabi, a le sens de " rabbin » (en hébreu : « mon maître »). Le mot a la même étymologie que l'arabe ربّ Justement, dans un souci de distinction entre les deux, l'accent est mis sur l'emphase du second: rabbi / rabbi pour le «rabbin» et raḅb ${ }^{w i}$ pour "(mon) Dieu». Toutefois, à ce sujet Leslau (1945:67) manifeste une certaine retenue et ne parle que de probable distinction phonologique. A Fès, l'emprunt hébreu a également le sens de «maitre d'école talmudique » ou "lettré qui exerce une fonction religieuse ou publique ». D'après Brunot et Malka, l'étymologie «mon seigneur » n'est plus ressentie, ce qui permet un emploi plus large de la formule, qui peut désormais venir introduire les patronymes de notaires, sacrificateurs, professeurs et juges (Brunot \& Malka $1940: 49){ }^{15}$.

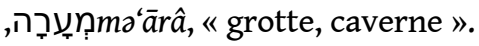

Réalisé me'āra / mitāra, il a le sens de "cimetière ». Au niveau étymologique, il est à rapprocher de l'arabe maḡära, "grotte ». Non seulement le sens s'est contextualisé, en témoignant manifestement de vieilles pratiques troglodytes, mais son emploi connait aussi une nuance selon l'appartenance communautaire du locuteur. Pour le locuteur juif, le terme a le sens de « cimetière » et peut par exemple désigner le cimetière musulman ; $l$ me‘ạra d-l-msolminn, alors qu'à la Médina, il renvoie uniquement au cimetière juif (Brunot \& Malka 1940 : 129).

\section{Créations de verbes}

Le cas des verbes est lui aussi particulier puisque par définition, pour s'employer, un verbe doit pouvoir se conjuguer, et donc avoir pleinement intégré le système d'accueil. L'arabe marocain a tendance à adapter des verbes qu'il emprunte à la seconde forme fa “ $\partial l$, mais quand il prend des verbes de première forme hébraïque, ils restent, le plus souvent, à la première forme dialectale $f a l$ :

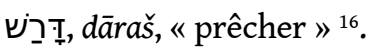

Réalisé dṛș / dorrs, il conserve son sens. La réalisation en sifflante /š/ > /s/ est attendue. Le tout est emphatisé : /ṛ/ et /ṣ/ est emphatisé. M. Cohen le mentionne aussi pour Alger.

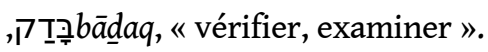

Réalisé bdəq, il conserve le sens de « vérifier » mais ne s'emploie que dans des contextes spécifiques. Il est emprunté à l'expression hébraïque : badīiqat hāmeșs, "vérification du hămēes (de l'absence de levain dans les foyers avant la fête de Pessah) ». Le verbe signifie donc plus précisément « vérifier l'absence de hāmēsṣ » et s'emploie comme il suit : howa kaibdəq ḥāmēș, «il vérifie le hâāmeṣ ».

D'autres verbes se créent à partir d'extraits de racines hébraïques, de verbes ou de noms, et s'intègrent dans un schème arabe dialectal de forme I ou II : 
Le mot qui vient est construit à partir du verbe הִִ̣̣, hidpiss, « imprimer ». En hébreu, il est le résultat du croisement de la forme hifil (qui est l'équivalent de la forme IV arabe 'af'al), et de la racine VD.P.S. Il est réalisé en judéo-arabe sur une première forme tfos (avec assourdissement du /d/ initial ${ }^{17}$ ), « imprimer » et connait une variante passive $n t f a s$, " être imprimé ». Le passif n'est pas un emprunt direct au passif hébreu nidpas; si c'était le cas, il serait réalisé ntpas, avec maintien $\mathrm{du} / \mathrm{p} /$, dont le /f/ n'est qu'une variante allophonique. Si le mot dans le parler arabe est prononcé $n t f \partial s$, c'est qu'il se construit bien à partir du nouveau verbe tfəs, sans considération pour l'alternance /p/-/f/, propre à la

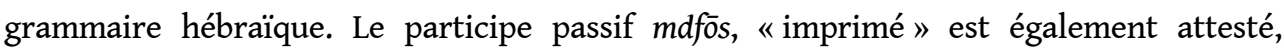
toujours avec $/ \mathrm{f} /$.

Des verbes courants de deuxième forme apparaissent construits à partir de substantifs :

,Uł'̣ppiyyūt, « poème liturgique »

Le mot hébreu est lui-même dérivé du grec poietes, « celui qui fait, artificier » et apparaitt dans la langue post-biblique, dans le sens de « histoire inventée, narration, poème ». En hébreu médiéval, le sens se précise en « poème liturgique, chant » (Klein 1987 : 504 ). Dans le parler arabe des Juifs de Fès, un verbe payyot ${ }^{18}$ s'est construit à partir de ce substantif (réalisé piyōț) et à le sens de "chanter un piyyūṭ » ou même de "chanter», en se substituant au verbe ġonna.

Sur le même modèle, J. Tedghi (1995: 60-61) note les verbes miyyal, « circoncire », formé sur l'hébreu millâ, « coupure, circoncision » ou encore kəššər, " cachériser ", construit sur l'hébreu kāšēr, «cacher, licite » (et bien d'autres). Leslau (1945: 70) et Brunot \& Malka (1940 : 117) mentionnent quant à eux le cas du terme kōah, «force, vigueur » (< héb. nूỉĐ, $k \bar{o}^{a} h$, «force »), qui ne donne pas de verbe mais un participe et un mașdar de forme II mkowoh, «fort, brutal » et tkwiha, « force brutale ».

Il arrive enfin que des verbes soient construits sur des racines trilitères inconnues de l'hébreu, suite à de mauvaises identifications du schème d'origine. C'est le cas d'un terme emprunté à

la bénédiction sur le pain, dans laquelle il est dit de Dieu qu'il est :המוציא לחם מן הארץ, ham-mōṣi $i^{(1)} l e h e m$ min hā-'āreș, mot à mot «celui qui fait sortir le pain de la terre ». En hébreu, mōși $i^{(1)}$ 《 celui qui fait sortir » est le participe actif du verbe yāṣa $\bar{a}^{()}$, «sortir » à la forme causative (schème hifîli). Le mot est emprunté dans le parler arabe des Juifs de Fès (ainsi que dans l'ouest algérien) et réutilisé comme s'il était construit sur une racine VMṢY (la racine hébraïque est $\sqrt{ } Y S^{\prime}$ < WṢ̂*) et s'articule $m s ̦ a \bar{a} / i m s ̦ i^{19}$, sur le modèle de verbes arabes comme mšă/imšĩ. Cet emprunt, figé dans sa forme se manifeste figé dans le sens également. Le mot en judéo-arabe ne signifie pas (ou plus) «faire sortir» mais uniquement « faire la bénédiction sur le pain ».

\section{Hypercorrection}

Pour terminer, il faut noter un cas particulier d'hypercorrection autour du mot sémitique «chien» (<kalb*). Une confusion s'est formée à partir de plusieurs éléments grammaticaux réels. En hébreu, sa forme est kele $\underline{b}$ et son pluriel $k \partial l a ̄ b i m^{20}$, pluriel régulier des mots de forme $\mathrm{CeCeC}$ dits "ségolés ", qui maintiennent une trace de pluriel interne, bien présent en arabe, comme dans le même mot kalb / kilāb et en darija kəlb / klāb. Face à ces différentes formes et à la conscience du fait que l'hébreu / $k$ / connait une variante allophonique spirante / $\underline{k} /$, les locuteurs ont créé une forme hybride pseudo-hébraïque 
Halāb (kalāb), qui ne connait toutefois pas de pluriel et ne se trouve que dans l'expression f-ḩâll-Halāb, « comme un chien» (Brunot \& Malka $1940: 43$ et Leslau $1945: 76$ ).

\section{Conclusion}

Comme le rappelle J. Tedghi (2003) ; depuis le début des années 80 , la recherche sur la composante hébraïque du judéo-arabe s'est accélérée. Ces avancées ont pu démontrer que le lexique hébreu est, surtout dans la littérature écrite, bien plus large que celui consacré au culte et à la culture juive, même si le nombre de ces éléments ayant couramment intégré le langage courant, reste limité. De plus, s'il est désormais reconnu qu'ils ne nomment pas toujours directement des faits du monde juif (religion, quartier juif, imaginaire juif ....), ils y sont malgré tout forcement connecté au départ, puisque les seules sources d'apports lexicaux hébreux ou araméens viennent du corpus de textes étudiés dans le cadre de la vie juive. Ces emprunts lexicaux apparaissent dans des contextes spécifiques mais ne manquent pas d'évoluer localement et librement, que ce soit sémantiquement ou formellement, en se remodelant selon le moule articulatoire du parler arabe dans lequel ils s'insèrent. Ces deux aspects, d'évolution de sens et de forme les font sortir de leur cadre d'origine, jusqu'à les rendre méconnaissables.

W. Leslau (1945 : 71-76) organise les catégories sémantiques représentées comme il suit : une majorité de termes relatifs au religieux, les noms des mois et des vacances (issus du calendrier religieux), l'organisation de la vie du quartier juif, les formules / énoncés religieux, l'éducation, la vie sociale, les institutions, la vie familiale et la vie affective. Il note aussi une série d'adjectifs qualificatifs tels que « fameux, fort, parfait », des insultes et malédictions et enfin, des "varia» comme hatìma, «signature ». En fait, un tel mot devrait intégrer la catégorie des "énoncés religieux " puisqu'il est très certainement emprunté à l'expression hébraïque prononcée autour du Yom Kippour : gamar hăạīma țōbâa ${ }^{21}$.

Finalement, ce qui rassemble tous ces termes est qu'ils renvoient, ou qu'ils ont renvoyé dans le passé, aux corpus textuels de référence du judaïsme, ou à la vie juive, le plus souvent face à la nécessité de désigner des choses précises, objets ou concepts, n'ayant pas d'équivalents en langue arabe. Pour les termes ayant un parfait équivalent, comme pour le cas de certains adjectifs, les mots arabes et hébreux sont employés alternativement.

Certains mots hébreux sont connus de tous les locuteurs, comme hāạām (« sage »), bəkōr (« ainé »), brāâkâ («bénédiction»); ils appartiennent au registre du religieux ou de la famille, donc aussi de l'intime. Mais pour le cas de mūplä('), «parfait» (réalisé moflì), gāmūr, "complet " (réalisé gamōor) ou encore bațūlâ, "femme en âge de se marier " (réalisé biţōa), W. Leslau (1945: 71) rappelle qu'ils ont des équivalent arabes dialectaux usités : moflī = mazyān, gamōr = kbīr et biţōla = 'āta' ('ātaq). Ces mots sont également pris, au départ, du contexte religieux mais ils s'en écartent avec le temps et l'usage, laissant libre court à l'évolution sémantique et formelle, se propageant chez les non lettrés, les femmes et les enfants, et même pour de rares termes, chez les locuteurs musulmans. 


\section{BIBLIOGRAPHIE}

Bar-Asher, Moshé. 1978. "Les éléments hébreux dans le judéo-arabe marocain ", dans Ləšōnēnū, 48-49, 163-189 [en hébreu].

Bar-Asher, Moshé. 1992. La composante hébraïque du judéo-arabe algérien, communautés de Tlemcen et de Ain-Temouchent, Jérusalem, Magnes Press.

Brunot, Louis \& Malka, Elie. 1939. Textes judéo-arabes de Fès, Rabat, Ecole du Livre.

Brunot, Louis \& Malka, Elie. 1940. Glossaire judéo-arabe de Fès, Rabat, Ecole du Livre.

Cohen, Marcel. 1912. Le parler arabe des Juifs d'Alger, Paris.

Cohen, David. 1964. Le parler arabe des Juifs de Tunis - Textes et documents linguistiques et ethnographiques I, Paris-La Haye.

Cohen, David. 1975. Le parler arabe des Juifs de Tunis II : étude linguistique, Paris-La Haye.

Cohen, David. 1981. « Remarques historiques et sociolinguistiques sur les parlers arabes des Juifs maghrébins ", International Journal of the Sociology of Language, 30, 91-105.

Henschke, Yehudit. 2007. Langue hébraïque dans un parler arabe, le lexique hébreu dans l'arabe parlé des Juifs de Tunisie, Jerusalem, Institut Bialik [en hébreu].

Klein, Ernest. 1987. A Comprehensive Etymological Dictionary of the Hebrew Language for Readers of English, Foreword by Haïm Rabin, Carta Jerusalem, Haifa, The University of Haifa.

Leslau, Wolf. 1945. « Hebrew elements in the Judeo-Arabic dialect of Fez », The Jewish Quatterly Review, 36, 61-78.

Levy, Simon. 1990. Parlers arabes des Juifs du Maroc : particularités et emprunts (histoire sociolinguistique et géographie dialectale), thèse de doctorat d'Etat, Paris, Université-Paris VIII.

Levy, Simon. 1994. «De quelques hébraïsmes en arabe marocain et de leurs voies de passage », Approches linguistiques : universaux et paramètres, Hommage au professeur Driss Seghrouchni, Rabat, Université Mohammed V, Publications de la faculté des lettres et des sciences humaines, $35-43$.

Levy, Simon. 2013. « Les parlers arabes des Juifs du Maroc », Langage et société 2013/1, n¹43, p. 41-51.

de-Prémare, Alfred Louis. 1999. Dictionnaire arabe-français, Langue et culture marocaine, 12 tomes, Paris, L'Harmattan.

Tedghi, Joseph. 1995. «Les interférences de l'hébreu dans les langues judéo-arabes d'Orient et d'Occident musulmans », Tedghi, Joseph (éd), Les interférences de l'hébreu dans les langues juives, Paris, Publications du centre de documentation et de recherches Etudes hébraïques et juives modernes et contemporaines, 41-66.

Tedghi, Joseph. 2003. “Evolution des recherches sur la composante hébraïque dans les parlers judéo-arabes maghrébins modernes ”, Alvarez-Péreyre, Frank \& Baumgarten, Jean (eds.), Linguistique des langues juives et linguistique générale, Paris, CNRS Editions, 157-190. 


\section{NOTES}

1. La mention «pseudo » recouvre ici plusieurs choses : des mots araméens, grecs ou arabes sont parfois identifiés à tort comme hébreux par les locuteurs quand d'autres, réellement hébreux, sont utilisés de façon inédites dans le dialecte arabe, ils sont en ce sens à considérer comme (judéo-)arabes.

2. Les chiffres mentionnés sont donnés dans Tedghi $2003: 169$ et renvoient à une publication de David Cohen n'ayant pas vu le jour à l'époque de l'article, mais que J. Tedghi a pu consulter.

3. Les emprunts aux langues romanes ne sont pas spécifiques aux parlers juifs.

4. Les translitérations en caractère latin de l'hébreu et de l'arabe résultent de traditions distinctes prenant en compte les particularités étymologiques et phonologiques de chaque langue. Pour l'exemple bəkōr / běHôr, il n'y a pas de différence de réalisation entre / $\underline{k}$ / hébreu et / $\mathrm{H} /$ arabe ; ils renvoient tous deux à une réalisation $[\mathrm{x}]$. Cependant, pour l'hébreu, il s'agit d'une variante allophonique du phonème $/ \mathrm{k} /$. En arabe, une telle variante allophonique du phonème / $\mathrm{k} /$ n'existe pas, et le son $[\mathrm{x}]$ ne peut être que la réalisation du phonème / $\mathrm{H} /$ noté par le graphème $\dot{\tau}$

Dans leur étude de 1940, Malka et Bruno notent logiquement ce terme en graphie arabe : بخور. Selon les normes de translitération de l'arabe maghrébin, le graphème $خ$ se transcrit se transcrit $\mathrm{H}$ ou $\mathrm{x}$. Si c'est bien le seul moyen de noter précisément la réalisation de ce terme pour le dialecte marocain, ce choix orthographique mène à une confusion étymologique ; la racine hébraïque est $\sqrt{ } B K R$ alors que la notation en caractères arabes, comme sa transcription en caractères latins, peut faire croire à une racine $\sqrt{ } \mathrm{BH}$.

5. Il apparait aussi chez les communautés de l'Ouest algérien sous la forme biHūr.

6. La majorité des mots hébreux intégrés à l'arabe dialectal des communautés juives s'intègrent parfaitement dans la langue d'accueil et se comportent par la suite comme n'importe quel mot arabe. En ce sens, les noms communs prennent l'article arabe. Les emprunts de mots «fonctionnels » sont très rares puisqu'ils impliqueraient une véritable rencontre et imbrication de deux systèmes linguistiques dont la source ne pourrait être qu'un parfait bilinguisme, ce qui n'est pas le cas ici. Les locuteurs sont des arabophones de culture juive; ils parlent arabe et étudient l'hébreu. Les seules occurrences dans lesquelles il est possible de voir apparaître l'article défini hébreu sont celles d'expressions figées empruntées dans leur intégralité et dans lesquelles l'article n'est pas en première position, comme par exemple les compléments de noms / états construits de type nom article-nom. C'est le cas de l'expression ere hassim, « religieux » (<héb. yore $\bar{e}^{(')}$

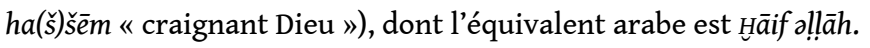

7. L'origine hébraïque du terme est également ignorée des locuteurs. Pour cette raison, son emploi s'est perpétué sous une forme figée dans le sociolecte hébreu des israéliens d'origine marocaine. Ils pensent qu'il existe un mot d'arabe dialectal fșāra signifiant « mauvaise posture ». Étant aujourd'hui majoritairement hébréophones monolingues, ils n'identifient pas la préposition $\mathrm{f}$ - de l'arabe dialectal et en font un nom en lui antéposant l'article défini hébreu : hafsara, la «mauvaise situation" et même ha-fsara še-ba-fsara "la pire des situations ». Ils connaissent pourtant le mot șāra, " peine, soucis » en hébreu moderne qu'ils réalisent tsara (avec perte de l'emphase et affrication $\mathrm{du} / \mathrm{s} />/ \mathrm{ts} /$ ), sans savoir qu'il s'agit du même. Sa trajectoire dans le temps et l'espace est la suivante : hébreu ancien șāra, "peine, soucis » > judéo-arabe marocain șăra, "peine soucis", intégré dans une construction $f$-ș-ṣāra $(f-l-s ̣ a ̄ r a)$, "dans une mauvaise situation ", conscientisé comme arabe dialectal > ré-emprunté en hébreu moderne sous une forme figée et refondue dans l'hébreu israélien fsara "mauvaise situation ». Ce qui mène à une situation de doublon difficile à identifier comme telle : fsara / tsara.

8. Ce participe apparaît en hébreu à la période médiévale. 
9. La racine hébraïco-araméenne $\sqrt{K P R}$, « cacher, pardonner, expier », est la même que la racine arabe VKFR, qui apparaît dans le terme كافر, kāfir, "incroyant» et même dans une forme identique au mot hébreu كفّارة, kaffāra, " expiation ».

10. Expression attribuée à David Cohen dans Tedghi $2003: 169$.

11. L'expression apparaît en hébreu postbiblique et suit les normes orthographiques de l'araméen (aleph final). Elle est probablement construite sur le verbe wādâa, « confesser », dans le sens de « avec ma confession ».

12. Mot d'origine araméenne qui apparaît en hébreu à l'époque postbiblique. Il s'orthographie

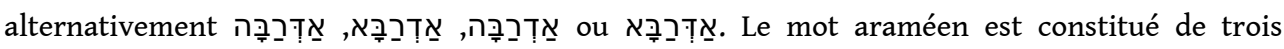
éléments : 'a, « sur », do, « lequel » et rabbāa, « fort ».

13. Au niveau étymologique, le sens de la racine $\sqrt{H M}$ Ș $^{*}$ en sémitique ancien est « aigreur ». Le phonème archaïque /ṣ́/ passe à /ṣ/ en akkadien, ougaritique et hébreu mais à /ḍ/ en arabe (en passant par $/ \mathrm{d}^{\mathrm{l}} /$ ). Les réalisations de cette racine sont alors emẹs en akkadien, " être aigre, acide", en ougaritique hamș, "vinaigre » en hébreu hōmeș, "vinaigre " et hāmēṣ "pâte levée (celle qui est aigre, dont le goût est amer) » et en arabe, la racine est VḤMD et non VḤMS (racine des " pois chiches »). Le mot arabe cousin du ḥāmeș hébreu est ḥāmiḍ, " aigre » (et non hammoṣ, " pois chiche », d'ailleurs réalisé hims ou hemș dans le parler juif). En arabe ancien hamid̆l

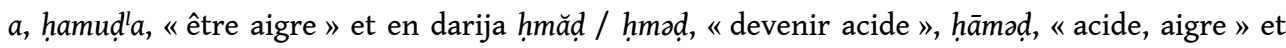
l'adjectif substantivé hāmod, « citron » (désigne parfois une « variété de grenade »).

14. Enoncé extrait d'un texte rédigé par Jules Danan, cours de judéo-arabe de l'Inalco du CNED, ancienne mouture.

15. A ce sujet, il faut noter que si certains mots arabes ont un sens légèrement différent chez les locuteurs juifs et musulmans (par exemple mṣhāf signifie «Coran » à la Médina et "livre » au Mellah, madrasa signifie " école » à la Médina et « école coranique » au Mellah ...), c'est aussi le cas de certains de ces emprunts hébreux. Comme le rappelle J. Tedghi (2003, p. 177) ; à la Médina, le rabbin est nommé hazzāan ou ḥāHām, deux mots d'origine hébraïque (hazzān et ḥākāām) qui signifient respectivement dans le parler judéo-arabe « homme de religion, sacrificateur juif » et « savant en théologie » (et en hébreu « chantre » et « sage »!).

16. Mentionné par Leslau $1945: 69$.

17. Ce type d'assourdissement de la consonne initiale, résultat d'une assimilation régressive partielle sous influence d'une consonne médiane sourde, ici $/ \mathrm{f} / \rightarrow / \mathrm{d} /=/ \mathrm{t} /$, est courant dans les parlers pré-hilaliens. C'est un phénomène courant en judéo-arabe fassi, le cas de nombreux

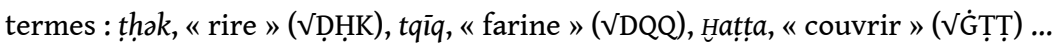

18. Le verbe judéo-arabe semble bien dériver du substantif piyyūt et non du verbe hébreu piyyett, d'apparition plus tardive. De plus, le verbe hébreu signifie «composer un piyyūṭ » et non le chanter.

19. De la même manière, le français connait l'expression «faire le motsi » dans le sens de «faire la bénédiction sur le pain ".

20. Si la voyelle longue de ces pluriels hébreux rappelle bien le pluriel interne, cette langue a toutefois uniformisé ses pluriels sur le modèle externe, d'où l'ajout, probablement ultérieur, de la marque du pluriel en suffixe -īm, sur des formes déjà marquées en interne kalāb : kalābīm.

21. «Que tu sois signé et scellé (dans le livre de la vie)». 


\section{RÉSUMÉS}

Le parler judéo-arabe de Fès est une déclinaison de l'arabe fassi dont la culture spécifique et le mode de vie des locuteurs engage un renvoi vers la culture juive et se réfère constamment aux corpus de références de celle-ci (Bible hébraïque, Talmud etc.). En cela, nombre de mots hébreux et araméens s'immiscent dans la langue. Ces apports apparaissent majoritairement à l'écrit ou dans la langue des lettrés. Pourtant, une quantité plus modeste d'entre eux, mots hébreux ou pseudo-hébreux, s'intègre dans la langue parlée courante des hommes comme des femmes du quartier juif.

INDEX

Mots-clés : Maroc, Judéo-arabe, Dialectologie, Hébreu, Fès

\section{AUTEUR}

\section{JONAS SIBONY}

GEO - Université de Strasbourg

4 rue Blaise Pascal, CS 90032, F-67081 Strasbourg cedex

sibony.jonas@gmail.com 


\title{
Étude des particules apparentées aux vocatifs/exclamatifs yā et iyy $\bar{a}$ (k)
}

\author{
Catherine Taine-Cheikh
}

\section{Introduction : le vocatif}

\subsection{Les particules vocatives ou exclamatives}

1 - L'arabe standard connaît différentes particules vocatives ou exclamatives servant à interpeler ( $y \bar{a}$, hay $\bar{a}, a-y \bar{a},{ }^{?}$ ayyuhāa) ou à mettre en garde ( $\left.{ }^{?} i y y \bar{a}-k a\right)$.

$2{ }^{2}$ ayyuhā est une variante du vocatif alors que ${ }^{2} a$ - est une variante archaïque.

3 Signalons également le cas de $w \bar{a}-$-... $\bar{a} h$ qui encapsulent l'objet de l'exclamation.

4 - Dans les dialectes, $y \bar{a} / y a$ est la particule la plus fréquemment employée pour le vocatif et sa présence devant les termes d'adresse a été relevée à maintes reprises.

5 La variante $\bar{a}$ s'est imposée dans certains parlers, notamment maghrébins, probablement sous l'influence du berbère. La variante $a / \bar{a}$ est préférée chez les Chleuhs du Sous (Destaing 1937 : 327) et, dans le Nord Constantinois, elle est plus fréquente chez les ruraux que chez les citadins (Marçais 1956 : 602-3).

\subsection{Constructions}

6 En général, la particule introduit un syntagme nominal plus ou moins complexe.

7 - En arabe littéraire, les constructions de $y \bar{a}$ et de $y \bar{a}{ }^{2}$ ayyūh $\bar{a}$ (fém. $y \bar{a}{ }^{2}$ ayyatuh $\bar{a}$ ) se distinguent par le fait qu'après yō, N n'est jamais accompagné de l'article (Badawi \& al. 2004 : 287-9)

8 - Dans de nombreux dialectes, yā peut être suivi d'un nom précédé de l'article défini. L'usage semble courant au Yémen (Piamenta 1990: 534), mais il paraît plus spécifique 
dans certains parlers. Pour Marçais (1908: 198), l'usage avec l'article (ī̄-rr-ṛâžel 'hé l'homme!') tend à s'imposer quand on interpelle un individu éloigné alors que la construction sans article est usitée quand on s'adresse à un interlocuteur, au cours de la conversation. En Tunisie, c'est la différence de sens qui a été mise en avant (Marçais \& al. 1958-1961: 4403 et sq.). Chez les Marazig, la présence de l'article marque une certaine nuance affective (Boris 1958: 685). Ailleurs, c'est la présence conjointe de l'article et du démonstratif ( $i \bar{a}$ hăde-r-r-râžel: construction classique) qui donne une nuance de mépris (Marçais 1908 : 198).

\subsection{Valeurs}

Indépendamment de ces nuances associées à des constructions particulières, les valeurs d'emploi des vocatifs/exclamatifs varient régulièrement en fonction de l'intonation et du contexte, tant linguistique qu'extralinguistique.

\subsubsection{SN : particule $+[$ art $]+($ pro $) \mathrm{N}$}

10 Si Philippe Marçais (1956: 603) insiste sur l'emploi extensif de yā dans des tournures exclamatives (joie, douleur, surprise, souhait : 'que je suis heureuse...', 'quelle perte...', 'ô ma douleur...'), Marçais et Guiga (1958-1961 : 4403-4) mettent l'accent sur la fonction phatique : «i $i \bar{a}$, interjection monosyllabique employée pour interpeller, exhorter, appeler l'attention. Elle précède toujours immédiatement le vocable sur quoi l'interlocuteur doit être mis en éveil (ce qui désigne cet interlocuteur lui-même ou toute autre chose) et forme avec lui un mot phonétique. À l'intérieur de ce complexe, la voyelle finale de la particule interjectionnelle est sujette à de notables variations de timbre, de longueur et d'accentuation, dépendant à la fois de l'ambiance phonétique et de l'intention du sujet parlant. »

Quant aux entrées des dictionnaires plus récents, elles soulignent surtout la distinction entre les valeurs d'emploi centrées sur le locuteur et celles centrées sur l'interlocuteur. Cf. «y $\bar{a}$ and $y \bar{a} h \bar{a} \mathbf{1}$ /voc[ative] part[icle]/ used to attract attention or to address s'one hey! o! [...] 2 /part[icle]/ used to express a wish, or admiration [...]» (Holes $2001: 570){ }^{1}$

\subsubsection{Particules seules : interjections}

12 Employée seule, la particule ya devient une interjection, ainsi en tchadien (Jullien de Pommerol 2000 : 1325). Ses valeurs sont souvent variées. Marçais et Guiga (1958-1961: 4409) remarquent que la variation de la valeur dépend en partie de la place de iâh dans la proposition : " $1^{\circ}$ 'attention !' pour mettre en éveil un interlocuteur, un auditoire : à la fin de la formule de tašìd. $2^{\circ}$ en tête de proposition 'tiens!' pour marquer une surprise, la constatation d'un fait inattendu ; souvent suivi d'une énonciation de forme interrogative, ou de ton interrogative : iâh žê 'tiens ! il est arrivé ?' ».2

À noter que, comme interjection, la particule prend parfois la forme yū. C'est notamment l'interjection des femmes Baharna «used to chivvy, or express disapproval or anxiety " (Holes 2001 : 573). Relevé à Damas chez les femmes (J. Lentin, communic. pers.), yū a été signalé aussi dans le quartier de Žima ${ }^{\mathrm{q}}$, à Tozeur (Tunisie), comme dans le maltais du continent (Saada $1981: 136)$. 


\subsubsection{Aspects pragmatiques et stylistiques} fois le caractère conventionnel de l'interpellation se marque par le choix du prénom.
C'est ainsi que quelqu'un dont on ne connaît pas le nom sera interpelée, selon la
communauté, avec un $y \bar{a}^{-}{ }^{-} b d_{-}{ }^{2}$ llah ou (à Takroûna) un ya-sī-muhámməd (Roth $1995: 221$ ). ${ }^{3}$ maghrébines et montre que, dans ce corpus particulier, yā joue un rôle important d'opérateur stylistique. On retiendra notamment les valeurs d'exhortation à la sagacité ou d'insulte, en fonction de la place du syntagme introduit par $y \bar{a}^{4}$

\section{De la particule vocative à la conjonction de but}

L'interpellation s'accompagne souvent d'une mise en garde ou d'un souhait. Employée en dehors du mode exclamatif, la particule vocative en vient à exprimer une relation d'enchaînement, consciemment recherchée (but) ou non (consécution).

\subsection{Mode exclamatif}

\subsubsection{Mise en garde}

Il arrive que la particule ${ }^{?} i y y \bar{a}$ (ou une de ses variantes) soit usitée pour la mise en garde.

Feghali (1928 : 366 n.1) donne un exemple libanais avec le pronom de $1^{\text {re }}$ personne :

1) '̊īyâ-né ' gare à moi !'

Cependant, la mise en garde s'adresse en général à un interlocuteur. (-)k semble alors représenter le pronom affixe de $2^{\mathrm{e}}$ personne, ainsi au Caire dans :

2) iyyāk nisitt! 'hüte dich davor, dass du es vergessen hast!'

En effet Woidich donne dans sa grammaire, non seulement iyyāk 'hüte dich', mais aussi, avec le même sens, iyy $\bar{a}+(2006: 272,313)$.

Pour l'arabe littéraire moderne, la grammaire de Badawi \& al. (2004:291) ne donne que la forme ${ }^{2}$ iyyāka (non décomposée) dans deux constructions distinctes, mais il s'agit à chaque fois d'une mise en garde adressée à un interlocuteur (masculin) ${ }^{5}$ :

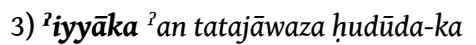

'I warm you not to exceed your limits'

4) ${ }^{2}$ iyyāka wa kalāma fì hādā l-muawdị $\bar{u}^{\Upsilon} i$

'be careful not to talk about this subject' 
Quant au Dictionnaire COLIN (1993) pour le Maroc, il donne deux exemples similaires sous deux entrées distinctes, d'une part (5a) sous ${ }^{2} i y y$ (p. 38), d'autre part (5b) sous yyāk (p. 2092):

5a) ${ }^{?}$ iyyāk təkdəb 'garde-toi de mentir'.

5b) wa-yyāk ttē $b$ b-Y 'garde-toi bien d'ajouter foi à ses dires !'

\subsubsection{Souhait}

$y \bar{a}$ peut être employé pour exprimer un souhait (voir Holes 2001:570), mais la particule de souhait prend souvent une forme plus étoffée pour introduire une proposition. Là encore, le $-k$ fait plus ou moins partie intégralement de la particule.

Au Caire (Woidich 2006: 369, 339), 'hoffentlich' se dit iyyāk, même quand le souhait concerne une $1^{\text {re }}$ personne pluriel (6a), mais l'apparition de la marque -i du féminin en (6b) semble indiquer que $-k$ conserve sa valeur pronominale originelle dans certains cas :

6a) iyyāk yigi-l-na min-ha fayda

'hoffentlich haben wir einen Nutzen davon!'

6b) iyyāki ma-kunši dayi ${ }^{2} t-i k$

'hoffentlich habe ich dich nicht belästigt !'

L'existence, à côté de $y \bar{a} k$ 'dans l'espoir que peut-être, afin que peut-être', d'une forme de pluriel $y \bar{a} k o$, prouve qu'au Maroc la conjonction qui introduit un soupçon n'est pas non plus complètement invariable (Colin 1993 : 2091-2).

En hassāniyya, par contre, la particule iyyāk/əyyāk 'pourvu que, en espérant que' est toujours invariable, qu'elle soit utilisée dans les formules de salutation - quels que soient le genre et le nombre des interlocuteurs - ou dans des souhaits :

7a) iyyāk lā bës

'(j'espère qu') il n'y a pas de mal ?!'

7b) iyyāk stṛhtu l-bârəh

'(j'espère que) vous vous êtes bien reposés hier ?!'

7c) iyyāk mān-ik marị̀̂a

'(j'espère que) tu n'es pas malade ?!'

7d) iyyāk žä

'(j'espère qu') il est venu ?!'

Voir aussi la présence de əyyāk dans les vers suivants (poésie de Seddûm Ould Abbe) :

8) əyyā $k$ y $\partial^{\complement}$ vi mulā-nä

'Que Dieu pardonne à Bakar

əl yäv $v^{\complement}$ al mən xiyānä

'Tous les péchés qu'il a commis durant sa vie

w-əyyā $\mathbf{k}$ yäžbar murā-nä...

'Et qu'il trouve dans l'autre monde...'

\subsection{Mode déclaratif : consécution et but}

Parfois iyyāk introduit des propositions subordonnées de but ou de simple consécution. Dans ce cas la particule est toujours invariable en genre et en nombre.

Là encore, un exemple de ce type a été relevé au Caire (Woidich 2006 : 369) :

9) ${ }^{2}$ umt atmašša fi l-?ōọa iyyāk yigīl-i nōm

'ich begann im Zimmer auf und ab zu gehen, damit mir der Schlaf kommen möge.'

iyyāk 'afin que' est fréquent en hassāniyya. Cohen (1963 : 226) en donne un exemple ${ }^{6}$ :

10) lə-klām... yəsbəg və-l-gaḷb iyyā $\mathbf{k}$ ittașal mən vämm lə-l-hnū k 
'les discours... passent d'abord par le cœur afin que de là ils puissent être transmis aux mâchoires'

Mais iyyāk (+ verbe à l'inaccompli) peut avoir le sens de 'pour (que), dans l'intention de' :

11) mšä iyyā $\mathbf{k}$ yäžma $a^{\varsigma}$ lo-ḥtāb 'il est parti pour (dans l'intention de) ramasser du bois'

En (11) iyyāk alternerait avec yäkān-u 'pour (dans l'espoir de)' et en (12) il alternerait aussi avec $b \bar{a} \check{s}^{\prime}$ '(pour) que' ou avec zéro :

12) a $a^{\mathrm{i} t \hat{-}-n i ~ m ̣ m a ̈ y h a ̈ ~[b a ̄ s ̌ ~ / ~ i y y a ̄ k ~ / ~ y a ̈ k a ̄ n-i] ~ n ə s ̌ r ə b ~}$

'donne-moi de l'eau (pour) que je boive'

Le sens de 'afin que' se retrouve chez les Zaër du Maroc, soit sous la forme de yākši, soit sous la forme de $y \bar{a} k$ mais chez les seuls Beni Mellal (Loubignac 1952 : 589, 220 / 335).

$\mathrm{Vu}$ la rareté de cette évolution et l'histoire de la région, on peut penser à un trait linguistique hérité des $\mathrm{Ma}^{\mathrm{I}}$ qil que les hassanophones et certains Zaër auraient conservé.

\section{Interrogatifs et interrogations}

On peut interpeller quelqu'un pour de multiples raisons, mais c'est souvent pour poser une question ou lui demander confirmation de quelque chose. Ceci pourrait expliquer les similitudes entre les vocatifs et les interrogatifs ou le passage du mode exclamatif au mode interrogatif.

\subsection{Interrogatifs : ’ay- > yā}

$y \bar{a}$ a des emplois interrogatifs dans certaines aires dialectales.

En Iraq, $\boldsymbol{y} \overline{\boldsymbol{a}}$ est le signifiant de la particule du vocatif, mais aussi, comme variante de ${ }^{2} a y$, celui de l'indéfini ‘any’ et de l'interrogatif ‘which? what?' (Erwin 1963 : 361-2) :

13) yā bët?

'which house?'

$y \bar{a}$ se retrouve dans certains adverbes interrogatifs du yéménite (Piamenta 1990 : 534-5) :

14a) yā hìn?

'when?'

14b) yān?

'where?'

$\mathrm{Au}$ Tchad et au Soudan, $y \bar{a}$ a fourni une base pour la formation du pronom interrogatif yātu (Roth-Laly 1969-72 : 538, Reichmuth 1983 : 118). Pour Jullien de Pommerol (2000 : 1327), yâtu (" peut-être contraction de âyât hû ») est variable en genre et en nombre:

15) yâti sâtat êc?

'qui a fait cuire la boule?' (litt. laquelle...)

2 À noter que dans le pidgin-créole arabe de Juba, Manfredi (2017: 183) a observé une différence d'accentuation, entre le pronom yatú 'lequel' et l'adjectif yátu 'quel'.

\subsection{Interrogation rhétorique}

À côté de ces formes lexicalisées, sans doute apparentées à ${ }^{?} a y(y)$, on trouve des adverbes de phrase de sens interrogatif ou pseudo-interrogatif. 


\subsection{1. yā au Moyen-Orient}

Pour les dialectes de Syrie (au sens large), Barthélémy (1969: 913) définit yā 'n'est-ce pas ?' comme une « particule interrogative pour solliciter l'approbation d'autrui ».

Borg (2004: 472) donne un exemple de cet[te] « emphatic particle roughly equivalent to a tag question ", réalisé[e] ya dans l'arabe de Chypre :

16) $y a-l^{5} a p t u$

'but you shot it (the fox), didn't you?'

\subsection{2. yāk au Maghreb}

La particule pseudo-interrogative existe aussi au Maghreb (occidental surtout), mais avec un $k$ final : yāk 'n'est-ce-pas?' (Lentin 1959: 311). Marçais en souligne la fréquence d'emploi chez les Ūlâd Brāhîm de Saïda, dans l'est de l'Algérie (1908:199), mais elle a été surtout relevée au Maroc (y compris chez les Zaër, cf. Loubignac 1952 : 589).

À Rabat (Brunot 1952 : 829), la particule yāk peut être employée seule, au sens de 'n'est-ce pas ?'. Sinon, elle se place au début de la proposition et signifie 'est-il vrai que ? n'est-il pas vrai que ? est-ce que ?' :

17) $y \bar{a} k$ Hdemţi ?

'as-tu travaillé ?'

Dans le Dictionnaire COLIN (1993: 2091-2), on passe du yāk d'étonnement (parfois mêlé d'ironie) au yāk interrogatif appelant confirmation :

18a) $y \bar{a} k$ ? lā-bās ?

'tout va bien? pas de malheur arrivé ?...'

18b) yāk $m a$ Hुō-k?

'ne serait-ce pas, par hasard, ton frère ?'

9 D'après Harrell (2004: 224), cependant, la particule peut venir aussi bien en tête qu'en fin de proposition ${ }^{7}$ :
19a) yak qolt-ha-l-ek?
'I told you, didn't I?'
19b) - ma-mša-š, yak?
'He hasn't gone, has he?'
19c) - yak ma-m̌sa?
'Has he left (already)?'

Des emplois tout à fait comparables existent dans le hassāniyya du Mali (Heath 2004 : 292), ainsi que le montrent les exemples fournis par les textes recueillis par l'auteur (Heath 2003 : 102.24, 134.15, 206.12) :

20) $y \bar{a} k t$ t-trāb mā fi-ha- 'Didn't the land have-

t-träb mnaddsa wall ahi 'The land was wild (had wild animals), by God.'

21) ['Heard about it? His story too is good, just like that (other) situation.']

$-y \boldsymbol{y a} k$ ? 'Really?'

- hagg, hagg, gāl- 'Yes, yes, he says-'

22) lli mā-hu da da, bārəd hatta, yyāk ?

'(Let's do) something other than this, it's (too) sedate, isn't it?'

51 Les emplois en isolation et en fin de proposition comme en (21) et (22) n'ont jamais été relevés dans le hassāniyya de Mauritanie et, d'après mes informations personnelles, ils sont inacceptables dans la région du S.-O. Il est très probable que le hassāniyya du Mali a subi là l'influence de l'arabe maghrébin ${ }^{8}$. 


\subsection{Interrogation indirecte} introduit une interrogation indirecte.

23) $X, \dot{g} \bar{a} d i k \bar{a}$-itləffət $\boldsymbol{y} \bar{a} \mathbf{k}$ ma $t \bar{a} b^{\varsigma}-o$ ši hadd

' $X$ marche en se retournant pour voir si, d'aventure, quelqu'un ne le suivait pas.'

24) țāḥ li fi-h š-šəkk yā $\mathbf{k}$ mā huwwa ìhūdi

'je me suis demandé s'il n'était pas, par hasard, un juif.'

Dans ces deux exemples, l'interrogation semble accompagnée d'une nuance de doute, proche de celle qui caractérisait le yāk optatif marocain ('dans l'espoir que peut-être, afin que peut-être'). La grammaticalisation de yāk comme subordonnant de l'interrogation indirecte paraît donc, non seulement plus rare, mais aussi moins aboutie que celle de yāk comme particule de l'interrogation directe.

\section{Insistance, topicalisation et focalisation}

Attirer l'attention est l'une des fonctions des particules vocatives. Cette propriété est susceptible d'éclairer tout ou partie des emplois de yā (ou de ses variantes) qui suivent (cf. figure 20 dans Manfredi \& Tosco 2014 : 349).

\section{1. 'ijyā + pronom}

Certains arabisants présents au colloque AIDA doutaient que les emplois de ${ }^{2} i y y \bar{a}$ listés cidessous aient un rapport avec mon sujet. Les articles de Wilmsen (notamment celui de 2013) m'incitent cependant à ne pas passer ces faits sous silence, même si je ne peux ici approfondir la question.

\subsubsection{Avec effet d'insistance}

En arabe littéraire, l'antéposition de l'objet implique la présence de ${ }^{\top} i y y \bar{a}$, mais la construction produit un «rhetorical effect» (Badawi \& al. 2004 : 291) :

25) 'iyy $\bar{a}-k a^{2} a^{\complement} n \bar{\imath}$ 'you I mean' i.e. 'you are the one I mean'

$57 \mathrm{Au}$ Caire, en revanche, l'emploi de iyyā n'est pas (ou plus) stylistique. Il est devenu lexicalisé : iyyā+ (pronom) 'der gewisse' (Woidich $2006: 235)^{9}$.

26) iș-șuwar iyyā-ha 'die gewissen Bilder'

\subsubsection{Sans effet rhétorique}

- Après certains verbes (ditransitifs notamment), l'emploi d'une particule est assez fréquent au Moyen-Orient. Ainsi la particule invariable $y \bar{a}-\left(<\right.$ cl. $\left.{ }^{P} \bar{y} y \bar{a}-\right)$ est-elle usitée au Liban (Feghali $1928: 287-8$ ) en cas de double accusatif (avec deux pronoms suffixes) :

27) 'țait-ak yā-ha 'je te l'ai donnée'

Elle l'est aussi pour l'accusatif simple, après un complément introduit par la préposition l-

28) ' $m e l-l-e ́ y \bar{a}-h$ 'fais-le moi' (cl. i ímal-hu l-î)

Dans un cas comparable à (28), le suffixe est -yyā- en iraquien (Erwin $1963: 144$ ) : 
29) jïb-l-i-yy $\bar{a}-h a$ 'bring me it (fém.)'

61 - iyya est ajouté après $w$ pour coordonner deux pronoms. C'est le cas notamment en Syrie, mais aussi au Maroc (Colin 1993 : 38 et 2091-2) :

30) āna u-yyā-k 'toi et moi'

Le second pronom est souvent celui de $2^{\mathrm{e}}$ personne, mais ce n'est pas la seule possibilité.

\subsection{La particule yā}

yâ 'c'est... que' marque l'insistance en tchadien (Jullien de Pommerol 2000 : 1325) :

31) bêku intu, yâ anâ bigît râjil!

'c'est grâce à vous que je suis devenu un homme!'

64 Owens (1996: 151) précise, dans son étude des pidgins et des créoles, que la particule yá suit le constituant focalisé (kátifu wáraga en (32)), celui-ci pouvant être de n'importe quelle nature :

32) Kátifu wáraga yá máriya dé só.

'Write a letter is what my wife did.'

Dans le créole nubi d'Ouganda, 'ya sert aussi à la topicalisation contrastive (Wellens 2003 : 185), sauf pour le syntagme verbal comme en (32):

33) Nyere'ku 'ya a'dan 'to 'ma

'The child, its ears are not there.'

De plus, il existe un emploi typique du nubi parlé dans le district du Nil occidental, au Nord-Ouganda, celui où 'ya (ou l'une de ses variantes 'yaw et 'ya'de), placé en fin de proposition, emphatise toute la phrase (Wellens $2003: 169$ ) :

34) Ma'ma, je're 'ma 'ya!

'Mama, definitely do not run!'

67 Par ailleurs 'yala/'ya et 'dukuru ont pris le sens de 'thus, therefore, so' (Wellens 2003: 167-8) quand ils sont placés en tête de proposition ${ }^{10}$ :

35) 'Bes 'an(a) 'ain 'Ya 'an(a) 'aba 'mafi

'Well, I understood. Therefore I did not refuse.'

Dans l'arabe de Juba, ya est un multifonctionnel qui a, entre autres emplois, celui d'«emphasis marker» (Manfredi \& Tosco 2014: 339) ${ }^{11}$. L'une de ses particularités, par rapport aux précédents ya, est de précéder le terme emphatisé (bíu 'buy' en (36)) :

36) úo ya bíu fi yugánda de

(discussing a motorbikes dealer) 'He buys them in Uganda.'

Manfredi et Tosco terminent leur article par un tableau intitulé «The diachronic development of ya in Juba Arabic and Ki-Nubi» (2014 : 348). Voir Tableau 1. 
Tableau 1

\begin{tabular}{|l|c|c|c|c|}
\hline value historical & vocative & attention- & emphasis & contrastive \\
development & & calling & marker & focus \\
\hline Sudanese Arabic & $\checkmark$ & & \\
\hline Early Pidgin Arabic & $\checkmark$ & $\checkmark(?)$ & & \\
\hline Juba Arabic & $\checkmark$ & $\checkmark$ & $\checkmark$ & \\
\hline Ki-Nubi & $\checkmark$ & $\checkmark(?)$ & $\checkmark(?)$ & $\checkmark$ \\
\hline
\end{tabular}

\section{Conclusion}

J'ai laissé de côté des ya/yā qui m'ont semblé ne pas avoir de rapport avec la particule du

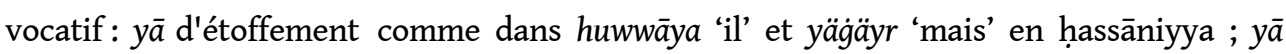
fonctionnel comme 'jusqu'à' dans ya-l-leil et ya l bilad en arabe tachado-soudanais (RothLaly 1969-1972 : 539) ; yā... yā... 'ou... ou...' dans de très nombreux parlers ${ }^{12}$.

71 En revanche, j'ai traité ensemble aussi bien $y \bar{a}$ et iyyā que yāk et iyyāk. Le $k$ final des deux dernières variantes a clairement pour origine un figement du $k$ de $2^{\mathrm{e}}$ personne et s'explique par le lien quasi ontologique du vocatif avec cette personne. Toutefois, cela ne permet pas de comprendre dans tous les cas pourquoi certains dialectes ont un $-k$ final et d'autres, non (ainsi pour la pseudo-interrogation).

Les particules du vocatif/exclamatif sont souvent employées avec différentes valeurs dans un même parler, mais elles sont susceptibles de prendre une valeur spécifique selon le mode (exclamatif $v$ s interrogatif $v s$ assertif...), la construction (+ (pro)nom, +verbe...), la place (en tête $v s$ en fin de proposition...) et l'intonation choisis. Aussi n'est-il pas rare qu'un dialecte présente plusieurs emplois grammaticalisés (et lexicalisés) de ces particules.

73 En faisant une grande place au classement selon le mode énonciatif, je pense avoir apporté un éclairage utile sur le fonctionnement de $y \bar{a}(k)$ et iyya $(k)$ et montré que, à l'instar d'autres 'petits mots' comme le mā arabe (voir Lentin 1995) ou le déictique (a)d berbère (voir Taine-Cheikh 2010), ils présentent une polygrammaticalisation remarquable.

\section{BIBLIOGRAPHIE}

Badawi, El-Said, Carter, Mike G., \& Gully, Adrian. 2004. Modern Written Arabic. A Comprehensive Grammar. London/New York: Routledge. 
Badawi, El-Said, \& Hinds, Martin. 1986. A Dictionary of Egyptian Arabic. Arabic-English. Beirut: Librairie du Liban.

Barthélemy, Adrien. 1969 [Fasc. 1-5, 1935-1936-1942-1950-1954]). Dictionnaire Arabe - Français. Dialectes de Syrie : Alep, Damas, Liban, Jérusalem. Paris : Geuthner.

Borg, Alexander. 2004. Comparative Glossary of Cypriot Maronite Arabic (Arabic-English). With an Introductory Essay. Leiden/Boston: Brill.

Boris, Gilbert. 1958. Lexique du parler arabe des Marazig. Paris : Klincksieck.

Brunot, Louis. 1952. Textes arabes de Rabat. II. Glossaire. Paris : Geuthner.

Cohen, David. 1963. Le dialecte arabe hassāniya de Mauritanie. Paris : Klincksieck.

Colin, Georges S. 1993 [1993-1997]. Le Dictionnaire COLIN d'Arabe Dialectal Marocain, édité par Zakia Iraqui-Sinaceur. Rabat/Paris : Al Manahil.

Destaing, Edmond. 1937. Textes arabes en parler des Chleuhs du Sous (Maroc). Paris : Geuthner.

Erwin, Wallace M. 1963. A Short Reference Grammar of Iraqi Arabic. Washington, D.C.: Georgetown University Press.

Farghal, Mohammed, \& Shakir, Abdullah. 1994. "Kin Terms and Titles of Address as Relational Social Honorifics in Jordanian Arabic". Anthropological Linguistics 36 (2). 240-253.

Feghali, Michel M. 1928. Syntaxe des parlers arabes actuels du Liban. Paris : Geuthner.

Harrell, Richard S. 2004. A Dictionary of Moroccan Arabic: Moroccan-English. Washington: Georgetown University Press.

Heath, Jeffrey. 2003. Hassaniya Arabic (Mali): Poetic and Ethnographic Texts. Wiesbaden: Harrassowitz.

Heath, Jeffrey. 2004. Hassaniya Arabic (Mali)-English-French Dictionary. Wiesbaden: Harrassowitz. Henkin, Roni. 2010. Negev Arabic. Dialectal, Sociolinguistic, and Stylistic Variation. Wiesbaden: Harrassowitz.

Holes, Clive. 2001. Dialect, Culture and Society in Eastern Arabia. Volume 1. Glossary. Leiden: Brill.

Jullien de Pommerol, Patrice. 2000. Dictionnaire de l'arabe tchadien. Paris : Karthala.

Kazimirski, Albert de Biberstein. 1860. Dictionnaire arabe-français, tomes I et II. Paris, Maisonneuve \& Cie.

Lentin, Albert. 1959. Supplément au Dictionnaire pratique arabe-français. Alger : La Maison des Livres.

Lentin, Jérôme. 1995. "Kān ya ma kān : sur quelques emplois de ma dans les dialectes arabes du Moyen-Orient", Studia Orientalia 75. 151-161.

Loubignac, Victorien. 1952. Textes arabes des Zaër. Transcription, traduction, notes et lexique. Paris : Max Besson.

Madouni-La Peyre, Jihane. 2003. Dictionnaire Arabe Algérien-Français. Algérie de l'Ouest. Paris : Langues \& Mondes - L'Asiathèque.

Manfredi, Stefano. 2017. Árabi Júba: un pidgin-créole du Soudan du Sud. Leuven, Peeters.

Manfredi, Stefano, \& Tosco, Mauro. 2014. "The Morphosyntax and Prosody of Topic and Focus in Juba Arabic", Journal of Pidgin and Creole Languages 29 (2). 319-351. 
Marçais, Philippe. 1956. Le parler arabe de Djidjelli (Nord Constantinois, Algérie). Paris : AdrienMaisonneuve.

Marçais, William. 1908. Le dialecte arabe des Ūlâd Brāhîm de Saïda (département d'Oran). Paris : Champion.

Marçais, William, \& Guiga, Abderrahmân. 1958-61. Textes arabes de Takroûna, II. Glossaire. Paris : Geuthner.

Owens, Jonathan. 1996. “Arabic-based Pidgins and Creoles”, Thomason, Sarah G. (éd.), Contact languages: A Wider Perspective. Amsterdam/Philadelphia: Benjamins. 125-172.

Piamenta, Moshe. 1990. Dictionary of Post-Classical Yemeni Arabic. Leiden/New York/København/ Köln: Brill.

Reichmuth, Stefan. 1983. Der arabische Dialekt der Shukriyya im Ostsudan. Hildesheim/Zürich/New York: Georg Olms.

Roth-Laly, Arlette. 1969-1972. Lexique des parlers arabes tchado-soudanais. Paris : CNRS.

Roth-Laly, Arlette. 1995. “La particule yā comme opérateur stylistique dans quelques énigmes arabes maghrébines", Studia Orientalia 75. 217-227.

Saada, Lucienne. 1981. Etudes sur le parler arabe de Tozeur (Tunisie). Paris : Geuthner.

Taine-Cheikh, Catherine. 1999. "Eléments d'anthroponymie maure : enjeux et significations du nom d'ego", Littérature orale arabo-berbère 27. 167-206.

Taine-Cheikh, Catherine. 2010. "The role of the Berber deictic and TAM markers in dependent clauses in Zenaga". Bril, Isabelle (éd.), Clause Linking and Clause Hierarchy. Syntax and pragmatics. Amsterdam/Philadelphia, Benjamins. 355-398.

Wellens, Ineke. 2003. An Arabic Creole in Africa. The Nubi Language of Uganda. Leiden: Brill.

Wilmsen, David. 2013. "Grammaticalization of the Arabic Demonstrative iyy $\bar{a}$ - as a Pronominal Object Marker in Ditransitive Verbs: An answer to Bravmann", Journal of Semitic Studies 58/1. 149-167.

Woidich, Manfred. 2006. Das Kairenisch-Arabische. Eine Grammatik. Wiesbaden: Harrassowitz.

\section{NOTES}

1. À noter, l'existence possible d'une troisième subdivision, intermédiaire entre les deux autres, celle de «self-apostrofization» (Badawi \& Hinds 1986 : 960).

2. Cf. l'emploi de yaah? 'yes?', en réponse à un vocatif, relevé dans le hassāniyya du Mali (Heath $2004: 288)$

3. Il existe en Mauritanie un curieux patronyme porté, entre autres, par Aḥmed Fāḍl ould YāMoḥammed. La présence de ce yā devant le prénom masculin le plus porté chez les Maures (cf. Taine-Cheikh 1999: 174) s'explique peut-être par un emploi générique comparable de Mohammed.

4. Il serait intéressant de savoir dans quelle mesure ces valeurs sont spécifiques à ce corpus particulier - comme l'est peut-être aussi l'emploi de yā avec un adjectif de couleur.

5. Le dictionnaire de Kazimirski (1860: 73) donne un féminin ${ }^{3} i y y a ̄ k i$.

6. Il précise : «Cette forme qui, étymologiquement, semble comporter un suffixe personnel, est invariable ».

7. Il en est de même dans l'ouest de l'Algérie où wâk remplace yâk (Madouni-La Peyre 2003 : 525) : 
i) šeftî-h ki xrej, wâk ? 'tu l'as vu quand il est sorti, n'est-ce pas ?'

ii) wâk, gult-ha l-ek! 'n'est-ce pas? je te l'avais dit !' (=je te l'avais dit, n'est-ce pas ?).

8. L'emploi de iyyāk en tête de proposition est possible mais dans le sens optatif (plus qu'interrogatif) vu en 2.2.

9. Au Soudan (Reichmuth 1983 : 122), le cas de $y \bar{a}$ 'jeder, der' constitue aussi une lexicalisation.

10. Des trois variantes, seule 'ya introduit optionnellement l'apodose (Wellens $2003: 168$ ).

11. Dans l'arabe de Juba, l'intonation basse sur le ya marqueur d'emphase (elle est très haute sur le terme qui suit) se distingue du pitch extra haut qui caractérise le ya du vocatif. D'autre part, l'intonation de yáwu, marqueur de focus informatif ( $\neq$ pré-supposé) diverge de celle de yawú, marqueur de focus ré-assertif.

12. Il s'agit d'un emprunt ancien au persan (Marçais \& Guiga 1958-1961 : 4407).

\section{RÉSUMÉS}

L'arabe standard connaît différentes particules vocatives ou exclamatives servant à interpeller ( $y \bar{a}$, hay $\bar{a}, a-y \bar{a},{ }^{?}$ ayyuh $\left.\bar{a}\right)$ ou à mettre en garde $\left({ }^{?} i y y \bar{a}-k a\right)$.

Dans les dialectes, $y \bar{a} / y a$ est la particule la plus fréquemment employée pour le vocatif et sa présence devant les termes d'adresse a été relevée à maintes reprises. Mais on relève aussi des attestations de $y \bar{a} / y a$ comme particule interrogative ou pseudo-interrogative 'n'est-ce pas ?', comme particule d'insistance 'c'est... que' ou comme marqueur de focus.

D'autres attestations de sens plus ou moins proches ont été relevées avec les formes yāk ou iyyāk, notamment au Maghreb.

Si l'on excepte la conjonction alternative $y \bar{a}$ 'ou' et $y \bar{a} . . . y \bar{a} . .$. 'ou bien... ou bien...', bien attestée mais vraisemblablement d'origine persane, les autres particules en $(i y) y \bar{a}(k)$ pourraient avoir un étymon, sinon identique, du moins proche. Mon article consiste, une fois les données réunies, à analyser la nature de ces relations et à préciser les chaînes de grammaticalisation.

INDEX

Keywords : grammaticalisation, vocatif, souhait, but, interrogatif, topicalisation, focalisation

\section{AUTEUR}

\section{CATHERINE TAINE-CHEIKH}

LACITO (CNRS, Universités Paris Sorbonne Nouvelle et Inalco) 


\title{
Vowel Harmony in Old and Central Asian Arabic Dialects
}

\author{
Zviadi Tskhvediani
}

\section{Introduction}

1 In the works of medieval Arab grammarians vowel harmony, interpreted as a sequence of identical vowels in successive syllables, is denoted by the term al-'itb $\bar{a}^{c}$ and viewed as a result of assimilation. The term al-'itbā' occurs in the works by al-Farrā'. Ibn Ğinnī uses it to describe vowel harmony. In Ibn Ğinni's treatise vowel harmony is associated with al-'idg்ām al-'aṣgar, the latter being explained as follows: "وأما الإدغام الأصغر، فهو تقريب (الحرف من الحرف undated: 2/141).

2 Cases of vowel harmony are attested in a limited number of words and therefore medieval Arabic grammatical treatises do not pay much attention to them. Nevertheless, a number of sources contain valuable information regarding this phenomenon both at isolated and syntagmatic levels of the word-forms and most of the cases discussed are confirmed by evidence in classical Arabic; for instance, in some cases prosthetic 'alif of the imperative mood (az-ZamaHšrariy argues that pronouncing hamzat al-wașl (syntagmatic position) is not a specifically Arabic phenomenon and it can be qualified as lahn (solecism) (az-ZamaHšariy $1323 \mathrm{AH}: 137)$ ), in the imperative mood of the geminated verb stem and pronoun suffix are vocalized identically: ruddu-hu, ruddi-hi, rudda-ha 'Return it'; in the name stems, doublets of one-syllable roots and pausal forms as well as in -ät plural anaptyctic vowels are harmonized with stem vowels (Lekiashvili 1977: 55; Rabin 1951: 97). Thus, in classical Arabic we have stem parallelism and doublets that, according to the medieval Arabic grammatical treatises, can be identified in the tribal dialects and explained by the areal distribution. 
'ilmi l-'Arabiyya by az-ZamaHsšarìy, 6) Tāğ al-'arūs by az-Zabīdīy, 7) aṣ-Ṣăhibìy by Ibn Fāris, etc.

Generally speaking, cases of vowel changes in the word-forms are discussed in terms of al-'imāl $a^{1}$ and $a l^{-} i t b \bar{a}^{\prime}$ in medieval Arabic grammatical texts.

5 Some cases of vowel harmony in old dialects are still preserved in modern ones reflecting tribal rather than areal dialectic phenomena. In this respect the data of peripheral Arabic dialects, having been separated from the Arabic continuum for centuries and having evolved in an alien linguistic environment, are particularly interesting. For instance, Central Asian Arabic dialects (Qashqadarian and Bukharian Arabic dialects) provide ample material for the study of old form preservation and various changes caused by linguistic as well extra-linguistic factors. In this paper I will concentrate on the attested cases of vowel harmony in old and Central Asian peripheral Arabic dialects (regions of Qashqadaria and Bukhara, Republic of Uzbekistan) that are at the same time common in Arabic dialects. Vowel harmony in classical Arabic is investigated in A. I. Alfozan's dissertation ${ }^{2}$. Vowel systems and vowel changes in the Central Asian Arabic dialects have been studied from different angles by Acad. G. Tsereteli, Prof. V. Akhvlediani ${ }^{3}$ and Prof. G. Chikovani. In the present paper the data of the Central Asian Arabic dialects are taken from the dialectological materials recorded by Prof. Chikovani in 1980, 1986, 2000 and published in 2002, 2007 and $2009^{4}$.

\section{Vowel harmony in $\mathrm{C}_{1} \mathrm{aC}_{2} \mathrm{IC}_{3}$ and $\mathrm{C}_{1} \mathrm{aC}_{2} \mathrm{iC}_{3}$ type word- forms}

Discussing regressive assimilation, Sibawayhi remarks that in $\mathrm{C}_{1} \mathrm{aC}_{2} \mathrm{iC}_{3} / \mathrm{fa} \mathrm{i}^{\prime} \mathrm{l}$ type names in which $C_{2}$ is represented by a guttural consonant, we encounter two forms $f a^{\prime} i \bar{l}$ and fi'il:

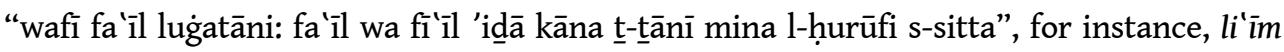
'ignoble, vile', šihid 'martyr', si' ìd 'happy', nihif 'slender', rigif 'loaf - portion of baked bread, usually of a standard size or shape', bituil 'miserly', bi' is 'overwhelmed with sorrow or grief' (Sïbawayhi 1982: 107-108). Ibn Ğinnī also suggests examples of such forms in fa'īl type with $C_{2}$ guttural consonant: ši îr 'barley', bi'îr 'camel - long-necked animal', zi'îr 'roaring, growl', wi' id 'menacing', 'threat' (Ibn Ğinnī undated: 143).

7 The same can be said of the perfective forms of verbs. Sỉbawayhi notes: "'id̄a kāna sifatan 'aw fi'lan 'awisman" (Sībawayhi 1982: 107-108). Thus, $C_{2}$ guttural always occurs in fi' il type: li 'ib 'played' (III. Masc. Sing.).

The same holds true for $\mathrm{C}_{1} \mathrm{VC}_{2} \mathrm{VC}_{3}$ structure names, for instance: la' $i b$ > li'ib 'kidder, unserious', wa'ik > wi' 'ik 'indisposed', mahik > mihik 'standard; norm', waHim > wiHim 'adverse, hostile, harmful', etc. (Sïbawayhi 1982: 108).

Sibawayhi attributes Word-forms of $\mathrm{C}_{1} \mathrm{iC}_{2} \mathrm{iC}_{3}$ and $\mathrm{C}_{1} \mathrm{iC}_{2} \mathrm{iC}_{3}$ structure (with vowel harmony $i-i / i)$ to the speech of Tamim tribal confederation and Hudayl tribe (Sibawayhi 1982: 440), Ibn Fāris to that of 'Asad (Ibn Fāris 1997: 34) and az-Zabiidìy to the speech of Rabī'a tribal confederation (az-Zabìdiyy 1965: 52).

In modern Arabic dialects fi'il form is not confined to $C_{2}$ guttural type. Kibir 'big', kirim 'noble', ğilil 'grand, splendid, majestic, lordly' forms could have developed at an early stage what is confirmed by Ibn Ğinnī's comments on harmony that occurs in the derivative form $m u f i / i l$ due to regressive assimilation $(u>i): m u f i / i l>m i f i / i l$ : 


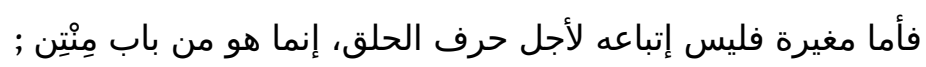

fa'ammā migìira-tun falaysa 'itbā'uhu li'ağli harfi l-ḥalqi, 'innamā hūa min bābi mintin" (Ibn Ğinnī undated: 143). Also, 'ușìy > 'ișīy 'sticks', țudiyy > tidìy 'breasts', etc. (Sïbawayhi 1982: 374-375). az-Zabīdīy confirms the same in "tā̆g al-'arūs": "wahakā šs-šayHu (n-nawawiyy) fi tahrīini 'ani l-layți 'anna qawman mina l-'arabi yaqūlūna dِālika wa' in lam takun 'aynuhu harfa halqin ka(kibir) wa(kirìm) wa(ğilil)" (az-Zabīdiyy 1965: 391; 'Āl Ġunaym 1985: 72).

11 The same can be said of $\mathrm{C}_{1} \mathrm{VC}_{2} \mathrm{~V}: \mathrm{C}_{3}$ fi'il type word-forms in the Arabic dialects of Qashqadaria kisir // kisir 'a lot', kivïr > // kbïr: kisir gania kisir pūlqizil kēyin 'inda 'owned a great fortune' (Chikovani 2007: 20); ğūdó kivir // kivir mínu (rarely) 'larger, greater' (Chikovani 2002: 87-88). Cf. kasir and kabir in Bukharian Arabic, for instance ba'da: kabir beytin ahāni harr șōr, harr i $i$ wahad bēt - qāl. -ațrofu kasìr, hatabāt miği bin. 'then [next condition]: a big house is on fire, [flaming/blazing fire] in one house - said [Pasha]. Extinguish [the fire as soon as possible so that] you escape (from the house) unharmed (Chikovani 2009: 60). Or, bintin kabira usma barfei... 'The elder daughter's name was Barfey...' And, diklōya mara i-zōğ šuglun kasīr sawō 'This wife did a lot of things for his husband [This wife proved useful to his husband]' (Chikovani 2009: 62).

\section{Vowel harmony in $\mathrm{C}_{1} \mathrm{VC}_{2} \mathrm{C}_{3}$ and $\mathrm{C}_{1} \mathrm{VC}_{2} \mathrm{C}_{3}{ }^{\text {-at }}$ type word-forms}

12 Vowel harmony in old Arabic dialects are attested in $\mathrm{C}_{1} \mathrm{VC}_{2} \mathrm{VC}_{3}$ structure word-forms and in some cases anaptyctic vowel form $\mathrm{C}_{1} \mathrm{VC}_{2} \mathrm{VC}_{3}$ structures in $\mathrm{C}_{1} \mathrm{VC}_{2} \mathrm{VC}_{3}, \mathrm{C}_{1} \mathrm{VC}_{2} \mathrm{VC}_{3}$-at type one-syllable words. The same is the case with -ât formant plural; for instance, 'unq // 'unuq 'neck', husn // husun 'beauty', yawm-u l-ğum 'a ${ }^{-t i}$ (Tamìm speech) // l-ğuma' $a^{- \text {ti }}$ ('Uqayl tribe speech) // l-ğumu ' $a^{-t i}$ 'friday' (al-Farrā' 1983: 186). In Ch. Rabin's opinion, "It cannot always be said that the Hijazi form is older and the Eastern is produced by elision." (Rabin 1951: 97).

Sïbawayhi refers to halaq 'earring' and halq-at 'circle' as $\mathrm{C}_{1} \mathrm{VC}_{2} \mathrm{C}_{3} / \mathrm{C}_{1} \mathrm{VC}_{2} \mathrm{C}_{3}$-at structure word-forms. Cf. halaq-at used by 'Abū 'Amr (Sïbawayhi 1982: 583-584; 'Āl Ġunaym 1985: 85). 'Āl Gunaym points out that muwaffaq ad-Dīn al-Baǵdādìy confirms the existence of halaq-at variant in Bagdad speech and describes 'Uqayl speech in which under the influence of $\mathrm{C}_{2}$ guttural (/h/) vowel a (al-fatha) appears: halaq-at ('Āl Ǵunaym 1985: 86).

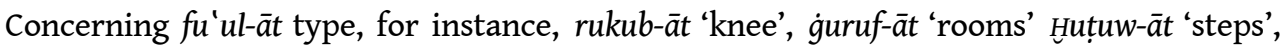
etc., Sïbawayhi notes: "wamina l-arabi man yaftaḥu l-'ayn 'id rukabāt wagiurafāt... wamina l'arabi man yada'u l-ayn mina ḍ-ḍmmati fì fu'latin, fayaqūlu: 'urwāt waHuțāat" (Sïbawayhi 1982: 579-580). This case of vowel harmony is attributed to Hijaz dialects. ('Āl Ǵunaym 1985: 84).

In Qashqadaria Arabic Dialect $\mathrm{C}_{1} \mathrm{iC}_{2} \mathrm{iC}_{3} / / \mathrm{C}_{1} \mathrm{iC}_{2} \mathrm{i} \mathrm{C}_{3}$ structure nouns are to be found, for instance: gidir // gidir 'saucepan' (cf. ğədər // ğədrəyya in Baghdad Arabic (Abu-Haidar 2006: 223)), dihin // dihin 'oil, fat', tibin 'hay', hilim 'dream' (Tsereteli 1956: 79, 164; Vinnikov 1969: 164). $\mathrm{C}_{1} \mathrm{VC}_{2} \mathrm{~V}: \mathrm{C}_{3}$ model unites the following subclasses: $\mathrm{C}_{1} \mathrm{aC}_{2} \overline{\mathrm{a}} \mathrm{C}_{3}$ : bahāar

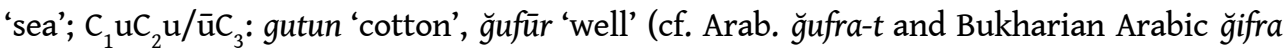
(sing.) and ğifr-āt (pl.), e.g.: snēna aqaīnin mui ğarrū min ğifrāt. 'The two brothers took water from the well.' (Chikovani 2009: 35, 56)). However, in Qashqadaria Arabic Dialect we find: Hubz 'bread', kezb 'lie', and in Bukharian Arabic šuğl and šugul 'job, occupation' (Chikovani 
2002: 82-83, 166; Chikovani 2009: 62). Cf. in Bahraini Arabic as well: $\mathrm{C}_{3}$ is $/ \mathrm{l}, \mathrm{n}, \mathrm{r} /: \mathrm{C}_{1} \mathrm{VC}_{2} \mathrm{VC}_{3}$ is normal, with vowel harmony, e.g. šugul, duhur 'noon', dihin, kufur 'amount' (Holes 2006: 244).

As for the verb forms, $\mathrm{C}_{1} \mathrm{iC}_{2} \mathrm{iC}_{3}$ type occurs: lihig 'caught up with, reached...', lifib, šibik (Chikovani 2002: 102). In Bukharian Arabic the dominant type in the perfective is $\mathrm{C}_{1} \mathrm{aC}_{2} \mathrm{aC}_{3}$ , e. g.: lahag 'reached', while $\mathrm{C}_{1} \mathrm{iC}_{2} \mathrm{iC}_{3}$ occurs relatively rarely (Chikovani 2009:17, 35) In Qashqadaria Arabic Dialect $\mathrm{C}_{1} \mathrm{uC} \mathrm{C}_{2} \mathrm{u} / \overline{\mathrm{u}} \mathrm{C}_{3}$ type of $\mathrm{C}_{1} \mathrm{VC}_{2} \mathrm{~V}: \mathrm{C}_{3}$ structure has been identified: ugu/ūb // ogū $b$ Arab. 'aqba // 'aqiba 'then', e.g.: morā Hubz, muya anțat, ugūb min pōšō sayalt 'The woman gave him some bread and water, then she asked Pasha...'(Chikovani 2007: 20; Chikovani 2002: 156, 160). Cf. Kuwaiti Arabic: 'ugub, duhur (Holes 2007: 611).

Basic stems of what is $\mathrm{C}_{1} \mathrm{VC}_{2} \mathrm{VC}_{3}$ structure in the isolated position form $\mathrm{C}_{1} \mathrm{VC}_{2} \mathrm{C}_{3}$ structure in the contextual position or in - $\mathrm{V}(\mathrm{C})$ type affixal derived forms, e. g.: ğisim 'body' and ğism-a 'her body', rağul 'man, husband' rağl-ič 'your husband' (Belova 2000: 115). Consequently, vowel harmony does not occur at $\mathrm{C}_{1} \mathrm{VC}_{2} \mathrm{VC}_{3}+-\mathrm{V}(\mathrm{C})$ contextual/syntagmatic level.

\section{Vowel harmony in verbal domain}

Vowel harmony occurs if we have a high-pitched / $\mathrm{u} /$ vowel in the root of the imperfective verb in Central Asian Arabic dialects. In Qashqadaria Arabic Dialect: yu-ktub 'he writes'(masc. sing.), tu-ktub (III, fem. sing; II, masc. sing.), tu-ktubin (II, fem. sing.), yu-ktubūn (III, masc. pl.) (Chikovani 2002: 104). In Bukharian Arabic: $m u-t+$ ul 'he enters' (masc. sing.), tu-tHul (III, fem. sing; II, masc. sing.),

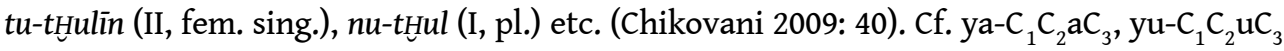
and yi- $\mathrm{C}_{1} \mathrm{C}_{2} \mathrm{iC}_{3}$ forms in modern dialects (Monaham 2009: 677).

\section{Conclusion}

Being of limited usage in old Arabic dialects, vowel harmony occurs in a much wider range of word-forms in modern dialects. As a rule, the quality of anaptyctic vowel is determined by its harmonization with stem vowel (vowel harmony achieved through assimilation).

21 Vowel harmony is one of the major distinctive elements between old western and eastern Arabic dialects (Veersteegh 2014: 47-48). The phonetic quality of /i/ is harmonized in the Eastern dialects but not the Western dialects (Monaham 2009: 676). Vowel harmony was typical to the speech of Bedouins and, therefore, when attributing it to Hudayl speech, they supposedly had in mind the nomadic clan that had residing in Nağd of this tribe and the territories adjacent to its borders. The same also applies to other Bedouin clans in the Hijaz and Yemen (al-Sharkawi 2008: 697). 


\section{BIBLIOGRAPHY}

Abu-Haidar, Farida. 2006. "Baghdad Arabic", Verteegh, Kees (ed.), Encyclopedia of Arabic language and Linguistics, volume I. Leiden-Boston: Brill. 222-231.

Akhvlediani, Vladimir. 1985. Bukharski Arabski Dialekt: Fonologia I morphologia. "Bukhara Dialect of Arabic". Tbilisi: "Metsniereba".

Alfozan, Abdulrahman Ibrahim. 1986. Assimilation in Classical Arabic - A phonological study. A thesis submitted to the faculty of Arts of the University of Glasgow in fulfillment of the requirements for the degree of Doctor of Philosophy.

Belova, Anna. 2000. Vokalicheskaia sturktura slova v vostochnoarabskikh dialektakh. "The Vocalic Structure of the Word in the Eastern Arabian Dialects", Typological Researchers. Tbilisi: G. Tsereteli Institute of Oriental Studies. 114-125.

Chikovani, Guram. 2009. Arabuli enis bukharuli dialeqt'i. "Bukhara Dialect of Arabic Language”. Tbilisi: "Mtsignobari".

Chikovani, Guram. 2007. Tsentraluri aziis arabuli dialqt'ebi - K'ašk'adariuli dialeqt'i (t'eqsti, targmani, ganmart'ebebi). "Central Asian Arabic Dialects - Qashqa-darya Dialect (Text, Translation, Comment)". Tbilisi: "khironi”.

Chikovani, Guram. 2002. Šua aziis arabuli dialeqt'ebi - K'ašk'adariuli dialeqt'i (fonologia, gramat'ik'a, leqsik'a). “Central Asian Arabic Dialects - Qashqa-darya Dialect (Phonology, Grammar, Vocabulary)”. Tbilisi: Ena da K'ultura.

Ibn Fāris, 'Abū l-Ḥusayn 'Aḥmad. 1997. aṣ-Ṣạhibìy fi fiqhi l-lugati l-'arabìati wamasā'ilihā wasunani l-'arabi fì kalāmihā. Bayrūtu: Dāru l-kutubi l-'ilmiyyati.

al-Farrā', 'Abū Zakariyyā Yahyya bnu Zīād. 1983. Ma'ānì l-qur'ān. al-ğuz'u ț-țānī. Bayrūtu: 'ālamu lkutubi.

Ibn Ğinnī, 'Abū l-Fatḥ 'uțān. Undated. al-Hașā' iṣ. al-Qāhiratu: dāru l-kutubi l-mișriyyatu.

'Āl Ġunaym, Sāliha Rāšid Ġunaym. 1985. al-Lahağātu fïl-kitābi liSībawayhi. Ğidda: Dāru l-madanīy.

Holes, Clive. 2007. "Kuwaiti Arabic", Verteegh, Kees (ed.), Encyclopedia of Arabic language and Linguistics, volume II. Leiden-Boston: Brill. 608-620.

Holes, Clive. 2006. "Bahraini Arabic”, Verteegh, Kees (ed.), Encyclopedia of Arabic language and Linguistics, volume I. Leiden-Boston: Brill. 241-255.

Lekiashvili, Alexi. 1977. Arabuli ena I. “The Arabic Language I”. Tbilisi: Tbilisi University Press.

Levin, Arieh. 2012. A new contribution to the history of the modern Arabic dialects of Iraq. Jerusalem Studies in Arabic and Islam. Volume 39. Jerusalem. 411-422.

Levin, Arieh. 2007. 'Imāla. Verteegh, Kees (general ed.), Encyclopedia of Arabic language and Linguistics, volume II. Leiden-Boston: Brill. 311-315.

Monaham, Philip J. 2009. “Vowel harmony”, Verteegh, Kees (ed.), Encyclopedia of Arabic language and Linguistics, volume IV. Leiden-Boston: Brill. 676-677.

Rabin, Chaim. 1951. Ancient West Arabian. London: Tailor's Foreign Press. 
al-Sharkawi, Muhammad. 2008. "Pre-Islamic Arabic". Verteegh, Kees (ed.), Encyclopedia of Arabic language and Linguistics, volume III. Leiden-Boston: Brill. 686-699.

Sībawayhi, 'Abū Bišr 'Amru bnu 'Uämān.1982. al-kitāb, al-ğuz'u r-rābi 'u. al-Qāhiratu: Maktabatu 1-Hुāniğ̄̄.

Tsereteli, George. 1970. The influence of the Tajic language on the vocalism of Central Asian Arabic Dialect. BSOAS, volume XXXIII, 1.

Tsereteli, George. 1956. Arabckie dialekti srednei azii. T. I. “Central Asian Arabic Dialects. V. I”. Tbilisi: Georgian Acadamy of Sciences.

Versteegh, Kees. 2014. The Arabic Language. Edinburgh: Edinburgh University Press.

Vinnikov, Isaac N. Yazik I folklore Bukharskikh Arabov. "The Language and folklore of Bukharian Arabs". Moscow: "Nauka".

az-Zabīdīy, Muḥammad Murtaḍā l-Ḥusaynīy. 1965. Tāğu l-'arūs min ğawāhiri l-qāmūs. al-ğuz'u țālițu. al-Kuwaytu: Matba 'atu ḥukūmati l-Kuwayt.

az-ZamaHšsarīy, 'Abū l-Qāsim Maḥmūdu bnu 'Umar. 2004. Al-Mufașṣalu fi 'ilmi l-'arabiyati. 'Ammān: Dāru 'Ammār lin-našri wat-tawzī'.

\section{NOTES}

1. See Levin 2007 and Levin 2012.

2. Alfozan 1986.

3. Tsereteli 1970; Ahvlediani 1985.

4. Chikovani 2002; Chikovani 2007; Chikovani 2009.

\section{ABSTRACTS}

Vowel harmony in the word-forms of old Arabic dialects is discussed in the works of medieval Arab grammarians. Valuable information regarding vowel harmony is provided by Sibawayhi, Ibn Jinni and others. In the medieval Arabic grammatical tradition the vowel harmony is denoted by the term al-'itbo $\bar{a}^{\prime}$ and is viewed as assimilation both at isolated and syntagmatic levels of the word-forms. For example, in the basic $\mathrm{C}_{1} \mathrm{VC}_{2} \mathrm{~V}: \mathrm{C}_{3}, \mathrm{C}_{1} \mathrm{VC}_{2} \mathrm{C}_{3}>\mathrm{C}_{1} \mathrm{VC}_{2} \mathrm{VC}_{3}$ and $\mathrm{C}_{1} \mathrm{VC}_{2} \mathrm{VC}_{3}$ structures: $f a^{\prime} i / i l>f i^{\prime} i / i l l$ as well as in the derived forms with $-C_{1} C_{2} V_{3},-C_{1} V: C_{3}: m u-f^{\prime} i / i l>m i f^{\prime} i / i l$ and $C_{1} V_{2} Y_{3}$ stems: for instance, 'așiy 'ișiy formant vowel change ( $a>i)$ in isolated and syntagmatic position. In addition to the above-mentioned cases vowel harmony is analyzed in: the stem words and affixes, prosthetic 'alif of the imperative mood, doublets of one-syllable roots and pausal forms, $-\bar{a} t$ plural of $f u / i^{\prime} l$-at type names in which anaptyctic vowels are combined with root vowels, for instance, rukb-at (sing.) and rukub-āt (pl.), sidr-at (sing.) and sidir-āt, etc. In the Arabic dialects of central Asia the vocal structure of derived roots is relatively inconsistent. For example, $\mathrm{C}_{1} \mathrm{VC}_{2} \mathrm{VC}_{3}$ structure in the isolated position is subject to changes on the syntagmatic level due to vowel harmony (šugul and šugll-ak). C1VC2VC3 structure can be identified in verb stems + through vowel harmony (cf. tu-ktub in the imperfect). Some stem structures are characterized by synharmonism 
peculiar to old Arabic dialects; for instance, kivir, gilil. Anaptyctic vowels are combined with stem vowels in one-syllable forms: gidir<qidr, gutun<qutn etc. Vowel harmony in a number of wordforms reflects the general situation in old Arabic dialects of central Asia and conforms to the common Arabic dialectical forms.

INDEX

Keywords: Old Arabic Dialects, Central Asian Arabic, vowel harmony

\section{AUTHOR}

\section{ZVIADI TSKHVEDIANI}

Akaki Tsereteli State University, 9 Giorgi Shavgulidze St., Kutaisi 4600, Georgia, zviadi_2008@yahoo.com 


\title{
Origin of the Plural Adjectives of the $F u^{\prime} a \bar{l}$ Pattern in the Modern Arabic Dialects
}

\author{
Marijn van Putten
}

\section{Introduction}

1 An oft-cited common morphological feature of the Modern Arabic dialects as opposed to Classical Arabic, is the reflex of the plural pattern of some of the $f a$ i $i$ adjectives. Where in Classical Arabic the pattern is fi'a $\bar{l}$, in modern dialects have $f u^{\prime} a \bar{l}$, whenever a reflex of * $u$ is retained (Ferguson 1959: 627; Cohen 1962: 137; Blau 1977: 24). This can be seen through labialisation in Maghrebi, e.g. kbir pl. $k^{w}$ bar 'big' (Heath 2002: 307), and the vowel $u$ in Cairene Arabic, e.g.:

\begin{tabular}{|c|c|c|}
\hline CAr. & Cairene & \\
\hline kabīr pl. kibār & kibir pl. kubặr & 'big' \\
\hline sagīir pl. șiḡār & șuǵayyạr pl. șugāạr & 'small' \\
\hline qașīr pl. qișār & 'ạșir pl 'ușậr & 'short' \\
\hline Hafif pl. Hifāa $f$ & Hafif pl. Hufäf & 'light' \\
\hline ğadìd pl. ğidād & gidìd pl. gudād & 'new’ \\
\hline
\end{tabular}

2 While it is true that this development has taken place both in Cairene and Maghrebi Arabic, one cannot simply project this to a "Proto-dialectal" Koiné-phase (if there ever was such a thing), as it is simply impossible to see this contrast in the vast majority of the dialects, as they have lost these short vowels. Nevertheless, the fi' $\bar{a} l$ to fu' $\bar{a} l$ development 
is an innovation which must be explained. No satisfying explanation has been posited so far. Both Ferguson and Blau suggest an ad hoc assimilation to the adjacent labial consonant, e.g. kibār > kubār, which would have subsequently spread to all other adjectives. This development has not taken place in otherwise identical environments, so this explanation introduces more problems than it solves. Moreover, this development did not just affect this plural adjective pattern but also fi'âl nouns, e.g. Cair. humāạr 'donkey' (CAr. ḥimār) and Cair. ḥuṣạ̄n 'horse' (CAr. hiș̣ạn).

It seems then, that we are dealing with a phonetic development which not only affected the plural adjectives, but also affected some nouns. This paper aims to examine this innovation, and the conditioning of the shift of $i$ to $u$.

\section{Conditioning of $i$ and $u$ in Eastern Libyan Arabic}

A solution to the conditioning of these vowels, might be found in dialects such as Eastern Libyan Arabic. In this dialect, the vowels $i$ and $u$ are phonetic reflexes of the same phoneme $/ \tilde{1} / .^{1}$ As the original short vowels ${ }^{*} i$ and ${ }^{*} u$ have been lost in open syllables, this pattern no longer affects the vowel in *kibār as it has become ELA ukbār. However, new high vowels that are the result of ${ }^{*} a>/ \tilde{l} /$ in open syllables as well as epenthetic vowels are affected by it, e.g. ELA libas 'he dressed' but ELA țubạ 'he cooked' < labasa, țabaHa. ${ }^{2}$

Owens (1984: 36ff.) shows that the $i$ and $u$ can be predicted by the phonetic environment. If the word contains an emphatic consonant, $/ \tilde{l} /$ becomes $u$, whereas in non-emphatic environment the vowels becomes $i$. This is demonstrated in the overview below:

\begin{tabular}{|c|c|c|c|}
\hline tubạ 'he cooked' & $<$ *țabaHa & kitab 'he wrote' & $<{ }^{*} k a t a b a$ \\
\hline rubaț 'he tied' & < rabața & žibal 'mountain' & < *̌gabal- \\
\hline nudar 'he watched' & $<{ }^{*}$ nadara & mišat 'she went' & $<{ }^{*}$ mašata \\
\hline
\end{tabular}

6 ELA $g(<q)$ may also be associated with a back vowel harmony, when there are no high vowels in the word (Owens 1984: 38).

7 Finally, the phoneme $/ \mathrm{r} /$ in the environment $a r, r a, r \bar{a}$ and $\bar{a} r \#$ triggers this vowel harmony as well (Owens 1984: 39). This is even true if synchronically the $r$ is no longer next to an a vowel, e.g. uHružat 'she left' < *Harağat. A small number of words remain, whose back vowel harmony cannot be easily explained, e.g. lubaz 'rubbish'.

8 This conditioning also affects original high vowels and epenthetic vowels when they are not syncopated, e.g.

\begin{tabular}{|c|c|c|c|}
\hline kātib 'he has written' & $<{ }^{*}$ kātib & kabiš 'ram' & $<{ }^{*} k a b s ̌$ \\
\hline rạgud 'asleep' & $<*$ rāqid & țabuH 'cooking' & $<{ }^{*} t a b_{H}$ \\
\hline hāmud 'bitter' & <*hāmid & & \\
\hline
\end{tabular}




\section{$F u ' a ̄ l n$ nouns and adjectives in Cairene Arabic}

It seems to be possible to explain Cairene Arabic nouns with a fu'âl $(a)$ pattern $\left(<{ }^{\prime} f_{i}{ }^{\prime} \bar{l} l(a h)\right)$ with a vowel harmony rule similar to that found in Eastern Libyan Arabic. Whenever a Classical Arabic fi'äl(ah) noun has become fu'äl(a) in Cairene it is in an emphatic environment. ${ }^{3}$ As with Eastern Libyan Arabic, ar, ra, rā and $\bar{a} r \#$ also trigger back vowels. The forms are taken from Hinds \& Badawi (1986).

\begin{tabular}{|c|c|}
\hline burạzz 'excrement' & CAr. birāz \\
\hline busạṭ 'carpet' & CAr. bisāt \\
\hline husșạ̄n 'stallion' & CAr. ḥiṣān \\
\hline ḥumāar ‘donkey' & CAr. himāa r \\
\hline rubāț 'tie' & CAr. ribāt \\
\hline fir $\bar{a}$ ', fur $\bar{a}$ ' 'separation, partition' & CAr. firāq \\
\hline 'umạ̄r 'gambling' & CAr. qumār \\
\hline 'umāṭt 'infant's binder' & CAr. qimātt \\
\hline 'ušāț, 'išāṭ 'leather strap' & CAr. qišāṭt \\
\hline țirạšš, țurāạs ‘deafness’ & țirāšs \\
\hline tigạarạ, tugậrạ 'trade' & CAr. tiğārah \\
\hline gubạ̄rạ, gibārạ 'splint' & CAr. ğibārah \\
\hline šikạrạ, šukāạa 'gunny sack' & CAr. šikārah \\
\hline dumậdạ 'bandage' & CAr. dimādah \\
\hline nišărạ, nušạrạ̣ 'sawdust, shaving' & CAr. nišārah \\
\hline il-g்uțās, il-gițās 'epiphany’ & CAr. giț̣ās \\
\hline
\end{tabular}

10 While it is clear that whenever a noun has a fu'äl(a) pattern where fi'a ${ }^{\prime}(a)$ is expected, the word is in an emphatic environment, the opposite is not true: There are several examples of $f^{\prime}{ }^{\prime} a l(a)$ patterns in emphatic environments, e.g.

\begin{tabular}{|l|l|}
\hline sitạ̄r 'curtain, screen' & CAr. sitār \\
\hline bițāna 'lining' & CAr. bițānah \\
\hline biḍạ̄'a 'goods, merchandise' & CAr. biḍā'ah \\
\hline
\end{tabular}




\begin{tabular}{|c|c|}
\hline 'ițārạ 'spices and herb trade' & CAr. 'ițārah \\
\hline țibạ 'ạ 'printing' & MSA țibā'ah \\
\hline 'imāra 'apartment building' & MSA 'imārah \\
\hline
\end{tabular}

11 Sound laws operate without exception, therefore these exceptions require an explanation. It is possible to identify at least one source, namely, Modern Standard Arabic. Words like tibặ a 'printing' and 'imậra 'apartment building' are likely MSA borrowings. This however does not yet explain all exceptions.

12 For other exceptions, we may take into account the specific linguistic situation on which Hinds \& Badawi's dictionary is based. As pointed out by themselves (1986: XI), the dictionary is primarily based on the dialect of Cairo. Already by the time of writing the dictionary, Cairo had seen massive growth ${ }^{5}$ and a certain amount of dialect mixing must have resulted from this. ${ }^{6}$ This can plausibly be taken as one of the causes for the somewhat obscured signal in the reflexes of Cairene Arabic.

13 A large number of the fu' $\bar{a} l$ plural formations of adjectives found in Cairene Arabic can be explained as the result of this vowel harmony pattern, e.g.

14 kibìr pl. kubạ̄r 'big'

kitīr pl. kutặr 'many'

riH̄iṣ pl. ruHāṣ 'cheap'

șugayyạr pl. șugạarr 'small'

'așī pl. 'ușậr 'short'

lațîf pl. luțậf'kind'

niḍif pl. nuḍậf 'clean'

sarī pl. surạ ' 'swift, fast'

15 While in nouns the fu'all(a) pattern can only occur in emphatic environments, this is not the case for the adjective, where the pattern has become regular for non-emphatic adjectives as well, e.g.

ra'ì' pl. ru' $\vec{a}$ ' 'delicate, fine'

'adīm pl. 'udām 'old'

gidìd pl. gudād 'new'

Hafif pl. Hufāf'light'

gamil pl. gumāl 'beautiful'

tiHìn pl. tuHān 'thick'

17 These forms are best explained as the result of analogy that spread from the adjectives that regularly received the fu' $\bar{a} l$ pattern through vowel harmony. As nouns did not have an analogical base to spread such a pattern, fi ${ }^{i} \bar{l}(\mathrm{ah})$ nouns retain this original phonetic conditioning, which has been lost in the adjectives.

\section{Labialisation in Skūra Arabic}

18 The fu'āl plural pattern attested in Cairene Arabic is often associated with the labialization that we find in Maghrebi Arabic in several of the adjectival plural forms, e.g. Ferguson (1959: 627) who cites $\mathrm{k}^{\mathrm{w}}$ bar (<kubārp in his transcription) as a reflex of this 
pattern. While Ferguson is correct to say that "in some dialects, such as Moroccan, the loss of / $\mathrm{u}$ / often leaves labialized consonants", it is not necessarily proven that this is the only origin of labialization, and it is therefore not established that the labialization in these adjectives must be attributed to a shared innovation ${ }^{*} f_{i}{ }^{\prime} \bar{a} l>f u^{\prime} \bar{a} l$ in adjectives with Cairene. To put this hypothesis to the test, we will look at the Moroccan Arabic dialect of Skūra as described by Aguade \& Elyaacoubi (1995).

19 In this dialect, the plural adjective has labialization: sHūn 'warm' pl. $s^{w} H \bar{a} n$ (Aguade \& Elyaacoubi 1995: 108, sec. 5.1.2). The other adjectives with a CCiC pattern are not explicitly mentioned as having labialization, but Aguade \& Elyaacoubi (1995: 33) mention several examples in the section on labialization:

kbir pl. $k^{w} b \bar{a}$. 'big, old'

qdìm pl. $q^{w}$ dām 'old'

ktīr pl. $k^{w}$ tār 'much'

rqī pl. $r^{w} q \bar{a} q$ 'soft, fine'

șïir pl. ș șīăr 'small'

tqïl pl. $t^{w} q \bar{a} l$ 'heavy'

Hfif pl. $H^{w} f a \bar{f}$ 'light'

It is clear that an original adjacent short ${ }^{*} u$ can labialize velar or uvular consonants from the diminutive formations $\left({ }^{*}{ }^{*} u^{\prime}\right.$ ayl), although in these it only affects a consonant if it is the first stem consonant. This is presumably because the consonant in second position is next to a high vowel, blocking the labialization (Aguade \& Elyaacoubi 1995: 112):

\begin{tabular}{|c|c|}
\hline With $\mathrm{C}^{\mathrm{w}}$ & Without $\mathrm{C}^{\mathrm{w}}$ \\
\hline kəlb dim. $k^{w} l i b$ 'dog' & škəl pl. škīl 'shape' \\
\hline$k ə f f \operatorname{dim} . k^{w} f i f$ 'palm of the hand' & \\
\hline gdəh dim. gw dịh 'bowl' & \\
\hline qŭbba dim. $q^{w} b i ̄ b a$ 'dome' & həqq pl. hqiq 'truth, reason' \\
\hline ġəlla pl. $\dot{g}^{w} l i ̈ l a ~ ' h a r v e s t '$ & 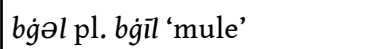 \\
\hline
\end{tabular}

Therefore, it is at least possible that the plural adjectives go back to a *fu' $\bar{a} l$ pattern rather than the expected fi $\bar{c} \bar{l}$. However, if we examine nouns with labialization in similar environments, we find that labialization is not exclusively linked to a vowel ${ }^{*} u$. Several examples of labialization are linked to an emphatic environment rather than an etymological ${ }^{*} u$ :

$g^{w} t \underline{a} a r^{\text {'hectare' }<\text { Fr. hectare 'hectare" }}$

$\dot{g}^{w} t \underline{t a}$ 'cover' < $\dot{g} i \bar{a}^{\prime}$

gəș'a pl. $g^{w} s \bar{a}^{\prime}$ 'large wooden dish' < qaș'ah pl. qișa $\bar{a}^{\prime}$ (qașa'ah, qișa')

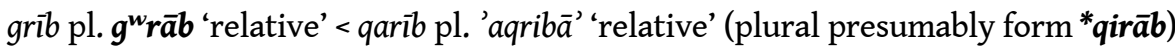

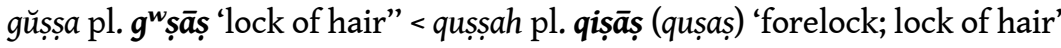

nqŭb pl. $\boldsymbol{n}^{w} q \bar{a} \boldsymbol{b}$ 'hole' < naqb pl. 'anqāb, niqāa 'hole' 
Ferguson (1959: 627, fn. 21) cites yet another example which would point to the adjectival pattern *fu'al in the modern dialects. He points out that Haim Blanc noticed that for several dialects, namely Mosul, Jewish Baghdadi and Aleppo Arabic, the adjectival plural is $C C \bar{a} C$, whereas the original shape * $F_{i}$ 'āl undergoes $i$-umlaut, yielding klēb, klīb 'dogs' < kilāb; lsēn, lsīn 'tongue' < lisān; jmēl, jmīl 'camels' < ğimāl, but smān, ktāar, mlāh.

To test this claim, I have consulted Haim Blanc's description of the communal dialects in Baghdad, who reproduces this claim for the Jewish and Christian dialect of Baghdad (Blanc 1964: 79-81). Here adjectival plurals indeed always have a CCāC pattern in Jewish and Christian Arabic, whereas nouns with an original pattern fi $\bar{a} l$ have a reflex $\bar{\imath}$ in Jewish, and $\bar{e}$ in Christian Arabic. The examples of adjectives cited by Blanc are:

\begin{tabular}{|c|c|c|c|}
\hline $\mathrm{J}$ & C & CAr. & \\
\hline smān & smān & simān & 'fat' \\
\hline$k b \bar{a} \dot{g}$ & $k b \bar{a} \dot{g}$ & $k i b \bar{a} r$ & ‘big' \\
\hline$z \dot{g} \bar{a} \dot{g}$ & $z \dot{g} \bar{a} \dot{g}$ & $s ̦ i g \bar{g} \bar{a} r$ & 'small' \\
\hline$t w \bar{a} l$ & $t \underline{t w a \bar{l}}$ & țiwāl & 'long' \\
\hline$n \underline{d} \bar{a} \bar{f}$ & $n \underline{d} \bar{a} f$ & $n i d \underline{a} \bar{f}$ & 'clean' \\
\hline ' $\dot{g} \bar{a} \underline{d}$ & ' $\dot{g} \bar{a} \underline{d}$ & 'irād & 'broad' \\
\hline mlāḥ & mlāḥ & milāḥ & 'nice' \\
\hline$q s ̦ a \bar{g} \dot{g}$ & $q s ̦ \bar{a} \dot{g}$ & $q i s ̦ \bar{a} r$ & 'short' \\
\hline$q w \bar{a} y$ & $q w \bar{a} y$ & $q i w \bar{a}^{\prime}$ & 'strong' \\
\hline
\end{tabular}

Nouns with the $f^{\mathrm{c}}$ āl pattern with $i$-umlaut are: ${ }^{8}$ 


\begin{tabular}{|c|c|c|c|}
\hline $\mathrm{J}$ & C & CAr. & \\
\hline$l \sin$ & lsèn & lisān & 'tongue' \\
\hline lhîf & lhẹef & liḥāf & 'quilt' \\
\hline ḩzìm & ḩzèm & ḩizām & 'belt' \\
\hline lbiss & lbēs & libās & 'underpants' \\
\hline$(k t \bar{a} b)$ & $k t \bar{e} b$ & $k i t a \bar{b}$ & 'book' \\
\hline hsiib & $(h s \bar{a} b)$ & ḥisāb & 'account' \\
\hline gjjìl & $\dot{g} j \mathrm{je} l$ & riǧāl & 'men' \\
\hline klïb & $k l e \bar{b}$ & kilāb & 'dogs' \\
\hline jmìl & jmēel & ğimāl & 'camels' \\
\hline$s b i^{i}$ & $s b e^{-c}$ & $s i b \bar{a}^{c}$ & 'lions' \\
\hline šmīc & šme $\bar{e}^{-c}$ & šim $\bar{a}^{c}$ & 'candles' \\
\hline slì & slēl & silāl & 'baskets' \\
\hline ḥbil & $h b \bar{e} \bar{l}$ & hibāl & 'ropes' \\
\hline jbìl & jbēl & ğibāl & 'mountains' \\
\hline
\end{tabular}

31 The way the data is presented, one gets the impression that there is absolutely no doubt that the fi'a $\bar{l}$ nouns underwent $i$-umlaut, whereas the adjectives did not. However, as we have already seen in the previous sections, emphatic consonant play an important role in the $i / u$ alternation of nouns of this type in Cairene and Skūra Arabic. All but two adjectives cited are emphatic, whereas none of the nouns cited are. Blanc cites several CCāC nouns, which have not undergone $i$-umlaut. While indeed some of these can be explained as being originally fu'āl (e.g. flān 'so-and-so'), or being borrowed from the Muslim dialect (e.g. ' $g \bar{a}$ ! 'rope for headdress'). Several words have the $i$-umlaut blocked due to emphaticness of the sequence $\bar{a} \# / r a$.

\begin{tabular}{|l|l|l|l|l|}
\hline J & C & CAr. & & \\
\hline$h m a \bar{a} \dot{g}$ & $h m a \bar{a} \dot{g}$ & $h i m a \bar{r} r$ & 'donkey’ & \\
\hline$z y \bar{a} r a$ & $z y a \bar{a} a$ & $z i y \bar{a} r a h$ & 'pilgrimage’ & \\
\hline blād & blād & bilād & 'country’ & (M blād) \\
\hline$z m \bar{a} l$ & $z m \bar{a} l$ & $z m \bar{a} l$ & 'donkey’ & $($ M zmāl) \\
\hline
\end{tabular}


A further study of the glossary of Abu Haidar's Christian Baghdadi description (1991) uncovers more examples:

\begin{tabular}{|c|c|c|}
\hline C & CAr. & \\
\hline$d \dot{g} \bar{a}^{c}$ & $\underline{\operatorname{dir}} \bar{a}^{c}$ & 'old measurement' \\
\hline$q m \bar{a} \dot{g}$ & qimāar & 'gambling' \\
\hline$q m \bar{a} t \underline{t}$ & qimāt & 'swaddling cloth' \\
\hline ḥִāan & hiș̣ān & 'horse' \\
\hline nğ $\bar{a} \dot{a} a$ & niğārah & 'carpentry' \\
\hline təğā $\dot{g} a$ & tiğāărah & 'commerce' \\
\hline nəḍ̄ām & nid̄ām & 'order' \\
\hline
\end{tabular}

In other environments emphatic consonants also block the $i$-umlaut, as pointed out by Abu Haidar (1991: 29): ğawègīn ‘neighbours' vs. fașāțīn ‘dresses' and ğémə' 'mosque' vs. tấləb 'student'.

The material as attested in Christian (and probably Jewish) Baghdadi Arabic is comparable to Cairene Arabic: $i$-umlaut is blocked when there is an emphatic consonant in the root. This is similar to the environment that turns Cairene Arabic * fíal(ah) into $f u^{\prime} \bar{a} l(a)$. As fu'āl obviously blocks $i$-umlaut, one is able to interpret the distribution of the Baghdadi material as having originally had the same $f^{\prime}{ }^{\prime} a l(a h)>f u^{\prime} a \bar{l}(a)$ shift in emphatic environments, preceding the $i$-umlaut and syncope. The spread to the few non-emphatic adjectives is then a simple analogy identical to what we find in Cairene and Skūra Arabic.

\section{A Neo-Arabic innovation?}

The $f i^{\prime} \bar{a} l>f u^{\prime} \bar{a} l$ shift in the plural adjective, so often cited as a "Neo-Arabic" innovation, has so far not received a clear explanation in terms of historical development. By examining Cairene Arabic, Skūra Arabic and Baghdadi Christian Arabic, I hope to have shown that fu'al form must be understood within a broader pattern of vowel harmony that shifts the high vowel ${ }^{*} i$ to $u$ in emphatic environments. This splits the historical fi'al(ah) pattern into two groups:

\begin{tabular}{|c|c|c|}
\hline & fíâl(ah) [-emphatic] & $f i^{\prime} a ̂ l(a h)$ [+emphatic] \\
\hline Cairo & Cicāc(a) & Cucạ̄c(a) \\
\hline Skūra & CCāc(a) & $\mathrm{C}^{\mathrm{w}} \mathrm{C} \overline{\mathrm{a}} \mathrm{C}(\mathrm{a})$ \\
\hline Baghdad & Ccēec(i) & CCāC(a) \\
\hline
\end{tabular}


what is probably a statistical accident, the majority of adjectives that had an original fi'a $\bar{l}$ plural contained emphatic consonants in the root, or became emphatic in the plural due to the emphasization of the sequence ār\# > ăr\#. As a result, most of them regularly became fu'a l plurals in these dialects. This pattern was then spread to all adjectival plurals.

This split should probably be understood as a shift $*_{i}>u$ before $\bar{a}$ in an emphatic environment for these dialects. ${ }^{9}$ There are however several questions that are relevant to the history of the modern Arabic dialects. First, one needs to answer whether this is a shared innovation between the modern dialects; Second, one needs to answer whether this truly is a pan-Arabic innovation, and happened at an early enough period to be considered a true shared "neo-Arabic" innovation.

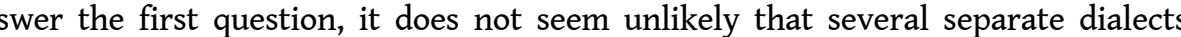
would have innovated the vowel harmony as we find it. Even Classical Arabic $i$ and $u$ are not very contrastive (for a discussion see Owens 2006: 51-67), this low contrastive value of the high vowels as well as the backing effect of emphatic consonants is found in most - if not all - Arabic dialects. The phonetic conditioning of the vowel harmony therefore cannot be taken as a convincing case of a shared innovation. Parallel development is also possible. The analogy of the fu'a l plural to adjectives whose stems do not trigger the vowel harmony is more difficult to explain as parallel development; This is a specific analogical innovation, and it does not seem likely that every dialect would have participated in this development in the same way.

14) for example, point out the Jiblih dialect does not seem to have the fu'al plural for adjectives. Jastrow (1986) does not contain enough data to fully confirm this: samin(ih) pl. simān 'fat', șagìr(ih) pl. șigāar 'small'. Șan'ānī provides us with more data, and seems to generally point in the same direction. There are clear cases of $f^{\prime}(\bar{a} l$ adjectival plurals in Șan'ānī Arabic, but Watson (1993; 1996), Qafisheh (1992: 175f) and Behnstedt (1992-2006) seem to disagree on whether the plural is always fi'āl or occasionally fu'a ${ }^{\prime}$. The list below is the list as given by Qafisheh, but forms added by Watson and Behnstedt are given.

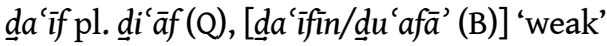

gașir pl. gișār (Q), [gașwar/gașirīin (B)] 'short'

hawis pl. hiwāṣ 'narrow'

wasiH pl. wisäH 'dirty'

ğadìd pl. ğidād (O), ğudād (B) 'new'

tagil pl. tigāl 'heavy'

dagìg pl. digāg 'thin'

kabir pl. kibār (Q, B, W), kubār (W) 'big'

galie pl. gilāa 'fat'

nadi îf pl. nidāâf'clean'

galì pl. gilāl 'little; few'

țawil pl. țuwāl (Q, B, W) 'long; tall'

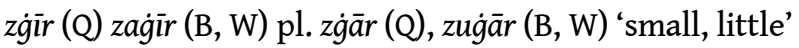

$\operatorname{samin}(\mathrm{B})$ pl. simān (B) 'fat'

41 The Șan'āni data suggests that there is either variation in this position (due to dialect mixing? Free variation?) or that $i$ and $u$ are not actually contrastive in this position. Whatever the case may be, it seems clear that there was no general shift of the adjectival 
plural from $f_{i}{ }^{\prime} \bar{a} l$ to $f u^{\prime} \bar{a} l$. From this data we may tentatively suggest that the innovation to have $f u^{\prime} a \bar{l}$ in all adjectival plurals is not a pan-Arabic innovation that affected all modern dialects.

Also Andalusi Arabic does not appear to have undergone this development. This much can be deduced from the cases of Andalusi Arabic transcribed in the Latin script (forms taken from Corriente 1997):

While it is true that Alcalá's dictionary, from which most of the Latin-script transcriptions of Andalusi Arabic stem, has a fair share of classicisms (e.g. Corriente 2013: $126,130)$, it also contains many vulgarisms. It seems unlikely that something so basic, and well outside of Classical Arabic phraseology, as adjectival plurals would be classicized, and I am therefore inclined to take them as true examples of retained fical plurals in Andalusi Arabic.

If the interpretation of the Șan'āni and Andalusi data is correct, it shows that the innovative fu'a l adjectival plural did not spread over the complete dialect continuum of the modern dialects, the original situation being retained on the two edges of this continuum; Its absence in Andalusi, but presence in Maghrebi - with which Andalusi otherwise shares many similarities - may even suggest that this innovation only spread over the Arabic dialect continuum fairly late, and therefore did not affect Andalusi. The possibility of late and (almost) universal spread of innovations is something that needs to be taken into account at all times when discussing the history of the modern dialects, as these dialects should be seen as a large dialect continuum.

\section{Conclusion}

Cairo Arabic, Skūra Arabic and Christian (and Jewish) Baghdadi Arabic all appear to have innovated a new adjectival plural fu'āl instead of the Proto-Arabic * fi $^{\prime} \bar{a} l$ (as attested in Classical Arabic and Andalusi Arabic). I have argued that this innovation is an analogical generalization due to the large amount of adjectives affected by the conditioned shift of ${ }^{*} f_{i}{ }^{\prime} \bar{a} l(a h)>f u^{\prime} \bar{a} l(a h)$ in emphatic environments. The dialects discussed all show signs of this conditioned development in nouns. This established conditioning gives a clear motivation for this morphological innovation, which has previously remained unexplained.

47 It has been argued that, while this vowel development and subsequent analogy in the adjectival plural might be a shared innovation, it cannot be an innovation that should be reconstructed back to a koiné ancestor of all the modern Arabic dialects as such the innovation would have to postdate the breakup of a single ancestor, since Andalusi Arabic and several varieties of Yemeni Arabic have not undergone this innovation. 
thestion that has not been dealt with in this paper, but certainly warrants further study, is whether there are other environments in which ${ }^{*} i$ shifts to $u$ besides emphatic fi'äl(ah) patterns.

It is hoped that this paper has shown the importance of the application of the comparative method to the Arabic dialects, and that a careful examination of the conditioning factors that motivate reflexes of Arabic dialects allows us to better understand their historical development.

\section{BIBLIOGRAPHY}

Abu-Haidar, F. 1991. Christian Arabic of Baghdad. Wiesbaden: Harrassowitz.

Aguadé, J. \& Elyaacoubi, M. 1995. El dialecto Arabe de Skūra (Marruecos). Madrid: Consejo Superior de Investigaciones Científicas.

Behnstedt, P. 1994. Der arabische Dialekt von Soukhne (Syrien), Teil 2: Phonologie, Morphologie, Syntax. Wiesbaden: Harrassowitz.

Behnstedt, P. 1992-2006. Die nordjemenitischen Dialekte Teil 2: Glossar. Wiesbaden: Ludwig Reichert Verlag.

Behnstedt, P. \& Woidich, M. 2005. Arabische Dialektgeographie. Eine Einführung. Leiden \& Boston: Brill.

Blanc, H. 1964. Communal Dialects in Baghdad. Cambridge: Harvard University Press.

Blau, J. 1977. "The Beginnings of the Arabic Diglossia. A Study on the Origins of Neoarabic", Afroasiatic Linguistics 4(3). 175-201.

Cohen, D. 1962. "Koinè, langues communes et dialects arabes", Arabica 9. 119-144.

Corriente, F. 1997. A Dictionary of Andalusi Arabic. Leiden \& Boston: Brill.

Corriente, F. 2013. A Descriptive and Comparative Grammar of Andalusi Arabic. Leiden \& Boston: Brill. Ferguson, C. 1959. “The Arabic Koine”, Language 35(4). 616-630.

Heath, J. 2002. Jewish and Muslim Dialects of Moroccan Arabic. London: RoutledgeCurzon.

Hinds, M. \& Badawi, E.-S. 1986. A Dictionary of Egyptian Arabic. Beirut: Librarie du Liban.

Ingham, B. 1973. "Urban and Rural Arabic in Khūzistān", BSOAS 36(3). 533-553.

Ingham, B. 1994. Najdi Arabic. Central Arabian. Amsterdam \& Philadelphia: John Benjamins.

Jastrow, O. 1986. “Alles über Qāt. Ein Text im arabischen Dialekt von Jiblih (Nordjemen)”, ZDMG 136. 23-55.

Owens, J. 1984. A Short Reference Grammar of Eastern Libyan Arabic. Wiesbaden: Harrassowitz. Owens, J. 2006. A Linguistic History of Arabic. Oxford: Oxford University Press.

Qafisheh, H. 1990. Yemeni Arabic. Beirut : Librairie du Liban

Raymond, A. 2000. Cairo. Cambridge, MA: Harvard University Press.

Schreiber, G. 1970. Der Arabische Dialekt von Mekka. Abriß der Gammatik mit Texten und Glossar. PhD thesis, Münster.

Watson, J. 1993. A syntax of Șan'āni Arabic. Wiesbaden: Harrassowitz Watson, J. 1996. Șbahtūu ! A Course in San'ani Arabic. Wiesbaden: Harrassowitz. 


\section{NOTES}

1. I follow the transcription of Benkato (2016), which is an excellent reexamination and of the vowel harmony system as described by Owens (1984).

2. Very similar processes take place in Najdi Arabic (Ingham 1994: 14), Khuzistani Arabic (Ingham 1973: 534ff.) and Muslim Baghdadi Arabic (Blanc 1964: 34ff.).

3. However, original * $u$ is retained in Cairene Arabic. Unlike Eastern Libyan Arabic the high vowels have not merged, e.g. fulān 'so-and-so', buhūr 'seas', suxām 'filth, dirt', hubb 'love'.

4. The CAr. verbal noun of 'to be deaf' is țaraš. But CiCāC is a productive verbal noun formation.

5. In the period from 1882 and 1937, the population of Cairo more than tripled (Raymond 2000: 319).

6. The earlier dictionary by Spiro (1895) already shows much of the same mixed pattern, but whenever both a fi'all(a) and fu'äl(a) options are possible for Hinds \& Badawi, Spiro only lists the $f u^{\prime} \bar{a} l(a)$ form. I have identified two forms that have a fu'all(a) pattern, where only $f^{\prime}{ }^{\prime} \bar{l}(a)$ is recorded by Hinds \& Badawi, namely: buḍ̂a 'a 'merchandise' and buṭ̂na 'lining'.

7. While not of ancient origin, this example shows that labialization is not linked to the presence of ${ }^{*} u$.

8. Words in brackets are likely loans from Muslim Baghdadi.

9. And certainly several more dialects, e.g. the Syrian Soukhne dialect lacks $i$-umlaut in the adjectival plural (Behnstedt 1994: 29) and Mekkan Arabic seems to have $u$ in adjectival plurals like Cairene Arabic (Schreiber 1970: 64).

\section{ABSTRACTS}

In several modern Arabic dialects the noun pattern fi'äl(ah) shifts to fu'äl(ah) in emphatic environments. This development also affects adjectival plurals with an original shape fi ${ }^{i} a$ l. From this conditioned shift the innovative $f u^{\prime} a \bar{l}$ pattern was generalized to all adjectives. It is not likely that this development goes back to a Proto-dialectal "koiné".

\section{INDEX}

Keywords: Historical Linguistics, Koiné, vowel harmony, shared innovation, broken plural

\section{AUTHOR}

\section{MARIJN VAN PUTTEN}

Leiden University 


\title{
On Morpho-Syntactic Levantisms in Maltese
}

\author{
David Wilmsen and Amany Al-Sayyed
}

\section{Introduction}

1 The peripheral Arabic variety Maltese is usually classed amongst the North African dialects of Arabic. Yet, what Mifsud has called, "some curious similarities with the Eastern dialects" (2008: 46) are obvious in the language, such that Stumme (1904: 83) was moved reservedly to suggest that Maltese be classified as Levantine not North African, supposing that its obvious affinities with North African varieties of Arabic came about through its neighbouring proximity to North Africa. Zammit (2014) has established the close relation between Tunisian Arabic and Maltese (cf. also Čeplö et al 2016). Meanwhile, Borg (1994 \& 1997) has examined some of its Levantine traits, casting most attention upon the phonology and to a lesser degree on the lexicon and morphology. He also remarks one singularly Levantine syntactic feature, direct object marking with /1-/ (Borg 1994: 57-59; 1997: 138-139).

2 That, however, is not the only syntactic feature that Maltese shares with Levantine varieties of Arabic. We have been examining the morpho-syntactic affinities between Maltese and Levantine Arabic varieties and have already reported on some (Al-Sayyed \& Wilmsen 2017; Wilmsen 2016a \& 2016b). Others we are presenting here for the first time. Altogether, the features we have been examining, either singly or in collaboration, are the following:

- Polar interrogative $\check{s}$ (Wilmsen 2016a)

- Prohibitive $t$... š; dehortative muš/mhux (Wilmsen 2016b; Al-Sayyed \& Wilmsen 2017)

- Double object marking with 1 -/lil

- Pronominal circumstantial clauses 


\section{Data sources}

Our data come largely from electronically searchable corpora, especially the Korpus Malti (mlrs.research.um.edu.mt), encompassing 250 million tokens. In addition to the extensive searchable texts that the Korpus Malti makes available, we have been scouring Maltese blogs and online news sources, mostly for corroborating evidence and the occasional particularly apt example of the phenomena under examination. The Arabic data come from Tunisian Arabic Corpus (http://tunisiya.org/), comprising 818,310 tokens, and the Egyptian Arabic material from arabiCorpus (arabicorpus.byu.edu) with 140,234 tokens. We also took advantage of our presence in the Levant to glean examples of usage from that milieu.

\section{Polar interrogative $\check{s}$}

A polar interrogative -š has been documented in some Arabic dialects (Obler 1975: 45-46; Holes 2004: 192; Woidich 2006: 358; Gibson 2008; Wilmsen 2014: 53-55 \& Chapter 5 and references). Wilmsen (2016a) examines the phenomenon in Maltese in greater depth. Here is an example from our data:

(1) Maltese: pseudo-verb

Ghandekx hila tinsieni ?

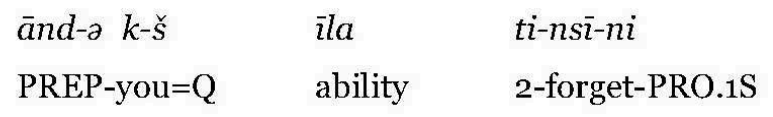

'Have [lit. 'at'] you the ability to forget me?' (cf. Sutcliffe 1936: 211: ghandekx il-hila tmur? 'Do you have the temerity to go')

(2) Maltese: Verb

hrigtx flus ?

irig-t-š flus

extract.PFV-2M=Q money

'[Have] you taken out money [from your pocket]?' (cf. Borg \& AzzopardiAlexander 1997: 4: Hrigtux mill forn?)

In Maltese, polar interrogative š follows the verb or pseudo-verb; in Levantine Arabic, it can as well, but it often, perhaps usually, comes at the end of the utterance (Holes 2004: 192).

(3a) Levantine Arabic

\begin{tabular}{llll}
$\check{s} u f t-u$ & \multicolumn{1}{c}{ si } & la & murād \\
see.PFV-PRO.3MS Q & ACC & name \\
'[Have] you seen Murad?' & &
\end{tabular}

$(3 b)$ 


$\begin{array}{llll}\check{s} u f t-\bar{a} & l a & \text { fat } m a & \check{s} i \\ \text { see.PFV-PRO.3FS } & \text { ACC } & \text { name } & \text { Q }\end{array}$

'[Have] you seen Fatma?'

5 These examples also exhibit another trait that Maltese shares with Levantine varieties of Arabic: the double object marker /l-/. We shall return to this presently.

\section{Prohibitive $t \ldots \check{s}$}

6 Another well-documented phenomenon is the prohibitive formed with a post-positive $-\check{s}$ alone. This is, in fact, a defining feature of southern Levantine dialects of Arabic:

(5) Levantine Arabic

$$
\begin{aligned}
& \begin{array}{l}
t i-n s \bar{a}-\check{s} \\
\text { 2S-forget-PROH }
\end{array} \text { DET-b̌ant } a \\
& \text { '[Do] not forget the [your] bag' }
\end{aligned}
$$

7 It is also the usual manner of forming the prohibitive in Maltese (Borg and AzzopardiAlexander 1997: 27):

(6) Maltese

Tinsiex li Gesù wkoll ibati mil loneliness bhalek u bhali

$\begin{array}{llll}\text { ti-nsī-s } & l i \quad \text { ğ esu } & w k o l & \bar{i} \text {-bati } \\ \text { 2S-forget.PROH-NEG } & \text { REL name } & \text { also } & 3 \text { MS-suffers } \\ \text { mi-l-loneliness } & b \text {-āl-ek } & \bar{u} & b \text { - } \bar{a} l-i \\ \text { PREP-DET-loneliness } & \text { PREP-self-PRO.2 } & \text { CONJ } & \text { PREP-self-PRO.1S }\end{array}$

'[Do] not forget that Jesus also suffers from loneliness, as you [do]'

\section{Dehortative mūš}

8 Negating verbs with a reflex of miš/muš has been commented upon (Brustad 2000: 302303; Doss 2008) with the assumption that it represents a language change in progress unique to Egyptian Arabic. It rather is a regular pragmatic feature, imparting shades of meaning to the negated predication (Håland 2011). Among these is the dehortative (Wilmsen 2016b). Not restricted to Egyptian Arabic, Levantine Arabic exhibits it, too:

(7) Levantine Arabic

$$
\begin{aligned}
& \text { ba-' zim-kon 'alā 'ahwe muš ti-šrab-u šāy } \\
& \text { 1-invite.IPFV-PRO.2PL PREP coffee NEG 2-drink.IPFV-PRO.PL tea } \\
& \text { 'I'm inviting you for coffee; [mind] you not drink tea' }
\end{aligned}
$$


Negating verbs with $m \bar{u}$ š is used with the same dehortative effect in Maltese. We have examined this in detail (Al-Sayyed and Wilmsen 2017). A difference between the dehortative and a prohibitive is that dehortatives are not restricted to the 2nd person, to which a prohibitive necessarily must be:

(8) Maltese

mhux jghid li jiena ivvintajt xi hag̀a

$m$ mūš yi-id li yena ivvint-ayt

NEG 3MS-say.IPFV REL PRO.1S invent.PFV-1S some thing

'He [should] not say that I invented something'

\section{Double object marking with /-/lil}

Researchers have remarked this phenomenon in Levantine Arabic (Koutsoudas 1967; Levin 1987), and it is the sole syntactic affinity between Levantine Arabic and Maltese that Borg (1994: 57-59; 1997: 138-139) addresses. In Levantine Arabic, marking a direct object with /1-/ is optional, but common. When it occurs, the nominal direct object is usually preceded by an "anticipatory object pronoun" (Levin 1987: 33; Abu-Haidar 199: 116).

(9) Levantine Arabic

$$
\begin{array}{lll}
k i f f & t i-z ̌ a w w i z-\bar{a} & \text { la-l-binit } \\
\text { Q } & \text { 2-marry.IPFV-PRO.3FS } & \text { ACC-DET-girl }
\end{array}
$$

'How can you marry the girl?'

11 What is more, double object marking itself is optional, with no difference in meaning between a phrase with or without an anticipatory pronoun (Koutsoudas 1967: 33):

(10)

$\begin{array}{lcc}\text { badd-ak } & \text { ti-žawwiz } & \text { hal-binit } \\ \text { wish-PRO.2M } & \text { 2-marry.IPFV } & \text { DET-girl } \\ \text { 'You want to marry the girl?' } & \end{array}$

This kind of variability is not usually seen in Maltese, which requires /lil/, a grammaticalization of the preposition /li-/ 'to' and the definite article /il-/, with animate direct objects. Generally, this appears without the anticipatory object pronoun of Levantine Arabic (11a), but an anticipatory pronoun does sometimes appear, usually in literary registers (11b):

(11) Maltese

a. 
Nistaqsu lil San Pietru

ni-staqs-u lil San Pietru

1-ask.IPFV-3PL ACC name

'We ask St Peter'

b.

habbejtha lil din 1- art hanina

a bb-eyt-a lil din l-art ànina

love.PFV-1S-PRO.3FS ACC DEM DET-land beloved

'I loved this beloved land'

Notice that the object in (11b) is inanimate. Such objects are usually not marked with /lil/ in Maltese, but they can be marked with /la-/ in Levantine Arabic:

(12) Levantine Arabic

a.
$b-h i b b-\bar{a}$
la-hal-musī a
HAB-love.IPFV-PRO.3FS
ACC-DET-music

'I love this music!'

b.
$k i \bar{f}$
$m i-n-h i b b-u$
la-libnān
EXCLAM
HAB-1PL-love.IPFV-PRO.3MS
ACC-place.name

'How we love Lebanon!'

In (11b) and (12b), the inanimate objects din l-art 'this land' and libnān might be seen as embodying personality, but in (12a) it is not.

\section{Pronominal circumstantial clauses}

12 As we were investigating double object marking in Maltese, we chanced upon this phrase: Hi u tisma' lil Rasha tagHtiha r-ragunijiet tagHha gHaliex bdiet tilbes il-velu 'As she was listening to Rasha giving her the reasons she began to wear the veil', in which the order of the pronoun and the verb in the circumstantial clause is the reverse of their usual order in most varieties of Arabic.

(13) Maltese

$\begin{array}{lllll}\bar{\imath} & u & \text { ti-sma } & \text { lil } & \text { Rasha } \\ \text { PRO.3S } & \text { CONJ } & \text { 3FS-listen.IPFV } & \text { ACC } & \text { name }\end{array}$

'While she was listening to Rasha' 
13 This also occurs in the same order in Levantine Arabic. According to Cowell (2005 [1964]: 532), it sometimes happens in Syrian Arabic. To the contrary, in our observations, it is common in Syrian Arabic, and it is the usual sequence in Lebanese Arabic:

(14) Levantine Arabic

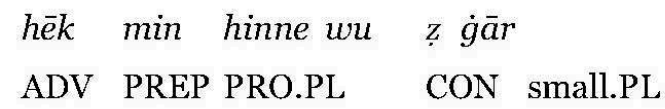

'[It has been] thus from when they [were] small'

14 In the usual Arabic order, these would be expected to be as follows:

(15) a.

wa hi ti-sma

CONJ PRO 2f-listen.IPFV

'As she was listening'

b.

min $w u$ hinne $z \dot{g} \bar{a} r$

PREP CONJ PRO small

'From when they were young'

15 Along with double object marking, the reversal of elements in pronominal circumstantial clauses looks to be another "striking parallel ... in the realm of syntax" (Borg 1997: 138).

\section{Are these Levantine traits alone?}

16 Many of these parallels had already been observed in Arabic varieties other than the Levantine.

\subsection{Polar interrogative $\check{s}$}

17 Tantāwi (1846) documents the use of a post-positive -š in polar interrogatives in Egyptian Arabic before the middle of the 19th century:

(17) Egyptian Arabic (19th century)

a.

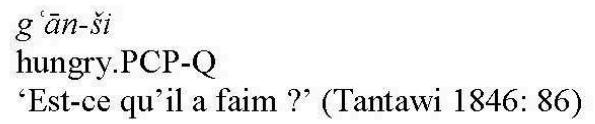

b.

$q \bar{a} m-\check{s}$

stand.PFV-Q

'Est-ce qu'il est levé ?' (ibid.)

c. 
ḥ add-š gā gā

'[some]one-Q come.PFV

'Est-ce que quelqu'un est venu ?' (ibid.)

Somewhat later, Șabbāg (1886) explains the principle in Egyptian Arabic: "They [Egyptians] add the šin at the end of the perfective and imperfective verb and the active and passive participle in interrogation. They say, drbt-š meaning 'Have you struck?' (hal darabta?) ... and in the present, 'adrab-š meaning 'Do I strike?' (Sabbāg 1886: 14), also providing this example:

(18) Egyptian Arabic (19th century)

$\begin{array}{cllr}\text { inda- } k-\check{s} & h \text { ugga } & f i \quad \partial a \bar{l} l i k \\ \text { PREP-PRO.3M-Q } & \text { excuse } & \text { PREP DEM }\end{array}$

'Have you and excuse for that?' (Sabbāg 1886: 16)

19 By the 20th century, polar interrogative -š in Egyptian 'ind expresses a negative hedge, with an approximate meaning of 'you wouldn't happen to have?' (Badawi and Hinds 1986: 449; Woidich 2006: 358-359).

Nevertheless, it retains its interrogative quality in Tunisian Arabic. Gibson (2008) gives an example in which it simply means 'have you?' (cf. example [1]), echoing Șabbāò's explanation: "interrogation can be expressed by the suffix -ši, sometimes shortened to -š" (Gibson 2008: 570). The following example is from our data:

(19) Tunisian Arabic

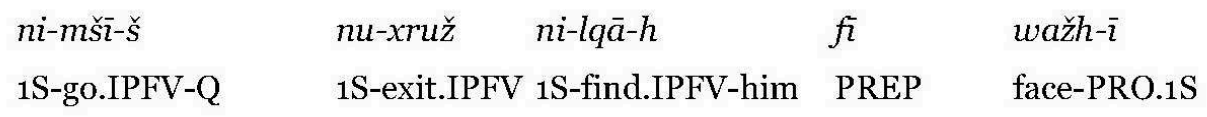

'Am I to go out and find him in my face [everywhere]?'

\subsection{Verbal negation with muš/mhux}

Brustad (2000: 302-303) and Doss (2008) have remarked verbal negation with miš/muš in Egyptian Arabic, without, however, exploring its pragmatics in detail. Håland (2011) examines three pragmatic functions in negating verbs with miš/muš. A common reason for it is when, "one negated and one positive fact stand in contrast to each other" (Håland 2011: 30). We have found almost exact doublet of this between Egyptian Arabic and Maltese:

(20) a. Egyptian Arabic

$\begin{array}{lllll}\text { bi-ya-ah ud } & \text { fulūs } & \text { miš } & b i-y-g \bar{\imath} b & \text { fulūs } \\ \text { HAB-3M-take.IPFV } & \text { money } & \text { NEG } & \text { HAB-3M-get.IPFV money }\end{array}$

'He takes money; not gets money'

b. Maltese 
jaghti 1- flus u mhux jiehu

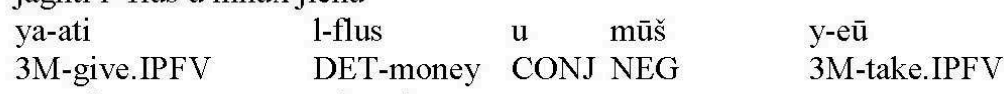

'He gives money; not takes [it]' negation, the negator miš poses a question of the type 'is not X?' and in metalinguistic negation registers an objection to the content or the form of an utterance, not to the proposition itself. We have found examples of all of these in Arabic varieties throughout the eastern Mediterranean (Al-Sayyed \& Wilmsen 2017: 248-252).

\subsection{Dehortative mūš}

Another type of negation with miš/muš that has received scant attention is with dehortatives (cf. Wilmsen 2016b). In his examination of negation in Irbid, northern Jordan, Alqassas (2012: 22, 121, 127-134) seems puzzled by the phenomenon. Doss (2008) gives an example of it in Egyptian Arabic without recognizing it as such:

(21) Egyptian Arabic

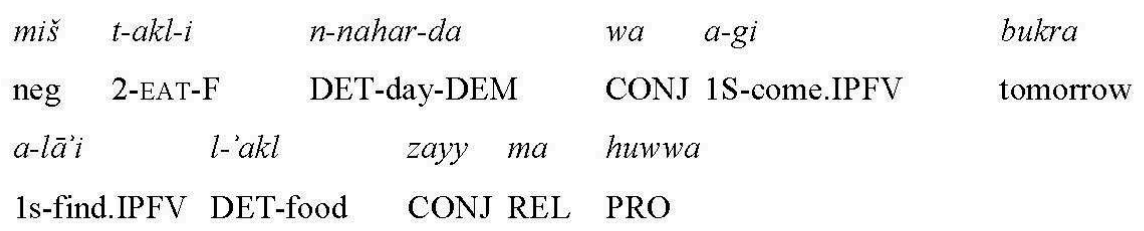

'[Mind] you not eat today and then I come tomorrow to find the food as is [uneaten]' (Doss 2008: 87)

24 We see analogous dehortatives in Tunisian Arabic:

(22) Tunisian Arabic

mūšs $y i-q \bar{u} l-\bar{u} \quad$ illi $\quad$ Eamma $\hbar \bar{a} z ̌ a ~ i s m-h \bar{a} \quad$ istimrāriyya

NEG 3-say.SBJV-PL CONJ EXIST thing name-PRO.3FS continuation

'[Let] them not say that there is something called continuity'

\subsection{Double object marking with I-/lil}

Borg supposes that this is a feature of Arabic varieties that had been in close contact with Aramaic. Indeed, it is found in all Arabic dialects of the Fertile Crescent. In Iraqi Arabic, as in Syro-Lebanese, it can mark animate and inanimate objects:

(23) Iraqi Arabic
$\bar{a} n i$
šāyf-a
l-il-mathaf

PRO.1S

see.PCP-PRO.3MS

ACC-DET-museum

'I've seen it the museum' (Erwin 1963: 334; see also, \& Jastrow 1979: 49; Levin 1987; Abu-Haidar 1991: 116) 


\subsection{Pronominal circumstantial clauses} in the uncharacteristic word order of pronominal circumstantial clauses. But Woidich has documented it in a dialect of Upper Egypt:

(24) Egyptian Arabic (B`ēri - Upper Egypt)

a.
šuf-t-u
hūwwa
$w$
$a-y i-\hbar r i t$
see.IPFV-1S-PRO.3MS
PRO.3MS CONJ

'I saw him while he was plowing'

b.

$\begin{array}{lllll}\text { tă-kil } & \text { min-ha } & \text { n-naas } & \text { hiya } & w \quad \text { h ad ra } \\ \text { 2-eat.IPFV } & \text { PREP-PRO.3FS } & \text { DET-people } & \text { PRO.3FS } & \text { CONJ green }\end{array}$

'People eat it while it is green' (Woidich 2005: 308: see also Woidich 1980: 235)

27 What is more, we have found it in use in some dialects of the United Arab Emirates.

(25) Emirati Arabic

a. Fujairah

$\begin{array}{lllll}\text { yi-ġīb sana } & h \bar{u} & w a & f i-l-b l a \bar{d} \\ \text { 3S-be.absent.IPFV year } & \text { PRO.3MS } & \text { CONJ } & \text { PREP-DET-locality. }\end{array}$

'[Would] he stay away for a year while he is [still] in town?'

b. Fujairah

\begin{tabular}{|c|c|c|c|c|c|}
\hline ana & $w$ & rāyith & il-mahkama & $b-a-x \underline{d}-a$ & $\min -k$ \\
\hline PRO.1S & CONJ & go.PCP.MS & DET-court & FUT-1S-take.IPFV-PRO.3FS & PREP- \\
\hline
\end{tabular}

'When I'm going to the court, I'll get it from you'

\section{Discussion}

What appears to be a polar interrogative with pronouns that is characteristic of Maltese usage (Wilmsen 2016a) is documented in Andalusi Arabic from 13th and 14th centuries, for example anā-š nadri 'Do I know?' This has usually been read as a negation (cf. Corriente 2013: 126-127), and that is what its pragmatics accomplish, but it remains an interrogative analogous to the Levantine expression šu bi-ya'rifni and the Egyptian anā ' $\bar{a}$ rif, both meaning 'what do I know?' but the pragmatic effect is of firm denial, that is, a negation (Wilmsen 2014: 69-70). So, too, is double object marking an Andalusi Arabic feature (Corriente 2013: 107-108).

We may, thus, tentatively conclude that speakers of Andalusi Arabic dialects with precursors in the Levant may have entered Malta from Al-Andalus, perhaps by way of Sicily, as part of what Agius calls "a period of continuous immigration from North Africa 
and al-Andalus" (2007: 25). This is consistent with Mifsud's observation: "It is likely that successive waves of impact reached the Maltese shores from different Arab stations and at different points in the island's history" (Mifsud 2008: 146).

This, however, does not preclude the possibility that what are now emblematic features of North African varieties of Arabic and of Levantine dialects alike had their origins in the Levant or inland from it. Writing about similarities between Moroccan Arabic and Aramaic, Retsö makes this observation:

It is hereby suggested that these characteristics are a testimony of their originally belonging to a continuous linguistic continuum. It would have encompassed an area from central Syria to north-western Arabia (= the Syrian desert). The origins of the Maghribi dialects of Arabic are to be looked for in that area. We happen to know that the first wave of conquerors to North Africa were dominated by the so-called Qudā'a tribes, whose original habitat was Syria. (Retsö 2000: 116).

These scenarios are not mutually exclusive. Speakers of Arabic dialects were present in the Fertile Crescent before the first Arabic speaking Muslims arrived in the 7th century. They would have been in close contact with Aramaic, and many were probably bilingual in both. Speakers of those dialects of Arabic were involved in the push westward during the expansion of Arab/Islamic civilization in the 7th and 8th centuries. Once that expansion had reached its full extent, Arabic speakers moved more-or-less freely throughout the Mediterranean. With that, we may suppose that both Mifsud and Retsö have described separate dimensions to the presence of a variety of Arabic on Malta one at and the other after the arrival of Arabic speakers on Malta some time between 870 and 1090 (Brincat 1995, 2008). Speakers of what we now call North African dialects must surely have come to Malta by way of Tunisia, but they will also have come by way of AlAndalus, where Levantine traits must have been in place since the first entry of Arabic speakers onto the Peninsula in 711, and surely after the entry of the Syrian Umayyad prince Abdel Rahman arrived in 756. Indeed, the features that Arabic dialects of the Fertile Crescent and the Syrian Steppes acquired through contact with Aramaic should be considered an adstratal not a "substratal feature[s] carried over from Aramaic" as Borg (1994: 58). With that, the Levantine features found in Maltese are not curious at all.

\section{BIBLIOGRAPHY}

Abu-Haidar, Farida. 1991. Christian Arabic of Baghdad. Wiesbaden: Harrassowitz.

Agius, Dionisius A. 2007. “Who Spoke Siculo Arabic?”, Morrigi, Marco (ed.), XII Incontro Italiano di Linguistica Camito-semitica (Afroasiatica). Soveria Mannelli: Rubbettino. 25-33.

Alqassas, Ahmad. 2012. The Morpho-Syntax and Pragmatics of Levantine Arabic Negation: A synchronic and diachronic analysis. Ph.D. dissertation, Indiana University.

Al-Sayyed, Amany \& Wilmsen, David. 2017. "Verbal negation with muš in Maltese and Eastern Mediterranean Arabics", Tosco, Mauro \& Saade, Benjamin (eds), Advances in Maltese Linguistics. Berlin: de Gruyter Mouton. 239-260. 
Badawi, El-Said \& Hinds, Martin. 1986. A Dictionary of Egyptian Arabic. Beirut: Librairie du Liban. Borg, Albert \& Azzopardi-Alexander, Marie. 1997. Maltese. Oxford: Routledge.

Borg, Alexander. 1994. "Some evolutionary parallels and divergences in Cypriot Arabic and Maltese", Mediterranean Language Review Vol. 8. 41-67.

Borg, Alexander. 1997. “On some Levantine linguistic traits in Maltese”, Izre'el, Shlomo \& Raz, Shlomo (eds.) Studies in modern Semitic languages. Leiden: E.J. Brill. 133-152

Brincat, Joseph M. 1995. Malta 870-1054: al-Himyarī's account and its linguistic implications. Valletta/ Malta : Said International.

Brincat, Joseph M. 2008. “Malta”. Versteegh, K., Eid, M., Elgibaly, A., Woidich, M. \& Zaborski A. (eds.), Encyclopedia of Arabic Language and Linguistics. Leiden: Brill. 141-145.

Brustad, Kristen E. 2000. The Syntax of Spoken Arabic: A comparative study of Moroccan, Egyptian, Syrian, and Kuwaiti dialects. Washington, D.C.: Georgetown University Press.

Corriente, Federico. 2013. A Descriptive and Comparative Grammar of Andalusi Arabic. Leiden: Brill.

Cowell, Mark. 2005 [1964]. A Reference Grammar of Syrian Arabic: Based on the dialect of Damascus.

Washington, D.C.: Georgetown University Press.

Čeplö, Slamovír, Bátora, Ján, Benkato, Adam, Milička, Jiří, Pereira, Christophe \& Zemánek, Petr. 2015. "Mutual intelligibility of spoken Maltese, Libyan Arabic and Tunisian Arabic functionally tested: A pilot study", Folia Linguistica 50. 583-621.

Doss, Madiha. 2008. "Evolving Uses in Cairene Egyptian Arabic Negation Forms", Estudios de dialectología norteafricana y andalusí 12. 83-91.

Erwin, Wallace. M. 1963. A Short Reference Grammar of Iraqi Arabic. Washington, D.C.: Georgetown University Press.

Gibson, Maik. 2008. "Tunis Arabic”, Versteegh, K., Eid, M., Elgibaly, A., Woidich, M. and Zaborski, A. (eds), Encyclopedia of Arabic Language and Linguistics. Leiden: Brill. 563-71.

Håland, Eva Marie. 2014. miš yinfa' a change in progress? A study of extended usage of the negation marker miš in Cairene Arabic. Master's thesis, University of Oslo.

Holes, Clive. 2004. Modern Arabic: Structures, functions, and varieties. Washington, D.C.: Georgetown University Press.

Jastrow, Otto. 1979. “Zur arabischen Mundart von Mossul”, Zeitschrift für Arabische Linguistik 2. 36 -75 .

Koutsoudas, Andreas. 1967. “Object Particles in Lebanese”, Journal of the American Oriental Society 87/4. 512-517.

Levin, Aryeh. 1987. "The Particle la as an Object Marker in some Arabic Dialects of the Galilee”, Zeitschrift für Arabische Linguistik 17. 31-40.

Obler, Loraine. 1975. Reflexes of Classical Arabic šay'un in the Dialects: A study in patterns of language change. Unpublished Ph.D. dissertation, The University of Michigan.

Mifsud, Manwel. 2008. "Maltese”, Versteegh, K., Eid, M., Elgibaly, A., Woidich, M. and Zaborski, A. (eds), Encyclopedia of Arabic Language and Linguistics. Leiden: Brill. 146-159.

Retsö, Jan. 2000. “Kaškaša, T-passives and the Ancient Dialects in Arabia”, Oriente Moderno 19/80 (n.s.)/1.111-118. 
Ṣabbāğ, Mîkhâ-îl. 1886. Grammatik Arabischen Umgangssprache Syrien Aegypten (H. Thorbecke ed.). Strassburg: Karl J. Trübner.

Stumme, Hans. 1904. Maltesische Studien: Eine Sammlung prosaischer und poetischer Texte in maltesischer Sprache nebst Erläuterungen. Leipzig: Hinrichs.

Sutcliffe, Edmund F. 1936. A grammar of the Maltese language with chrestomathy and vocabulary. Oxford: Oxford University Press.

Ṭanțāwī̄, Muhammad Ayyad. 1846. Traité de la langue arabe vulgaire. Leipzig: Guillaume Vogel fils.

Thackston, W.M. Jr. 1996. The Vernacular Arabic of the Lebanon. Cambridge: Dept. of Near Eastern Languages and Civilizations, Harvard University.

Wilmsen, David. 2014. Arabic Indefinites, Interrogatives, and Negators: A linguistic history of western dialects. Oxford: Oxford University Press.

Wilmsen, David. 2016a. "Polar interrogative -š in Maltese: Developments and antecedents", Puesch, Gilbert \& Saade, Benjamin (eds.), Shifts and Patterns in Maltese. Berlin: Mouton de Gruyter. 79-102.

Wilmsen, David. 2016b. "The Dehortative in the Spoken Arabics of the Eastern Mediterranean". Romano-Arabica XVI. 133-150.

Woidich, Manfred. 1980. “Texte aus il-Bi'raat”, Fischer, Wolfdietrich \& Jastrow, Otto (eds.), Handbuch der arabischen Dialekte. Wiesbaden: Harrassowitz. 235-242.

Woidich, Manfred. 2005. “B'ēri ArabicVersteegh, K., Eid, M., Elgibaly, A., Woidich, M. and Zaborski, A. (eds), Encyclopedia of Arabic Language and Linguistics. Leiden: Brill. 299-308.

Woidich, Manfred. 2006. Das Kairenisch-Arabische: Eine Grammatik. Wiesbaden: Harrassowitz.

Zammit, Martin R. 2014. “The Sfaxi (Tunisian) element in Maltese”, Borg, Albert, Caruana, Sandro and Vella, Alexandra (eds.), Perspectives on Maltese Linguistics. Berlin: De Gruyter. 23-44.

\title{
Corpora:
}

arabiCorpus (http://arabicorpus.byu.edu)

Korpus Malti (http://mlrs.research.um.edu.mt)

Tunisian Arabic Corpus (http://tunisiya.org )

\section{APPENDIXES}

\author{
Abbreviations \\ ACC accusative \\ ADV adverbial \\ CONJ conjunction \\ DET determiner \\ EXCLAM exclamative \\ EXIST existential \\ $\mathrm{F}$ feminine
}


FUT future

HAB habitual

IPFV imperfective

M masculine

NEG negative

PCP participle

PFV perfective

PL plural

PREP preposition

PRO pronoun

$\mathrm{PROH}$ prohibitive

Q interrogative

REL relative

s singular

SBJV subjunctive

1 1st person

2 2nd person

3 rrd person

\section{ABSTRACTS}

Maltese is usually classified as a North African Arabic variety. Yet some researchers have remarked "some curious similarities with the Eastern dialects". Investigations of these tend to concentrate upon the phonology and lexicon, with slight attention paid to morphology and syntax. We report on a long-term project in documenting some of those, including polar interrogation with a reflex of /š/; the prohibitive/dehortative system, also exhibiting reflexes of /š/; double object marking with reflexes of /1-/; and pronominal circumstantial clauses. None of these is excusive to Maltese and the Levant alone. Polar interrogation with /š/ is found in the Levantine, and North African, and Andalusi Arabic. The Maltese prohibitive is largely southern Levantine in form, but its dehortative is common to eastern Mediterranean dialects of Arabic. Double object marking with reflexes of /l-/ appears in Andalusi, Levantine, and Mesopotamian varieties. The Maltese pronominal circumstantial clause is similar to Syro-Lebanese Arabic, the Be ēeri Arabic of Upper Egypt, and some dialects of the United Arabic Emirates.

\section{INDEX}

Keywords: Arabic dialects, circumstantial clauses, dehortative, double object marking, polar interrogatives, Maltese, prohibitive 


\section{AUTHORS}

\section{DAVID WILMSEN}

American University of Sharjah

dwilmsen@aus.edu

Department of Arabic and Translation Studies, PO Box 26666, Sharjah, United Arab Emirates 61485

\section{AMANY AL-SAYYED}

American University of Beirut

aa139@aub.edu.lb

P.O. Box 11-0236, Department of Writing Studies, Riad El-Solh, Beirut 1107 2020, Lebanon 
Issues in Sociolinguistics: Contact and Change, Discourse Analysis, Cultural Practises, Mixed Styles and Written Sources 


\title{
The Impact of Topic on Hybrid Forms: The Case of Arabic in Morocco
}

\author{
Mina Afkir
}

\section{Introduction}

1 Diglossia has been approached differently by scholars since the classic description of Ferguson (1959). “The most widely articulated criticism [of Ferguson's model] concerns the rigid intercontextual compartmentalization of SA and QA" (Albirini 2016: 21). Ferguson (1959) described diglossia as a language situation that is characterized by a strong dichotomization of the situations in which the high variety and the low variety are used. Later on, linguists shifted from this sharp dichotomization to models that integrate the notion of continuum.

Blanc (1960), for instance, identified five levels of speech between pure $\mathrm{H}$ and pure L, ranging from what he calls plain colloquial to standard classical. Badawi (1973), examining diglossia in Egypt, also posited five mustawayāt 'levels' to describe the varieties between the two idealized poles of the Arabic continuum. He dealt with diglossia from a sociolinguistic perspective, focusing on the variable of education, but it is important to note that "using education as a criterion can be considered a problem in his description. It is not clear whether the colloquial levels are built on socio-economic variables like education or are just 'stylistic registers', or whether they can be both." (Bassiouney 2009: 275).

3 The notion of levels pushed linguists to introduce new terms to describe the varieties along the continuum. Mitchell $(1980,1986)$ proposed for the mixed forms the term Educated Spoken Arabic while Youssi $(1983,1995)$, describing the diglossic situation in Morocco, used the term 'triglossia', stating that it is a language situation that involves "the alternative use" of three varieties rather than two. Hary (1992: 12) rather coined the term 'multiglossia', strongly claiming that: 
it is imperative to remember that this area in the middle is not composed of only one variety, or of three varieties as proposed by Badawi (1973); there can be a countless number of lectal varieties on the continuum between the two ideal types [...] Since we are dealing with the notion of a continuum, there are no boundaries and no commitment to discrete categories, thus allowing more flexibility in analyzing texts.

Models based on the notion of continuum, which is considered as one of the basic developments of Ferguson's classic concept of diglossia, presupposes the existence of inbetween spaces and hence the existence of mixed Arabic. From a historical perspective, this form of Arabic has an older and a more recent manifestation. Den Heijer (2012) talked about pre-modern and modern, written and oral manifestations of mixed Arabic. The older form of this form of Arabic, referred to as Middle Arabic by specialists, has been subject to analysis within philological studies while contemporary mixed Arabic has been investigated from a sociolinguistic approach starting from the classic model of diglossia proposed by Ferguson (1972 [1959]) till today with the emergence of new approaches.

The present study is a contribution to this very interesting socio-linguistic phenomenon which is the oral manifestation of mixed Arabic in modern times. It seeks to explore more specifically the impact of topic on the occurrence of hybrid forms. Hybridity is a term and a concept that refers to mixture. It has been and is used across different disciplines such as biology, postcolonial studies, cultural studies and globalization theory. In linguistics, "it refers to a word parts of which come from two different languages" (Eid 2007: 408). Van Mol (2003: 89) pointed out that "when within one word a mixture occurs of two language levels, we can talk about hybrid forms." Hybrid forms in Arabic are those words that mix features from both Standard Arabic and colloquial Arabic. The rationale that motivates my investigation is to bring some empirical evidence for this oral manifestation of mixed Arabic from the Moroccan context, which is quite underresourced as it has not received as much attention from native linguists as other Arabicspeaking communities. More extensive research needs to be done on this area, which constitutes an important facet of the Arabic language and which has started to be recognized as a sub-discipline within Arabic linguistics.

\section{Method}

\subsection{Data}

6 The overall data consists of 24000 words produced in panel discussions broadcast on one of the two main national television channels in Morocco: 2M. The program that was targeted discusses current political, economic and social issues in Moroccan society. The program is hosted by an interviewer who would initiate a specific topic and then direct the talk. The data consists of two episodes, one about sexual harassment and one about excommunication and extremism. This type of programs was chosen because it constitutes a semi-formal or 'hybrid context' (Eid, 2007) where one may expect speakers to mix different forms of Arabic and to move along the diglossic continuum. Speakers of Arabic would choose "from a range of forms according to parameters set by [...] degree of formality." (Mitchell 1980, 1986, as reported in Owens, 2001: 427). 


\subsection{Data analysis}

\subsubsection{Categorization of words in the data}

7 The first step in the analysis consisted of categorizing words in the examined data. Words were classified into four categories:

-Standard Arabic (SA) words: Words in this category belong to SA as it is used in contemporary Morocco. They generally contain ' $t$ ' and ' $d$ ' instead of ' $\underline{t}$ ' and ' $\underline{d}$ '. Case endings are also in the majority of cases absent.

-Moroccan Arabic (MA) words: Words in this category are words that belong to plain colloquial Arabic.

-Shared words: Shared words have a neutral character in that they are common to both SA and MA. Bassiouney (2006) refers to them as neutral. Eid (2007) refers to them as 'ambiguous' or 'unspecified' because they are non-distinct, or not specified as to language variety. The following shared words, for example, were produced in the data.

\begin{tabular}{|l|l|}
\hline Neutral words & Gloss \\
\hline d-din & 'religion' \\
\hline l-muškil & 'the problem' \\
\hline l-ḥužža & 'the proof' \\
\hline s-sunna & Sunna \\
\hline mumkin & 'It is possible' \\
\hline
\end{tabular}

9 -Hybrid words: Hybrid words, also referred to as 'mixed', are described as intermediate forms because they mix features from both SA and MA.

\subsubsection{The notion of topic}

Discourse analysts tried to construct a theoretical notion of topic based on both formal and functional features. In this study, topic is defined from the viewpoint of content; the definition drawn on is a content-based definition. As Brown and Yule (1983: 70) stated, the notion of topic is "an intuitively satisfactory way of describing the unifying principle which makes one stretch of discourse 'about something and the next stretch 'about' something else." In the examined television panel discussions, the topic is suggested by the program interviewer/commentator, and the participants are expected to be 'speaking topically' by making their contribution relevant in terms of the topic framework. There are, however, instances in the data where the participants are simply speaking on the topic and not topically. 


\section{Results and discussion}

\subsection{Overall use of Arabic forms}

11 The quantitative analysis, which is based on 9862 words, has revealed, as Table 1 shows, that the linguistic practice observed in speakers is characterized by the presence of different forms of Arabic, including SA, MA, hybrid, and shared forms. The Speakers switch from one form to another within the same utterance. These findings corroborate the notion of continuum, which is one of the basic developments of Arabic diglossia, and provide additional evidence to what other researchers have found about mixed Arabic in other contexts (Holes 1993, Mejdell 2006, Bassiouney 2006, Eid 2007).

Table 1. The overall use of Arabic forms

\begin{tabular}{|c|c|c|c|c|c|}
\hline \begin{tabular}{|l|} 
Arabic \\
forms
\end{tabular} & SA & MA & Hybrid & Shared & Other $^{*}$ \\
\hline Topic ${ }^{* *}$ & $\mathbf{3 4 . 8 7 \%}$ & $43.05 \%$ & $16.07 \%$ & $5.23 \%$ & $0.78 \%$ \\
\hline Topic 2*** & $61.30 \%$ & $18.61 \%$ & $12.84 \%$ & $6.91 \%$ & $0.31 \%$ \\
\hline Topic 1\&2 & $48.08 \%$ & $30.83 \%$ & $14.45 \%$ & $6.07 \%$ & $0.54 \%$ \\
\hline \multicolumn{6}{|c|}{${ }^{*}$ words in French } \\
\hline
\end{tabular}

However, it is noteworthy that the pattern of distribution of these forms is affected by the structure of the discourse. SA forms, for instance, are clustered at the opening of the panel where the choice of codes is neutralized. The opening of the panel is not, in fact, what triggers the use of SA; it is rather the reading style, which still resists mixing (Afkir 2015). Classificatory problems also emerged when assigning some words to the hybrid category. A pertinent question is: at what point, can we consider a hybrid form as becoming integrated in MA and becoming part of it?

\subsection{Hybrid forms}

13 Hybrid forms in the analyzed media data include different subcategories. Very frequent hybrid forms are those in which SA words are different from their hybrid counterparts by the different realization of one speech sound as in the following example, where the vowel 'a' has been replaced by the central vowel ' $\theta$ ', which is very typical of the colloquial Arabic spoken in Morocco.

(2)

\begin{tabular}{|l|l|l|}
\hline SA & Hybrid forms & Gloss \\
\hline
\end{tabular}




\begin{tabular}{|c|c|c|}
\hline tahlìd & tọhlid & 'limitation' \\
\hline tạhditt/t & tọhdìt & 'modernization' \\
\hline$t \underline{a} \underline{t} b \hat{l}^{-1}$ & $t \underline{\partial} \underline{t} b \vec{l}^{i}$ & 'normalization' \\
\hline$n \underline{a} z w a$ & nazzwa & 'sexual whim' \\
\hline takfir & tökfir & 'excommunication' \\
\hline tațarruf & tațarrruf & 'extremism' \\
\hline taharrruš & tahạrruš & 'harassment' \\
\hline ramzī & $r \underline{\partial} m z \bar{\imath}$ & 'symbolic' \\
\hline
\end{tabular}

15 Other hybrid forms include vowel shortening as illustrated in example (3), where one or two vowels have been shortened in the mixed form.

$16 \quad$ (3)

\begin{tabular}{|c|c|c|}
\hline SA & Hybrid forms & Gloss \\
\hline l-muwāțana & l-muwațana & 'citizenship' \\
\hline l-mafātin & l-mafatin & 'erotic parts of the body' \\
\hline ș-ṣaḷāhhiyyyāt & ș-șaḷahiyyat & 'prerogatives' \\
\hline
\end{tabular}

17 Another subcategory of hybrid words is that in which words that have lexico-semantic features of SA are completely dialectalized by integrating within them, to a greater extent, phonological and morphological features from the low variety. Example (4) is an illustration of this type of mixing.

$18 \quad(4)$

\begin{tabular}{|l|l|l|}
\hline SA & Hybrid forms & Gloss \\
\hline ta-tažaḍdar & ta-ttžəḍḍr & 'It gets rooted' \\
\hline u-marrrị & $t a-n$-mərrrər & 'I transmit' \\
\hline
\end{tabular}

19 There are also instances of hybrid words in which the bound morpheme is in SA and the free morpheme is in MA. In (5), $f a$ 'so', the bound morpheme, is in SA, and kifaš, 'how', the free morpheme, is in MA. In this type of hybridization, each form retains its identity.

20 (5) - aṣbah-a yåni waḩad t-toțbî fa+kifašy yo-mkan n-fassr-u had lo-zdiwāžiyya.

- The phenomenon has become I mean normalized. So, how can we explain this double standard? 


\subsection{Topic and hybrid forms of Arabic}

21

$$
\begin{aligned}
& \text { amounts of hybrid forms, } 16.07 \% \text { for the topic about sexual harassment and } 12.84 \% \text { for } \\
& \text { the topic about excommunication and extremism. Predictability has always been invoked } \\
& \text { as an important aspect when describing speakers' shift from one variety to another along } \\
& \text { the diglossic continuum. Despite apparent chaos due to the immediate choices speakers } \\
& \text { make as the talk unfolds, there are, in fact, certain factors that affect their shift toward } \\
& \text { the standard or the colloquial end of the continuum. First, since hybrid forms can be } \\
& \text { interpreted as close to both the High variety and the low variety, their occurrence is, } \\
& \text { therefore, expected in media programs that are more informative than entertaining and } \\
& \text { that deal with current and serious debatable issues. Holes (2004: } 344) \text { stated that: } \\
& \text { in any passage of Arabic speech, whether monologue or conversation, one cannot } \\
& \text { track, still less make sense of, the moment-by-moment, unpredictable changes in } \\
& \text { language form unless one is also aware of co-occurrent changes in the ideational } \\
& \text { content of the discourse [...]. }
\end{aligned}
$$

two topics triggered different amounts of SA and MA forms, but they triggered close

In addition to the ideational content of the analyzed media talk, the semi-formality of the setting and the speakers' skills in SA can also be invoked as leading to the occurrence of intermediate Arabic forms.

A finding, however, that stands out as interesting is that the switching to hybrid forms is undoubtedly motivated by the seriousness of the topic, but the way a given topic fits in the communicative habits of a speech community may increase the predictability of such forms. For Holes (1995: 280), "there are few variables where one of the variants which constitute it always occurs in one level and never in the adjacent one." In the sexual harassment topic, words that express ideational content related to verbal or physical conduct of a sexual nature do, in the overwhelming majority of cases, occur as hybrid forms. For instance, the verb taharraš 'to harass sexually', as Table 2 shows, was used by speakers 24 times and in $79.16 \%$ of them, there was a shift to the hybrid form. No one of the participants expressed this word by its variant in colloquial Arabic.

Table 2. The variants of the verb taharraš 'to harass sexually' in the data

\begin{tabular}{|l|l|l|l|l|}
\hline Verb & Total number & SA & MA & Hybrid forms \\
\hline To harass & 24 & $5(20.83 \%)$ & o (o\%) & $19(79.16 \%)$ \\
\hline
\end{tabular}

To talk about sexuality in MA is perceived by Moroccans as vulgar and taboo (Bourquia 1996, Miller and Cheikh 2012) and hence a shift to another language is very likely. This is why when it is not French or SA, it is the intermediate forms where the SA lexical content is blended with the phonological and morphological structure of colloquial Arabic and hence colloquialness is avoided. What one of the female participants said when she took the floor reflects to what the extent it is taboo to deal with this topic in public discourse.

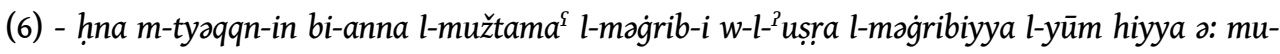

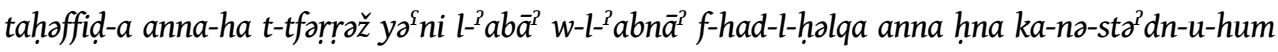
u-b-kull htirāam anna-hum i-sam ${ }^{\mathrm{S}}$-u l-ha.

- We are sure that Moroccan society and the Moroccan family today are uh reserved to 
watch, I mean parents and children, this episode. We request their permission, and with all respect, to listen to it.

In the data, MA is never employed to talk about sexual desire or erotic parts of the body. When the speakers do not use SA, they resort to hybrid forms. nəzwa 'sexual whim', rəg் $b a$ 'desire', mafatin 'erotic parts of the body' are all encoded mixing the lexical content of SA with features from MA.

With respect to the second topic, which is about excommunication and extremism, the participants resorted to hybrid forms because many of the terms triggered by this topic do not have equivalents in MA. Words like takfir 'excommunication', tažrim 'criminalization', zandaqa 'infidelity', kufr 'disbelief' are either in SA or in mixed Arabic. Moreover, while hybrid words constitute $12.84 \%$ of the overall amount of words, the percentage of SA is very high; it is $61.30 \%$ compared to only $18.61 \%$ for colloquial Arabic. The following extract illustrates the dominance of Standard Arabic.

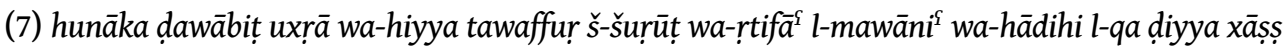

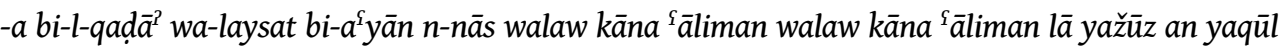
fulān hāda l-fulān kāfir

There are other controls which are the provision of conditions and the absence of prohibitions and this matter is the duty of judicial authorities and not people. And even if the person is a scholar and even if the person is a scholar, he does not have permission to say that so and so is a disbeliever.

\section{Conclusion}

The goal of this study has been to investigate the impact of topic on Moroccan speakers' use of hybrid forms. The findings have shown that the examined media talk covers a linguistic space where different forms of Arabic occur, including SA, MA, shared and hybrid forms; that is, the participants constantly shift between the idealized poles of the diglossic continuum. The two topics triggered close amounts of mixed forms, but the motivation behind mixing features from the high and low varieties differs from one topic to another. In the topic about sexual harassment, the degree of colloquialness decreases and that of hybridity and standardness increases because this is how language is used in public discourse to talk about sexuality, which is still taboo in Moroccan society. Content related to verbal or physical conduct of a sexual nature is never expressed in colloquial Arabic. In the topic about excommunication and extremism, hybrid forms are needed because many terms in religious discourse do not have their equivalents in MA. Moreover, SA forms are very dominant; $61.30 \%$ of the analyzed talk was produced in the high variety, shifting the discourse more towards the standardness pole of the continuum.

One implication of these findings is that the notion of use is as important as grammatical constraints in any study of mixed Arabic. In addition to structural rules that govern the process of hybridization, there are also pragmatic rules at play. In fact, despite apparent chaos, there are certain variables such as topic that predict the use of mixed forms in a specific context, making hybridity to a great extent predictable rather than random. More importantly, hybridity was found to be constrained by the way a given topic fits in the communicative habits of a speech community and should hence be approached within the framework of the socio-cultural context of the latter. 


\section{BIBLIOGRAPHY}

Afkir, Mina. 2015. “Arabic in the Moroccan Media Space: What Implications for Diglossia?”, Paper presented at the Forum for Arabic Linguistics, Essex University, Colchester, United Kingdom.

Albirini, Abdulkafi. 2016. Modern Arabic sociolinguistics: Diglossia, variation, codeswitching, attitudes and identity. New York: Routledge.

Badawi, Elsaid M. 1973. Mustawayaat al- ${ }^{\mathrm{f}}$ arabiyya al-mu $u^{\mathrm{f}}$ aașị̦a fi mișr. Cairo: Dar al-Ma ${ }^{\mathrm{f}}$ aarif.

Bassiouney, Reem. 2006. Functions of code-switching in Egypt: Evidence from monologues. Leiden, Boston: Brill.

Bassiouney, Reem. 2009. "The variety of housewives and cockroaches: Examining code-choice in advertisements”, Al-Wer, Enam, \& de Jong, Rudolf (eds.), Arabic dialectology. Leiden, Boston: Brill. 273-284.

Blanc, Haim. 1960. "Stylistic variations in spoken Arabic: A sample of interdialectal educated conversation", Ferguson, Charles (ed.), Contributions to Arabic linguistics. Cambridge: Center for Middle Eastern Studies. 81-156.

Bourquia, Rahma. 1996. Femmes et fécondité. Casablanca : Afrique-Orient.

Brown, Gillian \& Yule, George. 1983. Discourse analysis. Cambridge: Cambridge University Press.

Den Heijer, Johannes. 2012. "Introduction: Middle and Mixed Arabic, a new trend in Arabic studies", Zack, Liesbeth \& Schippers, Arie (eds.), Middle Arabic and Mixed Arabic: Diachrony and synchrony. Leiden: Brill. 1-25.

Eid, Mushira. 2007. "Arabic on the media: Hybridity and styles”, Ditters, Everhard, \& Motzki, Harald (eds.), Approaches to Arabic linguistics presented to Kees Versteegh on the occasion of his sixtieth birthday. Leiden, Boston: Brill. 403-434.

Ferguson, Charles. 1972 [1959]. "Diglossia”, Giglioli, Pier Paolo (ed.), Language and social context. Harmondsworth, Middlesex: Penguin Books.

Hary, Benjamin H. 1992. Multiglossia in Judeo-Arabic. Leiden, Boston: Brill.

Holes, Clives. 1995. "The Uses of Variation: A Study of the Political Speeches of Gamal Abd alNasir", Perspectives on Arabic Linguistics V.13-45.

Holes, Clives. 2004. Modern Standard Arabic: Structure, functions and varieties. London: Longman.

Mejdell, Gunvor. 2006. Mixed styles in spoken Arabic in Egypt: Somewhere between order and chaos. Leiden, Boston: Brill.

Miller, Catherine, \& Cheikh, Myriam 2010. «Les mots d'amour : dire le sentiment et la sexualité au Maroc. De quelques matériaux », Estudios de Dialectología Norteafricana y Andalusí(EDNA)13. 173-199.

Mitchell, T. F. 1980. "Dimensions of Style in a Grammar of Educated Spoken Arabic", Archivum Linguisticum 11. 89-106.

Mitchell, T. F. 1986. “What is Educated Spoken Arabic?", International Journal of the Sociology of Language 61. 7-32. 
Owens, Jonathan. 2001. “Arabic Sociolinguistics”, Arabica XLVIII. 419-469.

Van Mol, Marc. 2003. Variation in Modern Standard Arabic in Radio News Broadcasts: A Synchronic Descriptive Investigation into the Use of Complementary Particles. Leuven, Paris: Peeters.

Youssi, Abderrahim. 1983. « La Triglossie dans la Typologie Linguistique », La Linguistique 19 (2). 71-83.

Youssi, Abderrahim. 1995. "The Moroccan Triglossia: Facts and Implications”, International Journal of the Sociology of Language 11. 29-43.

\section{ABSTRACTS}

One of the basic and well-established developments of Arabic diglossia is the notion of continuum, which was proposed by linguists who were critical of Ferguson's classic model to reflect the existence of more than two varieties between the poles of pure $\mathrm{H}$ and pure L. Studies done on spoken Arabic in Morocco (Youssi 1983, 1995, Afkir 2015) or in other Arabic speech communities (Blanc 1960, Badawi 1973, Bassiouney 2006, Mejdell 2006) have all shown that Arabic language variation is to be viewed as a hierarchy of 'levels' or 'varieties' between the poles of pure $\mathrm{H}$ and pure L. The Arabic forms which mix features from both Standard Arabic (SA) and Moroccan Arabic (MA) are referred to as 'hybrid', 'mixed', and 'intermediate' forms. The present study seeks to explore to what extent the variable of topic has an impact on Moroccan speakers' shifts to these hybrid forms. The data consists of 24000 words produced in television panel discussions. This type of programs was chosen because it constitutes a semi-formal or 'hybrid context' (Eid 2007) where one may expect speakers to move along the diglossic continuum and produce mixed Arabic. The choice of one of the different varieties of Arabic is certainly motivated by shifting value systems attached to them and by their social meaning to the Moroccan speech community. The frequency-based quantitative analysis in this study has revealed that in addition to all these variables that are at play when codes interact, topic stands out as a variable that also predicts a specific form of Arabic. More importantly, hybridity is constrained by the way a given topic fits in the communicative habits of a speech community and should hence be approached within the framework of the socio-cultural context of the latter.

\section{INDEX}

Keywords: mixed Arabic, hybrid Arabic forms, multiglossia in Morocco

\section{AUTHOR}

MINA AFKIR

Hassan II University, Casablanca

mina_afkir@yahoo.com

Post address:

Rue Cadi Ayad, Imm 42, Appt 9

Diour Jamaa, Rabat, Maroc 


\title{
A Lexicological Study of Arabic and Judaeo-Arabic in Iraqi Hebrew Novels
}

\author{
Mohamed A. H. Ahmed
}

\section{Introduction}

\subsection{Iraqi Judaeo-Arabic Literature}

1 As a result of contact between Hebrew and other languages since the dispersion of the Jews, many linguistic varieties were being developed and used by Jews according to the linguistic and geographical locations in which communities resided. These different languages share the use of Hebrew script as well as the use of loan words from biblical Hebrew and Aramaic on the one hand and adopt the lexical, syntactical and grammatical rules of the adopted languages (i.e. non Hebrew) on the other. By mentioning JudaeoArabic, I refer to Arabic texts which were written in Hebrew script. ${ }^{1}$ Judaeo-Arabic can be defined as a linguistic variety that has been used by Jews in the Middle East and North African countries from the $9^{\text {th }}$ century up to the modern times. The most obvious feature in Judaeo-Arabic texts is orthographical: the use of Hebrew script. ${ }^{2}$ Another important and common feature of such texts is the employment of Aramaic and Hebrew lexical elements. Although Arabic is the dominant language in Judaeo-Arabic texts, Hebrew is used in two main forms; the first form is that the texts are written mainly in Hebrew typescripts, and second with the use of Hebrew lexicon in terms of implementing single lexical items or phrases in Judaeo-Arabic texts.

2 In almost all Judaeo-Arabic texts the dominant language is Arabic, although the Hebrew script was mainly and widely used to write these texts. The linguistic features and the style of Arabic used in these texts were derived primarily from classical or middle Arabic. The significance in Judaeo-Arabic texts also stems from the diversity and the varieties of themes, style, registers, the portion of languages involved and the different genres 
employed in these texts. This includes fiction, poetry, philosophy, science and religious texts.

3 Iraq was one of the famous rabbinic learning centres in the Middle Ages; the assertion that the Jewish people adopted Arabic during this period is demonstrated by the fact that Jews were sharing Arabic with other communities in Babylon (Ben-Shammai: 16). The themes used in Iraqi Judaeo-Arabic texts at the time were mainly associated with religious, e.g. the translation and the interpreting of Bible and other sacred Judaic texts into Judaeo-Arabic, as well as liturgical texts concerning Judaic ceremonies, like the Passover Haggada (Avishur 1979: 84). Indeed, this remains close to the macro level of Judaeo-Arabic.

4 One of the most significant contributions in the history of Iraqi Judaeo-Arabic are the works of Saadia Gaon ${ }^{3}$ (882-942 C.E) who is famous for the translation of the Pentateuch into Judaeo-Arabic. His writing style, probably based on earlier Bible translations, became highly influential for the development of a literary standard Judaeo-Arabic throughout the Middle East and North Africa due to the popularity of his work. The works of Saadia Gaon were diverse, although lots of them were discovered incomplete, in fragments or have been mentioned in quotations in other works by later writers (Malter 1921: 137). His works also cover many fields of knowledge including, as Malter (1921: 137) counts: "Hebrew philology, Liturgy, Halacha, Calendar and Chronology, Philosophy, and Polemics".

5 As for the literary contributions of Iraqi Jews in modern times, the majority of Jewish writers, for instance, preferred to compose poetry and fiction in Modern standard Arabic (Snir 2005: 79-134). However, Jewish folklore writings flourished and were written in Iraqi Judaeo-Arabic from the mid-nineteenth century. The folklore literature of JudaeoArabic written by Iraqi Jews can be divided into three categories: 1) Translations and copies from Jewish sources, 2) Translations and copies from foreign sources, and 3) Local folklores written by Iraqi Jews themselves (Avishur 1979: 84-86).

6 Iraqi Judaeo-Arabic has also been employed in the literary works written in Arabic script by Iraqi Jews; the Arabic novels and short stories written in Israel by Samir Naqqāsh (b. Baghdad, 1938-2004), for instance, are full of entire paragraphs written in JudaeoArabic. Hebrew words are inserted here and there in the novels in Arabic script, Naqqāsh provides a glossing in the footnotes for such words or/ and sentences. ${ }^{4}$

7 Judaeo-Arabic periodicals that appeared in the nineteenth century in Iraq can be considered among the late literary contributions of Iraqi Jews in Judaeo-Arabic before their mass immigration to Israel during the 1950s. With the emergence of the industry of printing in the nineteenth century, there were more than fifteen printing presses in Iraq between 1850 and 1950 that offered publications on a range of various topics related to Jewish life in Iraq (Al-Ma'adīdi 2001: 31-37).

\subsection{Some Linguistic Features of Iraqi Judaeo-Arabic}

8 In general, Iraqi Judaeo-Arabic was spoken mainly by Jews at home in Iraq, this vernacular was different, regarding some phonological and lexical aspects, from other Arabic dialects spoken by both Muslims and Christians in Iraq (Blanc 1964). The distinctions between Arabic dialect spoken by Jews and other dialects in Iraq at the time was due to the influence of Classical Arabic on the vernacular spoken by Jews, as well as the use of Hebrew and Aramaic lexical items. It has been noticed that the Iraqi Judaeo- 
Arabic was spoken only by Jews in Iraq, neither Muslims nor Christians spoke this indigenous vernacular, and because Judaeo-Arabic was a minority vernacular in Iraq, most communication between Muslims and Jews was mainly by means of the MuslimArabic vernacular (Moreh and Bramson 1997: 215). Blanc (1964) concluded with an important historical aspect of the three main dialects spoken in Iraq by Jews, Muslims and Christians. Comparing the two main dialects spoken at the Mesopotamian area; qeltudialects and gelet dialects, ${ }^{5}$ he pointed out that Muslims communicated in the newer, more rural variety gelet-dialects, while Jewish-Christian spoke in the older, Metropolitan qeltu-dialects.

With reference to consonants, the Judaeo-Arabic spoken in Iraq shared almost the same consonants of both Arabic dialects spoken by Muslims and Christian (Blanc 1964: 17). Yet the way in which such consonants are connected to short vowels was not the same in the three main dialects spoken in Iraq by Muslims, Jews and Christians (Blanc 1964: 31). Blanc claimed that: "In M (Muslim dialect) [...] the /e/ has allophones clustering about a higher, more forward position than the /e/ of JC (Jewish and Christian Arabic dialects, M.A) (1964: 31). ${ }^{6}$ One should add here the different accent and pronunciation of Iraqi JudaeoArabic according to the geographical locations, e.g. Baghdadi Jews, Mosul, Aqrah and Erbil. $^{7}$

10 From a phonological comparison between Classical Arabic, the Arabic dialect of Iraqi Jews and the Arabic dialect of both Muslims and Christians, one can sum up with a result that the Arabic dialect spoken by Jews in Iraq was much closer to Classical Arabic than the other two dialects spoken by Muslims and Christians (Mansour 1991: 26-32; Blanc 1964: 20).

Iraqi Judaeo-Arabic is famous for the pronunciation of the Arabic consonant $/ \mathrm{r} /$, which is pronounced as $/ \dot{\mathrm{g}} /$, different from any other Arabic dialect spoken in Iraq. ${ }^{8}$ Blanc (1964: 23-25) asserts that the use of $/ \mathrm{r} /$ and $/ \dot{\mathrm{g}} / \mathrm{had}$ a long history in the Iraqi Judaeo-Arabic paradigm and was associated with the way Iraqi Jews read the Tanakh (Hebrew Bible). He noted that the $/ \mathrm{r} /$ sound, according to Saadia Gaon, had two ways of pronunciation (together with the b, g, d, k, p, and t), one is soft, and the other is hard.

12 Another comparison between some Arabic consonants that were spoken by Jews in Baghdad is the pronunciation of $/ \mathrm{q} /$ and $/ \mathrm{k} /$. The pronunciation of the Jews regarding these consonants is quite close to Classical Arabic. On the other hand, they are not pronounced in the same way among Muslims and Christians (Blanc 1964: 26).

In the realm of syntax, the Iraqi Judaeo-Arabic shares linguistic elements concerning syntactic structure from Mishnaic Hebrew. The linguistic elements which are incorporated in Iraqi Judaeo-Arabic not only derived from Aramaic and Hebrew languages, but also from Persian and Turkish. It has been thought that this linguistic influence may have contributed to the lexical and syntactic constructions of Iraqi JudaeoArabic (Mansour 1991: 25-50).

In respect to lexicography, the use of some Hebrew lexical items in the Iraqi JudaeoArabic is not determined exclusively by religious discourse; rather there are also secular uses of Hebrew elements. ${ }^{9}$ 


\subsection{Semantic Field Analysis}

15 According to the semantic field theory, the lexical sets can be arranged in groups of words of which their meanings are closely interconnected. Semantic field theory can be defined as "an approach which developed in the 1930s: it took the view that the vocabulary of a language is not simply a listing of independent items (as the headwords in a dictionary would suggest), but is organized into areas, or fields, within which words interrelate and define each other in various ways" (Crystal 2008: 429).

German and European linguists have mainly developed the semantic field theory from the 1930s onwards. Preliminary work on semantic field theory was undertaken by Porzig, Ipsen and Trier. Trier's ideas are the most important concept in the semantic field theory (Nerlich 1992). He introduced the notion of semantic filed in the 1930s, in which "meaning was defined by the relations between words, not by reference to things, representations or any other external yardstick" (Nerlich 1992: 117-118). ${ }^{10}$

Semantic field theory is based on three main perspectives: the diachronic, the synchronic and the lexicography. In addition, "other areas of semantics include the diachronic study of word meanings (etymology), the synchronic analysis of word usage (lexicology), and the compilation of the dictionaries (lexicography)" (Crystal 2008: 429). The study at hand is concerned with the synchronic analysis of the Iraqi Judaeo-Arabic lexical items used in the corpus. Although a sociolinguistic study of the Arabic use in the Iraqi Jewish fiction is opportune, this study tends to introduce a lexicological investigation of the use of Arabic in modern Hebrew texts.

\section{The Data}

The data is derived from six Hebrew novels written by three Iraqi Jewish authors: Ballas (1964; 1991), Michael $(1974 ; 1993)$ and Amir (1983; 1992). Every instance of Arabic is counted in the analysis. Proper names are excluded from the linguistic analysis of the study, although they have a great deal in the novels. However, they are discussed with examples in the paper due to their importance. For the precise purpose, the data is gathered from the first 100 pages of the six novels, 600 pages are the total page numbers in the analysis.

Arabic instances are written in Hebrew script in all novels by Iraqi Jewish authors. The paper at hand inspects all Arabic terms in the texts, including both standard Arabic and Iraqi Judaeo-Arabic. The study at hand also consulted some Iraqi Judaeo-Arabic dictionaries concerning the analysis of the extracted Arabic examples from the novels, such as Yona-Swery 1995, Yosef 2005 and Ben-Jacob 1998.

The Judaeo-Arabic instances are categorised into lexical sets according to the semantic field analysis of the data. All Arabic extracts found in the corpus were linguistically investigated by the contextual settings in which the embedded Arabic terms occur. In addition, the study indicates whether the Arabic uses in the corpus occurs in the narrative or the dialogue mode. ${ }^{11}$ Table 1 demonstrates the Arabic and Iraqi JudaeoArabic instances found in the Hebrew novels according to the semantic fields and other lexical categories. 
Table 1. Arabic and Judaeo-Arabic according to semantic fields and other lexical categories

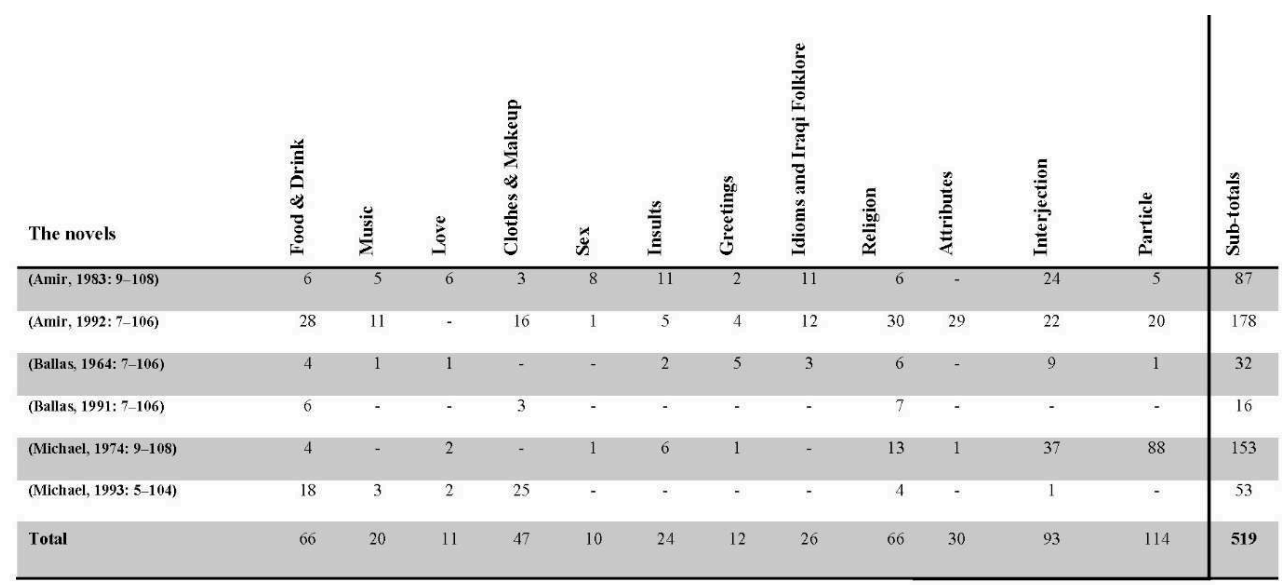

\section{Arabic use in the corpus}

\subsection{Lexical sets}

21 According to the table, particles are the dominant lexical set in the corpus with about $22 \%$ followed by interjections of approximately $18 \%$, and religion with $12,7 \%$. The food \& drink in the corpus has the same portion of religion with $12,7 \%$ of the total lexical sets extracted from the Hebrew novels.

The use of Arabic particle, as pointed out above in the table, is the dominant lexical set used. The main particle used is /yâ/. Interesting is that this particle the particle, mainly the use of /yā/, is the most used item in Michael's novels (1974; 1993). Indeed, /yā/ particle is employed in various ways in the corpus. The main purpose of inserting such

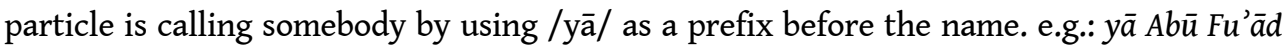
"hey Abū- Fu'ād" (Ballas 1964: 8). Besides, /yā/ has other uses that call attention to the Arabic Iraqi vernacular. For instance, the use of /yā/ in combination with Alla is associated with expressing the feelings of anger and sorrow; Abū-Shaul, the father of David, the protagonist in the novel Shavim ye-shavim yuter ("More and More Equal"), expresses his annoyance and anger with the bitter life in the $M a^{\prime}$ 'abara, he says:

(1)

יא-אללה, אשה - - לכל הפחות לטבול לחם במשהו

yā-Alla iša - likol ha-pahot litvol lehem bi-miših $\bar{u}$

"Oh God, woman - at least to dip some bread in anything"

(Michael 1974: 13)

Another use of /yā/ is to be added to Hebrew lexical items/adjectives giving different denotations, e.g. to express humour, like in the dialogue between David and his colleague from Yemen during their military service in the 1967 war. The 'Yemenite' offers David a cigarette:

(2)

קח יא ממזר

qaḥ yā-memazer

"take it bastard"

(Michael 1974: 14)

The particle /yā/ is also used in referring to non-human objects: 
(3)

לא כל כך מהר, יא-רכבת

lo kol kaHु mahēr yā-rakkevet

"hey train, do not go so speedy"

(Michael 1974: 23)

Shaul, one of the main protagonists in Michael novel, said the above sentence while he was trying to catch and spring outside the moving train in which all his family was riding. The use of Arabic particle, mainly /yā/, which is associated with the act of calling someone, is a unique feature in the Hebrew texts. Indeed, the use of this particle reflects the Iraqi vernacular used by some characters in the novels. Some novels used Arabic particle extensively in almost every dialogue between the characters when it involves calling someone by his name.

Interjections come in the second place after particles. They are used mainly in the

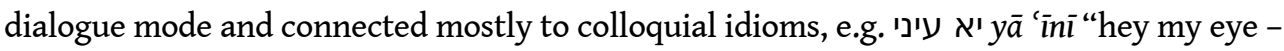
cool" (Amir 1983: 174); wללה wallah "I swear to God" (Michael 1974: 14); יאבוי yābüy "hey my father - Oh God" (Ballas 1964: 29); mäšallah "God bless" (1992: 23); יאללה tabärak Allah "God bless" (1992: 52, 53) "Lets go" (1983: 18);

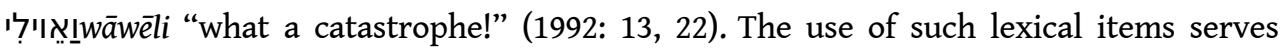
likewise as a stylistic device reflecting the use of many Iraqi characters employed in the novels of the corpus. Also, such uses of vernacular items, interjection and particle, imbue the conversations in the three early Hebrew novels with the local colour of Iraq/Baghdad. According to semantic analysis in the data collected from the six Hebrew novels, the use of Arabic lexical sets varied. This includes, for instance, foods: ה'פאצ pazžeh ${ }^{12}$ (Ballas 1964: 28, 77), קבַמִbamyeh (Michael, 1993: 14) קובה 72) and also in (Michael 1993: 48); music: חפלה hafla "party" (Amir 1983: 106), תקסים

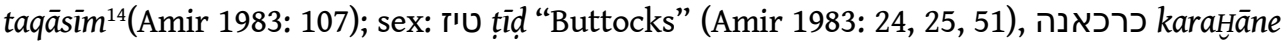
15(Amir 1983: 58), שארמוטה šarmūṭa "bitch" (Michael 1974: 24); and clothes: תרבוש tarbūš

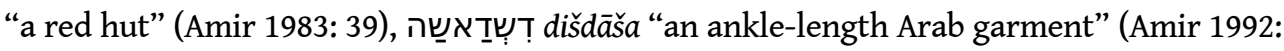
94; Ballas 1991: 103); and Arabic games, like טאולה (Ballas 1964: 11).

The table shows that the differences between the total portions of lexical sets of the corpus are to some extent narrow. Keeping this fact in mind, the use of Arabic andIraqi Judaeo-Arabic can be arguably seen as variable and not limited to certain lexical sets.

\subsection{Orthographic Observations}

Spoken Judaeo-Arabic by Iraqi Jews is well represented in the corpus; this is shown in the ethnographic style of writing some Judaeo-Arabic lexical items using Hebrew graphemes, such as this example:

(4)

עמעכל טיז יסוה אל

kol țị̣̂ yeswa al-'umeg

"Each Buttock is worth a life - what a beautiful ass"

(Amir 1983: 19)

This example shows a significant feature in the Iraqi Judaeo-Arabic consonants. which is the use of Arabic constant $/ \dot{\mathrm{g}} /$ instead of $/ \mathrm{r} /$, a feature that distinguishes the JudaeoArabic variety and gives distinction to it. Only Jews in Iraq adopted this feature as it is 
discussed by Blanc (1964: 20). Here Eli Amir writes the word 'umeg with $(\nu ') / \dot{\mathrm{g}} /$ to highlight this orthographic feature.

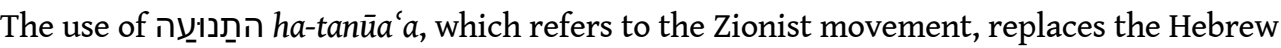
equal idiom התְנוּעָה הציונית ha-tenu'a ha-tsyonit. The comparison below between the origin and the hybrid phonological structure is to illustrate phonological Arabic/Hebrew interference:

(5)

a - התחנכוּעָה הציונית ha-tenu'a ha-tsyonit

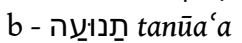

The comparison between (a) and (b) shows that the way the Hebrew lexical item ha-tenu' $a$ differs from the spoken term by the Jews at the time; in (b) the short vowel /a/ comes instead of /e/ in (a). The Hebrew definite article /ha/ is not used in (b) either.

The use of Arabic language here shows that the existence of Arabic is not only assembled in adding Arabic codes to the Hebrew texts; rather it proves that the Arabic influence affects both the phonological and semantic levels. The term tanūa $a$ is not just an alternation of the Hebrew phonological structure of the origin lexical ten $\bar{u} a^{\prime} a$; rather it was used in Iraq shortly before 1948 to refer semantically to ha-tenu'a ha-tsyonit "the Zionist movement".

Another observation from the data collected from the Hebrew novels is associated with the method of writing the Arabic letters in Hebrew script. The examples below show the way in which each author has a different style concerning the orthography of some Hebrew graphemes:

(6)

a -

b - ד' daHïlak "please, I beg you" (Ballas 1964: 63)

The consonant $/ \mathrm{k} /$ is written in two forms, the first in (6-a) is written in the regular form of Hebrew $/ \mathrm{k} /$, whereas in (6-b) the author uses the final Hebrew form of $/ \mathrm{k} /$. Besides, in (6-a) the $/ \mathrm{k} /$ comes with a dot (dagěs qal) to be distinguished from the consonant $/ \mathrm{H} /$. On the other hand, in (6-b) the $/ \mathrm{k} /$ comes without the dot. This observation reflects a long history of such orthographic features in the Judaeo-Arabic paradigm back to the 13th century. ${ }^{17}$ The same holds true for the next two cases of writing the Arabic consonant $/ \mathrm{H} /$ in Hebrew script. In (7-b) it is written with stroke above the Hebrew consonant /h/, while in (7-a) the Hebrew consonant is written without stroke:

(7)

a -קאזHinazū "impalement" (Michael 1974: 78)

b- - -

\subsection{Morphological and syntactic observations}

The corpus shows an interesting phenomenon regarding some syntactic and morphological aspects. This is obvious, for instance, in the use of Hebrew inseparable prepositions (ל, ב, ב' כ) as wa-Jarre "the water jug" (Amir 1992: 7) with Arabic lexical items instead of using Arabic definite article /ال/ אל-מוח'אבראת al-muHābarāt "the Intelligence" (Ballas 1991: 37);

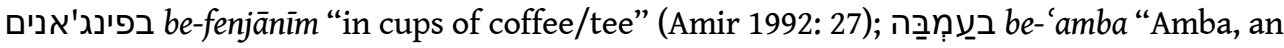
Iraqi traditional dish" (Amir 1992: 35); לחַפְלות הליליות la-haflot ha-lelyilyot "to the night parties" (Amir 1992: 36). The repeated use of 'abāye in Michael's sample shows an 
interesting aspect which is associated with Arabic and Hebrew morphological interference and demonstrates how Arabic lexical items are integrated into the Hebrew texts. Besides, Michael incorporated 'abāye into the Hebrew text using the rules of the Hebrew adjunct. For instance, עבית משי 'abayet mēšī "Abaya made of silk” (1993: 30).

Amir has a distinct style of employing some Arabic nouns in the sample. He often uses the Hebrew female plural suffix for Arabic lexical items:

(8)

גברים בעביות כהות ובכפיות מנוקדות

gevārìm be-'abāyot kehot 'u-bekofiyot menuqadot

"Men in dark cloaks and dotted Keffiyehs"

(Amir 1992: 17)

In this example, the two Arabic lexical items 'abaye and kefiyye are loaned into Hebrew using the Hebrew suffix /ot/ associated with Hebrew female plural terms. The other Hebrew form of plural used for the masculine plural, the suffix /im/, is also employed by Amir to make the plural of Arabic lexical item וזיר wazir "minister" and 'שֶš̄êt "sheikh", they appear in Amir's text as: (1992: 36). Arabic, in view of this, is more integrated into Hebrew texts. This was not done only by means of inserting Arabic lexical items, but also in applying Hebrew morphology to them.

Iraqi Judaeo-Arabic is also pointed out in Michael's novel. The next example demonstrates the use of Hebrew lexical items in Arabic spoken by Jews in Iraq. The author here inserts the Judaeo-Arabic paragraph in the Hebrew text followed by his translation into Hebrew:

(9)

The text as appears in the Hebrew novel:

ג'מיע אל עאלם יטלבון רזק מן השם יתברך והוא יעטיהום, ולאכן פקט תלאת'ה צאחבין מצלחה למן יצלון ט'

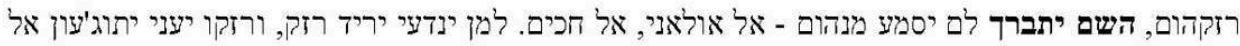
נאס לחתה ירוח ידאויהום. אל ת'אני, אלד'י עמאל יביע צנאדיק אל יחטון פ'יהא אל מיית, ורזקו יכון ימותון אל נאס לחתה יתרזק. ואל ת', מחילה, אל זונה. הד'ול אל ת'לאת'ה מן יצלון ט' רזקהום השם יתברך לם

[...] החכם התחיל מפרש את הכתוב. "הבריות כולם," נאמר בפתק, "מבקשים פרנסה מאת השם יתברך והוא

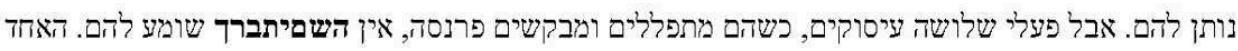
הוא המרַפא המייחל לפרנסה, ופרנסתו משמעה שיפלו הבריות למשכב כדי שיטפל בהם. השני הוא מוכר

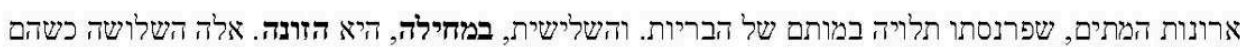
מתפללים ומבקשים פרנסה השם יתברך אינו שומע להם."

(Michael 1993: 67)

The Arabic transcription

$$
\text { 18 }
$$

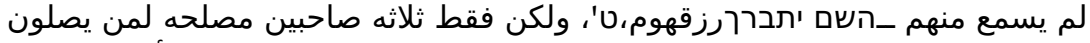

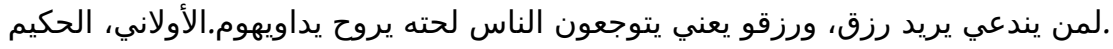

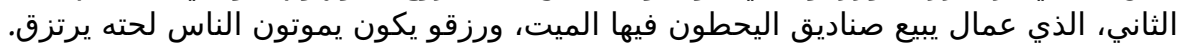

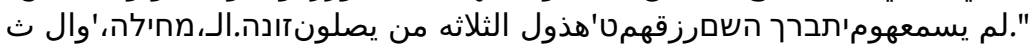

The English translation 
"The HaHām began to explain what is written: "All people", he said in commenting on the text, "ask for livelihood from the Blessed Lord, and he gives them. However, there are three professions when their practitioners worship and ask for livelihood, but the Blessed Lord does not listen to them. The first is the physician who hopes for livelihood, and his livelihood means that people get ill and he treats them. The second is the seller of coffins, whose livelihood is reliant upon the death of people. And the third, forgiveness, is the prostitute. Those three, when they worship and ask for livelihood, the Blessed Lord does not listen to them."

In Michael's novel Viktoryah, three girls found a piece of paper blowing in the air when they were on the roof of the house. Because they were illiterate, they asked for help to know what was written on the paper. They went to HaHam, who examined the paper and read it to them. The paper was written in Iraqi Judaeo-Arabic followed by a translation into Hebrew on the same page. The influence of the biblical Hebrew on the Arabic text is obvious, as Blanc noted in his study about the dialects in Baghdad (1964: 140-141); for instance: השם יתברך hashēm yitbarrēen "The Blessed Lord", מחילה mehilla "forgiveness" and אל זונה al-zona "prostitute". Note here the use of Hebrew word mehila without the Hebrew preposition $/ ב$ /. In addition, note the use of the word zona with the Arabic definite article /al/. The Hebrew/Arabic morphological and syntactic interference are obvious in this example.

\subsection{Contextual settings}

41 Contextual settings analysis, in which the context of the plot associated with uses of Arabic, can also provide a general picture of the contextual moods by means of testing the frequencies of each category. In the sample, as illustrated in Figure 1, the use of Arabic terms in the corpus is associated mainly with the highly charged emotions mode, such as exciting $21 \%$, happy $25 \%$ or angry $18 \%$. On the other hand, the use of Arabic is associated only with normal context by $30 \%$, especially in connection with the narrative or the non-dialogue technique.

Figure 1. Arabic Contextual settings

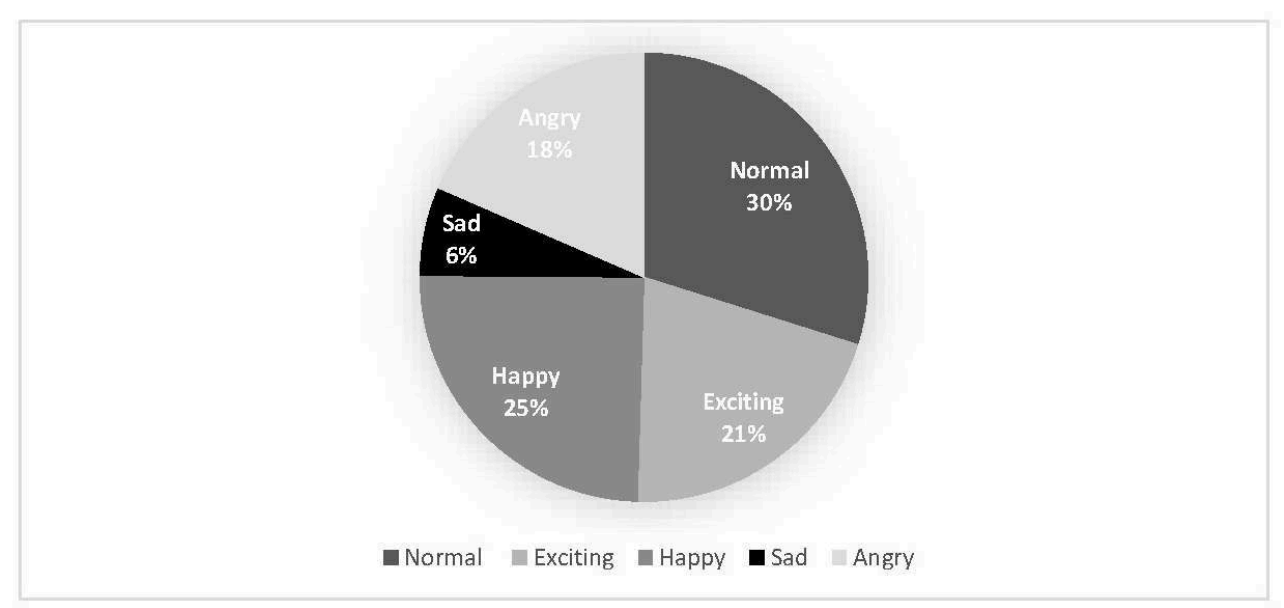

42 According to Figure 2, it is clear that Arabic use is repeatedly related to highly charged emotions, like exciting, sets that include for example fear and surprise. Happy, exciting and anger modes constitute a high rank as a semantic set in the Amir sample in both of his early novels (1983; 1992). The set angry, for instance, is associated principally with the 
use of Iraqi vernacular insults, e.g. כוס אם אל יהוד kos um el-yahūd (1992: 11) "get the hell up!"; אחרא דין בוק ihra din būk "wish your father's religion is to be burnt - fuck you" (1983: 14). This observation points out the mutual relation between the contextual settings and the expected strategy used by the bilingual author. Moreover, the use of Arabic in the angry mode is mainly done by inserting Arabic terms in the Hebrew text without translation or glossing. Sad ranks lowest as a context in which Arabic is used in the sample. The so-called normal set, which is associated mainly with the narrative mode, is used extensively in the sample from Amir's novels.

Figure 2. Contextual Settings of Arabic Use according to each author

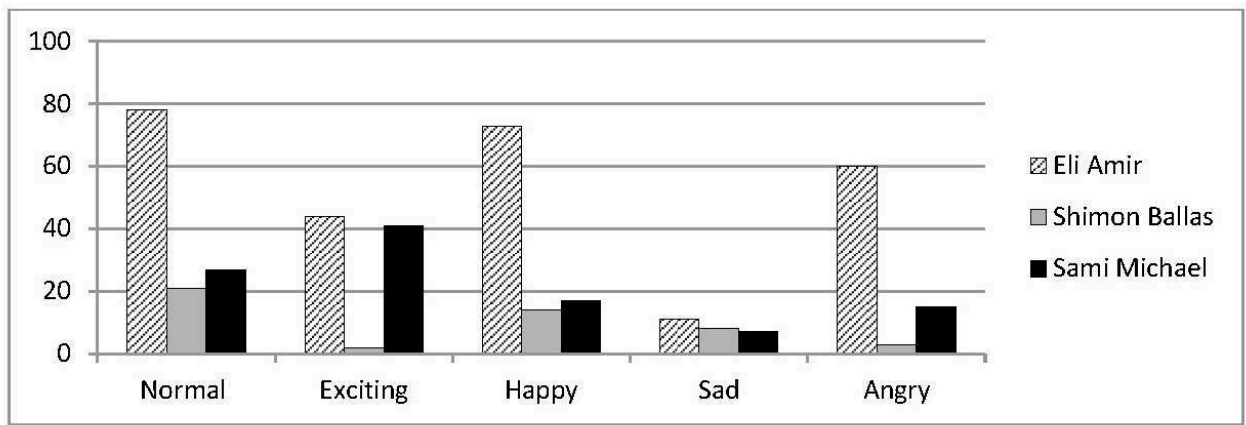

It is also clear from Figure 2 that Arabic use in Ballas' sample is associated largely with the normal mode, in which the author uses mainly the narrative or the non-dialogue technique. The use of Arabic is also linked to emotional contexts, e.g. in connection with happiness and sadness. By contrast, Arabic use is quite sparse in relation to contexts of anger and excitement.

The contextual settings analysis of the sample gathered from the two novels written by Michael shows, too, that the use of Arabic is to some extent related to and associated with highly charged emotions, categories like exciting, angry, sad and happy. The analysis also indicates that in the Hebrew novels, the contextual settings in the first Hebrew novel (1974) are greater than in the second novel (1993) in all categories. There is also a place in Michael's style allocated for sadness, although it constitutes the lowest frequency in contextual modes in which Arabic is used in Michael's sample.

\subsection{Loan words}

In addition to the fact that the Arabic lexical items used in the Hebrew novels reveal the variety and multiplicity of borrowing from the Arabic lexicon in the Hebrew texts, exemplifying internal borrowing and occurring at the micro level, there are some cases of external borrowing that were employed by the authors in their early Hebrew manuscripts. These cases of external borrowing show the diachronic process of inserting some lexical items into the Hebrew lexicon, mainly slang, which are borrowed from Arabic, such as when a lexical item like masțul "drunk" was used in Ballas' first Hebrew novel (Ballas 1964: 181). The author added a Hebrew glossing of the Arabic term masțull in the footnote. Yet currently, the Hebrew lexicon includes this word (Sagiv 2008: 764), which occurs mainly in Israeli spoken language. This attitude towards such a word from Arabic would not exist if the lexical item mastūl had already been a borrowed lexical item in Hebrew of the 1960s. In other words, if the Hebrew speakers in Israel at the time 
the novel Ha-ma'abara (Ballas 1964) appeared had been familiar with this lexeme, Ballas would not have had to add a footnote glossing the term.

This example given here is neither to claim that the novel of Ballas was the first medium that introduced the loaned term masțūl to the modern spoken Hebrew lexicon, nor to assert that this lexical item belongs only to Iraqi Jews. However, it is important to reflect on such issues from a diachronic perspective.

\section{Conclusion}

47 To conclude, a corpus of 600 Hebrew pages taken from six Hebrew novels written between 1964 and 1993 were analysed linguistically regarding the Arabic terms inserted in the texts by three Iraqi Jewish authors. The Arabic and Judaeo-Arabic instances were extracted and arranged according to semantic field and other lexical sets. The study showed that the use of Arabic in the given corpus varies. The lexical items sets were analyzed from orthographic, morphological and syntactic perspectives.

It is evident from the corpus that Arabic is employed in the Hebrew texts in several ways. This finding is based on the wide range of Arabic lexical items found in the texts, as well as the variety of strategies employed by the authors. Arabic is used in the texts in both dialogue and narrative modes, in different contextual settings.

The use of such lexical items serves likewise as a stylistic device reflecting the use of many Iraqi characters employed in the novels of the corpus. In addition, such uses of vernacular items, interjection and particle, imbue the conversations in the Hebrew novels with the local colour of Iraq/ Baghdad.

\section{BIBLIOGRAPHY}

Al-Ma'adīdi, I. 2001. Al-Ṣiḥāfah al-Yahūdīyyah fĩ al-'Irāq. Cairo: a-ddār al-Dawlīyah lil-Istițmārāt altaqāfīyah.

Amir, E. 1983. Tarnegōl kapparōt (Scapegoat). Tel Aviv: Sifriyat ofaqim.

Amir, E. 1992. Mafriạ̣ ha-yōnîm (Farewell, Baghdad). Tel Aviv: Sifriyah la-'am.

Appel, R., \& Muysken, P. 2005. Language contact and bilingualism. Amsterdam: Amsterdam University Press.

Avishur, Y. 1979. “Ha-sifrut ha-'mamit shel-yehude bavel be-'aravit Yehudit”, Pe'amim. 3, 83-90.

Ballas, S. 1964. Ha-ma'abara (the transit camp). Tel Aviv: 'Am 'oved.

Ballas, S. 1991. Ve-hu ahẹer (the other one). Tel Aviv: Zmora-Bitan.

Ben-Jacob, A. 1998. Ōṣār ha-mešālīm weha-pitgāmīm šel yehude Bābel ba-dōrōt ha-aharōnīm (Treasury of proverbs of Iraqi Jews in the last era). Jerusalem: Yerid ha-sefarim. 
Ben-Shammai, H. 1997. “Jewish Thought in Iraq in the 10th Century”, in: Golb N. (ed.) JudaeoArabic studies: Proceedings of the Founding Conference of the Society for Judaeo-Arabic Studies, 15-32. Amsterdam: Harwood Academic Publishers.

Blanc, H. 1964. Communal Dialects in Baghdad. Cambridge: Harvard University Press.

Blau, J. 1971. "ben 'aravit yehudìt le-Quran”. Tabriz. 4, 512-514.

Blau, J. 1980. Diqduq.ha-'Arbìt-ha-Yehudìt šel yeme-ha-bēnayim. Jerusalem: Magnes Press.

Blau, J. 1981. The Emergence and Linguistic Background of Judaeo-Arabic: A Study of the Origins of Middle Arabic. Jerusalem: Humanities Press.

Blau, J. 2001. “The Linguistic Character of Saadia Gaon's Translation of the Pentateuch", Oriens. 36,1 .

Brody, R. 2013. Sa'adyah Gaon. Oxford: Oxford University Press.

Bullock, B. E., \& Toribio, A. J. 2009. The Cambridge handbook of linguistic code-switching. Cambridge: Cambridge University Press.

Crystal, D. 2008. A dictionary of linguistics and phonetics. Malden: Wiley-Blackwell.

Hary, B. H. 2009. Translating Religion: Linguistic Analysis of Judeo-Arabic Sacred Texts from Egypt. Leiden: Brill.

Jackson, H., \& Zé Amvela, E. 2000. Words, meaning, and vocabulary: An introduction to modern English lexicology. London: Continuum.

Jastrow, O. 1990. Der arabische Dialekt der Juden von 'Aqra und Arbïl. Wiesbaden: Otto Harrassowitz.

Khan, G. 2007. "Judaeo-Arabic", Versteegh K. et al. (eds.), Encyclopedia of Arabic Language and Linguistics. 2. Leiden: Brill. pp. 526-536.

Khan, G. 2013. "Transcriptions into Arabic script: medieval Karaite sources”, Khan G. et als. (eds.), Encyclopedia of Hebrew Language and Linguistics. 3. Leiden-Boston: Brill. 792-799.

Kleparski, G. A., \& Rusinek, A. 2007. "The tradition of field theory and the study of lexical semantic change", Zeszyt. 47, 188-205.

Kraus, P. 2009. "Hebräische und syrische Zitate in ismā 'illitischen Schriften", Der Islam: 19(4), pp. 243-263.

Malter, H. 1921. Saadia Gaon: His Life and Works. Philadelphia: The Jewish Publication Society of America.

Mansour, J. 1991. The Jewish Baghdadi Dialect: Studies and Texts in the Judeo-Arabic Dialect of Baghdad. Or-Yehuda: The Babylonian Jewry Heritage Center, the Institute for Research on Iraqi Jewry.

Michael, S. 1974. Šāỵim ve-šā ạim yotēr. Tel Aviv: Bustan.

Michael, S. 1993. Victoria. Tel Aviv: 'Am 'oved.

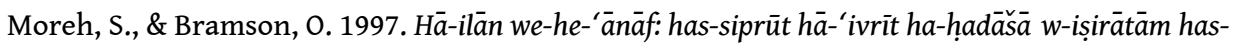
sifrūtìt hāa-'arāvìt šel yoṣe' 'e 'îrāq. Jerusalem: Magnes.

Myers-Scotton, C. 1993. Social motivations for codeswitching: Evidence from Africa. Oxford: Clarendon Press.

Naqqāsh, S. 1980. Yawm habilat wa-ağhaḍat al-dunyāa qișaṣ 'irāqīya. Jerusalem: Matba'at al-šarq al-' arabiyah. 
Nerlich, B. 1992. Semantic theories in Europe, 1830-1930: From etymology to contextuality. Amsterdam: John Benjamins Publishing Company.

Poplack, S. 1980. "Sometimes I'll start a sentence in Spanish Y TERMINO EN ESPAÑOL", Linguistics. 18: 7/8. 581-618.

Reif, S. 2000. A Jewish Archive from Old Cairo. The History of Cambridge University's Genizah Collection. Richmond, Surrey: Curzon.

Sagiv, D. 2008. Qāmūs Sagìv. Jerusalem: Shoken.

Simon, R. S., Laskier M. M., \& Reguer, S. 2003. The Jews of the Middle East and North Africa in Modern Times. New York: Columbia Univ. Press.

Snir, R. 2005. 'Arviyūt, yahadūt, șiyonut: Ma'avaq zehūyōt be-yeșīratām šel yehūde 'îrāq. Jerusalem: Yad Yitshak Ben-Tsevi.

Thomason, S. G. 2001. Language contact. Edinburgh: Edinburgh University Press.

Vollandt, R. 2015. Arabic Versions of the Pentateuch: A Comparative Study of Jewish, Christian, and Muslim Sources. Leiden: Brill.

Wagner, E.-M. 2010. Linguistic variety of Judaeo-Arabic in letters from the Cairo Genizah. Leiden: Brill. Yona-Swery, G. 1995. Milōn imrōt o-mešălīm šel lahag yehūde Bābel. Jerusalem: agudat ha-akadema' im yotṣ'ē 'īrāq be-yisra' el.

Yosef, D. 2005. Sefat ha-ēm: Milōn ha-nōsțalgeyāh šel ha-'īrāqim be-lahag ha-sāfah ha-'iraqìt ha-yehūdit. Tel Aviv: Y. David.

\section{APPENDIXES}

The appendices contain all Arabic and Judaeo-Arabic examples that are extracted from six Hebrew novels. The Arabic extracts are arranged alphabetically in six tables, in which each table contains the collected Arabic terms from each novel. The tables indicate the reference page of each example, the semantic category, the contextual settings and the dialogue/narration mode in which the insertion of each Arabic term occurs.

\section{Abbreviations used in the tables:}

N = Narration; D = Dialogue; NO = Normal; EX = Exciting; HA = Happy; SA= Sad; AN = Angry; FU = Funny 
Table 2 (Amir 1983: 9-108)

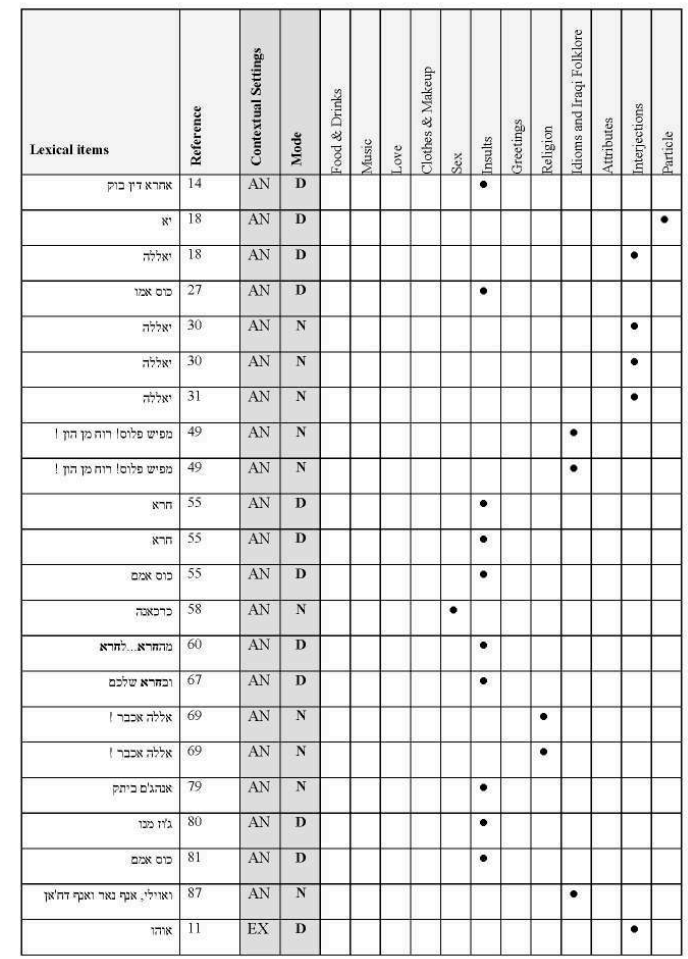

Table 2 (Amir 1983: 9-108)

\begin{tabular}{|c|c|c|c|c|c|c|c|c|c|c|c|c|c|c|c|}
\hline Lexical items & 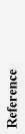 & 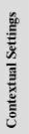 & $\frac{\mathrm{g}}{2}$ & 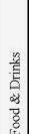 & 密 & ؛े & 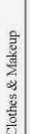 & $\%$ & $\frac{2}{2}$ & & $\frac{5}{\frac{5}{20}}$ & & 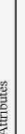 & & 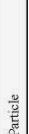 \\
\hline 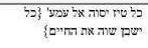 & 19 & $\mathrm{EX}$ & D & & & & & $\bullet$ & & & & & & & \\
\hline אייה טשי & 24 & $\mathrm{EX}$ & $\bar{N}$ & & & & & $\cdot$ & & & & & & & \\
\hline מ"טיז" עירקי ל"טיז" רומני & 25 & EX & $\mathrm{N}$ & & & & & $\bullet$ & & & & & & & \\
\hline שי & 25 & $\mathrm{EX}$ & $\overline{\mathrm{N}}$ & & & & & - & & & & & & & \\
\hline או אללה, אא אללה & 25 & $\mathrm{EX}$ & $\mathrm{N}$ & & & & & & & & & & & • & \\
\hline יא אללה, אידה מיז & 32 & $\mathrm{EX}$ & $\mathrm{N}$ & & & & & & & & & & & - & \\
\hline אסללה עלד, אל קיבוץ & 39 & $\mathrm{EX}$ & $\mathrm{N}$ & & & & & & & - & & & & & \\
\hline אראלמה עליד & 39 & EX & $\mathrm{N}$ & & & & & & & • & & & & & \\
\hline אי אילה & 39 & $\mathrm{EX}$ & $\overline{\mathrm{N}}$ & & & & & & & & & & & - & \\
\hline ואללה & 40 & $\mathrm{EX}$ & D & & & & & & & & & & & • & \\
\hline שמנכר, מז הפתמ, ב"שיז" & 41 & $\mathrm{EX}$ & $\mathrm{N}$ & & & & & - & & & & & & & \\
\hline שיז & 51 & $\mathrm{EX}$ & $\bar{D}$ & & & & & $\bullet$ & & & & & & 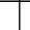 & \\
\hline יא אללדה & 51 & $\mathrm{EX}$ & D & & & & & & & & & & & • & \\
\hline עיוני & 78 & EX & D & & & $\bullet$ & & & & & & & & & \\
\hline עיני & 78 & $\mathrm{EX}$ & $\bar{D}$ & & & $\bullet$ & & & & & & & & & \\
\hline $1, \%$ & 78 & $\mathrm{EX}$ & D & & & & & & & & & & & • & \\
\hline אודו & 12 & $\mathrm{HA}$ & D & & & & & & & & & & & • & \\
\hline אי אללדה & 20 & $\mathrm{HA}$ & $\bar{D}$ & & & & & & & & & & & - & \\
\hline פריו, חביבי, סטיון & 19 & $\mathrm{HA}$ & D & & & - & & & & & & & & & \\
\hline א & 19 & HA & D & & & & & & & & & & & & $\bullet$ \\
\hline אהילו וסדיל & 19 & $\overline{\mathrm{HA}}$ & D & & & & & & & & & & & b & \\
\hline דימיל'מות & 20 & $\mathrm{HA}$ & D & & & & - & & & & & & & & \\
\hline
\end{tabular}


Table 2 (Amir 1983: 9-108)
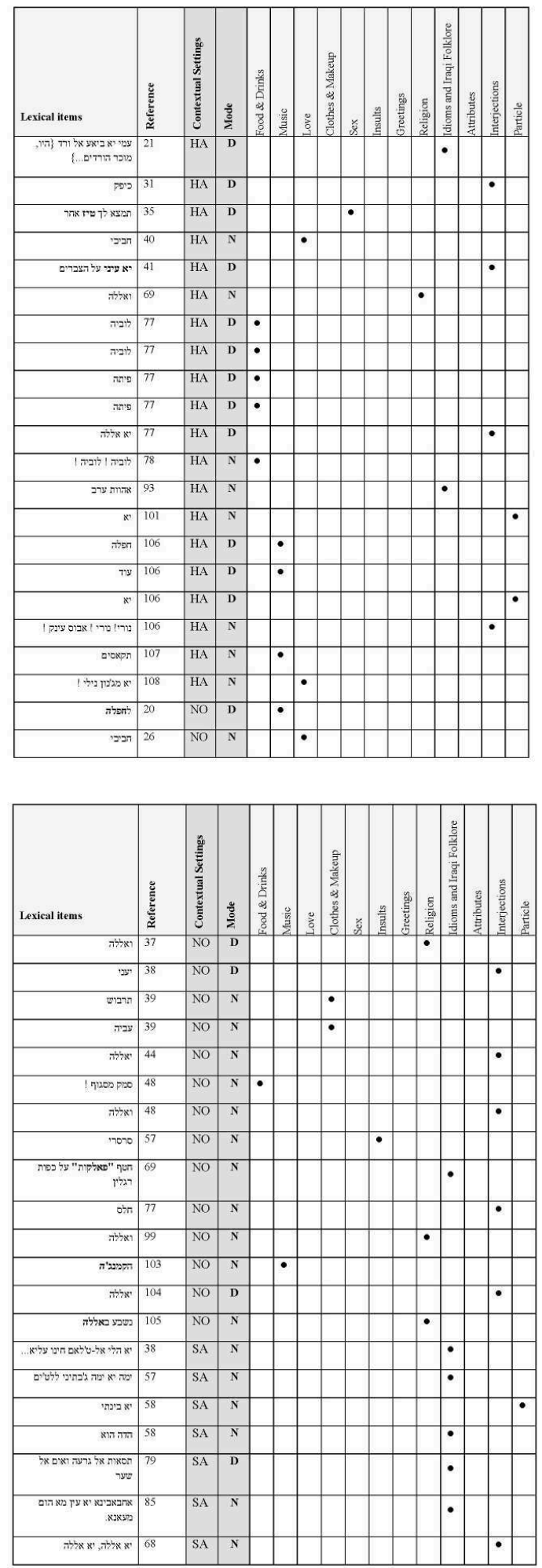
Table 2 (Amir 1983: 9-108) Table 2 (Amir 1983: 9-108)

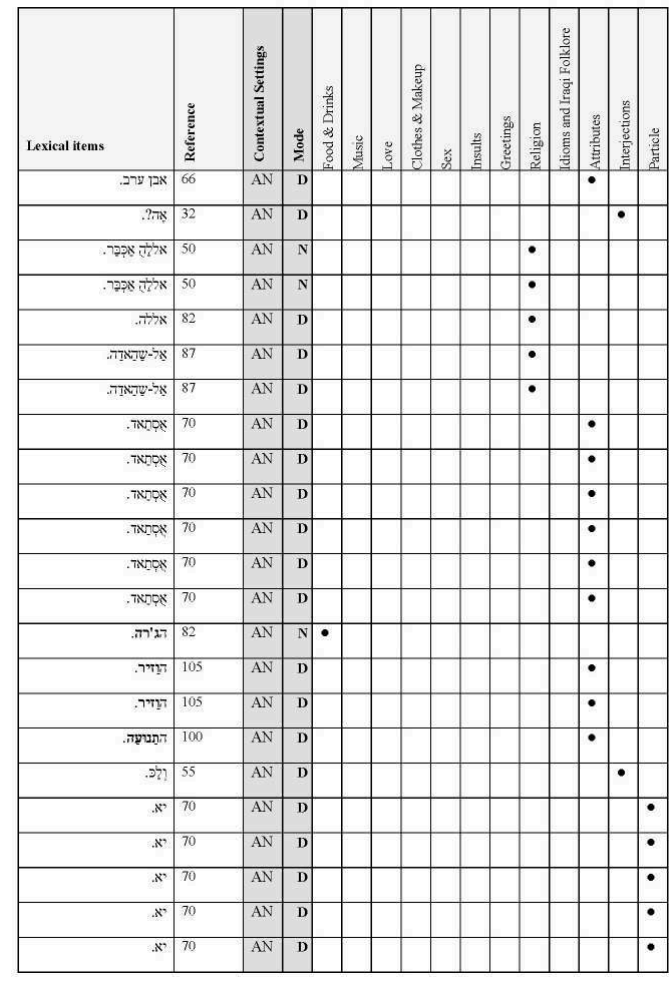

Table 3. (Amir 1992: 7-106)

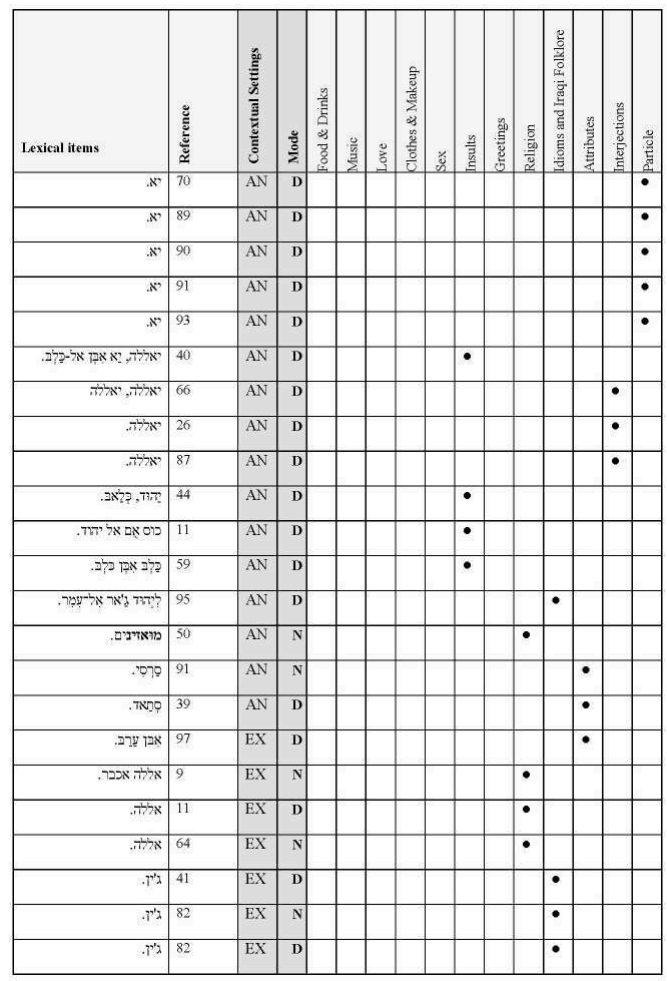


Table 3. (Amir 1992: 7-106)

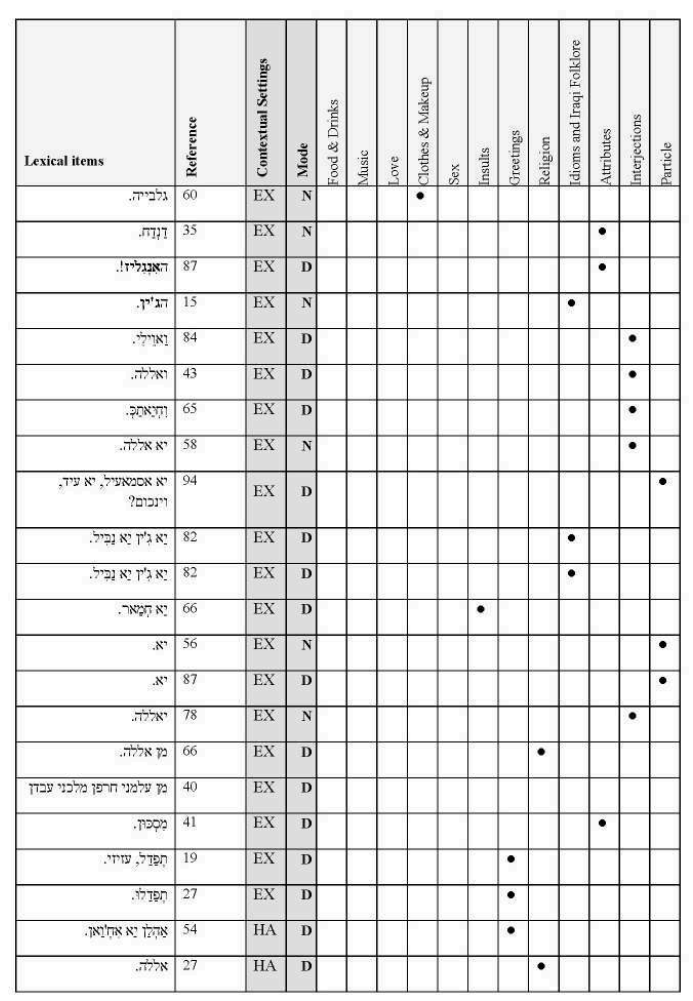

Table 3. (Amir 1992: 7-106)

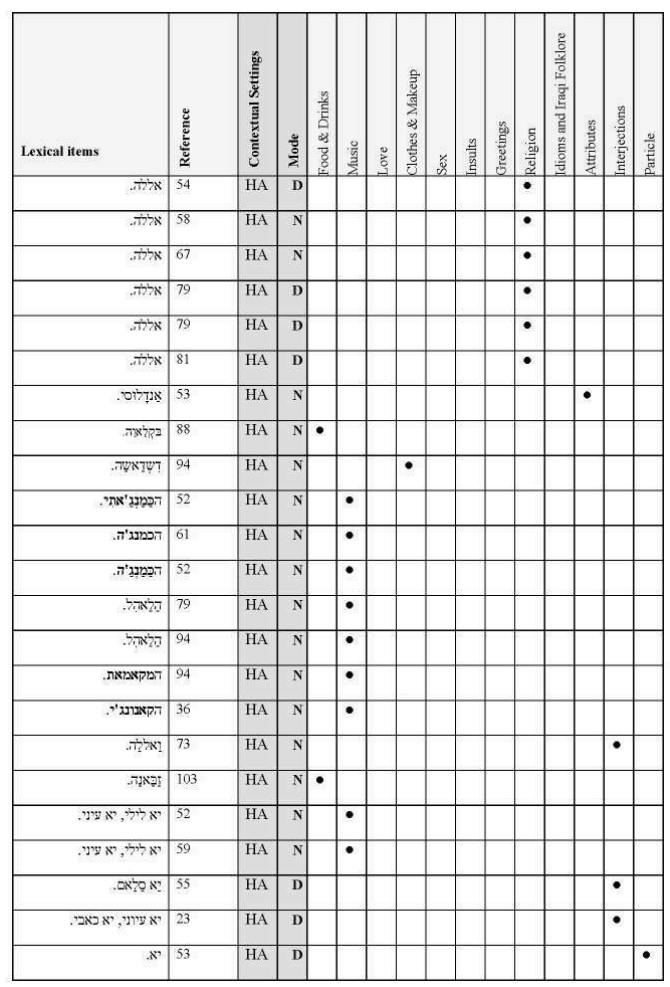


Table 3. (Amir 1992: 7-106)

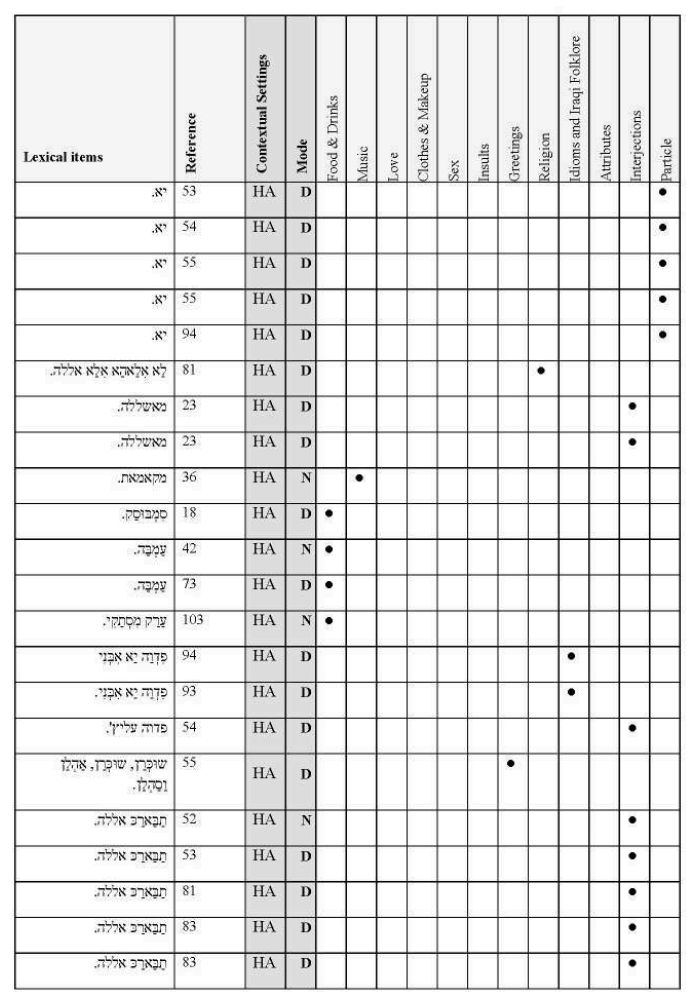

Table 3. (Amir 1992: 7-106)

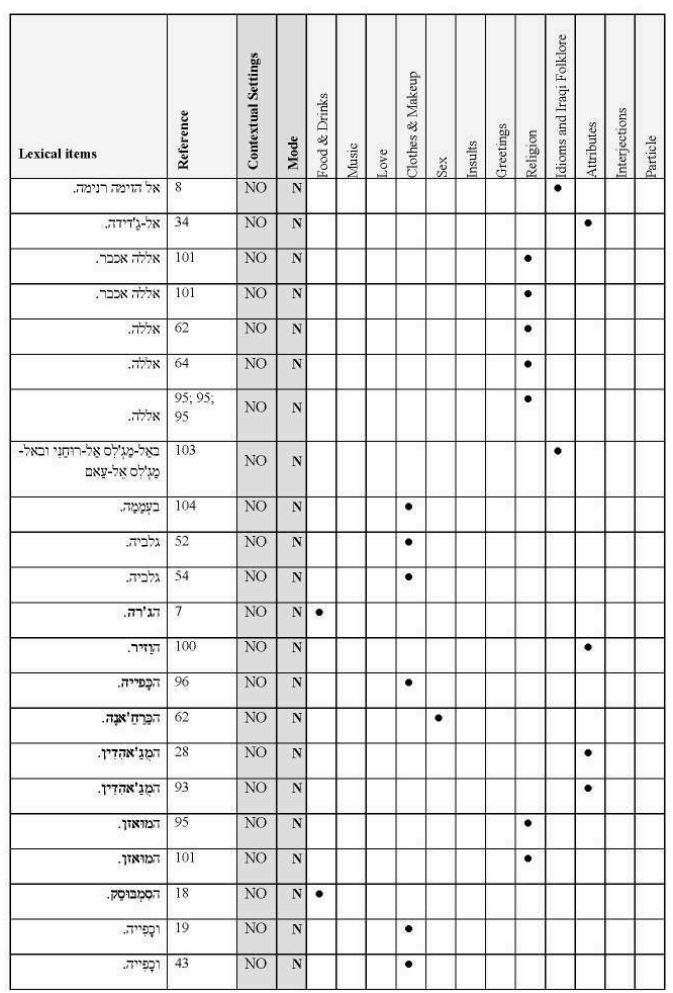


Table 3. (Amir 1992: 7-106)

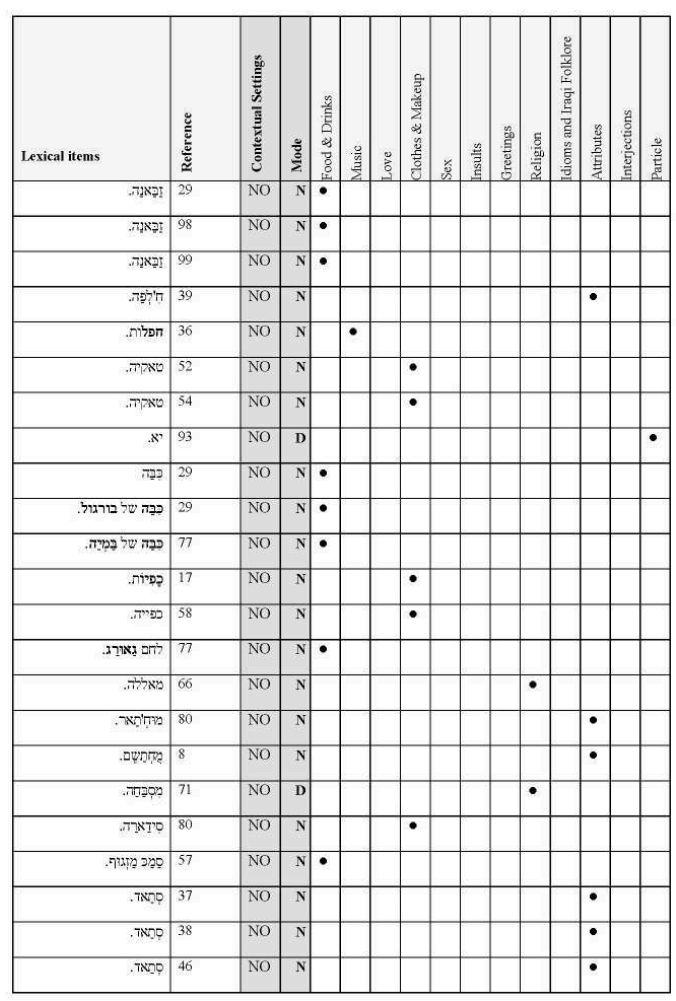

Table 3. (Amir 1992: 7-106)

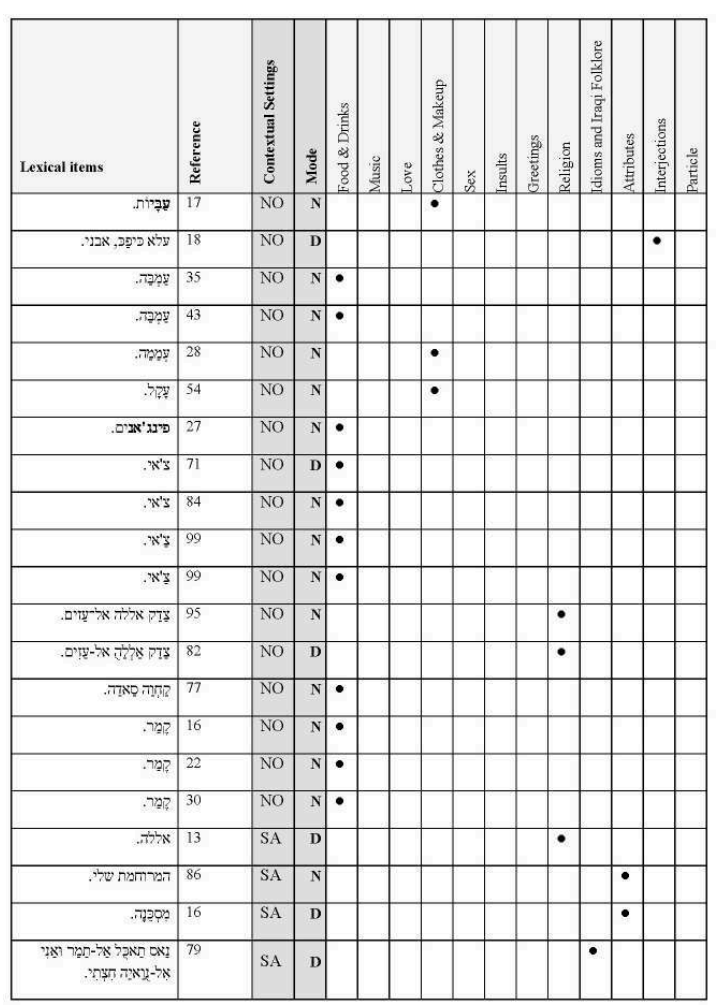


Table 3. (Amir 1992: 7-106)

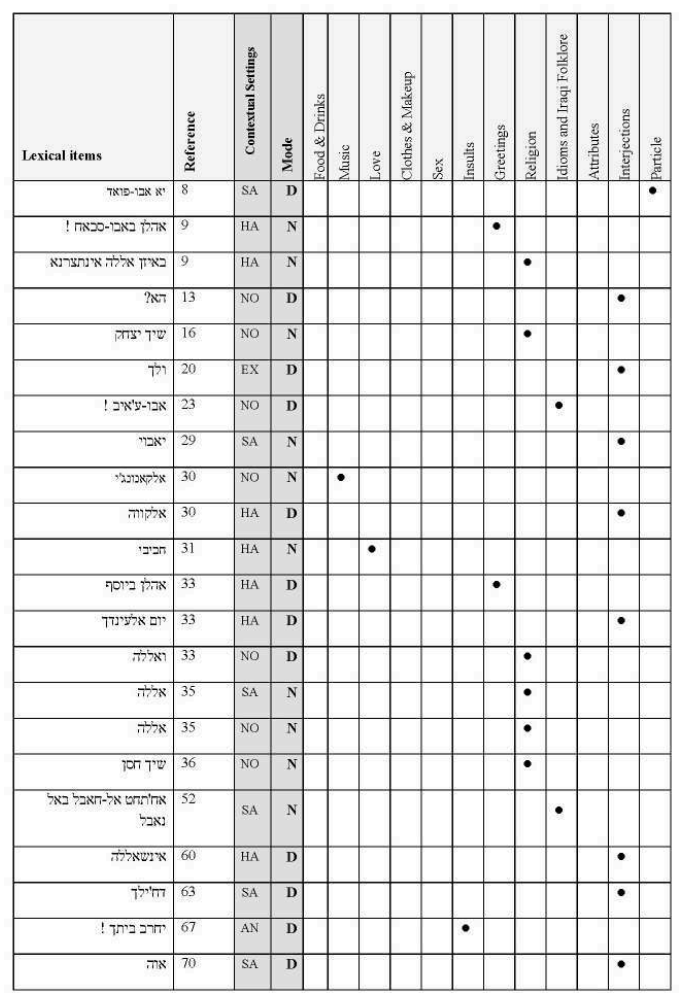

Table 4. (Ballas 1964: 7-106)

\begin{tabular}{|c|c|c|c|c|c|c|c|c|c|c|c|c|c|c|c|}
\hline Lexical items & 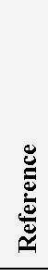 & 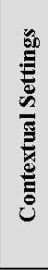 & $\frac{\pi}{0}$ & 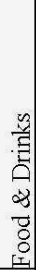 & 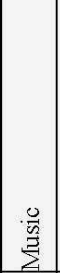 & 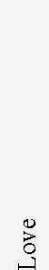 & 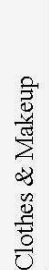 & 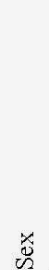 & $\begin{array}{l}\text { 号 } \\
\overrightarrow{3} \\
\underline{3}\end{array}$ & 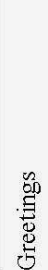 & $\begin{array}{l}5 \\
\frac{5}{00} \\
\frac{00}{2}\end{array}$ & 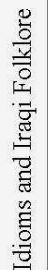 & 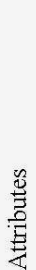 & 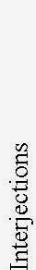 & 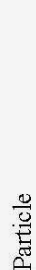 \\
\hline ואללה & 76 & SA & $\mathbf{N}$ & & & & & & & & & & & $\bullet$ & \\
\hline אבו-'עגוב & 84 & EX & $\bar{N}$ & & & & & & & & & $\bullet$ & & & \\
\hline תפדל & 86 & HA & $\mathrm{D}$ & & & & & & & $\bullet$ & & & & & \\
\hline יזיד פדלכום & 86 & HA & $\bar{D}$ & & & & & & & $\bullet$ & & & & & \\
\hline מסטול & 96 & NO & D & & & & & & $\bullet$ & & & & & & \\
\hline אהלן בחיים & 99 & $\mathrm{HA}$ & $\mathbf{N}$ & & & & & & & $\bullet$ & & & & & \\
\hline סעצד & 16 & NO & $\mathbf{N}$ & $\bullet$ & & & & & & & & & & & \\
\hline פאצ'ה & 28 & $\mathrm{HA}$ & D & $\bullet$ & & & & & & & & & & & \\
\hline אום-אלפלום & 28 & $\mathrm{HA}$ & $\bar{D}$ & $\bullet$ & & & & & & & & & & & \\
\hline פאצ'ה & 77 & SA & $\mathbf{N}$ & $\bullet$ & & & & & & & & & & & \\
\hline
\end{tabular}


Table 4. (Ballas 1964: 7-106)

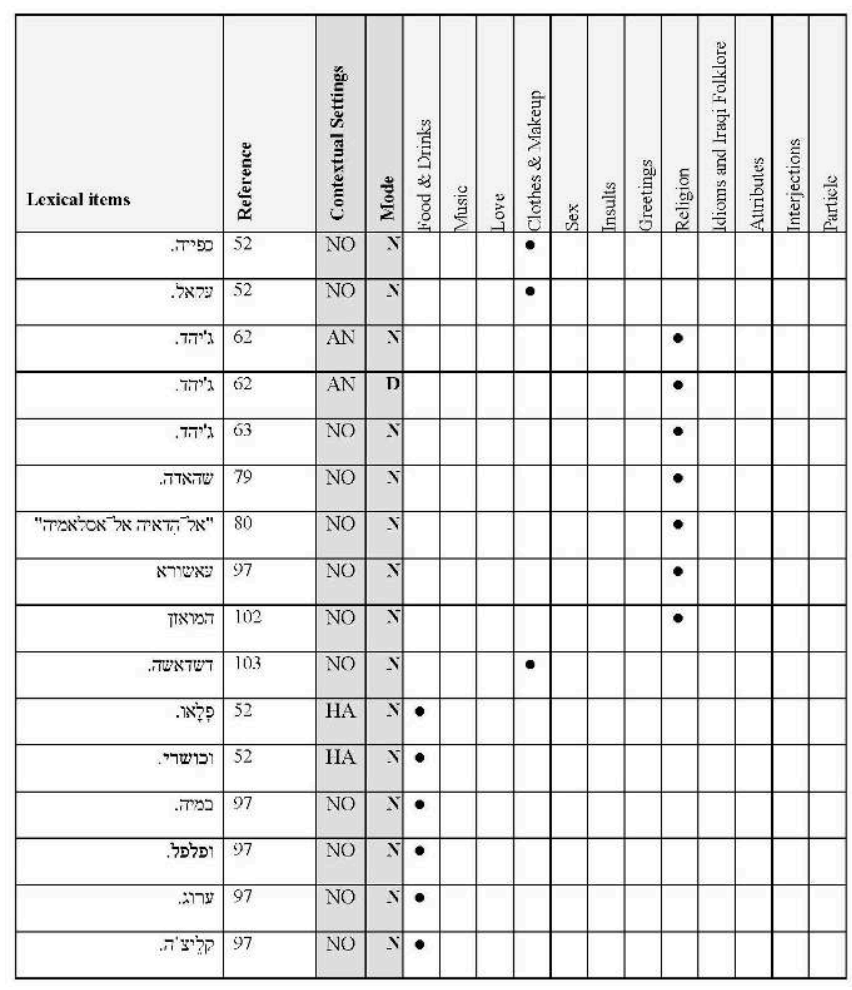

Table 5. (Ballas 1991: 7-106)

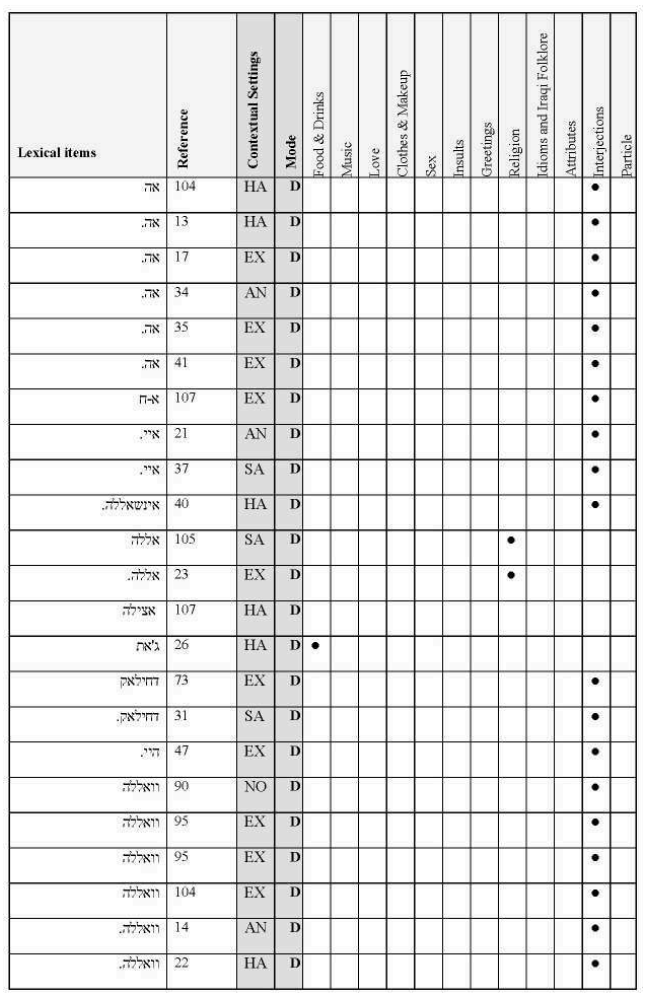


Table 6. (Michael 1974: 9-108)

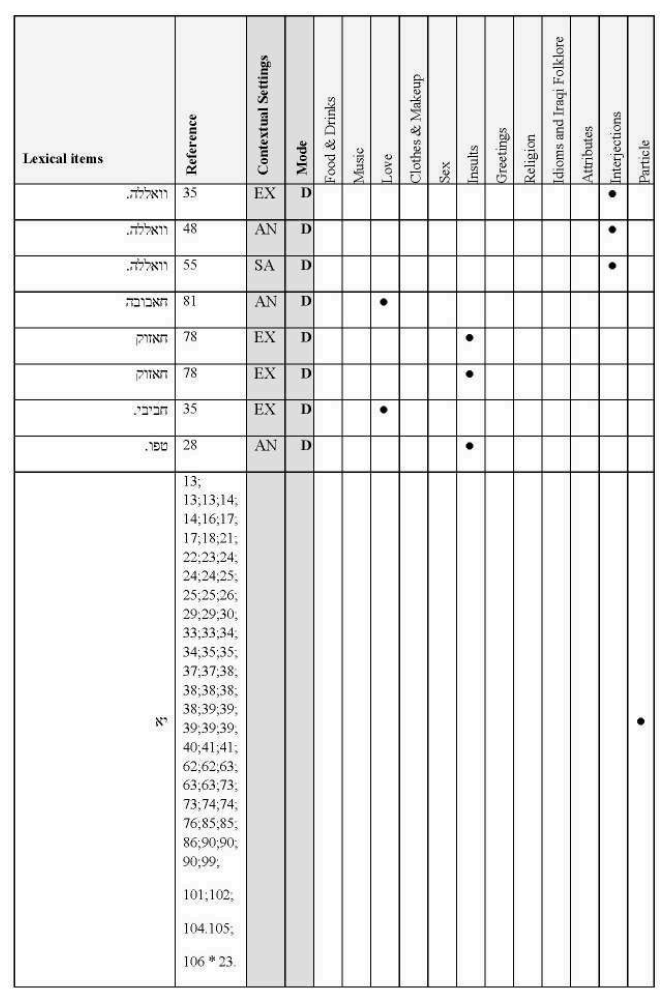

Table 6. (Michael 1974: 9-108)

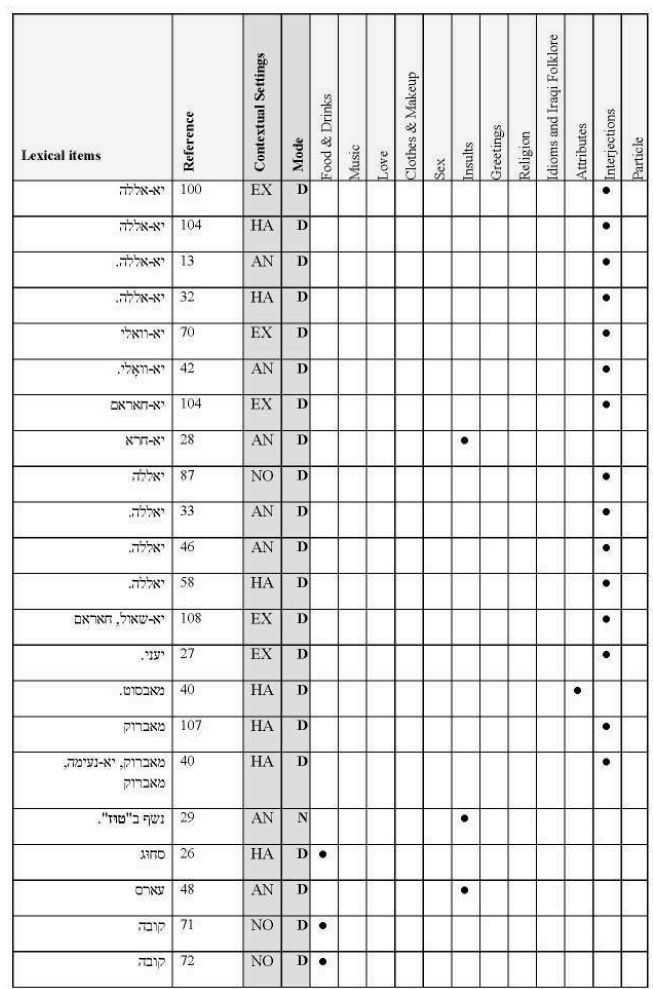


Table 6. (Michael 1974: 9-108)

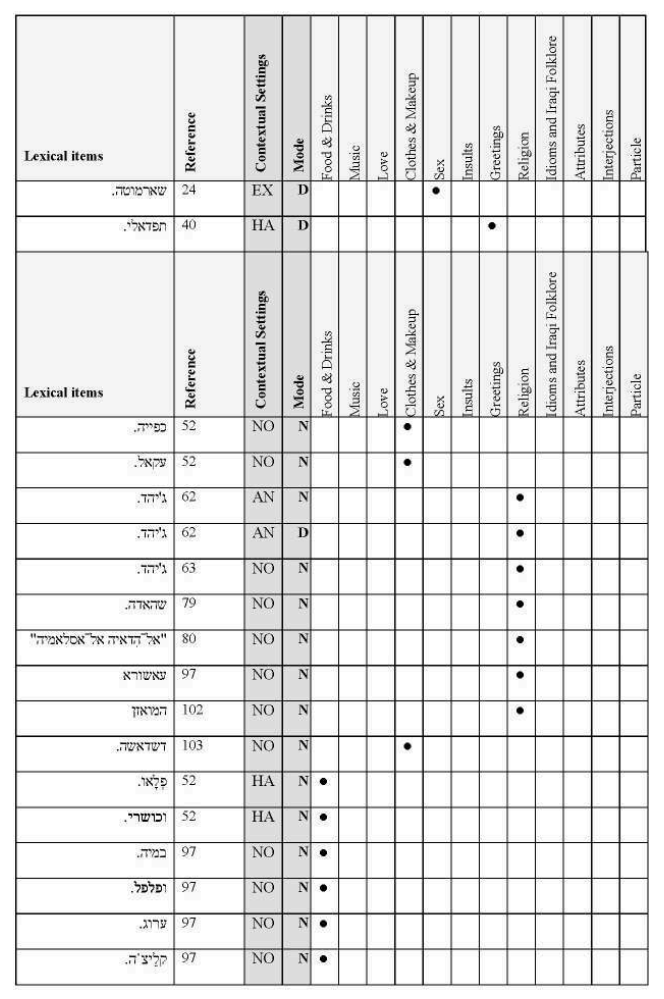

Table 6. (Michael 1974: 9-108)

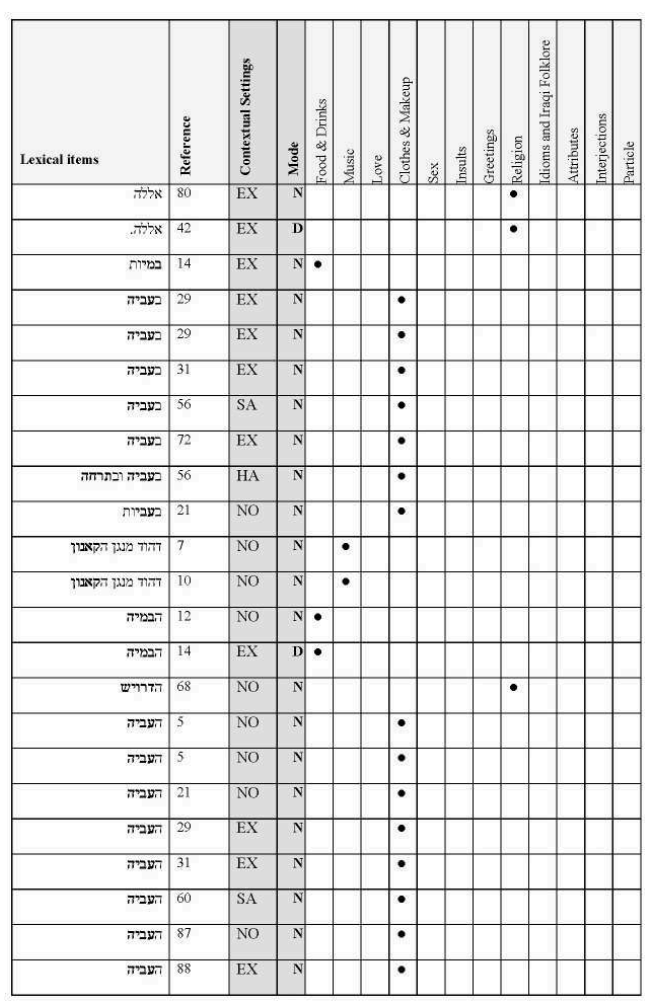


Table 7. (Michael 1993: 5-104)

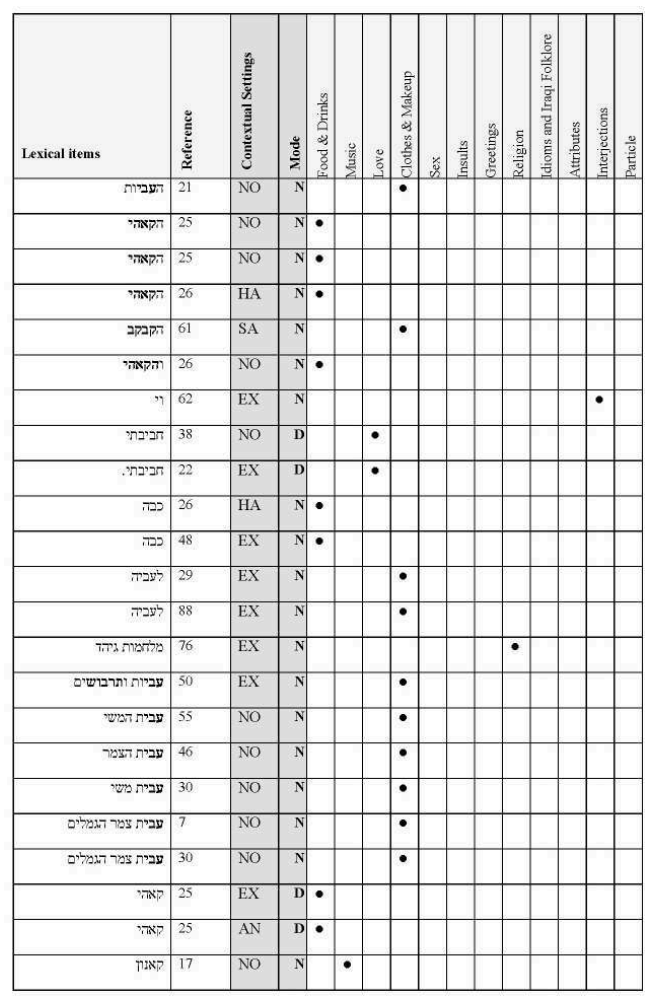

Table 7. (Michael 1993: 5-104)

\begin{tabular}{|c|c|c|c|c|c|c|c|c|c|c|c|c|c|c|c|}
\hline Lexical items & 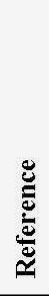 & 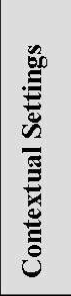 & $\stackrel{8}{\frac{\pi}{0}}$ & $\begin{array}{l}\frac{y}{1} \\
0 \\
\infty \\
0 \\
0 \\
0\end{array}$ & 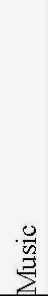 & 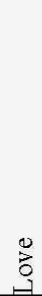 & 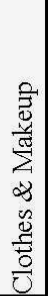 & $\begin{array}{l}x \\
ٍ \\
ٌ\end{array}$ & 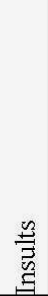 & 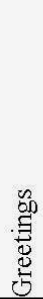 & $\begin{array}{l}\frac{5}{0} \\
\frac{00}{20} \\
\frac{3}{2}\end{array}$ & 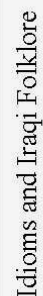 & 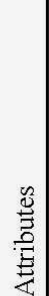 & 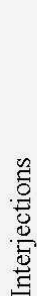 & 造 \\
\hline קוראיה & 81 & $\mathrm{NO}$ & $\bar{D}$ & - & & & & & & & & & & & \\
\hline קוראיה & 82 & EX & $\bar{D}$ & $\bullet$ & & & & & & & & & & & \\
\hline קוראיה & 82 & $\mathrm{NO}$ & $\mathbf{N}$ & $\bullet$ & & & & & & & & & & & \\
\hline קוראיה & 82 & $\mathrm{NO}$ & $\mathbf{N}$ & $\bullet$ & & & & & & & & & & & \\
\hline קוראיה & 82 & EX & D & $\bullet$ & & & & & & & & & & & \\
\hline קוראיה & 83 & $\mathrm{AN}$ & D & $\bullet$ & & & & & & & & & & & \\
\hline
\end{tabular}

\section{NOTES}

1. This study uses Geoffrey Khan (2007: 526) terminology of Judaeo-Arabic. 
2. It is important to point out the variety of Hebrew/Arabic uses; not only Jews wrote their Judeo-Arabic manuscripts using Hebrew characters. Rather, there is an evidence that the Judeo-Arabic texts were also written in Arabic script (Blau 1981: 40-43). This phenomenon, although rare in Judeo-Arabic literature (Blau 1981: 41), touches on the variety of forms Arabic/Hebrew can engender. It is interesting to know that the varieties of using Hebrew script have been extended covering even Arabic sacred texts, e.g. the Quran was also written in Hebrew script in the Middle Ages (Blau 1971: 512; Vollandt 2015). Contrariwise, the Hebrew version of the Bible was written in Arabic script as well (Khan 2013; Reif 2000: 106-109). In addition, there were some Islamic texts embedded with Hebrew and Aramaic lexical items (Kraus 1930).

3. Saadia Gaon al-Fayyūmi (882-942 C.E) is one of the most famous Jewish thinkers, philosophers and intellectuals during the Middle Ages in Iraq. He was born in the village of Dilaz in Faiyum which is located in Upper Egypt. For more information about Saadia Gaon, see Malter 1921, Blau 2001, Brody 2013 and Vollandt 2015.

4. See, for example, the Hebrew words (עמידה, שבחות, נשמתו) appear in Arabic script respectively:

(in Naqqāsh (العميدة، الشباحوث ، نشمتو) (1980)

5. For more information about the qeltu-gelet dialects, see Blanc 1964.

6. For more information and examples about this phenomena, see Blanc 1964.

7. See, for instance, the study of Judaeo-Arabic in Aqrah and Erbil (Jastrow 1990).

8. For more debate on this issue, see Mansour 1991.

9. See, for instance, the use of mazzal [luck] and sakkana [danger], among others, in Judaeo-Arabic spoken by Iraqi Jews (Mansour 1991).

10. For more information about the semantic field theory see Kleparski \& Rusinek 2007; Jackson \& Zé Amvela 2000.

11. For more information see the appendices of this paper, which contain all Arabic extracts from the six Hebrew novels of the study arranged alphabetically in six tables.

12. An Iraqi dish, it is a soup made from certain parts of the sheep's meat, like stomach, tongues, cheeks and head. See also the dictionary of Iraqi Judaeo-Arabic in Yosef (2005). 13. This is also an Iraqi Jewish favorable dish, see Yosef (2005).

14. An art of playing Arabic music using only one instrument. According to the dictionary of Iraqi Judaeo-Arabic, it refers to melody or tune Yosef (2005).

15. KaraHāne is a Turkish term used during the Ottoman Empire to refer to a brothel. Many Arabs borrowed it and it is used still in some Arabic dialects.

16. Tawla is a famous Arabian play, this is also a play that Iraqi Jews love to play, see Yosef (2005); Yona-Swery (1995).

17. See for instance: (Wagner 2010: 27; Blau 1980: 47).

18. The transcription follows the Hebrew equivalent in Arabic Alphabet.

\section{ABSTRACTS}

Sami Michael (b. Baghdad, 1926), Shimon Ballas (b. Baghdad, 1930) and Eli Amir (b. Baghdad, 1937) are three Iraqi Jewish authors who immigrated to Israel, having left Iraq during the mass 
migration of Jews from Arab countries during the 1950s. Although their mother tongue is Arabic, these three Iraqi Jewish authors felt that they needed to write in Hebrew if they were to have successful literary careers in Israel. Nonetheless, Arabic still appears in their literary works. Yet, the Arabic variety employed in their literary works belongs, in many aspects, to the so-called Iraqi Judaeo-Arabic.

This study investigates the Judaeo-Arabic lexical items used in six modern Hebrew texts written by the three Iraqi Jewish authors mentioned above. The novels were published between 1964 and 1993. A semantic field analysis is applied to a corpus of six hundred pages, in which the first 100 pages of each novel are taken as a sample. The study shows in numerical statistics the portion of each semantic field used in the corpus followed by a discussion of the data in the view of the linguistic analysis of the phonological, morphological, syntactic and ethnographic aspects of the Iraqi Judaeo-Arabic lexical items in accordance with the texts.

INDEX

Keywords: Iraqi Judaeo-Arabic, Hebrew, Arabic, Semantic field analysis, Code-switching, Borrowing

\section{AUTHOR}

\section{MOHAMED A. H. AHMED}

University of Cambridge \& Woolf Institute, maha2@cam.ac.uk 


\title{
De la mise en mots de la masculinité et de la féminité en arabe marocain
}

\author{
Karima Ziamari et Alexandrine Barontini
}

\section{Cadrage}

1 C'est d'abord à travers des études dialectologiques corrélées à des fins variationnistes que la variable sexe/genre a été prise en compte, aussi bien au Maroc que dans le monde arabe (Miller \& Caubet 2010; Vicente 2009a, 2009b; Bassiouney 2009; Al-Wer 2014; Boucherit \& Lentin 1989). La dimension phonologique est largement étudiée comme pouvant amener un changement linguistique. Dans ces recherches, les femmes peuvent apparaitre comme celles qui initient cette dynamique de changement (par exemple : AlWer ibid. en Jordanie, Bassiouney ibid. en Égypte), ou bien, à l'inverse, elles peuvent se révéler plus conservatrices (Sadiqi au Maroc).

\subsection{Multilinguisme et statut des langues}

Dans d'autres travaux, aborder le genre, c'est situer les pratiques dans un cadre glottopolitique général exigé par la spécificité de la situation linguistique marocaine. Selon Ennaji (2009: 75) «Une étude du phénomène du genre au Maroc nécessite une compréhension de la situation linguistique, et de la hiérarchie des langues en fonction des sexes ».

3 Sadiqi est pionnière en la matière, son livre Women, Gender and Language in Morocco (2003), présente une étude du genre en relation avec les langues au Maroc. Selon Sadiqi, le multilinguisme génère des variations au niveau du genre. Les langues vernaculaires du Maroc étaient (à l'époque) strictement orales et marginalisées, tandis que les langues écrites avaient un pouvoir normatif considérable dans la société marocaine. Les femmes analphabètes, plus souvent en milieu rural, maitriseraient plus les langues dites orales (Ibid. : 198). Alors que les femmes éduquées, plus souvent citadines, auraient plus de choix et donc un répertoire linguistique multilingue qui les exposerait moins à la discrimination que les femmes de milieu rural. 
4 Dans cette perspective, l'amazighe, langue minorée et discriminée, serait une langue féminine. De l'autre côté, le prestigieux standard arabe qui synthétise toute une culture religieuse et lettrée serait une langue masculine. L'arabe marocain et le français seraient des langues à la fois masculines et féminines.

\subsection{Parlers masculins versus parlers féminins}

5 L'approche « existentialiste » (cf. Dorlin 2008; Cameron 2005; Cameron \& Kulick 2006) considère la différence sexuelle binaire homme vs femme comme déterminante de façons de parler féminines $v s$ masculines.

Dans ce cadre, les hommes et les femmes ayant participé dès leur enfance à des processus de socialisation différents et différenciés n'interpréteraient pas de la même façon les ressources linguistiques dans l'interaction et seraient destiné-e-s à un éternel malentendu dans la conversation. (Greco $2014: 19$ ).

6 Les études partant de ce postulat sont les plus importantes et les plus visibles au Maroc (hormis les travaux essentiellement dialectologiques, on pourrait citer Sadiqi 2003; Mouhcine 1997 ; Kharraki 2001 ; Hachimi 2001 ; Ziamari \& Meskine 2014).

7 Ainsi, selon Mouhcine (1997 : 27), « le parler masculin » est considéré comme « la norme » et :

Le parler féminin est considéré comme une "déviance", un "défaut". L'appartenance à un groupe social "femmes" reconnu, le fait de parler dans un style qualifié par la société de "spécifiquement féminin", et de faire l'objet de stéréotypes reconnus par la communauté comme étant des défauts, nous amène à dire que le parler féminin est stigmatisé. (Ibid.).

8 Pour les linguistes qui ont travaillé sur cet axe, on isole certaines expressions ou certains mots qui sont utilisés seulement par les femmes (Ibid. : 28). Elles seraient polies dans leur discours, moins agressives que les hommes, et plus sensibles aux relations sociales positives (Ennaji 2009: 59). Bien sûr la plupart des linguistes insistent sur le fait que l'on ne peut généraliser ces variantes féminines à toutes les femmes (marocaines en l'occurrence).

\subsection{Quand dire c'est être}

9 Selon le paradigme de la performance, le genre n'est pas vu comme quelque chose que nous sommes, c'est plutôt quelque chose que nous incorporons/que nous mettons en œuvre et surtout qui est performé (Eckert \& Mc Connell-Ginet 2003 : 10; Butler 2004, 2005).

Le paradigme de la performance est très influencé d'une part, par le féminisme de la troisième vague de Butler (1990), De Lauretis (1991) et Kosofsky Sedgwick (1990) dont les travaux ont radicalement questionné la dimension essentialiste et binaire des catégories, et, d'autre part, par un ensemble de recherches issues du poststructuralisme et du postmodernisme ayant mis le langage au centre des processus de construction du social. (Greco $2014: 20-21$ ).

10 Le genre pris dans sa dimension performative a été rarement pris en compte par les travaux sociolinguistiques concernant le Maroc.

11 Hors de la vision binaire, il ne s'agit donc pas de toujours associer sexe biologique et construction du genre : le genre s'accomplit et s'affirme en discours (Barontini \& Ziamari 2009). Compte tenu des diversités de répertoires à la disposition d'une personne et des 
diversités de situations d'interaction, nous considérons que le genre est fluide. Une femme peut se présenter discursivement comme homme, et vice versa.

\section{Le corpus et les informateurs}

Il s'agit d'environ quatre heures d'enregistrement (recueillis par Karima Ziamari de janvier à mars 2017) auprès de trois hommes et huit femmes, âgés de 14 ans à environ 55 ans.

Tableau 1. Participant-e-s aux interviews.

\begin{tabular}{|c|c|c|c|}
\hline Jamila & $\begin{array}{l}18 \text { ans, de Sidi Kacem, elle a vécu } \\
\text { à Ouazzane, } 1 \text { ère année du lycée. }\end{array}$ & Yasin & $\begin{array}{l}19 \text { ans, de Meknès, } \\
\text { dernière année du lycée } \\
\text { (baccalauréat). }\end{array}$ \\
\hline Halima & $\begin{array}{l}19 \text { ans, de Sidi Kacem, } 2^{\text {ème }} \\
\text { année du collège. }\end{array}$ & & \\
\hline Loubna & $\begin{array}{l}26 \text { ans, de Meknès, niveau } \\
\text { études primaires, travaille dans } \\
\text { une usine à Casablanca. }\end{array}$ & & \\
\hline Rabia & $\begin{array}{l}\text { environ } 55 \text { ans, d'Agouray, } \\
\text { analphabète, travaille comme } \\
\text { journalière agricole, mariée et } \\
\text { mère de trois enfants ( } 2 \text { jeunes } \\
\text { garçons et une adolescente). }\end{array}$ & Bilal & $\begin{array}{l}\text { 3o ans, de } \\
\text { baccalauréat, } \\
\text { travaille } \\
\text { dans une société } \\
\text { pharmaceutique, marié. }\end{array}$ \\
\hline Asmae & $\begin{array}{l}47 \text { ans, de Meknès, licence en } \\
\text { biologie et formation de sage } \\
\text { femme ( } 2 \text { ans), travaille comme } \\
\text { sage femme, mariée à Hakim et } \\
\text { mère d'Ines (et d'un garcon de } 11 \\
\text { ans). }\end{array}$ & & \\
\hline Ines & $\begin{array}{l}15 \text { ans, de Meknès, } 1^{\text {ère }} \text { année du } \\
\text { lycée. }\end{array}$ & Hakim & $\begin{array}{l}49 \text { ans, de Meknès, } \\
\text { professeur de collège, } \\
\text { marié à Asmae et père } \\
\text { d'Ines (et d'un garcon de } \\
11 \text { ans). }\end{array}$ \\
\hline Saida & $\begin{array}{l}14 \text { ans, de Meknès, } 9^{\text {ème }} \text { année du } \\
\text { collège (privé). }\end{array}$ & & \\
\hline
\end{tabular}

\section{Ce qui constitue la masculinité (rožōliyya)}

Les interviewé-e-s ont été interrogé-e-s sur ce que signifie pour eux/elles la masculinité, être un homme, la féminité, être une femme. Sans surprise, on retrouve une distribution des représentations telle que le montre le tableau 2.

Tableau 2. Distribution des représentations.

\begin{tabular}{|l|l|l|l|l|}
\hline $\begin{array}{l}\text { Représentations positives } \\
\text { qualités }\end{array}$ & $\begin{array}{l}\text { rāžə̌ } \\
\text { homme }\end{array}$ & $\begin{array}{l}\text { ka-yxdəm ṛā̌zl } \\
\text { il se conduit en } \\
\text { homme }\end{array}$ & $\begin{array}{l}\text { mṛa u nəṣṣ } \\
\text { une femme et } \\
\text { demie }\end{array}$ & $\begin{array}{l}\text { rožūla/ṛožōliyya } \\
\text { virilité, } \\
\text { masculinité }\end{array}$ \\
\hline
\end{tabular}




\begin{tabular}{|l|l|l|l|l|}
\hline $\begin{array}{l}\text { Représentations négatives / } \\
\text { défauts }\end{array}$ & $\begin{array}{l}\text { mṛa } \\
\text { femme }\end{array}$ & $\begin{array}{l}\text { ce n’esāžəl pas un } \\
\text { homme }\end{array}$ & $\begin{array}{l}\text { Enība/ṣəlgōṭa } \\
\text { minet / salope }\end{array}$ & $\begin{array}{l}\text { zāmal/qaḥba } \\
\text { pédé/pute }\end{array}$ \\
\hline
\end{tabular}

14 Les termes rāăžol, rožōla, rožōliyya, etc., ne renvoient pas seulement à la dimension proprement masculine, mais également, dans un sens figuré, à des qualités qui se trouvent associées à la virilité, telles le courage et la droiture (cf. Caubet 2016). Par exemple, le dictionnaire Colin (Iraqui-Sinaceur 1993 : 606) indique pour le nom rāažl: « 1. avec pl. ržăl (...) homme (par opposition à femme) ; mari, époux. (...) 2. avec pl. rəžžăla. homme digne de ce nom, homme de cœur, sur qui l'on peut compter, courageux, viril, entreprenant.»

\subsection{Un homme, c'est la parole}

15 Avoir une parole et la tenir est indéniablement la principale caractéristique masculine mentionnée chez tous les informateurs, tous sexes et tous âges confondus.

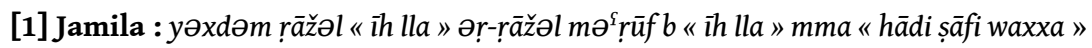
Qu'il soit homme! Oui, non! L'homme est connu pour ça (sa parole), mais pas qu'il dise oui d'accord

[2] Halima : «īh" nətqəbbəl-ha mən mra, ka-tkūn bhāl dāba məšḡūla ka-tkūn ma

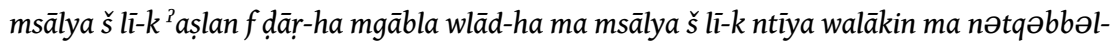

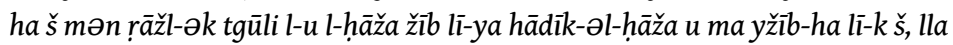

Oui, je l'accepte de la part d'une femme, elle peut par exemple être occupée elle peut être prise, s'occuper de sa maison et de ses enfants, elle n'a pas le temps pour toi mais je ne l'accepte pas de ton mari tu lui dis ramène-moi ce truc et il le fait pas non.

[3] Karima : fūqāš əṛ-rāāžll ma ka-ykūn š ${ }^{\complement}$ ənd-u mawāqif rižāliya?

Quand est-ce que l'homme perd ses postures masculines?

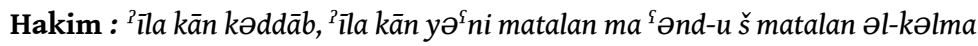

S'il est menteur, si par exemple il n'a pas de parole

Un homme qui ne tient pas parole n'est pas un «homme » complet, il ressemble alors à une femme. Or si l'on ne s'attend pas à ce qu'une femme tienne parole, ce serait, selon les informatrices, à cause de ses nombreuses occupations et responsabilités (qui n'incombent pas aux hommes). L'homme ne semble pas bénéficier des mêmes circonstances atténuantes. S'il ne tient pas sa promesse, il peut même être comparé à une prostituée, parce que celle-ci ne dit jamais non, figure ultime de stigmatisation. Et, selon cette logique, la prostitution est réservée aux femmes.

\subsection{Un homme a une forte personnalité}

Tenir parole va avec l'affirmation de soi : avoir une forte personnalité est une autre qualité masculine indispensable. Pour les adolescentes, avoir une forte personnalité pour un garçon revient à éviter toutes les activités considérées comme féminines.

[4] Saida : ykūn ${ }^{\complement} \partial n d-u$ əš-šəxșiyya ma ykūn š ka-ydīr dāk-əš-ši dyāl lə-bnāt Qu'il ait une forte personnalité, il ne doit pas faire les trucs des filles

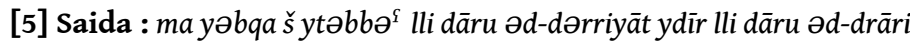
Il ne doit pas faire comme font les filles, il doit faire ce que font les garçons

Ines : ma ydir š l'imitation

Qu'il évite d'imiter (les filles) 
Saida : ykūn qāadd ${ }^{\mathrm{f}} l a$ rāạ-u, ma ykūn š xəwwāf

Qu'il soit capable, et ne soit pas lâche

Pour Yasin, un homme doit faire preuve de générosité et doit aider les autres, sa rožōliyya se manifeste dans son comportement social. C'est l'homme de cœur, sur qui on peut compter.

[6] Yasin : ərr-ružūla (rire) ta-y $y^{\varsigma} \bar{a} w \partial n$ ən-nās șāfi

La masculinité c'est aider les gens, c'est tout

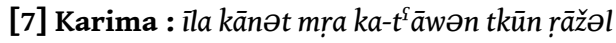

Si c'est une femme qui aide, on pourrait dire que c'est un homme?

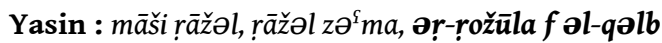

Ce n'est pas un homme, homme genre, la masculinité elle est dans le cœur.

\subsection{Ce sont des postures (mawāqif) : être digne de confiance, être responsable}

19 Ainsi, la masculinité se caractériserait par des postures, des façons de se comporter, des prises de positions : être digne de confiance (ce qui rejoint le fait de tenir parole), être responsable, prendre ses responsabilités.

[8] Bilal : b ən-nisba l-i hiyya mawāqif, mawāqif, ər-rožūla hiyya l-mawāqif (...) hād-əšši lli kāyən tkūn šəxșiyyt-ək qwiyya təfṛ

Pour moi, c'est des postures, des postures, la masculinité c'est les postures (...) C'est tout, avoir une forte personnalité que tu peux imposer aux gens, tu n'es pas faible

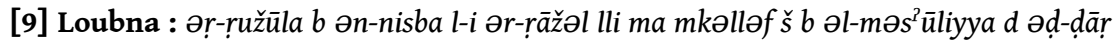

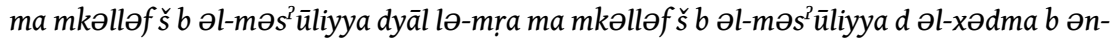
nisba lī-ya māši ṛāžəl ma xəddām ma rəddām ṛā-h māši ṛāžəl b ən-nisba l-i āna

La masculinité pour moi, l'homme qui ne s'occupe pas des responsabilités de la maison, ne s'occupe pas des responsabilités de la femme, ne s'occupe pas des responsabilités du travail, pour moi, l'homme qui ne travaille pas, ce n'est pas un homme pour moi

Karima : w ìla kān zwīn, u mḅōgəss u mbūdər?

Et s'il est charmant, beau gosse et bien fait?

Loubna : bla xədma bla wālu?

Sans travail, sans rien?

Karima : ih

Oui

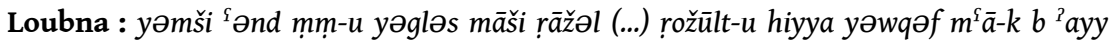

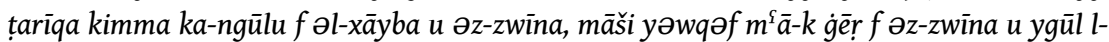

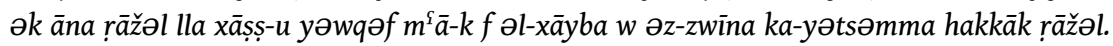

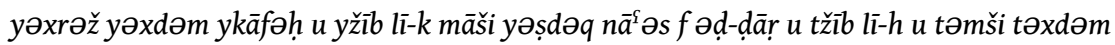

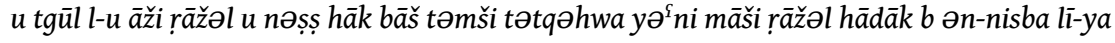

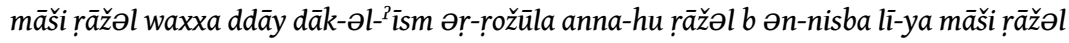

Qu'il reste chez sa maman, ce n'est pas un homme (...) Sa masculinité ça implique qu'il t'aide de n'importe quelle façon comme on dit pour le meilleur et pour le pire, qu'il ne soit pas là que pour le meilleur et te dise moi je suis un homme, non il doit être avec toi pour le pire et pour le meilleur, comme ça c'est un homme. Il sort travailler, il lutte et il t'aide, c'est pas qu'il reste endormi à la maison, et c'est toi qui l'assistes, tu pars travailler et tu lui dis viens mon vrai homme, tiens de l'argent pour aller prendre un café, donc ce n'est pas un homme ça pour moi, ce n'est pas un homme même s'il porte ce nom, la virilité, qui fait que c'est un homme, pour moi il ne l'est pas. 


\section{Ce qui ne constitue pas la rožōliyya : le concept de ¿nība}

Les adolescents avancent un autre concept et champ sémantique, plus difficile à traduire :

${ }^{\complement} n \bar{\imath} b a, t \partial^{\complement} n \bar{a} b, t^{\complement} \partial n n \partial b, m^{\complement} \partial n n \partial b$.

21 Il semble que ce soit une dérivation de ${ }^{\complement}$ nəb, raisin, dans l'idée qu'il est sucré et se présente toujours en grappe. Le terme est employé en rapport à la drague, pour désigner un garçon doux, mou (féminin), flatteur, qui fait de la lèche, passe la pommade, efféminé ou en tout cas toujours avec les filles/femmes, toujours entouré et beau parleur.

[10] Ines : min bayni əl-mușțalahăt əš-šabābiyya li ${ }^{\text {}}$ adam ər-rožūla hiyya $t-t{ }^{\complement} n a \bar{a} b$

Parmi les concepts de la jeunesse de la non-masculinité (absence de masculinité)

c'est le fait de faire le minet

[11] Saida : bhāl dāba wəld ma ka-yəhdər š gă $\bar{a}^{\S} m^{\uparrow} a$ əd-drāri aktariyya ka-yəhdər $m^{\uparrow} a$ lə-bnāt wəld $m^{\complement}$ ənnəb

Par exemple un gars qui parle pas du tout aux garçons, il parle aux filles la plupart du temps, c'est un garçon qui fait le minet

Ines: ${ }^{\complement}$ niba

une petite minette

Karima : šn $\bar{u} y \partial t^{\S} \partial n n ə b$ ?

C'est quoi faire le minet?

Ines : $m^{\complement}$ Ollək $m^{\complement}$ əssal

être " visqueux ", mielleux

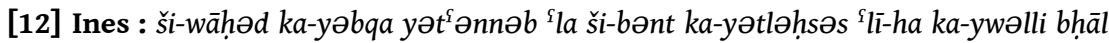
ši-bnita qəddām-ha ka-yəbqa yəhdər $m^{\S} \bar{a}-h a$ b wähəd-ət-țarīqa māši dokūriya $b$ wāḥd-

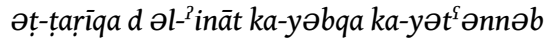

Quelqu'un qui fait le minet vis-à-vis d'une fille, il commence à lui passer la pommade, il devient comme une nana devant elle, il lui parle d'une façon qui n'est pas virile, d'une façon efféminée il est en train de faire le minet.

Karima : a::h ka-yəbqa yət $t^{2} \partial n n ə t$ ?

Ah d'accord, il est efféminé ?

Saida : lla māši mưnnat

Non, il n'est pas efféminé

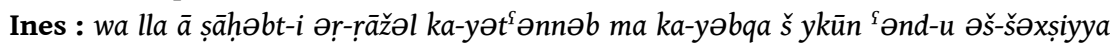
«hbïba » $u$ kda ayy wəh̆da ygūl l-ha hād-əl-hədra!

Mais non mon amie, l'homme qui fait le minet il n'a pas de personnalité, «mon amour » (prononcé d'une façon féminine exagérée) et tout à n'importe quelle fille il lui dit ça comme ça!

[13] Ines : l-wəld huwwa lli ka-ngūlu l-u ka-yət ${ }^{i} ə n n ə b$

C'est le garçon dont on dit qu'il fait le minet

Karima : 'lāš əl-bənt ma ngūlu l-ha ka-tət ${ }^{i} \partial n n \partial b$ ?

Pourquoi on dit pas de la fille qu'elle fait la minette?

Saida : əl-bənt ḡādi təbqa tətbə $\partial^{\varsigma}$ əd-drāri u tgūl l hāda nta beau gosse ?

La fille va suivre les garçons, les draguer, et dire toi tu es un beau gosse?

Karima : ìla dārət hākka?

Si elle faisait ça?

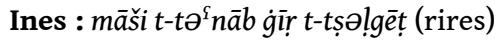

C'est pas faire la minette, c'est seulement faire la pétasse 


\section{Ce qui constitue la féminité, représentations associées aux femmes}

son article de 2011, Sadiqi fait une corrélation entre les expressions qualifiant une femme et les stéréotypes socio-culturels propres au Maroc: la femme est associée à la faiblesse, n'inspire pas confiance (2011: 226). Ainsi qu'on l'a vu dans les extraits du corpus relatifs à la parole tenue, les stéréotypes associés aux femmes restent très négatifs et constituent une certaine forme de violence contre elles (Ziamari \& Meskine 2014).

Toutefois, les représentations exprimées par les interviewé-e-s se révèlent à la fois plus pragmatiques et plus complexes que la vision binaire courante.

24

Asmae insiste sur les capacités propres des femmes et refuse de leur reconnaitre un côté masculin, surtout quand il s'agit de qualités que, par conséquent, on ne pourrait pas mettre du côté féminin. Elle exprime aussi ici une vision bien différenciée des deux sexes.

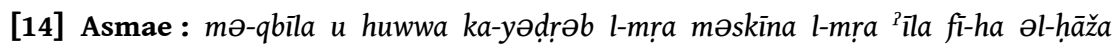
məzyāna ka-ttənsəbl lərr-rāžəl, ər-ṛožūla u l-mra rā-ha mrra fi-ha kull-ši

Depuis tout à l'heure il critique la femme, la pauvre, on attribue les points positifs de la femme à l'homme, à la masculinité, alors que la femme, la femme elle a tout

Karima : kïfăš ?

Comment?

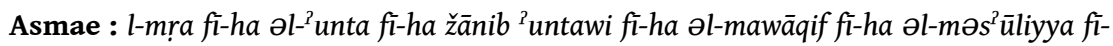

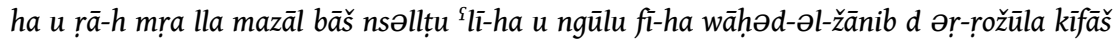

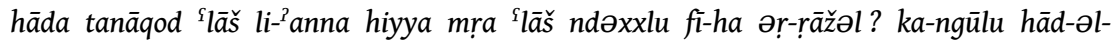

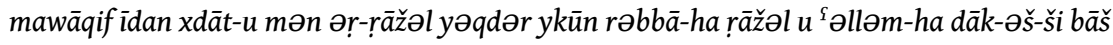
tkūn fəl-mawāqif walākin...

La femme a tout, un côté féminin, une femme dans ses postures, la responsabilité et elle reste une femme, pour la dominer on dit qu'elle a un côté masculin, comment? C'est une contradiction. Pourquoi ? Parce que c'est une femme, pourquoi l'associer à l'homme? On parle de postures qu'elle prend de l'homme, possible qu'elle soit élevée par un homme qui lui a appris ça, pour qu'elle ait des postures mais...

Karima : les valeurs hūma?

Les valeurs, c'est?

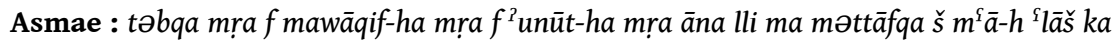

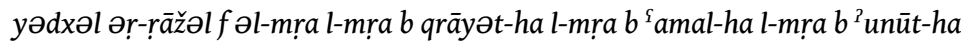

Elle reste femme dans ses postures, une femme quand elle est féminine, c'est une femme, moi, je ne suis pas d'accord sur le fait qu'on associe toujours le masculin à la femme, c'est une femme avec ses études, femme avec son boulot, femme avec sa féminité

Certaines informatrices insistent aussi sur les capacités, le fait d'être capable, et respectable.

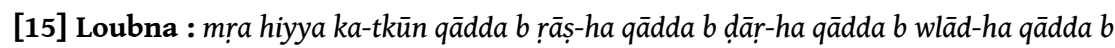
xdəmt-ha qādda b kull-ši ka-ttsəmma mra u nəșs

Une femme, elle s'occupe d'elle-même, s'occupe de sa maison, elle est capable de s'occuper de ses enfants, de son travail, capable de tout, c'est celle qu'on appelle une femme et demie

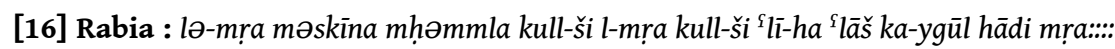

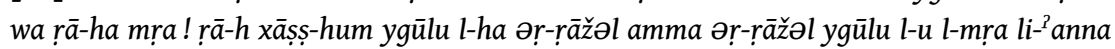

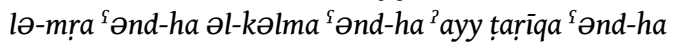

La femme la pauvre, elle supporte tout, tout repose sur la femme, pourquoi on dit, ça c'est une vraie femme! C'est une femme évidemment, on doit la surnommer homme, or l'homme doit être surnommé femme parce que la femme tient sa parole, elle l'a (la parole) quoi qu'il en soit 


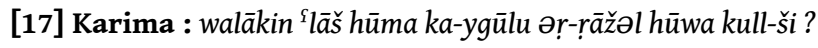

Mais pourquoi on dit que l'homme c'est tout?

Rabia : ma kāyən š əṛ-rāžžl huwwa kull-ši ki r-ṛāžəl ki lə-mra u dāba wəlla əd-dərk ${ }^{\complement} l a$

l-mra ktər mən əṛ-rāžžl

Ce n'est pas vrai, l'homme ce n'est pas tout, l'homme est comme la femme, et maintenant la femme est plus sollicitée que l'homme

Karima : bhāalāš ?

Comment?

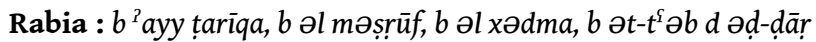

De n'importe quelle façon, côté ménage, côté travail, côté corvées de la maison

Rabia va plus loin encore, pour elle, de par les responsabilités qu'elle assume (Rabia le vit ainsi elle-même), une femme vaut plus qu'un homme.

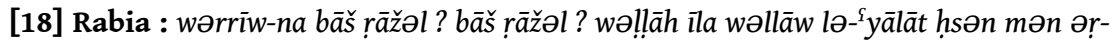

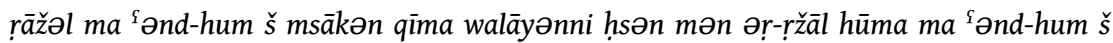

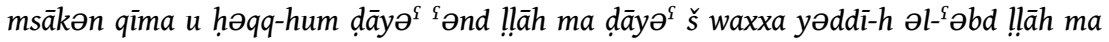

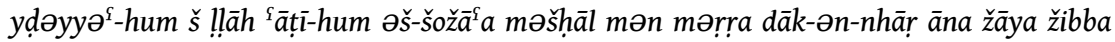

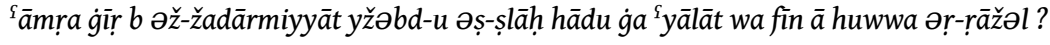
Montre-nous comment tu es un homme? Homme comment? Je te jure que les femmes sont devenues meilleures que les hommes, certes on ne leur reconnaît pas de valeur les pauvres mais elles sont mieux que les hommes. Elles n'ont pas de valeur les pauvres et leurs droits sont perdus, pas perdus pour Dieu, mais perdus avec les humains, Dieu leur a donné de la bravoure, combien de femmes sont braves, l'autre fois j'ai vu une jeep pleine de femmes gendarmes avec des armes et tout, celles-là ne sont que des femmes, alors où est l'homme?

\section{La masculinité ou la féminité ne sont pas biologiques}

Enfin, certains interviewé-e-s formulent des définitions de la masculinité/féminité non pas biologiques et essentialisantes mais bien fluides, performatives, interactionnelles, sociales. Tel que Yasin l'exprime dans l'extrait [7] : « ərr-rožūla f əl-qəlb», la masculinité est dans le cœur, ce dernier compris comme le siège symbolique (et non organique) du comportement et la «masculinité » comme une qualité exprimable par chacun-e, le terme étant à comprendre avec les sens de courage, civilité.

[19] Bilal : b ən-nisba l-i hiyya mawāqif, mawāqif, or-ṛožūla hiyya l-mawāqif

Pour moi, c'est des postures, des postures, la masculinté c'est une question de postures

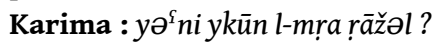

Donc la femme peut être un homme?

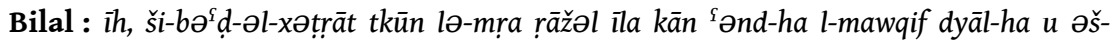
šəxșiyya dyāl-ha

Oui, des fois, la femme est un homme si elle a des postures et une forte personnalité

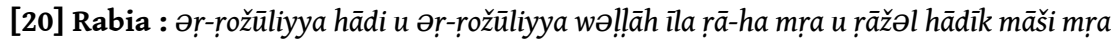

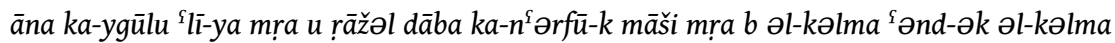

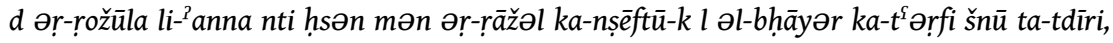

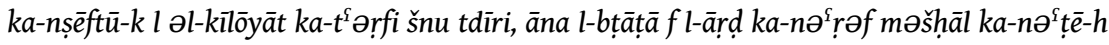
əl-qadār məšhāl ġādi tə⿳亠丷厂 țe-h

La masculinité celle-là, la masculinité je te jure que c'est une femme et un homme, ce n'est pas seulement une femme, on dit que je suis à la fois une femme et un homme, on me dit on te connait, tu n'es pas une femme parce que tu tiens ta parole, tu as la parole d'un homme, toi tu es mieux qu'un homme, on t'envoie dans des endroits tu sais ce que tu fais, on t'envoie peser la marchandise, tu maitrises, tu es 
compétente, moi la pomme de terre est encore dans la terre, je peux lui donner une idée de combien ça va donner.

\section{Synthèse}

Avec ces entretiens et les extraits présentés, nous n'avons pas cherché l'exhaustivité. Ces discours situés nous renseignent néanmoins sur une part des représentations et des termes associés au masculin et au féminin au Maroc, aujourd'hui.

On note une certaine continuité avec des sens et des réalités sociales déjà recensés dans d'autres travaux, mais également de nouveaux termes et concepts comme ${ }^{\text {I }}$ niba et ses dérivés.

Les visions essentialisantes autant que fluides traversent les discours de tous les interviewé-e-s: jeunes et moins jeunes, femmes et hommes. Cela étant, les représentations globales restent partagées entre un pôle positif du côté du masculin et un pôle négatif du côté du féminin - mais les deux pôles interagissent entre eux -, tout en nous confirmant les transgressions possibles de l'ordre social sexué.

\section{BIBLIOGRAPHIE}

Al-Wer, Enam. 2014. « Language and Gender in the Middle East and North Africa », Ehrlich, S., Meyerhoff, M. \& Holmes, J. (eds.), The Handbook of Language, Gender, and Sexuality. Chichester: Wiley Blackwell. 396-411.

Barontini, Alexandrine \& Ziamari, Karima. 2009. « Comment des (jeunes) femmes marocaines parlent "masculin" : tentative de définition sociolinguistique », EDNA 13. 153-172.

Bassiouney, Reem. 2009. Arabic sociolinguistics. Edinburgh: Edinburgh University Press.

Boucherit, Aziza \& Lentin, Jérôme. 1989. « Les dialectes féminins dans le monde arabe : des dialectes minoritaires et leur évolution », Linx 21.17-37.

Butler, Judith. 2005. Trouble dans le genre. Pour un féminisme de la subversion. Paris : La Découverte. Butler, Judith. 2004. Le pouvoir des mots : Politique du performatif. Paris : Éditions Amsterdam.

Cameron, Deborah. 2005. "Language, gender and sexuality: current issues and new directions", Applied Linguistics 26/4. 482-502.

Cameron, Deborah \& Kulick, Don (eds.). 2006. Language and Sexuality. A reader, New York, Routledge.

Caubet, Dominique. 2016. " "Rajel”, "rojola" ou le dépassement possible du genre », communication à la journée d'étude "Faire genre" : pratiques performatives, textes, voix, discours et représentations, GRAL-LaRCGL (UMI, Meknès) et LaCNAD (Inalco), 11 novembre 2016, Université Moulay Ismaïl, Faculté des Lettres et Sciences Humaines (Meknès, Maroc). https:// www.youtube.com/watch?v=i3UrYmggw4o\&feature=youtu.be Dorlin, Elsa. 2008. Sexe, genre et sexualités. Paris : Presses Universitaires de France. 
Ennaji, Moha. 2009. « Multiculturalisme, genre et politique au Maroc », Diogène 225. 55-69.

Eckert, Penelope \& Mc Connell-Ginet, Sally. 2003. Language and gender. Cambridge: Cambridge University Press.

Greco, Luca. 2014. «Les recherches linguistiques sur le genre : bilan et perspectives ", Langage et Société 148. 11-29.

Hachimi, Atiqa. 2001. « Shifting sands. Language and gender in Moroccan Arabic », Hellinger, M. \& Bußmann, H., Gender Across Languages: The linguistic representation of women and men. Amsterdam : John Benjamins. Vol. 1 : 27-51.

Iraqui Sinaceur, Zakia (dir.). 1993. Le dictionnaire Colin d'arabe dialectal marocain (arabe français). Rabat : Al Manahil (8 volumes).

Kharraki, Abdennour. 2001. "Moroccan sex-based linguistic difference in bargaining", Discourse and Society 12/5. 615-632.

Mouhcine, Ouafae. 1997. «Parler féminin : stigmatisation sociale au Maroc », Peuples Méditerranéens 79. 25-34.

Miller, Catherine \& Caubet Dominique. 2010. « Arabic sociolinguistics in the Middle East and North Africa (MENA)», Bal, M. J. (ed.), The Routledge Handbook of Sociolinguistics Around the World. London-New York: Routledge. 238-256.

Sadiqi, Fatima. 2011. "Women and the violence of stereotypes in Morocco », Ennaji, M. \& Sadiqi, F. (eds.), Gender and Violence in the Middle East. New York: Routledge. 221-230.

Sadiqi, Fatima. 2003. Women, Gender and Language in Morocco. Leiden-Boston: Brill.

Vicente, Ángeles. 2009a. « Women's World - Women's Word: Female Life as Reflected in the Arabic Dialects », EDNA 13. 153-172.

Vicente, Ángeles. 2009b. « Gender and language boundaries in the arab world. Current issues and perspectives », EDNA 13. 7-30.

Ziamari, Karima. 2014. « Des femmes contre les hommes : les rapports de genre dans un travail agricole ", Benitez Fernández, M. (ed), Trabajo y palabra: dos formas de expresión de la mujer marroqui . Zaragoza: Universidad de Zaragoza. 143-160.

Ziamari, Karima \& Meskine, Driss. 2014. « Lorsque le Maroc nomme ses femmes : cas de Meknès », Durand, O., Langone, A. D. \& Mion, G. (eds.), Alf lahğa wa lahğa. Proceedings of the 9th AIDA Conference, Neue Beihefte zur Wiener Zeitschrift für die Kunde des Morgenlandes Bd. 8. Wien/Berlin: Lit Verlag. 479-488.

\section{RÉSUMÉS}

$\mathrm{Au}$ Maroc, les gender studies en sociolinguistique sont jeunes. Les paradigmes de la domination et de la différence, selon lesquels les femmes ne parleraient pas comme les hommes et respectivement, ont largement orienté les études linguistiques (dialectologiques) des gender studies. Une autre perspective est celle de la performance, plus fluide et interactive. Le genre n'est pas vu comme quelque chose que nous sommes, c'est surtout quelque chose que nous incorporons/que nous mettons en œuvre et surtout qui est performé (Eckert and Mc ConnellGinet, $2003: 10)$. C'est dans ce cadre que nous nous situons. Notre objectif consiste à interroger «la performance de genre » (Butler 2004) - dans la mesure où les énoncés performatifs ne sont 
pas les seuls à pouvoir signifier et agir, les actes du corps et le discours, aussi, deviennent performatifs - à travers la mise en mots et en discours de la masculinité et de la féminité.

A partir d'entretiens menés, en arabe marocain, avec des femmes et des hommes marocains, nous analyserons, d'un point de vue linguistique et sociolinguistique, comment ces deux concepts sont nommés, définis, reconnus, identifiés, faits et défaits, par les locuteurs/locutrices.

INDEX

Mots-clés : Gender studies, sociolinguistique, performativité, masculinités, féminités, arabe marocain

\section{AUTEURS}

\section{KARIMA ZIAMARI}

Faculté des Lettres de Meknès (Maroc), GRAL / Inalco (Paris), LaCNAD

karima_ziamari@yahoo.fr

\section{ALEXANDRINE BARONTINI}

Inalco (Institut National des Langues et Civilisations Orientales), LaCNAD

alexandrine.barontini@inalco.fr

Inalco, 65 rue des Grands Moulins, 75013 Paris 


\title{
Une approche sociolinguistique $\mathrm{du}$ parler arabe de Ouezzane depuis la perspective du genre
}

\author{
Montserrat Benítez Fernández
}

\section{NOTE DE L'AUTEUR}

Cette recherche s'inscrit dans le cadre du projet de recherche « Patrimonio sociolingüístico en el Magreb : tradición oral y capital cultural (FFI2014-54495-C2-1-P) » dirigé par le Dr. Ángeles Vicente et financé par le Ministerio de Economía y Competitividad, dont le financement a rendu possible aussi bien les missions de travail de terrain que la participation au $12^{\mathrm{e}}$ colloque de l'Association Internationale de Dialectologie Arabe.

\section{Introduction}

1 Il y a trois ans j'ai commencé une recherche sur le dialecte de la ville d'Ouezzane, car j'y avais trouvé une lacune bibliographique. Le parler en question n'avait jamais fait l'objet d'une description complète, j'ai donc cru intéressant de me pencher sur ce parler afin de fournir plus d'informations sur les variétés du Nord du Maroc. Étant donné que quelques étudiants faisaient déjà des recherches de terrain sur la région ${ }^{1}$, dont les résultats viennent de paraitre sous forme de deux chapitres dans l'ouvrage collectif La région du Nord-Ouest marocain : Parlers et pratiques sociales et culturelles, je me suis concentrée sur des recherches de type sociolinguistique. Dans cet article, je vais présenter les résultats d'une recherche en cours sur la variable du genre. Mes analyses, pour le moment, se sont concentrées sur deux points de phonétique et un aspect relatif à la morphologie. 


\section{Informateurs}

2 J'ai établi un corpus à partir d'enregistrements obtenus lors de deux séjours sur le terrain (en février 2014 et en décembre 2016) et j'ai retenu 5 informateurs dans chaque mission. Les données succinctes concernant les informateurs sont :

3 - A. est un garçon de 18 ans. Il est né et a grandi dans la ville, sa mère est originaire de Brikcha (nord de Ouezzane), dans la région Jbala proche de la ville. Il préparait son Baccalauréat.

4 -Y. est un garçon de 20 ans. Il est né et a grandi dans la ville. Sa mère est aussi originaire de la région Jbala avoisinante, plus précisément de Mokrisset au nord-est de la ville. Au moment de l'enregistrement il habitait à Kenitra où il poursuivait ses études universitaires.

5 -M. est un jeune homme d'environ 35 ans. Né dans la ville, il est issu d'une famille originaire de Zoumi (à l'est d'Ouezzane). Il a fait ses études universitaires à Kenitra.

$6 \quad$-R. est une femme de plus de 50 ans. Elle habite la campagne proche de la ville et s'y rend pour travailler quotidiennement comme femme de ménage dans un hôtel. Son niveau éducatif est très élémentaire.

7 -L. est une autre femme d'environ 50 ans aussi, originaire de la ville. Au moment de son mariage elle s'est rendue chez son mari, dans la tribu de Beni Hmad, près de Tétouan. Actuellement elle habite à Ouezzane et elle voyage à Casablanca de temps en temps afin de rendre visite à l'une de ses filles.

8 Ra. est une jeune femme d'environ 30 ans. Elle est originaire de la ville. Elle a suivi ses études universitaires à Larache où elle a vécu 7 ans approximativement, car elle s'y est mariée. Maintenant elle habite de nouveau à Ouezzane.

9 F. Il s'agit aussi d'une femme âgée d'environ 35 ans, mariée et mère de deux enfants. Elle est neggāfa et gère son commerce avec son mari. Son niveau éducatif est moyen, car elle n'a pas poursuivi d'études universitaires. À cause de son travail elle se rend à Fez très souvent afin d'acheter des nouveautés.

10 WH. C'est une dame de 43 ans originaire de la ville. Elle est mariée et mère de deux enfants. Elle a dû quitter l'école très jeune à cause de la perte de son père, son niveau éducatif est élémentaire. Elle a vécu pendant une période de 5 ans à Tanger avec son mari pour des raisons professionnelles.

11 B1. Est un jeune artisan âgé de moins de 30 ans. Il a appris son métier avec sa mère et il a commencé à travailler alors qu'il étudiait encore, son niveau éducatif est donc moyen, il est arrivé jusqu'aux études secondaires.

B2. Il s'agit aussi d'un artisan, âgé de 38 ans. Il est né et a grandi dans la ville. Il dit que son grand-père faisait partie de ceux qui sont venus y vivre il y a longtemps. Son niveau éducatif est basique car à l'âge de 14 ans il est parti à Casablanca pour apprendre son métier de brodeur où il y a passé deux ans. Il habite dans la ville où il est marié et père de deux enfants.

Le temps total d'enregistrement que j'ai exploité dans le corpus est d'environ 6 heures. 


\section{Phonétique}

\subsection{Réalisation de /q/}

14 Nombreuses sont les études consacrées à cette question, or le sujet n'est pas clos. À Ouezzane, j'ai relevé des occurrences des quatre allophones du [Q] : de l'uvulaire sourde [q], de l'occlusive vélaire sonore [g], de l'occlusive glottale ['] et même de la fricative vélaire sourde $[\mathrm{H}]$ avec des expressions composées par le mot waqt.

Ex. : qăllat n-nı̆yya (R) 'manque de bonne volonté', naqqi-ha (WH) 'nettoies-la', ġa$y l q \bar{a}-n i$ muwwžda (L) 'Il va me trouver présente', ma kāyna š farq (WH) 'il n'y a pas de différence';

Ex. : ka-ngūll l-a nū di (Y.) 'je lui dis lèves-toi'.

Ex. : 'a n' ūl l-ək (A) 'Je te dirai', bā’i (B2) 'encore' zuwwā' (B1) 'brodeur'

Ex. : füyaH (R) 'Quand', ka-yddi ma-ha l-wăHtt (R) 'Il passe du temps avec elle'.

15

Il est bien connu que les variantes occlusive uvulaire sourde [q] et occlusive glottale ['] sont caractéristiques des parlers sédentaires aussi bien des citadins que des montagnards (Cantineau, 1960: 69). Je vais donc centrer mon analyse sur ces variantes car c'est à travers ces traits qu'est apparue la variation du genre, ainsi que certaines références le montrent.

La bibliographie précédente signale la réalisation de différents allophones. Premièrement, Heath (2002: 20) affirme que le parler de la communauté musulmane d'Ouezzane est proche de ce qu'il appelle «mainstream Moroccan Arabic» en ce qui concerne la phonologie et la morphologie, donc on doit supposer la réalisation de l'uvulaire sourde [q]. En revanche, il mentionne la réalisation occlusive glottale ['] chez la communauté juive située aux alentours d'Ouezzane (2002 : 142). Mais le reste des travaux ne corroborent pas ces affirmations. Par exemple, dans le mémoire de licence de Khoukh (1993), auquel j'ai eu accès grâce à l'analyse publiée par Caubet dans l'article « Les parlers žbāla à partir de corpus recueillis dans la région en 1992-1995 (sous la direction de Simon Lévy)», il signale, je cite Caubet (2017: 114), que la variante occlusive glottale ['] est réalisée par les femmes âgées n'ayant pas fréquenté l'école, tandis que les hommes réalisent l'occlusive uvulaire sourde. On est donc, déjà en 1993, face à une variation de genre dans le parler de la ville. En 2012, El Khomsi et Malki ont effectué des recherches de terrain qui ont été publiées en 2017. Il s'agit respectivement des articles "Étude des particularités linguistiques du parler žəoli de la région d'Ouezzane» et de "Quelques traits linguistiques du parler de Mokrisset (Province d'Ouezzane)». Parmi les particularités du parler žəbli El Khomsi (2017: 160-161) confirme la réalisation des deux allophones [q] et ['] mais seulement chez les femmes. En revanche, dans le parler de Mokrisset (Malki $2017: 144$ ) la réalisation uvulaire [q] est généralisée à l'exception du mot ḩrəg, qui serait emprunté à d'autres variétés d'arabe. Enfin, moi-même dans une recherche précédente (Benítez Fernández 2015: 102), j'ai observé que la réalisation uvulaire apparaissait d'une façon majoritaire, cependant le trait occlusif glottal me semblait être en retrait, car je l'avais observé chez un locuteur âgé, ancien artisan, que je n'avais pas pu enregistrer.

D'après les données récoltées dans la ville en 2014 et 2016, j'ai remarqué que les femmes de tout âge et niveau éducatif réalisent ce phonème comme uvulaire sourde. D'ailleurs, j'ai recensé 257 items dans le corpus et seulement deux (2) ont été réalisés avec 
l'allophone occlusif glottal ['], et ceci chez la même informatrice âgée de plus de 50 ans. Lorsque j'ai interrogé une des informatrices à propos du phonème [q] et de ses

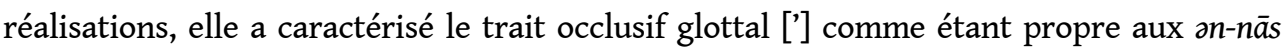
$d y \bar{a} l$ l-bādit (les gens de la campagne), donc le trait serait plutôt stigmatisé, même pour les femmes.

Chez les hommes, la question est un peu plus complexe. L'analyse du corpus a relevé 318 items dont 265 réalisés avec l'uvulaire [q] et 53 avec l'occlusive glottale [']. Parmi ceux réalisés avec l'occlusive glottale ['] seulement 2 occurrences appartiennent à un informateur ayant un niveau éducatif haut, les 51 items restants correspondent à des informateurs ayant un niveau éducatif élémentaire : les artisans, ayant un niveau éducatif bas ou moyen.

\section{TABLE 1}

\begin{tabular}{|l|l|l|l|}
\hline & {$[\mathrm{q}]$} & {$\left[{ }^{\prime}\right]$} & Total \\
\hline Femmes & $255(99,2 \%))$ & $2(0,8 \%)$ & 257 \\
\hline Hommes & $265(83,3 \%)$ & $53(16,7 \%)$ & 318 \\
\hline
\end{tabular}

19 Mes données vont donc dans le même sens que les affirmations sur les réalisations de /q/ présentées par Hachimi (2011) sur les Fassi de Casablanca et par Vicente sur différentes situations au Nord du Maroc (sous presse): l'allophone occlusif glottal n'est pas caractéristique d'un dialecte mais il s'agit d'une variante d'un sociolecte. La nouveauté que mes données présentent est que cet allophone serait propre au sociolecte des hommes citadins ayant un niveau d'alphabétisation élémentaire. Le fait qu'ils appartiennent tous au secteur artisanal pourrait jouer aussi un rôle important, mais cette hypothèse reste à prouver, car il faudrait élargir l'échantillon dans ce groupe professionnel. Caubet (1993: 15) affirme avoir «rencontré cette prononciation chez certains boutiquiers musulmans" dans la ville de Fès. C'est-à-dire, de nouveau un sociolecte très précis. Ce constat viendrait renforcer l'hypothèse d'une réalisation ['] propre au sociolecte des artisans à Ouezzane.

Comment pourrait-on justifier le décalage existant entre mes données et celles proposées par les études précédentes (Khoukh 1993; El Khomsi 2017; Malki 2017)? Les études menées par Khoukh, El Khomsi et Malki se sont concentrées sur des variantes žabli, alors que ma recherche a été menée dans la ville et tous les informateurs y sont nés et y ont grandi. Il se peut que la réalisation uvulaire du [q], présente majoritairement chez les femmes, en général, et les hommes hautement alphabétisés, soit un des signes marquant un certain degré d'urbanisation de ce parler.

\subsection{Amuïssement de /h/}

21 L'autre trait sur lequel je veux m'attarder est l'amuïssement de la consonne fricative glottale sourde [h]. Il s'agit d'un phénomène qui est aussi bien connu dans les parlers sédentaires du Nord du Maroc. Cantineau (1960 : 75) explique, pour les dialectes du Nord de l'Afrique, que le «h peut parfois s'affaiblir jusqu'à disparaitre complètement » plus concrètement dans les pronoms suffixés de $3^{\mathrm{e}}$ personne au masculin, au féminin et au 
pluriel, ainsi que dans d'autres contextes ${ }^{2}$ lorsqu'ils sont annexés à des mots finissant par une consonne. De plus, ceci a été montré par Lévy-Provençal à Ouargha (Lévy-Provençal, $1922: 36)^{3}$, par Colin dans la région du Nord de Taza (1921: 72-73), plus récemment à Anžra par Vicente (2000 : 49), ainsi que partout au Nord du Maroc.

En principe, à Ouezzane, les pronoms suffixés fonctionnent de la même façon que dans le reste des variétés sédentaires, c'est à dire, après une voyelle, on trouvera les formes habituelles partout au Maroc, avec la fricative glottale sourde [h], donc $-h$ pour la $3^{\mathrm{e}}$ p.m. sing., -ha pour la $3^{\mathrm{e}}$ p.f. sing. et -hum pour $3^{\mathrm{e}}$ p. pl., tandis qu'après une consonne on retrouve les formes avec amuïssement de [h] - $a$ et -um respectivement. Mais aussi, lors de certaines occasions, les pronoms suffixés de la $3^{\mathrm{e}}$ p.f. sing. -ha et de la $3^{\mathrm{e}} \mathrm{p}$. pl. -hum peuvent accompagner aussi des mots finissant par une consonne, comme Guerrero (2015 : 144) l'a montré dans son étude sur le parler arabe de Larache. Jusque-là, donc, aucune nouveauté, mais y a-t-il une variation selon le genre dans l'amuïssement de [h] ?

À Ouezzane j'ai répertorié 272 items du pronom de 3e p.f. sing. [-ha] dont $52 \%$ (141) avec amuïssement de [h] et $48 \%$ (131) avec [h].

Dans le cas du pronom suffixé de 3e p.f. sing., 64\% (90) des occurrences avec amuïssement ont été réalisées par les femmes et $36 \%$ (51) par les hommes. La forme -ha a, quant à elle, été utilisée à 56\% (73) par les femmes et à 44\% (58) par les hommes.

TABLE 2

\begin{tabular}{|l|l|l|l|}
\hline & -ha & -a & Total d'occurrences \\
\hline Femmes & $73(56 \%)$ & $90(64 \%)$ & 163 \\
\hline Hommes & $58(44 \%)$ & $51(36 \%)$ & 109 \\
\hline Tous les informateurs & $131(48 \%)$ & $141(52 \%)$ & 272 \\
\hline
\end{tabular}

Mais lorsqu'il s'agit des formes annexées à des mots finissant par une consonne, les femmes ont eu recours à -ha seulement dans 3 occurrences, donc $2 \%$, alors que dans le cas des hommes, ils ont utilisé - $h a 15$ fois, donc dans $11 \%$ des cas. Les hommes semblent donc préférer la forme sans amuïssement. Si l'on se penche sur le pluriel, dans l'alternance -um, -hum, c'est la forme avec amuïssement qui l'emporte. J'ai en effet répertorié 106 occurrences, dont 67\% (71) des items relevés du corpus sont réalisés -um, alors que seulement 33\% (35) sont réalisés -hum . Mais dans ce cas, hommes et femmes préfèrent cette forme -um, car 33 fois chez les femmes et 38 fois chez les hommes le pronom utilisé est -um, alors que seulement 22 fois chez les femmes et 13 fois chez les hommes ils utilisent -hum.

TABLE 3

\begin{tabular}{|l|l|l|l|}
\hline & -hum & -um & Total d'occurrences \\
\hline Femmes & 22 & 33 & 55 \\
\hline Hommes & 13 & 38 & 51 \\
\hline
\end{tabular}


\begin{tabular}{|l|l|l|l}
\hline Tous les informateurs & $35(33 \%)$ & $71(67 \%)$ & 106
\end{tabular}

Alors qu'au pluriel l'ensemble du groupe penche vers la forme avec amuïssement de la fricative glottale sourde [h], qui est la forme habituelle des parlers sédentaires, seulement les femmes auront une préférence pour la forme $-a$ du pronom féminin singulier. Il est évident que les femmes ont une préférence pour les formes avec amuïssement qui, de plus, s'est développée dans des termes autres que les pronoms suffixés, par exemple, les pronoms sujets [uwwa] et [iyya] et le démonstratif [ādi] sont parfois aussi atteints par ce phénomène.

\section{Morphologie}

Le dernier élément de cette analyse sociolinguistique est l'utilisation de la forme passive. On pourrait s'attendre à ce que la formation de la forme passive dans la variété arabe d'Ouezzane coïncide avec celle des variétés sédentaires proches, comme cela a été le cas lors des questions phonologiques que j'ai traitées auparavant. Par exemple, pour la variété arabe de l'Ouargha, Lévy-Provençal (1922 : 31) explique qu'elle est « indiquée, en principe, par l'emploi des septième et huitième formes, elle est quelquefois aussi marquée par la présence de la voyelle - $a$ à la seconde radicale : qabḍo 'ils ont arrêté' > qbādo 'ils ont été arrêtés'. En revanche, la forme passive est obtenue à Ouezzane comme dans d'autres variétés arabes localisées au sud d'Ouezzane, c'est-à-dire avec l'introduction d'un morphème [t-] devant la forme verbale, ainsi que, dans un nombre encore plus réduit d'occurrences avec la forme V ( $t f a$ “ $\partial l-y \partial t f a ” l)^{4}$.

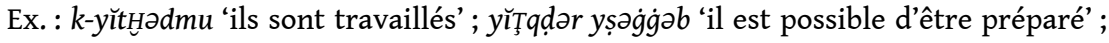
hāda k-yị̧bərm 'la l-ymin 'celui-ci est tourné vers la droite'; yatharras 'il est brisé/il se casse'.

Là aussi, j'ai observé une légère variation suivant le genre. L'analyse des données a montré un emploi de la forme passive plus fréquent chez les locuteurs que chez les locutrices. Ces dernières, lorsqu'il s'agit de donner des indications, utilisent la forme active ou l'impératif.

Ex. : ka-tqəșs-a 'tu la haches', ka-ŢbaHHar $r$-rb $\vec{\imath}$ 'tu fais bouillir (selon contexte) les pousses' ; ka-Ţəqtă 'tu coupes', ka-ddir 'tu fais'.

Je n'ai pas donné de pourcentages, car l'emploi de la forme passive reste faible, et il n'y a aucune occurrence chez les femmes. D'après cette circonstance, je me suis demandée pourquoi les femmes utilisent moins, voire pas du tout, la forme passive. À la lumière des données, l'emploi de la forme passive pourrait être conditionné par une certaine influence du sujet de conversation, ainsi que de l'importance donnée au sujet de l'action. Les sujets choisis ont souvent un rapport avec la vie quotidienne, le travail, la famille, etc. des informateurs. En raison de la répartition des tâches ménagères, les femmes parlent souvent de recettes de cuisine, des enfants ou d'autres occupations informelles, alors que les hommes parlent de leur travail en dehors de la maison. Donc une femme peut très bien imaginer qu'on puisse, plus ou moins, reproduire la recette de la būqqūla, ou les gâteaux pour les enfants, alors qu'un homme verra difficilement son interlocutrice (femme et étrangère, en l'occurrence) devant un métier à tisser, ou à couper, coudre ou broder une žallāba. 

d'une thématisation de l'objet. Retsö $(1983$ : 33) affirme « the FPV [Finite Passive Voice] is the result of an optional topicalization of the object of a transitive sentence » et Caubet $(1987: 121)$ s'aligne sur cette idée de thématisation "d'un repère constitutif différent de l'agent et, éventuellment, de rhématisation de l'agent ». Cette auteure ajoute une analyse de la relation entre la forme passive et l'aspect et elle conclut qu'il n'y a pas de restriction à l'usage du passif à l'accompli qui, comme à l'actif, a des valeurs de parfait et d'aoriste. D'un autre côté, le passif à l'inaccompli est restreint à la valeur de gnomique, « doublée ou non d'une valeur modale marquant le potentiel ou la permission : 'ce qui se fait ou ne se fait pas' » (Caubet 1987 : 116-117). C'est-à-dire que les hommes, lorsqu'ils emploient la forme passive, donnent de l'importance à l'objet (le fil à broder, l'objet brisé, les matériaux travaillés, etc.) et à la façon dont cet objet doit être employé (comment le fil doit être enroulé, comment les matières doivent être préparées, etc.). Tandis que les femmes, lorsqu'elles donnent des instructions ou des indications, mettent l'accent sur le sujet qui exécute l'action.

\section{Conclusions}

Le but principal de ma communication était d'analyser la variation selon le genre dans le parler d'Ouezzane. Afin d'y parvenir j'ai élaboré un corpus formé par les enregistrements des conversations que j'ai obtenu avec 10 informateurs, 5 femmes et 5 hommes, appartenant à différentes tranches d'âges et ayant aussi des niveaux éducatifs différents. J'ai donc choisi d'explorer deux aspects phonologiques et un morphologique, car à la lumière de mes données ils semblaient significatifs dans la variation de genre.

Tout d'abord, j'ai analysé la réalisation de /q/ comme uvulaire sourde [q] ou comme occlusive glottale ['] et j'ai découvert que, malgré les informations données par des recherches précédentes, les femmes et les hommes hautement alphabétisés choisissent, presque exclusivement, la réalisation uvulaire. Cependant, les artisans, peu alphabétisés utilisent l'occlusive glottale [']. Le fait que la réalisation ['] soit qualifiée comme étant caractéristique des n-nās dyāl l-bādī' (les gens de la campagne), ne nous dit pas seulement qu'il s'agit d'un trait stigmatisé, mais confirmerait également le fait que nous sommes face à un certain degré d'urbanisation.

Le deuxième point d'analyse était l'amuïssement de la fricative glottale sourde [h] dans les pronoms suffixés et on a vu que ce phénomène est présent aussi bien chez les hommes que chez les femmes, mais il y aurait une plus claire préférence des formes avec amuïssement chez les femmes que chez les hommes.

Finalement, j'ai observé l'emploi de la forme passive lorsqu'on donne des instructions. Il s'agit d'un usage exclusif chez les hommes, tandis que les femmes utilisent la $2^{\mathrm{e}} \mathrm{p}$. sing. D'après les études publiées sur cette question, la forme passive correspond à une thématisation de l'objet et, lorsqu'elle est employée à l'inaccompli, possède une valeur gnomique. On pourrait conclure que les femmes ne considèrent pas leurs discours comme étant exemplaire.

Après ce résumé, je peux, effectivement, affirmer qu'il y a une certaine variation de genre dans le parler d'Ouezzane, mais à quel point est-elle significative ? Sur la question de la réalisation de l'occlusive glottale, en plus d'une variation de genre, on trouve aussi des motivations de prestige - car les femmes considèrent ce trait comme propre aux gens de 
la campagne - ou des motivations ayant un rapport avec le niveau éducatif, puisque les hommes qui maintiennent ce trait disposent d'un niveau éducatif assez élémentaire. À propos de la variation qui se produit dans l'emploi de la forme passive, à côté du fait qu'elle soit propre au sociolecte des hommes, il faudrait ajouter un certain auto-mépris du discours des femmes.

En conclusion, d'après les données que j'ai analysées, la variable de genre n'est pas complètement figée, au contraire elle s'accompagne souvent d'autres variables.

\section{BIBLIOGRAPHIE}

Aguadé, Jorge. 1994. «La formation du réfléchi-passif dans le dialecte arabe de Skūra (Maroc) », D. Caubet \& M. Vanhove, Actes des premières journées internationales de dialectologie arabe de Paris. Paris : INALCO. 71-78.

Benítez Fernández, Montserrat. 2015. « Notes sur le sociolecte des jeunes d'Ouezzane (Nord du Maroc) », G. Grigore \& G. Bituna (eds.), Arabic Varieties : Far and Wide. Proceedings of the $11^{\text {th }}$ International Conference of AIDA - Bucharest. Bucharest : Editura Universitatii din Bucuresti. 99-105. Cantineau, Jean. 1960. Cours de phonétique arabe. Paris : C. Klinicksieck.

Caubet, Dominique. 1987. «Passif et transitivité : étude comparative de l'anglais et de l'arabe marocain ». La transitivité domaine anglais. Saint-Etienne : Centre Interdisciplinaire d'Étude et de Recherche. 109-126.

Caubet, Dominique. 1993. L'arabe marocain. Tome I : Phonologie et Morphosyntaxe; Tome II : Syntaxe et Catégories Grammaticales, Textes. Paris-Louvain : Éditions Peeters.

Caubet, Dominique. 2017. «Les parlers žbāla à partir de corpus recueillis dans la région en 1992-1995 (sous la direction de Simon Lévy) », Á. Vicente, D. Caubet \& A. Naciri-Azzouz (eds.), La région du Nord-Ouest marocain : Parlers et pratiques sociales et culturelles. Zaragoza : Prensas de la Universidad de Zaragoza. 109-141.

Colin, Georges. S. 1921. « Notes sur le parler arabe du nord de la région de Taza », Bulletin de l'Institut Français d'Archéologie Orientale 18. 33-119.

El Khomsi, Rajae. 2017. «Étude des particularités linguistiques du parler žəbli de la région d'Ouezzane ", Á. Vicente, D. Caubet \& A. Naciri-Azzouz (eds.), La région du Nord-Ouest marocain : Parlers et pratiques sociales et culturelles. Zaragoza: Prensas de la Universidad de Zaragoza. 159-175. Guerrero Parrado, Jairo. 2015. El dialecto árabe hablado en la ciudad marroquí de Larache. Zaragoza : Prensas de la Universidad de Zaragoza.

Hachimi, Atiqa. 2011. « Réinterprétation sociale d'un vieux parler citadin maghrébin à Casablanca », Langage et société 138. 21-42.

Heath, Jeffrey. 2002. Jewish and Muslim Dialects of Moroccan Arabic. London \& New York: Routedge. Khoukh, A. 1993. El habla jebli de la ciudad de Wazzan en 1992. Mémoire de licence d'espagnol non publié sous la direction de Simon Lévy. Rabat : Université Mohamad V. 
Lévi-Provençal, Evariste. 1922. Textes arabes de l'Ouargha, dialecte des Jabala (Maroc septentrional). Paris : Ernest Leroux.

Marçais, Philippe. 1977. Esquisse grammaticale de l'arabe maghrébin. Paris : Librairie d'Amérique et d'Orient.

Malki, Mohamed. 2017. «Quelques traits linguistiques du parler de Mokrisset (Province d'Ouezzane) ", Á. Vicente, D. Caubet \& A. Naciri-Azzouz (éds.), La région du Nord-Ouest marocain : Parlers et pratiques sociales et culturelles. Zaragoza : Prensas de la Universidad de Zaragoza. 143-158.

Vicente, Ángeles. 2000. El dialecto árabe de Anjra (Norte de Marruecos). Estudio lingüístico y textos. Zaragoza : Universidad de Zaragoza.

Vicente, Ángeles. (Sous presse). «l-hədṛa b-əl-qāla (ou la réalisation [?] de /q/) dans les parlers arabes du Nord-ouest du Maroc ». Paris.

Vicente, Ángeles, Caubet, Dominique, \& Naciri-Azzouz, Amina. 2017. « Introduction », Á. Vicente, D. Caubet \& A. Naciri-Azzouz (eds.), La région du Nord-Ouest marocain : Parlers et pratiques sociales et culturelles. Zaragoza: Prensas de la Universidad de Zaragoza. 9-12.

\section{NOTES}

1. Il s'agit des étudiants chercheurs formés dans les «Journées de formation en dialectologie pour des jeunes chercheurs, étudiants en master ou en doctorat " dans les universités de Fès et d'Oujda, organisées par le Laboratoire de Recherches et d'Etudes Linguistiques (Labo-REL) et le Programme Jbala-Nord Taza du Centre Jacques Berque (CJB), dont les résultats de travaux de recherche ont été présentés lors des Journées d'étude « La région du Nord-Ouest marocain - Pour une valorisation des parlers et des pratiques sociales, culturelles et environnementales » à l'Université Abdelmalek Essaâdi (Tanger-Tétouan). Pour plus d'information consulter Vicente, Caubet \& Naciri-Azzouz $2017:$ 9-10.

2. monna < mən hna ; fwāki < fawākih, etc. (Cantineau, 1960 : 75).

3. «Dans les affixes -hu, -hā, -hūm, la consonne h disparaît généralement dans la prononciation, quand la consonne immédiatement précédente n'est pas vocalisée : blādəm 'leur pays' ; rīŢ-a ‘je l'ai vue'».

4. Sur l'utilisation des F. V et VI come réfléchi passif de la F. II et III respectivement, consulter Aguadé 1994 : 73-74 ; Caubet 1993 : 47-50 (vol. I) ; Marçais $1977: 58$ et suiv.

\section{RÉSUMÉS}

Cet article explore la variation sociolinguistique qui se produit dans la variété arabe parlée à Ouezzane, selon la variable du genre. On a choisi trois points d'analyse où la variation de genre est considérable d'un point de vue quantitatif. D'abord, on analyse les deux réalisations de /q/ les plus significatives dans le corpus -l'occlusive uvulaire sourde [q] et l'occlusive vélaire sonore [g]-, puis l'amuïssement de /h/ dans le pronom objet et, en dernier lieu, on examine l'emploi de la forme passive. En plus de l'approche quantitative, on a aussi tenu compte des propos des informateurs afin de qualifier les résultats de l'analyse. 
INDEX

Mots-clés : Sociolinguistique, Genre, Dialectologie, Ouezzane, Maroc

\section{AUTEUR}

MONTSERRAT BENÍTEZ FERNÁNDEZ

Escuela de Estudios Árabes-CSIC 


\title{
Le soi jeune dedans et dehors
}

\author{
Laila Ben Salah
}

\section{Introduction}

Dans les parlers jeunes, objet de notre étude, les références à l'identité sont aussi variées qu'originales. Ainsi, la notion d'identité est multiforme et complexe en raison de sa transversalité disciplinaire : le terme " identité » renvoie au résultat d'un processus qui se développe dans une intrication intime entre le psychologique et le social. Autrement dit, le sentiment d'identité émerge de l'intériorisation des modèles sociaux et de la perception que le sujet a de lui-même dans son engagement au sein d'une réalité sociale mouvante.

2 Dès lors, notre propos s'inscrit dans le cadre du rapport discours, pratiques langagières et identité, et tentera d'apporter des éléments de réponse à la problématique suivante : comment est construite linguistiquement l'image du soi jeune à Fès?

3 Deux grandes articulations sous-tendront notre réflexion. Après la mise en place de quelques précisions méthodologiques consistant en la présentation de remarques sur le phénomène de socialisation, nous montrerons comment les jeunes développent une image de soi à travers les différents espaces de sociabilité, ensuite il sera l'occasion de voir comment est verbalisée cette mise en scène de soi et de l'autre.

\section{Ancrage théorique}

\subsection{La socialisation}

4 Claude Dubar, le sociologue français, qui a largement étudié les identités professionnelles souligne que l'identité est une évolution qui se construit dès le plus jeune âge par le processus de socialisation, il avance, à ce titre que l'identité est un "produit de socialisations successives» (Dubar 1992: 7) ; La socialisation est donc un mot clé pour expliquer en grande partie le phénomène de construction identitaire. 
5 C'est l'américain George Herbert Mead qui a travaillé sur le concept de "socialisation » par le biais des interactions sociales. Celui-ci considère que c'est grâce à l'échange avec les autres membres de la société que l'homme intègre et intériorise les normes de cette société. La socialisation est donc la manière dont l'individu s'ajuste à son environnement social. Ce concept est ainsi défini comme un " processus qui lie un organisme aux autres dans les interactions en cours » (Mead $2006: 243$ ). C'est donc un processus permanent qui permet à un individu de former sa propre identité (personnelle et sociale) par interaction avec les différents éléments de la culture de son groupe. En effet, cette socialisation dépend des évaluations et des performances scolaires, des jugements de l'institution, mais elle résulte aussi de l'activité propre du sujet, de sa capacité à réagir, à s'adapter et à se frayer sa propre voie.

6 Les experts distinguent deux types de socialisation: La socialisation primaire qui se déroule pendant l'enfance par le biais des interactions avec les parents et l'école, et la socialisation secondaire correspond à l'âge adulte. C'est cette socialisation secondaire qui va nous guider pour comprendre nos informateurs, tous adolescents.

7 Ainsi, en se référant à M. Fize (1998), l'adolescence est décrite comme une période délicate à négocier. Ce dernier avance le terme de «crise adolescente » qui est le résultat d'attitudes sociales niant tout statut aux adolescents. Cette crise représente entre autres un fait culturel, c'est une construction sociale.

De même, il faut mentionner que la catégorie « adolescent » est ignorée voire stigmatisée et considérée comme violente par les adultes qui sont socialement et culturellement majoritaires et dominants.

9 Cette attribution négative vis-à-vis de ce groupe minoritaire et dominé tend à concrétiser cette «identité négative » (Trimaille 2003: 159) dans un contexte social profane. Cette identification négative des jeunes coïncide effectivement avec la problématique sociolinguistique qui est la nôtre, vu que ce moment de latence sociale ne passe pas « sans conséquence sur la propension à transgresser, à cacher, à s'individuer » (Trimaille 2003 : 88) en adoptant des pratiques corporelles et linguistiques contradictoires et violentes.

C'est pourquoi, tout en intégrant la dimension interactive de la construction de la réalité sociale des informateurs, nous allons les présenter en se basant sur l'observation à la fois des relations qui existent à travers des actions, des discours et des modalités d'interaction. En effet, les relations interindividuelles comme le précise E. Goffman sont basées sur le même schéma que la représentation théâtrale : "quand une personne se présente aux autres, elle projette, en partie sciemment et en partie involontairement, une définition de la situation dont l'idée qu'elle se fait d'elle-même constitue un élément important » (Goffman 1973 : 229).

\subsection{Corpus et informateurs}

11 La présente étude est le résultat de la collaboration entre l'enquêtrice et la population enquêtée. L'enquête a débuté en juin 2013 et s'est achevée en mai 2014. Nos informateurs sont des jeunes garçons et des jeunes filles élèves au lycée ou personnes qui ont quitté l'école, voire même des personnes qui travaillent.

12 Le corpus recueilli équivaut à cinq heures d'enregistrement dans différents contextes sociolinguistiques auprès de vingt-trois informateurs. Il est constitué de cinq conversations. 
Les extraits qui seront analysés sont produits par les informateurs suivants :

A : il avait dix-neuf ans ; il était originaire du Rif. Enregistré quand il était en tronc commun au lycée Allal el-Fassi. Il vivait dans le quartier « Moulay Abdellah » avec sa mère et son beau-père. Il ne voyait pas son père. Dans le corpus, c'est lui qui avait produit le plus d'énoncés vu qu'il avait participé à deux conversations.

$\mathbf{H}$ : il avait dix-huit ans; il avait commencé une formation à l'école hôtelière qui n'avait pas abouti ; Il habitait dans le quartier «Moulay Abdellah». Son père est d'origine berbère il travaille comme chanteur dans les fêtes de mariage et sa maman est d'origine jebli. Il avait des problèmes avec son père. Ses cousins et cousines étaient des trafiquants de drogue.

$\mathbf{R}$ : il avait vingt ans ; Il participait à des activités d'animation à Dar chabab el-Qods.

Si : il était âgé de dix-neuf ans ; Il était en tronc commun au lycée Abd el-Karim Daoudi. Il était originaire du Sahara. Il habitait le quartier « Sidi Boujida ».

Ys : il avait vingt ans ; il était en deuxième année du baccalauréat. Il habitait au quartier Nassim. Il apprenait la tapisserie pendant les vacances. Il était issu de Ain Médiouna qui se trouve dans le territoire des Jbala.

An : il avait dix-huit ans. Il habitait à Ain Chqef. C'était un élève du tronc commun dont le père était forgeron ; sa mère ne travaillait pas ; il était d'origine jebli.

$\mathrm{Z}:$ il avait vingt-et-un ans. Il était en deuxième année du baccalauréat. Il était d'origine snoussi.

0 : il avait dix-huit ans. Il était en première année du baccalauréat spécialité économie. Il habitait à Oued Fès.

Z.h : il avait dix-neuf ans ; il était en première année du baccalauréat. Il habitait le quartier « Adarissa » à route Ain Chqef.

Zi : elle avait dix-neuf ans. Elle était issue de Quelâat Sraghna.

Sa : elle était âgée de vingt ans et originaire de Taounat.

\section{Socialisation et image de soi dans les parlers jeunes}

Il s'agit de voir comment le locuteur effectue une mise en scène de sa personnalité et comment il puise dans les ressources langagières à des fins communicationnelles diverses, sans oublier la manière dont l'image de soi se construit et se positionne face à un « vous » dans l'échange verbal.

D'ailleurs, la présentation de soi dont il est question est aussi désignée par le terme « éthos » emprunté à la rhétorique et à l'analyse du discours d'après R. Amossy (2010). L'élaboration de l'éthos se manifeste aussi sur des plans corporels et comportementaux et se fonde sur l'image préalable que l'interlocuteur se fait du locuteur, ce qu'Amossy (2010) appelle éthos préalable, ainsi que l'appartenance à tel ou tel groupe, éléments rattachés au contexte extralinguistique.

Dans le même contexte, l'auteur du livre «la présentation de soi : éthos et identité verbale » affirme, en abordant la question de la subjectivité et de l'identité, que l'image de soi que construit le «je» est, par définition dialogique, traversée par la parole de l'autre ${ }^{1}$ adoptant ainsi les propos de P. Bourdieu (1982), M. Pêcheux (1969) et F. Flahaut (1978) tout en critiquant Benveniste qui dit que le locuteur reprend et rejoue les éléments extralinguistiques par l'exercice de la langue. «Il les entraîne dans le dynamisme de 
l'échange où le 'qui je suis pour moi', 'qui je suis pour toi' et surtout 'qui je veux être pour toi' sont renégociés » (Amossy $2010: 105)$.

De manière générale, on peut affirmer que le soi se dit en énonçant, et se fait en parlant de soi-même. Autrement dit, il peut être sujet de l'énonciation ou sujet de l'énoncé :

«L'image de soi peut découler du dit: ce que le locuteur énonce explicitement sur lui-même en se prenant comme thème de son propre discours. En même temps, elle est toujours un résultat du dire: le locuteur se dévoile dans les modalités de sa parole même lorsqu'il ne se réfère pas à lui-même [...] éthos dit et éthos montré » (Amossy 2010 : 113).

On voit clairement que l'image, qu'elle soit individuelle ou collective, qui se construit dans les interactions verbales, repose toujours sur des éléments extralinguistiques et une négociation de l'identité à partir de laquelle le locuteur se pose et tente d'imposer ou de faire partager ses façons de voir.

En partant de ce postulat, la parole sera donnée aux jeunes enquêtés afin de les identifier verbalement en les écoutant se dire et se façonner en se disant.

\subsection{Le soi jeune et les adultes}

Le locuteur A se présente et présente le groupe de pairs auquel il appartient en tant que génération qui doit profiter de cette phase pour vivre des moments agréables avant l'accès à l'âge adulte.

[41] - A : hịt ṛabb-ī f kull 'umr 'țā-nā wāḥad-la-ḥlāwa w la-ḥlāwa d əš-šabāb buḥdithā mā kāyən š gā' ši ḥlāwa bḥāl-hā ' lā š bnādəm xəșș-u yduwwəz f hād əl-wəqt hādā

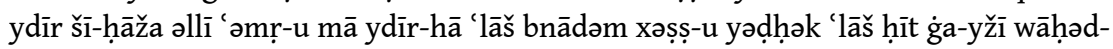
ən-nhāṛ mā ġa-yəlqā š hād-əḍ-ḍəḥk dyāl hād-əš-šabāb hādā

- Parce que Dieu nous a donné un plaisir à chaque période de notre vie, le charme de la jeunesse est unique et n'a pas d'égal, c'est pour cela qu'il faut profiter de ces moments et faire tout ce que nous ne pourrons pas faire après. C'est pour cette raison qu'il faut s'amuser, car un moment viendra où le bonheur de cette jeunesse va nous manquer.

21 Dans ce sens, il ne faut pas assimiler l'adolescence uniquement aux problèmes que l'accès à l'âge adulte apporte aux personnes qui la traversent ou aux comportements que de tels problèmes provoquent chez la plupart de ces personnes.

La jeunesse, dont il est question dans le discours de A, est considérée comme une phase de transition par excellence, entre l'adolescence et l'âge adulte. Cette phase qui correspond à un moment d'attente durant lequel n'ont pas encore été résolues les questions par rapport auxquelles l'âge adulte est défini, c'est-à-dire: le choix d'une carrière, le rôle social et le style de vie.

La situation est différente pour $\mathrm{R}$ qui se voit appartenant à une catégorie stigmatisée et mal comprise par les autres acteurs de la société.

[281] - R : haḍ̣ū m'a əš-šabāb aḍ-ḍā ${ }^{\prime} i^{c}$

- Parlez aux jeunes défavorisés!

Dans la même optique, M. Taborda-Simões (2005) met l'accent sur les tensions inévitables et sur les conflits provoqués par le besoin d'indépendance de l'adolescent vis-à-vis de ses parents. Ainsi, elle soutient sa thèse en citant des spécialistes en sciences sociales (comme Coleman 1961 ; Keniston 1965 ; Mead 1970) qui affirment que « l'expérience adolescente, entraîne inévitablement des conflits entre les jeunes et leurs parents et entre la 
génération des adolescents et les générations des adultes » (Taborda-Simões 2005 : 550). Ces conflits sont exprimés dans les discours de R, de Si et de $\mathrm{H}$.

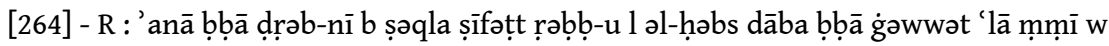
dịabt-u

- J'ai envoyé mon père en prison parce qu'il m'a giflé. Mon père a crié sur ma mère, je l'ai tabassé.

[325] - Si : xì:::t-i xī:::t-i bḥāl dāba nəhḍar dāba ' anā 'lā ṛās-ī bḥāl dāba f əd-dāṛ 'ənd-

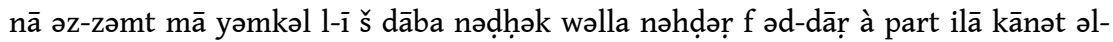
'â'ila məžmū'a nəḍhək wa lakinn fāš ka-nəxrəž bhāl dāba l əz-zənqa ka-nāxud ṛāhtì tamma nxașṣar al-həḍ̣a hatttā nəšbə' m'a wlād la-qhāb

- Ecoute ma sœur, par exemple ma famille est très conservatrice je ne peux pas rigoler ou même parler sauf s'il y a des membres de la famille chez nous. Mais quand je sors dehors je me sens à l'aise, je dis les gros mots et je m'amuse avec les fils de putes.

[650] - H : 'anā w ḅ̣āa əl-'ağlabiyya ka-nətdābzu 'əl lə-quāaya

- Il y a toujours un conflit entre moi et mon père à cause des études.

Ces conflits et ce non-respect des adultes sont dus selon $\mathrm{R}$ à l'usage excessif des réseaux sociaux, facebook entre autres.

[308] - R: 'anā ṛā gult l-ək allī mḍaș̣arr-nā 1 facebook huwwa əllī dāỵ̣ hād-əš-šĩ kāməl huwwa əllī ta-yḍ̣ş̦̣ər 'lī-nā hād-lə-bṛāhəš w hād-əl-bəṛhūšāt hādu

- Je t'ai dit que c'est Facebook qui nous pousse à faire ces bêtises, c'est Facebook qui nous pousse à plaisanter ainsi.

[1150] - Sa : ḥna déjà 'ām 'lā 'ām ən-nās ta-yzīdu yətqəzdṛū

- Ces dernières années les gens deviennent non respectueux.

[1152] - Sa : žỉ qimmiš mā yəḥ̌sm mā yṛimmi š ḥna dāba hād-əl-žīl hāda tqəậ̣i

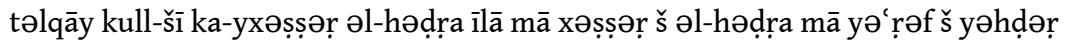

- C'est une génération qui ne connaît pas le respect, il y a des personnes qui ne peuvent pas parler sans passer par la transgression verbale.

L'image que se font les jeunes d'eux-mêmes est dépendante du point de vue des autres,

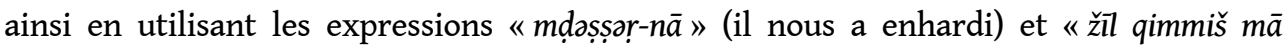
yəh̆̌̌əm mā yrimmi š » (une génération qui ne connaît pas le respect), « ta-yzïdu yətqəzdrū " (ils deviennent de plus en plus irrespectueux), $\mathrm{R}$ et Sa témoignent de cette conception négative qu'ont les adultes envers cette catégorie sociale dont l'image, dans la plupart des cas, est associée à une dépendance soit à la drogue, soit à l'alcool, soit à une autre pratique réprouvée.

[305] R : šətti les jeunes d hād-əl-wəqt kāmal šatti gā‘ allī t'arfî̀-h mā məblī mā taydīr ḥəttā ši-ḥāža 'ənd-u bəlya aḷlā yə'fu 'lī-h 'əṛ̂i-h zāməl

- Tous les jeunes de cette époque sont dépendants de quelque chose. Si tu vois quelqu'un qui n'est accro à rien et ne fait rien sache bien qu'il est un pédé.

Les informatrices quant à elles disent qu'il ne faut pas attribuer une image dévalorisante aux jeunes filles fassies qui utilisent des mots vulgaires dans leur parler. Autrement dit, on ne doit pas identifier les locutrices des gros mots à des filles qui ont des mauvaises attitudes.

[1203] - Sa : əl-fikṛa 'anna gā' ən-nās əlli ka-yhədṛū b hād-langage ṛā-h mussxāt hādi ṛā-h mā kāynā š

- On dit que c'est seulement les mauvaises filles qui parlent de cette façon, cela n'est pas vrai.

\subsection{Le soi jeune et la ville}

Les jeunes locuteurs se font une représentation d'eux-mêmes en rapport avec ce que pensent d'eux les habitants des autres villes marocaines. Ainsi, l'image négative du 
groupe de jeunes Fassis est associée à l'idée qu'ont les habitants de ces villes. En fait, ces personnes représentent une classe dangereuse qui instaure la peur et l'insécurité.

[948] - Z : bhāl dāba nqārən l-ək əl-mudūn dyāl əš-šamāl m'a fās lā 'alāqa təmmā ən-nās bhāl lli tḥəḍ̣̂ūū šwiyya 'lī-nā hnā hnā mazālīn la mentalité dyāl əlḥayawānāt

- Si on compare la ville de Fès aux villes du Nord, on remarquera une différence totale, là-bas les gens sont plus civilisés par contre ici les mentalités demeurent arriérées.

[949] - Z.h : tgūl l-hum nta mən fās mā ka-yəbg்īw š yhəḍ̣ū m`a-k w ḥəqq əḷ̣āh əl'aliyy əl-'adìm

- Je te jure que l'on évite de te parler quand tu dis que tu es de Fès.

[950] - 0 : y'ərrūu-k wəld fās mā ytīqū š fì-k

- On ne te fait pas confiance si on sait que tu es de Fès.

[951] - Z : ta-y'ərf̣ū fāsī šnū ḍārab f žīb-u lə-mḍā ta-yətḥəššəš wəllā ta-yšəmm əssilicium hād-əš-šì əllī ta-y'əṛ̂ū 'lā ffāsa

- Les fassis sont connus pour l'usage de l'arme blanche, de la drogue et pour le silicium.

[952] - 0 : ta-yxāfū mən ffāsa

- On craint les Fassis.

[953] - Z.h : ta-yəbqā 'lī-k ntūma wlād əd-dāxil mā məzyānīn š

- On nous dit : « vous êtes mauvais vous les habitants des villes de l'intérieur »

Ces attitudes délinquantes représentées dans les paroles de $\mathrm{Z}$ constituent, pour d'autres informateurs, des marques de courage, de force et de virilité des Fassis qui en sont fiers. Contrairement aux informateurs des extraits qui précèdent, nous allons voir que les locuteurs procèdent à «l'estime de soi » ou «l'appréciation de soi $»^{2}$ à travers ces attitudes, par rapport aux jeunes des autres villes, comme Casablanca dont les habitants sont considérés comme des adversaires, voire comme des ennemis.

[463] - R : kazāwa ta-ytəḥtəṛ̂̄ l-nā

- Les jeunes Casablancais nous respectent.

[464] - Si : w țanžāwa

- Même les jeunes Tangérois.

[465] - R : 'ṛəfti 'lāš ka-ytəḥtəṛfū l-nā 'lā ḥsāb lə-ḥ̌šřs 'lā ḥsāb əl-kimmiyya

- Tu sais pourquoi ils nous respectent c'est grâce à la drogue, grâce à la quantité de

drogue.

[466] - Si : ḥīt ḥnā 'ond-nā lə-ḥ̌šřs zwì:::won

- Parce que nous avons une drogue de bonne qualité.

[872] - An : hūma 'ārfīn-nā əḍ-ḍ̂ṛ w əl-žəṛh

- Ils savent bien que nous sommes dangereux.

Cette image valorisante du groupe Fassi est associée à la notion d'espace, ainsi être viril consiste à se battre et se défendre en dehors de son quartier ou de sa ville ou lors d'un déplacement pour assister aux matchs de football.

[873] - Ys : ffāsa ka-yxəṛ̌̌ū ' lā fās ka-ysuppṛimīw əl-'â'ila yə'nī nmūtu nətxəșșru

- Les Fassis quand ils quittent leur ville, ils oublient leur famille, c'est-à-dire qu'ils sont prêts à tuer ou mourir.

[874] - An : fāš ta-təxṛวž 'lā ḥūmt-ək 'ād ka-tsəmmā hiyya əṛ-ṛužūla ta-ygūl l-ək xṛəž mən ḥūmt-ək 'lā bəṛ̣̂ā w žīb l-ī ṛūḥ-ək f blādāt ən-nās

- Il faut montrer son virilisme en dehors du quartier ou loin de sa ville.

[875] - E : 'lā bərṛ̂ā ka-tqaṣdū bi-hā xāṛiž fās?

- Tu veux dire en dehors de la ville de Fès.

[876] - Si : 'āh ! məknās əd-dāṛ əl-bīụā

- Oui, comme Meknès par exemple ou Casablanca.

[877] - E : ka-təmšīw 1 kāza tətfəŗ̣̣əžū ?

- Vous allez assister à des matchs à Casa? 
[878] - An : f'ayy match ka-ndēplasēw

- On se déplace pour voir n'importe quel match.

[879] - Si : ta-nțəl'u b zāyəd

- On y va nombreux.

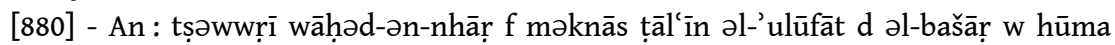
mxəbb'īn mənnā mkānsa ḥnā gāāyīn b əš-šūha yā mkānsa w təxṣạ̣̄ əl-həḍ̣a w ka-

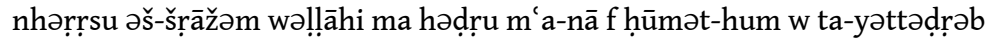

- Un jour nous sommes allés à Meknès, les meknassis se sont cachés, car nous étions des milliers qui insultent et cassent les vitres, ils n'ont pas pu s'approcher de nous même s'ils se trouvaient dans leur propre ville. connue des Fassis envers les jeunes Casablancais est «bīdāwā wlād as-sa' ūdiyya » (les Casablancais, les descendants des Saoudiens), c'est-à-dire que la plupart des femmes à Casablanca s'adonneraient à la prostitution avec les Orientaux.

[871] - Ys : ḥnā ta-ngūlu l-hum wlād วs-sa'ūdiyya fāš ka-nțəl'u l วt-tịrān ka-nkūnu lā'bīn m'a əṛ-ṛāžā ka-ngūlu 'ā bịḍ̄wā 'ā wlād əs-sa'ūdiyya

- On leur dit « les enfants des Saoudiens", quand on va au stade pendant les matchs avec le Raja on insulte les Casablancais en disant : hé Casablancais fils des Saoudiens !

\subsection{Le soi jeune et le quartier}

31 En évoquant toujours « l'estime de soi » Gurtner (2003 : 361) précise qu'à l'adolescence, la dimension globalement la plus importante pour l'appréciation de soi, pour le degré de satisfaction personnelle et l'estime de soi, semble être la dimension de l'apparence physique.

C'est ce dont témoigne le locuteur $\mathrm{A}$ en se référant au quartier populaire qu'il décrit comme l'endroit où sont élevés les jeunes les plus dangereux de la ville.

[331] - A : 'anā wəld mūlāy 'obd alḷā îlā qəddīti āžī

- Je suis issu du quartier Moulay Abdellah si tu peux, viens te battre.

[267] - A : 'anā wəld mū:::lay ' abd əḷ̣āh būmbāy əl-ḥūma d əz-zanāḍēq 'aḥsən ḥūma

- Je suis issu du quartier Moulay Abdellah, Bombay le quartier des Vaillants le meilleur des quartiers.

\subsection{Le soi jeune au sein du groupe}

En parlant des examens le locuteur A se présente comme quelqu'un qui est sûr de ses performances scolaires et qui a une grande confiance en lui-même. Mais à la fin de l'enquête, nous avons découvert qu'il a échoué plusieurs fois à l'école.

Nous allons voir dans les répliques suivantes comment l'informateur A cherche à se montrer viril et courageux au sein du groupe en évoquant les études.

[28] - A : əl-muhimm 'anā fāhəm duṛūs-ī w gāāī nənžh-u nšāà ə!̣̣āh

- Moi, je comprends bien mes leçons et je réussirai si Dieu le veut.

[29] - E : mətfāhəm m'a əl-'asāsid məzyān kull-šì bi xị̣

- ça se passe bien avec les professeurs? Vous vous comprenez?

[30] - A : l-'asāsid 'la hasāāb ka-ygūl l-ək rạbb-ī xləq w faṛ̣əq kīmmā ḥnā nās məxtālfin ḥətta al-'asāsid ḍaṛūịi məxtālfin

- ça dépend des professeurs, on dit Dieu crée et différencie les êtres. Chacun des professeurs est différent des autres comme nous les élèves.

[31] - E : w nta hạafad šī wəlla wālu?

- Et toi tu as appris tes leçons? 
[32] - A : šwiyya əl-muhimm əl-muhimm ḥāfạ̣ šwiyya w șāfī

- Un peu, j'ai appris peu de leçons.

[33] - E : mā moxlū'īn š

- Vous n'avez pas peur?

[34] - A : 'anā ka-nxāf hī m əț-ṭbīb huwwa əllī ka-nxāf mənn-ū huwwa w ṛəbb-ī

- Je n'ai peur que du médecin et de Dieu.

À partir de cet énoncé et de la posture du locuteur $\mathrm{A}$, on remarque que ce dernier adopte une position de chef de groupe ou de «leader » (Trimaille 2003:56) vu qu'il s'est chargé, pendant la conversation, d'organiser la discussion en la présence de plusieurs personnes. Ensuite, il a répondu à plusieurs interrogations de l'enquêtrice sans hésitation et c'est lui, aussi, qui l'a défendue contre un agresseur en entrant avec lui dans un affrontement dangereux. Il parait de plus comme le garant de l'ordre au sein du groupe, car nous allons voir dans les extraits qui suivent qu'il interdit qu'on insulte les filles.

[228] - Si : lā ḥottā hādīk ṛā-h hādīk gì qəḥba

- Celle-là n'est qu'une pute.

[229] - A : lā ma tțiyyəh š əl-həḍ̂ra 'a l-quwwād

- Ne dis pas les gros mots proxénète!

[230] - E : ' lāš ka-yṭiyyəh əl-həḍ̣a yāk ntūma bīnāt-kum hād-əl-həḍ̣ra 'ādiyya

- Pourquoi lui dis-tu ça ? L'usage de la violence verbale ne pose pas de problème

pour vous.

[231] - A : mā xəșṣ-u š yṭiyyəh əl-həḍra əz-zāməl əllī wəld-u

- Il ne doit pas dire les gros mots ce fils de pédé.

On peut conclure d'ailleurs qu'en l'absence de toute institution explicite, le statut de A s'acquiert de fait et en interaction, il exerce par conséquent une influence sociale sur les membres de tout le groupe de pairs.

Par ailleurs, l'informateur An souligne que les identités individuelles des personnes sont mises en mots en choisissant des expressions révélant le caractère personnel de chacun ou d'autres termes qui ne disposent d'aucune référence concernant leurs personnalités.

[705] - E : îlā bgīiti t'iyyวṭ l šì-șāḥb-ək šnū gaa-tqūl l-u

- Pour appeler un ami qu'est-ce que vous dites?

[706] - Ys : lākān 'ənd-u šī-laqab mləqqbīn-u bī-h w 'anā mət'วwwəd ka-n'iyyəț l-u

bī-h ṛā-h ġa-n'iyyəț l-u bī-h bhāl dāba hāda ġa-n iyyəț l-u 'ā əl-məšš

- Je vais utiliser son surnom pour l'appeler par exemple, on appelle celui-ci əl-məšš

(le chat).

[708] - An : 1 hāda ġa-n 'iyyəṭ l-u 'ā konān

- Et celui-là Conan.

[709] - E : w hāda?

- Et lui?

[710] - Si : 'anā ḥanāfī ḥanāfī əl-'ubbaha

- On m'appelle Hanafi əl-'ubbaha

[534] - E : šnū ka-yqūlū l-ək smə‘t ka-yqūlū mīlīngi

- Comment t'appelle-t-on? J'ai entendu Milingui.

[535] - A : mị̣ingi əl-lqāb bāš mə'ṛūf f dīk-la-blāṣa

- On m'appelle Miringui là-bas.

Même dans le contexte féminin, on utilise des expressions pour se désigner entre filles. Ces expressions renvoient le plus souvent à leur état physique, psychique ou à leur comportement.

[1106] - Sa : bḥāl dāba 'anā yqədṛū yqūlū l-î̀ 'a bāțūza matalan 'anā mā ka-yəțlə' l-ī

š əd-dəmm

- On peut m'appeler l'obèse, je ne me fâcherai pas.

[1107] - Zi : kulla wəḥda mləqqbīn-hā 
- Chacune a un surnom.

[1108] - Sa : māšī mləqqbīn-hā b šīlaqab dīma ka-n'iyyțu l-hā bī-h ça dépend 'la ḩāāb la situation

- On n'utilise pas toujours le même surnom, ça dépend de la situation.

[1254] - Sa : lā hādi ka-ngūlu l-hā əl-gəzzāṛ ka-ngūlu l-hā ' a xāy widād 'lā ḥsāb dīma lābsa kiṭmāt lābsa sṛāwəl kaskīta mā ka-təlbəs š 'ayy ḥāža əṣ-șāk 'əmməṛ-hā mā həzzāt-u 'aṣlan əš-šəxṣiyya dyāl-hā māyla l əd-dṛāṛī

- On appelle celle-ci le boucher, ou frère Ouidad parce qu'elle porte souvent un survêtement, un pantalon et une casquette, elle ne s'habille pas comme nous elle n'a jamais porté un sac à main, elle a un caractère masculin.

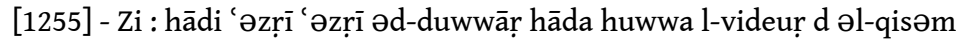

- Elle ressemble à un mec, c'est le mec du quartier, le videur de la classe.

\section{Conclusion} comment les jeunes locuteurs se présentent et s'identifient par rapport aux adultes, à la ville, au quartier et par rapport au groupe de pairs, ces derniers s'attribuent à chaque fois une identité au-dedans et au dehors de chacun de ces éléments. Nous pouvons aussi constater que la langue constitue un élément essentiel de l'identification et de la reconnaissance de soi chez l'individu comme chez le groupe. Elle est utilisée par les locuteurs pour marquer leur identité et se démarquer des autres.

Cette étude a tenté de conjuguer sociolinguistique et parlers jeunes dans le but de déceler comment est verbalisée, façonnée et perçue l'identité jeune. De nombreuses pistes restent à explorer et d'autres disciplines à interroger (psychologie, sociologie, etc.).

\section{BIBLIOGRAPHIE}

Amossy, Ruth. 2010. La présentation de soi. Ethos et identité verbale. Paris : PUF.

Bourdieu, Pierre. 1984. Questions de sociologie. Paris : Éditions de Minuit.

Coleman, James. 1961. Adolescent Society: The Social Life of the Teenager and Its Impact on Education. New York: The free Press of Glincoe.

Dubar, Claude. 1992. « Formes identitaires et socialisation professionnelle », Revue française de sociologie Vol. $33 \mathrm{n}^{\circ}$ 4. 505-529.

Fize, Michel. 1998. Adolescence en crise ? Vers le droit à la reconnaissance sociale. Paris : Hachette.

Flahaut, François. 1978. La parole intermédiaire. Paris : Seuil.

Goffman, Erving. 1973. La mise en scène de la vie quotidienne. Paris : Minuit.

Gurtner, Jean-Luc. 2003. " Adoslescent self and identity development ", Feldman, S. S. \& Elliot, G. R. (eds), At the threshold: The developping adolescent. Cambridge : Harvard University Press. 352-387.

Keniston, Kenneth. 1965. The Uncommitted: Alienated Youth in American Society. New York: Harcourt, Brace \& World. 
Mead, George Herbert. 1970 [1934]. Mind, Self, and Society. Charles W. Morris (ed.). Chicago:

University of Chicago Press.

Mead, George Herbert. 2006. L'esprit, le soi et la société. Paris : PUF.

Pêcheux, Michel. 1969. Analyse automatique du discours. Paris : Dunod.

Taborda-Simões, Maria da Conceição. 2005. «L'adolescence : une transition, une crise ou un changement?", Bulletin de psychologie 459. 521-534.

Trimaille Cyril, 2003, Approche sociolinguistique de la socialisation langagière d'adolescents, Thèse de doctorat en Sciences du langage, Grenoble III.

\section{NOTES}

1. Le « je » implique un « tu » dont la relation constitutive donne la subjectivité qui est aussi une identité selon Amossy (ibid.)

2. L'estime de soi est défini par Jean-Luc Gurtner (2003: 361) comme l'image ou la perception qu'un individu a de lui-même dans plusieurs domaines de sa vie et la réaction affective que lui inspire cette image. Qui existe indépendamment des raisons objectives de satisfaction ou de mécontentement que l'on peut avoir envers soi-même.

\section{RÉSUMÉS}

Cette présentation se propose de passer en revue, dans une perspective sociolinguistique, les expressions utilisées par les jeunes fassis pour peindre leur propre identité par rapport à l'espace qu'ils occupent dans la finalité de se donner une image distinguée et imposante. Nous allons donc essayer d'examiner les mises en mots de l'identité par les jeunes informateurs qui se façonnent et se définissent par rapport aux autres acteurs sociaux, construisant ainsi des représentations et des visions. Cette recherche résulte d'une enquête de terrain auprès de jeunes informateurs issus de la ville de Fès dont l'âge varie entre seize et vingt-quatre ans. L'enquête a été effectuée au cours des années 2013 et 2014. Il s'agit de cinq heures d'enregistrements réalisés dans différents espaces : à la piscine, au café et au centre commercial de la liberté.

\section{INDEX}

Mots-clés : Identité, soi, parlers jeunes, socialisation, représentation

\section{AUTEUR}

\section{LAILA BEN SALAH}

Doctorante à l'Université Sidi Mohamed Ben Abdellah laila_bensalah@hotmail.fr; n 23 avenue Beyrout résidence Zaytoune route imouzzar, Fès. 


\title{
Vers une littératie numérique pour la darija au Maroc, une démarche collective
}

\author{
Dominique Caubet
}

1 Je travaille sur le passage à l'écrit de la darija depuis le tout début des années 2000. Je me suis intéressée à ce phénomène que j'observais tout en y prenant part. Dès que j'ai eu mon premier téléphone portable avec une puce marocaine en 2002, j'ai moi-même communiqué par SMS (Short Message Servicing), sans imaginer l'ampleur qu'allait prendre ce mode de communication dix ans, puis quinze ans plus tard. Je relis avec amusement ce que j'entrevoyais en 2003 (Caubet 2004a: 248), à une époque où le Maroc comptait moins d'un million de SMS par jour (ce qui était déjà énorme !) :

Il semble bien que cet événement ait des répercutions sur les pratiques sociales et qu'il y ait des enjeux sociolinguistiques inattendus. Je m'attacherai donc à montrer, au-delà de la description des usages, les conséquences au niveau sociolinguistique de l'arrivée massives des téléphones portables, et de l'utilisation des SMS par les jeunes scolarisés issus des milieux modestes.

2 Le Maroc a été pionnier en Afrique et dans le monde arabe pour le développement des téléphones portables dans toutes les couches de la société, pas seulement pour une élite urbaine. Le SMS étant le moyen le plus économique de communiquer, leur nombre va aller croissant jusqu'en 2014 avec plus 19,67 milliards de SMS envoyés. Ensuite, on constate une baisse assez soudaine et régulière avec 16,60 milliards en 2015 , pour chuter de 50\% en 2016, avec seulement 8 milliards et revenir aux chiffres de 2012. La tendance se confirme en 2017, avec 3,13 milliards pour les deux premiers trimestres ${ }^{1}$. En novembre 2017, on fête les 25 ans de l'apparition des SMS dans le monde.

3 C'est que le SMS est lié aux téléphones mobiles de première génération, alors que des applications comme WhatsApp ou Messenger de Facebook, sont venus les remplacer pour les propriétaires de smartphones dont le nombre a explosé. Les pratiques de communication ont donc changé, mais on reste dans le domaine de l'écrit informel. 
4 Pour ce qui est des statistiques, le taux d'équipement des individus (12 à 65 ans) en téléphone mobile est généralisé pour la quasi-totalité des ménages en 2016 ( $95 \%$ contre $94,4 \%$ en 2015), aussi bien en milieu rural qu'urbain. L'équipement des individus en smartphone enregistre une évolution notable et passe à $67 \%$ (soit plus de 18 millions), au lieu de 54,7\% en 2015 et 38,2 \% en 2014 (ANRT 2017a : 6, 9, 15).

5 Ce qui est remarquable c'est ce passage à la communication écrite par le biais de claviers et d'écrans, majoritairement de téléphones, plus abordables que les ordinateurs ou, plus récemment, les tablettes.

6 Un passage à l'écrit progressif depuis 2001, qui s'est développé sans aucune prise en charge officielle, en l'absence de reconnaissance de cette langue, et donc, par le biais d'un apprentissage collectif, non-institutionnel. Il ne s'agit donc pas d'une standardisation, comme le rappelle Catherine Miller (Miller 2017: 109). On analysera cette démarche comme relevant du DIY (voir Caubet 2018), Do It Yourself -ou en darija «Debber It Yourself» (débrouille ça toi-même), et comme une action spontanée et collective -voire citoyenne (voir plus bas)- d'acquisition de la lecture et de l'écriture d'une langue noncodifiée. Cette démarche est individuelle au départ (Miller 2017: 107), mais se révèle collective dans l'échange et aboutit à une forme de "conventionnalisation » (comme le suggérait Gunvor Mejdell²), par la force combinée de l'action collective et de l'usage répété.

7 On commencera par faire un historique des différents supports de ces nouvelles écritures de la darija, en graphie latine puis arabe, avant d'aborder les derniers développements apparus surtout à partir de 2013, marqués par l'arrivée de textes plus élaborés en graphie arabe, tant au niveau du contenu que de la forme -plus littéraire. On peut désormais parler d'une véritable littératie numérique, telle qu'en connaissent tous les pays, mais s'agissant ici d'une langue sans statut ni support institutionnel, la darija (voir Caubet 2017 et Caubet 2018). Cette littératie est généralement associée à la citoyenneté numérique (voir habilomedias.ca), ce qui rejoint les remarques sur la démarche nécessairement collective évoquée ci-dessus. On finira en analysant les habitudes orthographiques constatées dans cette nouvelle graphie arabe (voir Caubet 2017b).

\section{Un historique des différents supports et lieux}

8 Avant de passer aux écritures numériques, on rappellera une expérience antérieure datant de la fin du $20^{\mathrm{e}}$ siècle. En 1995, l'épreuve facultative d'arabe dialectal au baccalauréat français qui était un oral, passe subitement à l'écrit pour la session de 1995. L'organisation en est confiée à l'INALCO pour les vingt-huit langues éligibles à l'époque qualifiées de «langues ne faisant pas l'objet d'un enseignement » (Caubet 1999). Il faut donc en deux ou trois mois faire des choix graphiques et les rendre accessibles aux futurs candidats. Ceci fut fait en double graphie, partant du principe que les jeunes qui parlent l'arabe maghrébin en France ne savent pas forcément lire l'arabe standard et qu'il faut les aider à passer brusquement d'une épreuve orale à une épreuve écrite. De plus il s'agit d'une épreuve pour des « langues ne faisant pas l'objet d'un enseignement », c'est-à-dire qu'il s'agit de tester des connaissances acquises en dehors de l'école. 


\subsection{Préhistoire : essai de « notation usuelle »}

9 L'épreuve aura duré cinq ans, pendant lesquels 37.857 copies $^{3}$ ont été corrigées pour l'arabe maghrébin (algérien, marocain et tunisien) uniquement, avec un pourcentage croissant de candidats au fil des années (voir Caubet 1999, 2004b).

10 Nous nous étions réunis pour essayer de décider de quelques normes de notation usuelle de l'arabe maghrébin en vue de publications de textes de la création contemporaine maghrébine, lors de Journées d'Etudes organisées à l'INALCO les 24 Mai et 6 Décembre 1997. Le Père Pierre Georgin, du Centre des Glycines d'Alger, $\mathrm{y}$ a participé très activement, mais il est décédé le 14 janvier 2000 ; nous avons dédié la publication d'une synthèse de ces travaux à sa mémoire en juin 2000 (Caubet 2000). Une publication a également rendu compte des résultats d'un colloque sur les questions de graphie pour les «Langues de France » (dont le berbère et l'arabe maghrébin font partie, voir Caubet 2002).

11 Ceci se passait déjà en l'absence de normes graphiques officielles. Le choix de deux graphies (arabe et latine) était destiné à permettre l'accès aux textes à une jeunesse éduquée en Europe qui, bien que parlant couramment l'arabe maghrébin, n'avait jamais étudié l'arabe standard en milieu scolaire ou religieux et ne savait pas déchiffrer la graphie arabe ${ }^{4}$.

12 Tout ceci se passait avant l'arrivée des nouvelles écritures sur ordinateurs et téléphones mobiles qui doivent se limiter à la graphie latine pendant une petite dizaine d'années, faute d'avoir des claviers arabes ou de savoir taper en arabe pour la majorité.

\subsection{Les premiers pas en graphie latine sur internet au Maghreb :}

\section{2-2011}

13 - Sur ordinateurs

On rappellera brièvement la création de réseaux sur ordinateur par des pionniers, en particulier via la communauté virtuelle MiRC (Chat Internet Relay Connexion) ${ }^{5}$ (voir Babassi 2004 pour l'Algérie et Berjaoui 2001 pour le Maroc). Il s'agissait de «chatcommunications » sous pseudonymes, réservées au début à des gens qui possédaient des ordinateurs. La popularisation viendra plus tard avec Msn Windows Live et dans les cyber-cafés qui vont fleurir au début des années 2000. On voit par exemple la liste des pseudos dans la colonne de droite dans la figure 1 (@PaSsion, @slider, @MillrTime, @tommygrl).

14 - Sur téléphones portables:

En parallèle, se développe, toujours en graphie latine, une communication écrite sur téléphones portable par le biais des SMS ou textos, c'est-à-dire avec des formes courtes qui vont cependant permettre l'établissement de véritables littératies pour des jeunes qui ne maîtriseraient pas la communication dans d'autres langues que la darija, en français ou arabe standard par exemple (voir Caubet 2004a).

15 En quinze ans d'observations, j'ai assisté incrédule au départ, à ce processus de passage à l'écrit fait par les utilisateurs qui ont su dans un premier temps, utiliser et mettre au point une graphie latine, puis passer à la graphie arabe, tout en étant capable de manier les deux. 


\section{Graphie latine} donné à cette pratique, mais il diffère d'une région à l'autre. Dans l'est du monde arabe jusqu'à la Tunisie, le nom de Arabizi (comme Arab et easy), souvent curieusement écrit comme ça et non pas 3rabizi. En Egypte on trouve également le nom Franco qui se rapproche, on le verra d'un nom récent au Maroc. En effet, au Maroc, on a commencé par utiliser l'expression e-darija (comme e-commerce) dès 2006, pour voir réapparaître un vieux mot valise 3aransiya. Le mot formé de 3arbiya et faransiya, désignait le codeswitching darija-français dans les années 80 et qui connaît un revival pour désigner la darija écrite en graphie latine. Un blogueur marocain a même forgé le mot far3abiya sur le modèle inverse (faransiya et 3arbiya), avec une métathèse.

lien de cette graphie latine avec le codeswitching français-arabe ou anglais-arabe, est confirmé par le film de la réalisatrice jordanienne Dalia Al Kury (2006), Arabizi, consacré au codeswitching anglais-arabe au Moyen-Orient (voir aussi Gonzalez-Quijano 2012).

\subsection{Nouveaux Réseaux sociaux: Msn, Facebook et WhatsApp}

Jusque vers 2009-2010, la seule graphie utilisée au Maroc est la graphie latine, sur les réseaux sociaux successifs, Msn, puis Facebook, qui se développe à partir de 2008-9 pour connaître un pic spectaculaire début 2011 avec le 'printemps arabe' et le Mouvement du 20 février marocain.

Msn permettait la pratique du chat qui ne se développera qu'à partir de 2014 sur Facebook Messenger, puis sur WhatsApp à partir des smartphones. Récemment, on est passé à la communication orale qui a fait reculer de façon significative le nombre de messages écrits et de SMS (voir tableau 1). Twitter a toujours été très marginal au Maroc.

21 Pour donner les derniers chiffres, le taux de pénétration de l'Internet dans les ménages atteint 68,5\% en 2016 contre 66,5\% en 2015 (ANRT 2017: 7). Il y a un net avantage pour la connexion sur téléphones mobiles qui équipent $66,5 \%$ des ménages $(20,7 \%$ ont un accès Internet fixe). En 2017 (ANRT 2017: 10), 99,52\% des ménages sont équipés d'un téléphone mobile et $85,9 \%$ des individus de 12 à 24 ans équipés en téléphonie mobile ont un smartphone contre 27,5\% pour la tranche d'âge 55-64 ans 2017 (ANRT 2017: 16).

En ce qui concerne la communication écrite via SMS, elle a connu un pic en 2014, voyant son chiffre chuter trimestre après trimestre à partir de 2015 (ANRT 2015, 2016, 2017), pour retrouver les chiffres de 2011 pour l'année 2017 en cours (voir tableau 1). 
Tableau 1 - Nombre de SMS sortants - D. Caubet à partir des chiffres de l'ANRT

\begin{tabular}{|l|l|}
\hline Année (décembre) & Nombre de SMS sortants \\
\hline 2003 & 550 million (estim.) \\
\hline 2009 & 2.85 milliards \\
\hline 2011 & 5 milliards \\
\hline 2013 & 11 milliards \\
\hline 2014 & 19.7 milliards \\
\hline 2015 & 16.60 milliards \\
\hline 2016 & 8.03 milliards \\
\hline $20171^{\text {er }}$ sem. & 3.31 milliards \\
\hline
\end{tabular}

23 En 2016 les appels VOIP sont bloqués au Maroc, devant la chute des communications téléphoniques payantes. Elles seront rétablies début novembre 2016 et WhatsApp ainsi que Facebook messenger sont largement utilisés pour échanger gratuitement à partir de connexions internet dans des lieux publics.

\section{Arrivée de la graphie arabe}

La graphie arabe a commencé à arriver au Maroc en 2009, avec l'interface arabe de Facebook, mais elle est longtemps restée minoritaire (33\% fin 2014 voir Caubet 2017a).

\subsection{Sur ordinateur et sur smartphones}

La démocratisation des smartphones et les claviers téléchargeables vont complétement changer la donne à partir de 2014-2015. Les gens vont s'apprendre à saisir en arabe, y compris pour les plus arabophones, sur ordinateurs.

Des applications permettent même de transformer en graphie arabe ce qui est saisi sur des claviers latins, offrant des choix de longueur de voyelles ou de césure de mots (voir Figures 2 et 3 ).

Toutes ces techniques ont permis l'écriture directe depuis des claviers, reléguant le papier et le stylo aux oubliettes. On voit en effet aujourd'hui des artistes lire leurs textes à partir de leur écran de téléphones et non plus à partir de leurs carnets. Voir figure 4 (lecture sur papier début 2015) et figure 5 (lecture sur écran).

\subsection{Formes élaborées en graphie arabe post 2011}

Ce que la facilité d'écrire en graphie arabe a permis, c'est l'apparition de textes plus longs, plus élaborés, donnant lieu à un passage à l'écrit qualitativement significatif, à une 
forme réelle de littératie en darija, à partir de 2014-2015. Ce sont des textes en prose avec un contenu ou une valeur littéraire, et donc ni des formes rimées, ni des dialogues de théâtre.

J'ai étudié une cinquantaine de textes publiés en ligne soit sur des blogs, soit sur des sites de périodiques en ligne, comme goud.ma, soit de longs posts sur facebook. La longueur minimale étant une page. J'ai publié une analyse de ce phénomène nouveau dans Caubet 2017a et 2018, mais je voudrais m'attacher plutôt ici à décrire les habitudes orthographiques de ces auteurs.

\section{Analyse des habitudes orthographiques en graphie arabe}

En l'absence d'aménagement officiel, des habitudes ont été prises, consciemment ou pas, produisant une écriture régulière ou pas. Pour ce qui est des décisions conscientes, le point de vue dépend de la relation de la darija par rapport à l'arabe standard: veut-on s'en approcher et rendre la lecture plus facile? Ou, au contraire, veut-on marquer une rupture entre la darija et le standard? Parce que la façon d'écrire n'est jamais neutre (Miller 2017: 91). Il sera intéressant de noter d'ailleurs que des décisions ont été prises par des linguistes pour la publication d'un dictionnaire unilingue de la darija qui sont tout à fait différentes des pratiques que nous avons pu observer et que nous exposons ici (voir 4.2. et Zakoura 2017).

\subsection{Graphèmes et longueur des voyelles : des conséquences en chaîne.}

31 - Le phonème /g/ au Maroc se note avec la lettre kaf ( () , surmontée ou pas de trois

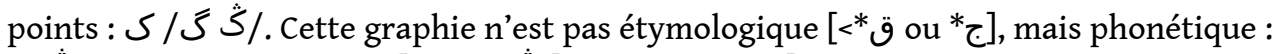
كاليه [gal liya, il m'a dit<*ain, assis <*], ou la marque Butagaz qui s'écrit (Figure 6) et qui est une translitération du 'g' français.

32 - Les interdentales -qui ne sont pas réalisées en darija- sont peu écrites, en particulier dans les déictiques et les conjonctions ديك نهار (dïk nhār, ce jour-là) ; حيت (hitt parce que) ;

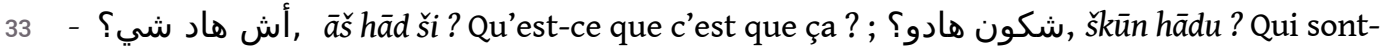
ils ; f-hād el-blād dans ce pays.

34 On trouve quelques occurrences de graphèmes

35

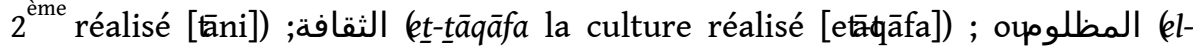
meậlūm l'opprimé réalisé [el-međ̃lūm]).

- Assimilations et aphérèses : vers une écriture phonétique.

On note chez certains une tendance à écrire la darija de façon phonétique, en " fondant » forme verbale et complément prépositionnel, comme dans كاليه (gäl li-h il lui a dit, écrit $g \bar{a} l i h)$, avec une assimilation de la dernière consonne du verbe $l$ à la préposition $l-$.

De même, l'indice de personne $t$ - assimilé par la consonne initiale $d$ du verbe, disparaitt dans la graphie هي كدير (katdir, elle fait, écrit kadir). On peut le trouver écrit, comme dans كاتدوز فيه (katdūz fi-h tu y passes). 
39 Enfin, la préposition ḥta est souvent prononcée [ta], avec aphérèse du h. Nombreux sont ceux qui l'écrivent comme elle se prononce : تاحد (ta ḩədd personne); تاهي (ta hiya elle aussi)

40 - Hésitation sur la longueur des voyelles. La longueur des voyelles en darija est l'un des points clefs de cette nouvelle orthographe. On remarque des différences d'un auteur à l'autre et chez le même auteur. Ces décisions ont des conséquences sur la morphologie et la syntaxe de la langue à tous les niveaux, amenant des réactions en chaîne.

41 - Pour ce qui est conjugaisons, comment marquer les indices de personnes et les pronoms affixes?

42 - À la conjugaison suffixale l'indice suffixé $2 S G$-ti s'écrit comme une longue (la forme est rare) : kun-ti (tu étais) où les deux voyelles sont brèves peut se trouver écrit avec deux

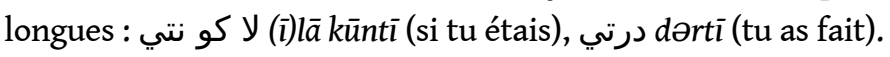

43 De même la 2PL de la conjugaison suffixale s'écrit avec une longue دوزتئ (dūztū vous êtes passés) ; ou le pluriel des verbes : كنشوفو (kanšūfū nous voyons) ; تفارقو و (tfārqū ils se sont séparés).

44 Il en est de même pour les pronoms affixes 3MS après consonne, réalisés [u] en darija ; ils sont très majoritairement écrits سميتو و (smîtū son nom) ; القصة ديالو (el-qasšsa dyālū son histoire) ; شكارتو (škārtū son sac).

45 Par contre le dictionnaire Zakoura a choisi une graphie • (ديالة : dyāl-h à lui), comme nous l'avions d'ailleurs fait dans le groupe de travail de la fin des années 90 (Caubet 2000: 6), dans un souci pan-maghrébin à l'époque, pour être compatible/lisible avec tous les parlers nord-africains.

$46-$ - dyāl-kŭm (votre) lī-kŭm (à vous) kŭll ši (tout)

47 - On trouve des allongements dans les quantificateurs kŭll (tout) ou les pronoms affixes kŭm / -hŭm: ديالكوم -dyāl-kūm (votre); ليكوم lī-kūm (à vous) ; كولشيlll šî (tout). Ces pronoms sont en réalité des brèves : ديالهم dyāl-hŭm (à eux).

48 - Comment noter le préverbe de l'inaccompli $k a-/ t a-$, la particule de futur $\dot{g} a$ - ou le morphème négatif $m a$ ? La décision concernant la longueur va en entraîner toute une série d'autres qui relèvent de la morphosyntaxe. Dans un premier temps, se pose la question de la longueur de ces formes courtes considérées comme des préfixes, 5 ou $\zeta, \dot{\varepsilon}$ ou $\rho$ ou $م$. Ensuite vient le statut de ce morphème : est-il ou pas rattaché à la forme verbale ? Enfin, l'indice $y$ - de $3^{\text {ème }}$ personne du masculin est-il écrit long ou bref après le préverbe $k a-$, puisqu'une diphtongue se forme $k a-y$ - qui se trouve souvent réduite à $k i-$ : [kāy> kăy > kī> kī]. Ka-y-hdor > ki-hdar et si le $i$ est considéré comme bref, il n'est pas écrit : كهضر (k-h-d-r il parle) ; de même dans ka-y-ġawwet il crie, écrit $(k-\dot{g}-w-t)$ ou $k a-y$-șowwar il filme, écrit $(k-s ̣-w-r)$ كصور.

50 Parfois l'indice de personne est écrit comme une longue : $k(a)$-y-sāwi c'est égal à, écrit كيساوي.

51 On trouve des formes longues de la particule de futur qui est rattachée à la forme verbale : لمن غايشبه (lo-mman g்ä-yšbəh ? À qui va-t-il ressembler ?), ou des formes

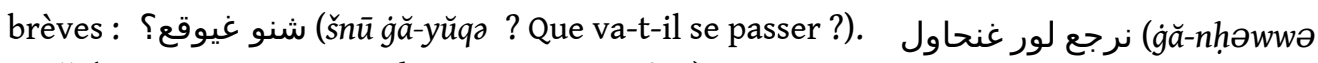
nərža' llür. Je vais essayer de revenir en arrière). 


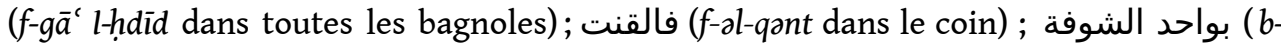
wahed-ə̌s-šūfa d'un regard) ; طلعات للطوبيس (țal 'āt l-əț-țūbiss elle est montée dans le bus).

57 - Hésitation sur la graphie de l'article, surtout en cas d'assimilation) :

58 - L'article est écrit : ديك الشارة (dīk əš-šāra ce badge) ; داك الشي علاش (dāk əš-ši 'lāš c'est pour cela) ; بواحد الشوفة (b-wahed-əš-šs̄fa d'un regard).

59 - L'article n'est pas écrit parce qu'il est assimilé : أش هاد شي (āš hād ši ? Qu'est-ce que c'est que ça ?) ; ستة دناس (sətta d nās six personnes) ; ديك نهار (dikk nhār ce jour-là).

60 - Le relatif $l l i$

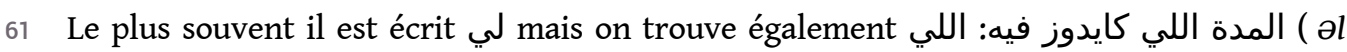

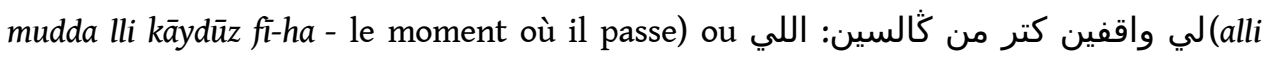
wāqfin ktər mən alli gālsin - il y a plus de gens debout qu'assis).

62 - La négation verbale discontinue ma... š est généralement écrite brève et attachée au verbe, produisant ainsi des mots très longs : مكنفكرش (ma kənfəkkər š je ne pense pas);

63 منشوفكش اليوم؟ (ma nšǔfuk š lyūm ? On ne te verra pas aujourd'hui ?) ; ou avec un complément prépositionnel assimilé, écrit attaché, lui aussi : مكيوصنيهش (ma kayūṣəl li-h $\check{s}$ - il n'y arrive pas). parfois avec un soukoun :

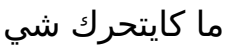

( $m \bar{a}$ kāytḩrrək š - il ne bouge pas)

Comment écrire la $3^{\mathrm{e}}$ personne du féminin de l'accompli qui est réalisée, brève (comme en AS) ou longue (comme elle est réalisée à Casablanca). Elle est écrite longue : طلعات (țal'āt - elle est montée) قربات (qərbāt - elle s'est approchée).

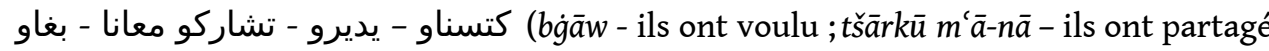
avec nous ; ydìrū - ils feront ; kaytsənnāw - ils attendent).

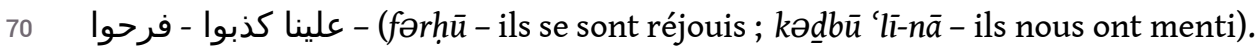

\subsection{Dictionnaire monolingue de Darija, une approche plus scientifique.}

71 Après avoir vu les pratiques réelles et les habitudes prises par les auteurs ou même par tout une jeunesse, on examinera brièvement quelques décisions prises par le dictionnaire Zakoura publié en 2017 (Figure 7). Il s'agit d'un dictionnaire monolingue, ce qui constitue 
une première. Ce travail a été fait par la fondation Zakoura, en vue d'une institutionnalisation de la darija, à l'époque où il était question de la faire entrer dans le système éducatif.

L'idée générale de ce dictionnaire était d'utiliser la darija pour mieux appréhender l'apprentissage du standard et la graphie choisie tend à se rapprocher de celle de l'AS. C'est d'ailleurs ce que nous préconisions dans le travail de la fin des années 90 pour faciliter la lecture à ceux qui savent déjà lire en standard (Caubet 2000), bien avant le passage massif à l'écrit sur claviers.

73 Voici quelques points notables, outre ceux déjà évoqués plus haut:

- Les interdentales sont notées, bien que non-réalisées ;

- La chedda est écrite, et parfois un soukoun ou des voyelles brèves;

- Place du ' $\mathrm{g}$ ' 3 dans l'ordre alphabétique se trouve entre $\tau$ et $\tau$, et non pas à côté du 5 ou du ق.

Il semble que ce travail remarquable ait été effectué sans tenir compte des pratiques acquises, avec l'idée de mettre en place une ébauche d'aménagement, sans que ce soit dit clairement, et ceci en prévision d'une introduction officielle dans le système éducatif qui n'a finalement pas eu lieu (sur ce débat depuis 2013, voir Miller 2015: 108, Caubet \& Miller 2016: 80-85 et Caubet 2017b: 214-217)

75 Il serait intéressant de questionner les chercheurs sur les raisons de leurs différentes décisions.

\section{Le monde du livre: deux expériences de publications récentes en darija}

Le monde du livre est assez réticent à utiliser l'3aransiya, du fait de la présence des chiffres utilisés comme graphèmes; or de nombreux locuteurs d'arabe maghrébin en Europe particulièrement, ne savent pas lire l'arabe et il est important qu'il puisse avoir accès à des textes en darija.

Nous avons ainsi réalisé deux expériences, l'une en France, à la demande de l'éditeur du Petit Nicolas, qui voulait traduire quelques histoires en arabe maghrébin, en tant que Langue de France ${ }^{6}$. Nous avons choisi avec les trois traducteurs ${ }^{7}$ de faire une publication en en double graphie, arabe et latine. Sur les neuf textes, trois étaient en marocain, trois en algérien et trois en tunisien. La graphie latine faisait usage de 3 chiffres, le 3 , le 7 et le 9 (Voir Figure 8 et Caubet 2013 b).

En 2015, nous avons décidé, Amine Hamma et moi, de consacrer un ouvrage aux textes de la nouvelle scène musicale marocaine pour rendre hommage à leurs auteurs, dans les domaines, du rap, du rock, de la fusion et du slam ; l'ouvrage est paru aux éditions Sirocco et Senso Unico en décembre 2016, avec le soutien de la Fondation BMCI qui a approuvé nos choix (voir Jil Lklam, Caubet et Hamma 2016 et figure 9). Les textes sont publiés en graphie arabe ou en 3aransiya, selon le choix de l'auteur (voir figures 10 et 11). Le livre a été très bien accueilli au Maroc et la lecture ne semble avoir posé aucun problème. 


\section{Conclusion et perspectives}

79

D'un côté un passage à l'écrit spontané et massif qui est pratiqué par une large proportion de la population marocaine sans que cela pose de problème; de l'autre un essai de planification en forme de publication d'un dictionnaire d'un millier de pages (Zakoura 2017), sans application directe.

Il serait intéressant de tester les facilités de lecture devant des textes inconnus et d'une certaine longueur. Si la lecture est fluide c'est qu'un apprentissage (non scolaire) a eu lieu, qu'il y a eu création d'une norme lâche et non contraignante -puisqu'aucune faute ne peut être reprochée et que la seule sanction serait l'illisibilité. Il y a bien eu dans le cas de la graphie spontanée une forme de conventionalisation, une action collective, mais sans standardisation (selon une formulation de Gunvor Medjdell (voir Caubet 2017a: 137).

Figure 11 - Jil Lklam - Editions du Sirocco et Senso Unico 2016

\section{BIBLIOGRAPHIE}

Al Kury, Dalia. 2006. Arabizi. Film, 03 Productions, Dubai.

ANRT. Décembre 2014. Tableau de bord du marché du mobile au Maroc [Accessible à https:// www.anrt.ma/sites/default/files/2014_T4_TB_mobile_fr.pdf] consulté le 15 Octobre 2017.

ANRT. Décembre 2015. Tableau de bord du marché du mobile au Maroc [Accessible à https:// www.anrt.ma/sites/default/files/2015_T4_TB_mobile_fr.pdf] consulté le 15 Octobre 2017.

ANRT. Décembre 2016. Observatoire de la téléphonie mobile au Maroc, Situation au 4e trimestre 2016 [Accessible à https://www.anrt.ma/sites/default/files/publications/2016_t4_tb_mobile_fr.pdf] consulté le 15 Octobre 2017.

ANRT. 2017a. Enquête annuelle de collecte des indicateurs TIC auprès des ménages et des individus Année 2016, Rabat. 62 p.

[Accessible à https://www.anrt.ma/sites/default/files/publications/enquete_tic_2016_fr.pdf] consulté le 15 Octobre 2017.

ANRT. 2017b. Observatoire de la téléphonie mobile au Maroc, Situation au 2ème trimestre 2017. Rabat.

[Accessible à https://www.anrt.ma/sites/default/files/publications/2017_t2_tb_mobile_fr.pdf] consulté le 15 Octobre 2017.

Babassi, Ouahida. 2004. "Peut-on parler d'une communauté 'virtuelle' bilingue franco-arabe 'algéroise' sur l'Internet Relay Chat ?, in Caubet, D., Bulot, T., Léglise, I. et Miller, C. (dir.), Parlers jeunes, ici et là-bas, pratiques et représentations, Paris, L'Harmattan, 271-286.

Berjaoui, Nasser. 2001. "Aspects of the Moroccan Arabic Orthography with Preliminary Insights from the Moroccan Computer-Mediated Communication". In Beißwenger, Michael, ChatKommunikation. Sprache, Interaktion, Sozialität \& Identität in synchroner computervermittelter 
Kommunikation. Perspektiven auf ein interdisziplinäres Forschungsfeld. Stuttgart: Bidem-Verlag. 431-468.

Caubet, Dominique. 1999. “Arabe maghrébin : passage à l'écrit et institutions”, in Faits de Langue n. 13, Parole orale / Parole écrite : Formes et Théories. 235-244.

Caubet, Dominique. 2000. Propositions concernant la notation usuelle de l'arabe maghrébin : graphie arabe et graphie latine, Synthèse élaborée par D. Caubet, document CERBAM-INALCO, $2^{\text {ème }}$ édition.

Caubet, D., 2002. Arabe maghrébin, langue de France : entre deux graphies. In: D. Caubet, S. Chaker, and J. Sibille (éds.) Codification des langues de France. Paris : L'Harmattan. 307-330.

Caubet, Dominique. 2004a. "L'intrusion des téléphones portables et des 'SMS' dans l'arabe marocain en 2002-2003”, Caubet, Dominique, Billiez, Jacqueline, Bulot, Thierry, Léglise, Isabelle \& Miller, Catherine (éds.), Parlers jeunes ici et là-bas, Pratiques et Représentations. Paris : L'Harmattan. 247-270.

Caubet, Dominique. 2004b. “A propos de la linguification de l'arabe dialectal-darja, langue de France”, in Eloy, Jean-Michel, Des langues collatérales, Problèmes linguistiques, sociolinguistiques et glottopolitiques de la proximité linguistique, Vol. II, Paris : L'Harmattan. 511-530.

Caubet, Dominique. 2012. “Apparition massive de la darija à l'écrit à partir de 2008-2009 : sur le papier ou sur la toile : quelle graphie ? Quelles régularités ?”, in Meouak, M., Sánchez, P. \& Vicente, Á. (éds.) ; De los manuscritos medievales a internet : la presencia del árabe vernáculo en las fuentes escritas, Estudios de dialectología árabe n. 6 ; Zaragoza: Universidad de Zaragoza. 377-402.

Caubet, Dominique. 2013a. "Maroc 2011 - Messagerie instantanée sur l'internet marocain : facebook, darija et parlers jeunes”, in Benitez, M, Miller, C., de Ruiter, JJ \& Tamer, Y. (éds) Evolution des pratiques et des représentations langagières dans le Maroc du $21^{\text {ème }}$ siècle, Volume 1, Paris :

L'Harmattan. 63-88.

Caubet, Dominique (dir.) 2013b. Le Petit Nicolas en arabe maghrébin, Langue de France, de Sempé et Goscinny, Paris IMAV éditions.

Caubet, Dominique. 2017a. "Morocco: An Informal Passage to Literacy in Darija (Moroccan Arabic)”, Høigilt, Jacob \& Mejdell, Gunvor (eds.), The Politics of Written Language in the Arab WorldWriting Change, Leiden: Brill. 116-141.

Caubet, Dominique. 2017b. "Darija and the Construction of 'Moroccanness"', Bassiouney, Reem (ed.), Identity and Dialect Performance: A Study of Communities and Dialects. London-New York: Routledge. 189-229.

Caubet, Dominique. 2018. "New elaborate written forms in Darija: blogging, posting and slamming in Morocco", Abbas Benmamoun and Reem Bassiouney (eds), The Routledge Handbook of Arabic Linguistics, Routledge. 387-406.

Caubet, Dominique \& Miller, Catherine. 2016. "Quels enjeux sociopolitiques autour de la darija au Maroc ?", Sini, Chérif \& Laroussi, Foued (dir) Langues et Mutations sociopolitiques au Maghreb, PURH, Collection « Plurilectal», Rouen. 67-89.

Caubet Dominique \& Hamma Amine. 2016. Jil lKlam, Les poètes urbains. Senso Unico \& Éditions du Sirocco, Casablanca, $245 \mathrm{p}$.

Gonzalez-Quijano, Yves. 2012. Arabités numériques. Le printemps du Web arabe. Actes Sud, 192 p.

Habilosmedias.ca. Les fondements de la littératie numérique. [En ligne à http://habilomedias.ca/ litt\%C3\%A9ratie-num\%C3\%A9rique-et-\%C3\%A9ducation-aux-m\%C3\%A9dias/informations-g\% C3\%A9n\%C3\%A9rales/principes-fondamentaux-de-la-litt\%C3\%A9ratie-num\%C3\%A9rique-et-de-l 
\%C3\%A9ducation-aux-m\%C3\%A9dias/les-fondements-de-la-litt\%C3\%A9ratie-num\%C3\%A9rique]. Consulté le 23 Octobre 2017.

Miller, Catherine. 2015. "Evolution des pratiques, évolutions des représentations ? Petit retour sur le débat autour de la valorisation de la darija au Maroc", Revue des Etudes berbères, Volume 10. Paris, INALCO. 101-120

Miller, Catherine. 2017. "Contemporary Dārija Writings in Morocco: Ideology and Practices", Høigilt, Jacob \& Mejdell, Gunvor (eds.), The Politics of Written Language in the Arab World Writing Change, Brill. 90-115.

Zakoura. 2017. Qāmūs ad-dārija al-mağrïbiya. Markaz tanmiya ad-dārija. Casablanca. 872p.

\section{ANNEXES}

Figure 1 - Conversation sous Mirc

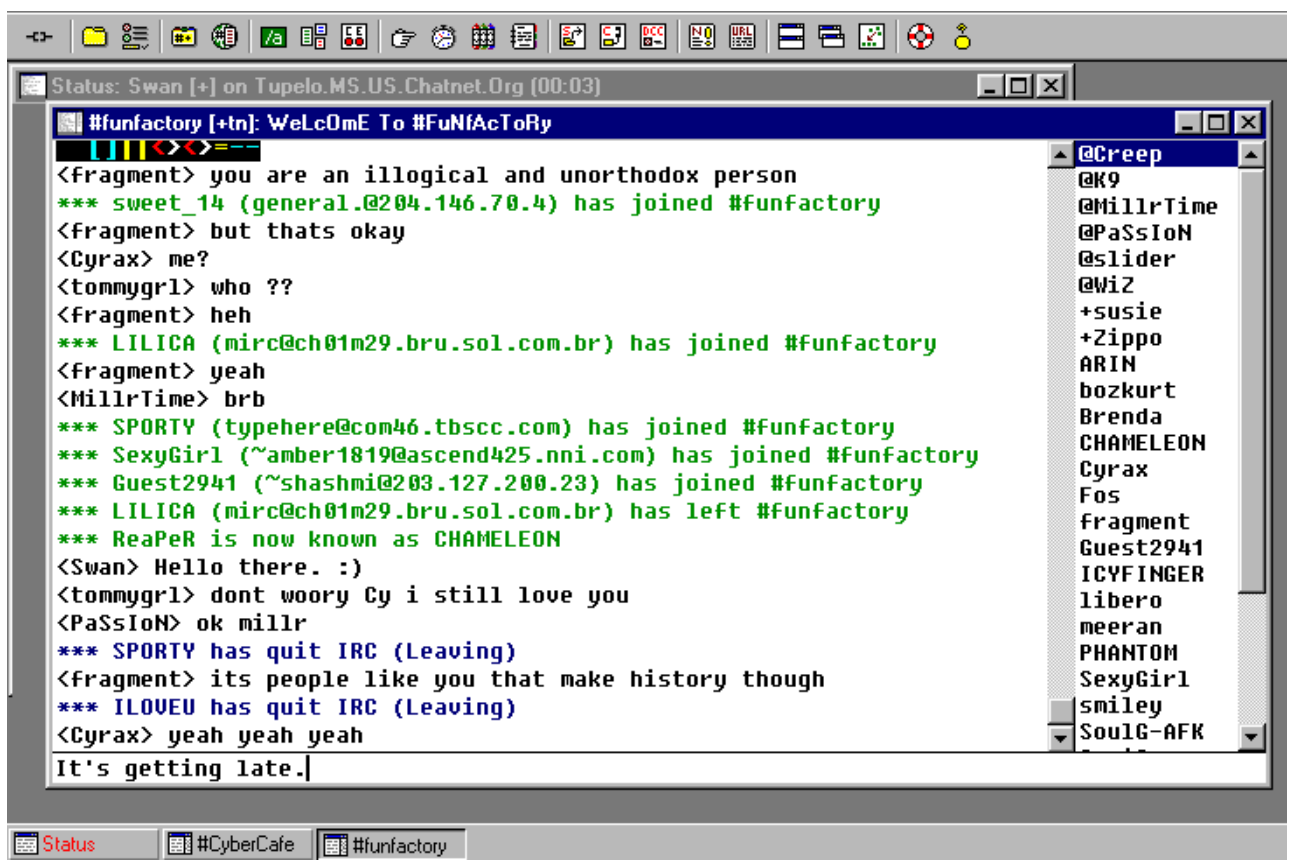

\section{Figures 2 et 3}

Exemple d'un clavier arabe « intelligent » transformant la saisie latine en graphie arabe, offrant des choix : http://www.yamli.com/clavier-arabe/ (téléchargé le 6 novembre 2017)

La négation ma (ma l9it) pouvant être liée ou mot ou détachée, tout comme la conjonction ma (ma ndir), avec une voyelle longue ou brève :

ما ندير / مندر ملقيت / مالقيت

Ex : ma l9it ma ndir (Je n'ai pas trouvé quoi faire) 


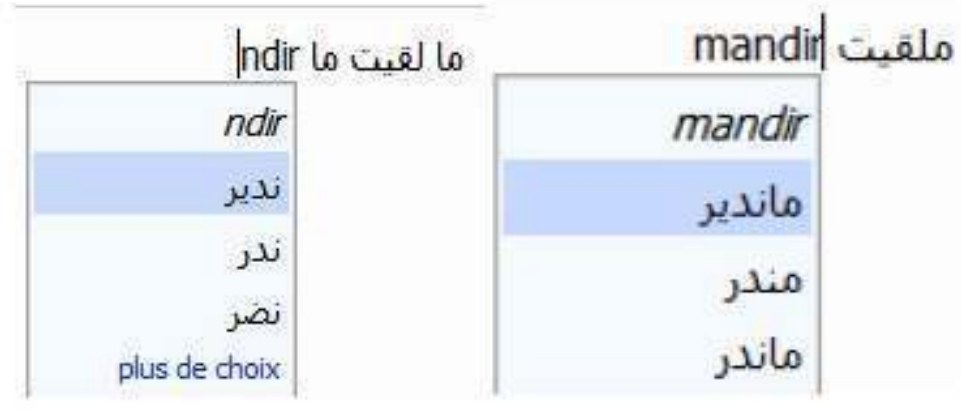

Figure 2 et 3 - Clavier arabe intelligent

Figure 4

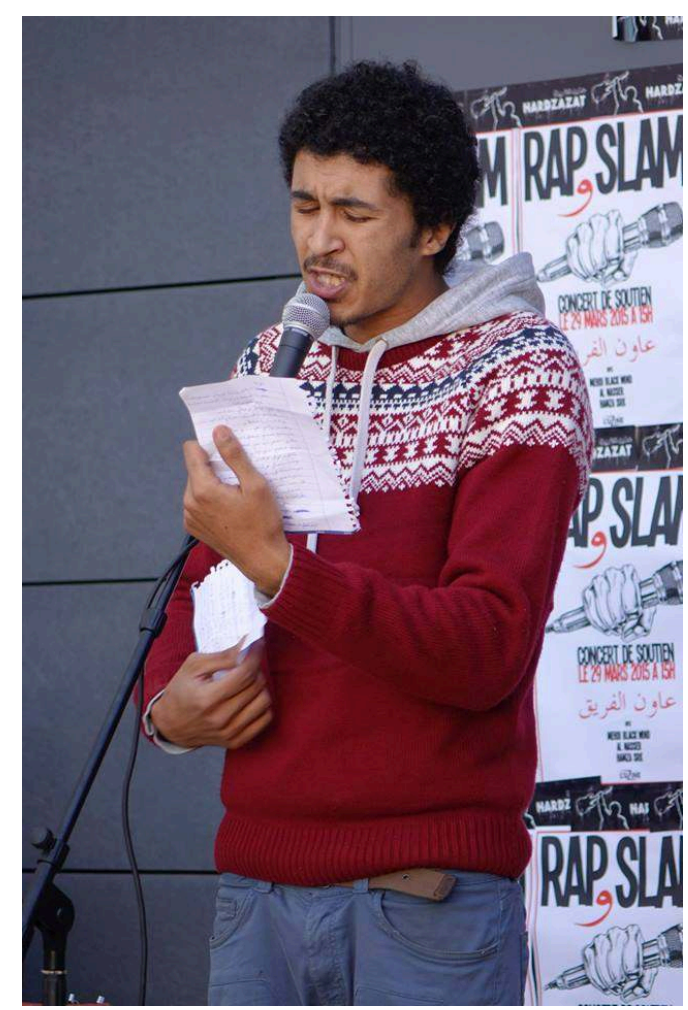

Figure 4 - Hamza El Mssati lisant son texte le 30 mars 2015 (voir ses textes dans Caubet 2017a et 2018) Photo Sarah Schwartz mars 2015

\section{Figure 5}


Khalld Hoummas a partagè la vidéo de BOUMMASK I'M FLOW *. MAN.

$16 \mathrm{~h} \cdot \mathrm{C}$

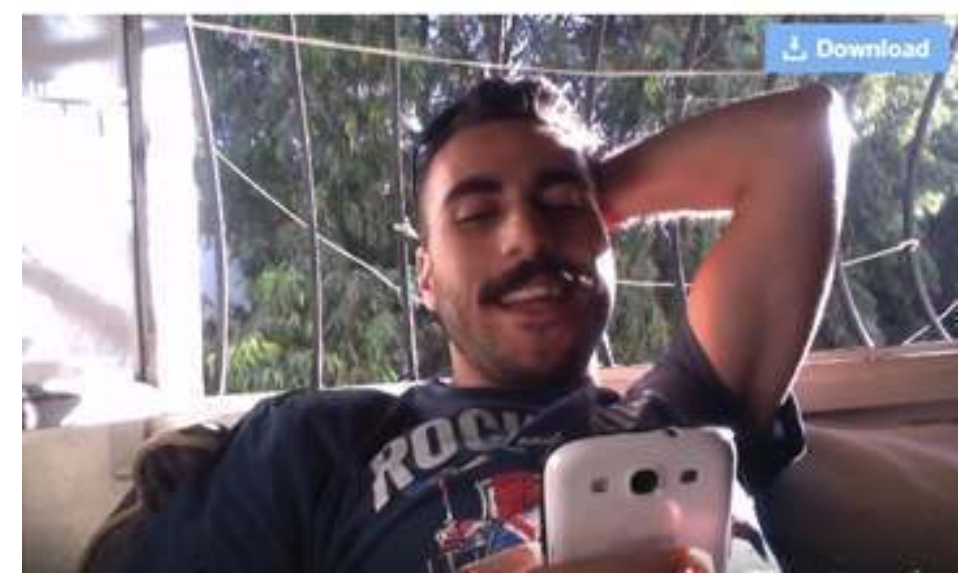

Figure 5 - Capture d'écran : Flowman lisant un freestyle - 6 novembre 2017

Figure 6

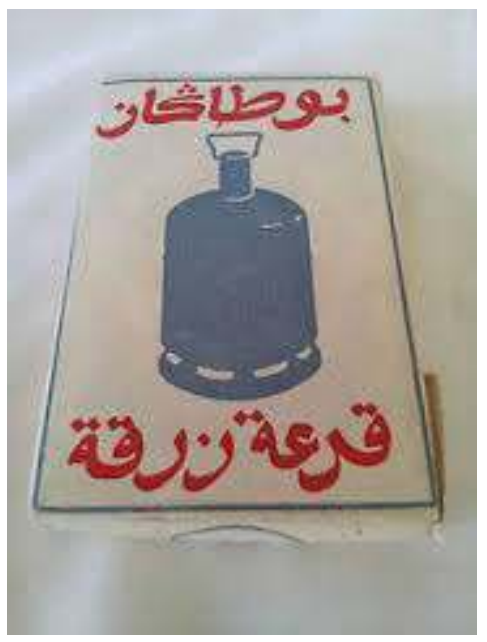

Figure 6 - Butagaz, bouteille bleue - Plaque publicitaire

Figure 7 

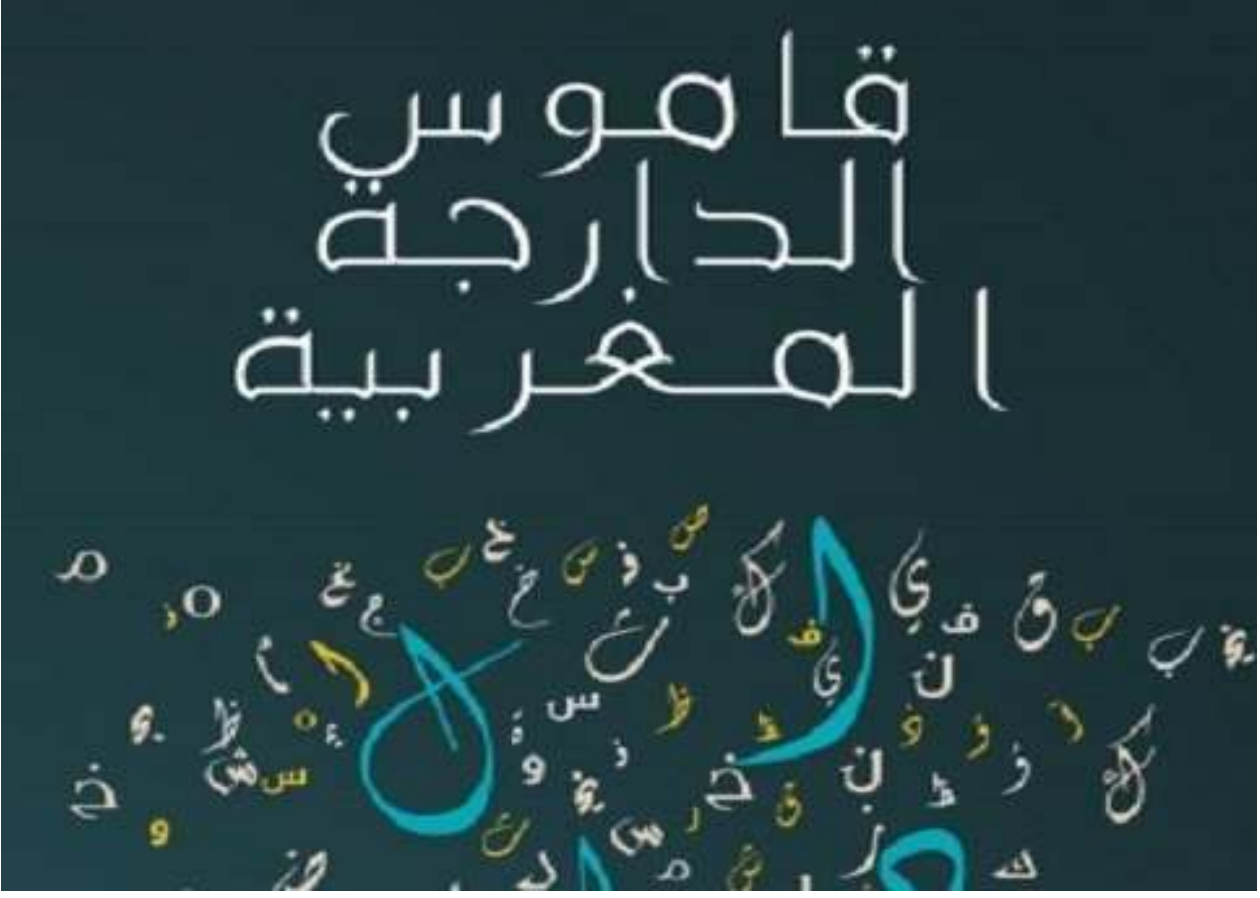

Figure 7 - Dictionnaire Zakoura 2017

Figure 8 


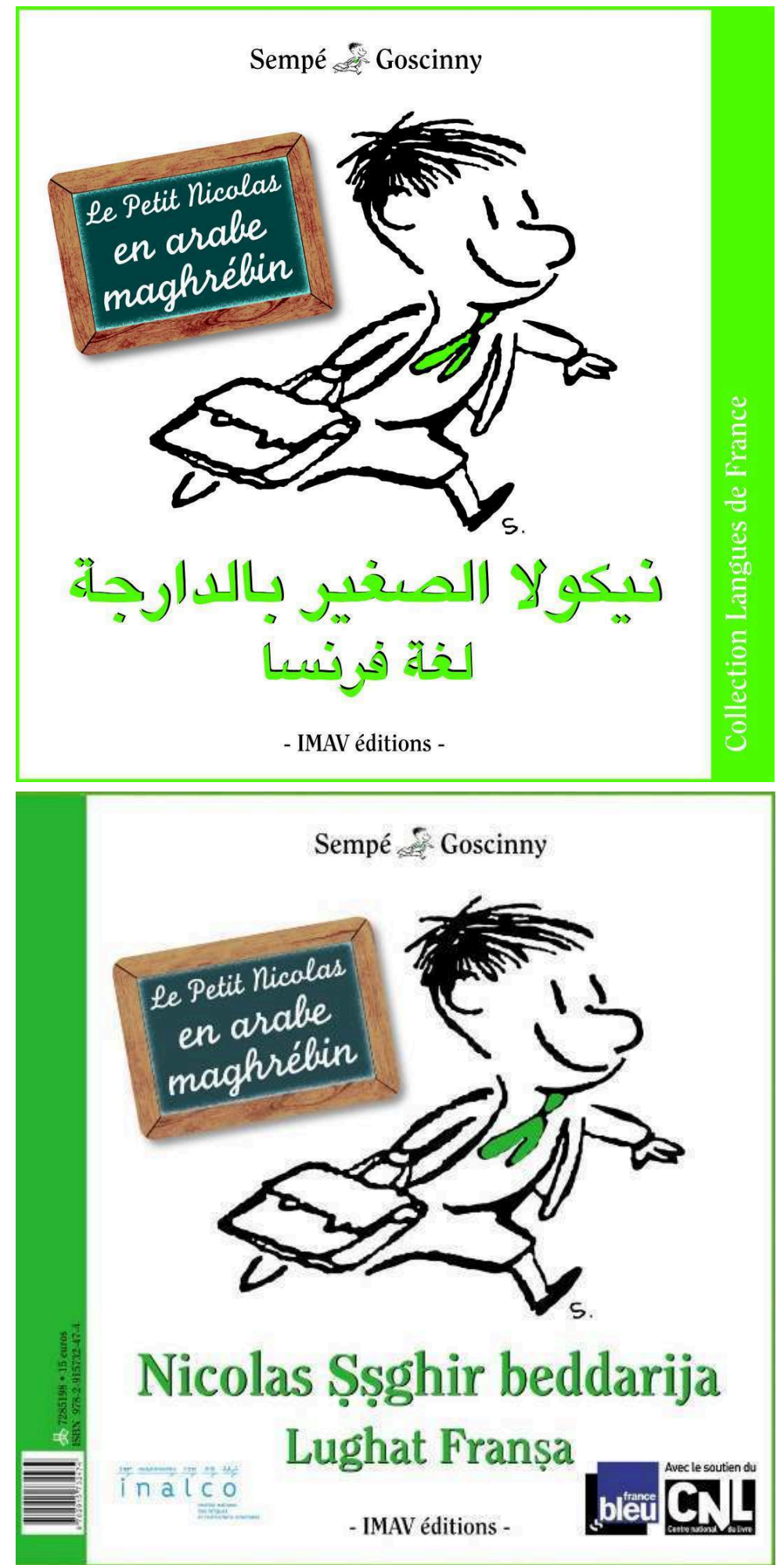

Figure 8 - Le Petit Nicolas en arabe maghrébin, Langue de France : les deux graphies

Figure 9 


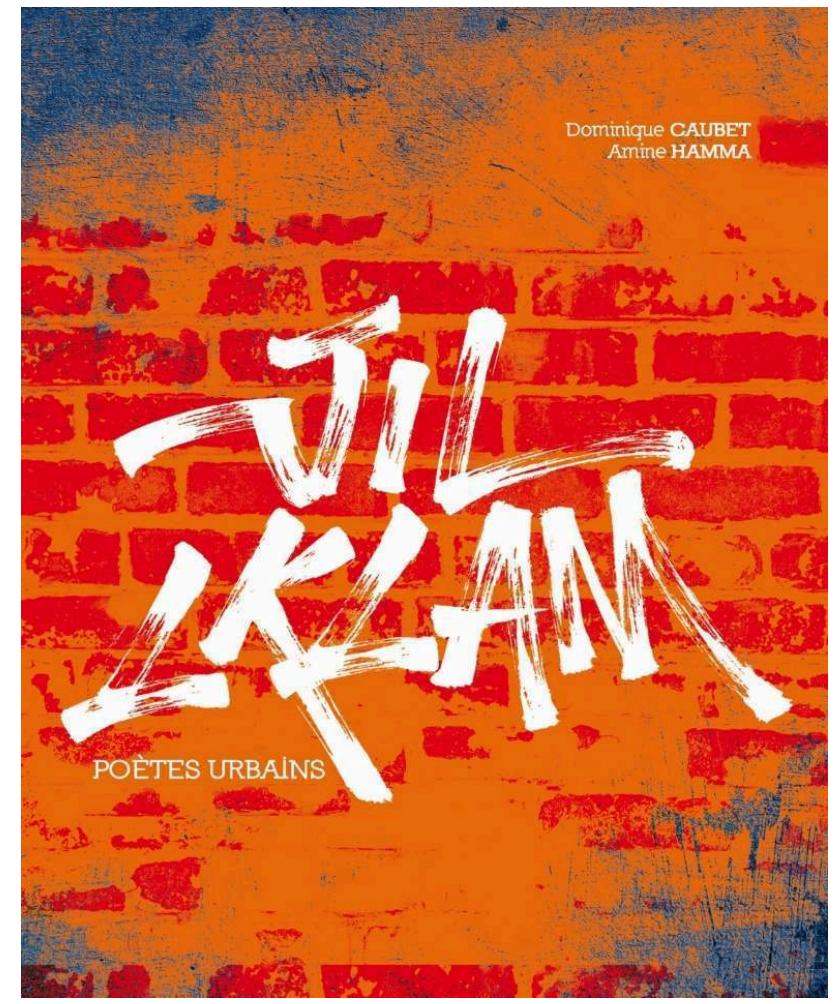

Figure 9 - Jil Lklam - Editions du Sirocco et Senso Unico 2016

\section{Figure 10}

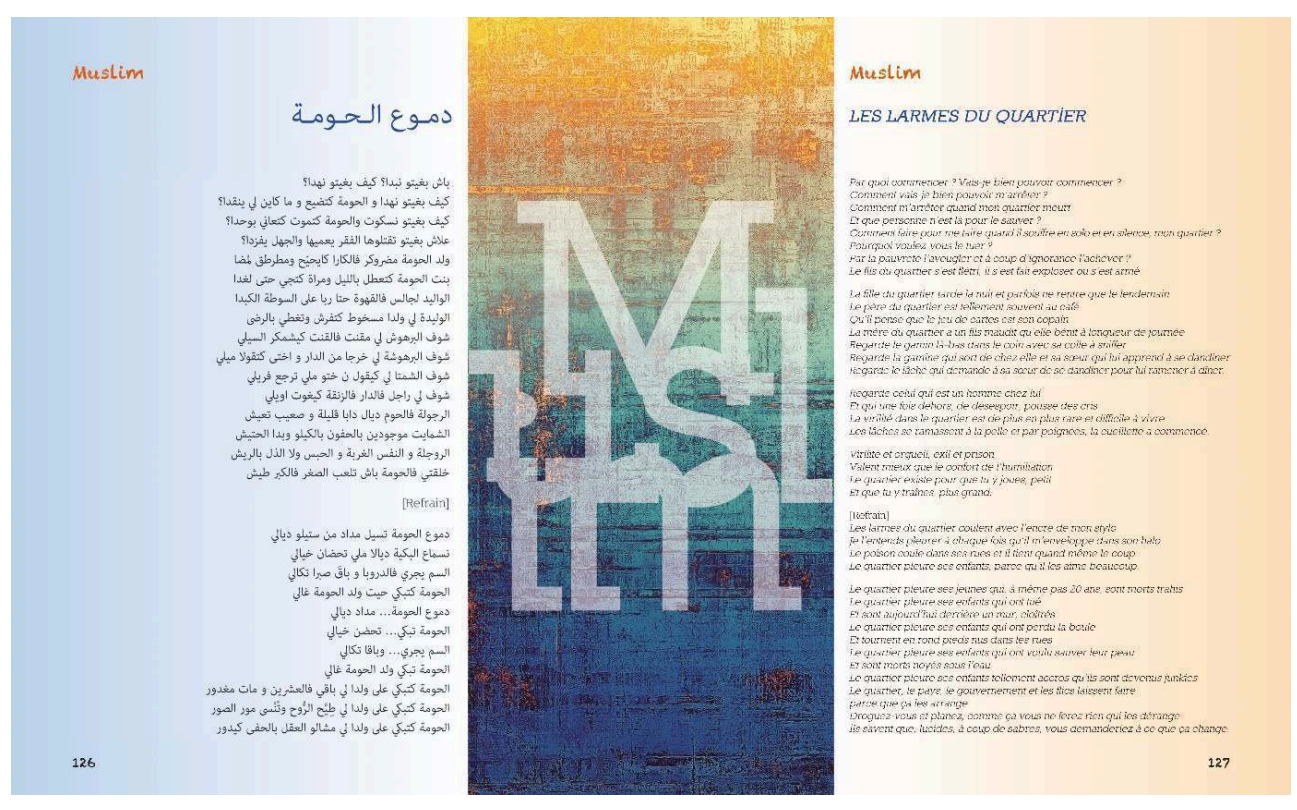

Figure 10 - Jil Lklam - Editions du Sirocco et Senso Unico 2016

\section{Figure 11}




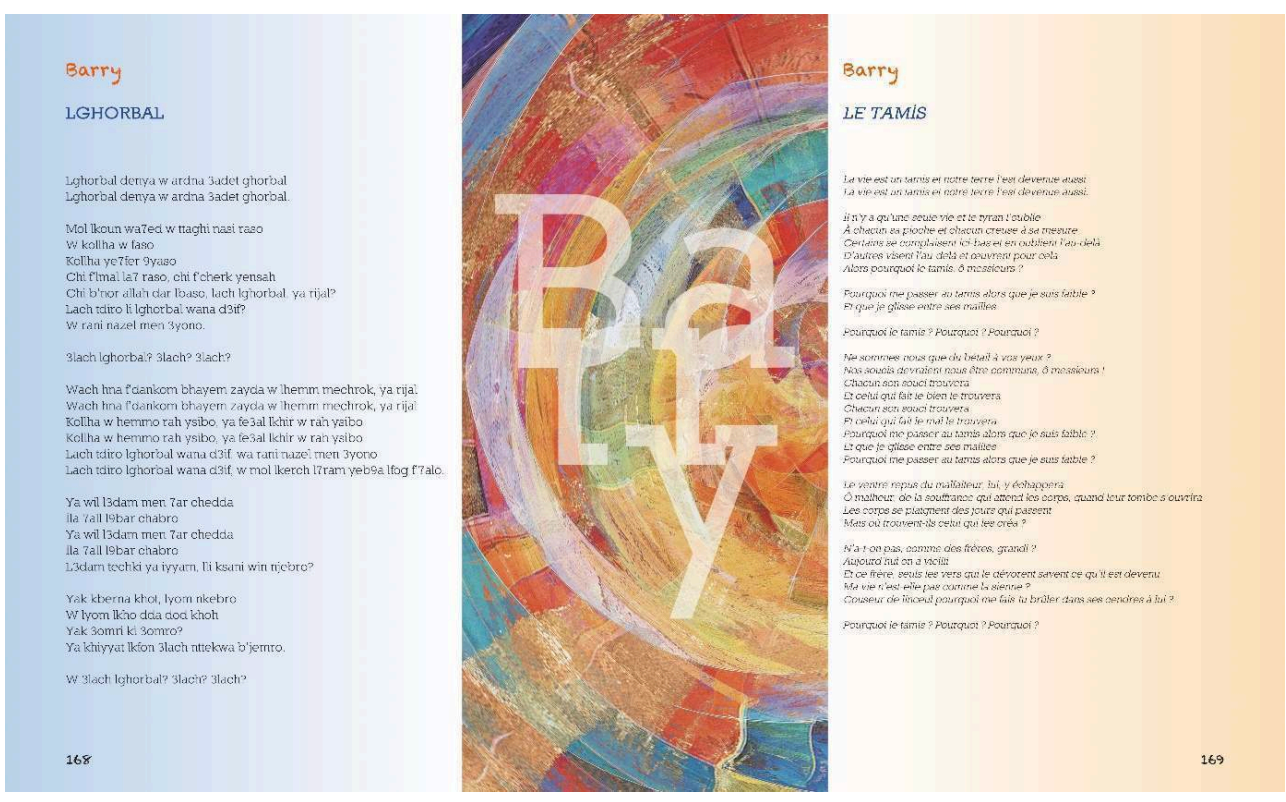

\section{NOTES}

1. Pour tous ces chiffres, voir les rapports de l'ANRT, Agence Nationale de Réglementation des Télécommunications qui sont publiés que leur site depuis 2004, anrt.ma, et en particulier le TABLEAU DE BORD du MARCHÉ DU MOBILE AU MAROC publié en décembre de chaque année (voir ANRT dans les références)

2. Communication personnelle, voir aussi Caubet 2017 : 137).

3. Nombres de copies corrigées en arabe maghrébin : 1995=5225, $1996=6976,1997=7517,1998=$ 8253, $1999=9886$. Total : 37857. Chiffres de Dominique Caubet responsable de l'épreuve à l'INALCO, 1995-1999. À titre de comparaison, pour l'arabe oriental, il y a eu dans le même temps $1995=155,1996=172,1997=216,1998=230$ et $1999=225$, copies corrigées, soit 998 en tout.

4. Pour avoir une idée des chiffres, il y avait en 1999, 1500 candidats dans toute la France qui présentait l'arabe en tant qu'épreuve de langue vivante enseignée (en $1^{\text {ère }}, 2^{\text {ème }}$ ou $3^{\text {ème langue) }}$ contre 10.000 qui choisissait l'épreuve d'arabe « dialectal ».

5. Le mIRC est un shareware client IRC pour Windows qui a été créé et développé par Khaled Mardam-Bey en 1995 (Babassi 2004).

6. L'arabe maghrébin a été reconnu comme faisant partie des Langues de France en 1999, en tant que langues parlées par des citoyens français, aux côtés de toutes les langues régionales et du berbère, entre autres.

7. Amine Hamma pour le marocain, Jihane Madouni pour l'algérien et Abdelwahid Fayala pour le tunisien. 


\section{RÉSUMÉS}

Il s'agit de revisiter l'historique du passage à l'écrit de la Darija à travers les réseaux sociaux et de voir comment, en dehors de toute initiative officielle et de toute reconnaissance, une génération s'est prise en main et a réalisé un travail collectif sans a priori idéologique. Ils se sont emparé de ces nouveaux moyens de communication en les détournant, pour écrire leur langue, la Darija, que ce soit dans une graphie latine réinventée ou dans une graphie arabe malmenée.

INDEX

Mots-clés : Littératie numérique, citoyenneté numérique, démarche collective, habitudes orthographiques, conventionnalisation

\section{AUTEUR}

DOMINIQUE CAUBET

LaCNAD - INALCO- Paris 


\title{
Cross-generational Differences in Spatial Language in aṣ-Șāni’ Arabic
}

\author{
Letizia Cerqueglini
}

\section{AUTHOR'S NOTE}

Abbreviations in Figures: E=East; L=Letizia; N=North; S=South; W=West

\section{Linguistic Change and Spatial Representations in aș-Ṣāni‘ Arabic}

1 This work describes linguistic changes that occurred in the domain of spatial representations in the last seventy years in aș-Ṣāni ' Arabic (Cerqueglini 2015), a tribal variety of Negev Arabic (Blanc 1970; Henkin 2010). I experimentally surveyed the spatial language of aș-Ṣāni' community members, from elders (Traditional aș-Ṣāni` Arabic, TAA) to teens (New aș-Ṣanni' Arabic, NAA). By spatial language, I mean the linguistic descriptions of the relations between objects in space, such: 1. "The cat is inside the car" and 2. "The child is in front of the house." The object to be located is Figure (F) and the object in relation to which F is located is Ground (G) (Levinson 2003). Here "the cat" and "the child" are Fs, "the car" and "the house" are Gs, and the prepositions "inside" and "in front" represent the relations. In sentence $1, F G$ coincide in space, as $G$ contains $F$. This is a topological relation. In sentence 2, FG are separated in space and speakers need axial information to detect the search domain of $F$ in relation to $G$, i.e. this spatial relation requires the projection of a coordinate system to establish G's front/back and right/left axes. This is a projective relation. Coordinate systems in human languages are called frames of reference (FoRs) (Carlson-Radvansky \& Irwin 1993; Levinson 2003). Scholars classify FoRs differently by number and type. I follow Levinson's classification of three FoRs: Intrinsic, Relative, and Absolute (Levinson 2003). 


\subsection{The Frames of Reference}

2 In the Intrinsic FoR, the coordinate system radiates from G. "Marc is in front of the house" means that F-Marc is in the region projected from the part of G-house that is seen as G's inherent front. In order to become the center of the coordinate system, some inherent functional or geometric asymmetry of $G$ on the front/back axis must be recognized by speakers. Thus, a house is generally conceptualized as having an inherent front, where the front door is located. This can be seen as its "face," whereas "faceless" objects, such as ball/stone/pole, are generally less eligible for the Intrinsic strategy and more likely to prime one of the other FoRs. The coordinate system of the Absolute FoR is derived from some environmental feature, such as the four cardinal directions or a known landmark that provides a fixed bearing in space, e.g. "Marc(F) is north of the house(G)." In the Relative FoR, the body of the observer (O) is the origin of the coordinate system. "The cat is in front of the ball of wool" means that F-cat is in a region of space contiguous to that part of the G-ball of wool where O projects his front. This FoR can easily be primed by faceless Gs such as ball/tree/stone/pole, which lack intrinsic salient asymmetry, so that some salient asymmetry must be mapped onto them from an external source. According to Levinson (2003: 86-88), Relative FoR is applied according to different strategies: Reflection, Translation and $180^{\circ}$ Rotation:

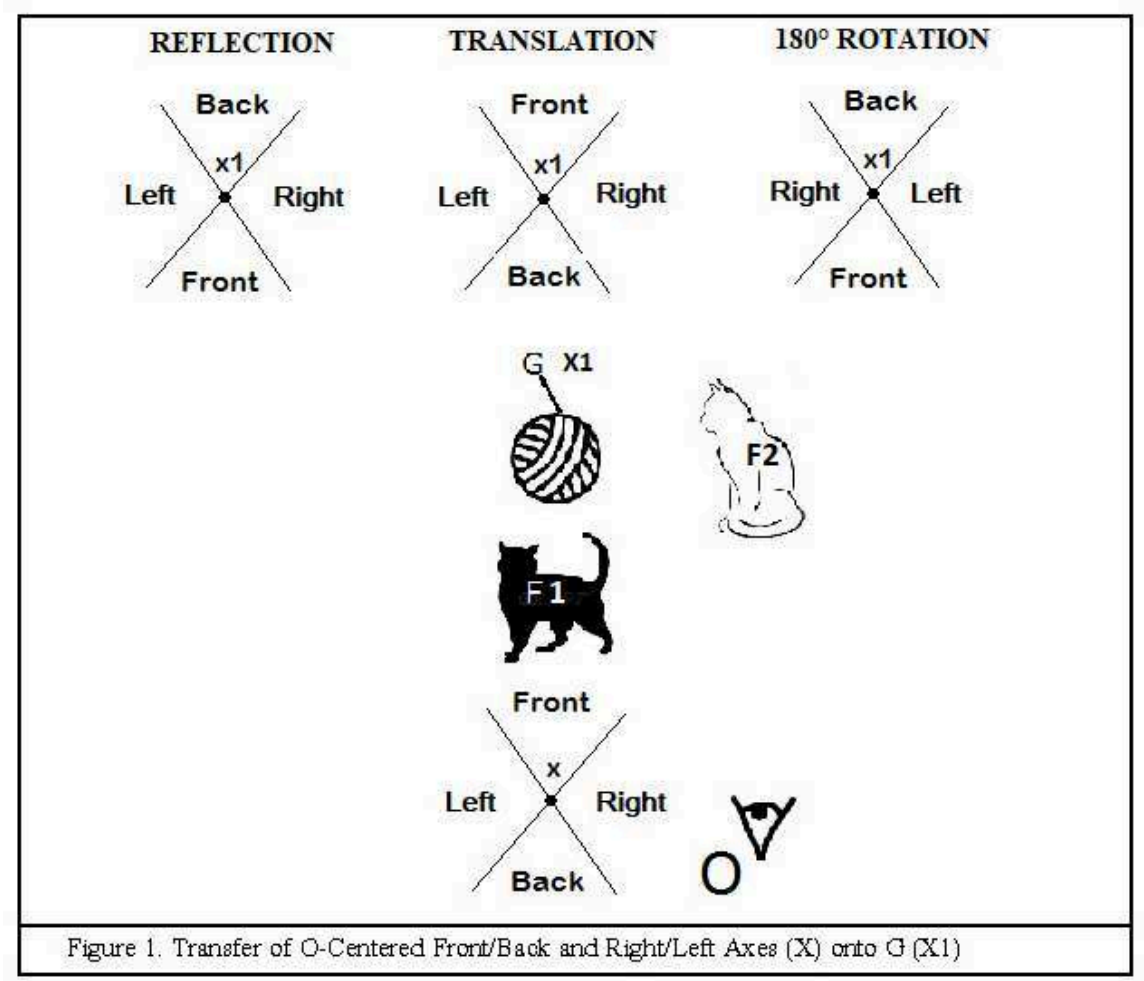

In Figure 1, the black cat is F1, the white cat F2 and the wool ball G. Reflection and $180^{\circ}$ Rotation transfer the front/back axis from O (X) to G-wool ball (X1), so in Figure 1 "F1black cat is in front of G-wool ball." Translation treats the $\mathrm{X} 1$ axial system as a direct replica of X, so "F1-black cat is behind G-wool ball." Reflection and Translation keep the right/left axis from $\mathrm{X}$ to $\mathrm{X} 1$ unchanged, so "F2-white cat is right of $\mathrm{G}$-wool ball"; according to $180^{\circ}$ Rotation "F2-cat is left of G-wool ball." 


\subsection{The Speakers' Community}

4 The aș-Ṣani ' tribe traditionally inhabits the northern Negev. The elders were seminomadic shepherds prior to 1948 , when the aș-Ṣāni ${ }^{i}$ were temporarily relocated. Later, they moved back into a sector of their original land, where they built the village of Al-Ligiyyih, the site of my fieldwork. Some elderly men still perform short-distance migrations with flocks. Their education consisted, at most, of some rudimental Classical Arabic acquired by memorizing the Koran and some arithmetic. Women TAA speakers were mainly illiterate and monolingual in their tribal dialect, socially more inhibited, and thus less exposed to the outside world. Beginning in the 1950s, the Negev Bedouin underwent modernization, abandoning nomadism and acquiring formal education, while women became more mobile (Marx \& Shmueli 1984; Kressel 1996). In the new, sedentary lifestyle, NAA speakers have been born and raised in contact with Hebrew, standard Arabic, and koineized Palestinian Arabic. After the establishment of Israel, the aș-Ṣānic rapidly became familiar with the western lifestyle. NAA speakers are largely literate in Arabic and Hebrew. Many people now in their fifties and early sixties became professionals, educators, activists, politicians, and opinion-makers in Israel and abroad. Socio-cultural changes within the community, make the aș-Ṣanni' a particularly interesting case to study. Tribal language, especially spatial language, changed dramatically, often preventing mutual understanding between TAA and NAA speakers.

One of the most evident cross-generational differences is NAA's lack of cardinal directions, used widely in TAA, in small-scale descriptions (Cerqueglini 2015). When a TAA speaker asks an NAA speaker to look for something ğuwwa l-Hazānih, garb, "inside the locker, west," for example, the latter has difficulty processing this request, even in a familiar space. The situation is different for aș-Ṣāni ' people aged 35 to 66, who still understand TAA spatial language, yet no longer use it actively. So, I consider all speakers younger than 67 as one NAA group in the current analysis.

\section{Background Research and Study Scope}

6 This study compares TAA and NAA strategies of linguistic representation of projective spatial relations. The parameters of change analyzed are prepositions and FoRs. Projective relations between FG on the horizontal plane occur on both the front/back and the right/left axis, as in "Marc is behind me" and "I am left of the car." The right/left axis is absent from TAA (Cerqueglini 2015). As Cerqueglini \& Henkin (2017) state, TAA speakers distinguish right and left exclusively in relation to human hands. Right and left hands have high cultural and ritual importance, representing respectively positive and negative values. But right and left are not grammaticalized in TAA as spatial prepositions, and when any $F$ is located laterally to any $G$, the relation is expressed by cardinal directions in accordance with the Absolute FoR. The prepositional use of "right" and "left" occurs in NAA, in accordance with the Relative FoR.

7 This description is rooted in previous studies (Cerqueglini 2015, 2016) on the spatial system of TAA. Tribal elders currently over 67 years old share a culture-specific system of prepositions and FoRs hardly predictable outside their age group. TAA selects for smallscale location from among the three FoRs according to a complex system of semantic properties culturally attributed to Gs and some axial distinctions. Distinctive features of 
Gs are largely based on a domain- and culture-specific ontology in which Gs are classified more according to cultural saliency in the traditional world [FAMILIARITY] than to other metric and formal features, such as [FACEDNESS], i.e. [-SYMMETRY] along the front/back axis. In brief, right/left distinction is not used and lateral representations are processed in the Absolute FoR with all types of Gs. Intrinsic and Relative FoRs are exclusively applied to the front/back axis according to neatly distinguished sets of prepositions for each ("the FoR-based prepositional split." See Cerqueglini 2016). The Intrinsic FoR is primed by [+FAMILIAR] [+FACED] Gs (man/horse/camel/coffee-pot/tent). Speakers do not recognize the front/back axis of [-FAMILIAR] Gs (chair/shoe/computer/cow/dinosaur), i.e. these Gs attract the use of the Absolute FoR independently of their axial asymmetries due to shape and/or function. The front/back axis of [+FAMILIAR][-FACED] Gs (tree/ stone/sheep/goat/pole) is processed according to the Relative FoR by Translation when they are in the middle of O's visual field, i.e. FGO [+ALIGNED], while they prime the Absolute FoR in every other position, i.e. FGO [-ALIGNED]. Intrinsic and Absolute FoRs show two sub-types, distinguished by the parameter FGO [+/- ALIGNED]. Figure 2 presents a graphic sketch of TAA referential practices:

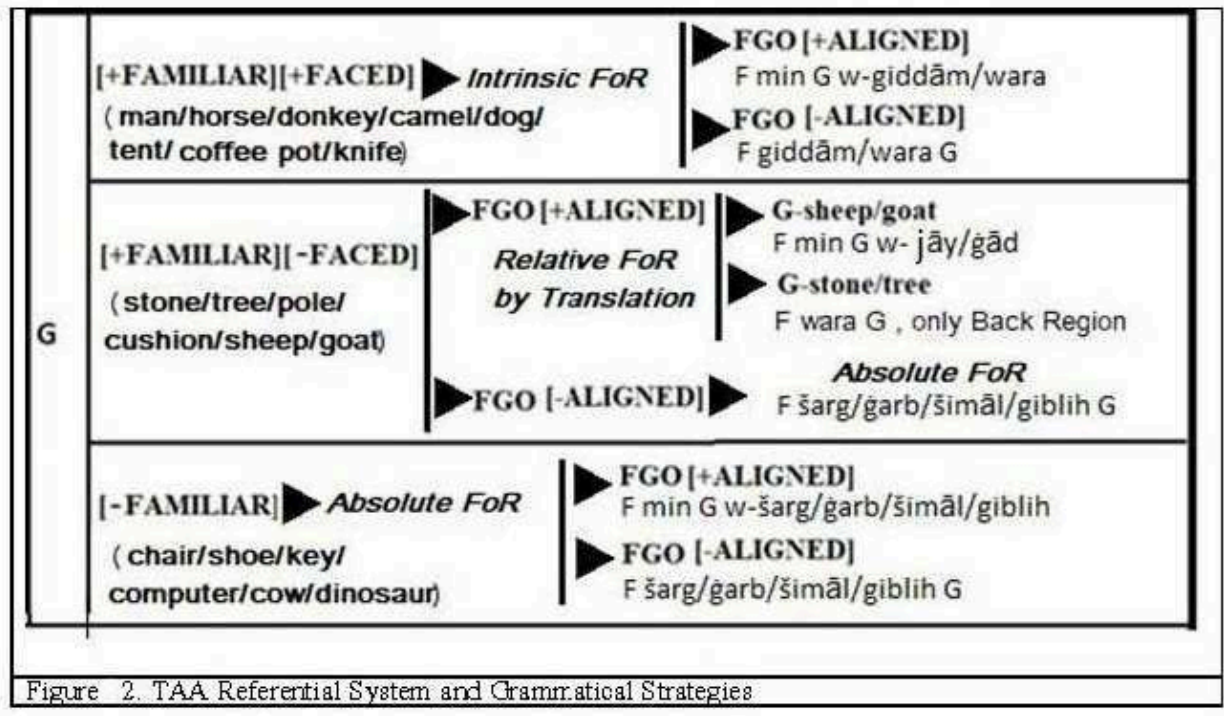

The cultural dimension of the TAA referential system appears in the treatment of Ganimals, whose anatomical partition is less relevant than their cultural salience. So, unlike G-horse/camel/donkey, G-sheep/goat never attracts the Intrinsic FoR, but is treated according to the Relative and Absolute FoR, like G-stone/tree/pole/cushion, while G-dinosaur/cow, which is [-FAMILIAR], always primes the Absolute FoR. Furthermore, TAA has two sub-types for Intrinsic and Absolute FoRs: one is the basic strategy and the other marks O's position in relation to FG array and is represented by the min-chain. The reported TAA strategies are illustrated in detail below in comparison to NAA responses to the same arrays.

The broad range of world-wide explorations of FoRs focuses primarily on establishing their typology and the relationship between linguistic FoRs, cognitive structures, and neural correlates (O'Keefe 1996). A cross-generational change in FoRs allows us to observe why or, at least, how a language changes and what happens to its speakers' mind. This work is the first experimental description of the parameters of FoRs' cross-generational change within a genetically, culturally, and linguistically conservative Arab community. I 
focus on the comparison of linguistic spatial representations in TAA and NAA, leaving out cognitive results.

\section{Methodology}

10 The fieldwork took place between 2014 and 2017. Approximately 12,000 people from different tribes inhabit Al-Ligiyyih, among them some 300 aș-Șānic. I planned an extensive cross-generational survey of spatial strategies, interviewing about 70 people, male and female, from elders to teenagers. Although I filmed the experiments, the informants forbade me to show their faces to the public. The experiments were inspired by Man and Tree pictures (Levinson et al. 1992) and Ball and Chair pictures (Bohnemeyer 2008). Since the "director-matcher" modality and picture stimuli did not produce relevant responses, I adjusted the methodology, testing each informant separately, showing FG arrays of real and toy objects. Danziger \& Gaskins (1993) found that in some languages people use different FoRs for real and toy objects. TAA speakers recognize toy objects as representing the original entities. I placed a series of FG arrays before the informants, asking win $F$ min G?, "where (is) F in relation to G?" for each. Before every session, I agreed with the informants on the words designating the objects. Every session was divided into thematic sequences to test specific semantic categories ([FACEDNESS], [MOBILITY], [ANIMACY], etc.). FG were constantly changed to avoid responses that contained sequential topological information such as " $\mathrm{F}$ has come closer to/gone away from/moved to the other side of G." The same questions on given arrays were repeated several times, not consecutively, while I changed my position. I minimized the presence of additional people or objects around the array. The camera was on my chest, moving with me, to avoid it becoming an external reference. The same arrays were tested in the informant's house, in a traditional tent, and in an open space outside the village. Objects of testing were: spatial language pertaining to different categories of Gs; the effect of the axial conditions of $F$ in relation to $G$; and of $G$ and $F$ in relation to the middle of O's visual field, with various Gs and arrays. Thus, various Gs were set in different orientations and positions relative to O's visual field: [+ALIGNED] to the center of O's visual field or [ALIGNED], e.g. perpendicular, so as to be seen by 0 from the side or set outside of the center of O's visual field. In order to test Absolute representations, informants were individually transported by car to two different places, at least 30 kilometers apart, one for each cardinal axis (NS and EW). There, I asked them about the relative location of cities, villages, rivers, and mountains, aligned both to the speaker's location along the same cardinal axis and along the other one. The landmark task was also performed at the informants' homes and investigated the criterion FGO [+/-ALIGNED] in Absolute representations. This double check served to disambiguate the possibility that the layout of the village could prime O's perspective. As TAA has been already extensively studied, here it is considered the control group.

\section{Data}

11 I show a sequence of stimuli. Each stimulus represents a semantic category identified in the TAA control group and is shown together with two concrete responses that represent the dominant responses given by TAA and NAA, respectively, for immediate comparison. 
Responses deviating from the average presented here were close to zero in TAA and scant in NAA. Their significance will be discussed in a separate study.

\subsection{Animal Gs}

In TAA, not all animal Gs have the same semantic properties in spatial representations. Prepositions and FoRs depend on two criteria: [+/-FAMILIARITY] and [+/-MOTOR INTELLIGENCE]. Unlike G-horse/donkey/camel/sheep/goat, G-cow/dinosaur are [FAMILIAR], so they prime the Absolute FoR in all axial conditions, as anatomical partition of [-FAMILIAR] animals does not affect TAA spatial semantics. Unlike G-dinosaur, G-cow is known to TAA speakers, yet not culturally salient, as cows symbolize sedentary people. Within [+FAMILIAR] animal Gs, TAA speakers further distinguish [+MOTOR INTELLIGENT] G-horse/donkey/camel (including human G) from [-MOTOR INTELLIGENT] G-sheep/goat. The former prime the Intrinsic FoR in all axial conditions, while the latter are treated according to the Relative FoR by Translation when FGO [+ALIGNED] and according to the Absolute FoR when FGO [-ALIGNED]. In NAA, all animal Gs are treated according to the Intrinsic FoR, without axial conditions. Figure 3 shows cross-generational differences:

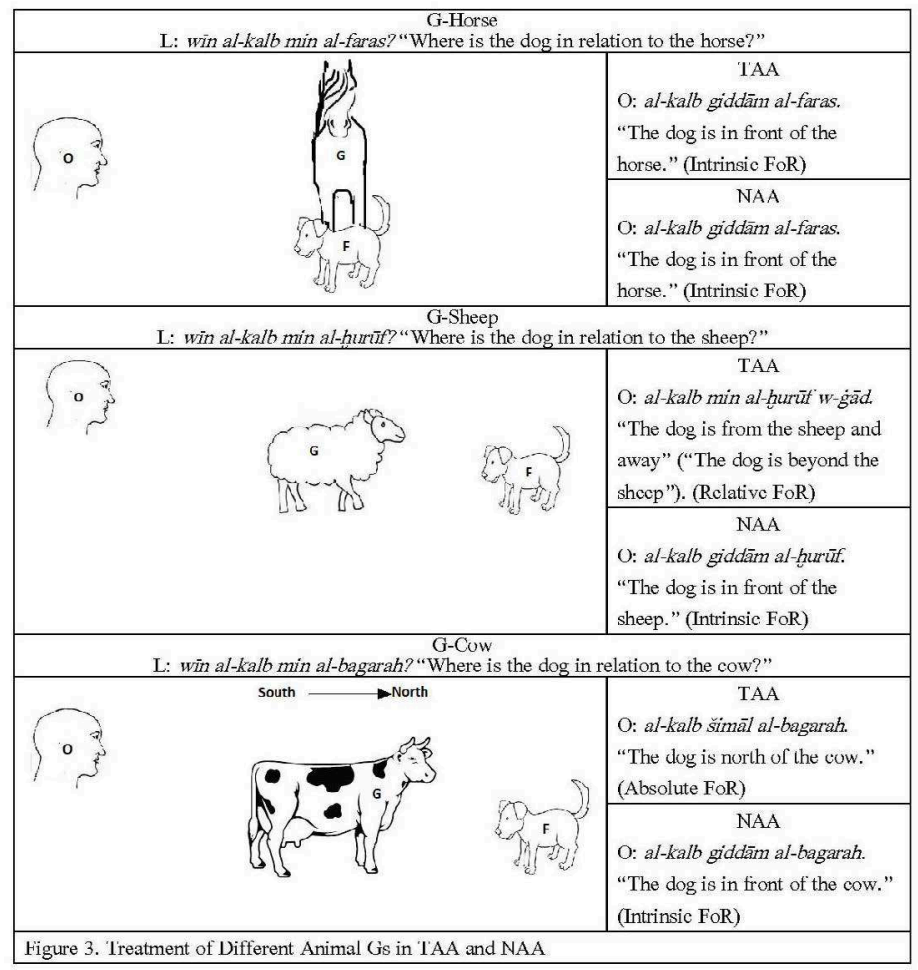

13 In NAA, the intrinsic value of anatomical partition prevails on the criterion of [+/FAMILIARITY], strongly affecting TAA.

\subsection{G-stone/tree/pole/cushion}

G-stone/tree/pole/cushion are treated in TAA according to the Relative FoR by Translation when FGO [+ALIGNED] and according to the Absolute FoR when FGO [ALIGNED], like G-sheep/goat. In NAA, all [-FACED] Gs, independently of [+/FAMILIARITY], prime the Relative FoR by Reflection on the front/back axis and by Translation on the right/left axis: 


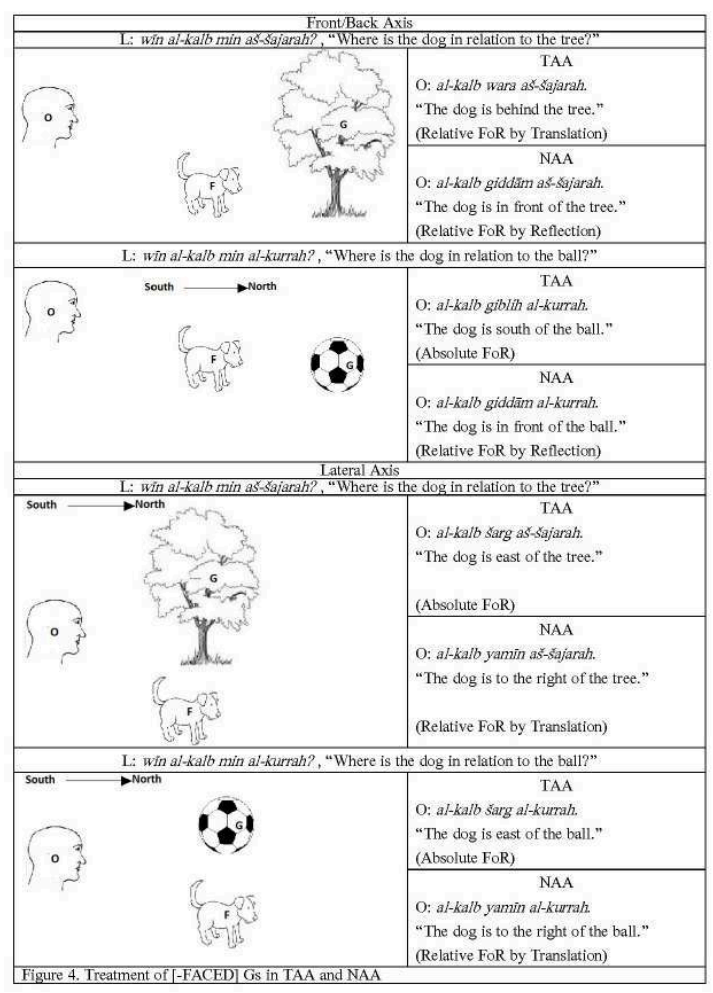

15 In Figure 4, we notice the absence of the criteria of [+/- FAMILIARITY] from the NAA system and the presence of two types of Relative FoR, namely Reflection for the front/ back axis and Translation for the right/left axis, that are also recognized for [-FACED] Gs. Unlike TAA, NAA uses giddām in the Relative FoR applied by Reflection.

\section{3. [+FACED] [+/- FACING-EACH-OTHER] FG}

The front region of the Intrinsic FoR, i.e. of [+FAMILIAR][+FACED] Gs (man/horse/camel/ tent/coffee-pot), is a culturally salient space in TAA represented by a set of prepositions: gabl when FG [+FACING-EACH-OTHER], giddām when FG [-FACING-EACH-OTHER], ('a)wijh when $\mathrm{F}$ is not prototypically and inappropriately too close to G's front. In NAA, the function of ('a)wijh remains unchanged, while the distinction between gabl and giddām works differently. gabl is no longer used with all [+FAMILIAR][+FACED] Gs when FG [+FACING-EACH-OTHER], but only with FG [+HUMAN][+FACING-EACH-OTHER], while giddām is applied in all other cases, as shown in Figure 5: 


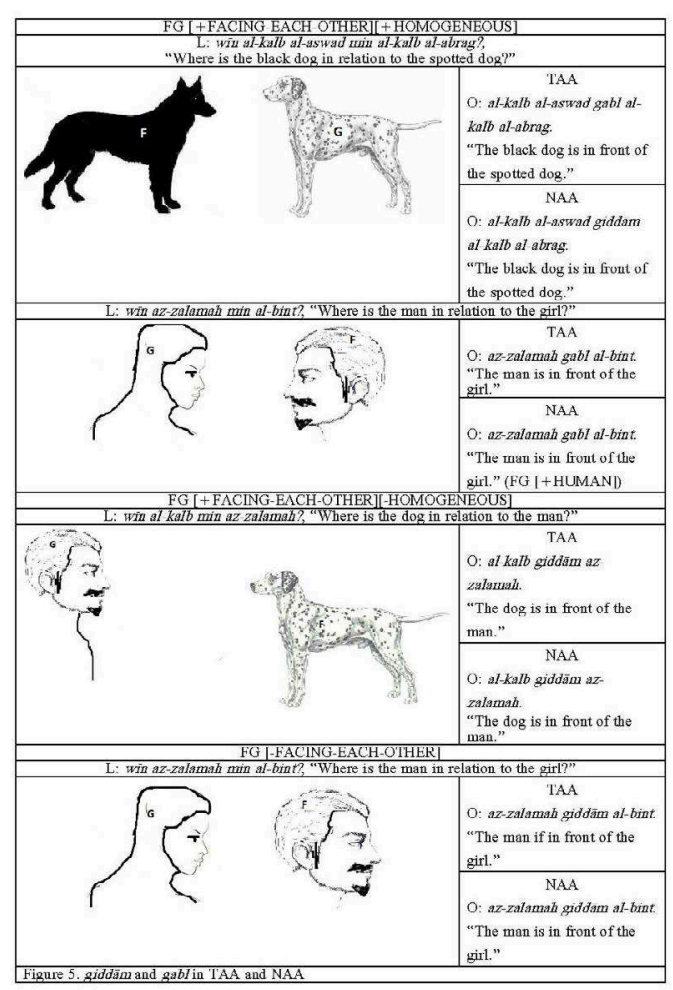

17 As shown by its use of gabl, NAA has a finer sensitivity to F's importance in selecting FoR and prepositions. Indeed, gabl is used in NAA only when FG face each other and are both [+HUMAN]. NAA distinguishes the special criterion [+HUMAN] among other [+FACED] Gs, such as animals. Furthermore, the use of giddām within both Intrinsic and Relative FoRs indicates that the prepositional split is absent from NAA, while in TAA each preposition is used exclusively with one FoR, except wara, which is applied in both Intrinsic and Relative FoRs; giddām is used only in the Intrinsic FoR.

\subsection{FGO [+/- ALIGNED]: Intrinsic and Absolute Sub-Types in TAA}

18 TAA applies Intrinsic and Absolute FoRs by means of two distinct grammatical strategies, i.e. "basic strategy" and "min-chain":

a. Intrinsic: "The dog is in front of the horse" basic strategy: al-kalb giddām al-faras; min-chain: al-kalb min al-faras w-giddām; b. Absolute: "Kseyfe is east of Beer Sheva" basic strategy: Ksīfih šarg Bir Sabi'; min-chain: Ksïfih min Bir Sabi 'w-šarg.

19 In a. and b., the English translation of both strategies is the same, as English cannot encode the distinction entailed in the use of basic strategy vs. min-chain, namely the axial condition of alignment between $\mathrm{O}$ and the array, i.e. FGO [+/-ALIGNED]. The cases above are represented in Figure 6: 


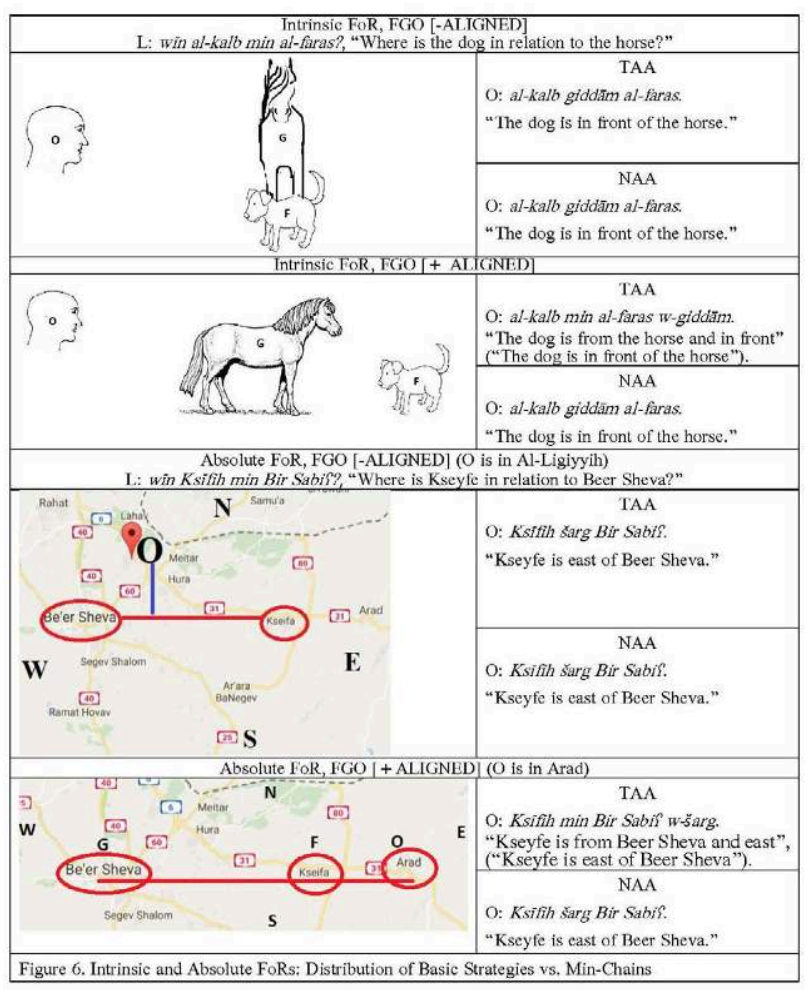

20 TAA's rich referential system includes O's perspective even in Intrinsic and Absolute FoRs considered O-independent strategies (Levinson 2003). Min-chains are absent from NAA, which does not apply the criterion FGO [+/-ALIGNED].

\subsection{Absence of Absolute FoR and Use of Right/Left in NAA}

NAA uses the Absolute FoR exclusively on a large scale, like modern European languages. In TAA the Absolute FoR can be considered the default strategy that solves all problematic cases of [-FAMILIAR] Gs and non-prototypical axial conditions, as in Figures 3 and 4. One of the basic applications of the Absolute FoR in TAA is the representation of the lateral axis of all Gs, a practice unknown in NAA, which uses the prepositions "right" and "left." As Figure 4 shows, "right" and "left" are projected by NAA speakers onto Gs according to the Relative FoR by Translation, even when Gs are inherently asymmetric along the right/left axis, as in Figure 7: 


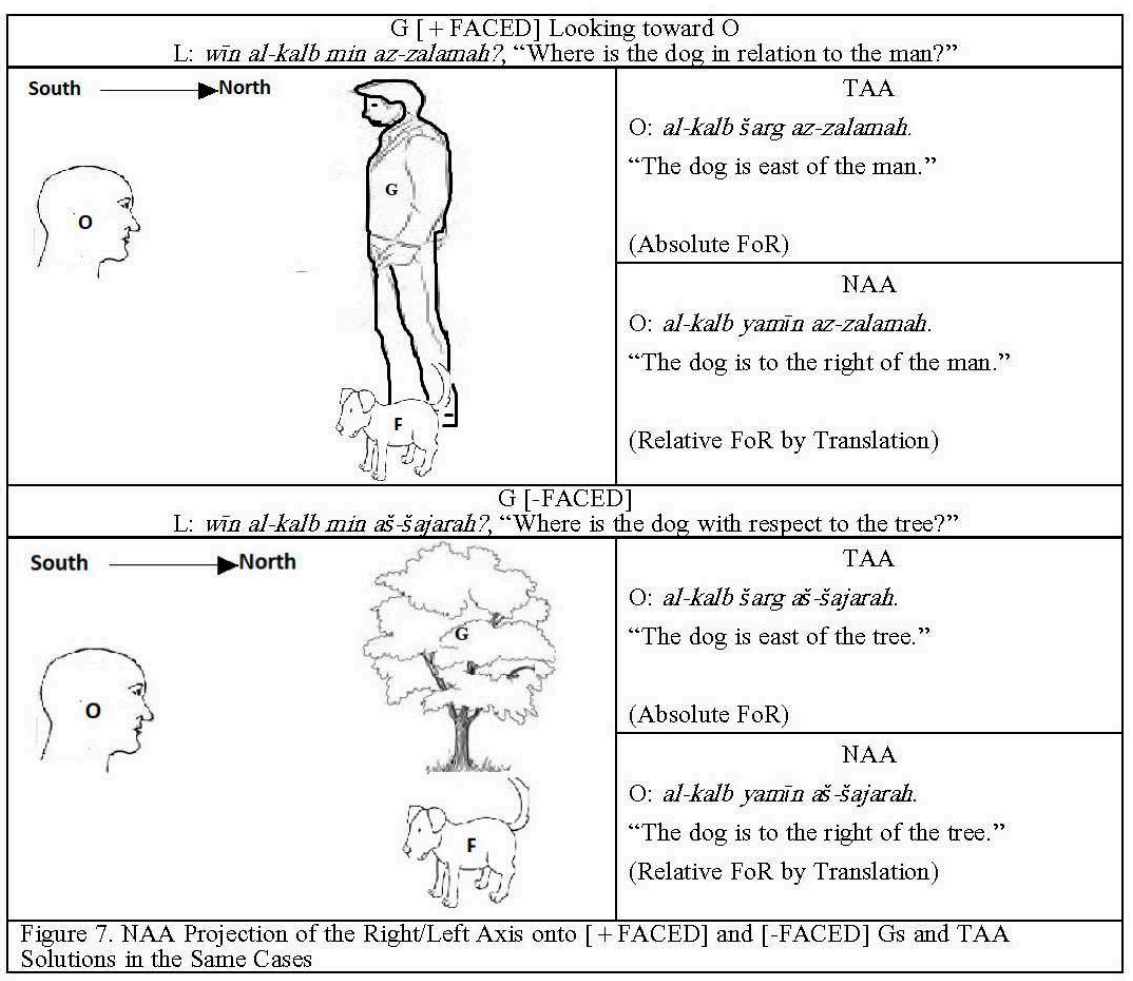

The lack of the criterion [+/- FAMILIARITY] and the use of right/left distinction determine the absence of the Absolute FoR from NAA's referential system.

\section{Discussion and Conclusion}

The differences between TAA and NAA described here can be summarized as follows: TAA uses the Absolute FoR in small-scale descriptions in problematic cases of [-FAMILIAR] Gs, in non-prototypical axial conditions, and to supply the lateral axis. NAA uses the Absolute FoR only on a geographic scale: the criterion of [+/- FAMILIARITY] is not applied and the right/left distinction is fully grammaticalized. In particular, the right/left axis is projected in NAA according to the Relative FoR by Translation and, when G [-FACED], the front/back axis according to Reflection. TAA applies the Relative FoR only by Translation to [+FAMILIAR][-FACED] Gs. The prepositional split that characterizes TAA is absent in NAA, where the selection of prepositions works according to different criteria (Figure 5). In particular, NAA distinguishes [+HUMAN] Gs within the set of [+FAMILIAR][+MOTOR INTELLIGENT] Gs where they were fully included in TAA. Intrinsic and Absolute referential sub-types entailing O's perspective (min-chains) identified in TAA are absent in NAA (Figure 6).

Factors that trigger changes in spatial representations within the same genetic and linguistic group are multiple. Cognitive linguistic studies (Li \& Gleitman 2002) stress that the acquisition of writing practices can significantly enhance the right/left distinction, as can driving cars and moving within the geometric paths of urban spaces instead of moving freely along individual trajectories. The impact of linguistic contact on spatial representations is clear. After 1948, aș-Ṣāni' people gradually became becoming multilingual in Standard Arabic, Palestinian koineised Arabic, Hebrew, and European languages such as English, German, or Italian, whose semantic features are similar to 
those shown here for NAA. The transition to a sedentary lifestyle also contributed to these changes. According to Brown (2006), the acquisition of specific spatial linguistic (and cognitive) strategies is greatly influenced by a consistent cultural organization of space in every aspect of life. The abandonment of traditional garments with their right/ left symmetric decorative patterns and interaction with new technologies, telephones, computers, cars, and electrical appliances have primed the extension of the Intrinsic FoR from a restricted set of Gs, as in TAA, to a more generalized and intensive use in NAA. Ultimately, while TAA referential and prepositional strategies are based more on cultural criteria than on geometric and metric features, the opposite is true for NAA, which is similar to most modern languages spoken in the globalized world.

\section{BIBLIOGRAPHY}

Blanc, Haim. 1970. "The Arabic Dialect of the Negev Bedouins", Proceedings of the Israel Academy of Sciences and Humanities IV/VII. 112-150.

Bohnemeyer, Jürgen. 2008. "Elicitation Task: Frames of Reference in Discourse - the Ball and Chair Pictures”, MesoSpace: Spatial Language and Cognition in Mesoamerica, 2008 Field Manual. Buffalo: SUNY. 34-37.

Brown, Penelope. 2006. "Language, Culture and Cognition: The View from Space", Zeitschrift für Germanistische Linguistik 34. 64-86.

Carlson-Radvansky, Laura A., \& Irwin, David E. 1993. "Frames of Reference in Vision and Language: Where is above?", Cognition 46. 223-244.

Cerqueglini, Letizia. 2015. Object-based Selection of Spatial FoRs in aș-Ṣāni Arabic. Pisa: PUP.

Cerqueglini, Letizia. 2016. "Etymology, Culture and Grammaticalization: A Semantic Exploration of the Front/Back Axis in Traditional Negev Arabic”, George, Grigore, \& BiȚună, Gabriel (eds), Arabic Varieties: Far and Wide. Proceedings of the 11th International Conference of Association International de Dialectologie Arabe - Bucharest, 2015. Bucharest: Editura UniversităȚii din București.175-183.

Cerqueglini, Letizia, \& Henkin, Roni. 2017. "Spatial Language and Culture: Cardinal Directions in Negev Arabic", Anthropological Linguistics 58 (2). 171-208.

Danziger, Eve, \& Gaskins, Susanne. 1993. “Exploring the Intrinsic Frame of Reference”, Levinson, Stephen C. (ed.), Cognition and Space Kit (Version 1.0). Nijmegen: Max Planck Institute for Psycholinguistics. 53-64.

Henkin, Roni. 2010. Negev Arabic: Dialectal, Sociolinguistic and Stylistic Variation. Wiesbaden: Harrassowitz.

Kressel, Gideon. 1996. Ascendancy through Aggression: Anatomy of a Blood Dispute between Urbanized Bedouin. Wiesbaden: Harrassowitz.

Levinson, Stephen. 2003. Space in Language and Cognition: Explorations in Cognitive Diversity. Cambridge, UK: Cambridge University Press. 
Levinson, Stephen, Brown, Penelope, Danziger, Eve, De León, Lourdes, Haviland, John, Pederson, Eric, \& Senft, Gunter. 1992. "Man and Tree and Space Games", Levinson, Stephen C. (ed.), Space Stimuli Kit 1.2. Nijmegen: Max Planck Institute for Psycholinguistics. 7-14.

Li, Peggy, \& Gleitman, Lila. 2002. “Turning the tables: language and spatial reasoning”, Cognition, 83(3). 265-94.

Marx, Emanuel \& Shmueli, Avshalom (eds). 1984. The Changing Bedouin. New Brunswick, NJ: Transaction Books.

O'Keefe, John. 1996. “The Spatial Preposition in English, Vector Grammar, and the Cognitive Map Theory”, Bloom, Paul, Garrett, Merrill, Nadel, Lyn \& Peterson, Mary (eds), Language and Space. Cambridge, MA: MIT Press. 277-316.

\section{ABSTRACTS}

I compare linguistic representations of projective spatial relations in two varieties of aṣ-Ṣannic Arabic: Traditional aș-Ṣāni' Arabic (TAA), spoken by those over age 67, and New aș-Ṣāni` Arabic (NAA), spoken by the rest of the tribe. My comparison pertains to spatial prepositions and Frames of Reference (FoRs). FoRs - Intrinsic/Relative/Absolute- are semantic strategies used to project coordinate systems onto spatial arrays in order to locate an object $\mathrm{F}$ (figure) in relation to another object $G$ (ground) (Levinson 2003). TAA selects the appropriate FoR in context in accordance with Gs' cultural properties and axial constraints: Intrinsic FoR applies only to [+FAMILIAR][+SHAPED] Gs (man/horse/camel/tent/coffee-pot) with prepositions giddām/gabl/ ('a)wijh, while ('a)wijh/gabl serve when FG [+FACING-EACH-OTHER] and giddām when FG [FACING-EACH-OTHER]. Relative FoR is applied via Translation to [+FAMILIAR][-SHAPED] Gs (stone/tree/pole/pillow); Absolute FoR is used with [-FAMILIAR] Gs (cow/dinosaur/shoe/chair). Relative and Absolute FoRs are represented by two grammatical strategies: basic prepositions (F wara/šarg G) and "min-chains" (F min G w-ǧāy/g்ād/šarg) following Gs and axial distinctions. Each FoR correlates exclusively to certain prepositions (prepositional split). NAA loses traditional ontology of Gs and axial oppositions; prepositional split regresses: gabl applies only when FG [+HUMAN][+FACING-EACH-OTHER]; giddām/('a)wijh serve Intrinsic and Relative FoRs, on all Gs, without axial constraints; Absolute FoR is used only on geographic scale; Relative FoR is applied via Translation and Reflection; the opposition between basic prepositions vs. min-chains in Absolute and Relative FoRs disappears, as min-chains vanish. Beginning with the establishment of the State of Israel and through the early 1950s, the generational gap between TNA and NAA shows how material culture, formal education, language contact, and life style modify the semantics of space and its experience.

\section{INDEX}

Keywords: Spatial Frames of Reference; Spatial Prepositions; Bedouin Arabic; Cross-Generational Semantic Change; Cultural Ontologies 
AUTHOR

LETIZIA CERQUEGLINI

Tel Aviv University, Department of Semitic Linguistics

lutezia7@gmail.com, Web Building, Room 517 


\title{
Linguistic Analysis of Puns and Common Sayings in Texts of Bilād aš-Šām
}

\author{
Emanuela De Blasio
}

\section{Introduction}

1 In some artistic expressions the main aim is to transmit serious messages through irony or sarcasm. The choice of language and of stylistic means is fundamental in order to give a humoristic effect. This work is based on the analysis of word play and common sayings in text cartoons produced in Arabic varieties of the Syrian-Lebanese-Palestinian area. Colloquial expressions and puns play a predominant role in these artistic productions, in which the form is as important as the content.

2 The term "pun" is a common literary device that can be defined as a play on words. So in order to make a pun it is necessary to use words in an amusing and ingenious manner. The linguist Crystal (2004: 408) asserts that a pun focuses on the double meaning of a word or phrase and on the play of different words that sound alike.

Speech plays, such as puns, tongue twisters, riddles, jokes and proverbs mainly belong to the realm of the spoken language. These forms in Arabic language have not yet been thoroughly investigated. Prochazká (2008) in his paper has examined tongue twisters in Arabic dialects, dealing also with puns. He claims that tongue twisters are yet another aspect of the linguistic creativity of the Arabs and belong almost exclusively to the domain of the dialects, which are the variant of Arabic where ordinary people can reveal and express their creativity.

Plays on words are often used to transmit a thought or a message: these are prevalent in cartoons, songs, especially rap songs, commercials, slogans, literary forms, and so on.

In cartoons, in order to give impetus to a text or a concept, the author makes use of puns based on double meanings or on words that sound alike but which are distant in meaning. The aim is to provoke irony or arouse other feelings, thus reawakening the consciousness. 
6 In the texts of cartoons colloquial expressions are also often to be found: they are used to engage the reader in the reality that the author wishes to communicate, provoking a smile. Idiomatic expressions used in everyday life in the Arab world play a very important role: they are part of 'adab "good manners" (greetings, requests, thanks, various exclamations).

7 Cartoons are mostly in Arabic varieties, so they can be a rich source for improving the study and the knowledge of Arabic dialects; for example, Zack (2014) analyses the use of the Egyptian dialect in the satirical newspaper Abu Nadd̄a ra Zara $a$.

The aim of cartoons is to speak sometimes about serious problems or topical issues while provoking in the reader a sense of irony or humour, and that occurs through word plays in the form of puns, common sayings, and double meanings.

\section{Material and methodology}

9 I have examined approximately one hundred cartoons, but the corpus selected in this paper comprises fifteen cartoons.

10 The authors of the cartoons are some of most representative contemporary cartoonists from the Syrian-Lebanese-Palestinian area. The majority of the selected texts are part of a cartoon collection from the year 2000 up to 2010. Thus, some cartoons refer to past political and historical events.

11 As regards the Palestinian texts, the authors taken into consideration are Baha Bukhari and Omayya Geha; the author of the Lebanese texts is Stavro Jabra. The Syrian cartoons are taken from the Syrian press and from websites (in the footnotes I have specified the author and the source).

12 The main content of the selected material is political and social. In this context I am not dealing with a study regarding the socio-political content or message of the texts, but only the linguistic and stylistic aspects.

13 I have divided the corpus into two parts: in the first I analyse puns (9 texts) and in the second I examine sayings, idioms and proverbs (6 texts). Sometimes puns and common sayings are together in the same text.

14 As regards the textual transcription methodology, I have referred to the system of Durand (2009).

\section{General remarks about the texts}

The selected cartoons (in Arabic kārikkātūr or kārïkatìr from French "caricature") are all in Colloquial Arabic: the choice of the dialect enables the message to be understood by the majority of people and at the same time the reader feels close to that way of speaking, because they find expressions and common sayings that are in daily use. Whereas the text outside the cartoon bubbles is mostly in Standard Arabic.

These cartoons reflect the linguistic reality of the Arab world; in the texts the language level varies in relation to many factors: the situation, the speaker, and the subject dealt with. The linguistic phenomenon of code-switching in the cartoons can be observed: so if the speaker is in a formal situation, that is, at a political meeting, on television, or in the 
case of a newspaper article, the author adopts a high register that tends to use Standard Arabic, in all other informal situations Spoken Arabic is employed.

As regards phonetics and phonology, I have reproduced some typical features of urban dialects of Palestine, Lebanon and Syria, specifically the varieties of Jerusalem, Beirut and Damascus: so the phenomenon of imāla (palatalization of $/ a /$ to $/ i /$ with an intermediate degree /e/); the uvular phoneme $/ q /$ realized as laringal occlusive [?], the realization in [3] of the palatal affricate phoneme / $\check{g} /$; and the substitution of interdental consonants / $\underline{t}$ $/$ and $/ \underline{d} /$ with dentals $/ t /$ and $/ d /$. The interdental enphatic $/ \underline{d} /$ realized as $\left[d^{i}\right]$ or more rarely $[z](\underline{d}>d, z)$.

As regards the morphology, an analytic tendency can be noted, such as the use of a noun to mark the dual, and a variety of preverbs for the different aspects of a verb.

In the syntax a simplification of structures can be seen. The verb usually agrees in gender and number with its subject and the adjectives are often put in the plural to agree with inanimate plural nouns.

20 As regards the lexicon, there are variations linked to the different contexts of the cartoons. Although foreign words (English or French) are sometimes used for ironic purposes, there is a tendency towards a total Arabization of the texts.

Due to the absence of formal recognition, the Arabic dialects are affected by a lack of orthographic conventions: this factor is also shown in the texts of the cartoons, in which each author invents a graphematical expression. Graphematical aspects depend on the phonetics of the dialect.

In the case of interdentals, they are sometimes realized as occlusives. For example, the demonstrative: hāda هادا is written with the phoneme /d/ in place of hāda هith the

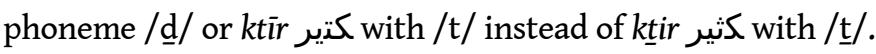

The phoneme $/ \mathrm{h}$ / of the suffixed pronouns of the third singular person is sometimes (but not always) omitted, revealing the effective phonetic realization: قلو a al-lo, قطعو atta'-o آiva $m a^{\prime} n \bar{a} t-(h) a$.

In other cases, on the contrary, Standard Arabic interferes in the written texts: the interdental consonants are sometimes found, for example tzakkar تذكر; the phoneme /q/ graphematically is always given: وقت wa wa $q^{q} t$, قتل ${ }^{q} a t^{2} l$.

All these factors demonstrate that there is not a normalization regarding the graphematic aspect.

The authors of cartoons use different ways of foregrounding: this term refers to the various techniques with which it is possible to cause linguistic deviation; among them, one of the most immediate is the violation or break of a linguistic rule (Douthwaite, 2000). So the cartoons have peculiarities that sometimes make them indecipherable: language deformations, metaphorical language, and cultural references.

The humorous mechanisms of the examined texts are realized on different levels: phonological, lexical and semantic, grammatical and syntactic, and cultural.

\subsection{Puns}

In on-line dictionaries, the term "pun" is translated lu'bat al-kalimāt. Many of my informants gave me kalām malḡüm "mined speech" as translation; this definition can also be found on the web. In the al-Manhal dictionary (2000: 687), under the term jeu de mots 
we find جناسinās. In his paper, Munthir (2011) asserts that the Arabic equivalents for the English term "pun" are both ğinās 'iḍmār ma'nawiyy or تورية tawriya and ğinās lafziyy tāmm.

* Phonetic and morphological peculiarities

- Alliteration: a figure of speech which consists in the repetition of certain phonemes in consecutive words.

- Consonance and assonance: the repetition of consonants and sequences of consonants or vowels in words in close proximity.

- Metathesis: the juxtaposition of words showing metathesis of the root consonants.

- Juxtaposition of similar consonants.

- Juxtaposition of two words similar in sound but different in meaning.

- Also rhyme as the repetition of final sounds constitutes a means to creating a humorous effect. Final rhymes, for their position, represent an end focus (Douthwaite 2000: 314), that is words characterized by a high informative and communicative content. The rhymes, in this case, are used in order to give a special emphasis to information.

* Lexical peculiarities

Puns are based on ambiguity through polysemy, homonymy, and literal meaning against metaphoric meaning. Neologisms, or sometimes resemantization, that is giving a new meaning to an existing lexical element, can be observed.

Some cases of transglossia can also be noted: the authors sometimes resort to foreign words or loan words in order to arouse humour.

\subsection{Common sayings}

Common sayings, or more technically idiomatic expressions, generally refer to conventional expressions, characterized by the combination of a fixed signifier to a meaning which is not predictable from the meaning of its components (Casadei 1995: 335; Cacciari \& Glucksberg 1995: 43). These kinds of expressions would mean nothing if you considered them just as the sum of the meanings of their components (Cacciari \& Glucksberg 1991: 217); if taken as a block, they refer to a figurative meaning, sometimes resulting from metaphorical procedures, and shared by the entire linguistic community. Expressions, such as "to be broke" or "to kick the bucket" do not mean anything if you consider their literal meanings.

Generally in Arabic the translation of common sayings or idioms is 'ibāra iștilāhiyya.

35

In the selected texts, the proverbs, idioms, sayings, often used with a double meaning, make the language familiar to the reader, provoking laughter. The use of some sayings which regard oral traditions can be explained by their location, and thus they can vary from region to region; in other cases, some sayings are known to people of diverse dialectal backgrounds. 


\section{Texts}

\subsection{Analysis of puns}

\subsubsection{Palestinian cartoons ${ }^{1}$}

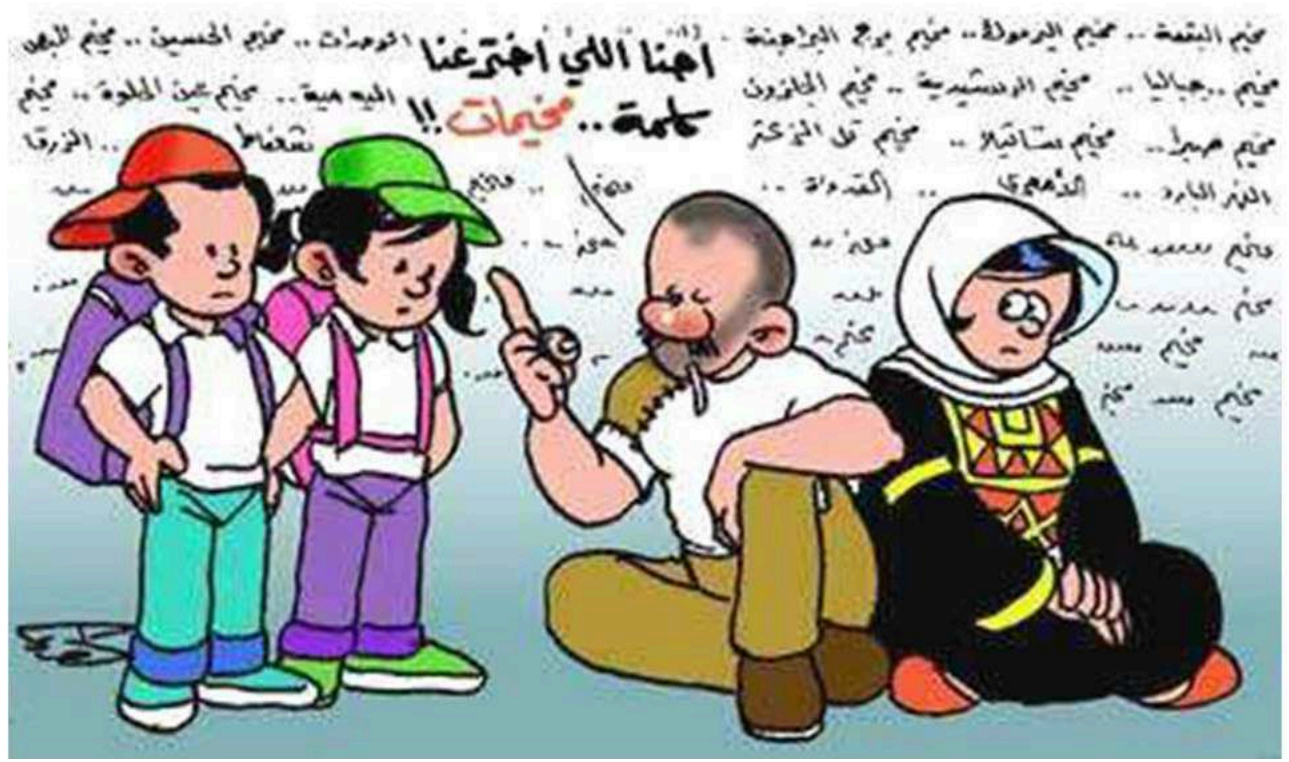

(At the bottom there are the names of the Palestinian refugee camps scattered around the Arab world)

- iṇna lli ḩtara'na kilmet... muhayyamāt!

TRANSLATION

- "We are the people who invented the word 'camping'!".

Analysis: The author has based the word play on polysemy in which the different meanings associated with the same signifier/lexeme are related to each other. In fact, the term muHayyamāt means both "refugee camps" and "camping" (we notice that the children are equipped with backpacks and caps to go camping). 


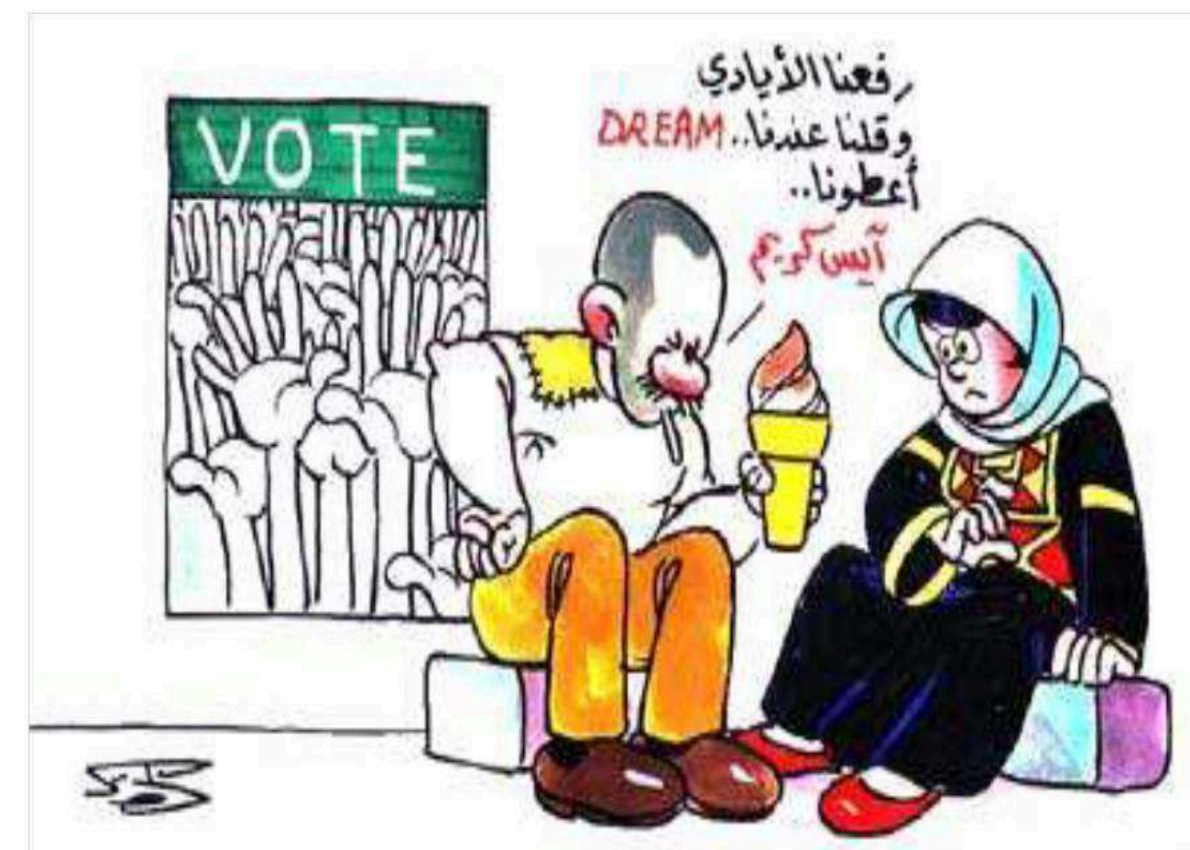

- rafa'na l-ayād-i w-qulna 'and-na... DREAM a'țū-na āys-krīm!

TRANSLATION

- "We raised our hands and said: we have a DREAM... give us ICE-CREAM".

37 Analysis: This cartoon plays on the first words of a famous speech by Martin Luther King that began with the phrase "I have a dream". Here the irony comes from the assonance 
and rhyme in English between DREAM and ICE-CREAM. Probably the author ironically wants to say that people are happy with little things or treats.

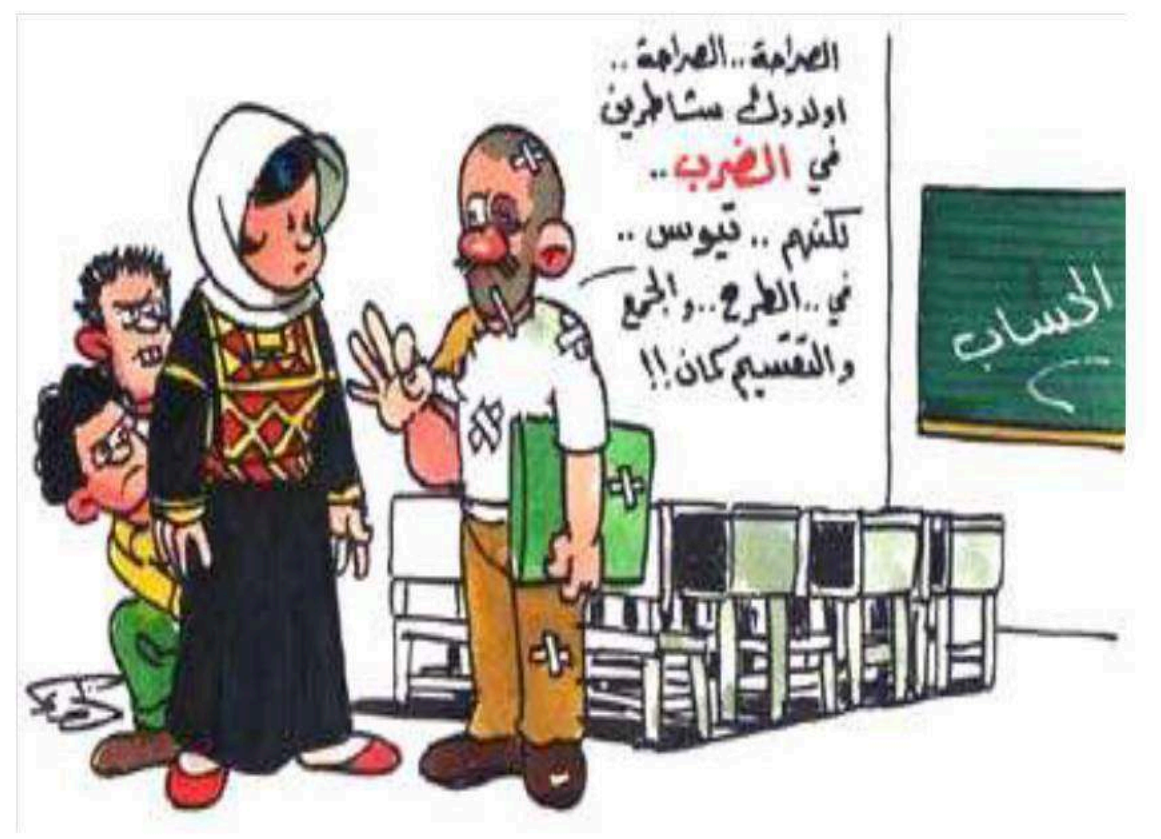

(on the blackboard): al-hisāb

- iṣ-șarāḥa... iș-șarāḥa... wlād-ek šațrīn fi-ḍ-ḍarb... lakin-hom... tyūs... fi-ț-țar'ḥ... w-iž-žam ' w-it-taq sìm kamān

TRANSLATION

(on the blackboard): "maths"

- "Really, really your sons are good at multiplication... but they are ignorant as goats in subtraction, addition and division!"

Analysis: Here the pun is based on the homonymy of the term darb which means both "thump" and "multiplication". The lexemes are formally equal, but have different meanings. 


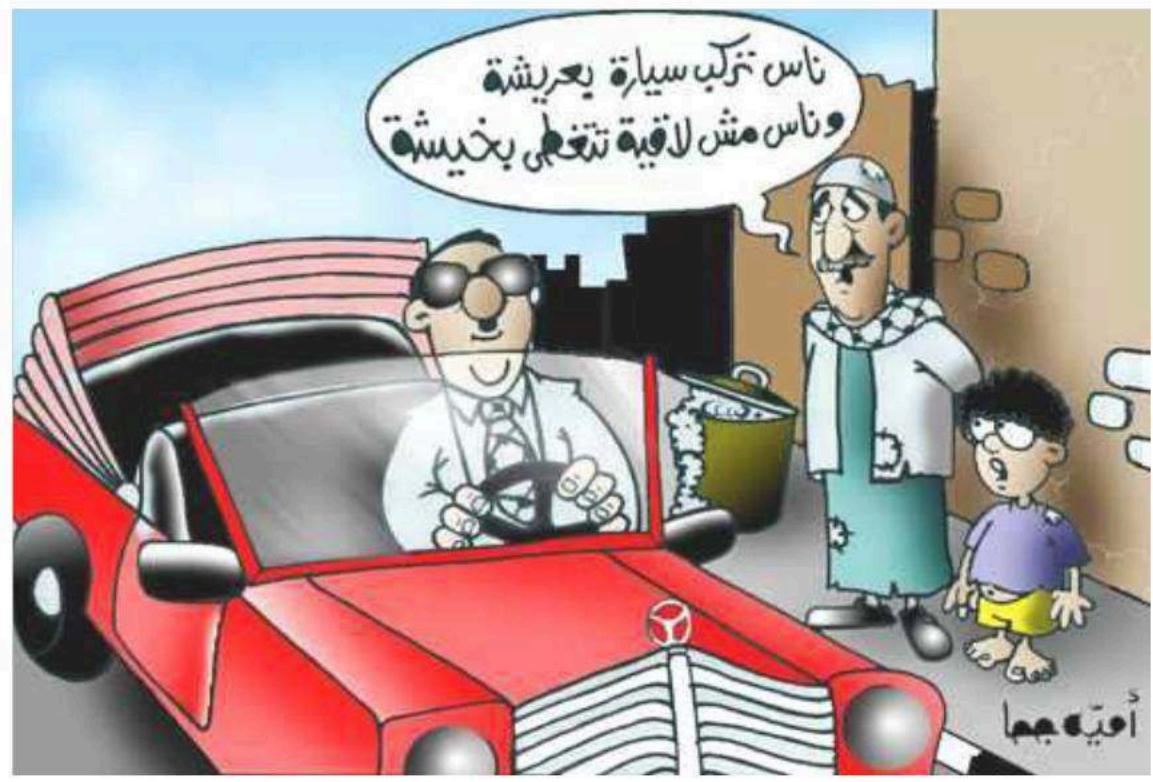

- nās tirkab siyyāra bi-'arēše w-nās miš lāaye titg̉ațța bi-ḩēše.

TRANSLATION

- "There are people who drive cars with detachable covers and people who can't even cover themselves with sacks".

39 Analysis: In Arabic the pun foregrounded through the rhyme ēše can be observed between the words 'arēše and Hūeše. 


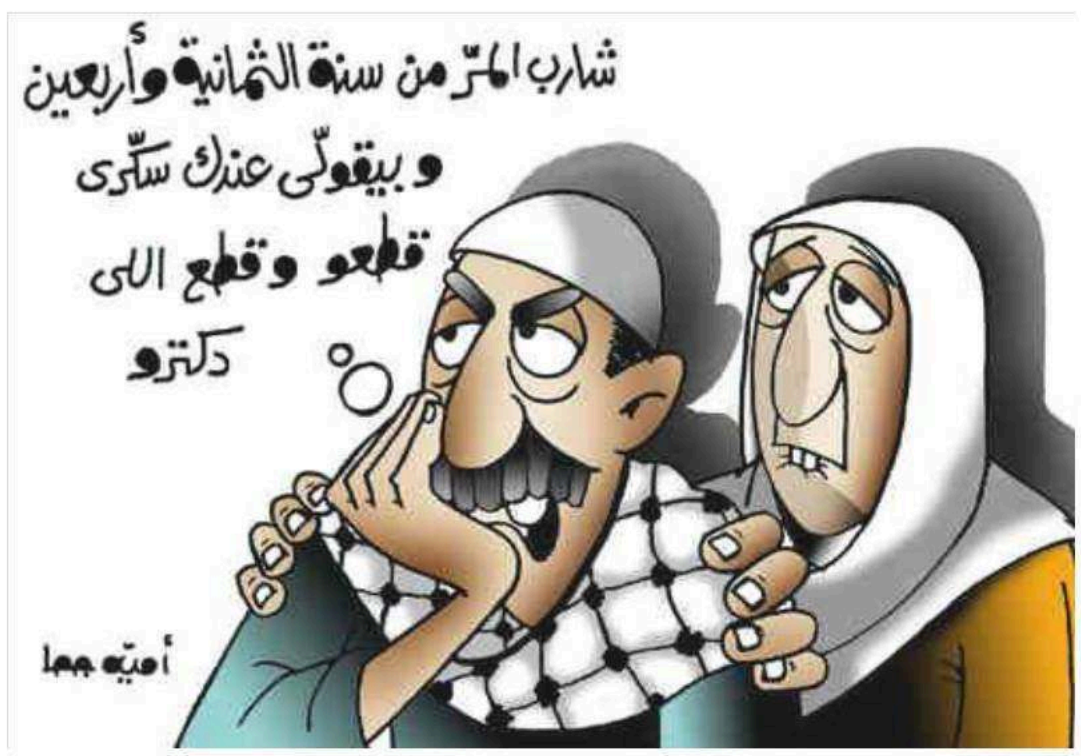

- šāreb il-murr min senet it-tamāniye w-'arb'īn w-biāül-li 'and-ak sukkari a ațța'-o, w-âațta' illi daktar-o.

\section{TRANSLATION}

- "I've been drinking bitter since ' 48 and he tells me you have diabetes, damn him and damn whoever made him a doctor".

40 Analysis: Here the irony arises from the contrast between the meanings of the terms murr "bitter" and sukkari "diabetes" (literally: "sweetened") and the concept that the person who has diabetes has consumed a lot of sweet substances in his life, but the man in question says he has consumed only bitterness.

41 illi daktar-o: "whoever made him a doctor". Here we notice a neologism: the author creates jokingly the quadriconsonantal verb daktar taken from a foreign word (en. doctor or fr. docteur).

Moreover, we find the idiomatic expression "atța'-o, it literally means "God cut it" and it is used to curse someone. 


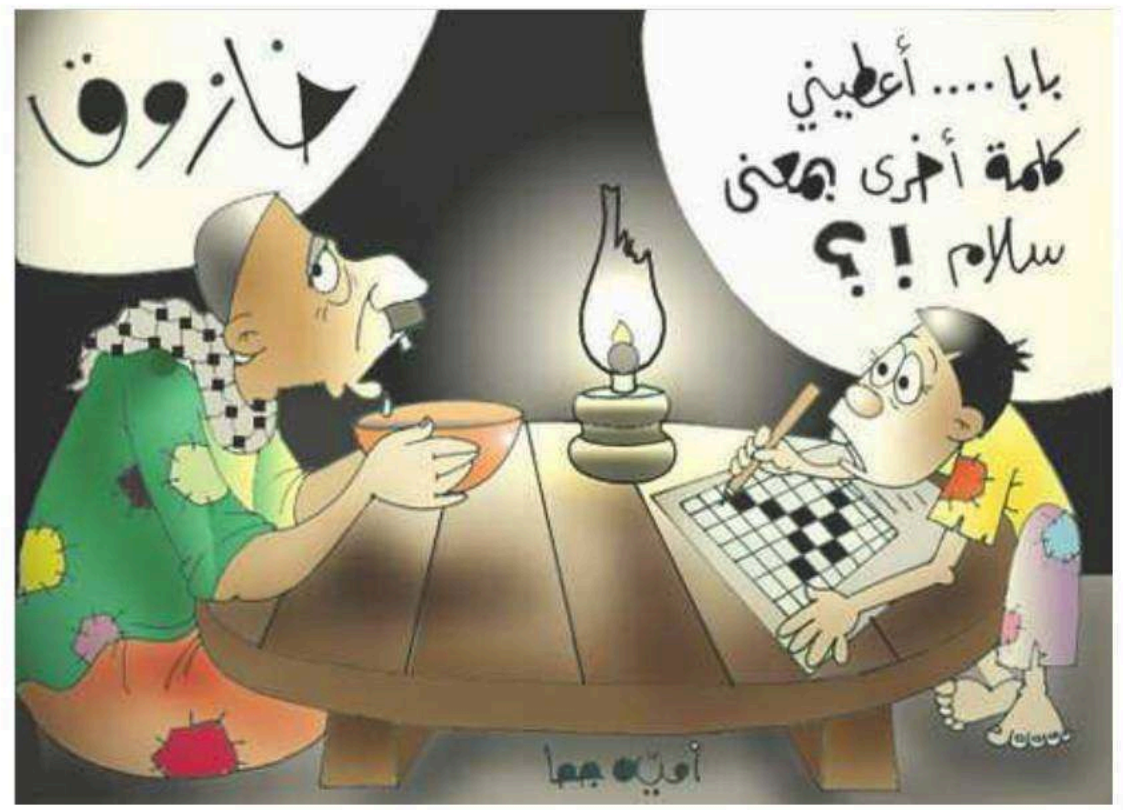

- bāḅa... a'ți-ni kilme uhra bi-ma'na salām?!

- ḩāzūq.

\section{TRANSLATION}

- "Daddy... give me a synonym of peace?!".

- "Scam".

43 Analysis: The author uses the device of polysemy to make sarcastic remarks: the term Hōzū $q$ (pl. Hawāzīq) means "pointed pole", (derived from a torture instrument) but in colloquial language it takes the meaning of "scam". 


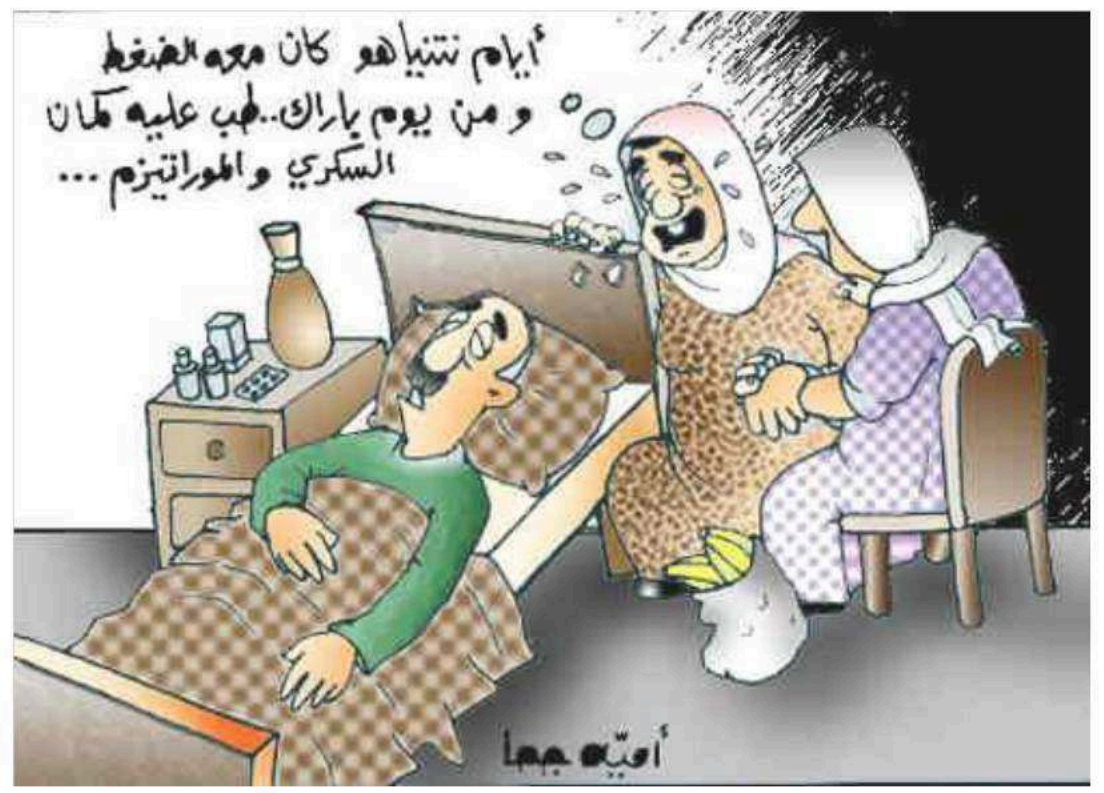

- ayyām Netanyāhū kān ma'-o ḍ-ḍag̣ț w-min yōm Bārāk țabb 'alē-(h) kamān is-sukkari w-il-mūrātīzm... TRANSLATION

- "In the time of Netanyahu he had pressure problems but since Barak he has also had diabetes and 'muratism'...".

44 Analysis: mürätizm: from French rhumatisme, but being a foreign word the woman does not know how to pronounce it well and distorts it. In Arabic rūmātism should be correct: here here is a consonant metathesis rūmātism and mūrātīzm. 


\subsubsection{Lebanese cartoons ${ }^{2}$}

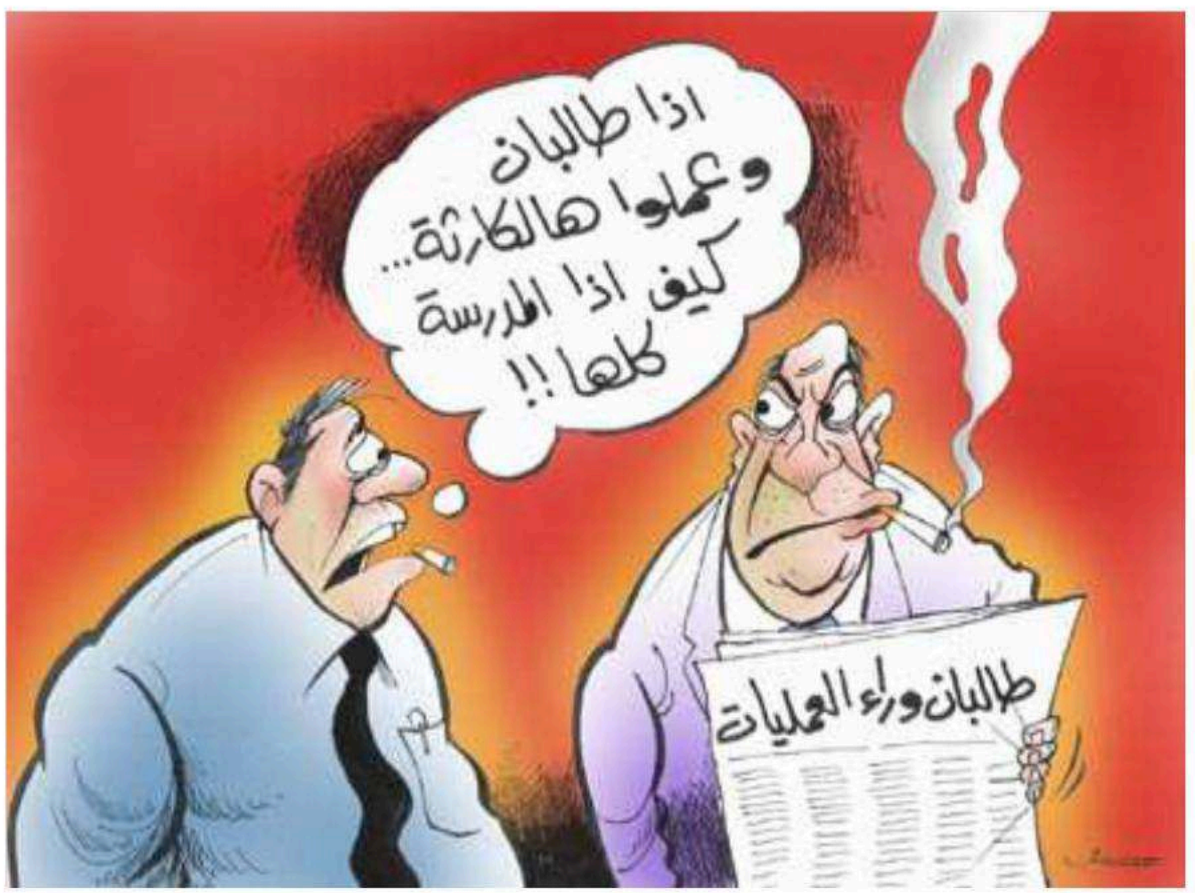

(in the newspaper): țālibān warā' l-'amaliyyāt

- iza țalibān w-'əmlu ha-l-kārisi kîf iza I-madrasi kəll-ha!!

TRANSLATION

(in the newspaper): "the Taliban behind the operations"

- "If two students carried out this disaster, think what a whole school could do!"

Analysis: The author plays with the morphological aspect of word țalibān: in Arabic -ān is the suffix of the dual (grammatically in Persian the suffix $-\bar{a} n$ is for the plural).

The man, pictured on the left, interprets the term as dual and with its literal meaning, that is "two students". 


\subsubsection{Syrian cartoons ${ }^{3}$}

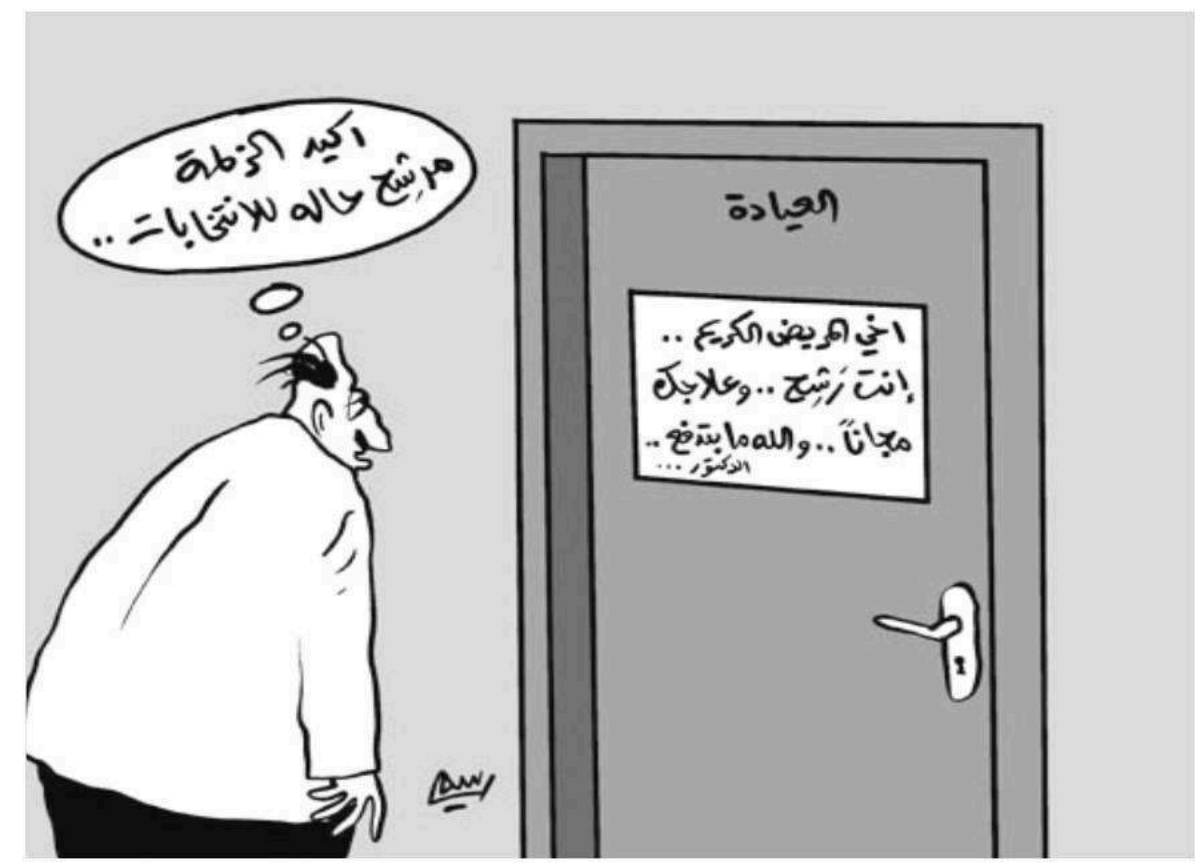

(on the door): al-'iyāda

(on the sign): ah-i l-marīd əl-karīm... ənte raššeh... w-'ilāž-ak mažžānan.. w-Alla ma btədfa' ...d-duktūr... - akīd əz-zalame mraššeh hāl-o lə-lintiḩābāt...

\section{TRANSLATION}

(On the door): "Clinic"

(On the sign): "Dear patient, cool down and I will take care of you for free, I swear you won't have to pay ... the doctor..."

- "This guy must be standing for election..."

47 Analysis: There is a clear pun based on the homonymy: the verb rašša means both "to cool down" and "to stand for election". 


\subsection{Analysis of common sayings}

\subsubsection{Palestinian cartoons ${ }^{4}$}

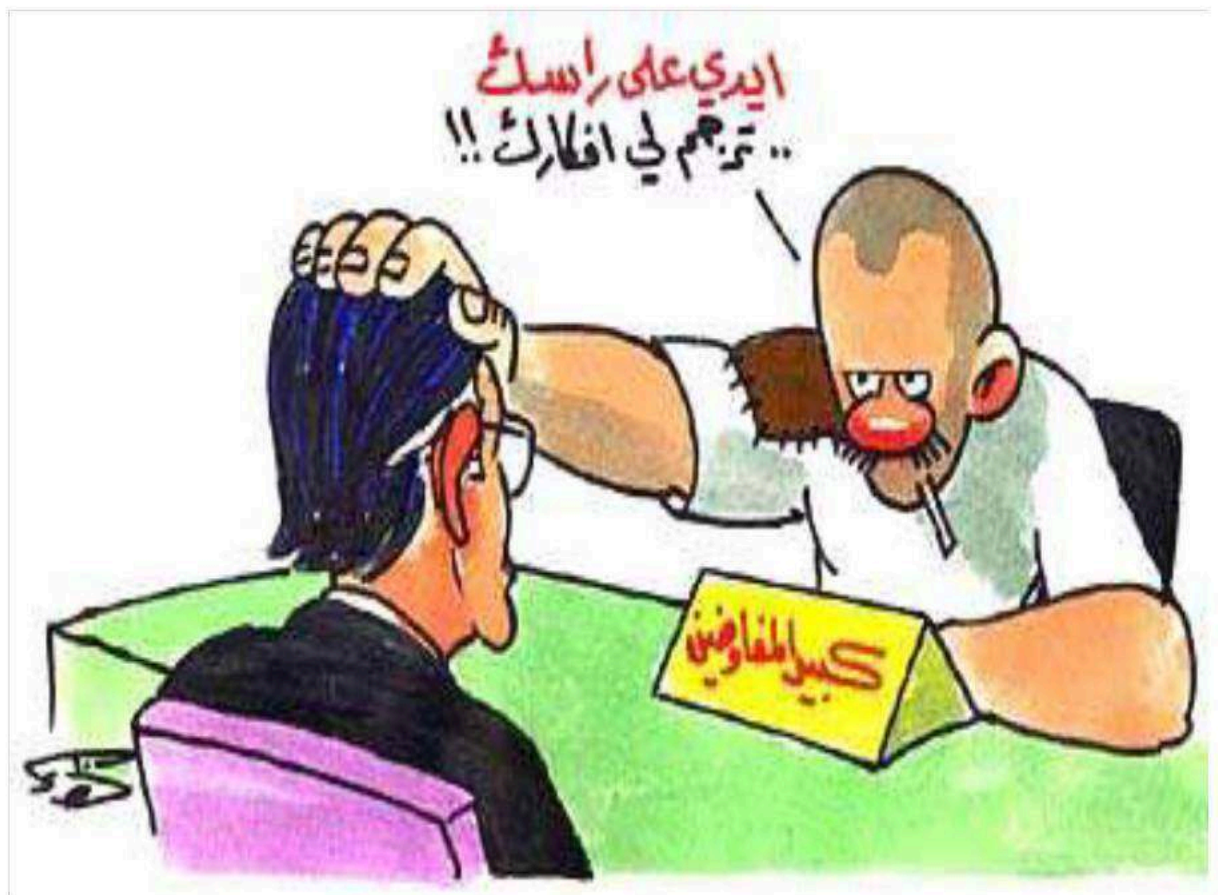

(on the plaque): kabìr al-mufāwadīn

- ìd-i 'ala rās-ak... taržem-li afkār-ak!!

TRANSLATION

(on the plaque): "the chief delegate"

- "I beg you, tell me what you're thinking!"

Analysis: The expression i $i d-i$ 'ala răs-ak, literally "my hand is on your head", is a common saying in Colloquial Arabic. And the gesture of the character underlines the literary meaning. It is used as a petition or request for something. 


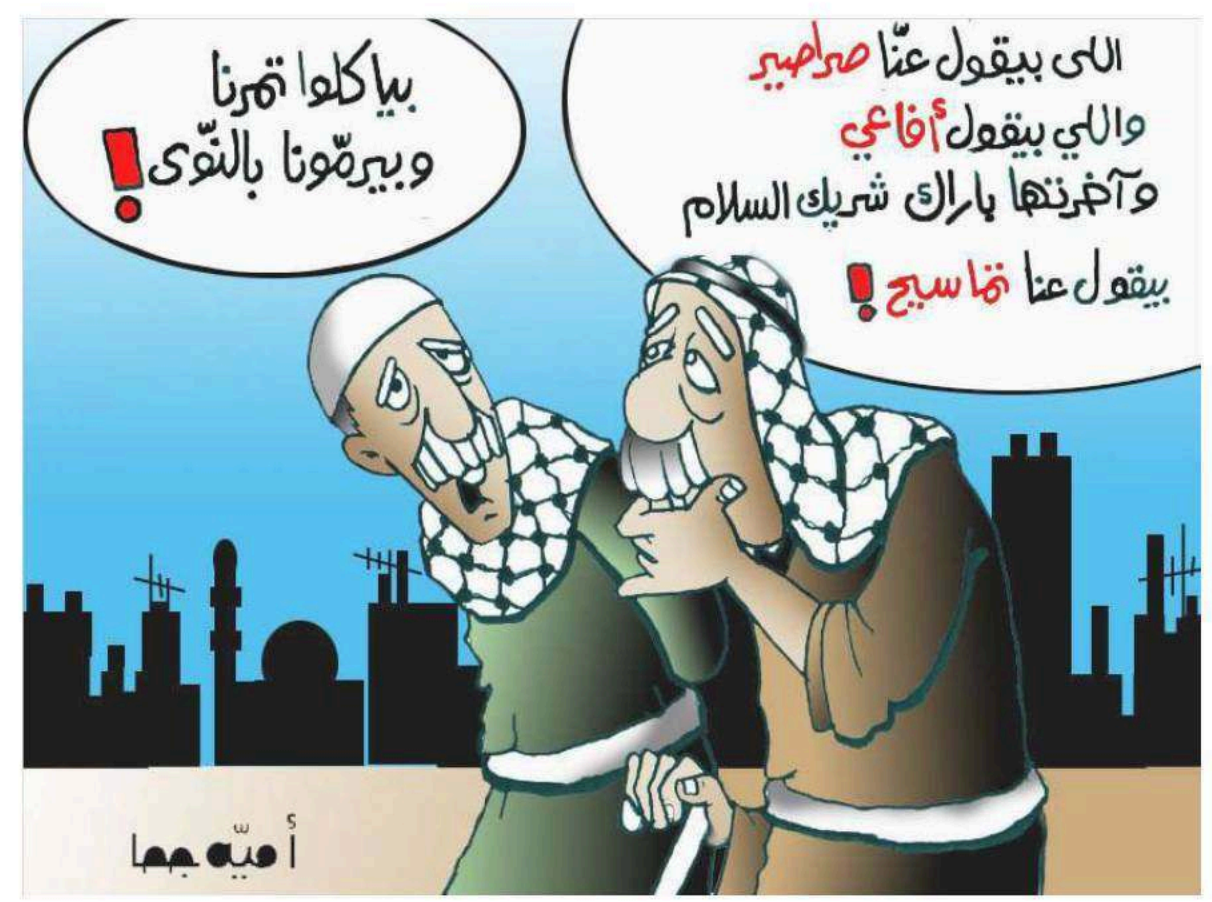

- illi biqūul 'an-na șarāṣîr w-illi biđūl afā'i w-āhret-ha Bārāk šarìk is-salām bịūl 'an-na tamāsīḥ!

- byāklu tamir-na w-birammū-na bi-n-nuwa!

\section{TRANSLATION}

- "Some people say we are cockroaches, others say we are vipers and finally Barak, the peace coworker, says we are crocodiles!".

- "They eat our dates and throw the kernels back to us!".

Analysis: The expression byāklu tam ${ }^{i} r$-na w-birammū-na bi-n-nuwa is a common saying or a kind of proverb. It refers to those who get the best and give back the scraps. 


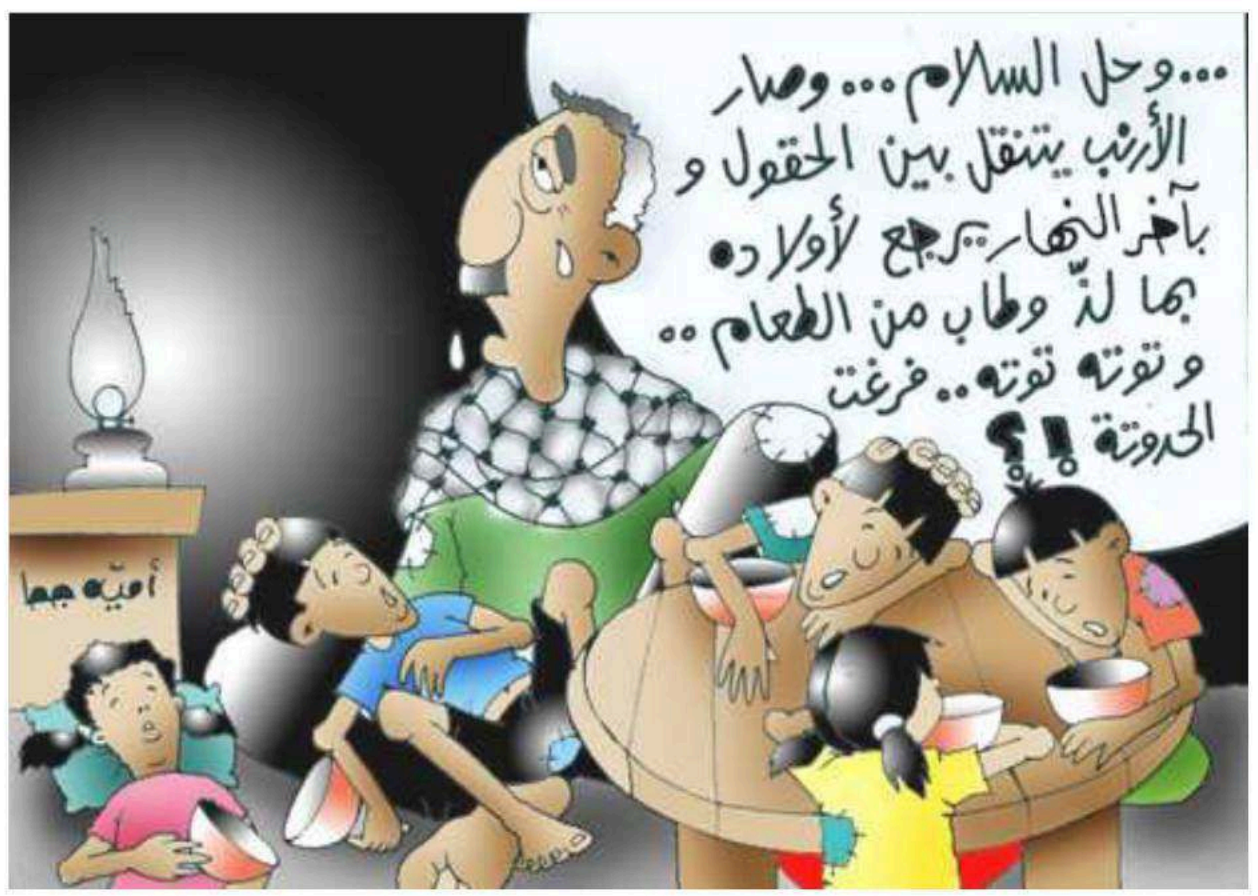

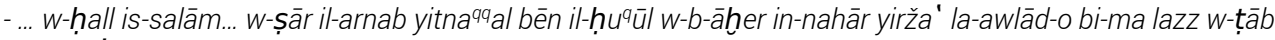
min ițța'ām... w-tūte tūte... farg̉at il-ḥadūte!

\section{TRANSLATION}

- "... And peace came ... and the rabbit began to wander among the fields and at the end of the day it came back to its children with good and tasty things to eat ... and so they all lived happily ever after!"

Analysis: tūte tūte... fargat il-hadūte it is the typical formula that is used at the end of a fairy tale, story; Literally it means: "blackberry, blackberry, the story is finished". The formula tūte tūte Halšet il- hattūte is more frequent.

șār yitnaqqal "began to wander": the verb șār, lit. "to become", followed by a imperfect verb, indicates the beginning of an action in the past and which gives it inchoative value. 


\subsubsection{Lebanese cartoons ${ }^{5}$}

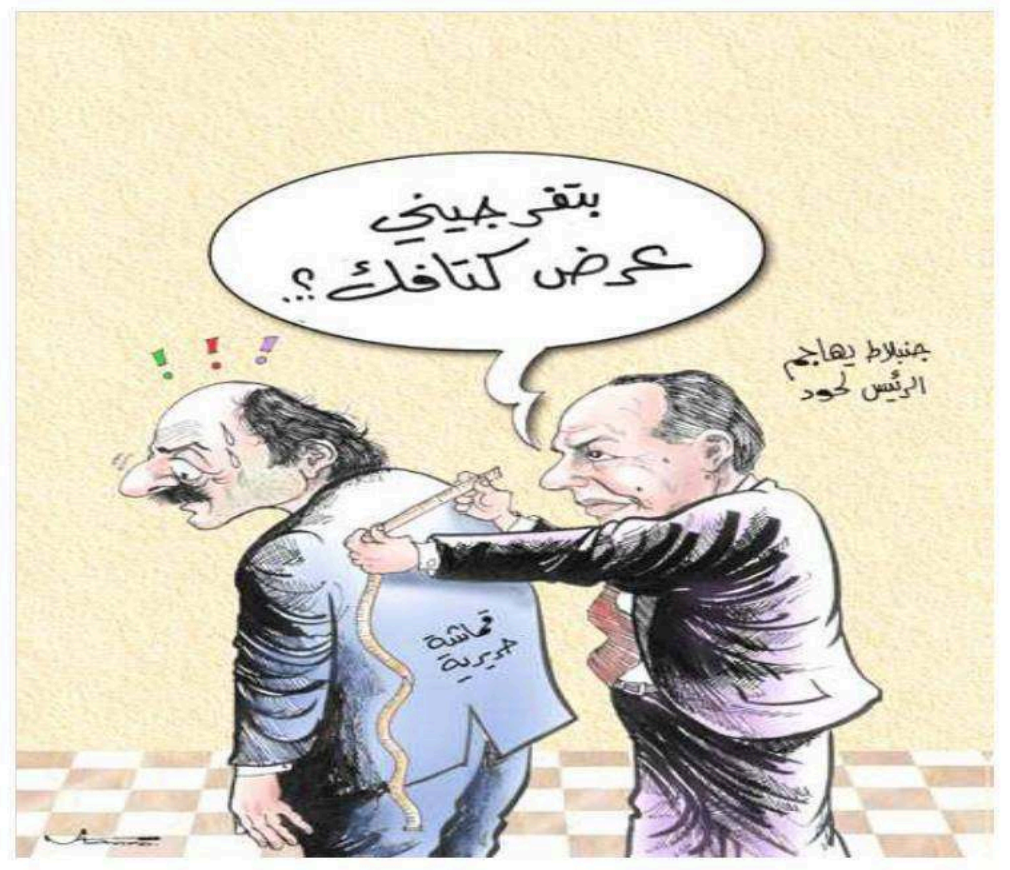

(on the right): Ğunblāt yuhāğimu r-raîs Lahḥūd

(on the jacket): qumāša ḥarîriyya

- bətfaržī-ni 'ard əktāf-ak?

\section{TRANSLATION}

(on the right): "Jounblatt attacks President Lahoud"

(on the jacket): "silk fabric"

- "Would you show me the width of your shoulders?"

52 Analysis: In the cartoon, caricatures of Walid Jounblatt, leader of the Druze Community and of Émile Lahoud, the former President of Lebanon are represented.

The sarcasm comes from the colloquial expression bətfaržī-ni 'arḍ ${ }^{\partial} k t a \bar{f}$-ak, literally "show me the width of your shoulders", but the real meaning is "get out of the way".

It is also a pun: the noun harir means "silk" and the adjective haririyya "silky"; but in this case there is a double meaning with the name of the Lebanese Prime Minister Hariri. 


\subsubsection{Syrian cartoons ${ }^{6}$}

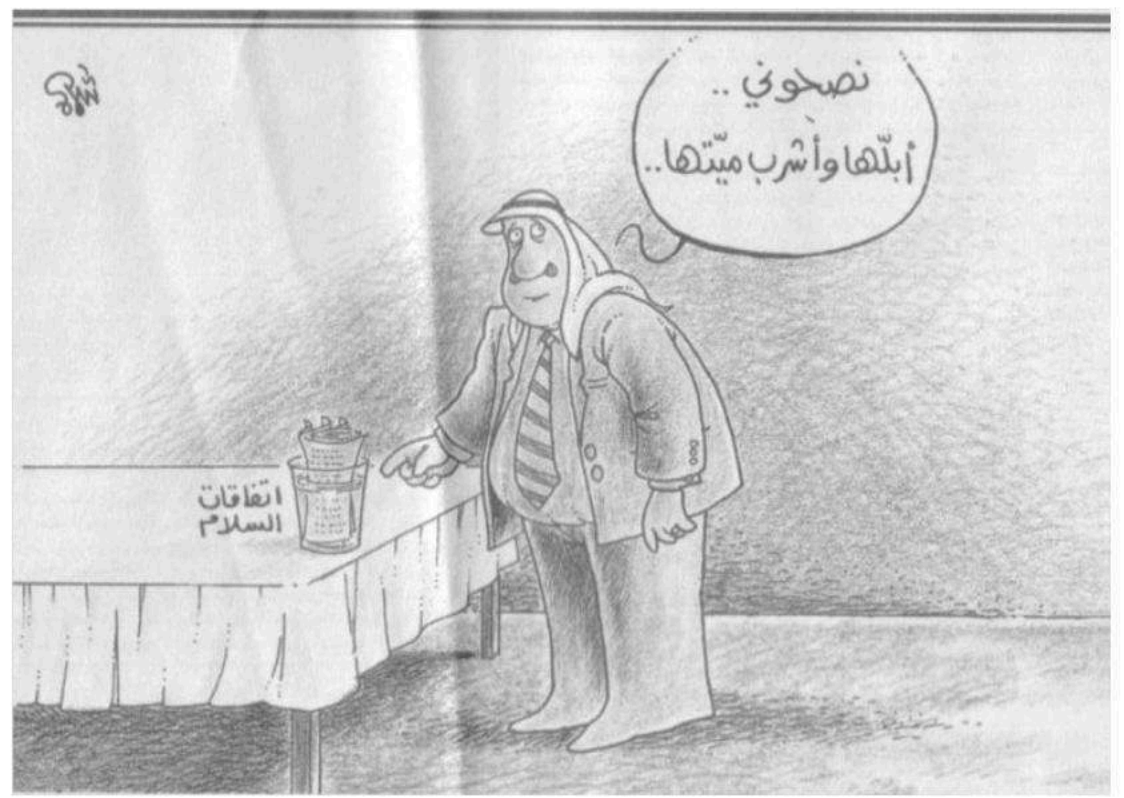

(on the table): 'ittifāqāt as-salām

- nașahū-ni... əbəll-ha w-əšrab mayyet-ha...

\section{TRANSLATION}

(on the table): "peace agreements"

- "They advised me to keep them hydrated and drink water..."

53 Analysis: əbəll-ha w-əšrab mayyet-ha: is a common saying for something that has no value (in this case it refers to the peace agreements). It corresponds to "to throw them away". 
- māma šū ma'nāt-ha "I-ḩəbb a'ma"?

- iza bəțțalle' bə-wəžəh abū-k əbta'ref šū ma'nāt-ha!!

TRANSLATION

- "Mom, what does it mean 'love is blind'?"

- "If you look at your father's face, you will understand what that means!"

54 Analysis: l-həbb a 'ma "love is blind", is a common saying. This kind of expression would mean nothing if you consider it just as sum of the meanings of its components. It refers to a figurative meaning, resulting from metaphorical procedures. This expression means that a person in love does not see the flaws of the other person. This expression exists in different languages.

\section{Conclusion}

In the cartoons selected here, in order to express the message, the authors have chosen Spoken Arabic of their areas. The language employed in the texts of the analysed cartoons reflects the reality of the linguistic situation of the Arab world. So the collection of these texts can also be a rich source of morphological, syntactic and lexical information about Arabic dialects.

Beyond the visual aspect, the linguistic and stylistic means chosen by the author to transmit the message to the reader is fundamental.

In order to give an impetus to the cartoons, the authors employ puns. They are a way of taking advantage of the double meanings inherent in language. In the analysed cartoons, irony comes from puns based on different stylistic devices, such as polysemy, homonymy, neologisms, consonant metatheses, assonance or consonance, and rhyme.

Another technique used by the authors to arouse humour is to take colloquial expressions or common sayings used in everyday life and to alter them slightly for comic or ironic effect. 
The collection of humorous cartoons, as well as jokes, proverbs and other texts, is a rich source for sociology, folklore and linguistics. Through these texts it is possible to shed light on some areas of shadow or more inaccessible aspects of a culture: mentality, public opinion, sensitivity, taboos, transgressions.

Cartoons often refer to current events, political facts that the reader is aware of; so in order for humour to be effective, the reader must understand the context to which it refers. The reader must have a set of linguistic and extra-linguistic information with which to interpret the text.

61 Through the communication of a message to the reader, the cartoonist aims to surprise, shock, or cause a reaction, thus making him/her smile.

2 In societies where there is often censorship, humour is a way of transmitting a message that otherwise could not be formulated. One of the roles of humour is to produce a liberating effect in the reader, who, by laughter, unloads his anxiety. Another role is to give the opportunity to see defects or mistakes, and generate a constructive critique, which can become the motivation for positive transformation.

Beyond the visual aspect of the cartoon, the linguistic medium chosen by the author is essential to convey the message to the reader and, at the same time, to provoke laughter and arouse humour.

\section{BIBLIOGRAPHY}

al-Manhal, 2000, Dictionnaire Français-Arabe, Beirut: Dār al-Adāb.

Cacciari, C. \& Glucksberg, S. 1991. "Understanding Idiomatic Expressions: The Contribution of Word Meanings". Advances in psychology 77. 217-240.

Cacciari C., \& Glucksberg, S. 1995. “Understanding Idioms: Do Visual Images Reflect Figurative Meanings?", European Journal of Cognitive Psychology 7 (3). 283-305.

Casadei, F. 1995. "Flessibilità delle espressioni idiomatiche" Casadei, F., Fiorentino, G., \& SamekLodovici, V. (eds.), L' italiano che parliamo. Santarcangelo di Romagna: Fara Editore. 11-33.

Crystal, D. 2004. The Language Revolution. Malden, MA: Polity Press.

Douthwaite, J. 2000. Towards a Linguistic Theory of Foregrounding, Alessandria: Edizioni dell'Orso.

Durand, O. 2009. Dialettologia araba. Roma: Carocci Editore.

Munthir, M. 2011. "Glottal Stop in R.P English and Standard Arabic with Reference to Some Other Varieties", Al-Adab 109 (109). Baghdad: University of Baghdad. 52-82.

Procházka, S. 2008. "Let's Twist Again! Tongue Twisters in Arabic Dialects”. Procházka, S., \& RittBenmimoun, V. (eds), Between the Atlantic and Indian Oceans: Studies on Contemporary Arabic Dialects. Proceedings of the 7th AIDA Conference, held in Vienna from 5-9 September 2006. WienMünster: Lit. 349-362. 
Zack, L. 2014. "The Use of the Egyptian Dialect in the Satirical Newspaper Abu Naḍ̂āa Zar'a". Durand, O., Langone, A. D. \& Mion, G. (eds.), Alf lahğa wa lahğa: Proceedings of the 9th Aida Conference . Wien: Lit. 465-478.

www.teshreen.com/daily/2002/care.asp

www.omayya.com/pod.htm

www.baha-cartoon.net

www.stavrotoons.com

\section{NOTES}

1. Fig. 1, Fig. 2, Fig. 3: Baha Bukhari; Fig. 4, Fig. 5, Fig. 6, Fig. 7: Omayya Geha.

2. Fig. 8: Stavro Jabra.

3. Fig. 9: www.teshreen.com/daily/2002/care.asp

4. Fig. 10: Baha Bukhari; Fig. 11, Fig. 12: Omayya Geha.

5. Fig. 13: Stavro Jabra.

6. Fig. 14: Šallāh, from the newspaper al-Ba'ț; Fig. 15: Muhannad Farzat (son of the famous cartoonist Ali Farzat).

\section{ABSTRACTS}

This paper analyses puns and idioms in humorous cartoons produced in dialectal variants of the Syrian-Lebanese-Palestinian area. Colloquial expressions and puns play a predominant role in these artistic productions.

In order to give impetus to a text or a concept, the author makes use of puns based on double meanings or on words that sound alike but which are distant in meaning. The aim is to create irony, to arouse other feelings in the reader in order to reawaken the consciousness.

The use of colloquial expressions is necessary to engage with and transport the reader to the reality that the author wishes to communicate: it is interesting to examine the various expressions used in everyday life in the Arab world. Idiomatic expressions play a very important role: they are part of 'adab "being well brought-up" or "good manners", and they are numerous (greetings, requests, thanks, various exclamations). The collection of such expressions constitutes a rich source for linguistics, sociology and folklore.

\section{INDEX}

Keywords: puns, sayings, linguistics, Arabic dialectology, Bilād aš-Šām 
AUTHOR

EMANUELA DE BLASIO

University of Tuscia, Viterbo, Italy, emanueladeblasio@gmail.com 


\section{Communication écrite sur Internet et par sms en arabizi : analyse de corpus relevant des glosses dialectales libanaise et marocaine}

Joseph Dichy, Fatima-Zahra Driss, Hassiba Lagraf et Djamel Mostefa

\section{Introduction}

1 La présente contribution porte sur un aspect assez récent de la dialectologie et de la communication en arabe : l'usage de caractères latins pour transmettre des messages, soit par SMS, soit sur Internet. Ce phénomène a été appelé arabizi, mot-valise construit à partir de « Arab » ou « Arabic » et « easy ».

2 Nos analyses s'inscrivent dans le projet de recherche PARADE («Plateforme d'Analyse et de Recherche en Arabe et ses DialectEs »), en cours depuis la fin de 2016 (partenaires: SYSTRAN SA [www.systran.com] ; Laboratoire ICAR, UMR 5191, CNRS/Université Lyon 2, ENS-Lyon [http://icar.univ-lyon2.fr]; ARADIC Editions [www.aradic.fr]). Ce projet porte au premier chef sur l'arabizi.

3 Nous chercherons à décrire ce dernier à partir de corpus provenant d'Internet et principalement de Twitter. Nous associerons aux informations générales du début des analyses précises d'extraits de corpus, afin de donner une idée des phénomènes en jeu.

\subsection{L'explosion d'internet dans les pays arabes}

4 Globalement, tous les pays arabes ont enregistré une forte hausse du nombre d'utilisateurs d'Internet au cours des 10 dernières années (Figures 1 et 2). La particularité de ces utilisateurs est qu'ils sont très ancrés dans les nouvelles formes de communication telles que les réseaux sociaux, où des pseudonymes leur permettent de s'exprimer librement et dans la forme linguistique de leur choix. 
5 Le nombre total d'utilisateurs de Facebook dans le monde arabe fin mai 2013 s'élevait à 55 millions, avec une progression annuelle de 22\% par rapport à mai 2012 (10 millions de nouveaux utilisateurs en un an). Twitter est également en pleine expansion dans cette aire : l'Arabie Saoudite est le premier pays au monde, en pourcentage, d'utilisateurs de Twitter (peerreach.com, 2013).

Figure 1 : Taux de pénétration d'Internet en pourcentage de la population totale (source ICT Statistics Database)

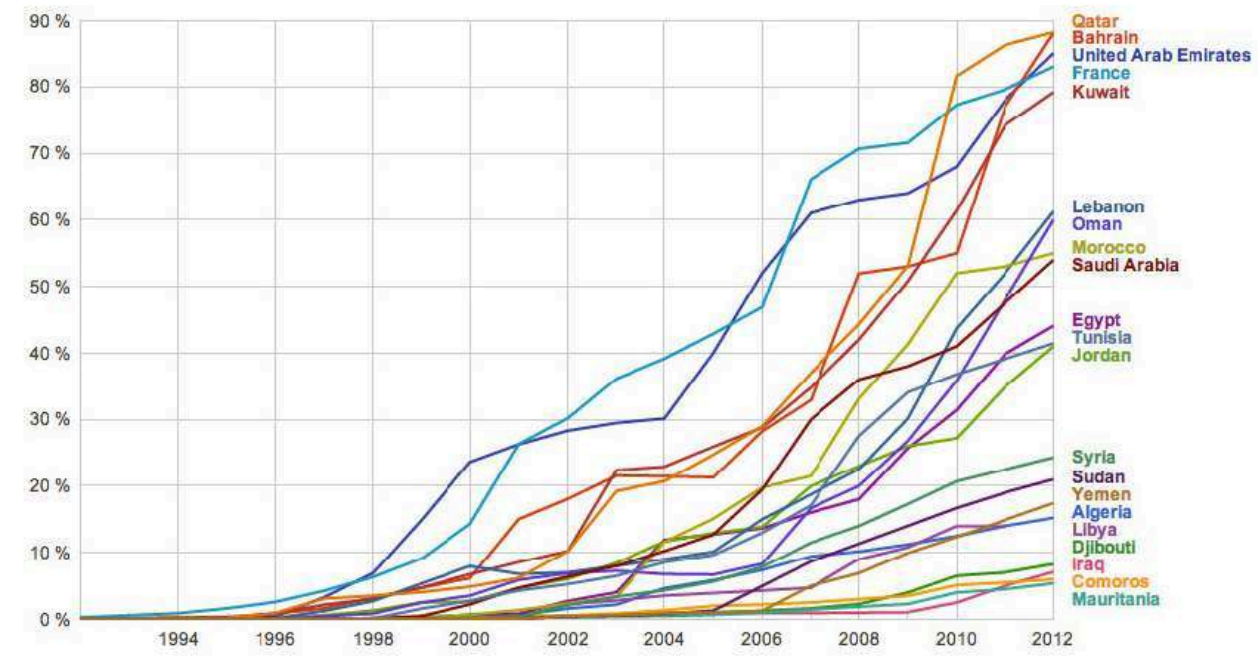

Figure 2 : Nombre d'utilisateurs de Facebook dans le monde arabe (source Arab Social Media Report V)

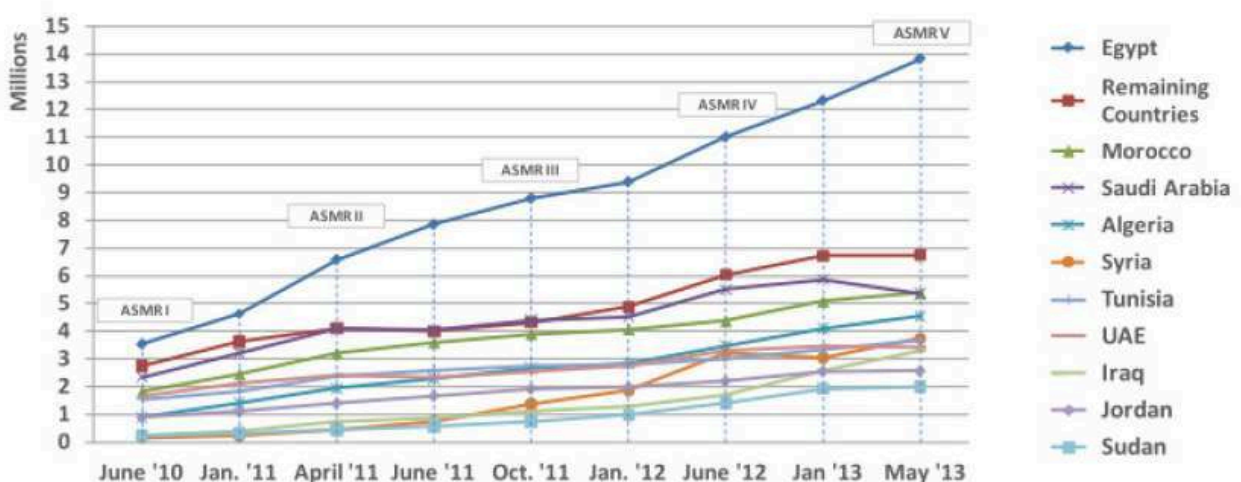

\subsection{Internet dans le monde arabe - formes et variétés linguistiques}

6 Les utilisateurs d'Internet et des réseaux sociaux ont recours à diverses formes (ou glosses ) de l'arabe et s'expriment souvent dans des dialectes translittérés. Cela rend l'analyse et plus encore, l'analyse automatique - de ces données plus difficile. En effet, en fonction de l'origine des auteurs, de leur dialecte ou des claviers utilisés par eux, une forte hétérogénéité apparait dans les textes transcrits en caractères arabes ou latins, et combinant l'utilisation de variantes dialectales et des mélanges de mots en français ou anglais et en arabe. Les variétés ou glosses de l'arabe ainsi réalisé diffèrent d'un pays à 
l'autre et sont influencées par le français au Maghreb et par l'anglais au Machrek (une partie du Liban mise à part), ainsi naturellement que par les dialectes locaux. L'arabizi est en outre utilisé par les enfants de la diaspora arabe qui ne maitrisent pas l'écriture arabe, mais parlent - peu ou prou - le dialecte de leurs parents, pour communiquer, par exemple, avec leurs relations habitant leur pays d'origine (famille, amis). Un domaine d'analyse relativement nouveau s'offre donc à la dialectologie et à ses descriptions.

Plusieurs approches existent pour la notion d'arabizi (Denis, Fréard, Détienne, Baker, \& Barcellini, 2012), (Aboelezz, 2009), (Bahrainwala, 2011), (Bianchi, 2012), (Elmahdy, Gruhn, \& Minker, 2012), (Yaghan, 2008), (Gonzales-Quijano, 2012 a \& b). Sa naissance remonte aux premiers claviers d'ordinateurs et de téléphones portables, qui ne permettaient pas la saisie des caractères arabes. La première apparition de cette forme de notation était dans les SMS, le chat et les courriels informels (Elmahdy et al, 2012).

8 Mona Randa, Nariman Elshamly \& Nady (2011) ont réalisé une étude sur les utilisateurs de Facebook, montrant que $82 \%$ des sondés utilisent l'arabizi, $40 \%$ déclarent l'utiliser la plupart du temps et $22 \%$ l'utilisent systématiquement. Aboelezz (2009) examine un corpus de 253 courriels provenant de plus de 70 personnes de 16 à 25 ans en Egypte, et montre que $52,4 \%$ des messages contenaient de l'arabizi et que ce dernier représentait au moins $60 \%$ des messages concernés. Al-Khatib \& Sabbah (2008) ont collecté un corpus de SMS provenant d'étudiants jordaniens âgés de 17 à 25 ans dans lequel $61 \%$ des messages étaient en arabizi.

\section{Le travail sur corpus marocains, syro-libanais et égyptiens}

9 La présente contribution vise à affiner la définition de l'arabizi à partir d'analyses de corpus. Le projet PARADE porte sur des corpus collectés essentiellement sur Twitter, dans les trois zones dialectales marocaine, syro-libanaise et égyptienne (que nous n'étudions pas dans cette communication).

10 Voici de premiers résultats d'observation:

- On constate, comme on pouvait s'y attendre, des échanges faisant intervenir plusieurs langues et plusieurs types de caractères ou de transcription,c.-à-d., de l'arabe en caractères latins et arabes, mêlé à de l'anglais, du français, de l'espagnol ou de l'italien.

- On trouve donc aussi de l'arabizi alternant avec des échanges en caractères arabes.

- Dans ces échanges, l'arabe littéraire moderne peut alterner avec du dialecte.

11 En termes linguistiques plus précis, ce qui précède peut être schématisé comme suit :

1) Au sein de la langue arabe considérée dans la multiplicité de ses formes, c.-à-d., au sein de la polyglossie de l'arabe, (Dichy 2010), on rencontre dans les échanges en arabizi :

- deux types d'écriture (caractères arabes ou latins);

- différentes glosses (dialectes, arabes moyens, arabe littéraire moderne).

2) À cela s'ajoutent des phénomènes d'alternance codique (en anglais, code-switching) entre l'arabe et l'anglais ou le français, voire avec de l'espagnol ou de l'italien. 


\subsection{Définition « basique » de l'arabizi}

12 À partir de nos observations, nous essayerons de donner une définition linguistique opératoire de l'arabizi. Citons en première approche la description d'Yves GonzalezQuijano, à qui l'on doit par ailleurs de précieuses observations sociologiques :

«Il s'agit d'une forme écrite de l'arabe née du développement des appareils électroniques : au début, les ordinateurs et autres téléphones portables n'avaient pas de clavier arabe. Les utilisateurs ont donc transposé l'alphabet arabe en alphabet latin. Et quand ils ont buté contre des sons sans équivalent, ils ont introduit des chiffres. Le 3 pour la gutturale 'ayn par exemple, comme dans 3rabya « arabe» (Gonzalez-Quijano 2012b).

13 On remplace ainsi les sons correspondant par exemple aux lettres hă ou 'ayn respectivement par 3 et par 7, comme dans mar7aba, «bonjour ou bienvenue » et 3ayni (Liban)/3eni (Syrie), «mon œil». Pour le $H \vec{\omega} \vec{a}$, on utilise soit le chiffre 5, soit les deux lettres «kh», pour le šīn, on a soit "sh » (régions où l'anglais est en usage), soit «ch » (régions où la langue étrangère est le français). On observe en outre des notations relâchées, intuitives, et donc souvent approximatives.

14 La diversité des usages est une caractéristique ancienne de la polyglossie de l'arabe, qui n'en a pas affecté à ce jour l'unité plurielle (Dichy 2010 et 2017 - mais voir aussi les travaux de J. Fück, J. Blau ou J. Lentin sur ce que nous appelons les arabes moyens, au pluriel). L'« arabe moyen » étant un mixte d'arabe littéraire moderne et d'un dialecte, il s'ensuit qu'il y a autant d'arabes moyens - au pluriel - que de dialectes.

\subsection{L'arabizi se réduit-il à un mode de transcription?}

Une toute première définition réduit donc l'arabizi à un mode de transcription. $\mathrm{Ce}$ dernier utilise des équivalences entre lettres latines pour les sons ou phonèmes communs aux deux langues (arabe algérien et français par exemple) et des chiffres ou couples de lettres pour des phonèmes présents dans le dialecte arabe mais absents du français ou de l'anglais :

- Lettres arabes avec équivalent en caractères latins, exemples : $d=d a \bar{l}, m=$ mīm.

- Lettres arabes sans équivalent en alphabet latin et remplacées par des chiffres

dont la graphie est en analogie partielle avec la forme de la lettre arabe, exemples :

etc. (La ressemblance, pour les exemples précédents est en,$\tau=7 ; \tau=5 ; \varepsilon=3$

« image de miroir».)

- Utilisation de digraphes pour certains phonèmes, exemple : $\mathrm{dh}=$ dạd, etc.

Enfin, les règles de notation ne sont pas univoques: certaines lettres présentent des confusions de transcription, ex: $\mathrm{k}=q \bar{a} f$ ou $k \bar{a} f$. De notables confusions proviennent du caractère peu normé de ces notations. Voici une phrase en arabizi qui mélange lettres latines, chiffres et utilisation de deux lettres pour représenter certains sons : allah yr7mek ya khali, «Paix à ton âme, (ô) mon oncle » (dialecte algérien).

17 Cette description formelle de base est essentielle. On verra toutefois que l'on ne doit pas s'arrêter à ce niveau d'analyse. 


\section{Analyse de corpus}

Considérons ci-dessous quatre exemples d'échanges en arabizi sur Twitter : deux extraits marocains et deux extraits libanais. Ces extraits ont été modifiés de manière à en assurer l'anonymat (suppression des logos, pseudonymes et adresses). Chaque exemple permet d'illustrer un aspect de la communication en arabizi ou des formes qu'elle prend.

\subsection{Exemple marocain $n^{\circ} 1$ : présence de dialecte marocain en graphie arabe et en arabizi, associé à une combinaison d'émoticônes}

Figure 3 : Reproduction anonymée du premier extrait

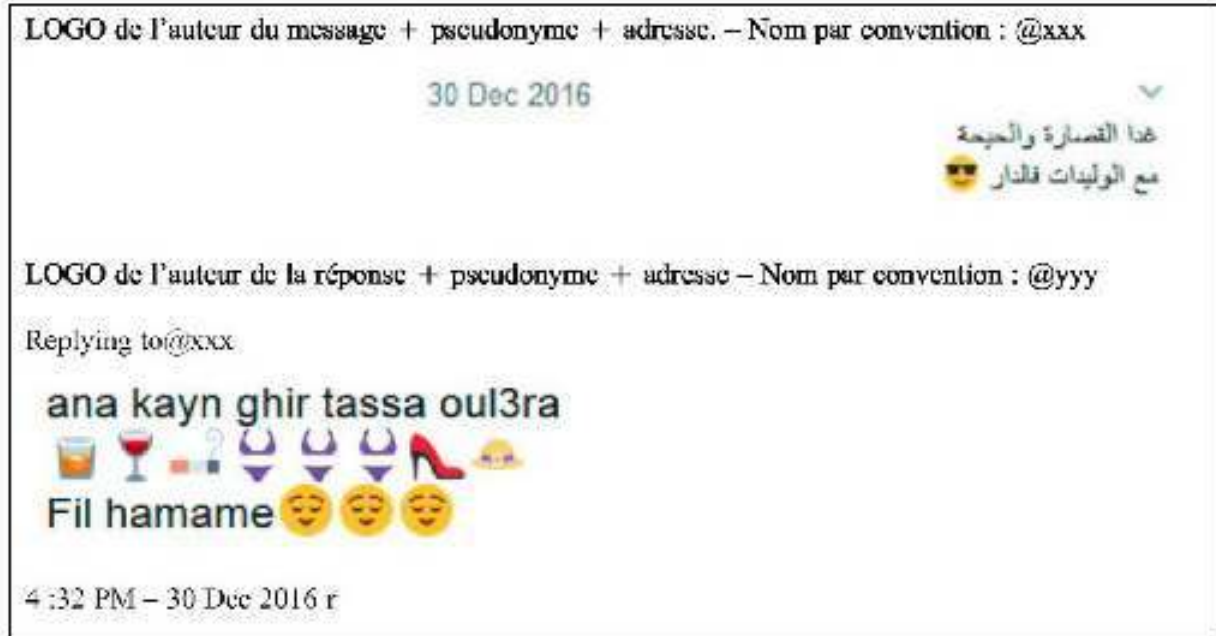

\section{Observations sur les données de l'échange}

$1^{\text {er }}$ interlocuteur, @xxx

Traduction : « Demain on va s'éclater et bavarder [en toute convivialité] avec les enfants à la maison » - « To-morrow, it'll be a great time and cool exchanges with the children at home »

Commentaires : Le texte est en dialectal marocain et en caractères arabes, suivi d'une seule émoticône suggérant l'idée de loisirs et d'un bon moment.

2nd interlocuteur, @yyy

Traduction : "Pour moi rien que des verres [d'alcool] et la nudité dans le hammam »«Me, nothing but drinking glasses [of alcoholic drinks] and nudes in the hammam ». (Le mot noté « tassa » en arabizi, en transcription țāsa $a$, désigne la petite bassine utilisée pour s'asperger d'eau chaude ou froide dans le hammam, dans un grand nombre de dialectes arabes (notamment au Proche-Orient). C'est très probablement un emprunt à l'italien. En arabe marocain, ce mot désigne bien un verre à boire, ici de l'alcool, comme l'indique en outre l'une des émoticônes du message).

Commentaires :

(1) Le texte est en arabizi, avec beaucoup d'émoticônes humoristiques, qui expriment une forme d'auto-dérision. Le twitteur @yyy manifeste ainsi que son ami(e) @xxx est en 
réalité plus heureux(se) que lui, qui est pourtant plus libre, étant apparemment sans enfants. Nous présumons qu'il s'agit d'un homme qui exprime ici, de manière en partie ironique, un fantasme. On peut en outre se demander si la cigarette allumée ( $3^{\mathrm{e}}$ émoticône) n'est pas une cigarette de hachich.

(2) Quoiqu'il en soit de nos interprétations, le rôle des émoticônes comme complément sémantique est considérable, et remet partiellement en cause la notion de corpus en arabizi ou en caractères arabes sur réseaux sociaux ou par SMS comme étant uniquement textuel.

(3) L'extrait comporte en outre une combinaison d'émoticônes, incluant des itérations (émoticônes répétées). Rappelons que les émoticônes répondent en partie à la fonction expressive du langage. Mais ils constituent aussi un moyen d'expliciter le sens dans l'interaction (par ex., le smiley pour dire " je plaisante »). Ces itérations expriment :

- soit une insistance de nature exclamative, comme dans merciiiiiiiii en français,

l'itération du symbole correspondant à une façon de mimer par écrit l'intonation ;

- soit l'expression de la quantité par itération (comme dans «des voitures, des voitures, des voitures et des voitures : il n'y a que ça dans cette ville », ou encore : «il est très très très très grand »). Ici, l'image de femmes en sous-vêtements ou en maillot de bain et celle du visage exprimant contentement et satisfaction, sont répétées trois fois.

21 Ces deux interprétations peuvent bien entendu s'additionner. Une étude des émoticônes et du langage affectif dans notre corpus serait à faire (voir plus loin, §3.3), avec des comparaisons à d'autres langues.

\subsection{Exemple marocain $n^{\circ} 2$ : recours à une image ; usage d'arabe moyen marocain en caractères arabes, présence d'implicites conversationnels}


Figure 4 : Reproduction anonymée du deuxième extrait

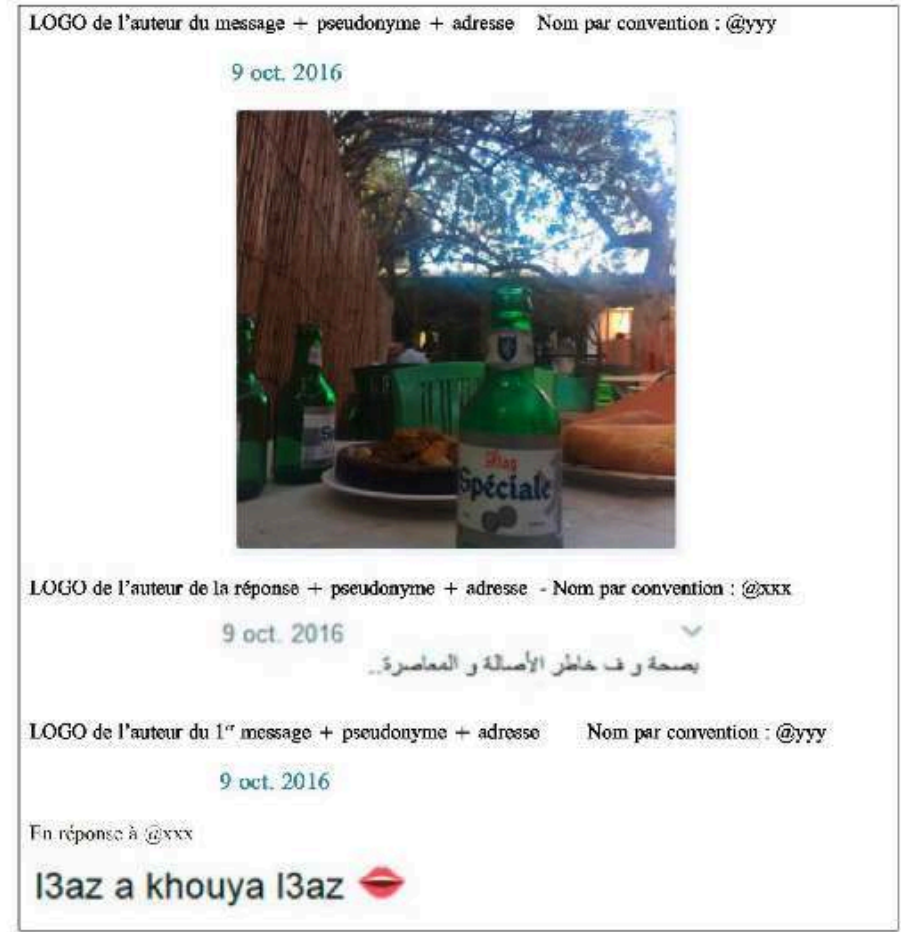

\section{Observations sur l'échange}

Les interlocuteurs @yyy et @xxx sont les mêmes que dans l'extrait précédent.

$1^{\text {er }}$ interlocuteur, @xxx

Commentaire : Le message est entièrement composé d'une image qui présente une bouteille de bière de marque «Flag " posée sur une table dans un café, à côté de deux assiettes. (Flag est une bière marocaine de luxe commercialisée dans plusieurs pays d'Afrique de l'Ouest.)

$2^{\text {nd }}$ interlocuteur, @yyy

Traduction : "A ta santé et en l'honneur de l'authenticité ('așāla) et de la modernité ( $\left.m u^{\prime} a s ̦ a r a\right) »-~ " T c h i n-t c h i n$ (to your good health) and in honour of authenticity and modernity»

Commentaire: Le texte est en caractères arabes. La référence à l'authenticité et à la modernité relève d'un discours «intellectuel»: il y a une forte connotation de ces termes dans la culture arabe contemporaine (problématique de la modernité, du renoncement, ou non, à ses traditions, etc.). Mais on peut se demander également si l'interlocuteur ne fait pas allusion au parti marocain de l'« Authenticité et la Modernité ", ce qui donnerait à la réponse un contenu politique, voire politico-religieux, la consommation d'alcool étant prohibée en islam. Le sens sous-entend donc: soit (a), "Quelle chance tu as d'être dans ce bel endroit ", où il y a sur la table à côté de la bière un tagine marocain d'accompagnement des consommations; soit (b) une allusion politicoreligieuse ironique, la bière étant elle-même, comme le tagine qui l'accompagne " authentiquement " marocaine, tout en apparaissant comme signe de "modernité ", cette dernière étant ici transgressive par rapport à la religion dominante. Les deux interprétations sont probablement vraies en même temps. 
Traduction: «C'est classe, mon frère, classe », " great/splendid, brother, gerat/splendid " Commentaire: La réponse est en arabizi, et suivie d'une émoticône (bouche féminine), pour dire, nous semble-t-il: "c'est bon, c'est raffiné comme nourriture, boisson et endroit ».

Notons que la réponse se fait par rapport à un sens sous-entendu (acte de langage implicite), de ce que dit le $2^{\mathrm{e}}$ interlocuteur, ce qui est une caractéristique de l'interaction. Ces implicites comportent comme on l'a vu, beaucoup de contenus, dont certains ne sont pas directement accessibles à partir du texte.

Si dans l'exemple précédent les émoticônes jouaient un rôle central, on voit ici que dans le premier message, ce rôle est tenu par une image. On voit également que le $2^{\text {nd }}$ locuteur, qui écrit en caractères arabes, faisait usage du parler marocain dans le premier extrait, et d'un arabe moyen dans le second.

\subsection{Exemples $n^{\circ} 3$ et 4 , en arabe libanais}

Les extraits ci-dessous font apparaître un usage exclusif de l'arabizi, ainsi que des alternances codiques avec l'anglais dans le premier exemple, mais pas du tout dans le second. Le premier extrait comporte une image, le second un logo objet de commentaires acerbes.

On observe dans les deux cas une utilisation expressive ou affective de la dimension des caractères (comme aussi pour @xxx dans les extraits marocains). Les grands caractères sont accompagnés d'émoticônes dans l'exemple $n^{\circ} 3$, mais pas dans l'extrait $n^{\circ} 4$. On a donc, pour l'expressivité, le schéma de possibilités suivant:

Figure 5 : Fonction expressive des émoticônes en relation avec la dimension des caractères : (schéma des possibilités)

\begin{tabular}{|c|c|c|c|}
\hline $\begin{array}{c}\text { Dimension } \\
\text { des caractères et des } \\
\text { émoticônes }\end{array}$ & \multicolumn{3}{|c|}{ Emoticône(s) } \\
\hline standard & absente & unique & itération de l'émoticône \\
\hline agrandie & absente & unique & itération de l'émoticône \\
\hline
\end{tabular}

\subsection{Exemple $n^{\circ} 3$, arabe libanais}


Figure 6 : Reproduction partiellement anonymée du troisième extrait

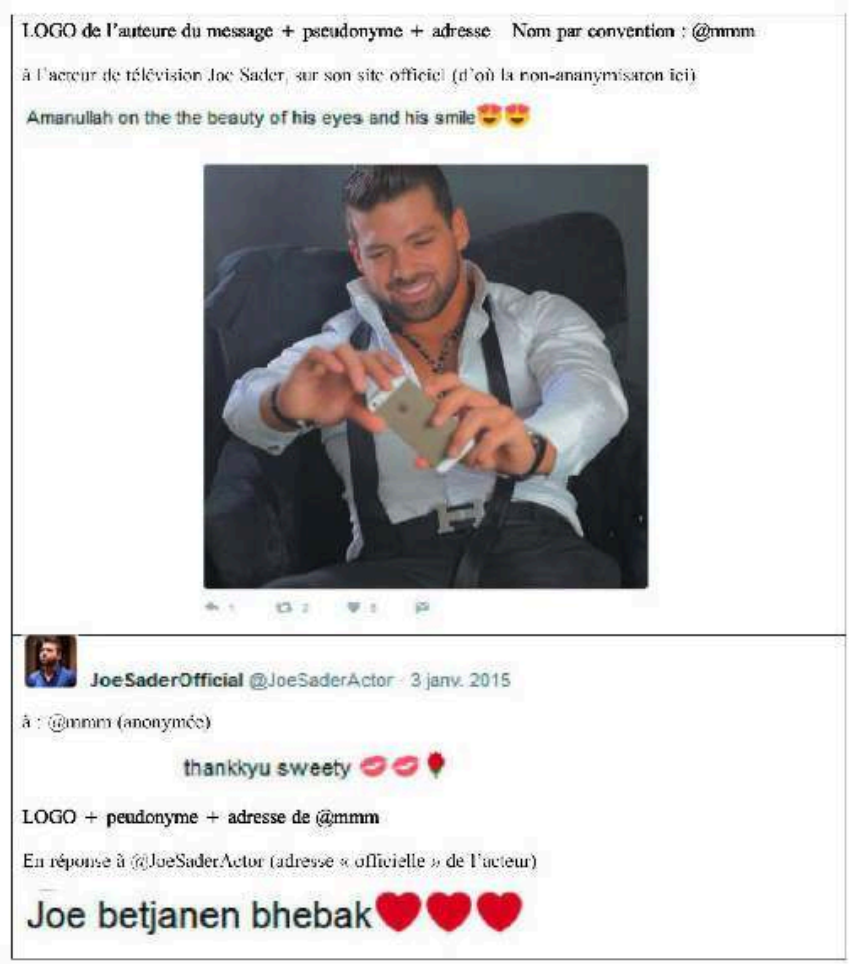

\section{Observations sur cet extrait}

$1^{\text {re }}$ interlocutrice, @mmm

Traduction: Mot-à-mot, «La protection de Dieu sur la beauté de ses yeux et de son sourire ».

\section{Commentaire :}

(1) Nous n'avons pas anonymisé ce qui concerne l'acteur Joe Sader, car il s'agit de sites «officiels ». Ceux-ci sont très élaborés; ils fonctionnent par abonnement gratuit et annoncent selon le cas, plusieurs centaines à plusieurs milliers d'abonés - voir https:// www.instagram.com/joesaderofficial/?hl=fr.

(2) La première expression est en arabizi. Il s'agit de conjurer le mauvais œil (cette superstition pèse toujours sur les compliments, concernant notamment les yeux). L'usage de l'arabe s'impose donc, l'alternance codique avec l'anglais intervenant juste après. Suivent deux émoticônes exprimant une admiration amoureuse. Au-dessous est placée la photographie de la vedette, empruntée de toute évidence à l'un de ses sites.

(3) Dans sa deuxième réplique ci-dessous, l'admiratrice, qui communique sur Twitter (adresse : JoeSaderOfficial) exprime son «amour » pour l'acteur. De telles déclarations adressées à des vedettes sont très courantes, tant en France qu'au Proche-Orient, comme le montrent les phone-in analysés par V. Traverso (2006).

Réponse de Joe Sader

Traduction de l'anglais : "Merci ma douce (sweety) ", réponse suivie de deux émonicônes «baiser » et d'une émoticône « fleur »

Commentaire : La réponse est conventionnelle et polie.

31 Dernière réponse de la $1^{\text {re }}$ interlocutrice, @mmm

Traduction de l'arabe dialectal libanais noté en arabizi : "Joe tu es magnifique, je t'aime » 
- « Joe, I’m mad for you, I love you ». Réponse suivie de l'émoticône « cœur » répétée trois fois.

Commentaire: L'expression betjannen, mot-à-mot «tu rends fou » (comparer avec, en arabe dialectal tunisien bethabbel, qui a le même sens) signifie ici un compliment appuyé, d'où la traduction proposée ci-dessus. Comme nous l'avons indiqué, ces déclarations d'amour à une vedette sont beaucoup plus conventionnelles qu'il n'y paraît à première vue.

De la même manière que pour la conjuration du mauvais œil ( $1^{\mathrm{er}}$ mot de l'échange), l'arabe dialectal permet de dire les choses dans le cadre de la culture quotidienne des locuteurs. La transcription est en arabizi, et non en caractères arabes.

\subsection{Exemple $n^{\circ} 4$, arabe libanais}

Figure 7 : Reproduction anonymée du quatrième extrait

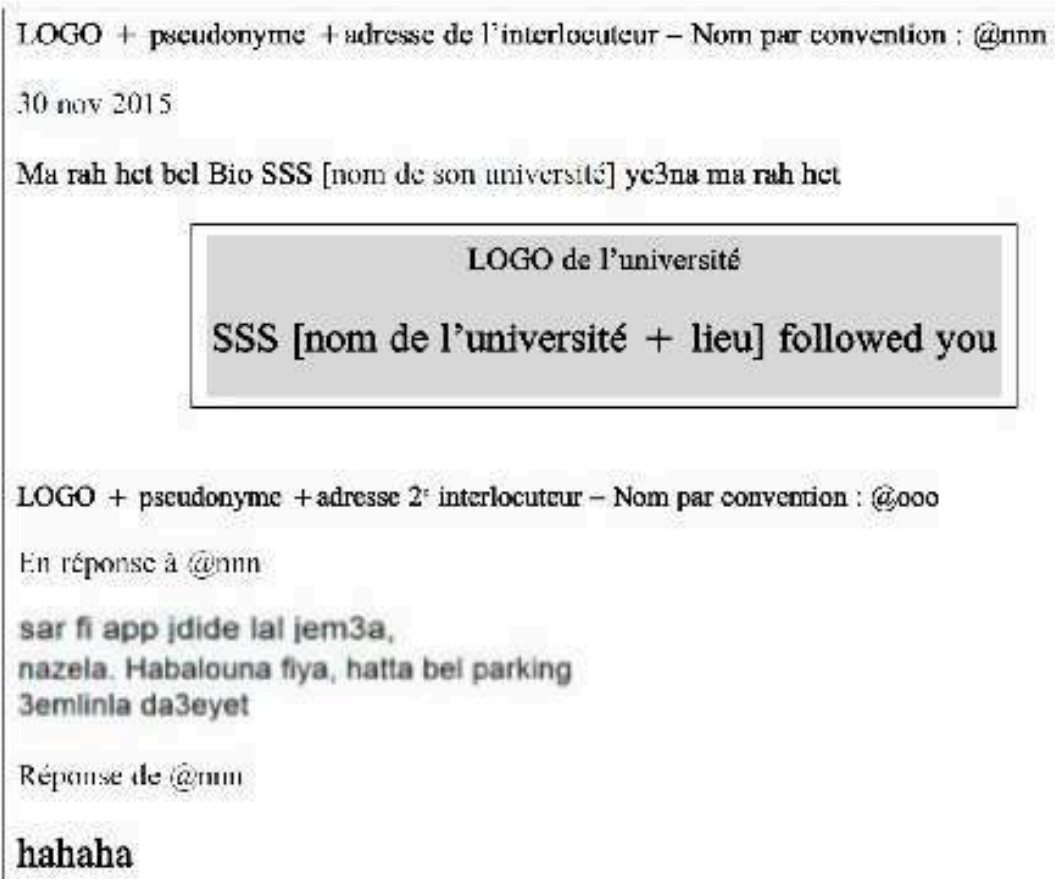

\section{Observations sur les données}

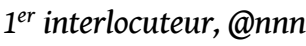

Traduction : «Je ne vais pas mettre dans ma Biographie SSS [nom de l'Université], ça veut dire, je ne le mettrai pas » - "I'm not going to put in my Bio SSS |name of University], that is, I am not». Suit une image de la notification reçue sur son téléphone, indiquant que son université «le suit».

Commentaire: Tout l'échange est en arabe dialectal libanais et en arabizi, avec un seul emprunt à l'anglais, le mot Bio (noté avec une majuscule, s'agissant du CV « officiel » sur Internet), le mot parking (utilisé par @ooo) étant entré de longue date dans ce parler. Le ton de cette réplique indique que l'interlocuteur est en colère, en raison sans doute de la notification qu'il reproduit. 
Traduction: «Il y a maintenant une nouvelle application de l'université, qu'ils ont mise en route. Ils nous rendent fous avec ça, même sur le parking, ils nous envoient des pubs " - "There's now a new app from the university, in use. They madden us with it, even in the parking they send us adverts. "

Commentaire: Il est fait usage des grands caractères, ce qui indique une volonté d'expressivité. L'interlocuteur attire l'attention de son ami sur ce qui se produit dans leur université privée. L'expression est entièrement en dialectal noté en arabizi.

Réponse de @nnn

Il écrit : « hahaha ».

Commentaire : Les deux camarades d'université s'expriment en arabe dialectal libanais et en arabizi comme s'ils se parlaient. On est donc devant une interaction écrite, avec réaction quasi immédiate, analogue en partie à ce qu'on observe à l'oral.

\section{Conclusion : vers une définition élargie de l'arabizi en interaction dans un contexte de communication multiforme}

36 (1) La définition de l'arabizi comporte deux aspects : «qu'est-ce que l'arabizi ? d d'une part et «comment fonctionne l'arabizi?» de l'autre. Le travail sur corpus conduit, comme on a pu le voir, à mettre l'accent sur le second.

(2) La littérature sur l'arabizi remonte, on l'a vu, à un peu moins d'une décennie. On lui doit un ensemble d'observations sur la transcription en caractères latins de l'arabizi.

(3) Mais les travaux cités, au-delà des aspects linguistiques, s'interrogent sur la libération de la parole sur les réseaux sociaux. Par exemple, ci-dessus, nous avons mis «interlocuteur» au masculin, en supposant qu'il s'agit d'hommes, au vu des pseudonymes; or l'anonymat de ceux-ci permet toutes sortes de combinaisons s'inscrivant dans une libération de la parole entre personnes de sexe différents.

(4) Ce travail, inscrit dans le projet PARADE et dans ses analyses de corpus, montre que 1 arabizi ne peut se réduire à des transcriptions, même si celles-ci constituent un aspect important de l'analyse. Dans nos corpus, nous avons observé la complexité des données «para-textuelles » : rôle de l'image ; rôle expressif des émoticônes et de la dimension des caractères.

(5) Le contexte sémantique et interactionnel des échanges en arabizi constitue un autre aspect essentiel : l'interprétation de nombreux détails des échanges provient de données contextuelles au sens large, y compris, comme on l'a vu, de données conversationnelles : il s'agit en fait d'échanges en interaction, ce qui suppose la mise en œuvre d'analyses fines.

41 (6) Il s'ajoute à cela la présence de données linguistiques plurielles: polyglossie à l'intérieur de la langue arabe considérée dans la multiplicité de ses usages (y compris à l'écrit, avec l'arabizi d'une part et l'usage de caractères arabes de l'autre), et alternance codique (code-switching) avec l'anglais ou le français.

42 (7) La présence de ces langues mises à part, les données indiquent que la communication en arabizi relève de l'ensemble complexe des usages inscrits dans la polyglossie de l'arabe, ce que donnent à voir les phénomènes relevant des arabes moyens ou 
l'alternance, dans la transcription entre l'arabizi et des énoncés en dialecte transcrits en caractères arabes. L'arabizi n'est donc pas, comme certains ont pu le penser, une « langue en soi » : il n'y pas de signes de créolisation ou de «métissage » linguistique inscrit dans un système. Les données montrent clairement qye l'on n'y fait rien d'autre que ce que l'on fait en parlant.

(8) Notre enquête préliminaire sur corpus permet à la fois d'affiner la définition de la communication en arabizi, et de montrer la difficulté du travail sur des données aussi complexes (que faire par exemple des émoticônes?). Des décisions devront être prises quant au niveau de granularité auquel l'analyse de corpus ou les traitements automatisés devront s'attacher. Mais pour la dialectologie arabe, un nouveau domaine, avec des types de corpus inconnus jusqu'à la dernière décennie, s'ouvre à la recherche.

\section{BIBLIOGRAPHIE}

Aboelezz, M. 2009.. Latinised Arabic and connections to bilingual ability. Lancaster UniversityPostgraduate Conference inLinguistics \& Language Teaching. Department of Linguistics and English LanguageLancaster University .

Al-Khatib, M. \& Sabbah, E. 2008. Language Choice in Mobile Text Messages among Jordanian. SKY Journal of Linguistics 21.

Bahrainwala, L. .2011. You say Hello, I say Mar7aba: Exploring the digi-speak that powered the Arab revolution. Michigan State University.

Bianchi, R. .2012. 3arabizi - When Local Arabic Meets Global English. Acta Linguistica Asiatica 2.

Denis, A., Fréard, D., Détienne, F., Baker, M., \& Barcellini, F. 2012. Détection de conflits dans les communautés épistémiques en ligne. Actes de la Conférence sur le Traitement Automatique des Langues Naturelles. Grenoble.

Dichy, J. 2010. La polyglossie de l'arabe, illustrée par deux corpus d'époques et de natures différentes : un échange radiophonique syrien et un conte des Mille et Une Nuit. M. Bozdemir et L.-J. Calvet (éds.). Les politiques linguistiques en Méditerranée,. Paris : H. Champion.

Elmahdy, M., Gruhn, R., \& Minker, W. 2012. Novel Techniques for Dialectal Speech Recognition. Springer Ed.

Gonzales-Quijano, Y. 2012a. Arabités numériques. Le printemps du Web arabe, Arles : Actes Sud.

Gonzales-Quijano, Y. 2012b. « Arabizi, le printemps linguistique. » From Le Temps: http:// www.letemps.ch/Facet/print/Uuid/9d166cb8-1227-11e2-ae93-607a56226934/

Arabizi_le_printemps_linguistique.

peerreach.com. 2013. 4 ways how Twitter can keep growing. From http://

blog.peerreach.com/2013/11/4-ways-how-twitter-can-keep-growing/

Randa, M., Mona, F., Nariman Elshamly, E. \& Nady, A.-G. 2011. Summary of Arabizi or Romanization: The dilemma of writing Arabic texts. Jil Jadìd Conference. Austin,: University of Texas. 
Traverso, V. 2006. Des échanges ordinaires à Damas: aspects de l'interaction en arabe. Lyon: Presses Universitaires de Lyon/Damas : Institut Français du Proche Orient .

Yaghan, M. A. 2008. “Arabizi”: A Contemporary Style of Arabic Slang. Design Issues.

\section{RÉSUMÉS}

Cette communication, inscrite dans le projet de recherche PARADE (partenaires: SYSTRAN, Laboratoire ICAR et ARADIC Editions), porte sur des analyses de copus en arabizi, qui correspond à l'usage sur Internet, réseaux sociaux ou SMS de l'arabe noté en caractères latins selon des modes de transcriptions issus de l'uage. Après un bref rappel de l'expansion d'Internet dans le monde arbe, de la littérature sur l'arabizi et des transcriptions qu'on y rencontre, les auteur(e)s procèdent à l'analyse de quatre brefs échanges sur Twitter. Deux concernent des internautes marocain(e)s et deux autres, des internautes libanais(es). Protégées par des pseudonymes, ces personnes s'expriment librement, à la fois quant au contenu et quant aux formes linguistiques qu'elles choisissent. Les données sont complexes. On y trouve: (1) des textes en arabizi, transcrivant le dialecte de l'auteur(e); (2) des textes en caractères arabes dans l'un des dialectes, l'un des arabes moyens ou en arabe littéraire moderne ; (3) de l'anglais ou du français (voire de l'espagnol ou de l'italien), soit en tant que tels (alternance codique), soit sous forme d'emprunts ; (4) des émoticônes qui sont parfois répétées (itération) ; (5) un usage de caratères de grande dimension, à côté des caractères habituels, ce qui correspond à une fonction expressive ; (6) des images. Les échanges relèvent la plupart du temps d'une analyse interactionnelle, ce qui rend leur interpétation fortement dépendante du contexte. Cette première intervention montre que la question fondamentale - pour un linguiste - est, au-delà de « qu'est-ce l'abizi ?», celle de savoir «comment fonctionne l'arabizi?»

\section{INDEX}

Mots-clés : arabizi, transcription, interaction écrite, polyglossie, arabes moyens, alternance codique, corpus complexes, réseaux sociaux, émoticônes

\section{AUTEURS}

\section{JOSEPH DICHY}

Professeur de linguistique arabe à Lyon et Laboratoire ICAR (UMR 5191, CNRS/Lyon 2, ENS-Lyon) http://.icar.univ-lyon2.fr

Joseph.Dichy@yahoo.fr

\section{FATIMA-ZAHRA DRISS}

Aradic éditions et Laboratoire ICAR (UMR 5191, CNRS/Lyon 2, ENS-Lyon) http://.icar.univlyon2.fr

fatima-zahra.driss@aradic.fr 


\section{HASSIBA LAGRAF}

Université Lumière-Lyon 2 et Laboratoire ICAR (UMR 5191, CNRS/Lyon 2, ENS-Lyon)

http://.icar.univ-lyon2.fr

hassibalg86@yahoo.fr

DJAMEL MOSTEFA

SYSTRAN SA - R\&D, www.systran.com

djamel.mostefa@systrangroup.com 


\title{
Better Sound Rural or Criminal? Data from a Case Study: The City of Temara, Morocco
}

\author{
Jacopo Falchetta
}

1 Following urbanisation and the development of mass media, a group of "supralocal" spoken varieties ${ }^{1}$ of Arabic has apparently emerged in many Arabic-speaking countries in the last 50-150 years. Such "varieties" could be defined as codes employed in contexts of communication that involve Arabic speaking compatriots whose regional origins are diverse, or unknown to the participants. This is what is also happening in Morocco, although here, unlike other countries, it is not clear whether the supralocal variet(ies) that seem(s) to be currently spreading have directly originated from any of the Arabicspeaking centres of the country.

2 In previous sociolinguistic works concerning Morocco, this phenomenon has been approached under two different focuses: some scholars, such as Youssi (1992), have followed the same line as, for example, Mitchell (1986, cited in Vicente 2008) and dealt with formal and semi-formal contexts of communication, in which, according to their view, an intermediate variety between Modern Standard Arabic (fușhā) and Moroccan Arabic dialect (or spoken Moroccan Arabic, commonly called dāriža) is usually employed. This variety (which Youssi calls arabe marocain moderne), supposedly uniform for all Moroccan Arabic speakers, virtually consists of a mixture of prevalently dāriža grammar and morphosyntax, with frequent usage of fuṣh $\bar{a}$ lexical items (Messaoudi 2003: 145). Others, such as Messaoudi $(2001,2003)$ and El Himer $(2015)$, have moved from the classical distinction operated in studies on Maghrebi dialects between parlers citadins ("old urban varieties") and parlers ruraux ("rural varieties") and identified a third type of emerging variety, parlers urbains ("new urban varieties"); these present a mixture of linguistic features drawn from the first two types, although rural features prevail (at least in the context studied by these two authors, i.e. the towns of Rabat and Sale respectively).

3 The studies mentioned above have the merit of focusing on phenomena which are central to the understanding of ongoing socially-related language development in Morocco; however, they all attempt to describe a more or less stable variety (or type of varieties) 
consisting of a co-occurring set of features and a sort of "grammar" rules. In fact, in each of the cases described, the use of such features seems to be too variable to prove the existence of a single "variety", with its distinctive grammar and structure. Therefore, if one is to analyse the nature of the supralocal "way of speaking" that Moroccan Arabic speakers recur to, it seems preferable to first find out which contexts require a "supralocal" (i.e. "national" and "de-localised") code, and then focus on the single linguistic features which are employed to communicate and express oneself in such contexts, rather than describe a whole, supposedly homogeneous "variety". A list of such contexts may be drawn that includes the following:

- Talk to Moroccans of regional origin other than one's own

- National media, i.e. media addressing a Moroccan audience (radio, television and internet)

- Political and scientific debates

- University lectures

4 The list does not imply that local dialects, fușhā, Amazigh or even a foreign language will never be employed in any of these contexts. However, empirical observations suggest that these are the situations where it is most likely that a "supralocal" way of speaking Arabic will be chosen for communication.

\section{The field study and the media corpus}

5 From September 2015 to July 2016, a field study conducted in the Moroccan town of Temara, situated ca $6 \mathrm{~km}$ south-west of Rabat, aimed at collecting data in the form of live conversations in Moroccan Arabic among the residents. The purpose was to build a picture of sociolinguistic variation in spoken Moroccan Arabic in the context of interactions among Moroccans of different regional origin (one of the contexts that, as has just been observed, would demand a de-localisation of one's speech).

From this point of view, Temara is ideal for the circumstances of its urbanisation: a rural municipality until as close as 1983, it has witnessed a dramatic growth of its population in the last few decades (from ca 20.000 in $1971^{2}$ to over 300.000 people in $2014^{3}$ ) following massive immigration from other Moroccan areas, both rural and urban. Previous sociolinguistic studies on Moroccan towns (particularly: Messaoudi 2001; El Himer 2015) have described dynamics concerning cities with an historical urban population that was characterised by an ancient urban culture; on the other hand, Temara has a sort of "newtown" status as its original nucleus was rural rather than urban, with possibly different implications on the town's inter-group dynamics. Besides this, the mere fact of hosting a great number of immigrants from many areas of the country raises questions about whether this socio-demographic situation will affect the way of speaking of the people that grow (and learn to speak) in this new reality, with Moroccan families of different regional origin living side by side in the same neighbourhood. Similar cases have already been widely studied in the domain of new-dialect formation in English-speaking areas ( $c f$. Kerswill 1996; Trudgill et al. 2000, among others), although the same kind of phenomena will not necessarily produce the same linguistic outcomes in Temara, given the social, cultural and linguistic differences of the area.

7 In order to answer these questions, a corpus of approximately 30 hours of recordings (before selection for the analysis) was collected during the field study, so as to obtain a sample of the actual speech of Moroccan Arabic speakers residing in Temara. Since the 
aim was for the informants' speech to be as spontaneous as possible (acknowledging to have been influenced in this by a Labovian concern for the Observer's Paradox; $c f$. Labov 1972: 208-209), it was decided to record either spontaneous conversations whose participants were not aware of being recorded in that specific moment, or focus groups made up of people well acquainted with each other. However, as this data collection "policy" only allowed to collect the speech of youth, ordinary interviews were also done to extend the sample of informants to elder elements of the community: as a result, about 40 informants were included in the final sample.

The analysis of the corpus will aim at identifying which linguistic features vary by effect of being charged with any kind of social value, and how speakers exploit the social significations of these variables in the frame of their interactions in contexts that require a de-localised linguistic code. This approach is in line with the choice, stated above, of focusing on single features rather than looking for what constitutes a Moroccan supralocal "variety"; it also rests on the scientific works of Eckert $(2003 ; 2008)$ and Silverstein (2003), which bring forward a view of the language-speaker relationship that is based on the speaker's active work of interpretation and assignment of meaning to form, as well as on a comprehensive view of language variation which goes beyond the idea that language is a mere dependent variable of social categories.

Following what has been said, the next question to be answered in order to proceed with the analysis of the data is: how can socially-marked linguistic features be identified, and how can their social meaning be defined?

\section{The media corpus}

10 To partially solve these issues, another corpus consisting of media products of the fiction genre has been tentatively added to the field corpus; this second corpus includes:

- Foreign soap-operas dubbed in Moroccan Arabic

- Moroccan sit-coms

- Youtube animated series (e.g. Bouzebbal) ${ }^{4}$

11 The usefulness of the media corpus as a term of comparison is based on three assumptions:

- Speech in this kind of products is script-based, and therefore not only "thought in advance", but also (presumably, or in most cases) faithfully reproduced by the performer (be it a dubber or a real actor) in the same form conceived by the scriptwriter.

- The scriptwriter's own use of language in writing the script (i.e. in choosing how to make each character in the plot speak) should reflect the connotational values that he/ she assumes their audience assign to linguistic features. This way, it seems that the texts could at least provide an interpretation (made by native speakers, i.e. the scriptwriters) of the link between certain linguistic features and the value that Moroccan Arabic speakers charge them with.

- The advantage of the texts of media fiction is that the connotation of a feature is usually straightforward: if the scriptwriter does associate a given trait to a certain social group, then that trait will be equally found in the speech of all the members of that group who are in the storyline; conversely, if he/she does not associate that trait to the same group, then its members will not show it in their speech, or at least not consistently. 
The problem of the interpretation of sociolinguistic variation offered by the media is obviously that it will not be necessarily representative of that found in the community. On the other hand, the shortcoming of the data obtained from the field corpus is that the speakers' interpretation of the sociolinguistic meaning of a feature is less explicit (whereas in the media texts it is more easily inferable from the pattern of association between a character and its way of speaking); conversely, the utility of the field corpus is that it constitutes a sample of the real everyday speech of the community. In sum, if the pictures given by the two corpora are by no means complementary, they allow at least a double perspective: features that are variable in both of them can be picked out for analysis, differences in their distribution in the field and media corpora can be examined and, finally, an interpretation of the sociolinguistic value that speakers charge those features with can be made on the basis of such analysis.

\section{The features chosen for analysis}

13 A first analysis of the two corpora has led to the individuation of a great number of relevant linguistic features; however, only four have been selected for analysis: - The phoneme / $t$ /, which presents a wide number of allophones that go from [t] to

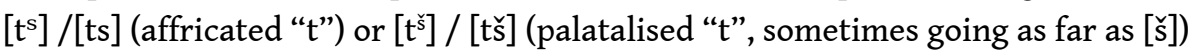
- The alternation between the phonemes /q/ and /g/ in a selection of lexemes where such alternation is found to be socially relevant both in the media and in the community studied

- The alternation between the seemingly semantically equivalent verbs /hdər/ and / $d w a /$, both approximately combining the meanings of the two English verbs "to talk" and "to speak"

- The deceleration of the end of sentences, also affecting the length of vowels, in what could be called a prosody-affected phonetic phenomenon (e.g. š-bāl li-k $f$ hād-əl-filəm [S-boellikf-ho::d l-fi::ləm], where the decelerated part is underlined: in it, the word [film] undergoes an ultra-lengthening of the already long [i] and the insertion of a [ə] where it is usually not pronounced ${ }^{5}$ )

14 A schematic summary of the use of these four variables (as it emerged from this first analysis) is reported in Table 1 . The media products analysed so far (with more to be included) are three foreign soap operas dubbed in Moroccan Arabic (Diablo, Mar de Amor and Samhini), two Moroccan sit-coms (L'Coupl and Loberj) and a Youtube animated series (Bouzebbal); two hours have been analysed for each series, except for Diablo (for which only one episode was available on Youtube) and Loberj (for which analysis is not complete). In the column "Occurrences in field study", a confrontation with Casablancan speech is reported when relevant (a group of Casablancan informants was included in the sample for inter-urban comparison purposes).

15 A few, partial observations can be made at this stage; further analysis of the data will allow a clearer view of the phenomena at hand and, consequently, confirm or relativise the following remarks:

- /t/ allophones: both in the field and in the media corpus, the general trend is for palatalised allophones ([ $\left.\mathrm{t}^{\grave{ }}\right]$ and $\left[\mathrm{tss}^{\mathrm{s}}\right]$ ) to be produced by young men and fricatised allophones $\left(\left[\mathrm{t}^{\mathrm{s}}\right]\right.$ and $\left.[\mathrm{ts}]\right)$ by elder people ${ }^{6}$. However, as far as the palatalised ones are concerned, their frequency and degree of palatalisation are much lower in the media than in the field corpus, where almost all young male informants constantly palatalise in 
linguistic environments allowing this, with many of them almost going as far as full fricativisation (thus pronouncing / $t$ / very close to [š]). This suggests that the media's policy may be that of dealing with palatalisation of $/ t /$ in a somewhat "moderating" way, which could possibly be due to a negative connotation of this phenomenon. It is therefore interesting to observe its widespread use in the community studied, as well as among Moroccan youth in general (cf. Caubet et al. forthcoming)

\begin{tabular}{|c|c|c|c|}
\hline Feature & Usage in media & Value in media & $\begin{array}{l}\text { Occurrences in field } \\
\text { study }\end{array}$ \\
\hline $\begin{array}{l}\text { Allophones of } / \mathrm{t} /\left([\mathrm{t}],\left[\mathrm{t}^{\mathrm{s}}\right],[\mathrm{ts}] \text {, }\right. \\
\left.[\mathrm{s}],\left[\mathrm{t}^{\mathrm{s}}\right],[\mathrm{s}]\right) \text { unrelated with } \\
\text { linguistic context }\end{array}$ & $\begin{array}{l}\text { Urban young men (high-middle } \\
\text { class): }[\mathrm{t}]>\left[\mathrm{t}^{\mathrm{s}}\right]>\left[\mathrm{t}^{\mathrm{s}}\right]>\left[\mathrm{tss}^{\mathrm{s}}\right] \text { (1 } \\
\text { character) } \\
\text { Urban young women (high- } \\
\text { middle class): }[\mathrm{t}]>\left[\mathrm{t}^{\mathrm{s}}\right]>\left[\mathrm{t}^{\mathrm{s}}\right] \\
\begin{array}{l}\text { Elder people (high-middle } \\
\text { class): }[\mathrm{t}]>\left[\mathrm{t}^{\mathrm{s}}\right]\end{array} \\
\text { Rural: }[\mathrm{t}]\left(>\left[\mathrm{t}^{\mathrm{s}}\right], \mathrm{F}\right)\end{array}$ & $\begin{array}{l}{\left[t^{\grave{s}}\right]=>\text { young }>\text { masculine }} \\
{\left[t^{\mathrm{s}}\right]=>\text { feminine }>\text { old }}\end{array}$ & $\begin{array}{l}\text { Young men: }\left[\mathrm{t}^{\grave{s}}\right] \approx[\mathrm{tš}]> \\
{[\check{s}]>[\mathrm{t}]} \\
\text { Elder people: }[\mathrm{t}]>\left[\mathrm{t}^{\mathrm{s}}\right] \approx \\
{\left[\mathrm{t}^{\mathrm{s}}\right]}\end{array}$ \\
\hline $\begin{array}{l}\text { /g/ vs /q/ in } 7 \text { common items: } \\
\text { /fūg/ vs / fūq/ "above" } \\
\text { /gbe l/ vs /qbe l/ "before" } \\
\text { /ge ddām/ vs /qə ddām/ "in } \\
\text { front of" } \\
\text { /t le g/ vs /t le q/ "to } \\
\text { release" } \\
\text { /wge f/ vs /wqə f/ "to stop" } \\
\text { (intransitive) } \\
\text { /ga/ vs /qa/ "to find" } \\
\text { /gə lb/ vs /qə lb/ "heart" }\end{array}$ & $\begin{array}{l}\text { Urban young: /q/ (low class: } \\
\text { /füg/,/ga ddām/) } \\
\text { Rural:/g/ } \\
\text { Other: /q/ }\end{array}$ & $\begin{array}{l}/ \mathrm{g} / \Rightarrow \text { Rural (except for } / \mathrm{g} a \bar{l} / / \text {, } \\
\text { maybe low literacy }\end{array}$ & $\begin{array}{l}\text { Alternation for all items } \\
\text { Eg.: /fūg/ (C), /fūq/ (T) }\end{array}$ \\
\hline
\end{tabular}

\begin{tabular}{|c|c|c|c|}
\hline Feature & Usage in media & Value in media & Occurrences in field study \\
\hline /hde $\mathrm{r} /$ ss/dwa/ & 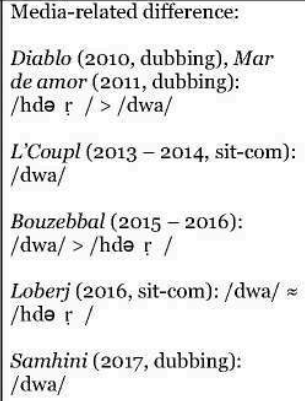 & $\begin{array}{l}\text { /dwa/ => rural; Stylistic } \\
\text { (colloquial / rude)? } \\
\text { Casablancan? In expansion? } \\
\text { /hde r / => originally urban? } \\
\text { Stylistic (formal / kind)? } \\
\text { Regional? In regression? }\end{array}$ & $\begin{array}{l}\text { Temara: / hdo } \mathrm{r} />/ \mathrm{dwa} / \\
\text { (context to be checked) } \\
\text { Casablanca: /dwa/ }\end{array}$ \\
\hline $\begin{array}{l}\text { Sentence-final deceleration } \\
\text { with vowel modification }\end{array}$ & $\begin{array}{l}\text { Bouzebbal characters : constant } \\
\text { Other media fiction : only } \\
\text { found in some convicts' speech, } \\
\text { less marked than in Bouzebbal }\end{array}$ & Very low class / criminal & $\begin{array}{l}\text { Inter-speaker variation (to be } \\
\text { checked) }\end{array}$ \\
\hline
\end{tabular}

- /q/ vs /g/: the lexemes listed in the table are those for which phonemic variation has been observed both in the media and on the field. However, sociolinguistic distribution in the media is much more "straightforward", with rural characters invariably producing all these lexemes with $/ \mathrm{g} /$ and all other characters (with a few exceptions such as suburb residents in Bouzebbal) producing them with /q/. On the other side, field informants show a much greater instability in the selection of /g/ vs /q/, with some invariably choosing either of them and some alternating between the two of them even in the same sentence (obviously, and in addition to that, each lexical item tends to be treated differently by each speaker). However, /q/ is in general much more frequent than /g/. This could signal that, for some reason to be enquired, recently urbanised (also young) Témarois are "late" in abandoning rural features (such as $/ g /$ ), but it could also indicate that young speakers 
are reinterpreting either the meaning of traits once considered as merely urban or rural, or the concepts of urbanity and rurality themselves.

17 - /hdər/vs /dwa/: the inter-corpus comparison seems to suggest that /dwa/ is a word mainly used in Casablanca, whereas /hdər/ may be more diatopically "neutral". In fact, /hdər/ is the most frequent (but not exclusive) choice in both corpora, with three remarkable exceptions: a group of Casablancan youth included in the field sample, Bouzebbal (which is set in Casablanca) and Samhini, a Turkish soap-opera dubbed in Moroccan Arabic and still airing on Moroccan TV to this date; in these three domains, / $d w a /$ is almost categorically used instead of /hdər/. Indeed, in all three of these contexts, one would expect to hear people speak "like Casablancans": the youth are from Casablanca, as well as the Bouzebbal characters. As for Samhini, why should members of high class Turkish families speak like Casablancans? In fact, Moroccan Arabic speakers have already been observed to perceive translations of foreign soap-opera scripts to Moroccan Arabic as closer to the Casablancan dialect: this, at least, has been the case for the Mexican soap-opera Las dos caras de Ana (Miller 2012: 172; Barontini \& Ziamari 2013: 121). Coincidentally (or not?), the translation and dubbing of Samhini has been taken charge of by Plug-In, the same company that managed the translation and dubbing of Las dos caras de Ana. This may indicate that $/ \mathrm{dwa} /$ is truly closer to Casablancan speech. If this is the case, then the analysis can be directed at evaluating the occurrence of either lexeme when we would not expect it, i.e. of /hdər/ in supposedly Casablancan speech and of /dwa/ in supposedly nonCasablancan speech.

18 - Sentence-final deceleration: this is a supra-segmental feature involving both a decrease in articulation rate before a pause and a lengthening of the vowels involved (usually those in the last word preceding the pause). It seems to serve the purpose of sounding aggressive, "dangerous", like "gangsters" or "criminals" (but not necessarily with the intent of making other people believe that one is a criminal). To use a lexicon more familiar to Moroccans, this feature allows the speaker to sound like a mcharmel (/mšərməl/, approximately "petty criminal") in order to give the impression of being mqawed (/mqəwwəd/, approximately "badass") $)$. While the characters that use this feature in the media corpus (petty criminals in Bouzebbal and two convicts in the Mar de amor dubbed soap-opera) seem to confirm its original association to people of low morality, the tropic use (Agha 2007) of it seems to be only found among a part of the youth in the field corpus. Further analysis will shed light on whether young speakers "speak like mcharmlin" in order to "get a mcharmel attitude" or are just used to speak like that, possibly by effect of their social origin (e.g. having grown up in an environment "full of mcharmlin")".

\section{Conclusion}

19 This brief article aimed at giving a general presentation of an ongoing research project on sociolinguistic variation in Moroccan Arabic as it is spoken in the city of Temara, and mainly focused on the theoretical motivations underlying the choice of the object of study and the method of analysis adopted, with the addition of a few observations drawn from a first, partial analysis of the data. The completion of the compared analysis of the field and the media corpora, which constitutes the next step in the treatment of the data, will be guided by the following questions:

- How do the media and the informants of the sample differ in interpreting sociolinguistic variation in spoken Moroccan Arabic? 
- How do the speakers give a sense to the use of alternative linguistic features, in the frame of their language practices and the urban context examined?

- Do media-vs-society differences in sociolinguistic choices exclude, or affect, the possibility that a shared, pan-national spoken variety of Moroccan Arabic may be taking shape?

Answering these questions will hopefully shed light on how Moroccan Arabic speakers not only make use of their linguistic repertoire in order to express themselves and be understood, but also on how they interpret the linguistic variation they are faced with in their social environment, in the frame of the development of national contexts of communication and the ongoing elaboration of the Moroccan national identity.

\section{BIBLIOGRAPHY}

Agha, Asif. 2007. "Introduction", Language and social identities. Cambridge: Cambridge University Press. 1-13.

Ait Mouloud, Hassan. 1998. Urbanisation et aménagement de Témara. Mémoire pour l'obtention du diplôme des études supérieures en Aménagement et Urbanisme. Rabat : Institut National d'Aménagement et d'Urbanisme.

Amara, Muhammad. 2005. "Language, migration, and urbanization: The case of Bethlehem". Linguistics 43(5). 883-901.

Barontini, Alexandrine, \& Ziamari, Karima. 2013. « Ana: parlez-vous arabe marocain ? Quand les séries réconcilient avec la darija ». Montserrat Benítez Fernández et al. (eds.), Evolutions des pratiques et des représentations langagières dans le Maroc du XXI siècle, Vol. I. Paris: L'Harmattan. 119-142

Bennis, Saïd. 2014. “At-tcharmil” mina z-zāhirati š-šabābiyyati 'ila z-zāhirati l-muğtama“iyya (consulted on $21^{\text {st }}$ November 2017 at http://www.hespress.com/writers/216761.html).

Caubet, Dominique, Miller, Catherine, Vicente, Ángeles, \& Ziamari, Karima. Forthcoming. «Eléments de caractérisation de pratiques linguistiques de jeunes Marocains (Casablanca, Meknès, Tétouan, Marrakech) ».

Eckert, Penelope. 2003. "Social variation in America", Publication of the American Dialect Society 88 (1). 91-113.

Eckert, Penelope. 2008. "Variation and the indexical field", Journal of Sociolinguistics 12/4. 453-476.

El Himer, Mohammed. 2015. Dynamique linguistique dans la ville marocaine : l'espace urbain de Salé. Rabat: Rabat Net.

Kerswill, Peter. 1996. "Dialect levelling, koinéisation and the speech of the adult migrant", University of Pennsylvania Working Papers in Linguistics 3 (1). 18.

Labov, William. 1972. Sociolinguistic patterns. University of Pennsylvania Press.

Messaoudi, Leila. 2001. « Urbanisation linguistique et dynamique langagière dans la ville de Rabat », Cahiers de sociolinguistique 1. 89-100. 
Messaoudi, Leila. 2003. Etudes sociolinguistiques. Kénitra: Faculté des Lettres et des Sciences Humaines.

Miller, Catherine. 2004. "Variation and Changes in Arabic Urban Vernaculars", Martine, Haak, Kees, Versteegh, \& Rudolf, Dejong (eds), Approaches to Arabic Dialects: Collection of Articles presented to Manfred Woidich on the Occasion of his Sixtieth Birthday. Amsterdam : Brill. 177- 206.

Miller, Catherine. 2012. "Mexicans speaking in dârija (Moroccan Arabic): Media, Urbanization and language changes in Morocco", Reem, Bassiouney, \& Graham, E., Katz (eds.), Arabic language and linguistics. Washington DC: Georgetown University Press. 169-188.

Mitchell, Terence F. 1986. “What is educated spoken Arabic?", International Journal of the sociology of language 61(1). 7-32.

Silverstein, Michael. 2003. "Indexical order and the dialectics of sociolinguistic life", Language \& Communication 23(3). 193-229.

Trudgill, Peter, Gordon, E., Lewis, G., \& Maclagan, M. 2000. “Determinism in new-dialect formation and the genesis of New Zealand English", Journal of Linguistics 36(02). 299-318.

Vicente, Ángeles. 2008. "Génesis y clasificación de los dialectos neoárabes”, Federico, Corriente, \& Ángeles, Vicente (eds.), Manual de dialectología neoárabe. Zaragoza: Instituto de Estudios Islámicos y del Oriente Próximo. 19-67.

Youssi, Abderrahim. 1992. Grammaire et Lexique de l'arabe marocain moderne. Casablanca: Wallada.

\section{Online sources}

http://rgphencartes.hcp.ma/\# (Official site of the 2014 moroccan census), consulted on $6^{\text {th }}$ November 2017.

https://www.youtube.com/watch?v=VS2evj4wb48\&t= (Bouzebbal episode: "L3id lkbir") consulted on $6^{\text {th }}$ November 2017.

\section{NOTES}

1. This corresponds to what Miller (2004: 179) calls "national or regional standard"; however, the issue of what is or is not standard being left apart for the present paper, the somewhat neutral expression "supralocal (spoken) variety" or similar will be preferred.

2. Ait Mouloud 1998: 25.

3. http://rgphencartes.hcp.ma/\#, consulted on 6th November 2017.

4. The idea of using Moroccan media products, particularly dubbed soap-operas, for the aim of sociolinguistic analysis was taken from Barontini \& Ziamari (2013), although their purpose was analysing sociolinguistic variation in the speech of the soap operas itself rather than making inferences on the speakers' "daily" interpretation of the meaning of variables.

5. The example is taken from the episode no. 16 (sec. 8. 44) of the Youtube animated series of Bouzebbal; the meaning of the sentence is: "What do you think of this story?"

6. Unfortunately, the field corpus includes no young women and only two elder ladies, which makes it impossible to counter-check media stereotypes on women's speech; this is obviously also true for the other variables, but for this one gender variation is probably most relevant. Further field enquiries will therefore be aimed at filling this gap.

7. For this and the previous word, the italic transliteration is the one most commonly found on the web. 
8. I am indebted to my friend Ahmed, a.k.a. "David Luiz", who suggested the English translation of this term to me.

9. For more details on the social phenomenon of tcharmil, "petty criminality", in Morocco $c f$. Bennis 2014.

\section{ABSTRACTS}

This paper moves from the following issue: is there a homogeneous variety of spoken Arabic in expansion in Morocco? An ongoing research project on language practices in the Moroccan town of Temara, a sort of "new-town" that has been growing dramatically in the last four decades by the effect of internal immigration, seeks to partially answer this question by analysing language in an urban context, which by its very nature demands a "delocalisation" of speech from its dwellers. After stating why the focus is placed on the social interpretation of single linguistic features rather than on the definition of a "variety", the paper goes on to motivate the choice of comparing the data collected on the field with the use of spoken Moroccan Arabic in fiction as a technique to acquire more information on the sociolinguistic connotation of linguistic traits in the community. Finally, a brief sketch of the linguistic features selected and the first results of the analysis are provided.

\section{INDEX}

Keywords: Moroccan Arabic, sociolinguistics, urban standards, koineisation, indexicalisation, language in the media

\section{AUTHOR}

\section{JACOPO FALCHETTA}

PhD student, Aix-Marseille Université / IREMAM, CNRS/ Aix-Marseille Université, Aix-enProvence, France

jacopo.falchetta@gmail.com 


\title{
On the Way to Understand the Pan- Arab Voice
}

\author{
Mona Farrag Attwa
}

\section{Introduction: framework}

Morrow \& Castleton (2007) state that satellite channels and the Internet have spread Modern Standard Arabic (MSA), strengthened the bond among the Arab countries and help standardize the Arabic dialects. In 2011, after the Arab Spring, Temlali argues that the transnational Arab satellite channels solidify the unity of the Arabic language. On the one hand, he views MSA as entering "its golden age" (p.49), facilitating communication between the elites from across the Arab world, a communication that had in earlier times been hindered by national varieties. On the other hand, an increased sense of pride in one's home country brought more dialects to be heard on home TV. The direct coverage of the ordinary people who incited the Arab Spring demonstrations increased the amount of dialectal broadcast.

These features of dialects and MSA create superdiversity on transnational TV channels in the Arab world in line with the label Blommaert \& Backus (2011: 4) gave it: a "tremendous diversification of diversity". In cross-dialect communication, each Arab individual brings biographical indexicalities of values, meanings, and identities, while at the same time projects a commonly shared pan Arab history, culture, and ideologies.

In a superdiverse communicative practice, Jørgensen (2008) claims that polylingualism is the norm of communication. Following this norm:

language users employ whatever linguistic features are at their disposal to achieve their communicative aims as best they can, regardless of how well they know the involved languages; this entails that the language users may know _ and use _ the fact that some of the features are perceived by some speakers as not belonging together. (Jørgensen 2008: 163)

Accordingly, Jørgensen, Karrebæk, Madsen, and Møller (2011) suggest the linguistic "feature" to be the level of linguistic analysis in superdiverse societies. This level is more dynamic and is expected to provide a better representation of the sociocultural values, 
meanings, and attitudes associated with language use. They define features in terms of units and regularities:

Units are words, expressions, sounds, even phonetic characteristics such as rounding. Regularities are traditionally called "rules", but they are not rules in the legal sense, or even the normative sense. They are regularities of how units are combined into larger units in processes through which the larger units become associated with meanings. (Jørgensen et al 2011: 30)

This paper presents the preliminary results of a data-driven $\mathrm{PhD}$ dissertation. Applying the linguistic feature as the unit of analysis, the study takes the Arabic version of The Voice, the pan-Arab TV singing competition known also as 'Ahlā Ṣōt, as a case study to investigate linguistic features accessible to and employed by Arabs in cross-country communication, relating the indexicalities of these features to identity and ideology. This paper explores the use of features of national dialects, the interlocutors' dialects, and MSA presenting the outcomes of a first analysis. The complete analysis and results will be presented in the thesis that is to appear in 2020.

It is first important, however, to provide meanings of three fundamental terms used in the study: Arabism, Arabness, and identity. I will then shed light on recent studies done on Arabic cross-country communication.

\section{Definitions}

In this section I will provide a global view of three fundamental terms used in this study: Arabism, Arabness, and identity. The terms are discussed in more details in the larger $\mathrm{PhD}$ dissertation.

\subsection{Arabism}

Looking up the term Arabism, Encyclopaedia Britannica Online refers to the entry "PanArabism (Ideology)". The Encyclopedia defines the terms as:

Nationalist notion of cultural and political unity among Arab countries. Its origins lie in the late 19th and early 20th centuries, when increased literacy led to a cultural and literary renaissance among Arabs of the Middle East. This contributed to political agitation and led to the independence of most Arab states from the Ottoman Empire (1918) and from the European powers (by the mid-20th century).

Albirini (2016) discusses the term in light of the terms "nation", "state", and "Arab nationalist movement". He also makes the reference to the Arabic concept qawmiyya, from "qawm" or folk or people, meaning 'nationalism'. He cites Kallas (2007) saying that this term has been used in literature to refer to Arab's sense of their "common ethnic and linguistic heritage" (p. 128). It is noteworthy to see how Albirini concludes that Arab nationalism:

falls under what Smith (1986) calls "essentialist" view of the nation, in which the nation is materialized or theorized through political myths of common descent, history, culture, territory, sense of solidarity, and other sociocultural symbols. In this approach, language is often a key component of national identity construction. (Albirini 2016: 129)

Two points attract the attention in these two sources. First, where Encyclopedia Britannica Online bracketed the term as (ideology). Second, where Albirini uses the expression "political myth". Both instances imply the term may be an imaginable idea; 
may not be a factual reality. By looking at my data, I will try to see where my informants stand from that.

\subsection{Arabness:}

Arabness is different from Arabism. Nydell (2012) produced an informative study on understanding Arabs. In order to describe what and how Arabs are, she covers aspects such as beliefs and values, friends and strangers, emotion and logic, personal issues, men and women, social formalities and etiquette, the role of the family, religion and society, Islamism, similarities and differences between Arab countries, and the Arabic language. She introduces Arabs as "the people in some eighteen countries who speak the Arabic language" (Nydell 2012: xi). Emphasis is mine to reflect how speaking Arabic is in the heart of understanding what and how an Arab is. She argues further that Arabs do not have the same ethnic (Arabian) origin, they speak different dialects of the language, and have different costumes and appearance. Then she says, not all Arabs are Muslims. Christians make up 5\% of Arabs, and there are a few thousand Jews in the Arab countries. She rightly says "Arab is a cultural and political term" (ibid.) (emphasis not mine). Arabness as a term used in this study embraces all the above aspects and I check the results of my analysis as well on instances that may relate to Arabness.

\subsection{Identity}

Albirini (2016), reviewing others, describes identity as "a dynamic construct that is negotiated among social actors within immediate situational elements such as time, place, event, and occasion as well as in larger social norms, power relationships, cultural traditions, ideological concepts, and discursive practices" (Albirini 2016: 123). I find it is also important to mention how he elaborates on this definition. He argues that at the same time where Arab social and political systems provide the framework and boundaries within which Arabs define themselves in relation to others, the social system does not prevent the speakers' ability "to exercise their choices and make decisions based on their membership in the social system and their understanding of different contextual factors" (ibid). Albirini (2016) raises three issues to which this research, in its larger scale, may contribute to as well. The issues are: first, to find if and how language contributes to Arabs' projection of their identity; second, the influence of diglossia on the formation of personal and social identities and the related indexicalities; third, the significance of the existence of local and global languages side by side in the same social sphere.

\section{Arabic Cross Country Communication}

Studies on Arabic cross country communication are still rare. While the results in the existing studies (see Soliman (2015) for an extensive review) reflect the mechanism of communication between Arabs, globalized pan-Arab media setting imposes new factors on the dynamics and powers of this communication. First, it is important to briefly look at the communication studied in research-created settings on formal and informal topics. I mention the results of Soliman (2015), Abu-Melhim (2014), and Chakrani (2014).

Soliman (2015) finds that Arabs in cross country communication predominantly maintain their own dialects. Resorting to MSA to facilitate communication is rare compared to 
older studies or to her expectations. Intelligibility happens through a number of strategies by the speaker and the listener. Speakers may replace localised lexis with a more common one or MSA equivalent, or acquaint their listener with the meaning of the localised lexis. As for the listeners, they depend on a number of strategies for comprehension: 1. Familiarity with the item due to previous exposure of the dialect. 2. Guessing the meaning from the context. 3. Guessing the meaning by relating it to familiar cognates in other Arabic varieties. 4. Asking their interlocutor for meaning. 5. Ignoring an item if it is not a content word. From her data, Soliman reports cases of comprehension failure due to unfamiliarity of a non-cognate and absence of contextual clues.

Abu-Melhim (2014) finds that when conversing together in an informal setting, Arabs adopt different linguistic accommodation strategies such as switching between different Arabic varieties, including MSA. His data show that speakers tend to use Educated Spoken Arabic (ECA) over MSA, especially when the interlocutors' dialects are in cases unintelligible. These strategies are used to ensure the listener understands what the speaker is saying, and to negotiate or clarify the meaning. The prime goal of all these strategies is clarity of communication.

Chakrani (2014) looks at the attitude behind accommodation strategies used in interdialectal communication. He finds that capitalizing on the prestige of Mashreqi Arabic obliges the non-Mashreqi Arabic speakers to accommodate and style shift. Agreeing with the findings of S'hiri (2002) and in line with Hachimi (2013), Mashreqi Arabic speakers feel no obligation to style shift due to their attitude that they possess the prestigious form of Arabic, and they are expecting the non-Mashreqi Arabic speakers to accommodate due to the attitude of the allegedly incomprehensible dialects. However, Maghrebi Arabic speakers tend to use humour to challenge this norm. By insisting on using their own dialect, Maghrebi Arabic speakers assert their in-group identity and defy the pretext of incomprehensibility, which Mashreqi Arabs capitalize on. These accommodative strategies are used due to the burden caused by this attitude to the conversation. This burden sometimes pushes Chakrani's informants to shift to English for "communicative efficiency and to level linguistic asymmetries" (ibid.)

\section{Study and Research Questions}

The setting in the above studies causes Arabs to employ certain strategies to have a successful communication. Looking at communication taking place in a globalized panArab TV setting, it is observed that Arabs display different dynamics. This study aims to answer the following questions: In order to have a comprehensible communication in a globalized pan-Arab TV setting, 1. To what extent do Arabs use features of their national dialect? 2. To what extent do Arabs use features of their interlocutor's dialect or MSA? The rest of this section briefly introduces the setting and the data. Since this paper presents preliminary results of the study, these questions are phrased in order to focus on the results presented here.

It is important to note that the results are seen within media context as well; trying to understand where pan-Arab media stands from the use of these features. The media is represented, at least in this paper, by the presenters and teleprompters (the reading screens provided to presenters in live shows). Since the $\mathrm{PhD}$ study aims as well to relate the results to questions of Arabism, Arabness, Identity, and ideology, a brief reflection on 
Arabism and Arabness questions is presented at the end of the discussion section as a lead to the results of the PhD study.

\subsection{The Setting:}

The Voice, 'Ahlā Șōt, (debuted on September 14, 2012) is one of the most popular talent shows in the Arab world. It is broadcast worldwide from Beirut, Lebanon, from the studios of the Middle East Broadcasting Centre (the Saudi-owned MBC Group). The format of the show is based on its original Dutch format created by media tycoon John de Mol. The case study, the second season of the program premiered on Saturday, December 28, 2013 , is composed of three stages that run over 14 weekly episodes: the blind auditions (5 episodes), the battle rounds (3 episodes), and the live performances (6 episodes). (In Arabic: Eș- șōt we Bas, El-muwāgha, and El-'urūẹ El-mubāšra).

In order to guarantee a wider viewership, MBC Group aired the show at 9 pm, KSA time, on two consecutive weekend days. On Friday, a rerun of the previous week's episode is broadcast, while the new one is broadcast on Saturday. This peak time on television and the strong social media platform contributed to the high rate of viewership that was estimated in the finale by 100 million viewers (Vivarelli, 2014).

The couches are Kazim As-Saher, an Iraqi composer, singer, and poet; Asi El-Hellany, a Lebanese singer; Saber Reba'y, a Tunisian composer and singer; and Sherin Abdelwahab, an Egyptian singer (Representing four of the five main dialectal regions of the Arab world, Versteegh 1997: 145). Moreover, the main presenter of the show is the Egyptian actor and presenter Mohammed Kareem, who is joined in the live performances by the Lebanese presenter, Emee Saiyah. The Lebanese presenter Nadine Najim presents the backstage sections from the blue room.

The globalized and superdiverse aspects in the show do not come only from the diversity of the judges, presenters, and the contestants, but also through the interplay of international, pan-Arab, and national traits that are present in the show. Reaching an international audience outside the Arab world is clear from preserving the name of the show, The Voice, and the international format that is repeated in all countries hosting the same show. Moreover, the invitation of Ricky Martin at the end of season 2 to debut his new songs "Adrenalina" and "Come With Me" (Vivarelli, 2014) gives the show a wider international resonance.

\subsection{Data Description:}

For this paper, a corpus is built from the "communication instances" in episodes 1, 2, 6, 7, 9 , and 10 (two episodes of each different phase of the competition respectively). This selection is to include any different type of communication in the different phases of the program. The corpus of the $\mathrm{PhD}$ study will include 4 more episodes.

By "communication instance" I mean the parts of the show where a conversation between at least two people is taking place. Therefore, when an informant is addressing the audience, their speech is not considered a communication instance. Likewise, when a speaker appears to be talking to someone else but there is no response on the screen from the interlocutor, their speech is not included in the data. This is to ensure that communication is taking place; either by conveying or negotiating the meaning. 
Transcription is made using the CLAN program of CHILDES (Child Language Data Exchange System). As mentioned, linguistic features are the units of analysis ${ }^{1}$.

The 72 informants and their dialects are: 13 from Egypt (egy); 13 from Lebanon (leb); 13 from Morocco (mrc); 12 from Iraq (irq) - one of them is from Kurdistan Iraq but introduces himself as Iraqi; 7 from Syria (syr); 4 from Tunisia (tun); 4 from Saudi Arabia (sau), 2 from Jordan (jor); 1 from Palestine (pal); 1 from Palestine, Tunisia, and England (pal, tun, eng); 1 from Sudan (sud), and 1 from Algeria (alg). This means there are 18 informants from the Maghreb countries.

\section{Analysis and Results}

A number of practices characterize communication in the data. These practices will be fully analyzed and discussed in the PhD thesis. This paper focuses only on two practices: The first concerns the issue of to what extent the informants use features of their national variety of Arabic. The second practice relates to the question to what extent the informants use features of their interlocutor's dialect or MSA. As a kind of spin off the paper reflects on the notions of Arabness, Arabism and identity.

\subsection{Using national dialects:}

In this section, I provide examples that the informants communicate, predominantly, using the distinctive features of their national dialects. Following general linguistic conventions (Versteegh, 1997; Holes 1995), I analyze the examples looking at the distinctive features of the dialects on the phonological, lexical, morphosyntactic, syntactic, and idiomatic levels. However, the analysis presented in the tables reflect the levels of the distinctive features as they appear in each example. This means that one example may show all five levels of analysis while another may show only two levels. In the feature analysis tables below, the following abbreviations are used: interdents: interdentals; inter: interrogative; demo: demonstrative; prep: preposition; pron: pronoun; v: verb; and neg: negation. ${ }^{2}$

The 13 Egyptian informants in the data mainly use Egyptian dialect features. For example:

Ex. 1. Sherin, in episode 1, speaking to Lebanese Asi

$\bar{e} h$, 'enta țab 'enta we hịyāt 'abū-k gebt dih menēn? ya'nī 'amal' ta-hā wallā 'enta 'eš' tarit-h $\bar{a}$ gahzah?

What? You, by the life of you father, where did you get this from? I mean did you make it or buy it ready-made?

Table 1.1. Distinctive features of the Egyptian dialect in the example:

\begin{tabular}{|l|l|l|l|l|l|}
\hline $\begin{array}{l}\text { Ex. } \\
1 .\end{array}$ & Phonological & Lexical & Morphosyntactic & Syntactic & Idiomatic \\
\hline
\end{tabular}




\begin{tabular}{|c|c|c|c|c|c|}
\hline $\begin{array}{l}\text { Egy } \\
- \\
\text { Leb }\end{array}$ & 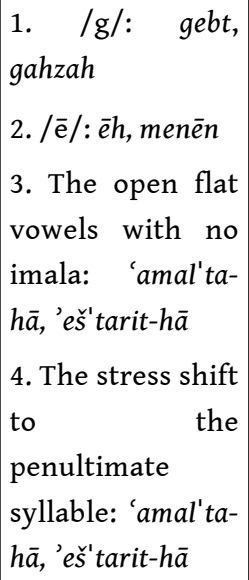 & $\begin{array}{l}\text { 1. Inter: èh, menēn } \\
\text { (what, from where) } \\
\text { 2. Demo: dih (this) }\end{array}$ & 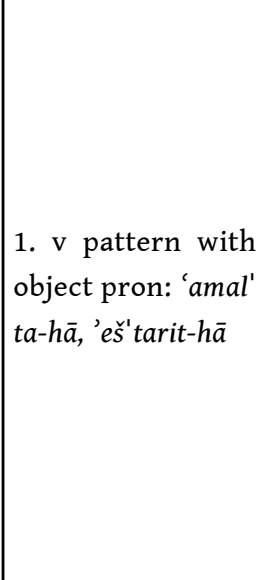 & $\begin{array}{l}1 . \quad \text { The } \\
\text { inter word } \\
\text { at the end } \\
\text { of the } \\
\text { question. }\end{array}$ & $\begin{array}{l}\text { 1. we hiyāt 'ab } \\
\bar{u}-k\end{array}$ \\
\hline
\end{tabular}

The 7 Syrian informants in the date use distinctive features of the Syrian dialect. For example:

Ex. 2. Hala, in episode 2, speaking to the four judges:

'anā 'awal ši biddī 'il-kun 'ino 'intu bi-l-nisbả 'il-lì 'arba ' madārảs, bidd̄̄ 'iHțãr (singing) I, first thing, would like to say to you that, for me, you are four schools, I would like to choose (singing)

Table 1.2. Distinctive features of the Syrian dialect in the example:

\begin{tabular}{|c|c|c|c|c|}
\hline Ex. 2. & Phonological & Lexical & Morphosyntactic & Idiomatic \\
\hline $\begin{array}{ll}\text { Syr } & \text {-Leb/ } \\
\text { Egy/Tun/Ira }\end{array}$ & $\begin{array}{l}\text { 1. The shift of /q/ to /'/:' } \\
\text { il-kun } \\
\text { 2. The high rise imala: bi- } \\
\text { l-nisbả, madārảs }\end{array}$ & $\begin{array}{l}\text { 1. } \quad \text { ši (a } \\
\text { thing) } \\
\text { 2. biddi (I } \\
\text { want) }\end{array}$ & $\begin{array}{l}\text { 1. Prep and attached pron: } \\
\text { 'il-lī (for me) } \\
\text { 2. The object pron: "kun": ' } \\
\text { il-kun } \\
\text { 3. v pattern: 'iHțãr }\end{array}$ & $\begin{array}{l}\text { 1. bi-l-nisbả } \\
\text { il-lì }\end{array}$ \\
\hline
\end{tabular}

The 13 Lebanese informants use distinctive features of the Lebanese dialect. For example:

Ex. 3. Asi, in episode 1 speaking to Egyptian Wahm:

wahm, men wẻn hạdret-ék?...tahịyẻ kibïrẻ lā 'il-ik wa li-'ada'-ék wa hay el-ğarḥa bi-ṣawt-ék 'llì bi-tšla' el-' 'älib min ğuwā

Wahm, where are you from?...Greetings to you, your performance, and your husky voice that takes the heart from inside.

Table 1.3. Distinctive features of the Lebanese dialect in the example:

\begin{tabular}{|c|c|c|c|}
\hline $\begin{array}{l}\text { Ex. } \\
3 .\end{array}$ & Phonological & Morphosyntactic & Idiomatic \\
\hline $\begin{array}{l}\text { Leb - } \\
\text { Egy }\end{array}$ & $\begin{array}{l}\text { 1. Imala: wẻn, hadretẻe, tahiyẻe, kibìrẻ, li-'ada'-ẻk, bi- } \\
\text { șawt-ék } \\
\text { 2. /ğ/: el-ğarḥa, ğuwā }\end{array}$ & $\begin{array}{l}\text { 1. Inter: wẻn } \\
\text { 2. Demo: hay } \\
\text { 3. Prep and attached } \\
\text { pron: 'il-ik (for you) }\end{array}$ & $\begin{array}{l}\text { 1. bi-tšla' el-"' } \\
\text { ālib min ğuwā } \\
\text { 2. lā 'il-ik }\end{array}$ \\
\hline
\end{tabular}


The 13 Moroccan informants in the data use distinctive features of Moroccan dialect. For example:

Ex. 4. Khawla, in episode 9 speaking to Lebanese Nadine and sending a message to Iraqi Kazim:

'anā ka new'ad-u baš kul marra n-qadim makțar min dak šì 'illì ka n-qadim min qabl, hint min gìr-u huwā 'anā ma-n-qdir-š n-dìr fi had̄ā el-birnāmă̌.

I promise him that every time I will give more than what I gave before, because without him I would not be able to manage in this program.

Table 1.4. Distinctive features of the Moroccan dialect in the example:

\begin{tabular}{|c|c|c|c|}
\hline Ex. 4. & Phonological & Lexical & Morphosyntactic \\
\hline $\begin{array}{l}\text { Mrc } \\
\text { Leb/Irq }\end{array}$ & $\begin{array}{l}\text { 1. /q/: qabl } \\
\text { 2. /ğ/: el-birnāmaǧ } \\
\text { 3. CCV cluster: n- } \\
\text { qadim, ma-nqdir-š }\end{array}$ & 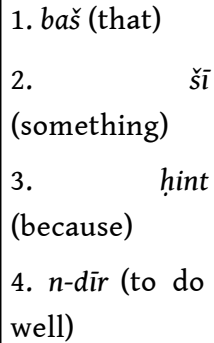 & $\begin{array}{l}\text { 1. Aspect marker: } k \text { - } \\
\text { 2. The use of (n) in first person indicative: } n i- \\
w^{\prime} a d-u, n \text {-qadim, ma-n-qdir-š, } n \text {-diir } \\
\text { 3. The neg: ma-n-qdir-š } \\
\text { 4. Demo: dak }\end{array}$ \\
\hline
\end{tabular}

It should be noted that, during the show, sometimes $\mathrm{MBC}$ provides subtitles to the Moroccan contestants and their family and friends. However, the informants themselves on the show are not affected by this practice since it is only provided to the audience. Discussing this practice is not within the scope of this paper but it will be treated in the thesis.

The 12 Iraqi informants in the data use distinctive features of the Iraqi dialect. For example:

Ex. 5. Mihvaan, an Iraqi from Kurdistan Iraq in episode 1, speaking to the four judges:

šint 'a-tmanā ya'nī kursī te, te-tlaf 'alai-yah, we ha-l-yōm, 'ețnēn șãra-t 'aș'ab 'alai-yẻ. fo ha-l-yōm 'ānī yi-šarf-nī 'a-H̦țãr 'ustāa kãdim el-sāhir

I was hoping one chair turns for me. Today, I have two chairs. It became harder for me. Today I am honored to choose Mr. Kazim As-Saher.

Table 1.5. Distinctive features of the Iraqi dialect in the example:

\begin{tabular}{|c|c|c|c|c|}
\hline Ex. 5. & Phonological & Morphological & Morphosyntactic & Idiomatic \\
\hline $\begin{array}{l}\text { Irq } \\
\text { Tun/ } \\
\text { Leb/Egy/ } \\
\text { Irq }\end{array}$ & 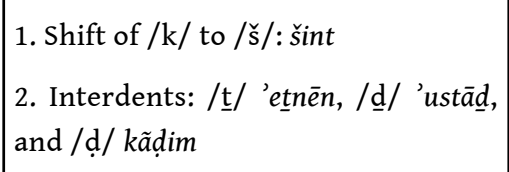 & 1.'’ānì (I) & $\begin{array}{l}\text { 1. v pattern: te- } \\
\text { tlaf } \\
\text { 2. Demo: ha- }\end{array}$ & $\begin{array}{l}\text { 1. te-tlaf } \\
\text { alai-yah }\end{array}$ \\
\hline
\end{tabular}

The 4 Tunisian informants use distinctive features of the Tunisian dialect. For example:

Ex. 6. Aida, in episode 9 speaking to Lebanese Nadine:

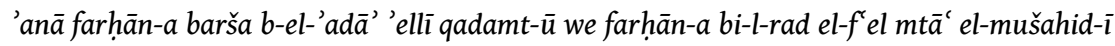

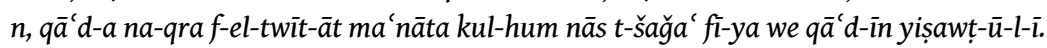


I am so happy with the performance I gave and I am so happy with the reaction of the audience. I am reading the tweets, and all the people are encouraging me and voting for me.

Table 1.6. Distinctive features of the Tunisian dialect in the example:

\begin{tabular}{|c|c|c|c|c|}
\hline Ex. 6. & Phonological & Lexcial & Morphosyntactic & Idiomatic \\
\hline $\begin{array}{l}\text { Tun - } \\
\text { Leb }\end{array}$ & 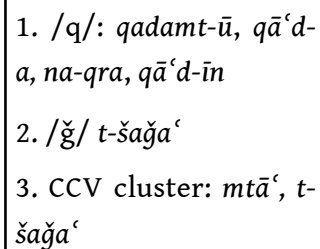 & 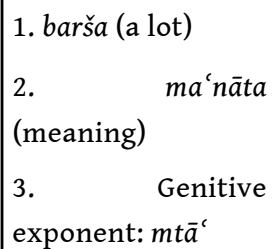 & $\begin{array}{l}\text { 1. The use of (n) in first } \\
\text { person indicative: na-qra } \\
\text { 2. Gerund: } q \bar{a}^{`} d-a \text { na-qra, } q \bar{a}^{`} d- \\
\text { in yișawt }-\bar{u}-l-\bar{l}\end{array}$ & $\begin{array}{l}\text { 1. ma'nāta } \\
\text { 2. } t \text {-šağa' fi- } \\
y a\end{array}$ \\
\hline
\end{tabular}

The 4 Saudi informants use distinctive features of the Saudi dialect. For example: Ex. 7. Muhammed Hashem, in episode 6, speaking to Egyptian Sherin: 'anā bas ğìt 'ustāza širīn 'ašān 'agul-ik 'and-ì el-muškila fi-ț-țabaga. el-'uginiya 'anā bi-șa rãha ya'nī mā-nī murtāḥ fì-hā...wallah, mmm, ya'nī, mū lōn-ī.

I just came, Mrs Sherin, to tell you that I have a problem with the tone. The song, I am, honestly, not comfortable in it....by God, mmm, it is not my style.

Table 1.7. Distinctive features of the Saudi dialect in the example:

\begin{tabular}{|c|c|c|}
\hline Ex. 7. & Phonological & Morphosyntactic \\
\hline Sau - Egy & $\begin{array}{l}\text { 1. /ğ/: ğit } \\
\text { 2. Shift of /q/ to /g/: 'agul-ik, fi-ț-țabaga } \\
\text { 3. The damma in active participle: murtāh }\end{array}$ & 1. Neg: $m \bar{a}-n \bar{\imath}, m \bar{u}$ lōn-i \\
\hline
\end{tabular}

The Palestinian informants use distinctive features of the Palestinian dialect. For example:

Ex. 8. Sherin, a contestant in episode 1, speaking to Egyptian Kareem:

šugil-ì 'ad mā 'ațān-ī quwẻ, 'ad mā Hallā 'alb-ī biğad yișī 'aqwā lessa.

My work, as it gave me power, it made my heart even stronger.

Table 1.8. Distinctive features of the Palestinian dialect in the example:

\begin{tabular}{|c|c|c|c|}
\hline Ex. 8. & Phonological & Lexical & Idiomatic \\
\hline Pal - Egy & $\begin{array}{l}\text { 1. Imala: quwẻ } \\
\text { 2. /q/: quwẻ, 'aqwā } \\
\text { 3. /ğ/: biǧad }\end{array}$ & $\begin{array}{l}\text { 1. yișir (to become) } \\
\text { 2. 'ațān-ī (gave me) }\end{array}$ & 1. lessa \\
\hline
\end{tabular}

\subsection{Shifting to another dialect or MSA:}

The data shows in cases that informants use features of dialects that are not their national one. From the data it can be concluded that this use is not to facilitate communication nor for the sake of clarity. The main aim for this use seems to be to create 
a funny light atmosphere. The use of non-national dialect or MSA are marked in bold in the examples.

Ex.9. In Episode 2:

\begin{tabular}{|c|c|}
\hline *SHR: šū ha-l-malāk el-'abyaḍ! & *SHR: What a white angel! \\
\hline gamila gedan, šakl-ek helw gidan we 'inšallah & So beautiful, your look is very nice! God's willing, HE will \\
\hline rabena yuwafa-'ik, lākin miš ha-ywafa' șāber & grant you success, but HE wont grant Saber success. \\
\hline & *SBR: (laughing) This is far from you! \\
\hline *SBR: (laughing) dah bo'd-ek! & *NNC: God will grant Saber success because I am with \\
\hline *NNC: rabena ha-ywafa' șāber li-'an-nī ma'- & him. \\
\hline$a h$ & *SBR: (laughing) This is far from you! \\
\hline *SBR: (laughing) dah bo'd-ek, dah bo'd-ek & This is far from you! \\
\hline $\begin{array}{l}\text { *ASI: șāber bad-ak šñ? (running after } \\
\text { Nancy) }\end{array}$ & $\begin{array}{l}\text { *ASI: Saber, do you want something? (running after } \\
\text { Nancy) }\end{array}$ \\
\hline 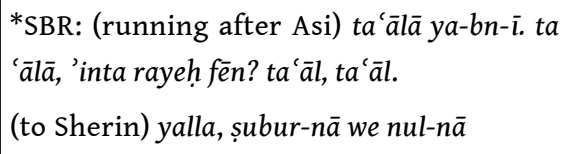 & $\begin{array}{l}\text { *SBR: (running after Asi) Come, my boy, come! Where } \\
\text { are you going? Come! Come! (to Sherin) We were } \\
\text { rewarded for our patience! }\end{array}$ \\
\hline *SHR: șehete-en 'a 'alb-ak & *SHR: You have it with double health on your heart! \\
\hline
\end{tabular}

In this example, there are features from different dialects. Sherin says 'šū ha-l-malāk el-' abyad" using Lebanese features with an Egyptian accent to praise Lebanese Nancy on her outlook. Then she continues the rest of her utterance with Egyptian features. Second, Saber responds to Sherin's teasing using Egyptian idiomatic expression "dah bo'd-ek". Saber keeps using Egyptian features even when he talks to Lebanese Asi who is chasing beautiful Nancy outside the stage, saying: "ta' āla ya-bn-i. ta'ālā," and "inta rayeh fēen?"

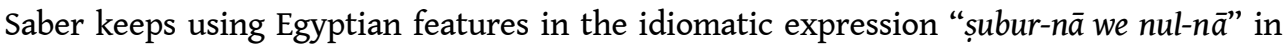
order to tease Sherin. Interestingly, Sherin replies to him using a Shami idiomatic expression pronounced in Egyptian accent "șehet-ên ' $a$ 'alb-ak".

In this example, shifting to Lebanese features on Sherin' part is one of her ways to be funny; either with the Lebanese constant or the Tunisian colleague. Likewise, Saber's one of the ways to be funny is to use Egyptian features, either with Egyptian Sherin or Lebanese Asi. An important thing to note is that idiomatic non-national features are used, not just common everyday language lexis. These are idiomatic expressions to praise, to challenge, to wonder about an action, to praise one's own achievement, and to wish a good health after a meal respectively.

Ex.10. In Episode 2, Asi to Kazim

\begin{tabular}{|l|l|}
\hline *ASI: $h$-'aw'ed-ak bi-munāfasẻ țahnẻe & *ASI: I promise you a fierce competition \\
wa sa-'urìk-a 'ayu-hā al-qayṣar & And I will show you, Ceaser! \\
*KDM: (laughing) na'am, na'am & *KDM: yes, yes \\
*ASI: man huwa al-hilānī & *ASI: Who is the Hilaanii. \\
\hline
\end{tabular}

Although, Asi starts using Lebanese features, his following utterances are in MSA "wa sa'urik-a 'ayu-hā al-qayșar" where the future aspect marker "s-", the verb pattern and 
morphology "sa' sa-'urik-a", the calling particle "'ayu-hä" and the nickname of Kazim in the Arab world as "al-qayșar". The whole MSA features may have been triggered by this nickname, which in itself is used commonly with the MSA features "al", "/q/", and "/ai/". In addition, the use of MSA adds a funny comic touch to the challenge Asi is presenting to Kazim. It alludes to historical Arabic movies where it is a common thing among Arabs to imitate and act out in funny situations by using MSA features.

Ex.11. In Episode 9, Kareem to Saber:

\begin{tabular}{|l|l|}
\hline *KRM: 'entā 'ešnū ḥwāl-ak? & *KRM: How are you? \\
*SBR: lā bās el-ḥamdulillah & *SBR: Fine! Thanks God! \\
*KRM: lā bās? & *KRM: Fine? \\
*SBR: ca va! & *SBR: Ca va! \\
*KRM: 'ahwāl-ak merīgla? & *KRM: You are doing fine? \\
*SBR: ca va, aussi? & *SBR: Ca va, aussi? \\
*KRM: (laughing) mumkin ti'alim-nì kalām gedidd & *KRM: (laughing) You can teach me new words \\
ba'a & then. \\
\hline
\end{tabular}

In this example, the last sentence "mumkin ti' alim-nī kalām gedìd ba' $a$ " (you can teach me new words then) is in Egyptian features. It shows two things: the awareness of an intended use of the features of his interlocutor's Tunisian dialect, and that there are metalinguistic discussion and learning happening backstage. This last sentence is triggered when Saber asks Kareem in French "ca va, aussi?", which is a typical Tunisian dialect feature. He uses this feature in a funny gest to challenge Kareem's knowledge of the Tunisian dialect.

Kareem shows a repeated pattern of using features of different dialect with his interlocutors mainly asking "How are you?" This is repeated with Moroccan, Iraqi, Tunisian, and even Kurdish interlocutors. This use can be seen as a gesture from the media host to welcome the different Arab countries and dialects.

In episode 10, an important instance in the data suggests an attitude of avoidance to mention incomprehensibility. In an interview between a Moroccan contestant and a Tunisian contestant hosted by the Lebanese presenter, Nadine, the Tunisian contestant said clearly that he did not understand what the Moroccan contestant was saying. Nadine, said "we will cut on this talk" then she addressed the Moroccan saying of course we are sure of your good intentions, which implies that she did not fully understand what he was saying. This instance suggests other important strategies as discussed in the coming section.

\section{Discussion and conclusion}

This study investigates the extent Arabs use features of their national dialect and the extent they use features of their interlocutor's dialect or MSA in order to have a successful communication in a pan-Arab globalized TV setting. In line with Soliman (2015), the above analysis shows that Arabs predominantly use distinctive features of their own dialects in their cross country communication. The use of MSA features or the interlocutors' dialect features are used to add a funny tone or to be friendly and 
welcoming to the interlocutors. Use of features of the interlocutor's dialect or MSA is not mostly used in order to have a comprehensible successful communication.

What is presented in the show is basically polylingualism guiding mutual comprehensibility among and between Arabs. Despite the subtitles added by MBC to the viewers in case of Maghrebi speaking informants, informants on the show appear in no need of subtitles to achieve comprehensibility. Informants do not explicitly resort to the strategies mentioned in previous literature: no use of MSA or the interlocutor's dialect, no asking for meaning, or even the speaker acquainting their listeners with meanings. Example 11 suggests that resort to these strategies is happening backstage, but not on the screen.

The instance of episode 10 mentioned above, which comes once in this part of the data, may suggest that Arabs in this globalized show avoid expression of incomprehensibility. In this setting, Arabs are intentionally using distinctive features of their own dialect as a clear statement of their Arab belonging and identity. Asking for clarity or negotiation of meaning might have undermined the idea of pan-Arabism, and distracted everybody away from the show. The other side of the coin of this intentional choice is an equally intentional choice to use or not use features of another dialect.

Although the Maghrebi-Mashreqi ideology (Hachimi 2013) is not within the scope of this paper, but this instance beside the subtitles, draws the attention to the position of the media with regard to the attitude of incomprehensibility towards the Maghrebi Arabic mentioned above in Chakrani (2014). At the time where MBC has the practice of providing subtitles to Moroccan contestants, they cut on any explicit speech of incomprehensibility (towards Moroccans in this instance), even if this speech is coming from a Maghrebi Tunisian.

This instance as well, if seen while considering the teleprompters provided to the presenters, imply that media is actually encouraging national dialect use. Both presenters of the live shows, the Egyptian Mohammed Kareem and the Lebanese Emee Saiyah, mostly maintain their dialects while introducing the show and addressing the judges. It is a common procedure for media during live shows to provide script to be read by the presenters on teleprompters to help them remember their speech and maintain professionalism while talking. Seeing both presenters each speaking in his own dialect suggest that the teleprompter are actually written in two different dialects; the Egyptian and the Lebanese. This result may need further investigation though. However, as a preliminary result, it can be said that media in pan-Arab TV setting encourages national dialect use while avoiding expression of incomprehensibility.

It is important to note that the media, the judges, and the contestants share a common repertoire of the diverse features of all the dialects and MSA. They also have one topic of discussion: singing. This facilitates comprehension. However, strategies like classicizing, rephrasing, and negotiation of meaning is not present in the data under concern. The challenge that Saber presents to Kareem in Example 11 implies that levelling is the strategy that the informant use. From this example, it seems that Saber intentionally uses a feature of Tunisian dialect that he was not using before. The reason he chooses to use it is to challenge Kareem in his knowledge of Tunisian dialect. It seems that he wants to take Kareem to another level of the dialect. However, one instance is not enough to generalize and this result needs further analysis to be detected.

Actually the practice of Kareem, the media, to use features of his interlocutor's dialect create a feeling of embracing of all Arabs. Use of features from the interlocutor's dialect 
send the message of a warm welcome, respect, and acknowledgment of the individuality of the country of this dialect. Some even respond back by saying people in this country love Kareem when he speaks their dialect. This means this practice of Kareem is received as a message of love.

Overall in the show, linguistic differences are reduced in favor of what seems like a sense of celebration of Arabic and Arab diversity. Arabism embraces the show while informants express their Arabness through their national dialect and feeling of belonging to their Arab country. As shown in the examples of section 5.1, informants address each other using the distinctive features of their dialect, in a clear expression of their national identity. However, they avoid expression of incomprehensibility of another dialect, giving the impression that all features used in the communication belong to one repertoire of Arabic language. All these distinctive features and national differences presented in the data index a wider meaning of Arabness. The boundaries of Arabness is widening in this show. If Nydell (2012) above defines Arabs to be in an Arab country and speaks the Arabic language, in this show, Arabness is widened to embrace Arabs living in foreign countries, speak a dialect of Arabic, understand other Arabic dialects, and other practices that are to be discussed in the PhD study.

What embraces the informants is the idea of Arabness and not MSA. MSA as seen in the examples of section 5.2 still maintains a role shared by Arabs together; but this shared role is not to facilitate cross-country speaking communication in a globalized pan-Arab setting. The humor that surrounds MSA in the examples alludes to Arabism, yes. Common history, common culture, common language and the other ideas that constitute Arabism are still present, cherished I would say. Arabism seems to come as a white sphere surrounding and supporting the whole production and success of this show. But, yet, in this white sphere there are clear distinctive colors of national identities, all belong in the sphere because they express their Arabness as defined and accepted in this setting. The research and analysis are still going. More analysis will help understand how communication is taking place, and the indexicalities of the use/no-use of some features to identity and ideology.

\section{BIBLIOGRAPHY}

Abu-Melhim, A. 2014. "Intra-lingual Code Alternation in Arabic: The Conversational Impact of Diglossia", Theory and Practice in Language Studies, vol. 4, no. 5, pp. 891-902. ACADEMY PUBLISHER Manufactured in Finland, DOI: 10.4304/tpls.4.5.891-902

Albirini, A. 2016. Modern Arabic Sociolinguistics: Diglossia, variation, codeswitching, attitudes and identity. $1^{\text {st }} \mathrm{Ed}$. Routledge.

Blommaert, J. \& Backus, A. 2011. "Repertoires Revisited: 'Knowing Language' in Superdiversity”, Working Papers in Urban Language and Literacies, paper 67. At www.kcl.ac.uk/ldc. 
Chakrani, B. 2014. "Arabic Interdialectal Encounters: Investigating the Influence of Attitudes On Language Accommodation", Language \& Communication. http://dx.doi.org/10.1016/

j.langcom.2014.10.006

Hachimi, 2013. “The Maghreb-Mashreq language ideology and the politics of identity in a globalized Arab world". Journal of Sociolinguistics 17/3, 2013: 269-296.

Holes, C. 1995. Modern Arabic: Structure, Functions, and Varieties. New York: Longman Group Limited.

Jørgensen, J. 2008. "Polylingual Languaging Around and Among Children and Adolescents", International Journal of Multilingualism 5:3, 161-176, DOI: 10.1080/14790710802387562.

Jørgensen, J. et al. 2011. "Polylanguaging in Superdiversity", Language and Superdiversity. 13(2).

Morrow, J. \& Castleton, B. 2007. “The Impact of Globalization on the Arabic Language”, Intercultural Communication Studies. XVI(2). 202-212.

Nydell, M. 2012. Understanding Arabs: A Contemporary Guide to Arab Society. 5th ed. Nicholas Brealey. S'hiri, S. 2002. "Speak Arabic Please!: Tunisian Arabic Speakers' Linguistic Accommodation to Middle Easterners.", Language Contact and Language Conflict in Arabic, ed. Rouchdy, A. London/New York: Routledge-Curzon.

Soliman, R. 2015. Arabic Cross-dialectal Conversations with Implications for the Teaching of Arabic as a Second Language. University of Leeds, Leeds.

Temlali, Y. 2011. 'The Arab Spring' Rebirth or Final Throes Of Pan-Arabism? In: Layla Al-Zubaidi, ed. People's power: the Arab world in revolt. Heinrich Böll Stiftung, pp. 48-49. Available from: https://www.boell.de/sites/default/files/assets/boell.de/images/download_de/ Perspectives_02-06_Yassine_Temlali.pdf.

The Editors of Encyclopaedia Britannica. "Pan-Arabism (Ideology)". Encyclopaedia Britannica Online (https://www.britannica.com). Retrieved: March 26th, 2018.

Versteegh, C. H. M \& Eid, M. 2006. Encyclopedia of Arabic Language and Linguistics. Leiden: Brill Publishing.

Versteegh, C. H. M. 1997. The Arabic Language. Columbia University Press.

Vivarelli, N. 2014. “Talent Shows Give Voice to Pan-Arabic Youth”. Retrieved: 9 March, 2015, from: http://variety.com/2014/tv/news/mbc-talent-shows-give-voice-to-pan-arabicyouth-1201162373/.

Vivarelli, N. 2014. “The Voice Arabia' Crowns Iraqi Singer Sattar Saad”. Retrieved: 30 March, 2014 | 06:08AM PT. from: https://variety.com/2014/tv/news/1201150095-1201150095/.

\section{NOTES}

1. In the PhD study, a detailed description of the distinctive linguistic features of the varieties in the data is compiled from Versteegh (1997), Holes (1995), and Encyclopedia of Arabic language and linguistics (2006).

2. Transliteration system used: ISO 233-2, 1993 provided by AIDA. I added symbol $\tilde{a}$ for the emphatic long vowel, symbol ả for the high rise imala, symbol $e$ for the low imala, and symbol $e$ for $/$ ə/. 


\section{ABSTRACTS}

This paper presents the preliminary results of a PhD dissertation that investigates the linguistic features accessible to and employed by Arabs in their cross-country communication in a panArab globalized TV setting, relating the indexicalities of these features to identity and ideology. The framework that guides the study is polylingualism in superdiverse communities. The scope of this paper focuses on the use of features of national dialects, the interlocutors' dialects, and Modern Standard Arabic (MSA). The results show that Arabs dominantly use distinctive features of their national dialects. Using features from MSA or the interlocutor's dialect, in most cases, is not to ensure clarity of communication. The use of these features serves functions such as creating a funny atmosphere and embracing everybody into the big sphere of Arabism and Arabness within. Results also show that in a globalized TV setting, Arabs tend to avoid getting into circumstances of incomprehensibility and project a sense of celebration of their superdiversity within an Arab world that is perceived as one.

\section{INDEX}

Keywords: Pan-Arabism, Arabness, inter-dialectal communication, Arabic varieties, superdiversity, polylingualism, identity

\section{AUTHOR}

\section{MONA FARRAG ATTWA}

Department of Culture Studies, Tilburg University. https://www.colorado.edu/alc/mona-attwa 


\title{
Standard Arabic and Moroccan
}

\section{Arabic in the Royal Academy of Morocco Latest Publications (2010-2013)}

\author{
Laura Gago Gómez
}

\section{EDITOR'S NOTE}

The references to Arabic authors in the text sometimes appear in the order 'Author + year + page', and sometimes 'Year + Page + Author', this variation is due to the constraints of the software.

Les références aux auteurs arabes dans le texte apparaissent parfois dans l'ordre 'Auteur +année+page', et parfois 'Année+Page+Auteur' cette variation est due aux contraintes de la mise en ligne.

\section{Introduction: the sociolinguistic situation in Morocco and the role of the Royal Academy}

Morocco, as a multilingual country, has adopted different measures and political decisions to handle multilingualism since its independence in 1956, running from monolingual policies to multilingual tolerance and, since the 2011 Constitutional reform, through official bilingualism, Arabic and Tamazight. The acceptance by the people of the 2011 Constitution initiates, officially, a new paradigm in the linguistic policy and, somehow, puts an end to a linguistic policy based exclusively on Arabicization. While the early stages of this policy were characterized by a neglect of the other linguistic varieties in the official discourse (Tamazight, Dāriğa, Hassāniyya), the stance on French has continued to swing throughout the decades (Benítez 2010; Benítez, de Ruiter \& Tamer 2010). 
2 Before the acceptance of the 2011 Constitution, Morocco's sociolinguistic situation has seen a number of important changes in recent years (Ziamari \& de Ruiter 2016; Miller 2014). Two of these major changes concern the steady introduction of Tamazight in public areas and the spread of Moroccan Arabic (MA), which has grown astonishingly since 2000.

3 The use of MA has spread into new settings, including formal and semi-formal domains (Benítez et al. 2013). This spread has been accompanied by a revalorization of this variety. This functional expansion of MA has been explained by social, political and economic changes, including Muhammad VI's enthronement, the decline of pan-Arabism ideology and neoliberal measures (Miller 2014; Benítez et al. 2013; Ziamari \& de Ruiter 2016). So far, a lot of recent attention has been dedicated to this development and to the debate around MA, with its supporters advocating for its standardization and, even, officialization. Indeed, the overwhelming use of Dāriğa in domains previously reserved exclusively for SA caused certain voices to raise against this vulgarisation (Miller 2012). While the claims and arguments of the 'Dāriğa advocates' have been thoroughly studied, less attention has been given to the opponents to this variety, who prefer and defend SA. In fact, 'Standard Arabic advocates' formulate many of the arguments against Dāriğa, considering it a mere dialect stigmatized for its 'impure' nature and linguistic 'incompleteness'.

4 SA advocates harbour a conservative vision, which pursues the pan-Arabic postcolonial discourse on SA perceived as representing the sense of authenticity and national identity, which were allegedly stolen by colonialism. Arguments are based on a monolingual ideology that, in its turn, is based on the enhancement of values associated with the standard variety: its religious nature, its historic, literary and scientific heritage, the supremacy of this variety, the national Arab-Islamic identity, and so on (see Høigilt and Mejdell 2017). At the same time, they criticize the promotion of Dāriğa as being intentionally anti-SA: for them, the movement represents a vulgarization of the public sphere designed to disrupt national identity and the very foundations of the State itself (الودغيري 2010 ; العربي المساري ).

5 For the Royal Academy of Morocco the spread of Dāriğa has not gone unnoticed. This institution, founded in 1977 by a dahir signed by King Hassan II, functions as an Academy of Sciences, meaning its work is not restricted to linguistic issues alone (unlike the Académie de la langue française). The Royal Academy is an intellectual forum which aims to encourage research in different intellectual areas and bring together some of the leading thinkers from inside and outside the Kingdom. In contrast with Institut d'Études et des Recherches pour l'Arabisation (IERA) is not attached to any other institution. Nevertheless, it does not mean it is an ideologically independent organization. As patron of the Royal Academy, the King appoints the institution's permanent secretary.

6 Even though its purpose is not restricted to linguistic issues, the Academy has shown a great concern for the latest sociolinguistic developments. Since 2000, it has organized several conferences and has published several reports devoted specifically to linguistic issues. In the period between 2005 and 2010, the Academy has published these proceedings: 


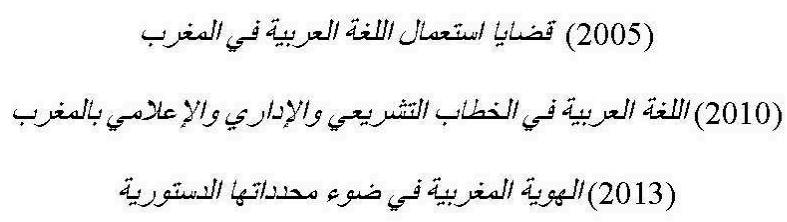

7 Being an active partner in the sociolinguistic debate in Morocco, the viewpoint of the Academy needs to be taken into account. It is of great relevance to dissect the arguments that help build and support its stance. This paper analyzes the texts published by this institution before and after the acceptation of the 2011 Constitution (2010 and 2013 proceedings). This enables us to understand better the sociolinguistic debate in Morocco and to offer a general, comprehensive picture of the different discourses running on the public arena and the impact of the new constitutional frame.

8 Although the Academy does not take responsibility for any of the views or opinions expressed by individual members, there is indeed a common theme and shared perceptions running through the various ideas and points of view. It is important to note that all authors in these publications belong to a specific social stratum: they are highly educated, many of them work in the intellectual or academic milieu, they share a close relationship with the Palace and some of them have important roles in the political field ${ }^{1}$. Therefore, taking into account the relevance, functions and active role of the Academy, my paper tries to provide an answer to the following questions:

9 1. How does the Academy depict MA and SA through its publications during this important period?

2. Has the stance of the Academy evolved during these years or because of the acceptance of the 2011 Constitution?

3. Does this portray imply a new or a different stance on the part of the Academics?

10 In order to appropriately answer these questions and as a first attempt to dissect the viewpoint of this institution, this paper adopts the following structure. Section (2) tackles the stance of the Academy's authors on multilingualism in the 2010 and 2013 Proceedings. This is followed by the depiction of SA (3) and MA (4) by authors in the 2010 and 2013 publications. The closing section (5) presents the conclusions.

\section{Multilingualism: an overview}

11 In both the 2010 and 2013 Proceedings, there is a recognition of multilingualism, but with important nuances. In 2010, multilingualism is depicted in two non-opposing ways:

12 First, it is portrayed as a reality of the Moroccan context. Researchers use to express their appreciation for the benefits of multilingualism, but as long as it does not hinder the role of the official language, i.e., SA. They describe the Moroccan multilingualism as being unbalanced in favour of French or MA. The limited space allocated to SA, especially in the Media, the Economy and the Administration leads to the 'linguistic subjugation' of the Moroccan citizen:

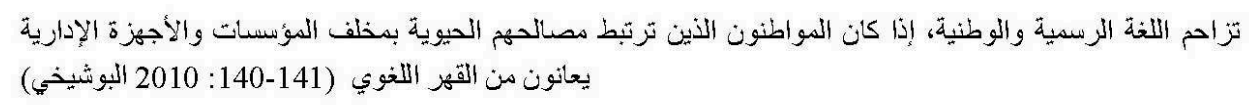


all proposals provided by authors in this publication aim at redressing the functions allocated to every linguistic variety (specially, French and SA). In particular, authors in these proceedings seek to give SA the place it deserves as the only official language by limiting the use of all other varieties:

$$
\begin{aligned}
& \text { فان من مهام التخطيط اللغوي أن يدبر هذا التهدد راعيا التوازنات اللغوية، وذلك بإعطاء اللغة العربية المكانة التي ينبخي }
\end{aligned}
$$

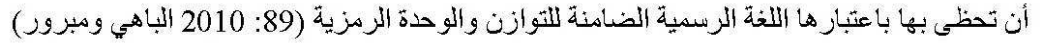

14

The second way in which multilingualism is described is in connection to ideology. More specifically, multilingualism is seen as a foreign ideology or an ideological tool whose aim is to replace SA and other 'minor' languages. Thus, multilingualism is seen as a facilitator of the crumbling of social cohesion and national unity (see for ex., $260: 2010$ وكاگ). In this sense, multilingualism is related to globalization and other 'international' policies, like francophonie and hispanophonie. All these foreign agenda are dangerous for the country, as they seek to impose their domination over other nations (ibid.). SA is then a victim in the struggle between French and English for the world's domination

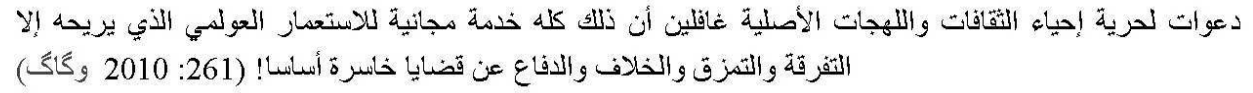

In any case, multilingualism is not a central point in 2010: the all perspective is drawn upon the continuation and the implementation of the Arabicization policy. The multilingual situation is seen as the result of a failed policy. A common trend is to call for a final, decisive policy that ends the overuse of French, because it is, in their viewpoint, a matter of coherence and compliance with the Constitution (for ex. الباهي ومبرور 2010:112)

In contrast with this situation, multilingualism is, in 2013, an official fact and a reality. Therefore, it becomes a central issue. Thus, while in 2010 , there was no need to justify the focus on SA; this stand is no longer valid in the 2013 official multilingual context. In fact, most of the ideas and arguments turn around the defense of the supremacy of SA in a multilingual setting ${ }^{2}$.

17 Therefore, while in 2010 the official status of SA was a very strong argument, in 2013 the defense of the supremacy of this variety in Moroccan society has to find different basis and arguments, as it will be shown below.

\section{Standard Arabic before and after the 2011 Constitution}

18 In the 2010 Proceedings, SA is the main axis around which all the content turns around. This variety is described as being under attack, abandoned, mistreated, threatened and suffering belittlement:

لذلك سينالها الكثيرُ من الإهمال والإفساد والاشاءة والتهميش (240-239 :2010 الودغيري)

This is due to the aforementioned unbalanced multilingualism.

19

Moreover, SA is, according to Academics, falsely accused of petrification, cultural decline, backwardness (جمود، تخلف، تراجع حضاري); it is said to be a freezed language with a very poor lexicon closed to modernization (الودغيري 2010: 217-212, تخاري (217). 
But, according to the Proceedings' authors, all these false statements are far from the true nature of Arabic, because

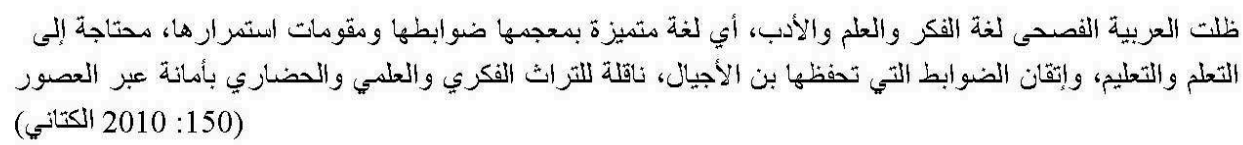

Besides its linguistic values and the cultural, scientific and historical legacy it encapsulates, SA is strongly linked to national identity and national cohesion, because it is considered the foremost bond: SA embodies the culture, the history, the civilization, the past and the future of all Moroccans. Therefore, it is an unifying factor of all the citizen

$$
\text { نرى فيها هويتنا وتاريخنا ونبض قلوبنا (2010 العبلالمي) }
$$

Consequently, Arabicization is still presented as a means to restore the lost identity as against French, because it is a matter of sovereignty:

$$
\text { وقد كان القرار بتعريب البلاد قرار سياديا (2010 (الثتازي) }
$$

The amalgam and the symbiosis between language and nation is so strong that any attack against the language (SA) is understood as an attack against the identity and sovereignty ( (150), any perversion of this variety is felt as against the linguistic identity ( (52: 2010 العبدلاوي) (159), because, according to, 2010 الكتاني

$$
\text { اللغة العربية جزء لا يتجزأ من الوجدان الاجتماعي والثقافي للشعوب والأمم }
$$

SA is the essential bond that links Moroccans, not only among themselves, but also with the rest of the Arabs and the Islamic world (228). Therefore, it is easy to understand the relevance of the protection of SA, because it is not a mere linguistic issue: it is the nation and the sovereignty that are at stake. Thus, all the suggestions and proposals advanced by authors are framed under the Arabicization policy.

24 The promotion and preference for SA not only rests on the belief in the Arabicization policy and the portrayal of the variety itself. Neither it is only justified in its description as an essential part of the national identity and the national cohesion. The foremost argument exposed in these Proceedings is based upon the contradiction between the official role and the actual use. Then, the official status is in itself a strong reason for the defense of SA:

$$
\begin{aligned}
& \text { ويرتب على إضفاء طابع الرسمية على لغة من اللخات وجوب استحمالها في إدارات الدولة ومر افقها ومصالحها وجوبا } \\
& \text { قانو نيا، ومنع مخالفة ذلك تحت طائلة المساءلة القانونية والمتابعة القضائية (133: } 2010 \text { البوشيخي). }
\end{aligned}
$$

The implications of the official status go far beyond. As a matter of fact, القاسمي: 208) states that the current situation of SA infringes upon human rights, especially, children's human rights. According to this author, the language, the religion and the values are part of the right for children's own identity. Thus, by using a different language other than the official one, the children's right to their identity is marginalized: 
ويتسائل المره: كيف تحافظ وسائل الإعلام لدينا على هُويَّة الطفل، الشخصية أو الوطنية، إذا كانت تهمّش لخته الوطنية

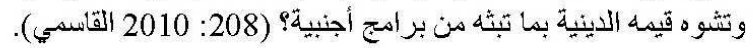

26 offer a different perspective in some aspects, but the positive portrayal of SA is kept and treasured. In other words, many of the ideas, values and features associated to SA in 2010 are also found in the 2013 Proceedings, but differently stressed and enhanced.

As in the 2010 Proceedings, the official status of SA is frequently mentioned in connection to its struggles to fulfill this role, which is always at stake due to the threats posed against it. Again, one such threat comes from the policies of the francophonie policies and the presence of the French in Morocco, but also the spread of Dāriğa. This is perceived and presented in warlike terms: Arabic suffers from

$$
\text { . 217). } 2010 \text { الودغيري) هجمات وحملات ومسخ وتشويه وتهميش وتهجين. }
$$

Once more, this variety receives the highest consideration: its high linguistic qualities and the heritage it carries are praised. Nevertheless, in contrast with 2010 Proceedings, the religious dimension of SA is enhanced more frequently:

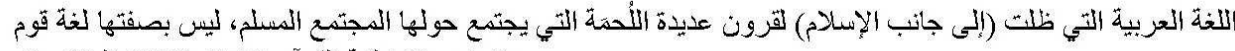

$$
\begin{aligned}
& \text { و إنما بصفتها لغة القر آن (375: } 2013 \text { المكاو يلمي). }
\end{aligned}
$$

Both the portrayal of its linguistic qualities and its religious aspect are key to understand the underliying rationale in a context of official multilingualism:

First, in a context in which political decisions concerning the languages are yet to be taken, the description of the varieties becomes very relevant, since it is the basis upon which the type of multilingualism is to be build. In 2013 the organical laws on the implementation of the official role of Tamazight were not yet drafted, meaning the specific measures of the linguistic policy are yet to be decided. In other words, because Tamazight is an official language alongside Arabic, it is no longer a matter of implementing a policy already initiated (Arabicization); it is no longer a matter of compliance with the Constitution: it is a matter of building a new policy. Thus, in contrast with 2010, the portrayal of SA adopts a comparative perspective as against all the other varieties of the country (Gago, forthcoming).

31 As of the religious dimension, the link of SA with Islam becomes highly relevant, since its unifying role is derived from its relation to the holy revelation, as the previous quote from (المدوغيري 2013: clearly shows (see also, among others, المكاوي (2013: 169 ). SA becomes a shared good among all Muslims and all Moroccans. And this consideration as a shared language lends it a degree of neutrality, because it belongs to all citizens and it is not attached to a specific ethnic nor political group. Therefore, it is a neutral language as far as politics is concerned:

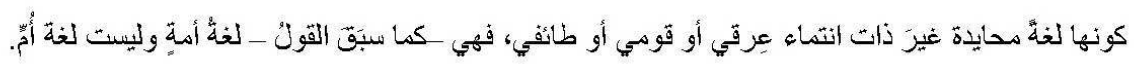

32 This perspective contrasts with the 2010 Proceedings. In both publications (2010 and 2013), SA is the unifying bond, but the arguments and the rationale that support this claim are different. In the 2010 Proceedings, the official status, the cultural legacy, the history and, above all, the nationalist ideology back this consideration of SA as the 
'unifying bond'. Nevertheless, in 2013 this role of SA derives, above all, from its relation with Islam, which is, in turn, a shared religion by almost all Moroccans. Moreover, the political arguments and associations related to SA are almost thoroughly erased in 2013 Proceedings, in contrast with the 2010 publication.

\section{MA before and after the 2011 Constitution}

MA is portrayed, in both 2010 and 2013 proceedings, as lahğa. Many of the characteristics typically associated to lahğăt are found here: first, it is local, diversified, fragmented; second, it is a simplified variety, poor in lexicon, with no rules and limited to 'basic' functions because it is unable to convey complex ideas and thoughts; and third, it has undesirable features. The following excerpts illustrate these statements:

MA as a local and fragmented variety:

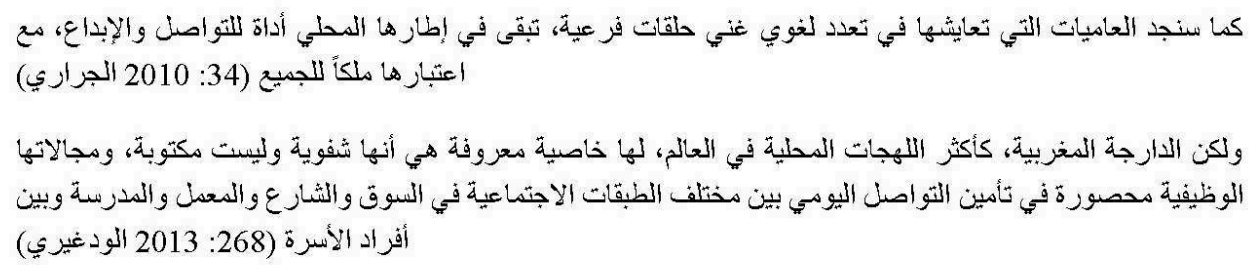

MA as a simplified variety:

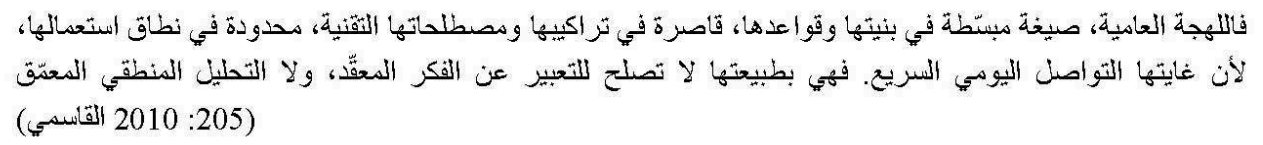

MA and its undesirable features:

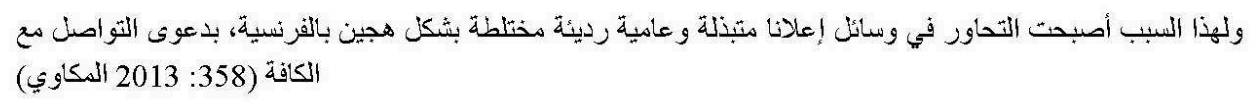

But above all, the portrayal of this variety is frequently accompanied by words of 'warning', because Dāriğa represents a danger in many ways:

First, it contributes to the social worsening and decline of the education:

$$
\text { وإذا كان الإشهار يستخدم اللهجة الدارجة، فإنّ له تأثيرات سلبية شديدة عل لغة الأطفال (199: } 2010 \text { القاسمي) }
$$

Second, and most important, it is a dividing factor. It is a colonial tool whose aim is to break the national cohesion:

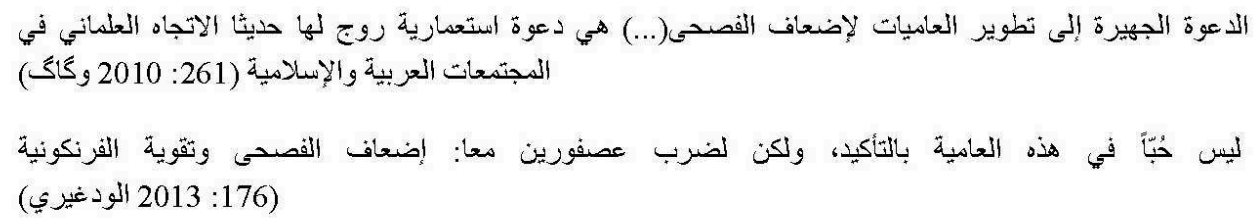


In this sense, the promotion of MA is put into relation with the 'multilingualism ideology' explained above. In any case, the portrayal of MA remains essentially unchanged. The main difference between 2010 and 2013 Proceedings does not concern the depiction in itself, but the degree of attention payed to this variety. In 2010, in the course of the heated debate around MA, its astonishing spread was the main concern. In 2013, the Academy shifts its attention to Tamazight, the new official language who might threat the privileged status of SA.

\section{Conclusions}

Coming back to the three research questions exposed in the introduction of this paper, the above analysis enables the following statements.

Concerning eventual changes affecting the depiction of MA and SA, the analysis has shown that, despite the important changes at the levels of the legal frame and the social context, the portrayal of these varieties has not evolved regarding on the essential. Thus, in relation to the second and third questions (on the impact of the 2011 Constitution), we confirm that the stance of the Academy stays the same, but the arguments to build its position have evolved towards a more religious-like approach and, at the same time, Academics downgrade or even erase any political asssociation of SA.

\section{BIBLIOGRAPHY}

Benítez, Montserrat. 2010. La política lingüística contemporánea de Marruecos: de la arabización a la aceptación del multilingüismo. Zaragoza: Instituto de Estudios Islámicos y del Oriente Próximo.

Benítez, Montserrat; Ruiter, Jan Jaap de, \& Tamer, Youssif. 2010 Le développement du plurilinguisme: le cas de la ville d'Agadir. Paris: L'Harmattan

Benítez, M., Miller C., Ruiter, J.J. de, \& Tamer, Y. 2013. "Panorama: Évolution des pratiques et représentations langagières dans le Maroc du XXIème siècle". In Benítez, M. et al. (dirs.). Évolution des pratiques et représentations langagières dans le Maroc du XXIe siècle. Paris: L'Harmattan. I, 14-59.

Gago, Laura (forthcoming). "The stance of the Royal Academy of Morocco towards the sociolinguistic context of the country following the 2011 Constitution”, Sociolinguistic Studies.

Høigilt, Jacob \& Mejdell, Gunvor 2017. Introduction. In Høigilt, J. and G. Mejdell (eds.). The Politics of Written Language in the Arab World. Writing Change. Leiden/Boston: Brill. 1-17.

Miller, C. 2012. Mexicans speaking in dârija: Media, Urbanization and Language Changes in Morocco. In Bassiouney, R. and Graham Katz, E. (eds.) Arabic Language and Linguistics. Washington: Georgetown University Press. 169-188.

Miller, C. 2014. Évolution des pratiques, évolutions des représentations ? Petit retour sur le débat autour de la valorisation de la darija au Maroc. Retrieved on 11 March 2014 from https://goo.gl/ Il2Ur7. 
Ziamari, K. and Ruiter, J. J. de. 2016. Les langues au Maroc: réalités, changements et évolutions. In Dupret, B. \& Rhani, Z. \& Boutaleb, A. \& Ferrié, J.-N. (eds.). Le Maroc au présent d'une époque à l'autre, une société en mutation. Casablanca: Fondation du Roi Abdul-Aziz/Rabat: Centre Jacques-Berque.

441-462.

\section{APPENDIXES}

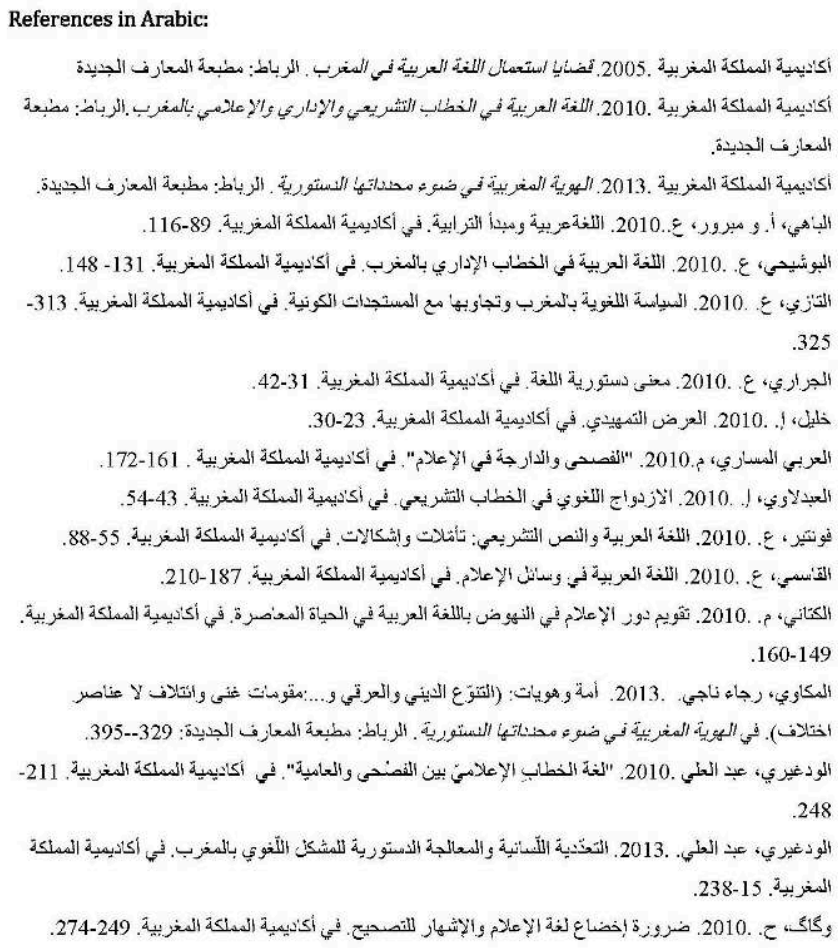

\section{NOTES}

1. Some examples, among others, may illustrate this point: Rajaa Naji Mekkaoui, the first Moroccan female Doctor of Law, was also the first woman to lecture in front of the King in the 'Hassanian Lessons'; El-Oudghiri worked as a Professor at the Universities of Fes and Mohammed $\mathrm{V}$; Abbès Jirari completed his $\mathrm{PhD}$ in Literature (El-Cairo University) and worked in the Ministry of International Relations.

2. This applies to the articles dealing with linguistic issues. As it can be deducted from the titles, the 2013 Proceedings tackle a more general, multidimensional topic (the Moroccan identity), in contrast to the 2010 Proceedings where the theme is the Arabic language itself. 


\section{ABSTRACTS}

The stance of the Royal Academy of Morocco, an active partner in the sociolinguistic debate in Morocco, is analyzed through the texts published in 2010 and 2013 (before and after the acceptance of the 2011 Constitution). The purpose of this paper is to portray Academy's stance regarding Moroccan Arabic (MA) and Standard Arabic (SA) along this period in order to elucidate possible changes in the Academy's discourse.

INDEX

Keywords: Standard Arabic, Moroccan Arabic-Dāriğa, official language, multilingualism, linguistic policy

\section{AUTHOR}

\section{LAURA GAGO GÓMEZ}

Universidad de Salamanca, Facultad de Filología. Plaza de Anaya, s/n. 37008. Salamanca (Spain). lgago@usal.es 


\title{
Amin SO9RAT: a Moroccan Rapper from the North-Eastern Region
}

\author{
Jairo Guerrero
}

\section{Introduction}

1 This paper aims at providing some data on the main features shown by the Arabic dialects spoken in North-eastern Morocco. Furthermore, it seeks to explore how regional identity helps preserve the local dialect. Our study is mainly based on the linguistic analysis of a corpus of rap songs composed by Amin So9rat, a Moroccan artist from Berkane, a northeastern Moroccan city standing out for its singular location in a border context. This thriving agricultural centre lies just $23 \mathrm{~km}$ from Algeria and $97 \mathrm{~km}$ from the Spanish enclave of Melilla. Furthermore, Berkane is located within the eastern confines of the Tarifit-speaking area $^{1}$. In Morocco, the town is renowned for its oranges and for the jokes about its people who are always featured as fools's

2 We are fully aware of the risk involved in using musical material as linguistic evidence for the description of dialects. Thus, the features found in song lyrics may not necessarily correspond to those of the singer's dialect. Nevertheless, we have good grounds for believing that the dialect of So9rat's songs contains typical Eastern Moroccan features. This assumption is supported by the fact that many of the traits to be found in So9rat's songs fit well with what we know thus far of north-eastern Moroccan Arabic. Moreover, the artist himself states he chose to sing in what he calls l-lahža š-šarquyyya 'the Eastern dialect'.

\section{The rap singer Amin So9rat}

After the emergence of the so-called Arab spring in 2011, new rappers arrived on the scene with protest songs against their political leaders. So9rat, though, is not one of those newly-arrived rappers, as he allegedly started singing rap in 1996, in the city of Melilla, where he lived for a few months at a shelter for unaccompanied minors: 


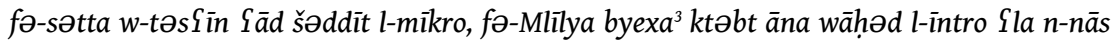

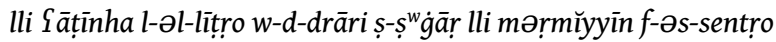

Adracadabra (2013)

'it was in 1996 that I first held a microphone, in Melilla's old city I wrote an intro about the people who drank 1-liter beer bottles and the kids that were sprawled in the shelter'.

4 Although his songs are by no means as explicitly critical of the system as those of other Moroccan rappers such as Mouad El Haked or Madi, they have acquired a clearer political colour since the Arab spring. I could not find much information on So9rat's life and background. Named Amin, he uses three main stage names: Soqrāt 'Socrates', Imbrațor 'Emperor', and l-məskūn 'the possessed one'. He was born in the city of Berkane where he has lived most of his life. Besides a short stay in the Spanish enclave of Melilla, he also spent some time in southeastern Spain in 2003:

fə-Almerya kŭnt nəddābəz gìr b-əl-bŭnya, fə-doșmïltreș dxŭlt āna Sla Mursya, Țorre Pačeko, kartaxena Səndi stūrya, fə-Ṭorrebyexa kānt Səndi n-nobya, l-găwrĭyya rəgdət $m \complement \bar{a} y a$ f-əz-zūbya, f-əl-bərd w-țlă lina lāžūbya, tlāqa șoșyo mS a la-propya, wəllìt propr

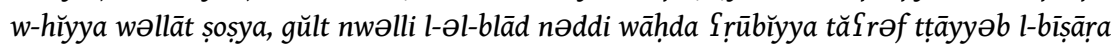
w-l-lübya.

Adracadabra (2013)

'In Almeria I used to fight with my fists, in 2003 I got to Murcia, Torre Pacheco and Cartagena. I have stories to tell from the time I was there. (When I was) in Torrevieja I had a girlfriend, the Christian girl slept with me in a dump, it was cold and we got caught in the rain. A "dirty boy" met a "clean girl", but I became clean and she became dirty, so I said to go to my country and marry a bumpkin girl who knows how to cook dried fava bean soup and beans'.

5 It was probably during this period that he learnt some Spanish, a language which he often uses in his songs.

6 If we believe what he says in his lyrics, he must be nearly 31 years old as he was aged 10 when he arrived in Melilla in 1996:

w-āna mūl §ăšrra snīn $\uparrow a \bar{d}$ bāqi pekenyo

'I was 10, I was still young'

Adracadabra (2013)

7 So9rat boasts about representing the Eastern Morocco region and singing with a rural accent $^{4}$ :

ma Səndī-š l-fărq la bīn hāda w la hāda, kīma nās Ahfir kīma nās tā̧ re-roggāda, kŭllna wlād š-šəra trabbina fə-lə-hdāda, kìma lə-brākna kīma l-wžāda, nəqtăৎ lsāni īla gŭlt həḍ̂ra zyāda Səndi kìma Tāwrīrt ki lă-Syūn kîf žrāada, r-ṛāp dyāli yrprezenți l-mințaqa ššarq̆yya, la hḍ̆ật Sla Bəṛkān rāni hḍ̆ărt Sla l-bāqŭyya

ma3ndich lfar9 (2012)

'To me there is no difference between this and that, between the people from Ahfir and the people from Reggada, we are all from the East, were brought up in the borders. The people from Berkane are the same as the ones from Oujda, I will cut my tongue off if I say more than I should. The people from Taourirt are the same as the ones from Laâyoune and Jerada, my rap represents the Eastern region, when I talk about Berkane I also mean the rest of the cities in the East'

rap el berkani za3za3 el mamlaka (2013)

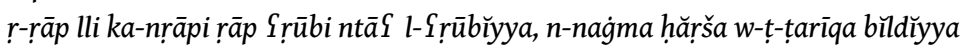

'The rap I rap is a rude rap from the countryside, the melody is harsh and the style is rural'.

Q paSa (2013) 
So9rat engages with sociopolitical topics in his lyrics. Issues dealt with range from drug abuse to political corruption. So9rat sings about substance abuse among young Moroccans, prostitution, smuggling across the Algeria-Morocco border or from Melilla into Morocco and bribery amongst other social issues. So9rat holds conservative views about women's emancipation and most of his songs contain misogynistic messages. He is also against freedom for homosexuals and usually calls into question the manhood of politicians. Manliness often appears in So9rat's songs as an attribute of old Arabs which is rarely found nowadays.

Regarding political issues, we may mention the following: linguistic policy (the spread of foreign languages such as French or Spanish at the expenses of Arabic and Berber), the political enmity between Morocco and Algeria, the Arab spring and the new Moroccan constitution.

\section{Linguistic study}

In what follows I will point out some of the significant linguistic features to be found in So9rat's songs with the goal of comparing them to what we know from north-eastern Moroccan Arabic. Currently we have interesting data on the dialects of Oujda (Elbaz 1980; Heath 2002; Benítez 2017, Behnstedt \& Benabbou 2002, Lafkioui 2013) and Ain Beni Mathar in the Jerada province (Gutova (draft paper)). Besides these, other works covering various north-eastern Moroccan localities are: Behnstedt \& Benabbou 2005, Behnstedt 2002, Heath 2002.

\subsection{Phonetic features}

\subsection{1. /q/-/g/}

11 Regarding the reflexes of OA $q \bar{a} f$, the dialect under study shows an alternation between the voiceless stop /q/ and the voiced stop /g/. However, it should be noted that Hilali /g/ is over-represented in the selected data: $y g \bar{u} l$ 'he says', gŭ $\mathrm{u} d a$ 'sitting', gəțrān 'tar', gălb 'heart', rgəd 'he slept', gŭddām 'before, in front of', yțərrrəg 'he pounds', ygəșs 'he cuts', țrig 'way, road', füg 'up, on, above's. Below one may find some of these items used in their context.

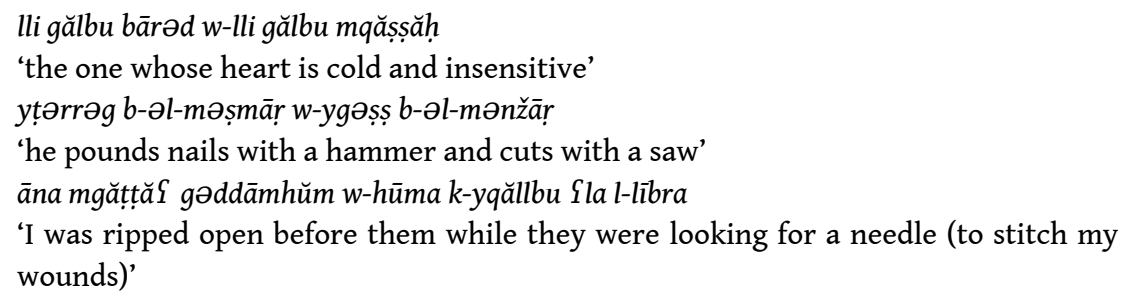

\subsubsection{Realization of $* / g ̆ /$}

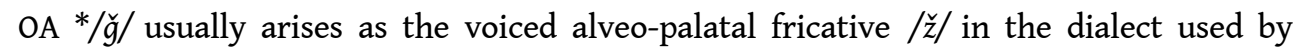

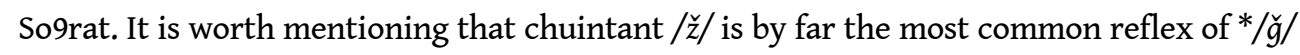
among Maghrebi Bedouin dialects. Examples from our corpus are: žbāl 'mountains', §la žāl 'because of', sǔžžāda 'prayer rug', žədd 'grandfather'. As usually occurs in Moroccan dialects, OA ğim is rendered by $/ g /$ in stems containing a following sibilant: gzāra 
'butchering', gəzzār 'butcher', məgzāra 'slaughterhouse', găbbāṣ 'plasterer', gləst 'I sat down'. According to Behnstedt \& Benabbou (2005: 24-25) this trait is found throughout North-Eastern Morocco.

Interestingly enough and as occurs in most Algerian dialects, there are no instances of right-to-left sibilant harmony. This phonetic phenomenon whereby the voiced sibilant /z/ assimilates to a subsequent / $\check{z} /$ is considered to be a distinguishing feature of the major Moroccan dialects. Thus, in So9rat's songs we find $z \bar{u} z ̌ z$ ' $t w o$ ' instead of pan-Moroccanžǔž:

ālfāyn w-wāḥəd füwwətha āna gìr sbāsa, ālfāyn w-zūž žərrrāw Ylĭyya m-əl-mədṛāsa 'I spent 2001 smoking hash pipes. (Then), in 2002 I got expelled from school'.

\subsubsection{Interdentals}

Like many dialectologists carrying out research on Moroccan Arabic, I have always claimed in my papers that interdental phonemes are nowadays absent from the phonemic inventory of Moroccan dialects. But such a statement is not true for the North-Eastern region, where some dialects still display interdental fricatives ${ }^{6}$.

Generally speaking, the preservation of old interdental fricatives is a common feature of Bedouin Arabic dialects. As pointed out above, only north-eastern varieties seem to have maintained them. In the rest of Morocco and even in Bedouin dialects, /t $/$, /d / and /d/ have merged with their occlusive counterparts. A similar fate is forecast for some NorthEastern varieties such as Oujda, a city where these phonemes have already started to fade out $^{7}$. This is also true for the dialect used by So9rat. In his songs, the only interdental fricative which shows a certain stability is the emphatic voiced dental fricative /d/, e.g.: mandar 'landscape', dăhru 'his back'. Moreover, this phoneme also occurs for the old emphatic voiced dental stop /ḍ/: mādi i 'sharp, crafty, wise', bid̄ā $a$ a 'goods', wād̄ băyda 'egg'. Concerning the two other interdental fricatives, I came across a sole example of / $/$ / and no instances of / $/ \underline{t} /:$ hādi 'this (f.)', but dənb 'fault, sin', tāni 'also', tlāta 'three'. Dialect levelling and koineisation seem to be responsible for this gradual loss of interdentals, but sociolinguistic factors may also have played a role in it as this Bedouin pronunciation is often perceived as crude by city-dwellers and therefore looked down upon.

\subsubsection{Labiovelarization}

16 Another typically Bedouin feature which has been observed in our corpus of songs is a dominant trend towards labiovelarization: ș $\underline{w}^{w} \bar{a} r$ 'small ones', $x^{w} b \bar{a} r$ 'news', šk $k^{w} \bar{a} r a$ 'bag,

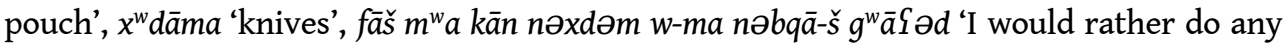
job than stay seated'. This phenomenon has also been recorded by Benítez (2017: 6) and Behnstedt \& Benabbou (2005: 20).

\section{Morphosyntactic features}

17 3.1. The passive voice is expressed by means of the prefix $n$ - and to a lesser extent $t$-:

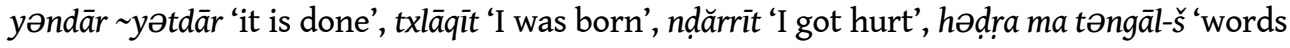
which must not be said', llāh yənโəl žədd l-moro lli yəttəšra b-əl-mārūxa 'may God curse the grandfather of the Moroccan who is bought off with a Maruja chocolate bar'. This feature is also attested in Oujda, cf. Behnstedt \& Benabbou 2005: $28^{8}$. 

nəbgïhŭm 'these are the fellow countrymen I want', s-səli a ka-tədxŭl b-əž-žəmla mən lālžeri: $z$-zìt $w$-d-dgìg $w$-l-fāriña $w$-vāškīi 'large quantities of goods are introduced (into Morocco) from Algeria: oil, flour, refined flour and The Laughing Cow cheese'. On the other hand, there are also several cases where verbs are used without any present marker, e.g.: nəstăYrəf bəlli ybəkkər ss-şŭbh 'I think highly of those who get up early in the morning', ma nəhd̆ăr-š fronșe ‘I do not speak French'. Algerian border, e.g.: kŭll ši ḡädi yfūt 'everything will pass', ġädi ngūl lək 'I am going to tell you'. This particle is morphologically the active participle of $\dot{g} d a$, yag du, a verb meaning 'to go' which is nowadays absent from the lexicon of Moroccan Arabic.

3.4. Regarding defective verb inflection, it is worth mentioning the paradigm reconstruction in the imperfective plural forms (-iw), which alternates with the $-u$ forms characteristic of Bedouin dialects: yərmiwha 'they throw it', l-gārrro də-șäka hna ma ka$n ə k m \bar{u}-s ̌$ 'we do not smoke tobacco from the government-licensed-tobacconist's shop',

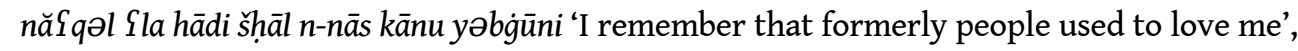
tnəssini hăža wāhda ysəmmūha la doz 'there is only one thing they call dose that makes me forget', l-wlād wāšta yəb̆gīw lə-bnāt wāšta yhăbbu? 'what do boys love and what do girls love? ${ }^{10}$.

3.5. A striking feature of many central and western Algerian dialects is the use of consonant gemination as a device to preserve short vowels when in non-final open syllable (W. Marçais 1902: 61; 1908: 76; Grand'Henry 1972: 45; Guerrero 2015: 225). This phenomenon of ressaut occurs in several north-eastern Moroccan dialects ${ }^{11}$ and in our corpus of songs as well, e.g.: yă؟Yărfu 'they know', ka-nă؟Yărfu 'we know', k-yəssəmiūni 'they hear', ma nərrrəhmūu-šs 'I will not take pity on him', təkkărhi 'you (fem.) hate', $k$ yəddŭxlu 'they enter'. As one can see in these examples, it is always the first radical of the stem that is geminated. Furthermore, this way of resolving triconsonantal clusters by gemination may also apply to nouns in construct with a V-initial possessive suffix, for instance: l-maxzən dār xəddəmtu 'the Police did their job', ṛŭkkəbti 'my knee'. Though it currently occurs in several sedentary Algerian dialects, ressaut may be regarded as a genuine Bedouin feature.

3.6. The active participle of the verb kla, yākŭl 'to eat' is kāli, which also shows up in the Algerian dialects of Oran and Saïda ${ }^{12}$. In the main core of Moroccan Arabic, this active participle is wākel.

23 3.7. The commonest genitive particles used in So9rat's songs are $n t \bar{a} Y$ and, to a lesser extent, dyāl ${ }^{13}: d$-drāri țālqīn $d$-dīsk dyāli f-əl-kärretetera 'the boys play my disc on the road', $r$ rāp ntā Si rāp ntā S s-șăhh ma-ši rāp ntā S čatarrạa 'my rap is true rap, it is not crappy rap'.

24 3.8. The $3^{\text {rd }}$ masc. sing. pronoun is $-u$ : lli šəftu lli dərtu 'what I've seen, what I've done', yzīd l-rāsu gi $d n \bar{u} b$ 'he will only accumulate sins', șāḥbu 'his friend'.

\section{Lexical features}

25 It is at the lexical level that the "Algerian" colour of the dialect under study is more remarkable. Interestingly enough, one may also observe how sometimes typically western Algerian terms alternate with Moroccan lexical items ${ }^{14}$. 

fhāl 'like'15, b-əṣ-șăhḥ b-əl-hăqq 'but', drū̄k dāba 'now', Slašān hịt 'because of, for' ${ }^{16}$; bālāk 'perhaps' ${ }^{17}, \dot{g} \partial d d a$ 'tomorrow', šəlla 'a lot of ${ }^{18}$, wāh 'yes', bārka 'enough', ġāya 'well; good'. These four adverbs are also very common in Algerian Arabic. Unlike Moroccan baraka, bārka may take a suffixed pronoun, e.g.: bārkākŭm mən nifāa w-lə-kdūb 'stop being hypocrites and telling lies'. interrogatives, it is worth noting that wā̌s is typically Algerian, while wāšta is characteristic of the Bedouin dialects spoken in a region extending from Berkane in Morocco to Algiers in Algeria ${ }^{20}$.

4.3. Algerian vocabulary: Typically western Algerian terms are: xīr 'better', füwwət 'to pass, spend', tšəffaf 'to feel sad about sth.', rgəd 'to sleep', zūbya 'rubbish dump', xwən 'to steal', gābər 'to chat up', xməž 'dirt', stənna 'to wait', ma Sla bālī-š b- 'I do not care about' ${ }^{21}$, $x \breve{u} d m i$ 'knife', tūmər 'to struggle, to have a tough time of it', gSəd 'to sit down' (alongside gləs), ḥāsi 'well', bəllăs 'to close' kāren 'a certain pie made of mashed chickpeas', săqșa 'to ask', șra 'to happen'22, șwāləḥ 'things, stuffs' ${ }^{23}$, həbbəl 'to drive crazy', g்ăši 'people'.

orthern Moroccan terms: The dialect under investigation shows a certain number of lexical items which are likely to have been borrowed from northern Moroccan varieties. An example of this is the expression šənni 〔ăndək? (together with Algerian wāš $b i k$ ?)'what is wrong with you?' which is usually rendered by $m a$ lək? in the Moroccan koiné. Another example is biba! a Spanish loanword (<viva) which is used as a formula to say "thanks" or "bravo"24. Further loanwords from Spanish have been found in So9rat's songs, a fact that may be accounted for by the proximity of Berkane from the Spanish enclave of Melilla. Besides this, it should be recalled that Berkane is not far away from the area occupied by the Spaniards during the colonial period.

4.5. French loanwords: As regards the vocabulary, another aspect worth pointing out is the presence of numerous French loanwords,e.g.: ynāvīgi 'he gets by' (<naviguer), ytrāfiki 'he traffics' (<trafiquer), bațwār 'slaughterhouse' (<abattoir), trīisiti 'electricity' (<électricité), zālāmet 'matches' (<les allumettes), yrīski 'he risks' (<risquer), dəṛwa 'law' (<droit), tbāṣa 'to suffer, to be taken to a police station' (<passer).

\section{Conclusions}

5.2. Many of these features may be regarded as typically Algerian which goes along the same line as Heath's claim (2002: 25) that Oujda Arabic is an extension of western Algerian dialects:

"The core dialect of Wj-M is an extension of western Algerian dialects, and it is a historical accident that $\mathrm{Wj}$ is separated by the border from its natural hinterland. However, in recent decades the border has been closed more often than not, and with excellent transportation connections to the major Moroccan cities to the west, $\mathrm{M}$ residents of $\mathrm{Wj}$ have become partially koiné-ized. A more thorough investigation, including some work in the villages nearby, would bring out more substantial "Algerian" 
features, but even my urban data show some cases of "ressaut" (3.7.1.) a common feature of western Algerian dialects".

5.3. On the other hand, as hinted at by Heath and as I mentioned previously, several linguistic facts suggest that the so-called Moroccan koiné is gaining ground in northeastern Morocco at the expense of local varieties:

- Loss of the voiceless dental fricative / $t /$ and the voiced dental fricative / $d /$ in some localities. The only interdental fricative which still seems to survive in most northeastern dialects is emphatic $/ \underline{d} /$.

- Alternation between prefixes $n$ - and $t$ - to express the passive voice.

- Alternation between $-i w$ and $-\mathfrak{u}$ suffixes in the imperfective plural forms of defective verbs.

- Use of both dyāl and $n t \bar{a} S$ to express possession. I think that $n t \bar{a} S$ is the original genitive particle in north-eastern Moroccan Arabic, whereas dyāl may be regarded as a borrowing from the dialects of the central urban belt.

- As far as the vocabulary is concerned, we note the alternation between western Algerian lexical items and others belonging to the lexicon of the Moroccan koiné: the occurrence of drūū 'now' alongside dāba, kiff and fhāl for 'now', b-əș-șăhḥ 'but' along with b-əl-ḥăqq, or giəd 'to sit down' together with glos.

To sum up, the Moroccan imprint on the north-eastern Moroccan varieties is becoming increasingly noticeable as a consequence of dialect levelling and koineization. Nevertheless, there seems to be evidence that the main core of the local dialects is still resisting the spread of the national koiné. Such an assumption is particularly true at the lexical level with an important number of items being shared by western Algerian dialects. The intricate relationship between regional belonging and linguistic identity might be among the reasons for this attachment to the local dialect. This is confirmed by So9rat himself who always stresses his belonging to the so-called "Eastern region" (lmințaqa š-šarqŭyya), boasts of representing it and is proud of using the "Eastern dialect" (llahža š-šarqŭyya).

\section{BIBLIOGRAPHY}

Behnstedt, Peter. 2002. "La frontera entre el bereber y el árabe en el Rif", in Estudios de Dialectología Norteafricana y Andalusí 6, 7-18.

Behnstedt, Peter \& Benabbou Mostafa. 2002. "Notes sur les parlers arabes de la région d'Oujda", in A. Youssi et al. (eds.), Aspects of the Dialects of Arabic Today - Proceedings of the $4^{\text {th }}$ Conference of AIDA, Marrakesh Apr. 1-4, 2000. Rabat: Amapatril, 7-13.

Behnstedt, Peter \& Benabbou Mostafa. 2005. “Données nouvelles sur les parlers arabes du NordEst marocain", in Zeitschrift für Arabische Linguistik 44, 17-70.

Benítez, Montserrat. 2017. "Variation linguistique dans le parler arabe d'Oujda: nord-est marocain vs. Communauté marocaine dans la diaspora", in Dialectologia 18, 1-18. 
Elbaz, S. 1980. Parler d'Oujda. Application de la théorie fonctionnelle, Phonologie, Inventaire, Syntaxe. PhD thesis, Paris: University of Paris.

Grand'Henry, Jacques. 1972. Le parler arabe de Cherchell (Algérie). Louvain-la-Neuve: Université Catholique de Louvain.

Guerrero, Jairo. 2015. "Preliminary notes on the current Arabic dialect of Oran (Western Algeria)”, in Romano-Arabica 15, 219-233.

Gutova, Evgeniya. "Settled nomads: The dialect of Ain Bni Mathar (Eastern Morocco)". Draft paper.

Heath, Jeffrey. 2002. Jewish and Muslim Dialects of Moroccan Arabic. London-New York: Routledge curzon.

Kossmann, Maarten. 2013. The Arabic Influence on Northern Berber. Leiden: Brill.

Lafkioui, Mena. 2013. "Negation, grammaticalization and language change in North Africa: the case of the negator NEG_*bu”, in G.F. Acordia, F. Da Milano, G. Iannàccaro, P. Zublena (eds.), Tilelli. Scritti in onore di Vermondo Brugnatelli. Cesena-Roma: Caissa Italia. 113-130.

Marçais, Philippe. 1977. Esquisse grammaticale de l'arabe maghrébin. Paris: Maisonneuve.

MARÇAIS, William. 1902. Le dialecte arabe parlé à Tlemcen. Grammaire, textes et glossaire. Paris: Leroux.

Marçais, William. 1908. Le dialecte arabe des Ūlād Brāhîm de Saïda (Département d'Oran). Paris: E. Bertrand.

THE OXFORD BUSINESS GROUP. 2014. The Report: Morocco 2014. Oxford: The Oxford Business Group.

White, Kenneth. 2006. Le rôdeur des confins (traduit de l'anglais par Marie-Claude White). Paris: Albin Michel.

\section{NOTES}

1. Cf. Kossmann 2013: 34 .

2. On the agricultural production of Berkane and its famous oranges, see The Oxford Business Group 2014: 230. On the jokes about the people of Berkane, see White 2006.

3. A borrowing from Spanish vieja 'old'.

4. It should be noted that the Eastern region of Morocco is often regarded as a rural area in the Moroccan collective imagination.

5. /g/ /q/ variation with prevalence of the former is also found in Oujda (Benítez 2017: 5) and Huwwāra (Behnstedt \& Benabbou 2005: 26).

6. On the preservation of the triad of interdentals in Morocco, see Heath 2002: 132.

7. Cf. Behnstedt \& Benabbou 2005: 24; Benítez 2017: 5.

8. This is also true for the neighbouring Algerian dialects of Saïda (1908: 97) and Oran (Guerrero 2015: 226).

9. Note that the absence of present markers is characteristic of western Algerian dialects, cf. Guerrero 2015: 226.

10. This variation $-\mathfrak{u} /-\bar{i} w$ has also been recorded elsewhere in north-eastern Morocco by Behnstedt \& Benabbou 2005: 28.

11. Cf. Benítez 2017: 6; Behnstedt \& Benabbou 2005: 27.

12. Cf. Guerrero 2015: 226. 
13. A similar alternation is also found in Oujda, cf. Benítez 2017: 7.

14. Apart from this, we may point out some interesting terms which seem to be characteristic of the Berkani speech: šin 'ugly' (instead of xāyəb), zìn 'beautiful, handsome' (instead of zwìn), hdầda 'borders' (instead of hudūd).

15. E.g.: hta āna kîfi kîfkŭm 'me either, I am like you'

16. E.g. bdìt f-ər-rāp nğănni ma-ši Ylašān š-šuhra 'I started singing, (but) not because of the fame',

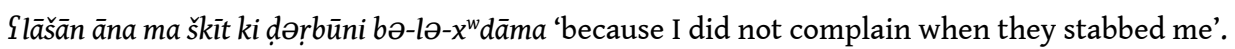

17. A Turkish loanword which is quite frequent among Algerian dialects. E.g.: bālāk hādi gīir ši

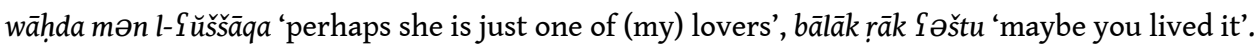

18. E.g.: šəlla mu? minin təṛu dīnhŭm 'many believers left their religion'.

19. E.g.: l-maḥd̆ăr wāšta ygūl w-f-əš-šikāya wāšta gālu 'what does the Police report say and what did

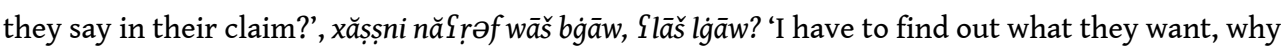
did they call (me)?'.

20. See for instance the dialect of Oujda (Benhstedt \& Benabbou 2005: 30), that of the outskirts of Tlemcen (W. Marçais 1902: 174) or the one spoken in the Algerian Tell (Ph. Marçais 1977: 201).

21. E.g.: ma Sla bālī-š b-əl-ḥukūma 'I don't care about the government'

22. E.g.: gūl li kîfāš șrāt lhŭm ḥătta šəržāâwk 'tell me how it happened that they sought you'.

23. E.g.: bă $\underline{\text { d }}$ n-nās lli ma bg்āwni-š ngūl ši șwālah gŭlthŭm '(this is a reply to) some people who do not want me to say some things I have said'.

24. E.g.: bỉba l wəld blādi, reāk Gzīz Ylŭyya bəzzāf 'bravo to my compatriot! I hold you dear'.

\section{ABSTRACTS}

Rap has become among the most cultivated musical genres in the Arab world. This is particularly true for the post-Arab spring Maghreb. As their counterparts in other countries, Moroccan rappers usually boast of representing their towns and/or regions. Given that dialect is an important element of regional identity, many of these rappers strive to sing songs in their own local accent. As regards the so-called Eastern Region of Morocco (l-mințaqa š-šarqŭyya), its most popular rapper is probably Amin So9rat, a committed youngster from the city of Berkane. The present paper aims at analyzing So9rat's songs in order to provide some data on the main features of what the rapper himself calls l-lahža š-šarqǔyya 'the Eastern Moroccan accent' and, more specifically, on the spoken Arabic of Berkane. Furthermore, we will comment on the main topics dealt with in the lyrics.

\section{INDEX}

Keywords: Rap, Morocco, North-eastern Moroccan Arabic, Berkane Arabic

\section{AUTHOR}

\section{JAIRO GUERRERO}

University of Granada jairoguerrero@ugr.es 


\title{
Exploring the Conventionalized
} Directional Greetings with 'Where?' in the Southeastern Gilit Dialects Area

\author{
Qasim Hassan
}

\section{Introduction}

In the past, the rural areas in southeastern Iraq were typified by high population density with adherence to crop production and animal husbandry. The situation is different now: Changes in social, political, and environmental frameworks have extremely altered the characters of this area. Following serious changes related to water scarcity and droughts, the acceleration of the process of increased urbanization, and the corruption-induced failure of the implementation of development projects made the southeastern rural area look completely different to how it looked in the past.

For these reasons and due to the transition from the countryside to the city, some villages and hamlets in the southeastern gilit dialects area have been virtually depopulated. As a result, rural areas are nowadays characterized by an open space dominated by endless horizons of dry and hot steppes with almost treeless farmland where most villages are only sparsely populated.

However, the scattered population in the remote southeastern rural areas is still heavily guided by tradition. The inhabitants there live in small communities with just blood relatives, close friends, and maybe some acquaintances whom they know well. Such community life is particularly important because it reinforces the feeling of intimacy and prevails the spirit of cooperation among the southeastern rural inhabitants when times are hard. In addition, people there should even, as a general rule, never hide anything from each other, a fact which can be confirmed by the further discussion of the widelyused conventionalized directional 'Where?' greetings in this gilit dialects area. 


\section{Data Corpus}

Due to a general lack of enough linguistic sources on the southeastern gilit dialects of Iraq, I had serious problems in establishing a significant theoretical data corpus during the course of this study. However, the corpus I am analyzing in the present paper has been collected from various sources. I was first of all concerned with the most recent frameworks on the issue of greeting behaviors, particularly with Duranti (1997: 21-23) and Enfield \& Comrie (2015: 267-269), among others. Duranti (1997: 21), for instance, claims that 'Where?' greetings can be used as"an attempt to sanction the reciprocal recognition of one another's presence with some specific requests of information that may or may not receive a satisfactory response."

The data I gathered on the southeastern gilit dialects confirm Duranti's conclusions, and they offer at the same time an evidence against Searl's (1976: 12) and Norrick's (1978: 279) expressive account of greetings. Information on the usage of 'Where?' greeting and its variants in the southeastern dialects area has been mainly collected by spending plenty of time in talking to selected rural inhabitants as well as in observing and paper-pencilinterviewing people in public gatherings.

\section{3. 'Where?' greetings: Features and uses}

Based on self-gathered examples, I would like to discuss in what follows some specific features and uses of the 'Where?' greetings in the southeastern gilit dialects area. It has been observed during the course of this study that directionality is the most important feature of these social greetings. That is, it is an essential condition for choosing a certain variant of 'Where?' greetings to recognize the direction of the moving party. When the greeted person is going outside the rural area, a 'Where are you going?' is then used for greeting. The following is an example. ${ }^{1}$

1)

\begin{tabular}{|l|l|}
\hline wēn & rāyị \\
\hline WHQ & go:PRS.2SG.M. \\
\hline 'Where are you going?' & \\
\hline
\end{tabular}

In contrast, when this person is seen while coming inside the rural area, a 'Where are you coming?' is then expected as a greeting.

2)

\begin{tabular}{|l|l|}
\hline 'mnēnn & ğāy \\
\hline WHQ & come:PRS.2SG.M. \\
\hline
\end{tabular}

'Where are you coming?' 
Often enough, 'Where?' greeting questions are used in conjunction with the hortative $h \bar{a}$ in a cautionary sense ( $3 a \& b)$, with an adverbial $(4 a \& b)$, or with both $(5 a \& b)$ :

3a)

\begin{tabular}{|l|l|l|}
\hline$h \bar{a}$ & wēn & rāyih \\
\hline INTR & WHQ & go:PRS.2SG.M. \\
\hline 'Where are you going?' & & \\
\hline
\end{tabular}

3b)

\begin{tabular}{|l|l|l|}
\hline$h \bar{a}$ & 'mnēn & ğ $\bar{y} y$ \\
\hline INTR & WHQ & come:PRS.2SG.M. \\
\hline 'Where are you coming?' & & \\
\hline
\end{tabular}

4a)

\begin{tabular}{|l|l|l|}
\hline wēn & rāyih & il-yūm \\
\hline WHQ & go:PRS.2SG.M. & ADV. \\
\hline 'Where are you going today?' & & \\
\hline
\end{tabular}

4b)

\begin{tabular}{|l|l|l|}
\hline 'mnēn & ğa y & il-yūm \\
\hline WHQ & come:PRS.2SG.M. & ADV. \\
\hline 'Where are you coming today?' & & \\
\hline
\end{tabular}

5a)

\begin{tabular}{|l|l|l|l|}
\hline$h \bar{a}$ & wēn & rāyih & il-yūm \\
\hline INTR & where & go:PRS.2SG.M. & ADV. \\
\hline 'INTR Where are you going today?' & & & \\
\hline
\end{tabular}

5b) 


\begin{tabular}{|l|l|l|l|}
\hline$h \bar{a}$ & 'mnēen & ğ $\bar{a} y$ & il-yūm \\
\hline INTR & WHQ & come:PRS.2SG.M. & ADV. \\
\hline 'INTR Where are you coming today?' & & & \\
\hline
\end{tabular}

It is, however, unpredictable which party will initiate the greeting when two parties pass each other on a road, so that failure in exchanging a 'Where?' greeting is highly probable. The following is an example:

A:

\begin{tabular}{|l|l|l|}
\hline$h \bar{a}$ & $w \bar{e} n$ & $r \bar{a} . . . ?$ \\
\hline INTR & WHQ & $\ldots .$. \\
\hline 'INTR Where ...?' & & \\
\hline
\end{tabular}

B:

\begin{tabular}{|l|l|l|}
\hline$h \bar{a}$ & wēn & $r \bar{a} \ldots ?$ \\
\hline INTR & WHQ & $\ldots .$. \\
\hline 'INTR Where ...?' & & \\
\hline
\end{tabular}

However, such a failure might be corrected by interrupting the greeting by, say, party (A) and repairing it by party (B) as shown in the following examples.

A:

\begin{tabular}{|l|l|l|}
\hline$h \bar{a}$ & wēn & $r \bar{a} \ldots .$. \\
\hline INTR & WHQ & $\ldots .$. \\
\hline 'INTR Where ...?' & & \\
\hline
\end{tabular}

B:

\begin{tabular}{|l|l|l|l|}
\hline$h \bar{a}$ & wēn & rāyih & il-yūm \\
\hline INTR & where & go:PRS.2SG.M. & ADV. \\
\hline 'INTR Where are you going today?' & & & \\
\hline
\end{tabular}


For reasons of simplicity, such conventionalized directional greetings can sometimes be reduced to just 'Where?' in conjunction with a haptic gesture such as hand raising or pointing in a particular direction, mostly the direction of the moving party. In addition, 'Where?' greetings are most commonly used at distance, hence they are restricted to outdoor contexts only, and they must therefore be performed loudly to bridge the spatial gap between both interlocutors. Saying these greetings loudly in public is a sign of having an open and frank life style, so that everyone in the neighborhood can clearly hear where the greeted person is going to or coming from.

\section{Responses to 'Where?' greetings}

It should first of all be noted that there are no definite, generally applicable, permanent responses to 'Where?' greetings in the southeastern dialects area. Based on this, responses to 'Where?' greetings vary according to mood and situation of the party greeted. For the most part, the initiator usually expects one of the following two responses. First, the person greeted may stop for a while to tell the other party the goal he is going to $(6 \mathrm{a} \& \mathrm{~b})$, the place he is just coming from $(7 \mathrm{a} \& \mathrm{~b})$, or the task he has to do/ done $(8 \mathrm{a} \& \mathrm{~b})$.

\section{Greeting Question (Where are you going?)}

6a)

\begin{tabular}{|l|l|l|l|}
\hline$h \bar{a}$ & wēn & rāyih & il-yūm \\
\hline INTR & WHQ & go:PRS.2SG.M. & ADV. \\
\hline 'INTR Where are you going today?' & & & \\
\hline
\end{tabular}

\section{Possible Response}

6b)

\begin{tabular}{|l|l|}
\hline rāyih & li-l-sūg \\
\hline go:PRS.2SG.M. & PREP-DET-market \\
\hline 'I am going to the market.' & \\
\hline
\end{tabular}

\section{Greeting Question (Where are you coming?)}

7a) 


\begin{tabular}{|l|l|l|l|}
\hline$h \bar{a}$ & 'mnēn & ḡa $y$ & il-yūm \\
\hline INTR & WHQ & come:PRS.2SG.M. & ADV. \\
\hline 'INTR Where are you coming today?' & & & \\
\hline
\end{tabular}

\section{Possible Response}

7 b)

\begin{tabular}{|l|l|l|}
\hline ğ $\bar{a} y$ & $\min$ & il-sūg \\
\hline come:PRS.2SG.M. & PREP & DET-market \\
\hline 'I am coming from the market?' & & \\
\hline
\end{tabular}

\section{'Where?' greeting (Telling the task)}

8a)

\begin{tabular}{|l|l|l|l|}
\hline$h \bar{a}$ & 'mnēen & $\check{g} \bar{a} y$ & il-yūm \\
\hline INTR & WHQ & come:PRS.2SG.M. & ADV. \\
\hline 'INTR Where are you coming today?' & & & \\
\hline
\end{tabular}

\section{Possible Response}

8b)

\begin{tabular}{|l|l|l|}
\hline činit & asği & il-g $\bar{a}^{\prime}$ \\
\hline be: PST.1SG. & irrigate:PRS.2SG.M. & DET-earth \\
\hline 'I was irrigating to the field.' & & \\
\hline
\end{tabular}

In contrast to the aforementioned possible responses, the second response option to these directional greetings can be uninformative and noncommittal. During the study period, recordings of people talks and face-to-face interviewing have shown that some responses to 'Where?' greetings can be insignificant and unclear. That is, when the asked party does not wish to disclose any aspects of his private life, he might be satisfied with a pointing in the direction he is going to or coming from, without saying a single word. In 
the following examples, the person greeted satisfies in answering the 'Where?' greeting in (10a \& 11a) with the demonstrative particle hič in (10b \& 11b).

10a)

\begin{tabular}{|l|l|l|l|}
\hline$h \bar{a}$ & wēn & rāyih & il-yūm \\
\hline INTR & WHQ & go:PRS.2SG.M. & ADV. \\
\hline 'INTR Where are you going today?' & & & \\
\hline
\end{tabular}

10b)

\begin{tabular}{|l|}
\hline hǐč. \\
\hline DEMO \\
\hline 'That way.' \\
\hline
\end{tabular}

11a)

\begin{tabular}{|l|l|l|l|}
\hline$h \bar{a}$ & 'mnēn & $\check{g} \bar{a} y$ & il-yūm \\
\hline INTR & WHQ & come:PRS.2SG.M. & ADV. \\
\hline 'INTR Where are you coming today?' & & & \\
\hline
\end{tabular}

11b)

\begin{tabular}{|l|}
\hline hǐč. \\
\hline DEMO \\
\hline 'That way.' \\
\hline
\end{tabular}

In addition, depending on the mental state and mood of the party greeted, responses to 'Where?' greetings might be offending, a case which may invite countermeasures. Accordingly, one might hear uninformative, aggressive responses such as the following:

12a)

\begin{tabular}{|l|l|l|l|}
\hline$h \bar{a}$ & wēn & rāyih & il-yūm \\
\hline INTR & WHQ & go:PRS.2SG.M. & ADV. \\
\hline 'INTR Where are you going today?’ & & & \\
\hline
\end{tabular}


12b)

\begin{tabular}{|l|l|}
\hline rāyih & li-l-Hara \\
\hline go:PRS.2SG.M. & PREP-DET-shit \\
\hline 'I am going to the shit.' & \\
\hline
\end{tabular}

13a)

\begin{tabular}{|l|l|l|l|}
\hline$h \bar{a}$ & 'mnēen & $\check{g} \bar{a} y$ & il-yūm \\
\hline INTR & WHQ & come:PRS.2SG.M. & ADV. \\
\hline 'INTR Where are you coming today?' & & & \\
\hline
\end{tabular}

13b)

\begin{tabular}{|l|l|l|}
\hline ğāy & $\min$ & il- Hara \\
\hline come:PRS.2SG.M. & PREP. & DET-shit \\
\hline 'I am coming from the shit.' & & \\
\hline
\end{tabular}

Such instances of uninformative, noncommittal responses are typically restricted to ordinary people of the same social class, so that it is strictly prohibited to use them when speaking to influential people such as tribal leaders, righteous or even elderly people. Doing so will be deemed abusive or insulting, and it can far too quickly turn into antipathy, which does not infrequently lead to a discontinuation of the contact between the families of the parties involved, or it might result in a fine.

\section{Possible Leave-takings for 'Where?' greetings}

After a 'Where?' greeting, the interlocutors take leave using a variety of contextdependent expressions and physical gestures such as kisses, hugs, hand raising, hand shaking and the like. With the exception of some situations like those in examples (12a \& b) and (13a \& b), one might use, among other things, the standard leave-taking formulae in examples (14a, b, c \& d) and (15a, b, c \& d).

\section{Greeting Question (Where are you going?)}

14a)

\begin{tabular}{|l|l|l|l|}
\hline$h \bar{a}$ & wèn & rāyih & il-yūm \\
\hline
\end{tabular}




\begin{tabular}{|l|l|l|l|}
\hline INTR & WHQ & go:PRS.2SG.M. & ADV. \\
\hline 'INTR Where are you going today?' & & & \\
\hline
\end{tabular}

\section{Possible Response}

14b)

\begin{tabular}{|l|l|l|}
\hline rāyih & asği & $i l-g \bar{a}^{\prime}$ \\
\hline go:PRS.1SG.M & irrigate:PRS.1SG.M. & DET-earth \\
\hline 'I am going to irrigate the field.' & & \\
\hline
\end{tabular}

\section{Possible Leave-taking expression}

14c)

\section{Greeting Question (Where are you coming?)}

15a)

\begin{tabular}{|l|l|l|l|}
\hline$h \bar{a}$ & 'mnēn & ğāy & il-yūm \\
\hline INTR & WHQ & come:PRS.2SG.M. & ADV. \\
\hline 'INTR Where are you coming today?' & & & \\
\hline
\end{tabular}

\section{Possible Response}

15b)

\begin{tabular}{|l|l|l|}
\hline činit & asği & il-gā' \\
\hline be: PST.1SG. & irrigate:PRS.2SG.M. & DET-earth \\
\hline 'I was irrigating to the field.' & & \\
\hline
\end{tabular}

\section{Possible Leave-taking expression}

15c) 


\begin{tabular}{|c|c|c|c|}
\hline $\bar{a} n \bar{l}$ & \multicolumn{2}{|l|}{ atwakal } & hassa \\
\hline $1 S G$. & \multicolumn{2}{|c|}{ go:PRS.1SG.M. } & ADV. \\
\hline \multicolumn{3}{|c|}{ 'I go now.' } & \\
\hline \multicolumn{2}{|l|}{$h \bar{a}$} & \multicolumn{2}{|l|}{$H \overline{o ̄ s}$} \\
\hline \multicolumn{2}{|l|}{ INTR } & \multicolumn{2}{|l|}{ good } \\
\hline \multicolumn{2}{|c|}{ 'INTR good.' } & & \\
\hline
\end{tabular}

Specifically mentionable is that leave-taking formulae are frequently accompanied by other pleasantries such as magdiya (all the best), biltawfiq (I wish you success), among others. Note too that 'Where?' greetings can occur in groups of more than two peoples and they are also permissible with the opposite sex, excluding body contacts such as kisses, hugs, hand-shakes and the like.

\section{Conclusion}

This paper dealt with the interesting sociopragmatic topic of 'Where?' greetings in the southeastern gilit dialects area which has so far not been discussed in cross-dialectal studies. It has been shown that 'Where?' greetings present an indispensable mean of social communication for the southern rural population to interact and to share common issues usually at distance. The paper has, moreover, discussed some most common features of 'Where?' greetings such as directionality, noncommittality, uninformativity, as well as the possible responses and Leave-takings for these greetings.

\section{BIBLIOGRAPHY}

Bach, Kent \& Robert M. Harnish. 1979. Linguistic Communication and Speech Acts. Cambridge: MIT Press.

Duranti, Alessandro. 1997. "Universal and Culture-Specific properties of Greetings", Journal of Linguistic Anthropology 7 (1): 63-97.

Enfield, Nick James \& Comrie, Bernard. 2015. Languages of Mainland Southeast Asia. Walter de Gruyter: Berlin/Boston.

Firth, Raymond. 1972. "Verbal and Bodily Rituals of Greeting and Parting", La Fontaine, J. S. (ed.), The Interpretation of Ritual: Essay in Honor of A.I. Richards. London: Tavistock. 1-38.

Gregor, Thomas. 1977. The Mehinaku: The Drama of Everyday Life in an Brazilian Village. Chicago: University of Chicago Press. 
Hoem, Ingjerd. 1993. "Space and Morality in Tokelua", Pragmatics 3:137-153.

Norrick, Neal R. 1978. Expressive illocutionary acts. Journal of Pragmatics 2 (3): 277-291.

Searle, John. 1976. A classification of illocutionary acts. Language in Society 5: 1-23.

Wehr, Hans. 1961. Dictionary of Modern Written Arabic. Wiesbaden : O. Harrassowitz.

\section{NOTES}

1. The transliteration system of Hans Wehr's Dictionary of Modern Written Arabic (1961) will be employed throughout this paper.

\section{ABSTRACTS}

Many studies have shown that in some cultures questions like 'Where are you going?' and 'Where are you coming?', or even 'Where are you?' do not necessary demonstrate that the initiator is really interested to know where the other party is actually going to, coming from, or where he is, but they are simply types of conventionalized directional greetings amongst people in some language communities (Firth 1972, Keenan 1976, Gregor 1977, Bach \& Harnish 1979, Hoem 1993, Duranti 1997, Enfield \& Comrie 2015; to name but a few). In the southeastern gilit dialects area of Iraq, however, 'Where are you?' and related greetings ('Where?' greetings, henceforth) are deeply rooted and remained strong throughout the years, although with some signs of softness due to the partly urbanization of these dialect communities, among other reasons. The aim of this study is to identify for the first time some of the key features and uses of the greeting questions in the southeastern gilit dialects area of Iraq. The data on which this study is based come from the author's daily observations of his own speech community as well as from recorded conversations with inhabitants in the remote southeastern rural areas.

\section{INDEX}

Keywords: southeastern Iraq, gilit dialects, greetings, directional greetings, Leave-taking.

\section{AUTHOR}

QASIM HASSAN

University of Basra 


\title{
Ways of Expressing Verbal Aggression in Egyptian Arabic
}

\author{
Valeriia Lakusta
}

1 Nowadays the research on aggression is being carried out in various human sciences: psychology, sociology, philosophy, cultural studies, and linguistics. As the aggression is considered to be a psychological phenomenon first of all and in linguistics, the study of aggression as verbal communication phenomenon has started recently. No one can deny the fact that obscene words exist in every language due to the need of self-expression, but in its under taboo.

2 It is quite difficult to establish a universally valid definition of offensive language. Due to the absence of clear distinctions of definitions of the notions, in my paper, I equate the notion of verbal aggression to the notion of invective. So in general an invective is a verbal demonstration of aggressive attitude to an opponent or a situation with the use words or expressions that are inappropriate to be used publicly or in an everyday normal conversation. Based on the collected data from the social media websites, four types of verbal aggression were marked out during the research: zoomorphic invectives, sexually related invectives, invectives of mental and behavioral characteristics, interjectional invectives.

3 Zoomorphic invective is a lexeme (a name of an animal), that evolved from a figurative representation of an animal, used to name a person with negative traits associated with A particular animal. This type of abuse words is presented by quite a small amount of examples in EA comparing to the other types. Due to the fact that most of the invectives were developing in a language of peasants, zoomorphic invectives are presented in most cases by domestic animals, which is confirmed by the EA too. The animal hayway by itself has an abusive shade of meaning if we say it with an aggressive tone.

The key zoomorphic invective is kelb "dog". Due to the common opinion in Islam, a dog is nağis "dirty" animal. So this word can be used as a separate way to describe a person, but in general, it's being used in complex constructions:

(1) ibn kelb "son of a dog"

(2) ya bni sittīn kilāb "son of 60 dogs"

(3) ya ahū-l-'ahba kilāb ibn kelb "brother of a slut, son of the dogs" 
Zoomorphic invectives can also describe inanimate beings:

(4) dī šerika bint kelb "bad company"

(5) mišwār ibn kelb "long way"

(6) ța'mu ibn kelb "awful food"

6 Thus the invective "dog" also refers to the thematic group "behavior" and is used to describe a dishonest man with dirty chores, or used as a part of phrase with ibn, bint lexemes for reinforcement of negative characteristics of the subject. Among other widespread zoomorphic abuse words there are:
(6) Hanzï "pig"
(7) 'ird "monkey"
(8) dub "bear" silly person
(9) ba'ra "cow" fat person
(10) tays "bull" human without morals
(11) timsāh "crocodile" nymphomaniac man
(12) labwa "lioness" nymphomaniac woman
(13) gāmūs wi lābis badla "cow wearing a suit"
(14) bağidu Hanzìr àtfūūūūh "he is a pig!"

Thus, each zoomorphic invective lexeme can be used as a non-invective word, on the other hand, a neutral word in certain contexts can be offensive.

\section{Sexually related invectives}

One of the most important features of Arab invective is a combination of sexuality, that addresses to everyday life and to the characteristics of people (Zawrotna 2014: 322). There is no doubt that sexual abuse words are the strongest in terms of emotionality. Magdalena Zawrotna has marked out three types of sexual abuse words in EA: abuse words for the description of the sexual behavior of woman; words connected with the sexual; expression kuss 'umm-ak (due to the differences in classification, I refer the last type to the class of interjectional invective).

The image of female relatives (mother and sister) is strongly implemented into Arabic swearing tradition and this phenomenon has A strong cultural background, as woman is the symbol of morality and the reputation of relatives depends on her behavior.

The most common way of insulting someone is to cast doubts on the chastity of one's family. It should be pointed out, that unlike some languages of the Islamic world, like Kazakh or Caucasian languages, where sexual abuse words are aimed at a father; EA is rich at swearwords, which include such units as "mother" and "sister. This linguistic behavior makes the first group of sexually related invectives, among them:

(15) ibn el-wisHa "son of the dirty woman"

(16) awlādu harām "kids of fornication"

(17) bint šarmūța, āhira "daughter of a whore"

11 Besides, the lexeme umm "mother" contextually has an aggressive shade of meaning, when used in expressions like (18) enta māl 'umm-ak enta "not your business" or "what is wrong with you?!".

It is important to note that the image of mother is often used in European swear culture too (English: son of a bitch; Polish: sukinsyn; French: fils de pute), but it is worth noting that the word "mother" in these expressions loses its connection to a real mother of a real person, while in Arabic speaker addresses to a mother of the opponent. 

gay.

(28) di 'ayel Hawal ibn šarmūța "he is a gay, son of a bitch" large amount of the sexual partners. Twitter (about $60 \%$ of collected tweets contained it). fucking pimp". is also abusive for a man. (Amine 213: 215).

(26) yā Sīsī yā Hawal "Sisi is such a faggot" faggot" possible to hear English variant (29) al-ğay. sex act between the speaker and the mother or sister of the opponent. Al-Asmai (740-828) wrote in his poem: girls...."

In fact, the image of the father in the Arabic swear culture is not common, so any insults regarding family relationships of any kind are aimed mostly at the woman.

The phrases (19) 'umm-ak kelba (bitch) or (20) 'umm-ak labwa (lioness) are pointing to a

One of the most abusive profanities for a man is being called a gay (in all its variations) or (21) 'ars "faggot". In fact, during my research, the last lexeme was the most frequent in

(22) ma'leš aṣl 'anda-nā zurūf b-yahkumnā 'ars "Not a problem, we are ruled by a

Expressions that show the sexual dysfunction or a small size of penis as well are considered to have a high level of offensiveness due to the fact that in terms of psychology the genitals are the symbol of the identity of a man. A comparison to a woman

(23) yalla zibb-ak ma-b-yiw'af-š “your penis does not grow up" (Zawrotna 2014: 324)

Expressions that indicate a homosexual orientation of the opponent is highly insulting. There are two main abuse lexemes for naming homosexuals in EA: (24) Hawal, (25) 'il'.

Ahmed Amine in his book "Dictionary of Egyptian traditions and customs" claims that in the Middle Ages in Egypt lexeme Hawal ("slave" in Standard Arabic) was used to name men who were wearing women's clothes and danced belly dances, therefore now in modern language this word describes a man with a female type of behavior in sex act

During this research, I've found, that most of the examples with this word are used with a meaning "faggot", which is the second appropriate translation of the word.

(27) di ibn šarmūṭa Hawal wa hāydaya anā asanādī "he is such a son of a bitch and

Another sexual invective for a man is ' $i l$ ', used for describing a heterosexual acting like a

Ahmed Amine suggests, that probably the word ' $i$ ' comes from the word 'alaq "leech" or another version that it comes from word 'ilğ "nonbeliever" (Amine 2013: 268).

Codeswitching is also common as a way to reduce the level of aggressiveness, so it's

The second group of sexual invectives is the expressions that combine a verb with the semantics of sex act that points to sexual intercourse. Usually, the expression points at

nâka in its original form has been existing in Arabic for hundreds of years, this lexeme can be found in every Classical dictionary of Arabic Fusha. Even Arabic philologist

Wa niktu al-riğala wa naktu al-nisā'... wa niktu albanāta ... "I had sex with men, women,

Gabriel Rosenbaum in his work "The use of slang and swear words in Egyptian Arabic" writes about several Egyptian authors (like Saad Alkhadem and his novel "al-Tayun") that criticizes Nasser's regime in Egypt, is loaded with coarse words (Rosenbaum 2004: 198). The following is an example taken from the novels: 
(30) 'āyyizīn kamān yanìkū fi-l-blad bibalāš "they also want to have sex for free"

(31) Nīk ar-rāgil ya miš tnīk kalām-u "fuck man, but do not fuck his words"

The example (31) is a coarse proverb that means "you should respect man's words"

The verb nāka was also used as the main refrain in the poem "Kuss ummiyat" by the famous Egyptian poet Nagib Suroor:

ya nīk ya nīk ya layl...ya nīk ya nīk ya 'ayn instead of a traditional for Arabic poetry

refrain ya layl ya layl ya 'ayn (Surroor).

Also, the verb naka is being integrated as a passive participle into the examples for expression of anger:

(32) 'yiša bint mitnāka wa šug̉l ibn mitnāka "a fucking life, a fucking job”

\section{Invectives of mental and behavioral characteristics}

The compilation of the semantic and thematic classification of invectives allows us to identify the value system and the hierarchy of human vices condemned by Egyptian society. Analysis of the semantics allows us to distinguish the following lexical-semantic groups:

1. negative features of a character (in particular, mendacity, talkativeness, stubbornness)

2. laziness

3. Stupidity

4. appearance

(33) ahțal , (34) 'abiț "fool”, (35) ğazma "shoe",

(36) тuHH-u ğazma "he is stupid as a shoe (literally: his brain is a shoe)"

(37) ya bni ğazma "son of a shoe"

(38) ya bni sittin ğazma "son of 60 shoes"

According to an article popular in the Internet, word 'abit comes from Coptic language and consists of two lexemes: $\bar{a}$ "person" and bit "donkey". But due to the absence of a scientific source, this information can not be considered as reliable.

(39) rūh umm-ak, (40) hilit umm-ak "weak-willed person"

(41) HīHa "milksop"

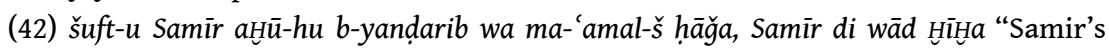

brother bits him, but he says nothing, he is a susy"

(43) lū h "heartless, insensible", literally: a piece of wood.

\section{Interjectional Invective}

Interjectional invective is the use of tabooed vocabulary to express one's attitude not to a person, but to the situation. Interjectional invectives are also called aggressive imperatives and they contain the orders to do or not to do something. Ukrainian linguist Lesia Stavytska gives the following types of aggressive imperatives that we can also implement to EA background (Stavytska 2008: 47):

1. Religion-oriented expressions where the speaker asks God to deal with the opponent:

(44) allah lā ya'ațik al-'āfìya "may Allah take your health"

(45) allah yal'an-ak "may Allah curse you"

(46) yil'an 'abū 'umm-ak "may [Allah] curse your grandfather"

(47) yā'ti-k darba fì 'alb-ek "may [Allah] give you a heart attack"

(48) yaHrab bēt-ak "may [Allah] destroy your house"

(49) ya'ta'a 'umr-ak "may [Allah] shorten your life" 
existence of this type of invectives can be explained by the fact that Arabic curses are associated with solemn, ceremonial or domestic vows. While pronouncing the invective, the speaker calls to God to witness and he asks Allah - a symbol of supreme power, to punish the opponent.

2. Orders to disappear in all its variations:

(50) imšì barra, (51) barra, (52) 'ittakil 'alā allah, (53) rūh fì sittīn 'alf dāhiyya "go to 60 thousand hells", (54) yallā barra yā ibn 'aḥba "get out of here, son of a bitch".

3. Vulgar expressions that contain (usually) sexually related verbs in imperative form.

(55) muṣ zibb-i "suck my dick"

(56) 'ilhas țiz-i "kiss my ass"

(57) kul Harā "eat shit"

(58) nayyik nafs-ak "go fuck yourself"

Speaking about the features of Arabic swear words, it is necessary to take into account the patriarchal traditions, where the male role is dominant and active, thus the swearing is more often built from the male perspective. One must admit, that the role of women is understated, and as a consequence, the image of a woman plays a big role in swearing culture.

Expression kuss umm-ak is based on the violation of a taboo of two types: on the one hand, the inviolability of the sanctity of the mother, and the other - the taboo of sexuality (Zawtotna 2014: 327).

umm is a targeted personalized expression that does not have an English equivalent and depending on the context may be translated as a verb, adjective or a noun.

(59) kuss umm aš-šugil "fucking work"

(60) kuss umm aš-šahādāt "fucking documents"

(61) yā kuss umm-ak "motherfucker"

(62) kuss umm adahk biṣrāha "shit, this is very funny"

(63) kuss umm ḥāyātì 'an kuss umm el-ğāmi'a bint el-wisHa "fuck my life and fuck

university, daughter of a prostitute"

The lexeme (64) ahhhā in Arabic slang has two different meanings: the first is equal to "shit" in English and used to express the feeling of anger, and the second is equal to "wow" and used to express the feeling of astonishment. But this word is considered by most of the people in Egyptian society as offensive, even if it expresses surprise. The etymology of this interjection is being associated with a sound of woman orgasm, that's why it is considered to be very vulgar.

(65) wa 'ay ta' lì' 'an el-wad̆' el-ḥâli bidūn aḥḥ̄ "Is there a comment on the present situation without aḥhā?"

(66) b-yatșaūru silfi ma'a alhādița yā āhī aḥhā fin damīr-kum "They are taking a selfie in front of the accident, dude, shit, where is your conscience?"

(67) yā ǧed 'ān aḥhā muš kedā habì el-'uġnìya "Wow, guys, I loved this song so much!”

\section{Conclusion}

The study of verbal aggression cannot go aside from studying the context of the use of expression and interpersonal relationships. A lot depends also on the intonation that cannot be reproduced by the text. Also, the study of this topic is complicated by the difficulty of finding an open-minded native speaker able to discuss tabooed topics. 
41 Nevertheless, there is an urgent need to study this rich layer of vocabulary, that reflects the culture. This study investigated the pragmatic categories of offensive language used on Twitter and YouTube and the expressive functions embedded in theuse of offensive language, and as a result, the research proved, that the female images plays one of the key roles in EA swearing model, as it was mentioned in earlier M. Zawtotna's paper (Zawrotna 2014: 328). As for the male-oriented swear words, it's common to blame the man for homosexual relationships and question the chastity of the women of his family.

\section{BIBLIOGRAPHY}

Amine, Ahmed. 2013. Qāmūs al-'ādāt wa at-taqālīd al-mișriyya. Cairo: Kalimat Arabia.

Rosenbaum, Gabriel. 2004. "Egyptian Arabic as a Written Language”, Jerusalem Studies in Arabic and Islam 28. 281-340.

Stavytska, Lesia. 2008. Ukrainain language without taboo. Kyiv: Krytyka.

Zawrotna, Magdalena, 2014. "Sexual, Impure, Vulgar: An Analysis of the Intimate Body-Part

Terms in Egyptian Arabic”, The Body in Language 8. 316-331.

\section{ABSTRACTS}

The paper is focused on the Phenomenon of abuse words in Egyptian dialect of Arabic (EA). Being tabooed not only in media but in everyday life, different types of obscene words are still being widely used by native speakers. A particular attention is paid to the typologization of invectives in Egyptian Arabic. This paper examines the expressive functions of offensive language. The data is based on a corpus of 114 tweets collected from the Twitter website and 98 YouTube comments from Egyptian users writing in colloquial Arabic.

In general, swearing as a language phenomenon can tell about some national traits associated with a particular nation. They can be caused by various factors, which makes it an interesting field for research.

\section{INDEX}

Keywords: verbal aggression, invective, obscene language, insult, Egyptian Arabic

\section{AUTHOR}

\section{VALERIIA LAKUSTA}

Taras Shevchenko National University of Kyiv

leralaku@gmail.com

Ukraine, Kyiv, 02090 Khorolska st, 1a, app.143 


\title{
Le Journal de la Médina. Un récent projet éditorial en arabe tunisien
}

\author{
Angela Daiana Langone et Giuliano Mion
}

\section{NOTE DE L'AUTEUR}

Ce bref travail a été conçu conjointement par les deux auteurs. Cependant, plus en détails, ADL est responsable de l'Introduction et des paragraphes 1 et $2 ; G M$ est responsable des paragraphes $3,3.1$ et 3.2.

\section{Introduction}

1 Tout au long des deux dernières décennies, et plus particulièrement à partir du début des années 2000, des expériences journalistiques en arabe dialectal ont vu le jour au Maghreb.

2 Les cas les plus significatifs sont, sans aucun doute, liés au Maroc, où certaines publications et certaines revues se sont distinguées par l'usage journalistique de l'arabe dialectal marocain. Il s'agit, en particulier, des périodiques Hbār Blād-na, al-Amal, TelQuel et Nī̌ān, auxquels on ajoutera l'expérience journalistique la plus récente de Baboubi, qui sont au centre d'une vaste littérature scientifique ayant analysé soigneusement leurs caractéristiques (voir, entre autre, Aguadé 2006 et 2012, Benítez Fernández 2012a et 2012b, Langone 2003 et 2016, Miller 2012).

Dans la littérature scientifique consacrée au phénomène de l'écriture du dialecte et à son passage à des domaines d'usage qui normalement appartiennent à la fușhā, la Tunisie n'entre qu'assez rarement. Mais le pays, qui en 2011 a connu ladite "Révolution des Jasmins » et provoqué le Printemps Arabe dans plusieurs nations arabes, a commencé, plus récemment, à s'interroger sur le statut de sa forme d'arabe dialectal. C'est ainsi que la Tunisie a, elle aussi, commencé à connaître les premiers mouvements de promotion de l'arabe dialectal. Parmi ces initiatives, il est possible d'isoler deux cas, qui apparemment 
n'ont aucune relation entre eux, mais sont certainement le symptôme qui indique, sans aucun doute, que « quelque chose bouge ».

D'un côté, il faudra rappeler la création d'une Association de sauvegarde et de promotion de l'arabe tunisien, dont le nom officiel actuel est symboliquement Derja. De l'autre, on signalera la publication du Journal de la Médina, qui fait l'objet de cette contribution, dont on proposera ici quelques observations.

\section{L'Association Derja}

5 L'association Derja œuvre à travers son réseau et ses initiatives, qui sont visibles dans le site internet nommé www.bettounsi.com, qui a pour but de promouvoir la standardisation et la normalisation de l'arabe tunisien.

6 Parmi ses objectifs, le principal vise à standardiser la derja afin de la faire reconnaître officiellement en tant que langue tunisienne par excellence. En même temps, l'association vise également à créer une bibliothèque d'ouvrages et d'écrits publiés en derja ainsi que l'élaboration d'une grammaire prescriptive et d'un dictionnaire de cette langue.

7 Le fait que les militants de l'association qualifient l'arabe dialectal tunisien de «langue tunisienne » tout court, a incité certains d'entre eux à la réflexion, comme par exemple éliminer complètement le nom Derja de la dénomination officielle de leur association afin de choisir d'autres dénominations idéologiquement plus neutres ${ }^{1}$. Mais le débat, actuellement, est en cours.

8 En plus de sa visibilité sur son site internet, l'association a inauguré officiellement ses activités auprès de la société tunisienne, lors d'une brève présentation qui a été organisée à la dernière minute, hors programme, pendant les sessions d'un colloque sur la Sicile et la Méditerranée qui se sont déroulées à l'Institut Culturel Italien de Tunis au mois de février $2017^{2}$.

Quelques jours plus tard, l'association a organisé une première conférence à Tunis qui a été suivie par un ou deux journalistes marocains de militance berbère.

Dans leur site, la dārža est transcrite dans les deux alphabets, latin et arabe, mais avec une prédilection majeure pour les caractères latins, comme le démontre cet extrait tiré justement du site :

Netkallem w nxammem tounsi...NHebb nekteb bet-tounsi, El-louga mtèci w mtès ajdèdi...

Ed-dèrja hiyya lougetna et-tounsiyya, elli täki waHadha Ela t-tèrix mtèEna. Mel amazig ou karțàj netEaddèou Ear-roumèn, w el-wendàl, lel-bizanțiyyin w el-Erab, louġetna hiyya tćakcika Hlouwwa fiha kelmèt ou qwè3ed aclha amazigi, bouniqi, làtini, talyèni, frànsàwi $w$ Earbi... Xalța tounsiyya mizyèna barća tfasser tafattoH el-Haḍ̀ra mtèEna el-hèyla.

'Ma langue est la langue de mes ancêtres.

La derja est notre langue tunisienne, c'est la seule qui parle de notre histoire. Des Berbères en passant par les Carthaginois jusqu'aux Romains, aux Vandales, aux Byzantins et aux Arabes, notre langue est un beau mélange dont les mots ont une origine berbère, punique, latine, française et arabe... Un mélange tunisien très beau qui explique l'ouverture de notre superbe civilisation'.

11 Ses militants sont actuellement en train de discuter sérieusement sur les modalités d'écriture de l'arabe tunisien à travers un débat fortement passionné.

12 Mais cette initiative n'est qu'une parmi les changements linguistiques que la Révolution des Jasmins a, d'une certaine manière, mis en œuvre. 
rappellera qu'à l'aube de la victoire du parti islamo-conservateur ou islamiste Ennahdha, des déclarations officielles affirmaient que le français devait reculer dans la société tunisienne en faveur d'un avancement de l'arabisation. Et les tons employés dans ces déclarations semblaient faire revivre les spectres d'un processus de ré-arabisation à l'algérienne. Ainsi Rached Ghannouchi, le leader d'Ennahdha a déploré en 2011, lors d'une interview à la radio Express FM, que la société tunisienne est devenue franco-arabe, en qualifiant cette situation de "pollution linguistique " ${ }^{3}$. De même, Néji Jelloul, ancien ministre de l'Education, issu du parti Nidaa Tounes, lors d'une autre interview en 2015, prône le renforcement de l'apprentissage de l'arabe classique au cours des trois premières années du cycle primaire afin de consolider l'enracinement de l'identité arabomusulmane ${ }^{4}$.

\section{Le journal sous analyse} Médina de Tunis, et jusqu'à présent, il sort à une cadence fortement irrégulière. Il se trouve dans deux points de distribution fixes, le Café El Amba sis Nahj Souq Rba' et la Librairie Espace Diwan.

Le journal est écrit en arabe dialectal et seulement quelques passages sont en anglais et en français.

Il a un format $25 \times 35$ et il est imprimé en noir et blanc. Son tirage est d'environ 4.000 exemplaires pour chaque numéro. Il compte à peu près 15 pages par numéro et il est financé par l'Institut Für Auslandsbeziehungen (IFA) de Stuttgart. Des organisations nongouvernementales locales, telles que l'Association de Sauvegarde de la Médina de Tunis (ASM), Carthagina, Al Rachidia (héritage de la musique traditionnelle tunisienne) et pour finir l'Association Aswar El Médina, ont intégré l'équipe. dans la Médina.

Curieusement, le " project manager » n'est pas un tunisien, mais il s'agit de l'architecte Raoul Cyril Humpert, formé à l'Ecole Nationale Supérieure d'Architecture de Montpellier et à l'Université de Stuttgart. En 2014, il a participé à l'échange culturel «Cross Cultural Program» de l'IFA (rattaché au Ministère des affaires étrangères allemandes) avec l'Association pour la Sauvegarde de la Médina, association fondée en 1967 par le maire de l'époque, Hassib Ben Ammar, pendant une période où la médina risquait fortement une dévalorisation socio-économique. L'Association pour la Sauvegarde de la Médina était composée d'architectes, d'historiens, de sociologues et de chercheurs qui militaient pour la préservation de cette partie historique de la ville de Tunis.

21 Et encore aujourd'hui, l'ASM continue à jouer un rôle actif dans la préservation de la Médina de Tunis. 


\section{Structure du journal}

Comme énoncé auparavant, le journal est entièrement rédigé en arabe dialectal tunisien. Apparemment aucun numéro publié jusqu'ici, ne contient des pages ou des passages en arabe littéral.

Par contre, de brefs morceaux sont rédigés en français et, quelques fois, en anglais. Il s'agit dans ces cas-là, de traductions de passages originairement écrits en arabe tunisien, comme par exemple la quatrième édition qui s'ouvre avec un très petit éditorial dont le titre est tabba'ni ‘Suis-moi - Follow me', signé par la žmā'ət žarïdət əl-madina 'l'équipe du Journal de la Médina'.

Tout d'abord, on constatera que le choix méthodologique de l'équipe consiste à écrire en alphabet arabe non vocalisé.

L'alphabet latin ne s'applique qu'à quelques titres de rubriques comme dans les cas suivants : «Les joggeurs de la Médina », « Medinapedia » ou encore « El Warcha ». Plus rarement, certains articles contiennent des éléments en alphabet latin.

Bien que la quasi totalité du journal soit rédigée en arabe et bien qu'il soit destiné à un public arabophone, on signalera que, curieusement, la section contenant la structure de la rédaction et les références administratives est complètement rédigée en français et en anglais.

27 Il y a une rubrique fixe, nommée " Doolesha ", avec un graphisme de nature anglophile plutôt que francophile qui rend l'arabe dialectal dūlāša 'promenade' (à partir du verbe dūləšydūləš ‘promener').

\subsection{Aspects graphiques et orthographiques}

28 Sur le plan général, il semble que les bases de l'orthographe de la fuṣhā soient maintenues assez fidèlement.

Ce phénomène est particulièrement évident dans le traitement de certaines prépositions, notamment في qui apparaît de façon assez stable sans affaiblissement du graphème $y \vec{a}$. Si cela est évident lorsqu'il n'est pas suivi d'un article, il l'est encore plus lorsqu'il en est suivi d'un. Ainsi, on pourra comparer l'exemple de وفي ذاكرة ناسها عمرها ما وفات w-fi dakirət nās-ha 'mur-ha ma wfāt 'et dans la mémoire impérissable des gens', avec celui de

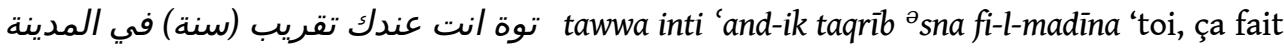
presque un an que tu es dans la Médina'.

A l'inverse, un cas de concrétion graphique systématique est représenté par le démonstratif invariable préfixe hā-, comme dans le cas de و اللي أقوى في هالحكاية w-illi aqwa fi-hā-l-hkāya 'et ce qui est l'aspect le plus fort de cette histoire'.

31 Un autre cas de concrétion graphique, un peu plus complexe que le précédent, est constitué par la locution محلاها mā-hla -ha 'qu'elle est belle !' qui montre la chute complète d'un alif de l'élément $m \bar{a}$.

Enfin, un cas intéressant d'assimilation graphique complète, fruit de l'interférence de la compétence phonologique du locuteur, est représenté par la présence systématique d'un seul nūn dans toutes les occurrences des premières personnes du verbe nažžim 'pouvoir', 
comme le démontrent les exemples qui suivent: نجموا نقولوا ${ }^{\circledR}$ nnažžmu nqūlu 'nous pouvons dire', نجم نصنع حاجة 'nnažžim nașna' ḥāža 'je peux construire un truc'.

Mais au-delà des exemples cités jusqu'ici, la lecture du journal donne l'impression que l'équipe de la rédaction a déployé de grands efforts pour normaliser l'aspect orthographique, même s'il n'est pas possible d'affirmer si cet effort est conscient ou est seulement le fruit d'une sorte d'alignement aux traditions de la fușhā. Cela pourrait bien être confirmé, si l'on pense à d'autres matériels disponibles dans la Tunisie contemporaine qui sont écrits en arabe tunisien et en alphabet arabe comme, pour ne citer que quelques exemples, les recueils de poésie populaire d'auteurs tels que Qāsim Šakrūn ou 'Abd ar-Raḥmān al-Kāfī (voir Mion 2012), ou des travaux littéraires généralement considérés comme plus cultivés, tels que les œuvres des écrivains 'Alī alDū'āğì (1909-1949) ou Bechir Khrayyef (1917-1983), ou encore l-Amir əș-şgayyər (Le Petit Prince) de Hédi Balegh (voir Mion 2007), ou pour finir les bandes dessinées.

Un coup d'œil aux pages du journal révèle que le processus d'élaboration est assez évident: pour ne citer qu'un exemple parmi les différentes possibilités, la marque principale du futur propre à l'arabe tunisien, au-delà des distinctions diatopiques, connaît des allomorphes tels que $b \bar{a} \check{s}, b ə \check{s}, m \bar{a} \check{s}, m ə \check{s}$, mais les textes présentent constamment le graphisme باش.

\subsection{Aspects linguistiques}

Malgré une extension assez limitée du territoire national tunisien, l'arabe dialectal dans son ensemble se caractérise par la présence de nombreuses variétés citadines, villageoises et bédouines.

Dans l'analyse du journal, le premier point à observer, bien même avant les aspects les plus purement dialectologiques, est le style employé de la prose.

En fait, les articles présentent un style assez essentiel, typique de la chronique journalistique, avec une certaine tendance à la parataxe, où certaines fois, on aurait la tentation de qualifier certaines solutions langagières d'arabe médian. On considérera par exemple la phrase suivante :

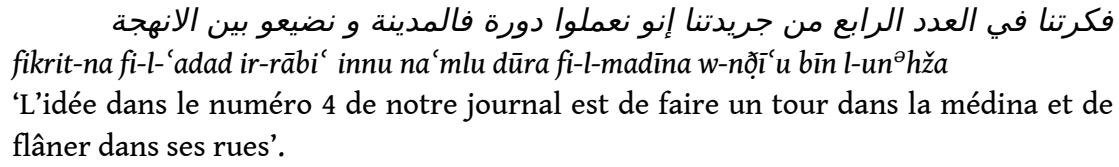

Ii nous nous limitons seulement à l'analyse de cette ligne, ce n'est que la présence d'une conjugaison maghrébine (na'mlu 'nous faisons', nợi $u$ 'nous flânons') qui permet de classifier la variété d'arabe qui a été employée comme non orientale. Par contre, ce n'est qu'un seul fait lexical (nahə̌̌ 'rue', pl. unhža) qui permet de la caractériser comme tunisienne.

Et à ce nombre très réduit d'éléments, on ajoutera que l'énoncé possède une syntaxe assez classicisante, avec l'emploi de constructions synthétiques (žarïdət-na 'notre journal' au lieu du tunisien al-žarìda $m t \bar{a} \bar{a}^{c}-n a$ ) et de coordonnants pseudo-classiques (innu 'que' au lieu de illi), proche de la forme dudit arabe médian qui, par exemple, a été décrite à propos d'autres régions arabophones comme, pour ne faire qu'un exemple maghrébin, le Maroc (Youssi 1992). 
Par contre, le style s'avère concrètement plus ancré dans la réalité linguistique tunisoise dans les interviews faites aux habitants de la Médina de Tunis, comme le révèle la présence du français dans le discours suivant :

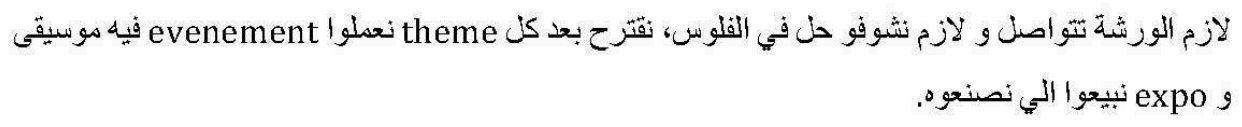

lāzim il-warša titwāṣil w-lāzim nšŭfu hall fi-l-flūs, naqtrih ba'd kull thème na'mlu événement fi-h müsíqa $w$-expo nbï u lli nașn ${ }^{\prime} \bar{u}-h$.

'Le laboratoire doit continuer et nous devons trouver une solution pour l'argent. Je propose, après chaque thème, un événement avec de la musique et une exposition où y vendre ce que nous produisons'

Du point de vue strictement dialectologique, au-delà des textes caractérisés par un style propre à l'arabe médian, le lexique employé est nettement tunisien, comme on peut le constater à partir de quelques éléments généraux comme par exemple tawwa 'maintenant', nažžim 'pouvoir', $m t \bar{a}$ ' 'de' orthographié régulièrement avec un segment $m$ initial, etc.

Si nous voulons classifier la variété d'arabe tunisien utilisée dans le journal, on n'hésitera pas à la qualifier de préhilalienne.

La prononciation du graphème $q \bar{a} f$ dépend naturellement des habitudes langagières du lecteur et d'autres faits phonétiques et phonologiques qui sont naturellement obscurés par l'écriture arabe. En revanche, la conjugaison des verbes défectueux s'avère un indicateur assez fiable pour l'identification du dialecte employé : des formes comme يجيو ou بداو, transcrites respectivement yžīw 'ils viennent' et bdāw 'ils commencèrent', attestent les segments finaux $-\bar{i} w$ et $-\bar{a} w$ qui sont rattachables à une typologie tunisienne typiquement citadine.

\section{Conclusions}

L'initiative journalistique tunisienne que ces pages viennent de présenter s'insère dans une nouvelle politique linguistique plus large, tant au niveau régional, ou tunisien, qu'au niveau suprarégional, ou maghrébin.

L'expérience du Journal de la Médina est certainement intéressante et potentiellement prometteuse mais certaines analogies avec les expériences marocaines doivent être sans doute rappelées : à l'instar de la revue tangéroise Hbār Blād-na, la revue tunisoise est à diffusion gratuite et reçoit un soutien financier étranger ; à l'instar d'autres publications marocaines, la régularité de publication de la revue tunisoise s'avère fortement discontinue.

Mais au-delà de ces considérations et de ces analogies, le Journal de la Médina reste une expérience à observer et à suivre avec soin, parce qu'il représente un petit segment de ce nouveau climat d'effervescence linguistique et métalinguistique qui caractérise la Tunisie d'après la Révolution. 


\section{BIBLIOGRAPHIE}

Aguadé, Jordi. 2006. « Writing Dialect in Morocco », Estudios de Dialectología Norteafricana y Andalusí 10. 253-274.

Aguadé, Jordi. 2012. " Monarquía, dialecto e insolencia en Marruecos: el caso de Nichane ", Meouak, Mohamed et al. (eds.), De los manoscritos medievales a internet: la presencia del árabe vernáculo en las fuentes escritas. Zaragoza : Universidad de Zaragoza. 441-464.

Benítez Fernández, Montserrat. 2012a. « al-1 Amal. Otro intento fallido de escribir en dāriža marroquí », Barontini, Alexandrine et al. (eds.), Dynamiques langagières en Arabophonie : variations, contacts, migrations et créations artistiques. Hommage offert à Dominique Caubet par ses élèves et collègues. Zaragoza : Universidad de Zaragoza. 379-391.

Benítez Fernández, Montserrat. 2012b. «TelQuel. Una fuente contemporánea para el estudio del árabe marroquí ", Meouak, Mohamed et al. (eds.), De los manoscritos medievales a internet: la presencia del árabe vernáculo en las fuentes escritas. Zaragoza : Universidad de Zaragoza. 403-417. Langone, Angela Daiana. 2003. « Hbār Blādna. Une expérience journalistique en arabe dialectal marocain », Estudios de Dialectología Norteafricana y Andalusí 7. 143-151.

Langone, Angela Daiana. 2016. «Lingua araba in vecchi e nuovi media. Riflessioni sull'interferenza dell'arabo dialettale come lingua scritta in epoca contemporanea», AION 76. $51-76$.

Miller, Catherine. 2012. «Observations concernant la présence de l'arabe marocain dans la presse marocaine arabophone des années 2009-2010», Meouak, Mohamed et al. (eds.), De los manoscritos medievales a internet: la presencia del árabe vernáculo en las fuentes escritas. Zaragoza : Universidad de Zaragoza. 419-440.

Mion, Giuliano. 2007. «La versione del Piccolo Principe in arabo tunisino», Fazzini, Elisabetta (éd.), Didattica e ricerca tra due sponde. Lanciano : Carabba. 103-126.

Mion, Giuliano. 2012. « La Zabbūbiyya de 'Abd ar-Raḥmān al-Kāfī. Un poème obscène de l'époque du Protectorat en Tunisie », Romano-Arabica 12.169-184.

Youssi Abderrahim. 1992. Grammaire de l'arabe marocain moderne. Rabat : Amapatril.

\section{NOTES}

1. Communication personnelle d'un des membres faite à GM (mois de février 2017).

2. La présentation de l'association a été confiée à un de ses membres, Mme Kawthar Ellouze, au sein du $3^{\circ}$ Convegno Internazionale di Studi Mediterranei, organisé par l'Université de La Manouba de Tunis, l'Institut Italien de Culture de Tunis, l'AISLLI, le Penn-Center for Italian Studies, qui s'est tenu du 20 au 22 février 2017.

3. Voir, par exemple, le lien https://www.tunisienumerique.com/rached-ghannouchi-notrelangue-cest-larabe/.

4. Voir, par exemple, le lien http://www.jeuneafrique.com/mag/234897/societe/arabisation-entunisie-la-guerre-des-langue-aura-t-elle-lieu/. 


\section{RÉSUMÉS}

Over the past few years the North African press exhibits some initiatives of publication of newspapers and magazines which are written in the Arabic dialects of the region. In particular, the Moroccan experiences have been largely investigated by the dialectological and the sociolinguistic literature. The present paper deals with a new editorial project which is published in Tunisia and is entitled Le Journal de la Médina, a magazine written mostly in Tunisian Arabic ( dārža). The contribution aims to present some reflections on the Tunisian post-revolutionary sociolinguistic context that led to this type of publication as well as on the language(s) used in this magazine.

INDEX

Keywords : Tunisian Arabic, Written Dialects, Journalistic Use of Colloquial Arabic

\section{AUTEURS}

\section{ANGELA DAIANA LANGONE}

Université de Cagliari/IREMAM, Aix Marseille Université, Cnrs, Aix-en-Provence, France

\section{GIULIANO MION}

Université de Chieti-Pescara 


\title{
The Spoken Omani Arabic of 'Ibrī : A "Crossing Point" in Gulf Dialects
}

\author{
Letizia Lombezzi
}

\section{Oman: Territory and Geography}

1 Oman covers a wide territory, from the Arab Gulf to the inner desert of the Arab Peninsula. The natural environment is characterized by the sea, the mountains and the desert. The sea and the desert are separated by a mountain chain that makes harder the free circulation of people and goods across the east-west axis. A second axis, the northsouth one, is characterized by the prevailing presence of the desert and sand fringes that arrive to the doors of the main cities. For this reasons, the best and safest route runs through the foothills of the Jebel Akhdar and reaches the coastal cities of Șūr and Ras elHadd. In between the mountains and the sea lays a fertile strip of land, dedicated to agriculture and cultivation. Agriculture is practiced in the inner part of the country too, by farmers of rural villages.

2 The sea and the coastal strip represent the easiest path for communication and travelling. The cities of the coast play a key-role in the fishing activities and commerce, which require to manage relations with some bedouin tribes in charge of trafficking goods to and from the desert. Another very important route for communication is the one that connects Buraymi with Masqat, and 'Ibrī is placed in the middle. Buraymi is the twin city of Al-'Ayn in the Emirates, and linguistically they share some common traits. The path from Buraymi to'Ibrī conveys many elements of Emirati Arabic into the local Omani variety. More, 'Ibrì borders with the inner desert, thing that explains the contamination with Gulf Arabic, to be intended here as macro-category or badawiyy (B) of the Peninsula. This definition is opposed to hadariyy $(\mathrm{H})$, which means sedentary of the cities. In this regard, Holes offered a well-known partition of $\mathrm{H}$ and $\mathrm{B}$ into subgroups, so obtaining four classifications: $\mathrm{H}_{1}$ and $\mathrm{H}_{2}, \mathrm{~B}_{1}$ and $\mathrm{B}_{2}$.

In brief, $\mathrm{H}_{1}$ is the spoken variety of the main inner cities, while $B_{1}$ is the variety of the desert areas of the north. $B_{2}$ is spoken in the southern part of the country and shares 
some characteristics, for examples the syllabic structure, with $\mathrm{H}_{1} \cdot \mathrm{H}_{2}$ is a "rural hadariyy", found for example in Rustāq. $\mathrm{B}_{1}$, bedouin and nomadic of the north, is also found in the coastal city of Șūr and Ras el-Ḥadd. In fact, for the reason hinted at before, some nomadic groups followed the route from the Jebel to the sea, and established there because of their business activities. For a similar reason, the inner $B_{2}$ variety is found in Suwair: its speakers moved to the coast and brought their Arabic with them.

I offer below a table with the synthetic description of the four families, as Holes provided it.

Table 1. “Omani dialect types” (Holes 1989: 453-454)

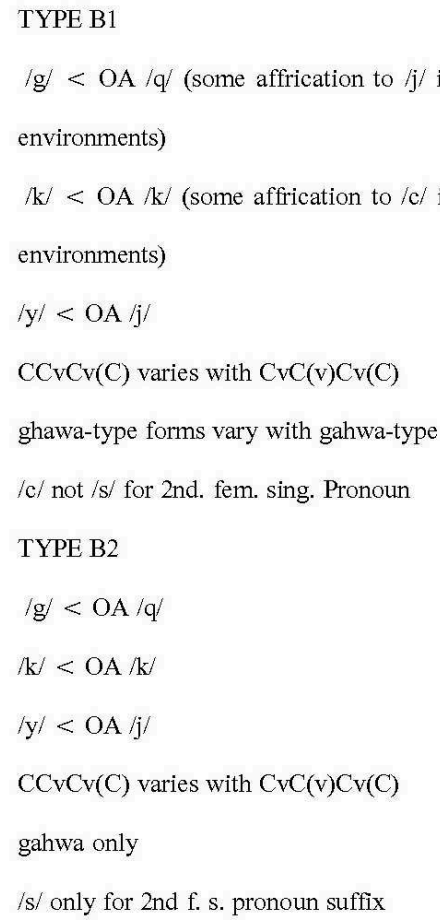

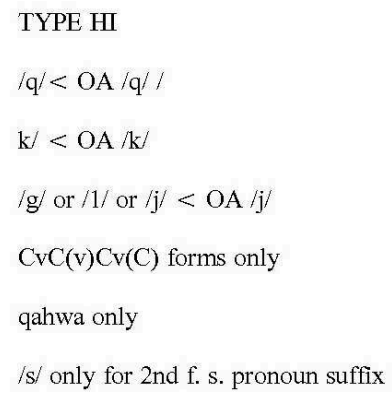

\section{Oman: Tribes and Ties}

In general, it is observed that the sharp contrast between the two categories of "sedentary and nomadic" is well reduced in Oman, as the economic and social differences among groups are not very significant. In practice there is more homogeneity among Omani inhabitants and the badawiyy or hadariyy life is not fully demarcated like in the Fertile Crescent. Many of the hadariyy citizens of Oman are ex-badawiyy, just recently settled. By the way, the structure of the society attests a minimal influence from the cities toward the vast bedouin and desert area while spoken varieties, albeit originally sedentary, contain a lot of bedouin features. Additionally, there are several on-going processes of accommodation among different Gulf accents (Holes 2001), which are in daily contact inside the Peninsula.

6 It is crucial to have in mind the name and collocation of some main tribes, in order to understand how the specific social composition of Oman affects the language. I proceed now associating tribes to cities (Eades 2008), and I also try to motivate the presence of a 
social group in a certain area. It is important to recall that inner Oman offers two main settings: mountains (H) and desert (B), in the middle of which we find many rural areas and inhabitants.

7 The members of the Šawāwī tribe live in the mountains that extend from Musandam to Ras el-Hadd. They are nomads and move for grazing their herd and selling their products. Their specificity is that they move across short distances and camp for very long periods in the same location. They are a sort of "settled nomads" of the rural area, thing that justifies the presence of many $\mathrm{H}$ elements in their speech. A huge community of Šawāwīs lives in Izki, their elected homeland.

8 Al-Darīz is the city where the Haritî tribe's members live. They are a settled community, sedentary of the mountains, but surrounded by a Bedouin environment to which they accommodate their speech. The inhabitants of Al-Dariz came from the southern part of the city of Ibrä', with which they maintain close contacts. This tight connection with a sedentary environment explains the persistence of many sedentary features in the speech of Al-Darīz, although placed in a numerically prevailing nomadic environment. This group adopts a precise marriage politic, which welcomes weddings with internal members and a limited selection of external elements that live in the surrounding cities. This way, the Haritî tribe keeps a stronger traditional network, thus accommodating less to external factors, language included. Differently, Al Mintirib stays on the border with the Wahiba Sands and is the capital city of the Hağiriyin sedentary tribe, whose speech has been heavily affected by B elements. In fact, this city is relatively far from any other sedentary environment and does not receive any support from settled neighbours. This weakness has led the Hağiriyin to react with an attitude of openness toward the bedouin tribe of the Āl-Wahỉba, as reflected linguistically too.

\section{The Key Concept of "Transitional Dialect"}

9 The fact of being a country that has only recently undergone a political unification with a central Government, has kept intact the social fragmentation of Oman into several local entities. These have been self-regulated for a long time, and they have directly decided how to conduct their daily politics and business. The examples of cities and tribes given above clearly explain this point. Establishing or not alliances with bedouin neighbours, welcoming external marriages or posing obstacles to any local interlinkage is something that has exclusively depended on the tribe choices without interference from any external actor. The only factor that may have determined the tribe's attitude toward "the other" is the natural environment, not very friendly in Oman.

10 In fact, living close to the sea, the mountain or in the desert puts different constraints to one's style of life. Effectively, it has been proved that the coastal cities, Masqat included, have been exposed to many influxes from outside that have caused daily changes in the society and in the local speech. The maritime vocation of the coastal cities prevailed over any other matter, so the degree of interaction and contamination, linguistic or not, became higher.

11 Instead, in the inner areas appeared a "gap to fill", which was left between the nomadic environment of the desert and the sedentary realities of the cities: the rural villages.

12 Many nomads settled close to the rural areas, and give birth to new born villages or cities where different speeches came in contact. This contact meant some linguistic 
implications, in particular resulted in a process of accommodation of the different varieties of the language. Every group reacted differently to this accommodation, which not always was reciprocal between two communities. In different words, the direction of the accommodation process was driven by social factors and elements pertaining the political and economic spheres. If badawiyy-s were numerically preponderant, then a nomadic variety was adopted; if the ties of the sedentary tribe were stronger, more hadariyy features have been retained in the local speech. Although with differences in the degree of accommodation, Oman shows that no clear demarcation exists in between the traditional $\mathrm{H}$ and $\mathrm{B}$ categories of Arabic. Any place and any speaker in Oman manifest to some extent a mixed variety, influenced by other Omani elements or by Gulf macro-traits. In fact, many Omani speakers perform a transitional dialect to be defined as a mixture of urban, rural, and bedouin characteristics, sometimes arriving from other cities of the Gulf outside Oman.

Here are a couple of examples of accommodation that testify the transition from a totally sedentary city dialect, to one containing also badawiyy markers (Eades 2008)

14 al-Darīz

$-/ \mathrm{q} />/ \mathrm{q} /$

- / $\mathrm{g} />/ y /$ approximant palatal, from influx of $B$

15 al-Mintirib

- /q/ > /g/ as typical Gulf pronunciation

- gahawa (or ghawa) syndrome

- ik in the place of -iš

\section{Main General Characteristics of the Omani Arabic}

According to the description provided by eminent scholars (Reinhardt 1894[1972], Holes 1984 and 2013, Brockett 1995) I quickly list some of the main features of Omani Arabic, to be compared later on with the variety of 'Ibrī , which remains the target of this article.

\subsection{Phonology}

$17-$ /q/ > /q/ or / $/$ if rural (both are voiceless, as typical for hadariyy)

$-/ \mathrm{q} />/ \mathrm{g} /$ in a limited number of lexems (Gulf pronunciation )

$-/ \mathrm{k} />/ \mathrm{k} / ; / \check{s} /$ if stands for the suffix 2 nd fem.sing.

$-/ \check{\mathrm{g}} />/ \mathrm{g} / ; / \check{\mathrm{g}} /$ if rural

\subsection{Morphology}

18 Suffixes that mark the fem. plural are retained

$--k>-s$ suffix 2 nd fem.sing.

$-(-k u n n a)>-k a n$

- (-hunna) >-henna

19 Verb endings that mark the fem.plural are retained

- (-tunna) $>-$ tan

$-(-n a)>-a n$

20 Prefix yo-for some weak verbs $>$ yokul 
The direct object marked by -inn that works as a subordinating particle in between the verb and its direct object.

The internal or apophonic passive persists in Omani Arabic, $\mathrm{H}$ or $\mathrm{B}$, and it is not substituted by any analytic construction or periphrasis. The only exception to this regularity, as expected, comes from the coastal cities where the level of exposure to different varieties increases so leading to the loss of this passive, which is retained only in proverbial expressions.

\section{The city and the variety of 'Ibrī}

'Ibrì is located in the Dhahira region and its wilāyat has over 100,000 inhabitants. The city itself is home to 40,00 citizens. 'Ibrī occupies a strategic position between Oman and the other cities of the Gulf: for example it is equally far from Muscat, Dubai and Abu Dhabi, between 220 and $250 \mathrm{~km}$. Nizwa and Sohar, on the Omani Gulf coast, are less than two hours' drive from 'Ibrī . This geographic collocation motivates the meaning of its name: "crossing point" or "point of transit". Historically too the city has played a crucial role to trade routes, and its $s \bar{u} q$ was one of the most important in the region for ready-made goods and livestock.

4 The economy of 'Ibrī is based on herding and farming, which developed exploiting an ancient irrigation technique by the aflāğ, special canals.

The spoken variety of 'Ibrī contains a mixture of both rural and urban features. In addition to this, it shows some bedouin characteristics too, varying from speaker to speaker. This, in the general frame of the influx received from the Gulf accent, as macrocategory.

We also find track of the gahawa syndrome, as De Jong described it (cfr. De Jong 2007 in EALL, s.v. gahawa syndrome):

"In many dialects hamza initial forms lose the hamza together with the vowel [...]", so that the entire syllable is dropped. This seems to be well exemplified by the typical greeting "hala wa ghala", where hala has replaced 'ahlan.

8 It is also noted a sort of overuse of the final $/ \mathrm{h} /$ specifically in the personal pronouns, some interrogatives, some imperative endings, and some adverbs.

Hypothetically the final / $h$ / may replace the loss of the initial hamza, as in the case of pronouns and imperatives, but what about interrogatives and adverbs? In general the final /h/ plays an emphatic role in the spoken varieties and it is found in many other accents too, as marker of the pausal form. Data from Yemen an adjacent areas, collected by Behnstedt (Behnstedt 2016, infra), show that this /h/ is quite regularly found at the end of personal pronouns, interrogatives and demonstratives: 'inti(h), "you"; hiyyeh, "she"; dah, "this" (masculine) tah, "this" (feminine); māh, "what"; lēh or lamūh or'awēh, "why".By the way, the same final /h/ can be found in not pausal forms as in mahūhda', "who is this?". Considering that some Saudi accents show the same feature, this /h/ can be considered both a marker of emphasis and a typical Gulf trait.

More data are needed to my investigation in order to better understand the use and scope of this final $/ \mathrm{h} /$ in the variety of 'Ibrì . I describe below some characteristic of the spoken Arabic of 'Ibrī , as it resulted from my collection of data. 


\subsection{Phonology}

\subsection{Morphology}

43 Suffixes

$-k>-s$ for the 2nd fem.sing.

(-kunna) $>-$ kan

(-hunna) >-henna

44

$$
\begin{aligned}
& \text { (-tunna) }>- \text { tan } \\
& \text { (-na) }>-a n
\end{aligned}
$$

$-y o$ as initial prefix for some weak verbs $>$ yokul

45 The direct object

-inn works as a subordinating particle in between the verb and its direct object:

Duktūr, bāǵ-inn-ek t-šūf $\underline{d} a-d$-dars, " Doctor, I want you to see this tooth".

46

47

ntāh, ntīh

huwwah, hiyyah

(nə)hnah

ntūh, ntan

hummah, hennah

48

$m \bar{u} \boldsymbol{h}<\boldsymbol{m u}$ hada , "what?" 
hmmuh $<$ hāl mu, "why?"

mtah $<$ mata, "when?"

49

$$
\text { -āh/-ìh/-ūh/-nnah }
$$

Rābāh!, "look!" (2nd m.s)

rābīh!, "look!" (2nd f.s)

rābūh!, "look!" (3rd m.pl.)

rābannah!, "look!” (3rd f.pl.)

In conclusion, the Arabic of 'Ibrī can be considered a transitional dialect and in any case it contains mixed features, as the table below sums up

Table 2. "The Arabic of 'Ibrī"

\begin{tabular}{|c|c|c|c|c|c|}
\hline & $/ g /$ & $/ q /$ & $\mathrm{k} /$ & $\begin{array}{l}\text { Syllable } \\
\text { structure }\end{array}$ & $\begin{array}{l}\text { Gahawa } \\
\text { syndrome }\end{array}$ \\
\hline 'Tbrì & $/ g /$ & $\begin{array}{l}\text { mostly } \\
/ \mathrm{q} /, / \mathrm{k} / \\
\text { possible /g/ }\end{array}$ & $\begin{array}{l}/ \mathrm{k} / \text { and } \\
/ \check{s} / \text { if suffix } 2 \mathrm{ndfs}\end{array}$ & $\mathrm{CCvC}(\mathrm{C})$ & $\begin{array}{l}\text { Cfr. } \\
\text { Hala wa gala }\end{array}$ \\
\hline hadarĩyy urban & $/ g /$ & $/ \mathrm{q} /$ & $/ \mathrm{k} /$ & $\begin{array}{l}\text { mostly } \\
\text { CvCvC }\end{array}$ & qahwa \\
\hline hadariìyy rural & $/ \check{g} /$ & $\mathrm{k} /$ & $/ \check{c} /$ & $\begin{array}{l}\text { mostly } \\
\text { CvCvC }\end{array}$ & kahwa \\
\hline $\begin{array}{l}\text { badawīyy } \\
\text { or Gulf }\end{array}$ & $\begin{array}{l}\text { mostly } \\
/ \mathrm{y} /\end{array}$ & $/ g /$ & $\begin{array}{l}/ \mathrm{k} / \text { and } \\
/ \check{c} / \text { with front } \\
\text { vowels }\end{array}$ & $\mathrm{CCvC}(\mathrm{C})$ & $\begin{array}{l}\text { gahawa or } \\
\text { ghawa }\end{array}$ \\
\hline
\end{tabular}

\section{A Text from 'Ibrī : "Fi maḥall”}

51 Fatima: ḥayyā-š 'uHt-ī Salìma

Salima: Allah yi-ḥayyi-š wa yi-bārek fi-š Fattūm

Maryam:.da al-mahall wāgid fihi 'ag̉rād

Fatima: ḥnā dōm-nā n-qūl ka-dak, n-rūḥ l-ho n-šūf ši gadīd fihi

Salima : Bass ya- ${ }^{\complement}$ tamid 'ala nōîyya al-'ag̉rāḍ, kull mā kān al-mahall 'ağrāọ 'aṣliyya kān 'aḥsan wa ha-ni-tbaḍ̣̂a ${ }^{\text {` }}$ ala raḥət-nā

Maryam: Hualā n-rūḥ gesəm an-na ${ }^{\mathrm{I} l a ̄ n}$, 'ašūf 'aškāl wāgid ḥəlwa

Fatima:Qūman ${ }^{\mathrm{S}}$ asa 'as āer-henna mā ġāliyya

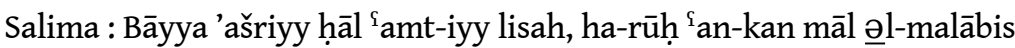

Maryam:șabr-ī šiwayyət ha-giyy ma $a^{\mathrm{q}}$ aš

Salima: T-ḥarrak-î ^ād nəss əl-lēl 


\section{BIBLIOGRAPHY}

BEHNSTEDT Peter (2016), Dialect Atlas of North Yemen and Adjacent Areas, Leiden, Brill.

BROCKETT A. A. (1995), “The Spoken Arabic of Khabura on the Batina of Oman" in Journal of Semitic Studies, Manchester, University of Manchester.

EADES Domenyk , “A Transitional Arabic Dialect of the Northern Omani interior” in Proceedings of 8th Conference of the International Association of Arabic Dialectologists, The University of Essex, UK, 28-31 August 2008

HOLES Clive (1984), Colloquial Arabic of the Gulf and Saudi Arabia, London, Boston, Kegan Paul International.

HOLES Clive (1989), "Towards a Dialect Geography of Oman" in Bulletin of the School of Oriental and African Studies, vol. 52, n. 3, University of London, pp.446-462.

HOLES Clive (2001), Dialect, Culture, and Society in Eastern Arabia, Leiden, Brill.

HOLES Clive (2013), "An Arabic Text from Șūr, Oman" in HOLES Clive, and JONG Rudolf de, Ingham of Arabia, Leiden, BRILL, pp. 87-108.

JONG Rudolf de (2007), s.v. gahawa syndrome in VERSTEEGH Kees, Eid, M. (eds.), Encyclopedia of Arabic language and linguistics, vol. II, 151-153

REINHARDT C. (1894), Ein arabischer Dialekt gesprochen in Omān und Zanzibar, Amsterdam, Philo Press Repr. 1972.

\section{APPENDIXES}

\section{Notes}

$/ k />/ \check{s} / 2^{\text {nd }}$ person feminine singular.

(ha) $\underline{d} a>\underline{d} a$, interdentals are generally retained.

$\boldsymbol{y i}$-hayyi-š wa yi-bārek, the suffix of the present tense is preferably maksur.

wāgid, / $\check{g} />/ g /$ is hadariyy of the city vs. / $\check{g} />/ 3 /$ hadariyy of the countryside.

$/ q>/ q /$ pronounced as an uvular occl. in hadariyy urban variants and velar occl. in hadariyy rural variants. Speakers of 'Ibrī may perform both. Additionally, /q/ > /g may be found, but resulting as a loan from bedouin or Gulf variants:agsam, šgadd.

$-a w>\bar{o}$ nōinyya.

Ha- works as marker for the future tense (cfr. rāh in Buraimi , sār elsewhere).

ni-t-badda , the suffix of the present tense is preferably maksur.

$|q|>|g|$

gesəm When found in 'Ibrī , it derives from contact with badawiyy variants (cfr. Holes B1 and B2) and it is used for a limited number of words. Feminine pl. markers are retained: 
-an, feminine marker for the imperative mood, $2^{\text {nd }}$ feminine plural;

-henna, suffix (adj.) for the 3rd person feminine plural.

bāya feminine of $b \bar{a} y$, «desiring».

hāal , preposition ("for") or genitive marker.

-kan, suffix (adj.) for the 2nd person feminine plural Feminine pl. markers are retained.

T-harrak-ī, syllable structure $\underline{\mathrm{CCvC}(\mathrm{C})}$ from contact with badawiyy variants vs. $\mathrm{CvCvC}$, mostly found in the hadariyy variety.

\section{Translation}

Fatima: Hello my sister Salīma!

Salima: Hello to you and may God benedict you, Fațțūm.

Maryam: In this shop there are many goods.

Fatima: We always say like this: we go there and see it has something new.

Salima: But it depends on the kind of goods, every time the shop has original goods it is better and we do shopping in peace.

Maryam: Let's go to the shoes section, I see very beautiful models.

Fatima: Let's go quickly , their price is not expensive.

Salima: I want to buy a turban for my aunt I leave you and go to the dress section.

Maryam: Wait a moment, I come with you.

Salima: Hurry up, it's about midnight!

\section{ABSTRACTS}

'Ibrī is located half-way in between Mascat and Dubai, and is very close to the Emirates border. This proximity facilitates young male citizens that look for job opportunities in the rich Emirates. Effectively, it is easy to find an occupation beyond the border: in Dubai, for the business sector; in Buraymi or Al-'Ain for administration or health sector related professions (health sector for female nurses too); in various locations across the Emirates if serving as military or police staff (airport and border police includes female staff too).

'Ibrī speakers, the majority of whom come back home after work, have daily contacts with their Gulf neighbours. This style of life makes the speech of 'Ibrì inhabitants critical for developing two levels of analysis:

1-features of the 'Ibrī Spoken Arabic, in the general frame of Omani Arabic;

2-tracks of contamination among Gulf variants, due to both recent and historically motivated 'contacts and changes.'

Several pairs of variables must be taken into account: social, referring to badawiyy or hadariyy; geographical, referring to the inner part of the country, or to west/east and north/south sides. In principle, the area of "Ibri should be "hadariyy of the north". Nevertheless, we find elements that go beyond this classification. Phonology, for example, shows a series of combinatorial possibilities that hardly fit a schematic and annotated classification; then, we may also find the gahwah syndrome in occasional 'Ibri speeches. 
According to what emerged from my collection of data in the city, I offer here a general morphophonological description of the local register. I also provide unpublished Omani texts, composed by teachers of "dialect", with examples of syntax and lexicon.

I intend to demonstrate how strong is the mismatching between political and linguistic borders in the Gulf area.

INDEX

Keywords: Oman, Arabic, transitional dialect, Gulf, hadariyy, badawiyy

\section{AUTHOR}

LETIZIA LOMBEZZI

Sapienza Università di Roma-Universidad de Cádiz letizia.lombezzi@uniroma1.it 


\title{
Le discours politique en Tunisie entre fuṣhāa et 'āmmiyya
}

\author{
Cristina La Rosa
}

\section{Le discours politique en Tunisie ${ }^{1}$}

1 À partir de l'étude pionnière de Holes (1993) sur les discours du Président Egyptien Nāṣir, différents chercheurs ont consacré leurs études au discours politique arabe en se concentrant surtout sur l'Egypte (pour citer seulement les plus récentes, voir AbdelMoety 2015 et Hussein 2016) et sur le Machrek (Matar 2015 et al-Momani 2017). Quelques auteurs ont adopté une approche comparative entre l'Orient et l'Occident (Mazraani 1997, Majali 2015). Plus réduits en nombre sont les études sur le Maghreb (entre autres, TaineCheikh 2002 et Boucherit 2012). Seuls quelques-uns de ces auteurs, toutefois, ont privilégié une véritable approche dialectologique, se concentrant plutôt sur d'autres aspects, tel l'usage et la fonction des pronoms personnels, qui décèlent l'idéologie et la stratégie politique des locuteurs.

2 Lorsqu'on se penche sur le discours politique tunisien, on ne peut éviter de penser au célèbre discours de Zayn al-'Ābidīn b. 'Alī à la Nation, tenu au moment où éclatait la révolution tunisienne de 2011 et prononcé intentionnellement dans une variété dialectale influencée par l'arabe standard, alors que Zayn al-'Ābidīn b. 'Alī, dans ses discours, utilisait presque toujours la fușhā. C'est probablement pour cette raison que les études existantes sur le discours politique tunisien se concentrent sur les monologues de Zayn al-'Ābidīn b. 'Alī (Maalej 2012 et Jarraya 2013 mémoire non publié). Dans ces études, le recours à la variété dialectale tunisienne n'est pas central, mais est analysé en tant que l'une des stratégies de persuasions adoptées par b. 'Alī.

Les nombreux discours de Bourguiba qui, par contre, optait souvent pour le tunisien lors de ses discours publics, viennent également à l'esprit. Célèbre, à cet égard, est celui tenu à l'occasion de l'éclatement des émeutes du pain en 1984, auquel fut comparé, par les journalistes tunisiens, le discours tenu par l'actuel président El-Sebsī le 22 janvier 2016 à la suite des manifestations d'al-Qașrīn. Dans ce discours, El-Sebsī utilise en effet l'arabe 
tunisien et emploie aussi toute une série de formules et phrases typiques du langage de Bourguiba. Ce qui peut tantôt être dû au rapport personnel, très fort, entre El-Sebsī et Bourguiba, tantôt à une stratégie de construction et de légitimation de son pouvoir. Dans cette étude, on se concentrera sur quelques passages tirés d'un discours du président ElSebsī, tenu le 20 mars 2015 au Palais Présidentiel de Carthage, à l'occasion du $59^{\text {ème }}$ anniversaire de la Fête de l'Indépendance, célébrée dans une situation nationale particulièrement critique : à peine deux jours après l'attentat du musée du Bardo. Le contexte historique et politique était donc très délicat, mais al-Bēğì Qā’id El-Sebsī a décidé de fêter, malgré tout, l'anniversaire de l'indépendance et il a prononcé un important discours d'environ 50 minutes, s'adressant aux 'jeunes' de la Tunisie - par quoi il entendait les moins de 50 ans. Comme il l'a déclaré dans une interview au magazine Le Point, il a choisi de tenir son discours sans avoir recours à ses notes, en parlant dans 'la langue du peuple', et il a donc annulé son discours officiel en fușhāa (disponible sur la page Facebook officielle Présidence Tunisie) pour laisser la place - déclara-t-il - à l'improvisation. La première stratégie discursive adoptée par El-Sebsī, c'est-à-dire le choix intentionnel de s'exprimer en dialecte, est ainsi ouvertement assumée.

4 Il s'agit, en réalité, d'un monologue savamment construit : sur une 'base' très dialectale, le Président insère des éléments en fuṣh $\bar{a}$, et particulièrement des citations érudites, des anecdotes humoristiques et des proverbes populaires.

5 Le discours en question est disponible en deux parties sur Youtube ${ }^{2}$. Les thématiques-clés abordées par le président sont la lutte contre le terrorisme, la sécurité, l'unité nationale et les réformes.

6 Cette étude portera sur les fonctions des variétés linguistiques utilisées par El-Sebsī, en mettant l'accent sur les changements de registre et les buts communicatifs sous-jacents. On examinera aussi l'utilisation de quelques signaux discursifs typiquement dialectaux en tant que composants de la stratégie de persuasion et manipulation politique employée par El-Sebsī face à la crise nationale que la Tunisie était en train de traverser. ${ }^{3}$

\section{Stratégies de persuasion : emploi et fonctions de l'arabe tunisien}

7 L'usage du dialecte, généralement, rend le locuteur plus proche de son public surtout dans les situations critiques, telle celle où El-Sebsī cherche à partager sa solidarité avec le peuple tunisien et, en même temps, à lui faire comprendre que des sacrifices communs sont nécessaires pour sortir de l'impasse dans laquelle la Tunisie se trouve. L'emploi de l'arabe tunisien contribue, en fait, à véhiculer l'idée d'intimité et de collaboration pour surmonter les obstacles et résoudre les problèmes (Mazraani $2008: 666$ ).

El-Sebsī, en effet, utilise l'arabe tunisien dans la plus grande partie de son discours, lequel est plutôt 'influencé' par la fuṣhā, pour entretenir un rapport plus personnel avec le public, afin que son message paraisse spontané et naturel et qu'il puisse communiquer son empathie et son implication dans les questions traitées (Mazraani 2008: 666). Il emploie un ton de voix manifestant ses émotions et exprimant sa sincérité. On ne s'attardera pas, ici, sur les caractéristiques linguistiques typiques du dialecte tunisien employé par El-Sebsī, qui sont suffisamment connues grâce aux nombreuses études des dialectologues modernes et contemporains. Il est toutefois opportun de souligner que le lexique utilisé dans le discours n'est jamais trop soutenu ou recherché et est 
principalement constitué de termes dialectaux et pandialectaux, tels šăf, bilēš, barša, yēsir, 'alā Huātir, mū̌s/mānišs, ellī, māa 'ādiš, waqtellī, tawwa et škūn, ou de mots 'classiques' prononcés de façon dialectale. Très rarement, à l'emploi d'un mot ou d'une expression dialectaux correspond celui d'un mot ou d'une expression en fușhā comme dans le cas de

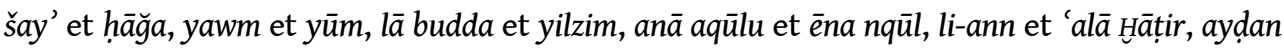
et zēda et wa- et $w$ -

En outre, le Président n'a pas recours à des emprunts étrangers, sauf al-bāndiyya "les bandits", mot utilisé, entre autres, en Tunisie et au Maroc et qui a été adapté du français, premièrement par modification phonétique avec passage du son nasal du français /an/ à /ān/ [bāndi] et allongement de la voyelle brève; deuxièmement, le pluriel externe a été formé en ajoutant le suffixe -iyya (Mzoughi 2015 : 214, 276).

\section{Code-switching ${ }^{4}$ : le rôle de la fușhāā}

10 Le choix de la variété linguistique employée et le passage de l'une à l'autre dépendent de plusieurs variables situationnelles et sémantiques et des fonctions et stratégies associées au niveau linguistique sélectionné (Mazraani 2008 : 664-665). Dans le discours d'El-Sebsī, les changements prosodiques et, surtout, d'intonation et de rythme ont pour fonction de mettre l'accent sur certains concepts ou encore de prévenir le public qu'un changement va survenir (ibid.). Le président prononce, en effet, d'un ton autoritaire des citations en arabe standard, qui ont pour fonction de véhiculer un message solennel et indiscutable. El-Sebsī cite des vers poétiques, des proverbes populaires, des versets coraniques et d'autres tirés des ahāaitị avec lenteur, en les faisant précéder d'une pause qui accentue la signification du message. L'ír rāb les rend encore plus solennelles.

11 Le président emploie donc des registres différents pour s'adresser à ses soutiens et, afin d'augmenter l'impact de ses énoncés sur eux, il a recours à des citations qui produisent un grand effet persuasif sur les auditeurs, lequel se traduit concrètement par de longs applaudissements.

12 La première citation en fușhā qu'El-Sebsī utilise est une variante d'un vers contenu dans le dīwān d'Abū Tammām (m. 845 après J.-C.) Ağmalu min nawrin tufattihu al-șabā bayāạdu l'ațāya a fi sawādi l-mațālibi [1-29.39] «La meilleure fleur que la brise fait éclore est la blancheur de la générosité (des dons) dans la noirceur des requêtes $»^{5}$ qu'El-Sebsī attribue à Farazdaq (m. 732 après J.-C.). ${ }^{6}$ Selon El-Sebsī, le requêtes sont 'noires', c'est-à-dire, le fait de demander de l'aide aux autres pays est tout à fait inconvenant et gênant pour la Tunisie: ahnna mā nuṭlubūšs, "nous ne demandons pas » est l'affirmation qui suit la citation. Le but est, à la fois, de mettre en relief le faHr, l'orgueil et le courage de la Tunisie, d'anoblir et de rendre ses mots fermes.

13 Le vers est suivi d'une deuxième citation [2-0.17] : wa-l-hurratu tamūtu ğu' $\bar{c}^{\prime} a n$ wa-lā tašrabu min tadyay-hā c'est-à-dire « la femme libre préfère mourir de faim que boire de ses seins ». Il s'agit d'un matal 'arabiyy, qui fait donc partie de la culture populaire arabe, prononcé par al-Ḥārit Ibn Sulayl al-Asad allié de 'Alqama Ibn H̦așafa al-Ṭầ ì. Cette phrase renforce le concept exprimé dans la citation précédente. Ici, El-Sebsī se réfère à la Tunisie qui plie, mais ne se rompt pas et ne demande rien à personne. Toutefois, le Président termine cette partie de son discours en disant lākin elli yihhibb yisā'ad-nā maraḥbē bi-h « celui qui désire nous aider est le bienvenu ", en montrant son appréciation et sa reconnaissance envers les pays qui ont manifesté leur solidarité avec la Tunisie. 

soutien de Dieu est avec la communauté et non avec le consensus général ", dont la première partie est tirée du célèbre hadịit 2167, contenu dans l'œuvre al-Ğāmi' d'al-Tirmidīi (m. 869, voir Halīl, 2007: 227) qui a pour objectif de donner un caractère divin à la souveraineté du peuple et d'encourager les Tunisiens à l'unité. El-Sebsī souligne le fait que Dieu est avec le peuple et non avec ceux qui s'éloignent de la communauté. De façon subtile, El-Sebsĩ s'adresse à ceux qui s'opposent à sa politique.

La quatrième citation, enfin, est tirée du verset 20 de la sourate 14 d'Ibrahīm : wa mā dāka 'alā Allāhi bi-'azizz « cela n'est nullement difficile pour Dieu» [2-22.56]. El-Sebsī prononce cette phrase solennelle, qui laisse la place à l'espoir qu'avec l'aide de Dieu le peuple tunisien vaincra et sortira de la crise, après avoir lui-même affirmé que la Tunisie sortirait de la crise.

\section{Les marqueurs discursifs ${ }^{7}$}

Les marqueurs discursifs contribuent à la construction du message à véhiculer. Ceux qu'El-Sebsī utilise le plus fréquemment sont ya'nī et sa variante ma'nēh/hā pour 'je veux dire'; ensuite, il emploie fhamt wella lā ? 'C'est bon ? Vous voyez ?' et li-ann 'parce que', en alternance avec la variante dialectale 'alā Hūațir.

El-Sebsī a recours à des marqueurs dialectaux ou standards et, en revanche, n'utilise pas de marqueurs empruntés à des langues étrangères. Voyons quelques exemples de leurs usages et fonctions dans le monologue.

$18 Y a^{\prime} n i ̄$. Le connecteur le plus employé dans le discours d'El-Sebsī est le panarabe ya'nī. Il peut avoir différentes fonctions : signaler qu'une unité sémantique nouvelle, semblable à la précédente, va être prononcée; que le locuteur va donner ou bien demander une clarification; ce peut encore être une tentative de clarification lorsque le locuteur cherche les mots à prononcer; il peut enfin signifier 'donc' et 'comme ci comme ça' (Owens \& Rockwood 2009: 83-85, 111). Dans la majorité des exemples, El-Sebsī emploie $y a^{\prime} n \bar{l}$ pour chercher les mots à prononcer et, plus rarement, comme marqueur exemplificatif signalant qu'une unité sémantique nouvelle va être introduite.

Quelques occurrences du premier cas :

waqtellī al-ša 'b al-tūnusī yikūn mwahhhd, ya'nī, yantașir dä'iman

« lorsque le peuple tunisien est uni, je veux dire, il vainc toujours » [1-19.13] ;

w-nšallāh, ma'nēhā, nuwaṣlū fi l-a'māl hāạayya, ya'nī bēš ya'nī Tūnis tuHruğ min l-waḍ'

elli hiya fi-h

« et si Dieu le veut, je veux dire, nous arriverons à ces résultats, je veux dire, pour

que, je veux dire, la Tunisie sorte de la situation dans laquelle elle se trouve "

[2-22.45];

wa-lā budda nuHruğū min-hā w-mā nneğmūš nuHruğ $\bar{u}$ min-hā bilēš, ya'nī, al-wahda al-

wațaniyya

« nous devons en sortir et nous ne pouvons pas en sortir sans, je veux dire, l'union

nationale » [1-23.15];

anā aqūlu, ya'nī, yadu llāha $m a^{c}$ al-ğamác $a$

« je dis, je veux dire, le soutien de Dieu est avec la communauté » [2-8.40].

Des exemples de la fonction explicative de ya'nī: ya'nī yilzim Tūnis, al-šá $b$ al-tūnisī, yatașarraf ka-umma « c'est-à-dire, la Tunisie, le peuple tunisien, doit se comporter comme

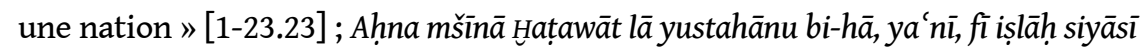


'Nous avons fait des avancées considérables, je veux dire, dans une réforme politique' [2-22.01].

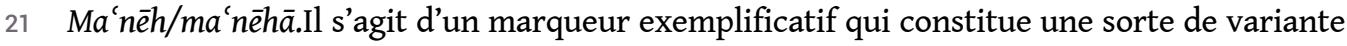
de $y a^{\prime} n i \bar{a}$ aux fonctions semblables. Parmi les exemples attestés on peut mentionner :

wa-l-mușālhāa al-wațaniyya muš ma'nēhā, rāhu, al-bāndiyya

« et la réconciliation nationale, c'est-à-dire, bien entendu, ce n'est pas les bandits ».

[2-10.48]

bēš 'al-aqall mā yūqālš wa-anna al-dawla al-tūnisiyya, ma'nēhā, titnakkr iltizamāt-hā

«pour que, au moins, on ne dise pas que la Tunisie, je veux dire, renie ses engagements » [2-21.08].

al-'âlam ağma', mūš al-kullu, ġayr min-nā zeda, ma'nēhā, ta'rfūh ; ahna mā yihimmnāš mā

dām al-tuwānsa radyyīn w naḥna farhānīn $w$ aḥna mu 'tazzīn bi-had̄a al-mawḍ̆ ${ }^{\prime} w$ nšallāh, ma'nēhā, nușlū fì l-a'māl hāạayya

«le monde entier, sauf nous, je veux dire, vous le savez; à nous cela n'importe pas, nous sommes encore satisfaits, heureux et fiers de cela et, si Dieu le veut, je veux dire, nous arriverons à ces résultats ». [2-22.23]

Rāhu. Du point de vue morphosyntaxique, le marqueur rāhu, composé du verbe rā 'voir' et du pronom suffixe - $h u$, peut être fléchi et accordé, en personne, nombre et genre, au sujet de la phrase nominale dans laquelle il se trouve. ${ }^{8}$ Son accord ne dépend pas seulement de règles syntaxiques, mais aussi de la signification profonde du message que le locuteur désire véhiculer. Au niveau pragmatique, c'est un marqueur procédural et non un véritable connecteur puisqu'il opère à l'intérieur de la phrase nominale et ne relie pas les phrases entre elles. Rāhu, en outre, ne semble pas avoir de contenu lexical : il est un marqueur purement procédural. En effet, il ne véhicule aucun contenu conceptuel à l'auditeur, mais il le guide dans l'interprétation (Adams 2012:27-30). Rāhu signifie 'bien entendu' et indique à l'auditeur que l'information contenue dans la phrase est de première importance pour le discours et ne doit pas être perdue (ibid.).

On relève deux occurrences dans le discours d'El-Sebsī dans lesquelles peuvent être repérées ces deux différentes fonctions de rāhu :

wa-l-mușālhā al-wațaniyya muš ma'nēhā, rāhu, al-bāndiyya

" et la réconciliation nationale, c'est-à-dire, bien entendu, ne sont pas les bandits » [2-10.48]

ahna nqūiū w-nqūl-kum wa-ahna l-ḥukūma aḥna, rānī, ra'īs l-ğumhūriyya, muntaHab fì nițāq al-dustūr la-hu mašmūlāt, ya nì, marbūța [1-26.42]

«Nous vous disons et je vous dis que nous, le gouvernement, que moi, bien entendu, je suis le Président de la République, élu dans le cadre de la Constitution, ayant des fonctions, je veux dire, fixes ».

Dans le premier exemple, le marqueur rāhu n'est pas accordé avec le sujet de la phrase qui est al-mușālhā, mais avec la phrase entière à laquelle il se réfère et souligne l'importance. Dans le second cas, en revanche, malgré l'hésitation d'El-Sebsī entre les pronoms 'nous' et 'moi' et les ajustements qu'il effectue, rānī est accordé au sujet de la phrase qui est «le Président ». El-Sebsī utilise rānī pour mettre l'accent sur son rôle.

Fhamt wella $\bar{l} \bar{e}$ ? Littéralement 'tu as compris ou non?'. Expression typique du langage familier, est un marqueur discursif propositionnel typique, mais non exclusif, de l'arabe maghrébin et tunisien. Plusieurs exemples attestés :

wa-naqūl kullu l-nās sāhmū fi-hā, ellī šuwaya w-ellī barša, fhamt wella lā ?

"Je dis que tous les gens ont contribué à cela, ceux qui ont peu et ceux qui ont

beaucoup, vous voyez?» [2-22.11].

Wazîftì bēš nqūl l-haqq, fhamti wella lā ?

«Mon rôle est de dire la vérité, vous voyez? » [2-8.24]. 

effets de causalité du discours (Bidaoui 2016: 598-599). Il oscille avec sa variante dialectale 'alā Huațir qui apparaît plusieurs fois dans le reste du monologue. L'oscillation entre li-ann et 'alā Hुățir pourrait être due à l'influence de l'arabe standard, influence qu'El-Sebsī subit du fait du caractère officiel de la situation d'énonciation du discours, mais les deux variantes sont équivalentes et remplissent la même fonction de guidage de l'auditeur ans le processus d'inférence de la partie de l'énoncé suivant (Bidaoui 2016: 607). Il est toutefois possible qu'El-Sebsī avait besoin de souligner qu'il était lui-même le sujet de l'action et il le fit en choisissant li-ann auquel il est possible d'attacher le pronom suffixe de première personne singulière -î.

\section{Observations conclusives}

Dans l'analyse présentée on a tenté de montrer comment le choix de registre contribue à construire et renforcer l'idéologie et les buts politiques d'El-Sebsī qui utilise la langue et le langage pour exprimer ses croyances et marquer sa position dans le processus d'interaction avec le public. Le tunisien engendre, en ce sens, une sensation d'harmonie, d'intimité et de complicité entre le président et le public chez qui il crée un sentiment de coparticipation et de patriotisme en l'invitant à rester soudé face au danger. El-Sebsī prône l'unité devant l'ennemi pour le vaincre et il le fait en parlant de façon persuasive, tantôt presque paternelle, tantôt forte et assertive. L'usage du tunisien joue donc un rôle fondamental parce qu'il constitue la langue de tous; c'est la variété des sentiments, capable de rapprocher le président de tous les citoyens et de favoriser l'esprit d'unité nationale face au terrorisme.

Dans le long discours d'El-Sebsī, le code-switching est une stratégie linguistique fondamentale pour maintenir l'attention du public (Mazraani $2008: 670$ ). Les citations en fuṣhā, tirées du Coran, de la poésie classique, des aḥādịt et des amțāl 'arabiyya, ne sont pas, d'ailleurs, un simple choix de registre visant à élever son discours ; le président, en fait, a l'habitude de s'adresser aux Tunisiens en dialecte. L'usage de ces citations, qui sont peu nombreuses et insérées en certains points stratégiques de son discours permet, en revanche, d'attirer l'attention du public, de rendre les affirmations du président définitives et, enfin, de communiquer l'idée que la victoire contre le terrorisme et la sortie de la crise économique, avec l'aide de Dieu, sont proches. 


\section{BIBLIOGRAPHIE}

Abdel-Moety, Doha M. 2015. “A Rhetorical and Linguistic Analysis of President El-Sisi's first Inaugural Address”, Global Journal of Human-Social Science: G Linguistics and Education 15.

https://socialscienceresearch.org/index.php/GJHSS/article/view/1547/1488

Adams, Chris. 2012. Six Discourse Markers in Tunisian Arabic: A Syntactic and Pragmatic Analysis. Mémoire de MA, University of Dakota.

Bidaoui, Abdelaadim. 2016. "Discourse Markers of Causality in Maghrebi and Egyptian Dialects: A Socio-Pragmatic Perspective", Open Linguistics 2. 592-609.

Blau, Joshua. 2003. "Classical Arabic, Middle Arabic, Middle Arabic Literary Standard, Neo-Arabic, Judaeo-Arabic and related terms", Lentin, Jérôme \& Lonnet, Antoine (éds), Mélanges David Cohen. Études sur le langage, les langues, les dialectes, les littératures, offertes par ses élèves, ses collègues, ses amis. Paris : Maisonneuve \& Larose. 257-258.

Boucherit, Aziza. 2012. «De l'usage de formes mixtes dans un discours de persuasion. Étude d'un sermon religieux », Bettini, Lidia, \& La Spisa, Paolo, (éds), Au-delà de l'arabe standard. Moyen arabe et arabe mixte dans les sources médiévales, modernes et contemporaines. Florence : Dipartimento di Scienze dell'Antichità, Medioevo e Rinascimento e Linguistica Università di Firenze. 35-57.

Halīl, Abū. 2007. Ğāmi` at-Tirmid̄ì. Riad : Maktaba dār as-salām.

Holes, Clive. 1993. "The uses of Variation: A study of the political speeches of Gamal Abd al-Nasir" , Eid, Mushira, \& Holes, Clive (éds), Perspectives on Arabic Linguistics V. Amsterdam: John Benjamins. 13-45.

Hussein, Inas. 2017. "Critical Discourse Analysis of the Political Speech of the Egyptian President, Abdel Fattah Essisi, at the New Suez Canal Ceremony", International Journal of Language and Literature 4. 85-106.

Jarraya, Soufien. 2012. Persuasion in Political Discourse: Tunisian President Ben Ali's Last Speech as a Case Study. Mémoire de MA, Université de Syracuse.

Kesseiri, Radia. 2015. "The Political Discourse of the Arab Revolution: The Case of Egypt, Tunisia, Libya, and Syria", Raddawi Rana (éd.), Intercultural Communication with Arabs. Singapore :

Springer. 237-257.

Lentin, Jérôme. 1997. Recherches sur l'histoire de la langue arabe au Proche-Orient à l'époque moderne. Thèse de Doctorat d'état ès-lettres. Université de la Sorbonne Nouvelle-Paris III.

Lentin, Jérôme. 2004. « Réflexions sociolinguistiques sur la coexistence des langues dans l'histoire du Maghreb : les sources et leur interprétation », Dakhlia, Jocelyne (éd.), Trames de langues. Usages et métissages linguistiques dans l'histoire du Maghreb. Paris : Maisonneuve et Larose. 341-49.

Maalej, Zouheir. 2012. “The 'Jasmine Revolt' has made the 'Arab Spring': A Critical Discourse Analysis of the last three Political Speeches of the Ousted President of Tunisia", Discourse and Society 23. 679-700.

al-Majali, Wala'. 2015. "Discourse Analysis of the Political Speeches of the Ousted Arab Presidents during the Arab Spring Revolution using Halliday and Hasan's Framework of Cohesion", Journal of Education and Practise 14. 96-108. 
Matar, Dina. 2015. "Hassan Nasrallah: the cultivation of image and language in the making of a charismatic leader", Communication, Culture and Critique 8. 433-447.

al-Momani, Hassan Ali. 2017. "Political Discourse of Jordan: A Critical Discourse Analysis", International Journal of English Linguistics 7. 90-98.

Mazraani, Nathalie. 1997. Aspects of Language Variation in Arabic Political Speech Making. Richmond: Curzon.

Mazraani, Nathalie. 2008. "Political Discourse and Language”, Versteegh, Kees et al. (éds), Encyclopedia of Arabic Language and Linguistics, III. 663-671.

Mzoughi, Ines. 2015. Intégration des emprunts lexicaux au français en arabe dialectal tunisien. Thèse de doctorat. Université de Cergy Pontoise.

https://tel.archives-ouvertes.fr/tel-01220289/document

Owens, Jonathan, \& Rockwood, Trent. 2009. "YaIni: What it really means", Dilworth Parkinson (éd.), Perspectives on Arabic Linguistics XXI. Amsterdam : John Benjamins. 83-113.

Taine-Cheikh, Cathrine. 2002. "De la variation linguistique dans le prêche populaire mauritanien", Rouchdy, Aleya (éd.), Language Contact and Language Conflict in Arabic. Variations on a Sociolinguistic Theme. London/New York : Routledge Curzon.177-203.

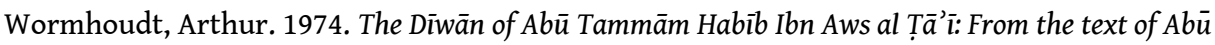
Zakariya Yahya Ibn 'Ali al Khatib al Tibrizi (d. 512 a.h.). Oskaloosa: William Penn College.

\section{NOTES}

1. Je tiens à remercier Jérôme Lentin pour avoir lu mon texte avant ma présentation à la conférence de AIDA 12 et pour ses précieux conseils. Je remercie également Fouad Omeghras et Nadia Tebbini avec qui j'ai discuté de quelques expressions contenues dans le discours analysé. Merci, enfin, aux réviseurs anonymes.

2. La première est disponible sur: https://www.youtube.com/watch?v=j1KnOskoxbA; et la seconde, sur : https://www.youtube.com/watch?v=g6jouSsJFsc.

3. Quelques exemples des autres stratégies de persuasion utilisées par El-Sebsī dans son monologue, incluant aussi l'utilisation des pronoms déictiques et de la répétition lexicale, ont été présentés à l'occasion de ma communication à la Conférence de AIDA 12 et feront l'objet d'une prochaine étude.

4. Dans le monologue analysé, le code-switching concerne principalement fușhā et 'āmmiyya, alors qu'El-Sebsī a rarement recours à l'alternance arabe-français-arabe comme dans la phrase « Suft le système? Lākin famma ă̆āz mā 'annēš " 'Tu as vu le système? Mais il y a des autorisations que nous n'avons pas' [2-2.25]. Il utilise encore le français et l'anglais, dans deux cas seulement, pour citer des journalistes et pour faire de la satire. L'impression est que le président n'utilise pas d'autre variété que l'arabe volontairement.

5. La traduction que Wormhoudt (1974: 46) en donne est "The finest flower kindness blooms with brightness of gifts in the dark desire".

6. Il dit que le vers appartient à une 'qașìda imtāḥhu'.

7. Ce n'est pas ici le lieu pour discuter le thème controversé de la terminologie concernant le nom donné aux particules analysées en tant qu'éléments dialectaux ou standards, insérés par ElSebsī dans son discours comme faisant partie de sa stratégie discursive. Sur la question terminologique, voir Bidaoui (2016 : 592-593). 
8. Rāhu à la troisième personne du masculin singulier peut aussi se référer à une phrase entière (voir Adams 2012 : 30).

\section{RÉSUMÉS}

Le discours politique tunisien a toujours accordé à la fușhā une place de choix dans les situations officielles exigeant le recours à un registre de langue élevé ; quelques hommes politiques et chefs d'États, toutefois, ont à l'occasion prononcé des discours dans lesquels ils utilisaient d'autre variétés d'arabe, à savoir la 'āmmiyya, et une troisième variété 'mixte', caractérisée par des éléments dialectaux ou dialectalisants (Blau 2003). L'emploi de cette langue 'mélangée', dans laquelle les variétés linguistiques passent graduellement de la fușhā à la 'āmmiyya et ne sont pas délimitables de façon nette (Lentin 1997, 2004), peut être un choix, volontaire ou inconscient, du locuteur. Dans le premier cas, bien que le destinataire du monologue demeure le peuple, lorsque l'occasion et les objectifs du discours changent, le chef d'État opte pour un registre différent tendant tantôt vers le haut, tantôt vers le bas du continuum linguistique, en fonction de la stratégie discursive retenue (Maalej 2012, Kesseiri 2015).

L'analyse de quelques extraits d'un monologue du président El-Sebsī fera l'objet de cette étude. Il s'agit du discours tenu par le président tunisien le 20 mars 2015 au Palais Présidentiel de Carthage, à l'occasion du $59^{9}$ ème anniversaire de la Fête de l'Indépendance, célébrée deux jours après l'attentat du musée du Bardo. Je me concentrerai sur l'analyse des variétés linguistiques utilisées par El-Sebsī pour en mettre en relief les buts communicatifs. Seront ici pris en compte l'utilisation des signaux discursifs et le recours à des éléments 'mixtes' 'āmmiyya/fușhā en tant qu'éléments d'une véritable stratégie de persuasion adoptée par El-Sebsī.

\section{INDEX}

Mots-clés : arabe tunisien, 'āmmiyya, variétés mixtes, code-switching, analyse du discours politique.

\section{AUTEUR}

\section{CRISTINA LA ROSA}

Université de Catane, Dipartimento di Scienze Umanistiche (Italie). cristinalarosa@unict.it 


\title{
Le texte inédit de la première
} constitution mauritanienne écrite en hassāniyya en 1959. Historique et analyse des traits linguistiques du manuscrit

\author{
Ahmed Salem Ould Mohamed Baba
}

\section{Introduction}

1 La présence ancienne de documents écrits dans les différents dialectes arabes est attestée de longue date, notamment pour la poésie. Nous en avons quelques exemples en alAndalus (Booth, 1992 : 421) ${ }^{3}$ comme le Dīwān de Ibn Quzmāñ . Dans le cas du ḥassāniyya, il existe des textes de la tradition orale mauritanienne qui ont été mis à l'écrit beaucoup plus tard que la période où ils ont été créés. C'est le cas du recueil de poésie hassān de Saddūm Wuld Ndartu (1710-1812) transmis oralement et édité et publié en $1996^{5}$ et

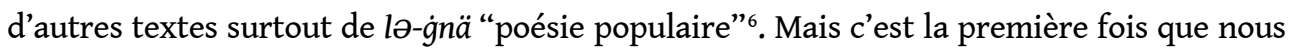
trouvons un texte juridique écrit en hassāniyya, lequel malgré son ancienneté était passé inaperçu jusqu'à présent. Cet intéressant document juridique est appréhendé ici en tant que source dialectologique où l'on peut découvrir les traits généraux du hassāniyya pratiqué dans les années 1960. Ce texte est le fruit des rapports entre la France et la Mauritanie notamment au moment de la décolonisation. Le texte original fut rédigé en français et il s'est largement inspiré de la Constitution française. Pour cette raison, nous allons présenter un bref historique de ces rapports. 


\section{Historique}

2 Les contacts commerciaux entre la France et la Mauritanie remontent au XVIII ${ }^{e}$ siècle ${ }^{7}$. Il s'agissait généralement de pactes et d'accords ponctuels avec les émirats dans le cadre de la traite de la gomme arabique. Vers la fin du XIXe siècle, la France commença sa pénétration du territoire, rapidement suivie de l'arrivée des premiers administrateurs coloniaux français. Le premier qui s'installa fut Xavier Coppolani ${ }^{8}$ qui arriva au Bilād Șinqịt (ancien nom de la Mauritanie) en $1898^{\circ}$. C'est lui qui proposa le nouveau nom du pays, la Mauritanie, qui fut approuvé plus tard.

3 Le 27 décembre 1899, le Ministère français des Colonies, en s'appuyant sur les rapports envoyés par Coppolani, remit au Gouvernement un projet de création d'une région appelée «Mauritanie Occidentale» pour «l'étude des conditions pratiques de réalisation $»^{10}$.

4 Le 30 décembre 1899 une décision ministérielle du gouvernement français organise sous le nom de "Mauritanie Occidentale » les régions s'étendant de la rive droite du fleuve Sénégal et de la ligne de Kayes et Tombouctou jusqu' au Cap Juby, à l'ouest, c'est-à-dire jusqu'aux confins du Maroc et au nord jusqu'au Sud algérien ${ }^{11}$.

5 Un accord signé le 29 juin 1900 entre l'Espagne et la France établit les frontières de la Mauritanie qui sont toujours actuelles (Ruiz de Cuevas $1977: 50)^{12}$.

6 En 1920, la Mauritanie rejoint l'Afrique Occidentale Française (AOF), avec comme capitale administrative Saint-Louis du Sénégal.

7 En 1946, elle devient un territoire d'Outre-mer. Horma Ould Babana fut le premier député mauritanien à entrer à l'Assemblée Nationale Française.

8 En 1957, le premier Conseil de gouvernement, tenu sous la tente à Nouakchott, propose le transfert de la capitale de Saint-Louis à Nouakchott. Le décret est signé par la France la même année.

Le 28 septembre 1958, un référendum est organisé et la Mauritanie adhère à la "Communauté ». L'assemblée Territoriale se transforme en Assemblée Constituante et adopte la première constitution du pays qui est promulguée le 22 mars $1959^{13}$.

Le 28 novembre 1960, la Mauritanie proclame son indépendance.

11 Le 20 mai 1961, une deuxième constitution est rédigée qui est une version modifiée de celle de 1959.

12 La première constitution fut écrite par un Comité de Rédaction formé par les membres suivants : le professeur Ould Hamidoun; Mohamed Moktar, dit Marouf; Bouna Moktar; Dembelé Tiecoura ; professeur Seurin; Yahya Kane et Abdel Wahab Ould Cheïguer (Ould Daddah $2003: 184)^{14}$.

13 Le texte de cette première constitution traduite en hassāniyya est conservé sous forme de manuscrit aux archives nationales de Mauritanie de Nouakchott. Ce manuscrit inédit est celui que nous présentons ici. Au vue du texte, plusieurs questions se posent : pourquoi at-il été traduit et écrit en hassāniyya ? Qui l'a traduit? Est-ce le Comité qui l'a rédigé, des membres de celui-ci ou Wuld aš-Šaygir dont le nom figure sur la couverture et à la fin du manuscrit? Nous allons essayer de trouver des éléments de réponse à ces questions avant d'aborder l'analyse des traits linguistiques du texte. 


\subsection{Pourquoi le texte de cette constitution fut-il traduit et écrit en ḥassāniyya?} (1960-1978), que j'ai trouvé des données qui pourraient servir comme éléments de réponse à cette question. En effet, après avoir cité les noms des membres du Comité Consultatif constitutionnel et ceux du Comité de Rédaction, Ould Daddah affirme que le projet de la première constitution fut présenté au peuple mauritanien avant d'être approuvé (Ould Daddah 2003: 184) ${ }^{15}$. Pour cela, une délégation dont il faisait lui-même partie visita tous les chefs-lieux de cercle du 11 au 23 février 1959. Il semble raisonnable que, pour pouvoir présenter un tel projet à un peuple qui ne parle pas le français, il fallait traduire le texte en arabe dialectal pour qu'il soit à la portée de toute la population arabophone.

Une fois traduit et après l'avoir présenté aux populations mauritaniennes, le gouvernement aurait pensé qu'il serait utile de le diffuser para la radio et c'est à ce moment que le responsable du Service d'information à la Radio de Mauritanie aurait été chargé de cette mission.

\section{2. 'Abd al-Wahhāb Wuld aš-Šaygir, traducteur ou scribe?}

16

Nous savons que Wuld aš-šaygir ${ }^{16}$, au moment où il a écrit (ou traduit?) le texte, était le directeur du Service des Informations, c'est la raison pour laquelle il semble que l'objectif était de diffuser le texte à la radio mauritanienne afin qu'il soit connu par le reste de la population que la délégation n'avait pas pu visiter. La couverture du manuscrit contient, outre le titre 'dustūr mūritān', la phrase suivante : naqalahu ${ }^{17}$ li-l-hassāniyya wa-Hatța-hu littașwīr wa-'ašrafa 'alà 'ixrāği-hi 'abd al-wahhāb aš-šaygir 'traduit en hassāniyya, manuscrit pour être polycopié et édité par 'Abd al-Wahhāb aš-Šaygir". Et à la fin du texte, au folio 18, il est écrit ce qui suit : katabahu ${ }^{18}$ bi-l-hassāniyya wa-tawalla tașhịha-hu wa-tașwīra-hu watab 'a-hu mudir mașlahat al-'anbā' al-mūrìtāniya as-sayyid 'abd al-wahhāb ibn aš-šaygir 'écrit en hassāniyya corrigé et polycopié par le directeur du Service des Informations de Mauritanie 'Abd al-Wahhāb ibn aš-Šaygir". Les verbes naqalahu et katabahu de ces deux énoncés semblent indiquer qu'il a écrit le texte en hassāniyya, mais pas qu'il l'ait traduit. Devant cette ambiguïté nous pouvons nous demander si c'était Wuld ǎs-Šaygir qui l'a traduit ou bien si c'était le Comité de rédaction cité plus haut qui s'était occupé de la traduction et Wul aš-Šaygir a agi en tant que scribe, et responsable, étant le directeur du Service des Informations de Mauritanie, de sa diffusion à Radio Mauritanie.

Sans trancher, on peut poser plusieurs hypothèses. La première est qu'il s'agit d'un travail commun entre l'historien et érudit MuHtāar Wuld Ḥāmidun, grand connaisseur de l'arabe classique et du hassāniyya dans sa dimension historique ${ }^{19}$ et Wuld aš-Šaygir et que ce dernier en serait le scribe et le chargé de sa diffusion à la radio. Une deuxième hypothèse est que la traduction soit l'œuvre du comité de rédaction ou de quelques-uns de ses membres avec une importante participation de Wuld aš-šaygir. Mais, dans l'état actuel de la recherche, il n'est pas aisé d'affirmer que 'Abd al-Wahhāb Wuld aš-Šaygir en soit le seul traducteur car le texte original en français a été rédigé par un comité. Il semble, par conséquent, raisonnable que la traduction soit aussi à la charge de plusieurs 
personnes, mais sans exclure, faute de preuve du contraire, que Wuld aš-šaygir en aurait été le traducteur.

Wuld aš-Šaygir, indépendamment d'être le scribe ou le possible traducteur du texte était le responsable des Services d'Information à la « Radio Nationale de Mauritanie ${ }^{20}$ ", radio qui joua un important rôle dans la politique du pays depuis sa création en $1958^{21}$ et pendant les premières années de l'indépendance. Elle porta la voix du nouvel Etat et sa réalité dans les régions et campagnes les plus éloignées du pays et participa ainsi au programme de l'éducation des masses. La Radio Nationale de Mauritanie s'occupa de diffuser, outre en français et un arabe (standard et dialectal), dans les langues nationales (wolof, halpoular, soninké) des programmes d'information et de formation pour les populations du pays. Malgré ses moyens très limités, elle s'occupa aussi de faire connaitre aux mauritaniens les symboles du nouvel État, à savoir, l'hymne national (musique et texte); les grandes questions nationales (faire face aux revendications du Maroc sur le pays $^{22}$; la diversité géographique et culturelle du pays; les événements nationaux les plus importants (inaugurations, visites des hôtes illustres, etc.), etc. C'est dans le cadre de cet ambitieux projet de Radio Mauritanie que se situe probablement la diffusion du texte officiel en hassāniyya de cette première constitution ${ }^{23}$. À ceci s'ajoute l'intérêt du parti politique de l'époque (le P. R. M..$^{24}$ de Ould Daddah) d'élargir sa liste d'adhérents au moyen de ce genre d'informations et de campagnes de sensibilisation. Tout en étant une question qui mérite d'être étudiée, ce qui importe à ce moment, c'est le manuscrit lui-même car il constitue - a priori- une importante découverte pour la dialectologie arabe.

\subsection{Le manuscrit}

Le texte traduit en hassāniyya et manuscrit comprend une couverture et 18 folios qui contiennent le texte intégral de la première constitution mauritanienne du 22 mars 1959.

Sur la couverture, il y a le cachet du Service des Informations appartenant à la Présidence du Conseil de Gouvernement de l'époque. Le texte comprend un préambule et 9 titres avec un total de 53 articles ${ }^{25}$.

La couverture contient le dessin d'un croissant et une étoile et un rectangle où figure en ḥassāniyya le titre :

مُورِيتَان دُسْتُور

'constitution de la Mauritanie'.

Et en arabe standard :

$$
\text { الشيكر الوهاب عبد إخراجه على واشرف للتصوير وخطه للحسانية نقله }
$$

21 Au folio 1, il y a un cachet en arabe standard avec le texte suivant :

$$
\text { الجمهورية الإسلامية الموريتانية رئاسة مجلس الحكومة ادارة الأنباء }
$$

'République islamique de Mauritanie - Présidence du Conseil de Gouvernement - Direction des Informations'.

Le reste des folios contiennent le texte intégral en hassāniyya.

23 À la fin du dernier folio, il y a le texte suivant en arabe :

عبد السيد الموريتانية الأنباء مصلحة مدير وطبعه وتصويره تصحيحه وتولى بالحسانية، كتبه الشيكر ابن الوهاب

'écrit en hassāniyya corrigé et polycopié par le directeur du Service des Informations de Mauritanie 'Abd al-Wahhāb ibn aš-šaygir'. 

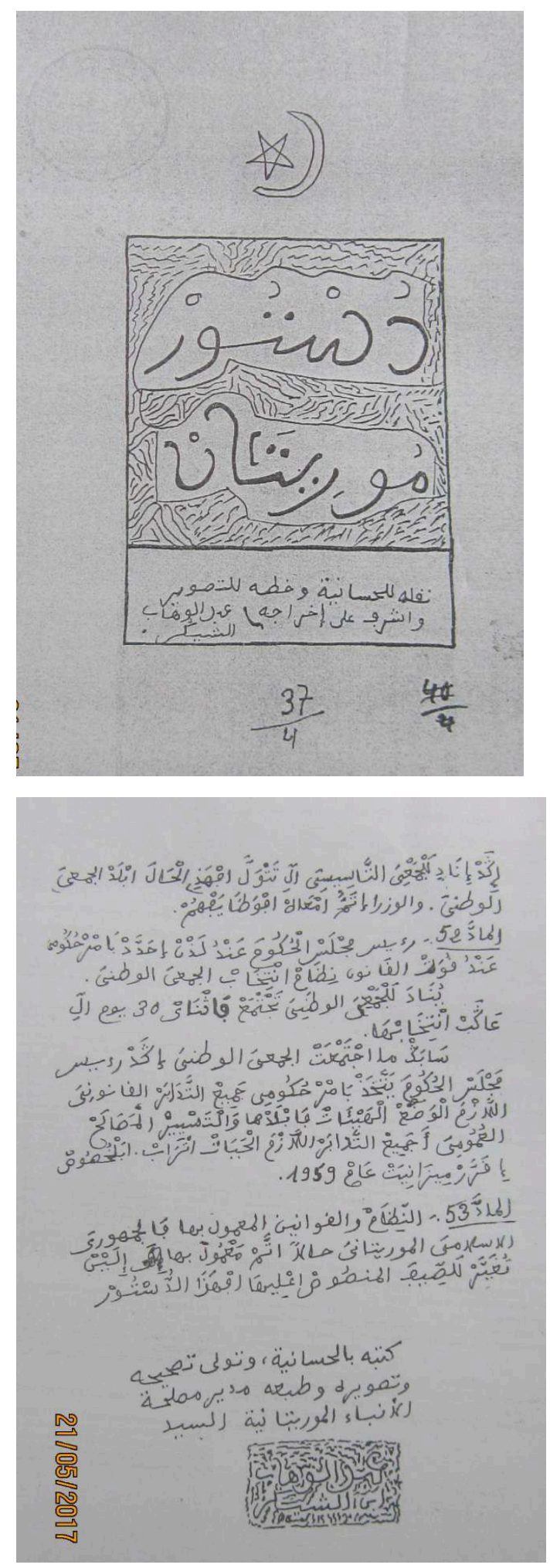

\section{Traits linguistiques du texte}

Le texte présente les traits linguistiques suivants :

a) Du point de vue de l'écriture : L'écriture de l'arabe dialectal pose des problèmes partout dans le monde arabe parce qu'il n'existe pas de code unifié, mais en hassāniyya, il 
y a eu plusieurs essais de codification notamment pour écrire la poésie populaire Ḥassān dont on trouve plusieurs recueils écrits comme signalé plus haut. Dans le cas du présent texte, le type d'écriture est maghrébin, car les graphèmes qāa et $f \bar{a}^{\prime}$ portent respectivement un point suscrit et un point souscrit. Elle appartient au genre utilisé chez les étudiants de certaines Mahadras mauritaniennes ${ }^{26}$.

Voici quelques éléments du code d'écriture utilisé en ḥassāniyya que l'on trouve dans le texte :

- Le phonème g est écrit avec le graphème S, exemple, كالزر 'suffrage', etc.

- La morphème du féminin, tā marbūṭa, n'apparait pas comme dans 'état';

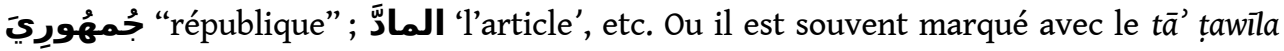

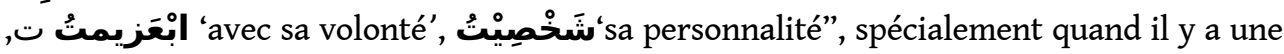

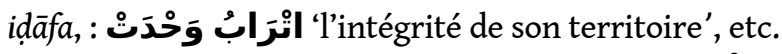

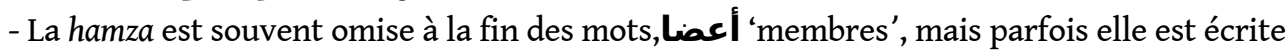
27, الأشياء 'les choses'.

\section{b) Du point de vue phonétique}

- Tout le texte, exception faite de quelques mots, est voyellé ce qui permet d'analyser les signes utilisés afin de les comparer avec ceux de la transcription :

- La fatha représente aussi bien le phonème a que le phonème $\theta$, exemple نَتْوَكَّلَ

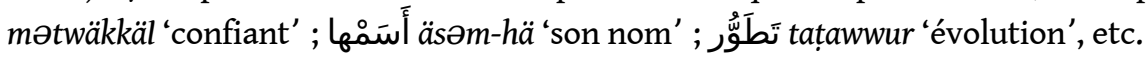

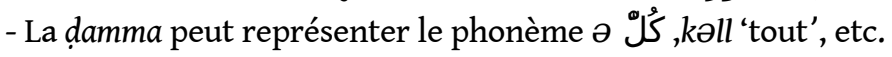

- La diphtongue /aw/ est écrite ainsi dans le texte, افطَوْر f-tawr 'dans l'étape'.

- Les groupes de deux consonnes consécutives à l'initiale (CC-) est indiqué généralement

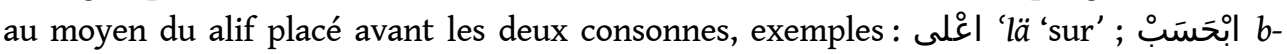
hasab 'selon', etc.

- Le groupe de consonnes (- CC) final est marqué au moyen d'une šadda avec sukūn,

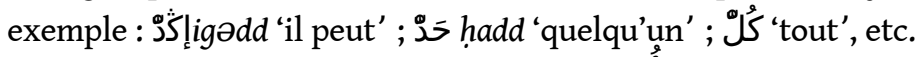

- La conjonction de coordination est écrite İ 'u devant consonne, exemple أُ أتامِينْ 'et la

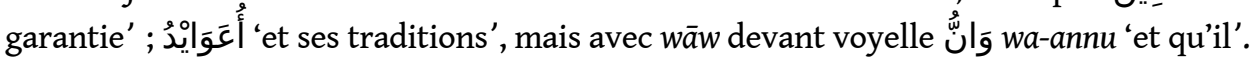

c) Quelques Aspects sémantiques et lexiques

En tant que premier texte légal écrit en dialecte hassāniyya, il représentait un défi pour le (s) traducteur(s). Néanmoins, son habileté et fidélité au texte français lui a permis de traduire le texte français en hassāniyya avec beaucoup d'exactitude en trouvant les expressions et les mots adéquats. Les termes juridiques ont été parfois traduits par des tournures et des paraphrases mūritān dawlä žumhūriyyä mā tnəqsäm 'la Mauritanie est un État républicain, indivisible'.

Par ailleurs, les traducteurs ont profité d'un grand nombre de mots appartenant au fonds lexical historique de ce dialecte formé par les mots spécifiques de la culture Ḥassān dans cette traduction. En voici ci-après quelques exemples :

la Communauté est traduite par əl-žăm'a; la moralité, par l-ädäb; välš '(question de) confiance' ; mälāmä 'motion de censure' ;'lām 'drapeau' ; šädd l-axbār 'les débats' ; təštädd l-axbār 'discuter'; əd-däwāyər tətwällä ämər-ha mäžāləs mahaliyyä 'les cercles s'administrent par les conseils locaux' ; hadd mn-ähl ət-träb 'citoyen” ; v-äyd-u 'il dispose', exemple : v-äydu l-idāra u-quwwāt l-ämn ə-dāxili 'il dispose de l'administration et des forces de sécurité intérieure' ; yubārk m'a ... 'il sera procédé à ...' ; tbäyyän žtihād-hä $v$-šhar wāḥəd 'elle doit se prononcer dans le délai d'un mois' ; zärg 'suffrage' ; mästūr 'secret' ; șāybä, (m. șāyəb) 'vacant ; libre'; yädən + pronoms suffixes 'certainement', exemple : yädənni nəštġal b-əș-șva... 'certainement, je servirai loyalement' ; mahadd + pronoms suffixes 
'pendant que .....', exemple: mā yəmkən l-ən-nəwwāb mahadd-hum v-ən-niyāba 'les députés pendant la durée de leur mandat' ; lä-'ād mqaddmu hadd mn-ən-nuwāb 'lorsqu'il est déposé par l'un des députés'.

Nous trouvons également l'usage de mots anciens qui ne sont plus utilisés aujourd'hui : əl-xāwa 'fraternité', (actuellement, on utilise 'uxuwwa); zärg 'suffrage; vote' (actuellement, on utilise tașwit) ; ət-ta 'lim l-äwwäl w-ət-țāni 'l'enseignement primaire et secondaire' (actuellement, on utilise ta' 'ìm ibtidà'i u-ta' lìm tāanawì par influence de l'arabe standard moderne), b-əș-șva 'loyalement' (actuellement, on utilice bi-wafä').

Après 60 ans, ce texte nous permet de voir l'évolution phonétique de quelques mots, par exemple: Le mot أُوخَرَxar telle qu'il est écrit se prononçait différemment de sa réalisation actuelle, äwxar.

Malgré la présence de nombreux emprunts au français en hassāniyya ${ }^{28}$, la traduction du texte de la constitution ne contient que les trois suivants : dä̉ira, särkäl ${ }^{29}$ 'cercle' ; muhāo đạa kummin 'commune' ${ }^{30}$; əl-bätānāt ${ }^{31}$ ( fr. patente) 'impôt' est utilisé isolément ce qui veut dire qu'il était pris pour un mot arabe. Cette absence d'emprunts peut s'expliquer par la recherche du plus pure hassāniyya afin d'attirer l'attention des citoyens sur cette nouvelle réalité qui est l'État souverain au moyen d'un langage simplifié et proche.

Il faut indiquer que le ou les traducteurs a/ont respecté le texte auquel il n'ont presque rien ajouté sauf quelques explications qui apparaissent entre parenthèses : (əz-zäg) pour expliquer at-tașwit; (māhi äkțäriyyət l-hāḍin mən-hul) pour expliquer qu'il s'agit uniquement de ceux qui son présents ; särkäl pour expliquer ad-dā'ira ${ }^{32}$ 'cercle' ; kumminn ${ }^{33}$ pour expliquer al-muhāfađađa 'commune'.

\section{Quelques échantillons du texte}

Voici ci-après le texte ${ }^{34}$ de l'article 41 du Chapitre V.

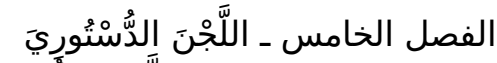

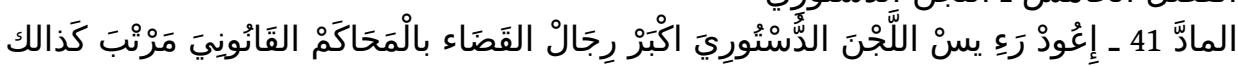
عُضْْوْ من رجال القُانون الإدَارِي؛ عضو إعِيْنُ الوزير لَوَّلٌْ؛

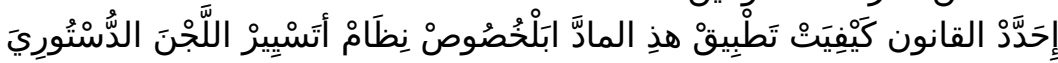

TITRE V De la Commission constitutionnelle

Article 41.- La Commission constitutionnelle est présidée par le plus haut magistrat de l'ordre judiciaire. Elle comprend en outre :

- Un membre des juridictions de l'ordre administratif ;

- Un membre nommé par le Premier Ministre ;

- Un membre nommé par le Président de l'Assemblée Nationale ;

- Un professeur des facultés de droit ;

La loi détermine des modalités d'application du présent article et notamment les règles d'organisation et de fonctionnement de la Commission Constitutionnelle. 


\section{Conclusions}

Nous pouvons au vue de cette traduction du texte de la première constitution mauritanienne de 1959 faire les réflexions suivantes :

Le dialecte hassāniyyä, en se complétant avec un apport du lexique de l'arabe standard, a démontré qu'il est capable d'accueillir un texte légal long comme celui de cette constitution. Ceci démontre que le dialecte peut profiter de l'arabe des mahadras (anNaḥwī 1987: 53) ${ }^{35}$ mauritaniennes où beaucoup de termes d'arabe classique étaient utilisés quotidiennement dans les explications des différentes matières enseignées et ce pour élargir les possibilités d'expression comme cela a été le cas ici. L'usage de l'arabe classique en code-switching avec le hassāniyyä est, depuis longtemps, habituel dans les milieux scolarisés et même en poésie populaire. C'est dans ce niveau/registre de langue que le ou les traducteur/s a/ont puisé beaucoup de mots et d'expressions pour cette traduction.

La décision prise par les premiers responsables du nouvel Etat mauritanien de traduire le texte de la constitution en hassāniyyä démontre qu'il y avait -a priori- la volonté de la faire connaitre au peuple mauritanien dans sa langue maternelle.

\section{BIBLIOGRAPHIE}

Booth, Marilyn. 1992. "Colloquial Arabic poetry, politics, and the press in modern Egypt", International Journal of Middle East Studies 24-3, 419-440.

Corriente, Federico. 2013. Dīwān Aban quzmān al-qurțubi « 'Ișābat al-'agrrāẹ fi dikr al-'a'rāạd » 'imām az-zağğālin al-mutawaffà sanat 555 hiğrī= 1160 mìlādī. Taḥqīq fīdīrīku kūrriyantī. Rabat: Dār Abī raqrāq li-ț-ṭibā'a wa-n-našr.

Hammām b. Muḥammad b. al-Muxtār. 1978. Dīwān Hammām. Nuakchott: Maṭba'at aš-šarika almūrītāniyya li-ṣ-ṣahāâa wa-ț-țibā'a.

An-Naḥwī, Hูalīl. 1987. Bilād Šinqịt. al-manāra wa-r-ribāṭ. Tunis. Al-munađ̣amma al-'arabiyya li-ttarbiyya wa-ț-taqāfa wa-l-'ulūm.

Ould Bouboutt, Ahmed Salem. 1989 «L'évolution des institutions de la République Islamique de Mauritanie ", Revue du monde musulman et de la Méditerranée ํำ54, p. 131.

Ould Hamidoune, Moktar. 1952. Précis sur la Mauritanie. Saint-Louis : Centre IFAN-Mauritanie.

Ould Daddah, Moctar. 2003. La Mauritanie contre vents et marées. Paris : Karthala.

Ould Mohamed Baba, Ahmed Salem. 2003. “Emprunts du hassāniyyä au français : Lexique des institutions, produits manufacturés, marques et ustensiles inconnus pour les nomades (aspects morphologiques et sémantiques)", Ferrando, Ignacio \& Sánchez Sandoval, Juan José (éds). AIDA $5^{\text {th }}$ Conference Proceedings, Cádiz: Servicio Publicaciones Universidad de Cádiz. 61-74. 
Ruiz de Cuevas, Teodoro. 1977. Apuntes para la historia política de África. II. Estados saharianos. Tomo VI. Mauritania. Madrid : Ministerio de Asuntos Exteriores. Dirección General de Asuntos Culturales.

Wuld Aḥmad Sālim, Sīd Aḥmad et alii (éds.). 1996. Saddūm wuld Ndartu (1122-1710/1227-1812) Dīwān $a \check{s}$-ši $r$ r aš- $\bar{a}$ ' $b \bar{b}$. Nouakchott. Institut Mauritanien de Recherche Scientifique.

Wuld Ma' lūm Wuld Zarrūq, Sīd Aḥmad. 2007. Dīwān 'Abd Allāh Wuld A'mar al-'Abyayarī (m. 1936). Nuakchott: Polycopié.

\section{NOTES}

1. Quelques mois après, le 20 mai 1961, une deuxième constitution est écrite.

2. Je remercie le Professeur Elemine Ould Moustapha de m'avoir proportionner la copie du présent manuscrit.

3. «Colloquial Arabic poetry is a centuries-old practice with its earliest preserved written attestation in medieval Andalusia ».

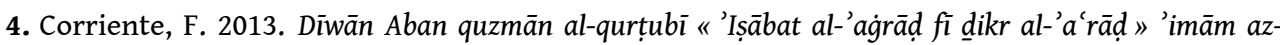
zağğālīn al-mutawaffà sanat 555 hiğrī = 1160 mìlādì. Taḥqīq fīdīrīku kūrriyantī. Rabat : Dār Abī raqvāq li-ț-țibā'a wa-n-našr.

5. Wuld Ahmad Sālim, S.-A et alii (éds.). 1996. Saddūm wuld Ndartu (1122-1710/1227-1812) Dīwān ašši'r aš-ša bì. Nouakchott : Institut Mauritanien de Recherche Scientifique.

6. Parmi les recueils de poètes hassān publiés : Hammām b. Muhammad b. al-MuHtāā. 1978. Dīwān Hammām. Nuakchott: Maṭba'at aš-šarika al-mūrītāniyya li-ṣ-șahāfa wa-ț-țibā'a ; Wuld Ma'lūm Wuld Zarrūq, S-A. 2007. Dīwān 'Abd Allāh Wuld A'mar al-'Abyayarī (m. 1936). Nuakchott : Polycopié. 7. V. Wuld As-Sa'd, M. 2002.Imārat at-Trārza wa-'alāqātuhā at-tiḡāriyya wa-s-siyāsiyya ma'a alfaransiyyīn min 1703 ilà 1860. Rabat: Ma'had ad-dirāsāt al-'ifrīqiyya, p. 12.

8. Xavier Coppolani (1866 - 1905) fut le premier Commissaire du Gouvernement général en Mauritanie. V. Désiré-Vuillemin, Geneviève. 1962. Contribution á l'histoire de la Mauritanie 1900-1934. Dakar : Éditions Clairafrique, pp. 89-151.

9. V.Ould Hamody, Mohamed Saïd. 1993. "Mauritanie : le face à face pluriséculaire avec l'Europe (1415-1960)", Attaalim no 24, p. 64.

10. Désiré-Vuillemin, Geneviève. 1962. Contribution á l'histoire de la Mauritanie ..., op. cit. p. 94.

11. Désiré-Vuillemin, Geneviève. 1962. Contribution á l'histoire de la Mauritanie..., op. cit. P. 95.

12. Le territoire devient un protectorat sous le nom des pays mauritaniens du bas Sénégal par decret datant du 12 mars 1903 du Ministère des Colonies.

13. Ould Bouboutt, A. S. 1989. "L'évolution des institutions de la République Islamique de Mauritanie", Revue du monde musulman et de la Méditerranée nํ5 54 (1989/4), p. 131.

14. “... le 15 janvier 1959, première reunion du Comité consultatif constitutionnel, dont les membres avaient été désignés par le Gouvernement et pour moitié des membres désignés par l' Assemblée constituante. Lors de cette réunion, il élit son bureau: Ahmed Ould Aïda, président, ;Yahya Kane, vice-président ; Mohamed Moktar, dit Marouf, rapporteur ; Dembelé Tiecoura, rapporteur adjoint. Le lendemain était pareillement élu son comité de rédaction: professeur Ould Hamidoun ; Mohamed Moktar, dit Marouf ; Bouna Moktar ; Dembelé Tiecoura ; professeur Seurin ; Yahya Kane et Abdel Wahab Ould Cheïguer.

15. "Le 21 janvier [1959], le Gouvernement mis au point le programme de la tournée de présentation du projet de constitution au peuple mauritanien à travers tout le pays. De fait, du 11 au 23 février, une délégation composée de Sidiel, de Moktar Ould Hamidoun, rapporteur du projet, et moi-même visita tous les chefs-lieux de cercle". 
16. Ould Daddah (2003 : 184) mentionne le nom de Ould Cheïguer comme membre du Comité Consultatif constitutionnel et membre de son comité de rédaction.

17. naqalahū, litt. : "il l'a copié".

18. katabahū litt. : "il l'a écrit".

19. Dans ce sens, il faut signaler ses collaborations avec le Centre IFAN Mauritanie où il publia son ouvrage Précis sur la Mauritanie, Centre IFAN-Mauritanie, Saint-Louis, 1952.

20. La "Radio Nationale de Mauritanie", créée le 27 juin 1958 à Saint Louis d'où elle émettra plusieurs années, fut transférée à Nouakchott le 1er janvier 1962. Elle avait pour mission, entre autres, l'éducation des masses à travers ses programmes de divulgation. Selon le document (ws/0861/88) publié le 11 août 1961 par l'UNESCO, il y avait 2 émetteurs de $250 \mathrm{kw}$ à Nouakchott et 2 émetteurs de 4 et $1 \mathrm{kw}$, à Saint-Louis.

21. Selon le témoignage de l'un des premiers speakers mauritaniens qui commença à travailler dès la création de Radio Mauritanie, il y avait un bulletin d'information en hassāniyya pour informer des activités du gouvernement et donner des conseilles d'hygiène aux populations.

22. Il y avait un programme de Radio Mauritanie qui neutralisait la campagne menée par 'Allāl al-Fāsi réclamant le territoire mauritanien.

23. La radio mauritanienne avait un bulletin d'information radiodiffusé quotidiennement dont des fragments se trouvent en ligne: exemple: inauguration de la première mosquée de Nouakchott https://www.youtube.com/watch ?v=28YaHzgrOfQ; https://www.youtube.com/ watch ?v =tN9fWRg37yc) ;

24. Le Parti du Regroupement Mauritanien (P. R. M.) de Moctar Ould Daddah qui deviendra plus tard le Parti du Peuple Mauritanien (PPM, parti unique).

25. La deuxième constitution du 20 mai 1961, en comparaison avec la première, comprend un préambule 9 titres et un total de 60 articles.

26. Ce genre diffère du type que l'on peut dénommer écriture anadalouse-šinqītīi utilisée souvent au Trārza.

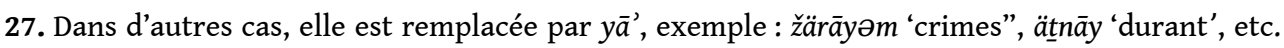
ou par wāw, exemple : wäkkäd 'il affirme'.

28. V. Ould Mohamed Baba, A. S. 2003. «Emprunts du ḩassāniyyä au français: Lexique des institutions, produits manufacturés, marques et ustensiles inconnus pour les nomades (aspects morphologiques et sémantiques) ", in AIDA $5^{\text {th }}$ Conference Proceedings, Cádiz, 2003. Dans cet article, nous en avions signalé 266 dont beaucoup sont anciens.

29. V. Ould Mohamed Baba, A. S. 2003. « Emprunts du ḥassāniyyä au français..., op. cit. p. 63.

30. L'usage de ces emprunts démontrent qu'ils étaient déjà intégrés à l'époque plus que les deux mots d'arabe standard, dā'ira et muhāvađạa. V. infra.

31. V. Ould Mohamed Baba, A. S. 2003. « Emprunts du ḩassāniyyä au français..., op. cit. p. 63.

32. Le mot arabe ad-dā'ira est suivi de mot särkal mis entre parenthèses ce qui indique que ce dernier était bien connu et le premier ne l'était pas autant.

33. Le mot arabe al-muhăfađạa "commune" est suivi de mot kummin mis entre parenthèses ce qui indique que ce dernier était bien connu et le premier ne l'était pas autant.

34. En écriture maghrébine, le $q \bar{a} f$ et le $f \bar{a}$ ' portent respectivement un point suscrit et un point souscrit, mais nous n'avons pas la possibilité de les écrire ainsi pour des raisons informatiques.

35. Voici la définition de la maḥaḍra selon an-Nahwīi : المحضرة جامعة شعبية، بدوية، متنقلة، تلقينية، فردية التعليم، طوعية الممارسة 


\section{RÉSUMÉS}

En 1958, la Mauritanie devint une république autonome et se dota une année plus tard, le 22 mars 1959, d'une première constitution. Le pays obtint son indépendance de la France le 28 novembre $1960^{1}$. Le texte de la première constitution fut traduit du français en hassāniyya et conservé dans un manuscrit inédit ${ }^{2}$ jusqu'à ce jour. Il semble que le texte fut traduit en hassāniyya afin qu'il soit connu par toute la population arabophone dans sa langue maternelle, le hassāniyya. Le texte fut manuscrit par Abdel Wahhab Ould Cheïguer en tant que membre du Comité de Rédaction de la constitution. L'article présente un historique des conditions socio-politiques dans lesquelles le texte fut traduit en hassāniyya et analyse les principaux traits linguistiques de ce texte juridique écrit en dialecte ; le code de l'écriture du texte dialectal et le vocabulaire hassāniyya utilisé pour rendre les termes juridiques ainsi que quelques échantillons du texte.

INDEX

Mots-clés : Mauritanie, dialectologie arabe, Hassāniyya, Manuscrits et textes juridiques écrits en dialecte ḥassāniyya

\section{AUTEUR}

\section{AHMED SALEM OULD MOHAMED BABA}

Université Complutense de Madrid 


\title{
Euphémisme et/ou violence verbale féminine. Sur le comportement langagier de jeunes filles cairotes
}

\author{
Sherin Rizk
}

\section{Introduction}

1 Cet article présente les grandes lignes d'une étude sociolinguistique comparative, mais dû à la nature de cette conférence je ne présenterai que des exemples de la langue «arabe ». Les enquêtées françaises ne seront mentionnées que pour des buts comparatifs. J'ai mené une enquête en 2003 / 2004 auprès de jeunes étudiant(es) cairotes sur les procédés de formation du langage des jeunes et les attitudes sociolinguistiques à son égard (Rizk 2007). J'ai conclu que l'aspect du lexique perçu comme agressif et inapproprié pour une fille a causé une forte stigmatisation de celles qui utilisaient ce langage. Cela explique pourquoi peu de mes enquêtées à ce temps-là se sont affichées comme usagers de ce langage même si elles l'utilisaient effectivement. C'est ainsi que mon intérêt s'est dirigé vers le lien violence verbale et femmes cherchant à répondre à ces questions : Est-ce que les filles ont recours à un langage poli et euphémique ou peut-on parler de "violence verbale féminine" ? Et si les filles adoptent un langage "violent», partagent-elles les mêmes catégories de violence verbale avec les jeunes garçons?

\section{1. «Gender studies » et différences sexolectales}

2 L'hypothèse de la politesse du langage des femmes liée au début au nom de Labov (1966, 1976) était reprise par beaucoup d'études linguistiques de différentes langues. Elle parle d'un langage féminin plus normé, plus poli et plus conservateur que celui des hommes. Pour comprendre les facteurs qui régissent le comportement langagier des femmes, j'ai classé les différentes interprétations apportées à cette hypothèse en 3 catégories. Cette classification différente de celle présente dans quelques ouvrages clefs sur la variation sexolectale (Cameron 1995, Bucholtz 2004) me parait plus représentative des études 
effectuées sur la question. La première interprétation adoptée par Labov $(1966,1976)$ et Robin Lakoff (1975) mais également par beaucoup d'autres linguistes parle de l'insécurité sociolinguistique des femmes et de leur subordination sociale et économique surtout celles qui ne sont pas entrées sur le marché du travail. Ce peu de pouvoir qu'elles ont dans la société les poussent à adopter un langage très poli et plus proche de la norme comme stratégie de mobilité sociale. La deuxième interprétation trouve les femmes biologiquement plus développées que les hommes en ce qui concerne les fonctions linguistiques, c'est pourquoi leur langage est plus normé et plus poli que celui des hommes (Chambers 1995). La troisième, particulièrement utile dans mon analyse, était celle de la différence socioculturelle. Selon cette interprétation, il y a une différence de comportement communicatif et éducatif de la part des parents envers les enfants selon leur sexe. Cette éducation parentale fait écho à des pressions sociales qui favorisent cette différence sexolectale (Maltz et Borker 1982, Tannen 1986). Qui n'était pas témoin, sinon producteur, d'énoncés comme «ne pleure pas comme une fille, ne crie pas comme un garçon, parle bien et ne dis pas de gros mot t'es une fille ».

\section{Collecte des données (2014 - 2015)}

3 J'ai collecté premièrement des données sur le journal du Facebook de certain(e)s internautes en me reposant sur la méthode d'observation participante. Ensuite en utilisant ces données j'ai formé un guide d'entretien composé de "déclencheurs". Ces questions semi-directives accompagnées de citations, d'images ou même de vidéos ont " déclenché » des débats incitant les enquêté(e)s à parler en favorisant les confrontations discursives entre eux. A travers ce guide d'entretien, mes assistantes techniques ont enregistré elles-mêmes leur groupe d'ami(e)s, en s'appuyant sur la technique de "sessions de groupe» (Gumperz 1989). Cette technique permet de collecter des conversations assez authentiques puisque la chercheuse n'est pas présente lors de l'enregistrement. Un des déclencheurs a permis d'étudier l'évaluation de l'enquêté(e) de son propre comportement linguistique en indiquant s'il utilise ou non telle ou telle expression. De plus, l'enquêté(e) devrait ajouter si telle expression est plus dite par une fille ou par un garçon, ce qui a permis d'étudier les attitudes sociolinguistiques et les attentes sociales à l'égard de ces pratiques langagières. Le guide d'entretien contenait également des questions sur le point de vue des enquêtés sur les femmes usagers de ces pratiques langagières "violentes ", l'éducation sociolinguistique des filles et des garçons, le rôle du cinéma et des médias dans la diffusion ou la création de ce genre de violence verbale et le taux de liberté d'expression dans les médias sociaux comme Twitter et Facebook. Mon troisième genre de corpus était un questionnaire qui copiait en quelques sortes le guide d'entretien sous forme de questions fermées pour faciliter le traitement des données avec un logiciel statistique comme SPSS (Statistical Package for the Social Sciences).

\section{Catégories de violence verbale}

4 «L'euphémisme est la manifestation d'un tabou » (Tournier 1985: 261). Il parait comme une phase intermédiaire entre ce qui est dit et ce qui n'est pas dit. Cette manière de voiler le signifiant perçu comme choquant laisse apparaitre un de ses éléments permettant de le décoder par l'interlocuteur intégré. Et comme l'affirment D. Jamet et M. Jobert 
«l'euphémisme se situerait donc clairement du côté de la politesse linguistique » (2010 : 17). Cela le met de l'autre extrémité de la violence verbale. C'est pourquoi je ne pouvais pas étudier la violence verbale séparément de l'euphémisme. J'ai pris appui sur l'analyse des catégories de violence verbale de Pierre Guiraud (1975), qui a classifié les gros mots en blasphèmes, sexe et excréments. J'ai ajouté une quatrième catégorie que j'ai appelée dégradation de l'autre et qui comprend toutes assimilations animalières et toutes imperfections physiques et morales. Pour faciliter l'analyse des données, les énoncés étaient présentés dans le guide de l'entretien sous une forme dichotomique : l'expression ou le mot tabou et son euphémisme. Je ne présenterai ici que deux exemples de chaque catégorie.

\subsection{L'euphémisme détourne-t-il le blasphème?}

Maudire les parents ainsi que les morts est un blasphème dans la religion islamique. Dans le guide d'entretien arabe, sont conçus comme blasphématoires les énoncés yel'an abū elli $g \bar{a} b a-k$ (littéralement $=$ que Dieu maudit le père de celui qui t'a engendré) et lāzem teštem fi maîtin om el-fēlm (littéralement = devrais-tu insulter les morts de la mère du film). L'expression maitīn est souvent utilisée par aphérèse du juron yel'an maitin = maudit soit les morts de... Lors des enregistrements, les enquêtées nient tout recours à ce genre de blasphèmes, selon elles, «violent » et donc «masculin ». De même, l'expression dīn abū n'est que l'abréviation du juron yel'an din abu (= maudit soit la religion du père de...). Cette expression abrégée subit un processus d'euphémisme par substitution du $/ \mathrm{n} /$ en $/ \mathrm{k} /$ pour donner dỉk abū. L'expression, même sous sa forme euphémique, est conçue par nos enquêté(e)s comme un usage linguistique masculin.

\subsection{La dégradation de l'autre, entre violence et connivence}

6 À chaque société ses normes et ses idéologies. De plus, une même comparaison peut avoir un sens ambivalent au sein du même groupe. Comparer quelqu'un à des chaussures est injurieux que ce soit en arabe dialectal ou en français. Pour certains usagers, la même insulte, ainsi que beaucoup d'autres, peuvent être une marque d'affection et de connivence si elles sont adressées à quelqu'un du groupe. Dazma est l'euphémisme de gazma (= chaussure), par déformation formelle en substituant $/ g / \mathrm{par} / \mathrm{d} /$. Le locuteur tend ici à atténuer le mot pour marquer la connivence et ne laisser aucune équivoque. L'usage fréquent de cet euphémisme peut être lié au film "jeune " șeî̀ili fi-l-gām'a elamrikia (1998). Le héros prononce l'insulte de cette manière à cause de son origine șaîîi (c.-à-d. provenant de la Haute Égypte). Nos enquêtées admettent l'usage de l'insulte euphémisée pour un but ludique avec des personnes très proches. Elles lient le recours à cet euphémisme à un autre film "jeune » el-lembi (2002) qui, en fait, a été beaucoup critiqué à cause du langage utilisé par le héros. C'est un simple exemple du rôle que jouent le cinéma et les médias en général dans la légitimation de l'usage d'un tel langage.

Malgré son effet injurieux, nous pouvons entendre l'expression ebn el-kalb (=fils du chien) dans beaucoup de films arabes et de séries télévisées. Mais cela n'empêche que certains cherchent à réduire l'effet "violent » en altérant les phonèmes /b/ et /l/ ebn el-kābl (littéralement= fils de câble ». On doit se demander si la présence de cette expression verlanisée dans la série théâtrale télévisée tiātrū mașr (2014) est celle qui a entamé cet usage ou au moins a contribué à sa diffusion. Un autre moyen pour atténuer l'expression 
ebn el-kalb est d'utiliser l'emprunt anglais puppy (= petit du chien) prononcé en arabe būbì comme dans l'énoncé euphémique ebn el-būbī. L'emprunt en général permet d'atténuer l'effet «tabou » d'un mot surtout s'il provient d'une langue considérée par la société en question comme plus élégante et plus raffinée (Chamizo-Dominguez 2005). Tous nos enquêtés soulignent qu'il s'agit d'un terme à usage féminin. Nos observations ethnographiques variées attestent la présence d'une version utilisée plus par les hommes : welād ed-dog.

\subsection{La scatologie : gros mots et euphémismes}

Dans la catégorie scatologie, le mot Harā (=merde) est le Tabou par excellence. Harā occupe les mêmes fonctions diverses que son équivalent français merde. Ce gros mot qui réfère à la matière fécale peut être utilisé comme une interjection qui marque la dépression et le mécontentement comme dans l'expression Harā es-senin (littéralement = merde des années). Et il devient une insulte dès qu'il vise à qualifier quelqu'un pour lui montrer qu'il est sans valeur enta hetet Harā (littéralement = tu es une espèce de merde). Nos enquêté(e)s affirment l'usage masculin du terme.

Bïbī référant à l'urine est la prononciation arabe du mot français pipi. Il peut également être un redoublement de l'emprunt anglais monosyllabique pie. Cet euphémisme appris à beaucoup d'enfants égyptiens est dit aisément depuis longtemps dans beaucoup de films d'où l'usage mixte attribué au terme. Il faut dire qu'en préparant le guide de l'entretien, j'avais choisi de ne pas y insérer l'équivalent non euphémique yešoH (= uriner) malgré l'avoir rencontré maintes fois lors de la collecte du corpus ${ }^{1}$. Or, j'étais étonnée d'entendre l'héroïne du film wāhed şahịh (2011) dire anā Harā (=je suis une merde) et abū šaHa (littéralement = le père du pipi c-à-d. celui qui a fait le pipi) pour parler de quelqu'un sans valeur. Cette expression dégrade l'autre en laissant entendre qu'il est idiot et immature comme un enfant qui a mouillé sa culotte. On peut entendre d'autres termes violents dans la bouche des acteurs du film. L'effet sur le spectateur est fort surtout que ces derniers jouent le rôle de personnes très riches, adorables et réussies.

\subsection{Le sexe: tabou des tabous}

10 Attaquer l'honorabilité de la mère de quelqu'un est la forme la plus crue de l'insulte. En Egypte, qualifier la mère de quelqu'un de wesHa (= sale) c'est l'accuser d'être une femme sale qui cherche sans cesse son plaisir sexuel. L'adjectif présent dans différents énoncés garde son aspect érotique désignant ou non une certaine femme. Cela explique pourquoi les enquêté(e)s lui attribuent un usage masculin, surtout dans l'expression weläd el-wesHa équivalente à fils de pute. Pour certaines personnes, wesHa est devenu un adjectif presque tabou chargé de cet aspect érotique du sens figuré. Ces personnes optent pour la litote meš nedîfa (= qui n'est pas propre) pour éviter l'adjectif wesHa. Cette substitution sémantique devient pour certains usagers un euphémisme de prostituée. Ainsi l'expression ebn el-mara ellī meš neḍifa (littéralement= fils de la femme qui n'est pas propre), énormément utilisée sur la toile, est l'équivalent de fils de pute. Un autre moyen d'atténuer l'aspect violent et érotique de l'adjectif wesHa est d'utiliser son emprunt anglais dirty. Fils de pute devient donc ebn el-mara ed-dirtĩ. Ici, l'emprunt ne cherche pas vraiment à préserver la face de l'autre atteinte par le sens même de l'expression mais il préserve la face du locuteur même. Ne voulant pas être stigmatisé et jugé comme 
vulgaire, on a recours à l'emprunt pour montrer qu'on est assez cultivé faisant partie de l'élite qui utilise cette langue "élégante». Nos enquêtés trouvent que l'énoncé où apparait l'adjectif emprunté dirty est plus utilisé par des filles que par des garçons.

\section{Néologisme : bīp, tīt, no'aṭ ...euphémismes passe- partout}

11 Avant de passer aux résultats de l'enquête, il est intéressant de savoir que les jeunes égyptiens ont créé un néologisme euphémique que nous considérons «passe-partout»: tit équivalent à bīp en France. Ce néologisme est une onomatopée évoquant un son utilisé souvent dans les médias pour censurer un mot ou un énoncé conçu comme vulgaire ou choquant. Certains euphémismes acquièrent le même aspect tabou des expressions qu'ils remplacent. Leur usage est donc parfois évité par certains locuteurs comme tá rị̣, dỉk, ... A l'encontre de ces euphémismes, tìt et bīp paraissent comme des euphémismes neutres, qui préservent la face du locuteur et de l'interlocuteur en même temps. Cela explique l'usage fréquent de tit par les deux sexes selon nos enquêtées. No'at est un euphémisme pareil. C'est une production orale de signes typographiques (astérisques ou points de suspensions) utilisés souvent par des internautes comme procédé euphémique pour camoufler complétement ou partiellement un mot. Cet euphémisme est le titre d'une chanson de Ramy Essam connu parmi les jeunes comme un des emblèmes révolutionnaires à cause de la nature de ses chansons. Les lexèmes remplacés par no'at no'at varient chaque couplet. Par exemple, dans un des couplets il chante we tetalla' $\bar{u}$ no'at no'at ahalīn $\bar{a}$ (littéralement = vous faites sortir point point nos parents). Un interlocuteur natif initié pourrait facilement comprendre que les points remplacent din (= religion). Il s'agit donc ici de camoufler l'énoncé blasphématoire yetala din (pousser quelqu'un à renoncer à la religion). Nous trouvons ce genre d'euphémisme «interactif » dans la mesure où il appelle l'interlocuteur à remplir les espaces vides.

\section{Résultats}

Les résultats de l'enquête quantitative (comprenant 58 répondants dont 34 sont des femmes) font échos à ceux de l'enquête qualitative (basée sur 5 heures d'enregistrement avec 19 enquêtés, 16 femmes et 3 hommes). Les enquêtes montrent que les femmes insultent tout comme les hommes, même si cela est à plus basse fréquence. De plus, le recours à l'euphémisme comme stratégie de politesse n'est pas exclusif aux femmes même si elles le privilégient. Comme on peut le voir également sur ce tableau le taux d'usage des filles d'une catégorie de violence verbale et une autre diffère dans les deux sociétés (française et égyptienne), ce qui est logique puisque chaque société a ses propres tabous (tableau 1).

Une des conclusions de ces enquêtes est que les filles égyptiennes tendent plus à camoufler le mot tabou, soit par emprunt soit par substitution formelle ou sémantique, tandis que les enquêtées françaises cherchent à amoindrir l'effet des gros mots à travers la forme impersonnelle (dire par exemple ça me fait chier au lieu de tu me fais chier) ou par le passage d'une catégorie de violence verbale à une autre (dire par exemple fils de chien au lieu de fils de pute). De plus, les filles françaises éprouvent la nécessité d'accommoder leur langage selon la relation qu'elles ont avec leur interlocuteur tandis 
que les filles égyptiennes tendent plus à changer leur langage selon le sexe de l'interlocuteur plutôt que leur relation avec lui. J'ai prouvé également que le taux d'usage des énoncés euphémiques augmente lors des conversations mixtes comparativement à une augmentation du taux d'usage d'énoncés non euphémiques lors des conversations unisexes cela en France tout comme en Egypte. Ce qui permet de conclure que l'euphémisme est un facteur important d'accommodation, dans la mesure où il permet aux locuteurs de modifier leur production en fonction du sexe de leur interlocuteur.

\section{Construction de l'idéologie linguistique}

D'après l'analyse, trois facteurs ont une influence directe sur le langage des filles et contribuent à expliquer le recours de certaines jeunes filles à des pratiques langagières marquées. Prenons un par un.

\section{1. Famille, école et attentes sociales}

15 À travers la famille et l'institution scolaire, les filles apprennent les normes sociolinguistiques prescrites pour leur sexe et apprennent également que celles qui ne suivent pas ces normes risqueront d'être stigmatisées. Cette recherche prouve que l'usage de la violence verbale est partagé par les femmes et les hommes. L'apport de cette recherche est qu'elle montre que la différence réside sur le plan idéologique plutôt que linguistique. Tous les enquêtés français se sont montrés prêts à adopter la même éducation pour leurs enfants quel que soit leur sexe alors que la moitié seulement des enquêtés égyptiens adoptent ce point de vue. Le reste des enquêtés égyptiens trouvent nécessaire d'éduquer les filles différemment des garçons. Il s'agit donc d'un changement d'attitudes sociales à un degré plus élevé en France qu'en Egypte. Ce sont 31, $58 \%$ des répondants hommes comparativement à $76,92 \%$ des répondantes femmes qui encouragent cette éducation non discriminatoire. Cet écart entre les 2 chiffres montre une volonté très ferme de la part des femmes égyptiennes à changer cette idéologie sociolinguistique dominante. Selon elles, cette éducation est injuste puisqu'elle ne cherche pas à contrôler le flux de gros mots dans la bouche des garçons, tandis que l'usage d'énoncés violents par une fille met en risque sa réputation. En ce sens, une étude sur les différences de comportement communicatif des parents selon le sexe de leur enfant semble intéressante surtout dans le monde arabe où ces recherches sont rares si elles ne sont pas absentes.

\subsection{Prestige latent et fréquentation}

16 Cette recherche montre qu'en Egypte tout comme en France, les jeunes femmes qui ont recours à des mots socialement conçus comme violents, le font pour des buts ludiques mais aussi identitaires. Certaines enquêtées ont admis avoir recours à de telles pratiques langagières violentes par provocation. Elles cherchent à bouleverser ces normes et ces représentations sociales déjà établies. Ces pratiques langagières violentes sont leur moyen d'éprouver des liens de complicité avec les membres du groupe de pairs (Nous/ Nous) (ce que R. Nicolaï (2000) appelle clôture positive) et en même temps elles se démarquent du groupe de l'autre que constituent l'école et la famille (Nous/ Eux) (clôture négative). Cela explique pourquoi on trouve des jeunes filles et garçons qui utilisent entre 
eux des termes injurieux sans troubler la conversation comme entī ya gazma wahaštinī en Egypte ou le fameux « t'es con » en France. Toutes pratiques langagières hors-norme ont ce que Labov appelle un prestige latent qui les associent à des valeurs de solidarité, d'humour et de franchise. C'est pourquoi je n'étais pas étonnée quand mes enquêtées françaises et égyptiennes ont affirmé être plus à l'aise avec les garçons trouvant les conversations plus directes, simples et pleines d'humour. J'ai conclu que cette fréquentation mixte est en corrélation directe à l'usage de pratiques langagières violentes par les filles. En d'autres termes, plus une fille a des amis garçons, plus elle a recours à des pratiques langagières violentes.

\subsection{Médias : légitimation et homogénéisation}

17 L'une des conclusions de cette recherche est le rôle des médias dans la transformation de la culture juvénile en culture générationnelle. Et ce rôle semble être plus évident en Egypte qu'en France. La diffusion d'un terme «tabou» dans les films et les différentes émissions télévisées donne une sorte de légitimation à son usage et transmet ces pratiques langagières à toutes les classes sociales, de tout sexe et de tout âge, ce qui crée une sorte d'homogénéisation de la langue. Ainsi les filles utilisent les pratiques langagières violentes autant que les garçons et les couches cultivées commencent à s'approprier les particularités du parler des couches modestes de la population dans le but de paraitre «franc, spontané et sans façons » (Dubois 1994 : 372). Je me permets alors de parler d'un changement en cours où le prestige latent de ces pratiques langagières hors normes devient en quelques sortes un prestige ouvert, déclaré. Il serait intéressant de mener une recherche étudiant ce changement en cours. Les jeunes usagers de pratiques langagières particulières étaient présentés dans le cinéma des années quatrevingt et bien avant comme délinquants et en échec scolaire. De nos jours, le cinéma présente les jeunes de ce qu'on appelle la génération Y (M. Serres 2012), génération de la nouvelle technologie, au langage marqué, hors norme ou même violent dans une image très positive. J'ai également conclu que les médias sociaux, plus que les médias audiovisuels traditionnels permettent une sorte de métissage socioculturel à cause de leur nature interactive et acheminent donc plus le langage vers la voie d'homogénéisation. Ce genre de supports permet des communications à mi-chemin entre oral et écrit, formel et informel, liberté d'expression et autocensure présentant ainsi une mine inexploitée de recherches.

Zawrotna (2016) traite dans son article les mots tabous référant aux parties intimes du corps et les stratégies d'euphémisme utilisées pour les contourner. La méthode et la problématique sont différentes des nôtres. Son article traite seulement de la catégorie « sexe » tandis que le nôtre présente les différentes catégories des gros mots. Mais en fait, ces deux articles ont le mérite d'être parmi les rares études effectuées sur cette question dans le monde arabe contrairement au même type de recherches dans le domaine français. A mon avis, il y a encore plus à dire sur la violence verbale dans le langage des femmes, surtout arabes. 


\section{BIBLIOGRAPHIE}

Bucholtz Mary 2004. Language and Woman's Place: Text and Commentaries. New York: Oxford University Press.

Cameron Deborah 1995. Verbal Hygiene. London: Routledge.

Chambers Jack 1995. Sociolinguistic Theory. Linguistic Variation and Its Social Significance. OxfordCambridge: Blackwell.

Chamizo-Dominguez Pedro 2005. "Some Thesis on Euphemisms and Dysphemisms", Studiac Anglicac Resoviensia 25. 9- 16.

Dubois Jean 1994. Dictionnaire de linguistique et des sciences du langage. Paris : Larousse.

Guiraud Pierre 1975. Les gros mots. (Que sais-je ?). Paris : PUF.

Gumperz John 1989. Sociolinguistique interactionnelle. Une approche interprétative. Paris :

l'Harmattan.

Jamet Denis \& Jobert Manuel (dir.). 2010. Empreintes de l'euphémisme. Paris: l"Harmattan,

Labov William 1966. The Social Stratification of English in New York City. Washington : Center for Applied linguistics. En ligne sur http://idiom.ucsd.edu/ bakovic/variation/Labov-2006.pdf Labov William 1976. Sociolinguistique. Paris : Ed. de Minuit.

Lakoff Robin 1975. Language and Woman's place. New York: Harper and Row.

Maltz Daniel \& Borker Ruth 1982. "A cultural approach to male-female miscommunication", J. Gumperz, Language and social identity. 196-216. En ligne sur http://ebooks.cambridge.org/ chapter.jsf?bid=CBO9780511620836\&cid=CBO9780511620836A017

Nicolai Robert \& Bourlier-Berkowicz Juliette, 2000, « Feuilletage linguistique, stéréotypes et (re)constructions : réflexions sur les dynamiques d'élaboration normative », Actes du colloque France, pays de contact de langues. Tours.

Rizk Sherin 2007. “The Language of Cairo's Young University Students”, Miller et al. (eds.), Arabic in the City: Issues in Dialect Contact and Language Variation. London-New York: Routledge. 291-305 Serres Michel 2012. Petite Poucette. Paris : Le Pommier.

Tannen Deborah 1986. That's Not What I Meant! How Conversational Style Makes or Breaks Relationships . New York : Ballantine.

Tournier Jean 1985. Introduction descriptive à la lexicogénétique de 365 l'anglais contemporain. Paris Genève : Champion-Slatkine.

Zawrotna Magdalena 2016. "The Use of Taboo-Related Words in Egyptian Arabic a Sociolinguistic Approach to (Im)politeness", Grigore \& Bituna (eds.), Arabic Varieties : Far and Wild. Bucharest: Université de Bucharest. 


\section{ANNEXES}

\begin{tabular}{|c|c|c|}
\hline & Enoncées non -euphémiques & Enoncées euphémiques \\
\hline France & 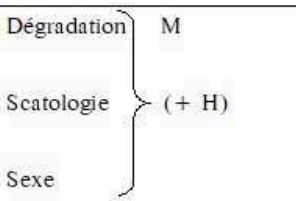 & $\begin{array}{l}\text { Blasphème } F \\
\text { Scatologie } M(H=F) \\
\text { Sexe } M(+H)\end{array}$ \\
\hline Egypte & $\left.\begin{array}{l}\text { Blasphème } \\
\text { Sexe }\end{array}\right\} \begin{array}{l}H \\
\text { Dégradation } \\
M\end{array}$ & $\left.\begin{array}{l}\left.\begin{array}{l}\text { Blasphème } \\
\text { Sexe }\end{array}\right\} \begin{array}{c}\mathrm{M} \\
(+\mathrm{H})\end{array} \\
\text { Dégradation } \\
\text { Scatologie }\end{array}\right\}$ \\
\hline
\end{tabular}

Usage des catégories de violence verbale et de lars euphémismes

$$
(\mathrm{H}=\text { masculin } \mathrm{F}=\text { féminin } \mathrm{M}=\text { mixte } \quad \text { + prédominance égalité })
$$

\section{NOTES}

1. Cela fait partie de la part de subjectivité nécessaire pour la construction du corpus et acceptable dans toute recherche, subjectivité appelée par R. Nicolaï "paradoxe de l'archéologue" (2000)

\section{RÉSUMÉS}

Si la «violence verbale» est une transgression des tabous langagiers, «l'euphémisme » est un moyen de les contourner. L'étude de ces deux concepts dans ce qu'on appelle «le langage des jeunes » est intéressante dans la mesure où elle pose la question de son " caractère masculin ». J'aborde la question des pratiques langagières des jeunes de ce nouvel angle qu'est le sexe en mettant à l'épreuve l'hypothèse de la politesse du langage des femmes auprès de groupes de jeunes filles cairotes. J'ai cherché mes réponses à travers un guide d'entretien semi-directif formé à la lumière de données collectées sur le journal du Facebook de certains internautes. Un questionnaire copiant ce guide d'entretien sous forme de questions fermées a facilité le traitement statistique des données. 
INDEX

Mots-clés : langage des jeunes, langage des femmes, variation sexolectale, violence verbale, euphémisme

AUTEUR

SHERIN RIZK

Université de Helwan 


\title{
Negotiating Authenticity in Casual Speech: Moroccan Rappers and the /t/ Variable
}

\author{
Sarah Ruth Schwartz
}

\section{Introduction}

1 The following is a sociophonetic analysis of variation in affricated realizations of the voiceless coronal stop / $t /$ in two dialects of Moroccan Arabic - the coastal Atlantic dialect that stretches from the city of Sale to the city of El-Jadida and realizes / $t /$ as the palatoalveolar affricate [tš], and the dialect in the central region encompassing Fès, Meknès, and Taza that realizes / $t$ / as the alveolar affricate [ts] - that seeks to connect pronunciation of this feature to the exchange of symbolic power within the community of Moroccan rappers, as well as the issue of authenticity and "keeping it real" as a Hip Hop artist. This study will answer the questions: Is affricated / $t$ / a linguistic marker within Moroccan Hip Hop community? Do Moroccan Hip Hop artists strategically use this feature to help position themselves within the Moroccan Hip Hop community? And finally, what implications does this have for the meaning of authenticity within the Moroccan Hip Hop community?

2 The paper presents a case study of four Moroccan rappers: two from the coastal region (from the cities of Salé and Casablanca), and two from the city of Meknès. Casablanca and Salé host two of the most prominent rap scenes in the country, and Meknès hosts a rap scene that is prominent, but less prominent than the Cassaoui rap scene. Thus, we may assume that the street speech of Casablanca and Salé hold prestige within the Moroccan Hip Hop community, and we might expect the Meknassi respondents to accommodate to the Cassaoui pronunciation of $/ \mathrm{t} / \mathrm{by}$ realizing the phoneme as [tš], rather than their native [ts]. However, the results suggest that the relationship between regional dialect and the Hip Hop community is more complicated than this. While the analysis definitively shows regional variation in the affricated realization of $/ t /$, it does not definitively show accommodation to the Cassaoui dialect: one Meknassi speaker claimed to try to use 
Cassaoui features, but on average produced / $t$ / in a manner consistent with the Meknassi dialect, and the other Meknassi speaker intentionally refused to use features of the Cassaoui dialect in order to better represent his local heritage. This result indicates two main findings: first, that variation in / $t$ / affrication may not be a salient linguistic capital in this community, and second, that accessing authenticity in the Moroccan Hip Hop community reflects an inherent tension between accessing the prestige of street code and repping one's hometown.

\section{Background}

\subsection{Language, Style, and the Global Hip Hop Nation}

The connection between street language and Hip Hop culture is critical - Hip Hop is an essentially urban art form, and the language of the streets is the language of the art. Alim states in his (2003) study of the casual speech and performance styles of the rappers Eve and Juvenile that rappers must cultivate a "street-conscious identity" in their lyrics in order to create a sense of familiarity between themselves and the urban African American community. He compares rates of copula deletion, the "showcase variable" of AAE (2003: 46), between the respective artists' casual speech and their lyrics, and finds significant differences in the rate of copula deletion between both artists' respective casual speech and performance speech. Alim posits that this represents "street-conscious copula deletion": a conscious shift away from Standard American English (SAE) in order to express kinship with the African American community. Maintaining a street-conscious identity, he concluded, is crucial to rappers' success within the Hip Hop community, because it was a sign that they could authentically identify with Hip Hop's main audience.

4 The concept of authenticity, or "keepin it real", is a significant feature of Hip Hop culture. However, in the context of the Global Hip Hop Nation (GHHN) "authenticity" becomes a complex matter - while rappers across the globe are still expected to pay homage to Hip Hop's origins in the US Black community, a rapper from Korea, for example, could not claim authenticity if they only repped US Hip Hop culture and not their own culture. As such, on one level maintaining authenticity in Hip Hop manifests as a dialectic between the global and the local, or the "glocal", to use a term common in Hip Hop scholarship (Androutsopoulos 2009: 44). Furthermore, as Pennycook (2007: 103) explains, neither can authenticity be limited to "an individualist obsession with the self". Instead, authenticity to oneself requires a "dialogical engagement with community" - balancing repping oneself and repping one's community.

5 As one may expect, this process is highly variable - the balance between the global and the local, and the individual and the communal, that rappers must attain in order to access authenticity differs widely between Hip Hop communities. In the Hip Hop literature, the process of negotiating these tensions and defining authenticity is called "localization" (Pennycook 2007). For example, Hassa (2010) describes the use of codeswitching within French rap as a form of localization - the Arab-French rappers she studies use Arabic terms in order to represent their home cultures and the French streets, evoking the connective marginality between Arab immigrants in France and African Americans in the US (Osumare 2007 cited in Terkourafi 2010a: 3), and use Verlan in order to specifically represent their local southern French identity. In Morocco, as I will explain 
below, localization involves both language and subject matter, resulting in a highly diverse Hip Hop community.

\subsection{Setting the Scene: The Moroccan City and Hip Hop Culture}

6 This study centers on speakers from two dialect regions in Morocco representing two prominent Hip Hop scenes ${ }^{1}$. The first area I will consider is the dialect region between the western coastal cities of Casablanca and Salé. Both Casablanca and Salé represent a type of new urbanism that is reflective of the urban culture to which global Hip Hop culture pays homage. Since the rapid urbanization of 1970's, Casablanca has become the economic powerhouse of the country, with the economic expansion serving wealthy capital owners while creating the conditions for the type of poverty and economic depression amongst the lower classes that mirror the conditions under which Hip Hop was born in the Bronx in the 1970's and 1980's (Miller 2007). Salé underwent a similar process of rapid urbanization in the 1970's (Triki 1991). Unsurprisingly, Casablanca and Salé are home to two of the oldest Hip Hop scenes in Morocco.

7 Meknès, on the other hand, is both a relatively smaller city and an imperial city, with deep ties to traditional Moroccan culture; one of the city's main claims to fame is the Issawa Sufi brotherhood, which is also the subject of Meknassi rap crew H-Kayne's most famous track, "Issawa Style". H-Kayne produces taqlìdī ('traditional') rap: rap about traditional Moroccan values (Almeida 2015). Here we see localization at work - whereas the music of Hip Hop artists in Casablanca is typically more reflective of broader themes found in Hip Hop throughout the GHHN, taqlidi rap consists of a call to respect the dominant Muslim nationalist culture. While Meknès has a history of being a center for Hip Hop culture in Morocco, it hosts a less prominent rap scene than larger urban centers, with rappers and producers often leaving the city in order to find more opportunities in Casablanca.

\subsection{Affrication of /t/}

8 The two regions described in this study also differ with respect to dialect. This study focuses in particular in variation in the production of the phoneme / $t /$, with the two regions varying in place of articulation of the frication period. In Meknès (as well as in neighboring Fès) / $t$ / is typically realized as the alveolar affricate [ts], and throughout the Atlantic coast, from Salé to as far south as El-Jadida, /t/ is typically realized as the palatoalveolar affricate [tšs] (Caubet, personal communication). According to Naciri (2014), affrication may be blocked by a preceding sibilant or following sonorant consonant, but the affricated realizations of the phoneme are otherwise universal in these dialects. In general, these two features are not well described in the literature on Moroccan dialectology. Furthermore, no prior study has described these variants acoustically: this study constitutes the first acoustic analysis of affricated / $t$ / in Moroccan dialects.

9 Affrication of $/ t /$ is well described in the sociolinguistic literature on urban dialects of French. Several works cite the affricated realization of $/ t /$ as being a prominent feature of cité or beur speech, or the French equivalent of what Alim (2004) describes as "the code of the streets" - in French society the affricated realization of / $t /$ is generally stigmatized, but has covert prestige largely because of the connection between street speech and Hip 
Hop culture, similar to AAE in the United States (Gasquet-Cyrus 2013, Jamin, Trimaille, and Gasquet-Cyrus 2006, Jamin 2004, Gadet and Hambye 2014).

\section{Data and Methodology}

\subsection{Data Collection}

The data included in the study was collected over a 2-month period of fieldwork in Morocco in 2016. I collected 14 sociolinguistic interviews in total (7 with slam poets and 7 with rappers), and the current study includes data from 4 interviews. The 4 informants were chosen and labeled in this study based on their city of origin - informants M1 and $\mathrm{M} 2$ are from the city of Meknès, and informants $\mathrm{C}$ and $\mathrm{S}$ are from the cities of Casablanca and Salé, respectively. All of them are male rappers between the ages of 22 and 27 at the time of interview, and educated at the university level. Informants M1, S, and C have spent their entire lives primarily living in the cities of their birth, with some travel, and M2 moved to Casablanca from Meknès in 2009 for university and has lived there ever since.

11 All interviews were recorded with a Tascam DR-100mkIII Linear PCM Recorder and a Shure A-10 head mounted microphone, sampled at a rate of $44.1 \mathrm{kHz}$. The elicitation involved a variation on the traditional variationist sociolinguistic model following Labov (1984) with a semi-structured interview intended to elicit casual speech, reading speech (from a word list), and a performance register. The semi-structured interview was adapted from the traditional Labovian interview to include questions about the informants' experience as artists, their political opinions, and metalinguistic questions about their perception of dialect variation in Morocco. This study focuses on data from the semi-structured interviews.

\subsection{Data Analysis}

12 All data was annotated and measured in Praat 6.0.14 (Boersma and Weenik 2016). The primary acoustic metric used in this study was center of gravity (henceforth CoG). Given that the primary goal is to differentiate between tokens of [ts] and tokens of [tš] in the data, I focused on the CoG of the frication duration - that is, the alveolar sibilant [s] versus the palato-alveolar sibilant [š]. Measurements were taken using a Praat script written by Wendy Elvira-Garcia (2015) that measures the average CoG over the entire frication period. Following Kolgini's (2004) thesis on affrication in Albanian, each token of $/ t /$ was separated into the closure period and the frication period, with the frication period measured from the onset of aperiodic high-amplitude frication noise until the offset thereof. Figure 1 below shows this coding system, where "f" on the first and second tiers of the text grid indicates the frication period following the stop closure. Tokens of / $t$ / following a sibilant or preceding a sonorant consonant were coded but excluded from analysis, because these phonological environments block the affrication of / $t$ / (Naciri 2014: 70-72). 
Fig. 1 Example of coding system for /nta/ ("you")

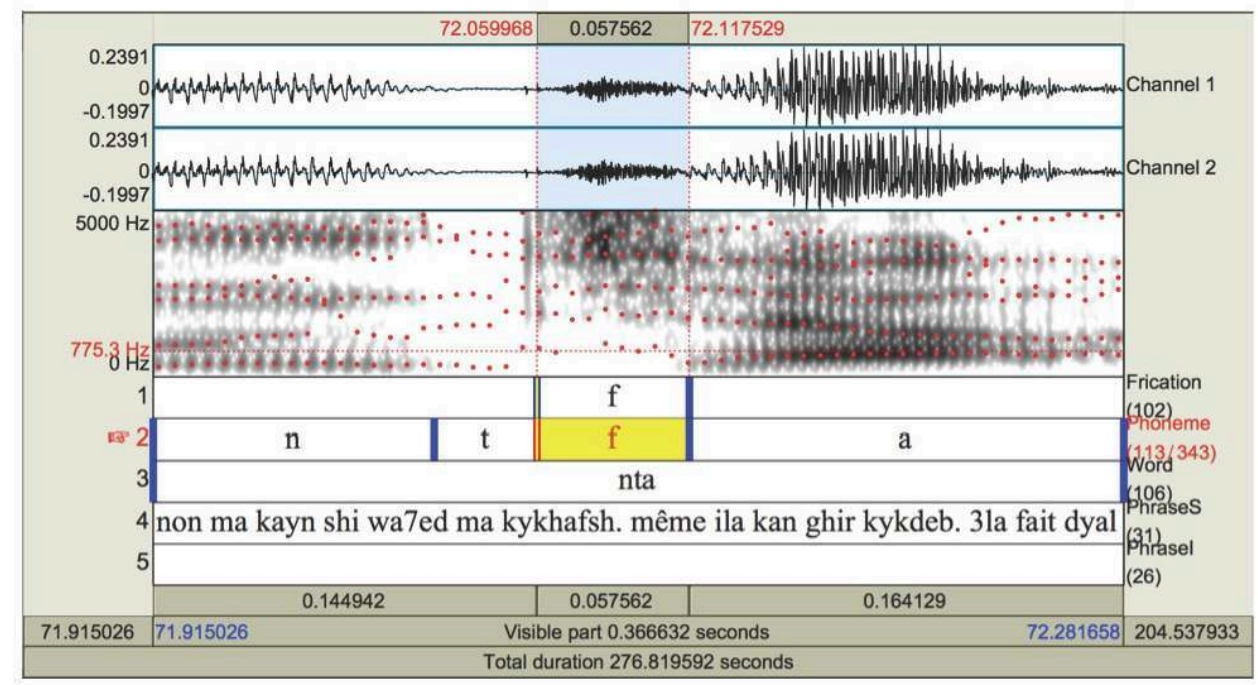

For statistical analysis of the data set, a linear mixed effects model using the lmer function of the lme4 package was fit with the continuous dependent variable of CoG, and presence of closure period (Closure) and city of origin (OriginMeknes and OriginCasaSale) as binary fixed effects, an interaction between closure and origin (Origin*Closure), and Speaker as a random effect. P values were obtained using the mixed function of the Matrix package. After determining the significant predictors of CoG in the mixed effects model, inter-speaker variation was tested with unpaired two-tailed $t$ tests between each of the speakers.

\subsection{Hypotheses}

14 1. There will be a main effect for Origin.

2. While Origin will be a significant predictor of CoG, the Meknassi informant M1's average CoG values will be closer to those for [š] than those for [s].

\section{Results}

The study analyzed 2 hours of interview data, resulting in 673 tokens of affricated / $t /$. Table 1 describes the data, divided by speaker. Tables 2 and 3 give the results of the linear mixed effects model with a dependent variable of CoG. The model found main effects ( $\mathrm{p}$ .001) for both Closure and Origin, and no significant effect for the interaction between Closure and Origin. CoG values for OriginMeknès are estimated to be around $739 \mathrm{~Hz}$ higher than CoG values for OriginCasa-Sale, and CoG values for ClosureYes are estimated to be around $393 \mathrm{~Hz}$ higher than CoG values for ClosureNo. Thus, within the linear mixed effects model both Closure and Origin (but not the interaction between Closure and Origin) have been found to be reliable predictors of CoG, with Speaker as a significant source of variance. This suggests that the speakers' pronunciation of $/ t /$ most closely resembled that of other speakers with the same value for Origin. 
Table 1: Total tokens of affricated / $t$

\begin{tabular}{|c|c|c|c|c|c|c|c|}
\hline Speaker & \multicolumn{3}{|c|}{ ClosureYes } & \multicolumn{2}{|l|}{ ClosureNo } & \multicolumn{2}{|l|}{ Total } \\
\hline M1 & \multicolumn{3}{|l|}{83} & \multicolumn{2}{|l|}{105} & \multicolumn{2}{|l|}{189} \\
\hline M2 & \multicolumn{3}{|l|}{138} & \multicolumn{2}{|c|}{74} & \multicolumn{2}{|l|}{213} \\
\hline$S$ & \multicolumn{3}{|l|}{114} & \multicolumn{2}{|c|}{44} & \multicolumn{2}{|l|}{158} \\
\hline C & \multicolumn{3}{|l|}{59} & \multicolumn{2}{|l|}{54} & \multicolumn{2}{|l|}{113} \\
\hline \multicolumn{8}{|c|}{ Table 2: Fixed effects in linear mixed effects model } \\
\hline \multicolumn{2}{|l|}{ Fixed Effects } & $\begin{array}{l}\text { Estimate } \\
\text { Std }\end{array}$ & $\mathrm{t}$ value & $\begin{array}{l}\text { Std } \\
\text { Error }\end{array}$ & \multicolumn{2}{|c|}{ Degrees of Freedom } & p value \\
\hline \multicolumn{2}{|l|}{ (Intercept) } & 3449.89 & 46.146 & 74.76 & \multicolumn{2}{|l|}{43.60} & $\begin{array}{l}<2 \mathrm{e}-16 \\
* * *\end{array}$ \\
\hline \multicolumn{2}{|l|}{ OriginMeknès } & 739.20 & 7.958 & 92.89 & \multicolumn{2}{|l|}{26.90} & $\begin{array}{l}1.51 \mathrm{e}-08 \\
* * *\end{array}$ \\
\hline \multicolumn{2}{|l|}{ ClosureYes } & 393.58 & 4.223 & 93.19 & \multicolumn{2}{|l|}{505.50} & $\begin{array}{l}2.86 \mathrm{e}-05 \\
* * *\end{array}$ \\
\hline \multicolumn{2}{|c|}{ OriginMeknès:ClosureYes } & -183.59 & -1.544 & 118.88 & \multicolumn{2}{|l|}{557.30} & 0.123 \\
\hline \multicolumn{8}{|c|}{ 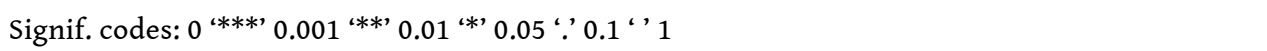 } \\
\hline \multicolumn{8}{|c|}{ Table 3: Random effects in linear fixed effects model } \\
\hline Random Effects & \multicolumn{3}{|l|}{ Variance } & \multicolumn{2}{|c|}{ Standard Deviation } & & \\
\hline Speaker & 357.6 & & & 18.91 & & & \\
\hline Residual & 545965.6 & & & 738.89 & & & \\
\hline
\end{tabular}

Having established that city of origin is a reliable predictor of CoG in this data set, which suggests that each informant for the most part produced CoG values consistent with the other informant native to his region, it would be pertinent to understand how close the CoG values were within the two groups of informants and between the groups, still keeping in mind that Speaker was not a fixed variable in the regression model. Figure 2 and Table 4 depict the average CoG values produced by each of the speakers in the data set. C, who has lived in Casablanca his entire life, grew up in the old city, and considers himself authentically Cassaoui, has the lowest median CoG value and the shortest interquartile range. M2, the Meknassi who moved to Casablanca in 2009, has the highest median CoG - higher than the Meknassi speaker (M1) who had never lived in Casablanca. Pair-wise comparisons confirm the results of the mixed effects model (see Table 5). As 
previously established, Origin was a significant predictor for CoG, which suggests that speakers with the same Origin value should not have a significant difference in their CoG values. This is the case between $C$ and $S$ and between M1 and M2. The $t$ values for each pair further confirms this result - the $t$ values for the M1-S and M1-C pairs are significantly lower than the $t$ values for the M2-S and M2-C, respectively.

Fig. 2: Plot of CoG values per Speaker

\section{Center of Gravity per Speaker}

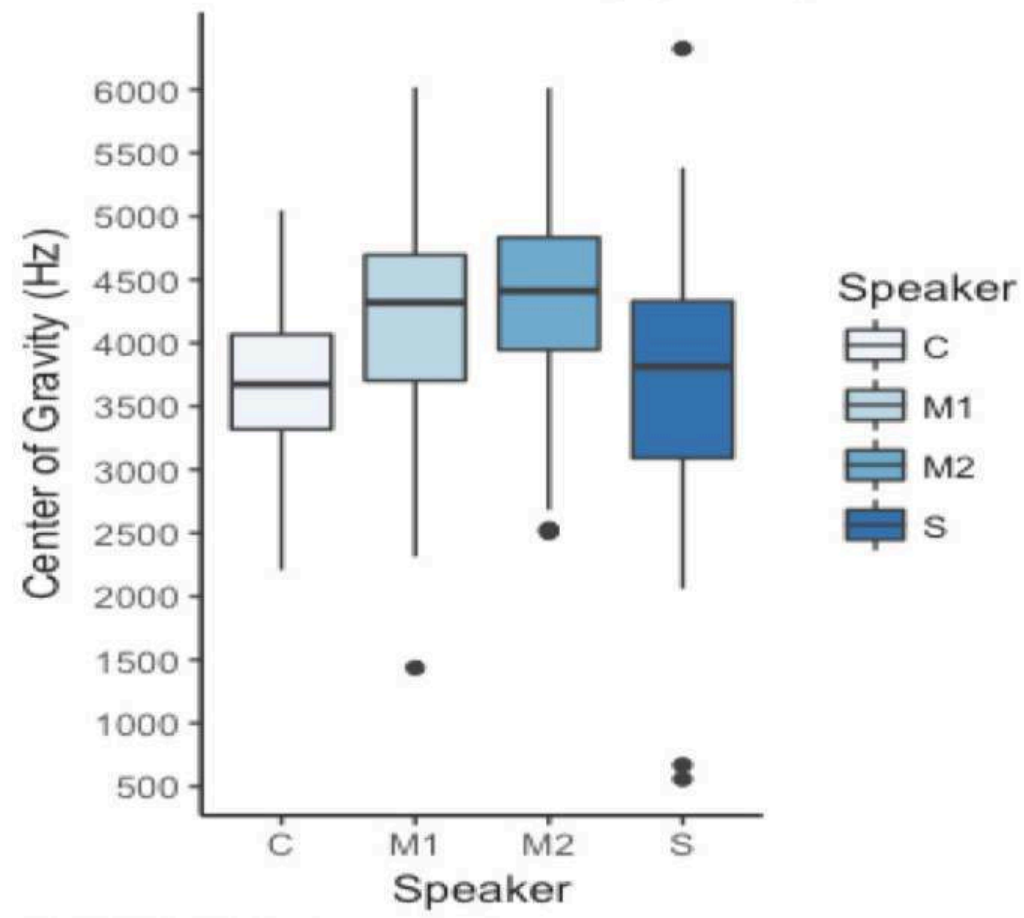

Table 4: Mean CoG values and Std Deviation per speaker

\begin{tabular}{|l|l|l|l|l|}
\hline $\begin{array}{l}\text { Values/ } \\
\text { Speaker }\end{array}$ & M1 & M2 & C & S \\
\hline $\begin{array}{l}\text { Mean } \\
\text { CoG (Hz) }\end{array}$ & 4207.96 & 4382.19 & 3654.91 & 3725.17 \\
\hline $\begin{array}{l}\text { Std. Deviation } \\
(\mathrm{Hz})\end{array}$ & 777.39 & 710.38 & 562.75 & 882.4 \\
\hline
\end{tabular}

Table 5: Unpaired t tests between speakers

\begin{tabular}{|l|l|l|l|l|}
\hline Pair & t value & Std Error & Degrees of Freedom & p value (adjusted with bonferroni correction) \\
\hline C-S & 0.7422 & 94.662 & 268 & 2.7516 \\
\hline M1-M2 & 2.3502 & 74.116 & 401 & 0.1152 \\
\hline
\end{tabular}




\begin{tabular}{|l|l|l|l|l|}
\hline M1-S & 5.4242 & 89.008 & 346 & $<0.0001^{* * *}$ \\
\hline M1-C & 6.5793 & 84.06 & 300 & $<0.0001^{* * *}$ \\
\hline M2-S & 7.939 & 82.754 & 369 & $<0.0001^{* * *}$ \\
\hline M2-C & 9.3926 & 77.427 & 323 & $<0.0001^{* * *}$ \\
\hline
\end{tabular}

\section{Discussion}

\subsection{Response to Metalinguistic Questions}

It is pertinent to discuss the informants' self-evaluation, given that inter-speaker variation is a major focus of this case study and the speakers' perceptions of their own speech is informative of their general position vis-à-vis the phoneme in question and phonetic variation as a marker of dialect in general. I will draw attention to two metalinguistic questions that informed this study:

1. How can you differentiate accents from around Morocco?

2. Have you ever changed the way you speak for any reason?

When asked to explain different dialects in Morocco, none of the informants explicitly mentioned the variable examined in this study. Furthermore, none of the informants specified differing pronunciation of individual phonemes as significant dialect markers. In fact, when asked about pronunciation, $\mathrm{C}$ stated that sounds are neither important to the way one speaks nor to the way one raps. M1 alluded to the palatalized realization of / $\mathrm{t} /$ when asked to imitate the Cassaoui accent, with very exaggerated [tšs] pronunciation, but did not mention it outright. In responding to the question about changing dialect, both $\mathrm{S}$ and $\mathrm{C}$ mentioned shifting to French in formal environments. M2 mentioned that he changed his speech to sound "more Cassaoui" when he moved, but in the previous few years he had tried to shift his accent back to what he evaluated as his native dialect. Finally, M1, who had never lived outside of Meknès long-term, did not mention shifting his regional pronunciation, but when questioned after the interview about his production of [tš] during the course of the interview, he responded, "Oh, I guess sometimes I try to sound more like my Cassaoui friends."

\subsection{Discussion of Statistical Results}

The results confirm one of the two hypotheses. Origin was shown to be a reliable predictor of $\mathrm{COG}$ value, indicating that the respondents largely produced affricated realizations of / $t /$ consistent with respondents from the same region. This would also indicate that $\mathrm{COG}$ is a reliable acoustic correlate of regional variation in the realization of this phoneme - the respondents from the coastal area stretching between Salé and Casablanca reliably produced CoG values on the lower end of the spectrum, and the speakers from Meknès reliably produced CoG values on the higher end of the spectrum. This result constitutes an acoustic confirmation of regional variation in production of 
affrication, which I intend follow up with a more extensive acoustic study of affrication of $/ t /$ in collaboration with colleagues in Morocco.

Pair-wise comparisons between the informants confirm this relationship between Origin and CoG, refuting my hypothesis that M1's CoG values would skew closer to those from S and C. M1's CoG values were not significantly lower than those of M2, the other Meknassi rapper who intentionally modified his speech to sound more Meknassi. None of the informants specifically noted alveolar or palato-alveolar affrication of $/ t /$ as a salient feature of either dialect, though M1 recognized it when prompted.

\subsection{Affrication and the Street-Conscious Identity}

But what do these results mean from a broader perspective? The data for this study was taken entirely from the semi-structured interview, the most casual style of speech tested in the sociolinguistic interview, unlike Alim's $(2003,2006)$ study of the casual speech and rap lyrics of Eve and Juvenile, which proposed the cultivation of a "street-conscious identity" (2006: 113) within these artists' performance registers but not in their casual speech. What are the implications of these respondents consciously choosing, or not choosing, to shift their casual speech style? To put this in context, we must look at it from the dynamics of this particular community of practice - that is, the Moroccan Hip Hop community - and examine the role of linguistic capital both from the perspective of the role it plays in the community's power dynamics and from the perspective of artistic authenticity.

There is myriad evidence to point to Casablanca as a central location in Moroccan Hip Hop culture, from its status as Morocco's largest economic center and the site of rapid post-independence urbanization (Miller 2007), to its role in hosting major music festivals such as L'Boulevard, to its symbolic role as the birthplace of Nass el Ghiwane (Almeida 2013). However, M2 instead makes an active effort to rep his hometown of Meknès. This raises the question of "keepin it real" in the Moroccan context. As various chapters in Terkourafi (2010b) explore, the particular balance of these two elements that will allow Hip Hop artists to become successful is dependent upon the local Hip Hop culture - from the broader regional level, to the national level, to the community level.

Within Morocco in particular, different local rap scenes and even different styles of rap will use combinations of linguistic codes, depending on their message and audience. For example, "commercial" rappers in Morocco will rap primarily in English in order to directly invoke the global authenticity of American Hip Hop, whereas "conscious" rappers will rap almost exclusively in Moroccan Arabic (Harrouchi 2015). Furthermore, the degree to which localization of themes and language is concentrated at the community level or at the broader national level changes from city to city. All of this indicates that the process of localization of Moroccan rap is not uniform within the Moroccan Hip Hop scene, nor is the Moroccan Hip Hop scene itself a monolith - different artists with different styles localize their language to varying degrees in order to best represent their notion of authenticity. M1 adopts the street language of the country's largest urban center to access the authenticity of that city's Hip Hop artists, but M2 reverts to the speech of his hometown, to access the authenticity of keeping it local. This reflects the inherent tensions in "keepin it real," within a system as complex as the Moroccan HHN. In future research, I hope to determine and measure what the so-called 
"showcase" variables are in Moroccan street speech, to more fully understand the specific capital of this linguistic market.

\section{BIBLIOGRAPHY}

Alim, H. Samy. 2003. “'We Are the Streets': African American Language and the Strategic Construction of a Street Identity", Makoni, Sinfree, Smitherman, Geneva, Ball, Arnetha F., and Spears, Arthur K. (eds.), Black Linguistics: Language, Society, and Politics in Africa and the Americas. New York: Routledge. 40-59.

Alim, H. Samy. 2004. You Know My Steez : An Ethnographic and Sociolinguistic Study of Styleshifting in a Black American Speech Community. Durham: Duke University Press for the American Dialect Society.

Alim, H. Samy. 2006. Roc the Mic Right: The Language of Hip Hop Culture. New York: Routledge. Almeida, Cristina Moreno. 2013. "Unravelling Distinct Voices in Moroccan Rap: Evading Control, Weaving Solidarities, and Building New Spaces for Self-Expression", Journal of African Cultural Studies 25 (3). 319-32.

Almeida, Cristina Moreno. 2015. “The Politics of Taqlidi Rap: Reimagining Moroccanness in the Era of Global Flows", The Journal of North African Studies, 1-16.

Androutsopoulos, Jannis, Awad Ibrahim, and Alistair Pennycook. 2009. "Language and the Three Spheres of Hip Hop", Alim, H. Samy (ed.), Global Linguistic Flows : Hip Hop Cultures, Youth Identities, and the Politics of Language. New York: Routledge. 43-62.

Boersma, Paul, and David Weenik. 2016. Praat: Doing Phonetics by Computer (version 6.0.14). http:// www.praat.org/.

Elvira-Garcia, Wendy. 2014. Zero-Crossings-and-Spectral-Moments (version v.1.3).

Gadet, Françoise, \& Hambye, Philippe. 2014. "Contact and Ethnicity in 'Youth Language' Description: In Search of Specificity", Nicolaï, Robert (ed.), Questioning Language Contact: Limits of Contact, Contact at Its Limits. Leiden: Brill. 183-217.

Haeri, Nilofar. 1997. The Sociolinguistic Market of Cairo: Gender, Class, and Education. London: Kegan Paul International.

Harrouchi, Zineb. 2015. “Les Fonctions Des Languages Dans Le Rap Marocain”, Langues, Cultures, et Sociétés 1 (1).

Hassa, Samira. 2010. "Kiff My Zikmu: Symbolic Dimensions of Arabic, English and Verlan in French Rap Texts”, Terkourafi, Marina (ed.) Languages of Global Hip-Hop. London: Continuum International Publishing Group. 44-66.

Jamin, Mikaël. 2004. “'Beurs' and Accent Des Cités: A Case Study of Linguistic Diffusion in La Courneuve", Contemporary French and Francophone Studies 8 (2). 169-76.

Jamin, Mikaël, Trimaille, Cyril, \& Gasquet-Cyrus, Médéric. 2006. "De La Convergence Dans La Divergence: Le Cas Des Quartiers Pluri-Ethniques En France”, French Language Studies 16. 335-56. 
Kolgjini, Julie M. 2004. "Palatalization in Albanian: An Acoustic Investigation of Stops and Affricates", PhD, Arlington: University of Texas at Arlington.

Labov, William. 1984. "Field Methods of the Project on Linguistic Change and Variation", Baugh, J., \& Sherzer, J. (eds.) Language in Use: Readings in Sociolinguistics. Englewood Cliffs, NJ: Prentice Hall. 28-53.

Miller, Catherine. 2007. “Arabic Urban Vernaculars: Development and Change”, Catherine Miller, Al-Wer, Enam, Caubet, Dominique, \& Watson, Janet C.E. Arabic in the City: Issues in Dialect Contact and Language Variation. New York: Routledge. 1-31.

Naciri, Youssef. 2014. "Spirantization of the Voiceless Dental Stop in Rbati-Moroccan Arabic", BA, Rabat: Mohammed V University Agdal.

Pennycook, Alistair. 2007. "Language, Localization, and the Real: Hip-Hop and the Global Spread of Authenticity”, Journal of Language, Identity \& Education 6 (2). 101-15.

Terkourafi, Marina. 2010a. "Introduction”, Terkourafi, Marina (ed.) Languages of Global Hip-Hop. Advances in Sociolinguistics. London: Continuum International Publishing Group. 1-18.

Terkourafi, Marina (ed.). 2010b. Languages of Global Hip-Hop. London: Continuum International Publishing Group.

Triki, Laïla. 1991. “Réaménagement de Salé: La Ville-Dortoir Se Réveille”, L'Économiste. http:// www.leconomiste.com/article/reamenagement-de-sale-la-ville-dortoir-se-reveille.

\section{NOTES}

1. Three Hip Hop scenes, to be precise, but because of the demographic and cultural similarities between Casablanca and Salé I am subsuming them under one category.

\section{ABSTRACTS}

This study undertakes an acoustic analysis of the casual speech of 4 Moroccan rappers in order to: 1) acoustically describe the variation in realizations of the phoneme / $t /$ in two different dialects of Moroccan Arabic, 2) evaluate the extent to which Moroccan Hip Hop artists do or do not shift to the variant used in the city of Casablanca, 3) understand the role that linguistic styleshifting plays in the performance of authenticity, or "keepin it real", in the Moroccan Hip Hop community. The study definitively shows regional dialectal variation in realization of the phoneme, but the sociolinguistic implications of this variation were less definitive. While one Meknassi artist does claim that he tries to use Cassaoui speech, this was not borne out by acoustic measurements, suggesting that there may be other, more salient acoustic features that constitute linguistic capital within the Moroccan Hip Hop community. The results of the study also suggest an interesting divide in strategies for accessing power and artistic authenticity within the community - while the aforementioned speaker did affiliate the Cassaoui dialect with the code of the streets, and attempted to adjust his speech thusly, the other Meknassi speaker explicitly preferred to use his native pronunciation in order to remain authentically Meknassi. This reflects 
the inherent tensions in "keepin it real", with the first speaker focusing on the authenticity inherent in repping the larger Hip Hop community in Morocco, and the second speaker focusing on the authenticity inherent in repping his hometown.

INDEX

Keywords: Sociolinguistics, Phonetics, Hip Hop, Moroccan Arabic, Authenticity

\section{AUTHOR}

SARAH RUTH SCHWARTZ

University of Texas at Austin 


\title{
Perceptual Dialectology of Egypt. A View from the Berber-Speaking Periphery
}

\author{
Valentina Serreli
}

\section{Introduction}

1 Drawing on an attitudinal and perceptual dialectological survey, the paper presents the dialectology of Egypt, according to the perception of high school students from Siwa Oasis, a peripheral and non-native Arabic-speaking region of Egypt. Our aim is to answer two main questions: first, we want to individuate whether or to what extent linguistic boundaries drawn by professional dialectologists correspond to those drawn by nonspecialists; secondly, we are interested in the way speakers define the languages, varieties, or ways of speaking, whose existence they are aware of.

2 The paper is organized as follows: section 2 introduces the field of perceptual dialectology, and the studies conducted in the Arabic-speaking context. Section 3 presents the scope of the research and, more specifically, the map-drawing experiment used to collect the data discussed in this paper. Section 4 presents the results obtained, concerning dialect boundaries and metalinguistic labels. Short concluding remarks are given in Section 5.

\section{Perceptual dialectology}

3 Perceptual dialectology is a sub-branch of folk linguistics, the discipline that studies nonspecialists' ideas, beliefs, overt comments and subconscious responses about languages and linguistic facts (e.g. Preston 1999). Perceptual dialectology focuses on the beliefs about geographical variation, that is dialect distribution and boundaries. It starts from the consideration that "nonlinguists know not only that people in different parts of the world speak different languages, but also that people in different regions speak the same 
language differently" (Preston 2010: 89). The discipline began in the Netherlands and Japan in the 1920s, but it is with the works of Dennis Preston on the varieties of American English that it came to prominence starting from the late 1980s (e.g. 1989, 1999, 2010). One of the techniques used within this approach is mental mapping, borrowed from cultural geography, in which respondents are asked to draw linguistic boundaries on a blank or semi-blank map, according to their own awareness and beliefs. It is assumed that ordinary speakers' beliefs and perceptions of the distribution of linguistic varieties are important as well as their language productions as they help to understand sociolinguistic trends within a community and to explain linguistic variation phenomena.

\subsection{Arabic perceptual dialectology}

4 To my knowledge, only two studies using the map-drawing task in the Arabic-speaking context were recently published.

5 Theodoropoulou and Tyler (2014) present a perceptual dialectological study conducted in Qatar, using a map task, innovative in the Arabic-speaking context. Forty female undergraduate students of the Qatar University were given a blank map of the Arab world and asked to provide information about linguistic boundaries and labels. They clustered Arabic varieties into five groups: Maghreb, Egypt and Sudan, Levant, Gulf, and Somalia, and they also referred to an intermediary group identity (as "Shammi or Khaliji"), standing between the Arab speaking community as a whole and the national one. The authors obtained information about the way Arabic dialects are grouped, about hierarchies among Arabic dialect groups and about the way those groupings related to the labels applied.

6 Hachimi (2015) presents the results of a map-drawing and labelling task administered to fifty-two Moroccans in different cities of the country (Casablanca, Marrakesh, Meknes, and Agadir), diversified for age, social class, and gender. The study sought to explore perceptual linguistic boundaries of the Arabic speaking world and the ideologies that render varieties of Arabic good or bad. The participants identified five dialect areas: Arabian Peninsula, Iraq, the Levant, Egypt, and the Maghreb, and evaluated Syrian as the best Arabic, followed by Levantine and Egyptian, and, in turn, by Maghrebi and Gulf Arabic. Hachimi's twofold analysis of both map-drawing and post-mapping discussion aptly shows the potentials of a perceptual dialectological approach in the study of the ideologies and cultural stereotypes about regional Arabic varieties that are dominant in Morocco; the choice to target a diversified sample rather than a sample made of students only is also much valuable.

\section{Presentation of the study}

\subsection{Overview}

7 The research was conducted in the Oasis of Siwa, one of the five biggest oases of the Egyptian Western Desert and the only Berber-speaking area of the country.

8 Siwa is inhabited by about 28 thousand people (2015, personal communication, Governorate of Marsa Matruh), the vast majority of which is native speaker of Siwi, the easternmost Berber language. The rest of the oasis' population is Arabic-speaking: it 
includes the Shahibat tribe, who settled in the oasis at the beginning of the XX century and whose native variety is a Bedouin type of Arabic, and diverse Arabic speakers coming from different regions of Egypt together with their own native Arabic variety. The oasis population is hence constituted, according to the dwellers themselves, by "Siwans", "Bedouins", "Egyptians" and foreigners, who are distinguished by ethnicity, morality, traditions and language (see below for further information about this point).

Siwi is maintained by its native speakers, by now bilingual, with the exception of few monolingual Siwi speakers among children in preschool age and elders. Bilingualism is not symmetrical: while almost all Siwi speakers learn Arabic, only some of the Arabicspeaking dwellers learn Siwi, because of its pervasiveness in the oasis daily life and its value as a solidarity bounding tool.

The data presented were collected in 2011 and are extensively discussed in Serreli (2011).

A written questionnaire in Standard Arabic was administered to 90 students attending the last two years of secondary school in the city of Siwa. Students were chosen because of the need to find educated speakers who could read and write Standard Arabic, be familiar with completing a questionnaire and, at the same time, constitute a homogeneous group in terms of age, education and cultural background, easy to reach within our specific conditions. The questionnaire consisted of 23 questions, including personal information, questions about sociolinguistic data (i.e. language use) and psycholinguistic data (i.e. the relationship between speaker and language), and two mapdrawing experiments.

Most of the respondents were born in the oasis in a Siwi-speaking family (80\%) and are, most likely, Siwi native speakers who have learnt Arabic as a second language. They declared to be proficient in both Siwi and Arabic, but to use Siwi to a much greater extent than Arabic.

Considering that the more one travels, the more (s)he is aware of language differentiation and is likely to associate a given speech to its region, respondents were asked about the frequency and destinations of their travelling outside the oasis. The sample proved not to be very prone to traveling, as half of the respondents stated that they travel outside Siwa less than five times per year and only one third does it more than five times a year. Moreover, the frequency of their traveling to a specific city is related to its geographical proximity to Siwa: the nearest city, Marsa Matruh, was visited by almost everybody, while the furthest, Cairo, by half of the respondents (Serreli 2011: 62-66; Battesti 2006: 147).

\subsection{The map-drawing experiment}

The map-drawing task inquired respondents about 'the dialects used in Egypt'. This question was put towards the end of the questionnaire (No. 19), and it was intentionally introduced after a question asking to give direct evaluations concerning given dialects of Egypt, in order not to influence the respondents' ideas about the dialect areas. Two kinds of map were proposed:

1) Map1 is a map of Egypt with the indication of the main Egyptian cities, namely Siwa, Marsa Matruh, Alexandria, Port Said, Suez, Sharm el-Sheikh, Tanta, Cairo, Giza, al-Fayum, al-Minya, Asyut, Hurgada, Luxor and Aswan.

Map1 was supplied to 62 students, but 8 were left blank: the analysis is based on 54 maps.

2) Map2 is a map of Egypt with the indication of Cairo and Siwa only. Map2 was supplied to 28 students, 8 were left blank: the analysis is based on 20 maps. 

naps were introduced to avoid biases relate given in the map, for instance, the indication of a city can encourage the respondent to consider that area even if (s)he was not going to.

15 boundaries within Egypt and about the perceived relationship between language
varieties, based on the labels chosen.

Fig. 1. Example of Map1 compiled

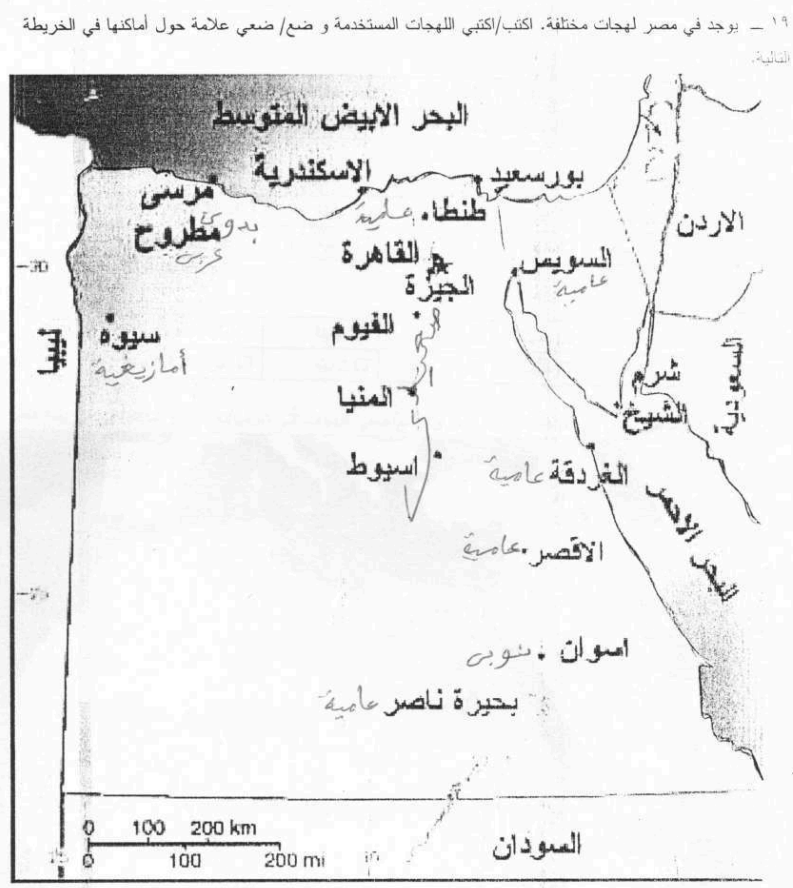


Fig. 2. Example of Map2 compiled

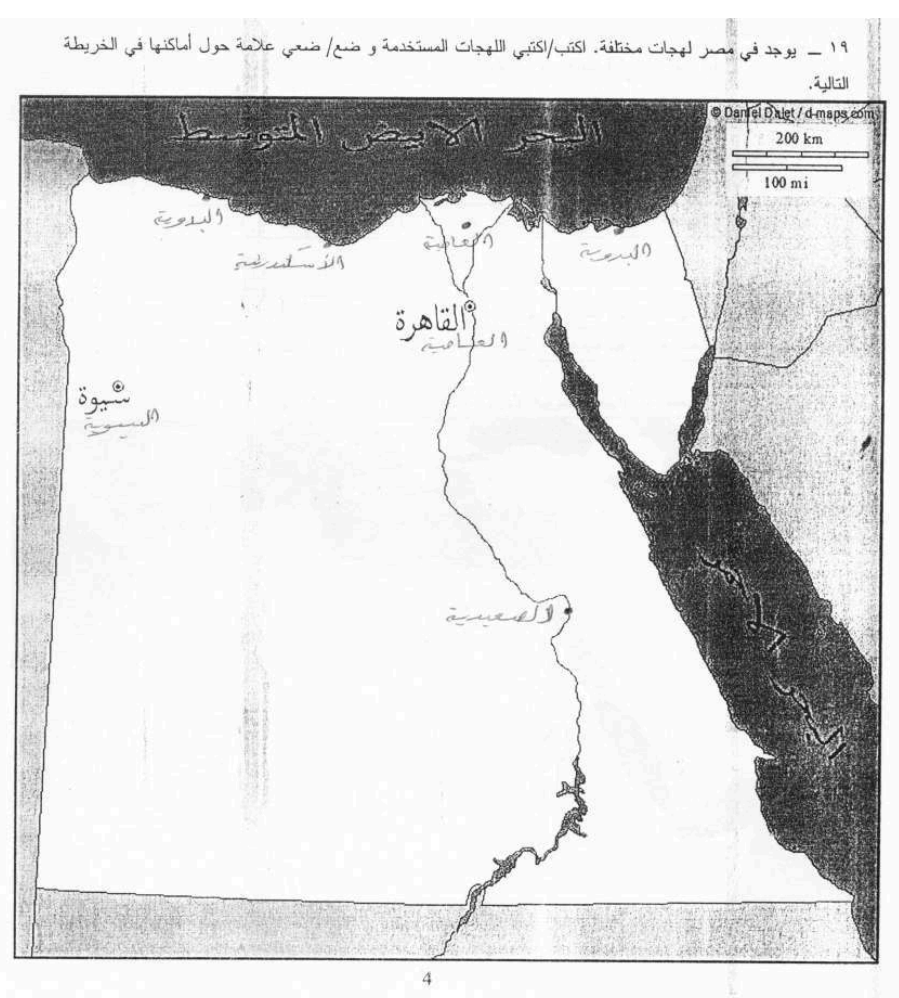

\section{Results and discussion}

\subsection{Perceived linguistic boundaries}

\section{Results of Map1}

In almost none of the 54 maps respondents traced boundary lines, but they either put signs or wrote labels to indicate a speech in the map.

9 maps were compiled putting a sign besides the name of the city: this only allows us to say that the most considered cities were Siwa and Aswan, followed by al-Minya and Marsa Matruh, but the lack of labels renders quite impossible to understand the connections between the varieties of different cities.

45 maps were compiled writing the name of a speech variety besides the name of a city. They show different degrees of detail, as the number of speech varieties indicated varies greatly. The resulting dialect areas are Siwa, the Nile Delta and the Sinai, Upper Egypt and Aswan.

1) Siwa was identified by $91 \%$ of the informants as a distinct dialect area speaking a Berber variety;

2) Marsa Matruh was mostly considered as a distinct dialect area, i.e. speaking a variety different from the one spoken in the Nile Delta (58\%), but a few respondents put it together with the Nile Delta (16\%);

3) The Nile Delta was considered a separate area in most cases, namely when the major cities of Cairo and Alexandria received the same label, mostly 'àmmiyya (36\%), and when only Cairo received a label, mostly 'ammmiyya (27\%); on the contrary, $11 \%$ of the 
respondents distinguished Cairene from Alexandrian by using different labels (e.g. mașri vs iskandarāni);

4) Upper Egypt was identified as a distinct dialect area corresponding to the region around the cities of al-Fayum, al-Minya and Asyut by the majority of the respondents (49\%) but percentages vary between one city and another. Some respondents (between 9 and $15 \%$ indicated the area as speaking the same variety as the Nile Delta;

5) In Aswan, many respondents indicated the presence of a different language (51\%), while a small percentage (7\%) included Aswan in the 'ämmiyya-speaking dialect area with Cairo and the other cities of the Delta and Sinai, and another 7\% included it in the șa ${ }^{\prime} i d i-$ speaking dialect area.

\section{Results of Map2}

Out of the 20 maps analysed, one student put marks only without writing down any label referring to varieties. The remaining 19 respondents wrote labels referring to the speech varieties and, in some cases, also the cities or the regions where they believed them to be spoken. Again, maps provide different degrees of detail. The most considered areas were Siwa and Cairo (94\%), followed by Alexandria and Upper Egypt (44\%), and Marsa Matruh (39\%); the least considered were the varieties of the Nile Delta and the Sinai Peninsula (28\%).

1) Siwa is one of the most frequently considered areas and it is recognized as a distinct Siwi-speaking dialect area;

2) Marsa Matruh was mostly considered a Bedouin-Arabic-speaking area set apart from the Delta region;

3) The Nile Delta was considered in $28 \%$ of the cases as an 'ammiyya-speaking area. Cairene was considered by $94 \%$ of the respondents, but mostly labelled 'àmmiyya as well: this tells us that, according the respondents, a type of Arabic based on Cairene is spoken in the Nile Delta. In fact, Cairene was distinguished only few times, as qāhirāwi or qāhiriyya . On the contrary, when Alexandrian was indicated, it was mostly to stress its specificity or difference from Cairene, by labelling it iskandarāni;

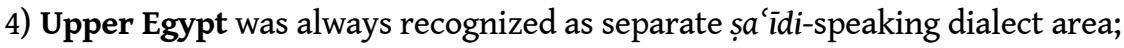

5) Sinai was mostly identified as a Bedouin-speaking area (22\% out of $28 \%$ total labels); one respondent used the label fușha to indicate that a Bedouin dialect was spoken (see below).

\section{Discussion}

Overall, there was a tendency to "assign" a dialect to the cities given on the map, that is why sometimes maps of the type Map1 appear more detailed than maps of the type Map2: this can explain why, for example, the areas around Luxor and Hurgada were never considered by respondents compiling the Map2 type. However, greater amount of information does not mean major accuracy or correctness, and, moreover, noticeable differences in the results between Map1 and Map2 appear in only in two cases: the nūbispeaking region around Aswan, recognized only by students filling in Map1; and the Sinai Peninsula, included in the 'ämmiyya-speaking region by the informant who filled in Map1, but recognized as a Bedouin-Arabic-speaking area by those who filled in Map2.

\section{1) Non-Arabic languages}

a) Siwi, indicated by the vast majority of the respondents, was correctly situated it in the oasis of Siwa and mostly labelled siwi or (as-)siwiyya. A few respondents used labels that reveal awareness of Siwi being a Berber language, that is barbar or 'amazigi(-yya). 
b) The Nubian language, attested in Egypt in two main dialects, is spoken in the Aswan Governorate and by Nubian migrants to Cairo and other big cities (Miller 1996; Wilmsen \& Woidich 2007: 1). The respondents who filled in Map1 correctly indicated the nūbi(-yya) speech besides the city of Aswan. Desert and the Mediterranean coast to the west of Alexandria, where dialects of the Sulaymi type are spoken (Wilmsen \& Woidich 2007: 2). The presence of a Bedouin type of Arabic around the city of Marsa Matruh was acknowledged by most of the respondents filling in both Map1 and Map2, through the labels badawi(-yya), 'arabi(-yya), 'arabāwi(-yya). On the contrary, only among the respondent who filled in Map2, some acknowledged the presence of Bedouin dialects in the Sinai Peninsula, and used the labels lahğa al-badu, 'arabiyya.

d) The dialects of the oases are connected both to the dialects of the Nile Valley, especially Middle Egyptian dialects, and to the Western Libyan Arabic, but they do not form a single separated group (Wilmsen \& Woidich 2007: 6-7). The oases were largely ignored by our respondents, as nobody indicated any of them in his/her map; 
accordingly, in the evaluation task, the speech of the oasis of Bahariyya resulted to enjoy no prestige nor was it considered at all. It is true that the oases were not indicated and this could have biased the results of the type Map1, but this is not true for the type Map2, where only Cairo and Siwa were given. Therefore, this result points to the scant importance of the oases in the respondents' lives.

Finally, a few respondents proposed a map characterized by the existence of a dialect labelled 'ammmiyya or mașri and spoken in almost all regions of the country, including Marsa Matruh, the Nile Delta, the Nile Valley and the eastern littoral and only excluding Siwa, or excluding Siwa and Marsa Matruh, which in this case is considered as Bedouinspeaking.

\subsection{Metalinguistic labels}

The analysis of respondents' labelling choices might reveal stereotypes and underlying ideologies. More precisely, "respondents' map-labelling task shows the evaluative richness that can be obtained from the association from dialect and place" (Hachimi 2015: 48). However, although our respondents were not very creative while filling in the maps, space constraints prevent us from extending the analysis to data collected through interviews and discussions. Therefore, we will limit our analysis to the labels found in the maps.

The labels that the informants assigned to the linguistic varieties proved to be unrelated to the type of map they were filling in. They can be classified into those that refer to a place, to an ethnonym, or to the status of the variety.

\section{Labels referring to the place where the variety is spoken.}

They are neuter and mostly refer unequivocally to one specific region, be it a city or a region.

Some examples are:

- al-qāhiriyya, qāhirāwi, qāhrāwiyya, named after al-qāhira, Cairo; it is rarely used, and always to indicate that the speech of the capital is distinguished from the others of the region;

- iskandarāni, named after the city of Alexandria; it is used when there is a need to distinguish it from the other dialects spoken in the Delta region;

- șa'îdi, aș-șa îdiyya, lahğa șa îdiyya, after the Upper Egyptian region, usually referred to as șa ìd mașr.

\section{Labels referring to the people who speak the variety}

Labels that come from an ethnonym are mostly used for linguistic minorities or for groups that are distinguished from the Egyptian-Arabic-speaking majority. There are three cases in our data:

- barbar, 'amāzigii(-yya), named after the Berber or Amazigh people; it is used to define the speech of Siwa Oasis, stressing its belonging to the Berber language family, as opposite to the Arab varieties;

- nübi(-yya), named after the Nubian people; although Nubia is also a region, it is with reference to the people that this label is used by our respondents, who never mentioned "Nubia" as a place where the variety is spoken nor as a geographical reference; 
- badu, badawi(-yya), 'arabāwi(-yya), named after the Bedouin or Arab people. A distinction between "Bedouins" or "Arabs", in the narrow meaning of the term, and "Egyptians" (see below, under mașri) is sharply drawn by both Siwans and Bedouins, based on the language difference and on a different cultural identity (Abu Lughod 1986; Cole and Altorki 1998; Serreli 2016).

Within this class also fall those labels that are used to refer to a people, but originally corresponded to a toponym:

- siwi(-yya), named after the Siwan people and Siwa Oasis. Siwa is used to address the place, the people and the language. siwi defines a well delimited cultural identity, it refers to the land, the people, the language, the habits, culture, traditions. For the oasis dwellers, a Siwan is not a resident of the oasis but a member of the Siwan group, that is one born in one of the ten Amazigh tribes; other people who were born and have always lived in Siwa are usually identified as badu, or mașri, or any other way according to their family's origin;

- mașri, named after the city of Cairo or the whole country of Egypt, and after mașriyyin, Cairenes or Egyptians; it can refer to Cairene Arabic or to Egyptian Arabic, as a synonym of 'ämmiyya. The term mașriyyin is ordinary used in Siwa to refer to those people who are neither siwiyyin (in the meaning referred to above) nor badu; it has a sociocultural meaning, and by no means implies that the latter two are not Egyptian citizens (a similar use of 'mișriyin' is attested among the Bedouins of the northwest coast, see Abu Lughod (1986) and Cole and Altorki (1998)). The use of this label in the maps is quite ambiguous, as it can refer to Cairene, as opposite to the rest of the Delta region (here mostly labelled 'āmmiyya); to Cairene, as opposite to Alexandrian (here labelled iskandarāni); to Egyptian Arabic (interchangeably with 'ämmiyya), spoken almost everywhere in the country and contrasting with Bedouin Arabic (here labelled badu, 'arabi, 'arabāwi); to Egyptian Arabic (interchangeably with 'ämmiyya), spoken in the Delta region, as opposed to both Bedouin Arabic and Upper Egyptian dialects (labelled șa $\left.{ }^{\dagger} i d i\right)$.

\section{Labels related to the social value or use of the variety}

The last class is constituted by labels that refer to the sociolinguistic status of the variety which is defined, or that imply a value judgement. Examples are:

- 'āmmiyya, lahğa 'āmmiyya is used with a double meaning. In some maps, it indicated any non-standard Arabic variety, that is every variety spoken by the Arabic-speaking Egyptian citizens; in this case it is only opposed to siwi and, sometimes, nūbi. In other maps, it indicates only some of the non-standard Arabic varieties spoken: in most cases it refers to the urban varieties of the Delta region as opposed to both non-Arabic languages and to Arabic specific speeches as Bedouin and Upper Egyptian dialects;

- fushhā is used only once, to define the dialect spoken in Sinai. The respondent is most probably indicating that a Bedouin speech is found there and uses fusha $\bar{a}$ to define it, in line with the longstanding stereotype of the similarity of Bedouin Arabic to the Standard language (e.g. Ferguson 1968).

\section{Closing remarks}

The paper presents a preparatory analysis of a small amount of data; moreover, due to space limits, we have chosen to forgo theoretical discussion and literature review and 
devote space to the data. A further publication based on a twofold analysis of mapdrawing tasks and interviews, conducted with a wider and diversified sample, is expected.

Besides providing a draft of the perceptual dialectological map of Egypt, an interesting finding of the study is the fact that places and population that one might assume to be somehow related or relevant in Siwa Oasis dwellers' lives, as the closest oasis of Bahariyya, were ignored, while places and population which are geographically further, as Upper Egypt and its speech, are always there in their linguistic map of the country. Further analysis is needed to reveal the actual extent to which each region is relevant and why. As for the labelling patterns, it is interesting, for example, the attribution of different meanings to labels as 'arabi, mașri, or 'ämmiyya, according to their context of use, and the denomination of people and languages in general; a deeper analysis of the reciprocal relation between labels chosen by each respondent is required.

On a wider perspective, our aim is to show that a perceptual dialectological approach that makes use of different kind of data, has much to provide in terms of our understanding of cultural and linguistic ideologies, stereotypes, ideas about one's own positioning within a wider context and about the relationships between one's own and other populations - and therefore languages. Finally, it is a valuable tool for investigating sociolinguistic trends and variation patterns.

\section{BIBLIOGRAPHY}

Abu Lughod, L. 1986. Veiled Sentiments: Honor and Poetry in a Bedouin Society. Berkeley and Los Angeles: University of California Press.

Battesti, V. 2006. “Pourquoi j'irais voir d'en haut ce que je connais déjà d'en bas?" Battesti, V. \& Puig, N. (eds.), Egypte/Monde arabe, Troisième série, Terrains d'Égypte, anthropologies contemporaines. 139-179.

Cole, D. \& Altorki, S. 1998. Bedouin, Settlers, and Holiday-Makers. Egypt's Changing Northwest Coast. Cairo: The American University in Cairo Press.

Ferguson, C. 1968 [1959]. "Myths about Arabic", J. Fishman (ed.), Readings in the Sociology of Language. Paris, New York: Mouton - The Hague. 375-381.

Hachimi, A. 2015. ““"Good Arabic, Bad Arabic”. Mapping Language Ideologies in the Arabicspeaking World", ZAL 61. 35-70.

Haeri, N. 1996. The Sociolinguistic Market of Cairo: Gender, Class and Education. London and New York: Kegan Paul International.

Miller, C. 1996. "Nubien, berbère et beja : notes sur trois langues vernaculaires non arabes de l'Égypte contemporaine", CEDEJ: Égypte/monde arabe, Première série, Les langue en Égypte. Retrieved on 09/08/2011 from http://ema.revues.org/index1960.html.

Miller, C. 2005. "Between Accommodation and Resistance: Upper Egyptian migrants in Cairo", Linguistics 43. 903-956. 
Preston, D.R. 1989. Perceptual Dialectology: Nonlinguists' Views of Areal Linguistics. Dordrecht: Foris Publications.

Preston, D.R. (ed.) 1999. Handbook of Perceptual Dialectology. Vol. 1. Amsterdam/Philadelphia: John Benjamins Publishing Company.

Preston, D.R. 2010. “Language, People, Salience, Space. Perceptual Dialectology and Language Regard”, Dialectologia 5. 87-131.

Rosenbaum, G.M. 2008. "Șa ìdī and Fallāḥi versus Cairene Dialects: Use and Function in Egyptian Culture and Literature", Prochàzka, S. \& Ritt-Benmimoum, V. (eds.), Between the Atlantic and Indian Oceans. Studies in Contemporary Arabic Dialects. Proceedings of the 7th AIDA Conference, held in Vienna from 5-9 September 2006. 383-393.

Serreli, V. 2011. Language attitudes in Siwa (Egypt). A Sociolinguistic Investigation. Unpublished MA Dissertation. University Ca' Foscari of Venice.

Serreli, V. 2016. Society, Language and Ideologies in the Oasis of Siwa (Egypt). Listening to people's voices. Unpublished PhD Dissertation. University of Sassari and University of Aix-Marseille.

Theodoropoulou, I. \& Tyler, J. 2014. "Perceptual Dialectology of the Arab World: A Principal Analysis", Al-'Arabiyya 47. 21-39.

Wilmsen, D. \& Woidich, M. 2007. “Egypt”, Versteegh, K. (ed.) EALL 2. Leiden: Brill. 1-12.

\section{ABSTRACTS}

Perceptual dialectology is a sub-branch of folk linguistics first systematized by Dennis Preston in the 1980s (e.g. Preston 1989, 1999). Through the technique of mental mapping, borrowed from cultural geography, perceptual dialectologists seek to discover the perceived distribution of speeches, populations, and prevailing ideologies. In the Arabic-speaking context, map task experiments were conducted by Theodoropoulou \& Tyler (2014) among students at Qatar University, and by Hachimi (2015) among Moroccans of different age, gender, social class and origin, to identify dialect boundaries and labels across the Arabic-speaking world and to understand the underlying ideologies.

This paper discusses lay speakers' perception of the linguistic boundaries in Egypt, based on a map-drawing experiment submitted to secondary school students, in the Egyptian Oasis of Siwa. Siwa is a Berber enclave situated $50 \mathrm{~km}$ away from the Libyan border, where the beginning of mass Arabization dates back to the 1980s and whose geographical and social peripherality limited dwellers' mobility and contact with outsiders. The map task, which asked the students to locate on a map of Egypt languages and dialects spoken in the country, was part of a questionnaire administered in 2011, with the aim of understanding the patterns of language use in the oasis, through the study of speakers' attitudes, beliefs and ideologies (Serreli 2011). The results show that the respondents are aware of the major linguistic boundaries within Egypt, although they did not pay the same attention to all areas: Siwa, the area around Marsa Matruh, the Nile Delta region and Upper Egypt were identified quite clearly by a great number of students, while the Sinai Peninsula was taken into account to a lesser extent and the oases were largely ignored. The paper also presents the respondents' labelling choices, which tell us something about their ideas and judgements of Egyptian communities and their reciprocal relationships. 
INDEX

Keywords: Perceptual dialectology, Metalinguistic Labels, Egyptian Arabic, Siwi Berber, Siwa Oasis

AUTHOR

VALENTINA SERRELI

University of Bayreuth, valentina.serreli@uni-bayreuth.de 


\title{
Mixed Varieties in Political Language in Egypt: the Presidential Debate between 'Amr Mūsa and 'Abd al-Min'im Abu l-Futūh
}

\author{
Nina van Kampen
}

\section{Introduction}

1 Whenever we speak, our goal is to make ourselves understood. We want to transfer a message to our audience, but more importantly, we want this audience to consider what we say as legitimate. When a politician speaks, his goal is to convince his audience of his legitimacy as a leader: he wants support from his people. Thus, he needs to make the right linguistic choices to use a language that is appealing and appropriate.

2 The diglossic situation in Arabic speaking communities greatly influences the linguistic choices that speakers continuously make (Ferguson 1959, 1996 [1991]). Whenever they produce an utterance, they situate themselves somewhere on the continuum between literary and dialectal Arabic (Hary 1996), considering the context in which they speak and the symbolic value of both varieties. If a politician uses literary Arabic when speaking to his audience, he could reinforce his image of a cultivated person - a legitimate ruler - but he could also seem too formal or distant. On the other hand, using dialect in political discourse could be perceived as a willingness to use a more 'democratic' language, emphasizing closeness to the people. At the same time, the speaker could seem too informal or linguistically unable.

3 As a result of these complex symbolic values, politicians often choose to use a mixed language containing features from both literary Arabic and their national dialect (Holes 1993; Mazraani 1997; Bassiouney 2006). The dialectal features in this mixed language should not be considered as errors, but rather as a strategic choice. 
This paper deals with the use of mixed language in an Egyptian political debate broadcasted on national television on the 10th of May 2012. The context of this debate was the Arab Spring: it took place between two candidates for the presidential elections after Mubārak's resignation. Starting from the idea that mixing between literary and dialectal Arabic does not occur freely but follows grammatical and pragmatic structures, I will analyze the use of mixed Arabic by three speakers of the debate: the two candidates ${ }^{\mathrm{c}} \mathrm{Amr}$ Mūsa and ${ }^{\mathrm{C}} \mathrm{Abd}$ al-Min'im Abu l-Futūh, and the moderator Muna aš-Šazlī.

The data used here is quite unique in two ways. Firstly, political debates are very scarce in this region where presidents often come into office without a debate or democratic election. This presidential debate was the first one of this kind in Egyptian history, and, as far as I know, the only one in Arabic speaking communities.

Secondly, most scholars investigating mixed Arabic in political language use speeches as data. However, speeches and debates differ on a number of points. Speeches are often monologues that have been written in advance: they could be considered as oral texts; debates leave more room for improvisation and interaction. The speakers of a debate have to deal with two types of addressees: on the one hand, the viewers of the debate - in this case the Egyptian people -; on the other hand, their fellow speakers on the set with whom they interact directly. This means that political debates emphasize the dialogical dimension of language and can consequently provide us with more information on the unconscious structures of diglossic mixing.

\section{Methods}

7 Mixed varieties in spoken Arabic have been studied using grammatical and pragmatic perspectives. Whereas grammatical methods analyze the morphosyntactic constraints on mixing, the pragmatic methods pay attention to the social motivations and communicative functions of diglossic switching. I will argue that both perspectives pose a number of challenges to analyzing spoken mixed Arabic.

\subsection{Pragmatic methods}

8 As far as the pragmatic analyses are concerned - like Holes (1993) and Mazraani (1997), and partly Mejdell (1999) and Bassiouney (2006) - they focus primarily on intersentential switching. But in actual data of spoken mixed Arabic, phrases are hardly ever entirely in one variety or the other: features from both varieties usually occur in the same phrase or even in the same word. Due to this extensive mixing, it seems almost impossible to define specific places in discourse where switching occurs - the reality of mixed Arabic is often too complex. Another issue encountered when trying to apply a pragmatic method is that the two varieties used in mixed Arabic have many words and morphemes in common. Consequently, a lot of features cannot be classified as either literary or dialectal Arabic.

\subsection{Grammatical methods}

9 The grammatical analyses of spoken mixed Arabic can also pose some challenges. A number of scholars, such as Bassiouney (2006) and Boussofara-Omar $(2003,2006)$, use the Matrix Language Frame model developed by Carol Myers-Scotton (1993). This model 
considers roughly that, when speakers switch between two varieties, one variety forms the morphosyntactic frame constituted by system morphemes, whereas the other variety is the 'embedded language' constituted by content morphemes.

Apart from the issue discussed above - namely, that literary and dialectal Arabic share a large amount of features - the main problem with this model is that it considers all morphosyntactic features to be on the same level. However, the reality of the data shows that some features are more likely to be found in a hybrid context than others, as has also been pointed out by Mejdell (2006). I will argue that some morphosyntactic features are more flexible than others. By 'flexible', I mean that a feature is often used in a hybrid context with morphosyntactic elements that are not from the same variety as the feature. On a quantitative level, this 'flexibility' of a feature means that it is used rather frequently.

\subsection{Analyzing flexibility: combining a grammatical and pragmatic method}

11 In order to take into consideration the differences in the flexibility of morphosyntactic features, it is clear that we need a more nuanced model than Meyers-Scotton's often-used Matrix Language Frame model. Gunvor Mejdell (2006) develops a very useful and interesting method, offering a quantitative and qualitative analysis of five morphosyntactic variables in several monologues of Egyptian academic discourse. Her analysis shows that some variables are more marked than others.

The grammatical analysis of my data follows Mejdell's method. I will focus on three morphosyntactic variables: relatives, demonstratives and negative markers. These variables are analyzed on a quantitative and a qualitative level. Which variants can be defined as flexible?

However, focusing exclusively on the frequency of the literary and Cairene Arabic variants and their syntactic context cannot explain why there are differences between the three speakers, or, for that matter, why one single speaker alternates between different - literary and Cairene Arabic - variants. In order to provide an answer to these questions, we need to take into consideration the context of enunciation in which the utterances are produced. The results of the in-depth grammatical analysis of the variables will serve as a starting point to examine this context of enunciation.

The purpose of this paper is not only to examine the flexibility of demonstratives, relatives and negative markers as used in my data, but also to offer an explanation for the differences in flexibility, combining grammatical and pragmatic methods.

\section{Results}

\subsection{The grammatical analysis}

15 The quantitative analysis of the data shows that out of the three variables, the relatives have on average the largest proportion of Cairene Arabic variants (56\%). Speakers tend to prefer the Cairene Arabic variant illi to the numerous literary Arabic variants. On the contrary, the negative markers have the smallest proportion of Cairene Arabic variants (31\%). An overview can be seen in table 1 . 
Table 1: Quantitative results: total use of the three morphosyntactic variables

\begin{tabular}{|l|l|l|}
\hline & Literary Arabic variants & Cairene Arabic variants \\
\hline relatives & $44 \%$ & $56 \%$ \\
\hline demonstratives & $62 \%$ & $38 \%$ \\
\hline negative markers & $69 \%$ & $31 \%$ \\
\hline
\end{tabular}

These quantitative results clearly show that the different variants do not have the same degree of flexibility and lead us to think that Cairene Arabic relatives are more flexible than the negative markers of the same variety. But how can we explain this difference in flexibility from a grammatical perspective? In order to answer this question, we will need to look at the syntactic structures that mark the use of these variables in literary and Cairene Arabic.

\section{Relatives}

As far as the relatives are concerned, one should note that the syntactic structures used in literary and Cairene Arabic are identical (Woidich 2006: 199-200; Badawi e.a. 2016: 549):

$\begin{array}{lllll}\text { Cairene Arabic } & \begin{array}{l}\text { (antecedent) } \\ \text { ir-rāgil }\end{array} & +\quad \text { relative } & + & \text { relative phrase } \\ \text { Literary Arabic } & \text { (antecedent) } & + & \text { relative } \\ & \text { ar-rağul } & & \text { allad̄i } & \text { relative phrase } \\ & & \ldots\end{array}$

The speakers in the debate tend to prefer using the dialectal variant of the relative rather than the literary Arabic variants. illi is very often used in hybrid contexts, as in (1):

\begin{tabular}{|c|c|c|c|c|c|c|c|}
\hline \multirow[t]{2}{*}{ (1) } & \multicolumn{2}{|c|}{ 'innama l-muhimm } & 'inn-aha & dawla & \multicolumn{2}{|c|}{ tastagīb } & li-mațālib \\
\hline & \multicolumn{2}{|c|}{ onlyART-important } & & state & meet.l & FV.3FSG & PREP-demands \\
\hline & $s^{c}{ }^{c} b-a h a$ & $w i-n-n \bar{a} s$ & illi & dِulimu & & katīir- & \\
\hline & people-its & and-ART-people & REL & oppress.PASS. & V.3MPL & a lot & \\
\hline & wa-humm & & katīi & an & & & \\
\hline & and-margi & PASS.PFV.3MPL & a lot & & & & \\
\hline
\end{tabular}

'But most importantly, it should be a state that meets the demands of its people and those who have been oppressed and marginalized for a long time'

In (1), illi is surrounded by literary Arabic features, such as the verbal morphology of tastagib (which, however, lacks verbal inflection), and the internal passive and aspectotemporal values of dulimu and hummišu.

The dialectal relative is also frequently followed by more hybrid verbal predicates like $b$ tușraf, containing both the dialectal aspectual preverb $b$ - and the literary Arabic internal passive, but lacking verbal inflection. Finally, illi can also be followed by completely Cairene Arabic verbal predicates as ha-yikkallim. 
21 These examples clearly show the flexibility of the Cairene Arabic relative and how it can be used in literary Arabic, Cairene Arabic or hybrid contexts. The literary Arabic relatives, on the other hand, are less flexible: they are usually followed by a verbal predicate following literary Arabic rules.

\section{Demonstratives}

22 As far as the demonstratives are concerned, one should note that they can have two functions. The first function is that of a determiner of a definite noun. For this function, Cairene Arabic and literary Arabic use different structures (Woidich 2006: 44-45; Badawi e.a. 2016: 149-150):

\begin{tabular}{|l|l|l|l|}
\hline Cairene Arabic & noun determined by DEF ART & + & demonstrative determiner \\
\hline & il-kitāa & $d a$ \\
\hline Literary Arabic & demonstrative determiner & + & noun determined by DEF ART \\
\hline & $h \bar{a} \underline{d} \bar{a}$ & $l-k i t a \bar{a} b$ \\
\hline
\end{tabular}

The second function of the demonstrative is that of a pronoun. It often has the role of an anaphoric subject, referring to a previous fragment of discourse or to an idea of the speaker. The syntactic structures in Cairene and literary Arabic are identical (Woidich 2006: 44; Badawi e.a. 2016: 151):

\begin{tabular}{|l|l|l|l|}
\hline Cairene Arabic & demonstrative & + & noun \\
\hline & $d a$ & kitā $b$ \\
\hline Literary Arabic & demonstrative & + & noun \\
\hline & $h \bar{a} \underline{d} \bar{a}$ & kitā $b-u n$ \\
\hline
\end{tabular}

When the demonstrative is the determiner of a definite noun, the speakers of the debate prefer using literary Arabic variants: $90 \%$ of the demonstrative determiners in the debate are literary Arabic variants.

The data shows that these literary Arabic variants of demonstratives determining definite nouns are flexible: they can be used in hybrid or dialectal clause level contexts.

\begin{tabular}{|c|c|c|c|c|c|}
\hline wa-'ana & ma-sa'altak-šo & hāda & S-Su'āl & li'inn $-i$ & $c_{\text {ārif }}$ \\
\hline and-I & NEG-ask.PFV.1SG-NEG & DEM & ART-question & because-I & know.PTCP.MSG \\
\hline il-balad & malyāna & & $\dot{g e ̄ r}$ daqüq & & \\
\hline ART-country & full of & & not precise & & \\
\hline
\end{tabular}

'I didn't ask you this question, because I know that the country is full of rumours' 
In the above example, we can clearly define several elements as dialectal Arabic, such as the negative marker $m a-\ldots-s$ s and the use of the active participle. However, it is more difficult to define the variety of the demonstrative determiner's local context. As has been noted above, the two varieties share a large number of words which cannot be classified as either literary or dialectal Arabic, such as su'āl in (2). I have not found any occurrence in the data of a literary Arabic demonstrative determining a noun that could be classified as exclusively Cairene Arabic.

27 As for the dialectal variant of the demonstrative determiner, it is not very flexible. It usually needs a dialectal syntactic context, as we can see in the following example:

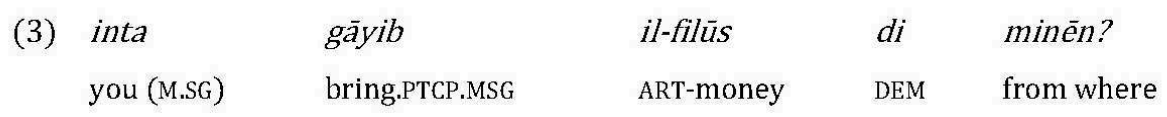

'Where did you get that money from?'

As far as the demonstrative pronouns are concerned, one can note that the patterns of use are quite different. The speakers of the debate tend to use dialectal variants for this function: $58 \%$ of the demonstrative pronouns are Cairene Arabic variants. These dialectal variants are quite flexible and can be found in hybrid contexts with features from literary Arabic, as in the following example. The same trend has been noted by Mejdell (2006: 229).

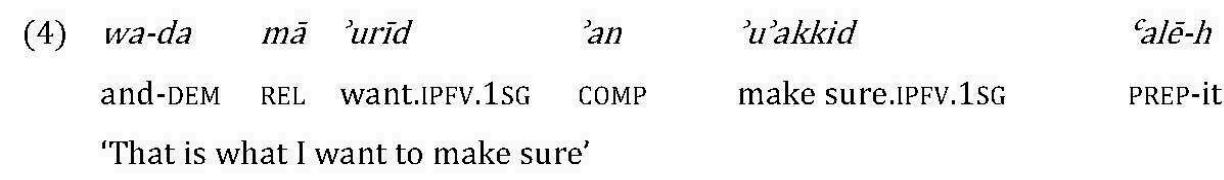

\section{Negative markers}

It was noted before that the data contained little dialectal variants of the negative markers, compared to the other morphosyntactic variables. Generally speaking, negative markers of both varieties are not flexible. Morphosyntactic features of the same linguistic variety usually surround them, and there is no switching between the negative marker and the (verbal) predicate. Thus, the data contains, for example: lam 'akun 'I wasn't', $m \bar{a}$ waqafna 'we didn't stand', lan yakūna 'He will not be', lastu šayxan 'I am not a religious scholar', miš 'ārif 'I don't know' or ma-ti'dirī-š tihlibi ba'ara wa-hiyya ma-'andahā-š laban 'you cannot milk a cow that doesn't have milk'.

Why are the negative markers not flexible? An explanation can be found in the fact that literary and Cairene Arabic both have different ways of expressing tense, aspect and modality, as has been discussed by Eid (1988). In literary Arabic, these notions are incorporated in the negative markers that can assign modal, temporal or aspectual values in the form of verbal inflections. Adversely, in Cairene Arabic it is the verb that carries the notions of tense, aspect and modality by the presence (or absence) of preverbs. The two systems are not compatible, so switching between them is problematic.

The only negative marker that proves to be quite flexible in my data is the literary Arabic marker $l \bar{a}$. Used in the lexicalized expression $l \bar{a} \operatorname{budd}(a)$ 'it is necessary', or with a following noun expressing the categorical negation, this negative marker is very frequently found in a hybrid syntactic context containing other dialectal features. When 
lā functions to negate a verb, this following verb usually follows the literary Arabic way of expressing tense, aspect and mood. However, the verbal predicate can also have a hybrid verbal morphology, as tatașawwari in (5). This example also shows how lā can be used alongside many other dialectal morphosyntactic features:

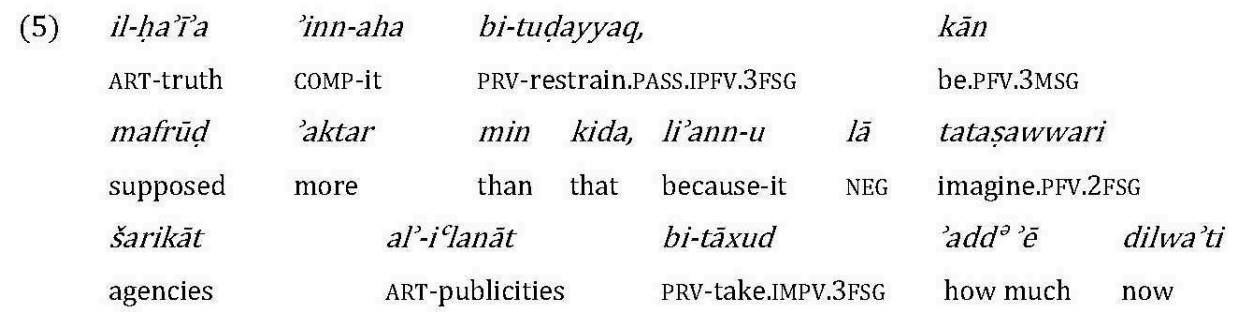

'Actually, it is restrained, it was supposed to be more, because you cannot imagine how much the publicity agencies ask nowadays'

Why is $l \bar{a}$ more flexible than other negative markers? As has been pointed out by Ayoub (1996: 1017-1018), this negative marker does not inherently carry aspectotemporal or modal value and does not assign an inflection to the verb - unlike, for example, lam and lan. This means that $l \bar{a}$ can be used in a more hybrid context. In my data, it seems to be used by speakers as a relatively simple tool to 'elevate' their language, as it does not require them to make any fundamental changes in the syntactic structure of the phrase.

It is clear that the three variables have different degrees of flexibility. The relevant question, now, is why some dialectal variants prove to be more suitable for a hybrid context than others. The 'compatibility' between the grammatical systems of literary and Cairene Arabic seems to play an important role in this. When the syntactic structures in Cairene and literary Arabic are similar, the speakers tend to use more dialectal variants and use them even in hybrid contexts. This was the case for the relatives and the demonstratives having a pronominal function: the syntactic structure in both varieties is similar, leading speakers to use Cairene Arabic variants. When the syntactic structures are different, however, speakers tend to use the literary Arabic variants, as was shown by the preference of speakers to use literary Arabic negative markers and demonstratives that determine a definite noun. However, it is not only the (lack of) similarity of the syntactic structures that influences patterns of use, but also the compatibility of variants with their local linguistic environment. Both negative markers and demonstrative determiners have different structures in literary and Cairene Arabic, pushing speakers to use more literary Arabic variants. As has been discussed above, not all negative markers are compatible with any local environment since some of them carry modal, temporal or aspectual value. Demonstrative determiners, however, are compatible with a great number of nouns given the large shared lexicon between both varieties. This can explain why literary Arabic variants represent such a large proportion of the demonstrative determiners in my data. 


\subsection{The pragmatic analysis}

The abovementioned results largely follow the conclusions of Mejdell and show how a grammatical method can explain the differences in flexibility. However, they fail to explain intra- and interspeaker differences. Table 2 shows these differences:

Table 2: Interspeaker differences

\begin{tabular}{|c|c|c|c|}
\hline & $\begin{array}{c}\text { Largest \% } \\
\text { of LA variants }\end{array}$ & $\begin{array}{c}\text { Smallest \% } \\
\text { of LA variants }\end{array}$ \\
\hline Muna aš-Šazlī & relatives (73\%) & $\begin{array}{c}\text { demonstratives } \\
(67 \%)\end{array}$ & $\begin{array}{c}\text { negative markers } \\
(48 \%)\end{array}$ \\
\hline${ }^{c}$ Amr Mūsa & $\begin{array}{c}\text { negative markers } \\
(62 \%)\end{array}$ & $\begin{array}{c}\text { demonstratives } \\
(56 \%)\end{array}$ & relatives (20\%) \\
\hline${ }^{\text {CAbd al-Min }{ }^{c} \text { im }}$ Abu-l-Futūh & $\begin{array}{c}\text { negative markers } \\
(80 \%)\end{array}$ & $\begin{array}{c}\text { demonstratives } \\
(66 \%)\end{array}$ & relatives (55\%) \\
\hline
\end{tabular}

For example, why does Muna aš-Šazlī use a much larger proportion of literary Arabic relatives than the other speakers? We need to consider the context of enunciation in order to provide an answer. The following sections will discuss a number of pragmatic factors influencing code choice in this debate.

\section{The spontaneity of discourse}

Almost all occurrences of literary Arabic relatives used by the moderator are found in the questions that she addresses to the candidates, as in (6). These fragments have been prepared in advance, and often when watching the video we can even see that she reads a written text out loud.

(6)

$\begin{array}{lcll}\text { wa-mā hiyya al-'āliyāt il-ficliyya } & \text { allati } & \text { kunta } \\ \text { and-what she ART-tools ART-concrete } & \text { REL } & \text { be.PFv.2MSG } \\ \text { sa-tuqdimu } & \text { calay-ha? } & & \\ \text { FUT-implement.IPFV.2MSG } \quad \text { PREP-it } & & \end{array}$

'What concrete tools would you implement?'

When the moderator uses the dialectal variant illi, however, it is often when something unexpected happens on the set, as we can see in (7): 
(7)

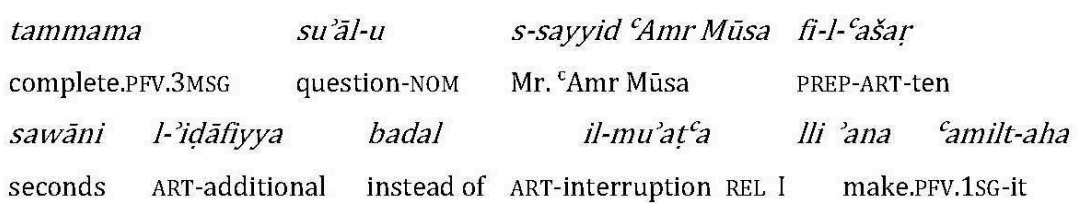

'Amr Mūsa's question was completed in the additional ten seconds that I granted him to replace the time lost during my interruption'

\section{The audience} with speakers alternating turns frequently, more dialectal features will be used Adversely, when the speakers address the audience rather than their conversation partners on the set, talking for a long time without interruptions, they hardly use any dialectal negative markers.

\section{The topic} more dialectal features, including ones that are normally not used frequently, like the dialectal demonstrative determining a definite noun in (9) and the negative marker in (10).

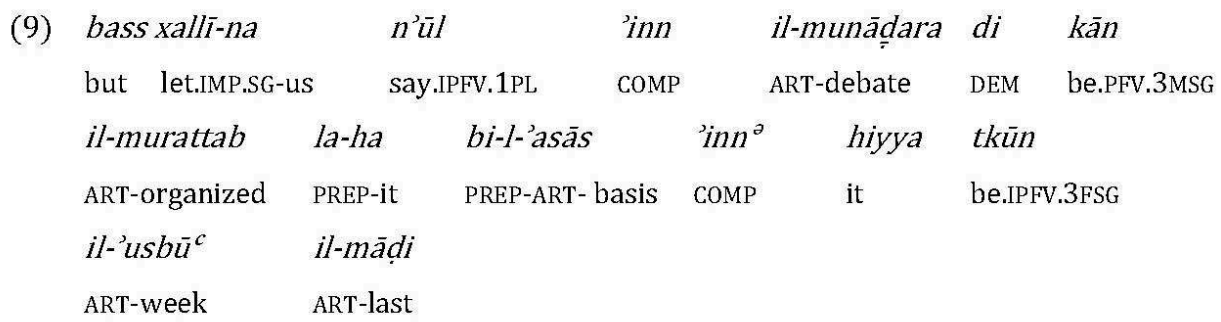




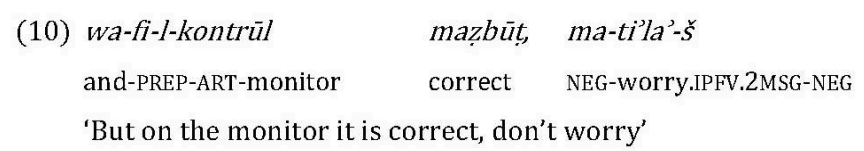

41 As far as these pragmatic factors are concerned, one can note one main principle. When the speaker talks spontaneously, when he interacts with his conversation partners directly, when speaker turns alternate quickly, and lastly, when the topic of his utterance is the debate or some technical aspect of it, the speaker inherently refers to the fact that he is on a set, participating in a debate with others, that he is producing utterances, and trying to make himself understood. This pragmatic analysis clearly shows that when the speakers inherently refer to their act of enunciation, they will on a general level use more dialectal features, including ones that were proven to be infrequent in our quantitative analysis.

get back to the three morphosyntactic variables analyzed before. Could we say that speakers tend to use the dialectal variants of some of these variables, because they inherently refer to the act of speaking? It was shown that speakers tend to use the dialectal variants of the relative and of the demonstrative functioning as an anaphoric subject. These features have anaphoric value: they refer to a previous fragment in discourse. But as this fragment is also product of the enunciation, we could say that it indirectly refers to this act.

Another dialectal morphosyntactic feature worth mentioning is the Cairene Arabic aspectual preverb bi-. It puts the verb in continuity with the moment of enunciation, which means that it also inherently refers to this act. My data, as well as the analyses of Bassiouney (2006) and Mejdell (2006), show that this feature is particularly flexible and that it is frequently used with a verb that follows literary Arabic verbal morphology. An example is shown in (11).

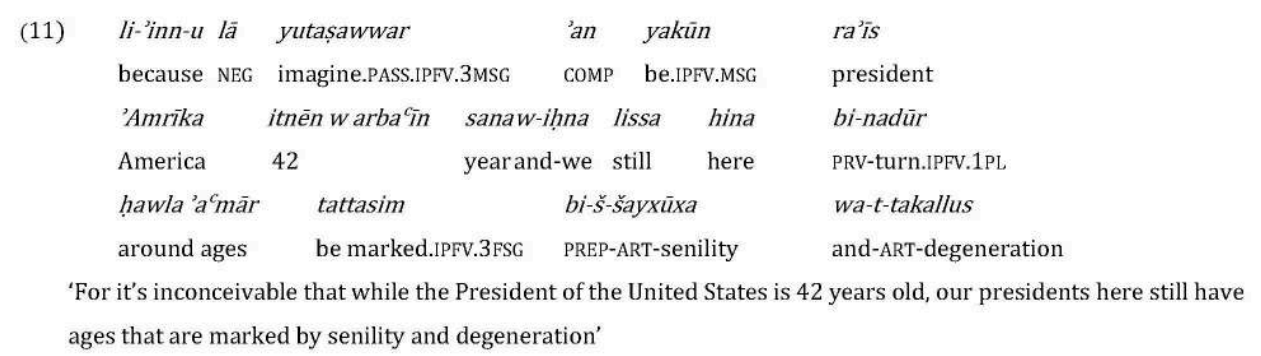

There seems to be a link between the inherent reference of a feature to the act of enunciation, and speakers' preference for dialectal variants of this feature. This possible link should be examined in more detail and for a larger amount of features, especially since previous models seem insufficient in explaining how mixed spoken Arabic works. This research shows some real indications that a further examination of this link could be of great value.

However, we cannot argue that every single time that a speaker inherently refers to his act of speaking, he will use dialectal features. For example, the demonstrative determining a definite noun also has deictic or anaphoric value, but as was discussed before, the speakers of the debate prefer using its literary Arabic variants. 
To conclude, I would like to argue that in the analysis of data of spoken mixed Arabic, we need to consider both types of 'flexibility criteria': the pragmatic factors involving the reference a speaker makes to his act of speaking, and the grammatical factors linked to the compatibility between literary and dialectal Arabic syntax. The question remains to be explored as to whether these flexibility criteria have some kind of universal validity in language or variety contact situations. Should we move towards a general model where the compatibility of language systems and the inherent reference to the enunciation are taken into account? Undoubtedly, further studies and a greater variety of data are needed to determine this.

\section{BIBLIOGRAPHY}

Ayoub, G. 1996. La question de la phrase nominale en arabe littéraire : prédicats, figures, catégories (Thèse de doctorat d'État). Villeneuve d'Ascq: Presses Universitaires du Septentrion.

Badawi, E., Carter, M. \& Gully, A. 2016 [2004]. Modern Written Arabic: A Comprehensive Grammar. London, New York: Routledge.

Bassiouney, R. 2006. Functions of Code Switching in Egypt: Evidence from Monologues. Leiden: Brill. Boussofara-Omar, N. 2003. "Revisiting Arabic Diglossic Switching in Light of the MLF Model and its Sub-Models: the 4-M Model and the Abstract Level Model", Bilingualism: Language and Cognition 6. 33-46.

Boussofara-Omar, N. 2006. "Neither Third Language nor Middle Varieties but Diglossic Switching”, Zeitschrift für Arabische Linguistik 45. 55-80.

Eid, M. 1988. "Principles of Code Switching between Standard and Egyptian Arabic", Al-cArabiyya 21. 51-79.

Ferguson, C. 1959. “Diglossia”, Word 15. 325-340.

Ferguson, C. 1996 [1991]. “Diglossia Revisited”, Elgibali, A. (ed.), Understanding Arabic: Essays in Contemporary Arabic Linguistics in Honor of El-Said Badawi. Cairo: American University in Cairo Press. 49-67.

Hary, B. 1996. "The Importance of the Language Continuum in Arabic Multiglossia”, Elgibali, A. (ed.), Understanding Arabic: Essays in Contemporary Arabic Linguistics in Honor of El-Said Badawi. Cairo: American University in Cairo Press. 69-90.

Holes, C. 1993. "The Uses of Variation: A Study of the Political Speeches of Gamāl cAbd al-Nāṣir", Eid, M. \& Holes, C. (eds.), Perspectives on Arabic Linguistics 5. Amsterdam: John Benjamins. 13-45.

Mazraani, N. 1997. Aspects of Language Variation in Arabic Political Speech-Making. Richmond: Curzon.

Mejdell, G. 1999. “Switching, Mixing: Code Interaction in Spoken Arabic”, Brendemoen, B., Lanza, E., \& Ryen, E. (ed.), Language Encounters Across Time and Space. Oslo: Novus Forlag. 225-241.

Mejdell, G. 2006. Mixed Styles in Spoken Arabic in Egypt: Somewhere between Order and Chaos. Leiden: Brill. 
Myers-Scotton, C. 1993. Social Motivations for Codeswitching: Evidence from Africa. Oxford: Oxford University Press.

Woidich, M. 2006. Das Kairenisch-Arabische: Eine Grammatik. Wiesbaden: Harrassowitz Verlag.

\section{APPENDIXES}

\section{Abbreviations}

\begin{tabular}{|l|l|l|l|l|l|}
\hline ART & article & IPFV & imperfective & PREP & preposition \\
\hline COMP & complementizer & M & masculine & PRV & preverb \\
\hline DEF & definite & NEG & negative & PTCP & participle \\
\hline DEM & demonstrative & NOM & nominative & REL & relative \\
\hline F & feminine & PASS & passive & SG & singular \\
\hline FUT & future & PFV & perfective & $1 / 2 / 3$ & first/second/third person \\
\hline IMP & imperative & PL & plural & & \\
\hline
\end{tabular}

\section{ABSTRACTS}

In the diglossic language situation existing in Arabic speaking communities, speakers continuously adapt their language to the context by moving up and down the linguistic continuum between literary Arabic and the various dialects, thus creating mixed varieties of Arabic. This paper deals with the use of mixed language in an Egyptian political debate, broadcasted on national television, between two candidates for the presidential elections of June 2012.

Focusing on the use of three morphosyntactic variables (relatives, demonstratives and negative markers) in the data, it was noted that these features have different degrees of 'flexibility': some are more likely to be used in a hybrid context than others. In order to offer an explanation for these differences in flexibility, grammatical and pragmatic methods are combined.

A grammatical analysis of the three variables in the data shows that speakers tend to use the dialectal variants when the syntactic structures for the use of a feature are similar in literary and Cairene Arabic. However, this cannot explain inter- or intraspeaker differences that occur in the data. A pragmatic analysis - looking at the context of enunciation in which the utterances are produced - shows that there seems to be a link between inherent references to the act of enunciation on the one hand, and speakers' preference for dialectal variants on the other.

\section{INDEX}

Keywords: mixed Arabic, diglossia, Egyptian Arabic, political language, morphosyntax, pragmatics 
AUTHOR

NINA VAN KAMPEN

INALCO 